

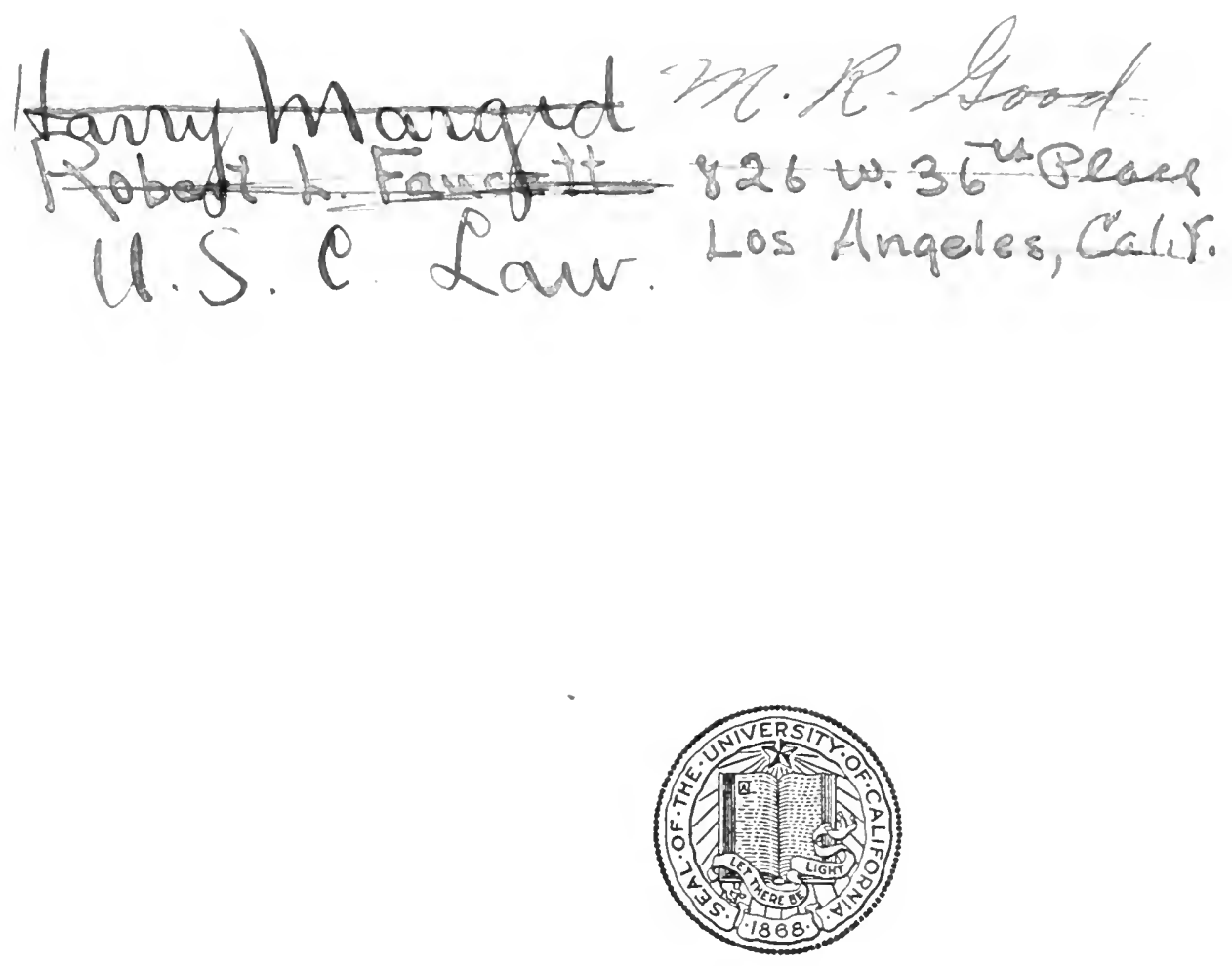

THE LIBRARY

OF

THE UNIVERSITY

OF CALIFORNIA

LOS ANGELES

SCHOOL OF LAW

GIFT OF

Harold E. Ives 
$2 x$

$-1+8$

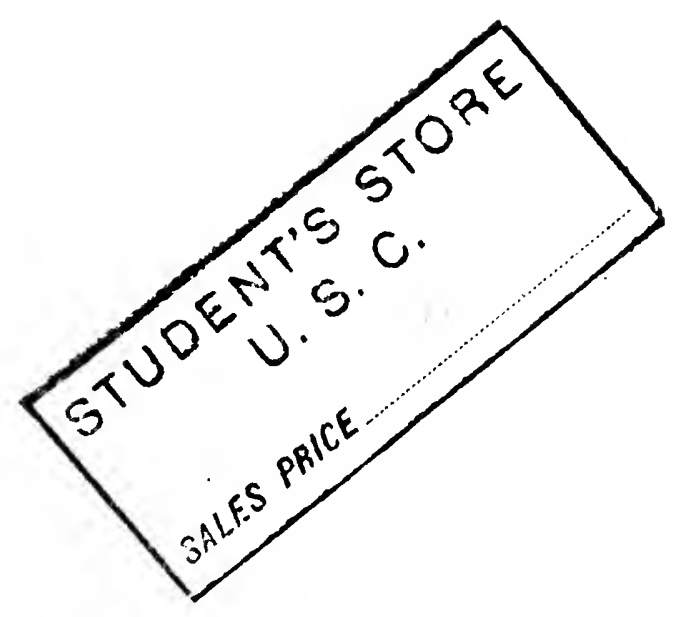






\section{CASES ON THE LAW OF PROPERTY}

VOL. I. PERSONAL PROPERTY.

By Harry A. Bisclow, Professor of Law in the Iniversits of Chicugo.

VOL. II. RIGHTS IN LAND.

liy llarry A. Higelow.

VOL. III. TITLES TO REAL PROPERTY.

By Rilph W. Aigler, Professor of Law in the Wiliversity of Michigan.

VOL. IV. FUTURE INTERESTS.

By Albert M. Kales, of the Chicago Bar, formerly Professor of Law in Harvard University.

VOL. V. WILLS, DESCENT, AND ADMINISTRATION.

By George P. Costigan, Jr, Professor of Law in Northwestern University. 
CASES ON THE LAW OF PROPERTY

\author{
VOLUME 3
}

\title{
TITLES TO REAL PROPERTY \\ ACQUIRED ORIGINALLY AND BY \\ TRANSFER INTER VIVOS
}

\section{BY RALPH W. AIGLER}

PROFESSOR OF LA W IN THE UNIVERSTT OF MICHIGAN LAW SCHOOL

AMERICAN CASEBOOK SERIES

WILLIAM R. VANCE

GENERAL EDITOK

ST. PAUL

WEST PUBLISHING COMPANY

1916 
Copyright, 1916 B 1

WEST PUBIISHING COMPANY

(AIg.Prop.) 
To Dean Henry M. Bates

in Appreciation of His Kindly Interest and Sympatiy

this Book is Dedicated.

(v)* 



\section{THE AMERICAN CASEBOOK SERIES}

THE first of the American Casebook Series, Mikell's Cases on Criminal Law, issued in December, 1908, contained in its preface an able argument by Mr. James Brown Scott, the General Editor of the Series, in favor of the case method of law teaching. Until 1915 this preface appeared in each of the volumes published in the series. But the teachers of law have moved onward, and the argument that was necessary in 1908 has now become needless. 'That such is the case becomes strikingly manifest to one examining three important documents that fittingly mark the progress of legal education in America. In 1893 the United States Bureau of Education published a report on Legal Edtcation prepared by the American Bar Association's Committee on Legal Education, and manifestly the work of that Committee's accomplished chairman, William G. Hammond. in which the three methods of teaching law then in voguc-that is, by lectures, by text-book, and by selected cases-were described and conmented upon, but without indication of preference. The next report of the Bureau of Education dealing with legal education, published in 1914 , contains these unequivocal statements:

"To-day the case method forms the principal, if not the exclusive, method of teaching in nearly all of the stronger law schools of the country. Lectures on special subjects are of course still delivered in all law schools, and this doubtless always will be the case. But for staple instruction in the important branches of common law the case has proved itself as the best available material for use practically everywhere. * * * The case method is to-day the principal method of instruction in the great majority of the schools of this country."

But the most striking evidence of the present stage of development of legal instruction in American Law Schools is to be found in the special report, made by Professor Redlich to the Carnegie Foundation for the Advancement of Teaching, on "The Case Method in American Law Schools." Professor Redlich, of the Faculty of Law in the University of Vienna, was brought to this country to make a special study of methods of legal instruction in the United States from the standpoint of one free from those prejudices necessarily engendered in American teachers through their relation to the struggle for supremacy so long, and at one time so vehemently, waged among the rival systems. From this masterly report, so replete with brilliant analysis and discriminating comment, the following brief extracts are taken. Speaking of the text-book method Professor Redlich says:

"The principles are laid down in the text-book and in the professor's lectures, ready made and neatly rounded, the predigested essence 
of many judicial decisions. The pupil has simply to accept them and to inscribe them so far as possible in his memory. In this way the scientific element of instruction is apparently excluded from the very first. Even though the representatives of this instruction certainly do regard law as a science-that is to say, as a system of thought, a grouping of concepts to be satisfactorily explained by historical research and logical deduction-they are not willing to teach this science, but only its results. The inevitable danger which appears to acconipany this method of teaching is that of developing a mechanical, superficial instruction in abstract maxims, instead of a genuine intellectual probing of the subject-matter of the law, fulfilling the requirements of a science."

Turning to the case method Professor Redlich comments as follows:

"It emphasizes the scientific character of legal thought; it goes now a step further, however, and demands that law, just because it is a science, must also be taught scientifically. From this point of view it very properly rejects the elementary school type of existing legal education as inadequate to derelop the specific legal mode of thinking, as inadequate to make the basis, the logical foundation, of the separate legal principles really intelligible to the students. Consequently, as the method was developed, it laid the main emphasis upon precisely that aspect of the training which the older text-book school entirely neglected-the training of the student in intellectual independence, in individual thinking, in digging out the principles through penetrating analysis of the material found within separate cases; material which contains, all mixed in with one another, both the facts, as life creates them, which generate the law, and at the same time rules of the law itself, component parts of the general system. In the fact that, as has becn said before, it has actually accomplished this purpose, lies the great success of the case method. For it really teaches the pupil to think in the way that any practical lawyer-whether dealing with written or with unwritten law-ought to and has to think. It prepares the student in precisely the way which, in a country of case law, leads to full powers of legal understanding and legal acumen; that is to say, by making the law pupil familiar with the law through incessant practice in the analysis of law cases, where the concepts, principles, and rules of Anglo-American law are recorded, not as dry abstractions, but as cardinal realities in the inexhaustibly rich, ceaselessly fluctuating, social and economic life of man. Thus in the modern American law school professional practice is preceded by a genuine course of study, the methods of which are perfectly adapted to the nature of the common law."

The general purpose and scope of this series were clearly stated in the original announcement:

"The General Editor takes pleasure in announcing a series of scholarly casebooks, prepared with special reference to the needs and limi- 
tations of the classroom, on the fundamental subjects of legal education, which, through a judicious rearrangement of emplasis, shall provide adequate training combined with a thorough knowledge of the general principles of the subject. The collection will develop the law. historically and scientifically; English cases will give the origin and development of the law in England; American cases will trace its expansion and modification in America; notes and annotations will suggest phases omitted in the printed case. Cumulative references will be avoided, for the footnote may not hope to rival the digest. The law will thus be presented as an organic growth, and the necessary connection between the past and the present will be obvious.

"The importance and difficulty of the subject as well as the time that can properly be devoted to it will be carefully considered so that each book may be completed within the time allotted to the particular subject. * * * If it be granted that all, or nearly all, the studies required for admission to the bar should be studied in course by every student-and the soundness of this contention can hardly be seriously doubted-it follows necessarily that the preparation and publication of collections of cases exactly adapted to the purpose would be a genuine and by no means unimportant service to the cause of legal education. And this result can best be obtained by the preparation of a systematic series of casebooks constructed upon a uniform plan under the supervision of an editor in chief.

"The following subjects are deemed essential in that a knowledge of them (with the exception of International Law and General Jurisprudence) is almost universally required for admission to the bar:

$\begin{array}{ll}\text { Administrative Law. } & \text { Equity Pleading. } \\ \text { Agency. } & \text { Evidence. } \\ \text { Bailments. } & \text { Insurance. } \\ \text { Bills and Notes. } & \text { International Law. } \\ \text { Carriers. } & \text { Jurisprudence. } \\ \text { Code Pleading. } & \text { Legal Ethics. } \\ \text { Common-Law Pleading. } & \text { Partnership. } \\ \text { Conflict of Laws. } & \text { Personal Property. } \\ \text { Constitutional Law. } & \text { Public Corporations. } \\ \text { Contracts. } & \text { Quasi Contracts. } \\ \text { Corporations. } & \text { Real Property. } \\ \text { Criminal Law. } & \text { Sales. } \\ \text { Criminal Procedure. } & \text { Suretyship. } \\ \text { Damages. } & \text { Torts. } \\ \text { Domestic Relations. } & \text { Trusts. } \\ \text { Equity. } & \text { Wills and Administration. } \\ \end{array}$

"International Law is included in the list of essentials from its intrinsic importance in our system of law. As its principles are simple in comparison with municipal law, as their application is less technical, 
and as the cases are generally interesting, it is thought that the book may be larger than otherwise would be the case.

"The preparation of the casebooks has been intrusted to experienced and well-known teachers of the various subjects included, so that the experience of the classroom and the needs of the students will furnish a sound basis of sclection."

Since this amnouncement of the Series was first made there have been published books on the following subjects:

Administratioc Law. By Ernst Freund, Professor of Law in the University of Chicago.

Agency. By Edwin C. Goddard, Irofessor of Law in the University of Michigan.

Bills and Notes. By Howard L. Smith, Professor of Law in the University of Wisconsin, and Underhill Moore, Professor of Law in Columbia University.

Carricrs. By Frederick Green, Professor of Law in the University of Illinois.

Conflict of Law's. By Eirnest G. Lorenzen, Professor of Law in Yale University.

Constitutional Law. By James Parker Hall, Dean of the Faculty of Law in the University of Chicago.

Contracts. By Arthur L. Corbin, Professor of Law in Yale University. Corporations. By Harry S. Richards, Dean of the Faculty of Law in the University of Wisconsin.

Criminal Law. By William E. Mikc11, Dean of the Faculty of Law in the University of Pennsylvania.

Criminal Procedure. By William E. Mikell, Dean of the Faculty of Law in the University of Pennsyl vania.

Damages. By Floyd R. Mechem, Professor of Law in the University of Chicago, and Barry Gilbert, of the Chicago Bar.

Equity. By George H. Boke, Professor of Law in the University of Oklahoma.

Eaidence. By Edward W. Hinton, Professor of Law in the University of Chicago.

Insurance. By William R. Vance, Professor of Law in Yale University.

International Law. By James Brown Scott, Professor of International Law in Johns Hopkins University.

Lcgal Ethics, Cases and Other Authorities on. By George P. Costigan, Jr., Professor of Law in Northwestern University.

Partncrship. By Eugene A. Gilmore, Professor of Law in the University of Wisconsin. 
Persons (including Marriage and Diz'orce). By Albert M. Kales, of the Chicago Bar, and Chester G. Ternier, Professor of Law in Stanford Lniversity.

Pleading (Common Law). By Clarke B. Whittier, Professor of Law in Stanford University, and Edmund M. Morgan, Proficssor of Law in Yale Lniversity.

Property (Titles to Reul Property). By Ralph W. Aigler. Professor of Law in the Lniversity of Michigan.

Property (Personal). By Harry A. Bigelow, Professor of Law in the University of Chicago.

Property (Rights in Land). By Harry A. Bigelow. Profesoror of Law in the University of Chicago.

Property (I'ills, Descent, and Administration). By Georse P. Costigan, Jr., Professor of Law in Northwestern (niversity.

Property (Future Interests). By Albert M. Kales, of the Chicago Bar.

Quasi Contracts. By Edward S. Thurston, Professor of I aw in Yale University.

Sales. By Frederic C. Wondward, Professor of Law in the University of Chicago.

Suretyship. By Crawford D. Hening, formerly Professor of I all in the University of Pennsylvania.

Torts. By Charles M. Hepburn, Dean of the Faculty of I aw in the University of Indiana.

Trusts. By Thaddeus D. Kemneson, Professor of Law in the University of New York.

It is earnestly hoped and believed that the books thus far published in this series, with the sincere purpose of furthering scientific training in the law, have not been without their influence in bringing about a fuller understanding and a wider use of the case method.

Wilimiam R. Vance, General Ëditor.

JUXE, 1921. 


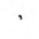

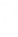




\section{AUTHOR'S PREFATORY NOTE}

Many law teachers have felt that Titles should be the basis of the beginning course in Property. Although this volume appears as number three in a series of casebooks covering the law of Property, it is believed that the subject-matter of the volume, with possibly some shifts in order of the topics, is such that it may well be used in that way.

That most of the topics taken up in this volume are appropriately considered under the head of Titles there cannot be much question. A word of explanation as to the editor's plan may perhaps dispose of any question that may arise as to why certain mattcrs were included here. It may be suggested, for instance, that the matter of Estates should not be gone into to the extent to which it is herein considered. It would be expected, however, that in a book on Titles there would be a treatment of the important and troublesome matter of the extent of the interest acquired or transferred. It has seemed wise not to limit here the discussion of Estates to thcir creation, but to take up the entire subject in the one connection and dispose of it, excluding, of course, the detailed consideration of Future Estates and kindred topics, treated elsewhere. In fact, throughout, the plan has been to place a topic where primarily it would seem to belong, for pedagogic or other reasons, and then dispose of it once for all.

In the treatment of Uses before the Statute of Uses the editor has frankly abandoned the case method as being unsuited to the accomplishment of the desired end, and has printed a very bricf statement, which may serve as an introduction to a more complete discussion by the instructor. The editor has yet to find a student who can gather any coherent ideas as to Uses before the Statute from the fragmentary extracts from secondary authorities printed in volume 1 of Gray's Cases. And this seems quite commonly to have been the expericnce of other teachers of the law of Real Property.

The editor desires, however, upon this occasion, to express his appreciation of and admiration for Gray's Cases on Property. Probably no man in the United States had so large an influence upon our law of Property as has Professor Gray, and the collection of cases which bears his name has played no inconsiderable part in exerting that influence.

The editor acknowledges his indebtedness to Mr. Grover C. Grismore. Instructor in Law in the University of Michigan Law School, for assistance in the preparation of this volume.

ANN ARBor, Mich., May 1, 1916. RALPH W. AIGLER. 


\title{
TABLE OF CONTENTS
}

\section{PAR'T I}

\author{
ORIGINAL TítLES
}

\section{CHAPTER I}

1. Seisin and Disseisin ............................ 1

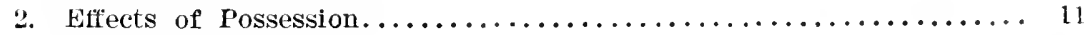

3. Lapse of Time $\ldots \ldots \ldots \ldots \ldots \ldots \ldots \ldots \ldots \ldots \ldots \ldots \ldots \ldots \ldots \ldots \ldots \ldots \ldots \ldots \ldots$. 19

4. Adverse Possession . . . . . . . . . . . . . . . . . . . . . 4 ?

5. Constructive Adverse Possession..................... s1

6. Disabilities ................................ 91

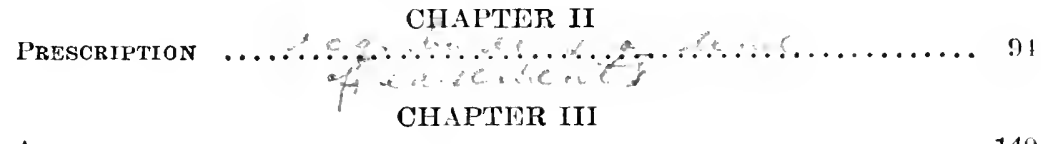

ACCPETION

\section{PART II}

\section{Derivative Tithes}

CHAPTER I

Mode of Conveyance

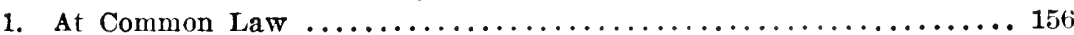

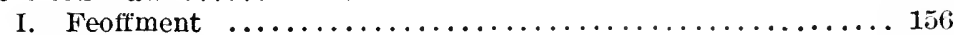

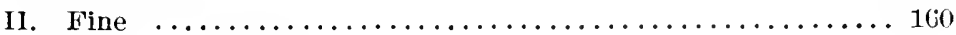

III. Common Recovery $\ldots \ldots \ldots \ldots \ldots \ldots \ldots \ldots \ldots \ldots \ldots \ldots \ldots$

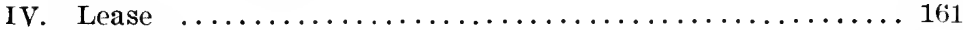

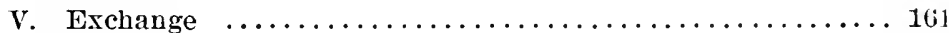

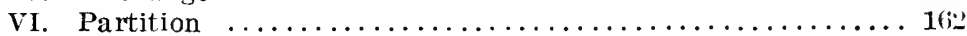

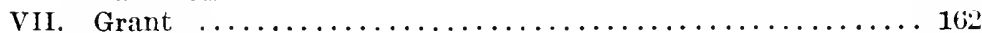

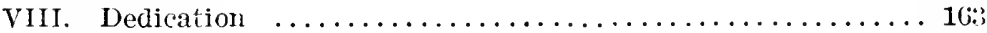

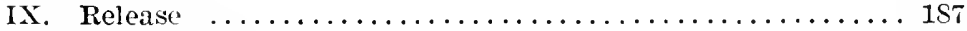

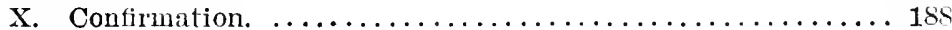

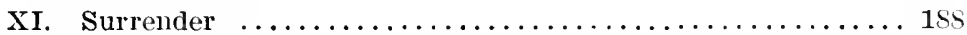

XII. Assignment .............................. $2: 1$

XIII. Defeasance $\ldots \ldots \ldots \ldots \ldots \ldots \ldots \ldots \ldots \ldots \ldots \ldots \ldots \ldots \ldots \ldots$

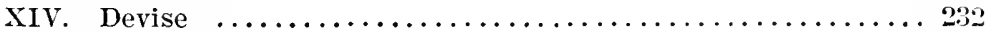

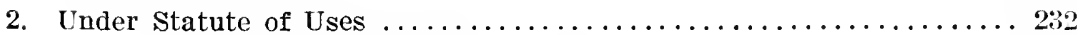

I. Uses Before Statute of Uses................. 23:

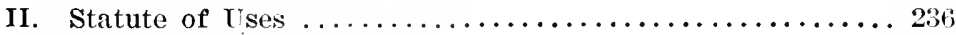

III. Uses after Statute of Uses..................... 290

Aig.Prop.

(xv) 
Section

2. Under Statute of Uses (Continued)

(A) Lses Raised in Connection with Common Iaw Con-

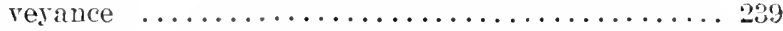

(B) Uses Raised Independently of a Common Law Converance ......................... 247

(C) Limitations Upon the Operation of the Statute of Uses 261

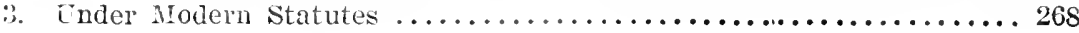

\section{CHAPTER II}

\section{Execution or DeEDS}

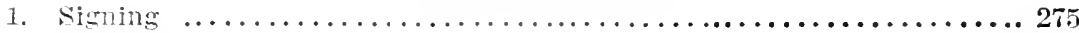

¿. Sealing ...................................... 275

3. Attestation ................................... 279

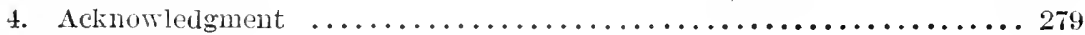

5. Delivery ....................................... 279

\section{CHAPTER III}

The Property Conveyed

1. Boundaries

\section{CHAPTER IV}

Creation of Easements by IMplication.

\section{CHAPTER V}

Estates Created

1. Estates in Fee Simple......................... 547

2. Estates in Fee Tail............................. $55 c_{0}$

3. Life Estates ...............................

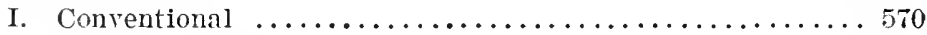

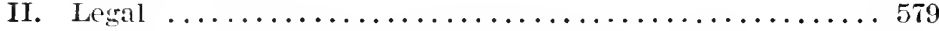

(A) In Tail after Possibility of Issue Extinct........579

(B) Husband's Interest in Wife's Realty ...........5s0

(C) Wife's Interest in Husband's Realty ........... 597

4. Estates for Years............................ 628

5. Estates at Will and from Year to Year.................63t

6. Concurrent Estates ............................ 685

7. Reversions and Remainders ....................... 731 Chapter vi
Covenants for Title $\ldots \ldots \ldots \ldots \ldots \ldots \ldots \ldots \ldots \ldots \ldots \ldots \ldots \ldots \ldots$

\section{CHAPTER VII}

Estoppel by DeEd

\section{CHAPTER VIII}

Prionities

1. Fraudulent Conreyances ............................. 810

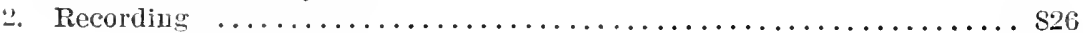

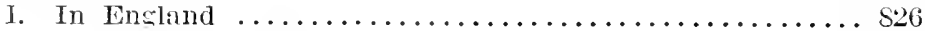

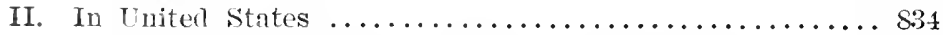

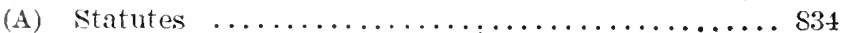

(B) Scoue of Operation and Effect of Statutes......... S37

(C) Effectiveness of Record....................914 


\section{TABLE OF CASES}

[CASES CITED IN FOOTNOTES ARE INDICATED BY ITALICS. WHERE SMALL CAPITALS ARE USED, THE CASE IS REFERRED TO IN THE TEXT]

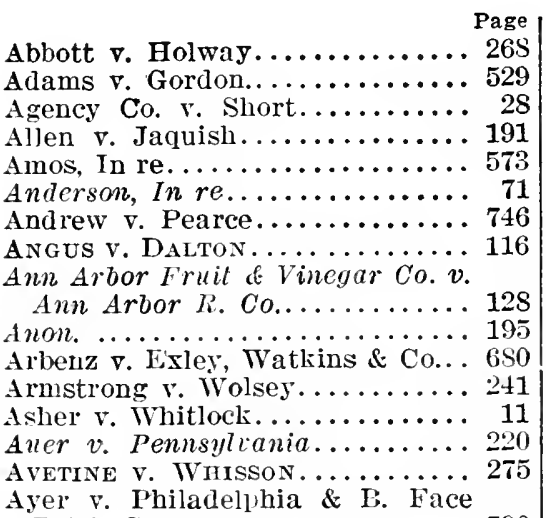

Brick Co. .............. 790

Eailey v. Agawam Nat. Bank.... 458

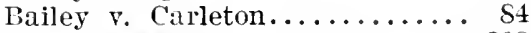
Baker v. Mather ........... \$93 Baker v. Rice .................. Baker v. Snavely........... 370 Bangor House Prollietary $v$.

Brown ............... 426 Banlis v. Ogden............ 436 Barher $r$. Bailes............. 125 Barlice v. Heete............ $: ; 0$ Barlow $v$. Fhodes........... 4nis Barlow v. Wainuright........ 665 Barnes v. Barnes........... 300 Bates . Bates...........602 Baxter v. Taylor............. 109 Bayley $\vee$. MćCoy........... 781 lieardsley $\vee$. Knight.......... 749 BEATTY v. KURTz........... 168 Bcclitith's Case.............. 235 Beddoe's Ex'r v. Wadswonth . .... T36 Bedford v. Bacchus.......... $\$ 2 \tau$

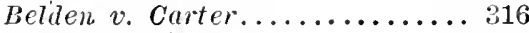

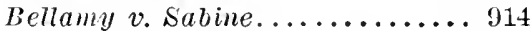
Blewilt v. Boorm.......... 344 Blight v. Schenck........... 354 BOARD v. BoARD........... 70 Bond v. O'Gara............. 61 Bolland's Lessee v. Marsluall. .... 588 Boyd v. Slayback............ 250 Boynton v. Haggart........... $\$ S 7$ Bradley v. Missouri Pac. R. Co... 278 Braythwayte $r$. Hitchcock...... 657 Brigham v. Smith..........444 Bromley v. Stanley........... 195 Broughton v. Randall.......... 597 Broun v. Alabaster...........47s
Page

Broncn v. Brown............ 616

Brown v. Cairns............. 221

Brown. . Fuller................ 511

BRYAN v. ATwater.......... 52

Buckuorth v. Thilkell. . ....... 59.

Burkholder v. Markley........ 405

Burnett v. Burnett........... 30.

Buss v. Dyer............... 518

Bussmeyer v. Jablonsky........ 521

Butler v. Butler ...........624

Butterworth v. Crawford....... 535

Calvert v. Aldrich.......... 716

Campbell v. Thomas.......... 357

Canby v. Porter............. 583

Carllee v. Ellsberry . . . . . . . . . 550

Carrier v. Price............. 573

Carter v. Barnard........... 26 Cassidy r. Sulliran........... 182

Caswell .. Districh...........6.630

Catlin v. Ware............6.2.

Chency v. Watkins........... 2:s

Chicago, \& E. I. R. Co. v. Willard 436

ChILD r. Starr.............. 423

Christmas ₹. Oliver......... 793

Cincinnati v. White......... 16.5

City of Battle Creek v. Goguac

Fesort Ass'n ............ 541

Garton v. Blaker.............66t

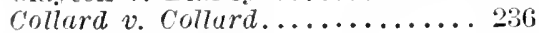

Cook v. Brolen...............316

Cooke v. Kell............... \$20

Coppy v. I. De B........... $\$ 66$ Coudert r. Cohn............66(i2 Cover v. James............. 5t!

Crenshaw . . Moore..........6.6.6

Cressey v. Cressey ........... 72.

CrossleY \& SONS $v$. LIGHTOWLER 483 Croxall v. Shererd.........262

Curry v. Colburn............ 2\$1

Curtis v. Galvin...........641

Dabney $\nabla$. Child. . . . . . . . . . . 495

Daries $v$. scar.............. 471

Davison ex dem. Bromley v. Stan-

ley .................. 195

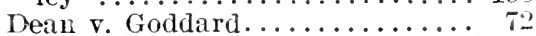

Dee v. King.............. 455

Dodd r. Witt..................4t

Doe r. Jesson.............. 91

Doe d. Murvell v. Miluard..... 194

Doe d. Netrman $i$. Rusllam..... 819

Doe $d$. Rigge v. Bcll......... 661

Doe d. Robinson v. Allsop....... 834

Doe $a$. Souter v. Hull.......... 6 S 
Page

Doe d. Thomson ₹. Amey........ 660

Doe ex dem. Carter . B. Barnard. . 26

Doe ex dem. Christmas r. Olirer 793

Dow ex dem. Galnons 5. Knight. . 2SS

Doe ex dem. Goody v. Carter..... 24

Doe ex dem. Harlan v. Bromn... 32

Doe ex dem. Llord $r$. Passingham 262

Doe ex dem. Otley $\nabla$. Manning. . \$ $\$ 12$

Doe ex dem. Parlier v. Gregors.. 66

Dorlell $v$. Collins............ 449

Dox $v$. Thhitney............ $\$ 92$

Downing r. Coatesville Borough. 1s3

Drury v. Holden............ 792

Dungan $\nabla$. Kline............ 566

Fdmards r. Bihb...........660?

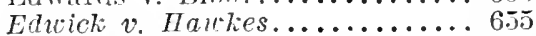

Egan r. Horrigan........... 300

Egcrton's Case .............. 239

Enliott v. Mumay........... 298

Ellis v. Krger..............60s

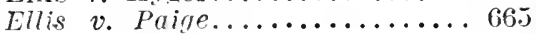

Elston r. Piggntt........... 703

Emerson $r$.Hooney......... 450

Everts v. Agnes............. 347

E.wing v. Nesbitt............ 560

Fancy $v$. Scott............. 452

Farley v. Palmer............. 362

First Unirelsalist Soc. v. Boland 552

Fitch v. Bunch............ 360

Fitsgerald $v$ Libl)y.......... $\$ 92$

Flower $г$. Darbs..............670

Flynn v. Flynn............ 612

Ford r. Metropolitan R. Cos...... 47T

Fortier $\nabla$. Ballance........... 65

Foster $\nabla$. Marshall............ 584

Erench $\nabla$. Pearce............ 51

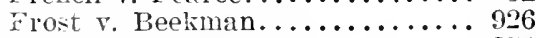

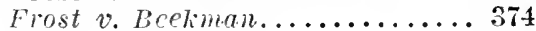

Fryer . Fryer............. 295

Galles. . Ward............. s9s

Gamons $v$. Kniglt............. 2ss

Geddes Coarse salt Co. $\nabla . \mathrm{Ni}$ aga ra, Locliport \& Ontario Pow-

er Co. ................444

Gee $v$. Hatley............... 66

German sarings \& Loan Co. $v$.

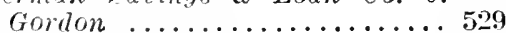

Gifford r. Yarborough ......... 140

Gilliland r. Woodruff......... s1

Golksborough v. Gable........ 675

Groody r. Carter.............. 24

Gouch r. VIool............ 275

qould $v$. Wagner............4.2

Grady v. MeCorlile..........6 620

Gray v. Kaufman Dairy \& Ice

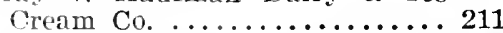

Green $v$. Wiseman........... 239

Grey \& Edwards' Case........ 24s

Griswold $\nabla$. Branford.
Gristvold 7. Johnson.......... 723

Hall v. Eaton. . . . . . . . . . . 411

Hall v. Harris. .............

Halsey v. McCormick.......... 14j

Hamerton $v$. Stead........... 197

Yannon $\nabla$. Christopher........ Ts:

Iranson $\nabla$. Johnson.......... 6 .

Hardin v. Jordan. .......... 426

Hare v. Cele..............6.6.

Harlan . Brown............ 32

Harris $\nabla$. Toodard........... 391

Havens $v$. Sea Shore Land ro... 2.

Haverhill Sav. Bank v. Griffin. 463 Hamksland $r$. Gatchel......... 335

Herter v. Mullen..........6.672

Hildreth $v$. Googins.......... 49.5

Iillary v. Gay............6.6. 638

Hine v. Dodd............ 834

Hoban $\nabla$. Cable.............. 402

Holbrook ${ }^{2}$. Finney........... 59s

Holden $\nabla$. Garrett.......... $86 \mathrm{~s}$

Holmes v. BellinghaM....... 431

Hubbard v. Greeley......... 352

Fiubbard. . Town..............117

Hudson v. Alexander.......... 245

Hughes $r$. Graves........... 21

Hull r. Sangamon River Drainage

Dist. ................. 361

Hunter's Lessee $\nabla$. Durrell....... 5s

Hurley $r$. Hurley.......... 706

Ingram v. Morris............619

Ive's Case.................. 195

Jackson r. Baird............. 709

Jackson ex dem. Gilliland $\nabla$.

Woodruff ............... s1

Jackson ex dem. Gouch $v$. Wood.. 275

Jackson ex dem. Hudson r. Alex-

ander ................. 215

Jackson ex dem. McCrackin $\nabla$.

Wright ................ $7 \mathrm{~s} 0$

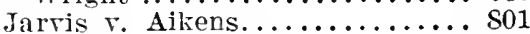

Jefferys v. Buelinell .......... $\mathrm{s} 9$

Johnson $\nabla$. Johnson........... 31t

Johmson v. Thomas.......... 56

Joxes $v$. SuITH............. $\$ 96$

Jordan $r$. Chambers......... 797

$K a y$ v. Oxley............ 466

Kelsey, Appeal of............ 722

Lennedy $v$. De Trafford....... T02

King $\nabla$. Durkee-Atwood Co.....6.677

King $v$. Leake.............. 1St

Kingdon. . Nottle.........755, 757

Kirlipatriek $\imath$. Hathiot........ 706

Kister v. Reeser........... 452

Ladd $v . \operatorname{Ladd} \ldots \ldots \ldots \ldots \ldots \ldots \ldots . \ldots 831$

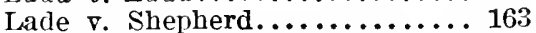

Lamb v. Crosland.............. 104 


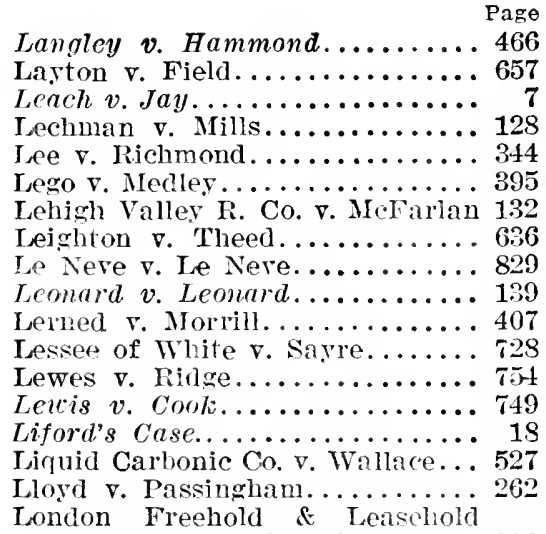
Property Co. v. Suffield....... . 936

Loomis $v$. Loomis............ 32

Loril Ward v. Lumley. . . . . . . . 190

Iosey v. Simpsoll........... 843

Lovingston $v$. St. Clai) Commly.... 1!7

Low v. Elwell............. 6.52

Low v. Tibbetts............. 45S

Lucy v. Levinuton........... Tit

Lutwich v. Mitton........... 248

Iyon v. Reed.............. 221

Lyons v. Pbiladelphia \& R. R. Co. 669

McCrackin $\nabla$. Wright........ 780

MIcCullock v. Holmes........... 54s

Mchensie $v$. Gleason.......... 440

McNeely v. Langan............ 36

Mallott $v$. Witson........... 3S3

Mancuso v. Riddlemoser Co. of

Baltimore City ........... 509

Mangold v. Barlow........... 929

Janning $v$. N.J. Short Line R. R.

Co. ................. 494

Markland $v$. Crump..........770

Mrarshall v. Roberts........... \$ 82

Mason v. Wierengo's Estate...... $6 \mathrm{SO}$

Mather $v$. Ministers of Trinity

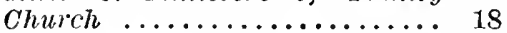

Matson v. Johnson........... 30:3

Mattocks v. Stearns........... 5s2

May v. Emerson............ 365

Maynard v. Esher.............441

Mrldmay's Case ........... 251

Mitchell v. Mrshane Immber Co. 79

Mitchell . Ryan...........297

Mitehell v. Ryin........... 385

Mitchell v. Seipel............ 504

Mitchell v. Warner........... 759

Moelle v. Sherwood . . . . . . . . 899

Mollet v. Bryne............. 206

Montgomery v. Tate......... 580

Moore v. Bennett. ........... \$92

Moore v. Trott.............. 316

Morecock v. Dicliins........... 827

Morehead v. Hall.
Morison $v$, Marquardt......... Page 494

Morse v. Curtis............. $8_{5}$

MURRay v. EARL of Statr......;

MIurray v. Kerney. . . . . . . . . 258

MURRAY v. STAIR (EARL)...... $\$ 41$

Murrelt v. Mitworrd............ 194

Mustain v. Gardner..........6900

Mutual L. Ins. Co. v. Dalie..... 9.97

Neuman v. Rushrm.......... 819

Nerton v. Marland...........

Nicilolas v. Cinamberlain . . . . 449

Niehots $v$. Luce............ 49.

Nickells $v$. Atherstonc........251

Noke v. Awdry............ 731

Noreross v. Grifiths..........4 426;

Nordman v. Rau............. $90 !$

Ogle $\nabla$. City of Cumleland..... ISt oldewurtel v. Wisenfell........21\% Gliver v. Hedderiy........... T06 Oliver v. Piatr............. SS: Oremon Laws............. S:7 Otley v. Mannin........... 812 Owings $\nabla$. First Nit. IBank..... 320

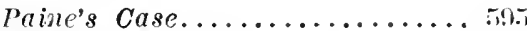
Patmer v. Conk............ . .t! Palmer v. Elims............ T:; Palmer v. Fletcher.......... 46. Parker v. Gregory............ 6ri I'arrott $\nabla$. Avery............. 2sti l'arry v. Carwarden.......... st! Patmian v. IItilland . . . . . . . \$! Paut v. Carver.............441 Pavey v. Vance............. 121 Pearson $v$. spencer............47t Peger v. Pegg. .............69 Perlins v. Coleman......... Perry v. Clissold............ 1:

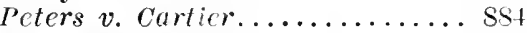
Petlingitl $v$. Porter.......... 495 Phillips v. Low. ............. 4st Pickering v. Pickeling........ 720 Pico v. Columbet. . . . . . . . . . 711 Pinnington v. Galland......... 4893 Polden v. Bastard.......... 471 Pollen and Wife v. Brewer...... 6:39 Preble v. Mine Cent. I. Co...... 56 Pringle v. Dunn............916 Prouty v. Marshall.......... 9:32 Pyer v. Carter.............4.2

R. Co. v. Walker........... 4 .5

Ralph v. Bayley........... Rankin v. Miller............ 845 Rathmell v. Shirey.......... $3: 1$ Ray v. Hazeldine.......... 491 Reader $\vee$. Purdy............645 Resser v. Carney............ 804 Rex v. Hudson............ 16:; Rex . Lloyd.................. 16t 


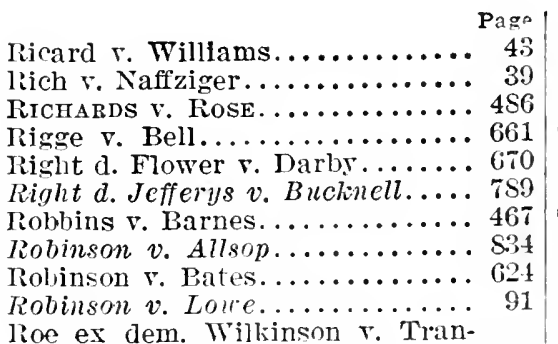

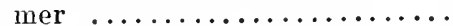
IRollo v. Nelson............. 529

Rosse's Case............... 578

Ruggles r. Lawson............ 312

Saccone $r$. Test Fnd Trust Co.. 429

St. Clair $\mathbf{v}$. Williams......... 75.3

Salter v. Jonas.............. 440

Sambach v. Dallon............ 262

Say v. Stoddard............642

Schaubuch v. Dillemuth......... 56

Schieffelin $r$. Carpenter.......... 200

Schotield r. Iowa Ilomestead Co... T6i

School Trustees v. Schroll...... 406

Schurtz v. Colvin............ 8.9.2

Scott $\mathrm{v}$. Stone................85

Seibert v. Leran.............

shannon $r$ Kinny............ 31

sharington $v$. strotlom......... 236

Sherin $\mathrm{r}$. Brackett........... 34

Shoenaker v. Walker........6.600

Shortrilge r. Lamphush........ 240

Siblry v. Holden............. $4: 39$

Sigmirney r. Lamed........... 914

simmons 2 . Paterenn..........443

Simonson v. Wenzel.......... sir

Sizer 5. Dererenx............. 421

sleeper $v$. Lumlia........... 44 s

Smiley v. smiley........... 329

Smith r. Purtis.............. 7

Smith v. Detioit L. \& B. Ass'n... 656

smith v. Garland........... $\$ 19$

Snith's Ex'r r. Jones......... 461

Smith's Heirs r. Branch Fank at

Tobile ................... ss5

Sohier $r$. Coffin.............. 17

Solbers v. Robinson.......... 740

souter v. Hull................ 68

Stanton r. Chamberlain........ 279

starr v. Child................ 443

Steel r. Frick...............6.6.

stein v. Hyman-Lexis Co........ 221

Stermberger \& Millar v. Ragland 872

Stone r. Durall............ 322

Stonehil r. Hastings........... 325

Strone v. Whybark.......... S77

sturgron v. Winaficla......... 796

stureses $r$. Brirlsman........... 114

SUfField v. Brown.......... 483

Taunton v. Costak............6 637
Page

Tefft v. Munson............. 858

Temple v. Benson............ 416

Terrell $\vee$. Andrew County....... 927

Thomas 5. Cook.............. 207

Thomas $\nabla$. Stone \& Graham...... s $\left.s_{(}\right)$

Thompson v. Baxter......... 575

Thompson 5 . Leach.......... 375

Thomson r. Amey............660

Thorn v. Nexsom............ 8s4

Thomburg v. Wigrgins......... 692

Tichtorne $v$. Weir............ 24

Tisher v. Beckwith........... 283

Toothe $r$. Bryce............. 521

Trowhridge $\because$ Ehrich......... 4t4

Turner v. Meymott.......... 626

Tyrrel's Case............... 261

Ure $\nabla$. Ure................ 266

Van Der Volgen v. Tates....... 241

Van Horne $r$. Fonda........... 700

Vax Rexseglaer v. Kearvey... TS6 Volcanic Oil \& Gas Co. r. Chaplin 147

Wallace $r$. Fletcher........... 94

Mallis v. Doe ex dem. Smith's

IIeirs ..................6 610

Walls v. Atcheson.............. 209

Walter v. Grecmerom ........... 720

Ward (Imorl) r. Lumley........... 190

Waters r. Philadelphia........ 174

Watson r. Watsum........... 595

Trob v. birl............. 112

Weeks $r$. New York, W. \& B. I.

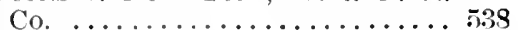

Welch r. Silckett................. 3st

West $v$. Woyre............. 715

IThalley $v$. Thompsom............ 466

Wheeldon r. Burrows......... 4is

Wheeler $r$. Young............ 862

Wheelwright $r$. Whedwright.... 308

Whitalier v. Bromn..........449

Whitehead r. Clifford.............. 206

Whitehead v. Ratan............. 405

Whiting $v$. Whiting..........6 616

Whittier $v$. Montpelier Ice Co..... 443

Whyddon's Cise............334

Wilkinson r. Tranmer......... 255

Williams r. Rurrell.......... 748

Williams $r$. Green............. 356

Trilliamson $v$ Brown...................... 902

Wilsox r. Hart................ $\$ 96$

Wilson v. Tarlor's Ex'rs....... Tif

Wipfler r. Wipfler............. 342

Woods r. Garmett........... 854

Trormley v. Wormley.......... 17 .

WrMaN v. Brow........... 270

Yard $\nabla$. Ford.............. 111

Youngblood $r$. Vastine............. S49

Zick v. London United Tramwas,

Limited .................. 197 


\title{
CASES ON PROPERTY
}

\section{TITLES TO REAL PROPERTY}

\section{PART I}

\author{
ORIGINAL TITLES
}

\author{
CHAPTER I
}

POSSESSORY TITLES

\section{SECTION 1.-SEISIN AND DISSEISIN}

\section{MAITLAND, THE, MYS'TERY OF SEISIN.}

Any one who came to the study of Cole upon Littleton with some store of modern legal ideas but no knowlectge of English Real Property law would, it may be guessed, at sone stage or another in his course find himself saying words such as these: "Evidently the main clue to this elaborate labyrinth is the notion of seisin. But what precisely this seisin is I cannot tell. Ownership I know, and possession I know, but this tertium quid, this seisin, eludes me. On the one hand, when Coke has to explain what is meant by the word he can only say that it signifies possession, with this qualification, however, that it is not to be used of movables, and that one who claims no more than a clattel interest in land cannot be seised, though he may be possessed. But, on the other hand, if I turn from definitions to rules, then certainly seisin does look very like ownership, insomuch that the ownership of land, when not united with the seisin, seems no true ownership."

The perplexities of this imaginary student would at first be rather increased than diminished if he convinced himself, as I have convinced myself and tried to convince others, that the further back we trace our legal history the more perfectly equivalent do the two words seisin and possession become; that it is the fifteenth century before English lawyers have ceased to speak and to plead about the seisin (thereby beAIg.Prop.-1 
ing meant the possession) of chattels. Certainly as we make our way from the later to the older books we do not seem to be moving towards an age when there was some primeval confusion between possession and ownership. We find ourselves debarred from the hypothesis that within time of memory these two modern notions have been gradually extricated from a vague ambiguous seisin in which once they were blent. In Bracton's book the two ideas are as distinct from each other as they can possibly be. He is never tired of contrasting them. In season, and (as the printed book stands) out of season also, he insists that seisina or possessio is quite one thing, dominium or proprietas quite another. He can say with Ulpian, "Nihil commune habet possessio cum proprietate."

2 Law Quarterly Rev. 481.

\section{POLLOCK \& MAI'TIAND, HIST. ENG. LAW.}

On the whole we nay say that the possession of land which the law protects under the name of a "seisin of freehold" is the occupation of land by one who bas come to it otherwise than as tenant in villeinage, tenant at will, tenant for term of years or guardian; that occupation leing exercised by himself, his servants, guardians, tenants in villeinage, tenants at will or tenants for term of years. This seems the best statement of the matter: Occupation of land is seisin of free tenement unless it has been obtained in one of certain particular ways. If, however, we prefer to look at the other side of the principle, we may say that the animus required of the person who is "seised of free tenement" is the intent to hold that land as though he were tenant for life or tenant in fee holding by some free tenure.

2 P. \& M. Hist. Eng. Law (2d Ed.) 40.

\section{MAITLAND, THE MIYTERY OF SEISIN.}

There is another side to the picture we have here drawn. He who is seised, though he has no title to the seisin, can alienate the land: he can make a feoffment and he can make a will (for he who has land is enabled to devise it by statute), and his heir shall inherit, shall inherit from him, for he is a stock of descent; and there shall be dower and there shall be curtesy, and the lord shall have an escheat and the king a forfeiture, for such a one has land "to give and to forfeit." This may make seisin look very much like ownership, and in truth our old law seems this (and has it ever been changed?) that seisin does give ownership good against all save those who have better because older title. Nevertheless we err if we begin to think of seisin as ownership or any modification of ownership : after all it is but possession. A termor was not seised. but certainly he could make a feoffment in fee and 
his feoffee would be seised. This seems to have puzzled Lord Mansfield, and puzzling enough it is if we regard seisin itself as a proprietary right, for then the termor seems to convey to another a right that he never had. But when it is remembered that substantially seisin is possession, no more, no less, then the old law becomes explicable. My butler has not possession of my plate, he has but a charge or custody of it; fraudulently he sells it to a silversnith; the silversmith now has possession: so with the termor, who has no seisin, but who by a wrongful act enables another to acquire seisin.

2 Law Quarterly Rev. 488.

\section{BRACTON, DE LEGIBUS ANGLIAE.}

Likewise a disscisin takes place, not only if any one ejects the true owner when present, or his agent, or his family, or does not admit him, or repels him on his return from market or from a jonrney, but he also effects a disseisin, if he shall not permit the owner or his agent or his family being in possession to make use of it, or at least hinders him from making a convenient use of it. And in which case, although he does not altogether expel [the owner], nevertheless he inflicts upon him a disseisin, since he talies away from him altogether the convenience of using it, or hinders him from using it conveniently, quietly, and in peace, by disquieting and disturbing his possession. Likewise a disseisin takes place not only according to what has been said above, but also if any person of greater power wishes to make use of the tenement of another against the will of the tenant, by ploughing, or by digging, by reaping and carrying away, contending that the tenement, which is another's, is his own; but if he has made no claim to the tenement, it will be another thing because then there will be a trespass, and not a disseisin from a freehold, or by turning in sheep, or in some other manner imposing a servitude upon land, which was free beforehand.

Bracton, fol. 161b; 'Twiss' Translation, 3 'Tw. Br. 17.

\section{LITTLE'TON'S TENURES.}

And note that disseisin is properly, where a man entreth into any lands or tenements where his entry is not congeable, and ousteth him which hath the freehold, etc.

Section 279.1

1 "Disseisin was the wrongful taking awas from the real owner of hts actual seisin. 'Disseisin was formerly a notorious act, when the disseisor put himself in the place of the disseisee as tenant of the freehold and performed the acts of the freeholder and appeared in that character in the lord's court.' Lord Ellenborough, in William v. Thomas, 12 East, 141, 155 (1810). Or, as Lord Mansfield put it: 'Disseisin, therefore, must mean some 


\section{LEAKE, LAW OF PROPERTY IN LAND.}

Disseisin was a wrongful entry upon the land and ouster or dispossession of the freeholder. An entry, or perception of rents and profits, under colour of an adverse title, although evidence of an ouster, might be explained by the circumstances, and not amount to a disseisin. The disseisor acquired, by his wrongful act, an estate in fee simple, as against all but the real owner, and upon this title he might maintain an action of ejectment against a stranger to the title who had ousted him. The disseissee retained a mere right of entry which, if exercised within the linits of time which were periodically fixed by law, revested the estate in him.

Disseisin of the tenant of a particular estate disseised or divested all the estates in remainder or reversion, and converted them into mere rights of entry, exerciseable in their order of succession.

The tenant himself of the particular estate whether for life, or for years, having the actual seisin, had it in his power to make a feoffment to another by livery, which effectually conveyed the fee, if it in terms imported to do so, irrespectively of his own estate or interest; and such feoffment disseised all the estates in remainder or in reversion dependent upon his seisin and converted them into rights of entry. Feoffment by tenant in tail operated rightfully at common law, but was provided against by the statute De donis, giving a writ of formedon to the issue or reversioner or remainderman. It therefore took away the right of entry and left only the right of action under the statute.

An entry on the land within the time allowed by law restored the seisin, and, if made by the tenant of a particular estate, it restored or revested the estates in remainder or reversion, which were dependent upon the same title. Hence a right of entry was sufficient to preserve a contingent remainder. It is to be observed that the entry of the disseisee before his right is barred by lapse of time restores him to his former title by relation back. He may therefore maintain an action

was or other turning the tenant out of his tenure and usurping his place and feudal relation. Tarlor v. Horde, 1 Burr. 60, 107 (1757). How this was accomplished originally, unless the lord conspired with the disseisor, we do not know. It is sufficient for our purpose that disseisin was early possible, and that every wrongful taking of seisin from the real owner was not necessarily a disseisin. That only was disseisin where some one entered upon and ousted one who had taken actual possession under claim of freetiold. Certainly this was true of actuar disseisin, though there was a dissersin by election, where persons, to arail themselves of the remedy by assize, frequently were allowed to suppose or admit themselves to be disseised when they were not. Whatever may be true of the law of to-dar. there was in the early common law a clear distinction between disseisin alid other forms of adverse possession; for unless actual seisin was intelfered with, or could be regarded as interfered with for the purposes of the action, there was no disseisin, though there might perliaps be an abatement or some other folm of adverse possession." Geo. P. Costigan, Jr., "Conveyance of Lands by Lisseisee," 19 Harr. Law Rev. 268, 269. 
against a trespasser for a wrong done between the date of disseisin and entry. And even before a change in the law enabled after-acquired freehold estates to be devised, the entry of the disseisee validated a devise of lands made while he was out of possession.

The right of entry, arising upon a disseisin, was lost in certain events; as by the seisin being cast by descent upon the heir of the disseisor; which was technically called a descent cast; also by an alienation of the fee by the disseisor to another, which was called a discontinuance of the possession. On the other hand, the right of entry might be kept alive against a descent cast by the process of continual claim.

Where the right of entry was lost there remained a mere right of action, to be prosecuted within certain limits of time in the form of real action provided for the circumstances of the case.

The doctrines concerning rights of entry and of action and the proceedings in real actions were highly technical and elaborate, and formed a large and complicated branch of the law of real property; until the amendments of the law made by the Real Property Limitation Act. 1833. By that statute, section 36, real actions were put an end to with three exceptions, which were subsequently abolished, and the action of ejectment or as it is now known, an action for the recovery of land, is the appropriate remedy at law for the recovery of the possession of land. By the same statute the right of entry or action is no longer defeated by a descent cast or a discontinuance (section 39); and it is exempted from all other casualties except lapse of time. But it must be prosecuted within twelve years next after the accrual of the right, unless the person entitled is under disability.

Law of. Property in Land (Randall's Ed.) p. 40 et seq.

\section{BUTLER \& HARGRAVE'S NO'TE TO COKE UPON LITTLETON.}

The different degrees of title which a person dispossessing another of his lands acquires in them in the eye of the law (independently of any anterior right), according to the length of time and other circumstances which intervene from the time such dispossession is made, form different degrees of presumption in favour of the title of the dispossessor; and in proportion as that presumption increases, his title is strengthened; the modes by which the possession may be recovered vary; and more, or rather different proof is required from the person dispossessed, to establish his title to recover.

Thus, if A. is disseised by $\mathrm{B}$. while the possession continues in $\mathrm{B}$. it is a mere naked possession, unsupported by any right, and A. may restore his possession, and put a total end to the possession of $B$. by an entry on the lands, without any previous action.

If $\mathrm{B}$. dies, the possession descends on the heir by act of law. In this 
case, the heir comes to the land by a lawful title, and acquires, in the eye of the law, an apparent right of possession; which is so far good against the person disseised, that he has lost his right to recover the possession by entry, and can only recover it by an action at law. The actions used in these cases are called Possessory Actions, and the original writs by which the proceedings upon them are instituted, are called Irits of Entry:

But if A. permits the possession to be withheld from him, beyond a certain period of time, withont claiming it, or suffers judgment in a possessory action to be given against him by default, or upon the merits; in all these cases, B.'s title in the eye of the law is strengthened, and A. can no longer recover by a possessory action, and his only remedy then is by an action on the right. These last actions are called Droiturel Actions, in contradistinction to Possessory Actions. They are the ultimate resource of the person disseised; so that. if he fails to bring his writ of right within the time limited for the bringing of such writs, he is remediless, and the title of the dispossessor is complete. The original writs by which droiturel actions are instituted are called Writs of Right.

The dilatoriness and niceties in these processes, introduced the $\mathrm{Writ}$ of Assize. The invention of this proceeding is attributed to Glanville, Chief Justice to Henry II. (See Mr. Reeves's History of the English Law, Part I, ch. 3.) It was found so convenient a remedy, that persons, to avail themselves of it, frequently supposed or admitted themselves to be disseised, by acts which did not in strictness amount to a disseisin. This disseisin, being such only by the will of the party, is called a disseisin by election, in opposition to an actual disseisin: it is only a disseisin as between the disseisor and the disseisee, the person, thus propounding himself to be disseised, still continuing the freeholder as to all persons but the disseisor. The old books particularly the Reports of Assize, when they mention disseisins, generally relate to those cases where the owner admits himself disseised. (See 1 Burr. 111; and see Bract. lib. 4, cap. 3.)

As the processes upon writs of entry were superseded by the assize, so the assize and all other real actions have been since superseded by the modern process of ejectment. This was introduced as a mode of trying titles to lands in the reign of Henry VII. From the ease and expedition, with which the proceedings in it are conducted, it is now become the general remedy in these cases. Booth, who wrote about the end of the last century, mentions real actions as then worn out of use. It is rather singular that this should be the case, as many cases must frequently have occurred, in which a writ of ejectment was not a sufficient remedy. Within these few years past, some attempts have been made to revive real actions; the most remarkable of these are the case of Tissen $\mathrm{v}$. Clarke, reported in 3 Vils. 419, 541, and that of Carlos and Shuttlewood v. Lord Dormer. The writ of summons in this last case is dated the 1st day of December, 1775. The summons to the 
four knights to proceed to the election of the grand assize, is dated the 22d day of May, 1780. To this summons the sheriff made his return; and there the matter rested. The last instance in which a real action was used, is the case of Sidney v. Perry. In this case, it was adjudged by De Grey, Chief Justice, and all the other judges, that the defendant, in a writ of right, by proving his actual possession, withont any evidence of his title, put the demandant to the necessity of producing and proving his title, a point, of which, till that decision, some doubts were entertained. That part of Sir William Blackstone's Commentary which treats upon real actions is not the least valuable part of that excellent work.

Note (1) to Coke upon Littleton, $\$ 239 \mathrm{a}^{2}$

\section{SMI'TH v. BUR'TIS.}

(Supreme Court of New Tork, 1\$10. 6 Johns. 197, 5 Am. Dec. 218.)

This was an action of ejectment, brought to recover the possession of a house and lot of land, in the city of New York. The cause was tried at the sittings, held in the city of New York, the 12th of June, 1809, before Mr. Justice Spencer.

The plaintiff proved, that Isaac Teller entered into possession of the.

2 In Leach r. Jay, I. R. 9 Ch. D. 42 (1S7S), a devisee sought to recorer possession of certain lands. "The will provided: "I also berueath and derise to him" (the plaintiff) "all real estate (if any) of which I may die seised." For some time rior to the death of the testatrix, the lands in question had been in possession of others who claimed to own same. The court held that the testatrix was not "seised" and that therefore the rolatiff did not succeed to the lands. James, L. I., sajd: "This lads, for" some reason or lnotive of her own, or for no reason, chose to use one of the most technical words in our law. The word has acquired no otler meaning than its technical meaning; it has never got into ordinaly use; therefore we are not at liberty to attribute to it any other meaning melely because we suppose that the testatrix did not know the true neaning of the worl. It has been argued in faror of the appellant that seisin now has lost its distinctive meaning, that all its consuluees have long ceased to rxist, and therefore that you cannot predicate of angthing that a testator died seised of it in any other sense than that it was part of his real estate. I am of opinion that there are such things as seisin and disseisin still. MH. Jushuil Williams says in his late book on Seisin: "If a person wrongfully gets possession of the land of another, he becomes wrongfully entitled to an estate in fee simple, and to no less estate in that lind; this, if a sruatter wrongfully incloses a bit of waste land and huilds a hut on it aurl lives there. he acquires an estate in fee simple by his own wong in the land which he has inclosed. He is seised, and the owner of the waste is disceised. It is true that. until by lenoth of time the statute of limitations shall hare confirmed his title, he may be turned out by legal process. But as long as he remains he is not a mere tenant at will, nor for yeal's, nol fol life, nor in tail; but he has an estate in fee simple. He has spisin of the freehoid to him and his heirs. The rightful owner in the meantime has but a risht of entry a right in many respects equivalent to seisin; but he is not actuilly seised, for if one person is seised another person camnot be so."

As to the meaning of seisin in connection with corenants for title, compare Marston $\nabla$. Hobbs, 2 Mass. 433, 3 Am. Dec 61 (1807), and Mercantile 'Tuust Co. v. South Parli Co., $9 \pm \mathrm{Ky}, 271,22$. . W. 314 (1898). 
premises in question, about the year 1765 , and erected a house thereon, in which he lived, with his family, from 1765 to 1775 , when he died in possession. At the time of his death, he left five children, John, his eldest son, and heir at law, Henry, his second son, one of the lessors, Nary, (who intermarried with Peter Thalkimer,) Remsen, and Isaac, other lessors of the plaintiff. The widow and children remained on the premises until the British army took possession of New York, when they left the place, and went to Hudson. John the eldest son, died in 1777 , aged about 14 years; and Henry was about 8 years old when his father died. After the British troops entered the city of New York, (in 1776,) they took possession of, and occupied the buildings and premises, and on application of one of the creditors of Isaac Teller, permitted him, for thirty guineas, to take possession of, and appropriate to his own use, the materials of the buildings, which were sold by him; out of the proceeds thereof he retained the amount due to him; and, a few years since, paid the residue to Henry, one of the lessors. The possession of the premises remained vacant during the war, and until 1795, when they were taken possession of by the defendants, or the persons under whom they claim.

The defendants offered to prove, that Isaac Teller, under whom the lessors claimed, had no title to the premises in question; and that the defendants had a good and complete title to the premises, which was not derived from Isaac Teller, or his children.

This evidence was objected to, by the plaintiff's counsel, on the ground that there having been a descent cast upon the immediate heirs of Isaac Teller, who died in possession; and that the possessory title being the only question in an action of ejectment, the plaintiff must recover.

The judge overruled the evidence offered by the defendants; and a verdict was thereupon found for the plaintiff.

A motion was made to set aside the verdict, for the misdirection of the judge, in overruling the evidence offered by the defendant, on the ground of a descent being cast; and aleo on account of newly discovered evidence.

Affidavits were read, stating the evidence discovered since the trial; but as the opinion of the court related only to the other ground, it is unnecessary to state it.

Kent, C. J., delivered the opinion of the court. The first and most important question raised in this case is, whether a descent was cast, upon the death of Isaac Teller, so as to toll the entry of the true owner.

The counsel, upon the argument, entered into a discussion of the general doctrine of disseisin; but I do not think it will be necessary to pursue at large that inquiry. All the books seem to agree that the ancient learning on this subject has become abstruse. Disseisin, in the age of Bracton, was considered in an extensive sense, and far beyond the idea which was first applied to it. Disseisin, by election, in opposition to actual disseisin, was introduced very early, and became very 
prevalent, in order to extend the remedy by writ of assise, which was devised by Glanville, in the reign of Henry II. It must, therefore, be difficult, in many cases, to know what species of disseisin was intended, though it is said that the old books, and particularly the book of assise, when they mention disseisins, generally relate to disseisins by election. The present question appears, however, to lie in a narrower compass; and by confining ourselves to a few plain and familiar authorities, we shall discover the principle, that the doctrine of descent cast applies only to a seisin, coinmencing by wrong, and founded on an ouster of the true owner. Whatever may be the meaning of disseisin, in other cases, its meaning, when applied to the subject before us, embraces a tortious ouster. There must be a disseisin in fact. The rightint owner nust have been expelled, either by violence, or by some act which the law regards as equivalent in its effects.

"Descents in fee, which toll entries," says Littleton, (section 385,) "are, as if a man seised of certain iands, is by another disseised, and the disseisor hath issue and dieth of such estate seised; now the lands descend to the issue of the disseisor, by course of law, as heir unto him. And because the law casts the lands upon the issue, by force of the descent, the entry of the disseisee is taken away." And in the next section, Littleton gives a like definition of a descent in tail, which tolls an entry. Both he and Gillert have a chapter devoted to the subject, and they always speak or refer to a descent founded on a seisin commencing by wrong. "In descents which toll entries, it behoveth," says Littleton, (section 387,) "that the man dic seised in his clemesne as of fee." A seisin in his demesne as of fee, is the strongest and highest estate wlich the subject can enjoy. It would then be very idle to talk of a descent cast, in the case of a rightful seisin in fee, for there would be no right of entry to be tolled in such a case. The doctrine can only exist and apply in the case of a tortious seisin.

At the common law, if the disseisor, abator, or intruder, (and these are mentioned by Coke, as the only wrongful acts of seisin, which will cast a descent,) had died seised soon after the wrong done, the disseisee and his heirs were barred of their entry. Co. Litt. 238, a. This was deemed too harsh a rule, and the statute of 32 Hen. VIII, c. 33, was passed, saving the right of entry to the disseisee, unless the disseisor had been in peaceable possession for five years next after the disseisin by him committed. This statute shows pretty plainly, what species of disseisin was then understood as applicable to this subject. It is entitled, "An act that wrongful disseisin is no descent in law ;" and it recites that whereas "divers persons have heretofore, by strength, and without title, entered into lands, and wrongfully disseised the rightful owner, and so being seised by disseisin, have thereof died seised, by reason of which dying seised, the disseisee or such other persons, as before such descent might have lawfully entered, were thereby excluded of their entry and put to their action." It is therefore enacted, "that the dying seised of any such disseisor of any lands, having no 
right or title therein, should not be taken or deemed any such descent in the law, for to toll or take away the entry of any person, which, at the time of the descent, had good and lawful title of entry, except," etc.

The disseisin intended by this act, was one founded on a tortious expulsion of the true owner. This is giving the term its primitive and genuine meaning; and in this sense it is also used, when applied to a descent east. A mere entry upon another is no disseisin, unless it be accompanied with expulsion, or ouster from the freehold. Disseisin is an estate gained by wrong and injury; and therein it differs from dispossession, which may be by right or wrong. This is the uniform language of the best atthorities, from the time of Littleton. Litt. $\S$ 279; Co. Litt. 3, b. 18, b, 153, b, 181, a; Cro. Jac. 685; 1 Salk. 246, n. $2 ; 1$ Durr. 109.

This tortions seisin, the lessors of the plaintiff were bound to show affirmatively, if they would put themselves upon the strict and ungracious right of a descent cast. A peaceable entry upon land, apparently, vacant, furnishes, per sc, no presumption of wrong. The benign and legal intendment is otherwise. According to Lord Holt, (1 Salk. 246,) a bare entry on another, without an expulsion, makes such a seisin only, that the law will adjudge him in possession that has the right. This court has frequently recognized the same rule, that an entry not appearing to be hostile, was to be considered an entry under the title of the true owner. It lay, then, with the plaintiff to show his entry not congeable, or to show a subsequent disseisin; for he entered upon vacant lands. We may infer title, from his ten years' possession, suffcient to put the tenant upon his defence: but we onght not to infer a tortious entry, or an actual ouster, sufficient to bar every defence. 'This would be a most rigorous conclusion, for it makes the ancestor or the plaintiff a disseisor; it tolls the entry of the true owner; it shuts out his defence, and drives him to his writ of right, which final remedy is now subject to the limitation of twenty-five years.

The subsequent use of the land by Teller was no disseisin. The case of Matheson v. Trot, 1 Leon. 209, is a strong authority on this point. In that case, Henry Denny, the heir at law, when he came of age, claimed and sued out livery, or restitution of lands, out of the hand: of the feudal lord, who had seised them as guardian for the infant. He then leased them for years, reserving a rent, and for years received the rents and profits from his tenant, and died so seised. This was held not to be a requisite seisin to cast a descent, though the court admitted, that his lessee had gained a wrongful possession in fee. If here was not, during all this time, an actual pedis possessio by the heir, (though the case says, he once walked over the lands with his tenant,) yct he held and enjoyed the lands by his tenant; and the case showed conclusively, that he held them without title, for the lands had been devised in fee to his younger brother. This case, I think is, in every view, much stronger in favor of a descent cast, than the one before us.

As it was, therefore, ruled, at the trial, that a descent was cast, and 
the evidence offered by way of defence, inadmissible, the court are of opinion, that there ought to be a new trial, with costs to abide the event of the suit.

New trial granted. ${ }^{3}$

SECTION 2.-EFFECTS OF POSSESSION

ASHER v. WHITLOCK.

(Court of Queen's Bench, 1S65.

L. I. 1 Q.

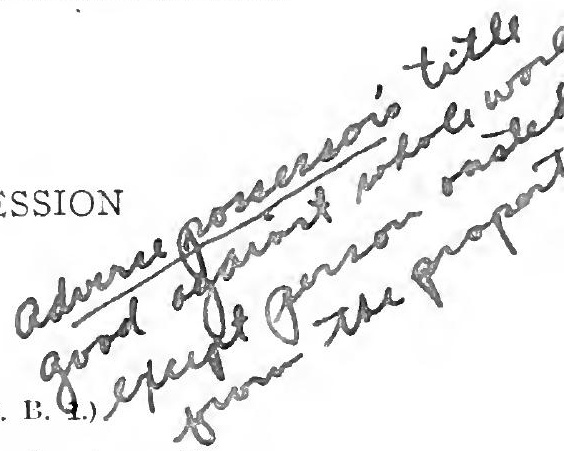

Ejectment for a cottage, garden, and premises, situate at Keysoe Row, in the parish of Keysoe, in the county of Bedford; the writ stated that the female plaintiff claimed possession as heir-at-law of Mary Ann Villiamson, an infant deceased.

The defendant defended for the whole.

At the trial before Cockburn, C. J., at the last Bedfordshire Spring Assizes, the following facts appeared in evidence: About Michaelmas, in the year 1842, Thomas Williamson enclosed from the waste of a manor a piece of land by the side of the highway; and in 1850 he enclosed more land arljoining, and built a cottage; the whole being the land as described and claimed in the writ. He occupied the whole till his death in 1860 . By his will he devised the whole property, describing it as "a cottage and garden, in Kersoe kow, in which I now dwell," to his wife Lucy Williamson, for and during so much only of her natural life as she might remain his widow ant unmarries ; and from and after her decease, or second marriage, whichever event might first happen, to his only child Jlary Ann W'illiamson, in fee. After the death of Thomas Williamson, his widow remained in possession with the daughter, and in April 1861 married the defendant; and from that time they all three resided on the property till the death of the daughter, aged eighteen years, in February 1863. On her death, the defendant and his wife, the widow of the testator, continued to reside on the premises; the widow died in May 1863, and the defendant still continued to occupy.

The female plaintiff is the heir-at-law of the testator's daughter, Mary Ann Willamson. The writ was issued 11th of April 1865.

These facts being undisputed, the Chief Justice directed a rerdict for the plaintiff for the whole of the property claimed; with leave to move

3 See, too, Slater v. Rawsou, 6 Metc. (Mass.) 439 (18t3).

Section 37t of the New York Code of Civil Procednre provides that "the riglit of a person to the possession of real property is not impaired or affected, by a descent being cast, in consequence of the death of a person in possession of the property." Legislation to the same effect is found in a number of states. See 1 Stimson's Am. St. Law, $\$ 1404$. 
to enter the verdict for the defendant, on the ground that the testator had no devisable interest in any part of the property.

A rule nisi was afterwards obtained to enter the verdict for the defendant, on the ground that no title in the plaintiffs was shown to either portion of the land enclosed.

Cockburn, C. J. I am of opinion that this rule should be discharged. The defendant, on the facts, is in this dilemma; either his possession was adverse, or it was not. If it was not adverse to the devisee of the person who enclosed the land, and it may be treated as a continuance of the possession which the widlow had and ought to have given up on her marriage with the defendant, then, as she and the defendant came in under the will, both would be estopped from denying the title of the devisee and her heir-at-law. But assuming the defendant's possession to have been adverse, we have then to consider how far it operated to destroy the right of the devisee and her heir-at-law. Mr. Merewether was obliged to contend that possession acquired, as this was, against a rightful owner, would not be sufficient to keep out every other person but the rightful owner. But I take it as clearly established that possession is good against all the world except the person who can show a good title; and it would be mischievous to change this established doctrine. In Doe v. Dyeball, Mood. \& M. 346 (E. C. L. R. vol. 22), one year's possession by the plaintiff was held good against a person who came and turned him out; and there are other authorities to the same effect. Suppose the person who originally enclosed the land had been expelled by the defendant, or the defendant had obtained possession without force, by simply walking in at the open door in the absence of the then possessor, and were to say to him, "You have no more title than I have, my possession is as good as yours," surely ejectment could have been maintained by the original possessor against the defendant. All the old law on the doctrine of disseisin was founded on the principle that the disseisor's title was good against all but the disseisee. It is too clear to admit of doubt that, if the devisor had been turned out of possession he could have maintained ejectment. What is the position of the devisee? There can be no doubt that a man has a right to devise that estate which the law gives him against all the world but the true owner. Here the widow was a prior devisee, but durante viduitate only, and as soon as the testator died the estate became vested in the widow; and immediately on the widow's marriage the daughter had a right to possession; the defendant, however, anticipates her, and with the widow takes possession. But just as he had no right to interfere with the testator, so he had no right against the daughter, and had she lived she could have brought ejectment; although she died without asserting her right, the same right belongs to her heir. Therefore I think the action can be maintained, inasmuch as the defendant had not acquired any title by length of possession. The devisor might have brought ejectment, his right of possession being passed by will to his datuhter, she could have maintained eject- 
ment, and so therefore can her heir, the female plaintiff. IVe know to what extent encroachments on waste lands have taken place; and if the lord has acquiesced and does not interfere, can it be at the mere will of any stranger to disturb the person in possession? I do not know what equity may say to the rights of different claimants who have come in at different times without title; but at law I think the right of the original possessor is clear. On the simple ground that possession is good title against all but the true owner, I think the plaintiffs entitled to succeed, and that the rule should be discharged.

MeLLoR, J. I am of the same opinion. It is necessary to distinguish between the case of the true owner and that of a person having no title. The fact of possession is prima facie evidence of seisin in fee. The law gives credit to possession unless explained; and Mr. Merewether, in order to succeed, ought to have gone on and shown the testator's title to be bad, as that he was only tenant at will, but this he did not do. In Doe v. Dyeball, Mood. \& M. 346 (E. C. L. R. vol. 22), possession for a year only was held sufficicnt against a person having no title. In Doe v. Barnard, 13 Q. B. 945 (E. C. L. R. vol. 66), 18 L. J. (Q. B.) 306, the plaintiff did not rely on her own possession merely, but showed a prior possession in her husband, with whom she was unconnected in point of title. Here the first possessor is connected in title with the plaintiffs; for there can be no doubt that the testator's interest was devisable. In the common case of proving a claim to landed estate under a will, proof of the will and of possession or recerpt of rents by the testator is always prima facie sufficient, without going on to show possession for more than twenty years. I agree with the Lord Chief Justice in the importance of maintaining that possession is good against all but the rightful owner.

Lush, J., concurred.

Rule discharged.*
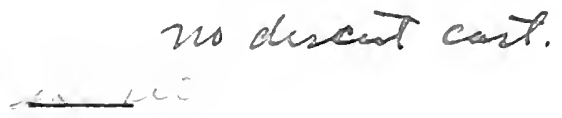

PERRY v. CILISSOLD.

(Privy Council. [1907] App. Cas. 73.)

LoRd Macnaghten." This was an appeal from a judgment of the High Court of Australia, dated June 20, 190t, reversing a judgment of the Supreme Court of New Solth Wales. It raised a questron under the Lands for Public Purposes Acquisition Act, 1880 (4t Vict. No. 160), now superseded by the Public Works Act, 1900, which consolidates the law on the subject.

The act of $1880 \mathrm{in}$ its preamble recites that it is expedient to make provision for the acquisition on behalf of the Crown of lands required

4 See, also, Hubbard v. Little, 9 Cush. (Mass.) 475 (1552); Illinois \& St. Louis Railroad \& Coal Co. r. Cobb. 94 Ill. 55 (1579).

5 The statement of facts is omitted. The case sufficiently appears from the opinion.

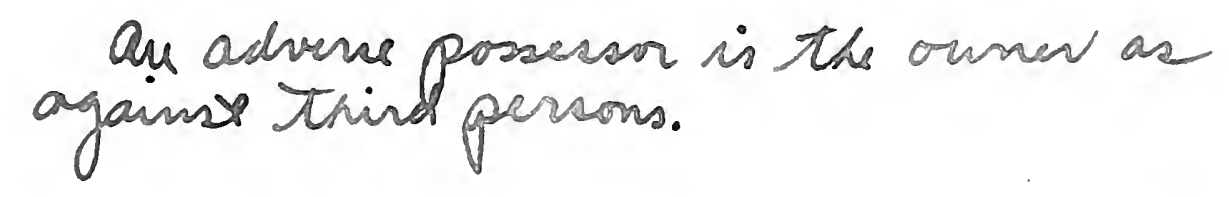


for certain purposes, including, among others, "sites for public schools," and "to provide compensation for lands so acquired."

The following are the material provisions of the Act.

When the Governor sanctions the acquisition of any land for a school site he may, by notification in the Gazette, declare that such land, if private property, has been resumed for such purposes.

Upon such publication the land is forthwith vested in the Minister of Public Instruction and his successors on behalf of the Crown, for the purposes of the Act, for an estate of inheritance in fee simple in pessession freed and discharged from all other estates and interests.

The owners of the land or the persons who, but for the provisions thereinbefore contained, would have been such owners are entitled to receive such sum of money by way of compensation for the land of which they have been deprived under the Act as may be agreed upon or otherwise ascertained under the provisions thereinafter contained.

The estate and interest of every person entitled to land so resumed, or any portion thereof, and whether to the legal or equitable estate therein, is by virtue of the Act deemed to have been as fully and effectually conveyed to the Minister as if the same had been conveyed by means of the most perfect assurances in the law. Every such estate and interest upon the publication of such notification as aforesaid is taken to have been converted into a claim for compensation in pursuance of the provisions thereinafter contained, and every person upon asserting his clain as thereinafter provided, and making out his title in respect of any portion of the resumed land, is entitled to compensation on account of such resumption in manner thereinafter provided.

Every person claiming compensation in respect of any land so resumed is, within ninety days from the publication of such notification or at any time afterwards, within such time as a judge of the Supreme Court appoints in that behalf, to serve a notice in writing upon the Minister and a like notice upon the Crown solicitor "which notice," it is declared, "shall set forth the nature of the estate or interest of the claimant in such land together with an abstract of his title."

Section 13 is in the following terms: "Within sixty days after the receipt of every such notice of claim by the Crown solicitor he shall forward the same, together with his report thereon, to the Minister, who shall thereupon (unless no prima facie case for compensation shall have been disclosed) cause a valuation of the land or of the estate or interest of the claimant therein to be made in accordance with the provisions of this Act, and shall inform the claimant, as soon as practicable, of the amount of such valuation by notice in the form of the Second Schedule hereto."

By notification published in the Gazette of July 17, 1891, a piece of land containing two acres and three perches at Canterbury, in the county of Cumberland, was resumed for a public school site. The land was at the time in the possession of one Frederick Clissold. Notice of the resumption was given to Clissold on July 22, 1891 ; but nothing 
further was done then. Clissold died shortly afterwards, and his will was proved on May 5, 1892.

In May, 1902, under an order of the Supreme Court, the respondents who are the present trustees of Clissold's will, and of whom three are his surviving executors, served notice of their claim to compensation in respect of the land resumed by the notification of July 17, 1891, stating that the claimants were the executors of Frederick Clissold, "who at the date of resumption was in possession of such land as the owner thereof, and in receipt of the rents of such lands, and had a title thereto by possession."

It appeared from the papers which were forwarded with the claim that in the year 1SS1 Frederick Clissold entered into possession of the land, which was then open and vacant, and enclosed it by a substantial fencing. and that ever since the enclosure, up to the time of resumption, Clissold held exclusive possession of the land without notice of any adverse claim, and let it to different tenants and received the rents for his own use and benefit, and duly paid all rates and taxes in respect of the land which stood in his name in the rate-boeks of the municipality of Canterbury.

The Minister refused to entertain the claim to compensation.

The Supreme Court upheld the view of the Minister. The High Court reversed this decision1, and granted a mandamus requiring the Minister to cause a valuation to be made.

The only question on this appeal was whether or not a prima facie case for compensation lad been disclosed.

On the part of the Minister it was contended that, upon the plaintiffs' own showing, Clissold was a mere trespasser, without any estate or interest in the land.

Their Lordships are unable to agree with this contention.

It cannot be disputed that a person in possession of land in the assumed character of owner and exercising peaceably the ordinary rights of ownership has a perfectly good title against all the world but the rightful owner. And if the rightful owner does not come forward and assert his title by process of law within the period prescribed by the provisions of the Statute of Limitations applicable to the case. his right is forever extinguished, and the passessory owner acquires an absolute title.

On behalf of the Minister reliance was placed on the case of Doe $v$. Parnard, 13 Q. B. 945 , which seems to lay down this proposition, that if a person having only a possessory title to land be supplanted in the possession by another who has himself no better title, and afterwards brings an action to recover the land, he must fail in case he shows in the course of the proceedings that the title on which he seeks to recover was merely possessory. It is, however, difficult, if not impossible, to reconcile this case with the later case of Asher $v$. Whitlock, L. R. 1 Q. B. 1 , in which Doe v. Barnard was cited. The judgment of Cockburn, C. J., is clear on the point. The rest of the Court con- 
curred, and it may be observed that one of the members of the Court in Asher v. Whitlock (Lush, J.) had been of counsel for the successful party in Doe v. Barnard. The conclusion at which the Court arrived in Doe v. Barnard is hardly consistent with the views of such eminent authorities on real property law as Mrr. Preston and Mr. Joshua Williams. It is opposed to the opinion of modern text-writers of such weight and authority as Professor Maitland and Holnes, J., of the Supreme Court of the United States.

Their Lordships are of opinion that it is impossible to say that no prima facie case for compensation has been disclosed.

They do not think that a case for compensation is necessarily excluded by the circumstance that under the provisions of the Act of 1900 the Minister acquired not merely the title of the person in possession as owner, but also the title, whatever it may have been, of the rightful owner out of possession, who never came forward to claim the land or the compensation payable in respect of it, and who is, as the Chief Justice says, "unknown to this day."

The Act throughout from the very preamble has it apparently in contemplation that compensation would be parable to every person deprived of the land resumed for public purposes. It could hardly have been intended or contemplated that the Act should have the effect of shaking titles which but for the Act would have been secure, and would in process of time have become absolute and indisputable, or that the Governor, or responsible Ministers acting under his instructions, should take advantage of the infirmity of anybody's title in order to acquire his land for nothing. Even where the true owncr, after diligent inquiry, cannot be found the Act contemplates payment of the compensation into Court to be dealt with by a Court of Equity.

It only remains for their Lordships to express their opinion that the valuation to be made should be a valuation of the land as at the date of the notification of resumption.

When the valuation is made it will be for the clamants to take such proceedings as they may be advised to recover the amount, unless the Minister thinks fit to pay them or to pay the money into Court.

For these reasons their Lordships humbly advised His Majesty that the appeal should be dismissed, and ordered the appellant to pay the costs of the appeal. ${ }^{6}$

${ }^{6}$ See Ex parte Winder, 6 Ch. D. 696 (1S7t). See, also, People $\nabla$. Shearer, 30 Cal. 645 (186ii), where the state claimed the power to tax the possessory interest of an occupant of public land of the United States.

$$
\begin{aligned}
& \text { Derdat. } 24 \text { K.T.347 Ex Pards Holeingumith }
\end{aligned}
$$

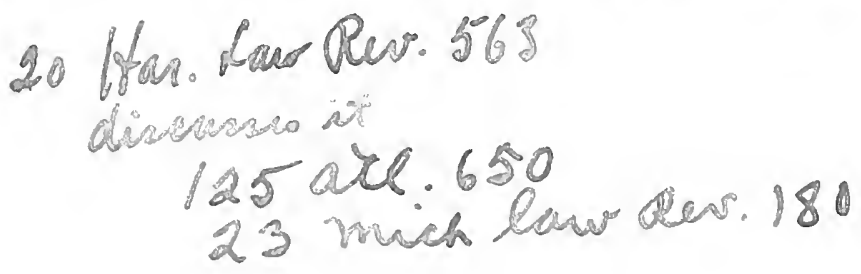




\section{SOHIER v. COFFIN.}

(Supreme Judicial Court of Massachusetts, 1S69. 101 Mass. 179.)

Writ of entry against John T. Coffin and the heirs of John C. Parkinson, to recover a lot of land in Brighton. Coffin was defaulted. Trial in this court, before Foster, J., who reported the case substantially as follows:

'To show title, the demandants, among other evidence, put in and proved a deed of the demanded premises from William F. Otis to Jolm T. Coffin, dated May 9, 1857, and a mortgage deed from saicl Coffin to themselves, dated September $12,1 \overline{57}$, to secure the payment of $\$ 5000$; both duly acknowledged and recorded. The heirs of Parkinson offered no evidence of any title by deed, or any conveyance of the premises, but claimed title by adverse possession.

There was evidence tending to show that John C. Parkinson was in possession and occupation of the premises for many years prior to his death in January, 1857, claiming title, and that in $18+2$ Coffin knew that he clained title; that a few days after John C. Parkinson's death. Coffin's agent called upon Parkinson's heirs and desired them to leain the premises, and they insisted that the premises were theirs; that afterwards and sometime before giving the deed under which the demandants claimed, Coffin himself called upon Parkinson's heirs, and wanted them to leave the premises, and they told him personally that they owned the land; that Coffin endeavored to buy them off, and they refused his overtures; and that the mortgage deed of September 12, 1857, from Coffin to the clemandants, under which they claimed, was executed, acknowledged and delivered in Boston.

At the close of the evidence, the presiding judge proposed to instruct the jury on the effect of disseisin as follows: "If, after the death of John C. Parkinson while Coffin owned the fee, the heirs of Parkinson were in actual possession of the demanded premises claiming a fee, and this was known to Coffin; and they continued in such possession at the date of the mortgage deed from him to the demandants; then Coffin was disseised so that nothing passed by his deed, and the demandant: cannot recover." Thereupon the demandants declined to go to the jury, and submitted to a verdict for the heirs of Parkinson, and the jury found specially for the latter upon the sole ground that the deed to the demandants passed no title. To this ruling the demandants excepted, and the presiding judge reserved for the full court the question whether the ruling was correct.

Chapman, C. I. The demandants claim title under a mortgage from Coffin, and therefore they have joined Coffin in the suit, as they are permitted to do by the Gen. St. 1860 , c. $140, \S \&$, though Coffin is not a tenant in possession. The tenants in possession are the heirs of John C. Parkinson, who died in January, 1857. A few days afterAIG.PBOP. -2

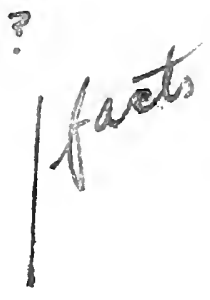


wards the agent of Coffin called upon them and desired them to leave the premises. They refused to quit, and claimed title. Afterwards Coffin himseli called upon them and wanted them to leave the premises. They again refused, claining title. He endeavored to buy them off, and they refused his overtures. They were thus in possession of the demanded premises, and claiming title adversely to him. There is nothing to show that they entered under him or by his permission. Indeed it is stated that their father was in possession for many years, claiming title, and that this was known to Coffin in 1842. While they were thus in possession, namely, on September 12, 1857, Coffin made the mortgage to the demandants. If he had a right of entry, he might have entered upon the land and there delivered the deed, and his title would have passed. But as he did not enter, but delivered the deecl while he was out of possession, and the tenants were holding the land adversely, his deed was inoperative to pass the title. Warner v. Bull, 13 Metc. 1. All the grantees could acquire was a right to bring an action for possession in the name of their grantor. Cleaveland $v$. Flagg, 4 Cush. 76 . The ruling is based upon the assunfution that the iitle of Coffin was good, and that the tenants were mere disseisors: and upon that assumption it was correct. Much more would the deed of Coffin to the demandants be inoperative if no title had ever passed to Coffin; for in such case no action would lie even in Coffin's name. It would be necessary to sue in the name of Otis or some other person who had good title.

The facts stated in the report do not present a case of mere disseisin at the election of Coffin; but this was an actual adverse occupation and holding him out. Sce Washb. Real Prop. (3d Ed.) bk. 3, c. 2, §7. Judgment for the tenants on the verdict. ${ }^{7}$

: A., the paper title owner of certain lands. sues B. in an action of trover for the conversion of stone and gravel dug out of and talien from said lands. On the trial it develops that $B$. has been in adrerse possession of the tract from which the stone and grave were taken. though for a period less than that of the statute of limitations. Can the action be maintained? Mather $r$. Ministers of Trinity Church, 3 Serg. \& R. (Pa.) 509, 8 Am. Dec. 663 (1817).

supose it had been C. who hab takeu the stone and grarel. Could A. have sued hiju in trespass quare clausum fregit? See Wheeler r. Hotchkiss. 10 conn. $225(1834)$.

A very interesting question is presented when the ousted owner recorer:s fossession and sues to recorer specitically for crops and other things severed from the land by the adrerse possessor. See Iiford's Case, 11 Co. 46b. 511, (1615); Page v. Fowler. 89 Cal. 412, 2 Am. Rep. 462 (1870); Hooser r. Hays, 10 B. Mon. 72. $50 \mathrm{Am}$. Dec. 540 (1849).

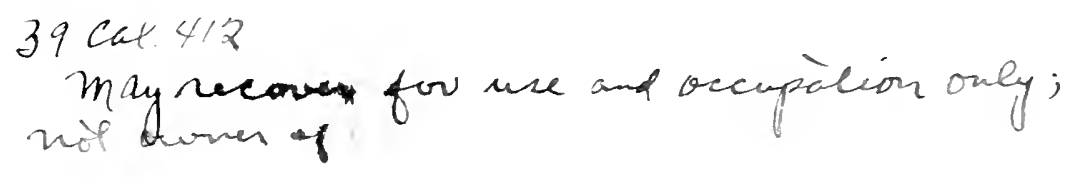




\section{SECTION 3.-LAPSE OF TIME}

\section{S'TAT. 3 EDW. I, c. 39 (1275).}

And forasmuch as it is long time passed since the writs undernaned were limited; it is provided, That in conveying a descent in a writ of right, none shall presume to declare of the seisin of his ancestor further, or beyond the time of King Richard, uncle to King Ienry, father to the King that now is; and that a writ of Novel disseisin, of Partition, which is called Nuper obiit, have their limitation since the first voyage of King Henry, father to the King that now is, into Gascoin. And that writs of Mortdancestor, of Cosinage, of Aicl, of Entry, and of Nativis, have their limitation from the coronation of the same King Henry, and not before. Nevertheless all writs purchased now by themselves, or to be purchased between this and the Feast of St. John, for one year complete, shall be pleaded from as long time, as heretofore they have been used to be pleaded.

\section{S'TAT. 21 JAC. I, c. $16, \S \S 1,2$ (1623).}

I. For quieting of men's estates, and aroiding of suits, be it enacted by the King's most excellent majesty, the lords spiritual and temporal, and commons, in this present Parliament assembled, That all writs of formedon in descender, formedon in remainder, and formedon in reverter, at any time hereafter to be sued or bought, of or for any manors, lands, tenements or hereditaments, whereunto any person or persons now hath or have any title, or cause to have or pur. sue any such writ, shall be sued and taken within twenty years next after the end of this jresent session of Parliament; and after the said twenty years expired, no such person or persons, or any of their heirs, shall have or maintain any such writ, of or for any of the said manors, lands, tenements or hereditaments; (2) and that all writs of formedon in descender, formedon in remainder, and formedon in reverter, of any manors, lands, tenements, or other hereditaments whatsoever, at any time hereafter to be sued or brought by occasion or means of any title or cause hereafter happening, shall be sued and taken within twenty years next after the title and cause of action first descended or fallen, and at no time after the said tiventy years; (3) and that no person or persons that now hath any right or title of entry into any manors, lands, tenements or hereditaments now held from him or them, shall thereinto enter, but within twenty years next after the end of this present session of Parliament, or within twenty years next after any other title of entry accrued: (4) and that no person or persons shall 
at any time hereafter make any entry into any lands, tenements or hereditaments, but within twenty years next after his or their right or title which shall hereafter first descend or accrue to the same; and in default thereof, such persons so not entering, and their heirs, shall be utterly excluded and disabled from such entry after to be made; any former law or Statute to the contrary notwithstanding.

II. Provided nevertheless, That if any person or persons, that is or shall be entitled to such writ or writs, or that hath or shall have such right or title of entry, be or shall be at the time of the said right or title first descended, accrued, come or fallen, within the age of one and twenty years, feme covert, non compos mentis, imprisoned or beyond the seas. that then such person or persons, and his or their heir and heirs, shall or may, notwithstanding the said twenty years be expired, bring his action, or make his entry, as he might have done before this Act; (2) so as such person and persons, or his or their heir and heirs, shall within ten years next after his and their full age, discoverture, coming of sound mind, enlargement out of prison, or coming into this realm, or death, take benefit of and sue forth the same, and at no time after the said ten years.

\section{HOW. ANN. ST. MICH. 1913, c. 383.}

Sec. 1. After the thirty-first day of December, in the year of our Lord eighteen hundred sixty-three, no person shall bring or maintain any action for the recovery of any lands, or the possession thereof, or make any entry thereupon, unless such action is commenced or entry made within the time herein limited therefor, after the right to make such entry or to bring such action shall have first accrued to the plaintiff, or to some person through whom he claims, to-wit:

First. Within five years, where the defendant claims title to the land in question, by or through some deed made upon a sale thereof by an executor, administrator or guardian, or by a sheriff, or other proper ministerial officer, under the order, judgment, decree or process of a court, or legal tribunal of competent jurisdiction within this state, or by a sheriff upon a mortgage foreclosure sale; or through a devise in any will which shall have been probated in this state for fifteen years. during which period no suit in chancery has been brought to test the validity of such devise: Provided, that in cases where such fifteen year period has already elapsed such rights of entry or action shall be barred after two years from the passage hereof, or in case such right has not accrued, then after two years from the accruing thereof;

Second. Within ten years, where the defendant claims title under a deed made by some officer of this state, or of the United States, authorized to make deeds upon the sale of lands for taxes assessed and levied within this State;

Third. Within fifteen years in all other cases. 
Sec. 5. If at the time when any right of entry, or of action, as aforesaid, shall first accrue or have accrued, the person entitled to such entry or action shall be, or shall have been, within the age of twentyone years, or a married woman, insane, or imprisoned, or absent from the United States, unless within one of the British provinces of North America, such person, or any one claiming from, by or under him, may make such entry, or bring such action, at any time within five years after such disability shall be or shall have been removed, although the time limited therefor in the first section of this chapter may have expired.

\section{HUGHES v. GRAVES.}

(Supreme Court of Vermont, 1867. 39 vt. 359, 94 Am. Dec. 331.)

This cause was an act of trespass quare clausum fregit, with counts in trespass on the case joined agrecably to the statutc. The action, by the agreement of the parties, was referred, to be decided according to law, and the defendant filed exceptions to the report of the referecs. On the hearing upon the said report and exceptions at the March Term, 1866, Kellogg, J., presiding, the court, pro forma, decided that the plaintiff was entitled to recover of the defendant the sum of ten dollars for his damages, as stated in the report, and rendered judgment in favor of the plaintiff on the report accordingly,-to this decision and judgment the defendant excepted.

The referees reported as follows: "The plaintiff and defendant, are severally the owners and occupiers of adjacent lots of land in the village of Fairhaven, both lots being originally parcels of an entire lot and each party deriving title to his lot from a common source. The west line of the plaintiff's lot, as shown by his title deeds, runs from the northwest corner of his dwelling house, southerly to the northwest corner of the Whipple lot. This line formed the eastern boundary of ancient highway, discontinued more than fifty years since, running over the lot of the defendant. Joshua Quenton an intermediate grantor of the plaintiff, obtained his title to the lot in 1806, and he and his heirs owned and occupied it until May, 1847. During this period, the Quentons enclosed with a fence a strip of land about ten feet wide at the north end, which extended southerly and adjoining the plaintiff's west line from the said northwest corner of the plaintiff's dwelling house, to and beyond the south line of the defendant's lot taken from said ancient highway, making a portion of their door yard, and continued to occupy peaceably and adversely claiming it as their own for more than fifteen years. In the fall of $18+7$ an intermediate grantor of the defendant, clains this strip of land, sawed the fence in two where the south line of the defendant's lot wonld strike it. But the fence after two or three months was rebuilt by the plaintiff's grantor and the occupation in them continued till March, 186́1, as the fence was still stand- 
ing when the plaintiff took possession under his deed, and when the defendant purchased his lot in April, 1862, he claimed it and in the summer of 1862 erected a store which extended eastward within about eight inches of the plaintiff's dwelling house and covered not only a portion of the strip of land so enclosed by the Quentons taken from the old highway and the plaintiff's lot, but also a small portion of land included within the boundaries of the plaintiff's lot. None of the deeds prior to the deed of Olive Kelsey to I. Davey, of March 23d, 1860, by and through which the plaintiff clains title to his lot, in their boundaries included the piece of land enclosed by Quenton and taken from said old highway, and which actually formed part of the door yard to the plaintiff's house. If the court shall be of opinion that the plaintiff takes nothing by Quenton's possessory title because the land so claimed was not included in the boundaries of his deed, then we only find for the plaintiff to recover of the defendant seven dollars damages and his costs, otherwise we find for the plaintiff to recover of the defendant ten doliars damages and his cost."

STEFLE, J. The plaintiff is in actual possession and by his deed from Olive Kelsey, is entitled to the benefit of her possession. Her possession was prior to any possession by the defendant or his grantors. The plaintiff will therefore maintain this action of trespass as against the defendant by virtue of mere prior possession, unless the defendant has a right to the possession. It is then the defendant's right and not the plaintiff's which we are required to examine. The defendant shows a faultless chain of title on paper, but it turns out he does not own the land. One Quenton acquired the ownership by fifteen years possession adverse to the defendant's grantors. The defendant's chain of deeds represents nothing in the disputed land except what his grantors lost and Quenton gained. If Quenton's title had been by deed from the defendant or his grantors, it is clear the defendant could not lawfully have disturbed the plaintiff's prior possession. Quenton had no deed, but his adverse possession for the statutory period gave him an absolute indefeasible title to the land against the whole world on which he could either sue or defend as against the former owner. That being the case is there sufficient virtue left in the defendant's paper title to warrant him in disturbing the plaintiff's possession. Under the present English statute of limitations it is settled there would not be. The case would stand precisely as if the defendant or his grantors had conveyed to Quenton. The plaintiff would be liable to be interrupted in his possession only by Quenton or some person under him. Holmes v. Newlands, 39 E. C. L. 48, (11 A. \& E. 44.) In Jukes v. Sumner, 14 Mees. \& Welsby, 41, Parke, B., remarking upon the present English statute 3 and $4 \mathrm{~W}$. IV, ch. 27, says the effect of the act is to make a parliamentary conveyance of the land to the person in possession after the period of twenty years has elapsed. The several English statutes, and their supposed points of difference, are commented upon in 2 Smith's 
Lead. Cases, 469, 559, et passim, and the case Fenner v. Fisher, Cro. Eliz. 288, is cited in Holmes v. Newlands, ubi supra, as an authority under the previous statutes against the application to these statutes of the full extent of the rule applied to the statute of William IV.

Any extended discussion of these English statutes would be unprofitable here for our statute, though mainly borrowed at the outset from the statute of James, was somewhat modified when transferred to Vermont, and has been materially altered in form in passing through the several revisions to which our laws have been subjected. It now provides after the section relating to actions that, "no person having right or title of entry into houses or lands shall thereinto enter but within fifteen years next after such right of entry shall accrue." The first section takes away the remedy, and the second the right. G. S. p. 442, $\S \S 1$ and 2. The title is vested in the adverse holder for the statutory period, or as is often said, "the adverse possession ripens into title." As a natural consequence the former owner is divested of all the new owner acquires. This interpretation giving to adverse possession for fifteen years the effect of a conveyance best accords with the other well settled doctrines upon the subject of limitations as applied to real property. A covenant to convey perfect title is satisfied by conveying a title accuired under the statute. In this country, as in England, an agremient made after the lapse of the statutory period to waive the benefit of the statute is not effective, but the title remains in the party who has acquired it under the stattute, notwithstanding his waiver, until he conveys it back with all the solemnities required in any deed of land. In langrage of the books, "by analogy" to the statute of limitations we presume a grant of incorporeal rights after adverse uses for fifteen years." It would certainly be an artificial construction of the statute which would make it a mere bar to the owner's right against the person only who occupied adversely. It relates to the rights of the party to the land. It makes no reference to persons.

In this case, if the plaintiff's enjoyment of the land subjects him to an action or entry by Quenton, on the ground that Qusnton and not the defendant is the true owner, it ought not at the same time so sulbject him to action or entry by the defendant, on the ground that the defendant is the true owner of the land. IVe are satisfied that no title remains in the defendant, and that under our statute, he has no right to the possession. It has been held that a plaintiff in possession without right could maintain trespass against even the true owner for a disturbance, while the right of possession was in a third person by lease from the owner. Phillips v. Kent \& Miller, 23 N. J. Law, 155. Here neither the right of possession nor the ownership was in the defendant.

The plaintiff claims that upon a correct construction of the deeds he has Quenton's title. This point we have not decided. The plaintiff's 
prior possession will enable him to recover as against the defendant whose grantors suffered Quenton to acquire the land by adverse possession for the statutory. period. Judgment affirmed. ${ }^{8}$

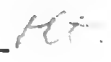

\section{DOE ex dem. GOODY v. CARTER.}

(Court of Queen's Bench, 18t7. 9 Q. B. 863.)

Ejectment for a cottage, garden, \&c., in Essex. Demise, Sth January, $18+5$.

On the trial, before Coleridge, J., at the Essex Summer Assizes, 1845, it appeared that the defendant was the widow of John Carter, who died in 1834, being then occupier of the premises, which he had held, as after mentioned, for a period short of twenty-one years; and the defendant had occupied them ever smce. The other material facts (as stated in the judgment of the Court delivered this day) were as follows. Robert Carter, the father of John, purchased the premises (amongst others) from one Havens, and was let into possession; but, as he did not pay all the purchase money, no conveyance was executed till the 14th December, 1824, some years after the purchase. In the meantime the father had let his son John, the husband of the defendant, into possession of part of the premises as tenant at will without paying any rent The father afterwards mortgaged the whole, on 231 1. tiff. The learned Judge directed the jury that, if they believed John Carter, the son, to have entered as tenant at will more than twenty-one years before the day of the demise laid in the declaration, this action was barred by Stat. $3 \& 4$ IV.IV, c. 27 (sections 2, 7). ${ }^{9}$ Verdict for defendant. Lush in the ensuing term obtained a rule nisi for a new trial

8 Premises were leased to $A$. for 89 years. Shortly after the lease was made, $G$. entered into possession and continued therein adversely to $A$. for to years, when ( $\mathrm{r}$. assigned the term to defendant. The rent was remularly pait by $\vec{G}$. during the 40 years. In an action log the present owner of the reversion for breach of a corenant to repair contained in the olisinal lease to A., it was held that defendant was not liable nnon corenants in saicl lease. Tirhborne v. Weir, \& R. 26, 67 L. T. 735 (159?). Compare Re Nisbet and I'otts' Contract, [1905] $1 \mathrm{Ch}$. 391, where a restriction under the doctrine of Tulk v. Moxhas, 2 Phillips, itt (1StS), was held enforceable against one who had acquired ownership by adverse nossession.

As to an adverse possessor acquiring a right of way by necessity where the property held adversely was surrounded by other lands of the paper title owner, see Willes v. Greenway, 6 T. L. R. 449 (1S90).

a Those sections provided as follows:

"II. And le it further enacted, that after the 31st day of December, 1S83, no person shall make an entry or distress, or bring an action to recover any land or rent but within twenty years next after the time at which the right to make such entry or distress, or to bring such action, shall have first accruerl to some person through whom he claims; or if such right shall not hare accrned to any person throngh whom he claims, then within twenty yea vis next after the time at which the right to make such entry or distress 
on the grounds of misdirection, and that the verdict was against the weight of evidence. Cur. adv. vult.

LoRd Denman, C. J., now delivered the judgment of the Court.

This rule was moved for on two grounds; misdirection, and that the verdict was against evidence. As to the latter, we think that there was abundant evidence to show that the defendant's husband John Carter entered into possession of all the premises sought to be recovered, as tenant at will to his father, more than twenty-one years before the bringing of this ejectment, which in truth was the only question for the jury.

The case, therefore, depends on the question whether the learned Judge misdirected the jury. The facts were: [His Lordship here stated them as they appear ante.] Under these circumstances, it was contended for the lessor of the plaintiff that, as the father was himself tenant at will to Havens till 14th December, 1824, when that tenancy was determined by the execution of the conveyance, the tenancy at will subsisting between the father and son was determined at the same time. We do not think that consequence followed, but are of opinion that the conveyance to the father had no operation on the tenancy at will between him and the son. Again, it was contended that the mortgage by the father in 1829 operated as a deternination of the will. Assuming this to be so, still the son would thereby become tenant by sufferance, and the twenty years under the late statute $3 \& 4$ W. IV, c. 27, having begun to run long before, would continue to run unless a new tenancy at will or for some other term were created; Doe dem. Bennett v. Turner, 7 M. \& IV. 226, Turner v. Doe dem. Bennett, 9 M. \& IV. 643 ; and, indeed, the same observation would apply if the conveyance in 1824 were treated as a determination of the will. Now there was no evidence in this case from which the jury could draw the conclusion that a new tenancy between the father and the son had been created at any time within twenty years before the bringing of this ejectment: and, therefore, the determination of the will of the father either in 1824 or in 1829 is not, in truth, material.

Upon the whole, we are of opinion that the learned Judge was right in telling the jury that, if they believed the son to have entered as tenant at will more than twenty-one years before the Sth of January $18+5$ (the day of the demise in the declaration of ejectnient), the statute 3

or to bring such action shall have first accrued to the person making or bringing the same.

"VII. And be it further enacted, that when any person shall be in possession or in receipt of the profits of any land, or in the receipt of any lent, as tenant at will, the right of the person entitled subject thereto, or of the person through whom he claims, to make an entry or distress or bring an action to recover such land or rent, shall be deemed to have first accrued, either at the determination of such tenancy or at the expiration of one year next after the commencement of such tenancy, at which time such tenancy shall be deemed to have determined: provided alwars, that no mortgagor or cestui que trust shall be deemed to be a tenant at will, within the meaning of this clause, to his mortgagee or trustee." 
\& 4 W. IV, c. 27 , was a bar to the action; and that the jury were right in finding that he did so enter. The rule for a new trial must, therefore, be discharged.

Rule discharged. ${ }^{10}$

\section{DOE ex dem. CARTER v. BARNARD.}

(Court of Queen's Bench, 1849. 13 Q. B. 945.)

Ejectment for a cottage in Essex. Demise, 13th May, 1848.

On the trial, before Coltman, J., at the Essex Summer Assizes, 1848, it appeared, from the evidence given for the lessor of the plaintiff, that in 1815 one Robert Carter purchased the premises, and was let into possession; but, as he did not pay all the purchase money until 1824, no conveyance was executed till that time. Robert Carter, immediately after his purchase in 1815, allowed his son John to occupy the premises rent free as tenant at will; and he continued so to occupy until 1834 , when he died, leaving a widow, who was the lessor of the plaintiff, and a son and other children. Robert Carter, the father, was at that time still living. The lessor of the plaintiff had occupied from the time of her husband's death, until a short time before the present action was brought. The defendant claimed under a mortgage made by Robert Carter in 1829. For the defendant it was contended, that, assuming a title to have been shewn in John Carter, the lessor of the plaintiff could not recover. The learned Judge directed a verdict for the plaintiff, and reserved leave to the defendant to move to enter a nonsuit.

Cur. adv. vult.

PatTeson, J., now delivered the judgment of the Court.

The lessor of the plaintiff proved no title, but relied on long possession; viz. her own for thirteen years, and her husband's before her for eighteen years; but, in so doing, she shewed that her husband left several children, one of whom was called as a witness. If the husband's possession raised a presumption that he was seised in fee, that fee must have descended on his child, and, of course, the lessor of the plaintiff must fail. But she contends that, because the husband's possession was for less than twenty years, no presumption of a seisin in fee arises; that she is entitled to tack on her own possession to his; and then that the 34 th section of Stat. $3 \& 4$ W. IV, c. 27 , which enacts "that at the determination of the period limited by this Act to any person for making an entry or distress, or bringing any writ of quare impedit or other action or suit, the right and title of such person to the land, rent, or adrowson for the recovery whereof such entry, distress, action, or suit respectively might have been made or brought within such period,

10 Willis v. Earl Howe [1593] 2 Ch. 545, 553; Kipp v. The Inc. Sruod, etc., 33 U. C. Q. B. 220 (1873), acc. Compare Dixon v. Gayfere, 17 Beav. 42 (1853); Ryerse v. Teeter, 44 C. C. Q. B. 8 (1Sis). 
shali be extinguished," has put an end to the right and title of all persons, and transferred the estate to her. If she had been defendant in an action of ejectment, no doubt the non-possession of the lessor of the plaintiff, evidenced by her husband's and her own consecutive possession for more than twenty years, would have entitled her to the verdict on the words of the $2 \mathrm{~d}$ section of the Act, without the aid of the 34th section. Therefore it is said that the 34th section must have some further meaning, and must transfer the right. Probably that would be so, if the same person, or several persons, claiming one from the other by descent, will or conveyance, had been in possession for the twenty years. But this lessor of the plaintiff showed nothing to connect her possession with that of her husband by right of any sort: and, if she be right in her construction of the 34 th section, the same consequence would follow if tiventy persons unconnceted with each other had been in possession, each for one year, consecutively for twenty years: yet it would be impossible to say to which of the twenty persons the 34 th section has transferred the title. Withotnt the aid of this statute twenty years' possession gave a prima facie title against every one, and a complete title against a wrongdoer who could not shew any right, even if such wrongdoer had been in posscssion many years; provided they were less than twenty; Doe dem. Harding v. Cooke, 7 Bing. 346 ; and the effect of the 34 th section wonld probably be to give the right to the possessor for twenty years, even against the party in whom the legal estate formerly was, and, but for the Act, would still be, where he had not obtained the possession till after the twenty years: but then we apprehend, as before stated, that such twenty years' pessession must be either by the same person or several persons claiming one from the other, which is not the case here.

The lessor of the plantiff must therefore rely on her own possession for thirteen years as sufficient against the defendant who has turned her out and shews no title himself. According to the case of Doe dem. Hughes v. Dyball, Moo. \& M. 346, that possession for thirteen years would be sufficient; for in that case the lessor of the plaintiff shewed only one year's possession, and yet Lord Tenterden said, "That does not signify; there is ample proof; the plaintiff is in possession, and you come and turn him out: you must shew your title." See also Doe dem. Humphrey v. Martin, Car. \& Marsh. 32. These cases would have warranted us in saying that the lessor of the plaintiff had established her case, if she had shewn nothing but her own possession for thirteen years. The ground however of so saying would not be that possession alone is sufficient in ejectment (as it is in trespass) to maintain the action; but that such possession is prima facie evidence of title, and, no other interest appearing in proof, evidence of seisin in fes. Here, however, the lessor of the plaintiff did more, for she proved the possession of her husband before her for eighteen years, which was prima facie evidence of his seisin in fee; and, as he dier in possession and left children, it was prima facie evidence of the title of his heir. 
against which the lessor of the plaintiff's possession for thirteen years could not prevail; and, therefore, she has by her own shewing proved the title to be in another, of which the defendant is entitled to take advantage. ${ }^{11}$ On this ground we think that the rule for a nonsuit must he made absolute.

Rule absolute for a nonsuit.

\section{AGENCY CO. v. SHORT.}

(Priry Council, 18ss. 13 App. Cas. 793.)

Appeal from a judgment of the Supreme Court (Oct. 27, 18S6) refusing a rule nisi for a new trial in an action of ejectment to recover fifty acres of land situate in Botany Bay, in the Colony of New South Wales.

The facts of the case are stated in the judgment of their Lordships. The proceedings in the Court below are reported in N. S. Wales Rep. vol. S (N. S.) p. 365.

Chief Justice Martin told the jury at the trial that when any person went into possession of another person's land, and exercised dominion over it with the intention of claiming it, and the Statute of Limitations thereupon began to run as against the owner of the land, such running was never stopped, notwithstanding that the intruder entirely abandoned the land long before the expiration of twenty years from bis first entry, and no other person took possession of such land, and that the right of the true owner of the land would not again arise without an entry by sich true owner with the intention of repossessing himself of such land; that at the expiration of twenty years after such taking possession of the land as against the true owner his right of action was defeated, notwithstanding that there may not have been twenty years' possession as against him; that if Meredith, throngh whose possession the defendant claimed, abandoned the land in the year 1853 , and afterwards, until the defendant came there, no person was in possession of the land, still the statute continued to run as against the plaintiff; and that the statute barred the plaintiff's right of action herein.

The Supreme Court (Martin, C. J., Faucett and Windeyer, JJ.) affirmed this ruling.

The judgment of their Lordships was delivered by

Lord Macraghten. On the 3rd of December, 1895, the appellants, as plaintiffs, brought an action against the respondent as defendant, to recover fifty acres of land situated in the district of Botany Bay, in the county of Cumberland, in the colony of New South Wales.

The defence was the Statute of Limitations (3 \& 4 WViil. IV, c. 27), which was adopted in the Colony by the Act No. 3 of 1837 .

The action came on for trial in September, 1S\$6, before the late Chief Justice Martin and a jury.

11 See Christy v. Scott, 14 How. 2S2, 292, 14 L. Ed. 422 (1S52), contra. 
For the present purpose the facts of the case may be stated very shortly. The land in dispute was, until recently, waste open bush. The plaintiffs at the trial proved a complete documentary title deduced from a Crown grant in 1810. But they falled to prove to the satisfaction of the learned judge at the trial that they or any person through whom they claimed had been in actual occupation of the land at any time during the period of twenty years immediately preceding the commencement of the action. On the other hand the defendant, who claimed to have purchased the land within the last few years, did not prove to the satisfaction of the learned judge that he and the person or persons through whom he claimed had been in continuous possession during the statutory period.

The Chief Justice told the jury that when any person went into possession of another person's land, and exercised dominion over it, with the intention of claiming it, and the Statute of Limitations thereupon began to run as against the owner of the land, such running was never stopped, notwithstanding that the intruder abandoned the land long before the expiration of twenty years from his first entry, and no other person took possession of such land, and the right of the true owner to the land would not again arise without an entry by such true owner with the intention of repossessing himself of such land. The Chief Justice also told the jury that at the expiration of the twenty years after such taking possession of the land, as against the true owner, his right of action was defeated, notwithstanding there may not have been twenty years' possession as against lim.

A verdict was found for the defendant.

On the 27 th of October, 1886 , the plaintiffs applied for a rule nisi for a new trial on the ground of misdirection. The application was heard before the late Chief Justice, Fancett, J., and Vindeyer, J., who refused the rule. The Chief Justice is reported to have said: "There is no doubt that there was evidence sufficient to justify the verdict of the jury as to the occupation of the land more than forty years ago, which caused the statute to run against the legal owner. That being so, there was no evidence whatever that the legal owner during that time ever retook possession, or even walked over the land. The statute having been set running there was nothing to stop it."

To this report Faucett, I., has been good enough to append the following memorandum for the information of their Lordships:

"This is substantially a correct note of the reasons given by the late Chief Justice for refusing the rule in this case. His judgment was given in very few words.

"I may add that it has been before held by this Court that when the rightful owner of land has been dispossessed, and the statute has once begun to run against him, the statute does not cease to run; in other words, the operation of the statute is not suspended until the rightful owner has exercised some act of ownership on the land; and that if the rightful owner allows twenty years to elapse, from the time when the 
statute so first began to run, without exercising any such act of ownership, he cannot recover in ejectment against any person who may happen to be in possession at the end of the twenty years, although there may have been an interval in the twenty years during which no one was in possession.

"To stop or suspend the operation of the statute there must be some new act of ownership on the part of the rightful owner. There must be, as it were, a new departure."

The doctrine appears to have had its origin in the case of Laing v. Bain, which was before the Supreme Court on a motion for a new trial in March, 1876. Their Lordships were referred to a note of the case in Oliver's Real Property Statutes, p. 79. Martin, C. J., is there reported to have said that "it was clear law that if the statute once commenced to run it would not stop except by the owner going into possession and so getting, as it were, a new departure."

Their Lordships are unable to concur in this view. They are of opinion that if a person enters upon the land of another and holds possession for a time, and then, without having acquired title under the statute, abandons possession, the rightful owner, on the abandonment, is in the same position in all respects as he was before the intrusion took place. There is no one against whom he can bring an action. He cannot make an entry upon himself. There is no positive enactment, nor is there any principle of law, which requires him to do any act, to issue any notice, or to perform any ceremony in order to rehabilitate himself. No new departure is necessary. The possession of the intruder, ineffectual for the purpose of transferring title, ceases upon its abandonment to be effectual for any purpose. It does not leave behind it any cloud on the title of the riglitful owner, or any secret process at work for the possible benefit in time to come of some casual interloper or lucky vagrant.

There is not, in their Lordships' opinion, any analogy between the case supposed and the case of successive disabilities mentioned in the statute. There the statute "continues to run" because there is a person in possession in whose favour it is running.

There is no direct authority on the point in this country. But such authority as there is seems to be opposed to the doctrine laid down by the Supreme Court. It is sufficient to refer to McDonnell v. McKinty, 10 Ir. L. R. 514, Lord St. Leonards' Real Property Statutes, p. 31, and Smith v. Lloyd, 9 Exch. (Welsby, H. \& Gor.) 562. In the latter case, which was decided in 1854, Parke, B., giving the judgment of the Court, says: "VVe are clearly of opinion that the statute applies, not to want of actual possession by the plaintiff, but to cases where he has been out of, and another in, possession for the prescribed time. There must be both absence of possession by the person who has the right, and actual possession by another, whether adverse or not, to be protected, to bring the case within the statute. We entirely concur in the 
judgment of Blackburne, C. J., in McDonnell v. McKinty, and the principle on which it is founded."

Their Lordships have only to add that, in their opinion, there is no difference in principle as regards the application of the statute between the case of mines and the case of other land where the fact of possession is more open and notorious. It is obvious that, in the case of mines, the doctrine contended for might lead to startling results and produce great injustice.

In the result, therefore, their Lordships have come to the conclusion that the direction given to the jury by the learned Chief Justice was not law, and they think that there was substantial miscarriage in the trial.

They will, therefore, humbly advise Her Miajesty that the judgment of the Supreme Court refusing the rule nisi ought to be reversed, that a new trial ought to be clirected, and that the costs in the former trial and of the application for the rule ought to be costs in the action.

The respondent will pay the costs of the appeal.

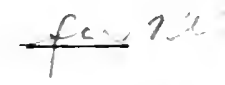

\section{SHANNON v. KINNY et al.}

(Court of Appeals of Kentucky, 1S17. 1 A. K. Marsh. 3, 10 Am. Dec. 705.)

Boyle, C. J. ${ }^{12}$ This was an action of ejectment. On the trial, after the plaintiff had exhibited the patent of the commontrealth to William Shannon for the land in controversy, and had produced evidence conducing to prove that William Shannon, the patentee, was the son of William Shannon, senior; that the plaintiff, John Shannon, was the eldest brother of the patentee; that the patentee was killed by the Indians in 1782; that Villiam Shannon, his father, died in a year or two thereafter, leaving John Shannon, the plaintiff, his eldest son; and after it had also appeared in evidence, that Hugh Shannon, a younger brother, had, in the year 178t, settled upon the land in controversy, claiming it as his own, and had used and sold part thereof, that for twenty years or upwards, John Shannon had been in habits of intimacy with his brother Hugh Shannon, and was fully apprised of his claiming and selling said land; the attorney for the defendant asked a witness whether said Hugh Shannon had not latterly become insolvent, avowing his object to be to prove by that and other circumstances, a collusive destruction of a writing evidencing a transfer of said land, betwixt the plaintiff and Hugh Shannon; to the asking and answering of which question, the plaintiff objected; but the court overruled the objection and instructed the witness to answer the question, to which the plaintiff excepted.

Whether the court below erred in their decision of this point, is the first question which is necessary to be determined. * * *

12 The part of the opinion relating to the first question is omitted. 
The only other question presented by the case is, whether the statute of limitation was a bar to the plaintiff's recovery. It appears that there was a continual adverse possession for more than twenty years, but that Hugh Shannon, who first took the possession of the land in controversy, before he had remained in posscssion twenty years, surrendered the possession to the defendants or those under whom they held, in pursuance of a decree entered upon an award giving them the land in virtue of an adverse claim, and that they had not had the land in possession twenty years prior to the commencement of this suit.

This circumstance, it is urged on the part of the plaintiff, prevents the statute from operating as a bar to his recovery. But we cannot perceive any principle upon which it can have such an effect. According to the literal import of the statute, the plaintiff could only enter upon the land within twenty years after his right of entry accrued, and, consequently, an adverse possession for that length of time, will toll his right. Nor can it, in the reason and nature of the thing, produce any difference, whether the possession be held uniformly under one title, or at different times under different titles, provided the claim of title be always adverse to that of the plaintiff, nor whether the possession be held by the same or a succession of individuals, provided the possession be a continued and uninterrupted one.

Judgment must be affirmed with costs. ${ }^{13}$

\section{DOE ex dem. HARLAN v. BROWN.}

(Supreme Court of Indiana, 1853. 4 Ind. 143.)

Error to the Fayette Circuit Court.

RoAche, I. Ejectment by the heirs of Joshua Harlan for a lot in the town of Connersville. Verdict and judgment for the defendant. Notion for a new trial overruled. The evidence is all set out in a bill of exceptions.

The plaintiffs were admitted at the trial to be the heirs of Joshua Harlan. They then gave in evidence a deed of convevance from John Conner to their ancestor, dated the 30th day of November, 1818 . It was further admitted by the defendant that Joshua Harlan, in his lifetime, laid out a portion of the land embraced in the deed, into town lots, as a part of the town of Connersville, and that the lot No. 87, in controversy in the suit, was one of those lots.

The defençe set up by Brown, who was admittedly defendant under the rule, was an adverse possession by himself and one Solomon Clay-

13 Accord: Fanning r. Wilcox, 3 Day (Conn.) 25S (1S0S); Smith v. Chapin, 31 Conn. $5: 30$ (1S63); Wishart v. MeKnight, 178 Mass. 356, 59 N. E. 10:S, S6 Am. St. Iiep. 486 (1901), explaining Sawyer v. Kendall, 10 Cush. (Mass.) 241 (1552), though the point perhaps was not necessarily inrolved. See, also, Scales v. Cockrill, 3 Head (Tenn.) 432 (1859); Davis v. Mcdrthur, 78 N. C. 357 (1STS). 
pool, of twenty years. The eridence introduced by him showed that Joshua Harlan died about the year 1827 ; that some time between 1826 and 1828, Solomon Claypool, claiming to be the owner of the lot, leased it for a term of years to be fenced and cleared; that it was accordingly fenced and cleared by the lessee, in one of those years, most probably in 1827 ; that at the expiration of that lease, he rented it to a tenant to make brick upon it. Shortly afterward, the fence was removed, it does not appear by whom, and the lot remained vacant and unenclosed up to $18+3$, a period of not less than ten years; but during all that period Claypool continuously claimed, and was gencrally understood, in the neighborhood, to be the owner; that from 1830 to 1845 , both inclusive, the taxes on the lot were annually charged to and paid by Claypool, in which latter year he died. The tax duplicates, which were in evidence, showed that in 1827, the lot was not assessed to any one; that in 1828 and 1829, it was placed on the duplicate, but was included in the list under the heading of "unknown owners"; and that in neither of those years were the taxes upon it paid by either Harlan or Claypool.

The defendant also proved by one Bundrant, that he had known lot No. 87 since 1837 ; that it was then unenclosed, and was called the property of Solomon Claypool; that in 1843, the defendant, (Brown,) went into possession of the lot, fenced it and built a house, and has occupied it ever since.

'This was all the evidence.

The plaintiffs asked for several instructions to the jury, all of which the Court refused to give. It is unnecessary, however, to exanine whether these instructions should have been given, as they were all substantially embraced in the charge which the Court gave. The jury were fully and correctly instructed as to the law of the case. It only remains to examine whether their verdict was sustained by the evidence.

In their instructions, the Court below charged the jury that a conjtinuous, uninterrupted, peaceable possession of twenty years, under a claim of title, was necessary to make out the defence relied on by the defendant, and that if it was necessary to add the possession of Brown to that of Claypool, to make up the twenty years. he, the defendant, must show that he was in possession under Claypool. 'This is the law. To defeat the recovery of a plaintiff who produces a regular legal tithe, by a title founded on possession, strict proof must be made not only that the possession was, from its inception, under a public claim of tithe adverse to that of the real owner, but that both such clain and possession have been continuous and uninterrupted. And this continuity must be kept unbroken through the full period of twenty years. If the chain is broken at any point within that period, no title is acquired. In the case where several tenants have, during the time, successively occupied the premises, to make their possession available it must be AIG.Prop. -3 
shown that each one claimed to hold, and was in possession, under his predecessor. Brandt v. Ogden, 1 Johns. (N. Y.) 156; Doe v. Campbell, 10 Johns. (N. Y.) 475; Hawk v. Senseman, 6 Serg. \& R. (Pa.) 21; Coburn v. Hollis, 3 Metc. (Mass.) 125.

In the case under consideration, Brown could not make ont the twenty years without connecting his possession with that of Claypool, by showing that he was in under him. If there was any evidence on this point, we should not be disposed to disturb the verdict of the jury. But if the bill of exceptions contains all the evidence, as it purports to do, there is no proof tending to connect the possession of Brown with that of Clarpool. Neither one of them was in possession for a period of twenty years. Claypool was occupying and claiming title for some sixteen years, from about 1827 to $18+3$. Then, it is in proof, Brown went into possession; but, how, or under what circumstances, is not shown. From aught that appears, he may have gone in as a mere trespasser, against the consent of Claypool. Having totally failed to establish that his possession of the premises was a continutation of that of Claypool, by showing that he was in under the latter, he has left a chasm in his title which is fatal to the defence he relies on.

The Court should have granted the motion of the plaintiffs for a new trial.

Per Curian. The judgment is reversed with costs. Cause remanded, etc.

\section{SHERIN et al. v. BRACKETT.}

(Supreme Court of Minnesotn, 1s56. 36 Minn. 152, 30 N. W. 551.)

The plaintiffs brought this action in the district court for Hennepin county, to recover the possession of a strip of land in Minneapolis. Upon the trial before Young, J., and a jury, the plaintiffs having rested their case, the action was dismissed, on defendant's motion, for plaintiff's failure to make out a case. Plaintiffs appeal from an order refusing a new trial.

BERRY, J. This is an action in the nature of ejectment, in which the plaintiffs, seeking to recover possession of a strip of land, alleged that on October 1, 1885, and long before, they were and now are owners thereof; and further that they and their ancestors, from whom they derive title, have been in the actual, peaceable, open, notorious, adverse. and continuous possession thereof for more than 25 years prior and up to October 8,1885 , that on that day, while they were in such actual possession, defendant unlawfully entered upon said strip of land and wrongfully ejected them therefrom, and ever since wrongfully detains possession thereof.

Doubtless the intent of the pleader was to set up title in fee based upon what is called adverse possession. But as the greater includes the less, the complaint sufficiently pleaded actual possession at the time of the defendant's alleged entry, so that if upon the trial the plaintiffs 
failed to make out adverse possession, such as would give them title as against the holder of the paper title, still, if they proved actual possession, they might properly insist that they were within the allegations of their complaint, and had made out a case as against a mere trespasser. For as against one showing no title in himself, possession is title. Wilder v. City of St. Paul, 12 Minn. 192 (Gil. 116); Rau v. Mlinnesota Valley R. Co., 13 Minn. 442 (Gil. 407); Sedg. \& V. Tr. 'Title Land, $\S \S 717,718$.

The evidence upon the trial below in the case at bar showed that plaintiffs were in possession of the strip of land in controversy at the time of defendant's entry upon it, and defendant gave no evidence of any right or title in himself. In this state of the evidence the plaintiffs were entitled to jurlgment, and hence the trial court erred in dismissing the action at the close of the plaintiffs' testimony. As this point is insisted upon by plaintiffs it cannot be disregarded, and so there must be a new trial.

This disposes of the present appeal, but (as we surmise) not of the real merits of the controversy, and therefore, with reference to a new trial, we deem it expedient to determine certain other questions raised upon the argument.

And, first, though there are a few cases which hold that the statutory period of adverse possession, which will bar an action for the recovery of land, may be maile up by tacking together the periods of the adverse possession of several successive bolders between whom there is no privity, (sce Scales v. Cockrill, 3 I Icad [Tenn.] 432; Smithv. Chapin, 31 Conn. 530 ; Davis v. Mc.1rthur, 78 N. C. 357.) the rule laid down by the great majority of courts and by the text-writers, and supported by the weight of authority, and which must be regarded as the true rule, is that privity between successive adverse holders is indispensable. And this upon the principle that mless the successive adverse possessions are connected by privity, the disseizin of the real owner resulting from the adverse possession is interrupted, and cluring the interruption, though but for a moment, the title of the real owner draws to it the scizin or possession. Melvin v. Proprietors, etc., 5 Metc. (Mass.) 15, 38 Am. Dec. 384: Haynes v. Boardman, 119 Mass. 414; McEntire v. Brown, 28 Ind. 347; Jackson v. Leonard, 9 Cow. (N. Y.) 653 ; Wood, Lim. sce. 271 ; San Francisco v. Fulde, 37 Cal. 349, 99 Am. Dec. 278; Crispen v. Hannavan, 50 גLo. 536; Shuffleton v. Nelson, 2 Sawy. 540, Fed. Cas. No. 12,\$22; Ang. Lim. \$§ 413, 41t; Sedg. $\&$ V. 'Tr. Title Land, $\S \S 740,745-747$; Riggs v. I'uller, $5+$ Ala. $141 .^{14}$

14 Lessee of Potts v. Gibert, : Wash. C. C. 475 , Fed. Cas. No. 11,917 (1s19); Ely v. Brown, 183 Ill. 575,56 N. L. 181 (1900): Sheldon v. Jichiman Cent. R. Co., 161 Mich. 503, 126 N. W. 10.56 (1910); Moore v. Collishaw, 10 Pa. 2.24 (1S49); Illinois Steel Co. v. Paczocha, 1:99 Wis. 29, 119 N. W. 550 (1909), acce.

Lnder the statute in North Dakota successive adrerse possessions could not be tacked even though there was privity. Streeter Co. v. Fredrickson, 11 N. D. 300, 91 N. W. 602 (1902). In South Carolina tacking is allowed between heir and ancestor, but not between grantee and grantor. Epperson $\mathrm{s}$. Stansill, 64 S. C. 485,42 S. E. 426 (1902). 
Second. The privity spoken of exists between two successive holders when the later takes under the earlier, as by descent, (for instance, a widow under her husband, or a child under its parent,) or by will or grant, or by a voluntary ${ }^{15}$ transfer of possession. Leonard v. Leonard, 7 Allen (Mass.) 277; Hamilton v. Wright, 30 Iowa, 480; Jackson v. Moore, 13 Johns. (N. Y.) 513, 7 Am. Dec. 398; McEntire v. Brown, supra; Weber v. Anderson, 73 Ill. 439; Wood, Lim. § 271; Sedg. \& IV. Tr. Title Land, $\$ \S 747,748$.

Third. While to operate as a bar, adverse possession must be continuous, continuity will not be interrupted by the possession, during any part of its period, of one who occupies the premises as a tenant of the alleged adverse possessor. In such cases the tenant's possession is that of his landlord. San Francisco v. Fulde, supra; Rayner v. Lee, 20 Mich. 384 ; Sedg. \& W. Tr. Title Land, § 747.

Fourth. Possession, to be adverse, so as to bar an owner's right of action, must be actual, open, continuous, hostile, exclusive, and accompanied by an intention to claim adversely. Sedg. \& IV. Tr. Title Land, sec. 731 et seq.

This is all which we deem it necessary to say in this case; for, as there is to be a new trial, we forbear to comment upon the evidence.

Order reversed, and new trial awarded.

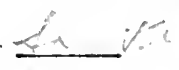

MCNEELY et ux. v. IANGAN.

(Supreme Court of Ohio, 1S71. 22 Ohio St. 32.)

Error to the Court of Common Pleas of Hamilton county, reserved in the District Court.

The original action was brought by the plaintiffs in error to recover a strip of ground three feet wide, fronting on Longworth street, in the city of Cincinnati.

The defense relied on was the statute of limitations. The case was submitted to the court upon the following agreed statement of facts:

Jane McNeely et al. v. Thomas Langan. No. 32,026. Hamilton Common Pleas.

It is hereby agreed between the parties that Stephen Burrows, on the 1st day of January, 1842, leased perpetually to R. G. Masterson the following described premises, to which the said Burrows had a good title in fee simple, viz.: beginning at a point in the south line of Longworth street as continued, and the east line of a lot of ground lately belonging to the estate of Samuel Still, deceased, extending thence south with said east line eighty feet, more or less, to the north line of a

15 See Memphis \& L. R. Co. v. Organ, 67 Ark. 84, 55 S. W. 952 (1899); Kendrick $Y$. Latham, 25 Fla. 819, 6 South. S71 (18S9); Mortenson v. Murphy, 153 Wis. 389,141 N. W. 273 (1913). 
ten foot alley; thence east along the north line of said alley twentythrce feet; thence north parallel with said Still's east line aforesaid eighty feet, more or less, to the south line of Longworth street as aforesaid; thence west along the south line of I,ongworth street twentythree feet to the beginning. That R. G. Masterson conveyed said lot and leasehold to Joseph More, May 20, 1850; said More to E. P. Cranch, April 10, 1854; and said Cranch to the defendant, Thomas Langan, August 29, 1860. It is hereby further agreed that said Masterson, on or about May, 1842, built a frame cottage on the west line of said lot and on the land described in the petition. It is further agreed that the plaintiffs are the owners of said land described in their said petition, if the same does not belong to the defendant by occupancy. It is further agreed between the parties that the land described in their petition was not conveyed by deed to Masterson, nor by Masterson to More, nor from More to Cranch, nor from Cranch to the defendant, Langan. That the said Masterson, at the time of taking possession under his lease from Burrows, entered into the possession of the premises described in the petition, fenced it in with the other property, built his house partly thereon, so as to occupy these three feet as above stated; and the said Masterson, More, Crancli, and the defendant, Langan, have, by transfer of possession made at the time of the several conveyances above mentioned, remained in continuons possession and actual occupancy of said premises and cottage, including said three feet, from May, 1S+2, to the present time. That neither the plaintiffs, nor those under whom they claim, nor the defendant, nor those under whom he claims, were aware of any question as to the title to this strip of three feet, nor as to any error made in the original location of said cottage and fencing, until October, 1860, when, by a survey then made, it was discovered by the plaintiffs that these three feet were not included in the perpetual lease made to Masterson; and thereupon the plaintiffs, in the year 1865, made, for the first time, a demand upon the defendant for the possession thereof, which was refused then as it is now, and hence this suit.

Wm. Disney, Attorney for Defendant.

S. Clark, Plaintiffs' Attorney.

The court found in favor of the defendant, and rendered judgment accordingly.

The plaintiffs filed a petition in error in the District Court, asking a reversal of the judgment on the general grounds that the court erred in allowing the defendant the benefit of the statute of limitation.

The case was reserved by the District Court for decision by this court.

WhiTe, J. By the agreed statement, the court below was warranted in finding the possession to have been sufficiently open, notorious, and adverse to bring it within the operation of the statute of limitations. The question is, whether it was, in a legai sense, continuous.

For the plaintiff in error, it is contended that the continuity of pos- 
session was broken by each successive transfer of the premises in controversy; and, consequently, that as neither the defendant nor any one occupier under whom he claims held possession for the period of limitation, the statute is not available as a bar to the action.

There are authorities supporting this view, but we think the better reason, as well as the weight of authority, is against the position. Fanning v. IVillcox, 3 Day (Conn.) 258; Smith v. Chapin, 31 Conn. 531; Shannon v. Kinny, 1 A. K. Marsh. (Ky.) 3, 10 Am. Dec. 705; Chilton v. Wilson's Heirs, 9 Humph. (Tenn.) 399; Cunningham v. Patton, 6 Pa. 355; Scheetz v. Fitzwater, 5 Pa. 126; Overfield v. Christy, 7 Serg. \& R. (Рa.) 173; Johnson v. Nash's Heirs, 15 Tex. 419; Alexander v. Pendleton, 8 Cranch (U. S.) 462, 3 L. Ed. 624.

Possession itself is a species of title, of the lowest grade, it is true, yet it is good against all who can not show a better, and by lapse of time may become, under the statute, perfect and indefeasible.

In considering the question before us, it should be observed that, in this state, it is not necessary to the running of the statute that possession be held under color of title. Where there is possession of the requisite character, the question, whether there is color of title or not, is wholly immaterial. Lessee of Paine $v$. Skinner, 8 Ohio, 167 ; Yetzer v. Thoman, 17 Ohio St. 130, 91 Am. Dec. 122.

The possession must be connected and continuous. But it is admitted that the possession will descend to the heir without interrupting the running of the statute; and we see no good reason why the ancestor may not voluntarily dispose of a possessory interest, which the law, in the absence of such disposition, will transmit to the heir.

The mode adopted for the transfer of the possession may give rise to questions between the parties to the transfer; but, as respects the rights of third persons against whom the possession is held adversely, it seems to us to be immaterial, if successive transfers of possession were in fact made, whether such transfers were effected by will, by deed, or by mere agreement either written or verbal. Judgment affirmed. ${ }^{16}$

16 Viking 11 fg. Co. r. Crawford, 84 Kan. 203, 114 Pac. 240.35 L. R. A. (N. S.) 498 (1911); Wishart v. McKnight, 17s Mass. 356. 59 ‥ E. 1028, $86 \mathrm{Am}$. St. Rep. 486 (1901); Vance 5 . Wood, 22 Or. 77,29 Pac. 73 (1S92); Gildeą $\mathrm{r}$. Warren, 173 Mich. 2S, 135 N. W. 292 (1912) (but see Lake Shore \& M. S. Ry. Co. r. Sterling [Mich.] 155 N. W. 383 [1915]); Rembert $r$. Edmondson, 99 Tenn. 15, 41 S. W. 935, $63 \mathrm{Am}$. St. Ren. $\$ 10$ (1897); Illinois Steel Co. ₹. Paczocha, 139 Wis. 23, 119 N. W. 550 (1909), acc. Vicksburg, S. \& P. Ry. Co. v. Le Rosen, 52 La. Ann. 192, 26 South. 85t (1899); Evans r. Welch, 29 Colo. 355, 6S Pac. 776 (1902); Messer r. Hibernia Sar. Soc., 149 Cal. 122, S4 Pac. 835 (1906), contra. See Erck v. Church, 87 Tenn. 575, 11 S. W. 794, 4 L. R. A. $6+1$ (1SS9), a case which probably was not well tried.

"If the possessions join by delivery from predecessor to successor, there is no opportunity for the true owner to become seised, and, after twenty Jears' submission to such inability, he becomes barred. * * * Possession and roluntary transfer thereof are physical facts provable by the testimony of an eye or ear witness or any other evidentiary fact or conduct. The only qualification to the possession is that it must be such as to exclude the true owner, not derived from or in subordination to him. The only essential of 


\section{RICH v. NAFFZIGER et al.}

(Supreme Court of Illinois, 1912. 255 Ill. 98, 99 N. E. 341.)

Appeal from the Circuit Court of Tazewell county; the Hon. T. N. Green, Judge, presiding.

FARMer, J. This case was before us at a former term and the opinion then delivered will be found at page 455 of volune 248 of the Illinois Reports, $9+$ N. E. 1. We reversed the judgment and remanded the case for error in an instruction given for appellecs, which, in effect, placed the burden upon appellant of proving that appellees did not have title to the disputed premises by adverse possession. Another trial in the circuit court resulted in a verdict and judgment for defendants, and plaintiff has again bronght the case to this court by appeal.

Our former opinion contains a statement of the case and a history of the controversy out of which this litigation arose. We will not repeat that statement here in full, but will briefly say the action was guare clansum fregit brought by appellant, and the issues made by the pleadings involved the title to a narrow strip of land off the west side of the north half of the south-east quarter of section 5, township 25 north, range 2 west of the third principal meridian, in Tazewell county. The strip of land involved is nine feet wile at the south end, fifteen feet wide at the north end, and extends from the south line of the north half of the sonth-cast quarter of section 5 to the north line of said tract. Appellant has title of record to the whole of the south-east quarter of said section 5. Christian Naflziger owns the north half of the south-west quarter of said section, and his son, Peter Naffziger, is his tenant. Before Christian Naffziger became the owner of said tract the whole of the south-west quarter of said section 5, belonged to Christian Schwarzentratub, who died in November, 18SS. By virtue of a decree in a partition suit between the heirs of Schwarzentraub the north half of the south-west quarter of section 5 was sold to Christian Naffziger on June 5, 1889, and a deed therefor executed to him by the master in chancery. At the time of said sale Fred Schwarzentraub was in possession of said eighty-acre tract as tenant, and the decree provided the purchaser should have the rents for the ycar 1889 and the possession of the prenises on March 1, 1890. While the strip of land in controversy was a part of the eighty acres to which appellant had paper title, it was in the enclosure with the north half of the southwest quarter from 1885 until April, 1009, when appellant, without leave of or notice to appeilecs, removed the sonth forty rods of fence from the line known in this record as the Oswald line, west to the line

the transfer is that the predecessor passes it to the anccessor by mutual consent, as distinguished from the case where a possessor abandons possession senerally, and another, finding the premises unoccupied enters without contact or relation with the former. **** Dodge, J., in Illinois Steel Co. v. Paczocha, supra. 
of the commission survey established in March, 1909. The fence was built on the Oswald line as early as 1885, and thereafter Schwarzentraub and his heirs had possession of and cultivated all the land on the west side of the fence until the sale to Christian Naffziger, and from March 1, 1890, he has continued in possession and cultivated all the land on the west side of the fence. Appellant and his predecessor in title have during all that time possesserl and cultivated the land on the east side of the fence.

It will be seen Christian Naffziger himself had not been in possession of the disputed premises quite twenty years, but if the possession of Schwarzentranb be tacked to his, the period of adverse possession is more than twenty years. The proposition principally relied upon by appellant for reversal of the jidgment is that there was no privity between Christian Schwarzentraub and Christian Naffziger, and therefore the possession of the former cannot be tacked to the latter. The rule of law as laid down by the decisions of this and other States is, that privity of estate or title is necessary between successive disseizors to authorize joining together the several possessions so as to make a continuous possession. Acts of possession at different times, by different persons between whom there is no privity, cannot be joined. Ely v. Brown, 183 Ill. 575,56 N. E. 181.

It is conceded by appellant that if Christian Schwarzentraub or his heirs, if adults, had conveyed the north half of the south-west quarter of section 5 to Christian Naffziger and had delivered to him possession of the entire enclosure up to the division fence, the possession of Schwarzentraub could be tacked to that of Naffziger and form a continuous possession, but it is insisted that as the conveyance of the eighty acres to Naffziger was made by the master in chancery under the decree in the partition suit there could be no privity of estate or title between Naffziger and Schwarzentraub and that the two possessions could not be joined. / Where a person having title, by deed, to a lot or tract of land described in the deed also has enclosed with it and is in possession of adjoining land to which he has no record title, and conveys the land by the description in the deed and delivers with it the possession of the entire enclosure, the continuity of possession will not be broken and the two possessions will be joined and considered as one continuous possession. This result, however, does not necessarily follow the making of the deed describing the land to which the grantor had paper title. The title to premises in possession but not described in the deed to the claimant does not depend upon a deed but upon possession alone, and for that reason will not pass by a conveyance describing only the land to which the grantor has record title, but possession of the land not described in the deed must be delivered. The privity between two disseisors which will authorize tacking their possessions is not, therefore, established by a deed from one to the other. Illinois Central Railroad Co. v. Hatter, 207 Ill. S8, 69 N. E. 751. The deed is proper to be considered in determining whether pos- 
session of the land in the enclosure not described in the deed was taken at the same time as the possession of the land described therein, and where the deed is followed by the delivery of possession of the entire enclosure it is sufficient evidence of a transfer of possession to raise the requisite privity between the parties. But a paper transfer is not necessary to connect adverse possessions. It may be a means in establishing the fact of privity but is not the only means. Illinois Steel Co. v. Budzisz, 106 Wis. 499, 81 N. W. 1027, 82 N. WV. 534, 48 I. R. A. 830, $80 \mathrm{Am}$. St. Rep. 54. In discussing the circumstances under which the possession of disseizors may be joined, the Visconsin Suprence Court said in Illinois Steel Co. v. Paczocha, 139 Wis. 23. 119 N. IV. 550: "The only essential of the transfer is that the predecessor passes it to the successor by mutual consent, as distinguished from the case where a possessor abandons possession generally, and another, finding the prenises unoceupied, enters without contract or relation with the former."

In Weber v. Anderson, 73 Ill. 439, the owner of a lot conveyed all of it but a ten-foot strip off one side to the president of a plank-road company. The grantee took possession of the entire lot and encloserl it with a fence, claiming title to the whole of it, and remained in possession from $18+9$ to 1863 . It then sold the premises, and in the conveyance described them as they were described in the deed made to it but delivered to the purchaser possession of the entire lot. The purchaser held possession until May, 1870, and then conveyed the entire lot to another. One of the questions in the case when it was before this court was whether the possession of the plankroad company and its grantee could be joined and considered as a continuous possession for twenty years. It was contended by the appellant that the transfer of possession conld not be proved by parol but must be proved by deed. This court held that no deed is necessary to support title by adverse possession, but that it is sufficient for a party to take possession under a claim of ownership and hold the premises for the time required by the statute to complete the bar; that a deed is not necessary to prove the transfer of the possession but such transfer may be shown by parol. The court referred to and quoted from decisions of other States, as follows: "In the case of Suith v. Chapin, 31 Conn. 531, the Supreme Court of Connecticut, in deciding a question similar to the one in this case, says: 'Doubtless the possession must be connected and continuous, so that the possession of the true owner shall not constructively intervene between them; but such continuity and connection may be effected by any conveyance, agreement or understanding which has for its object a transfer of the rights of the possessor or of his possession, and is accompanied by a transfer of possession in fact.' In Menkens v. Blumentlal, 27 Mo. 203, it was held whether one occupant receives his possession from a prior one or is a mere intruder upon an abandoned lot is a question of fact, which may be determined by any testimony which is legitimate and pertinent. 
We know of no rule of evidence which confines the proof to a deed or written instrument. In Crispen v. Hannavan, 50 Mo. 544, the doctrine announced in the last case cited is approved, and the court adds: 'Not even a writing is necessary if it appear that the holding is continuous and under the first entry.' In McNeely v. Langan, 22 Ohio St. 32, the same question arose, and it was there held: 'The mode adopted for the transfer of the possession may give rise to questions between the parties to the transfer, but as respects the rights of third persons, against whom the possession is held adversely, it seems to us to be immaterial, if successive transfers of possession were, in fact, made, iwhether such transfers were effected by will, by deed or by mere agreement, either written or verbal." "'

In Faloon v. Simshauser, 130 I11. 649, 22 N. E. 835, it was contended by the appellant that in orcier to avail of the bar under the Statute of Limitations, privity of estate with the prior disseizors must be shown by purchase and conveyance of disseizin. Upon this question the court said: "It is a sufficient answer to this claim, and to the anthorities cited to show it is essential to establish by a deed that appellees are connected with the adverse possessions of Allen and Sarah B. Withers, to say that the question is not an open one in this State, and that, the rule having been years ago determined otherwise by this court and it being a rule of property upon which many titles may depend, such former ruling will be adhered to without any re-examination of the conflicting authorities in respect thercto."

The privity required is that there must be a continuous possession by mutual consent, so that the possession of the true owner shall not constructively intervene. The possession of one who had abandoned the premises could not be joined with the possession of one who found them unoccupied, and, without any connection with the former possession, entered upon the land. In the case before us Christian Schwarzentraub was at the time of his death, and had been for some years, in the possession of the land in controversy. He was prima facie the owner of it, and upon his death his estate in it was cast upon his heirs, to whom his possession was transferred by operation of law. Gosselin v. Smith, 15+ I11. 74, 39 N. E. 980. They remained in possession until after the partition, when they surrendered their possession to Christian Naffziger. The title he acquired by the master's deed did not describe or embrace the strip of land in controversy, but the proof shows' he succeeded the Schwarzentratubs in the possession of it, and we are of opinion it must be held the two possessions are lawfully joined.

The proof of appellees was abundant to the effect that their possession was adverse, and it was not sufficiently weakened by the testimony on behalf of appellant that we can say the jury were not justified in finding the evidence established title in appellees by adverse possession, and in our opinion there was no error in the rulings of the court in the admission of testimony that unduly prejudiced appellant. We have 
read the evidence and are satisfied the verdict was warranted by it. We can see no reason to suppose that a different result might obtain on another trial. The proof of appellees met the requirements of the rule stated in Zirngibl v. Calumet Dock Co., 157 Ili. 430, 42 N. E. 431, and other decisions of this court, upon the degree of proof necessary to establish title by adverse possession.

No substantial error was committed by the trial court in giving and refusing instructions. Judgment affirmed.

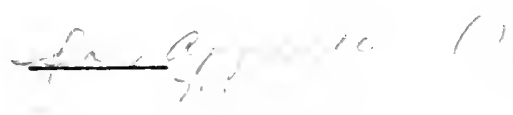

\section{SECTION 4.-ADVERSE POSSESSION}

RICARD v. WILLIAMS.

(Supreme Court of the United States, 1822. 7 Wheat. 59, 5 I. Ed. 398.)

Error to the circuit court of the United States for the district of Connecticut.

This was a suit instituted by the defendants in error against the plaintiff in error, in the court below. The original action is commonly known in Connecticut by the name of an action of disseisin, and is a real action, final upon the rights of the parties, and in the nature of a real action at the common law. The cause was tried upon the general issue, nul tort nul disseisin, and a verdict being found for the demandants, a bill of exceptions was taken to the opinion of the court upon matters of law at the trial.

The demandants claimed the estate in controversy by purchase from the administrator of William Dudley, at a sale made by him for the payment of the debts of his intestate, pursuant to the laws of Connecticut, which authorize a sale of the real estate of any person deceased, for the payment of his debts, when the personal assets are insufficient for that purpose. In order to establish the title of William Dudley in the premises, the demandants proved that Thomas Dudley, the father of William, was, in his lifetime, possessed of the premises, as parcel of what were called the Dudley lands, and died possessed of the same in 1769 , leaving seven children, of whom William was the eldest, being of about the age of fourteen years, and Joseph Gerriel, the youngest, being about four years of age. Upon the death of Thomas Dudley, Joseph Mayhew, the guardian of William, entered into possession of the Dudley lands, and of the demanded premises as parcel, taking the rents and profits in his behalf during his minority; and upon his arrival at full age William entered and occupied the same, taking the rents and profits to his own use, until his death, which happened in the year 1786, all his brothers and sisters being then living. During the 
life of William, no other person claimed any right to enter or occupy the premises, except that his mother received one third of the rents and profits, until she died in the year 17\$3. During his life, and while in possession of the premises, William always declared that he held the same only for life, and therefore would not allow any improvements on them at his expense; no leases were made by him except for short periods; and no attempt was made by him to sell or convey the premises; and he declared that he had no right to sell them, and that upon his death they would descend to his son Joseph Dudley, under whom the tenant derived his title, in the manner hereafter stated. No administration was ever taken in Connecticut upon the estate of William Dudley, until 1814, and his estate was then declared insolvent; and in 1817 , the lands in controversy were sold by the administrator, by order of the court of probates, for the payment of the debts found due under the commission of insolvency.

To rebut the title of the demandants, and to establish his own, the tenant proved that William Dudley died intestate, leaving seven children, the eldest of whon was Joseph Dudley. Upon the death of his father, the guardian of Joseph (the latter being within age,) entered into possession of the Dudiey lands, and of the demanded premises as parcel, and used and occupied the same, receiving the rents and profits in behalf of Joseph, until his arrival at full age, when Joseph himself entered into possession, claiming them as his own, and taking the rents and profits to his own use, and holding all other persons out of possession, until the year 1811 and 1812, when he sold the demanded premises, and the tenant, either by direct or mesne conveyances under Joseph, came into possession, and has ever since held the premises in his own right. In the year 1811, Samuel Dudley, the brother of Joseph, claimed title to some of the Dudley lands possessed by Joseph, and brought an action of ejectment for the recovery of them, but the suit was compromised by Joseph's paying him about $\$ 2,000$, and about the same time Joseph settled with another of his brothers, but did not pay him any thing. But Joseph never adnitted that his brothers or sister had any interest in the lands; and said he could hold them, and did hold them, in the same manner as he held the lands in Massachusetts.

The will of Gevernor Dudley, which was admitted to probate in Massachusetts in 1720, was also in evidence, but neither party established any privity or derivation of title under it.

Upon these facts, the tenant prayed the court to instruct the jury, that the demandants had not made out a title in themselves, nor in William Dudley. Not in themselves, because the sale by the administrator to the demandant was void, by force of the statute regarding the sale of disputed titles, the tenant being in possession of the property at the time of the sale, claiming it as his own, and that William Dudley had acquired no title to the property in question by possession, as he claimed to hold the same only during his life, and could therefore acquire no title, except for life by any length of possession, and that 
if he could acquire title by possession, if this estate descended from Thomas Dudley, said William could not in seventeen years, acquire a title against his brothers and sisters, or at least against those of them who had not been of full age for five years before the death of said William; and if the demandants could recover at all, it could only be for that proportion of the estate which descended from William as one of the heirs of Thomas Dudley.

The tenant further prayed the court to instruct the jury that if they found that Joseph Dudley had, for more than fifteen years before he sold the land in controversy, been in possession of the same, exclusively claiming them as his own, and holding out all others, he had gained a complete title to the property.

The tenant further claimed that the court ought to have instructed the jury, that under the circumstances attending the possession of said lands by William Dudley, the father, and by Joseph Dudley, and the length of time which had clapsed since the death of said William, withont any claim on the part of the creditors of said William, the jury might presume a grant from some owner of the land to William for life, with remainder to his eldest son. But the court did charge and instruct the jury that the sale by the administrator under an order of court was not within the statute regarding disputed titles, and was not therefore void. That William Dudley, by mistaken constructions of the will of Governor Dudley, might have claimed an estate for life in the premises, and that such mistake would not operate to defeat his title by possession. That the length of time in which this estate had been occupied by William and Joseph Dudley, would har any claims by the other children of Thomas Dudley, deceased, and that the jury were authorized to presume a grant by said children to their brother William Dudley, deceased, and therefore, if the demandants recovered, they must recover the whole of the promises.

The court also charged the jury that, as against the creditors of William Dudley, neither Joseph Dudley nor the tenant had gained title to the lands in controversy by possession, and that the jury were not authorized to presume a grant to Joseph.

To which several opinions of the court the tenant, by his counsel, excepted.

STORY, I. ${ }^{17}$ The principal questions which have arisen, and have been argued here, upon the instructions given by the circuit court, and to which alone the court deem it necessary to direct their attention, are: 1. Whether upon the facts stated, a legal presumption exists, that William Dudley died seised of an estate of inheritance in the demanded premises; and, if so, 2. Whether an exclusive possession of the demanded premises, by Joseph Dudley and his grantees, after the death of William, under an adversary claim, for thirty years, is a bar to the entry and title of the denandants under the administration sale.

17 Part of the opinion is omitted. 
It is to be considered, that no paper title of any sort, is shown in William Dudley or his son Joseph. Their title, whatever it may be, rests upon possession; and the nature and extent of that possession must be judged of by the acts and circumstances which accompany it, and quali-. fy, explain, or control it. Undoubtedly, if a person be found in possession of land, claiming it as his own, in fee, it is primâ facie evidence of his ownership, and seisin of the inheritance. But, it is not the possession alone, but the possession accompanied with the claim of the fee, that gives this effect, by construction of law to the acts of the party. Possession, per se, evidences no more than the mere fact of present occupation, by right; for the law will not presume a wrong; and that possession is just as consistent with a present interest, under a lease for years or for life, as in fee. From the very nature of the case, therefore, it must depend upon the collateral circumstances, what is the quality and extent of the interest claimed by the party; and to that extent, and that only, will the presumption of law go in his favor. And the declarations of the party, while in possession, equally with his acts, must be good evidence for this purpose. If he claims only an estate for life, and that is consistent with his possession, the law will not, upon the mere fact of possession, adjudge him to be in under a higher right, or a larger estate. If, indeed, the party be in under title, and, by mistake of law, he supposes himself possessed of a less estate in the land than really belongs to him, the law will adjudge him in possession of, and remit him to, his full right and title. For a mistake of law shall not, in such case, prejudice the right of the party; and his? possession, therefore, must be held coextensive with his right. This is the doctrine in Littleton, section 695, cited at the bar; and better authority could not be given, if indeed so obvious a principle of justice required any authority to support it. But there the party establishes a title in point of law greater than his claim; whereas, in the case now supposed, the party establishes nothing independent of his possession, and that qualified by his own acts and declarations. This is the distinction between the cases, and accounts at once for the different principles of law applicable to them.

It has also been argued at the bar that a person who commits a disseisin cannot qualify his own wrong, but must be considered as a disseisor in fee. This is generally true; but it is a rule introduced for the benefit of the disseisee, for the sake of electing his remedy. For if a man enter into possession, under a supposition of a lawful limited right, as under a lease, which turns out to be void, or as a special occupant, where he is not entitled so to claim, if he be a disseisor at all, it is only at the election of the disseisee. Com. Dig. Seisin, F. 2, \& F. 3; 1 Roll. Abrid. 662, L. 45; Id. 661, L. 45. There is nothing in the law which prevents the disseisee from considering such a person as a mere trespasser, at his election; or which makes such an entry, under mistake for a limited estate, a disscisin in fee absolutely, and at all events, so that a descent cast would toll the entry of the disseisee. But were it 
othe1wise, in order to apply the doctrine at all, it must appear that the party found in possession entered without right, and was, in fact, a disseisor; for if his entry were congeable, or his possession lawful, his entry and possession will be considered as limited by his right. For the law will never construe a possession tortious unless from necessity. On the other hand, it will consider every possession lawful, the commencement and continuance of which is not proved to be wrongful. And this upon the plain principle, that every man shall be presumed to act in obedience to his duty, tuntil the contrary appears. When, therefore, a naked possession is in proof, unaccompanied by evidence as to its origin, it will be deemed lawful and coextensive with the right set up by the party. If the party claim only a linited estate, and not a fee, the law will not, contrary to his intentions, enlarge it to a fee. And it is only when the party is proved to be in by disseisin, that the law will construe it a disscisin of the fee, and abridge the party of his right to qualify his wrong.

Now, in the case at bar, it is not proved of what estate Thomas Dudley clied seised in the premises. His possession does not appear to have been accompanied with any claim of right to the inheritance. It might have been an estate for life only, and as such have had a lawful commencement. If it were intencled to be argued that he had a fee in the premises, it should have been established by competent proof that he was in possession, claiming a fee by right or by wrong. No such fact appears. The only fact, leading eren to a slight presumption of that nature is, that his widow took one third of the rents and profits during her life. But whether this was under a clain of dower, or any other right, is not proved. The circumstance is equivocal in its character, and is unexplained; and the inference to be deduced from it, of a descendible estate in her husband, is rebutted by the fact that immediately on his death his son William entered into the premises, claining a life estate, and held them during his life as his own, without any claim on the part of the co-heirs of his father to share in the estate. There is then nothing in the case, from which it can be judicially inferred that Thomas was ever seised of an estate of inheritance in the premises, and, of course, none of a descent from him to his heirs.

Then, as to the estate of his son William, in the premises. It is argued that William had an estate in fee, by right or by wrong. 'That if his entry, either in person or by his guardian, was without right, it was a disseisin, and invested him with a wrongful estate in fee. If with right, then it must have been as a co-heir of his father, and a grant ought to be presumed from the other co-heirs to him, releasing their title and confirming his.

The doctrine, as to presumptions of grants, has been gone into largely on the argument, and the general correctness of the reasoning is not denied. 'There is no difference in the doctrine, whether the grant relate to corporeal or incorporeal hereditaments. A grant of land may as well be presumed as a grant of a fishery, or of common, or of a way. 
Presumptions of this nature are adopted from the general infirmity of human nature, the difficulty of preserving muniments of title, and the public policy of supporting long and uninterrupted possessions. They are founded upon the consideration that the facts are such as could not, according to the ordinary course of human affairs occur, unless there was a transmutation of title to, or an admission of an existing adverse title in, the party in possession. They may, therefore, be encountered and rebutted by contrary presumptions; and can never fairly arise where all the circumstances are perfectly consistent with the nonexistence of a grant; a fortiori, they cannot arise where the clain is of such a nature as is at variance with the supposition of a grant. In general, it is the policy of courts of law to limit the presumption of grants to periods analogons to those of the statute of limitations, in cases where the statute does not apply. But where the statute applies it constitutes, ordinarily, a sufficient title or defence, independently of any presumption of a grant, and therefore it is not generally resorted to. But if the circumstances of the case justify it, a presumption of a grant may as well be made in the one case as in the other; and where the other circumstances are very cogent and full, there is no absolute bar against the presumption of a grant, within a period short of the statute of limitations. See Phillips on Evidence, ch. 7, § 2, p. 126; Foley v. Wilson, 11 East, 56.

If we apply the doctrines here asserted to the case at bar, we may ask, in the first place, what ground there is to presume any grant of the premises to William Dudley, and if any, what was the quantity or quality of his estate? It has been already stated that there is no sufficient proof that his father died seised of a descendible estate in the premises; and if so, the entry of William by his guardian, or in person, cannot be deemed to have been under color of title as heir; and in point of fact he never asserted any such title. For the same reason, no estate can be presumed to have descended to his co-heirs; and if so, the very foundation fails ipon which the presumption of a grant from them to William can be built ; for if they had no title, and asserted no title, there is no reason to presume that he or they sought to make or receive an inoperative conveyance. There is no pretence of any presumption of a grant in fee from any other person to William; and as there is no evidence of any connection with the will of Governor Dudley, or of any claim of title under it by William, there does not seem any room to presume that he was in under that will, upon mistaken constructions of his title derived from it. There is this further diffculty in presuming a grant from the co-heirs to William, that at the time of his own entry, as well as that of his guardian, all of them were under age, and incapable of making a valid conveyance. During this period, therefore, no such conveyance can be presumed; and yet William, during all this period, claimed an exclusive right, and had an exclusive possession of the whole to his own use; and his subsequent possession was but a continuation of the same claim without any inter- 
ference on the part of the co-heirs. In point of fact the youngest brother arrived at age about the time of William's death; and as to two others of the co-heirs, the statute of limitations of Connecticut, as to rights of entry, would not then run against them. The presumption of a grant from them is therefore, in this view, also, affected with an intrinsic infirmity.

In addition to all this, William never claimed any estate in fee in the premises. His declaration uniformly was that he had a life estate only, and that upon his death they would descend to his son Joseph. Of the competency of this evidence to explain the nature of his possession and title, no doubt can reasonably be entertained. His title being evidenced only by possession, it must be limited in its extent to the claim which he asserted. If, indeed, it had appeared that he was in under a written title which gave him a larger estate, his mistake of the law could not prejudice him; but his seisin would be coextensive with, and a remitter to, that title. But there is no evidence of any written title, or of any mistake of law in the construction of it. For aught that appears, William's estate was exactly what he claimed, a life-estate only, and the inheritance belonged to his son Joseph. It is material also to observe that the acts of the parties, and the possession of the estates during the period of nearly fifty years, are in conformity with this supposition, and at war with any other. Why should IVilliam's brothers and sisters have acquiesced in his exclusive possession during his whole life, if the inheritance descended from their father? Why should Joseph's brothers and sisters have acquiesced in his exclusive possession during a period of twenty-five years without claim, if their father William was seised of the inheritance? Why should the guardians of William and Joseph have successively entered into the premises, claiming the whole in right of their respective wards, if their title was not deemed clearly and indisputably an exclusive title, or if they were in by descent under the title of their fathers? If, indeed, at presumption of a grant is to be made, it should be of a grant conforming to the declarations and acts of possession of the parties during the whole period; and if any grant is to be prestumed from the facts of this case, it is a grant of a particular estate to IVilliam, with a remainder of the inheritance to Joseph, or in the most favorable view of an estate tail to William, upon whose death the estate would descend to Joseph, as his eldest son per formam doni. If Thomas, the grandfather, were proved to have been the owner of the fee, there is nothing in the other circumstances which forbids the presumption of such a grant from him; but as the cause now stands, it may as well have been derived from some other ancestor, or from a stranger. It is therefore the opinion of this court that the circuit court erred in directing the jury that Willian, by mistaken constructions of the will of Governor Dudley, might have claimed an estate for life in the premises, and that such mistake would not operate to defeat his title by possession, for AIG.Prop. -4 
there was no evidence that Villiam ever claimed under that will; and also erred in instructing the jury that they were authorized to presume a grant by the children of Thomas to William. The compromise entered into by Joseph with two of his brothers is not thought to change the posture of the case, because that compromise was made with an explicit denial of their right; and is therefore to be considered as an agreement for a family peace. * * *

The remaining consideration under this head is, whether the possession of Joseph Dudley can be considered as an adverse possession so as to toll the right of entry of the heirs, and, consequently, extinguish, by the lapse of time, their right of action for the land, as well as extinguish by analogy of principle the power of the administrator to sell the land. It is said that the entry of Joseph into the premises is consistent with the potential right of the creditors; that he had a right to enter as a co-heir of his father, and if he entered as co-heir, his possession was not adverse, but was a possession for the other heirs and creditors, and he could not afterwards hold adversely, or change the nature of his possession, for the creditors might always elect to consider him their trustee. There is no doubt that in general, the entry of one heir will enure to the benefit of all, and that if the entry is made as heir, and without claim of an exclusive title, it will be deemed an entry not adverse to, but in consonance with, the rights of the other heirs. But it is as clear that one heir may disseise his co-heirs, and hold an adverse possession against them, as well as a stranger. And, notwithstanding an entry as heir, the party may, afterwards, by disseisin of his co-heirs, acquire an exclusive possession upon which the statute will run. An ouster, or disseisin, is not, indeed, to be presumed from the mere fact of sole possession; but it may be proved by such possession, accompanied with a notorious claim of an exclusive right. And if such exclusive possession will run against the heirs, it will, by parity of reason, run against the creditors. For the heirs, quâ heirs, are in no accurate sense in the estate as trustees of the creditors. They hold in their own right by descent from their ancestor, and take the profits to their own use during their possession; and the most that can be said is, that they hold consistently with the right of the creditors. The creditors, in short, have but a lien on the land which may be enforced through the instrumentality of the administrator acting under the order of the court of probates.

But in order to apply the argument itself, it is necessary to prove that the ancestor had an estate of inheritance, and that the party entered as heir. Now, in the case at bar, all the circumstances point the other way. There is not, as has been already intimated, any proof that William Dudley died seised of an inheritance in the land; and there is direct proof that he asserted the inheritance to be in his son Joseph; and the entry of the guardian of Joseph, as well as his own entry, after his arrival of age, was under an exclusive claim to the whole, not by descent, but by title distinct or paramount. There 
is certainly no incapacity in an heir to claim an estate by title distinct or paramount to that of his ancestor; and if his possession is exclusive under such claim, and he holds all other persons out until the statute period has run, he is entitled to the full benefit and protection of the bar. It appears to us, therefore, that the jury ought to have been instructed, that if they were satisfied that Joseph's possession was adverse to that of the other heirs, and under a claim of title distinct from, or paramount to that of his father, during lis twenty-five years of exclusive possession, the entry of the purchaser, under the administrator's sale, was not congeable, and that the power of the creditor over the estate was extinguished. There was therefore error in the opinion of the court to the jury, that, as against the creditors of William Dudley, neither Joseph nor the tenant had gained any title to the land in controversy by possession.

For these reasons the judgment of the circuit court must be reversed, and the cause remanded, with directions to the court to order a venire facias de novo. ${ }^{18}$

\section{FRENCH v. PEARCE.}

(Supreme Court of Errors of Connerticut, 1831. S Conn. 439, 21 Am. Dec. 650.)

This was an action of trespass quare clausum fregit; tried at Litchfield, February term, 1831, before Williams, J.

The plaintiff and defendant were adjoining proprietors of land; and the land in controversy was the border between them, which was wood-land, unfenced. Both parties claimed under Villiam French, the father of the plaintiff and of the defendant's wife. 'The plaintiff's title was admitted, unless the land was conveyed to the defendant's wife, by a deed dated the 11th of Nay, 1809; in which the line on the side adjoining the plaintift was particularly described. A part of the description was "from a butternut tree a straight line to Platt's corner" - said piece being the same land which the grantor bought of Rev. Mr. Benedict." The defendant contended, that as the deed to his wife referred to the land purchased of Mr. Benedict, he might shew where were the bounds of that lot; and claimed, that by those bounds, there was not a straight line from the butternut tree to Platt's corner. This was accompanied with evidence, by which he claimed to have shewn,

18 See Ewing v. Burnet, 11 Pet. 41, 9 L. Ed. 624 (1S37).

The possession and occupancy of vacant land by a mele squater is not adverse, so as to ripen into a title by adrerse possession. See Jusperson $r$. Scharnikow, 150 Fed. 571 , 50 C. C. A. 373,15 L. R. A. (N. S.) 1175 (1907); Mattson v. Warner, 115 Minn. 520, 13:2 N. W. 1127 (1911).

Whether the possession was under a claim of title or not. is a question of fact, to be handed as such on the trial, and conclusions thereon are ordinarily not disturbed by reviewing courts. Mattson v. Warner, supra.

There is no reguirement that the cluim of title be bona fide. Rupley $\nabla$. Fraser (Minn.) 156 N. W. 350 (1916); Ramapo Mfg. Co. V. Mapes, 216 N. Y. 362,110 N. E. 772 (1915). 
that he had occupied and possessed the land in question for more than fifteen years, although not included in the straight line mentioned in the deed. The plaintiff denied the occupation of the defendant; and denied also any difference in bounds in consequence of the reference to Mr. Benedict's deed, and any adverse possession by the defendant.

The judge charged the jury, that in considering where were the boundaries of this lot of the defendant's wife, if the description in the deed was doubtful, they might take into consideration the possession or occupation of the defendant, for the purpose of determining those bounds. But if they should find, that the defendant had possessed the land in question, for more than fifteen years, claining and intending only to occupy to the true line, as described in his deed and no further, then his possession must be referred to his deed, and it would not be adverse to the plaintiff; and the jury, notwithstanding such possession, must look to the deed, to determine the line of division.

The jury returned a verdict for the plaintiff; and the defendant moved for a new trial for a misdirection.

Hosmer, C. J. Whether the line of occupancy was the dividing line between them, was the point of controversy between the parties. The jury were charged, so far as relates to the deed, that if the line described in it was doubtful, they might take into consideration the possession and occupation of the defendant, for the purpose of determining it. This opinion seems not to be questioned; nor is it questionable. An occupation of land by the defendant as his own, under the plaintiff's eye, to what he supposed to be the dividing line between him and the plaintiff, and which, for many years, the plaintiff permitted without a question, from the mutual assent of the parties is strong presumptive evidence of the true place of the line. 1 Phill. Ev. $+20-422$.

On the point of title by fifteen years possession, as the only objection made at the trial, was, that the possession of the defendant was not adverse, it must be assumed, that none other existed. Of consequcnce, the controversy is confined to that single point.

By adverse possession is meant a possession hostile to the title of another; or, in other words, a disseisin of the premises; and by disseisin is understood an unwarrantable entry, putting the true owner out of his seisin. Co. Litt. 153, b. 181.

The enquiry, then, is preciscly this; what must be the character of the act, which constitutes an adverse possession?

This question was directly answered, in Bryan v. Atwater, 5 Day, 181, 5 Am. Dec. 136, and by this Court. A clear and unquestionable rule was intended to be given. The court commenced the expression of their opinion, by saying: "It will be necessary to ascertain precisely the meaning of the terms, 'adverse holding' or 'adverse possession." "The first principle asserted in that case is, that to render a possession adverse, it is not necessary that it should be accompanied with a claim of title and with the denial of the opposing title. The case 
next affirms that possession is never adverse, if it be under the legal proprietor and derived from him. After these preliminaries, it is enquired: "But more particularly, what, in point of law, is an adverse possession? It is," say the court, "a possession, not under the legal proprietor, but entered into without his consent, either, directly or indirectly given. It is a possession, by which he is disseised and ousterl of the lands so possessed." That there should remain no doubt, they next enquire, what constitutes a disseisin? After shewing negatively, that it is not requisite to enter claiming title, or denying the title of the legal owner, they remark affirmatively, that it is only necessary for a person to enter and take possession of land as his own; to take the rents and profits to himself; and to manage with the property as an owner manages with his own property; that is, the person thus possessing must act as if he were the true owner and accountable to no person for the land or its avails. A criterion is then given to determine whether a possession is adverse. "It is only necessary to find out," say the court, "whether it can be considered as the constructive possession of the legal proprietor."

I have been thus particular in analyzing this case, in which the reasons were drawn up, by a very able and eminent jurist; as it presents, in the plainest language, a sure and most intelligible land-mark, to ascertain when a possession is adverse. It is peculiarly observable, that by the reasons given, anxiously laboured as they were, it was intended to put the question at rest for the future. The possession alone, and the qualities immediately attached to it, are rcgarded. No intimation is there as to the motive of the possessor. If he intends a wrongful disseisin, his actual possession for fifteen years, gives him a title; or if he occupies what he believes to be his own, a similar possession gives him a title. Into the recesses of his mind, his motives or purposes, his guilt or innocence, no enquiry is made. It is for this obvious reason: that it is the visible and adverse possession, with an intention to possess, that constitutes its adverse character, and not the remote views or belief of the possessor.

It is not necessary that I should proceed further, as the point of decision, in the case before us, has been settled, by this Court, and witl great precision. At the same time, it may be the more satisfactory to shew, that the determination here is in harmony with the decisions of other courts.

In Westminster-Hall, the character of an adverse possession is well established. The possession of a person denying the title of the owner, or claiming the premises, or taking the whole rents and profits without accounting, is held sufficient evidence of actual ouster. Doe d. Fisher \& al. v. Prosser, Cowp. 217; Doe d. Hellings \& ux. v. Bird, 11 East, 49; Stocker v. Berny, 1 Ld. Raym. 741; s. c. by the name of Stckes v. Berry, 2 Salk. 421. The extent of the doctrine is defined by the following considerations. The possession of a tenant in common is held not to be adverse, without actual disseisin or its equiva- 
lent, as he is presumed to possess for his fellow commoner; but the possession of an individual entering not under another, is adverse, by a perception of the profits only to his own use.

In the state of New York, the entering on land under pretence of title, or under a claim hostile to the title of the true owner, constitutes an adverse possession. Brandt d. Walton v. Ogden, 1 Johns. (N. Y.) 156; Jackson d. Griswold v. Bard, 4 Johns. (N. Y.) 230, 4 Am. Dec. 267 ; Jackson d. Bonnell \& al. v. Sharp, 9 Johns. (N. Y.) 163, 6 Am. Dec. 267.

To the same effect is the law of Massachusetts. "To constitute an actual ouster," said Parsons, Ch. J., "of him who was seised, the disseisor must have the actual exclusive occupation of the land, claiming to hold it against him who was seised, or he must actually turn him wut of possession." Kennebeck Purchase v. Springer, 4 Mass. 416, 418, 3 Am. Dec. 227. Boston Mill Corporation v. Bulfinch, 6 Mass. 229, $4 \mathrm{Am}$. Dec. 120. It is obvious, that a person who takes possession, does not the less claim to hold it against him who before was seised, because he conscientiously believes, that he has right to possess.

The law of Maine, so far as it is expressed in the case of Kennewec Purchase v. Laboree \& al., 2 Greenl. (Me.) 275, 11 Am. Dec. 79, is in perfect harmony with that of the states already mentioned. "The doctrine on this subject," said Mellen, Ch. J., "seems to be plain and well-settled. A possession must be adverse to the true owner, in order to constitute a disseisin. The possessor must claim to hold and improve the land for his own use, and exclusive of others." He next states, that in a count on the demandant's seisin, it was never incumbent on the tenant to prove more than his continued possession and occupancy for thirty years next before the commencement of the action, using and improving the premises after the manner of the owncr of the fee; and he then subjoins, that such possession, unless explained, affords satisfactory evidence to the jury, that such tenant claimed to hold the land as his own.

In the case of Brown v. Gay, 3 Greenl. (Me.) 126, the question was, whether the tenant was in possession of certain land by disseisin. $\mathrm{He}$ owned a lot denominated No. 3, and was in possession of lot No. 4, claiming that it was part of the former lot. He was, therefore, in possession through mistake. This principle was advanced, by the court, to wit: "If the owner of a parcel of land, through inadvertency or ignorance of the dividing line, includes a part of an adjoining tract within his enclosure, this does not operate a disseisin, so as to prevent the true owner from conveying or passing the same by deed."

If the learned court meant to lay down the position, that although the possession was adverse and a disseisin, yet that it was of such a character as not to prevent the owner from transferring the land by deed, the case has no bearing on the one before us. But if it was intended to declare, that there was no disseisin at all, by reason of the before mentioned mistake, I cannot accede to the proposition. There 
was a possession, it was not under the true owner, but it was under a claim of right; and the rents and profits (if any) were received and appropriated to the possessor's use, without any supposed or assumed accountability. This is a disseisin, by all the cases on the subject, with every mark or indicium of one upon its face. If the possession were incidental to the taking of something off the property, it would be a trespass only. But when the possession is a permanent object, under a claim of right, however mistaken, what can be a disscisin, if this is not? That the possessor meant no wrong, might be very important, if he were prosecuted for a crime; for nemo fit reus, nisi mens sit rea. But the motive, which induced the taking possession, is remotely distant from the possession in fact under a clam of right, and in no respect tends to qualify or give character to the act. It was adverse possession and disseisin (innocently happening) with the full intention of the mind to possess exclusively; and by necessary consequence, a seclusion of the owner from the scisin of his property.

I agree with the learned court, that the intention of the possessor to claim adversely, is an essential ingredient. But the person who enters on land believing and claining it to be his own, does thus enter and possess. The very nature of the act is an assertion of his own title, and the denial of the title of all others. It matters not, that the possessor was mistaken, and had he been better informed, would not have entered on the land. This bears on another subject-the moral nature of the action; but it does not point to the enquiry of adverse possession. Of what consequence is it to the person disseised, that the disseisor is an honest nnan? His property is held, by another, uncler a claim of right; and he is subjected to the same privation, as if the entry were made with full knowledge of its being unjustifiable.

In the case of Ross v. Gould, 5 Greenl. (МIc.) 204, it is said, "a disseisin cannot be committed by mistake, because the intention of the possessor to claim adversely, is an essential ingredient in disseisin." I do not admit the principle. It is as certain that a disseisin may be committed by mistake, as that a man may by mistake take possession of land, claiming title and believing it to be his own. The possession is not the less adverse, because the person possessed intentionally, though innocently. But in the moral nature of the act, there is undoubtedly a difference, when the possessor knowingly enters by wrong.

I have been the more particular in my observations, for two reasons. The first is, that the evidence of adverse possession, which is of very frequent occurrence, might be placed on grounds clear and stable: The next, from a serious apprehension that in the law of disseisin, an important change is inadvertently attempted. Adopt the rule, that an entry and possession under a claim of right, if through mistake, does not constitute an adverse possession, and a new principle is substitutcd. The enquiry no longer is, whether visible possession, with the intent to possess, under a claim of right, and to use and enjoy as one's own, is a disseisin; but from this plain and easy standard of 
proof we are to depart, and invisible motives of the mind are to be explored; and the enquiry is to be had whether the possessor of land acted in conformity with his best knowledge and belief.

In the case before us, the plaintiff adduced evidence to show, that he entered on the land in question, and possessed it more than fifteen years, uninterruptedly and exclusively, under a claim and belief of right, and appropriating to his own use, without account, all the rents and profits. This was adverse possession and disseisin, and gave him titie under the law of the state.

Upon this principle, the charge was incorrect, and a new trial is advised.

the other judges were of the same opinion, except PETERS, J., who was absent.

New trial to be granted. ${ }^{10}$

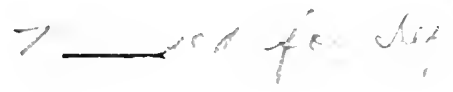

PREBLE v. MAINE CENT. R. CO.

(Supreme Judicial Court of Maine, 1893. 85 Me. 260, 27 Atl. 149, 21 L. R. A. 829, 35 Am. St. Rep. 366.)

This was a real action brought to determine the dividing line between adjoining owners.

The case is stated in the opinion.

A principal issue between the parties was that of adverse occupation, the plaintiff claiming that thereby he had acquired a title to the disputed premises. The testimony bearing upon this issue and coming from the plaintiff's cross-examination, is as follows:

"Q. Previous to your deed to the railroad of the two rod strip between you and them, was there anything to mark the western boundary of their location? A. Yes, there was a fence on their western boundary. Then they took two rods more and moved the fence. I deeded it to them.

$19 \mathrm{~A}$. conveyed fifty acres of his land to $\mathrm{B}$. In building a line fence between the two properties $A$., by mistake, inclosed serenteen acres of B.'s laud. and occupied same for the period of the statute of limititions. In ejectment by $\mathrm{B}$. against $\mathrm{A}$. to recorer possession of the serenteen acres, $\mathbb{A}$. claimed by adverse possession. B. offered to prore that after the fence was built $A$. said that "he thought the fence was on the correct line, but if it left B. with less than fifty acres, the fence would have to be mored." Was the eridence offered material? See King $\mathrm{r}$. Brigham, 23 Or. 202, 31 Pac. 6\%1, 15 L. R. A. 361 (189:); Schaubuch r. Dillemuth, 108 Va. 86,60 S. E. 745,15 Ann. Cas. S25 (190S); Searles v. De Ladson, S1 Conn. 193, 70 Atl. $5 \subseteq 9(1908)$.

An ignorant woman, a devisee of certain lands, inclosed 'more than she was entitled to, and occupied same for more than the period of the statute of limitations. In ejectment against her by the paper title owner, she set up the statute. Qn examination during the trial she ssia she "had nerer want. ed more than the will gave her, but she knew the will gave her what she had nnclored" Thas her possession adverse? Johnson v. Thomas, 23 dpp. D. C. 141 (1901). 
"Q. It was your understanding and also the understanding of the railroad company that the fence was moved back to correspond with the new line? A. Yes, sir.

"Q. Your occupation ever since has been based upon that understanding and supposition, has it not? A. I always supposed that was the line.

"Q. When you made your deed to the railroad company of the tworod strip, and then occupied afterwards up to this fence, you did not intend thereby to encroach on the land which you had just deeded to the railroad? A. I supposed I was using my own land. I moved the fence in at one time two feet.

"Q. Down to the time when you moved it in yourself, the fence was kept as it was put up shortly after the deed of the two-rod strip? A. They told me they had taken two rods.

"Q. How long after you delivered to the railroad company your deed of the two-rod strip was the fence moved back to correspond to the new line? A. The fence was moved back before I gave the deed; it was within that year. I was away at sea; when I came home they told me they had taken it.

"Q. From that time since you have regarded the fence line as the true line? A. I have.

"Q. And occupied up to it on that account and on that ground? A. Occupied it on account I thought it was my own land."

Whitehouse, J. In this writ of entry the plaintiffs seek to recover a small piece of land, triangular in shape, now covered by a portion of the defendant's freight platform at the Richmond station. The case is presented on report and discloses no material controversy respecting the facts. The rights of the parties must, therefore, be determined by applying the established principles of law to the fair and reasonable inferences drawn from the facts proved or admitted.

The original location of the defendant's railroad in 1848 was made four rods in width at the point in question, its westerly boundary being the easterly line of the premises then owned by the plaintiff's father. But in 1852 the company purchased of the plaintiffs, who had in the meantime acquired title to the property, an additional strip two rods in width, extending across their lot, and adjoining the original location on the westerly side. At the same time the fence which had been erected on the supposed boundary line in 1848, was moved westerly by the defendant's servants for the purpose of enclosing the two rods then purchased; but the plaintiff, Israel Preble, testifies that in re-building the fence in " 1864 or 1866" he moved it two feet further on to his own land. Prior to 1889 the defendants had used only a part of this additional strip, and hence there had been no occasion for an accurate survey of the land. But when at the last named date, it became necessary to enlarge the freight platform, measures were taken to have the boundary line between the parties definitely ascertained and fixed. It was then discovered from the record of the original lo- 
cation that the "central or directing line" of the railroad was not in the centre of the four rods of land taken for the construction of the road, but was twenty-eight feet from the easterly line and thirtyeight feet from the westerly line of the location. It accordingly appeared that the true boundary of the defendant's land on the west was thirty-eight feet and two rods or seventy-one feet from the centre of the main track of the railroad. By this measurement the boundary line was found to be west of the existing fence a distance of two feet and eight-tenths at the southerly end and eight feet and ten inches at the northerly end. Whether the mistake made by the defendant's servants respecting the distance the fence should have been moved in 1848 , arose in part from an erroneous assumption that the central line of the track was the centre of the location, or otherwise, does not appear, and it is not material to inquire. There is not only no evidence that the main track has been moved at this point since the original location but it is satisfactorily shown that it has not been moved; and the simple process of drawing a line seventy-one feet westerly from the centre of the main track and parallel with it now establishes beyond a doubt the location of the westerly line of the two-rod strip. The triangular piece in controversy is thus conclusively shown to be wholly on the east side of the true line, and hence a part of the land purchased of the plaintiffs in 1852 .

But Israel Preble, the surviving plaintiff, claims that he cannot at this date satisfactorily locate his easterly line by measurement; and says that he has continually occupied the land to the fence as it existed in 1889 upon the understanding and belief that it marked the true line, and he now claims title to the disputed piece by adverse possession. And the question is, can this claim on the part of the plaintiff be sustained on the facts here presented? Clearly not, unless the rule established by an unbroken line of the decisions of this court covering a period of nearly seventy years, is now to be overturned. That rule is that one who by mistake occupies for twenty years, or more, land not covered by his deed with no intention to claim title beyond his actual boundary wherever that may be, does not thereby acquire title by adverse possession to land beyond the true line. Brown v. Gay, $3 \mathrm{Me}$. (Greenl.) 126; Ross v. Gould, 5 Me. (Greenl.) 204; Lincoln v. Edgecomb, 31 Me. 345 ; Worcester v. Lord, 56 Me. 266, 96 Am. Dec. 456; Dow v. McKenney, 64 Me. 138.

We are aware that the soundness of this doctrine has been questioned in other jurisdictions. It has been said that the possession is not the less adverse because the person possessed intentionally though innocently; and the further objection has been made that it introduces a new principle by means of which the stable evidence of visible possession under a claim of right, is complicated with an inquiry into the invisible motives and intentions of the occupant. French v. Pearce, 8 Conn. 439, 21 Am. Dec. 680; Wood on Limitations, § 263, and authorities 
cited. It is manifest, however, that those holding these views have not critically distinguished the decisions of our court upon the subject, and hence have failed to apprehend their true import and exact linitations.

A frequent recurrence to elementary truths in any science is the greatest safeguard against error, and in the ultimate analysis of the doctrine of adverse possession the distinctive element which supports the rule above stated at once becomes apparent. Indeed it is aptly suggested in the familiar test imposed by Bracton: "Quærendum est a judice quo animo hoc fecerit." Co. Littl. 153 b; 8 Mod. Rep. 55. The inquiry must be quo animo is the possession taken and held.

There is every presumption that the occupancy is in subordination to the true title, and if the possession is clained to be adverse the act of the wrong-doer must be strictly construed, and the character of the possession clearly shown. Roberts v. Richards, 84 Me. 1, 24 Atl. 425, and authorities cited. "The intention of the possessor to claim adversely," says Mellen, C. J., in Ross v. Gould, supra, "is an essential ingredient in disseizin." And in Worcester v. Lord, supra, the court says: "To make a disscizin in fact there must be an intention on the part of the party assuming possession to assert title in himself." Indeed the authorities all agree that this intention of the occupant to claim the ownership of land not embraced in his title, is a necessary element of adverse possession. And in case of occupancy by mistake beyond a line capable of being ascertained, this intention to claim title to the extent of the occupancy must appear to be absolute and not conditional; otherwise the possession will not be decmed adverse to the true owner. It must be an intention to clain title to all land within a certain boundary on the face of the earth, whether it shall eventually be found to be the correct one or not. If for instance one in ignorance of his actual boundaries takes and holds possession by mistake up to a certain fence beyond his limits, upon the claim and in the belief that it is the true line, with the intention to claim title, and thus if necessary, to acquire "title by possession" up to that fence, such possession having the requisite duration and continuity, will ripen into title. Hitchings v. Morrison, $72 \mathrm{Me}$. 331, is a pertinent illustration of this principle. See, also, Abbott v. Abbott, 51 Me. 575 ; Ricker v. Hibbard, 73 Me. 105.

If on the other hand a party through ignorance, inadvertence or mistake, occupies up to a given fence beyond his actual boundary, because he believes it to be the true line, but has no intention to claim title to that extent if it should be ascertained that the fence was on his neighbor's land, ai indispensable element of adverse possession is wanting. In such a case the intent to claim title exists only upon the condition that the fence is on the true line. 'The intention is not absolute, but provisional, and the possession is not adverse. Dow v. McKenney, $64 \mathrm{Me} .138$, is an excellent illustration of this rule. In that case a fence had been maintained on a wrong divisional line by mistake, and it was found by the court as a matter of fact that "none of the 
parties had any idea of maintaining any line but the true divisional line and that they occupied according to the fence only because they supposed it was on the true divisional line between them." Upon this finding it was held as a matter of law that such possession was not adverse to the right of the true owner. The unconditional intent to claim title to the extent of the occupancy was wanting. See, also, Worcester v. Lord, 56 Me. 266, 96 Am. Dec. 456.

Thus it is perceived that possession by mistake as above described may or may not work a disseizin. It is not merely the existence of a mistake, but the presence or absence of the requisite intention to claim title that fixes the character of the entry and determines the question of disseizin. The two rules are expressly recognized and carefully distinguished in our recent decisions. The distinction between them is neither subtle, recondite or refined, but simple, practical and substantial. It involves sources of evidence and means of proof no more difficult or complex than many other inquiries of a similar character constantly arising in our courts.

The conclusions of fact which are fairly warranted by the evidence leave no room for doubt that the case at bar falls within the principle last stated. It has already been seen that, prior to 1889 , both parties were ignorant of the fact that the fence erected by the plaintiff in "1864 or 1866" was not on the true line. The plaintiff, Israel Preble, himself testifies that after he moved the fence he had always regarded it as the true line; that he had occupied the land up to the fence upon the supposition and belief that it was the true line and that he had so occupied it because he thought it was his own land. This testimony, viewed in the light of the circumstances and situation of the parties, emphatically negatives the idea that during this time the plaintiff had any intention to claim title to land which did not belong to him. IVe are warranted in believing that it would do injustice to the plaintiff himself, as well as violence to all the probabilities in the case, to assume that immediately after the plaintiff had conveyed the land to the defendant for a satisfactory consideration, he formed the intention of depriving the company of a portion of the same land by disseizin in case the fence should not prove to be on the true line.

The conclusion is irresistible that the plaintiff held possession of the locus by mistake in ignorance of the true line, with an intention to claim title only on condition that the fence was on the true line. His possession was, therefore, not adverse to the true owner, and cannot prevail against the valid record title of the defendant. Judgment for the defendant. ${ }^{20}$

Peters, C. J., Walton, Virgin and Haskeld, JJ., concurred. EmERY, J., did not concur.

20 See Richardson v. Watts, 94 Me. 476, 4S7, 4S Atl. 180 (1901); Doolittle v. Bailey, s. Iowa. 395, 52 N. W. 337 (1592) (but see Grube $\checkmark$. Wells, 34 Iowa, 14S [1s71]); Miller v. Mills County, 111 Iowa, 654, S2 N. W. 1035 (1000); 


\section{BOND v. O'GARA.}

(Supreme Judicial Court of Massachusetts, 1900. 177 Mass. 139, 5S N. E. 275. $83 \mathrm{Am}$. St. Rep. 265.)

Writ of entry, to recover a tract of land situated in Leicester. Plea, general issue. Trial in the Superior Court, before Gaskill, J., who allowed a bill of exceptions, in substance as follows.

The demandant claimed title through a deed to him on the premises by one Lanphear, dated March 11, 1899. Lanphear's title came from a deed dated January 5, 1899, also delivered on the land, to him, by Kate Hanlon and her children, being the children and heirs of her deceased husband, John Hanlon. The tenant clained title through a lease from the heirs of one Olney, deceased, dated December 9, 1898. The paper title was shown to be in the heirs of Olney by a series of conveyances beginning with the deed of one Burr to Buchanan, June 4, 1863. The demandant claimed that John Hanlon or his widow, Kate Hanlon, or his heirs who signed the deed to Lanphear, had acquired a title to the premises by possession for twenty years.

There was evidence tending to show that John Hanlon entered upon the premises about the year 186t, cut the wood and tinber, and thereafter occupied the same for a garden and for pasturing his cow and for other purposes, the evidence tending to show that this occupation was exclusive and continuous. There was evidence tending to show that John Hanlon entered upon the premises either in pursuance of a verbal gift of the land to him by Samuel L. Hodges, or by a permission to occupy the same granted to him by Hodges, who became owner of the premises by a deed from Patrick Hanover, dated October 30,1865 , and Hodges conveyed the same to one Gilbert and others on October 19, 1866. John Hanlon died in 1873, and thereupon his widow continued to occupy the premises in the way in which her husband had done, and in the way in which she occupied the adjoining farm, the title to which was in John Hanlon at the time of his death. Some of her children, the heirs of John Hanlon, lived with her and worked on the premises in question. The evidence tended to show that this occupation of John Hanlon during his life and that of Kate Hanlon was open and continuous and exclusive, and the principal question in controversy was whether the occupation was under a claim of right or under a license or permission from Hodges. Kate Hanlon testified, and some of her children testified, and there was evidence tending to show that the occupation was under the claim that Samuel L. Hodges had given the land to John Hanlon, and that Kate claimed to occupy it as her own because Hodges had given it to her husband.

Helmick v. Railway Co. (Iowa) 156 N. W. 736 (1916); Edwards r. Fleming, 83 Kan. 653, 112 Pac. 836, 33 I. R. A. (N. S.) 923 (1911); Slkansi v. Novak, 81 Wash. 39, 146 Pac. 160 (1915). 
This evidence was controverted by the tenant, who put in evidence that said Kate Hanlon had stated that Hodges had given to her husband and herself the right to occupy the premises and the right to cut the grass, etc. The deeds from Burr to Buchanan, from Buchanan to Hanover, and from Hanover to Hodges, reserved a right to the Leicester Reservoir Company, whose pond bordered on the premises, to take material for its dam from the premises; and there was evidence that an employee of the Leicester Reservoir Company had crossed the premises and had torn down a fence within twenty years, which had been put up by Kate Hanlon, and that thereupon Kate Hanlon had restored the fence. After the employee had torn it down the second time she left an opening where he could go through, and thereafter the fénce was left undisturbed.

There was no evidence, except such as may be inferred from the evidence herein stated, that any of the owners of the paper title of the land, except Hodges, had ever given any license or permission, or had any knowledge of any license or permission to John Hanlon or Kate Hanlon, or the heirs of John Hanlon, to occupy the premises.

The demandant asked the judge to instruct the jury as follows: 1 . If the owner of the land verbally gave the land to John Hanlon, and thereupon Hanlon entered on the premises and occupied them continuously till his death, claiming to own them, and was not interfered with in said occupation, and immediately upon his death his widow continued to occupy the same continuously in the same way, and the whole period of such continuous occupation amounted to twenty years, the jury would be authorized to find that the title was in Mirs. Hanlon, or in her and the heirs at law of said John Hanlon, and that the title passed to the demandant by virtue of deeds which were annexed as Exhibits A and B. 2. If the occupation of Mrs. Hanlon has been sufficient to give a title, under the rules of law given you, but for some license or permission which might qualify such occupation, then the said license or permission must appear to be a license or permission granted by the owner before or at the time the occupation is going on, or in force during the time of such occupation. 3. Any license or permission given by Hodges during his ownership is, in itself, of no legal importance, as affecting occupancy by Mrs. Hanlon subsequent to the date when he parted with his title, and it could have no force in this case, uniess there is evidence that the grantees of Hodges, while owners, renewed or adopted, or in some way intentionally continued or revived, such license or permission. 4. If the occupation of Mrs. Hanlon of the premises in question for twenty years was such that the real owner of the premises could have sued her for trespass for such occupation, then said occupation was adverse within the meaning of the law. 5. On the evidence in the present case the occupation by Mrs. Hanlon of the premises in question, cultivating the same, cutting the hay and grass on the same, and pasturing her cow thereon, was such 
occupation as would support an action of trespass on the part of the owner of the estate, in the absence of any license or permission given by the person who owned the premises at the time of said occupation.

The judge refused to give the instructions in the form requested, but after general instructions as to adverse possession instructed the jury, in substance, that if Hanlon's occupancy was not by gift," ${ }^{1}$ but by permission only, he did not acquire any right against the owner of the land; that the right of Hodges to continue that permission ceased, as matter of law, with the deed given by him on October 19, 1806; that if Hanlon, wife or children, continued to occupy on the belief that the permission continued, no right could be acquired, but that if the occupancy was on the belief that the land was theirs, and continued twenty years uninterruptedly, being adverse and open, a title would be acquired. He further instructed them that, if the first occupation by the father was adverse and the children continued their occupation, they could add the time of their occupation, if they claimed title, to that of their father, but, if not, then, if the mother's belief was that Hodges had given the land to her husband, her uninterrupted occupation for twenty years, if adverse and open, would give a good title; and that if the occupation by Mrs. Hanlon or the heirs was exclusive, except as to the right reserved to the Leicester Reservoir Company, it was sufficient, because that right was reserved by the deed and exercised thereunder.

The demandant excepted to the refusal to give the instructions prayed for, and to the actual instructions given so far as they differed from the instructions prayed for.

The jury returned a verdict for the tenant; and the demandant alleged exceptions.

Holmes, C. J. This is a writ of entry. The demandant claims title under $a$ deed from the widow and heirs of one John Hanlon, setting up a title in them by the running of the statute of limitations. There was evidence that the holding of John Hanlon and his widow and heirs had been under a claim of right adverse to all the world. There was also evidence that their occupancy had been under a license from one Hodges, who owned the land after October, 1865, and conveyed it in October, 1866. The question raised by the demandant's bill of exceptions is whether the fact that the license was ended in 1865 by the conveyance of Hodges necessarily made the occupation by the Hanlons adverse, if they supposed the license still to be in operation and purported to occupy under it, but were in such relations to the land that they would have been liable to an action of trespass, or, better to test the matter, to a writ of entry at the election of the true owner.

The answer is plain. "If a man enter into possession, under a supposition of a lawful limited right, as under a lease, which turns out to

21 As to the possession of a donee under a parol gift being adrerse or not, see Johus . Johns, 244 Pa. 48, 90 Atl. 535 (1914). 
be void, *** if he be a disseisor at all, it is only at the clection of the disseisee. $* * *$ If the party claim only a limited estate, and not a fee, the law will not, contrary to his intentions, enlarge it to a fee." Ricard v. Williams, 7 Wheat. 59, 107, 108, 5 L. Ed. 398; Blunden v. Baugh, Cro. Car. 302, 303; Stearns, Real Actions, (2d Ed.) 6,17 .

It is true, of course, that a man's belief may be immaterial as such. Probably, although the courts have not been unanimous upon the point, he will not be the less a disseisor or be prevented from acquiring a title by lapse of time because his occupation of a strip of land is under the belief that it is embraced in his deed. His claim is not limited by his belief. Or, to put it in another way, the direction of the claim to an object identified by the senses as the thing claimed overrides the inconsistent attempt to direct it also in confornity to the deed, just as a similar identification when a pistol shot is fired or a conveyance is made overrides the inconsistent belief that the person aimed at or the grantee is some one else. Hathaway v. Evans, 108 Mass. 267 ; Beckman v. Davidson, 162 Mass. 347, 350, 39 N. E. 38. See Sedgwick \& Wait, Trial of Title to Land (2d Ed.) § 757. So, knowledge that a man's title is bad will not prevent his getting a good one in twenty years. Warren v. Bowdran, 156 Mass. 280, 282, 31 N. E. 300.

In the cases supposed the mistaken belief does not interfere with the claim of a fee. But when the belief carries with it a corresponding limitation of claim the statute cannot run, because there is no disseisin except the fictitious one which the owner may be entitled to force upon the occupant for the sake of a remedy. Hoban v. Cable, 102 Mich. $206,213,60 \mathrm{~N}$. W. 466. Liability to a writ of entry and disseisin are not convertible terms in any other sense. It is elementary law that adverse possession which will ripen into a title must be under a claim of right. (Harvey v. Tyler, 2 Wall. 328, 349, 17 L. Ed. S71,) or, as it has been thought more accurate to say, "with an intention to appropriate and hold the same as owner, and to the exclusion, rightfully or wrongfully, of every one else." Sedgwick \& Wait, Trial of Title to Land (2d E d.) § 576. “As Co. Lit. 153b, defines, 'a disseisin is when one enters, intending to usurp the possession, and to oust another of his frechold;' and therefore quærendum est a judice, quo animo hoc fecerit, why he entered and intruded." Blunden v. Baugh, Cro. Car. 302, 303.

The other matters apparent on the bill of exceptions were sufficiently dealt with by the judge. Exceptions overruled. ${ }^{22}$

\footnotetext{
( 22 An administrator takes possession of land which belonged to the deceased under the supposed authority of his office as administrator, though in filct he had no such right to possession. Is his possession adverse to the heirs, who were entitled to possession? Suppose the administrator purports to convey the land to his wife, but continues to reside npon the premises. Is the 1rossession adrerse? See Ashford v. Asbford, 136 Ala. 631, 34 South. 10, 96 Am. St. Rep. \&2 (1902).
} 


\section{FORTIER v. BALLANCE.}

(Supreme Court of Illinois, 1849. 5 Gilman 41.)

Forcible detainer, brought by the appellee against the appellants, and originally heard before a justice of the peace of Peoria county, when a verdict was rendered in favor of the plaintifi. The defendants appealed to the Circuit Court, and the cause was tried at the October term, 184S, before the Hon. John D. Caton and a jury, when a verdict was again rendered in favor of the original plaintifi.

Trumbull, J. This was an action of forcible detainer, brought by Ballance against Fortier \& Blumb. Verdict and judgment of restitution in favor of Ballance.

The evidence shows that Ballance leased the premises for the term of six years from January $1,18+2$, at the rate of ten dollars to be paid every four months; that he reserved by the lease the right to re-cnter and take possession of the premises in case of failure to pay rent as it became due; that the lessees occupied the premises for some time, and afterwards assigned to Blumb, one of the defendants below, who entered into possession and paid rent for a time to Ballance; that about the month of February, 1846, Blumb made arrangenents for the occupation of the premises with his co-defendant Fortier, to whom he gave possession, and whose tenant he became, disclaiming to have anything more to do with Ballance, and alleging that Fortier was the owner of the land. Ballance, after having given notice and made demand in writing for the possession of the premises, on the second day of March, 1846, and before the expiration of the six years for which the premises had been let, commenced this action.

The defendants below set up title to the premises in Fortier.

Two principal causes have been assigned for the reversal of the judgment. First, that the action was prematurely brought, the time for which the premises were let not having expired. It is clear that Ballance could not maintain this action till he was entitled to the possession of the premises, and it may be true, as insisted by the appellants, that he was not entitled to the possession under the clause in the lease authorizing him to re-enter in case of failure to pay rent, for the reason that there is no evidence to show either that a demand had been made for the rent due, or any of those acts done which are necessary in the first instance to create a forfeiture for the nonpayment of rent; but be this as it may, the evidence shows that Blumb was the tenant of Ballance, that Fortier got into possession by arrangement with Blumb, who thereupon disclaimed holding under Ballance, and attorned to Fortier, as the owner of the premises. The moment that Blumb disavowed the title of Ballance and claimed to set up a hostile title in Fortier, the lease became forfeited, and Ballance's right of entr: AIG.PROP.-5 
complete. Adams on Ej. 199. "A tenant cannot make his disclainer and adverse ciam so as to protect hminselt during the unexpired term of the lease; he is a trespasser on him who has the legal title. The relation of landlord and tenant is dissolved, and each party is to stand upon his right. If the tenant disclaims the tenure, clams the fee adversely in right of a third person or his own, or attorns to another, his possession then becomes a tortions one, by the forfeiture of his right." Willison v. Watkins, 3 Pet. 43, 7 L. Ed. 596.

Notwithstanding blumb had a lease for a term not then expired, the moment he disclaimed to hold under the lease, and set up title to the premises, his possession became adverse to his landlord, and it would be strange if while his title was maturing by adverse possession, he could claim the protection of the lease to prevent his being turned out. "A tenant disclaiming his landlord's title, is not entitled to notice to quit; but is liable instantly to a warrant of forcible detainer." Bates v. Austin, 2 A. K. Marsh. (Ky.) 270, 12 Am. Dec. 395. Blumb, in setting up a title adverse to that of Ballance by his own act terminated the lease, and put an end to the time for which the premises had been let, just as effectually as if the full term of six years had expired.

The judgment of the Circuit Court is affirmed with costs. Judgment affirmed. ${ }^{23}$

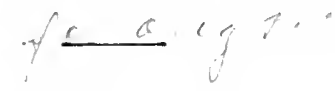

\section{DOE ex dem. PARKER v. GREGORY. \\ (Court of King's Bencli, 1834. 2 Adol. \& L. 14.)}

Ejectment for lands in Gloucestershire. On the trial before Alderson, B., at the last Gloucester Summer Assizes, the following facts were proved. Thomas Rogers, being seised in fee of the lands in question, derised them to his son Thomas Rogers for life, remainder to William Rogers in tail male, remainder to the devisor's right heirs in fee. The will gave a power to the tenant for life to settle a certain portion of the lands upon his wife for life, by way of jointure. After the death of the devisor, the son Thomas Rogers, being then tenant for life, settled the lands in question, being not more than the portion defined, upon his wife for life. He died in 1798, leaving his wife surviving, who afterwards married a person of the name of Tale. In 1810, Mr. and Mrs. Vale levied a fine of the lands to their own use in fee. In 1812, Mrs. Vale died, more than twenty years before

23 In England, excent in cases of periodic tenancies and of course tenancies at will, the disclaimer, in order to effect a forfeiture, must be by record. Doe d. Graves v. Wells, 10 A. \& 1. 427 (18:39). A tortious alienation by the tenant was also effective under the older law to bring about a forfeiture. Litt. $\S 415$. As to the situation to-day, where the tenant makes a conreyance in fee, see Gee v. Hatley, 114 Ark. $376.170 \mathrm{~S}$. W. 72 (1914). In this country a few early cases amnounced the same doctrine as Doe d. Graves v. Wells, supra. De Lancey $\vee$ Ganong, 9 N. Y. 9 (1S53); Rosseel r. Jarvis, 15 Wis. 571 (1862).

See Newman v. Rutter, \& Watts (I’a.) 51 (1839); Dahm v. Barlow, 93 Ala. 120, 9 South. 595 (1590). 
the commencement of this action. Mr. and Mrs. Vale had continued in possession of the lands until Mrs. Vale's death, and Mr. Vale from thenceforward continned in possession till his own death, which occurred in 1832. William Rogers died, leaving several children, all of whom died before Mrs. Vale; and of whom none left issue, except one daughter, who died one month before Mrs. Vale, leaving issue a son, who died without issue in 1814, within twenty years of the bringing of this action. The lessor of the plaintiff was heir at law to the derisor, Thomas Rogers. It did not appear how the defendant got into possession. On these facts, the learned judge nonsuited the plaintiff, on the ground that the right of entry was barred by the Statute of Limitations, but he reserved leave to move to set the nonsuit aside, and enter a verdict for the plaintiff.

PéR Curiam. The fine will make no difference; but, as to the question of the husband's adverse possession, we will take time to consider.

On a subsequent day Lord Denman, C. J., delivered the judgment of the court.

The other points moved by my Brother Talfourd were disposed of by the court, but we wished to consider whether he was entitled to a rule on the ground that there had been no adverse possession for twenty years. The fact was, that the defendant had been in possession for a longer period, from his wife's death, hut he came in originally in her right, and had not directly ousted the right ful owner, but merely continued where he was, to his exclusion. A case of Reading $\mathrm{v}$. Kawsterne, reported by Lord Raymond and Salkeld, (2 Idd. Raym. 830: s. c. 2 Salk. 423,) was mentioned; but in that citse, thongh an actual disseisin is declared necessary, those words must be taken with reference to the subject-matter, and are there contra-distmguished from the mere perception of rents and profits, in the case of jonnt-tenants. But in Doe dem. Burrell v. Perkins, 3 M. \& S. 271, the court was of opinion that a fine levied by a person who was in possession under the same circumstances as the defendant here, operated nothing, because he came in by title, and had no frechold by disscisin; and it was argued, that the defendant here was also to be considered as having entered rightfully, and committed no disseisin. We are, however, of opinion, that though this may be so for the purpose of aveiding a fine, it cannot prevent the defendant's possession from being wrongful, from the very hour when his interest expired by his wife's death. It is clear that he might hare been inmediately turned out by ejectment.

We think, therefore, that his continuing the same possession for twenty years entitles him to the protection of the Statute of Limitations, and that this action has been bronght too late. Rule refused. ${ }^{2+}$ ast.

24 Henry Souter, the owner of premises, devised them to his wife for life. The testator died in 1790, leaving John Solfer, mo caimed to be the eldest son and heir at law, and his said wife, him surviving. Tn 179!, the widow 


\section{HANSON et al. v. JOHNSON.}

(Court of Appeals of Maryland, 1\$\$4. 62 MId. 25, 50 Am. Rep. 199.)

Appeal from the Circuit Court for Kent County.

This was an action of ejectment, instituted on the 11th of April, 1882, by the appellants against the appellee. The case was tried upon an agreed statement of facts, which are sufficiently set forth in the opinion' of the Court. By consent a pro forma judgment was entered in the Court below in favor of the defendant, with the right of appeal by the plaintiffs.

Robixson, J. This is an action of ejectment, brought by the appellants, as heirs-at-law of Catherine $H$. Wroth, to recover an undivided half interest in a tract of land, of which she died seized.

The facts are these: Mrs. Wroth died in December, 1854, leaving a paper purporting to be a will, by which she devised the farm in controversy to her husband, Peregrine Wroth, for life, with remainder in fee to her nephew, George A. Hanson.

The will was not executed in due form to pass real estate, as required by the Act of 1S+2, chapter 293, then in force, because the consent of her husband, in writing, was not annexed thereto, and also because it was not executed sixty days before her death. It was admitted, however, to probate by the Orphans' Court of Kent County, and under it her husband, on the 1st of January, 1855, entered into possession of the property, claining title as tenant for life, and so continued in possession until the 5th of February, 1868, when he united with the remainderman, George A. Hanson, in a sale and conveyance of the same to the appellee, and who thereupon entered upon said property, and has continued in possession up to the institution of this suit.

Mrs. Wroth never had any children, and the appellants, as heirsat-law, are entitled to recover, unless their right is barred by the adverse possession of the appellee and of those under whom he claims.

A great deal has been said, as to what constitutes adverse possession, and it would be a wearisome task to examine at length the many cases in which this question has been considered. Prior to the Statute of 3 and 4 Will. IV, chapter 27, it was an ever-recurring and troublesome question in England, but by that Statute, passed in 1833, the

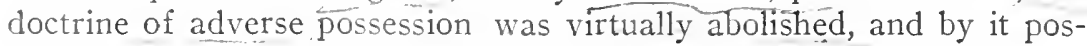

and John Souter joined in a capraxance of the oremises to Hull who topk possession and remained undisturbed therein till 1S14, when he died, leaving a IIII Wherebs he devised the oremises to defendants. In fact 1 Tालाer Souter was the eldest son and heir at law of Jenry Souter, whom he survived. In 1810, Whicher made his will, whereby he derised all his realty to trustees. Whicher Souter died shortly after making his will. In 1516 the plaintit as lessee of the sall trustees commenced an action of ejectment agallist the defendants to recorer possession. It was bed that the Diarun should recover, the judges reterring to Hull as a tenant at sufferance of Whicher souter. Doe d. Souter v. Hull, 2 Dowl. \& R. 3 S (1S22). 
session of any kind for twenty years was made a bar, unless there was either a payment of rent or an acknowledgnient of some kind by the party in possession. The effect of the Statute, says Lord Denman, in Culley v. Doe dem. Taylerson, 3 Per. \& Dav. 539, is to put an end to all questions and discussions whether the possession of lands be adverse or not; and if one party has been in possession for twenty years, whether adversely or not, the claimant whose original right of entry occurred above twenty years before bringing the ejectment is barrecl. Nepean v. Doe dem. Knight, 2 M. \& W. 911; Doe dem. Pritihaid v. Jauncey, 8 C. \& P. 99.

This Statute is not, however, in force in this State, and the question of possession in this case, is one to be determined by Stat. 21 Jas. I, cliap. 16, which provides that no one shall make an entry into any land but within twenty years after his right shall accrue.

Now when the question arose whether one was barred by twenty years possession, it was deternined by considering whether he had been out of possession under such circumstances as had reduced his interest to a right of entry; for if he had, then as that right of entry would be barred by the Statute at the end of twenty years, the possession during the intermediate time was adverse to him. And in order to determine whether he had been out of possession under such circumstances as reduced his estate to a right of entry, it was necessary to inquire in what manner the person who had been in possession during the time held. If he held in a character inconsistent with and hostile to the title of the claimant to the frechold, the possession was adverse. 2 Smith's Leading Cases, 531; Nepean v. Doe dem. Knight, 2 M. \& W. 910; Taylor ex dem. Atkyns v. Harcle, 1 Burr. 60.

"Twenty years adverse possession," says Lord Mansficld, in Taylor v. Horde, "is a positive title to the defendant; it is not a bar to the action or remedy of the plaintiff only, but takes away his right of possession."

The question then of adversary possession in this case, resolves itself into this, was the possession of Doctor Wroth, under whom the appellee claims, inconsistent with and hostile to the title of the appellants as heirs-at-law? And in regard to this question there ought not, it seems to us, to be any doubt. During the life-time of his wife he received, it is admitted, the rents and profits of the farm in controversy. To these he was entitled by virtue of his marital rights. Upon her death, this right ceased. He was not tenant by the curtesy, because his wife never had any children. He was not a tenant by sufferance, because an estate at sufferance is where one comes into possession by lawful title, but keeps it afterwards without any title at all. Or, as Lord Coke says, "one who originally comes in by right, but continues by wrong." It is a tenancy founded originally on contract and agreement, as a lessee for years, who continues in possession after the expiration of his term, and without a renewal of the lease, or a tenant at will, who holds over after the death or alienation of the 
lessor, or a tenant per autre vie, who remains in possession after the death of the cestui que vie. Coke on Little. $57 \mathrm{~b}$.

After the death of his wife, Doctor Wroth took possession, claiming a life estate under her will. His claim of title was inconsistent with and hostile to the title of the appellants as heirs-at-law. The property was a farm, under enclosure and under cultivation; his possession was actual, visible, and, according to all the authorities, adverse to the title of the lawful owner.

But then it is argued, to constitute adverse possession, one must claim the entire estate, or claim to the exclusion of all other rights. In one sense this is true. Possession will not be adverse if it be held under or subservient to a higher title, nor if it be consistent with the interest or estate of the claimant, for instance, where the possession of one is the possession of the other, or where the estate of one in possession and that of the claimant form different parts of one and the same estate. The mere entry and possession of one tenant in common, or joint tenant, or coparcener, will not be adverse to the co-tenant, because the possession of one, is the possession of the other. To constitute adverse possession in such cases, there must be an ouster, an entry and possession, lostile to the title of the co-tenant. Nor will the possession of a tenant for years, or tenant for life, be adverse to the reversioner or heir in remainder.

The decisions in Smith v. Burtis,9 Tolnns. (N. Y.) 1S0; Howard v. Howard, 17 Barb. (N. Y.) 667 ; Doe dem. Human v. Pettett, 5 Barn. \& Ald. 223; Dean et al. v. Brown, 23 MId. 16, 87 Am. Dec. 555; Bedell v. Shaw et al., 59 N. Y. 46, were decided upon these well settled principles.

In this case, however, Doctor Wroth entered into possession, claiming a life cstate under the will, the remainder being devised to another person. The estate claimed by him was a freehold, and as there could only be one possession or seizin of the same estate at the same time, his possession enured to the benefit of the remainder-man. His possession was in law the possession of the remainder-man, and as such it represented the entire estate, his own estate for life, and the estate of George A. Hanson in remainder. And his claim of title and possession being hostile to the title of the appellants as heirs-at-law, his possession was as against them, adverse and exclusive. The will was it is true invalid, but Doctor Wroth having entered into possession, claiming title under it, he would be estopped from denying the title of the remainder-man claiming under the same instrument. This was decided in Board v. Board, Law Rep. 9 Q. B. 48. In that case, a tenant by the curtesy undertook to devise the curtesy estate to his daughter for life, with remainder to his grandson. Upon the death of the testator, the daughter entered into possession, and having been in possession for twenty years sold and conveyed the property in fee to the defendant. In the meantime the grandson sold his reversionary right to the plaintiff, and upon the death of the daughter, he brought 
an action of ejectment, and it was held, that the daughter haring entered under the will, the defendant claiming under her, was estopped as against all those in remainder, from disputing the validity of the will, and that the plaintiff was entitled to recover.

Nellor, J., said, "The only person who could disjute the possession of Rebecca, under the will, was the heir-at-law. He nerer disputed the possession, and his title to the estate is barred by the operation of the Statute of Linitations. A person cannot say, that a will is valid to enable him to rake a benefit under it, but invalid so far as regards the interests of those in remainder, who clain under the same will." 25

This case was decided, it is true, after the passage of the Stat. of 3 \& 4. Will. IV, but the claim of title and possession by the daughter, being hostile and inconsistent with the title of the heir-at-law, her possession was alverse muder the Stat. 21 Jas. I, as againct the law ful title. And being adverse, the heir-at-law must hring his action within twenty years, or his tille will he barred by the Statute of I innitations. It is hetter, says the law, that the negligent owner who lias onlitted to assert his right within the time presciled by the Statute, slomili lose his rights than one should he rlistmiled in his possession, and harassed by stale demands after the profof on which lis title rests maty have been lost or destroyed. Put whaterer mathe the reasons or the pol icy of the law, twenty years alverse possession is a bar to the title, withont regard to the original right of the partics.

The possession being arlierse and exclusive in this case, the only to maining question is, whether it has been continuous for twenty years? And this depends upon whether the posseston of Doctor IVroth can be minited, or in other words tacked to the poscussion of the appellec.

Now the possession of sereral distinct occupants of land between whom no privity exists, camnot, it is true, he united to make up the statutory period, for the reason, if one quits or allandons the possession, the owner will be decmed to be in the constructive possescion of the property by reason of his title. The separate successive disscisins in such cases to not aid ench other, and their sereral possescinns cannot therefore be tacked, so as to make a continuity of posscssion.

But we take it to be well settled that where there is a privity of estate between the successive parties in possescion, then the possession of such parties may be united so as to make the twenty years required by the Statute. And it is equally well settled that such privity may be created by a sale and conveyance and possession under it, as well as by descent. As was said by Tilghman, C. J., in Orerfield v.

25 In England the rule of Foard $r$. Board is not consilered as apulicable in ficts such as appeared here. In l'e Anderson, [1005] "2 Ch. 70.

On the interesting question as between the life tenant and the remainderman, or those chiming under them, the lights of the true onner atmitted $y$ beins barred by the adrerse possession of the lite tenant, see, further, Dalton v. THzelald, [IST] 1 Ch. 440. 
Christie, 7 Serg. \& R. (Pa.) 177, "One who enters upon the land of another and continues to reside on it, acquires something which he may transfer by deed as well as by descent, and if the possession of such person, and others claiming under him, added together, amounts to the time limited by the Act of Limitations, and was adverse to him who had the legal title, the Act is a bar to a recovery." Angell on Imitations, 414, 420; Wood on Limitations, § 271; Tyler on Ejectment, 910.

In this case there was an adverse and exclusive possession of the farm in question by Doctor Wroth for thirteen years. He then united with George A. Hanson, the remainder-man, in a sale and conveyance to the appellee, who immediately entered and has continued in possession up to the present time; the possession of the appellee, thus added or tacked to the possession of Doctor Wroth, makes a continuous adverse possession of twenty-seven years. The possession under such circumstances is by the Statute of Limitations a flat bar to the right of the appellants as heirs-at-law.

The judgment below must therefore be affirmed. Judgment affirmed. ${ }^{26}$

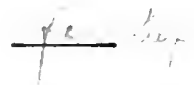

\section{DEAN v. GODDARD et al.}

(Supreme Court of Minnesota, 1893. 55 Minn. 290, 56 N. W. 1060.)

Appeal by defendant, Fred E. Goddard, from an order of the District Court of Hennepin County, Thomas Canty, J., made December 3, 1892, denying his motion for a new trial.

The plaintiff, Alfred J. Dean, brought this action September 2, 1891, under G. S. 1878 , ch. $75, \S 2$, to determine the adverse claims of Goddard, and all other persons or parties unknown claiming any right, title, estate lien or interest in the real estate described in the opinion. Goddard alone answered. He claimed to have the title in fee derived from the United States. Plaintiff replied that neither Goddard his ancestor, predecessor or grantor was seized or possessed of the lot within fifteen years next before the commencement of the action. That Alfred H. Lindley owned the lot in 1866 and he and wife on August 2S, 1866, conveyed it to William D. Washburn, that on or about June 1,1866, Washburn entered into actual possession of the lot under such deed and he and his grantees have ever since and for more than fifteen years prior to the commencement of this action,

26 Premises are owned by A., tenant for life, remainder in fee to B. X. enters into adrerse possession, and continues therein for more than the statutory period. What effect, if any, does such possession hare upon the rights of A.? Of B.? See Hoore v. Luce, 29 Pa. 260, 72 Am. Dec. 629 (1857) ; Baldridge $v$. McFarland, $26 \mathrm{~Pa}$. 338 (1S55), where the remainder may hare been contingent.

Suppose, in the above case, A. should make a deed purporting to convey the premises to $\mathrm{X}$. in fee, who takes possession, and contimues therein for the statutory leriod. See Cassem v. Prindle, 25S Ill. 11, 101 N. E. 241 (1913); Hooper v. Leavitt, 109 Me. $70, \$ 2$ Atl. 547 (1912). 
been in actual, exclusive, open, hostile and adverse possession thereof, under claim and color of title and that plaintiff is the remote grantee of Washburn.

A jury was waived and the issues were tried before the Court on August 2, 1892. Plaintiff submitted evidence of the possession of the lot by himself and his grantors and read in evidence the several instruments under which such possession had been held and rested. The defendant Goddard then proved his paper title from the Federal Government down and rested. The Court found plaintiff to be sole owner in fee and in possession of the lot and that he and his grantors and predecessors in interest had been in open, continuous, exclusive and adverse possession thereof, with color of title and paying taxes thereon, for a period of twenty years and ordered judgment for plaintiff as prayed in his complaint.

The defendant moved the Court to amend its findings so as to show that IVashburn's adverse possession commenced on or about August 28,1866 , the date of his rleed from Lindley and wife and not prior thereto. This motion was denied. Defendant then moved for a new trial, but was denied and he appeals, claiming the evidence does not show actual, continuous hostile occupation of the lot by plaintiff and his grantors for an uninterrupted period of fifteen years at any time since Washburn obtained his deed from Lindlcy. The discussion here was upon this evidence, whether it sustained the finding of adverse possession.

Buck, J. The question raised in this case is whether the plaintiff has acquired title by adverse possession to the premises described in the complaint, viz. the front half of lots one (1) and two (2) in block sixty-seven (67) in the city of Minneapolis.

The action was commenced in August, 1891. In his complaint the plaintiff alleges that he is in possession, and is the owner in fee simple, of the premises above described, and that the defendants claim some estate or interest in the premises adverse to the plaintiff, and prays that the claims of the respective parties be adjudged and cletermined, and that title to said premises be decreed to be in the plaintiff. The defendant Goddard answered, and alleged the title in fee to be in himself. The plaintiff replied, and such reply will be referred to hereafter. Plaintiff's contention is that he acquired title by possession held adversely for such a length of time as to create a title in himself.

Under G. S. 1878 , ch. $66, \S 4$, the time limited for commencing actions for the recovery of real property was fixed at twenty years; but on April 24, 1889, the law was changed to fifteen years, not to take effect, however, until January 1, 1891. The law, as amended, would be applicable to actions commenced after January 1, 1891, and prior to the time of the commencement of this action, in September, 1891; but this would not render the law existing prior to the amendment inapplicable to causes of action, when there was twenty years' arlverse 
possession before the time when the change took effect. The period, however, relied upon, need not be the twenty years immediately preceding the 1st day of January, 1891. It would be sufficient if the possession relied upon was continuous for tiventy years up to any certain or deninite time. Oi course, the twenty years would have to be complete before the bringing of the action; but such twenty years need not, necessarily, be those next before the time when the action is commenced. In this case, if the inception of the plaintiff's adverse possession was in the months of June or August, 1866, and became perfect by continued adverse possession until the month of June or August, iSS6, then the title thereby created would not be lost or forfeited by any subsequent interruption of the possession, unless by some other adverse possession for such a length of time as would create title in the possessor.

The court below found the allegations in the plaintifi's complaint to be true, and that he was, at the time of the commencement of this action, the sole owner, in fee, and in the lawful possession, of the premises described in the complaint, and that he and his grantors and predecessors in interest had been in the open, continuous, exclusive, and adverse possession of the premises, with color of title, and paying taxes thereon, for a period of twenty years, and that he was entitled to the decree and judgment of the court declaring him to be the absolute owner of the premises. We think a title acquired by adverse possession is a title in fee simple, and is as perfect as a title by deed. The legal effect not only bars the remedy of the orner of the paper title, but divests his estate, and vests it in the party holding adversely for the required period of time, and is conclusive evidence of such title. To say that the statutes upon this subject only bar the remedy, as some authorities do, is only to leave the fee in the owner of the paper title; thus leaving the owner with a title, but without a remedy. We think the better and more logical rule is to hold that the occupier of the premises by adverse possession acquires title by that possession, predicated upon the presumption or proven fact that the prior owner has abandoned the premises. Adverse possession ripens into a perfect title. This title the adverse possessor can transfer by conreyance, and when he does so he is conveying his own title, and not a piece of land where the title is in some other person, who is simply barred of any remedy from recovering it. See Campbell v. Holt, 115 U. S. 620, 6 Sup. Ct. 209, 29 L. Ed. 483; Baker v. Oakwood, 123 N. Y. 16,25 N. E. 312, 10 L. R. A. 387, and cases there cited. Now, if there is any cloud resting upon such title, he has a legal right to apply to the court, and have his rights adjudicated, and the title perfected by judgment record, if the evidence sustains his claim. Considerations of public policy demand that this should be so, for the claim of title to lands can thus be found of record, instead of resting in parol, with all of its incidental dangers and trouble in establishing title. 
Now let us consider the question raised by the defendant, as to whether one of the plaintiff's predecessors, IVashburn, entered into the adverse possession of the premises June 1, 1866, or August 28, 1866. The plaintiff clams such entry was on the 1st day of June, and the defendant insists that the true date, if there was any such adverse entry at all, is shown by plaintiff himself, in his reply, to be August 28 , 1866. The importance of these dates arises from the fact that there is evidence tending to show an adverse possession of the premises by the predecessors of plaintiff until the middle of July, 1886; and if the period of twenty years commenced June 1, 1866, of course, the expiration of that period would be June 1, 1886, and if the period commenced August 28, 1866, the twenty year period would expire August 23, 1886. Thus, the true date becomes material. The plaintiff, in his amended reply, inserted the following allegation, viz.: "That on or about the 1st day of June, 1866, and more than fifteen years prior to the commencement of this action, said William D. Washburn, under the deed hereinbefore recited, executed to him by said Lindley, and claiming thereby to be the owner of said premises, entered into possession and actual occupation of the same." The deed referred to bears date August 28, 1866. It may be that there is sufficient undisputed evidence to show an adverse possession during this particular time, but we think that, under the circunstances, the parties are entitled to the opinion of this court upon this phase of the case. 'The fault of the defendant's position is this: That he allowed the plaintiff to introduce and prove beyond dispute, by parol evidence, without objection, that Washburn entered upon these prenises June 1,1866 .

The rule, therefore, that the written allegations of the pleadings should control, does not apply. The defendant did not move to have the pleadings made certain and definite, nor to compel the plaintifi to elect upon which of the dates he would rely as the time of Washburn's entry upon the premises, but remained silent, and allowed the date of June 1, 1866, to be undisputably proven by the plaintiff. 'The allegations in the reply were repugnant as to the dates of Washburn's entry, but the defendant, by his conduct, waived his right to insist now that the date of such entry should be determined as of August 28,1866 . He is estopped by the admitted parol evidence from insisting that the written pleadings should be construed in his favor, and against the plaintiff.

There is no dispute, however, that Washburn did procure a deed of the premises from Lindley dated August 28, 1866; and the defendant therefore contends that Washburn's entry, if adverse at all, should only be considered as having commenced on the date of the deed. To support this contention, he invokes the doctrine that one who enters upon land under a mere agreement to purchase does not hold adversely, as against his vendor, until his agreement has been fully performed, so that he has become entitled to a conveyance. This 
doctrine is not applicable to this case. Washburn's entry and holding was not under this defendant, nor any of his predecessors holding paper title. As we have already stated, it appears that he was in possession on the 1st day of June, 1866; and whether by permission of Lindley, or by his own voluntary entry, is immaterial, as to his rights against parties other than Lindley, and Lindley is not complaining, or questioning his rights, or time of entry. Nor is defendant claiming title under Lindley. If permissive possession, with parol executory conditions attached, would not constitute adverse possession as between the parties, yet it might constitute adverse possession as against third persons or strangers. Washburn's entry was adverse as against those under whom defendant claims by paper title. If, therefore, Washburn's entry, of June 1, 1866, was his own adverse act, and he so continued in possession of the premises until long after August 28, 1866, there is no need of considering the doctrine of tacking, or the necessity of the continuity of possession. Obtaining a deed to the premises from Lindley would not destroy Washburn's previous adverse possession, nor break its continuity. He had a right to strengthen his adverse claim to the premises, if possible, by as many written conveyances from other parties claiming any interest therein as he saw fit, and thus give him color of title, and perhaps define the boundaries of the premises claimed by him.

The essential ingredients necessary to create title by adverse possession are now so well defined and understood that we shall not enter into any argument or discussion to show what they are. We merely state them in this connection that we may the more conveniently apply them to the undisputed facts in this case. "To be adverse, possession must be actual, open, continuous, hostile, exclusive, and accompanied by an intention to claim adversely." Sherin v. Brackett, 36 Minn. 152, 30 N. W. 551.

This leads us to the question raised by defendant, that the court below did not find, specifically, that plaintiff's possession, or the possession of his predecessors, was hostile. But it did find that such possession was open, continuous, exclusive, and adverse during the requisite period. The greater includes the less. If it was adverse, it was hostile. In Sedg. \& W. Tr. Title Land, $\S 749$, it is said that "it is tautology to say that adverse possession must be 'hostile.'" Such hostility may be manifested by acts of possession and use of the premises, plainly visible, actual, open, and continuous, such as appeared in this case, by using the premises for many years as a lumber yard, building a barn and shed thereon in 1866 or 1867, and keeping the same on the premises until they burned down, in March, 1884, and keeping a large number of horses on the premises and in the stables for many years. Also, storing machinery, lamp posts, castings, and other personal property, putting a large sign on the lot, with notice thereon that it was for rent, for a long term of years, were acts of hostility, as tending to show. very strongly that someone was assum- 
ing dominion over the premises, and had intended to, or was usurping the possession.

If, as was said by the Court in Stephens v. Leach, 19 Pa. 263, the adverse possessor "must keep his flag flying," yet it is no less essential that the actual owner should reasonably keep his own banner unfurled. The law, which he is presumed to know, is a continual warning to him that if he shall allow his lands to remain unoccupicd, unused, unimproved, and uncultivated, he may by adverse possession for a long period of time, fixed by law, be disseised thereof, and be deemed to have acquiesced in the possession of his adversary. In this case, the actual owners by paper title have never occupied the premises since the first owner obtained his title from the government, in 1855 or 1856 . Considerations of public policy demand that our lands should not remain for long periods of time unused, unimproved, and unproductive. Taxes should be promptly paid. It nowhere appears that the owners by paper title have ever paid any taxes, but they have allowed the adverse occupants, during a period of many years, to pay nearly $\$ 5,000$ taxes upon the premises. Payment of taxes shows claim of title. Paine v. Hutchins, 49 vt. 314 . We can readily understand how these statutes are called "statutes of repose." The burdens of government must be met; its educational interests provided for; its judicial, legislative, and executive functions maintained; and to do this our real property must be made productive, to the end, among other things, that taxes may be raised and paid from land not subject to continual litigation, but the titles thereto quieted. If the selfish, the indolent, and the negligent will not do this, there is no more merit in their clain than that of the adverse possessor, who does so, whatever may be said of the harshness of the statute of limitation. The settlement and improvement of the country, with its consequent prosperity, should be superior and paramount to the speculative rights of the land grabber, or selfish greed of those who seek large gains through the toil, labor, and improvements of others.

The hostile possession of the adverse claimants in this case fully appears. The possession has been open, visible, hostile, and notorions. as appears from the evidence. It has been exclusive, for no one else has made any claim to it. Those who have been on the premises, otl-er than plaintiff or his predecessors, have made no claim of right, but have paid rent to the adverse claimant, or were there simply as trespassers, which would not break the continuity of possession. The intent to claim may be inferred from the nature of the occupancy. Oral declarations are not necessary. Possessory acts, to constitute adverse possession, must necessarily depend upon the character of the property, its location, and the purposes for which it is ordinarily fitted or adapted. If a person should take possession of farm land, build a barn and shed thereon, and allow them to remain there for years, plow and cultivate the land and harvest the crops, pay taxes on the premises, and actually occupy them, for such a period of time, 
as is usually done by the actual owner of such farm land, with such open, notorious, visible, hostile, and exclusive acts as would destroy the actual or constructive possession of the true owner, if continued long enough, it would ripen into a complete title, although there might not be actual residence upon the premises by the adverse claimant or possessor. The acts necessary for such purpose night be different with a city lot. The question is to what purpose may it be ordinarily fit and adapted, and reasonably used. In a large manufacturing city, with vast lumber interest, the use of a lot for piling lumber thereon, and there storing it or keeping it for sale, might be the best use to which such lot could possibly be adapted. And, as part of such business, the building of a barn and shed thereon, for keeping and stabling horses used in procuring logs, as a part of such lumber business, would constitute a very strong ingredient of adverse possession.

The mere fact that time may intervene between successive acts of occupancy, while a party is engaged in such lumber business, as by taking his teams from such stable and shed, and using them in procuring logs to be sawed into lumber to be by him piled and stored upon such premises, does not necessarily destroy the continuity of possession. During such time, the lumber left upon the lot, the barn and shed there remaining, and various implements connected with such fumber business used upon the premises, would indicate that some one was exercising acts of dominion orer the lot, even though the party was occasionally and temporarily absent upon the business for which he was using such lot.

We think the whole record herein presents such a state of facts that the court below was justified in its finding and decision. If there was error in admitting testimony showing that sand was removed from the premises after the commencement of this action, it certainly could not have prejudiced the defendant.

We find no prejudicial error, and the order of the court below, denying a motion for a new trial, is affrmed. ${ }^{27}$

27 See Skipwith v. Martin, 50 Ark. 141, 6 S. W. 514 (1SS7). See, also, Rupley v. Fraser (Minn.) $156 \mathrm{~N}$. W. 350 (1910).

A. entered into the possession of land, supposing it belonged to the United states, and intending to acourre same under the United States laud laws. II fact the lind had alreaty been acouired from the goremment by $\mathrm{B}$. After A. Tas been in nossession for the period of the statute of limitations, he seeks to have his title quieted, or B. sues to recover possession. See Iowa Railroad Co. v. Blumer, 20 f U. S. 45\%. 27 Sup. Ct. 769, 51 L. Ed. 114 (1906): Maas צ. Burdetzke. 93 Minn. 295. 101 N. W. 182, 106 Am. St. Rep. 436 (1904); Boe r. Aruold, 54 Or. 52, 102 Pac. 290. 20 Anu. Cas. 533 (1909); Doe ex dem. Alabama State Land Co. v. Reck. $10 \mathrm{~S}$ Ala. 71, 19 South. 802 (1895): Heckescher v. Cooper, 203 Mo. 27S, 101 S. W. 658 (1907); Smith $\nabla$. Jones, 103 Tex. 632, 132 S. W. 469, 31 L. R. A. (N. S.) 153 (1910).

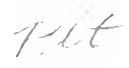




\section{MITCHELL v. MCSHANE LUMBER CO.}

(Circuit Court of Appeals, Fifth Circuit, 1915. 220 Fed. s78, 1966 C. C. A. 44 .)

IVAlkFr, Circuit Judge. The testimony of the plaintiff B. D. Mitchell was to the effect that he had liver on the land in guestion since 1889 and had been asserting claim to it since that time. He clirl not deny the making of the contract with the Beamont Lumber Company, which showed a lease by that company to him of the leagute of land which embraces the 160 acres sued for, but explicitly stated that he never relinquished his claim to the 160 acres, but claimed it all the time. The tendency of this evidence to prove adverse possession of the land in question by the plaintiffs for the length of time required to confer upon them the legal title wis not as a matter of law destroyed by the proof of the execution by one of them of the lease contract above mentioned. 'That contract evidenced an admission by B. D. Mitchell that he held the land, not as his own, but as the tenant si anether: lut that athission was not conclusive against him in favor of the defendant in this suit. In this suit it was permissible for the p antif B. D. Mitchell to contradict or explain away the statement or admission shown by his signing the lease contract, which embraced a league of land, and to prove that he in fact claimed the land sued for as his own all the time. That instrument did not give rise to an estoppel upon him in favor of the defendant to the suit, which is a stranger to that instrument, or debar him from proving that the fact was other than what the instrument indicated that it was.

"The rule against varying or contradicting writings by parol obtains only in suits between, and is confined to parties to the writings and their privies, and has no operation with respect to third persans, nor even upon the parties themselves in controversies with third persons. *** But this rule is confined in its operation to the parties to the written instrument. When it comes in question collaterally in a suit to which a third party, a stranger to the witings is a party neither party is estopped from contradicting it, or from proving facts $t$ inconsistent with it." Robinson v. Moseley, 93 Ala. 70, 9 South. 372; Myrick v. Wallace, 5 Ala. App. 398. 59 South. 704; Tohnson v. Portwood, 89 Tex. 235, 3+ S. W. 596, 787; Barreda v. Silsbee, 21 How. 146, 169, 16 L. Iid. 86: Sigua Iron Co. v. Greene, s8 Ferl. 207, 31 C. C. A. $477 ; 17$ Cyc. 750; Jones on Evidence, $\$ 296$.

The case of Robinson v. Bazoon, 79 Tex. 524, 15 S. IV. 585, which is much relied on by the counsel for the defendants in error, was one between the parties to a written contract relating to the land which was the subject of the suit. The rule there applied was the familiar one which forbids either party to such a contract in a suit between him and another party to it by parol evidence to contradict or vary the terms or effect of the contract. In the opinion rendered in that case 
it was recognized that that rule would not have applied in favor of the plaintiff if he had been a stranger to the contract.made by the defendants; the court saying of the case with which it was dealing:

"It is not like the case of Portis v. Hill, 14 Tex. 69, 65 Am. Dec. 99, in which it was held that the mere acknowledgment of title in a third party did not preclude the defendants from claiming that their possession was adverse to the plaintiff."

The situation dereloped by the evidence was that some of it-that showing the making of the lease contract-tended to prove that the plaintiff's adverse holding was interrupted on the 4th day of Jay, 1898, while some of it tended to prove that the plaintiffs' adverse holding was not terminated or interrupted by that incident. This state of the eridence made the question in issue one for the jury; and the court erred in its ruling to the effect that there was no evidence to support a finding in favor of the plaintiffs.

The judgment of the court below is reversed, and the cause is remanded. $^{28}$

28 Adverse Possession in Case of Minerals. - Tlien the minerals and surface are owned by the same party, as is ordinarily true, an adrerse possession of the surface is also an adverse possession of the minerals. But men the onluersip or possession is divided, the situation presents possibilities of serious difficulty. In the latter case possession of the surface by the one entitled thereto, no matter how long continued, can hare no effect ujon the rights of the party entitled to the minerals; and no lenath of nonusage min iffect his richts. Malace r. Elm Grove Coal Co., $5 \mathrm{~S} \mathrm{W.} \mathrm{Ya.} 419$, 52 S. E. 455, 6 Ann. Cas. 140 (1905).

B. entered into adrerse possession of land owned br A. Before the statutory bar mas complete, $\mathrm{B}$. sold and convered hy warrants deed the minerals to P., who until later made no entry thereundel. B. remained in possession of the sulface berond the statutory peliod, and then died. P. then entered into actual possession of the minerals and. Farning that $A$. made some claim thereto, sued to quiet title. Should he maintain his suit? Black Marrior Cuill Co. v. West. 170 Ala. 346,54 South. 200 (19T0), commented upon in 24 Harr. Law Rev. 582.

B. enteled into adrerse possession of land owned by A. After being in possession for a period short of the statutory period, $B$. conrered the land to $\mathrm{X}$.. leserving the minerals. $X$. ment into possession of the surface aur confinued therein until the full running of the statute of limitations. In

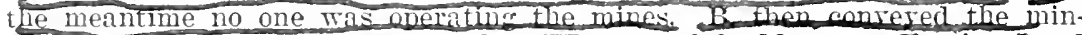
erals to $P$. who sues to owiet title. What result? Moore $v$. Empire Land Co., 151 Ala. 347, 61 South. 940 (1913). 


\title{
SECTION 5.-CONSTRUCTIVE ADVERSE POSSESSION
}

\author{
JACKSON ex dem. GILLILAND v. IVOODRUFF.
}

(Supreme Court of New Fork, 1S23. 1 Cow. $276,13 \mathrm{Am}$. Dec. 525.)

Ejectment, for one acre of land, at Salmon River, in Plattsburgh, Clinton county, called the Fairman lot, and for one half acre of land adjoining the same, on the north; tried before his honor, Mr. Justice Woodworth, at the Clinton Circuit, June, 1821. Defendant relied upon plaintiff's claim being barred by the Statute of Limitations.

WOODWORTH, J. ${ }^{29} * * *$ The remaining question is-have the defendants made out an adverse possession? The actual occupation of the premises, by the defendants, is less than twenty years, as appears by the testimony of Winchell. He says that Moses Soper had cleared ahout twa acres, not including the premises, at Salmon River Village, in 1797; that he, and Nathaniel Platt, claimed the whole property, while it was in woods. The validity of this claim will next be considered.

In September, 1794, Z. Platt executed a quit-claim deed to Jathaniel Platt, for 783 acres of fand purporting to convey, thereby, lands Tying between the east and south lines of allotted lands in Plattsburgh. and the line of Friswell's Patent. On examining the boundaries, and the map annexed to the case, it will be found not to include any land; for there is no gore between the two patents. The description follows: "Beginning at the distance of 7 cliains, 8 links, north from the south east corner of lot No. 99, in the second division of Plattsburgh; thence east, 27 chains and 50 links, to John Friswell's patent." Now, as it has been shown, that Friswell's Patent joins on Plattsbirgh, the line cannot be extended easterly. If it was so extended, it wonld run on lands included in that patent, which is not admissible, under the words of the deed. The next course is to the north-west corner of the patent, which must be understood the true north-west corner of Friswell, as proved by the plaintiffs: thence east, in the east bounds of Friswell's Patent, until the north line, to the lotted land in Plattsburgh, will include 783 acres, between that line and lot No. 101, in the second division of Plattsburgh. By tracing these lines, on the map. it will be seen, that a line, only, is given. No land is included: consequently, the deed is a nullity, inasmuch as nothing is granted. The question, then, is, whether a claim of title, under such an instrument. and an actual occupancy of part, can constitute a good adverse possession, beyond the parcel so occupied.

29 The statement of facts is abbreviated, and a portion of the opinion omitted.

Aig.Prop. 6 
It is well settled, that a continued possession, for 20 years, under pretence or claim of right, ripens into a right of possession, which will toll an entry. It has never been considered necessary, to constitute an adverse possession, that there should be a rightful title. Jackson v. Wheat, 18 Johns. 44; Smith v. Lotillard, 10 Johns. 356; Smith v. Burtis, 9 Johns. 180; Jackson v. Ellis, 13 Johns. 120; Jackson $v$. Todd, 2 Caines, 183. The party who relies on an adverse possession, must, in the language of Kent, Chief Justice, in Jackson v. Schoonmaker, 2 Johns. 234, show "a substantial inclosure, an actual occupancy, a pedis possessio, which is definite, positive and notoriaus, when that is the only defence to comntervail a legal title;" and in Doe r. Campbell, 10 Johns. 477, it is said, "adverse possession must be marked by definite boundaries and be regularly continued down, to render it availing." Brandt v. Ogden, 1 Johns. 156. There is no doubt, that actual occupancy, and a claim of title, whether such claim be by deed of 'otherwise, constitute a valid adverse possession, to that extent. But, when a party claims to hold, adversely, a lot of land, by proving actual occupancy of a part only, lis claim must be under a deed or paper title. This distinction has been uniformly recognized, and acted upon in this Court.

It is on this latter ground, the defendants must rest, if their possesion can avii. Then lefence is, that Z. Platt, in 1794, conveyed 783 acres to N. Platt, including the premises; that the first improvement was made in 1794, under Platt, being a small parcel, not exceeding 2 acres, which, together with the premises in question, afterwards taken under him, have been continued to the time of commencing this action. This proof does not make out an adverse possession to the premises. Color of title, under a deed, and occupancy of part, is suffcient proof as to a single lot; yet it follows, from the doctrine laid down, that the deed, or paper title, under which the claim is made, must, in the description, include the prenises. If the title is bad, it is of no monent; but if no lands are described, nothing can pass. The deed is a nullity, and never can lay the foundation of a good adverse possession, beyond the actual improvement. There is no evidence here. to show how far Platt's claim extended, unless resort is had to the deed. Boundaries, therefore, including the premises, were indispensable, in order to give this defence the semblance of platsibility. The defendants stand on the same ground as if no deed had been produced; and, then, the possession cannot extend beyond the place actually occupied. ${ }^{30}$

30 "The courts have concurred, it is believed. without an exception, in defuning 'oolor of title' to he that which in appearance is title but which in rality is no Tntr. Mr. Justice Daniel. in Wright r. Mattison, 1S I10w. 50, 56, 15 T. Ed. 280 (1555).

While thele is a decided conflict of authority the general rule seems clearly to be that "color of "title" lequires some sort of witing. See the many" ases collected in 1 Cyc. 10s:: 2 C. J. 170. See, also, 10-Cot:-Latr Rer. 59. so, also, the cases do not asree as to color of title being rrovided by an in- 
In Jackson, ex dem. Dervient v. Loyd, decided October term, 1820, but not reported, it appeared that the defendant had a deed for lot No. 4 , but took possession of lot No. 5, adjoining, believing it to be his lot, and claiming it as such. It was held, that the defendant could not establish an adverse possession, to the whole lot, by the actual improvement of a part, because no part of No. 5, was included in the deed.

But, if the deed had been perfect in the description, and included 783 acres of Friswell's Patent, the occupancy of a part would not make out an adverse possession to the whole quantity conveyed. The doctrine of adverse possession, applied to a farm, or single lot of land, is, in itself, reasonable and just. In the first place, the quantity of land is small. Possessions, thus taken, under a claim of title, are, generally, for the purpose of cultivation and permanent improvement. It is, generally, necessary to reserve a part for wood land. Good husbandry forbids the actual improvement of the whole. The possessions are, usually, in the neighborhood of others; the boundaries are marked and defined. Frequent acts of ownership, in parts not cultivated, give notoriety to the possession. Under such circumstances there is but little danger that a possession of twenty years will be matured against the right owner; if it occasionally happens, it will arise from a want of vigilance and care, in him who has title. It is believed, that no well founded complaint can be urged against the operation of the principle; but the attempt to apply the same rule to cases where a large tract is conveyed, would be mischierous indeed. Suppose a patent granterl to A, for 2000 acres; B, without title, conveys 1000 of the tract to $\mathrm{C}$, who enters under the deed, claiming title, and improves one acre only; this inconsiderable improvement may not be known to the proprietor, or if known, is disregarded for twenty years. Could it be gravely urged, that here was a good adverse possession to the one thousand acres? If it could, I perceive no reason why the deed from $\mathrm{B}$ to $\mathrm{C}$ might not include the whole patent, and after the lapse of twenty years, equally divest the patentee's title to the whole; for there would exist an actual possession of one acre, with a claim of title to all the land comprised in the patent. No sitch doctrine was ever intended to be sanctioned by the Court. It may, therefore, he safely affirmed, that a small possession, taken under the deed to N. Platt,

strument void on its face. Generalls, where the instrument, though roid on its face, would seem to the orlinary layman to be good, there is color. See the cases collected in 1 Cyc. 1057; 2 C.J. 176, 17\%. As to the necessity that the claimant under the color of title shall have acted in good faith in taking the deed or other instrument, see Gregg v. Sayre, S Pet. 253. S L. Ed. 932 (1S34) ;“'Foulke v. Bond, 41 N. J. Law, 527 (1S79); Lampman V. Van Alstyne, 94 Wis. 417,69 N. W. 171 (1S96); State r. King (W. Va.) S7 S. E. 170 (1915).

Color of title may also be of importance in other respects than constructire adrerse possession. Statutes of limitations not uncommonly provide for a different periad where there is adrerse possession under color of title. The state statutes should be consulted. 
cannot, under any circumstances, be a valid possession of the whole 783 acres, but is limited to the parcel improved. If the doctrine contended for, prevails, it would sanction this manifest absurdity, that a possession under Platt's deed, which conveyed no title, would, as to its legal effect, be more beneficial, than a possession taken under the proprietors of Friswell's Patent, where there is not only title, but a good constructive possession, in consequence of the grant, and actual occupancy and improvement of a part. It cannot be useful to pursue the subject farther. ${ }^{31}$

I am of opinion that the plaintiff is entitled to judgment, for an undivided fourth part of the premises.

\section{BAILEY V. CARLETON.}

(Supreme Court of New Hampshire, 1841. 12 N. H. 9, 37 Am. Dec. 190.)

Writ of entry, to recover two tracts of land in the lower village in Bath, one of said tracts being ten rods in length, and the other being four square rods of land, situated immediately south of and adjoining the first tract; both constituting a narrow strip of land, situated betwixt the main road through Bath village, and the Amonoosuck river.

The tract of land first described, and a house lot opposite to the same, on the other side of the road, were conveyed to Amos Toun by Moses P. Parson, by two several deeds, executed on the 27 th of ITrch. ISOF; and the tract containing four square rods was convered by said Payson, in November, 1807, to Buxton \& Blake, who sold to one Morrison, and, in 1810, Morrison sold to said Town.

In February, 1813. Amos Town sold the three tracts of land to his brother, Solomon Town, and in April, 1815, Solomon Town re-conreyed the house lot opposite the demanded premises, to Amos Torvn, but did not include, in the description, the strip of land opposite, and now in controversy.

October 19th, 1\$15, Amos Town convered the aforesaid three several tracts, giving separate descriptions of each tract, to Ebenezer Carleton, and subsequently Carleton's title was conveyed to these defendruter

Solomon Town in Tune 1830 , convered the demanded premises to one John Welsh. Welsh, in February, 1837, conveyed to the plaintiff,

31 Chandler r. Spear, 22 Vt. $38 s$ (1850); Thompson v. Burhans, 61 N. Y. J2 (1574); Louisville \& $\mathrm{N}$. R. Co. $\Gamma$. Gulf of Mexico Land \& Improrement Co., \&2 Miss. 180, 33 South. S45, 100 Am. St. Rep. 627 (1903). ace. Hicks r. Coleman Cal. $12285 \mathrm{Am}$. Dec. 103 (1864); Marietta Fertilizer Co. F. Blatr. 17.) A1a. 521, 55 South. 131 (1911), contra. See, also, Ellicott v. Pearl, 10 Pet. 412, 9 L. Ed. 475 (1S.86); Kentucky Conl, etc., Co. T. Kentucky Tnion Co. (1) C.) 214 Ferl. 590,629 (1914). The matter mas be affecterl br statute. See Sterens r. Martin, 168 Mo. 407, 68 S. W. 347 (1902). The state statutes slomeld be consulted. 
and this suit was brought for the recovery of the demanded premises, the 15th of April, 183\%.

It appeared that Ebenezer Carleton, on his purchase of Amos Town in October, 1815, entered into possession of the house lot named in his deed, and lived on and occupied the same for many years, until it was conveyed to the defendant, E. Carleton, Ir.

In 1821, Ebenezer Carleton caused a small building to be removed on to the land in controversy, and from that time to the present it has remained there, occupied by tenants under him and these defendants.

The defendants claimed to hold the land by virtue of peaceable and undistarbed possession, by themselves and their grantor, for a period of twenty years. It appeared that until 1821 no building had been, placed upon the premises, and that the premises had not been inclosed in any manner; that from 1815 to 1821 , and since, Ebenezer Carleton had been in the habit, occasionally, of leaving carts, ploughs and farming utensils tupon this land, and also of leaving lumber upon it. Evidence was offered to show that it had been a common practice, by teamsters and owners of lumber, for thirty or forty years, to lay lumber upon that side of the road, in Bath village, upon this tract, and above and below it, and that said Carleton and other individuals had been in the habit of laying lumber along the river bank in this manner.

It was contended, by the defendants' counsel, that Ebenezer Carleton having entered upon the house lot, claiming title to and occupying the same, such entry extended to the contiguous tracts described in the same deed, and that entry and occupation of one of the tracts extended to the whole in the same manner as though they had been conveyed in one description-that the defendants' grantor having entered upon and disseized the plaintiff's grantor, October 19th, 1815, and the plaintiff never having reentered before action brought, he had no legal seizin in the demanded premises within twenty years next before the commencement of his action, and his suit, therefore, could not be maintained - and that the laying of lumber on the demanded premises, by persons claiming no right thereto, would not affect the exclusive character of the defendant's adverse possession.

The court instructed the jury that an entry upon, and occupation ef one of the tracts conveyed, would not extend to the other tracts described in the deed, so as to give a title to them bv possession - that entry upon, and occupation of, any portion of the demanded premises would extend to the whole tract entered upon-that it was not essential that any portion of the land should be inclosed, in order to constitute an adverse possession-that such possession might be acquired by the laying of lumber upon said tract, or otherwise occupying it as a place of deposit for farming utensils, \&c., but that such possession must be an open, visible possession, such as would give reasonable notice of such adverse possession, to the owner. 
A verdict was rendered for the plaintiff, and the defendants moved to set the same aside, for misdirection.

PARKER, C. J. The general rule that where a party having color of title enters into the land conveyed, he is presumed to enter according $\{$ to his title, and thereby gains a constructive possession of the whole land embraced in his deed, seems to be settled by the current of authorities. Riley v. Jameson, 3 N. H. 27, 14 Am. Dec. 325; Lund v. Parker, 3 N. H. 49, and cases cited.

And such entry may operate as a disseizin of the whole tract; and the possession under it, continued for the term of twenty years, may be deemed an adverse possession, which will bar the entry of the owner after that lapse of time. 3 N. H. 49; Jackson v. Ellis, 13 Johns. (N. Y.) 118; Jackson v. Smith, 13 Johns. (N. Y.) 406; Jackson v. Newton, 18 Johns. (N. Y.) 355.

Exceptions have been suggested to the rule in some cases. One is, where a large tract of land is embraced in the deed, and a small part only has been improved. Jackson v. Woodruff, 1 Cow. (N. Y.) 276, 13 Am. Dec. 525; Jackson v. Vermilyea, 6 Cow. (N. Y.) 677. Another, where the deed under which the claim is made includes a tract greater than is necessary for the purpose of cultivation, or ordinary occupancy. Jackson v. Oltz, \& WVend. (N. Y.) $4+0$.

These exceptions secm not to be very definite in their application, for lots, like other things, are large or small by comparison, and a tract which would be much too large for cultivation by one, would not suffice for another. But they serve to show the principle upon which the rule is founded. It is, that the entry and possession of the party is notice to the owner of a claim asserted to the land: that the limits of such claim appear from the deed; and that if the owner for twenty years after such entry, and after notice, by means of the possession, that an adverse claim exists, asserts no rights he may well be presumed to have made some grant or conveyance, co-extensive with the limits of the claim set up; or that after such lapse of time, a possession under such circumstances, ought to be quieted.

There should be something more than the deed itself, and a mere entry under it-something from which a presumption of actual notice may reasonably arise. It is not necessary to show actual knowledge of the deed. Acts of ownership, raising a reasonable pressumption that the owner, with knowledge of them, must have understood that there was a claim of title, may be held to be constructive notice, that is, conclusive evidence of notice. Rogers v. Jones, S N. H. 264. The owner may well be charged with knowledge of what is openly done on his land, and of a character to attract his attention. The presumption of notice arises from the occupation, long continued; and the notice of the claim may well be presumed, as far as the occupation indicates that 
a claim exists, and the deed, or color of title, serve to define specifically the boundaries of the claim or possession. If the occupation is not of a character to indicate a claim which may be co-extensive with the limits of the deed, then the principle that the party is presumed to enter adversely according to his title, has no sound application, and the adverse possession may be limited to the actual occupation.

Thus cutting wood and timber, comected with permanent improvements, may well furnish evidence of notice that the claim of title extends beyond the permanent improvements, and the deed be admitted to define the precise limits of the clain and possession, provided the cutting was of a character to indicate that the claim extended, or might extend, to the lines of the deed. It might, at least, well indicate a claim to the whole of a tract allotted for sale and settlement, of which the party was improving part, unless there was something to linit the presumption.) But no presumption of a claim, and of color of title beyond the actual occupation, could arise resipecting other lots than that of which the party was in possession. And where the possession was in a township, or other large tract of land, which had never been divided into lots for settlement, no particular claim, beyond the actual occupation. would be indicated, and of course no notice of any such claim of title should be presumed. Jackson $r$. Richards, 6 Cow. ( $N$. Y.) 617 ; Sharp v. Brandow, 15 Wend. (N. Y.) 597.

If the possession was not of a character to indicate ownership and to give notice to the owners of an adverse claim, although the grantee might be held to be in possession according to his titic, in a controversy with one who should make a subsequent entry without right, his possession ought not to be held adverse to the true owner, to the extent of his deed, merely by reason of the deed itself, even if recorded, nor by any entry under it. There are several cases which tend to sustain this view of the principle. Poignard v. Smith, 6 Pick. (Mass.) 172, 176; Alden v. Gilmore, 13 Me. 178; Prop'rs of Kennebeck Purchase v. Springer, 4 Mass. 416, 3 Am. Dec. 227; Hapgood v. Burt, 4 Vt. 155 ; Eiving v. Burnet, 11 Pet. 41, 9 L. Ed. 624; Little v. Megquier, 2 Greenl. (Me.) 176.

We are of opinion that the rule cannot apply to a case where a party, having a deed which embraces land to which his grantor had goot title, and other land to which he had no right, enters into and possesses that portion of the land which his grantor owned, but makes no entry into that part which he could not lawfully convey. There is no notice in such case to the owner of the land thus embraced in the deed, and no possession which can be deemed adverse to him. If it may be said that the color of title gives such a constructive seizin and possession that the grantee could maintain trespass against any person who did not show a better right, (that is, a title, or prior possession, 2 there is nothing in the nature of it which can give it the character of a dis- 
seizin, or possession adverse to the true owner, so as to bind him. For that purpose, there must be actual possession of some portion of the land of such owner, and that of a nature to give notice of an adverse claim.

It is not necessary to settle whether an entry into an enclosed lot, under a deed purporting to convey unenclosed lands adjoining, belonging to the same person, would operate as a disseizin of the latter. Where two separate lots included in the same deed, belong to different owners, an entry into one can in no way operate as a disseizin in relation to the other.

The entry into the house lot, therefore, to which Amos Town, who conveyed, had title, was no disseizin of Solomon Town, who had title to the lot unenclosed, on the other side of the road.

The next question is, what entry into the land itself is sufficient.

Here was an entry in 1821, upon the tract in dispute, and a possession, by placing a building on it, by Ebenezer Carleton, the grantor of the defendants. This was, without doubt, an act of ownership. The character of it was adverse to the title of Solomon Town, and it was of a nature to give notice that Carleton claimed title to that land.

But the possession before that time was of a more ambiguous character.

Ebenezer Carleton, to whom the conveyance was made in 1815, made no entry or use of the lot up to 1821 except by laying lumber upon it, or placing farming utensils there. Those acts by one having a deed, if nothing further was shown, might be held to be a sufficient entry, and possession to operate as a disseizin of Solomon Town. But it appeared that so far as the laving of lumber on the lot was concerned, this was no more than Carleton, and divers other persons, had been in the habit of doing before, and that others continued to do the same afterwards. Those acts, prior to 1815, were done by him, and others, without claim of title, and of course in subservience to the title of the true owner. If not acknowledged trespasses, they must have been under a license from Solomon Town. The same acts continued after a deed of other lands, by a person having good title to those lands, could not operate as any notice to the owner of this tract, that a deed had been made covering his land also, and that there was an occupation under that deed, or under any claim of right to occupy adversely to him. The additional act of leaving farming tools on the lands does not seem to change the character of the possession.

It was not, therefore, until 1821, when the building was removed on to the land, that any entry was made upon it by Carleton, from which Solomon Town, with knowledge of the entry, should have understood that Carleton made any claim to the ojwnership of the lot; and until that time, therefore, there was nothing from which an ouster can be inferred, and no possession by him that can be deemed adverse, except 
at the election of the owner. Magoun v. Lapham, 21 Pick. (Mass.) 140; Thomas v. Patten, 13 Me. 336.

Judgment for the plaintiff. ${ }^{32}$

\section{RALPH v. BAYLEY.}

(Supreme Court of Vermont, 1839. 11 Vt. 521.)

Trespass for breaking and entering plaintiff's close, being lot No. 62, in the first division of lands in Warren, and cutting timber thereon.

Plea, not guilty, with notice of special matter. Issue to the country.

Upon the trial in the county court, the plaintiff gave in evidence a deed of the lot in question from Smith, Booth \& Ufford to the plaintiff, dated June 10th, 1836, and recorded in September, 1836.

The plaintiff also introduced testimony tending to prove that in July, 1837, he commenced clearing ten acres of said lot: that in the summer of that year he chopped down the trees growing on about three acres of the land, and that defendant, in January, 1838, entered upon the lot and cut down and carred away a spruce tree.

The defendant, on his part, gave in evidence a deed of the lot in question, together with two other lots of land lying in VVarren, from one Daniel Spencer to Aramnah Spear, dated July 18th, 1836, and recorded in August, 1536, and introduced testimony tending to prove that Spear, immediately after the recording of his deed and in the same month, commenced chopping on said lot, and cut down the timber growing on about one acre of land; that in August or September, 1837 , he caused the acre last mentioned to be cleared, and that the defendant entered upon the lot, by the direction of Spear, and cut the spruce tree before mentioned.

The plaintiff then introduced testimony tending to prove that the land cleared by Spear was not a part of lot No. 62 .

It was conceded that the tree cut by the defendant, was not upon that portion of the lot enclosed by, or in the actual possession of Spear.

The county court instructed the jury, that, if the plaintiff held a deed of lot No. 62, made an entry upon, and took possession of the lot, in the manner attempted to be proved, and the defendant entered thereon and cut the tree in the manner complained of, the plaintiff would be entitled to recover against the defendant, if he was a mere stranger, and did not act by the direction or consent of Spear, although, in fact, Spear made the first entry on the lot.

32 Kentucky Coal \& Timber Development Co. v. Kentucky Union Co. (I). C.) $21+$ Fed. 590 (1914), acc.

see Hornblower v. Banton, 103 Me. 375, 69 Atl. 568, 125 Am. St. Rep. 30 (1907). 
The jury returned their verdict for the plaintiff. The defendant excepted to the charge of the court.

Other questions were presented in the bill of exceptions, but, as they were not decided by this court, they are here omitted.

The opinion of the court was delivered by

BENNETT, J. We think there was error in the charge of the court, as applied to this case. The case shows that Araunah Spear received a deed of the lot in question from Daniel Spencer, in July, 1836, and the deed was put on record in August following, and that the said Araunah immediately entered into possession, claiming title to the whole lot under his deed, and commenced a clearing and chopped over about one aere, and that, in August or September, 1837, he caused the clearing of this acre to be completed. It appears, also, that evidence was given to the jury tending to prove the defendant's acts to have ien veve linder Spear.

The effect of this evidence is to extend the possession of Spear, by construction, to the whole lot, as described in his deed. The charge of the court assumes, that if the jury do not find that the defendant acted under Spear, the plaintiff is entitled to recover, though they should find Spear's possession prior to any possession of the plaintiff, it being an admitted point that the chopping of the defendant was not on that portion of the lot cleared by Spear.

The plaintiff is a stranger as to the title, and his possession to any part of the lot is subsequent to the possession of Spear, and it does not appear that the alleged trespass of the defendant was committed upon any part of the lot in the actual possession of the plaintift, Spear having had the first actual possession of a part, and constructive possession of the whole lot, there can be no subsequent conflicting possession extended by construction beyond the limits of the actual adverse possession. Crowell r. Beebe, 10 Vt. 33, 33 Am. Dec. 172; Barr v. Gratz, + Wheat. 213, 4 L. Ed. 553.

It is, then, clear that the plaintiffs could not maintain this action against Spear, and can he against a stranger? IVe think not. The doctrine is well settled, that, in ejectment, the defendant may set up, as a defense, an outstanding title still subsisting in a stranger, though he in no way connects himself with such title. In the present case, as between the plaintiff and Spear, the latter has the better title, that is, the first available possession of that part of the lot where the trespass was committed, and all acts of the plantiff there would be a trespass against Spear. If the plaintiff is permitted to recover against a stranger, for the trespass, it can be no bar to a second recovery, by Spear for the same trespass, and we see no good reason why a stranger, when sued by the plaintiff, may not set up a prior possession in Spear. It, in effect, is the same principle that permits a defendant in ejectment to set up an outstanding title in a third person. There is no occasion for 
deciding any other question, reserved by the bill of exceptions, as the judgment below must, on this point, be reversed. A new trial is, therefore, granted. ${ }^{33}$

\section{SECTION 6.-DISABILITIES}

\section{DOE v. JESSON.}

\section{(Court of King's Bench, 1805. 6 East, S0.)}

This was an ejectment for a house and a small parcel of land, which was tried betore Rooke, J., at the last assizes at Northampton; and the principal question was, whether the action were brotgnt in time withn the $2 \mathrm{~d}$ clause of exceptions in the statute of limitations, $21 \mathrm{Jac}$. I, c. 16. The person last seised of the premises, from whom the lessors of the plaintiff claimed, was one Thomas Jesson, on whose death in the year 1777, David, his elder brother, took possession of them, and transmitted the possession to the defendant his grandson. Thomas Jesson left a son John and a daughter Frances him surviving. John was baptized in 1767, and after the death of his father, being then about 10 years of age, was put out apprentice to the sea service by the parish, and was seen by a witness on his return from his first voyage

33 "The complaint is made that instruction $S$ was lefused plaintiffs. It reals as follows: "If the jury helieve trom the evillenre that $S$. I. Robinson under his patent entered non the lancl enluraced therein and took jossession of the same by hinself or his tenant, then he was in possession of the whole of said trict of land not actually in the possession of some other lalty; and if yon lelieve that such possession has continued for more than ten years by the said Robinson or his tenants, then his jossession under his natent gave him a pelfect title to the land actually in his possession, notwithstanding yon may believe some part of his survey may have been overlapled by an older patent.' This would suggest to the jury the question of an interlock of the defendant's older patent with plaintits younger patent, and, if there was. then plaintiffs would have the henefit of possession extending over on the defendant's land. But there conld not be such interlock when the plaintiffs' patent called for defendant's older patent, and to lun with its lines. Robinson v. Sheets, 69 W. Va. 394, 61 S. E. 347 (1905). This tended to give Robinson the benefit of possession orel his bounds. But there is other oljection to the instruction. Suppose an interlock between senior and junior srants. This instruction would say that a possession anywere on the land of the junior grant wonld take in land of the intellork, if possession under the senior is not within the intelock. The junior, though in possession within his bounds, cannot be accounted in possession of the interlock, mless he has actual phrsical possession in it. Coistructive actual jossession alising from possession elsewhere will not do. Wilson v. Braden, 48 W. Va, 199, 36 S. E. 367 (1900). I see that it was discussed and disalplored in former de. eision. Robinson v. Lowe, 50 W. Va. 70. 40 s. E. 454 (1901)." Erannon, J., in Rolinson v. Lowe, 66 W. Ya. 665, 66 s. E. $1001(1910)$.

As to tacking successive constructive adverse possessions, see Simpson $r$. Downing, 23 Trênd. (N. Y.) 316 (1St0). 
about a year after the father's death; soon after which he went to sea again, and had not been heard of since, and was believed to be dead. Frances the daughter, one of the lessors of the plaintiff, was baptized on the 21 st of May, 1771, and afterwards married George the other lessor.

It was contended at the trial by the defendant's counsel that the ejectment was out of time; for it was uncertain when John, the son of 'Thomas the ancestor last seised, died, and that the 20 years given by the statute began to run immediately on the death of Thomas in $177 \%$, and consequently expired in 1797; or that if the statute favoured Frances the daughter till 10 years after the disability of her infancy was removed, at any rate as she was of full age in 1792, she ought to have brought her ejectment in 1802, and consequently this ejectment brought in 1804 was too late. On the other hand, it was contended by the plaintiff's counsel that supposing John to have died abroad, the presumption of his death could not arise till seven years after he was last seen in England previous to his going to sea, which would not be till 1785 or 1786 , till when the right of entry of the lessor Frances did not accrue; and that she had 20 years in which to bring her ejectment after that time; the statute having never begun to run by reason of the continuing di:ability, and consequently that this action was well brought.

The learned Judge left it to the jury to say when and where John died; and observed, that it was fair to presume he had not died in England, as none of his family ever heard of his death. And as to the time, that it was incumbent on the jury to find the fact as well as they could under the doubt and difficulty of the case; that at any time beyond the first seven years they might fairly presume him dead, but the not hearing of him within that period was hardly sufficient to afford such a presumption. The jury found a verdict for the plaintiff, and that John died abroad about the years 1785,1786 , or 1787 , but not before. In the last term it was moved to set aside the verdict and grant a new trial, on the ground that Frances, the daughter, was at most only entitled to 10 years for bringing her ejectment after she came of age, which was in 1792, even if she were not bound to have made her entry within 10 years from the death of her brother, from whom she claimed.

Lord Elimenorough, C. J. The time allowed by the statute for making an entry might be indefinitely extended if the construction contended for by the plaintiff were to be admitted. There is no calculating how far it might be carried by parents and children dying under age, or continuing under other disabilities in succession. The brother, John, through whom the lessor of the plaintiff, Frances, claims, being under the disability of nonage at the time of his father's death, wher his title first accrued, and dying under that disability, it appears to me that the proviso in the second clause of the statute 
(where resort is to be had to it to extend the period for making an entry beyond the 20 years,) required the lessor Frances, as heir to her brother, to make her entry within 10 years after his death: and that not having done so, this ejectment was brought too late. The word "death" in that clause nuust mean and refer to the death of the person to whom the right first accrued, and whose heir the clainant is: and the statute meant that the heir of every person, to which person a right of entry had accrued during any of the disabilities there stated, should have 10 years from the death of his ancestor, to whom the right first accrued during the period of disability, and who died under such a disability, (notwithstanding the 20 years from the first accruing of the title to the ancestor should have before expired.) As to the period when the brother might be supposed to have died, according to the statute 19 Car. II, c. 6 . with respect to leases dependent on lives, and also according to the statute of biganiy, (1 Jac. I, c. 11.) the presumption of the duration of life, with respect to persons of whom no account can be given, ends at the expiration of seven years from the time when they were last known to be living. Therefore in the absence of all other evidence to shew that he was living at a later period there was fair ground for the jury to presume that he was dead at the end of seven years from the time when he went to sea on his second royage, which seems to be the last account of him. That was about the year 1778 , which would carry his death to about 1785 .

LAwrince, J. Upon the leath of the father Thomas Jesson, in 1777 , the right descended to John, the son, then under age, who died under that disability. The lessor Frances is the heir of John; and the statute gives to the party to whom a right of entry accrues, and who is under a disability at the time, 10 years after the disability removed, notwithstanding the 20 years should have elapsed after his title first accrued; and to his heir the statute gives 10 years after the death of such party dying under the disability. Here more than 10 years had elapsed after the death of the brother before this ejectment was brought. It appears probable enough upon looking into the case of Stawell v. Lord Zouch (Plowd. 355), that the word death was introduced into the statute of James in order to obviate the difficulty which had arisen in that case upon the construction of the statute of fines, 4 H. VII, c. 24, for want of that word.

Grose and LE BLANC, Justices, assenting.

Rule absolute. ${ }^{34}$

34 The construction of the American statutes of limitation generally has been the same. See 2 C. J. 117 et seq. 


\section{CHAPTER II}

\section{PRESCRIPTION}

\section{WALLACE v. FLETCHER.}

(Supreme Court of New Hampshire, 1855. 30 N. H. 434.)

This is an action on the case, for diverting the water from the plaintiff's mill, in New Boston, from May 1, 1848, to the date of the writ, April 26, 1850.

The plaintiff's evidence tended to show that one L. Lincoln, under whom he claimed, purchased the land on the south side of the Piscataquog river, in New Boston, bounded by the river, and in 1804 or 1805 erected thereon the gristmill now owned by the plaintiff, and extended his dam across the river to the north bank. J. McLaughlin then owned the land upon the north side of the river; and there was no evidence tending to show that any consent was asked of McLaughlin, or given by him, for the building of the dam, or that he, or any person in his behalf, or in his right, made any objection to its being built.

McLaughlin died in the spring of 1807 , and in September of that year, one John Kelso applied to Abner Dodge, who had become the owner and occupant of the gristmill and its appurtenances, through two or three intermediate conveyances from Lincoln, and asked him if he had any objection that said Kelso should move his fulling mill, then standing about half a mile above upon the river, and set it at the north end of his mill dam, if he would give Dodge an adequate compensation. Dodge told him that he had no objection, and Kelso moved his mill, but the compensation was not fixed, though Dodge objected to his cutting away the dam till it was done. Kelso cut away a part of the dam and constructed a flume, and put his fulling mill in operation, and continued to occupy the mill till his death, in 1822. It did not appear that any other agreement was made by Kelso with the owners of the gristmill, or that any compensation was paid by him, or any rate of compensation agreed on.

It appeared that the owners of the gristmill repaired and rebuilt the entire dam, when there was occasion, and that Kelso and his heirs, so long as they retained the property, did nothing and contributed nothing towards the repairs of the dam, except to their own flume, and a few feet of planking between the flume and the north bank of the river, except that on one occasion when the dam was destroyed by a freshet, said Kelso entertained at his house some of the neighbors who volunteered to assist in rebuilding it.

It appeared that at one time said Kelso, being asked why he did not assist in repairing the dam, said he expected to have to pay rent for it. 
In 1816, Kelso obtained of John McLaughlin, Jr., and a sister of his, two of the five children and heirs of J. McLaughlin before mentioned, a quitclaim deed of the land on the north side of the river, on which the fulling mill stood, and his administrator, in $182 S$, obtained of another daughter of said J. McLaughlin, Sen., a similar deed, and there was evidence tending to show that two others of said J. McLaughlin, Senior's, sons enlisted in the army in the War of 1812, and have never since been heard from.

It did not appear that said Kelso made any different claims, or made any change of any kind in his relations to the owners of the gristmill, after he obtained his deed of $\mathrm{J}$. McLaughlin, Jr., so long as he lived.

The evidence tended to prove that during the life of said Kelso, and ever afterwards, the owners of the gristmill claimed that they were entitled to the exclusive use and control of the entire water power created by their mill dam, on the ground that they acquired such right by first building a dam there and setting up a mill, and that it was considered in the neighborhood a disputable matter whether the owners of the north sicle of the river had any privilege there, but it did not appear that said Kelso ever disputed the claim in this respect made by the owners of the gristmill; on the contrary, the evidence tended to prove that during said Kelso's life, and until the sale of the interest of his heirs, in 1826, the owners of the sristmill were in the habit of calling on the occupants of the fulling mill, either personally or by rapping on the side of the gristmill, to shut down their gates, and they were accordingly closed when the river was low, and the water was neerled to carry the gristmill, and that in such dry times the gates of the fulling mill were sometimes closed by the occupants, of their own accord, and sometimes by the owners of the gristmill, and that sairl Kelso, at such times, sometimes fulled his cloth in the night, when the gristmill was not in operation, and sometimes took his cloth to be fulled at mills in other towns.

The evidence also tended to prove that the owners of the gristmill also claimed that the gristmill, as such, had a prior right to the use of the water, when necessary, before any other mill or machinery on the dam, and it did not appear that this right was denied or disputed by Kelso, or his heirs or representatives.

It appeared that at Kelso's decease his children were minors, and they so continued, except the eldest, for a short time, until their interest in the fulling mill and lot was sold by the eldest son, and by the guardian of the others, by license of the court of probate.

The fulling mill was leased by the administrator of Kelso's estate for two years, till 1824, and by the guardian of the children for two years more, to 1826, in March or April. These leases conveyed the fulling mill and water privilege for the clotining business, "except when there was not sufficient water for the gristmill," and it appeared that during those leases, the owners of the gristmill, when the water was 
low, drew all the water, and the gates of the fulling mill were shut down at such times.

A witness for the plaintiff testified that he was a referee with two others, now deceased, to settle a claim made by A. Dodge against the estate of Kelso, for compensation for the use of the water by the fulling mill. The parties stated to them that the owners of the gristmill had built the dam, and had done all that had been done to keep it in repair; that Kelso came in under an agreement to pay a reasonable compensation for the use of the water, though it had never been agreed what that compensation should be, and that Kelso had used the water for a number of years under that agreement; that the most of the year there was water enough for both, and when there was not water enough for both, the gristmill had the preference, and when the water was low, was to have all the water. The question submitted to them was, what the estate of Kelso should pay towards the expense of supporting the dam, or what should be paid for the use of the water, when there was water enough for both mills. He could not say what was said by Dodge or the administrator, but what was said by either was assented to by the other. There was no dispute between them. The award was produced and verified by him. It recited a submission by bonds, and among other things, had an award of "forty dollars to be paid to Dodge for the use of the water privilege," and was dated March 26, 1823. At the foot of it was written, "We agree to the above award," which was signed by Dodge and the administrator.

To all this evidence of the acts and admissions of the administrator of Kelso's estate, and of the guardian of his minor children, it was objected that neither an administrator nor guardian has any power, directly or otherwise, to create an easement on the minors' estate, or by his acts or admissions to furnish or make any evidence of such an easement, to affect any other persons than themselves, and the whole evidence was therefore inadmissible against the grantees of the minors' estate; but the evidence was admitted, subject to exception.

It was objected that the award was not evidence of the submission by bond, without the production of the bonds, or an account of their absence, but it was admitted on the proof of the agreement of the parties, written upon it, subject to the exception as to its admission and effect.

It appeared by deeds produced by the defendants, that one of the heirs of Kelso, then of age, and the guardian of the minor children, under a license from the court of probate, sold and conveyed the fulling mill to D. Smith, on the 5th of August, 1826. Smith soon after made a contract with the defenlant, Fletcher, and gave him a bond that he would convey the property, upon the payment of an agreed price, within a certain time; that in the meantime Fletcher should occupy the premises, paying a certain rent, and that when he paid $\$ 200$ toward the purchase, the rent should cease, and after that he was to pay only the interest on the balance of the purchase money. 
Fletcher occupied, paying rent for two years, till 182S, and then paid them $\$ 200$, and afterwards occupied as owner, paying interest only. During the time from August, 1826, to the fall of 1828, while Fletcher occupied as tenant, Smith paid to the owner of the gristmill half a dollar a month for the use of the water. He testified he paid it because it was unsettled and considered disputable, whether there was any privilege on the north side. He said he was offered a higher price, if he would warrant the water, but he considered it disputable, and declined to do it. In April, 1830, he conveyed to one Austin, under whom the defendants claim. While he owned the fulling mill, and paid rent, the owners of the gristmill claimed they had the first right to the water, and it was generally understood they had such right.

After the payment of the $\$ 200$ by Fletcher to Smith, the right of the plaintiff to a preference in the use of the water, or to any rent or compensation for the use of it, was denied by Fletcher, and he ceased to shut his gates when the owners of the gristmill requested it, but it did not appear how early this resistance to the plaintiff's claim was first made.

The court instructed the jury that if the owner of the mill privilege, under a claim of right, used and exercised the rights he claimed, without interruption or opposition, for a period of twenty years, this gave him a perpetual right, and that it was not material whether his claim of right was well founded in law, if it was so exercised and submitted to. That if a party had once acquired a right by such twenty years enjoyment, he would not lose it by any interruption afterwards, unless that interruption continued for twenty years, and the burden was on the party who asserted such interruption, to prove it. That if the jury should find that the plaintiff, under a claim of right, had used the water to the exclusion of the fulling mill, in the dry season, when there was only enough for the grist mill, or had permitted the owners of the fulling mill to draw water from the dam for the use of that mill, only on payment of a reasonable compensation, for the term of twenty years, without interruption, they should find their verdict in his favor, notwithstanding they should find that during a part of that time the title to the fulling mill was, by descent, in the hands of minors.

The jury found a verdict for the plaintiff, which the defendants moved to set aside, by reason of the said rulings and instructions of the court.

BELL, J. At common law, a title acquired by possession during the period and in the manner prescribed by the law, was called a title by prescription. By the lapse of the requisite time, what was at first a bare possession, becomes a right of property, perfect and indefeasible. Gale \& What. on Easements, 62.

The doctrine of the common law, as cited by Coke, (Coke's Litt. 113 , b,) from Bracton, (Lib. 2, fol. 51,) substantially agrees with the civil law. "Both to customs and prescriptions, these two things are inAIG.PRop: -7 
cidents inseparable, viz.: possession or usage and time. Possession must have three qualities, it must be long, continual, peaceable; longa, continua, et pacifica, for it is said, transferuntur dominia sine tituo et traditione, per usucapionem; sed, per longam, continuam, et pacificam possessionem. Longa, i. e., per spatium temporis per legam definitam; continua, dico, ita quod non sit legitime interrupta; pacificam, dico, quia si contentiosa fuerit, idem erit, quod prius, si contentio fuerit justa." "Longus usus, nec per vim, nec clam, nec precario," \&c. G. \& IV. 122.

By the civil law, the rule was "ut prescriptione longi temporis, id est decem annorum inter presentes, et viginti inter absentes, servitutes adquirantur." 1 Hei. ad Pan. part 2, § 158; 2 Ib. part 6, §§ 122125; Donat's Civil Law, $\S 2190$. But by the common law, the time was not fixed to a certain number of ycars, but as it was expressed by Littleton, (Ten. $\S 170$ ) it was "de temps dont memorie des homes ne curt a le contrarie," or as Coke (Coke's Litt. 115, a) quotes from Bracton, "Docere oportet longum tempus et longum usum illum; viz. qui excedit memoriam hominum, tale enim tempus sufficit pro jure."

In 1275 , by statute $3 \mathrm{Ed}$. I, writs of right were limited to rights actually enjoyed after the first ycar of Richard I, (1189,) and by analogy to the period fixed by that statute, it was held that time of legal memory reached to that date, and not beyond it. Being a fixed date, it was of course continually receding, until it became absurd, since it was practically impossible to prove any fact of so ancient date.

The courts might have held, when diffculties were found to result from this arbitrary rule, that the ancient law, which fixed the period beyond which actual memory did not reach, was still in force, or they might have availed themselves of the passage of the statute of 32 Henry VIII, which reduced the limitation of writs of right to three score years, to decide by analogy to that statute, as was done in the time of Edward I, that the time of legal memory was reduced sixty years. It appears by Littleton, sec. 170, that in his time it was seriously contended that the time of legal memory was not changed by the statute of Edward I. And Rolle, C. J., was of that opinion, though he adnits the practice was otherwise. 2 Rolle's Ab. Prescription, P. And many respectable authorities maintained, after the statute of 32 Henry VIII, that time of legal memory was sixty years, as Rolle, C. J., Sergeant Williams, 2 Wms. Saund. 175, n. a., Lord Nansfield, 2 Ev. Poth, 136, Blackstone, J., 2 Com. 31, Abbott, C. J., 5 B. \& A. 215, and Dallas, C. J., C. B. Moore, 558.

From causes which are not now apparent, neither of these views prevailed, and the consequence was that no title to any easement could be supported upon proof of occupation and enjoyment, however long continued, if its origin could be shown.

The natural and, indeed, necessary consequence of a rule so absurd, and one necessarily productive of so unjust consequences, was that the courts were driven to evade it by refinements and fictions. 
It seems by the case of Guernsey v. Rodbridge, Gil. Eq. Cases 4, s. c. 2 Vern. 390, under the name of Finch v. Resbridger, in 1707, that the court of chancery first adopted the principle of presuming the former existence and loss of a deed, where a long and uninterrupted possession of an easement was shown. It was not until 1761 that this principle was adopted in the courts of common law in England. Some of the judges there were, at times, inclined to give to this presumption the effect of a presumptio juris et de jure, a legal presumption binding on both courts and juries, as a rule from which neither had a right to depart, a presumption of a right constituting a perfect title or bar, as the case might be. Wilmot, J., in Lewis v. Price and Dougal v. Wilson, Saund. 175, a; Eyre, C. J., in Hed v. Holcroft, 1 B. \& P. 400; Lord Ellenborough, in Balston v. Benstead, 1 Camp. 163, and in Bealey v. Shaw, 6 East, 214; and Lord Mansfield in Darwin v. Upton, 2 Wms. Saund. 175, a, and Mayor v. Horner, Cowp. 102.

But the current of English decisions has gone no further than to hold that long continued and uninterrupted possession is evidence from which a jury may presume a deed. Keymer v. Summers, B. N. P. 74; Campbell v. Willson, 3 East, 294; Gray v. Bond, 5 Moore, 327, s. c. 2 B. \& B. 627 ; Cross v. Lewis, 2 B. \& C. 685; Darwin v. Upton, 2 Wms. Saund. 175, a; Livitt v. IVilson, 3 Bing. 115.

The instruction given to the jury that such proof is competent evidence, from which they may infer the existence and loss of a deed, is understood to be accompanied by a recommendation so to find the fact, whatever may be their individual impression of its truth, and it seems that verdicts rendered in conflict with such recommendations would be set aside. Bealey v. Shaw, 6 East, 214, per Ld. Ellenborough, C. J.; Bright v. Walker, 1 Cr., M. \& R. 217, per Parke, B.; Jenkins v. Harvey, 1 Cr., M. \& R. 894, per Alderson, B. ${ }^{1}$

Many cases, in this country, have followed in the tracks of the English decisions, though it is apparent that, in a newly settled country like ours, where to a great extent every thing is of recent date, and the history of our towns, of our roads, farms, mills and dwellings are known, a rule like that adopted in England is in no respect adapted to our situation. On other subjects, the common law has been every where modified, to adapt it to the wants of our community. The English decisions on this subject have been but modes of evading the effect of early decisions of their courts, which have been found inconsistent with the principles of justice; and it is clearly as much within the legitimate sphere and customary action of the courts to disregard or to overrule such decisions, as it can be to evade them by nice presumptions, either of fact or of law. It was the wise conrse, prescribed by principle as well as by public convenience, to overrule the absurd decisions which sanctioned a fixed point in the early history of England,

1 Sfe, also, Cockburn, C. J., in Angus \& Co. v. Dalton, 3 Q. B. D. 85, 103113 (1s7 i); Thesiger, L. J., in same case on appeal, 4 Q. E. D. 162, 170-1.75 (1STS). 
as the limit of legal memory, and at the same time to restore the principle upon which that decision appears to be made, that in cases where the Legislature have not fixed a precise rule of limitation, rights shall be acquired and barred by a prescription of such length of time as has been fixed by the Legislature as the proper limitation in analogous cases. Ricard v. Williams, 7 Wheat. 110, 5 L. Ed. 398; Hunt v. Hunt, 3 Metc. (Mass.) 185, 37 Am. Dec. 130.

$\sim$ It was to adopt here as the law, the strong view of Wilmot, J., in Lewis v. Price, that if a possession of twenty years is sufficient to give a man title to a house, there can be no reason why it should not be sufficient to give title to any easement belonging to the house.

Upon these views, we take the law to be here settled, as is laid down by Prof. Greenleaf, 2 Greenl. Ev. $\S 539$ : "By the weight of authority, as well as the preponderance of opinion, it may be stated as the gen(eral rule of American law, that an adverse, exclusive and uninterrupted enjoyment for twenty years of an incorporeal hereditament affords a conclusive presumption of a grant, or a right, as the case may be, which is to be applied as a presumptio juris et de jure, wherever by possibility a right can be acquired in any manner known to the law. In order, however, that the enjoyment of an easement in another's land may be conclusive of the right, it must have been adverse, that is, under a claim of title, with the knowledge and acquiescence of the owner of the land, and uninterrupted; and the burden of proving this is on the party claiming the easement." In support of this position, he cites Tyler v. Wilkinson, 4 Mason, 402, Fed. Cas. No. 14,312; Ingraham v. Hutchinson, 2 Conn. 584; Strickler v. Todd, 10 Serg. \& R. (Pa.) 63, 69, 13 Am. Dec. 649; Sherwood v. Burr, 4 Day (Conn.) 244, 4 Am. Dec. 211; Tinkham v. Arnold, 3 Greenl. (Me.) 120; Hill v. Crosby, 2 Pick. (Mass.) 466, 13 Am. Dec. 448; Ricard v. Williams, 7 Wheat. 109, 5 L. Ed. 398 ; Coolidge v. Learned, 8 Pick. (Mass.) 504; Sargent v. Baliard, 9 Pick. (Mass.) 251; Melvin v. Whiting, 10 Pick. (Mass.) 295, 20 Am. Dec. 524; Bolivar M. Co. v. Neponset M. Co., 16 Pick. 241; Morgan v. Banta, 1 Bibb (Ky.) 582; Simpson v. Hawkins, 1 Dana (Ky.) 306; Shaw v. Crawford, 10 Johns. (N. Y.) 236; John v. Stevens, 3 t. 316 . To which may be added, Stiles v. Hooker, 7 Cow. (N. Y.) 266; 1 Kent, Com. 444; 2 Hill. Ab. 60, 61; Shumway v. Simonds, 1 Vt. 53 ; Baldwin v. Calkins, 10 Wend. (N. Y.) 166; and Miller v. Garlock, \& Barb. (N. Y.) 153, where the principles applicable in cases of this kind are very clearly stated and condensed; Hoyt v. Carter, 16 Barb. (N. Y.) 219; Valentine v. Boston, 22 Pick. 80, 33 Am. Dec. 711; Atkins v. Bordman, 20 Pick. (Mass.) 302; Littlefield v. Maxwell, $31 \mathrm{Me}$ (1 Red.) 140, $50 \mathrm{Am}$. Dec. 653.

In this State, in Bullen v. Rumnels, 2 N. H. 255, 9. Am. Dec. 55, it was said by Woodbury, J., and held by the court, that the most conclusive evidence as to the interests of parties in water-courses, was the occupation of the parties during twenty years, because that is the common and peculiar mode of acquiring rights to the use of water, 
and because so long an occupation of a stream not navigable raises a presumption that the grants, now lost by time and accident, have passed between the parties, in conformity to the occupation.

In Gilman v. Tilton, 5 N. H. 231, Richardson, C. J., says: "Some have held that a term of twenty years of exclusive, uninterrupted enjoyment of the use of water, in a particular manner, is a conclusive presumption of right, presumptio juris et de jure." It was not the point directly before the court, and he says no more; but we think that the remark shows that the opinion met his approval. The point decided was, that an adverse enjoyment of water for any period less than twenty years is not alone sufficient to warrant the presumption of a grant.

In the case of Watkins v. Peck, 13 N. H. 360, 40 Am. Dec. 156, it was held that the adverse, exclusive use of water flowing through an aqueduct, by the owners and occupants of a house, for the term of twenty years, furnishes presumptive evidence of a grant from the owner of the land through which it is brought, to have it flow in the manner it has been accustomed to do for that period. And the learned chief justice who delivered the opinion of the court, remarks of the case: "During all that time, (more than twenty years,) the right of the plaintiffs, and those under whom they hold their lands, thus to take and use the water, has, so far as appears, not been contested by any one; nor is there any express evidence of any permission asked within the time or of any sum paid for the use, or any acknowledgment that the use was at the pleasure of those through whose land the aqueduct passed. These facts, if they stood alone, would furnish abundant evidence of title in the plaintiffs to take and use the water, as they and others, whose estates they hold, had been accustomed to do for such period." He subsequently says: "The plaintiffs' claim does not rest upon a prescription. There is no pretense that the use has extended beyond legal memory. The plaintiffs must rely upon the presumption of a grant, arising from an undisturbed enjoyment of the use of it, flowing through the land owned by the defendant for so long a period; which may be in the nature of a prescription, except se far as time is concerned."

It is apparent that the learned judge referred to a prescription such as is recognized by the ancient books of the law, founded upon such a length of possession as the memory of man does not reach to, going back to the first year of Richard I, three hundred years before the discovery of our continent. Such a prescription, of course, could not exist in this case, nor in any case arising in this country. And any attempt to reason from the nature of such a prescription, so far as it related to time, might be properly rejected. The analogy of the presumption of title, or of grant, as the case may be, to a prescription, except so far as time is concerned, is distinctly admitted. And there seems to us both convenience and propriety in applying the term prescription in cases of this kind, since the prescription of the ancient 
books can never exist here, and even as to time, the limit recognized here agrees with that of the civil law. Hein. ad Pand., before cited. However this may be, this case furnishes strong evidence of the concurrence of this eminent judge in the general current of decisions in this country, as stated by Prof. Greenleaf.

Upon this view of the law, we think the instruction given to the jury, that if an owner of a mill privilege, under a claim of right, used and exercised the rights he claimed, without opposition or interruption, for a period of twenty years, this gave him a perpetual right, was, upon the facts presented by the case, correct, unless the court erred in that part of the charge where they say that the exercise of the rights claimed for twenty years, without interruption, entitled the plaintiff to a verdict, notwithstanding they should find that during a part of that time the title to the property affected was, by descent, in the hands of minors.

This question, in a different form, came before the court in the case of Watkins v. Peck, and it was there said: "We are of opinion that no grant can be presumed from an adverse use of an easement in the land of another, for the term of twenty years, where the owner of the land was, at the expiration of the twenty years, and long before, incapable of making any grant, whether the disability arose from infancy or insanity. Perhaps a disability intervening during the lapse of the term, but not extending to the termination of the twenty years, might not be sufficient to rebut the presumption, but it would be absurd to presume a grant, where it was clear that no such grant could have existed." This case is relied on by the defendants as decisive of the present case, but we are unable so to regard it.

In the present case, the period of twenty years, necessary to give a title by presumption of a grant or title, commenced in 1807 , and ended in 1828 , after which time the right was denied, and its exercise interfered with. From 1822 to 1826 , the title of the defendant's estate, in which the easement was claimed, was in the minor children of Kelso, the former owner, then deccased, and their interest was sold in 1826 , by their guardian, by license from the court of probate. The disability of the owners did not extend to the end of the twenty years, but ceased two years previously. That case was not decided in Watkins v. Peck, but was in express terms left undecided.

The case then before the court did not require the decision of any question on the subject, since it was held that the then defendants taking the water by contract from the premises of a third person, could justify, under that person, if they could not stand on their own occupation. But it is not necessary here to question the ruling there made, in the case then before the court.

But we think that, in the present case, where it appeared that the parties interested were of full age at the time when the possession and user commenced, and for fifteen years after; and also at the time when the full time of twenty years was completed, and for two years 
before, and the title of the minors intervened for some three or four years between those periods, their disability would not prevent a title from being acquired by twenty years pessession.

We have already stated our impression that by the law, as generally recognized in this country, the party claiming title under such possession is not obliged to rely merely on a presumption of a grant, but he may rest on a presumption of right, or of any grant, reservation or record, which may be necessary to establish his title; and it seems to us this may properly be regarded as a species of prescription, established here by a course of judicial decisions, by analogy to the statute of limitations of real actions. Coolidge v. Learned, 8 Pick. (Mass.) 504; Melvin v. Whiting, 10 Pick. (Mass.) 295, 20 Am. Dec. 524.

In cases where the party claiming title under such presumption, may find it necessary to rely upon the presumption of a deed, we think that long continued user is evidence of a lost or non-existing grant, from some person who might, at some time, have made a valid grant to some person capable of accepting it. It camnot prove more than this. User cannot prove a grant by A. to B., on a given day, unless there be other circumstances, which confine the presumption to a particular time, and to those persons only. The evidence of such limitation forms no essential or natural part of the proof of user. Campbell v. Wilson, 3 East, 294; French v. Marstin, 24 N. H. 453, 57 Am. Dec. 294.

It strikes us that the legitimate and natural tendency of evidence of user may, in many cases, be rather to prove a deed existing before the commencement of the user, than one executed during the time of the use, or at its termination. Tinkham v. Arnold, 3 Greenl. (Ale.) 122. The earliest act of user proved, tends to prove a right then existing. upon the principle that he who witnesses any encroachment upon his rights, without objection or opposition, seems to admit, in some degree, however slight, a right in the party who does it. Such light evidence gains force by continued repetition, until at the end of twenty years it becomes, unexplained, conclusive evidence of right.

This species of prescription being established here upon the necessity existing among us, of some mode of determining the rights to easements, of a more rational character than the ancient rule of prescription, reaching back to the time of legal memory, and applicable to all cases, the analogy of the statute of limitations, by which the period of twenty years is adopted as the time of prescription, seems reasonable and proper to be followed likewise, as to the exceptions prescribed by that statute. Those exceptions are of two kinds, the case of a reversioner against whom the statute does not begin to run. and by parity of reason, the time of prescription does not begin to run until his interest becomes vested, so as to give him a right of action. The tenant for life or years may grant easements, or permit them to be acquired by user, and they will be valid against himself and those who hold his estate during its continuance, and perhaps not afterwards, where the reversioner had previously neither cause nor right to com- 
plain. Daniel v. North, 11 East, 370; Bradburg v. Gimsell, 2 Wms. Saund. 175, d; Barker v. Richardson, 4 B. \& A. 579; Ang. Adv. Enj. 46 ; 2 Greenl. Ev. 545.

(2) Ouners who are under disabilities when their rights are first encroached upon, and the right of action for such encroachment first accrues, have by the statutes five years to bring their actions, after the disability is remored, though the period of twenty years may have long expired. Foster v. Marshall, 22 N. H. 491. In such a case, we think there would be the strongest reason for applying to the privileges of the house the same rule we apply to the house itself, and to allow to the disabled owner the rule that he may have five years to contest his liability, after his disability has ceased. But under the statute it has always been held that after the statute has once commenced to run, no intervening disability will defeat the ordinary limitation arising from twenty years adverse possession. Howell v. Zouch, Plowd. 353; Doe v. Jesson, 6 East, S0; Eager v. Commonwealth, 4 Niass. 182; Jackson v. Johnson, 5 Cow. (N. Y.) 74, 15 Am. Dec. 433; Griswold v. Butler, 3 Conn. 227; McFarland v. Stone, 17 Vt. 165, 44 Am. Dec. 325; Mercer v. Selden, 1 How. 37, 11 L. Ed. 38.

The same rule seems to us proper to be applied, in case of disabilities arising to the owners of real estate, after the user and enjoyment of an easement has been commenced under a claim of right, with the knowledge of the owner, and without question or opposition on his part. Such intervening disabilities should not defeat the presumption of title resulting from twenty years possession. Tyler v. Williamson, 4 Mason, 402, Fed. Cas. No. 14,312; 2 Kent's Com. 445; 2 Greenl. Ev. 545; Cross v. Lewis, 2 B. \& C. 686; Best on Presumption, 89; Ang. Watercourses, 235.

The point relative to the award is not insisted upon, and the plaintiff's answer to it seems sufficient. Judgment on the verdict. ${ }^{2}$

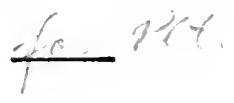

\section{LAMB v. CROSLAND.}

(Court of Appeals of South Carolina, 1851. 4 Rich. Law, 536.)

This was an action on the case for obstructing a ditch.

The lands of the parties were adjoining. The plaintiff's land, in 1817, belonged to her husband, one Alexander Lamb. The defendant's land, then, belonged to one Bartholomew Cosnahan. Near Lamb's house were some ponds, which, in wet seasons, were filled with water, and produced sickness. Lamb asked and obtained permission from Cosnahan to cut a ditch through his land, for the purpose of draining.

2 Mebane v. Patricl, 46 N. C. 23 (1553); Tracy v. Atherton, 36 Vt. 503 (1S64); Ballard v. Demmon, 156 Mrss. 449, 31 N. E. 635 (1S92); Scallon $v$. Manbattin Ry. Co., 1S5 N. Y. 359 , is N. E. 2St, 7 Anu. Cas. 168 (1906), acc. 
those ponds. The ditch communicated with an old ditch, called the meadow ditch, by which the water passed off into Crooked Creek. The land through which the ditch was cut by Lamb, was then woodland; it had since been cleared. The ditch had been kept open as a drain. for Lamb's land ever since, and worked on occasionally, when it suited the convenience of those who owned the land. The plaintiff was in possession of Lamb's land. Lamb died in 1836. No evidence of how the plaintiff derived title was given; but it was understood, from the course of the testimony, that it had been sold for partition, and she was the purchaser. B. Cosnahan died in 1820 , leaving a widow and infant children, one of whom was not of age until 1841. After his death, the land remained in the possession of his widow and the administrator, until 1833, when it was sold for partition, and purchased by one E. Cosnahan, who sold it to one Feagin in 1836. From him it passed to Green. About 1843, he sold to Dudley, and Dudley to the defendant. In 1847 (in January,) in consequence of the lower part of the ditch not being kept sufficiently open, four acres of the defendant's land, on the side of the ditch, were too wet to plough. He sent to the plaintiff, requested her to open it, but she did not do it. In March the defendant filled up the ditch with dirt and logs. Some negotiation took place, and the plaintiff opened the ditch, but as it turned out, not sufficiently, for in July there were very heavy rains, and the water ponded on the four acres, and injured the growing crop. The defendant again obstructed the ditch. It remained so four days, when the plaintiff's son removed the obstruction. But in these four days, the corn in the plaintiff's pond was destroyed. For this injury the action was brought, and the sole question presented by the case was, whether the plaintiff had a prescriptive right to drain her land through this ditch. If she had, the defendant had no right to obstruct it. If she had not, then the defendant had a right to fill it "u' on his own land.

Evidence was given on the question, whether the use had been adverse, or only permissive. That question was submitted to the jury, who found for the plaintiff.

In his report of the case, his Honor, the presiding judge (Evans, I.), says :

"It was clear, that from 1820 to 1833 , the land of defendant belonged to infants; and there was not the slightest evidence to change the original character of the use, up to the death of B. Cosnahan. My own opinion, founded on a pretty full argument, made in the case of Boykin v. Cantey, which I tried at Kershaw, was, that the presumption of title, arising from adverse use, did not arise when the owners were, at the time of its commencement, infants; and that, even in cases of intervening infancy, the presumption was suspended during infancy, for the presumption depends, not on the use alone, but the acquiescence of the owners. In this case, there is 110 doubt about the facts. The use began in 1817, and continued to 1847 , a period of thirty 
years. But during the time, the land belonged to infants thirteen years, leaving only seventeen years. Entertaining this opinion, if I had left that point to the jury, they of course would have found for the defendant; but I did not feel at liberty, after having spent more than a day on the trial, to arrest the case by a nonsuit, on an undecided point, and one of difficult solution. The case was sent to the jury on the other points, reserving to the defendant the right to renew his motion in the Appeal Court."

The defendant appealed, and now moved for a nonsuit, or new trial, on several grounds; the fourth ground for a nonsuit was as follows :

Because, admitting that the plaintiff had adverse possession for tiventy-nine years, it was in evidence, that for thirteen years of this time, the proprietors of the servient tenement were infants, against whom an adverse possession could not grow into a right.

Curia, per Evans, J. There are several questions presented by the brief in this case, but as the decision depends on the fourth ground for a nonsuit, none of the other questions will be considered. That ground is in the following words, to wit, "admitting that the plaintiff had adverse possession for twenty-nine ycars, thirteen years of this time the proprietors of the servient tenement were infants, against whom an adverse possession could not grow into a right." The facts of the case, necessary to be stated in order to understand this ground, are these. In 1817, the ditch, which was the subject of controversy, was dug by Lamb through Cosnahan's land, by his permission or consent, for the purpose of draining some ponds on the land of Lamb. The ditch has been kept open ever since, until obstructed by the defendant, who now owns the land. In 1820, Cosnahan died, leaving a widow and infant children his heirs at law, one of whom was not of age until 1841. In 1833, the land was sold, under a decree of the Court of Equity, for partition, and purchased by one E. Cosnahan, from whom, by several intermediate conveyances, the defendant derives his title.

The question arising on these facts is, whether the plaintiff, who is the owner of Lamb's land, to drain which the ditch was dug, has acquired, by the use thereof, a right of drainage against the owners of the land. 'There is no doubt that, according to our law, as declared in a great many cases, the adverse use of an easement for twenty years will confer a right to the use of it, as fully as if a deed for it were produced and proved. In the ordinary transactions of mankind, we find that men are not disposed to allow others to exercise dominion over their property. When, therefore, we find that such dominion has been exercised for a long period, without objection on the part of the owner, it is reasonable to conclude that such use began in right, or it would lave been objected to. This title is founded on the presumption of a grant, which time or accident has destroyed. But this is perhaps a legal fiction, which the law resorts to, to support 
ancient possessions, and to maintain what the acts of the parties show they considered to exist.

There can be no doubt that, if Cosnahan had lived for twenty years after the use of the ditch commenced, and Lamb had used it adversely, as the jury have found, the right would have been perfect; and I suppose it equally clear, that if the time before Cosnahan's death, added to the time which elapsed after the sale in 1833, together, made the full period of twenty years, the right would be beyond dispute. For in both cases there would be an adverse use, and an acquiescence by those laboring under no disability, for the full period that the law requires to support. the presumption of a grant.

In this case these two periods of time amount to only seventeen years, and unless the presumption can arise against the infants, the twenty years is incomplete.

In McPherson on Infants, it is said (p. 538): "It is a maxim of law, that laches is not to be imputed to an infant, because he is not supposed to be cognizant of his rights, or capable of enforcing them." In Bacon's Abridg. title Infant, G, (5 vol. 110,) last edition, it is said: "The rights of infants are much favored in law, and regularly their laches shall not prejudice them, upon the presumption that they understand not their rights, and that they are not capable of taking notice of the rules of law so as to apply them to their advantage." The same doctrine is to be found in all the elementary writers from Coke to the present time. The presumption arises from the acquiescence of the parties interested to dispute it, and it would be difficult to assign a reason for drawing any conclusion from the acquiescence of an infant, who is supposed in law not to be cognizant of his rights, or capable of enforcing them. Accordingly we find, that in all the cases which have been decided, so far as I know, no presumption has been allowed against the rights of an infant, whether the question related to the satisfaction of bonds for the payment of money, or the performance of other acts, or to rights growing out of what Best calls a non-existing grant. In Boyd v. Keels, decided in 1830, it was held that no presumption could arise that the condition of a bond of an administrator had been performed, because the distributee, to whom he was to account and pay over the money, was an infant. The same was affirmed in the case of Brown v. McCall, 3 Hill, 335. In Gray v. Givens, 2 Hill, Eq. 514, Judge Harper says: "I think it has not been questioned, that the time during which the party to be affected has been under disability, must be deducted in computing the lapse of time, in analogy to the Statute of Limitations. Such was the case in Riddlehoover v. Kinard, 1 Hill, Eq. 376. If the possession were taken in early infancy, the title might be matured before the infant arrived at age, and before the Statute of Limitations had begun to run against him. The decisions have been numerous, and the practice habitual and I am not aware of any doctrine or decision to the contrary."

We have no case involving the right to an easement, in which the 
question involved in this case has been decided by this court. In Watt v. Trapp, 2 Rich. 136, Judge O'Neall, on the circuit, expressed the opinion to the jury, that the presumption of a grant to a way would be arrested by infancy. But that point was not necessarily involved in the case, and this court declined to express any opinion, as, according to my recollection, it was not argued. In other States the question has been decided. In the case of Watkins v. Peck, 13 N. H. 360, $40 \mathrm{Am}$. Dec. 156, it was held, that a grant cannot be presumed from the use and enjoyment of an easement for the term of twenty years, when the party, who must have made the grant if it existed, was an infant at the time of making it. This does not come up fully to the case under consideration, because in this case the grant, if any, must have been made coeval with the use, and that was in the lifetime of Cosnahan, who was adult. But that can make no difference, unless we apply the rule, which has been adopted in relation to some of the clauses of the Statute of Limitations, viz., that where the Statute begins to run, it will not be arrested by any intervening disability. But this has not been contended for, and there is no semblance of authority to support it. This construction arises on a positive enactment, that the action must be within four years from the time the right of action accrued; whereas presumptions arise from the assertion of the right, and the acquiescence in it, during the whole period of twenty years, and how can it be said that the infants have acquiesced, when they were incapable of asserting their rights?

But the case of Melvin v. Whiting, 13 Pick. (Mass.) 190, was a case of intervening infancy. The plaintiff claimed title to a several fishery, on the defendant's soil, and relied, to support his title, on proof of an adverse, uninterrupted, and exclusive use and enjoyment for twenty years. The jury were instructed by the Chief Justice that, to raise such a presumption of conveyance, it must appear that such exclusive right had been used and enjoyed against those who were able in law to assert and enforce their rights, and to resist such adverse claim, if not well founded; and, therefore, if the persons against whom such adverse right is claimed, were under the disability of infancy, the time during which such disability continued, was to be deducted in the computation of the twenty years; and this construction was supported by the Court of Appeals. The only dictum which I have found to the contrary, is contained in the opinion of Judge Story, in the case of Tyler v. Wilkinson, 4 Mason, 402, Fed. Cas. No. 14,312. The action involved the priority of right to use the water in Pawtucket River, and in no way involved the question of the rights of infants. The question which he was discussing was, whether the presumption from adverse use was a presumptio juris et de jure, a question of law to be decided by the court, or a fact to be determined by the jury. In support of his argument, that it is a presumptio juris, he says the right by presumption of a grant is not affected by the intervention of personal disabilities, such as infancy, coverture, and inșanity. This dic- 
tum is noticed and disregarded in the New Hampshire case above referred to, and I may be permitted to say, without any disrespect to that great and learned judge, that he did not bear in mind the distinction between a right claimed by prescription, and a presumption of right irom a non-existing grant. The former requires a use beyond legal memory, the latter may arise within twenty years. Best on Presump. § 88; 3 Stark. Ev. 911, 3d Ed.; 2 Ev. Poth. 139.

We are of opinion, that the period of time during which the infant heirs of Cosnahan were the owners of the servient tenement, is not to be computed as a part of the twenty years' adverse use necessary to vest the easement in the plaintiff, and upon this ground the plaintiff should have been nonsuited on the circuit. It is therefore ordered that the verdict be set aside, and the defendant have leave to enter up a judgment of nonsuit.

O'NEALL and Frost, JJ., concurred. Motion granted. ${ }^{3}$

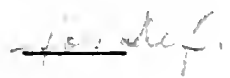

\section{BAXTER v. TAYLOR.}

(Court of King's Bench, 1832. 4 Barn. \& Adol. 72.)

Declaration stated that a certain close called Stoney Butts Lane, situate in the parish of Halifax in the county of York, was in the possession and occupation of J. H., J. E., and J. A., as tenants thereof to the plaintiff, the reversion thereof then and still belonging to the plaintiff; yet the defendant, well knowing the premises, but contriving to prejudice and aggrieve the plaintiff in his reversionary estate and interest, whilst the said close was in the possession of the said J. H., J. E., and J. A., to wit, on, \&c. wrongfully and unjustly, and without the leave and license, and against the will of the plaintiff, put and placed upon the said close diverse large quantities of stones, and continued the same for a long space of time, to wit, from thence hitherto; and also with the feet of horses, and the wheels of carriages, spoiled and destroyed divers parts of the said close, whereby the plaintiff was greatly injured in his reversionary estate and interest therein. Plea, not guilty. At the trial before Parke, J., at the last assizes for the county of York, it appeared that the plaintiff was seised in fee of the closes mentioned in the declaration, which he had demised to tenants; that the defendant had with his horses and cart entered upon the close called Stoney Butts Lane; and that after notice had been given him by the plaintiff to discontinue so doing, he claimed to do so in exercise of a right of way. The learned Judge was of opinion, that although that might be good ground for an action of trespass by the occupier of the plaintiff's farm, it was not evidence of any injury to the reversionary estate, and therefore that the action was not maintainable; and he

3 See Saunders v. Simpson, 97 Tenn. 3s2, 37 S. W. 195 (1896); Hodges v. Goodspeed, 20 R. I. 537, 40 Atl. 373 (1898). 
nonsuited the plaintiff, but reserved liberty to him to move to enter a verdict.

TAUnTon, J. I think there should be no rule in this case. Young v. Spencer, 10 B. \& C. 145 , is not in point. That was an action on the case in the nature of waste by a lessor against his own lessee. Here the action is by a reversioner against a mere stranger, and a very different rule is applicable to an action on the case in the nature of waste brought by a landlord against his tenant, and to an action brought for an injury to the reversion against a stranger. Jackson v. Pesked, 1 M. \& S. 234, shews, that if a plaintiff declare as reversioner for an injury done to his reversion, the declaration must allege it to have been done to the damage of his reversion, or must state an injury of such a permanent nature as to be necessarily prejudicial thereto, and the want of such an allegation is cause for arresting the judgment. If such an allegation must be inserted in a count, it is material, and must be proved. Here the evidence was, that the defendant went with carts over the close in question, and a temporary impression was made on the soil by the horses and wheels; that damage was not of a permanent but of a transient nature; it was not therefore necessarily an injury to the plaintiff's reversionary interest. Then it is said that the act being accompanied with a claim of right, will be evidence of a right as against the plaintiff, in case of dispute hereafter. But acts of that sort could not operate as evidence of right against the plaintiff, so long as the land was demised to tenants, because, during that time, he had no present remedy by which he could obtain redress for such an act. He could not maintain an action of trespass in his own name, because he was not in possession of the land, nor an action on the case for injury to the reversion, because in point of fact there was no such permanent injury as would be necessarily prejudicial to it; as, therefore, he had no remedy by law for the wrongful acts done by the defendant, the acts done by hin or any other stranger would be no evidence of right as against the plaintiff, so long as the land was in possession of a lessee. In Wood v. Veal, 5 B. \& A. 454, it was held that there could not be a dedication of a way to the public by a tenant for ninety-nine years, without consent of the owner of the fee, and that permission by such tenant would not bind the landlord after the term expired. I think therefore that the plaintiff cannot maintain the present action; and there is not doubt sufficient to induce me to think that there ought to be a rule nisi for a new trial.

PATTteson, J. I am of opinion that the nonsuit was right. Young v. Spencer, 10 B. \& C. 145 , was not an action by the reversioner against a stranger, but by a landlord against his tenant. It was an action on the case in the nature of waste. To entitle a reversioner to maintain an action on the case against a stranger, he must allege in his count, and prove at the trial, an actual injury to his reversionary interest. It is said that this action is maintainable, because the plaintiff's title may be prejudiced by a trespass committed under a claim of right; but then for 
such an injury the action must be brought in the name of the tenant, who is the person in the actual possession of the land. It is true the landlord cannot bring an action in the tenant's name without his assent; but that, generally speaking, would be obtained without difficulty, and may be always made matter of arrangement between the landlord and his tenant. The landlord may even provide by covenant in his lease that he shall be allowed to sue in his tenant's name for any trespass committed on the land.

PARKE, J. I am clearly of opinion that there was no injury to the plaintiff's reversionary interest; and to entitle him to maintain this action it was necessary for him to allege and prove that the act complained of was injurious to his reversionary interest, or that it should appear to be of such a permanent nature as to be necessarily injurious. A simple trespass, even accompanied with a claim of right, is not necessarily injurious to the reversionary estate, and what Lord Tenterden said in Young v. Spencer, 10 B. \& C. 145 , must be construed with reference to the subject matter then under consideration, an action on the case in the nature of waste by a reversioner against his tenant.

Rule refused. ${ }^{4}$

SERJEANT WILLIANIS' NOTE TO YARD v. FORD, 2 Wms. Saund. 172, 175: "In Lewis v. Price, Worcester Spring Assizes, 1761, which was an action on the case for stopping and obstructing the plaintiff's lights, Wilmot, J., said, that where a house has been built forty years, and has had lights at the end of it, if the owner of the adjoining ground builds against them so as to obstruct them, an action lies; and this is founded on the same reason as when they have been immemorial, for this is long enough to induce a presumption that there was originally some agreement between the parties; and he said that twenty years is sufficient to give a man a title in ejectment, on which he may recover the house itself; and he saw no reason why it should not be sufficient to entitle him to any easement belonging to the house. So in an action on the case for stopping up ancient lights, the defendant attempted to show that the lights did not exist more than sixty years, Wilmot, C. J., said, that if a man has been in possession of a house with lights, belonging to it for fifty or sixty years, no man can stop up those lights; possession for such a length of time amounts to a grant of the liberty of making

4 But see Lund v. New Bedford, 121 Mass. 2S6 (1876); Cross v. Jewis, 2 B. \& C. 686 (1824); Ballard v. Demmon, 156 Mass. 449,31 N. F. 625 (1892), where the user commenced less than the prescriptive period before the servient land was leased. See, also, Reimer v. Stuber, $20 \mathrm{~Pa}, 458,59 \mathrm{Am}$. Dec. $7+4(185:)$, where the user took place while the servient land was in the possession of tenants from sear to year.

A. owns lands in the possession of $\mathrm{B}$. under a lease of 99 year's. What would be the effect, as against $B$., of an adverse user for the prescriptive period? See Bright 5 . Walker, 1 Cr., M. \& R. 211 (1834); Wheaton v. Maple \& Co., [1S93] 3 Ch. 48; Kilgour v. Gaddes, [1901] 1 K. B. 457; Wallace v. Fletcher, 30 N. H. 453 (1555), supra, p. 94. 
them; it is evidence of an agreement to make them. If I am in possession of an estate for so long a period as sixty years, I cannot be disturbed even by a writ of right, the highest writ in the law. If my possession of the house cannot be disturbed, shall I be disturbed in my lights? It would be absurd. * * * Dougal v. Wilson, Sittings C. B. Trin. 9 Geo. III."

\section{WVEBB v. BIRD.}

(Exchequer Chamber, 1863. 13 C. B. [N. S.] S41.)

This was a writ of error upon a case stated by an arbitrator for the opinion of the Court of Common Pleas, upon the argument of which that Court held that the owner of a windnill cannot claim, either by prescription, or by presumption of a grant arising from twenty years' acquiescence, to be entitled to the free and uninterrupted passage of the currents of wind and air to his mill; and that such a claim is not within the $2 \mathrm{~d}$ section of the $2 \& 3 \mathrm{~W} . \mathrm{IV}$, c. 71 , which is confined to rights of way or other easements to be exercised upon or over the surface of the adjoining land.

Wightman, J., now delivered the judgment of the Court:

We took time for the consideration of this case on account of its novel character. It appears by the finding of the arbitrator to whom the case was referred by order of Nisi Prius, that the plaintiff was the owner and occupier of a windmill built in 1829 ; that, from the time of its being built, down to 1860 , the occupier had enjoyed as of right and without interruption the use and benefit of a free current of air from the west for the working of the mill; that, in the last-mentioned year, 1860 , the defendants erected a school-house within twenty-five yards of the mill, and thereby obstructed the current of air which would have come to it from the west, whereby the working of the mill was hindered, and the mill became injured and deteriorated in value. Two cases were cited and mainly relied on for the plaintiff, - - one in the 2 Rolle's Abridgment, p. 704, and the other in 16 Viner's Abridgment, tit. Nuisance (G), pl. 19 ; but both are shortly stated, and amount to little more than dicta; and it does not appear that they are anywhere else reported, or in what manner or the terms in which such a right was claimed, whether by prescription or otherwise. There is a third case, called Trahern's Case, Godbolt 233, which was the case of a nuisance caused by building a house so near as to hinder the working of the plaintiff's mill; and the judgment of the Court appears in the first instance to have been like that of the case in Rolle's Abridgment, that

5 "There mere two nisi prius decisions at an earlier day (Lewis $\mathrm{r}$. Price, in 1761, and Dongal $\mathrm{r}$. Wilson, in 1763); but the doctrine [that of acquisition of easement of light and air by user for a definite period of time] was not sanctimed in Westminster Tall umil 17\&6, when the case of Darwin $r$. Tpton was decided by the K. B. 2 Saund. 175, note (2). This was clearly a Teparture from the old law. Bury v. Pope. Cro. Eliz. 11s (15S7)." Bronsoll, J., in Parlier v. Foote, 10 Wend. (N. Y.) 309, 318 (1898). 
so much of the house should be thrown down as hindered the working of the mill. But, the plaintiff contending that the whole house should be thrown down, the ease was adjourned, and no ultimate decision appears to have been given. These are all the authorities which we have been able to find upon the subject.

We agree with the opinion of the Court of Common Pleas, that the right to the passage of air is not a right to an easement within the meaning of the $2 \& 3 \mathrm{~W}$. IV, e. $71, \S 2$.

The mill was built in 1829 , and so the claim cannot be by prescription.

The distinetion between easements, properly so called, and the right to light and air, has been pointed out by Littledale, J., in Moore v. Rawson, 3 B. \& C. 332, 340 (E. C. L. R. vol. 10), 5 D. \& R. 234 (E. C. L. R. vol. 16).

It remains, therefore, to be eonsidered, whether, independently of the statute, the right claimed may be supported upon the presumption of a grant arising from the uninterrupted enjoyment as of right for a certain term of years. We think, in accordance with the judgment of the Court of Common Pleas, and the judgment of the House of Lords in Chasemore v. Richards, 7 House of Lords Cases, 349, that the presumption of a grant from long-continued enjoyment only arises where the person against whom the right is elaimed might have interrupted or prevented the exercise of the subject of the supposed grant. As was observed by Lord Wensleydale, it was going very far to say that a man must go to the expense of putting up a screen to window-lights, to prevent a right being gained by twenty years' enjoyment. But, in that case, the right claimed, which was the percolating of water underground, went far beyond the case of a window. In the present case, it would be practically so difficult, even if not absolutely impossible, to interfere with or prevent the exercise of the right claimed, subject, as it must be, to so much variation and uncertainty, as pointed out in the judgment below, that we think it clear that no presumption of a grant, or easement in the nature of a grant, can be raised from the non-interruption of the exercise of what is called a right by the person against whom it is claimed, as a non-interruption by one who might prevent or interrupt it.

We are therefore of opinion that the judgment of the Court below should be affirmed.

Blackburn, J. I perfectly concur in the judgment, but wish, for myself, to guard against its being supposed that anything in the judgment affects the common-law right that may be acquired to the access of light and air through a window, or to the right to support by an ancient building from those adjacent. I agree with my Brother Willes, in the Court below, that the ease of the right to light, before the statute, stood on a peculiar ground.

Judgment affirmed.

AIG.PROP. - 8 


\section{STURGES v. BRIDGMAN.}

(Court of Appeal in Chancery, 1879. $11 \mathrm{Ch}$. Div. 852.)

The plaintiff in this case was a physician. In the year 1865 he purchased the lease of a house in Wimpole Street, London, which he occupied as his professional residence.

Wimpole Street runs north and south, and is crossed at right angles by Wigmore Street. The plaintiff's house was on the west side of Wimpole Street, and was second house from the north side of Wigmore Street. Behind the house was a garden, and in 1873 the plaintiff erected a consulting-room at the end of the garden.

The defendant was a confectioner in large business in Wigmore Street. His house was on the north side of Wigmore Street and his kitchen was at the back of his house, and stood on ground which was formerly a garden and abutted on the portion of the plaintiff's garden on which he built the consulting-room. So that there was nothing between the plaintifi's consulting-room and the defendant's kitchen but the party wall, The defendant had in his kitchen two large marble mortars set in brick-work built up to and against the party-wall which separated lis kitchen from the plaintiff's consulting-room, and worked by two large wooden pestles held in an upright position by horizontal bearers fixed into the party-wall. These mortars were used for breaking up and pounding loaf-sugar and other hard substances, and for pounding meat.

The plaintiff alleged that when the defendant's pestles and mortars were being used, the noise and vibration thereby caused were very great, and were heard and felt in the plaintiff's consulting-room, and such noise and vibration seriously annoyed and disturbed the plaintiff and materially interfered with him in the practice of his profession. In particular the plaintiff stated that the noise prevented him from examining his patients by auscultation for diseases of the chest. He also found it impossible to engage with effect in any occupation which required thought and attention.

The use of the pestles and mortars varied with the pressure of the defendant's business, but they were generally used between the hours $10 \mathrm{~A}$ : M. and 1 P. M.

The plaintiff made several complaints of the annoyance, and ultimately brought this action, in which he claimed an injunction to restrain the defendant from using the pestles and mortars in such manner as to cause him annoyance.

The defendant stated in his defence that he and his father had used one of the pestles and mortars in the same place and to the same extent as now for more than sixty years, and that he had used the second pestle and mortar in the same place and to the same extent as now for more than twenty-six years. He alleged that if the plaintiff had built 
his consulting-room with a separate wall, and not against the wall of the defendant's kitchen, he would not have experienced any noise or vibration; and he denied that the plaintiff suffered any serious amnoyance, and pleaded a prescriptive right to use the pestles and mortars under the $2 \& 3$ Will. IV, c. 71.

Issue was joined, and both parties went into evidence. The result of the evidence was that the existence of the nuisance was, in the opinion of the court, sufficiently proved; and it also appeared that no material inconvenience had been felt by the plaintiff until he built his consulting-room.

1879, July 1. Thesiger, L. J., delivered the judgment of the court (Jamis, Baggaliay, and Thesiger, L. JJ.) as follows:

The defendant in this case is the occupier, for the purpose of his business as a confectioner, of a house in Wigmore Street. In the rear of the house is a kitchen, and in that kitchen there are now, and have been for over twenty years, two large mortars in which the meat and other materials of the confectionery are pounded. The plaintiff, who is a physician, is the occupier of a house in Wimpole Street, which until recently had a garden at the rear, the wall of which garden was a party-wall between the plaintiff's and the defendant's premises, and formed the back wall of the defendant's kitchen. The plaintiff has, however, recently built upon the site of the garden a consulting-room, one of the side walls of which is the wall just described. It has been proved that in the case of the mortars, before and at the time of action brought, a noise was caused which seriously inconvenienced the plaintiff in the use of his consulting-room, and which, unless the defendant had acquired a right to impose the inconvenience, would constitute an actionable nuisance. The defendant contends that he had acquired the right, either at common law or under the Prescription Act, by uninterrupted user for more than twenty years.

In deciding this question one more fact is necessary to be stated. Prior to the erection of the consulting-room no material annoyance or inconvenience was caused to the plaintiff or to any previous occupier of the plaintiff's house by what the defendant did. It is true that the defendant in the 7 th paragraph of his affidavit speaks of an invalid lady who occupied the house upon one occasion, about thirty years before, requesting him if possible to discontinue the use of the mortars before eight o'clock in the morning; and it is true also that there is some evidence of the garden wall having been subjected to vibration, but this vibration, even if it existed at all, was so slight, and the complaint, if it could be called a complaint, of the invalid lady, and can be looked upon as evidence, was of so trifling a character that, upon the maxim de minimis non curat lex, we arrive at the conclusion that the defendant's acts would not have given rise to any proceedings either at law or in equity. Here then arises the objection to the acquisition by the defendant of any easement. That which was done by him was 
in its nature such that it could not be physically interrupted; it could not at the same time be put a stop to by action. Can user which is neither preventable nor actionable found an easement? We think not.

The question, so far as regards this particular easement claimed, is the same question whether the defendant endeavors to assert his right by common law or under the Prescription Act. That Act fixes periods for the acquisition of easements, but, except in regard to the particular easement of light, or in regard to certain matters which are immaterial to the present inquiry, it does not alter the character of easements, or of the user or enjoyment by which they are acquired. 'This being so, the law governing the acquisition of easements by user stands thus: Consent or acquiescence of the owners of the servient tenement lies at the root of prescription, and of the fiction of a lost grant, and hence the acts or user, which go to the proof, of either the one or the other, must be, in the language of the civil law, nec vi nec clam nec precario; for a man cannot, as a general rule, be said to consent to or acquiesce in the acquisition by his neighbor of an easement through an enjoyment of which he has no knowledge, actual or constructive, or which he contests and endeavors to interrupt, or which he temporarily licenses. It is a mere extension of the same notion, or rather it is a principle into which by strict analysis it may be resolved, to hold, that an enjoyment which a man cannot prevent raises no presumption of. consent or acquiescence. Upon this principle it was decided in Webb. v. Bird, 13 C. B. (N. S.) 841 , that currents of air blowing from a particular quarter of the compass, and in Chasemore v. Richards, $7 \mathrm{H}$. L. C. 349 , that subterranean water percolating through the strata in no known channels, could not be acquired as an easement by user; and in Angus v. Dalton, 4 Q. B. D. 162, a case of lateral support of buildings by adjacent soil, which came on appeal to this court, the principle was in no way impugned, although it was held by the majority of the court not to be applicable so as to prevent the acquisition of that particular easement. ${ }^{6}$ It is a principle which must be equally appropriate to the case of affirmative as of negative easements; in other words, it is equally unreasonable to imply your consent to your neighbor enjoying something which passes from your tenement to his, as to his subjecting your tenement to something which comes from his, when in both cases you have no power of prevention.

But the affimative easement differs from the negative easement in this, that the latter can under no circumstances be interrupted except by acts done, upon the servient tenement ; but the former, constituting, as it does, a direct interference with the enjoyment by the servient owner of his tenement, may be the subject of legal proceedings as well as of physical interruption. To put concrete cases, the passage of light and air to your neighbor's windows may be physically interrupt-

6 See the same case in the House of Lords. 6 App. Cas. 740 (18s1). 
ed by you, but gives you no legal grounds of complaint against him. The passage of water from his land on to yours may be physically interrupted, or may be treated as a trespass and made the ground of action for damages, or for an injunction, or both. Noise is similar to currents of arr and the flow of subterranean and uncertain streams in its practical incapability of physical interruption, but it differs from them in its capability of grounding an action. Webb v. Bird and Chasemore v. Richards are not, therefore, direct authorities governing the present case. They are, however, illustrations of the principle which ought to govern it; for until the noise, to take this case, became an actionable nuisance, which it did not at any time before the consulting-room was built, the basis of the presumption of the consent, viz., the power of prevention physically or by action, was never present. $^{7} * * *$

\section{HUBBARD v. TOWN.}

(Supreme Court of Vermont, 1860. 33 Vt. 295.)

Pierpoint, J. ${ }^{8}$ This action is brought to recover the damage claimed to have been sustained by the plaintiff in consequence of the defendant's obstructing his lights.

It appears from the case that the building which has been owned and occupied by the plaintiff and his tenants for more than twentyfive years prior to the acts complained of, stands upon the line between his premises and the premises of the defendant, and that the defendant has owned and occupied his premises during the aforesaid period; that the windows in the plaintiff's building opened out toward the premises of the defendant, admitting light from that direction, and that they have so remained without obstruction, and without question on the part of the defendant for the period of twenty-five years or more; that in 1859 the defendant erected a building on his own premises immediately adjoining that of the plaintiff, so as to exclude the light from two of the plaintiff's windows.

The only question involved in this case is, whether the plaintiff by such long and uninterrupted use of his windows, and the light passing through them, has thereby acquired the right so to continue his windows and thus to have the light pass through them, so that any act of the defendant which shall materially obstruct such light, will make him a wrong doer, and liable for any damage to the defendant that may ensue therefrom.

The rule seems now, to be well settled in England, that such long and uninterrupted use of light, gives the right to continue its use, and

7 The balance of the opinion is omitted.

8 The statement of facts is omitted. The case sufficiently appears from the opinion. 
to insist upon its remaining unobstructed by the adjoining proprietor for all time. The courts place this upon the same grounds as rights of way, and other rights acquired in and over the premises of another by long and undisturbed use; presuming from the long exercise of the privilege by the one and an acquiescence therein by the other, that the right had its origin in a grant.

While the general doctrine has been universally adopted in this country, its application to cases of this kind has not been generally recognized, and in many of the States has been-expressly denied.

Our statute of limitations cannot be brought in aid of the plaintiff's clain. The statute in terms only deprives the aggrieved party of the right of action after the limited period from the time the cause of action accrues, and although our courts have held that the exercise of the right by one party, and an acquiescence therein by the other, for such period, vests in the party so exercising it an absolute right, still in determining the question whether such right has in fact become an absolute one, the time that the one has so exercised it, is to be computed from the period when a cause of action therefor first accrued to the other, which he has omitted to enforce; so that no right can be lost or acquired by virtue of the statute, where there has been no act done by the one, for which the law gives a remedy by action to the other; and it is conceded in this case that the defendant had no right of action against the plaintiff for any act of his, in erecting his building and opening and continuing lis windows, on the side adjoining to, and overlooking the defendant's premises.

This reason would seem to apply with equal force, against the plaintiff's right to recover on the ground that a grant will be presumed from lapse of time to sustain his claim.

The principle upon which a grant is presumed is that in no other way can the acts of the parties be rationally accounted for. Such presumption is required to account for the exercise of the right by the one, and the acquiescence therein by the other, for so long a period.

The right must be exercised adversely or under a claim of a right so to exercise it, by the one, and it must be acquiesced in by the other.

This of itself presupposes that the exercise of the right by the one, without a grant, is a violation of some right of the other; otherwise it could not be adverse, within the meaning of the rule; neither could the other acquiesce, for that presupposes a legal right to object and resist.

If then there is no violation of the rights of another, no presumption of a grant by such other arises; there is no occasion for it. There is no right exercised or claimed by the one, that belongs to the other, or which he could grant, if he should attempt it.

How then can this doctrine of presumption apply to a case like the present? The erection of the building by the plaintiff on the line between him and the defendant was no violation of any right of the de- 
fendant; he could not complain of, or prevent it, and his assent or dissent could in no manner affect the transaction. The legal right to do the act was perfect in the plaintiff. His right to erect his building on the division line is not controverted, the wisdom of the act is more questionable. He might have made his walls solid, thus entirely excluding the light from that direction; he chose to leave apertures therein: thereby allowing the light to remain unaffected to that extent; but how can it be said that by excluding the greater part, he acquires any better right to the remainder, than he would have had to the whole, if he had not excluded any? He has not done any act which has had any effect to control or influence the light, except to exclude it. He did not draw or cause the light to pass in upon his premises in any other than its natural manner; it remained upon and over the defendant's premises as it had always been. As there was no interference with the rights of the defendant, it is difficult to see upon what the presumption of a grant can be based. Lapse of time and the presumption arising therefrom are resorted to, only to justify in one, that which would otherwise be a usurpation of the rights of another.

If a man can acquire, by use, a right to an uninterrupted enjoyment of light under circumstances like the present, why not acquire a right to a like enjoyment of the prospect from the same windows, or to a free access of the air to the outside of his building to prevent decay, and many other rights of a similar and no more ethereal character? The result of which would be, if allowed, an utter destruction of the value of the adjoining land for building purposes.

Windows are often of more importance for the prospect they afford, than for the light they admit. The light may be obtained from other directions, the prospect cannot. A pleasant prospect from the windows of a dwelling, always contributes more or less to the enjoyment of the occupants, and often enters largely into its pecuniary estimate. But to admit that a mere enjoyment of sucl prospect for fifteen years, gives him the right to insist that it shall remain uninterrupted for all future time, would be to recognize a principle at variance with well established rules, and one that could not be tolerated in this country.

No such right can be acquired by use for the same reason that its exercise by one is no infringement of the rights of another, for which the law gives an action. Le Blanc, J., in Chandler. v. Thompson, 3 Camp. 82, says, that although an action for opening a window to disturb the plaintiff's privacy, was to be read of in the books, he had never known such an action to be maintained, and that he had heard it laid down by Eyre, Ch. J., that such an action did not lie.

We think the English courts, in applying the doctrine of the presumption of grants from long use and acquiescence to this class of cases, clearly departed from the ancient common law rule as laid down in Berry v. Pope, Cro. Eliz. 118, and the error as it seems to us, consists in placing cases like the present upon the same footing and mak- 
ing them subject to the same rules that govern another class of cases, to which they really have no analogy. In Lewis v. Price, Wilmot, J., said "that when a house had been built forty years and has had lights at the end of it, if the owner of the adjoining ground builds against them so as to obstruct them, an action lies; and this is founded on the same reason as where they have been immemorial, for this is long enough to induce a presumption that there was originally some agreement between the parties, and that twenty years was sufficient to give a man a title in ejectment on which he may recover the house itself, and he saw no reason why it should not be sufficient to entitle him to an easement belonging to the house."

As we have already seen, no presumption of an agreement arises, as none was necessary to justify the act. The man who occupies his own house for twenty years has no better title to it at the end of that time, than he had in the outset. Does he acquire any greater right to the light by the occupation than to the house? Clearly not; liaving usurped no right he can acquire none by lapse of time.. 'The error in the reasoning is, in saying that because the man who takes possession of his neighbor's house and holds it adversely for twenty years (his neighbor acquiescing therein,) acquires a title to it, therefore the man who opens windows in his own house that in no way interferes with the rights of his neighbor, and of which such neighbor has no legal right to complain, and keeps them open for twenty years, thereby acquires a right to insist that no act shall be done by his neighbor on his own land, that in any respect interferes with, or obstructs the light to those windows. In the one case there is an infringement of the rights of another for which the law gives a remedy by action; in the other there is not. This constitutes a radical difference between the two cases, and that too in respect to the very point upon which the whole doctrine of presumption in cases like those under consideration depends.

It might be urged with much force that a man who conveys a house with the privileges, etc., would not have a right to make an erection on his own land adjoining, that would shut out the light from the windows in the house so conveyed, and it may be said that he who has occupied another's house for such length of time and under such circumstances that a grant will be presumed, stands upon the same footing as an ordinary grantee. However that may be, this case involves no such question. In those cases the question turns upon the fact that the title to the premises was derived by deed actual or presumed, from the party who seeks to deprive his grantee of the enjoyment of the right he has conveyed. The right does not depend upon the lapse of time, but is as perfect in the grantee the moment the deed is executed as it can ever be. Here the title to the premises of the plaintiff was never in the defendant, but has been in the plaintiff through the whole period.

This question was fully considered in New York in the case of 
Parker v. Foote, 19 Wend. (N. Y.) 309, Bronson, J., says: "Upon what principle courts in England have applied the same rule of presumption to two classes of cases so essentially different in character, 1 have been unable to discover. If one commit a daily trespass on the land of another under a claim of right to pass over, or feed his cattle upon it, or divert the water from his mill, or throw it back upon his land or machinery, in these and the like cases, long continued acquiescence atfords strong presumption of right. But in the case of lights there is no adverse user, nor indeed any use whatever of another's property, and no foundation is laid for indulging any presunption against the rightful owner." And again he says: "There is no principle I think, upon which the modern English doctrine of ancient lights can be supported."

The same doctrine was held in Pierce v. Fernald, 26 Me. 436, 46 Am. Dec. 573, and in Napier v. Bulwinkle, 5 Rich. (S. C.) 312, in both of which cases the subject was fully discussed.

We see no reasons growing out of the nature or necessities of this class of cases, that require us to extend the doctrine of the presumption of grants to them, but on the other hand, the establishment of a rule that would require a man to erect a building or wall, that he did not need, on his own premises, for the sole purpose of excluding the light from his neighbor's windows, would lead to continual strife and bitterness of feeling between neighbors, and result in great mischief.

The judgment of the county court is affirmed.?

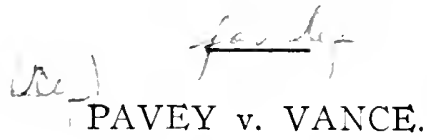

(Supreme Court of Ohio, 1897. 56 Ohio St. 162, 46 N. E. 898.)

Error to Circuit Court, Highland County.

Suit was brought by D. J. Vance and others to enjoin the defendant, A. E. Pavey, from closing up a certain way used by the plaintiffs over his land, which they claimed as appendant to their land. The defendant denied the right. The case was appealed to the circuit court, where at the trial on the issues, the.court, at the request of the defendant, made a finding of the facts and its conclusions of law separately. The finding of facts is as follows:

"That the plaintiffs are the owners in fee simple of the lands described as theirs in the petition, and that the defendant is the owner of the lands set out in the petition as his; that the plaintiffs acquired

9 As to the somewhat analogous situation where the easement of lateral support is claimed by prescription, see Richart $v$. Scott, 7 Watts (Pa.) 460,32 Am. Dec. 779 (1S38); Mitchell v. Rome, 49 Ga. 19, 15 Am. Rep. 669 (1S73); Tunstall v. Christian, so Va. 1, 56 Am. IRep. 581 (1S85); Sullivan v. Zeiner, as Cal. 346, 33 Pac. 209, 20 L. R. A. 730 (1593); Angus v. Dalton, 3 Q. B. D. S. (1S77), 4 Q. B. D. 162 (1878), 6 App. Cas. 740 (1851); Solomon v. Vintners' Co., 4 H. \& N. 585 (1859). 
the legal title from D. I. Vance; that D. J. Vance had occupied the lands from A. D. 1857; that the defendant acquired the title to his lands from Penelope Evans, who acquired it from Benjamin Barrere, now deceased; that defendant had notice after he contracted to buy said premises, and before his acceptance of the conveyance to him from Evans, that D. J. Vance claimed the right of way contended for by the plaintiffs in this suit; that, for more than twenty-one years prior to the acquiring of title by defenclant of the lands from Penelope Evans, D. J. Vance and his family, in going to and from his farm and divelling to the turnpike leading from Hillsboro to New Market, and others going to and from said pike to Vance's, had passed over the lands of defendant, using a way or road through defendant's farm as a foot way, wagon way, carriage way, and for hauling produce to and from said Vance's farm, and horseback way, without let or hindrance or obstruction from Benjamin Barrere in his lifetime, or Penelope Evans, or their tenants; that said road was used by said Barrere and his successors in ownership, during all of said period of time, as a farm road through lis farm from the pike to the divelling house on the D. J. Vance farm, and to the back part of the farm to the farm line of said Vance, said entire farm being inclosed during all of said period of time, being inclosed by fences and gates; that the Vances, and also the owners and occupants of defendant's lands, used said way whenever they saw fit, and was also used as one of the means of approach (but not the only road) to the Vance farm and house, and for departure therefrom, to and from the said turmpike, and was so used by said Vances and those going to and from the Vance place, without asking leave of the occupants of defendants farm and without objection.

"The said roadway is described as follows: Beginning in the line of the land of defendart and land of Jesse and Elizabeth McConnaughey (formerly owned by Benj. Barrere); rumning thence a northwesterly course over the lands of said defendant, Pavey, and, crossing a branch of Rocky Fork creek, passes by the dwelling house on the lands of said Pavey, and continued a northwesterly course to the said Ripley turnpike, at a point about twenty-seven rods southwest of the schoolhouse on said turnpike known as the 'Kansas Schoolhouse,' there being three gates on said roadway, viz. one gate at the pike, one at the Pavey dwelling house, and one at the line between the lands of the defendant and said Jesse and Elizabeth E. McConnaughey, and the length of said right of way from where it enters that land of said Pavey to its termination at said turnpike being about 116 rods. tThe court further finds that the defendant, A. E. Pavey, obstructed said roadway in the spring of A. D. 1893, prior to the bringing of this suit, by erecting a fence across the same, and ever since preventing the Vances' passing over the same.in vehicles and on horseback."

The court found as a matter of law from these facts that the plaintiffs were the owners of a right of way by prescription over the lands 
of the defendant, and rendered judgment for the relief prayed for, enjoined the defendant from obstructing the way, other than by the use of gates as before maintained, and ordered the removal of the obstructions. The defendant excepted to the court's conclusions of law and judgment on the facts, and prosecutes error here for a reversal of the judgment, on the ground that it is not supported by the facts.

Minshall, J. (after stating the facts). The plaintiff in error claims that the court erred in its judgment because it does not appear from its finding that the way was used for the requisite period adversely to the defendant and his predecessors in title, and under a claim of right, nor is it found that it was not permissive. The court found that, for more than 21 years prior to the time the defendant acquired his title to the land, D. J. Vance, the predecessor in title of the plaintiffs, and his fanily, "in going to and from his farm and divelling to the turnpike, and others going to and from said pike to Vance's, have passed over the lands of defendant, using a way or road through defendant's farm as a foot way, wagon way, carriage way, horseback way, and for hauling produce to and from said Vance's farm, without let or hindrance or obstruction" from the defendant's predecessors in title.

The plaintiffs' claim is based on a title by prescription to the roadway on the facts found. Easements of all kinds are said to lie in grant, and not in livery; "for the reason that, according to feudal ideas, they could not be created by livery, as livery would destroy the seisin of the owner of the land subject to the easement. But as a right to that which an individual has long used and enjoyed as his own without disturbance has ever been agreeable to a sense of natural justice, the courts of England at an early day aclopted the fiction of a lost deed in support of easements that had been enjoyed by the owner of the dominant estate and those under whom he claimed for a period beyond the memory of man. This was first fixed at a time beyond the reign of Richard I. But, by reason of the remoteness of the period, the proof became more and more difficult, if not impossible; and finally the courts adopted a shorter period of 20 years, in analogy to the limitation in possessory actions. Still in this state of the law, as the title rested upon the presumption of a lost deed, the courts held that it might be rebutted, so that long possession still continued subject to this contingency, and might be overthrown by a showing that it commenced and continued without deed.

This, however, is no longer the general doctrine. Washb. Easem. (4th Ed.) 130-135; Railroad Co. v. McFarlan, 43 N. J. Law, 605; Tracy v. Atherton, $36 \mathrm{Vt}$. 503. Where an easement, as a way, is now shown to have been used by an owner of land over the land of another for the requisite period, without interruption with all the incidents of ownership, the fact of such use is accepted as conclusive proof of the right. The extent of the right is determined by the nature 
and extent of the use. It is said: "Every species of prescription by" which property is acquired or lost is founded on the presumption that he who has had a quiet and uninterrupted possession of anything for a long period of years is supposed to have a just right thereto, "without which he could not have been suffered to continue so long in the enjoyment of it." Brown, Inst. 418.

This is the principle of the civil law from which title by prescription is derived. It must not be confonnded with usucaption, which simply, by the lapse of a short time, cured defects in titles otherwise good. Prescription was not regarded as a source of title, but as a means of defense against the assertion of an originally superior title,-one that would have prevailed but for the consideration given to longtime possession. It would seem that this was made available by the magistrate so framing the formula as to confine the inquiry of the judge to the simple question of long-time possession, and this was done by writing the limitation before the intentio. Hence the significance of the term "prescription," which from its etymology means a writing before. The prescription was inserted for the very purpose of excluding any other inquiry as to the rights of the party claiming thereunder than such as arose from long possession of the land in the character of owner. Sander, Just. Introd. § 10t; Hunter, Roman Law, 288; Postes, Gaius, 581.

But it is not material on which ground we regard that a right to an easement by prescription rests,-whether on that of a grant presumed from lapse of time, or from the justice and policy of protecting one who has long used and enjoyed a right in the character of owner,-the practical result is the same. The party so using and enjoying the easement is adjudged as possessing the right in connection with his land as an incident thereto. The substance, then, of a title by prescription, whether it relate to the land or an easement in it, is the use and enjoyment of the land, or the easement, for the requisite period as an owner. No inquiry beyond this is required. The establisliment of the claim, however, necessarily requires proof that the use was adverse to the real owner, and under a clain of right. Without such proof one could not be said to possess or use as an owner. Nor would the claim be consistent with a case where the possession is taken and held under the license or permission of the real owner. 'But' in the case of an easement it is not required that the use should be exclusive of the owner of the servient tenement. The latter may use a way in connection with the owner of the dominant tenement, as the two uses are consistent; and the owner of the servient tenement may maintain gates thereon where such was his custom during the period of prescription. The use made of the way and the mode of its enjoyment during this period determines the extent of the right acquired and its limitations. Washb. Easem. 135. These views are fully sustained by the authorities cited by counsel for the defendant in error. 
In this case the finding shows that the use made of the way was adverse to the owner of the land. It prevented him from cultivating it as he might otherwise have done, or from making any use of it inconsistent with the right of way as used. It also appears that it was under a claim of right, as it was used without "let or hindrance" and "without asking leave." These circumstances are sufficient to show that it was under a claim of right. It is not necessary that it should have been made to appear that the party using the way verbally asserted the right to do so when using it. This may appear from conduct as well as words; using a way without asking leave imports a claim of right to do so. It may be stated as a general rule that where a person uses a way in the enjoyment of his own land through the land of another, without let or hindrance, for the period of 21 ycars, in the absence of anything to the contrary, he thereby acquires a right by prescription to continue the use as an incident to his own land, and which will pass by a conveyance or descent of it. The fact of the use is open to explanation. It may be shown to have been permissive. But in such case the burden is upon the owner of the lant to show that the use was a permissive one. Gartett v. Jackson, 20 Pa. 331; O'Daniel v. O'Daniel, \&8 Ky. 185, $10 \mathrm{~S}$. W. 638. If the rule were otherwise, the burden of proof woukd be placed on the party holding the negative, which is selclom, if ever, done in civil suits; for it is easier to prove an affirmative than a negative. Such evidence may have been offered, but the court eviciently found, in this regard, against the defendant, in finding that it was without "let."

The evidence is not incorporated in the record, and the finding must govern the disposition of the case. Judgment affirmed. ${ }^{10}$

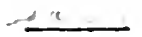

\section{BARBER v. BAILEY.}

(Supreme Court of Vermont, 1912. sf; rt. 219, S4 Atl. 60S, 44 L. R. A.

$$
\text { [N. S.] 9s.) }
$$

Powers, J. ${ }^{11}$ The orator owns a piece of land on the northerly side of Pine Street, in the village of Newbury, known as the "Spring 1 Iouse Pasture." The defendant lives in a house which stands just north of this pasture, and has lived there since sometime in $18+6$. During all this time, he, and the members of his family, in going to and from Pine Street and the postoffice, have taken a "short cut" through the pasture. No one has ever objected to this until on December 2, 1908 , the orator asked the defendant to take and carry away a certain timber which he, the defendant, had used as a bridge over a small brook in

10 See. also, Fleming r. Howarl. 150 Cal. 2S, S7 Pare 90ৎ (1906); Mitchell v.

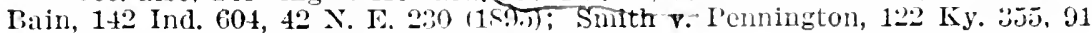
S. W. 730, 8 L. R. A. (N. S.) 149 (1906).

$11 \mathrm{~A}$ portion of the oninion is omitted. 
the pasture. This the defendant refused to do, and the orator cut the timber in two, and the water floated it away. 'The defendant sued the orator to recover damages for the loss of the timber, and with this action pending, the orator brought this bill in chancery to enjoin the action at law, to restrain the defendant from crossing the pasture, and for an accounting. A trial was had before the chancellor, who found and filed the facts, and a decree was thereupon rendered for the orator. From that decree the defendant appeals. The only question litigated below was as to the right of the defenclant to cross the pasture, a prescriptive right so to do being the defendant's only claim.

This brings us to a consideration of the main question in the case: Has the defendant acquired a prescriptive right to cross the orator's pasture? The finding is that for upwards of sixty years the defendant and his family have passed through the pasture to and from Pine Street "openly, notoriously and continuously, without interruption."

The right to an easement in another's land acquired by long use and enjoyment is analogous to the right acquired by adverse possession; and the rules of law applicable to the two cases are in harmony. Mitchell v. Walker, 2 Aikens, 266, 16 Am. Dec. 710 ; Tracy v. Atherton, $36 \mathrm{Vt}$. 503. One of the essentials, to the acquisition of such a right is that the use shail be adverse, - that is to say, it nust be under a claim of right on the part of the user. Mitchell v. Nalker, supra; Lathrop v. Levam, S3 Vt. 1, 74 Atl. 331; Goodall v. Drew, S5 Vt. 408, 82 1t1. riso. So the finding before us lacks one of the elcments of a prescription, for, as we have seen, it does not specify whether the defendant's use of the pasture has been adverse or permissive. Prima facie, the orator being the owner of the pasture, the defendant's acts were mere trespasses, The burden of proof was on the defendant to establish his prescriptive right, if he had one. Plimpton v. Comerse, $42 \mathrm{Vt}$. 712. And this was so, though the orator may have alleged in his bill that the defendant had no such riglit. For, though he alleges more, the orator need only prove that the defendant committed acts which, in the absence of excuse or justification, amounted to a trespass. Bosworth v. Bancroft, $74 \mathrm{Vt} .451,52 \mathrm{Atl}$. 1050. Our attention is called to the statement in the findings to the effect that the defendant never asserted that he crossed the pasture under a claim of right, but this obriously refers to an express assertion, and leaves untouched the effect of the defendant's conduct. It was not necessary for the defendant to make an express declaration of his claim; it was enough if his use of the way was of such a character as to indicate to the owners of the pasture that it was under a claim of right. Wilder v. Wheeldon, $56 \mathrm{Vt}$. 34t; Jangraw v. Mee, $75 \mathrm{Vt}$. 211, 54 Atl. 189, 98 Am. St. Rep. S16.

In establishing the adverse character of his use of the way, the defendant is aided by a presumption, which arises from the fact that the orator and the previous owners knew all about his crossing the 
pasture and made no effort to prevent it. This made it necessary for the orator to come forvard with evidence that the defendant's acts were, in fact, permissive. The rule in such cases was stated by Chief Judge Redfield in Arbuckle v. Mard, $29 \mathrm{Vt}$. 43, in these words: "The mere use, if so open and notorions as obriously to attract the notice of the owner of the soil, or if expressly shown to have come to his knowledge, will prima facic establish the right, and it will be incumbent upon the owner to show in some mode, that it was not used under a claim of riglit to the water, or that he did not so understand it, and was not bound to so regard it from the nature and extent of the use." The same thing was held in Perrin v. Garfield, 37 I't. 30t; Dodge v. Stacy, 39 Vt. 558 ; and in Vilder v. Wheeldon, $56 \mathrm{Vt} .3+4$. But notwithstanding this presumption, the character of the use remains a question of fact, unless the proof and inferences are all one way, Plimpton v. Converse, 42 Vt. 712, and the burden of proof remains on the defendant. And here the proof and infercnees were not all one way, for there were facts and circumstances shown from which we think it could reasonaly be inferred that the defendant's use of the pasture was permissive. The chatacter and situaim of the lanel, the use made of it by the other neighbors, and other circumstances, indicate, more or less strongly, that the defentiant's use of the pasture was ex gratia and not hostile. This heings so, there is nothing for this Court to do lut assume, in aid of the decree, that the court of chancery inferred this fact from those fomd, since whind it the decree could not stand. In re limaley's Fitate, 85 Vt. 351, 82 . 1t1. 5 ; Whiteheal v. Whituhearl. St Vt. 321, T) At. 516; Perkins \& Co.v. Perley, 82 Vt. 524, 7t A1. 231: Van Dyke v. Cole. S1 Vt. 37\%, 70 Atl. 593, 1103: Davenport $\because$ Crowell, $79>1$ t. 419, 65 1tl. 557; Sowles v. St. Albans, T1 Vt. 41S, 45 Atl. 10:0: Kuscell v. Daris, 69 V't. 275, 37 Atl. 7t6: Perrin v. Gurficle, 37 Vt. 30t. This is just what the Court did in the case last cited, except that it was there necessary in support of the judgment to assume that the court betow inferred that the use was hostile instead of permissive.

We realize that it is a serious matter to interfere with privileges enjoyed for more than sisty years, lut it must not be forgotten that this Court sits in error only, and nust deal with a record according to the establiched rules of law, and without regard to its own notions of the merits of the controversy.

Decree affirmed and cause remanded. ${ }^{12}$

12 See, also, Fradley's Fish Co. r. Dudley, 37 Conn. 1.8n (1670): Shea r.

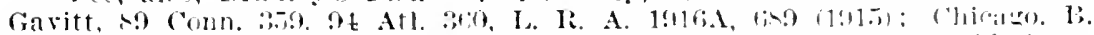

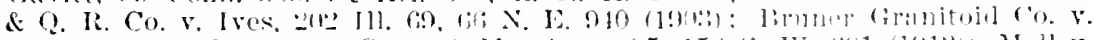

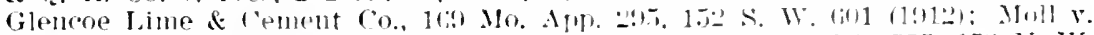
Hagerlummer, 97 Neb. s09, 151 N. W. 300 (1915); Il., 9s Neb. 5.5, 15:; N. W. $560(19) 15 \%$.

laud entirely surrounded by other lands of the grantor was conveger to A.. who for more than twenty years made ofren nse of a comveniont way from the highwa to his land over the land of the grantor. A. then buys at tract 


\section{LECHMAN v. MILIS.}

(Supreme Court of Washington, 1907. 46 Wash. 624, 91 Pac. 11, 13 I. R. A. [N. s.] $990,13 \mathrm{Ann}$. Cas. 923.)

HADLFY, C. J. This action was brought to enjoin the defendants from keeping and maintaining a canal on and across certain lands which the plaintiff claims to own, and also from overflowing with water any portion of said lands by means of said canal together with dams or dikes. Following largely the order of statement found in the brief of respondents, we believe the following is a fair statement of the facts in the case: In the year 1879 one Briggs was the occupant, but not the owner, of the land over which this controversy exists, and which land the plaintiff now claims to own. At that time it was believed the land would be included within the limits of the grant to the Northern Pacific Railway Company when those limits should be detcrmined by the adoption of the line of definite location of the road, such adoption not then having been made. Briggs expected to purchase the land from the railroad company as soon as the latter accuired the title and was in position to make a sale and conveyance. But the land was then a part of the public domain, and Briggs was a mere occupant. While such was the situation, Mr. Mills, one of the defendants in this action, constructed a water ditch and pond on part of said land to serve the purposes of power for the operation of a sawmill. The ditch led from the Yakina river down to a depression upon the land now claimed by the plaintiff, and by means of dikes and dams, together with the natural topography of the ground, the water was impounded in a lake or pond, a part of the land so flooded being a part of the land now claimed by the plaintiff. The lower end of the pond was upon land owned by Mills, and the water which flowed into the pond was released through an outlet upon the land of Mills. Mills also constructed a sawmill, and the water so impounded developed the power for the operation of the mill.

Prior to the construction of the ditch, reservoir, and mill, said Mills entered into an agreement with Briggs, the real nature of which is in issue. The plaintiff contends that it was a mere permission or revocable license to Mills to construct and maintain the ditch and reservoir. The defendants contend, and the trial court found, that it was a verbal grant from Briggs to Mills of the right to construct and maintain said works upon the land. It is not disputed that Briggs at that time, and as a part of the agreement, undertook and promised to execute a deed as soon as he should obtain title from the railroad

of land over which he may reach another highmay. Does he still have a right to use the first way? Suppose that for more than twenty years after his purchase of the second tract he continued to use the old way as before. Is the situation any different? See Ann Arbor Fruit \& Vinegar Co. V. Ann Arbor R. Co., 136 Mich. 599, 99 N. W. 869,66 L. R. A. 431 (1904). 
company. But the plaintiff claims that Briggs, in making the agreement, did not intend to give a deed without first being paid a further consideration in money, no amount being stated but the amount to be subsequently fixed by further agreement. T'Tre defendants contend that this verbal agreement contemplated, so far as a verbal agreement could, an absolute and perpetual grant. Mills has continued to operate his sawmill by means of the water so stored from the time of said construction up to the present time. In 1882 he granted to Hutchinson and Dreisner a one-half interest in the said power for the purpose of operating a flour mill, which was then by them erected. The said flour mill, together with the said conveyed interest in the water power, has by mesne conveyances passed to the defondants Kendall and Mack. The Northern Pacific Railway Company deeded the land to Briggs in 1857, and he continued to own and occupy all of the land except that occupied by the canal and reservoir, until October, 1898. During all of said time the defendants and their predecessors in interest continued to maintain the canal and reservoir, and to inpound the water therein, and to utilize the power for the operation of said mill plants. In October, 1898, Briggs executed to the Sullivan Savings Institution an instrument in the form of a decl purporting to convey to said grantee the title to said land. The plaintiff derives his title through said Sullivan Savings Institution. This action was brought in January, 1906, to enjoin the defendants, as aforesaid, from further maintaining the ditch and reservoir. The cause was tried before the court without a jury, and judgment was rendered for the defendants, to the effect that they have a perpetual cascment against the plaintiff and all persons claiming or to claim through or under him. The plaintiff has appealed.

Finding No. 2, as entered by the court, is as follows: "That just prior to the construction of said works the said defendant Mills entered into an agrement with one Wilkin Briggs, who was then the occupant of the land hereinabove described which land is claimed by the plaintiff, wherein and whereby the said Mills undertook and agreed to construct said canal, dams, reservoir and sawmill, and the said Wilkin Briggs, in consideration of said undertaking and agrecment of said J. L. Mills, gave and granted to said J. L. Mills verbally a perpetual right of way over and upon said land for said canal. ditch and reservoir, together with the right to construct and forcver maintain said canal, ditch, reservoir and dams upon said land and to convey said water through said ditch or canal into said reservoir and to impound said water in said reservoir and overflow the land occupied by said reservoir in order to make the required head of water for the operation of the mills that were to be run by said power. That at that time the said Willin Briggs had no title to the land now claimed by the plaintiff but the same was then a part of the public domain of the United States, but it was then supArg.Prop. -9 
posed that the same would be included within or covered by the land grant to the Northern Pacific Railroad Company as soon as the route of said company's railroad should be definitely located through said county, and the said Wilkin Briggs then expected to eventually purchase said land from said company. And at the time of said verbal agreement between the said Wilkin Briggs and the said J. L. Mills the said Briggs verbally agreed to execute and deliver to the said J. L. Mills a deed evidencing said grant of said right of way and easement upon the demand of said J. L. Mills as soon as the said Briggs himself received a deed to said land; and the said Briggs then and there waived any and all other or further compensation on account of the construction and maintenance of said works and for the overflowing of said land."

It was further found that Mills thereafter constructed said works and sawmill and entered into the enjoyment of the easement and of the rights thus verbally granted to him, openly, notoriously, and adversely as against Briggs and all other persons, under claim of right, and with the full knowledge and acquiescence of Briggs; that all of said construction was made in reliance upon, and on the faith of, the easement so granted and of the right to construct and perpetually maintain said works and conduct water through said canal and impound the same, at an expense of $\$ 10,000$, all of which was known to Briggs who, during all the time of his occupancy acquiesced in the claim of Mills and never disputed or denied it; that the grantees of Mills. who held the flouring-mill power, in like manner relicd upon the right to perpetually use said water and power and perpetually maintain the reservoir, and by reason thereof they constructed their flour mill at an expense of $\$ \$, 000$, all of which was known to Briggs during the time of his occupancy and claim of title to any of said land, and he never denied or disputed said rights, but always acquiesced therein. Errors are assigned upon the findings, but we think they are sustained by the evidence.

The findings establish that the agreement made by Briggs with Mills was not a mere revocable license or permission to occupy, but that it was intended to operate as a grant to be confirmed by deed when Briggs acquired the title so that he could convey it. We believe it is unnecessary to discuss the testimony in detail, since we are satisfied that it establishes the intention to make an absolute grant, the consideration of which was the construction and operation of the mill at that place. The use of the premises was thus initiated, and it continued uninterruptedly for more than twenty-five years, until this suit was brought. Such use must now be presumed to have been adverse, unless it is explained to have been otherwise.

"Where the use of an easement has continued for the prescriptive period unexplained, it will be presumed to have been adverse, unless it is of such a character, or the circumstances attending it are such, 
as to show that it was a mere privilege enjoyed by leave of the landowner." 22 Am. \& Eng. Ency. Law (2d Ed.) p. 1202. Moreover, the use was not deprived of its adverse character or rendered merely permissive for the purposes of the statute of limitations by a showing that it was preceded by an oral agreement amounting in terms to a grant, but void under the statute of limitations. "It is generaily agreed that use of an easement under claim of right by virtue of a parol grant, may be adverse so as to give a title by prescription, although the. parol grant itself is void under the statute of frauds.” 22 Am. \& Eng. Ency. Law (2d Ed.) p. 1198, and cases cited.

The following from the opinion in Coventon v. Seufert, 23 Or. 548, 32 Pac. 508, may also be set forth as pertinent to this subject: "An easement cannot be granted by parol; yet, if Mr. Simpson purchased from Mr. Jackson the right to use the ditch, and used the same for ten years, and such use was acquiesced in by Mr. Jackson and his grantees, it would be such an exercise of the easement, under a claim of right, as to give a prescriptive right to the same. It is no objection to granting an eascment by prescription that the same was originally granted or bargained for by parol. That the use began by permission does not affect the prescriptive right, if it has been used and exercised for the requisite period under a claim of right on the part of Mr. Simpson and his heirs, and their grantees. If the use of a way is under a parol consent given by the owner of the scrvient tenement to use it as if it were legally conveyecl, it is a use as of right: Gould, Waters, $\S 338$; Washburn, Easem. (2d Ed.) 127. The plaintiffs have used the ditch as if it had been legally conveyed to them, that is, they have exercised such acts of ownership over it as a man would over his own property,--and the court must presume, in the absence of any evidence to the contrary, that the settlement was a parol consent or transfer by Mr. Jackson to Mr. Simpson of the right to use the ditch, and hence it was a use as of right."

The facts in this case clearly show a continuous adverse use by respondents añ their grantors under claim of right for more than a quarter of a century. This establishes their title by prescription, and we find it unnecessary to discuss other reasons suggested in support of their title. $* * * 13$

The judgment is affirmed.

13 The remainder of the opinion relating to another point is omitted. 


\section{LEHIGH VALLEY R. CO. v. McFARLAN.}

(Court of Errors and Appeals of New Jersey, 1SS1. 43 న. J. Law, 60J.)

Depue, J. ${ }^{14}$ The defendant is the lessee of the Morris Canal and Banking Company. In IS7, the property, works and franchises of the latter company were granted to the defendant by a perpetual lease, under the authority of an act of the legislature. Pamph. L. 1871, p. 444.

The lessor was incorporated in 1824 , for the purpose of constructing a canal to unite the river Delaware, near Easton, with the ticle waters of the Passaic. Pamph. L. 182t, p. 158. The canal was constructed from the Delaware to the Passaic about 1830 . In 1845 it was enlarged throughout its entire length to provide for navigation with boats of greater capacity. In $185 \%$ the company renewed the timbers in its dam across the Rockaway river, and placed new flash boards upon it. In 1875 the flash boards were replaced by timbers firmly spiked on the top of the dam, and made part of its permanent structure.

The plaintiff is the owner of a mill situate on the Rockaway river, above the site of the dam. He complains of an injury to his mill by back water cast back upon it by means of the dam. The damages claimed are such as accrued between the 30th of Dccomber, 1876, and the 22d of September, 1877. As his declaration was originally framed, the theory of his action was that the dam at its increased height was an unlawful structure. At the trial the declaration was so amended as to present a claim for compensation for the damages sustained by the plaintiff between the days named, conceding that the canal company by its charter had power to take and appropriate to its use, lands and water, without compensation first made, and that therefore the dam was not, in itself, an unlawful structure.

The defendant also contended at the trial that the right to maintain its dam at its present height had been acquired by adverse enjorment. If the defendant, or the canal company, under whom it claims, has acquired the right in dispute by prescription the subject alrcady discussed becomes of no importance in this litigation. It will be necessary, therefore, to examine the instructions of the judge on this head.

C The instruction was, in substance and effect, that mere verbal protests and denial of the right, without any interruption or obstruction in fact, of the enjoyment of the right, would prevent the acquisition of an easement by adverse user. This instruction follows the opinion of the Vice-Chancellor, in Lehigh Valley R. R. Co. v. McFarlan, $30 \mathrm{~N}$. J. Eq. 180.

14 That portion of the opinion relating to the plaintiff's claim to compensation, in which the court concluded the plaintiff was so entitied, is omitted. Other parts of the opinion also are omitted. 
The owner of the servient tenement cannot overcome the presumption of right arising from an uninterrupted user of twenty years, by proof that no grant was in fact, made. He may rebut the presumption by contradicting or explaining the facts upon which it rests; but he cannot overcone it by proof in denial of a grant. He may show that the right claimed is one that could not be granted away, or that the owner of the servient tenement was legally incapable of making, or the owner of the dominant tenement incapable of receiving, such a grant. Rochdale Canal v. Radcliffe, 18 Q. B. 287; Ellwell v. Birmingham Canal, 3 H. of L. 812; Staffordshire Canal v. Birmingham Canal, L. R. 1 H. of L. 254; Thorpe v. Corwin, Spenc. 312. He may explain the user or enjoyment by showing that it was under permission asked and granted; or that it was secret and without means of knowledge on his part; or that the user was such as to be neither physically capable of prevention nor actionable. Chasemore v. Richards, 7 H. of L. Cas. 349; Webb v. Bird, 13 C. B. (N. S.) 841 ; s. c., 10 C. B. (N. S.) 268 ; Sturges v. Bridgman, $11 \mathrm{Ch}$. Div. 852. But if there be neither legal incompetency nor physical incapacity, and the user be open and notorious, and be such as to be actionable or capable of prevention by the servient owner, he can only defeat the acquisition of the right on the ground that the user was contentious, or the continuity of the enjoyment was interrupted during the period of prescription.

Th defining title by prescription, Sir Edward Cole says, both to customs and prescriptions, these two things are incidents inseparable, viz., possession or usage and time. Possession must have these qualities: It must be long, continual and peaceable; long, that is, during the time defined by law; continuous, that is, that it may not have been lawfully. interrupted; peaceable, bccause if it be contentious and the opposition be on good grounds, the party will be in the same condition as at the beginning of his enjoyment. Co. Lit. 113 b. By a long course of decision, the word "interrupted," when applied to acts done by the servient owner, has received a fixed meaning as indicating an obstruction to the use of the easement, some act of interference with its enjoyment, which, if unjustifiable, would be an actionable wrong. This meaning has been given to the word as used in the statite 2 and 3 IVilliam IV, (Parlic, B., in Olney v. Gardner, 4 M. \& WV. 495, ) and is its usual signification.

Sir Edward Cole gives no illustration of what was meant by contentious, except "opposition on good grounds," and by a quotation from Bracton, who wrote in a primitive era of English law, before the doctrine of prescription, as applied to incorporeal hereditaments, had been subjected to the formative processes of judicial expositions from which the present state of the law is derived. The expression "opposition on good grounds" implies an act which would afford an opportunity to submit its validity to the test of judicial decision and is more consistent with the idea of an interference with the enjoyment of the right, such as would give the owner ability to go into court and establish his right, 
than with the supposition that prescriptive rights should be forever kept in abeyance by acts which gave persons claiming them, no power by suit at law to establish the right. In the passage quoted by Coke from Bracton, this early writer says: "I use the term peaccable, because if it be contentious, it will be the same as before, if the contention has been just; as if the true lord forthwith, when the intruder or disseizor has entered into seizin, endeavors soon and without delay (if he should be present, or if absent when he shall have returned) to repel and expel such persons by violence, although he cannot carry out to its effect what he has commenced, provided, however, when he fails he is diligent in requesting and in pursuing." Bract. fols. 51, 52. Mr. Goddard, in discussing an enjoyment which is not peaceable, defines "vi" in the phrase "vi clam aut precario," to mean violence or force and strife, or contention of any kind; and the illustration he gives is where the enjoyment has becn during a period of litigation about the right claimed, or the user has been continually interrupted by physical obstacles placed with a view of rendering user impracticable. Goddard on Eas. 172. In the English cases, peacefulness and acquiescence (when the servient owner knows or might have known that a right is claimed against his interest) are used indifferently as equivalent to uninterrupted.

In this country several clecisions have been referred to as holding that prohibitions, remonstrances and denials of the right by the owner of the servient tencment, unaccompanicd by any act of interference with the enjoyment of the easement, will prevent the acquisition of the right. These cases are a legitimate outcome of the doctrine that the presumption is not a presumption juris et de jure, but is a presumption mercly, liable to be rebutted by the proof of circumstances overcoming the presumption of a grant. This doctrine is supposed to have its chief support in Powell v. Bagg, 8 Gray (Mass.) 441, 69 Am. Dec. 262.

In Powell v. Bagg, proof that the owner, when on the land, forbade the party claiming an easement of the flow of water over his premises to enter, and ordered him off, while there for the purpose of repairing the acqueduct, was adjudged to be competent evidence of an interruption and an instruction that words, however strongly denying the right claimed or forbidding its exercise unaccompanied by any act or deed, was not an interruption of the user or enjoyment, was held to be defective and tended to mislead the jury. The evidence before the trial court is not fully reported. Evidence that the owner of the land forbade the other party to enter, and ordered him off, was undoubtedly competent as part of the plaintiff's case. Whether what occurred at that time would amount to an interruption of the easement, would depend upon circumstances, upon the conduct of the party when forbidden to enter or when ordered off. If the owner of the servient tenement, being on the premises, forbids the owner of the easement to enter for the purpose of enjoying it and orders him off, and the latter, on a wcll-grounded apprehension that the former means to enforce obedience to his commands, desists and withdraws, an action on the 
case for disturbance of the right would lie. This view must have been present in the mind of the court, else why restrict the prolibition to place-on the land? To give certainty to the owner's purpose? A prohibition delivered elsewhere might be so vehement and emphatic as to leave the denial of the right equally beyond a doubt. On any other view of the case, as was said in C. \& N. IV. R. R. Co. v. Hoag, 90 I11. 340 , "the circumstances of the place where the forbidance was made, whethet on or off the land, would be immaterial." If facts such as are above indicated, appeared in the case, the charge was, in the language of the court, "defective, and tended to mislead the jury in applying the evidence to the rule of law upon which the title of the defendant to the easement rested." Certain expressions from the opinion have been quoted as indicating that a verbal denial of the right will operate, ipso facto, to determine the right. If that view be adopted, or the suggestion of Mr. Justice Voodbury, (3 Woodb. \& M. 551,) that complaints and the taking of counsel against such encroachments will bar the right, be followed, it is obvious that rights by prescription will be of little value.

None of the authorities cited by the learned judge in Powell v. Bagg, goes to the extent contended for. The passage guoted from Bracton, that an easement will be acquired by its exercise under a claim of right per patientiam veri domini qui scivit et non prohibuit sed permisit de consensu tacito, is followed by the comment that sufferance is taken for consent, and that if the lord of the property, throngh sufferance, has, when present and knowing the fact. allowed his neighbor to enjoy on his estate a servitude for a lons time peaceably and without interruption from such en joyment and sufferance, there is a presumption of consent and willingness. Iiract. lib. 2, c. 23 , $\$ 1$. Tn the passage re-t ferred to in Greenleaf, the language is that the user must be adversethat is, under a claim of title-with the knowledge and acquiescence of the owner of the land, and uninterrupted. 2. Greenl. Ev. \$ 539 . In Sargent v. Ballard, 9 Pick. (Mass.) 254, 255, Videld, J., in discussing the methods by which a claim of title by prescription may be controverted by disproving the qualities and ingredients of such a title, says that "evidence might be given to prove that the use had been interrupted, thereby disproving a continued acquiescence of the ovver for twenty years." In Arnold v. Stevens, 24 Pick. (Mass.) 112, 35 An. Dec. 305, the plaintiffs' claim was of a right to dig ore under a grant by deed. They had not exercised the right for forty years. In the meantime the owner had occupied and cultivated the suriace of the land. The court held that there was no enjoyment hostile to the easement, for the owner of the land had done "nothing adverse to the rights of the owners of the easement-nothing to which they could object, or which would apprise them of the existence of any hostile clain, and no acquiescence, therefore, existed from which a conveyance could be presumed." In Monmouthshire Canal Co. v. Harford, 1 C., M. \& R. 614, evidence was given of applications made on behalf of the claimants of the ease- 
ment for permission to exercise the right. The court held that permis sion asked for and received was admissible to show that the enjoyment was not of right nor continuous and uninterrupted, for "every time the occupiers asked for leave they admitted that the former license had expired, and that the continuance of the enjoyment was broken." In neither of these cases was the effect of verbal remonstrances or complaints, as evidence of an interruption of enjoyment, considered.

Nor do the additional English cases cited by plaintiff's counsel in his brief meet the point under consideration. In Livett v. Wilson, 3 Bing. 115 , it is stated in the report that "as to undisputed use of the way there was conflicting testimony, but the weight of the evidence showed that the alleged right had been pretty constantly contested, and the defenclant, upon recently taking some adjoining premises, the approach to which by the entrance he claimed into the yard, said 'ny' right of way from the street to the yard can now no longer be resisted." "The character of the acts of resistance does not appear in the repurt of the case, either in 3 bing. or in 10 Moore-whether they were verbal complaints or physical resistance. I do not find in either report of the case any warrant for the assertion of 'Tucker, P., (Nichols v. Aylor, 7 Leigh [Va.] 565, that "repeated complaints and denials of the title of his adversary were considered as sufficiently rebutting the presumption of a grant." The only pertinency this case has to the subject now considerell, arises from the manner in which the case was left to the jury. The judge left to the jury to find whether or not the right had been granted by deed, instead of submitting to them the questions of fact upon which the law presumes a grant. I agrce that, if the issue upon such a claim of right is whether a deed in fact has been made, proof of verbal complaints on or off the locus in quo, as well as proof that no deed in fact was male during the continuance of the user, would be admissible and competent evidence; and such evidence would generally determine the issue. But this method of leaving the question to juries has been condemned by the English courts, and is at variance with the doctrine generally received by the courts of this country.

In Olney v. Gardner, 4 M. \& IV. 495, the decision was that, where there was unity of possession of the dominant and servient tenements, the time during which such possession was continued must not only be excluded in the computation of the twenty years, but destroyed altogether the effect of the previous possession by breaking the continuity of enjoyment. In Bright v. Walker, 1 C., M. \& R. 211, it was held that, as against the reversioner, the enioyment of an easement during a tenanc for life was not to be reclioned as part of the prescriptive period.

Eaton v. Swansea Water Torks, 17 Q. B. 267, was an action for disturbance of a water-course claimed by adverse user. The court held that interruptions, though not acquiesced in for a year under statute 2 and $3 \mathrm{~W}$ illiam IV, might show that the enjoyment was never of right, but was contentious throughout; and there being evidence that the owner of the servient tenement was in the habit of stopping up the 
trench whenever it was made, the neglect of the judge to answer a question propounded by a juror as to what would be the effect in law of a state of perpetual warfare between the parties was not a satisfactory method of leaving the case to the jury. In Tickle v. Brown, $+\mathrm{A}$. \& I: 369 , it was held that the words "enjoyed by any person claining a right," and "enjoyment thereof as of right," in the statute, meant an enjoyment had not secretly, or by stealth, or by tacit sufferance, or by permission asked from time to time on each occasion or on many, and that, therefore, proof of a parol license was competent to show that the cnjovment was permissive, and not under a cham of right. The other two English cases referred to (liemeson v. Cartright, 5 B. \& S. 1 ; Glover v. Colcman, L. R. 10 C. P. 10S) were simply interpretations of section 4 of the statute 2 and 3 William $I V$, and are not authoritics with respect to the principles tipon which prescriptive rights are acpuired or prevented at common law. In each of the cases there was an actual physical obstruction of the user, ant these cases turned upon the meaning of the words "submitted to or acquiesced in," contained in section 4, which provided that no act or matter should be deemed an interruption unless it should have been strimitted to or acquiescel in for one year. Mr. Codllard, writing after all these cascs were decided, in his exeellent treatise, says: "It is commomly said that no easement can be acpuired by prescription if the neer has been enjoyed vi clam aut precario. 'The word vi does not simply mean by violence or force, but it means also by strife or contention of any kinelas, for instance, that the enjoyment has been durine a period of litisattion about the right claimerl, or that the user has been continually disputed and interrupted by plysical olstacles placed with a view of rendering the user impracticable." Coddard on Eas. 172.

I have not discovered in the Findish cases any intimation that mere denials of the right, complaints, remonstrances, or prohilitions of user, will be considered interruptions of the user of an easement, or as indicating that the enjoyment of it was contentious. On the contrary, whenever the subject has been mentioned, it has elicitel expressions efmarlecl dienprobation of such a proposition. This is conspicuonsly apparent in the opinions of Payley, J., in Cross r. Jewia, 2 1: \& $8 .(68)$; of Lush, J., in Anerus v. Dalton, 3 Q. B. D. 85: and of Thesiger and Cotton, Lords Justices, in the same cace, as reported in 4 Q. P. D. 172, 186. Thesiger, L. J., in consilering the nature of the evidence which shall contradict, explain or rebut the presumption of right arising from an uninterrupted possession of twenty years, say"s that it is "not sufficient to prove such circumstances as negative an actual assent on the part of the servient owner, or even evidence of dissent short of actual interruption or obstruction to the enjoyment." In Angus v. Dalton, the easement was not such as came within the statute 2 and 3 William II" and the case was discussed and deciderl upon the principles of the common law, independently of the statutory provision.

Some confusion on the subject has arisen from the failure to discrim- 
inate between negative and affirmative easements; negative easements, such as easements of light, and of the lateral support of buildings, which cannot lawfully be interrupted except by acts done upon the servient tenement; and affirmative easements, such as ways and the overflowing of lands by water, which are direct interferences with the enjoyment by the servient owner of the premises, and may be the subject of legal proceedlings as well as of physical interruption. 'This distinction is pointed out by the court in Sturges v. Bridgman, $11 \mathrm{Ch} . \mathrm{D}$. 852. In Angus v. Dalton, the Queen's Bench decided that the negative easement of lateral support of buildings could not be acquired by prescription, for the reason that the owner of the adjoining premises had no power to oppose the erection of the bulikling and no reasonable means of resisting or preventing the enjoyment of its lateral support from his adjoining lands. But this decision was overruled in the Court of Appeals. Angus v. Dilton, 3 Q. B. D. 55, 4 Q. B. D. 162. With respect to such an easement there is great force of reasoning in the contention that slight acts of dissent should avail to defeat the acquisition of a right; for it would be unreasonable to compel the owner of the adjoining lands to dig down and undermine the foundations or to put him to legal proceedings quia timet to preserve dominion over his property. But no such considerations of hardship or inconvenience exist when the easement is a right of way, which, whenever the right is exercised, is a palpable invasion of property and may easily be obstructed, or is an eascment of flooding lands, which is really, though not technically, a disscizin pro tanto, and can easily be interrupted.

The whole doctrine of prescription is founded on public policy. It is a matter of public interest that title to property should not long remain uncertain and in dispute. The doctrine of prescription conduces, in that respect, to the interest of society, and at the same time is promotive of private justice by putting an end to and fixing a limit to contention and strife. Proiests and mere denials of right are evidence that the right is in dispute, as distinguished from a contested right. If such profests and denials, unaccompanied by an act which in law amounts to a disturbamce and is actionable as such, be permitted to put the right in abeyance, the policy of the law will be defeated, and prescriptive rights be placed upon the most unstable of foundations. Suppose an easement is enjoyed, say, for thirty years. If after such continuance of enjoyment the right may be overthrown by proof of protests and mere denials of the right, uttered at someremote but serviceable time during that period, it is manifest that a right held by so uncertain a tenure will be of little value. If the easement has been interrupted by any act which places the owner of it in a position to sue and settle his right, if he chooses to postpone its vindication until witnesses are dead or the facts have faded from recollection, he has his own folly and supineness to which to lay the blame. But if by mere protests and denials by his adversary, his right might be defeated, he would be placed at an unconscionable disadvantage. He could neither sue 
and establish his right, nor could he have the advantage usually lerived from long enjoyment in quicting titles.

Protests and remonstrances by the owner of the servient tenement against the use of the easement, rather add to the strength of the claim of a prescriptive right; for a holding in defiance of such expostulations is demonstrative proof that the enjojment is moler a claim of right, hostile and adverse; and if they be not accompanied by acts amounting to a disturbance of the right in a legal sense, they are no interruption or obstruction of the enjoyment.

The instructions of the judge were erroneous in this respect. The jury should have been told that a continuous enjoyment under a claim of right for twenty years, not obstructed by some suable act, and haring the other qualities of an adverse user, confers an indeleasible risht. errect It is said that the instruction was given in view of evidence tending to show interruptions in fact of the right, and therefore the error was harmless. As the judgment will be reversel on other grounds, and the case may be retried, we prefer not to discuss the evidence at this time.

On the two exceptions considered here, we think the judgment should be reversed. ***1s

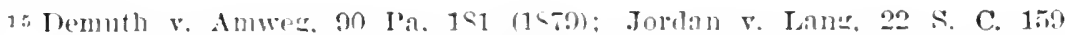

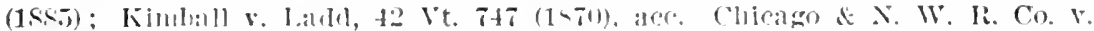

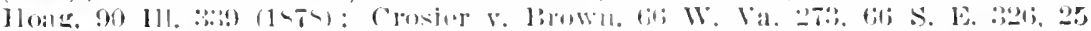

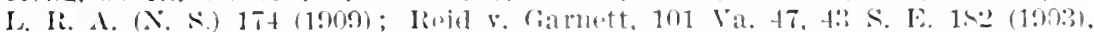

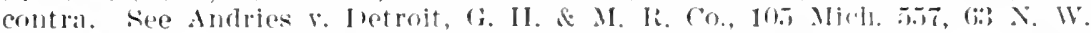

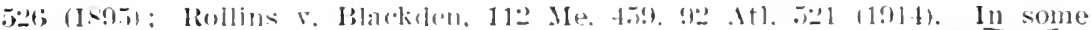

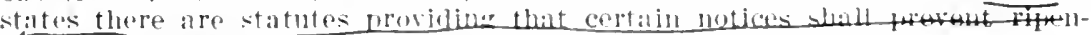

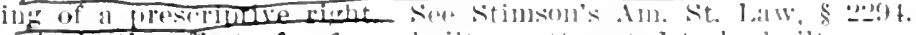

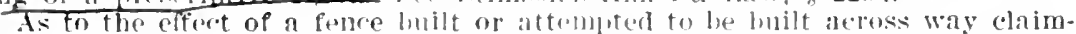

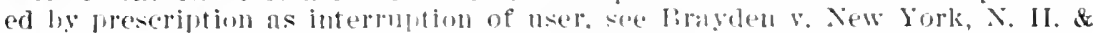
II. I. IR. (o., 172 Jass. 40 Comn. 26, 16; Am. R(t). 10 1167:i).

Quckiva.7. in connection with his use of IBlackare, had for five vears used allersely a way over 13. s laml; A, then ronseged IBlarkilere to C. "with

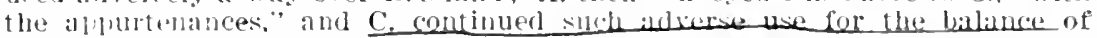

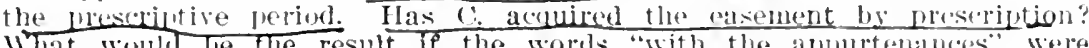
What would be the result if the worts "with the almurtenances" were
ontitted? What if C. Were A.'s heir, and as such succoeled to $A$.'s rigbts in Blackacre? See Leonard $\nabla$. Leoward, 7 Allen (Mass.) $27 t$ (1s6i3).

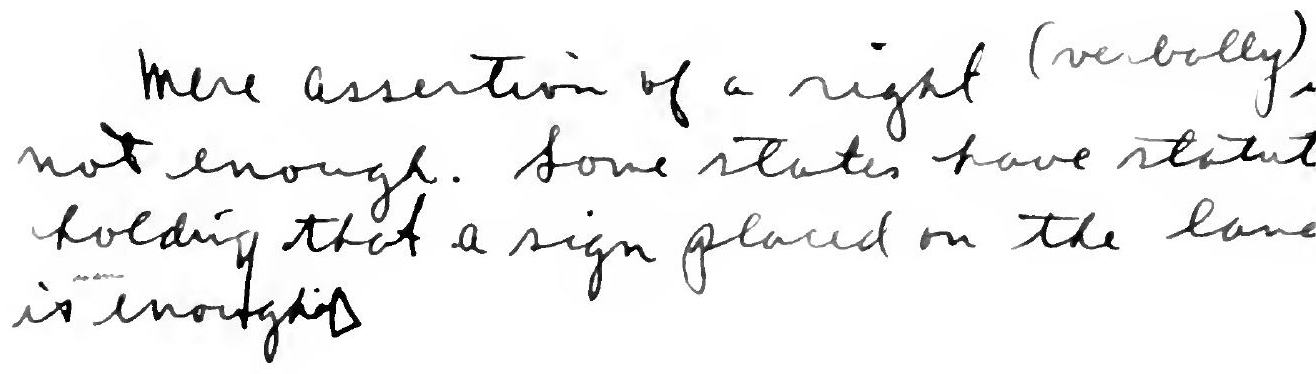




\title{
CHAPTER III
}

\section{ACCRETION}

\section{GIFFORD r. YARBOROUGH.}

\author{
(IIouse of Lords, 1s:- 5 Bing. 163.)
}

Brist, C. J. My Lords, the question which your Lordships have proposed for the opinion of the Judges is as follows: "A. is seised in his demesne as of fee of the manor of N., and of the demesne lands thereof, which said demesne lands were formerly lounded on one side by the sea. A certain piece of land, consisting of about 450 acres, by the slow, gradual, and imperceptible projection, alluvion subsidence, and accetion of ooze, soif, sand, and matter slowly, gradually, and imperceptibly, and by imperceptible increase in long time cist tp, deposited, and settled by and from thux and reflux of the tide, and wares of the sea in, upon, and against the outside and extremity of the said demesne lands hath been formed, and hath settled, grown, and acerned upon, and against, and unto the said demesne lands. Does strch piece of land so formed, settled, grown, and accrned as aforesaid, belong to the Crown or to A., the owner of the said demesne lands? There is no local custom on the subject."

The Judges have desired me to say to your Lordships that land gradually and imperceptibly added to the demesne lands of a manor, as stated in the introduction to your I.ordships' question, does not belong to the crown, but to the owner of the demesne land.

$\int$ All the writers on the law of England agree in this: that as the King is lord of the sea that flows around our coasts, and also owner of all $\{$ the land to which no individual has acquired a right by occupation and improvement, the soil that was once covercd by the sea belongs to him.

But this right of the sovereign might, in particular places or under circumstances, in all places near the sea, be transferred to ccrtain of his subjects by law. A law giving such rights may be presumed from cither a local or gencral custom, such custom being reasonable, and proved to have existed from time immemorial. Such as clain under the former must plead it, and establish their pleas by proof of the existence of such a custom from time immemorial.

General customs were in ancient times stated in the pleadings of those who claimed under them: as the custom of merchants, the customs of the realm with reference to innkeepers and carricrs, and others of the same description. But it has not been usual for a long time to allucle to such customs in the pleadings, because no proof is required 
of their existence; they are considered as adopted into the common law, and as such are recognized by the Judges without any evidence. These are called customs, because they only apply to particular descriptions of persons, and do not affect all the subjects of the realm; but if they govern all persons belonging to the classes to which they relate, they are to be considered as public laws; as an act of parliament applicable to all merchants, or to the whole body of the clergy, is to be regarded by the Judges as a public act.

If there is a custom regulating the right of the owners of all lands bordering on the sea, it is so general a custom as need not be set out in the plearlings, or proved by evidence, but will be taken notice of by the Judges as part of the common law. We think there is a custom by which lands from which the sea is gradually and inpercentibly remored by the alluvion of soil, becomes the pruperty of the person to whose land it is attached, although it has been in the funchs maris, and as such the property of the King. Such a custom is reasonable as regards the rights of the King, and the subjects claiming under it; beneficial to the public; and its existence is established by satisfactory legal cridence.

'There is a great difference between land formed by alluvion, and derelict land. Land formed by alluviun must become useful soil by degrees too slow to be derevived little of what is depsited by one tide will be so permanent as not to be removed by the next. An enbankment of a sufficient consistency and height to keep out the sea must be formed imperceptibly. Liut the sea irequently retires sudelenly, and leaves a larse suace of land uncovered.

When the anthorities relative to these suljects are considered, this difference will he found to make a material distinction in the law that applies to derelict lands, and to such as are formed by alluvion. Unless trodden by cattle. many years must pass away before lands formul by allurion would be hard enough or sufficiently wide to be used beneficially by any one but the owner of the lands adjoining. As soon as alluvion lands rise above the water, the cattle from the adjoining lands will give them consistency by treading on them; and prepare them for grass or agriculture by the manure which they will drop on them. When they are but a yarl wide the owner of the adjuining lands may render them productive. Thus lands which are of no use to the King will be useful to the owner of the adjoining lands, and he will acquirc a title to them on the same principle that all titles to lands have been

Locke in a passage in his Treatise on Government, in which he describes the grounds of the exclusive right of property, says: "God and man's reason command him to subdue the earth; that is, improve it for the benefit of life, and therein lay out something upon it that was his own, his labour. He that in obedience to that command 
subdued, tilled, and sowed any part of it, thereby amnexed to it something that was his property which another had no title to, nor could without injury take from him."

This passage proves the reasonableness of the curtom that assigns lands gained by alluvion to the owner of the lands adjoining.

The reasonableness is further proved by this, that the land so gained is a compensation for the expense of embankment, and for losses which frequently happen from inundation to the owners of lands near the sea.

This custom is beneficial to the public. Much land which would remain for years, perhaps for ever, barren, is in consequence of this custom rendered productive as soon as it is formed. Although the sea is gradually and imperceptibly forced back, the land formed by the alluvion will become of a size proper for cultiration and use; but in the mean time the owner of the adjoining lands will have acquired a title to it by improving it.

The original deposit constitutes not a tenth part of its value the other nine tenths are created by the labour of the person who has occupied it; and, in the words of Locke, the fruits of his labour camnot, without injury, be taken from him.

The existence of this custom is established by legal evidence. In Bracton, book 2, cap. 2, there is this passage: "Item, quod per allu. vionem agro tuo flumen adjecit, jure gentium tibi acquiritur. Est autem alluvio latens increncntum; et per alluvionem adjeci dicitur quod ita paulatim adjicitur quod intelligere non possis quo momento temporis adjiciatur. Si autem non sit latens incrementum, contrarium erit."

In a treatise which is published as the work of Lord Hale, treating of this passage, it is said: "That Bracton follows in this the ciril law writers; and yet even according to this the common law doth regularly hold between parties. But it is doubtful in case of an arm of the sea.:" Hale de Jure Maris, p. 2S. It is true that Bracton follows the civil law, for the passage above quoted is to be found in the same words in the Institute, lib. 2, tit. 1, § 20. But Bracton, by inserting this passage in his book on the laws and customs of England, presents it to us as part of those laws and customs. Lord Hale admits that it is the law of England in cases between subject and subject; and it would be difficult to find a reason why the same question between the crown and a subject should not be decided by the same rule. Bracton wrote on the law of England, and the situation which he filled, namely, that of Chief Justice in the reign of Henry the Third, gives great authority to his writings. Lord Hale in his History of the Common Laws (cap. 7) says, that it was much improved in the time of Bracton. This improvement was made by incorporating much of the civil law with the common law. 
We know that many of the maxims of the common law are borrowed from the civillaw, and are still quoted in the language of the civil law. Notwithstanding the clamour raised by our ancestors for the restoration of the laws of Edward the Confessor, I believe that these and all the Norman customs which followed would not have been sufficient to form a system of law sufficient for the state of society in the times of Henry the 'Ihird. Both courts of justice and law writers were obliged to adopt such of the rules of the digest as were not inconsistent with our principles of jurisprudence. Wherever Bracton got his law from Lord Chief Baron Parker, in Fortescue 408, says, "as to the authority of Bracton, to be sure many things are now altered, but there is no colour to say it was not law at that time. 'There are many things that have never been altered, and are now law." "The laws must change with the state of things to which they relite; but, according to Chief Baron Parker, the rules to be found in Bracton are grood now in all cases to which those rules are applicable. But the authority of Lracton has been confirmed by molern writers, and by all the decided cases that are to be found in the books. The same doctrine that Bracton lays down is to be found in 2 Rolle's Abr. 170; in Com. Dig. tit. Prerogative, (D. 61 ;) in Callis, (Broderip's edition,) p. 51 ; and in 2 Blac. Com. 261.

In the case of the Abbot of Peterborough, Hale de Jure Maris, p. 29, it was hollen: "Qurd, secuntum consuetudinem patrixe, domini maneriorum prope mare aljacentim, halebunt marettum et sabulonem per fluxus et refluxus maris per temporis incrementum ad terras suas costere maris adjacentes projecta." In the treatise of Lord Hale it is said, "here is custom tairl, and he relies not barely on the case without it." But it is a general, and not a local custom, applicable to all lands near the sea, and not to lands within any particular district. The pleadings do not state the lands to be within any district, and such a statement would have been necessary if the custom pleaded were local. 'The consuctudo patrice means the custom of all parts of the country to which it can be applied; that is, in the present case, all such parts as adjoin the sca.

The case of The King $r$. Oldsworth (Hale de Jure Maris, p. 14) confirms that of the Abbot of Peterborough as to the right of the owner of the adjoining lands to such lands as were "sccundum majus et minus propè tenementa sua projecta" (Id. p. 29). That case was decided against the owner, because he also claimed derelict lands against the crown.

Here it will be observed that there is a distinction made between lands derelict and lands formed by alluvion; which distinction, I think, is founded on the principle that I have ventured to lay down, namely, that alluvion must be gradual and imperceptible but the dereliction of land by the sea is frecuuently sudden, leaving at once large tracts of its

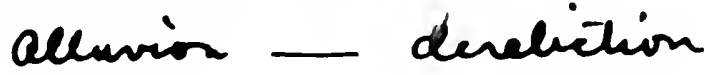


bottom uncovered, dry, and fit for the ordinary purposes for which land is used. But still what was decided in this case is directly applicable to the question proposed to us. The Judges are, therefore, warranted by justice, by public policy, by the opinions of learned writers, and the authority of decided cases, in giving to your Lordships question the answer which they have directed me to give.

My Lords, the answer to your Lordships' question is the unanimous opinion of all the Judges who heard the arguments at your Lordships' bar. For the reasons given in support of that opinion I alone an responsible. Most of my learned Lrothers were obliged to leave town for their respective circuits before I could write what I have now read to your Lordships. I should have spared your Lordships some trouble if I had had time to compress my thoughts; but I an now in the midst of a very heavy Nisi Prius sittings, and am obliged to take from the hours necessary for repose the time that I have employed in preparing this opinion. If it wants that clearness of expression which is proper for an opinion to be delivered by a Judge to this House, I hope that your Lordships will consider what I have stated as a sufficient apology for this defect.

The Lord Chaxcrilor. My Lords, I beg to express my thanks to the learned Chief Justice, and to the Judges, for the attention they have paid to this subject; and I have only to add that I entirely concur in the conclusion at which they have arrived; and I would recommend to your Lordships, as a necessary consequence of the opinion which has been expressed, that the judgment of the Court of King's Lench upon the matter should be affirmed.

EARL OF EIdDON. My Lords, I heard only part of the argument, and therefore I have some difficulty in stating my opinion in this case; but having had my attention called to subjects of the same nature on former occasions, it does appear to me, I confess, after reading the finding of the jury, that the opinion of the Judges must be that which the learned Chief Iustice has now expressed. I therefore concur in the opinion the Lord Chief Justice has expressed.

Judgment affirmed. ${ }^{1}$

1 "Tlackstone says (rol. II, chap. XVI), 'As to lands gained from the sea, ei. ther lic allurion, by the washing up of sand and earth, so as in time to make terra firma, or os dereliction. as when the sea shrinks back below the usuil water mark; in these cases the law is beld to be. that if this gain be little by little by small and imuercedtible derrees it shall so to the owner of the land ad joining. Blackstone then introduces hy way of explanation a reference ta a dontfor brocard de minimis non curat lex, which Lord Chelmstord in Attorney General $r$. Chambers, 4 De G. \& J. 55, at page 66 , properly disclaims. The true reason for the principle of law in regard to foreshores is the same reason as the principle in regard to river binks, $j$. e., that it is founded upon seculity ancl general convenience." Atty. Gen. of Sonthern Nigeria v. Holt, [1915] A. C. 599, 61:, ner Lord shaw of Dunfermline. See Banks v. Osden, 2 Wall. 57, 17 L. Ea. S1s (1S64).

"Courts and text-writers sometimes give rery inadequate reasons, born of a fancy or conceit, for very wise and beneficial principles of the common law;

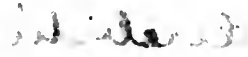




\section{HALSEY v. MCCORMICK.}

\section{(Court of Appeals of New York, 15.5. 1S N. Y. 147.)}

Appeal from the Supreme Court.

This was an action against Jacob McCormick, to recover a small piece of land in the village of Ithaca, lying between what was formerly the north bank of Six Mile Creek and the present centre of that creek. The lot of the plaintiff, which, as he ciaims, covers the land in dispute, is described in a conveyance to one Bennett, under whom he holds, as running "sonth from the turnpike to the bank of Six Nile Creek." Bennett was also the grantor of Jacob McComick, to whom, subsequently to the deed under which the plaintiff derives title, he conveyed a parcel of land lying in the bed of Six Mile Creek, adjoining the land of the plaintiff 'The water of the creek having been caused to recede, a strip of dry ground was formed at the foot of the bank, which was the land in dispute in this action.

On the first trial, in 1853, the court held that the plaintilf was bounded on the south by the high water mark of the north bank of the creck. Upon appeal to this court, the jurlgment was reversed, the court hold ing that the plaintiff's land extended to low water mark. 13 N. Y. 296. After this decision, the original defendant died, and the action was continued against his executors. Cpon the second trial, it appeared that formerly the north bank of the creek, at low water, formed the south line of the land in dispute, but that the original defendant, Jacol, McCormick, by deepening the bed of the stream on the south side, and placing stones upon a ridge in the centre, had turned the water so as

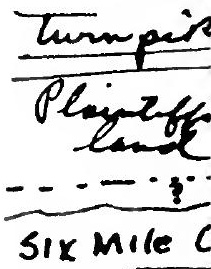
to leave a portion en the worth side of what was the bed of the stream drv and that upon this portion he had constructed a race to his mill, the north bank of which was the orisinal north lank of the strean.

The cause was tried without a jury, and the judge found as facts "that the south line of the plaintiff's land was north of the premises in question; that the waters of the creek, where they pass the plaintiff; lot, do now, and have for many vears, run further to the south than when the dike was erected, and that the change in the channel waseo caused by artificial means used by Jacob McCormick," the original dcfendant, as above indicated. He therefore ordered judgment for the

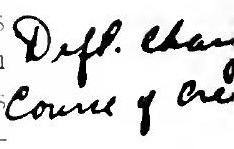

and we cannot help thinking this is somewhat so as to the right of a ripilian owner to accretions and relictions in front of his land. The reasons usually

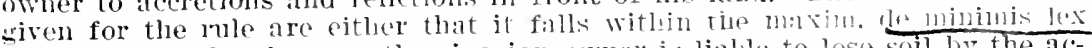
non curat or that beause the riparian owner is liable to lose soll by the action or encroachment of the water. he shorifl also hive the benefit of ang lant sained by llue same action. lint it seems to us that the rule lests upon al much broader princible, and las a moch more importint momose in view, viz., to ureserve the fundamental rinarian right on which all others repend, and

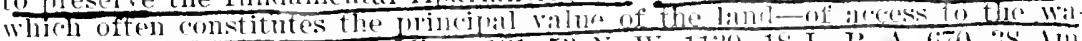

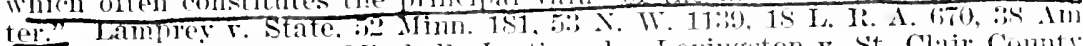

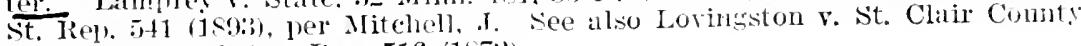

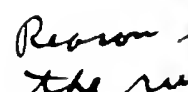
(it 1ll. 56, 5s, 16 Am. Rep. 516 (1572). 
defendants, which was affirmed at general term in the sixth district, and the plaintiff appealed to this court.

PRATT, I. It was settled by this court, when this cause was before it upon a former occasion, that the plaintiff's south line did not originally extend to the centre of the creck, but only to the line of low water on the north bank. Assuming this to be settled, the plaintiff does not claim that as the creek originally ran, the land in dispute was embraced within the boundaries of his lot. But if I understand it, he claims that the land in dispute is alluvion? and he is entitled to it as a riparian owner. But to acquire title to land as alluvion, it is necessary that its increase should be imperceptible-that the amount adcled in each moment of time should not be perceived. When the change is so gradual as not to be perceived in any one moment of time, the proprietor, whose land on the bank of a river is thus increased, is entitled to the addition. Ang. on liatercourses, § 53; 2 Bl. Com. 262; 3 Kent, 519.

It is cnough that no such fact is found in this case, as that this piece of ground is alluvion-that it was formed by inperceptible accretion. 'The evidence shows that it was not thus formed. McCormick deepened the bed of the stream on the south side, and placed stones along the centre so as to confine the water in the channel thus deepened, and by this means the land in question was left bare. He may have been gruilty, by these acts, of a violation of the riparian rights of the plaintiff or his grantors, but I know of no rule of law which would constitute an illegal act of the kind a transfer of the title.

As the case stands, it is not necessary to pass upon the question whether there is a distinction between the case of alluvion formed by natural or artificial means. I find no such distinction in the books. : If, by some artificial structure or impediment in the stream, the current should be made to impinge more strongly against one bank, causing it imperceptibly to wear away, and causing a corresponding accretion on the opposite bank, I am not prepared to say that the riparian owner would not be entitled to the alluvion thus formed, especially as against the party who caused it.

If the accretion was formed under all the other circumstances necessary to constitute it alluvion, I can scarcely suppose that a person could successfully resist the otherwise valid claim of the riparian owner, by alleging his own wrong, by showing that the accretion would not have thus formed if he had not himself wrongfully placed impediments in the stream. But that question is not before us. It is enough that this case does not show that the land in question was alluvion.

The judgment, therefore, must be affirmed with costs. ${ }^{2}$

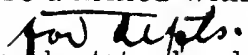

$\left\{\begin{array}{l}2 \text { "If portions of soil were added to rohl estate atready possessed, by gradual } \\ \text { deposition, through the operation of natural causes, or by slow and imperceptr- } \\ \text { ble accretion, the owner of the land to which the addition has been made has } \\ \text { a rerfect title to the addition. C Don no principle of reason or justice should }\end{array}\right.$ 


\section{VOLCANIC OIL \& GAS CO. v. CHAPIIN.}

(Ontario High Court of Justice, 1912. 27 Ont. Law Rep. 34.)

Action by the Volcanic Oil and Gas Company, John G. Carr, and the Union Natural Gas Company of Canada Limited (added by order in Chambers), plaintiffs, against Chaplin and Curry, defendants, for a declaration. of the plaintiffs' right of ownership of certain lands, and for an injunction and damages in respect of trespasses alleged to have been committed by the defendants thereon.

Falcondridge, C. J. The plaintiffs the Volcanic Oil and Gas Com pany carry on business in the counties of Essex and Kent in the pro duction and sale of petroleum and natural gas; the plaintiff Carr is a farmer; the defendant Chaplin is described as a wheel manufacturer; the defendant Curry is an oil and gas drilling operator.

The plaintiff Carr is the owner and occupant of the westerly half of lot 17S, Talbot road survey, in the township of Romney. It was granted by the Crown by patent dated the 29th January, 1825 , to Carr's predecessor. The lands are described in the patent in manner following, that is to say: "All that parcel or tract of land situate in the township of Romney, in the county of Kent, in the western district in our said Province, containing by admeasurement one hundred acres, be the same more or less, being the south-easterly part of lot number 178 on the north-westerly side of Talbot road west, in the said township, together with all the woods and waters thereon lying and being, under the reservations, limitations, and conditions hereinafter expressed, which said one hundred acres are butted and bounded or may be otherwise known as follows, that is to say: commencing at the : north-westerly side of the said road in the limit between lots numbers 177 and 178 at the easterly angle of the said lot 17S; thence on a

he be deprived of accretions forced upon him bz the labor of another without his consent or connivance, and thus cut off from the leenefits of lis original proprietorship. * * * In the case at bar, the accretions have not been sudden, but gritual, as we gather from the testimony. The city of st. Louis, to preserve its hilbor, and to prevent the channel from leavin's the Missouri shore, threw rock into the river, and the coal dykes were made to afford access to boats engaged in carrying across the liver. 'The ferry company protected such accretions by an expenditure of lator and money. The accretions, then, are partly the result of natural causes and structures and work erected and performed for the good of the public. Apuellants should not therebs lose their frontage on the river and be debarred of valuatse lights heretofore enjoted, Tovingston $v$. St. Clair County, 67 Tा. J6, 67, 65, 16 An1. Rep. 516 (1572), affirmed in 23 Wall. $46,23 \mathrm{~L}$. Ed. 59 (1S74); Adams v. Frothingham, 3 Mass. 352, $3 \mathrm{Am}$. Dec. 151 (1S07); Tatum r. St. Louis, 125 IIo. 648, 28 S. W. 1002 (1894), acc.

"Of course an excention must always be made of cases where the operations upon the party's own land are not only calculated, blit can be shemn to have been intended, to produce this gradual acquisition of the seashore, however difficult such proof of intention may be." Attorner-General v. Chambers, 4 De G. \& J. 55, 69 (1859), per Lord Chelmsford, L. C. See Revell v. People, 177 Ill. 468,52 N. E. 1052 , 43 L. R. A. 790,69 Am. St. Rep. 257 (189S); Attorney-(ieneral v. Holt, [1915] A. C. 599.

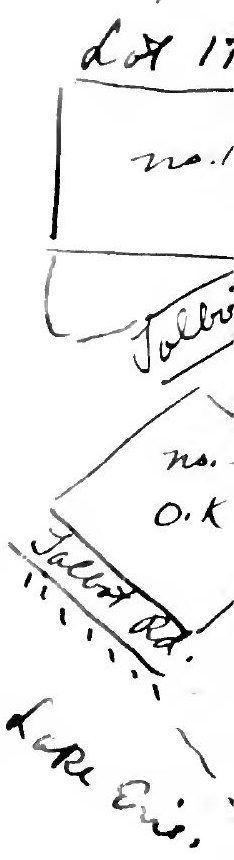


course about sixty degrees west along the north-westerly side of the said road twenty chains serenty-one links more or less to the limit between lots numbers 178 and 179; thence north forty-five degrees west sixty chains more or less to the allowance for road between the townships of Romney and Tilbury East; thence east twenty-nine chains more or less to the limit between lots numbers 178 and 177 ; thence south forty-five degrees east 47 chains more or less to the place of beginning."

The plaintiffs claim that the original Talbot road, which formed the south-westerly boundary of the lands included in the above patent, ran near the bank of Lake Erie, which at this point is many feet above the beach, and rises perpendicularly therefrom, having a clay front facing the waters of the lake. The plaintiffs further allege that along the shore of Lake Erie, in that locality, the waters of the lake have been encroaching upon the lands, undermining the bank, causing it to subside, and then gradually washing it away; that, by reason of this encroachment of the lake, 'Talbot road at an early period grew danger-

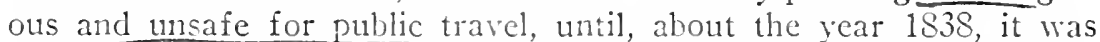
abandoned as a means of public travel, and a new road, which has for many years been known as the Talbot road, was opened up and dedicated to public travel; and that this road still continues to be the travelled road known as Talbot road, but the original Talbot road across the lake front has lons since been washed away by the waters of the late, and now those waters have advanced beyond where they were at the time of the original 'Talbot road survey; so that they have washed away the reserve left in front of the Talbot road, also the Talbot road itself and some rods of the front of the surveyed lots; so that now so mucl of the lands patented to Carr's predecessor, and now owned by him, as are now above the waters of Lake Erie, border on the waters of the lake, and not on the original 'Talbot road.

The above statements are denied by the defendants, but I find them to have been proved, as I shall hereinafter state.

On or about the th July, 190S, the plaintiff Carr executed and delivered to the plaintiffs the Volcanic company a grant and demise of the exclusive right to search for, produce, and clispose of petroleum and natural gas in, under, and upon the said lands, together with all rights and privileges necessary therefor, ctc.

By instrument under the Great Seal of the Province of Ontario, dated the 1st August, 1911, known as Crown lease number 1836, the Government of the Province demised and leased unto the defendant Chaplin, his heirs, executors, etc., the whole of that parcel or tract of land under the waters of Lake Erie in front of this lot, amongst others (the particular description of which is set out in paragraph 5 of the statement of defence of Curry).

About the month of September, 1911, the defendant Chaplin made a rerbal contract with the defendant Curry for putting down a well for the production of petroleum and natural gas in and upon the lands 
so demised by the Crown to Chaplin; and Curry, acting under such contract, entered upon what the plaintiff Carr claims to be his land, with men and teams, and constructed a derrick and engine-house, ctc.

The plaintiffs, claiming that this entry was wholly unlawful, made objection thereto; and, on the defendants persisting in their operations, the plaintiffs obtaincd an injunction from the local Judge, which injunction was continued until the trial. The plaintiffs now ask:

That the injunction be made perpetual; (2) a declaration of their rights as to the ownership of the Tand, and as to riparian rights ; and (3) damages.

The defendants claim that, if the waters of the lake have washed away the bank and encroached in and upon lot 178 the lands up to the foot of the high bank before-mentioned became the property of the Crown, and that the south-westerly external boundaries of the lot shifted as the waters of the lake encroached thereon, giving full right to the Crown to enter into the Crown lease before-mentioned.

The point involved is extremely interesting, and is one which, if I correctly apprehend the English and Canadian cases, has never yet been expressly decided, either in the old country or here.

The surveyors who were called all agree that, by reason of the original survey having been made so long ago, and of the disappearance of original monuments, etc., they could not now lay out upon the land and water, as they now exist, the old 'Talbot road. Numerous witnesses were called who remembered that road and could speak of its boundaries, and of the erosion of the beach causing the road to be carried away north to its present position-many rods north of its original situs. The evidence is overwhelming (I disregard the curious evidence of Samucl (ooper), and I find it to be the fact that the locus now in controversy is part of the lot 178 north of the old Talbot road.

Having come to this conclusion, it follows that, if the plaintiffs' contention in law is well founded, it is quite immaterial whether or not the construction of the derrick is entirely in the water, or partly in the water and partly on the beach-the fact being that it is on Carr's property.

In Gould on Waters (3d Ed.) para. 155, pp. 306 to 310, inclusive. after stating the general rule that "land formed by alluvion, or the gradual and imperceptible accretion from the water, and land gained by reliction, or the gradual and imperceptible recession of the water, belong to the owner of the contiguous land to which the addition is made," and that "conversely land gradually encroached upon by navigable waters ceases to belong to the former owner," quoting the maxim "Qui sentit onus debet sentire commodum," the author proceeds (p. 309); "But when the line along the shore is clearly and rigidly fixed by a deed or surver, it will not, it seems, afterwards be changed because of accretions, although, as a general rule, the right to alluvions passes as a riparian right." 
In Saulet v. Shepherd (1866) 4 Wall. (U. S.) 502, 18 L. Ed. 442, it was held that the right to alluvion depends upon the fact of contiguity of the estate to the river-where the accretion is made before a strip of land bordering on a river, the accretion belongs to it and not to the larger parcel behind it and from which the strip when sold was separated; citing at length the judgment in a case of Gravier v. City of New Orleans, which is in some little known report not to be found in our library at Osgoode Hall.

In Chapman v. Hoskins (1S51) $2 \mathrm{Md}$. Ch. 485, the general rule is stated as follows (paragraph 2, head-note): "Owners of lands bordering upon navigable waters are, as riparian proprictors, entitled to any increase of the soil which may result from the gradual recession of the waters from the shore, or from accretion by alluvion, or from any other cause; and this is regarded as the equivalent for the loss they may sustain from the breaking in, or encroachment of the waters upon their lands."

Now, in the case in hand, the plaintiffs say that they could gain nothing by. accretion, by alluvion, or other cause; and, consequently, they should not lose by encroachment of the water upon their land, to which fxed termini were assigned by the grant from the Crown. This doctrine seems to be well supported by decisions of Courts which are not binding upon me, but which command my respect, and which would seem to be accurately founded upon basic principles.

In Smith v. St. Louis Public Schools (1860), 30 Mo. 290, the principle is very clearly stated: "The principle upon which the right to alluvion is placed by the civil law-which is essentially the same in this respect as the Spanish and French law, and also the English common law-is, that he who bears the burdens of an acquisition is entitled to its incidental advantages; consequently, that the proprietor of a field bounded by a river, being exposed to the danger of loss from its floods, is entitled to the increment which from the same cause may be annexed to it. This rule is inapplicable to what are termed limited fields, agri limitati; that is, such as have a definite fixed boundary other than the river, such as the streets of a town or city." The reference in the judgment to the English common law is not quite so positive as the head-note states it. The Judge (Napton) in the course of a very learned opinion says (30 Mo. 300): "It will be found, indeed, that upon this subject the Roman law, and the French and Spanish law which sprung from it, are essentially alike, if we except mere provincial modifications; and it is believed that the English common law does not materially vary from them. This uniformity necessarily results from the fact that the foundation of the doctrine is laid in natural equity." In saying this he may have had in his mind the language of Blackstone, to be now found in book 2 (Lewis' Ed.) pp. 261-2, although he does not cite him. There are some earlier English authorities to which I shall refer later.

Then there is a case of Bristol v. County of Carroll (1880) 95 Ill. 
S4 (para. 3 of head-note): "3. To entitle a party to claim the right to an alluvial formation, or land gained from a lake by alluvium, the lake must form a boundary of his land. If any land lies between his boundary line and the lake, he cannot claim such formation."

In Doe dem. Commissioners of Beaufort v. Duncan (1853) $46 \mathrm{~N}$. C. 234, at page 238, Battle, J., says: "Were the allegations supported by the proof, an interesting question would arise, whether the doctrine of alluvion applies to any case where a water boundary is not called for, though the course and distance, called for, may have been coterminous with it? We do not feel at liberty to decide the question, because we are clearly of opinion that the evidence given on the part of the defenclant does not raise it."

Cook v. McClure (1874) 58 N. Y. 437, 17 Am. Rep. 270, is a judgment of the Court of Appeals of the State of New York. The headnote is as follows: "It seems, the rule that, where a boundary line is a stream of water, imperceptible accretions to the soil, resulting from natural causes, belong to the riparian owner, applics as well where the boundary is upon an artificial pond as upon a running stream. In an action of ejectment, plaintiff claimed under a deed conveying premises upon which was a mill and pond. The boundary line along the pond commenced at 'a stake near the high-water mark of the pond,' running thence 'along the high-water mark of said pond, to the upper end of said pond.' Held, that the line thus given was a fixed and permanent one, and did not follow the changes in the high-water mark of the pond; and that defendant, who owned the bank bounded by said line, could not claim any accretions or land left dry in consequence of the water of the pond receding, although the gradual and imperceptible result of natural causes."

In The Schools v. Risley, 10 Wall. (U. S.) 91, 19 L. Ed. 850, the decision was as follows: "A street or tow-path or passway or other open space permanently established for public use between the river and the most eastern row of blocks in the former town of St. Louis, when it was first laid out, or established, or founded. would prevent the owners of such lots or blocks from being riparian proprietors of the land between such lots or blocks and the river. But this would not be true of a passage-way or tow-path kept up at the risk and charge of the proprietors of the lots, and following the changes of the river as it receded or encroached, and if the inclosure of the proprietor was advanced or set in with such recession or encroachment."

In re Hull and Selby Railway (1S39) 5 M. \& IV. 327, the general law as to gradual accretion or recession is stated. Alderson, B., says (p. 333): "The principle laid down by Lord Hale, that the party who suffers the loss shall be entitled also to the benefit, governs and decides the question. That which cannot be perceived in its progress is taken to be as if it never had existed at all."

See also Giraud's Lessee v. Hughes (1829) 1 Gill \& J. (14 C. A. Md.) 249. 
The defendants' counsel, in the course of a very elaborate and careful argument, cited numerous authorities in support of the view that the plaintiff Carr had lost the land by the encroachment of the water. I do not cite all of these, because they are set out at large in the extended report of the argument; but I do not think that there is any case in which it has been expressly held that a person in the position of this individual plaintiff loses his property because of the gradual encroachment of the water past the land in front of the road, past the road, and past the fixed boundary of the plaintiffs' land. He could not have gained an inch of land by accretion even if the lake had receded for a mile; and, therefore, it seems that the fundamental doctrine of mutuality, formulated in the civil law and adopted into the jurisprudence of many countries, camnot apply to him.

Perhaps the strongest English case cited by the defendants' counsel was Foster v. Wright (1878) + C. P. D. 438: "The plaintiff was lord of a manor held under grants giving him the right of fishery in all the waters of the manor, and, consequently, in a river rumning through it. Some manor land on one side of, and near but not adjoining the river, was enfranchised and became the property of the defendant. The river, which then ran wholly within lands belonging to the plaintiff, afterwards wore away its bank, and by gradual progress, not visible, but periodically ascertained during twelve years, approached and eventually encroached upon the defendant's land, until a strip of it becane part of the river bed. The extent of the encroacliment could be defined. The defendant went upon the strip and fished there. Held, that an action of trespass against him for so doing could be maintained by the plaintiff, who had an exclusive right of fishery which extended over the whole bed of the river notwithstanding the gradual deviation of the stream on to the defendant's land."

That case goes a long way in support of the defendants' contention. But Lord Coleridge, C. J., concurs only in the result arrived at by Lindley, J. He thinks the safer ground appears to be "that the language (of the grant) conveys *** a right to take fish, and to take it irrespective of the ownership of the soil over which the water Hows and the fish swim. The worls appear to me to be apt to create a several fishery, i. e., as I understand the phrase, a right to take fish in alieno solo, and to exclude the owner of the soil from the right of taking fish himself: and such a fishery I think would follow the slow and gradual changes of a river, such as the changes of the Lune in this case are proved or admitted to have been."

There is a reference in the argument, and in the judgment in this case, to some of the old authorities; for example: Britton, book 2. ch. 2, sec. 7, Nichol's translation, p. 21S: "But if the increase has been so gradual, that no one could discover or see it, and has been added by length of time, as in a course of many rears, and not in one day or in one year, and the channel and course of the water is itself moving towards the loser, in that case such addition remains the 
purchase and the fee and freehold of the purchaser, if certain bounds are not found."

Lindley, J., seems to think that in In re Hull and Selby Railway, to which I have already referred, the Court declined to recognise this principle.

As against the authorities in the United States which I have citerl, there is a very strong case of 11 iddecombe $r$. Chiles (1903) $173 \mathrm{No}$. 195, 73 S. W. 444, 61 L. R. A. 309, 96 Am. St. Rep. 507, a judgment of the Supreme Court of Missouri. The note is as follows: "Defendant was the owner of the south half of a section of land between which and the river bed there was originally a strip of $S$ acres, forming the fractional north half, which had not becn patented. The river changed its bed until it had washed away the S-acre strip, and flowed through defendant's land, when it began to rebuild to defendant's land all that it had washed away, and about 200 acres additional. Plaintiff then received a patent for the fractional north balf of the section as rescribed by the original survey. Held, that, the accretion being to defendant's land, plaintiff took no title by his patent." And Tallant, I., says (173 Mo. at page 204, 73 S. IV. 446, 61 L. R. A. 309, 96 Am. St. Rep. 507): "This Conrt has not said in either of those cases, and we doubt if any Court has ever said, that land acquired under a deed giving metes and bounds which do not reach the river-which in fact did not reach the river when the deed was made-does not become riparian when the intervening land is washed away, and the river in fact becomes a boundary." "3

In considering authorities which are not binding upon me, and when I have to decide "upon reason untrammelled by authority" (per Werner, J., in Linehan v. Nelson [1910] 197 N. Y. 482, at page 485, 90 ‥ E. 1114, 35 L. R. A. [N. S.] 1119, 18 Ann. Cas. S31), I prefer those United States decisions, which I have earlier cited. 'There have also been cited to me authorities which it is contended dispose completely of the Widdecombe Case, viz., the Lopez Case, which is reported as Lopez v. Muddun Mohun Thakoor (1S70) 13 Moo. Ind. App. 467; Hursuhai Singh v. Synd Lootf Ali Khan (1S74) L. R. 2 Ind. Ipp. 28; and 'Theobald's Law of Land, p. 37.

It was strongly contended by the junior counsel for the plaintiffs that, apart from the main question, and granting that the erosive action of the lake has encroached upon the plaintiff Carr, and that he lias lost some of his land, then at any rate he only loses it down to the low water mark. But, having regard to the view that I take about the main question, it is not necessary to consider that argument.

${ }^{3}$ Heuker v. Canter, 62 Kan. 363,63 I'ac. 617 (1901); Welles r. Hailey, 55 Coun. 202, 10 Atl. 565, $3 \mathrm{Am}$. St. Rep. 4S (1S.57), ace. Ibut sce Gilbert v. Eldridge, 47

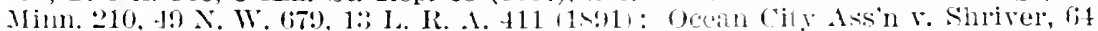

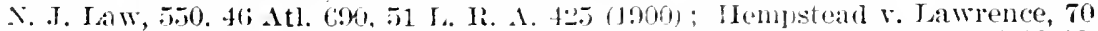
Misc. Rep. J2, 127 X. Y. Supp. $949(1910)$. Sies also Cool r. MLClure, jS N. Y. $4: 7,17$ Alu. Repr. 270 (1874), where the boundary was upon a millpond. 
I do not see that the statute $1 \mathrm{Gco} . \mathrm{V}$, ch. 6 , has any application to this case; nor do I see that the Attorney-General ought to bring the action or is a necessary party-the plaintiffs being concerned only with the trespass upon their lands, and not with any supposed public right.

The good faith, or the opposite of the defendants, in making the trespass, is a matter of no consequence in the disposal of the action.

I find, therefore, that there has been a trespass by the defendants upon the plaintiffs' land, and that they are entitled to have the injunction herein made perpetual, with full costs on the High Court scale and $\$ 10$ dannages. ${ }^{4}$

\section{SLIPLEMENTIII NOTE}

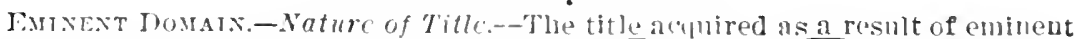

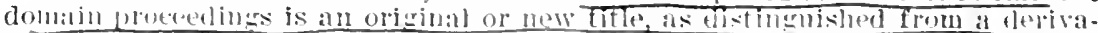

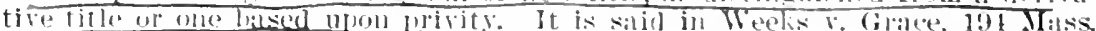

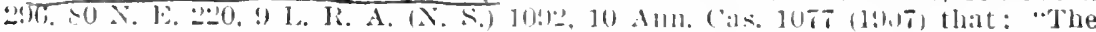

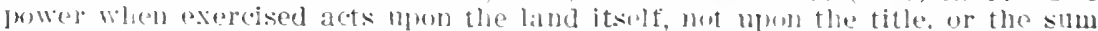

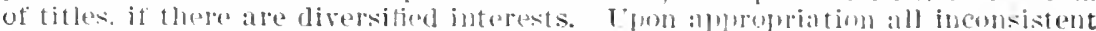

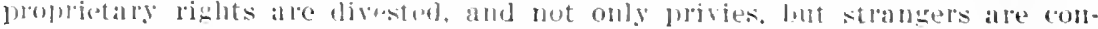

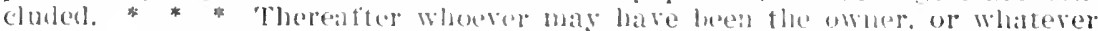

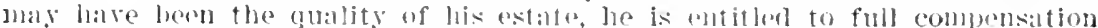

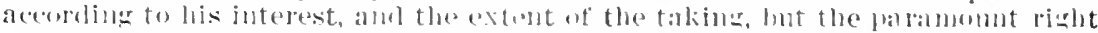
is in the pullic, not as elatimine murep him by a statutery arant, but by an

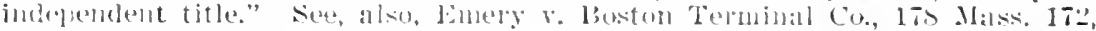

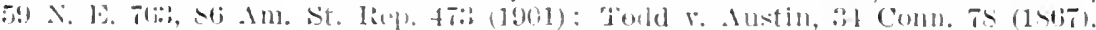

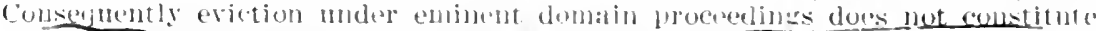

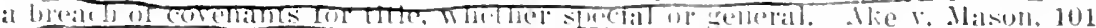

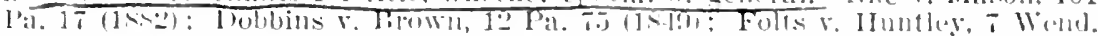

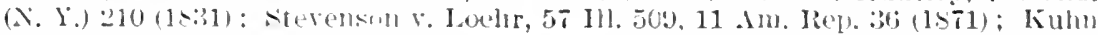

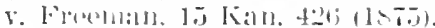

Litt nt of the luterest Acyuired.-In the alsence of constitutional rostric-

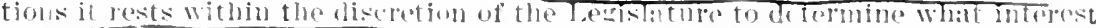

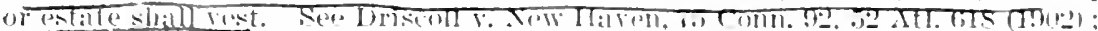

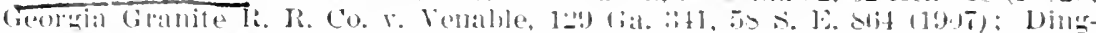

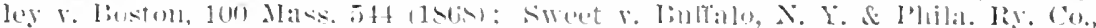

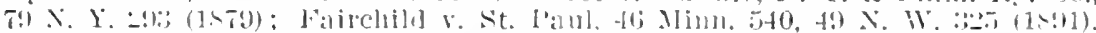

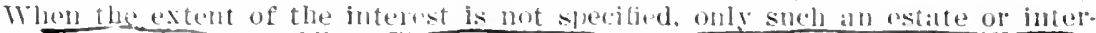

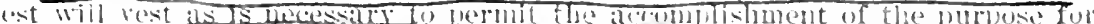

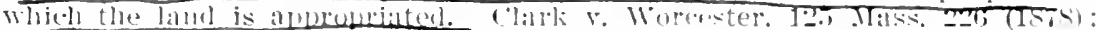

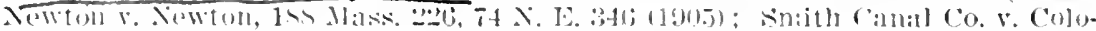

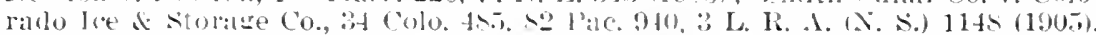

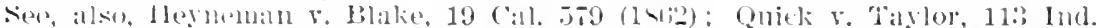

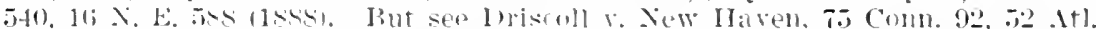

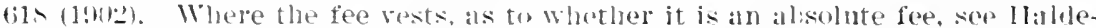

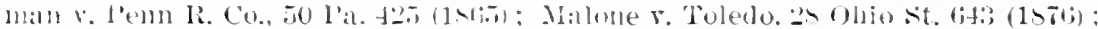

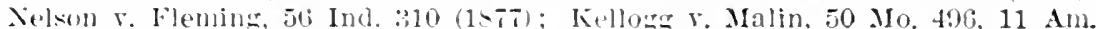

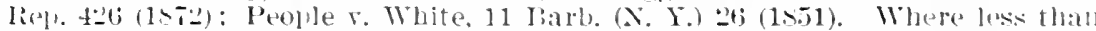
the fee rests. the reversion remains in the oririnal owner, his heirs and assisms. Chalmbers r. Givat Nolthem I'ower Co., 100 Minn. 214, 110 N. W. 112)

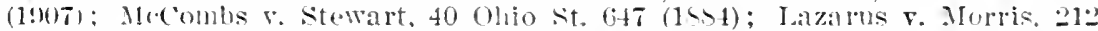

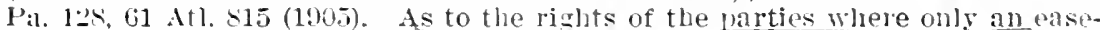

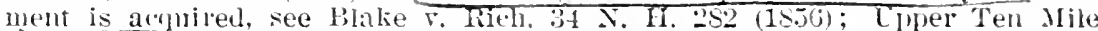
I'Tilli Road Co. v. Braden, $172 \mathrm{~Pa}, 460,3: 3 \mathrm{At}, 562,51 \mathrm{Am}$. St. Rep). 759 (1s96).

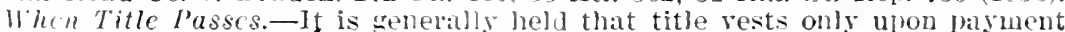

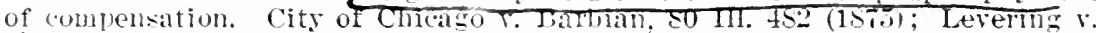

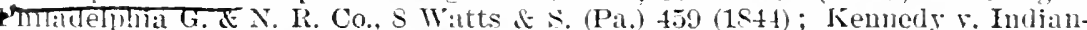
apolis, 103 L.S. 599,26 L. Ed. 550 (1つ๖0); New Or]eans \& S. R. R. Co. r. Jones,

4 Apportionmext of Accretioxs. - See case note to Nurthern Pine Land Co. r. Bigelow. S4 Wis. 157. 54 X. W. 494 11993), in 21 L. R. A. T76, et seq. also Angell on Water Courses (4th Ed.) tr et seu. 
68 Ala. 48 (18S0); Cushman v. Smith, 34 Me. 247 (1852); Staees v. Vermont Cent. IR. Co., 27 Vt. 39 (1554).

In the absenee of constitutionil restraints the legislature may in its discre-

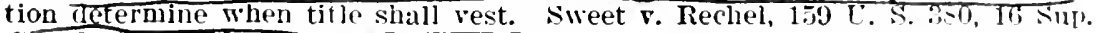
Ct. 43, 40 L. Ed. 155 (ISF). See, also, City of Pittsburg v. Scott, 1 Pa. 309 $(18+5)$.

No extended diseussion of this question will be attenuted as each case is very largely depeudeut upon the words of a particular statute or the state constitution.

Tax Trtues. -The nature and extent of the title acauired bs a purchaser at a tax sale depends largely unon the terms of the particular stiltute wuder which the taxes are levied. Where the tax is made a chilge directly upon the land itself, and the proceelings for its collection are strictly in ryu the tax deed (provided all the procecelings halve been regular) will bave the eltect of dest roving all wior interests in the estate, whether rested or contimbur execuled or executoly, ank whether in vossession. reverion or remilinder. sinch a title is in no sense derivative, lucas v. l'urdy, 14.2 Iowa, 35:1, 1:0 $N$. 11. 10 ti3, 24 I L R. A. (N. S.) 12!) 19 Ann. Cas. 97t (1909); lirown r. dustiu, 41 lt.

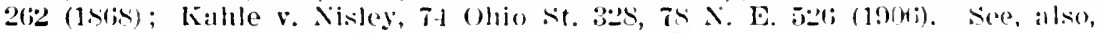

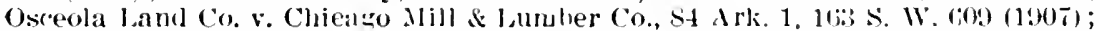

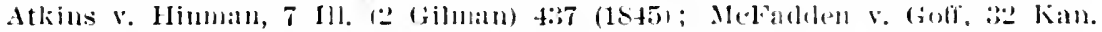

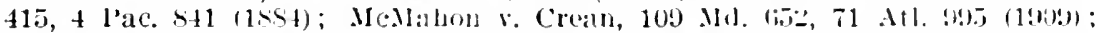

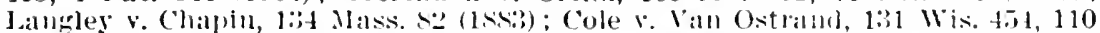

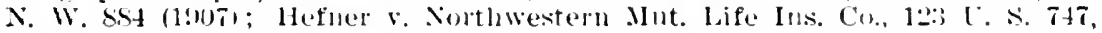

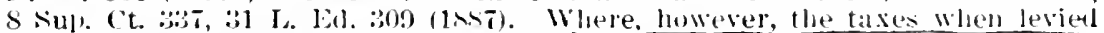
constitute a lebt lue from the owner when ma1 be collected in an action in

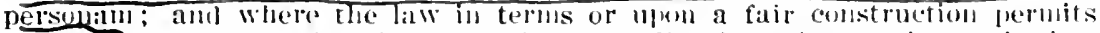

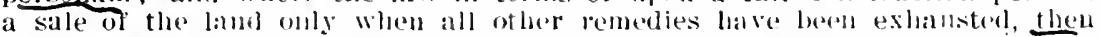
the title acouired is derivation, and includes ally the luterest of the jerson

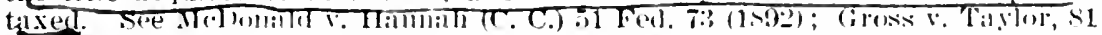

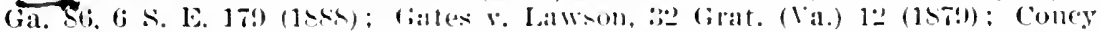

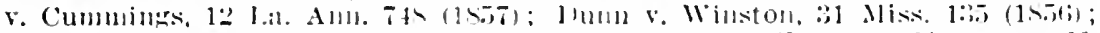

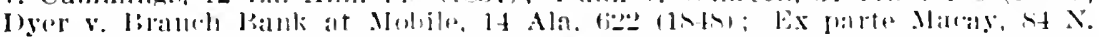

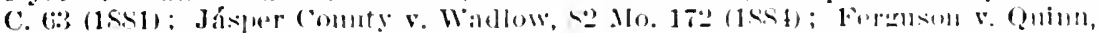

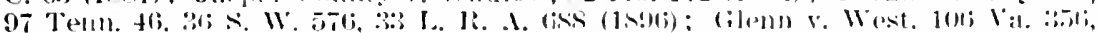

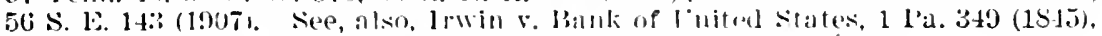
as to situation where sejulmite interests are separutely assessed.

See on the subject generally Blaleli on Tax Titles. 


\title{
PART II \\ DERIVATIVE TITLES
}

\author{
CHAPTER I \\ MODE OF CONVEYANCE'
}

\section{SECTION 1.-A'T COMMON LAW}

1. FEOFFMINT

\section{LITTLETON'S TENURES.}

But of feoffments made in the country, or gifts in tail, or lease for term of life; in such cases where a frechold shall pass, if it be by deed or without deed, it behoveth to have livery of seisin.

Section 59.

\section{CONE UPON LIT'TLETON.}

"Livery of seisin." 'Traditio, or deliberatio seisine, is a solemnity, that the law requireth for the passing of a freehold of lands or tenements by delicery of scisin thereof. Intervenire debet solennitas in mutatione liberi tenementi, ne contingat donationem deficere pro defectu probationis.

And there be two linds of livery of seisin, viz. a livery in deed, and a livery in law. A livery in deed is when the feoffor taketh the ring of the door, or turf of twig of the land, and delivereth the same upon the land to the feoffee in name of seisin of the land, \&.c., per hostium et per haspam et annulum vel per fustem vel baculum, \&e.

A livery in law is, when the fcoffor saith to the feoffee, being in the view of the house or land, (I give jon youder land to you and vour heirs, and go enter into the same, and take possession thereof accordingly and the feoffee doth accordingly in the life of the feoffor enter, this is a good feoffment, for signatio pro traditione habetur. And herewith agreeth Bracton: Item dici poterit et assignari, quando res rendita vel donata sit in conspectu, quam venditor et donator dicit

1 For the background of the subject-matter of this chapter, see 2 rollock \& Maitland, Hist. Eng. Law, So-106. 
se tratere: and in another place he saith, in seisina per effectum et per aspectum. But if either fcoffor or the feofice die before entry the: livery is void. And livery within the view is good where there is no deed of feoffment. And such a livery is good albeit the land lie in an other county. A man may have an inheritance in an upper chmmber. though the lower buildings and soil be in another and secing it is an inheritance corporeal it shall pass by livery.

$4 \overline{\mathrm{Sa}}, \mathrm{b}$.

\section{STATUTE OF FRALDS.}

For prevention of many fraudulent practices, which are commonly cndeavored to be upheld by perjury and subornation of perjury; (2) be it enacted by the King's most excellent majesty, by and with the advice and consent of the Lords Spiritual and Temporal, and the Commons, in this present Parliament assembled, and by the amthority of the same, 'That from and after the four and twentieth day of June. which shall be in the year of our Lord one thousand six hundred seventy seren, all leases. estates, interests of freehold, or terms of vears. or anv uncertam juterest of in, to or ont of ally mescuibes, manors. lands, tenements or heredilaments, malle or created by livery and seisin only, or be narol and not jut in writing and signed ly the parties so making or creating the same, or their agents theremto law fully authorized by writing shall have the force and effect of leases or estates at will only, and shall not either in haw or egluty be deemed on taken to have any olher or greater force or effect: any consicleration for making any such parol leases or estates, or any former law or usage, to the contrary notwithstanding.

TI. Execpt nevertheless all leases not exceeding the term of three years from the making thereof, wherempon the rent reserved to the landlord, during such term, shall amount unto wo third parts at the least of the full improved value of the thing lemised.

III. And moreover, 'That no leases, estates, or interests either of freehold, or terms of years, or any uncertain interest, not being copyhold or customary interest, of, in, to or out of any messuages, manors. lands, tenements or hereditaments, shall at any time after the saill four and twentieth day of June be assigned. arainted or surrendered._nnless it be by deed or note in writing, signed by the party so assinning. sranting or surrendering the same, or their agents thereunto lawfully authorized by writins, or by act and operation of $12 w^{3}$

2) Car. II, c. 3, \$ई 1-3.

2 For a long time prior to the Statute of Frands a writing though w. necessary to an effective reomment, was commonty emblored as eviclence of the trallsaction and its temes.

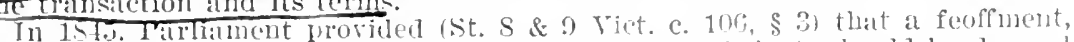

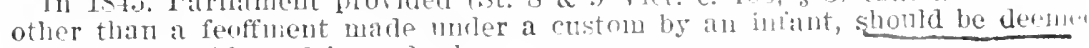
void unless evidenced by a deerl. 


\section{CHALLIS, REAL PROPERTY.}

A feoffment, the most venerable of assurances, survives to this day, but is now little used. It is believed that certain old corporate bodies still retain, at all events to some extent, the ancient practice of conveying by feoffment. It is the only assurance (not being matter of record, as a fine or recovery) by which, at the common law, legal estates of frcehold in possession can be conveyed to a person thaving no subsisting interest in the land and no privity with the person making the assurance. It consists simply and solely in the livery of the scisin; and some phrases in common use, which seem to imply a distinction between the feoffment and the livery, are so far incorrect.

By the common law, any person having actual possession (not necessarily actual scisin), of lands, could, by a feoffment, give to any person, other than the person having the next or the immediate estate of freehold in the lands, an immediate estate of frechold, having any : quantum. If the feoffor was actually seised, and the estate which passed by the fcoffment was no greater than the estate of the fcoffor, the feoffment took effect rightfully i but if the feeffor was not actually seised, or if the estate which passed by the feoffment was greater than his estate, the fooflment was styled a tortious feoffment, and was said to take effect by wrong.

In accordance with the maxim that no one can qualify his own wrong, a tortious feoffment devested the whole fee simple out of the rightful owner or owners. It does not follow that the tortious feoffment was necessarily a feoffment in fee simple; and it might in fact be for a less estate. In such a case, the fcoffee took only the less estate, but the whole fee simple was devested out of the rightful owner or owners, and such part of it as was not disposed of by the f coffment became vested in the feoffor by way of a tortious reversion upon the tortious particular estatc created by the feoffment.

The tortious operation of feofiments made after 1st October, 1845, is prevented by $8 \& 9$ Vict. c. $106, \S 4$.

The possession of a termor for ycars, or tenant at will, or by sufferance, sufficed to enable the termor, or tenant, to make a tortious feoffment; and thus to convey an immediate estate of freehold which fulfilled many of the purposes of a rightful estate, though it afforded no defence against the title of the rightful owner. Upon the subject generally, and especially upon the case of Doe v. Horde, 1 Burr. 60, in which Lord Mansfield, striving after an unattainable equity did his best to throw the law into confusion, see Butl. n. 1 on Co. Litt. 330 b.

If a tortious feoffment was made by any person other than a tenant in tail actually seised, the person rightfully entitled (or any other person acting in his name, even though without his assent) might at common law destroy the tortious estate of the feoffee by mere entry (Co. Litt. 258a); but if the feoffee's heir had succeeded by inheritance be- 
fore entry made, the heir's estate could not be affected by cniry, and the rightful claimant was put to his action. (Litt. sect. 355.) IHis entry was technically said to be tolled by decent/cast. Entry was tolled by a descent cast in fee tail When the disseisor nuade a git in tail) as well as in fee simple. (Ibid. sect. 386.) But on the extinction of the entail by failure of issue, the entry was revived against the remainderman or reversioner. (Co. Litt. 238b.)

The $3 \& 4$ Will. 4 , c. $27, \$ 39$, enacts that no descent cast after 31 st December, 1833, shall toll any right of entry. This enactment made the learning of descents cast, and also of continual claim whercby rights of entry might be protected therefrom, equally obsolete.

A feoffment, made by a tenant in tail actually seised, operated as a discontinuance of the estate tail, and devested all remainders, and the reversion, expectant upon it, unless they were vested in the king. Stone v. Newman, Cro. Car. 427, at p. 42S. Ey such discontinuance the persons entitled under the entail, and in remainder or reversion, were barred of their riglit of entry, and respectively put to their action as the only means to enforce their claims.

The learning relating to discontinuance, though obsolete in respect to the common practice, is still sometimes of practical importance. In $18 \mathrm{~s}$ t a case was litigated in the House of Lords in which the validity of a claim partly depended upon the properties at the common law of a tortious fee simple, which hat been gained by a diecontinuance effected in the preceding century, by a feoffinent made by the survivor of two joint donees in special tail.

In all cases where the risht of entry was tolled or barred, the need ful action to recorer the seisin was a real action. An zetion of ejectment (ciectione firmx) Wonkl not suffice. 2 l'rest. Abst.32s.

There were two tegrees of remoteness in a right of action, the first being said to be fomded upon a right of possession, and the second being styled a mere right; and there were two kinds of real actions corresponding thereto, possessory actions, grounled upon writs styled writs of eutry, and lroitural actions. grounded upon writs styled wits of riglit. A right of possession might be turned to a mere right, either by suffering such a time to elapse as would be a bar to a writ of entry, or by suffering adverse judgment by default in an action on such a writ. (See, on this subject, Butl. n. 1 on Co. Litt. 239a.) but the discontinuance of an estate tail by the tortious feoffment of the tenant in tail in possession, fortluwith turned the right of the issue in tail to a mere right, without passing through any intermediate stages. 3d Ed. by Sweet, pp. 397, 405 , et seq. ${ }^{3}$

${ }^{3}$ Eefefment strictly speaking. Was pronerly used only when the ennreyance was of fee simule. When the estate crealted was a fee fint the conivevance wis siff to be by gift ind when a lifo estate the conveyance was by lease. Blackstone's Comp pp. *316, *31 


\section{FINE \\ BLACKSTONE'S COMMENTARIES.}

A fine is sometimes said to be a feoffment of record: though it might with more accuracy be called an acknowledgment of a feofiment on record. Wy which is to be understood, that it has at least the same force and effect with a feofinent, in the conveying and assuring of lands: though it is one of those methods of transferring estates of freehold by the conmon law, in which livery of seisin is not vecessary to be actually given; the supposition and acknowledgnent thereof in a court of record, however fictitious, inducing an equal notoriety. But, more particularly, a fine may be described to be an amicable composifion or agreement of a suit, either actual or fictitious, by leave of the king or his justices: whereby the lands in question become, or are aclinowledged to be the right of one of the parties: In its original it was founded on an actual suit, commenced at law for recovery of possession of lands or other hereditaments; and the possession thus gained by such composition was found to be so sure and effectual, that fictitious actions were, and continue to be, every day commenced, for the sake of obtaining the same security.

Book 2, star p. $3+8$.

\section{COMMON RECOYERY}

\section{BLACKSTONE'S COMMEN'TARIES.}

A common recovery is so far like a fine, that it is a suit or action, either actual or fictitious; and in it the lands are recovered against the tenant of the frechold; which recovery, being a supposed adjudication of the right, binds all persons, and vests a free and absolute fec-simple in the recoveror. A recorery, therefore, being in the nature of an action at law, not immediately compromised like a fine, but carried on through every regular stage of proceeding, I am greatly apprehensive that its form and method will not be easily understood by the student who is not yet acquainted with the course of judicial proceedings; which cannot be thoroughly explained, till treated of at large in the third book of these Commentaries.

Book 2, star p. 357.4

4 For an account of the procedure in common recoreries. see Pollock, Land Laws, S0; Tilliams, R. P. 95 et seq.

By the Fines and Recoveries Act, 3 \& 4 W. IV, c. 74 , it is prorided that after December $31,15.33$, no fine shall be levied or common recovery suffered of lands of any temure. 
IV. LEASE

\section{BLACKSTONE'S COMMENTARIES.}

A lease is properly a conveyance of any lands or tenements (usually in consideration of rent or other annual recompense) made for life, for years, or at will, but always for a less time than the lessor hath in the premises, for if it be for the whole interest, it is more properly an assignment than a lease. The usual words of operation in it are, "demise, grant, and to farm let: dimisi, concessi, et ad firmam tradidi." Farm, or feorme, is an old Saxon word signifying provisions; and it came to be used instead of rent or render, because anciently the greater part of rents were reserved in provisions; in corn, in poultry, and the like; till the use of money became more frequent. So that a farmer, firmarius, was one who held his land upon payment of a rent or feorme: though at present, by a gradual departure from the oririnal sense, the word farm is brought to signify the very estate or lands so held upon farm or rent. By this conveyance an estate for life, for years, or atwill may be created, either in corporeal or incorporeal hereditaments; though livery of seisin is indeed incident and necessary to one species of leases, viz.: leases for life of corporeal hereditaments; but to no other.

Book 2, star p. 317.

\section{ExCHANGE}

\section{BLACKSTONE'S COMMENTARIES.}

An exchange is a mutual grant of equal interests, the one in consideration of the other. The word "exchange" is so individually requisite and appropriated by law to this case, that it cannot be supplied by any other word, or expressed by any circumlocution. The estates exchanged must be equal in quantity: not of value, for that is immaterial, but of interest; as fee-simple for fee-simple, a lease for tuvent years for a lease for twenty years, and the like. And the exchange may be of things that lie either in grant or in livery. But no livery of seisin, even in exchanges of freehold, is necessary to perfect the convevance: for each party stands in the place of the other and occupies his right, and each of them hath already had corporal possession of his own land. But entry must be made on both sicles, for, if either party die before entry, the exchange is vold, for want of sufficient notriety.

\section{Book 2, star p. 323.}

AIg.PRop.-11 


\section{PARTITION}

\section{BLACKSTONE'S COMMENTARIES.}

A partition is when two or more joint-tenants, coparceners, or tenants in common, agree to divide the lands so held among them in severalty, each taking a distinct part.

Book 2, star p. 323."

\section{Grant \\ BLACKSTONE'S COMMENTARIES.}

Grants, concessiones; the regular method by the common law of transferring the property of incorporeal hereditaments, or such things whereof no livery can be had. For which reason all corporeal hereditaments, as lands and houses, are said to lie in livery; and the others, as advowsons, commons, rents, reversions, etce, to lic in grant. And the reason is given by Bracton: "tralitio, or livery, nihil aliud est quam rei corporalis de persona in persunam, de manu in manum, translatio aut in possessionem inductio: sed res incorporales, quae sunt 'ipsum jus rei vel corpori inharens, traditionem non patiuntur" (livery is merely the transferring from one person to another, from one hand to another, or the incluction into possession of a corporeal hereditancnt; but an incorporeal hereditament, which is the right itself to a thing, or inherent in the person does not admit of delivery). These, therefore, pass merely by the delivery of the deed. And in scigniories, or reversions of lands, such grant, together with the attornment of the tenant (while attormments were requisite), were held to be of equal notoriety with, and therefore equivalent to, a fcoffment and livery of lands in immediate possession. It therefore differs but little from a feoffment, except in its subject-matter ; for the operative words thercin commonly used are dedi et concessi, "have given and granted." Book 2, star p. 317 .

- See infra, pp. 6S7, 689 .

6 See Litt. 551, 567-569; Co. Litt. 309, a, b.

"And he it further enacted by the authority aforesain. That from and after the first das of Trinity term, all griants or converances thereiffer to be made, bo fine or otherwise, of ans minors or rents, or of the reversion or remiainder of ans messuases or liands, shall be good and effectual, to all intents and purposes, without any atternment of the tenints of any such manors, or of the land out of which such rent shall be issuing, or of the par. ticular tenants upon whose particular estates any such reversions or remainders shall and may be expectant or derending, as if their attornment had been had and made." St. 4 Ame (1705) c. 16. $\$ 9$.

As to necessity for attornment in the United States, see Tiffany, Landlord \& Tellant, $\$ 140+$. 


\title{
VIII. Dedication \\ REX v. HUDSON.
}

(Court of King's Bench, 1732. 2 Strange. 909.)

On an information for stopping up a common foot-way, the prosecutor proved, that it had been a common passage under the defendant's house as far back as any witnesses could remember. But the defendant producing a lease made for fifty-six years of this way, to the intent it might be a passage during the term, and the term expiring in 1728; the Chief Justice (RAYMOND) held the defendant not guilty: and as to the leaving it open since, he said that it would not be long enough to amount to a gift of it to the pullic. ${ }^{7}$

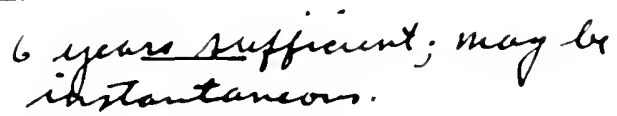

LADE v. SHEPHERD.

\author{
(Court of King's Bench, 17:3. 2 strangr, 1004.)
}

Upon trial of an action of trespass a case was made, that the place where the supposed trespass was committed was formerly the property of the plaintiff, who some years since built a street unon it, which has ever since been used as a highway. 'That the defendant had land contiguous parted only by a ditch, and that he laid a bridge over the ditch, the end whercof rented on the ligghway. Snl it was insisted for the defendant, that by the plaintifi's making it a strect, it was a declication of it to the public; and therefore however he might be liable to an indictment for a nuisance, yet the plaintiff could not sue him as for a trespass on his private property. Sed PER CURI, It is certaindy a dedication to the public, so far as the public has occasion for it wivich is only for a right of passage. But it never was understoged to be a transfer of the absolute property in the soil. So the plaintiff had judgment.

i That six vears mar be sufficient time wherein to presume a deflicution from user, see Rughy Chality ?. Merryesther, 11 Wast, 3it, note Tser for eighteen months where there was a declaration of intention to dedicuife hold

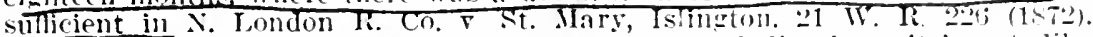
". oparticuar time is necessary for evilence of a dedication; it is not, like a crant, presumed from length of time: if the act of dediration be unduiv-

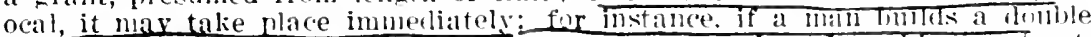
row of houses opening into an inclent street at e:ich emd miling a street, and sels or lets the houses that is instantle a highiva." Chambre, J., in movder r. Iladden, 5 Taunt. 1:5 (1S1:3).

$A$. is tenant for life, the remainder in fee being in B.; A. dedicates a portion of the land as a highway. What effert, if ans. Would such derlication have upon B.? See Farquhar v. Newbury Rual Couneil, L1:U9J $1 \mathrm{Ch}$. 12. 


\section{REX v. LLOYD.}

(Court of King's Dench, 180s. 1 Camp. 260.)

This was an indictment for obstructing a highway.

It appeared that the place in question is a narrow passage lying on the north side of Snow-Hill, called Cock-court; and being of an oblong shape, leads from one part of this street to another, without having any outlet elsewhere. The houses all the way round had once belonged to the same individual: and the defendant, having purchased those at the top of the court, built a wall across there, intercepting all conmunication between the two sides, the passage had been open as far back as could be remembered; and though it could in general be of no use to those walking up and down SnowHill being a most circuitous route which no one would willingly take, yet it was convenient for the public when the strect was blocked up by a crowd. The passage had been long lighted by the city of London and there had never been any chain across it, or any mark to denote its being private property.

LORD ELLFNBOROUn. I think, that if places are lighted by public bodies, this is strong evidence of the public having a right of way over them; and to say that this right cannot exist hecause a particular place does not lead convenientiv from one strcet to another, would go to exthinguish all highways where (as in Qucensquare) there is no thoroughfare. If the owner of the soil throws open a passage, and neither marks by any visible distinction, that he means to preserve all his rights over it, nor excludes persons from passing through it by positive prohibition, he shall be presumed to have dedicated it to the public. Although the passage in question was originally intended only for private convenience, the public are not now to be excluded from it, after being allowed to use it so long without any interruption.

The defendant was found guilty 8

$s$ That there cannot he a dedication to a portion of the publtc see Eagle $\nabla$.

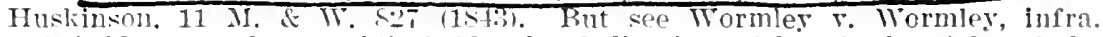
A bridge may be a public bride by dedication, although the riglit of the pullic to use same is limited to such times as the river is not fordable. Rex r. Northaupton, 2 II. \& S. 2062 (1814). As to dedication for limiter purposes, see Staftord $v$. Cornes, 7 B. \& C. 257 (1527); (Gowen v. Philadelphia Exchange Co.. 5 Watts \& S. (Pa.) 141, $40 \mathrm{Am}$. Dec. $4 \$ 9$ (1S42). And as to derlication subject to reservations on behalf of the owner, see Mercer v. Woodgite, L. R. 5 Q. B. 26 (1S69), where the owner claimed the right to plough up the way periodically; Attorney General v. Horner, [1913] $2 \mathrm{Ch}$. 140, where the owner claimed land had been dedicated for street purposes subject to a right of overflow from a private market; City of Noblesville r. Lake Erie \& W. R. Co., 130 Ind. 1,29 N. E. 484 (1S91), where the dedication of a street was claimed to be subject to the right to lay down a railroad therein. 


\section{CINCINNATI v. WHITE.}

(Supreme Court of the Lnited States, 1S:32. 6 I'et. 4:1, S I. Ed. 452.)

Error to the Circuit Court of Ohio. The case came before the court on a bill of exceptions, taken by the plaintiff $\mathrm{in}$ error, the defendants in the circuit court, to the instructions given by the court to the jury, on the request of the counsel for the plaintifts in that court; and to the refusal of the court to give certain instructions as prayed for by the defendants below.

In the opinion of the court, no decision was given on those exceptions, save only on that which presented the question of the dedication of the land in controversy for the use of the city of Cincinnati; which, and the facts of the case connected therewith, are fully stated in the opinion of the court. Whe arguments of the counsel in the case, on the matters of law presented by the exceptions, are, therefore, necessarily omitted.

Tinompon, J., delivered the opinion of the court. The ejectment in this case was brought by lidward 11 hite, who is also the defendant in error, to recover possession of a small lot of ground, in the city of Cincinnat, lying in that wart of the city usually denominater the comtyon.

'I'o the right understanding of the question upon which the opinion of the cuurt rests, it will be sufficient to state, gencrally, that on the 15th of October, in the year 1758 , John Cleves Symmes entered into a contract with the then board of treasury, under the direction of congress, for the purchase of a large tract of land, then a wilderness, including that where the city of Cincimanti now stands. Some negotiations relative to the payments for the land delayed the consummation of the contract for several years; but on the 30th of Seducmier 1794. a patent was issued, conreying to Symmes and lis associates, the lanr! contracted for: and as Symmes was the only person naned in the patent, the feewas, of course vested in him. Fefore the issuing of the patent, huwerer, and, as the witnesses say, in the year 178s, Matthias Demman purchased of Symmes a part of the trastincludedin the pat ent and embracing the land whereon Cincinunti now stands 'That in the same year, Dennan sold one-third of his purchase to Israel Lumd low, and one-third to Robert l'atterson. 'These three persons, Den man, Ludlow and Patterson being the equitable owners of the dand (no legal title having heen oraneded, procecied, in January, 1789, to lay out the town. A plan was made and approved of by all the proprictors; according to which, the ground lying between Front street and the river, and so located as to include the premises in question, was set apart as a common, for the use and bencht of the town for ever, reserving only the right of a ferry; and no lots were laid out on the land thus dedicated as a common. 
The lessor of the plaintiff made title to the premises in question under Matthias Demman, and produced in evidence a copy, duly authenticated, of the location of the fraction 17, from the books of John $\mathrm{C}$. Symmes, to Matthias Denman, as follows: "1791, April 4, Captain Israel Ludlow, in behalf of Mr. Matthias Denman, of New Jersey, presents for entry and location, a warrant for one fraction of a section, or 107.8 acres of land, by virtue of which he locates the 17 th fractional section in the 4th fractional township, east of the Great Miami river, in the first fractional range of townships on the Ohio river; number of the warrant, 192." In March 1795, Denman conveyed his interest, which was only an equitable interest, in the lands so located, to Joel Williams; and on the 14th of liebruary, 1SCO, John Cleves Symmes conveyed to Joel Williams in fee, certain lands clescribed in the deed, which included the premises in question; and on the 16th of April 1800, Joel Williams conveyed to Joln Daily the lot now in question. And the lessor of the plaintiff, by sundry mesne conveyances, deduces a title to the premises to himself.

In the course of the trial, scveral exceptions were taken to the ruling of the court, with respect to the evidence offered on the part of the plaintiff, in making out his claim of title. But in the view which the court has taken of what may be considered the substantial merits of the case, it becomes unnecessary to notice those exceptions.

The merits of the case will properly arise upon one of the instructions given by the court, as asked by the plaintiff; and in refusing to give one of the instructions asked on the part of the defendlant. $\sqrt{\mathrm{At}}$ the request of the plaintiff, the court instructed the jury, "that to enable the city to hold this ground, and defend themselves in this action, by possession, they must show an unequivocal, uninterrupted possession for at least twenty years." On the part of the defendants, the court was asked to instruct the jury, "that it was competent for the original proprietors of the town of Cincinnati to reserve and dedicate any part of said town to public uses, without granting the same by writing or deèd to any particular person; by which reservation and dedication, the whole estate of the said proprietors in said land, thus reserved and dedicated, became the property of, and was vested in, the public, for the purposes intended by the said proprietors; and that, by such dedication and reservation, the said original proprietors, and all persons claiming under them, are estopped from asserting any claim or right to the said land thus reserved and dedicated." The court refused to give the instruction as asked, but gave the following instruction: "That it was competent for the original proprietors of the town of Cincinnati to reserve and dedicate any part of said town to public uses, without granting the same, by writing or deed, to any particular person; by which reservation and dedication, the right of use to such part is vested in the public for the purposes designated; but that such reservation and dedication do not invest the public with the fee." 
The ruling of the court, to be collected from these instructions, was, that although there might be a parol reservation and dedication to the public of the use of lands; yet such reservation and dedication did not invest the public with the fee; and that a possession and enjoyment of the use for less than twenty years was not a defence in this action. The decision and direction of the circuit court upon those points come up on a writ of error to this court.

It is proper, in the first place, to observe, that although the land which is in dispute, and a part of which is the lot now in question, has been spoken of by the witnesses as having been set apart by the proprietors as a common, we are not to understand the term as used by them in its strict legal sense, as being a right or profit which one man may have in the lands of another; but in its popular sense, as a piece of ground left open for commons and public use, for the convenience and accommodation of the inhabitants of the town.

Dedications of land for public purposes have frequently come under the consideration of this court; and the objections which have generally been raised against their validity have been the want of a grantee competent to take the title; applying to then the rule which prevails in private grants, that there must be a grantee as well as a grantor. But that is not the light in which this court has considered such dedications for public use. The law applies to them rules adapted to the nature and circumstances of the case, and to carry into execution the intention and object of the grantor, and secure to the public the benefit held out, and expected to be derived from and enjoyed, by the dedication.

It was adnitted at the bar, that dedications of land for charitable and religious purposes, and for public highways, were valid, without any grantee to whom the fee could be conveyed. Although such are the cases which most frequently occur and are to be found in the books, it is not perceived, how any well grounded distinction can be macle between such cases and the present. The same necessity exists in the one case as in the other for the purpose of effecting the object intended. The principle, if well founded in the law, must have a general application to all appropriations and dedications for public use, where there is no grantee in esse to take the fee. But this forms an exception to the rule applicable to private grants, and grows out of the necessity of the case. In this class of cases, there may be instances, contrary to the general rule, where the fee may remain in abeyance, until there is a grantee capable of taking; where the object and purpose of the appropriation look to a future grantee, in whom the fee is to vest. But the validity of the dedication does not depend on this; it will preclude the party maling the appropriation from re-asserting any right over the land, at all events, so long as it remains in public use, although there may never arise any grantee capable of taking the fee. 
The recent case of Beatty v. Kurtz, 2 Pet. 266, 7 L. Ed. 521, in this court, is somewhat analogous to the present. There, a lot of ground had been marked out upon the original plan of an addition to Georgetown, "for the Lutheran Church," and had been used as a place of burial, from the time of the dedication. There was not, however, at the time of the appropriation, or at any time afterwards, any incorporated Lutheran church, capable of taking the donation. The case turned upon the question, whether the title to the lot ever passed from Charles Beatty, so far as to amount to a perpetual appropriation of it to the use of the Lutheran church. That was a parol dedication only, and designated on the plan of the town. The principal objection relied upon was, that there was no grantee capable of taking the grant. But the court sustained the donation, on the ground, that it was a dedication of the lot to public and pious uses; adopting the principle that had been laid down in the case of the Town of Pawlet v. Clark, 9 Cranch, 292, 3 L. Ed. 735, That appropriations of this description were cxceptions to the general rule requiring a grantee. 'That it was like a dedication of a highway to the public. This last remark shows that the case did not turn upon the bill of rights of Mlaryland, or the statute of Elizabeth relating to charitable uscs, but rested upon more gencral principles; as is evident from what fell from the court in the case of the 'Town of Pawlet $v$. Clark, which was a dedication to religivus uses; yet the court said, this was not a nurel doctrine in the common law. In the familiar case, where a man lays out a street or public highway over his land, there is, strictly speaking, no grantee of the easement, but it takes effect by way of grant or dedication to public uses. And in support of the principle, the case of Lade v. Shepherd, 2 Str. 100t, was referred to; which was an action of trespass, and the place where the supposed trespass was committed was formerly the property of the plaintiff, who had laid out a street upon it, which had continued thereafter to be used as a public highway; and it was insisted, on the part of the defendant, that by the plaintilf's making a street, it was a dedication of it to the public, and that although he, the defendant, might be liable for a nuisance, the plaintiff could not sue him for a trespass. But the court said, it is certainly a dedication to the public, so far as the public has occasion for it, which is only for a right of passage; but it never was understood to be a transfer of his absolute property in the soil. The doctrine necessarily growing out of that case has a strong bearing upon the one now before the court, in two points of view. It shows, in the first place, that no deed or writing was necessary to constitute a valid dedication of the easement. All that was cone, from wything that appears in the case, was barely laying out the street by the owner, across his land. (And in the second place, that it is not necessary that the fee of the land should pass, in order to secure thet easement to the public. And this must necessarily be so, from the nature of the case, in the dedication of all public highways. There is no grantee to take immediately, nor is any one contemplated by the 
party to take the fee at any future day. No grant or conveyance can be necessary to pass the fee out of the owner of the land, and let it remain in abeyance, until a grantee shall come in esse; and incleed, the case referred to in Strange considers the fee as remaining in the origi nal owner; otherwise, he could sustain no action for a private injury to the soil, he having transferred to the public the actual possession.

If this is the doctrine of the law, applicable to highways, it must apply with equal force, and in all its parts, to all dedications of land to public uses; and it was so applied by this court to the reservation of at public spring of water, for public use, in the case of McConnell $r$. 'T'rustees of the Town of Lexington, 12 Wheat. 582, $6 \mathrm{~L}$. Ed. 735. 'The court said, the reasonableness of reserving a public spring, for public use, the concurrent opinion of all the settlers that it was so reserved, the miversal adni-sion of all that it was never understood, that the spring lot was drawn by any person, and the carly appropriation of it to public purposes, were decisive asainst the claim.

The right of the public to the use of the common in Cincinnati must rest on the same principles as the right to the use of the strects; and no one will contend, that the original owners, after having laid out streets, and sold buikling lots thercon, and improvements made, conld claim the casement thus dedicated to the public. All public dedications must be considered with reference to the use for which they are made: and streets in a town or city may require a more enlarged right orer the use of the land, in order to carry into effect the purposes intended. than may le necesary in an appropriation for a highway in the commtry; but the principle, so far as respects the right of the origrinal owner to disturb the une, must rest on the sane gromml, in both cases; and applies eftrally to the dedication of the common as to the streets. It was for the pullic use, and the convenience and accommoration of the inhabitants of Cincinnati: and, douftiess, greatly enhanced the value of the private property adjoining this common, and therely compensated the owners for the land thus thrown out as pulblic grounds. And atter being thus set apart for public use, and enjoyerl as such, and private and individual rights acquired with reference to it, the law considers it in the nature of an estoppel in pais, which prechures the original owner from revoking such dedication. It is a violation of suorl faith to the public, and to those who have acquired private property with a view to the enjomment of the use thus publicly granted.

'The right of the public, in such cases, does not depend upon a twenty years' possession. Such a rloctrinc, applied to public highways and the streets of the numerous villages and cities that are so rapilly springing up in every part of our country, would be destructive of public convenienge and private right. The case of Jarvis v. Dean, 3 bing. $4+7$, shows, that rights of this description do not rest upon length of possesEion. The plaintiff's right to recover in that calse, turned sipon the iftestion, whether a certain street, in the parish of Islingtom, had been dedicated to the public as a common public highway. Chief Iustice 
Best, upon the trial, told the jury, that if they thouglit the street had been used for years as a public thoroughfare, with the assent of the owner of the soil, they might presume a dedication; and the jury found a verdict for the plaintiff, and the court refused to grant a new trial, but sanctioned the direction given to the jury and the verdict found thereupon; although this street had been used as a public road only four or five years; the court saying, the jury were warranted in presuming it was used with the full assent of the owner of the soil. The point, therefore, upon which the establishment of the public street rested, was, whether it had been used by the public as such, with the assent of the owner of the soil; not whether such use had been for a length of time, which would give the right by force of the possession; nor whether a grant might be presumed; but whether it had been used with the assent of the owner of the land; necessarily implying, that the mere naked fee of the land remained in the owner of the soil, but that it became a public street, by his permission to have it used as such. Such use, however, ought to be for such a length of time that the public accommodation and private rights might be materially affected by an interruption of the enjoyment.

In the present case, the fact of dedication to public use is not left to inference, from the circumstance that the land has bcen enjoyed as a pose is established by the ntist positive and conclusive eviclence. And indeed, the testimony is such as would have warranted the jury in presuming a grant, if that had been necessary. And the fee might be considered in abeyance, until a competent grantee appeared to receive it; which was as early as the year 1802 , when the city was incorporated. And the common having then been taken under the charge and direction of the trustees, would be amply sufficient to show an acceptance, if that was necessary, for securing the protection of the public right.

But it has been argued, that this appropriation was a nullity, because the proprietors, Denman, Ludlow and Patterson, when they laid out the town of Cincinnati, and appropriated this ground as a common, in the year 1789, had no title to the land, as the patent to Symmes was not issued until the year 1794. It is undoubtedly true, that no legal title had passed from the United States to Symmes. But the proprietors had purchased of Symmes all his equitable right to their part of the tract which he had under his contract with the government. This objection is more specious than solid, and does not draw after it the conclusions alleged at the bar.

There is no particular form or ceremony necessary in the dedication of land to public use. All that is required is the assent of the owner of the land, and the fact of its being used for the public purposes intended by the appropriation. This was the doctrine in the case of Jarvis v. Dean, already referred to, with respect to a street; and the same rule must apply to all public dedications; and from the mere use of the land, as public land, thus appropriated, the assent of the owner 
may be presumed. In the present case there having been an actual dedication, fully proved, a contined assent will be presumed, until a dissent is shown; and this should be satisfactorily established by the party claiming against the dedications In the case of Rex v. Lloyd, 1 Camp. 262, Lord Enlenborough says, if the owner of the soil throws open a passage, and neither marks by any visible distinction that he means to preserve all his rights over it, nor excludes persons from passing through it by positive prohibition, he shall be presuned to have dedicated it to the public.

At the time the plan of the town of Cincinnati was laid out by the proprietors, and the common dedicated to public use, no legal title had been granted. But as soon as Symmes became vested with the legal title, under the patent of 1794 , the equitable right of the proprietors attached upon the legal estate, and Symmes became their trustee, having no interest in the land but the mere naked fee. And the assent of the proprietors to the dedication continuing, it has the same effect and operation as if it had originally been made, after the patent issued. It may be considered a subsequent ratification and faffirmance of the first appropriation. And it is very satisfactorily proved, that Joel Williams, from whom the lessor of the plaintiff deduces his title, well understood, when he purchased of Denman, and for some years before, that his ground had been dedicated as a public common by the proprietors. The original plat, exhibiting this ground as a common, was delivered to him at the time of the purchase. And when he, afterwards, in the year 1800, took a deed from Symmes, he must, according to the evidence in the case, have known that he was a mere trustee, holding only the naked fee. And from the notoriety of the fact, that these grounds were laid open and used as a common, it is fairly to be presumed, that all subsequent purchasers had full knowledge of the fact.

But it is contended, that the lessor of the plaintiff has shown the legal title to the premises in question in himself, which is enough to entitle him to recover at law; and that the defendants' remedy, if any they have, is in a court of equity. And such was substantially the gpinion of the circuit court, in the fourth instruction asked by the plaintiff, and given by the court, viz: "that if the said proprietors did appropriate said ground, having no title thereto, and afterwards acquired an equitable title only, that equitable title could not inure so as to vest a legal title in the city or citizens, and enable them to defend themselves in an action of ejectment brought against them by a person holding the legal title."

We do not accede to this doctrine. For should it be admitted, that the mere naked fee was in the lessor of the plaintiff, it by no means follows, that he is entitled ta recover possession of the common, in an action of ejectment. This is a possessory action, and the plaintiff, to entitle himself to recover, must have the right of possession; and 
whatever takes away this right of possession, will deprive him of the remedy by ejectment. Adams's Eject. 32 ; Stark. part 4, p. 505-7. This is the rule laid down by Lord Mansfield in Atlyns v. Horde, 1 Burr. 119: An ejectment," says he, "is a possessory remedy, and only competent where the lessor of the plaintiff may enter; and every plaintiff in ejectment must show a right of possession as well as of property." And in the case of Doe v. Staple, 2 T. R. 684, it was held, that although an outstanding satisfied term may be presumed to be surrendered, yet an unsatisfied term, raised for the purpose of securing an annuity, cannot, during the life of the annuitant; and may be set up as a bar to the heir-at-law, even though he claim only subject to the charge. Thereby clearly showing, the plaintiff must have, not only the Tegal title, but a clear present right to the possession of the premises; or he cannot recover in an action of ejectment. And in the case of Doe w-Jackson, 2 Dow. \& Ry. 523, Bailey, Justice, says, "An action of ejectment, which from first to last is a fictitious remedy, is founded on the principle that the tenant in possession is a wrongdoer; and unless he is so, at the time the action is brought, the plaintifi cannot recover." If, then, it is indispensable, that the lessor of the plaintiff should show a right of possession in himself, and that the defendants are wrongdoers, it is difficult to perceive, on what grounds this action can be sustained.

The later authorities in England which have been referred to, leave it at least questionable, whether the doctrine of Lord Mansfield in the case of Goodtitle v. Alker, 1 Burr. 143, "that ejectment will lie by the orner of the soil for land, which is subject to a passage over it as the king's highway," would be sustained, at the present day, at Westminster Hall. It was not, even at that day, considered a settled point, for the counsel on the argument (page 140), referred to a case, said to have been decided by Lord Hardwicke; in which he held, that no possession could be delivered of the soil of a highway, and therefore, no ejectment would lie for it. This doctrine of Lord Nansfield has crept into most of our elementary treatises on the action of ejectment, and has apparently, in some instances, been incidentally sanctioned by judges. But we are not aware of its having been adopted in any other case, where it was the direct point in judgment. No such case was referred to on the argument, and none has fallen under our notice. There are, however, several cases in the supreme court of errors of Connecticut, where the contrary doctrine has been asserted and sustained, by reasons much more satisfactory than those upon which the case in Burrow is made to rest. Stiles v. Curtis, 4 Day (Conn.) 32S; Peck v. Smith, 1 Conn. 103, 6 Am. Dec. 216.

But if we look at the action of ejectment, on principle, and inquire what is its object, it cannot be sustained, on any rational ground. It is to recover possession of the land in question; and the judgment, if carried into execution, must be followed by delivery of possession to the 
lessor of the plaintiff. The purpose for which the action is brought, is not to try the mere abstract right to the soil, but to obtain actual possession; the very thing to which the plaintiff can have no exclusive or private right. This would be utterly inconsistent with the admitted public right; that right consists in the uninterrupted enjoyment of the possession; the two rights are therefore incompatible with each other, and cannot stand together. The lessor of the plaintiff seeks specific relief, and to be put into the actual possession of the larrd. The very fruit of his action, therefore, if he avails himself of it, will subject him to an indictment for a nuisance; the private right of possession being in direct hostility with the easement or use to which the public are entitled; and as to the plaintiff's taking possession suhject to the easement, it is utterly impracticable. It is well said, by Mr. Justice Smith, in the case of Stiles v. Curtis, that the execution of a judgment, in such case, involves as great an inconsistency as to issue an habere facias possessionem of certain prenises to A., subject to the possession of B. It is said, cases may exist where this action ought to be sustained for the public benefit, as where erections are placed on the highway, obstructing the public use. But what benefit would result from this to the public? It would not remove the nuisance. The effect of a recovery, would only be to substitute another offender against the public right, but would not abate the nuisance. That must be done by another proceeding.

It is said, in the case in Burrow, that an ejectment could be maintained, because trespass would lie. But this certainly does not follow. The object and effect of the recoveries are entirely different. TThe one is to obtain possession of the land, which is inconsistent with the enjoyment of the public right; and the other is to recover damages merely, and not to interfere with the possession, which is in perfect harmony with the public right. So also, if the fee is supposed to remain in the original owner, cases may arise where perhaps, waste, or a special action on the case, may be sustained, for a private injury to such owner; but these are actions perfectly consistent with the public right. But a recovery in an action of ejectment, if carried into execution, is directly repugnant to the public right.

Upon the whole, the opinion of the court is, that the judgment must be reversed, and the cause sent back with directions to issue a venire de novo. Judgment reversed. 


\section{WATERS v. PHILADELPHIA.}

(Supreme Court of Pennsylvania, 190t. 208 Pa. 189, 57 Atl. 523.)

Appeal from award of jury of view. Before Biddle, P. J.

The facts are stated in the opinion of the Supreme Court.

Verdict and judgment for plaintiff for $\$ 3,000$. Defendant appealed.

PotTer, J.o This was an issue framed under an appeal from the finding of a road jury upon a claim for damages caused by the widening of Walnut street. On the lot now owned by the plaintiff at the southeast corner of $15 \mathrm{th}$ street and Walnut, a building was erected some thirty-five or forty years ago upon a line about four feet from the street line, and the intervening space was left open for use and was used by the public as part of the sidewall. All the other buildings on the block were erected substantially on the same line. On June 30 , 1892, an ordinance was passed authorizing the bureau of surveys to revise the city plan so as to make the width of Walnut street conform to the line of the buildings erected thereon; and on January 15, 1894, in pursuance to the ordinance, the new south line of Walnut street was thus fixed.

Plaintiff purchased the property in question in 1898, and took down the old building and erected a new one upon the line established in 1894. This practically coincided with the line of the old buikling, although there is some evidence which indicates a further recession of a few inches. The plaintiff claimed damages for the value of the entire four feet between the original street line and that established in 1894. The city claimed that the plaintiff was entitled to no damages whatever, averring that the former owner had dedicated this four feet of ground to the use of the public. The court instructed the jury that there was no evidence in the case that would justify them in finding that there had been a dedication of the ground to public use, and restricted the jury to the single question of the amount of damages to be awarded. In this we think there was error.

There is much evidence in the case tending to show that the strip of ground in question was for many years used as part of the sidewalk, and that the owner made no use of it which would indicate that he regarded it as ministering in any way to his special benefit. There was no door upon the Walnut street end of the building and no steps leading to the street, as the entrance was from the 15 th street side. It is claimed by the city, and considerable evidence was offered tending to show, that, during a period of time extending for many years more than the statutory period of limitations, the owner never made any objection to the full and free use of this ground by the public as part of the highway, and never, during that period, made any clain of ownership therein.

Where there has been long continued use of land as a street by the public without objection on the part of the owner of the soil, the jury 
may presume a valid dedication. Schenley v. Com., 36 Pa. 29, 59, $7 \mathrm{~S}$ Am. Dec. 359. No particular formality is requisite to constitute a dedication upon the part of the owner. Any act which clearly indicates an intention to dedicate is sufficient. "Proof of the animus dedicandi may be by circumstances, and may rest in pais. One of such circumstances which will be considered evidence of dedication, is the use of the way by the public, with the knowledge and assent of the owner of the soil; and when such use extends through a long series of years, the animus dedicandi is presumed. 'The rcason of this rule is, that when the owner of the soil so long acquiesces in the ising the way, having knowled ge thereof he is estopped to deny his prior dedication." Witson v. Sexon, 27 Iowa, 15. It was also said, in City of.Richmond v. Stokes, 31 Grat. (Va.) 713: "Where streets and alleys have been opened by the owner of the soil and used by the public with his consent for years, a dedication of the easement may be presumed, and the continued and uninterrupted use with the knowledge and acquiescence of the owner will justify the presumption of a dedication to the pullic, provisled the use has been continued so long that private rights and public convenience might be materially affected by an interruption of the enjeyment. But any acts of ownership by the owners of the soil would repel the presumption."

In State v. K. C., etc., R. R. Co., 45 Iowa, 139, it was pointed out that in the strict sense of the term a highway cannot be established by prescripion, since there can be 110 such thing as a grant to the public, but common usage has applied the term to highways whose existence is based upon long use and occupation.

There are many cases holding that the period reguired for the statute of limitations to bar the right of the owner would from analogy be sufficient to establish a presumption of dedication from lapse of time. Thus Knox, J., says, in Com. v. Cole, 26 Pa. 187: "The use of the of ground by the public as a highway for more than twenty-one years made it a public road just as cffectually as though it had originally been laid out and opened by the proper authorities." And in Schenley v. Com., 36 Pa. 29, 59 (7S Am. Dec. 359) it is said: "The period of twenty-one vears of enjovment after which a presumption of a grant is made is fixed from analog to the statute of limitations."

There is also abundant authority for the proposition that the owner of the soil may be concluded by a user by the public for a much shorter period of time, when there are other circumstances from which the intention to dedicate may be inferred. - As in Pittsburg, etc., Railway Co. v. Dumn, 56 Pa. 280, Reed, J., says: "Eight vears is quite sufficient time for presuming a ledication of the way to the public. In a great case which was much contested, six years was held sufficient, 11 East, 375 (note); and in Jarvis v. Dean, 3 Ling. 447, Chief Justice Best said 'as it had been used for four or five years as a public road, the jury were warranted in presuming that it was used with the full assent of the owners of the soil.'" But where it is obvious that a space has been

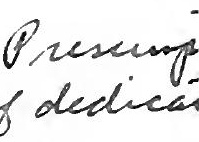


left open for the accommodation of the owner and not of the public the presumption of dedication does not arise. Gowen v. Phila. Exchange Co., 5 Watts \& S. 141, 40 Am. Dec. 489. And where the owner of land sets his fence back from the highway for his own convenience and uses. the intervening space until his cleath for private purposes, the municipal authorities cannot restrain a subsequent owner of the property, leven years after the death of the former owner, from setting back the fence to the old line and enclosing the intervening space: Griffin's Appeal, $109 \mathrm{~Pa}$. 150. But there the use of the land by the public was simply by sufferance of the owner: in that case Justice Green said (page 155): "Dedication is a matter of intention, and when clearly proved, it is as complete in one day as in tiventy-one vears. Where there is no opposing proof, long continued use by the public is evidence of an intention to dedicate, but it is by no means conclusive and always yields to contrary proof of a satisfactory character." In Weiss v. So. Bethlehem Borough, $136 \mathrm{~Pa} .294,20 \mathrm{Atl}$. S01, the question of the intention to dedicate was submitted to the jury, and they were instructed that a mere permissive use by the public of a piece of ground left open by the owner in front of his property, and used by him in his own business and for his own convenience, was not a dedication to public use and conferred no right upon the public as against the owner. The jury swere further told that the question whether or not there was a dedication depended upon the facts in evidence as to the opening of the land, the character of the use by the public, the character of the property, the nature of the land and its surroundings, and all the other circumstances in the case, and if they found that there was an intention to dedicate on the part of the owner, they would be warranted in finding that there was an actual derlication, and in that event their verdict should be in favor of the defendant.

A general statement of the doctrine applicable to this case is found in Dillon, Municipal Corprrations (tth Ed.) § 639, as follows: "A street may be widened by the dedication of a strip of land arljoining it and such dedication may be shown by long use by the public and acquiescence in such by the owner. And if the strect has been long used and built upon to a particular line, which has been acquiesced in by the adjoining owners, who have built and made improvements to correspond with sich line, such owners and the public acquire rights in consequence and one or more of such owners cannot afterwards change or narrow the street by showing that the original survey made the line of the street different from that which had been long regarded, built upon and acquiesced in as the line of the street."

In the present case, we think the question of dedication should have heen stbmitted to the jury. The evidence showed a long use of the strip of ground in question by the public, as part of the pavenent. Whether or not this was simply permissive, by the owner, and was accompanied by a course of conduct which would indicate a continued claim of ownership, was for the jury to deternine. Whether the own- 
er of the soil gave up the use of the strip to the public, without qualification, or whether he ever attempted in any way to limit the rights of the public therein, were cuestions of fact. "The court should have given to the jury an adequate definition of what facts or circumstances would amount to a legal dedication and it would then have been for them to find from the evidence and all the circunistances of the case, the existence of facts to fit the definition.

The fifth, sixth and seventh assignments of error are sustained.

The judgment is reversed and a venire facias de novo is awarded. ${ }^{8}$
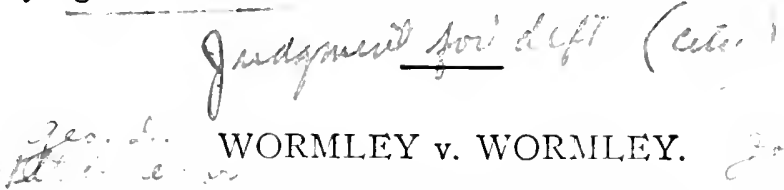

(Supreme Court of Illinois, 1901. 207 Ill. 411, 69 N. E. S65, 3 L. R. A.

[N. S.] 481.)

This is a bill in chancery, filed in the circuit court of Kendall county on June 10, 1899, by the plaintiff in error, George D. Wormley and all of the defendants in error except John $T$. Wormley, (said defondants in error, except John T. Wormley, being ten in number,) as complainants, against defendant in error, John ' $\mathrm{T}$. Wormley, as defendant. A general demurrer was filed to the bill. On January 4, 1901, the demurrer was sustained. Subsequently on April 3, 1901. the bill was dismissed for want of equity, and the costs were taxed against the complainants below, and it was ordered that the defend-

$\theta$ Not uncommonly it is said that an adrerse use of land for highway purposes by the puldic for the pesiou of the stiltute of linlitations will result in a himhar being created bs "urescriution." see Iemints r. Tishury, 5 Tray (Mass.) Tis (1850). Prescription in this connection can harlly have quite the sime meaning as in the case of the creation of private easements, at least in so far as it implies a sulposed lost grant. In this comection the presumption is of a past dedication. Thomas $\nabla$. Ford, 63 Mra. $346,75 \mathrm{Am}$. Rep. 5 (5) $(1 S(5)$.

There may be statutes directly applicable to the situation. In Californial, for instance. there is a statute that "all roads used as such for a period of more thindive years are highwass. This statnte was construed as in the nature of a statute of limitations. Bolser $\vee$. Foss, 6j Cal. 250, 3 I'ac. 57 (1s-4). There is a similar statute in Michiman, the period of time specified being ten years. 2 Comp. Laws, \$ 4001. The statute, howerer, does not aumly to a user which is merely permissive. Sticliley v. Township of sodus. 131 Mich. $510,91 \mathrm{~N}$. W. 745,59 L. R. A. $2 \$ 7(1902)$.

The owner of a tract of land in the outskirts of a city had the same platted into blocks, lots, anıl streets. A map was made, shoying the arrangement, and lots were sold and conveyed with reference to the map. Some of the streets were opened and used. In proceedings by the city to have onened certain other streets slown on the map the owners of lots abutting upon such streets claim compensition. Are they entitled to any? See Quicksall v. I'hiladelphia, 177 I'a. 301 , 35 Atl. 609 (1806); Ifarrington v. Mall'hester, 76 N. 1 . 347 , 82 Atl. 716 (1912); Ningor and City Council of Baltimore v. Frick, $\$ 2 \mathrm{Md}$. 77, 33 Atl. 435 (1895) : Reis v. City of New York, $18 \mathrm{~S}$ N. Y. 58,80 N. E. 573 (1907); State v. IIamilton, 109 Tenn. 276,70 S. W. 619 (1902). 
ant below have exectition therefor. The present writ of error is sued ont for the purpose of reviewing the decree, so entered, which dismissed the bill for want of equity.

In the bill, the orators therein being plaintiff in error, Gcorge D. Wormley, and ten other persons, who are defendants in error hercin with the defendant in error, John T. Wormley, alleged that in February, 1839 , and prior thereto and thereafter, one John H. Wormley was the owner in fee of a certain tract of eighty acres of land in said county and also was the owner in fee of other lands particularly described in the bill; that such other lands so descrited constituted in all one-half acre; that said one-half acre of land so described was generally known as the "Wormley cemetery," and had been so known and recognized ever since the year 1839; that, in February and June of 1839, two of John H. Wormley's relatives were buried in said one-half acre of land, that in 1845 a brother-in-law of his was buried on said half acre; that in $18+5 \mathrm{Jchn} H$. Wormley, being the owner of said one-half acre, and of other lands about the same whereon he resided, dedicated by words and acts said half acre for a burying ground for the uses of the IVormley family, and their relatives; that ever since 1839 said half acre has been used by the Wormley family, and the neighborhood, for the uses of sepulture; that, since the year 1845, there have been buried on said dedicated land many persons, the names of about thirty of whom are mentioned in the bill, being of the Wormley family, and relatives of orators: that monuments have been erected over the graves of many of said decedents, many of them by orators; that orators, and other relatives of said decedents, have continued to protect the remains of those buried in said cemetery, and to preserve the identity and memory of their said relatives; that orators have not in any manner neglected to preserve the monuments, erected to indicate the identity and preserve the memory of their said relatives, or to give and continue to said cemetery the character and name of a burial ground, except so far as they have been prevented by John T. IVormley, the defendant; that there were then, at the time of filing the bill, in said cemetery more than eighty graves, cared for and kept by orators, and other relatives of the deceased; that John $\mathrm{H}$. Wormley settled in Oswego, in Kendall county, several years before 1839, and resided on and owned the farm on which said cemetery is located, from the time of such settlement until the time of his death about the year 1890; that curing all that time he recognized said cemetery, as the burial ground of his relatives and the neighborhood, and assisted in maintaining the same as such; that, during his lifetime, he, with other relatives of those buried in said cemetery, caused to be erected and maintained a suitable fence, enclosing said half acre dedicated by him as a cemetery; that such fence was kept up by orators, and other relatives of the deceased, until prevented by the defendant in a violent and unlawful manner; that, upon the death of John H. Wormley, the defendant, 
John T. Wormley as his son and heir, came into the ownerslip and possession of the farm, on which said cemetery is located, and still owns and possesses the same; that, for many years after his coming into such ownership of said farm, he recognized the said cemetery as the burying ground of and for the Wormley family and neighborhood, and that the same had been dedicated by his father, John H. Vormley, for such purposes; that said cemetery is located on said farm on the line of the Aurora and Oswego wagon road, and ingress and egress in and out of said cemetery can be had without in any way interfering with, or trespassing on, the lands or premises of the defendant, John $T$. IVormley; that lately said defendant has torn down the fence, surrounding said cemetery, and is pasturing cattle, horses, and swine therein; that he has defaced and is defacing, the monuments and desecrating the graves in said cemetery: that he threatens to shoot and kill any persons, who attempt to fence said cennetery, or care for the monuments and graves therein; that he threatens to enter and remove the monuments therein, and to plow and cultivate the land therein; that, by threats and force, he prevents orators, and other relatives of the buried, from replacing the fence or caring for the monuments and graves in said cemetery; that orators fear that he will carry his threats into execution, wuless restrained by the order of the court. The bill thereupon prays that John 'T. Wormley may be restrained by injunction from defacing, or in any manner interfering with, the monuments and graves in said cemetery, or with orators, or any one of them, in fencing said cemetery and preserving the monuments and caring for the graves therein, or in any way interfering with the fence or fences of said cemetery, now or hereafter erected; that, upon a final hearing, it may be ordered and decreed that sail described onc-half acre of land, known as the "Normley cemetery," has been dedicated to the Wormley fanily, and their relatives, and neighborhood contiguous thereto, as a burying ground; that said injunction may be made perpetual, and orators may have such other relief as equity may require, etc.

Magruder, J. First-It is well settled in the United States, that cemeteries are among the purposes, for which land may be dedicated; and it is held that, upon such dedication, the orner is precluded from exercising his former rights over the land. 5 Am. \& Erig. Ency. of Law (2d Ed.) p. 7S4, and cases referred to in notes.

It is also well settled, that a court of equity will enjoin the owner of land from defacing, or medding with, graves on land, dedicated to the public for burial purposes, at the suit of any party, having deceased relatives or friends buried therein. Beatty v. Kurtz, 2 Pet. 5S5, 7 L. Ed. 521; Davidson v. Reed, 111 I11. 167, 53 Am. Rep. 613. In the case of Beatty v. Kurtz, supra, the Supreme Court of the United States, in speaking of property consecrated to cemetery purposes, held that the removal of the memorials, erected by piety or love to the memory of the good, are such acts as can not be "redressed by the 
ordinary process of law. The remedy must be sought, if at all, in the protecting power of a court of chancery; operating by its injunction to preserve the repose of the ashes of the dead, and the religious sensibilities of the living." In Davidson v. Reed, supra, two persons, residents in the neighborhood of a public burying ground, having friends buried there, filed a bill to enjoin the party owning the tract of land, on which it was located, from defacing the grave, and to preserve the ground for the public use for burial purposes; and it was there held that they could maintain the bill in their names, for the benefit of themselves, as well as if all others directly interested had joined.

It is also well settled, that no particular form or ceremony is necessary to dedicate tamd for the purposes of a cemetery. All that need be shown to constitute such dedication is the assent of the owner, and the fact that the land is used for the public purposes, intended by the appropriation. Staking off ground as a cemetery and allowing burials therein amounts to a dedication. An express setting apart of land for such a purpose by the owner may constitute a dedication of the land as a burial ground or cemetery. 5 Am. \& Eng. Ency. of Law (2d Ed.) p. 784; 9 Id. p. 2S; Hagaman v. Dittmar, 24 Kan. 42; Hayes r. Houke, 45 Kan. 466, 25 Pac. S60. It has been held that the notorious use of property for twenty years for burial purposes with the acquiescence of the owner affords presumptive evidence of its dedication for such purposes. Boyce v. Kalbaugh, 47 Md. 334, 28 Am. Rep. 464.

In Davidson v. Reed, supra, this court held that a dedication of land to the public for any public use may be shown by grant, by user, or by the acts and declarations of the owner, coupled with evidence of acceptance by the public; and that, where there was evidence of an intent to dedicate, no particular form or ceremony is necessary. In Daridson v. Reed, supra, it appeared that the owne- of a quarter section of land as early as $18+4$ buricd a child in a corner thereof, since which time the same had always been used by the people of the neighborhood as a public burying place, and the declarations of such owner showed an intent to derote the land to such use, and the subsequent owners of the quarter section of land made no objection to such use, but recognized the same as a public burial place; and it was there held that these facts were sufficient to show a dedication of the land so used to the public for a place for the interment of the dead.

In Alden Coal Co. v. Challis, 200 I1l. 222, 65 N. E. 665, we have recently held that the Statute of Frauds does not apply to dedication of ground to the public, but that the same may be evidenced by acts and declarations without any writing, and that no particular form is necessary to the validity of the dedication, it being properly a question of intention, and that a dedication may be established by parol. See also Cincinnati v. White, 6 Pet. 440, 8 L. Ed. 452. In Alden Coal Co. $\checkmark$ Challis, supra, we also held that the acceptance necessary to complete such dedication may be implied from acts and from user; and 
that, when the dedication is bencficial or greatly convenient ar necessary to the public, an acceptance will be implied from slight circumstances.

By comparing the allegations of the bill in the case at bar, as the same are set forth in the statement preceding this opinion, with the allegations of the bill, passed upon by this court in Davidson v. Reed, supra, it will be found that the two cases correspond in all essential particulars. It appears from the allegations of the bill in the present case that, during the lifetime of John $\mathrm{H}$. Wormley, the original owner of the land dedicated for the purposes of the Wormley cemetery, he recognized the half acre of ground here in question as a cemetery for a. period of about fifty-one ycars, to-wit, from 1839 to his death in 1802 During that time he not only buried his own relatives upon this half acre, and permitted others to bury their dead there, but he indicated his intention to make such dedication, and to continue it, by positive and open acts. He, with others who buried their dead upon the half acre, caused to be erceted and maintaincd a suitable fence, enclosing such half acre. He permitted the persons, who buried their dead there, to erect monuments over them, and to protect and prescrve the identity of the remains buried there. The bill alleges that morc than eighty persons have been buried in the cemetcry, and that their graves have been cared for and kept up by their rclatives. John $\mathrm{H}$. Wormley died in 1890, and the defendant, John 'T. Wormley, his son, for more than ten years after that date, recognized the half acre as a cemetery, and did nothing to interfere with its use as such, until about the time the present bill was filed. The bill also alleges that he has committed acts of depredation upon the cemetery by tearing down the fence surrounding it, and by pasturing his horses and catthe and swine therein; and also that he not only threatens to kill persons, who attempt to re-build the fence around the cemetery, or care for the monuments and graves therein, but also threatens to remore the nonuments erected to commemorate the dead, and to plow and cultivate the land thercin. The demurrer, filed by the defendant, admits all these allegations of the bill to be true. Then the land descended to John T. Wormley from his father, he inherited it subject to the rights, which had been acquired in this half acre as a cemetery. The assent of his father to its use for such purposes is clearly averred in the bill, and it is also alleged therein, and shown, that it was accepted by the parties using it for the purposes, for which it was dedicated by the owner.

Under the facts and under the authorities applicable thereto, we are of the opinion that the court below erred in sustaining the demurrer to the bill, and that such demurxer should have been overruled. 10

10 See Colbert v. Shepherd, \$9 Va. 401, 16 S. E. 246 (1892). 


\section{CASSIDY v. SULLIVAN.}

(Supreme Court of Nebraska, 1906. T5 Neb. 847,106 N. W. 1027.)

Aldert, C. This is an appeal from a decree enjoining the defendants from maintaining a fence on an alleged public road. 'The defendant Babcock owns the southwest quarter of the northwest quarter of a certain section of land, and his codefendant owns the southeast quarter of the northeast quarter of the section adjoining on the west. The road extends north and south on the section line between the two forty-acre tracts. That the defendants, a short time before the suit was commenced, erected a fence on the road is not disputed; the only controversy being the sufficiency of the evidence to show the existence of a public road. That the county board never made any order for the opening of the road is conceded. It does appear, however, that many years ago the county board entercd an order declaring all section lines. within the county public roads. But as this amounted to a reiteration of section 46. chapter 78, Compiled Statutes 1905 (Ann. St. 6049), it was mere brutum fulmen, and, of itself, has no bearing on the question at issue.

One contention of the plaintiff is that the alleged road is a highway by dedication. The evidence seems to bear out this contention. It appears that for many years the travel to and from the Black Hills country was along trails in the vicinity of this road. It does not appear to have been confined to any particular track, and as the county was largely unscttled section lines were disregarded. Although it was denied by the defendants, it sufficiently appears that almost 20 years ago the defendant Babcock and one through whom the other defendant traces his title, and who then owned the Sullivan forty, for the purpose of inducing the public travel to follow the section line betwcen their respective tracts, built fences and planted trees on their respective sides of the section line, leaving a space about 66 feet wide for public travel, and that thereafter, until about the time of the commencement of this suit, the travel was confined to that space, which has ever since been used by the public as a highway. Such use has been uninterrupted, save that about a year before this suit was begun one of the defendants placed a fence on the road, but was directed to remove it by the county attorney, and did so. It should be remarked, however, that there is evidence tending to show that the use of the easement was interrupted several years ago by a fence which was maintained for some time. But the evidence on this point is conflicting, and we are not prepared to say that a finding against the defendants thereon is not sustained by sufficient evidence. Taken in its entirety the evidence satisfies us that the owners of the land, more than 15 years ago, dedicated that portion now claimed as a public road to the public, and the public at once accepted the grant, and, practically speaking, have been in the uninterrupted enjoyment thereof ever 
since. It is true, there is no evidence that the public authorities ever authorized any work on the road, or did any act indicating an acceptance of the grant. But a dedication, in order to become binding unon the dedicator or his privies in estate, need not be accepted by the public authorities, but may be accepted by the general public. The general public accepts, as in this instance, by entering upon the land and enjoying the privilege offered, in other words, by user. Strecter v. Stalnaker, 61 Neb. 205, 85 N. W. 47; Attorney General v. Abbott, 154 Mass. 323, 28 N. E. 346, 13 L. R. A. 251 ; Rees v. City of Chicago, 38 Ill. 322; Alden Coal Co. v. Challis, 200 Ill. 222, 65 N. E. 665 .

Considerable stress is laid on the fact that the road in question is connected with no public road at the south, and that it is some 80 rods from the north line of the defendants' lands to a public road with which this road would connect at the north; in other words, that this read is disconnected from all other public roads. In view of the entire evidence, that fact has no special significance. The travel from other public roads to this roal is over private property and with the permission of the owners, who, unlike the defendants, are not slown to have dedicated a right of way for the use of the public. When such permission is withdrawn, if the travel over such lands is merely permissive, the authoritics may take the proper steps to estahlish highways connecting with this road, or, if the road is not required, the proper steps may be taken to relieve the defendants of the burden of the easement. But that has nothing to do with this case. The evidence shews that the road is a public highway, and so long as it remains such the defendants have no right te obstruct it.

It is recommended that the decree of the district court be affirmed.

Durite and JaCkson, CC., concur.

By the CourT: For the reasons stated in the foregoing opinion, the decree of the district court is affirmed.

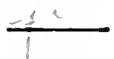

\section{DOWNING v. COAT'ESVILLE BOROUGH.}

(Supreme Court of Pennsylvania, 1906. 214 Pa. 291, 63 Atl. 606.)

Trespass to recover damages for personal injuries. Before Hemphill, P. J.

From the record it appeared that plaintiff was injured by falling in a hole on a sidewalk in the borough of Coatesville. There was evidence that the portion of the street in which the hole was located had been thrown open to public use by a former owner of an adjoining property, but there was no evidence that the strip in question had been accepted as a public street by the boroligh.

The court entered a compulsory nonsuit which it subsequently refused to take off.

Error assigned was refusal to take off nonsuit. 
Pen Curiam. The learned judge below conceding that throwing open a strip of his lot as a part of a street to the public for a number of years, may amount to dedication to public use as against the owner, nevertheless states accurately the rule that such action by the owner cannot of itself make the land part of the street so as to bind the municipality. Some act of acceptance on the part of the municipality must be shown before it can be held liable for failure to keep in repair, etc., citing In re Alley in Pittsburg, 104 Pa. 622; Com. v. Moorehead, 118 Pa. 344, 12 Atl. 424, 4 Am. St. Rep. 599, and Steel v. Borough of Huntingdon, $191 \mathrm{~Pa} .627,43$ Atl. 398.

Applying this rule to the facts before him the judge said: "In our case there was no evidence whatever of the acceptance of this siclewalk by the borough by either act or deed; it apparently was thrown open to the public street by Miss Perkins for the convenience and accommodation of her tenants, for on her property immediately north where she resides, she still retains her fence along the eastern side of the roadway."

This amply sustains the nonsuit. Judgment affirmed. ${ }^{12}$

\section{OGLE v. CITY OF CUMBERLAND.}

(Court of Appeals of Marsland, 1899. $90 \mathrm{MId}$.59, 44 Atl. 1015.)

Schmucker, J. This case was instituted by the appeliant to recover damages from the city of Cumberland for personal injuries sustained by him from falling into a ditch or sewer at the point where it crossed a road which he contends was a public street of that city. The facts of the case are substantially as follows:

Prior to the year 1887 persons and vehicles having occasion to pass in either direction between Creek street, in the city of Cumberland, and the basin of the Chesapeake \& Ohio Canal, were in the habit of crossing in a nearly direct line over the land of the canal company lying between the basin and the corner of Creek and Canal streets. Early in 1887 the West Virginia Railroad Company acquired this land from the canal company by condemnation, and erected trestles and other structures upon it, which prevented its use as a roadway, and thus made it necessary to provide a new way of access to the canal basin from the corner of Creek and Canal streets. In the condemnation proceedings by which the railroad company acquired this land, it was agreed in the presence of the jury, and set forth in the return of the inquisition, that another road, 24 feet wide, extending over the condemned

11 In King r. Leake, 5 B. \& Ad. 469 (1S33), a parish was held properly convicted under an indictment for the numrepair of a road, though there had heen no acceptance befond the public use theleof. The Highway det of 1885 15 \& $6 \mathrm{Wm}$. IV, c. $50, \$ 23)$, lowerer, prevents the liability of the parish to repair from arising until assent has been given as prescribed. See Cababé $\nabla$. IValtun D. C., [1911] A. C. 102. 
land from Creek street near its intersection with Canal street to the basin, should be "kept open for the use of the canal and the public for passing for all purposes for which a public road is commonly used to and between Creek street and the canal." This new road crossed the railroad track by passing under the trestle which supported the track, and just before passing under the trestle the road crossed the ditch or sewer into which the appellant fell when he was injured. The appellant kept a saloon in a house near the basin, which he rented from the canal company. He was injured by falling into the ditch after dark on the evening of February 1, 1894, as he was going from Creck street along the new road towards his saloon. He sued the city of Cumberland for damages, alleging that this new road was a public street, which it was the duty of the city to keep in repair, but that it had negligently been permitted to be in a dangerous condition, etc. There never was any grant to the city of the new road as a street, nor was there ever any formal acceptance by the city of its dedication to public use, but the appellant relies upon the facts about to be mentioned as amounting to an implied acceptance by the city: In January, 1891, the city council, in response to a petition addressed to it by the appellant, ordered a light to be placed "at or near the railioad crossing under the trestling of the West Virginia Railroad leading to the towpath," and appointed a conmittee to execute the order. This committee, finding a light already located within 50 feet of the place where the road crossed under the trestle, advised that this lamp be mored into such a position as would throw its light upon the crossing under the trestle; and the council ordered it to be done, but it had not in fact been done when the accident to the appellant occurred. The ditch into which he fell had for many years carried the surface water from Creek and other streets down to the canal basin, and on one or more occasions prior to the accident the employés of the city had been seen to clean out the ditch, and scrape the surface of the streets which it drained. In November, 18S6, the city council passed an ordinance accepting an offer of the railroad company to locate its freight depot so as to occupy a portion of the east side of the bed of Canal street at and near its intersection with Creek street, upon condition that the railroad company would give to the city sufficient land on the west side of the street to maintain its orisinal width.

The court below being of the opinion that none of the transactions appearing in evidence were legally sufficient to show an acceptance by the city of Cumberland of the 24 -foot road on which the accident occurred, as a public street, granted the prayer of the defendant, taking the case from the jury, and the plaintiff appealed.

There can be no question that the facts of this case establish a dedication to public use by the railroad company of the road upon which the appellant was injured. As between the owner of the land covered by the road, and the public, the latter were entitled to use it as a highway; but that did not of itself impose upon the city the obligation to 
keep the road in repair, nor make it liable for accidents occurring from the defective condition of the road. Before the appellee can be held liable for the injury for which the present suit was instituted, it must appear that there had been an acceptance by it, through the acts of its authorized public departments or officials, of the road on which the accident happened, as one of its public streets. Kennedy v. Mayor, etc., 65 Md. 520, 9 Atl. 234, 57 Am. Rep. 346; State v. County Com'rs of Kent Co., 83 Md. 377, 35 Atl. 62, 33 L. R. A. 291; Valentine v. City of Hagerstown, 86 Md. 486, 38 Atl. 931 ; 2 Dill. Mun. Corp. $\S 642$. These authorities hold that the acceptance of a street by a municipality "may" be either express, and appear of record, or they may be implied from repairs knowingly made or paid for by the authority which has the legal power to adopt the street or highway, or from long use by the public." They also hold that, when public use is relied on to establish the acceptance, there must have been an uninterrupted use by the public for at least 20 vears, and such use for a less time will be insufficient.

It is not contended in the present case that there has been an express municipal acceptance of the alleged street, or a public use of it for more than 20 years; nor is there, in our opinion, proof of any acts or transactions on the part of the city or its authorized officials, in reference to it, affording proper evidence of an implied acceptance. Certainly the occasional cleansing of the ditch, and the scraping of Creek and the other streets which it drains, by the employes of the city, can have no important bearing upon the subject; for it appears from the evidence that the ditch had been in existence for 40 years before the road was opened. Nor is the fact that the city council were willing to grant the appellant's request to have a light placed near the crossing of the road under the railway trestle important. The appellant hinself, although he offered the facts just alluded to in evidence, did not strongly rely upon them in argument; but he claimed that the leaving open by the railroad company of the new road, in its condemnation proceedings, and the passage shortly thereafter by the city council of the ordinance allowing the railroad company to use a portion of the bed of Canal street, must be taken as parts of a common scheme to accommodate both the railroad company and the city, from which an acceptance by the latter of the new road as one of its streets is to be implied.

An examination of these two proceedings makes it quite plain that this contention of the appellant cannot be maintained. Each of the two proceedings is complete in itself, and neither one refers to, or is dependent upon, the other. The condemnation proceedings tnok away from the canal company the land over which access had theretofore been liad to its wharf and basin from Creek street, and the new road was simply provided by the railroad company in lieu of the one taken away. The city was not a party to the condemnation proceedings, nor does the former road over the condemned land appear to have ever been accepted by the city as a street. The ordinance in reference to Canal street fully covers the matter to which it relates, and requires 
the railroad company to give to the city additional land on one side of Canal street in lieu of the portion on the other side of the street to be occupied by the depot. Further, this ordinance, on its face, recites that, when its terms have been carried out, "the width of said street for traffic purposes will be increased 33 per cent."

The record fails to disclose any such acceptance by the appellee as the law requires of the road on which the accident to the appellant occurred, and therefore the court below properly took the case away from the jury. The judgment will be affirmed, with costs. ${ }^{12}$

IX. RELLEASE

\section{BLACKSTONE'S COMMENTARIES.}

Releases; which are a discharge or a conveyance of a man's right in lands or tenements, to another that hath some former estate in possession. The words generally used therein are "remised, released, and forever quitclaimed." And these releases may enure either, 1. By way of enlarging an estate, or enlarger l'estate: as if there be tenant for life or years, remainder to another in fee, and he in remainder releases all his right to the particular tenant and his heirs, this gives him the estate in fee. But in this case the relessee must be in possession of some estate. for the release to work upon; for if there be lessee for years, and before he enters and is in his possession, the lessor rcleases to him all his right in the reversion such release is void for want of possession in the relessee. 2. By way of passing an estate, or nitter l'estate: as when one of two coparceners releaseth all her right to the other, this passeth the fee-simple of the whole. And in both these cases there must be a privity of estate between the relessor and relessee; that is, one of their estates must be so refated to the other, as to make but one and the same estate in law 3. Hy way of passing a right or mitter le droit: as if a man be disseised, and releaseth to his disseisor all his right, hereby the disseisor acquires a new right, which changes the quality of his estate and renders that lawful which before was tortious or wrongful 4. By way of extinguishment: as if my tenant for life makes a lease to $\mathrm{A}$ for life, remainder to $\mathrm{B}$ and his heirs, and I release to $\mathrm{A}$; this extinguishes my right to the reversion, and shall enure to advantage of $B$ 's remainder as well as of A's particular estate. 5 By way of entry and feoffment: as if there be two joint disseisors, and the disseisee releases to one of them, he shall be sole seised, and shall keep out his former companion; which is the same in effect as if the disseisee had entered, and thereby put an end to the disseisin, and afterwards had enfeoffed one of the disseisors in fee. And

12 See Arnold v. City of Orange, 73 N. J. Eq. 2S0, 66 Atl. 1052 (1907), where the construction of a sewer in a dedicated street by direction of a village ordinance was deemed sufiticient to show acceptince. 
Teteupon we may observe, that when a man has in himself the passesion of lands, he must at the common law convey the freeliold by feofiment and livery; which makes a notoriety in the country: but if a man has only a right or a future interest, he may convey that right or interest by a mere release to him that is in possession of the land: for the occupancy of the relessee is a matter of sufficient notoriety already. Book 2, *p. 324. ${ }^{13}$

\section{Confirmation}

\section{BLACKSTONE'S CONIMENTARIES.}

A confirmation is of a nature nearly allied to a release. Sir Edward Coke defines it to be a conveyance of an estate or right in esse whereby a voidable estate is made sure and unavoidable, or whereby a particular estate is increased: and the words of making it are these, "have given, granted, ratified, approved, and confirmed."

Book 2, *p. 325 . $^{*}$

\section{SURRENDER}

\section{COKE UPON LITTLETON.}

"Surrender," sursum redditio, properly is a yielding up an estate for life or years to him that hath an immediate estate in reversion or remainder, wherein the estate for life or years may drown by mutual agreement between them. ${ }^{15}$

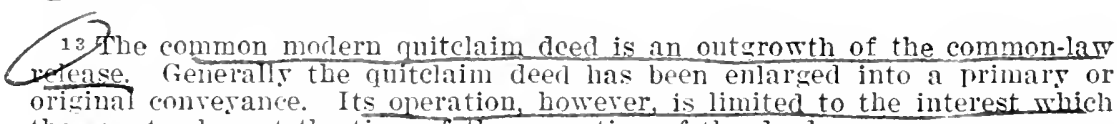
orisinal convesance. Its operation, however, is limited to the interest which the grantor has at the time of the execution of the deed.

14 In Eognillas I and \& Cattle Co. $\Gamma$. Curtis, 213 T. S. 339, 29 Sup. Ct. 498, 59 L. Ed. S22 (1909), it was contended that a confirmatory patent from the Lnited States enlarged the rights of a grantee from one of the Mexican states. The court said: "But, while it is trme that in Beard $r$. Federy, 3 Wall. 47S. 491, 18 L. Ed. SS (1S65). Mr. Justice Field calls such a patent a quitclaim, we think it rather shonld be descriled as a confirmation in a strict sense. "Confrmation is the approbation or assent to an estate already created. which. as far as in the contimer's power. malies it cood and valid; so that the confirmation doth not legularly create an estate; but ret such words mas be mingled in the contirmition, as ma create and enlare an estate; but that is by the force of such words that a re foreisu to the business of confirmation. Gilbert, Tenures $\%$. It is not to be understood that when the Cnited states executes a document on the footing of an earlier srant bs a former sorereign, it intends or purports to enlarge the grant." Per Holmes, J.

15 See Ileroy 5 . Reilly, S4 N. J. Law, 671, \&7 Atl. 112 (1913), in which suit was bronght against a lessee on a contract made with the plaintiff, whereby the lessec arieed in case of a sale, assigmment or transfer of the term to pay orer to the plaintiff one-third of the net profit from such sale or transfer. The lessee's administratrix had entered into an arrangement with the 
A surrender properly taken is of two sorts, viz., a surrender in deed, or by express words, (whereof Littleton here putteth an example,) and a surrender in law wrought by consequent by operation of law. Littleton here putteth his case of a surrender of an estate in possession, for a right cannot be surrendered. And it is to be noted, that a surrender in law is in some cases of greater force than a surrender in deed. As if a man make a lease for years to begin at Michaelmas next, this future interest cannot be surrendered, because there is no reversion wherein it may drown; but by a surrender in law it nay be drowned. As if the lessee before Michaelmas take a new lease for years either to begin presently, or at Michaelmas, this is a surrender in law of the former lease. Fortior et æquior est dispositio legis quam homnis.

- Also there is a surrender without deed, whereof Littleton putteth here an example of an estate for life of lands, which may be surren. dered without deed, and without livery of seisin; because it is but a yielding, or a restoring of, the state again to him in the immediate reversion or remainder, which are always favored in law. And there is also a surrender by cleed: and that is of things that lie in grant, whereof a particular estate cannot commence without deed, and by consequent the estate cannot be surrendered without deed. But in the example that Littleton here putteth, the estate might commence without deed, and therefore might be surrendered without deed. And albeit a particular estate be made of land by deed, yet may it be surrendered without deed, in respect of the nature and quality of the thing demised, because the particular estate might have been made without deed; and so on the other side. If a man be tenant by the curtesy, or tenant in dower of an advowson, rent, or other thing that lies in grant; albeit there the estate begin without deed, yet in respect of the nature and quality of the thing that lies in grant it cannot be surrendered without deed. And so if a lease for life be made of lands, the remaincler for life; albeit the remainder for life began without deed, yet because remainders and reversions, though they be of lands, are things that lie in grant, they cannot be surrendered without deed. See in miy Repcrts plentiful matter of surrenders.

$337 \mathrm{~b}, 338 \mathrm{a}{ }^{16}$

iessor whereby the former "waired, quitclaimed and surrendered" all richts to a renewal of the lease, and all rights hy rirtue thereor, and agrees to "assian, sublease and put the lessor in full contral." retaining the right to collect rents win to the date of the expiration of the lease. The plaint iff claimed that this arrangement entitled him under his contract to recorer onethird the profit made thereby.

16 See the Statute of Frauls, \& 3. supra, p. 157.

By the Real Property Act of 1845 (St. 8 \& 9 Vict. c. $109, \$ 3$ ) it is provided that surrenders of estates other than those which minht by law be created without writing, shall be roid at law, unless made by deed. 


\section{LORD WARD v. LUMLEY.}

(Court of Exchequer, 1960. 5 Hurl. \& N. 87.)

Declaration.--That the plaintiff by deed, dated the 6th May, A. D. 1856 , let and demised to the defendant all that building called "Her Majesty's Theatre," situate in the Haymarket, in the county of Middlesex, for the term of four years and nine calendar months, to be computed from the 25th day of March then last mentioned, at and under (amongst other rents) the rents following, that is to. say, the rent of $£ 1934$. 14s. for the first year of the said term, and the yearly rent of $\{6275$. for every of the second, third, and fourth years of such term, and the sum of $£ 4706$. 5s., for the last nine calendar months of the said term, such rents to be payable beforehand, or one quarter in advance, by four equal quarterly payments on each of the first four years of the said term. That after the making of the said deed, the defendant entered into and upon the said premises, for the said term, and afterwards, during said term, to wit, on the 21st June, A. D. $185 \mathrm{~s}$, the sum of $f 4569$., of the rent aforesaid, for three quarters then elapsed, became and was due and owing from the defendant to the plaintiff, and the same is still in arrear and unpaid.

Plea.-That the said deed, by which the plaintiff demised the said premises to the defendant, was made between the plaintiff and the defendant, and was sealed with the seal of the defendant; and tine defendant never was in any way liable to pay to the plaintiff the said rent or any part of it except under and by virtue of covenants made by the defendant with the plaintiff, and contained in the said deed; which covenants bound the defendant to pay the said rent to the plaintiff at the times and upon the terms in the declaration particularly mentioned; and the defendant never entered upon or occupied the said premises, or any part thereof, except under the said deed so made between the plaintiff and defendant, and sealed with their seals as aforesaid, and containing the said covenants. That after the making of the said deed, and before this suit, the said deed was and now is Wholly cancelled by and with the assent of the plaintiff and of the defendant; and also all the estate, term, and interest of the defendant in the said premises was duly surrendered to the plaintiff by act and operation of law, after the said rent became due under the said covenants as aforesaid and before this suit.

Demurrer and joinder therein.

MARTin, B. We are all of opinion that the plea is bad. When a man demises land for a term of years, reserving to himself a rent, the effect of it is to create two estates, viz., the estate of the lessee, and the reversion of the lessor, and the rent is incident to the reversion. When the day of payment arrives, the rent still remains annexed to the reversion. Here, the question is whether the simply cancelling a lease destroys the lessor's right of action for the recovery 
of the rent. I am of opinion that it does not, because the cancelling a lease does not destroy the estates already yested or their incidents

VAtson, B. I am of the same opinion. Where the contract arises from the deed itself, and the deed is destroyed, no action can be maintained in respect of it. But this case is very different, for here, upon the execution of the deed, there passed fram the lessor to the lessee an estate which was not affected by the cancellation of the lease. The lessee holds the estate subject to the rent which is incident to the reversion in the lessor. According to the argument for the defendant, he may hold the estate without payment of rent. But the authorities are clear that the cancelling a deed does not divest the estate of the lessee, or deprive the lessor of his right of action upon the demise.

MARTIN, B., added: The Lord Chief Baron, who has left the Court, requested me to say that he is of the same opinion.

Judgment for the plaintiff. ${ }^{27}$

\section{ALLEN v. JAQUISH.}

(Supreme Court of New York, 1839. 21 Wend. 62S.)

This was an action of ejectment, tried at the Delaware circuit in May, 1837, before the Hon. James Vanderpoel, then one of the circuit judges.

On the 25th August, 1834, an agreement under seal was entered into by the plaintiff and John Jaquish, Junior, whereby the plaintiff bound himself to furnish a mill on a certain stream and as much timber as could he cut and sawed into lumber and mannifactured into shingles by Jaguish during ten years next ensuing the date of the agreement, from certain specified lots; to keep the mill in repair, and within one year to make a good road from the mill to the river Delaware-giving by the agreement immediate possession to Jaquish of the mill, mill-lot and house, and anthorizing him to clear as much land as he saw fit. Jaquish on his part agreed to erect two shingle machines and put them in operation in the mill by the 1st June, 1835, to keep them in repair or supply their places, and to saw as much lumber and manufacture as many shingles as could be made during the stipulated time: for which privileges he agreed to leave at the mill one-third of all the lumber and shingles which should be manufactured. By an agreement endorsed on the above instrument, the plaintiff anthorized Jaquich to have a lack made at the expense of the plaintiff. In October, 1835, another agreement in writing, but not under seal, was signed by

17 See Beidler v. Fish, 14 Ill. App. 29 (1Ss3); Brewer $\nabla$. B'ld'g Assoc, 16 a Ill. 221,46 N. E. 752 (1597).

A term is properly creited by parol; may it he surrendered by parol? See Logan v. Barr, 4 Har. (Del.) $5+6$ (1s+7); Mckmney r. Reader. 7 llatts (Pa.) 12:3 (1s:3); Ross v. Schneider, 30 1nd. 42: (1sts); Smith v. Devlin, 23 N. Y. 363 (1561). 
John Jaquish, Jun., whereby, after reciting the former agreement on his part to put up two shingle machines in the mill of the plaintiff, he stipulated as follows: "I do hereby engage, if I do not put up the said shingle machines in the said mill and get them in operation by the first day of June, 1836 , I will then relinquish the contract and give up every thing I have done, and leave all things on the premises, provided I shall be entitled to receive two-thirds of all the lumber sawed at the mill until the said first of June, 1836." The shingle machines not being erected and put into operation by the first day of June, 1836 , the plaintiff caused a notice to quit to be served on John Jaquish, Jun., on the tenth day of June. A similar notice having two days before been served upon Cornelius Jaquish and John W. Jaquish, who were made defendants jointly with John Jaquish, Jun., in this action, which was commenced shortly afterwards; the declaration being returnable at July term, 1836.

'The plaintiff having rested, the defendant's counsel asked for a nonsuit on the following grounds: 1 . That the suit was prematurely brotight under the notice to quit; 2 . That the plaintiff had failed to shew performance of the stipulations on his part as contained in the contract, as to the making of a good road, \&c.; 3. That there was no proof of a joint possession of the premises by the defendants in the action; and 4 . That the second agreement was void, being without consideration and not sealed. The judge refused to nonsuiit the plaintiff. The defendants then offered to prove non-performance of sundry stipulations in the contract on the part of the plaintiff; which evidence being objected to, was rejected by the judge. The evidence of a joint possession of the premises by the defendants resting in circumstances, the counsel for the defendants asked the judge to require the plaintiff to elect against which of the defendants he would proceed, insisting that a joint possession had not been shewn, or to nonsuit the plaintiff. The judge refused to do either. Whereupon the cause was summed up and the jury found a verdict for the plaintiff against all the defendants; who now moved for a new trial.

COWEN, J.18 [After ruling against the defendants the minor objections raised in the case, such as that a joint possession was not shown in the defendants, and that the evidence offered of nonperformance by the plaintiff of the stipulations in the first contract on his part agreed to be performed ought not to have been rejected, the judge proceeded as follows:]

The second agreement was, I think, valid. One objection raised on the argument was, that the agreement not being under seal, it should have expressed a consideration. It was evidently intended as a modification of the first agreement or lease. It was signed by the defendant, John Jaquish, Jun., the original lessee, and accepted by the plaintiff on account of the delay and non-performance; perhaps, of both

$18 \mathrm{~A}$ portion of the opinion is omitted. 
parties. Jghn Jaquish, Jun., deeming himself most in fault, agreed, on account of his non-performance, mentioned in his second agreement, to repair the omission by a given day, or relinquish his original lease. He meant the last contract should operate as a part of the first; and the motive or consideration is plainly enough collectable from the face of the new contract. He was to have a share of the lumber sawed at the mill in the mean time, and the plaintiff had been damaged by the breach. Here are two concurring considerations, the satisfaction of damage to the plaintiff, and a clear right or benefit acquired by John Jaquish, Jun. It was not necessary that these should be expressly mentioned as the consideration. It is enough that they are obviously so in fact, from the recital and nature of the instrument.

If the lease became void, in consequence of not fulfilling the second agreement, or, if the latter operated as a surrender, the case was not one in which any notice to guit was necessary. That is never required where the parties have by mutual agreement fixed the terms on which the lease is to terminate. The lessee may always waive the right to require notice; and for the same reason, the right never arises where a lease for years expires by its own limitation, or the parties have otherwise made an end of it. Conventio vincit legem. If a party has, in any form, transferred all his interest to another, he is bound to quit the possession. If he do not, an ejectment lies against him immediately.

The important question is, in what way did the second writing between these two parties operate? Did it enure as a mere promise, a defeasance, or modification of the lease; or was it a surrender? If a mere promise, ejectment will not lie upon it; but only an action of assumpsit. To warrant the present action, therefore, it must have operated to extinguish the lease, or pass the interest of the lessee to the plaintiff.

The second agreement thus failing to operate as a defeasance, the next question is, whether it could operate as a contingent surrender, it being in the nature of a re-demise. There is no doubt that either a surrender or demise may be effected by a simple writing not sealed. Magennis v. FacCulogh, Gilb. Eq. Cas. 235, 6; Co. Litt. 33S, a, note (1); Farmer v. Rogers, 2 IVils. 26. The operative words of a surrender are, "liath surrendered, granted and yielded up." 2 Black. Comm. 326; Co. Litt. 337, b; Woodf. Land. and Ten. 185 (Lond. Ed. of 1804). There is no doubt, however, that a surrender may be effected by equivalent words; and when complete, it is as it were a re-demise. Woodf. Land. and Ten. (Ed. before cited) 186; Perk. sec. 607. It may be made upon condition; that is, to become void upon condition. Perk. sec. 624. And though no case goes so far as to say that a surrender may be made to become good upon condition precedent, yet there seems to be no objection to that in principle, if the interest surrendered be not a freehold. That cannot, in general, be

AIG.Prop. -13 
granted so as to take effect in futuro; but a term for years can. The surrender of a term to operate in futuro is equally free of the objection. Contracts of parties, whether by deed or otherwise, shall always take effect according to their real intent, if that be possible, consistently with the rules of law. In Whitlock v. Horton, Cro. Jac.

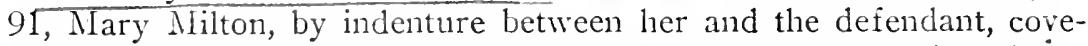
nanted, granted and agreed, that the defendant should and might, have, hold and enjoy, from and after the death of E. IV. the moiety of certain lands, for sixty years, \&c. And it was held that these were apt words to make a lease for years, and might enure as a lease in futuro. Richards v. Sely, 2 Mod. 79, is a like case. And there, Maynard, Serj., conceded that the word "covenant" would of itself make a lease, which is adopted and repeated in Moodf. Land. and Ten. 7 (Lond. ed. 180-4). The latter author, at p. 6 says it is a general rule, "that whatever words are sufficient to explain the intent of the parties, that one sliall divest himself of the possession, and the other come into it, for such a determinate time, whether they run in the form of a license, corenant or agreement, are of themselves sufficient; and will, in construction of law, amount to a lease for years, as effectually as if the most proper and pertiment words had been made use of for that purpose." Otherwise of the most apt words, if they appear to be only. preparatory to a future lease to be made. Bac. Abr. Leases, \&c. (K), S. P. We have seen that Woodfall, in another place, speaks of a surrender operating as of the nature of a re-demise. Suppose the owner of land promises another in writing, for good consideration, that on the other paying so much, he, the owner, will relinquish and give up the land to the promisee for ten years at such a rent. Is there a doubt, that on paying the money, the promisee might enter or bring ejectment as a lessee? I should think not. The case at bar is quite as strong; for the lessee agrees that if he fail to perform, he will-relinquish his lease and give up everything. No farther act is spoken of. The meaning was to annul and render the lease inoperative; and although it could not enure as a defeasance or as a demise, yet it may, I think, enure and take effect as a surrender, on the contingency happening. Test the case by the rule in IVoodfall. Can any one doubt that the lessee intended to divest himself of the possession, and let the lessor take it for the whole remaining term of the lease? In this view the verdict at the circuit is sustainable, and a new trial must be denied.

New trial denied. ${ }^{19}$

19 Mundy v. Warner, 61 N. J. Law, 395, 39 Atl. 697 (1S99), acc. "I am vers strongly of opinion that there cannot be a surrender to talie place in future" "arke, T., in Doe d. Nurrell r. Mifirard, 3 M. \& W. 328 (15.3S).

See Marris r. Hiscock, 91 N. Y. $3 \pm 0$ (1SS3), as to sulticiency of language to accomplish a surrender. 


\section{IVE'S CASE.}

\section{(Court of Common Pleas, 1597. 5 Coke, 11a.)}

Ive brought an action of waste against Sammes, and counted of a lease made to the defendant of the manor of Tottenhan in the county of Essex for 30 years; the defendant pleaded, non dimisit; and by special verdict it was found, that the lessor made a lease for 30 years of the said manor, except all woods and underwoods growing or being on the manor; and afterwards made a second lease to the same lessee of all the woods and underwoods growing or being on the said manor for the term of 62 years without impeachment of waste, and afterwards made a third lease of the said manor to the said lessee for 30 years, without exception, to begin at a day to come, scil, from the expiration of the said first lease for 30 years; and after the term 30 years expired; the lessee cut trees; Ive in reversion brought an action of waste; and it was adjudged for the plaintiff. And in this case three points were resolved. $* * * 20$

3. That by the acceptance of a future lease to begin divers years after, the said lease of the wood for 62 years was presently surrenclered, because the lessee by acceptance thercof had affirmed the lessor to have ability to niake the new lease, which he had not, if the first lease shall stand; as if lessee for 20 years takes a lease for three years, to begin 10 years after; it is a present surrender of the whole term, for it cannot be a surrender of the last 10 years, and remain for the first 10 years, and so to make a fraction of the term, nor can he who hath a lease for 20 years surrender the last 10 years by any express surrender saving to him the first 10 years. Vide $1+$ H. B, 15. 2 Mar. 112. 4 Mar. 141. 3 Eliz. 200. 10 Eliz. 272. 11 Eliz. 280. 35 H. 8, 57. 21 H. 7, 6. 31 Ass. p. 26. 32 H. 8, 46. 37 H. 6, 17. 14 H. $7,37$. 21 H. 7, 12, 40.13 R. 2. Dower. 40 E. 3, 24, 43. 41 E. 3, 13. 44 E. $3,25,26.25$ E. $3,13 .^{21}$

\section{DAVISON ex dem. BROMLEY v. STANLEY.}

(Court of King's Bench, 1768. 4 Burr. 2210.)

This was a case reserved from the assizes; upon an ejectment, tried before Mr. Justice Yates.

The short of it, so far as concerned the point now determined, was, that William Bromley, Esq., being seised in fee, in the year 1686, de-

20 That part of the report dealing with the first two points is omitted.

"Lessee for 21 rears tools a lease of the same lanus for 40 years to begin mmediately after the death of J. S. It was holden in this case that the same was not any present surrender of the first term; put if J. S. die within the term, then it is a surrender, for it mal $y$ be that J. S. shatr survive the first term" Alion., 4 Leon. 30 (15ss).

See Tracy v, Albany Exchange Co., 7 N. Y. 472, 57 Am. Dec. 538 (1852), where tha new lease was to take effect on expiratiou of existing term. 
mised far ninety-nine years, to hold from the day of the date. Afterwards, William Bromley, upon the marriage of Francis Bromley, with Ann Walsh, joined in a settlement with his uncle Francis Bromley, and reduced his former estate in fee to an estate for life. This was a voluntary settlement, and had a power in it; but it was not pretended that the second lease was made according to that power. After this, William (being then only tenant for life) in 1693, makes a new lease for ninety-nine years, to the same tenant, of the same premises, without communicating to the tenant the alteration which he had made of his estate, by reducing his fee to a life-estate; and this was acquiesced in, and the rent paid and received, for sixty years. In the mean time, and before any objection was made with regard to these leases, William Bromley died, and his effects came into the hands of Lord Montfort.

The lessor of the plaintiff was tenant in tail under the settlement; and claimed a right to dispossess the tenant.

The only question upon which the Court gave their opinion, was"whether the acceptance of the second lease operated as a surrender of the former lease."

LORD MANSFigla agreed, that the acceptance of a second good lease will operate as a surrender of a former. But the reason does not hold, in the case of accepting a new void lease, or one that the lessee can't enjoy.

In the present case, Mr. William Bromley had probably forgotten that he had altered his estate in fee to an estate for life; at least, he did not tell the lessee, that he had so done.

The first lease was for ninety-nine years from the day of the date: the second lease is for ninety-nine years, to commence immediately; and there is not a word said of the settlement or power. The tenant made a fair contract, bona fide, for a valuable consideration. The second lease was a deceit upon him; for the lessor had no title to grant this new lease. But the present lessor of the plaintiff says he shall lose the former lease too; because the latter is inconsistent with the former; and he could not hold under both.

Where the first could be of no use, if he had had the second; and both parties so intended; there is no inconsistency in the acceptance of a new good lease being a surrender of the former. But the accepting a new void lease, which the lessee is not to enjoy could not shew an intention to surrender the other. Therefore, the reason why this should be an implied surrender, totally fails. A void contract for a thing that a man cannot enjoy, cannot in common sense and reason, imply an agreement to give up a former contract. And Mr. Price has shewn that the law is so; and that cases of this nature appear to have been grounded upon solid reason, when they are well considered.

I am very clear that the acceptance of this new lease, which did not pass an interest according to the contract, cannot operate as a surrender of the former. And this is sufficient; I will not enter into any other questions about the other parts of the case. 
The second lease did not pass an interest according to the contract. The plaintiff has no right to recover.

I give no opinion whether the acts of the lessor have or have not made the new lease good for the whole of the term.

The three other Judges were clearly of the same opinion.

PER CuR'. Let the postea be delivered to the defendant; in order that a nonsuit may be entered. ${ }^{22}$

\section{ZICK v. LONDON UNITED TRAMWAYS, LIMITED.}

(Court of Appeal, King's Bench Dirision. [190S] 2 K. B. 126.)

Appeal from the judgment of Jelf, J., in an action tried by him without a jury. [1908] 1 K. B. 611.

The action was in form an action for trespass brought by the plaintiff Zick, who was the occupier of a shop, house, and forecourt, numbered 84, Merton High Street, Wimbledon, and carried on business there as a furniture dealer, to recover damages from the defendant company for entering and trespassing upon the plaintiff's premises on March 20, 1907, and the following days, and for depriving him of the use of the said forecourt and thereby interfering with his business.

On the pleadings the defendants, besides putting the plaintiff to the proof of his case, set up the following defence: (That by the London United Tramways Act, 1902 (2 Edw. VII, c. 247), incorporating the Land Clauses Consolidation Act, $18+5$, they were authorized to acquirc compulsorily the said forecourt for widening the roadway; that on Iay 2S, 1905, they served notice to treat on Coope and Heatley, the leaseholders, being mortgagees in possession of the said premises and forecourt, for the purchase of their interest in said forecourt; that at the date of the service of said notice the plaintiff was not the occupier nor in possession of the said premises or forecourt, and had no interest therein; that notwithstanding the service of the said notice, Coope and Heatley purported after the date of such service to grant to the plaintiff an interest in the said premises and forecourt by means of an agreement of tenancy, and that such an agreement of tenancy was invalid in law against the defendants.

22 Roe r. Archbishop of York, 6 East, SG (1S05). acc. See Doe r. Courtenar. 11 Q. B. 702 (1StS); Doe v. Poole. 11 Q. B. 713 (1StS).

Premises were in possession of $\mathrm{H}$. as tenant from sear to sear when $\mathrm{H}$. and M. agreed to take a lease of same for seven years at a yearly rental; the agreement was in writing. but the contemplated lease was never drawn: H. and M., howerer, enteled and held possession for a time, M. then dropping out, leaving $H$. as sole occupant. No rent having been paid, the lessor took possession and kept $S$. out. In an action by $S$. in trespass the question was whether the original tenancs from year to rear had been terminated. Held, that the former tenancy had come to an end by surrender in law. Hamerton จ. Stead, כ B. T. C. 4 S (1824).

23 The statement of the facts and pleadings is omitted; the case sufficiently appears in the opinions. The concurring opinion of Kennedy, L. J., is also omitted. 
The learned judge gave judgment for the plaintiff.

Sir Gorell Barnes, President. I am of opinion that the conclusion arrived at by the learned judge is right, and I can put my view of the case very shortly. An agreement was made on March 15, 1905, by which Fellowes, as agent for the mortgagees in possession of the premises in question, let them to one Sinclair for a term of three years, which would expire on March 14,1908. On May 15, 1905, the defendants served the notice to treat on the lessors' agent. By an agreement dated January 23, 1906, Sinclair, without any knowledge of the notice to treat, sold to the plaintiff Zick the furniture and effects on the premises, with certain exceptions, and agreed to stand possessed of the lease of the premises in trust for the plaintiff; and in February the plaintiff entered on the premises. Afterwards, in order that the plaintiff should have not only the beneficial but also the legal possession of the premises, Sinclair informed Fellowes that he desired to transfer to the plaintiff the unexpired portion of his tenancy, and Fellowes said that he thought he could arrange with his principals for a surrender of the existing tenancy and the granting of a fresh agreement to the plaintiff for a term of three years, instead of the plaintiff taking a transfer of a term which had only two years to run. The plaintiff accepted this proposal, and accordingly, on February 14, 1906, an agreement was executed for a new tenancy which would expire on February 14, 1909. Under these circunistances the defendants contend that the plaintiff is not entitled to any compensation. The objection taken by the defendants to the plaintiff's right to compensation appears to me to be purely technical and to have no merits. The parties to the transaction, Sinclair, the plaintiff, and Fellowes, entered into the agreement of February 14, 1905, for a new tenancy extending beyond the unexpired period of the former tenancy, thinking, no doubt, that it would operate as a surrender of the old term. But, in consequence of the service of the notice to treat, the mortgagees in possession of the premises had no longer any right to create a new tenancy which extended beyond the period of the existing tenancy. The result, as it appears to me, would be that the surrender never came into operation because the consideration for it failed. So Sinclair remained entitled to treat the original tenancy as subsisting, and to claim compensation in respect of it as trustee for the plaintiff. The plaintiff appears to have offered to join Sinclair as plaintiff in the action, but it does not seem to have been considered necessary, inasmuch as it was agreed that the real question for decision at the trial was whether the plaintiff, under the circumstances which I have mentioned, was a person who had such an interest as entitled him to compensation in respect of the period extending up to the date on which the original tenancy of Sinclair would have expired. For the reasons which I have given I think that the decision of the learned judge was in substance correct. If it be necessary to add Sinclair as a plaintiff, in order get over any technical difficulty, I think that should be done. 
FARWELL, L. J. This is in form an action of trespass, but it is agreed that the only question really involved is whether the plaintiff Zick is entitled to conpensation. In March, 1905, an agreement was made under which Sinclair became tenant of the premises in question for a term of three years from Narch 14 at a yearly rent of $£ .30$. In May of the same year notice to treat in respect of the premises was served on the lessor's agent? After service of that notice the lessors could create no new interest in the premises so as to throw any fresh burden on the defendants. In ignorance of the notice to treat Sinclair sold to the plaintiff his interest in the premises. Upon his informing the lessors' agent that he wished to transfer his interest, he and the plaintiff and the lessors' agent came to the conclusion that the better arrangement would be that the old tenancy should be surrendered and a new one created for a longer term, which was accordingly done by the agreement dated February 14, 1905. That agreement the defendants were entitled to treat as void, and they did so treat it. The law is laid down by Coleridge, J., in Doe $v$. Courtenay (15's) 11 Q. B. 688, at p. 712, "that, where the new lease does not jass an interest according to the contract, the acceptance of it will not operate a surrender of the former lease; that, in the case of a surrender implied by law from the acceptance of a new lease, a condition ought also to be unclerstood as implied by law, making void the surrender in case the new lease should be made roid; and that, in case of an express surrender, so expressed as to shew the intentjon of the partics to make the surrender only in consideration of the grant, the sound construction of such instrument, in order to effectuate the intention of the parties, would make that surrender also conditional to be void in case the grant should be made void." If the learned judge in the Court below has not expressed himself quite in the same terms, I think, by what he said on p. 616 of the report in the Law Reports, he meant the same thing. I do not think that he meant to say that the agreement for the new tenancy might be remodeled, so as to make the term co-extensive with the remainder of the term under the original tenancy, but that he acted on the well-established rule that, where a new lease is granted on the footing that an old lease is surrendered, upon the avoidance of the new lease the surrender is void, the consicleration for it having failed. I agree that this appeal should be dismissed. ${ }^{2 *}$

24 See Knight r. Williams, [1001] 1 Ch. 256. 


\section{SCHIEFFELIN v. CARPENTER.}

(Supreme Court of New York, 1S36. 15 Wend. 400.)

This was an action of covenant, tried at the New York circuit in April, 1834, before the Hon. Ogden Edwards, one of the circuit judges.

The plaintiff declared on a lease under seal, made by him to Edmund T. Carpenter, bearing date 1st April, 1829, demising a dwelling house and lot of ground of $51 / 2$ acres, sittate in the twelfth ward of the city of New York, for the term of six years, subject to an annual rent of $\$ 325$, to be paid quarterly. The lease was a tripartite indenture, Daniel S. Hawkhurst and Daniel Carpenter being parties thereto, and uniting with the tenant in the covenants to be performed on his part; and they were joined as defendants in the suit with the tenant. The defendants, amongst other things, covenanted for the payment of the rent; that the tenant should during the term, keep the dwelling house, fences and every part of the demised premises in good condition and repair, and, at the expiration of the term, yield them up in like good repair; that he would not remove, injure or destroy any root. plant, bush or tree growing on the premises, or suffer the same to be done; that he would not underlet or assign the premises, either directly or by operation of law, without the written consent of the landlord; and that during the term, the dwelling house should not be occupied as a public house, inn or tavern, without the like written consent. The plaintiff assigned, as breaches of the covenants: 1 . That on the 1st July, 1833, there was one year's rent in arrear and unpaid; 2. That on the 1st January, 1831, the tenant permitted the dwelling house and fences, \&c., to fall into bad condition, and to become ruinous and to decay for the want of necessary repairs, and so pernitted them to remain until the conmencement of the suit; 3 . That on the 1 st January, 1831, he suffered fruit trees, gooseberry bushes, asparagus roots, and ornamental flowering plants growing on the premises to be lopped, uprooted, removed and destroyed by persons and animals; 4. That from 1st November, 1832, until 1st June, 1833, the dwelling house was used and occupied as a public house, without the consent of the plaintiff. The defendants pleaded the general issue, and gave notice of various matters to be proved on the trial.

On the trial of the cause, the plaintiff claimed to recover the rent of a quarter of a year, ending 1st July, 1833, and damages for breaches of the covenants to keep the premises in repair, and not injure them, \&c. The plaintiff proved that the premises were in good repair at the date of the lease, and when the tenant went into possession; and that in February, 1833, the dwelling house was in a ruinous state, the fences prostrated, and the garden wholly destroyed, and that the expense of putting the premises in repair would be between $\$ 400$ and $\$ 500$. He also proved that the premises had been occupied for a year by two men 
of the name of Wood and Matthews, who were rail-road contractors, and had many persons in their employ who resided on the premises. The defendant offered to prove that the plaintiff held the demised premises only in right of his wife and insisted that inasmuch as an action of waste might be brought in the name of the husband and wife in the character of reversioners, the claim of damages for injury to the demised premises ought not to be sustained in the present suit; the evidence was rejected by the judge. The defendants also offered to prove that in the autumn of 1831, an agreement was entered into between the plaintiff, the defendant Edmund $T$. Carpenter and two persons of the names of Mills and Owen, that Carpenter should quit and surrender up the premises to the plaintiff, that the lease declared on should be delivered up and cancelled, and a new lease of the premises should be executed by the plaintiff to Mills and Owen for the term of 8 or 10 years. That in pursuance of such agreement, Carpenter, in the autumn of 1831, surrendered up the premises to the plaintiff, and paid all the rent then due to the plaintiff, and Mills and owen took possession of the premises and occupied the same pursuant to such agreement as tenants to the plaintiff, who accepted them as such, and received rent from them. That Mills and Owen occupied the premises until the autumn of 1832, when they left, and were succeeded in the possession by Wood and Matthews, to whom also the premises werc let by the plaintiff and from whom he also received rent; these facts the defendant offered to establish by parol proof. The counsel for the plaintiff objected that parol evidence of the alleged agreement or surrender of the lease was inadmissible; and also that the evidence, if intended to be urged in discharge of the covenants, ought not to be received, for the reason that a covenant cannot be discliarged by parol before breach. The judge sustained the objection. 'The defendants then proved that Mills and Oven went into possession of the prenises on the 1st November, 1831, and that previous to their entry, Edmund T. Carpenter (the tenant) put the premises in as good repair as they were in when he entered; they were thus repaired, because Mills and Owen were to take possession. The plaintiff, on being spoken to on the subject, said that he was satisfied with the repairs, if Mills and Owen were satisfied. It was also proved, that after Mills and Owen quit the premises, they were occupied by IVood and Matthews, who had a large number of men in their employment as laborers on a railroad and housed on the premises. Wood and Matthews were in possession six months, and paid rent to the plaintiff.

The counsel for the defendants insisted that the plaintiff was not entitled to recover in this action more than nominal damages for the breach of the covenant to keep the premises in repair, and for the injury done to the premises, as the tenant might put the premises in complete repair before the end of the term, and if he did so the plaintiff would have no cause of complaint; if he did not do so, then the plaintiff would be entitled to bring his action, and to recover damages, 
and requested the judge so to charge the jury. The judge declined to do so, and, on the contrary, charged the jury that the plaintiff was eptitled to his verdict for one quarter's rent, (which was admitted to be all that was due at the bringing of the suit;) and, further, that they were not bound to limit their verdict on the covenant of repairs to nominal damages but might give such sum as, under all the sircumstances, they should consider the plaintiff entitled to recever, provided they were satisfied that the defendants had violated their covenants. The jury found a verdict for the plaintiff with $\$ 481.25$ damages. The defendants ask for a new trial. The cause was submitted on written arguments.

Nelson, J. This case has been elaborately argued upon paper by the respective counsel, and all the authorities and principles bearing upon the points disputed, have been referred to and examined; and were it not for some recent cases in the English courts, that are very confidently urged by the defendant's counsel, it seems to me there would be but little difficulty in disposing of the case. A surrender is defined to be a yielding up of an estate for life or years to hini who hath the immediate estate in reversion or remainder, wherein the estate for life or years may drown by mutual agreement. Comyn's Fandlord \& Tenant, 337; 2 Co. 1.itt. 501; 4 Cruise, 155; 4 Bacon's Abr. 209; Shep. Touch. 300, 307. Before the statute of frauds and perjuries, any form of words without writing, whereby an intention appeared to surrender up the possession of the premises to the lessor or reversioner, was sufficient for that purpose. This was called a surrender in fact. There was also a surrender in law. It was effected by the acceptance of a new lease of the premises from the lessor, for the whole or a part of the time embraced in the former one, because it necessarily implied a determination and surrender of that lease; otherwise the lessor would be unable to make the second, or the lessee to enjoy it, and it was therefore but reasonable to presume both parties intended to waive and relinquish the benefit of the first one. The second lease before the statute referred to, of course need not have been in writing to operate an effectual surrender of the first one. The statute of 29 Car. enacted "that all leases, estates, interests of freehold or terms of years, or any uncertain interests of, in, to or out of any lands, \&c. made or created by livery and seizin only, or by parol, and not put in writing. \&c. shall have the force and effect of leases or estates at will only," \&c. excenting leases not exceeding the term of three years from the making thereof. "And also, "no leases, estates or interest either of freehold or term of years, or any uncertain interest, \&c. of, 111, to or out of any messuages, \&c. shall be assigned, granted or surrendered, unless by deed or note, in writing or operation of law." Our statute (2 R S. [1 St. Ed.] p. 134, sec. 6) provides that "no estate or interest in lands, other than leases for a term not exceeding one year, \&c. shall hereafter be created, granted, assigned, surrendered, \&c. unless by act or operation of law, or by deed or cun- 
veyance in writing" \&c. Sec. 8. "Every contract for the leasing for a longer period than one year, \&c. shall be void," unless in writing. Since these statutes, a parol lease in England for more than three years, and in this state for more than one, is entirely void; though if the tenant enters into possession, he shall be deemed a tenant at will, and for the purpose of notice to quit, from year to year, and notwithstanding the lease be void, it mav regulate the terms of holdingrats to rent, time to quit, \&c. 5 'T. R. 471; Comyn's L. \& T. S; Woodf. 14, 15 ; Bradley v. Covell, 4 Cow. 350; Jackson ex dem. Church v. Miller, 7 Cow. 747. But as a lease for the purposes for which it was given, it is considered wholly void. It is, however, conclusively settled by authority, that the sccond lease must be a valid one, so as to convey, the interest it professes to convey, to the lessee, and also to bind him to the performance of the covcnant or agreement in tavor of the Tessor, in order to operate as an effectual surrender of the first one. 3 Burr. 1807 ; 4 Burr. 1980, 2210; 6 East. 86; Comyn's Dig. tit. Estate, g. 13; 4 Bac. Abr. 215. Without this, the reason before given for the implied surrender would fail, and the intent of the parties be altogether defeated. Instead of being but a stirrender of the first lcase, it would be a surrender of the whole cstate and interest in the premises, and a virtual determination of the existence of any tenancy. Now the ground upon which the surrender in this calse is manly argued is, not that a new lease was given to the original lessee, but that it was given to Mills and Owen with his consent, for the period of eight or ten years. Assuming this, amounts to the same as if given to Carpenter; it is impossible to maintain that any valid lease las been proved in the case, or any lease whatever for a definite period. 'The most that was offered to be proved was, that Mills and Owen went into possession with the consent of the defendants, under a parol agrecment for a lease for eight or ten years; and if it be viewed as an agrecment for a leasc, or as a virtual lease for that time, it is void under the statute, and could! 1 ot be cnforced by either of the parties. An implied tenancy at will only was created which enabled Mills and Owen to hold trom year to ear, for the purpose of notice to guit, but which they could terminate at any moment they pleased. The agreement and entry in pursuance of it conferred no rights upon the plaintiff, further than to recover his rent while they continued to occupy, and perhaps a quarter's rent, if they abandoned the occupation after the commencenent of a quarter and before its termination.

Suppose this agreement had been made with the original tenant, and the defendants can claim no more from it as offered to be proved, could it be contended that it operated as a virtual surrender of the lease for six years, and that the plaintiff could dispossess the tenant on giving six months notice to quit? This would be the consequence of the doctrine urged in the defence. The tenant would become a mere tenant at will. The authorities already referced to clearly establish that the second lease, to have the effect claimed, must pass the inter- 
est in the premises according to the contract, or in other words, carry into legal effect the intent of the parties executing it. 3 Burr. 1807; 4 Burr. 1980, 2210; Comyn's Dig. tit. Estate, S, 12; 6 East, 661 ; Van Rensselaer's Heirs v. Penniman, 6 Wend. 569; 1 Saund. 236, n. b. It is stated by Baron Gilbert, 4 Bacon's Abr. 210, that since the statute of frauds the new lease must be in writing in order to operate as an implied surrender of the old one, for it is then of equal notoriety with a surrender in writing. This position is also adopteci by Serjeant Williams, in his notes upon the case of Thursby v. Plant, 1 Saund. 236, n. b. But as surrenders by operation of law are expressly excepted out of the statute, as a necessary consequence they are left as at common law; and there it is clear it need not be in writing to have the effect to surrender the old one, even if by deed. 2 Starkie's Ev. 342; 20 Viner, 143, L., pl. 1, n.; 1 Saunders, 236, n. c. I am inclined therefore to think that a valid parol lease, since the statute, might produce a surrender in law within the reason and principle upon which this doctrine is founded. The true rule seems to be that laid down by Mr. Starkie, 2 Starkie's Ev. 342, as follows: The taking a new lease by parol is by operation of law a surrender of the old one, although it be by deed, provided it be a good one, and pass an interest according to the contract and intention of the parties; for otherwise the acceptance of it is no implied surrender of the old one.

If the first lease in this case has not been surrendered, then there is no ground of defence against the action upon the express covenants contained in it, even if we should concede a legal assignment from the tenant to Mills and Owen, and the acceptance of them expressly or impliedly by the plaintiff. 4 T. R. 98, 100; 1 Saund. 241, n. 5; Woodf. 278; Cro. Car. 18S; Comyn's Land. \& Tenant, 275, and cases there cited. But the plaintiff stipulated against assignment or underletting unless permission was given in writing; and a parol license is therefore inoperative. 2 T. R. 425; 3 T. R. 590; 3 Madd. 218; Platt on Cov. 427. This clause in a lease would be nugatory, if courts should allow parol evidence to control in the matter. Besides a parol assignment is void under the statute of frauds. The case of Thomas v. Cook, 2 Starkie's R. 408, is supposed to have a strong bearing upon this one. In that case there was a parol lease from year to year to Cook, who under-let to Parkes. The rent being in arrear, Thomas distrained upon him, and he paid it by a bill of exchange; on receiving which he declared he would have nothing more to do with Cook. Afterwards, however, he brought his action against him for rent then due. For the plaintiff it was insisted that there was no surrender within the statute of frauds. Abbott, C. J., left it to the jury to say, whether the plaintiff had not accepted Parkes as his tenant, with the assent of Couk; and the jury finding in the affirmative, the plaintiff was nonsuited. The court at the ensuing term, when the case was noved, were of opinion there was a surrender by operation of law. They say if a lessee assign and the lessor accept the assignee of the les- 
see as his tenant that in point of law puts an end to the privity of estate, and an action of debt cannot be brought to recover the rent. That I admit to be true, but if the lease had been in writing, according to the cases above cited, a suit might still be maintained upon the express covenant in it, though the privity of estate was gone. Besides, the assignment was void as such under the statute of frauds. 1 Campb. 318; 5 Bing. 25; Comyn's Land. \& Ten. 55, and cases there cited; Woodf. 277. Again, the court say it is a rule of law, that the acceptance of a subsequent lease by parol operates as a surrender of a former lease by deed. That is true under the circumstances we have before endeavored to explain, and is undoubtedly the legal ground upon which that case may be maintained. The case sufficiently shows that the implied parol demise to Parkes was a valid one to the extent intended by both parties; the one to Cook was a lease from year to year, and the acceptance of Parkes, as tenant in his place, impliedly gave lim the same tenure and term; no writing was necessary for that purpose. This is the ground upon which the case is said to stand by the court, in commenting upon it in a subsequent term. 4 Barn. \& Cres. 922.

In the case of Grimman v. Legge, 8 Barn. \& Cres. 324, the lease was by parol for one year, for the first and second floor of a house, a dispute having arisen before the end of the year, the tenant said she would quit. The landlord said he would be glad to get rid of her. Slte accordingly left the premises, and possession was taken by him. The facts were submitted to the jury, to presume a rescindment of the original contract between the parties. The case of Stone v. Whiting, 2 Starkie, 235, is precisely like the case of Thomas v. Cook, and stands upon the same principle. In the case of Whitehead v. Clifford, 5 Taunt. 518, the lease was by parol from year to year, and stands upon the footing of Grimman v. Legge. In the case of Hamerton v. Stead, 3 Barn. \& Cres. 478, a tenant from year to year entered into an agreement in writing for a lease to him and another, and from that time both occupied. It was held that the new agreement, coupled with the joint occupation, determined the former tenancy, and opcrated as a surrender in law, though the lease contracted for was never granted. If the new agreement and occupation were viewed as a tenancy from year to year, which was of equal tenure with the first lease, there was at least no hardship in this decision. The judges obviously were somewhat embarrassed in their endeavors to place the case upon principle, and some of their observations conflict with the case in 6 East, 86, which they admitted to be good law. The first case was by parol from year to year, and might well have been put upon the footing of the cases to which I have referred, where the facts were submitted to the jury to find the first contract rescinded.

The law seems to be well settled, that under a covenant to repair like the one in question, the landlord need not wait till the expration of the term before bringing an action for the breach, under an idea 
that the tenant may, before he leaves the premises, put them in good condition. 1 Barn. \& Ald. 584; 2 Ld. Raym. S03, 1125; 1 Salk. 141; Platt on Cov. 289; Comyn's Land. \& Ten. 210. If the covenant was only to leave the premises in as good a condition as the tenant found them, it seems an action would not lie till the end of the term. Shep. Touch. 173; Platt on Cov. 289.

The defendant cannot question, in this action, the title of the landlord. The action is upon an express covenant between the parties, and the suit, if sustained at all, must be by the plaintiff alone.

New trial denied.

\section{WHITEHEAD v. CLIFFORD.}

(Court of Common Pleas, 1S14. 5 'Taunt. 518.)

This was an action for the use and occupation of a house, which was tried at the Middlesex sittings after last Michaelmas term, before Mansfield, C. J., when, after the Plaintiff had proved that the Defendant had been tenant from year to year of the Plaintiff's house, the Defendant proved a parol agreement, that the Plaintiff would give up his claim to the rent, on the Defendant's giving up immediate possession in the midule of the quarter: both parties accordingly went before a magistrate, and the Defendant then gave up the key, which the Plaintiff accepted, and the Defendant was never after that time in the possession of the premises. The Plaintiff sought to recover for a time subsequent to his resuming the key; and he insisted that the tenanicy was not thereby determnined, by reason of the statute of frauds; and cited Mollet v. Brayne, 2 Camp. 103. ${ }^{25}$ Mansfield, C. J., reserved the question, subject whereto the jury found a verdict for the Defendant.

Best, Serjé, in Hilary term, 1814, had obtained a rule nisi to set aside this verdict, and enter a verdict for the Plaintiff.

Girbs, C. J. The clause of the statute of frauds which restricts estates created by parol, to three years, has nothing to do with that which requires surrenders to be in writing. In Mollet v. Brayne both parties did not act on the parol notice to quit, but the tenant only. The present action can never succeed. The action for use and occupation

25 In the case cited the defendant had been in possession as tenant under a yearly rent for several months when a dispute arose between him and the lessor; the defendant threatening to quit the premises, the lessor said, "You may quit when you please." The defendant accordingly left a few dars later. The lessor sued for rent accrued after defendant quitted the premises. The defendant tendered the rent acerued up to a day after he had left. "Lord Ellenborough was of orjinion that the tenancy was not determined merely by the landord siving the tenant a parol license to quit, and the tenant quitting accordingly. At the time there was a subsisting term in the 1remises, and the statute of frauds (St. 29 Car. II, c. $3, \S 3$ ) provides that no leasc or term of yeal's, or any uncertain interest *** shall be surrencered, unless by deed or note in writing, or by act and operation of lay. Tere there was no deed or note in writing, and nothing is proved which can be considered a surrender by operation of law" (1S0\%). 
depends either upon actual occupation, or upon an occupation which the Defendant might have had, if she had not voluntarily abstained from it. Here the Plaintiff himself takes possession of the house, and makes the profit of the premises; and it was therefore impossible for the Defendant, during the same time, to have used and occupied the premises, if she would. As to the case in Campbell, it is very different from this, and we do not throw out any opinion against it; but when the like circumstances arise, it will be proper to consider them.

Rule discharged. ${ }^{26}$

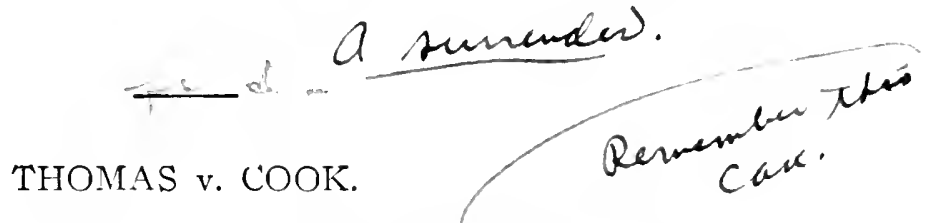

(Court of King's Bench, 1S1S. 2 Barn. \& Ala. 119.)

Action for use and occupation. At the trial of this cause at the London sittings after Trinity term before Abbott, J., it appeared that the plaintiff had originally let the premises, consisting of a house in Long-L ane to the defendant as tenant from year to vear. After he had resided there for some time, the defendant underlet them to one Perkes, commencing at Christmas 1816. At Lady-Day 1817, defendant distrained Perlie's goods for rent in arrear. Rent being then due from the defendant to Thomas, the latter gave notice to Perkes not to pay the rent to the defendant, but to him; and upon Cook's refusing to take Perke's bill for the amount then due, the plaintiff agreed to take it himself in payment of the rent due from Cook to him, saying that he would not have any thing further to do with Cook. And afterwards, in October, 1817, the plaintiff himself distrained the goods of Perkes for rent in arrear. The jury found, by the direction of the learned Judge, a verdict for the defendant, on the rround that Thomas had, with the assent of Cook, accepted Perkes as his tenant of the premises.

Topping moved for a new trial. By the third section of the Statute of Frauds, "No lease or term of years or any uncertain interest of or in any messuages, lands, tenements, or hereditaments, shall be surrendered unless by deed or note in writing." Now the utmost that appeared on the trial was a parol surrender by Cook of his interest in the premises, and in Mollett v. Brayne, 2 Campb. 103, it was held by Lord Ellenborough that a tenancy from year to year could not be determined by a parol license from the landlord to the tenant to quit, and the tenant's quitting accordingly. The same point was ruled in Doe v. Ridout, 5 Taunt. 519. Then if this surrender be void the case

26 See Phene v. Porplewell, 12 C. B. (N. S.) 334 (1S62): Millis v. Ellis, 109 Minn. 81, 122 N. W. 1119 (1909). Cf. Oastler r. Henderson, 2 Q. B. D. 575 (1с77): Newton 5 . Speare Laundering Co., 19 R. I. 546, 37 Atl. 11 (1S96); Smith r. Hunt, 32 R. I. 326, 79 Atl. 826,35 L. R. A. (N. S.) 1132, Aun. Cas 1912D, 971 (1911). 
falls within the authority of Bull v. Sibbs, 8 Term Rep. 327, and the plaintiff is entitled to a verdict.

Aввот' C. J. By the third section of the Statute of Frauds, it is (enacted "That no leases, estates, or interests, either of freehold, terms of years, or any other uncertain interest in any messuages, manors, lands, tenements or hereditaments shall be surrendered, unless by deed or note in writing or by act and operation of law." And the question in this case is, whether what has been done will amount to a surrender by act and operation of law. Now the facts of the case are these. The plaintiff Thomas had let the premises in question to the defendant as tenant from year to year, and the defendant underlet them to Perkes. The rent being in arrear, the defendant, on LadyDay 1817, distrained the goods of Perkes, who having tendered a bill in payment of the rent which the defendant had refused to receive, the plaintiff then interposed, took the bill in payment, and accepted Perkes as his tenant: and afterwards in October 1817, himself distrained the goods of Perkes for rent then in arrear. I left it to the jury to say whether under these circumstances the plaintiff had not, with the assent of Cook, accepted Perkes as his tenant of the premises, and the jury found that fact in the affirmative. I think, therefore, this amointed to a valid surrender of Cook's interest in the premises, being a surrender by act and operation of law. The consequence is that the plaintiff can have no claim for rent against the present defendant, and that the verdict therefore was right.

BAYLEY, J. If a lessee assigns over his interest, and the lessor accepts the assignee as his tenant, the privity of estate is thereby destroyed, and on that ground it is not competent for the lessor to bring debt against the lessee. Where, indeed, the contract is by deed, there he may bring covenant by the Statute of Hen. VIII. In this case, the landlord has accepted Perlies as his tenant, and must be considered to have made his election between Perkes and Cook. And the case of Phipps v. Sculthorpe, 1 Barn. \& Ald. 50, is an authority to shew that the plaintiff has no right to recover. This was a surrender of Cook's interest in the premises by act and operation of law, and the jury were quite right in presuming that Cook lad assented to the acceptance of Perkes as tenant to the plaintiff; for that assent was clearly for Cook's benefit.

Holroyd, J. It appears from the Statute of Frauds, that a surrender in order to be valid, must be either by deed or note in writing or by act and operation of law. In Mollett v. Brayne, 2 Campb. 103, there was only a parol surrender, and no circumstance existed in that case which could constitute a surrender by act and operation of law. But in this case, there is not merely a declaration by the plaintiff, that he will no longer consider Cook as his tenant, but there is also the acceptance by him of another person as the tenant, and that acceptance 1 assented to by Cook. Now, if a lease be granted to an individual, - and there be a subsequent demise of the premises by parol to the same 
person, that will amount to a surrender of his lease. Then the circumstances of Cook having first put in another person as undertenant, and having afterwards assented to a second demise by the plaintiff to that person, will in the present case amount to a virtual stirrender of his interest by act and operation of law. Notwithstanding therefore the third section of the Statute of Frauds, I am of opinion, that the facts here found by the jury amount to a valid surrender of Cook's interest, and a re-demise of the premises by the plaintiff to Perkes. In that case there will be no ground for disturbing the present verdict.

Rule refused. ${ }^{27}$

\section{WALLS v. ATCHESON.}

(Court of Common Pleas, 1S26. 11 Moore, 379.)

This was an action for assumpsit, for use and occupation. The cause was tried before Lord Chief Justice Best, at the sittings at Westminster, in the present Term.

The plaintiff, a widow, let to the defendant part of a furnished house in Manchester Square, at the rent of sixty-five guineas, for one year certain, from the 14th of September, 1824. The defendant quitted at end of the first quarter, viz. on the 14 th December, paying rent up to that day. About three weeks afterwards, the plaintıff let the apartments to another person, at the rent of one guinea per week. At the expiration of the second quarter, the plaintiff sent in an account to the defendant, charging him for a quarter's rent according to the terms of the original taking, deducting the sums received from the person to whom she had re-let the apartments, and making the defendant debtor to her for the sum of $f 7.5 \mathrm{~s}$. Od. ; which sum the defendant paid. The second tenant quitted in the beginning of July, 1825, from which time, until the 14th of December following, the apartments remained vacant. The plaintiff accordingly brought this action, to recover from the defendant, $£ 21$. Os. 6d., the balance of rent due to her from him, by the terms of the original letting.

His Lordship being of opinion, that, by letting the apartments to another, the plaintiff had rescinded the previous contract with the defendant, directed a nonsuit.

Mr. Serjeant Vaughan now applied for a rule nisi, that the nonsuit might be set aside and a new trial had.

LORD CHIEF JUSTICE BEST. By her own act, the plaintiff prevented the defendant from occupying these premises. She let them to another

27 See Walker v. Richardson, 2 M. \& W. SS2 (1S37); Lrnch v. Lynch, 6

Ir. Law Rep. 131 (1S43); Creagh v. Blood, S Ir. Eq. Rep. GSS (1S45).

Cf. Decker v. Hartshorn, 60 N. J. Law, 548 , ss Atl. $675(1597)$.

AIG.PROP. -14 
tenant. Can a landlord have two tenants, and be receiving rent from one, and at the same time holding the other liable? The case of Mollett v. Brayne is altogether distinguishable from the present. In Whitehead v. Clifford, 5 'Taunt. 518, it was held, that, if a landlord, in the middle of a quarter, accept from his tenant the key of the house demised, under a parol agreement, that, upon her then giving up the possession, the rent shall cease, and she never afterwards occupies the premises, he cannot recover, in an action for the use and occupation of the house, for the time subsequent to his accepting the key. Lord Chief Justice Gibbs there said: "In Mollett v. Brayne, both parties did not act on the parol notice to quit, but the tenant only. The present action can never succced. The action for use and occupation depends, either upon actual occupation, or upon an occupation which the defendant might have had, if she had not voluntarily abstained from it. Here, the plaintiff himself takes possession of the house, and makes the profit of the prenises; and it was therefore impossible for the defendant, during the same time, to have used and occupied the premises, if she would." I think both law and justice are with the defendant.

Mr. Justice PARk. I am of opinion that my Lord Chief Justice properly nonsuited the plaintiff; and that there is no colour for calling upon us to disturb that nonsuit. The case of Mollett v. Brayne is very different from the present: there, the tenant had a subsisting term, which could not be determined by a mere parol surrender. Here, the plaintiff, by her own act, rescinded the contract with the defendant, and dispensed with the necessity of a surrender. In Redpath $v$. Roberts, the landlord had only offered to let the premises, but had not in fact let them: thus there was nothing to obstruct the defendant's occupation of them, had he been so minded. In Lloyd v. Crispe, 5 Taunt. 257 the lessor having, by receiving rent from him, assented to the occupation of an assignee, he was held, by Sir James Mansfield, to have waived the necessity of a license for the subsequent assignment, notwithstanding a covenant in the lease, that the premises should not be assigned without the licence of the lessor. In Whitehead v. Clifford, the plaintiff, the landlord, had accepted the key, and thus the tenant was prevented from occupying the house. So, here, the conduct of the plaintiff in re-letting the apartments, signified as complete an acquiescence in the tenancy being determined, as could be conveyed by the acceptance of the key.

Mr. Justice Burrough. If the tenancy on the part of the defendant in this case were to be considered a continuing tenancy after the period at which he ceased to occupy the premises, the letting of them to another person was, on the part of the plaintiff, a tortious act; it was in the nature of an eviction. I think the case discloses abundant eridence that the contract was put an end to with the assent of the plaintiff herself. 
Mr. JUSTice Gaselez. If the plaintiff had given the defendant notice, that, if he would not occupy the apartments himself, she would let them to another tenant, on his account, the case would have been different. Under the circumstances, I see no reason for disturbing the nonsuit.

Rule refused. ${ }^{28}$

\section{GRAY v. KAUFMAN DAIRY \& ICE CREAM CO.}

(Court of Appeals of New York, 1900. 162 N. Y. 38s, 56 N. E. 903,49 L. R. A. $580,76 \mathrm{Am}$. St. Rep. 327 .)

Appeal from a judgment of the Appellate Division of the Supreme Court in the second judicial department, entered Mlay 5, 1897, affirming a judgment in favor of plaintiffentered upon a decision of the court at a Trial Term, a jury having been waived.

- This action was brought to recover two months' rent of the premises known as No Z8Z Eighth avenue, in the city of New York. In July, 1893, the plaintiff let the said premises to the defendant for ten years from August 1st, 1893, at the yearly rental of $\$ 2,400$, payable monthly in advance, and also the extra water rent charged against the defendant for its business. The defendant took possession about July, 1803 , and paid rent to November 1st, 1823 , but refused to pay for the months of November and December of that year, the rent of which became due and payable on the first days of those months respectively.

The answer, in effect, admits the making of the lease, but rlenies any indebtedness under it and sets up the eviction of the defendant a surrender and rescission of the lease, and claims credit for the rent received from the undertenant. On or about the 28 th or 29 th of October, 1893, the plaintiff had a conversation with Mr. Kalfman, the president of the defendant, upon the demised premises. The plaintiff's version of this conversation is as follows: "They were pulling up the store and the things, and were going to move out. They had not said anything to me about moving out prior to that time. I asked Mr. Kaufman what he was doing, pulling up the store. He said he was going to move out, and I asked him why, and he said because he couldn't make any money, and I told him that he had a lease on it, and that I would hold him responsible for the rent if he went out. 'Well,' he says, 'I am moving out, I don't want to stay where I don't make my rent.", The defendant moved out and sent the keys of the store to the plaintiff by mail. Plaintiff received them about the 2d of Novenber, 1893.

28 See, also, Nickells $\nabla$. Atherstone, 10 Q. B. $944(1 S+7)$; Haycock v. Johnston, 97 Minn. 289, 106 N. W. 30t, $11 \pm$ Am. St. Rep. 715 (1906); Rogers v. Doclistader, 90 Kan. 159, 133 Pac. 717 (1913); Hotel Marion Co. v. Waters (Or.) 150 Pac. 865 (1915). 
On the 3d of November, 1893, plaintiff served upon the defendant a notice of which the following is a copy:

"New York, November 3, 1893.

"To the Kaufman Dairy \& Ice Cream Co.:

"Yesterday I received the keys of 7S7 Eighth Avenue by mail. I hereby notify yout that I do not accept a surrender of the premises, and that I intend to hold you responsible for the rent under the lease. I shall let the premises on your account, and hold you for any loss which may be sustained.

"Yours, etc., John Gray."

The defendant made no answer to this notice. On the 17 th of November, 1893, the plaintiff went to Kingston and saw Mr. Kaufman, the president of the defendant, Mr. Spore, the secretary, and a Mr. Bruin. The plaintiff asked Mrr. Kaufman for the November rent, and the latter replied that no rent was due; that he had not made a lease; that there was nothing due and he would not pay; that he had given up the store and plaintiff could do what he liked with it. Thereupon the plaintiff started for home. The president and secretary of the defendant went to the railway station and there had a conversation with the plaintiff about compromising the matter by taking the cellar of said premises for fifty dollars a month for the term of the lease if the plaintiff would cancel the same as to the rest of the premises. The plaintiff said he would think over the matter and see what he could do with the remainder of the property, and let them know. The plaintiff testifies that thereafter, and on the 27 th of November, 1893, he wrote to the defendant as follows:

"Kaufman Dairy \& Ice Cream Co.:

"Gentlemen: I have an offer for the store you leased from me, 7S7 Eighth Ave. the parties will pay $\$ 1,500$ to the first of May and $\$ 1,600$ for three years from May. I think this is about as good an offer as can be expected, considering the times. Please let me know if you will keep the cellar and pay the difference between the $\$ 1,500$ and $\$ 2,400$ to MIay, and $\$ 1,600-\$ 2,400$ after. An early reply will much oblige. "Yours respect., J. Gray, 323 Washington Avenue."

The plaintiff further testifies that he inclosed this letter in an envelope directed to the defendant at Kingston, N. Y., deposited it prepaid in the post office at Brooklyn and received no reply thereto. The defendant had tenants in the cellar when it left the premises. These tenants attorned to the plaintiff.

On or about the 1st of December, 1893, plaintiff let the premises which had been previously demised to the defendant to one Mary Ann Keogh for the term of three years and five months at an annual rent of $\$ 1,500$ per year for the first five months, and $\$ 1,600$ per year for the remaining three years, to be paid in equal monthly installments in adrance.

The defendant plearled eviction, but gave no evidence upon that subject, and upon the trial admitted that it had no excuse for leaving the 
premises. Kaufman admitted having a conversation with the plaintiff before the defendant left the premises, in which the plaintiff stated that he would hold the defendant for the rent, but denied that he, Kaufman, had stated that the defendant would not stay where it did not make any money. Kaufman also admitted the receipt of the letter dated November $3 \mathrm{~d}$, but both he and Spore denied receiving the one dated November $27 \mathrm{th}$. Both admitted the conversation testified to by the plaintiff as having taken place at Kingston, and Spore testified that on that occasion Kaufman stated distinctly that the defendant did not owe any rent; that it had given up and surrendered the premises; that there was some talk at the railroad station about renting the cellar from the plaintiff at fifty dollars per month during the term of the lease, but there was nothing said in that conversation about plaintiff's reletting the premises on defendant's account. Abraham L. Gray, a son of the plaintiff, testified on the latter's behalf that he went to Kingston with his father to see Kaufman and was present at the conversation at the railroad station. He testified that $\mathrm{Mr}$. Spore offered the plaintiff fifty dollars a month for the basement if he would let the defendant off on the store, and the plaintiff replied that he would think it over and let them know. The lease to the defendant contained no provision against subletting, except for "any saloon or liquer business," and contained no provision for a reletting of the prenises by the plaintiff in case the defendant vacated the same during the term of the lease.

After the evidence was all in, the parties waived the jury and submitted the facts to the court for decision. The defendant admitted its liability for the November rent, but claimed that it was released as to the December rent by the reletting of the premises to said Mary Ann Keogh on the 1st of December. Upon these facts the court found that the plaintiff was entitled to recover rent for the months of November and December, less the amount received from the undertenants; that the plaintiff refused to accept a surrender of the premises; that the premises were at no time surrendered to the plaintiff, and that the reletting of the premises was done with the assent of the defendant.

TERNER, J. This controversy arises out of the conventional relation of landlord and tenant under circumstances governed by fixed principles of law. The first and most important question in the case is whether the plaintiff's reletting of the premises described in the lease, after the defendant's attempied surrender of the same, changed or af fected the legal status of the parties under the original lease. It is so well settled as to be almost axiomatic that a surrender of premises is created by operation of law when the parties to a lease do some act so inconsistent with the subsisting relation of landlord and tenant as to imply that they have both agreed to consider the surrender as made. It has been held in this state that "a surrender is implied, and so effected by operation of law within the statute, when another estate is created by the reversioner or remainderman with the assent of the termor incompatible with the existing state or term." Coe v. Hobby, 72 N. Y. 
145, $28 \mathrm{Am}$. Rep. 120. The existence of this rule has been recognized in this state in Bedford v. Terhune, 30 N. Y. 453, 86 Am. Dec. 394; Smith v. Kerr, 108 N. Y. 36, 15 N. E. 70, 2 Am. St. Rep. 362 ; Underhill v. Collins, 132 N. Y. 271, 30 N. E. 576, and in other jurisdictions in Beall v. White, 94 U. S. 389, 24 L. Ed. 173; Amory v. Kannoffsky, 117 Mass. 351, 19 Am. Rep. 416; Thomas v. Cook, 2 Barn. \& Ald. 119; Nickells v. Atherstone, 10 Ad. \& El. N. R. 944; Lyon v. Reed, 13 M. \& W. 306, and Washburn on Real Property, vol. 1, pp. 477, 478. It is conceded that defendant's offer of surrender was declined by the plaintiff, and that after the defendant's abandonment of the premises the plaintiff relet the same in his own name to one Mary Ann Keogh for a term of three years and five months. Such a situation, unqualified by other conditions, would create a surrender by operation of law IVe must, therefore, ascertain whether the conduct of the parties takes this case out of the operation of this rule.

It is urged by the learned counsel for the plaintiff that the reletting was done with the consent of the defendant under circumstances which bring the case directly within the rule laid down by Judge Haight in Underhill v. Collins, 132 N. Y. 270, 30 N. E. 576. In that case the landlord and tenant had a conversation a few days before the latter vacated the premises. The tenant asked the landlord to take the same off his hands. This the landlord declined to do, insisting that he would hold the tenant for the rent and would lease the premises for his benefit. In the case at bar there was also a conversation before the premises were vacated; but in this conversation there was nothing said about a reletting. The plaintiff simply saicl that he would hold the defendant for the rent. On the $2 \mathrm{~d}$ of November, 1893, a day or two after defendant's removal, the plaintiff received the keys of the premises. He returned them with a note stating that he would relet on defendant's account and hold it responsible for any loss that may be sustained. To this note the defendant made no reply. On the 17 th of November, 1893, the plaintiff and his son went to Kingston and saw Kaufman and Spore. In the conversation which took place between them and the plaintiff there was no suggestion of reletting. The plaintiff made a demand for the rent which was unpaid, and the defendant made an offer of compromise, under which it agreed to take the cellar of said premises at fifty dollars per month if the plaintiff would cancel the lease as to the store. This offer the plaintiff agreed to consider. On the 27th of November, 1893, the plaintiff wrote to the defendant that he had an offer for the store of $\$ 1,500$ per year to the first of the next ensuing May, and $\$ 1,600$ per year for three years thereafter. He requested the defendant to let him know if it would keep the cellar and pay the difference between the rent fixed by the lease and the amount offered by the intending tenant. To this letter the defendant made no reply.

It will be observed from this brief résume of the facts that there are several distinct features in which this case differs from the Underhill 
Case. In the latter case there was a personal interview before the tenant had vacated, in which the subject of reletting the premises was discussed. Here the subject of reletting was not mentioned until after the tenant went out, and then the suggestion came in a letter to which the defendant made no reply. Obviously the only theory upon which the defendant can be held to have assented to the reletting of the premises is that by its silence it acquiesced in the act of the plaintiff. We may assume, although we do not decide, that if the communications upon the subject of reletting had been made verbally in the course of conversation between the parties, even after the tenant had vacated the premises, the rule as to agreements by implication laid down in the Underhill Case might be held to apply. But here, as we have seen, the landlord's proposal to relet was in the form of two letters. In the first of these, dated November 31 , he makes the unequivocal assertion that he will let the premises on defendant's account, and will hold it for any loss that may be sustained. Defendant's failure to reply to this letter is followed by a personal interview on the 17 th of November, in which there is no reference to a reletting of the premises, and in which defendant's presilent, after denying any liability for rent, tells the plaintiff to do what he likes with the premises. Then follows the letter of November 27 th, informing the defendant of the offer which the plaintiff had received from an intending tenant, and asking defendant if it would pay the difference between the amount offered and the rent reserved in the original lease.

It will be observed that, even if we were to give these written communications the same force and effect as verbal statements made in personal interviews between the parties, the facts here are easily differentiated from those in the Underlill Case. There the tenant vacated the premises upon the offer of the landlord to relet for his benefit and under such circumstances as to permit the inference that he accepted the offer. Here the landlord's statement to that effect, made after the tenant's abandonment of the premises, is followed by negotiations in which the tenant expresses a willingness to keep the cellar at fifty dollars per month if the landlord will cancel the lease as to the rest of the premises. These steps are succeeded by a communication from the landlord, in which he requests the tenant to decide whether it will keep the cellar and pay the deficit which will arise by an acceptance of the offer which the former then had under consideration. It may well be doubted whether verbal declarations made in personal intervieus between the parties, under the circumstances above narrated, would support the plaintiff's theory of this action, To create a contract by implication there must be an unequivocal and ungulalified assertion of a right by one of the partics, and such silence by the other as to support the lesal inference of his acquiescence.

But it is clear, both upon principle and authority, that we have no right to indulge in the assumption that the letters above referred to have the force and effect of verbal statements made in the presence of 
the defendant's officers. The rule is precisely to the contrary. It is well expressed in Learned v. Tillotson, 97 N. Y. 12, 49 Am. Rep. 508, as follows: "We think that a distinction exists between the effect to be given to oral declarations made by one party to another, which are in answer to or contradictory of some statement made by the other party, and a written statement in a letter written by such party to another. It may well be that under most circumstances what is said to a man to his face, which conveys the idea of an obligation upon his part to the person addressing him, or on whose behalf the statement is made, he is at least in some measure called upon to contradict or explain; but a failure to answer a letter is entirely different, and there is no rule of law which requires a person to enter into a correspondence with another in reference to a matter in dispute between them, or which holds that silence should be regarded as an admission against the party to whom the letter is addressed. Such a rule would enable one party to obtain an advantage over another and has no sanction in the law." To the same effect are Bank of B. N. A. v. Delafield, 126 N. Y. 418, 27 N. E. 797, and Thomas v. Gage, 141 N. Y. 506, 36 N. E. 385.

It is manifest, therefore, that the act of the plaintiff in reletting said premises under the circumstances referred to operated as an acceptance of the defendant's offer to surrender. The judgment herein can be supported upon no theory that is consistent with the established rules of law. As the views above expressed are decisive of the case, it is unnecessary to discuss the other questions raised by the defendant.

The judgment of the court below should be reversed and a new trial granted, with costs to abide the event.

Landon, J. (dissenting). The trial court found that "Plaintiff refused to accept a surrender of the premises, and did not accept it, and the premises were at no time surrendered to the plaintiff. "The letting of the premises was done with the assent of the defendant." The order of affirmance by the Appellate Division does not state that it was unanimous, but that is not important here, for the record contains evidence tending to support the findings. The evidence tends to show that the defendant intended by its conduct to threaten the plaintiff with the loss of his rent, and thus to coerce him to relet the premises, and then deny its assent, notwithstanding after its receipt of the plaintiff's first letter, it told the plaintiff he could do as he liked with the premises. The defendant thus replied to the plaintiff's letter, at least so the trial court, in view of all the circumstances, might find, and did find.

Parker, Ch. J., and Gray, O'Brien and Haight, JJ., concur with WERNER, J., for reversal. LANDON, J., reads dissenting memorandum. CULleE, J., not sitting.

Judgment reversed, etc. ${ }^{20}$

29 See Welcome v. Hess, 90 Cal. 507, 27 Pac. 369, 25 Am. St. Rep. 145 (1S91); Pelton v. Place, 71 vt. 430946 Atl. 63 (1899).

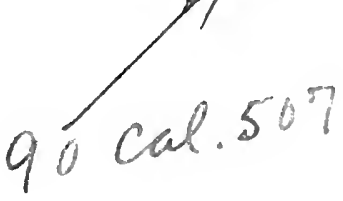




\section{OLDEWURTEL v. WIESENFELD.}

(Court of Appeals of Maryland, 1903. $97 \mathrm{Md} .165,54$ Atl. 969.)

Briscoe, J. ${ }^{30}$ On the eighth day of June, 1900, the appellees instituted a suit in covenant in the Superior Court of Baltimore City, against the appellant, to recover rent due and owing under a lease dated the 1st day of April, 1895, for a store and dwelling known as No. 507 South Broadway, Baltimore. The lease is in writing and is fully set out in the record. The property was rented for the term of five years, beginning on the first day of April, 1895, and ending on the 31st day of March, 1900, at $\$ 900$ per year, payable in equal monthly installments on the first day of each and every month. It was provided by the terms of the lease that its provisions and covenants should continue in force from term to term after the expiration of the term mentioned therein, provided the parties thereto or either of them could terminate it at the end of the term, or of any year thereafter, by giving at least ninety days previous notice thereof in writing. It was further provided, in case the rent should be ten days in arrear and not paid when the same should become due, then the lessor may re-enter and take back the premises without demand. There was no covenant in the lease for making repairs to the premises.

The declaration states that the sum of six hundred and five dollars was due and unpaid for rent with interest from April 1st, 1900, over and above all discounts, according to the following bill of particulars, which was filed, on demand, in the case.

\section{Bill of Particulars.}

Mr. Henry Oldewurtel to Bernard Wiesenfeld and Joseph Miller, Trustees of the Estate of Betsey Wiesenfeld.

To 5 years rent of No. 507 S. Broadway, at $\$ 300$ per year, as per

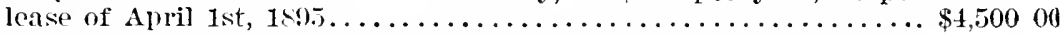

Less $\$ 10$ per month, waired for the months of Aug., Sept., Oct., Nov. and Dec., 1S97, and Jan., 1898 , respectively.................

Credits.

6000

$\$ 4,41000$

By cash from Aprll 1, 1895, to June 1. 189\$. ................. \$2,\$65 00

By Hughes \& Co., from Sept. 1, 189s, to Jan. 1, 1899........... 28000

By Wheeler \& Hughes, from Feb. 1 . 1899, to Aug. $1,1899 \ldots \ldots \ldots \ldots .3700$

By C. Walmacher, from Oct. 19, 1S99, to March $31,1900 \ldots \ldots \ldots \ldots .32000$

The undisputed facts of the case out of which the controversy arose briefly stated are these: The defendant, the lessee, continued in pos-

30 The portion of the opinion relating to the correctness of the form of action is omitted. 
session of the demised premises until June 1st, 1898, when he paid the rent to that date and left the key at the office of the plaintiff in his absence, stating to the clerk "that he had moved out the house and here was the key."

On June $2 \mathrm{~d}$, the next day, the plaintiff wrote him the following letter:

"Henry Oldewurtel, Esq.,

"Dear Sir: I have been informed that you left the key of No. 507 South Broadway at my office. I beg to notify you that I refuse to accept the key and that it is still at my office at your risk and disposal. I also hereby notify you that we will hold you subject to all the covenants of the lease, executed by you.
"Very truly yours,
Bernard Wiesenfeld."

The plaintiff not receiving a reply to the foregoing letter, a second letter dated June 3, 1898, was written the defendant as follows:

"Henry Oldewurtel, Esq.,

"Dear Sir: I herein beg to notify you that I intend to make an effort to get a tenant for the premises known as No. 50 \% South Broadway, without abandoning any rights, Mr. Miller and myself as executors and trustees may have against you as tenant under our lease to you for rent. In case we get a tenant we will allow you credit for such rent as we may collect, and hold you for the balance as due under your lease.
"Yours truly,
Bernard Wiesenfeld."

Subsequently a sign was put in the window of the premises that the property was for rent, and it was rented from time to time, and the defendant credited with the rent to the date of the expiration of the lease. The plaintiffs testified that they refused to accept a surrender of the premises, never made any alteration of the original lease, by a subsequent agreement, and never ousted the defendant from the premises, and that necessary repairs were made to the property. The defendant, on the other hand, testified that he vacated the property because it had been condemned by the building inspector of Baltimore, and was not tenantable, and he notified the clerk when he paid the rent that he would no longer be liable under the lease. There was other evidence in the case, but as the material facts are not disputed and have been heretofore stated it will not be necessary to further set them out. At the trial below, the Court granted the two prayers offered on the part of the plaintiff, and rejected those presented by the defendant, except the fifth. It also granted the plaintiff's special exception to the defendant's first prayer, that there was no legally sufficient evidence to show that the terms of the lease were ever modified by any legally binding agreement. The whole case was presented on the prayers and the special exception, and we shall proceed to consider them.

The prayers on the part of the plaintiff were demurrers to the evidence and were to the effect that as a matter of law there was no legal- 
ly sufficient evidence of the acceptance of a surrender, or of an ouster by the plaintiff.

The general rule is well settled that to constitute a valid surrender of rented premises by a tenant during the term there must be the assent of both parties to the rescinding of the contract of renting, and such assent may be expressed or implied from such acts as would reasonably indicate that the parties have agreed that the tenant shall abandon the premises, and the landlord assume its possession. Biggs v. Stueler, 93 Md. 110, 48 Atl. 727.

The appellants admit that the defendant returned the key before the expiration of the lease. It was not accepted and therefore up to this time no surrender took place. It is further conceded that the plaintiffs had a right to enter for the purpose of taking care of the property, of repairing the premises and to put a "for rent sign" in the window.

But it is earnestly urged that the re-renting of the property for the benefit of the tenant without his assent was an acceptance of a surrender, an ouster of the tenant, and released him from liability for rent under the lease.

There are some authorities to the effect that a re-entry and reletting of abandoned prenises by the landlord without the consent of the tenant; would create a surrender, by operation of law. Underhill v. Collins, 132 N. Y. 271,30 N. E. 576; Gray v. Kaufman, 162 N. Y. 388, 56 N. E. 903,49 L. R. A. 580 , 76 Am. St. Rep. 327 ; Day v. Watson, 8 Mich. 535 ; Rice v. Dudley, 65 Ala. 68.

The best approved cascs, however, assert the contrary doctrine, and hold that where a tenant repudiates the lease, and abandons the demised premises, and the lessor enters and relets the property, that such re-rcnting does not relieve the tenant from the payment of the rent under the covenants of the lease. Auer v. Penn. $99 \mathrm{~Pa} .370,44 \mathrm{Am}$. Rep. 114; Meyer v. Smith, 33 Ark. 627; Bloomer v. Merrill, 1 Daly (N. Y.) 485; Scott v. Beecher, 91 Mich. 590, 52 N. W. 20; Rich v. Doyenn, 85 Hun, 510, 33 N. Y. Supp. 341; Alsup v. Banks, 68 Miss. 664, 9 South. S95, 13 L. R. A. 598, 24 Am. St. Rep. 294.

In Biggs v. Stueler, 93 Md. 111, 48 Atl. 729, this Court said: "The acts upon which the appellee in this case relies to prove a surrender are the acceptance of the keys by the appellee, the repairs to the house and the reletting. Bit those are insufficient of themselies to show acceptance, unless under all the circumstances they are of such a character as to show a purpose on the part of the tenant to vacate and on the part of the landlord to resume possession, to the exclusion of the tenant."

In the case now under consideration all of the acts of the lessor, including the letters of June 2 nd and 3 rd clearly show that the appellees did not intend to accept a surrender of the property and to release the tenant from his liability for rent. On the contrary the letters distinctly state the property would be rented subject to the covenants of

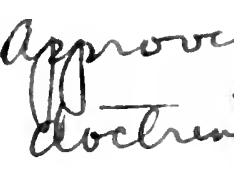


the lease and if a tenant could be secured, and rent collected, the lessee would be credited therewith, and be liable for the difference.

The case of Biggs v. Stueler, supra, is also relied upon by the appellant to sustain the proposition urged by him, that the assent of the tenant is absolutely necessary before the landlord can relet demised premises. In that case there was a statement that would seem to sustain the appellant's contention but an examination of the whole case, will clearly show that the case cannot be given such a construction. It was not necessary for the decision of the case, and would not be in accord with the conclusion reached by the Court, under the facts of the case.

As to the rulings of the Court on the first and second exceptions upon the admissibility of evidence but little need be said as the evidence was afterwards admitted, and the defendant was not injured thereby.

The plaintiff's special exception to the defendant's first prayer was properly sustained. There was no evidence legally sufficient to show that the terms of the lease had been modified by an oral agreement, and what was said by us on the demurrer to the declaration, disposes of this question.

For the reason we have given, the defendant's prayers were properly rejected, and as the correctness of the Court's rulings on the plaintiff's prayers established the right of the plaintifis ta recover, the judgment will be affirmed.

Judgment affirmed with costs. ${ }^{31}$

31 "Cpon the trial in the court below the learned fudge instructed the jury, as set forth in the second assignment of error, as follows: "If a mau refuses to continue your tenant, gives up the honse into your hands, why, then, sou have a right to put a bill upon the house and try to rent it; beeause, if you rent it, it is so much sared to Mr. Auer, so much sared to the surety of the tenant, because you have to gire an account of erery cent sou make ont of the house; and certainly it is much better for the tenant, that the landlord shonld rent the house and get something for it, than to simply lock the door and lay by and sue the tenant or surety for the whole amount of the rent for the whole term for which he has taken it; so that, being for the benefit of both parties, it is no presumption that the landlord has aceepted a surrender, that he has taken and leased the house.' We see no error in this. It is good sense as well as good law." Auer F. Pennsylvania, 99 P'a. 870,376 , 44 Am. Rel. 114 (1852), per Paxson, J. In the ease, howerer, it apleared that the landlord had notified the surety of the tenant who mored out that he would be looked to as continued seeurity for the rent.

"May a landlord, after his tenant has vacated and abandoned the premises without cause, resume lossession thereor, and re-lease the same to another, after giring notice to the original tenant of his intention of holding him for the rents reserved, and that he had resumed possession for the purpose of protecting the reversion, and had relet them to rednce the damages which he might otherwise sustain, without being held to have created ir surrender by operation of law. $* * *$ The reneral rule no donbt is that, if the tenant abandons the premises and the lindord Te-Tents them. a surrender is established. Stobie 5 . Dils, 62 TI. 42 (15\%2) But nearly every lute las its exceptions, and one of the escentions to the rule just cuoted is thit if the landlord re-leases them for andon account of the tenant is surrencer is not to be inferred. they intended to hold them for the rent, and re-rented simply to reduce the 


\section{LYON v. REED.}

(Court of Exchequer, 1844. 13 Nees. \& W. 285.)

PARKE, B. ${ }^{32}$ This was a special case argued in Easter Term. It was an action of debt by the plaintiff, as assignee of the reversion of certain houses and rope-walks at Shadwell, holden under a lease from the Dean of St. Paul's against the defendants, who are executors of Shakespeare Reed, Deceased. The plantiff chaims from the defendants nineteen years' rent, accrued due between Christmas, 1820, and Christmas, 1839, partly in the life time of Shakespeare Reed, who held the premises during his life, and partly since his decease, while the premises were in the possession of the defendants, his executors.

The material facts are as follows:-The premises in question are parcel of the possession of the Dean of St. Paul's, and it appears that, on the 26th of December, 1803, the then dean demised a large estate at Shadwell, including the houses and premises in question, to two persons of the names of Ord and Planta (wlio were in fact trustees for the Bowes fanmly) for a term of forty years, commencing at Christmas, 1803, and which would, therefore, expire at Christmas, 1843. On the 24th of March, 1808, Ord and Planta made an underlease of the houses and rope-walks in question to Strakespeare keed for thirty-four vears, commencing from Christmas, 1807 , so that the term created by this underlease would expire at Christmas, 1841, leaving a reversion of two years in Ord and Planta. The rent sought to be recovered is the rent which accrued due on the underlease between christmas, 1820, and Christmas 1s39. It appears that, previously to the month of October, 1811, Robert Hartshorn Barber and Francis Charles Parry were appointed by the Court of Chancery trustees for the Bowes family, in the place of Ord and Planta; and by an indenture dated the $3 \mathrm{~d}$ of October, 1511, endorsed. on the lease of 1803 , all the property at Shadwell demised by that lease was assigned by Ord and Planta to Barber and Parry, the new trustees. Soon after this assignment, the Bowes family appears to have negotiated with the dean for a renewal of the lease of 1803, and accordingly a new lease was executed by the dean,

damages-and this is made to appear by satisfactory evidence-there is no reason for holding that there was a surrender, and that the origilial temants were released from their obligation." Brown y. Caims, $10 \tau$ Iowa, $72 \boldsymbol{\tau}, 737$, 77 N. W. 47s, 482 (1s9s), per Deemer, C. J. See Kean v. Rogers, 140 Iowa, 559,123 N. W. $754(1909)$.

"What does or does not constitute a surrender of the lease and an accept. ance thereof mist be defermined from all the facts in eich pirticular case. itmout statmg in detail all the testimuny on that foint in this case, we think it is a fair deduction from the testimony that there matosuch al sulrender here, and an accentance of if, especially in riew of the fuct that the ajellant never motified the lessee at any time, not eren after receiving the noufication in December, 1905 , that they would not renew the lease, that he expected to hord the lessee ror the rent." Stein v. IIrman-Lewis Co., 95 Mirs 293, 209, 4S South. 225, 2:26 (1902), per Whitfield, C. J.

32 The opinion only is printed; the case sufliciently appears therefrom.

19 cheors 2

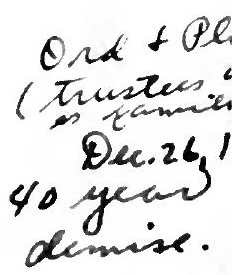

mar. 24,12

underceare

Reek - 3

from 1807.
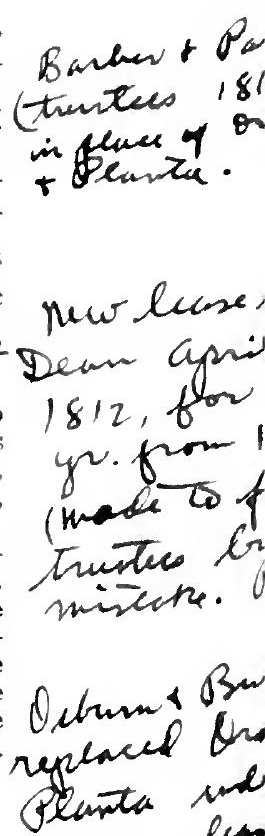

99

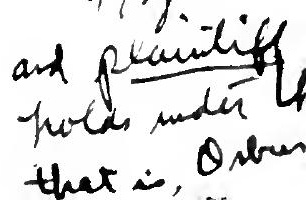


dated on the 7th of April, 1812, for a term of forty years, from Christmas, 1811, and which term, would therefore, endure till Christmas, 1851. Un fortunately this lease, instead of being made to Barber and Parry (the new trustees) in whom the old term (subject to the underlease to Reed) was vested, was made to Ord and Planta, the old trustees; the fact of the change of trustees and the assignment of the $3 \mathrm{~d}$ of October, 1811, having, at the time escaped observation. In this state of things, a private act of Parliament was passed, enabling the dean and his successor for the time being to grant leases of the Shadwell estate to the trustees of the Bowes fanily for successive terms of ninety-nine years, renewable for ever.

The act, which is intituled "An Act to enable the dean of St. Paul's, London, to grant a Lease of Messuages, Tenements, Lands, and Hereditaments in the parish of St. Paul's, Shadwell, in the County of Middlesex, and to enable the Lessees to grant Subleases for building on and repairing, that Estate," received the royal assent on the $22 \mathrm{~d}$ of July, 1812. It begins by reciting the will of Mary Bowes, whereby she bequeathed her leasehold estate at Shadwell, held under the Dean of St. Paul's, (being the estate afterwards demised by the leases of 26th December, 1803, and the 7 th April, 1812,) to Ord and Planta, on certain trusts for the Bowes family. It then recites the lease of the 7 th of April, 1812, and after stating that it would for the reasons therein mentioned, be beneficial for all parties that the dean should be empowered to grant long leases of the Shadwell property, perpetually renewable, and further stating that Ord and Planta were desirous of being discharged from their trust, and that John Osborn and John Burt had agreed to act as trustees in their place; it enacted, that it should be lawful for the dean and his successors for the time being, and he and they are thereby required, on a surrender of the existing lease, to demise the Shadwell estate to Osborn and Burt, their executors, administrators, and assigns, for a term of ninety-nine years, and at the end of every fifty years to grant a new lease on payment of a nominal fine, with various provisions (not necessary to be stated for securing to the dean and his successor a proportion of all improved rents to be thereafter obtained. And by the second section of the act it is enacted, that, immediately on the execution by the dean of the first lease for ninety-nine years to be granted in pursuance of the act, the lease of the 7 th of April, 1812, should become void. It is plain, from the provisions contained in this act, that the persons by whom it was obtained were not aware, or had forgotten that, in the month of October preceding, Ord and Planta had assigned their interest in the property to Barber and Parry, the new trustees appointed by the Court of Chancery. In pursuance of the act of Parliament by an indenture of three parts, dated the 31st day of August, 1812, and made between the dean of the first part, Thomas Bowes (the party beneficially interested for his life) of the second part, and Osborn and Burt of the third part, the dean demised the Shadwell property to Osborn and Burt for a term 
of ninety-nine years, and the demise is expressed to be made as well in consideration of the surrender of the lease of the 7 th of April, 1s12, "being the lease last existing," as also of the rents and covenants, \&c.

Mr. Bowes, and Osborn and Burt, his trustees, appear to have discovered, before the month of January, 1814, the mistake into which they had fallen, and two further deeds were then executed for the purpose of curing the defect. By the former of these deeds, which bears date the 6th January, 1814, and is made between Barber and Parry of the one part, and the dean of the other part, reciting that, at the time of the granting of the lease of the 7 th of April, 1812, the estate and interest created by the original demise of the 26 th of December, 1803, was vested in Barber and Parry, and also reciting that the fact of the assignment to them by the deed of the $3 \mathrm{~d}$ of October, 1811, was not known to the parties by whom the said act was solicited, it is witnessed, that Barber and Parry did bargain, sell and surrender to the dean the whole of the said Shadwell estate, to the intent that the term of forty years, created by the lease of the $26 \mathrm{th}$ of $\mathrm{D}_{\text {- }}$ cember, 1803 , might be merged in the freehold and that the dean might execute a new lease to Osborn and Burt according to the said act. By the other deed, which bears date the 29 th of January, 1814, and is made between the dean of the first part, and the said 'Thomas Bowes of the second part, and the said Osborn and Lurt, of the third part; the dean, in consideration of the effectual surrender of the two prior leases of the 26 th of December, 1803 , and the 7 th of April, 1812, and for the other considerations therein mentioned, demised the Shadwell estate, pursuant to the said act of Parliament, to Osborn and Burt, their executars, administrators, and assigns, for a term of ninety-nine years. The interest of Osborn and Burt, under these two leases to them, has, by various assignments, become vested in the plaintiff and there is no doubt but that he is entitled to recover the rent in question in this action, if Osborn and Burt would have been so entitled.

Such being the principal facts, we must consider how they bear on the several issues raised by the pleadings. The declaration, after stating the demise from the dean to Ord and Planta in 1803, and the underlease from them to Reed in 1808 , goes on to state, that, by the deed of the $3 \mathrm{~d}$ of October, 1811, Ord and Planta assigned all their interest in the premises to Barber and Parry, and that the dean, being seised of the reversion expectant on the term of forty years so assigned to Barber and Parry, by the indenture of the 31st of August, 1812, demised the premises to Osborn and Burt for a term of ninety-nine years by virtue whereof they became entitled to the reversion for that term. The declaration then goes on to state that, by the indenture of the 6th of January, 1814, Barber and Parry assigned their interest to the dean, to the intent that he might grant a new lease to Osborn and Burt; and that afterwards, on the 29th day of the same month of January, 1814, the dean, by the indenture of that date, made a new demise of the premises to Osborn and Burt for a fresh term of 
ninety-nine years, they by the same indenture surrendering the former term created by the demise of the 31st of August, 1812. The declaration then traces the title in the present plaintiff by assignment from Osborn and Burt previously to Christmas, 1820, and so claims title to the rent accrued due after that date.

To this declaration the defendants pleaded six pleas: First, a plea traversing the averment that, at the time of the demise to Osborn and Burt of the 31st of August, 1812, the dean was seised in fee of the reversion. Secondly a plea traversing that demise. Thirdly, a plea traversing the assignment by Barber and Parry to the dean, to the intent that he might grant a new lease to Osborn and Burt. Fourthly, a plea traversing the surrender by Osborn and Burt of the first term of ninety-nine years. Eifthly, a special plea stating the indenture of the 7th of April, 1812, whereby Ord and Planta became entitled to the reversion for forty years from Christmas, 1811, and so continued until, up to, and after the execution of the indenture of the 29 th of January, 1814. Sixthly, a plea traversing the demise to Osborn and Burt by the indenture of the 29th of January, 1814. Issue was joined on all the pleas except the fifth, and to that the plaintiff replied, that, after the making of the lease of the 7th of April, 1812, and before the lease of the 31st of August, 1812, the private act of Parliament was passed, authorizing the dean, on the surrender of the existing lease, to grant a lease for ninety-nine years to Osborn and Burt; and the replication then avers that the lease of the 31st of August, 1812, was duly made in pursuance of the act, and that, at the time when it was made, the lease of the 7 th of April, 1812, was duly surrendered. To this the defendants rejoin, traversing the surrender of the lease of the 7 th of April, 1812, and on this issue was joined. The second, third, and sixth issues, it will be observed, are mere traverses of the execution of deeds which are found by the special case to have been duly executed; and, as the traverse merely puts in issue the fact of the execution, and not the validity of the deeds or the competency of the parties to make them, the verdict on those issues must certainly be entered for the plaintiff; and so must that on the fourth issue, whereby the defendant traverses the surrender by Osborn and Burt of the first term of ninety-nine years, when the demise of the second term was made to them. It is quite clear that the acceptance of the second demise was of itself a surrender in law of the first, even if no surrender in fact was made. For whom, then, is the verdict on the remaining issues, the first and fifth, to be entered? The issue on the fifth plea is, it will be observed, whether the lease of the 7th of April, 1812, was duly surrendered at the time of the making of the indenture of the 31st August, 1812. And the issue on the first plea is substantially the same; for if the plaintiff succeeds in showing that the indenture of $\{$ the 7 th April, 1812, was duly surrendered as set forth in his declaration, then it follows that the dean was at that time seised of the reversion, and so the plaintiff must succeed on the first issue; if, on 
the 'other hand, he fail on the fifth issue, he must also fail on the first.

The real question, therefore, for our consideration is, whether the plaintiff has succeeded in showing that the term of the 7 th April was surrendered previously to the execution of the indenture of the 31 st of August, 1812. On this subject it was argued by the counsel for the plaintiff, first, that the circumstances of the case warranted the conclusion that there was an actual surrender in fact; and if that be not so, then, secondly, that they prove conclusively a surrender in point of law.

We will consider each of these propositions separately. And first, as to a surrender in fact. The subject-matter of the lease of the 7 th April, 1812, was, it must be observed, a reversion; a matter, therefore, lying in grant, and not in livery, and of which, therefore, there could be no valid surrender in fact otherwise than by deed; and what the plaintiff must make out, therefore, on this part of his case is, that. before the execution of the first lease for ninety-nine years, Ord and PTanta, by some deed not now forthcoming, assigned or surrendered than to the dean the interest which they had acquired under the lease of the 7 th of April. But what is there to warrant us in holding that any such deed was ever executed? Prima facie a person setting up a deed in support of his title is bound to produce it. But undoubtedly this general obligation admits of many exceptions. Where there has been long enjoyment of any right, which could have had no lawful origin except by deed, then, in favour of sinch enjoyment, all necessary deeds may be presumed if there is nothing to negative such presumption. Has there, then, in this case been any such enjoyment as may render it unnecessary to show the deed on which it has been founded? The only fact as to enjoyment stated in this case has precisely an opposite tendency; it is stated, so far as relates to the property, the rent of which forms the subject of this action, namely the houses, \&c., underlet to Reed, that no rent has ever been paid; and therefore, as to thiat portion of the property included in the lease of April, 1812, there has certainly been no enjoyment inconsistent with the hypothesis that that lease was not surrendered.

The circunstances on which the plaintiff mainly relies as establishing the fact of a surrender by deed, are the statements in the two leases to Osborn and Burt, that they were made in consideration, inter alia, of the surrender of the lease of the 7th April, and the fact of that lease being found among the dean's instruments of title. These circumstances, however, appear to us to be entitled to very little weight. The ordinary course pursued on the renewal of a lease is for the lessee to deliver up the old lease on receiving the new one, and the new lease usually states that it is made in consideration of the surrender of the old one. No surrender by deed is necessary, where, as is commonly the case, the former lessee takes the new lease, and all which AIG.PROP. -15 
is ordinarily done to warrant the statement of the surrender of the old lease as a part of the consideration for granting the new one, is, that the old lease itself, the parchment on which it is engrossed, is delivered up Such surrender aifords strong evidence that the new lease has been accepted by the old tenant, and such acceptance undoubtedly operates as a surrender by operation of law, and so both parties get all which they require. We collect from the documents that this was the course pursued on occasion of making the lease of the 26th December, 1803, and the lease of the 7th of April, 1812; and we see nothing whatever to warrant the conclusion that any thing else was done on occasion of making the lease to Osborn and Burt.

Where a surrender by deed was understood by the parties to be necessary, as it was with reference to the term assigned to Barber and Parry, there it was regularly made, and the deed of surrender was endorsed on the lease itself. There is no reason for supposing that the same course would not have been pursued as to the lease of April, 1812, if the parties had considered it necessary. If any surrender had been made, no doubt the deed would have been found with the other muniments of title. No such deed of surrender is forth-coming, and we see nothing to justify us in presuming that any such deed ever existed. We may add, that the statement in the new lease, that the old one had been surrendered, cannot certainly of itself afford any evidence against the present defendants, who are altogether strangers to the deed in which those statements occur.

It remains to consider whether, although there may have been no surrender in fact, the circumstances of the case will warrant us in holding that there was a surrender by act and operation of law On the part of the plaintiff it is contended, that there is sufficient to justify us in coming to such a conclusion, for it is said, the fact of the lease of the 7th of April, 1812, being found in possession of the dean, even if it does not go the length as establishing a surrender by deed, yet furnishes very strong evidence to show, that the new lease granted to Osborn and Burt was made with the consent of Ord and Planta, the lessees under the deed of the 7 th of April, 1812. And this, it is contended, on the authority of Thomas v. Cook, 2 B. \& Ald. 119, and Walker v. Richardson, 2 M. \& IV. S82, is sufficient to cause a surrender by operation of law.

In order to ascertain how far those two cases can be relied on as authorities, we must consider what is meant by a surrender by operation of law. This term is applied to cases where the owner of a particular estate has been a party to some act, the validity of which he is by law afterwards estopped from disputing, and which would not he valid if his particular estate had continued to exist. There the law treats the doing of such act as amounting to a surrender. Thus, if lessee for years accept a new lease from his lessor, he is estopped from saying that his lessor had not power to make the new lease; and, as the lessor could not do this until the prior lease had been surren- 
dered, the law says that the acceptance of such new lease is of itself a surrender of the former. So, if there be tenant for life, remainder to another in fee, and the remainderman comes on the land and makes a feoffment to the tenant for life, who accepts livery thereon, the tenant for life is thereby estopped from disputing the seisin in fee of the remainderman, and so the law says, that such acceptance of livery amounts to a surrender of his life estate. Again, if tenant for years accepts from his lessor a grant of a rent issuing out of the land and payable during the term, he is thereby estopped from disputing his lessor's right to grant the rent, and as this could not be done during his term, therefore he is deemed in law to have surrendered his term to the lessor.

It is needless to multiply examples; all the old cases will be found to depend on the principle to which we have adverted, namely, an act done by or to the owner of a particular estate, the validity of which he is estopped from disputing, and which could not have been done if the particular estate continued to exist. The law liere says, that the act itself amounts to a surrender. In such case it will be observed there can be no question of intention. The surrender is not the result of intention. It takes place independently, and cren in spite of intention. Thus, in the cases which we have adverted to of a lessee taking a second lease from the lessor, or a tenant for life accepting a feoffment from the party in remainder, or a lessee accepting a rent-charge from his lessor, it would not at all alter the case to show that there was no intention to surrender the particular estate, or even that there was an express intention to keep it mnsurrendered. In all these cases the surrender would be the act of law, and would prevail in spite of the intention of the partics. These principles are all clearly deducible from the cases and doctrine lail down in Rolle and collected in Viner's Abridgment tit. "Surrender," F and G, and in Comyns' Dirg. tit. "Surrender," T, and I, 2, and the authorities there referred to. But, in all these cases, it is to be observed, the owner of the particular estate, by granting or accepting an estate or interest, is a party to the act which operates as a surrender. That he agrees to an act done by the reversioner is not sufficient. Brooke, in his Abridgment, tit. "Surrender," pl. 48, questions the doctrine of Frowike, C. J., who says"If a termor agrees that the reversioner shall make a feoffment to a stranger, this is a surrender," and says he believes it is not law; and the contrary was expressly decided in the case of Swift v. Ileath, Carthew, 110, where it was held, that the consent of the tenant for life to the remainderman making a feoffment to a stranger, did not amount to a surrender of the estate for life, and to the same effect are the authorities in Viner's Abr. "Surrender," F, 3 and $t$.

If we apply these principles to the case now before us, it will be seen that they do not at all warrant the conclusion, that there was a surrender of the lease of the 7 th of April, 1812, by act and operation of law. Even adopting, as we do, the argument of the plaintiff, that 
the delivery up by Ord and Planta of the lease in question affords cogent evidence of their having consented to the making of the new lease, still there is no estoppel in such a case. It is an act which, like any other ordinary act in pais, is capable of being explained, and its effect must therefore depend, not on any legal consequence necessarily attaching on and arising out of the act itself, but on the intention of the parties. Before the Statute of Frauds, the tenant in possession of a corporeal hereditament might surrender his term by parol, and therefore the circumstance of his delivering up his lease to the lessor miglit afford strong evidence of a surrender in fact; but certainly could not, on the principles to be gathered from the authorities, amount to a surrender by operation of law, which does not depend on intention at all. On all these grounds, we are of opinion that there was in this case no surrender by operation of law, and we should have considered the case as quite clear had it not been for some modern cases, to which we must now advert.

The first case, we believe, in which any intimation is given that there could be a surrender by act and operation of law by a demise from the reversioner to a stranger with the consent of the lessee, is that of Slone v. Whiting, 2 Stark. 236, in which Holroyd, J., intinates lis opinion that there could; but there was no decision, and he reserved the point. This was followed soon afterwards by Thomas $v$. Coolie, 2 Stark. 40S, 2 B. \& Ald. 119. That was an action of debt by a landlord against his tenant from year to year, under a parol demise. The defence was, that the defendant Cooke, the tenant, had put another person (Parkes) in possession, and that Thomas, the plaintiff, had, with the assent of Cooke, the defendant, accepted Parkes as his tenant, and that so the tenancy of Cooke had been determined. The Court of King's Bench held, that the tenancy was determined by act and operation of law.

It is matter of great regret that a case involving a question of so. much importance and nicety, should have been decided by refusing a motion for a new trial. Had the case been put into a train for more solenm argument, we cannot but think that many considerations might have been suggested, which would have led the Court to pause before they came to the decision at which they arrived. Mr. Justice Bayley, in his judgment says, the jury were right in finding that the original tenant assented, because, he says, it was clearly for his benefit, an observation which forcibly shows the uncertainty which the doctrine is calculated to create.

The acts in pais which bind parties by way of estoppel are but few, and are pointed out by Lord Coke. Co. Little. 352a. They are all acts which anciently really were, and in contemplation of law have always continued to be, acts of notoriety, not less formal and solemn than the execution of a deed, such as livery, entry, acceptance of an estate, and the like. Whether a party had or had not concurred in an act of this sort, was deened a matter which there could be no difficulty in ascer- 
taining, and then the legal consequences followed. But in what uncertainty and peril will titles be placed, if they are liable to be affected by such accidents as those alluded to by Mr. Justice Bayley. If the doctrine of Thomas v. Cooke should be extended, it may very much affect titles to long terms of years, mortgage terms, for instance, in which it frequently happens that there is a consent, express or implied, by the legal termor to a demise from the mortgagor to a third person. To hold that such a transaction could, under any circumstances, amount to a surrender by operation of law ${ }_{2}$ would be attended with most serious consequences.

The case of Thomas v. Cooke has been followed by others, and acted upon to a considerable extent. Whatever doubt, therefore, we might feel as to the propriety of the decision, that in such a case there was a surrender by act and operation of law, we should probably not have felt ourselves justified in overruling it. And, perhaps, the case itself, and others of the same description, might be supported upon the ground of the actual occupation by the landlord's new tenants, which would have the effect of eviction by the landlord himself in superseding the rent or compensation for use and occupation during the continuance of that occupation. But we feel fully warranted in not extending the doctrine of that case, which is open to so much doubt, especially as such a course might be attended with very mischievous consequences to the security of titles.

If, in compliance with these cases, we hold that there is a surrender by act and operation of law where the estates dealt with are corporeal and in possession, and of which demises may therefore be made by parol, or writing, and where there is an open and notorious shifting of the actual possession, it does not follow that we should adopt the same doctrine where reversions or incorporeal hereditaments are disposed of, which pass only by deed. With respect to these, we think we ought to abide by the ancient rules of the common law, which have not been broken in upon by any modern decision, for that of Walker v. Richardson, 2 M. \& W. S82, which has been much relied on in argument, is not to be considered as any authority in this respect, inasmuch as the distinction that the right to tolls lay in grant was never urged, and probably could not have been with success, as the leases, perhaps, passed the interest in the soil itself. Moreover, according to the report of that case, it would seem that the new lessees had, before they accepted their lease, become entitled to the old lease by an actual assignment from the old lessee. If this were so, then there could, of course, be no doubt but that the old lease was destroyed by the grant and acceptance of the new one. It is, however, right to say, that we belicve this statement to have crept into the report inadvertently, and that there was not, in fact, any such assignment. The result of our anxious consideration of this case is, that the verdict on the issues on the first plea and on the rejoinder to the replication to the fifth plea, must be 
entered for the defendants, and as those pleas go to the whole cause of action the judgment must be for them.

In the case, as it was originally stated, it did not appear that there had been any change of dean since the original denise in 1803 . We desired to have the case amended on this point, in order that the fact might appear, if the case should be turned into a special verdict. Eor during the incumbency of the dean, who made the lease for ninety-nine years, that lease would be good independently of the private act, and as the immediate reversion, on which the defendant's lease depended, was assigned to the dean by Barber and Parry previously to the demise of the 29th of January, 1814, that reversion undoubtedly passed to Osborn and Burt and would enable them, or the plaintiff claining under them, to sue for the rent solong as the estate of the same dean continued, whether the lease for ninety-nine years was or was not warranted by the act; and so the plaintiff might possibly have been entitled to judgment non obstante veredicto. It appears by the case as now amended, that the Bishop of I.incoln who was the dean granting the leases of ninety-nine years, ceased to be dean, and was succeeded by Dr. Van Mildert in October, 1820 , before any part of the rent sought to be recovered in this action had accrued due, and therefore no question on this head arises.

Neither will the second private act stated in the case aid the plaintiff. It appears that, in 1820 , the diffictilties in which the parties had involved themselves by neglecting to get a proper surrender of the lease of the 7 th of April, 1812, was brought under the consicleration of the Conrt of Chancery, in a suit there pending relative to the affairs of the Bowes family. Master Cox, by his report of the 15 th of February, 1820, staterl, that he was of opinion that both the leases of ninety-nine years were void, the first because it was made when the original term of forty years was outstanding in Barber and Parry, and the latter because at the time of its creation the lease of the 7 th of April, 1812, was still outstanding, thus showing clearly his opinion that nothing had happened to cause a surrender of that lease by operation of law; and he recommended that an act of Parliament should be obtained to remedy the defect. His report was afterwards confirmed, and the second act stated in the case was accordingly obtained. The act receiver the Royal assent on the 15th of July, 1820, and it was thereby enacted, that the lease of the 29th of January, 1814, should be valid to all intents and purposes; and further, that inmediately after the passing of the act, the leases of the 26th of December, 1803, the 7 th of April, 1812, and the 31st of August, 1812, should be void to all intents and purposes. The effect of this was to destroy altogether the reversion in respect of which the rent now sought to be recovered was payable, and it may therefore well be doubted whether, even if all the issues had been found for the plaintiff, he could have had judgment. It is, however, sufficient for us to say that the act certainly does not entithe the plaintiff, to any thing which he would not have been entitlea to 
if no such act had passed. More especially when it is considered, that, by the saving clause, the defendants are excepted out of the operation of the act. The result therefore is, that the verdict on the 1 st and 5 th issues must be entered for the defendant, and on the other issues for the plaintiff, and the judgment will be for the defendant.

Judgment for the defendant. ${ }^{33}$

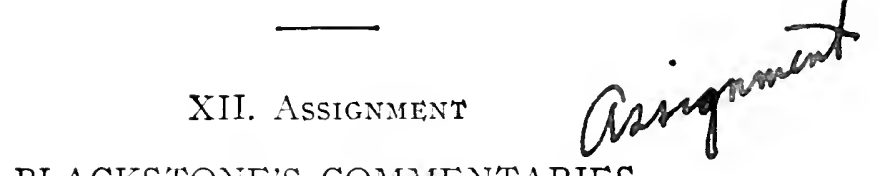

DLACKSTONE'S COMMENTARIES.

An assignment is properly a transfer, or making over to another, of the right one has in any estate; but it is ustually applied to an estate for life or years.

book 2, star p. 326.

XIII. DeFFASANCE

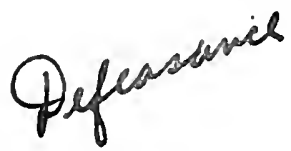

\section{DLACKSTONE:S COMMENTARIES.}

A defeasance is a collateraldeed, made at the same time with a feoffment or other converance, containing certain conditions, upon the performance of which the estate then created may be defeated or totally undene.

Book 2, star p. 327.

33 See 5 Irish Jurist, 117.

"In this case. the defembint hoing the lessee in possession of the premiscs, the plaintifi, lis landlord. With his consent, let them to a new tenant and gut hiu in dossesion. and discharad the defentant foom his liability as tenant. The judere who tried the case held that these farts constiluted a surrender by oberation of law, and therefore a detence anainst the plaintiff's clam for rent. The corjectness of that holding has been lironght into question before us in conseruence of the opinion exilressed by the court of lix-

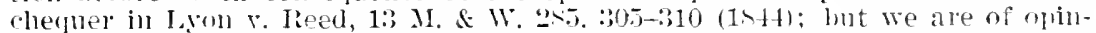
ion that it is correct. * * * Where there is an asreement to surrender a particular estate, and the possession is chanced accorlingly, it is mole luobable that the lesishature intenciol to give effect to an agleement so proved as a surrender by operation of law than to allow either party to defeat the agleement by alleging the absence of witten evidence. Althourh we do not assent to the observations ujon the line of cases, from Thomas r. Cook,

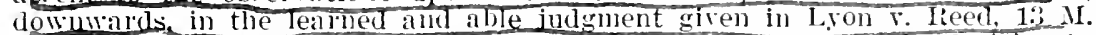
\& TI. $25 \overline{5}(15+7)$. Tre wish to express our entire concurtence in the decision bn that cuse," Lord "Denman, C. J., in Nekells r. Atlerstone, 10 Q. B. 94t (1s.77). See, also, Nallis r. Ilands, [1s9:3] 2 Ch. 75; Fenner v. Blake, [1900] L. R. 1 Q. B. 426 .

As to surrenders by operation of law acainst the intent of the parties, see, further. Van Reussalaer's Heirs r. I'enuman, 6 Wend. 509 (15:31); Smith $v$.

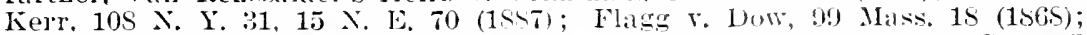
Thomas v. Kumbalen, 43 Mo. 471 (1St) ; Johmson s. Northern Trust Co., 265 11. 263,106 N. E. $81 \pm(191 t)$; U'Neil v. P'earse, 87 N. J. Law, 382, 94 Atl. :̈1:2 (1915). 
XIV. Devise

\section{LIT'TLETON'S TENURES.}

Also, in some boroughs, by the custom, a man may devise by his testament his lands and tenements, which he hath in fee simple within the same borough at the time of his death; and by force of such devise, he to whom such devise is made, after the death of the devisor, may enter into the tenements so to him devised, to have and to hold to him, after the form and effect of the devise, without any livery of seisin thereof to be made to him, \&c.

Section $167 . .^{34}$

\section{SECTION 2.-UNDER STATUTE OF USES}

\section{USIS REFORE THE STATUTE OF USES}

Shortly after the Norman conquest a practice began to grow up of making feoffments of lands to trusted friends to be held on behalf of the feoffer or a third person or to be disposed of as directed at the time of the conveyance or thereafter. ${ }^{35}$ Under such conveyances the legal ownership was of course in the feoffee, and in his hands was subject to all the burdens and incidents of the feudal land law, to avoid many of which it became common to make the conveyances to two or more as joint tenants. ${ }^{36}$ This method of disposition in its early use was resorted to in order that corporations, societies and individuals that were incapable under the law of owning land might have the benefit thereof ${ }^{37}$ Later it was availed of to secure the land to certain persons after the death of the feoffer or to such persons as he should nominate by his last will, and also as a means of avoiding forfeiture by reason of treason, etc. ${ }^{38}$

34 By the Statute of Wills (32 Hen. VIII, c. 1), power was given to every tenant in fee simple to dispose of all his lands held by socage tenure and of two-thirds of his lands held by knight-service The statute of 12 Car. II, c. 24 , which converted the tenure by knight-service into socage tenure, had the effect of making all lands of freehold tenure disposable by will. Further, on the history of the Taw of Wills, see Costigan's Cases on Wills, pp. 3-9.

There were other modes of conveyance by special custom, as in the case of copy hold lands. On this the student may well consult 2 Blackstone's Commentaries, c. 2'.

з5 2 P. \& M. Hist. Eng. Law (2d Ed.) 231. See the same, pp. 228-232, for an historical account of the origin and growth of "uses." See, also, Holmes in 1 I. Q. R. 162 et sec.

36 Williams, R. P. (220 E(1.) 170, 171; Leake, Prop. in Land, 80.

372 P. \& M. Hist. Eng. Law (2d Ed.) 231.

38 sinnders, Lises and Trusts, 16, 17. 
The person to whom the land was conveyed came to be called the "feoffee to uses," the person on whose behalf the land was held the "cestuique use," and the beneficial interest which the "cestui" had was known as the "use." This "use" was not in any sense ownership. On the contrary it distinctly was not ownership. ${ }^{30}$ The feoffee to uses was supposed to deal with the property as directed under the confidence in which the conveyance to him had been made and to allow the cestui que use to have the beneficial occupation of the land and to take the profits thereof. The cestui que use in possession with the consent of the holder of the legal estate, however, was in the position, so far as the common law courts were concerned, of a tenant at will, ${ }^{40}$ and a cestui que use out of possession in entering upon the land without consent could be proceeded against in those courts as a trespasser.

For many years after the practice of conveying land to uses liad become common there was no really effective way of compelling the feoffee to uses to observe the terms of the confidence, nor remedy against one who had proved unfaith ful. ${ }^{41}$ Some time during the reign of Edward III, however, it seems that the Chancellor, the head of the rapidly broadening Court of Chancery, began to entertain proceedings against such feoffees to compel their observance of the trust and the directions of the person on whose belialf they hell ${ }^{+2}$ During the time of Henry VI it was held that the heir of the feoffee to uses was subject in the chancery to the same duties as the feoffee himself, ${ }^{43}$ and only a little later the remedy was extended as against the transferee of the feoffee to uses who took as a volunteer or with notice. ${ }^{+4}$ Now that a really effective means of enforcing the terms of the trust was at hand, the custom of conveying lands to uses became even more popular, so popular in fact that Blackstone says that during the civil conmotions between the houses of Lancaster and York "uses grew almost universal." 45

After the jurisdiction of the Chancellor to enforce uses became well established and settled, gradually the use came to be considered the subject of ownership apart from the ownership of the land. Courts of law recognized still only the legal estates; to the law courts there

use is a trust or confidence reposed in some other, which is not issuint ont of the land, lunt as a thing collateral, annesed in privity to the estate of the land, and to the person touching the land, scilicet, thit cestui que use shatl take the plofit, and that the terre-tenant shall make an estate accorlins to his direction so as cestui que use has neither jus in re nol jus ad rem, Lut only a contidence and trust, for which he had no remedy by the common law, but for breach of trust his remedy was only by sibponil in chancery." Co. Litt. $272 \mathrm{~b}$.

\pm 0 Leake, Prop. in Land, 79 .

41 Jenks, A Short History of English Law, p. 97. In Williams, R. P. (22d Ed.) 171 , it is said that there was a remedy for breach of faith in the ecclesiastical courts. See Holmes in 1 L. Q. R. 162 et seq.

42 Keilw. 42, pl. 7, per Vavasour, J.

43 Id.

44 Iiurgess v. Wheate, 1 Eden, 177, 218 (1759), per Mansfield, C. J.

452 1:1. Comm. *329. 
could be no such interest as a "use." The "use" in equity thus became an equitable estate and equitable ownership therein was established. ${ }^{* 6}$

The "use" could be transferred, inherited, and devised, and the equitable ownership could be divicied up into equitable estates. It was possible to have in the "use" estates in fee simple, fee tail etc., in possession, or by way of remainder or reversion. ${ }^{4}$ The legal estates were restricted in their creation and conveyance by the demands of the law regarding the seisin, ${ }^{45}$ but these equitable estates were not subject to such restrictions, there being no seisin in the case of a "use." Accordingly an equitable estate of freehold could be provided for to arise in futuro. Such uses were known as springing uses. And it was possible to limit a use to a man and his heirs that should upon the happening of an event specified shift over to another person and his heirs. Such nses were known as shifting uses. Also uses could be devised by will, for no livery of seisin was required in the transfer of a use.

In case of the death of the cestrii que use intestate, the use was held to descend to his heirs according to the course of the common law. The equity courts allowed great latitude in the creation of equitable estates by purchase, bitt they did not allow the common law of descent to be varied even in the case of a use. ${ }^{49}$

46 \% 1 estates in nossession. remlinder, reversion estates descendible in this way or that." Mlaitland, Lquity, "̈̈.

$47 \mathrm{Id}$.

48 "A feofitment might be made with an express armomiation of the seisin to a series of estates in the form of particmal estate and remainders. and the livery to the immediate temant was then effectnal to transfer the seisin to or on belualf of all the temants in penainder. accoroing to the estates limited. lint future estates could only be limiter in the form of remiaimders, and any Iintations operating to slift the seisin othrowise than as demainders expectint mon the determination of the preceding estate were void at comuron law. Thus, ulon a feoffment, with livery of seisin, to A. for life or in tail, and nlon the determination of his estate to B., the futmre limitation takes effect as a remainder immediately exlectant upon A.'s estate. Sut upon a feoffunent to A. in tee or for life, and after one sear to $B$. in fee; or to A. in fee, and upon his mariage to $B$. in fee; or to $A$. in fee or for life, and upon B. paying A. a sum of moner to 1 . in fee.-the limitations sliting the soisin from $A$. to $B$. at the times and in the events specified. as they could not talie effect as re. mainders, were wholly vond at common law. Such limitations becane posisible in dealing with uses and in disposifions by will, as will appear hereaftel. The exigencies of tenure required that the seisin or immerliate fremold should never be in aberance, but that there should at all tines be a cenant invested with the seisin ready, on the one hand, to meet the claims of the lord for the duties and services of the temme, and, on the other lamm, to meet adverse claims to the seisin, and to preserve it for the surcessors in the title. 'This rule had important effects mon the creation of freehold estates: for it followed as an inmediate consequence of the rule, as also from the nature of the essential act of convesance by livery of seisin, that a grant of the freehola could not be made to commence at a futme time, learing the temanc racant during the inter.in. Is a conspruence or the same rule if a feoffuent were made to 1. for life and after lis death and one day atter to $B$. for life or in fee, the limitation to $B$. was roid, lecanse it wonld leave the frechold without a tent or in ibesance for a dis after the death of A." Leale, Prop. in Laid, 33.

49 Sugden's Gilbert on Lses, 26 et seq. 
In a use there was no such thing as dower or curtesy, ${ }^{50}$ and it could not be reached by creditors. ${ }^{11}$ Nor conld a use be forfeited for felony or treason. ${ }^{52}$ The conmon law incident's of tenure were not applicable to the use. It is not to be wondered that Bacon wrote: "A man, that had cause to sue for land, knew not against whom to bring his action or who was the owner of it. The wife was defrauded of her thirds; the husband of his curtesy; the lord of his warciship, relief, heriot, an 1 escheat; the creditor of his extent for debt; and the poor tenant of his lease." "To "Temedy these inconveniences abundance of statutes were provided, which made the lands liable to be extended by the creditors of the cestui que use (Stat. $50 \mathrm{Edw}$. III, c. 6; 2 Ric. II, sess. 2, c. 3; 19 Hen. VII, c. 15); made him liable to actions for waste (Stat. 11 Hen. V1, c. 5); established his conveyances and leases made without the concurrence of his feoffees (Stat. 1 Ric. III, c. 1); and gave the wardship of his heir, with certain other feudal perquisites (Stat. $4 \mathrm{Hen}$. VII, c. 17 ; 19 Hen. V1I, c. 15)." $5+$

These uses were created upon a common law converance, e. s. a g feoffment. and also independently of such a conveyance. A feofiment to A. and his heirs to the use of $\mathrm{L}$. and his heirs of course created a use in fee simple in B. So ccmmonly were conveyances made to hold to the use of the feoffer that it was presumed that the use was to remain in him." In such cases the use was said to result, and was known as a resulting use. This presumption could be rebutter by an express limitation of the use to designated parties; ${ }^{56}$ also by showing that consideration was given for the conveyance or that a consideration was expressed..$^{37}$ Relationship between ferffer and feofice was also sufficient to rebut the presumption of a resulting use. And the use could result in part, as in a feofiment to $\mathrm{A}$. and his heirs to the use of $\mathrm{A}$. for life. There the use is in A. for life, and the balance of the use in fee has resulted to feoffer. ${ }^{38}$ Consideration and recitals of consideration accordingly became very important in conveyancing.

50 Id. pp. 4s, 49.

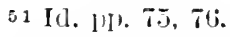

54 "2 131. Comm. *332.

os Reckwith's Case, 2 Co. 58a (15,5): Armstrong r. Wolsey, 2 Wils, 19 (1755).

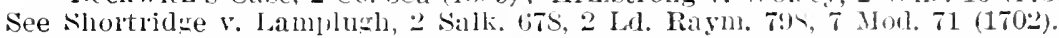

zo Stephen's Case, 1 Leon. 138 (15ss); Same's Case, 2 Roll. Alir. 791.

st l'orter's Case, 1 Co. $24 a$ (1592). See, generally, Sander's, Lses and Trusts, 60, 61. "If the feoffinent or conveyance of the legal possession be made for a particular estate only as a sift in tail, or a lease for life or for years, the tenure alone thereby created, with its attendant services and obligations, sur plied a consideration sufficient to prevent the use from resulting, and to carry it to the donee or lessee; and this doctrine alplies at the present day. But an express use declared in favor of another would rebut the use imillied from the temure in such cases." Leake, Prop. in Land, St.

s 8 Co. Litt. 271b; Sanders, Uses and Trusts, 101. And a consideration given or recited will be deented to be on account of the use expressly provided for. sanders, Tses and Trusts, 102. A feomment in fee to the use of the feoffor for life or vears will leave the use in fee in the feoffee, for to allow the undisposed of use to result would accomplish by merger a destruction of the use

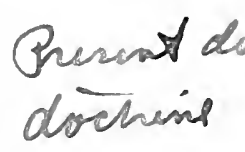


Uses arose indejendently of a common-law conveyance by an agreement of sale of the land supported by a valuable consideration. ${ }^{59}$ Also by a declaration or agreement in a writing under seal by the owner who was seised that he would thereafter "stand seised" for the benefit of some near relative. ${ }^{60}$ The former came to be known as a "bargain and sale," the latter as a "covenant to stand seised."

\section{THE STATUTE OF USES}

Where by the common laws of this realm, lands, tenements and hereditaments be not devisable by testament, nor ought to be transferred from one to another, but by solemn livery and seisin, matter of record, writing sufficient made bona fide, without covin or fraud; yet nevertheless divers and sundry imaginations, subtle inventions and practices have been used, whereby the hereditaments of this realm have been conveyed from one to another by fraudulent feoffments, fines, recoveries, and other assurances craftily made to secret uses, intents and trusts; and also by wills and testaments, sometime made by nude parolx and words, sometime by signs and tokens, and sometime by writing, and for the most part made by such persons as be visited with sickness, in their extreme agonies and pains, or at such time as they have scantly had any good memory or remembrance; at which times they being provoked by greedy and covetous persons lying in wait about them, do many times dispose indiscreetly and unadvisedly their lands and inheritances; by reason whereof, and by occasion of which fraudulent feoffments, fines, recoveries, and other like assurances to uses, confidences and trusts, divers and many heirs have been unjustly at sundry times disinherited, the lords have lost their wards, marriages, reliefs, harriots, escheats, aids pur fair fils chivalier \& pur file marier, and scantly any person can be certainly assured of any lands by them purchased, nor know surely against whom they shall use their actions or executions for their rights, titles and duties; also men married have lost their tenancies by the curtesy, women their dowers, manifest perjuries by trial of such secret wills and uses have been committed; the

for life or sears in the larger use in fee, which would manifestly be contrary to the intention. But it would be otherwise in case the feoffor should provide for the use to himself and the heirs of his body, for there a merger would be impossible. Dyer, $111 \mathrm{~b}$, in margill.

591 Co. Rep. 176a (15\&2-15St); Barker r. Keete, 1 Freem. 249,2 Vent. 35, 1 Mod. 262, 2 Mod. 249 (1677), where a rent of a peppercorn was deemed sufilcient to raise a use upon a bargain and sale.

60 Sharington v. Strotion, Plowd. 298 (1565). See Ricker v. Brown, 183 Mass. 424. 67 N. 1. 353 (1903). "But a covenant was not necessary; a declaratiou of intention made by deed poll would serve equally well (Slyep. I, 508); a mere larol promise was not sufficient (Collard r. Collard, Popl. 47, Serj. Moore's Rep. (ist, 2 Ander's. 6t [159:] ; Page v. Moulton, Dyer, 296a, pl. 22 [1570])." Challis R. P. (3d Ed.) $419,+20$. 
King's Highness hath lost the profits and advantages of the lands of persons attainted, and of the lands craftily put in feoffments to the uses of aliens born, and also the profits of waste for a year and a day of lands of felons attainted, and the lords their escheats thereof ; and many other inconveniences have happened and daily do increase among the King's subjects, to their great trouble and inquietness, and to the utter subversion of the ancient common laws of this realm; for the extirping and extinguishment of all such subtle practiced feoffments, fines, recoveries, abuses and errors heretofore used and accustoned in this realm, to the subversion of the good and ancient laws of the same, and to the intent that the King's Highness, or any other his subjects of this realm, shall not in any wise hereafter by any means or inventions be deceived, damaged or hurt, by reason of such trusts, uses or confidences: it may please the King's most royal majesty, That it may be enacted by his Highness, by the assent of the lords spiritual and temporal, and the conmons, in this present parliament assembled, and by the authority of the same, in manner and form following; that is to say, That where any person or persons stand or be seised, or at any time hereafter shall happen to be scised, of and in any honours, castles, manors, lands, tenements, rents, services, reversions, remainders or other hereditaments, to the use, confifence or trust of any other person or persons, or of any body politick, by reason of any bargain, sale, feoffment, fine, recovery, covenant, contract, agreement, will or otherwise, by any manner means whatsoever it be; that in every such case, all and every such person and persons, and bodies politick, that have or hereafter shall have any such use, confidence or trust, in fee simple, fee tail, for term of life or for years, or otherwise, or any use, cenfirdence or trust, in remainder or reverter, shall from henceforth stand and be seised, deemed and adjudged in lawful seisin, estate and possession of and in the same honours, castles, manors dands, tenements, rents, services, reversions, remainders, and hereditaments, with their appurtenances, to all intents, constructions and purposes in the law, of and in such like estates as they had or shall have in use, trust or confidence of or in the same; and that the estate, title, right and possession that was in stich persol or persons that were, or hereafter shall be seised of any lands, tenements or hereditaments, to the use, confidence or trust of any such person or persons, or of any body politick, be from henceforth clearly deemed and adjudged to be in him or them that have or hereafter shall have, such use, confidence or trust, after such quality, manner, form and condition as thej had before in or to the use, confidence or trust that was in them.

II. And be it further enacted by the authority aforesaid, That where divers and many persons, be or hereafter shall happen to be, jointly seised of and in any lands, tenements, rents, reversions, remainders or other hereditaments, to the use, confidence or trust of any of them that be so jointly seised, that in every such case that those person or persons which have or hereafter shall have any such use, confidence

\section{Statute of Uses:}

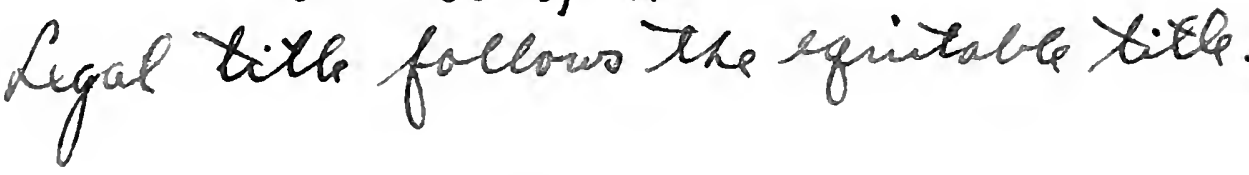


or trast in any such lands, tenements, rents, reversions, remainders or hereditaments, shall from henceforth have, and be deemed and adjudged to have only to him or them that have, or hereafter shall have any such use, confidence or trust, such estate, possession and seisin, of and in the same iands, tenements, rents, reversions, remainders and other herelitaments, in like nature, manner, form, condition and course as he or they had before in the use, confidence or trust of the same lands, tenements or hereditaments; saving and reserving to all and singular persons and bodies politick, their heirs and successors, other than those person or persons which be seised, or hereafter shall be seised, of any lands, tenements or hereditaments, to any use, confidence or trust, all such right, title, entry, interest, possession, rents and action, as they or any of them had, or might have had before the making of this act.

III. And also saving to all and singular those persons, and to their heirs, which be, or hereafter shall be seised to any use, all such former right, title, entry, interest, possession. rents, customs, services and action, as they or any of them might have had to his or their own proper 11se, in or to any manors, lands, tenements, rents or hereditaments, whercof they be, or hereafter shall be seised to any other use, as if this present act had never been had nor made; any thing contained in this act to the contrary notwithstanding.

IV. And where alco divers persons stand and be seised of and in any lands, tenements or hereditaments, in fee-simple or otherwise, to the use and intent that some other person or persons shall have and perceive yearly to them, and to his or their heirs, one annual rent of $x$. li. or more or less, out of the same lands and tenements, and some other person one other anmual rent, to him and his assigns for term of life or years, or for some other special time, according to such intent and use as hath been heretofore declared, limited and made thereof:

V. Be it therefore enacted by the authority aforesaid, That in every such case the same persons, their heirs and assigns, that have such use and interest, to have an 1 perceive any such annual rents out of any lands, tenements or hereditaments, that they and every of them, their heirs and assigns, be adjudged and deemed to be in possession and seisin of the same rent, of and in such like estate as they had in the title, interest or use of the said rent or prolit, and as if a sufficient grant, or other lawful conveyance had been made and executed to them, by such as were or shall be seised to the use or intent of any such rent to be had, made or paid, according to the very trust and intent thereof, and that all and every such person and persons as have, or hereafter shall have, any title, use and interest in or to any such rent or profit, shall lawfully distrain for non-payment of the said rent, and in their uwn names make avowries, or by their bailiffs or servants make conis-. ances and justifications, and have all other suits, entries and remedies for such rents, as if the same rents had been actually and really granted io them, with sufficient clauses of distress, re-entry, or otherwise, ac- 
cording to such conditions, pains, or other things limited and appointed, upon the trust and intent for payment or surety of such rent.

St. 27 Hen. VIII, c. $10 .{ }^{61}$

\section{Usts After Statute of Uses}

\section{(A) Uses Raised in Connection witi a Common-Law Convejance}

GREEN v. WISEMIAN.

(Court of Common Pleas, 1600. Owen S6.)

In an ejectment. The defendant pleaded that a feoffment was made to the use of J. S. the lessor of the defendant, who by force thereof, and of the statute, was seised, and made a lease to the defendant; and that one Green entered and made a lease to the flaintiff, and did not say that he entered upon J. S. And all the question was, whether when a feoffment is made to the use of another, if he have such a seisip before his eutry, whereof he may be disseisen.

Giavilu,. Ile hath no freehold, neither in deed nor in law before entry.

WaLMselay. This is contrary to all the books: for a possession in law is so translated from the feoffee to cestui que use, that the wife of the feoffec shall not be endowed.

OWE.N. He ought to have alleged a disseisin.

ANDERson. As he might have possession by force of a devise at common law, so he shall have possession of the land here by force of the statute, and it is in cestui que use, before agreement or entry, but if he disagree, then it shall be out of him presently but not before he disagree. And after viz. Hillar. 42 Filiz.

Williams moved the case again, and WALMSELEY said then, that he might be disseised before his entry or agreement, and the pleasling shall be that he did enter, and did disseise him, but he shall not have a trespass without actual entry for that is grounded on a possescion: GLANiLl agreed to this, and advised inilliams to adventure the case thereupon. ${ }^{62}$

"As to how far the Statute of rses is a part of the law of the American states, see 1 Perry on Trusts (tth Ed.) \$ 29 ?

62 See Heelis r. Blain, 1 C. B. (N. S.) 90 (1S64); Hadfield's Case, L. R. S C. P. 306 (1s72): Witham v. Brooner, G: Ill. $34 t$ (1572); Hutcilins v. Heywood, 50 N. H. 491 (1571).

In Egerton's Case, Cro. Jac. 525 (1619), it was held that a fine levied "to the use of the wife of J. S." gave to the wife an estate for life only. Lucas v. Brandreth, 28 Iear. 27.k (160); McElroy v. Salme, 113 Muss. 509 (1573); Selson v. Davis, 35 Ind. 474 (1571), ace.
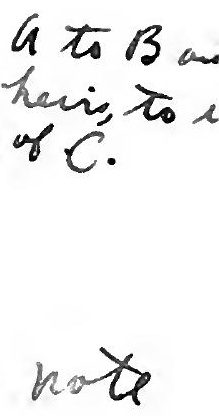


\title{
SHORTRIDGE v. LAMPLUGH.
}

\author{
(Court of King's Bench, 1702. 2 Salk. 678.)
}

$\mathrm{H}$. brought covenant as assignee of a reversion, and shewed, that the lessor, in consideration of $5 \%$. bargained and sold to him for a year, and afterwards released to him and his heirs, virtute quarundam indentur, bargainæ venditionis \& relaxationis necnon vigore statuti de usibus, \&c. he was seised in fee. And it was objected, that the use must be intended to be to the releasor and his heirs, because no consideration of the release nor express use appeared by the pleading; so that without considering the operation of the conveyance, the question was upon the pleading, Whether the use shall be intended to the releasor, unless it be averred to be to the releasee? Et per HoLT, C. J., to which the rest agreed.

This way of pleading was certainly good before the statute $27 \mathrm{H}$. 8 , so is Plowd. 478, and many precedents in Co. Ent. of feoffments averred in the same manner; for the use was a matter that was extrinsical to the decd, and depended upon collateral agreements at common law, and then the use might, as since the statute of frauds by writing, be averred by parol, and therefore in pleading the conveyance was taken to the use of him to whom the conveyance was made, till the contrary appeared; if it were otherwise, it ought to come on the other side; and $27 \mathrm{H}$. 8 has not altered the course of pleading, which is rather confirmed by the statute; because, if now the use be construed to be to the releasor or feoffor, the conveyance will be to no manner of purpose, it being still the old estate to which the old warranty and other qualities remain annexed; whereas before the statute there might be some end in making the feoffment, viz. to put the freehold out of him and prevent wardship; and Co. Lit. goes no farther, than where there is a feoffment to particular uses and estates, the residue of the use shall be to the feoffor, which is reasonable; for the raising those particular estates appears a sufficient reason for the conseyance. And Powts, J. doubted, whether there could be a resulting use on a lease and release, unless, where particular uses are limited; for this way of conveyance is grounded on the ancient way of releasing at common law, wherein there was a merger of estate, which is a good consideration, as where the lessor confirms to the lessee and his heirs. In error of a judgment of C. B. which was affirmed.

63 The case is also reported in $2 \mathrm{Ld}$. Raym. $79 \mathrm{~S}$, and in 7 Mod. 71. 


\section{ARMSTRONG v. WOLSEY.}

\section{(Court of Common Bench, 1756. 2 Wils. 19.)}

Ejectment tried at Norwich before Parker, Ch. Baron, who reserved this short case for the opinion of the Court. A. B. being in possession of the lands in question, levied a fine sur conusans de droit come ceo, \&c., with proclamations to the conusee and his heirs, in the 6th year of the present King, without any consideration expressed, and without declaring any use thereof: nor was it proved that the conusee was ever in possession.

So that the single question is, whether the fine shall enure to the use of the conusor or the conusee? And after two arguments, the Court was unanimous, and gave judgment for the plaintiff, who claimed as heir of the conusor.

CURIA-In the case of a fine come ceo, \&c., where no uses are declared, whether the conusor be in passession, or the fine be of a reversion, it shall enure to the old uses, and the conusor shall be in of the old use; and although it passes nothing, yet after five years and non-claim it will operate as a bar.

And in the case of a recovery suffered, the same shall enure to the use of him who suffers it, (who is commonly the vouchee,) if no uses be declared; but he gains a new estate to him and his heirs general; and although beiore the recovery he was seised ex parte materna, yet afterwards the estate will descend to his heirs ex parte paterna, as was determined in Martin v. Strachan, ante. (1 Vils. 2. 66.) Sed vide that case, 2 Stra. 1179.

In the case at Bar, the ancient use was in the conusor at the time of levring the fine; and it seems to have been long settled before this case, that a fine without any consideration, or uses thereof declared, shall enure to the ancient use in whomsoever it was at the time of levying the fine and as it was here in the conusor at that time, the judgerment must be for the plaintiff. ${ }^{64}$

\section{VAN DER VOLGEN v. YATES.}

(Court of Appeals of New York, 1853. 9 N. Y. 219.)

On the 27 th of April, 1790, Nicholas Van der Volgen owned a lot in Schenectady, the land out of which this controversy arose. On that day, by indenture of release reciting that the releasees were in possession of the premises "by virtue of a bargain and sale to them thereof made for one whole year, by indenture bearing date the day next be-

64 See Grey v. Grey, 2 Swans. 594, $59 S$ (167\%); Jackson v. Cleveland, 15 Mich. 94, $90 \mathrm{Am}$. Dec. $266(1866)$; Hlodgett $\mathrm{v}$. Hildreth, 103 Malss. 454 (1S70).

AIg.Prop. -16

$$
971.4 .219
$$

\section{Remenber that then is a consudention,}

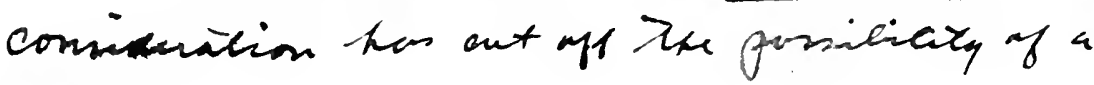


fore the day of the date of these presents, and by force of the statute for transferring uses into possession," and in consideration of $£ 100$. paid by the releasees, he released the premises to Robert Alexander and seven other persons named, of whom Joseph C. Tates, the original defendant in this action, was one, "and to their heirs and assigns forever." 'The deed then declared that the conveyance was "upon trust, nevertheless, to the only proper use, benefit and behoof of Cornelius Van Dyck," and twelve other persons named, "members of St. George's Lodge, in the town of Schenectady, and all others who at present are or hereafter may become members of the same, their survivors and successors forever, and to and for no other use, intent and purpose whatsocver." "Then follows a covenant for further assurance to the releasees, their heirs and assigns, "to and for the uses and purposes hereinbefore specified and more particularly mentioned;" and a covenant for the qiiet and peaceable possession of the releasees, their heirs and assigns, "for the uses and purposes aforesaid." No conveyance of the premises, subscquent to this, was ever made.

In 1797 Nicholas Van der Volgen died, leaving a will in which, not having specifically disposed of the reversion of the premises in question, he made Lawrence and Petrus Van der Volgen his residnary devisees. In 1819 Petrus died, having devised all his estate by will to Myndert Van der Volgen, Lawrence and Nyndert being thus the legal representatives of Nicholas in any devisable estate in the premises which he may have had at the time of his death.

In 1833 the act to incorporate the Utica and Schenectady Railroad Company was passed. Under its authority the company instituted proceedings to appropriate the lot in question to the use of the road. 'T'o these proceedings Lawrence and Myndert Van der Volgen, Joseph C. Yates, now the sole survivor of the releasees in the before mentioned conveyance, and certain persons claiming to be members of St. George's Lodge were made parties, all of the cestuis que use named in that instrument being dead. The commissioners awarded six cents to the two Van der Volgens, and $\$ 2755$ to Yates "as trustee under the release;" and the two former filed their bill in chancery against the latter to compel thic payment of the money to them as the representatives of the releasor, and entitied to the land or its proceeds. The rice-chancellor (Gridley) dismissed the bill, and this decree was affirmed by the chancellor (Wahworth). 3 Barb. Ch. 242. The complainants appealed to this court.

All the original parties to the action had died since the commencement of the sult, and their personal representatives were the present parties.

REGGLEs, Ch. I. In determining this case it will be assumed that the deed executed by Nicholas Van der Volgen to Robert Alexander and seven others for the use of Cornclius Van Dyck and twelve others, was a valid conveyance by lease and release, operating by force of the statute of uses, to rest in Lan Dyck and others who are specially nam- 
ed as cestuis que use, an estate for their joint lives and the life of the survivor, but not an estate in fee; and that the limitation of the further use to "all others who were then or thereafter might become members of St. George's Lodge, their survivors and successors forever," was void for uncertainty; and that the use of equitable interest thus attempted to be given to the members of the lodge not specially named, cannot be sustained cither as a legal estate by force of the statute of uses, or as an exccutory trust, or as a charitable use. Lipon these assumptions the only remaining question is whether upon the death of the last surviving cestui cule use the estate resulted back to the repre scntatives of the grantor, who are the complainants. If it did so, they are entitled to the money in controversy, otherwise not.

Before the statute of uses, and while uses were subjects of chancery jurisdiction exclusively, a use could not be raised by deed without a suficient consideration; a doctrine taken from the maxim of the civil law, ex nudo pacto non oritur actio. In conseguence of this rule the court of chancery would not compel the execution of a use, unless it had been raised for a good or valuable consideration; for that would be to enforce donum gratuitum. 1 Cruise, tit. xi, ch. 2, § 22. And where a man made a feofiment to another without any consideration, equity presumed that he neant it to the use of himedf; mintess he expressly declared it to be to the use of another, and then nothing was presumed contrary to his own expressions. 2 Bl. Com. 330 . If a person had conveyed his lands to another without consideration, or declaration of uses, the grantor becane entitied to the use or pernancy of the profits of the lands thus convered.

'This doctrine was not altered by the statute of uses. Therciore it became an established principle, that where the legal seizin or jossession of lands is transferred by any common law converance or assurance, and no use is expressly declared, nor any consideration or evience of intent to direct the use, such use shall result back to the original owner of the estate; for where there is neither consideration no. declaration of uses, nor any circumstance to show the intention of the parties, it cannot be supposed that the estate was intended to be given away. 1 Cruise, tit. ii. ch. $4, \S 20$.

But if a valuable consideration appears, equity will immediately raise a use correspondent to such consideration. 2 J31. Com., 330. And if in such case no use is expressly declared the person to whow the legal estate is conveyed, and from whom the consideration moved, will be entitled to the nse. The payment of the consideration lads the used unless it be expressly declared to some other person. The use results to the original owner where no consideration appears, becallse it cannot be supposed that the estate was intended to be given away; and by the same rule it will not result where a consideration has been paid, because in such case it cannot be supposed that the parties intended the land should go back to him who had been paid for it.

The statute of uses made no change in the equitalje principles which
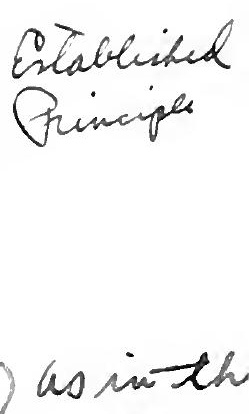

case. 
previously governed resulting uses. It united the legal and equitable estate, so that after the statute a conveyance of the use was a conveyance of the land: and the land will not result or revert to the original owner except where the use would have done so before the statute was passed. Cruise, tit. $x$, ch. $4, \S 20$.

It is still now, as it was before the statute, "the intention of the parties to be collected from the face of the deed that gives effect to resulting uses." 1 Sanders on Uses, 104 (Ed. of 1830).

As a general rule it is true that where the owner for a pecuniary consideration conveys lands to uses, expressly declaring a part of the 11se, but making no disposition of the residue, so much of the use as the owner does not dispose of remains in him. Cruise, tit. xi, ch. 4, § 21. For example, if an estate be conveyed for valuable consideration to fcoffees and their heirs to the use of them for their lives, the remainder of the use will result to the grantor. In such case the intent of the grantor to create a life estate only and to withhold the residue of the use is apparent on the face of the deed; the words of inheritance in the conveyance being effectual only for the purpose of serving the declared use. The consideration expressed in the conveyance is therefore deemed an equivalent only for the life estate. The residue of the use remains in or results to the grantor, because there was no grant of it, nor any intention to grant it, and because it has never been paid for.

But the general rule above stated is clearly inapplicable to a case in which the intention of the grantor, apparent on the face of the deed, is to lispose of the entire use, or in other words of his whole cstate in the land. Such is the case now before us for determination. The consideration expressed in Van der Volgen's dced was $£ 100$; and it is perfectly clear on the face of the conveyance that he intended to part with his whole title and interest in the land. He limited the use by the terms of his deed "to Cornelius Van Dyck and twelve other members of St. George's Lodge in the town of Schenectady, and all others who at present are, or hereafter may become members of the same, their survivors and successors forever." He attempted to convey the use and bencficial interest to the members of that lodge either as a corporate body, capable of taking by succession forever, or to that association for a charitable use or perpetuity. In either case, if the conveyance had taken effect according to the grantor's intention, it would have passed his whole title, and no part of the use could have resulted to him or his representatives.

Admitting that the declaration of the uses was void except as to the cestuis que use who were specially named, and good as to them only for life, yet it cannot be doubted that the parties believed when the deed was executed that the grantor conveyed his whole title in fee, and the intentions of the parties that the entire use and interest of the grantor should pass, is as clear as if the limitation of the whole use hat been ralid and effectual. This intent being established it follows, 
as a necessary consequence, that the sum of $£ 100$ consideration was paid and received as an equivalent for what was intended and supposed to have been conveyed, that is to say for an estate in fee. The express declaration of the use in the present case, instead of being presumptive evidence that the grantor did not intend to part with the use in fec, is conclusive evidence that he did so intend; and the extent of the express declaration is as much the measure of the consideration as if the whole of the declared use had been valid. The complainant's clain to the resulting use, or reversion of the land, being founded solely on the assumption that the grantor never was paid for it, must, therefore, $f$ ail because the assumption is disproved by the deed itself.

A use never results against the intent of the parties. "Where thene is any circumstance to show the intent of the parties to have been that the use should not result, it will remain in the persons to whom the legal estate is limited." 1 Cruise, tit. xi, Use, ch. 4, § 41 . In this case there are at least two such circumstances. They have already been alluded to ; first, the intent expressly declared to convey the land in fee or in perpetuity for the benefit of the members of St. George's Lodge. This effectually repels the idea of a resulting use. The two intents are incompatible. Secondly, the payment of the purchase money, of which enough has been already said.

If it be said that the express declaration is a presumptive proof that the grantor did not intend that the grantees of the legal estate should have that part of the use which was effectually declared, the answer is, that the express declaration is proof at least equally strong that he did not mean that the use should result to himself. Conceding then that the intention of the parties in regard to this residue of the use cannot be carried into effect, the equity which governs resulting uses settles the question between them. It gives the residue to the grantees because the grantor has had the money for it, and the language of the conveyance is sufficicnt to pass it. The grantor cannot have the purchase money and the land also. Payment of the purchase money for the entire title, vests the entire use in the grantees, excepting only so much of it as may be effectually declared for the benefit of some other person.

It was insisted on the argument that where an estate is conveyed for particular purposes or on particular trusts only, which by accident or otherwise cannot take effect, a trust will result to the original owner or his heir; and that the present case falls within that principle. We were referred on this point to Cruise, tit. Trust, ch. $1, \S 56$. But on looking at the cases cited by Mr. Cruise, they are found to be cases not of uses, but of active trusts; all excepting one created by devise, where of course no pecuniary consideration was paid, and the land therefore was not diverted from the heir-at-law on the failure of the trust. The case in which there was a conveyance in trust has no resemblance to the case now in hand. That the rule above cited from Cruise is inapplicable to the present case appears on Sir Edward Coke's author- 
246

DERIVATIVE TITLES

(Part 2

ity, in The Queen v. Porter, 1 Rep. 24, 26, that upon a feoffment made without consideration to charitable uses void by statute, the feoffee shoukl, notwithstanding the declaration of such uses, be seized to the feoffor and his heirs; but that if the feoffor had reserved but a penny rent, or had taken a penny in consideration of the feoffment, then, although the statute makes void the use expressed, yet the feoffee shall be seized to their own use and not to the use of the feoffor. This was said in the argument for the defendant Porter; and Coke, who was solicitor for the Queen, in a note at the end of the case, referring by a marginal note to this part of the argument, says: "And it is good policy upon every such feoffment (to charitable uses) to reserve a small rent to the feoffor and his heirs, or to express some such consideration of some small sum, for the cause before rehearsed." Thus it appears that upon a feoffment to a void use, upon a pecuniary consideration, however small, the title vests in the feoffee for his own benefit. The conveyance in the present case was by lease and release, which openate in this respect like a feoffment, and vested the estate, legal and equitable, in the releases, from and after the expiration of the valid use.

Whether they took this residue of the estate as tenants in common or as joint tenants is a question which does not arise in this case. It has been assumed that the use expressed in favor of the members of St. Georges Lodge, not specially named, was not valid as a charitable use. But it was not necessary to decide that question. The decision of this case must not be understood as settling any question as to the title to the money in controversy, except that no part of it belongs to the complainants.

Judges Mason, Morse, Johnson and Gardiner concurred in the foregoing opinion.

II millard and TaGGart, JJ., dissented.

Decree affirmed. ${ }^{65}$

65 Cf. McElroy v. McElroy, 118 Mass. 509 (1S73), where the case, as stated in the syllabus, was as follows: A, by deed of warmer, with covenants to the "grantee, his heirs and assigns," and in consideration of one dollar paid by 13. "(his brother), "trustee of" C. (another brother), and of "the love and alfectimon" he bore to C., conveyed a parcel of land to B., "it being ny intention" "to convey" to B., "in trust for" C." "to have and ho hold to the sild grantee, his heirs and assigns, to his and their use and behoof forever. It was herd that there was a resulting trust in the granter in the remainder after tole estate in C.

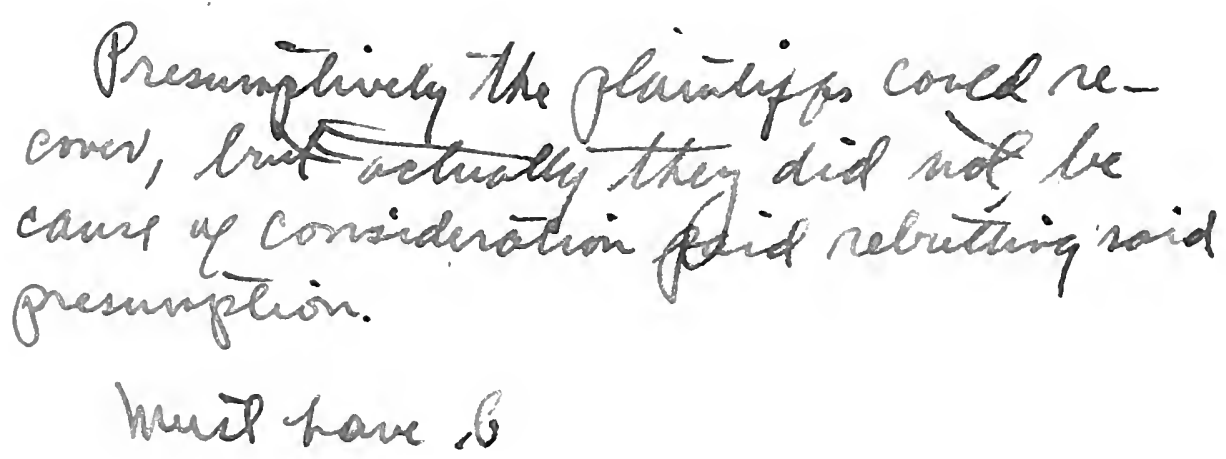




\section{(B) Uses Raised Independently of a Common Law Conveyance}

\section{THE STATUTE OF ENROLMENTS}

Be it enacted by the authority of this present Parliament, That from the last day of July, which shall be in the year of our Lord God 1536, no manors, lands, tenements or other hereditaments, shall pass, alter or change from one to another, whereby any estate of inheritance or freehold shall be made or take effect in any person or persons, or any use thereof to be made, by reason only of any bargain and sale thereof, except the same bargain and sale be made by writing indented sealed, and inrolled in one of the King's courts of record at Westminster, or eise within the same county or counties where the same manors, lands or tenements, so bargained and sold, lie or be, before the Custos Rotulorum and two justices of the peace, and the clerk of the peace of the same county or counties, or two of them at the least, whereof the clerk of the peace to be one; and the same enrolment to be had and made within six months next after the date of the same writings indented; the same Custos Rotulorum, or justices of the peace and clerk, taking for the enrolment of every such writing indented before them, where the land comprised in the same writing exceeds not the yearly value of forty slinlings, ii. s. that is to say, xij. d. to the justices, and xij. d. to the clerk; and for the enrolment of every such writing indented before them, wherein the land comprised excceds the sum of xl. s. in the yearly value, v. s. that is to say, ii. s. vi. d. to the said justices, and ii. s. vi. d. to the said clerk for the curolling of the same; and that the clerk of the peace for the time being, within every such county, shall sufficiently enroll and ingross in parchment the same deeds or writings indented as is aforesaid; and the rolls thereof at the end of every year shall deliver unto the said Custos Rotulorum of the same county for the time being, there to remain in the custody of the said Custos Rotulorum, for the time being, amongst other records of every of the same counties where any such enrolment shall be so made, to the intent that every party that hath to do therewith, may resort and see the effect and tenor of every such writing so enrolled.

II. Provided always, That this act, nor any thing therein contained. extend to any manner lands, tenements, or hereditaments, lying or being within any city, borough or town corporate within this realm, wherein the mayors, recorders, chamberlains, bailifts or other officer or officers have authority, or have lawfully used to enroll any evidences, deeds, or other writings within their precinct or limits; any thing in this act contained to the contrary notwithstanding.

St. 27 Hen. VIII, c. 16, (1536). 


\section{GREY \& EDWARDS CASE.}

(Court of King's Bench, 1577. 4 I.eon. 110.)

In an attaint by Grey against Edwards it was holden by Wray, "GAUDY, and JEOFFRIEs, that if one makes a deed, and that by these words (dedi) conveyeth lands to another, without any words of bargain and sale, and that for a sum of money; if the deed be debito modo enrolled, the use shall pass as well as if the words of bargain and sale had been in the deed, because that a sum of money was paid for the land.0

\section{LUTWICH v. MITTON.}

(Court of Wards, 1620. Cro. Jac. 604.)

It was resolved by the two Chief Justices, Montague and Hobart, and by TANFIELD, Chief Baron, that upon a deed of bargain and sale for years of lands whereof he himself is in possession, and the bargainee never entered; if afterwards the bargainors make a grant of the reversion (reciting this lease) expectant upon it to diverse uses that it is a good conveyance of the reversion; and the estate was executed and vested in the lessee for years by the statute; and was divided from the reversion, and not like to a lease for years at the common law; for in that case there is not any apparent lessee until he enters: but here, by operation of the statute, it absolutely and actually vests the estate in him, as the use, but not to have trespass without entry and actual possession: wherefore they would not permit this point to be further argued.

\section{JACKSON ex dem. HUDSON v. ALEXANDER.}

(Supreme Court of New York, 1S08. 3 Johns. 4S4, 3 Am. Dec. 517.)

This was an action of ejectment, for lot No. 68, in the town of Milton, in the county of Cayuga. The cause was tried before Mr. Justice Spencer, at the Cayuga circuit, on the 1st July, 1808. On the trial, the plaintiff gave in evidence an exemplification of a patent, dated the Sth July, 1790, granting the lot in question to Joseph Brown, for his military services, and a writing executed by Brown, in the following words :

"For value received of Daniel Hudson \& Co., I hereby make over and granit for myself, heirs, and executors, unto the said Daniel Hud-

86 Taylor v. Vale, Cro. Eliz. 166 (15S9), acc. 
son \& Co., his heirs and assigns, my right and claim on the public for 600 acres of land. Witness my hand and seal, thiis 7 th day of May, 1784 .

"In presence of

"Solomon Coures.

"John Dolson."

A verdict was taken for the plaintiff, subject to the opinion of the court, on a case containing the above facts; and it was agreed, that if the court should be of opinion, that the instrument in writing. from Brown to Hudson, one of the lessors of the plaintiff, was a sufficient conveyance of the premises in question, then judgment was to be eptered for the plaintiff; otherwise, the verdict was to be set aside, and a nonsuit entered.

The cause was submitted to the court without argument.

Thompson, J. This case has been submitted without argument, and the question presented for our decision is, whether the instrument in writing given by Joseph Brown to Daniel Hudson, be sufficient to convey the title to the premises in question. The want of any consideration either expressed on the face of the instrument, or proved at the trial, is the principal objection to its operation. All deeds by which land may be conveyed, derive their effect from the common law, or from the statute of uses. It cannot be pretended that this instrument can take effect as a common law conveyance, either original or derivative. 4 Cruise, on Real Property, 100. If it is to have any operation, it must be as a bargain and sale, by virtuc of the statute of uses. That statute has given rise to several new forms of conveyance, which operate contrary to the rules of the common lav. It is a gencral rule of the common law, that it is not absolutely necessary, that a consideration should be expressed in a deed. The thought and deliberation. which was supposed to attend the making and executing of deeds, rendered them valid, without any consideration expressed. Soon, however, after the chancellors had assumed a jurisdiction in cases of uses, they adopted the maxim of the civil law, "ex nudo pacto non oritur actio," and in conformity to it, they determined not to lend their aid to carry any deed into execution, unless it was supported by some consideration. 4 Cruise, 24 . Hence it has become a universal rule, that a use cannot be raised without a consideration; and a bargain and sale, being merely a conveyance of a use, it cannot be effectual without a consideration, which must be valuable, for the very name of the conveyance imports a quid pro quo. 1 Co. 176, a; Sanders on Uses, $340 ; 2$ Inst. $671 ; 4$ Cruise, 173-8. That a consideration is requisite to raise a use, is a principle recognized by almost every elementary writer on the subject; and has been repeatedly sanctioned by adjudged cases. The expression of Sir $\mathrm{W}$ m. Blackstone, (2 Comm. 296 ,) may be too broad when he says, that a deed or grant, made without any consideration, is of no effect, and is to be construed to enure, or be effectual only, to the use of the grantor; yet Professor Chris-

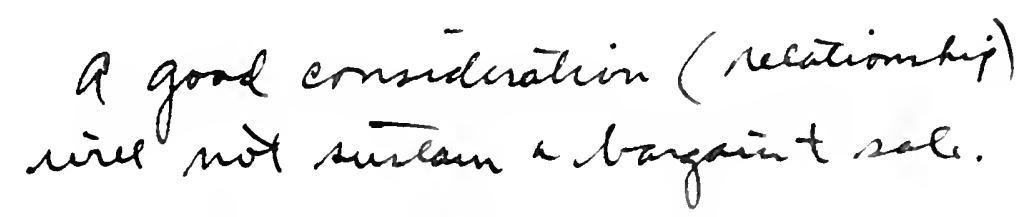


tian, in his note on this passage, admits this position to be true with respect to a bargain and sale. Baron Comyn, also, says, that a bargain and sale of land, whereby a use arises, ought to be made upon a valuable consideration, otherwise no use arises; and the consideration nust not be too general, but must import a quid pro quo. 2 Com. Dig. 6; 3 Conn. Dig. 275-7. We find the same principle recognized by the late editor of Bacon's Abridgment, (1 Bac. Abr. 469.) Shep. Touch. 220. It is there said, that by a bargain and sale of land no use arises, unless there be a consideration of money; for selling, ex vi termini, supposes the transferring a right of something, for money, and if there be no snch consideration, it may be an exchange, 3 covenant to stand seised, a grant, \&c., but can be no sale within the statute. The judgment of the court, in Mildnay's Case, 1 Coke, 176, was governed by the same principles; and in Doe ex dem. Milburn v. Salkeld, Willes, 675, Lord Ch. J. Willes, in delivering the opinion of the court, upon the nature and operation of a deed, set forth in the case, observes, it cannot be considered as a bargain and sale, because there was no money consideration.

In the case of Ward v. Lambert, Cro. Eliz. 394, the deed recited, "that whereas I. S. was bound in a recognizance, and other bonds for him, he, for divers good considerations, bargained and sold the land to him and his heirs; and this was held not to be a good hargain and sale. The court said, that in every bargain and sale there ought to be a quid pro quo; but the vendor there had notling for his land and, therefore, it was void. If a man give land, or bargain, and sell land to his son, no use arises thereby. If, then, a valuable consideration be necessary to raise a use, the next question will be, whether the instrument before us, upon the face of it, imports the consideration required in a bargain and sale, under the statute of uses. If it does, it must arise either from the internal force of the words "for value received," or by virtue of the seal. A valuable consideration is defined in the books, to mean money, or any other thing that bears a known value 4 Cruise, 24. This court, in the case of Lansing v. Mckillip, 3 Caines, 286, considered the words, for value reccived, of little force and importance of themselves, towards making out a consideration. Independently of that decision, however, I cannot discover more efficacy in these words than in many others which have been used in instruments, that have been adjudged inoperative as bargains and sales. All the cases I have cited to show the necessity of a consideration, plainly indicate, that if it is to be inferred from the face of the deed, it ought to be so expressed as neccssarily to muport value. It must not, in the language of Baron Comyn, be too general. It seems to me, that as much may be inferred from the word consideration as the word value. And it has repeatedly been adjudged, that an acknowledgment of the receipt of a consideration generally was not sufficient. Although this may have the semblance of a technical nicety, incompatible with the broad principles of justice, yet the rule appears 
to me to be too firmly established to be overturned. Many of the common law principles, applicable to other contracts, cannot be applied to bargains and sales under the statute of uses.

In Mildmay's Case, and also that of Ward v. Lambert, before referred to, the words, divers good considerations, were considered insufficient to raise a lise, being but general parlance, implying nothing, unless express considerations were shown; for otherwise none would be intended. So in Fisher v. Smith, 5 Vin. Abr. 406, note, the court were clear, that if one pleads a bargain and sale, in which no consideration of money is expressed, then he ought te supply it by an averment that it was for money; and that the words, for divers good considerations, shall not be intended for money, without an averment; but if the deed expresses, for a competent sum of money, it is sufficient, without showing the certainty of the sum; and none shall say that no moncy was paid; for against this express mention in the deed, no averment that $n o$ money was paid shall be admitted. In acknowledgment in the deed of the receipt of moncy, ex vi termini, imroorts value, and the amount of the consideration is inmaterial. It has been repeatedly rulcd that, if in pleading a bargain and sale, no valuable consideration is shown, it will be ill on demurrer. In many cases the verdict has been deemed to cure this defect, which must have been on the ground, that after verdict, the consideration is prestmed to have been proved on the trial. 1 Lord Raym. 111; 1 Wils. 91; 2 IL. Black. 261. Frum all the cases referred to it is erirlent that the court did not consider the seal, as virtually importing the requisite consideration; for the instruments, although under scal, were decmed inoperative, as bargains and sales. It would have been competent for the plaintiff, in the present case, to have proved a consicleration paid, (5 1 in. 507,) which, in my opinion, would have made the deed effectual to transfer the title; the word grant being sufficient to pass the land by way of use, (2 Mod. 253.) Under this view of the case, I should be inclined to grant a new trial, to give the plaintiff an opportunity of proslucing this proof, if in his power, without the expense of a new action; but according te the stipulation in the case, a judgment of nonsuit, in my opiniva, enghit to be entered.

KFNr, Ch. J. I am of opinion that the deed from Brown to Fiudson was sufficient to convey his interest in the premises.

I agree that the deed, if it operates at all, must operate as a bargain and sale under the statute of uses.

At the common law, a feoffment or lease was valid, without any consideration, in conscquence of the fealty or homage which was incident to every such conveyance. The law raised a consideration out of the tenure itself. But after the statute of Ouia Emintures (18 Ld. I,) Perkins says, that a consideration became requisite even to the validity of a feoffment, as none could be implicd, since, according to the statute no feudal duty or service resulted to the immediate feoffor, (Perkins, sects. 52S-537.) The general, and the better opinion is, that the no- 
tion of a consideration first came from the court of equity, where it was held necessary to raise a use ; and when conveyances to uses were introduced, the courts of law adopted the same idea, and held that a consideration was requisite in a deed of bargain and sale. This new principle in the doctrine of assurances by deed, met, at first, with a very strong resistance from the ablest lawyers of the age. Plowclen, in his argtment in the case of Sharington v. Stroffen, 1 Plowden, 308, 309, which arose upon a deed under the statute of uses, contended, with great force of reason and authority, that a decd, which was a solemn and deliberate act of the mind, did of itself import a consideration; that the will of the grantor was a sufficient consideration, and it never could be called a nudum pactum. Lord Bacon, in This reading on the statute of uses, takes notice of this argument of Plowden, and gives it the weight of his sanction. "I would have one case showed," said he, "by men learned in the law, where there is a deed, and yet there needs a consideration. As for parole, the law adjudgeth it too light to give an action without considcration; but a deed, even in law, imports a consideration, because of the deliberation and ceremony in the confection of it; and, therefore, in $\&$ Reginae, it is solemnly argued that a deed should raise a use without any other conIsideration." Bacon's Works, v. 4, p. 167. But notwithstanding this strenuous opposition, the rule from chancery prevailed, and it has been long settled, that a consideration, expressed or proved, was necessary to give effect to a deed of bargain and sale. I am not going to attempt to surmount the series of cases on this subject, though I confess myself a convert to the argument of Plowden. I admit the rule that a consideration is necessary to a conveyance to uses; but I think that here is evidence of a consideration, appearing on the face of the deed before us, sufficient to conclude the grantor, and to give effect to it as a bargain and sale.

The rule requiring a consideration to raise a use, has become merely nominal, and a matter of form; for if a sum of money be mentioned, it is never an inquiry whether it was actually paid, and the smallest sum possible is sufficient: nay, it has been solemnly adjudged, that a pepper-corn was sufficient to raise a use. 2 Vent. 35 . Since, then, the efficacy of the rule is so completely gone, we ought, in support of deeds, to construe the cases which have modified the rule, with the utmost liberality.

The deed in the present case states, that "for value received of the grantee, he doth grant," \&c., and can it now be permitted to the grantor to say there was no value received? Valuc received is equivalent to saying, money was received, or a chattel was received. It is an express averment, ex vi termini, of a quid pro quo. In Fisher v. Smith, Moore, 569, there was a bargain and sale for divers considerations, and it was held not to be enough, without an averment, that it was for money. "But if the deed express for a competent sum of money, this is sufficient without mentioning the certainty of the sum, 
and against this express mention in the deed, no averment or evidence shall be admitted to say that no money was paid." All the cases that I have examined, which say that a general consideration is not sufficient, are cases in which the words in the deed were for divers good considerations. I have not met with any case which goes so far as to say, that an averment in the deed of value received by the grantor. was not sufficient. It is said, in 2 Roll. Abr. 786, pl. $n$, that "an averment that a bargain and sale was in consideration of money or other valuable consideration given, was sufficient." If the words had been for money received by the grantor, then the deed would have fallen exactly within the decision in Moore, and woukl have been good, according to the admission in all the books. I cannot perceive any essential difference between the two averments; value received does, in judgment of law, imply money, or its equivalent. The grantor must be estopped by this express averment in his deed. He admits not only a value, but a value received from the grantee; and if we will not intend this value to be something valuable, or equal to a competent sum of money, we seem not to construe charters as they did in the case of Fisher v. Smith, and as the law axion requires them to be examined, benignly, and in support of the substance. 'The statute of 9 and $10 \mathrm{Wm}$. III, c. 17 , regards those words of so much import, that if a bill contains them, the holder is then entitied to recover interest and damages against the drawer and endorser; and in Cramlington v. Eivans, 1 Show. 4, Carth. 5, Lord Holt laid great stress on these words. "If the drawer," he says, "mention for value received, then he is chargeable at common law; but if no such mention is made, then must come upon the custom of merchants only." I mention these anthorities only to show that these words mean something; and that, in certain cases, at least, the law has attached the meaning of real actual value to the averment of value received, and that in those cases, it has been considered as equivalent to saying for money received.

The law from the beginning has been very indugent in helping out deeds, on the ground of consideration. If no consideration be expressed, one may be averred in pleading, or proved upon the trial. Nitdmay's Case, 1 Co. 175; Fisher v. Smith, Moore, 569. In pleading a bargain and sale, in which no consideration is expressed, it was held, in Smith v. Lane, Moore, 504, that the bargainee need not aver payment of money, because it was implied. 'This was afterwards held otherwise; but it has been lately held by the Court of C. B. (2 H. Black. 259) that this averment was but matter of form, and the omission of it cured, on a general demurrer. This last decision seems to have almost done away even the form of the old rule, for it can hardly be necessary to prove upon trial under the general issue, a fact which is matter of form, and not of substance. A plaintiff is bound to prove only what would be considered as material arerments, and matters which go to the substance of the action. 
But I place my opinion on the ground that the decd contains a sufficient averment of a consideration, to estop the grantor, and to give the deed operation under the statute of uses. I am not apprized of any case which is an authority against this conclusion. In Lansing v. McKillip, 3 Caines, 286, two of the judges intimated that value received did not supersede the necessity of averring and proving a consideration in a special agreement; but another of the judges went largely into the support of a contrary opinion. The case, however, was not decided upon that ground, but upon another, viz. that where the plaintiff alleges two good considerations in his declaration, he must prove them as laid.

The next point in the case is, whether the words, "make over and grant," be sufficient to convey Brown's interest in the land. The word grant has been held sufficient to pass land by way of use. 2 Nod. 253; T. Raym. 48. Though in its original meaning, the word applied only to a conveyance of incorporcal hereditaments, which could not pass by livery of scisin, yet in conveyances under the statute of uses, it is sufficient, if the granting words are competent to raise a tse; for the statute then performs the task of the ancient livery of seisin.

Iy opinion on both points, accordingly, is, that the plaintiff is entitled to jutlgment.

VAN NEss, J., and YATES, J., were of the same opinion. Judgment for the plaintiff. ${ }^{6}$.

67 The opinion of Spencer, J., to the same effect as the opinion of Thompson, J., is omitted.

In a deed the consideration was recited as "four thousand three bundred

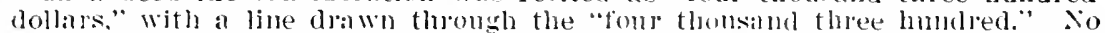
comsideration having been luoved, the question was whether the deed rould operate as one of bargain and sale. Catlin Coal Co. v. Lloyd, 1s0 Ill. 398, 54 N. F. ㄴ14. 72 Am. Nt. Rej. $216(1: 9))$.

"Wlenthe cousideration in a covenant to stand seised to uses, or in a bargain and sale. is good and the person certain. thele that person maly malie an averment that the consileuation was jaid, and aceoding to the trinth of The case; hat when the person is uncertain and the comsideration cemuev there no aremuent can be tilien by and jelson. In the first case the arernent by the barticnlar person is but reducing the general consideration to some certainfy, and maling out that in particular, in favou of the pers:m who was before inclufed in the generat wouls, which is very reasomal le, in case a good consideration Were hona file pajo by him; lut in the latter case the intent of the covenantor was roid ab initio. for it appearing that he desined nohody in particular, for the henefit of the use he would raise. no person in certain could aver any paticnlur consideration $\pi$ hy he shonld hare the use. becaluse it planing apjears by the deed he did not desinn him for the nse any more than any other person, and the law will not give a use to anviody contrary to the infent of the party mentioned in the settlement," etc. Gillert's Uses (S'vgden's Ld.) 419. see Mildmay's Case, 1 Co. 175 (15S2). 


\section{ROE ex dem. WILKINSON v. TRANMER.}

(Court of Common Pleats, 1757. 2 Wils. 75.)

Upon the trial of this cause it appeared in evidence, that Thomas Kirby, being seised in fee of the lands in question, made and executed certain deeds of lease and release. The lease, dated Norcmber 9, 1733 , made between the said 'Thomas Kirby of the one part, and Christopher Kirby his brother of the other part, whereby it is witnessed that the said Thomas Kirby, in consideration of 5s., did grant, bargain, and sell to the said C. Kirby, his executors, administrators, and assigns, the lands in curestion; to have and to hold the same minto the said C. Kirby, his executors, adninistrators, and assigns, from the day before the date thereof for the term of one year under a pepper-corn rent, to the intent that by virtue of these presents, and by force of the statute for transferring uses into possession, he the said Christopher may be in the actual possession of all the premises, and be enabled to take and accept of a grant, and release of the reversion and inheritance thereof to them and their heirs, to, for, and upon such uses, intents, and purposes, as in and by the said grant and release shall be directed er declared. In witness, \&c., executed by Thomas Kirby

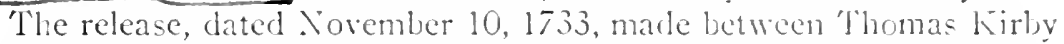
of the one part, and C. Kirby his brotler of the other part, witnesseth, that for the natmal love he beareth toward his sair brother, and for and in consideration of \pm 100 . to the said Thomas Kirby, naid by the said C. Kirby, he the said Thomas Kirby hath granted, released, and confirmed, and by these presents, doth grant, release, and confirm unto the said C. Kirby, in his actual possession the reof now being, by virtue of a hargan and sale for one whole year to him thereof made by the silid 'Thomas Kirby, by indenture dater the day next before the day of the date hereof, and by force of the statute marle for transferring of uses into possession, after the death of the said Thomas Kirby, all that one close, $\&$ c. (the prenises without any words of limitation to the releasee); to have and to hold the said premises unto the said C. Kirry and the heirs of his hody lawfully begotten, and after their derense to Thn Thikmson, eldest son of my well-beloved uncle John ll ilkinson of Yorth Dalton in the county of York, gentleman, to him and his heirs and assigns, and to the only proper use and behoof of lum the said John Wilkinson the Younger, his executors, administrators or.issigns forever, he the said John Wrilkinson the Younger baying or causing to be paid to the child or children of my well-beloved brother Stephen Kirby the sum of $E 200$; and for want of such ehild or children, then to the child or children of my well-beloved sister Jane Eirby; and for want of such issue, then to the younger chillen of my Well-beloved uncle, John Wilkinson, of North ISAtton aforesaid; and for want of such younger children, then the saicl estate above mentioned to be free from the payment of the above-named simn of $t 200$. 
Then the releasor covcnants that he is lawfully seised in fee, and that he hath good right and full power to convey the premises to the said C. Kirby and also that it may and shall be lawful to and for the said C. Kirby, or the said John Wilkinson the Younger, from and after the death of him the said Thomas Kirby, peaceably and quietly to have, hold, use, occupy, possess, and enjoy the said messuage, lands, and prenises, with the appurtenances, not only without the law ful let, suit, \&c. of him the said Thomas, but all others claining under him, \&c. free from all incumbrances. Then it is covenanted by all the parties, that all fines and recoveries, and dceds of the premises, levied, suffered, or executed by the parties or any of them, or by any other persons, shall be and enure to the use of the said C. Kirby and his heirs of his body lawfully begotten; and for want of such issue, then to the use of the said John VVilkinson Junior, his heirs and assigns for ever, according to the true intent of these presents. In witness, Ec. executed by Thomas Kirby.

It further appeared in evidence, that C. Kirby on the 10th of November 1733, paid to the said Thomas Kirby $£ 20$. in moncy, and gave him his note for $£ 80$. payable to the said Thomas Kirby, who signed a receint on the backside of the said deed of release in these words; viz. Received the day and year within written of the within named $\mathrm{C}$. Kirby the sum of one hundred pounds, being the full considerationmoney within mentioned to be paid to me. I say, received by me, Thomas Kirby. Witness M. J. S. T.

It further appeared in evidence, that C. Kirby died without issue in 1740, and that John Wilkinson the lessor of the plaintiff is the same John Wilkinson named in the deed of release; but it did not appear that the said John IVilkinson had notice of the said deeds of lease and release until a short time before this ejectment was brought.

This being the case for the consideration of the Court, the general

? question is, whether the lessor of the plaintiff las a title to recover upon the lease and release? ${ }^{68} * * *$

WiLLEs, C. I. It is admitted and agreed on all hands that this deed is void as a release because it is a grant of a freehold to commence in futuro; and therefore the only question is, whether it shall take effect as a covenant to stand seised to uses? and we are all of opinion that it shall (my Brother BATHURST, not being here, authorized me to say he is of the same opinion).

Many cases have been cited on both sides, some of which are very inconsistent with one another, and to mention them all would rather tend to puzzle and confound, than to illustrate the matter in question; and therefore I shall only take notice of those things we think most material, and of some few cases nearest in point for our judgment.

It appears from the cases upon this head, in general, that the judges have been astuti to carry the intent of the parties into execution, and to

68 A summary of the arguments of counsel given in Wilson's report is here omitted. 
give the most liberal and benign construction to deeds ut res magis valeat quam pereat. I rely much upon Sheppard's Touchstone of Common Assurances, 82, 83, (which is a most excellent book, where he says, when the intent is apparent to pass the land one way or another, there it may be good either way.

By the word intent is not meant the intent of the parties to pass the land by this or that particular kind of deed, or by any particular mode or form of conveyance, but an intent that the land shall pass at all events one way or other:

Lord Hobart, (who was a very great man,) in his Reports, fo. 277, says, "I exceedingly commend the Judges that are curious and almost subtil, astuti, to invent reason and means to make acts according to the just intent of the parties, and to avoid wrong and injury, which by rigid rules might be wrought out of the act;" and my Lord Hale in the case of Crossing and Scudamore, 1 Vent. 141, cites and approves of this passage in Hobart.

Although formerly, according to some of the old cases, the mode or form of a conveyance was held material, yet in later times, where the intent appears that the land shall pass, th has been ruled otherwise, and certainly it is more considerable to make the intent good in passing the estate, if by any legal means it may be done, than by considering the manner of passing it, to disappoint the intent and principal thing, which was to pass the land. Osman and Sheafe, 3 Lev. 370. Upon this ground we go.

We are all of opinion that in this case there is every thing necessary to make a good and effectual covenant to stand seised to uses. (Tiirst, here is a deed Secondly, here are apt words, the word grant alone would have been sufficient, but there are other words besides which are material; viz. a covenant that the grantor has power to grant, and a covenant that all fines, recoveries, \&c. of these lands shall enure to the uses in the deed. Thirdly? the covenantor was seised in fee. Fourthly, here appears a most plain intent that IVilkinson the lessor of the plaintiff should have the lands in case C. Kirby died without issue. And 4. lastly, here is a proper consideration to raise an use to the lessor of the plaintiff for the covenantor in the deed names him to be the eldest son $\mathbf{s}$ of his well-beloved uncle; these are all the circumstances necessary to make a good deed of covenant to stand seised to uses.

In support of their opinion the Chief Justice only cited and observed a deed . Opl wor
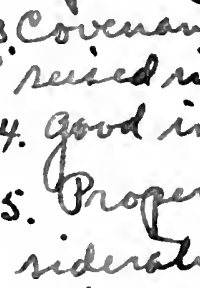
upon these cases, viz. Crossing and Scudamore, 1 Mod. 175, 2 Lev. 9, 1 Vent. 137; Walker and Hall, 2 Lev. 213; Coultman and Senhouse, Tho. Jones. 105, Carth. 38, 39; Baker v. Hil. 2 IV. \& M. B. R.; Osman and Sheafe, 3 Lev. 370.

The Chief Justice lastly cited two of the strongest cases mentioned for the defendants, as Hore and Dix, 1 Sid. 25, and Samoin and Jones, 2 Vent. 318, and said he did not (for his own part) understand them; and that if he had sat in judgment in those cases, he should have been 
of a different opinion in both; however, he said the present case differed from these two cases. Lastly, he said the whole court were clear of opinion that a man seised might covenant to stand seised to the use of another person after the covenantor's death. Postea delivered to the plaintiff. ${ }^{69}$

\section{MURRAY v. KERNEY.}

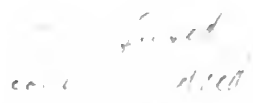

(Court of Appeals of Maryland, 1911. 115 Md. 514, 81 Atl. 6, 3S L. R. A. [N. S.] 9\%T.)

Pattison, J., delivered the opinion of the Court.

In this case the appellee, plaintiff below, filed his bill alleging that he was the owner, in fee simple, of a lot of land in Baltimore City, situated at the corner formed by the intersection of the west side of Central avenue and the southeast side of Gay street, that he had acquired from one Jane J. Murray by deed dated September 13th, 1905.

The bill alleges that Jane J. Murray acquired title to this property by written agreement executed on the $2 \mathrm{~d}$ day of December, 1885 , by the said Jane J. Murray and her three sisters who were at the time owners of said lands as tenants in common. The agreement was executed and acknowledged by them with all the formalities required in the execution and acknowledgment of deeds and was duly recorded, and is as follows:

"Ve, the undersigned, daughters of the late Peter and Elizabeth Murray, named and subscribed to this instrument of writing, do enter into an agreement that for the benefit of each and all of them named and subscribed to this agreement and are now living in and owners jointly the property being their joint interest left them, Lucy A. Nurray, Ann Murray, Sara A. Crawford and Jane J. Murray, as heirs of the above Peter and Elizabeth Murray, property situated on the southwest corner of Gay and Canal streets (now Central avenue); the object of this is that in case that if by death should take one of the parties, the other three sisters are the owners and if two are taken by death, then the two remaining sisters are the owners, and if by death one of the two sisters is taken then the last surviving sister is the owner and in order to carry faith fully this agreement, we hereunto set our hauds and seals and subscribe our names this second day of December, in the year eighteen bundred and eighty-five."

The bill further alleges that the three sisters all died in the lifetime

69 There have been many cases in which the courts have been astute to uphold a deed as operative in some manner. See chenes r. Matkins, 1 Har. I J. (1) $52 \pi, 2 \mathrm{Am}$. Dec. 5:30 (150t), sustaining as a feotionent a deed defective as a barsalu and sale for want of a jrojer consideration; l'ery r. Price, 1 .To. $565(1525)$, same; Havens $r$. Sea shole I.and Co., $4 \mathrm{~T}$ N. J. Eq. $365,20 \mathrm{~A}+1.497$ (1s90), sustaining as a harain and sale a converance in the words "remise, release and quitclaiw" rold as a l'elease hecalue the estalte was in expectancy; Iambert r. snith, 9 Or. 135 (1SS1); Field v. Colminet, 4 Sally. J25, Fed. Cas. No. $4,7(61$ (1ऽ6t). 
of Jane J. Murray, leaving her surviving them, the ovner, as it alleges, of said property under and by virtue of said agreement, and that she died on the 26th day of January, 1908. The bill also alleges that said property, for a long time prior to the acquisition of it by the plaintiff, was occupied by him and wa's in his possession at the time of the filing of the bill, That at the time of the death of the said Jane J. Murray, she was seized of the property adjoining the property so acquired by him, which was also embraced in the property mentioned and described in the agreement above mentioned, signed by the said Jane J. Murray and her sisters aforesaid, and which her heirs, after her death, agreed to sell to the North Gay Street Permanent Building and Loan Association of Baltimore City, but upon examination the purchaser was not satisfied with the title of Jane J. Murray thereto, its objection being based upon the sufficiency of the agreement above given to pass title to her in said lands, and proceedings were instituted in the Circuit Court for Baltimore City "for the sale of said property and the ratification of the contract of sale to the said corporation, which proceedings have long since been completed and the title of said adjoining property conveyed to the said corporation."

As the legal sufficiency of the title of Jane J. Murray in and to the lands sold as aforesaid had been questioned, the plaintiff thought it best, as he alleges, to have executed to him, by the licirs of Jane J. Iurray, a confirmatory deed for the property so conveyed unto him by her as aforesaid. To this end he called upon the hicirs to execute the confirmatory deed and all of them execuled the same except the defendants, who refused to do se It was then that he determined to file the bill asking the Court, as he did, to construe said agreement and by its decree "remove any cloud which might exist or be supposed to exist" upon his title to said lands.

The defendants Mary J. Murray and Villiam A. Murray answered, stating that as to the construction of the paper writing or agreement mentioned in the bill, and as to the relief prayed therein, they consented to and desired that the Court should pass such decree as to it might seem just and proper in the premises. The other defendants, James E. Murray and Thomas $F$. Murray, also answered neither admitting nor denying the things alleged in the bill, but requiring proof thereof.

To these answers the general replication was filed, and the testimony of the plaintiff alone was thercafter taken, which substantially sustains the allegations of the bill.

The question presented by this appeal is, did Jane I. Murray, the survivor of the sisters, who were, as it is conceded, at the time of the execution of the paper writing above set forth, the owners of said land involved in these proceedings as tenants in common, acquire their interest therein under and by virtue of such written agreement?

It is not difficult to ascertain the meaning of said paper writing. It was evidently the purpose and intention of the sisters that they should continue to own said property so long as all of them should live, and 
upon the death of any of them the three surviving sisters should be the owners of said property, and upon the death of the second sister the two surviving sisters should be the owners thereof, and upon the death of the third sister the surviving sister was to become the owner of the entire interest formerly held by the four sisters, or the owner of the property. But is this instrument of writing legally sufficiont to effect the purpose and meaning aforesaid? "Where the intent of the grantor to pass the land is apparent, if for any reason the deed or instrument by which the transfer of title was intended to be effected can not operate in the way contemplated by the parties, the Court, if possible, will give it effect in some other way, and judges have been very astute in such cases in their endeavors to make the conveyance operative one way or the other to carry into effect the intention of the grantor or donor." Bank of U. S. v. Housman, 6 Paige's Ch. (N. Y.) 534.

If for any of the reasons assigned by the appellant the instrument of writing mentioned in this case should be inoperative as a common law deed, we think that it is effective as a covenant to stand seized to uses under the Statute of Uses.

Blackstone defines a covenant to stand seized to uses as "A species of conveyance by which a man seized of lands, covenants in consideration of blood and marriage that he will stand seized of the same to the use of his child, wife or kinsman, for life, in tail, or in fee. But this conveyance can only operate when made upon such weighty and interlesting considerations as those of blood and marriage." Book 2, 338 .

"No particular word or form of words is necessary to constitute a 'covenant to stand seized.' The consideration is the chief requisite to characterize it and to support it as such a conveyance. This consideration is blood and marriage. If the consideration appears in a deed, though there be no express words of consideration, yet it is sufficient to raise a use by way of conveyance." Barry v. Shelby, 5 Tenn. (4 Hayw.) 229, 231.

Lord Coke, in treating the Statute of Uses, says: "The intention of the parties is the principal foundation of the creation of uses," and in Stay v. Mehan, 1 Lewt. 782, the Court says: "There is no covenant that admits of such a variety of words as that of a covenant to stand seized." Hayes v. Kershow, 1 Sandf. Ch. (N. Y.) 263.

The covenant must, of course, be by deed in order to constitute it a covenant; and the usual term employed in creating it is "covenant," though any other words may be adopted which are tantamount thereto. 2 Washburn on Real Property, § 1379.

The deed or instrument of writing that was before the Court in the case of Fisher v. Strickler, $10 \mathrm{~Pa} .348,51 \mathrm{Am}$. Dec. 48S, was as follows: "Now, know ye, that we, the said Jacob Strickler and Christian Strickler, have this day agreed with each other, that in case if one of them shall happen to die unnarried, or intermarried and without lawful issue or issues that should arrive to the age of twenty-one years, that then and in that case the survivor of them shall be the sole heir 
of the deceased one both to the real and personal estate of the deceased, without any further deed or conveyance; to hold the real estate as well as the personal estate of the deceased unto the survivor and to his heirs and assigns forever." The Court in adopting the opinion of the lower Court said: "The instrument of writing set forth in this case is what is technically called a covenant to stand seized to uses. The words are sufficient to create the covenant, the intention being apparent on the face of the deed, that each party should stand seized to the use of the other surviving him, under the circumstances stated. And the consideration of natural love, though not expressed, is manifest from the relation of the parties. Milbourn v. Salkeld, Nilles, 6/3; Dedell's Case, 7 Rep. 40; Crossing v. Scudamore, 1 Ventr. 137; 3 Cruise's Dig., Part. IV, 186-190."

In this case, as it is conceded, the four sisters were seized in fee, as tenants in common, of the lands in question, and being so seized executed the deed or agreement above set forth. Each was seized of ir one-fourth undivided interest in said land and by this cleed or instrument of writing each covenanted to stand seized of her interest therein to her use during her life and upon her death to the use of such of her sisters as survived her, successively to and including the last survivor, who became seized thereby, in fee, of the interest of all the sisters in said lands.

From what we have said we do not think the Court below erred in its ruling and will therefore affirm its decree.

Decree affirmed, with costs to the appellee.

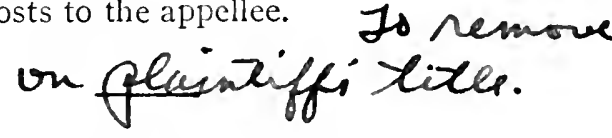

(C) Limitations Upon the Operation of the Statute of Uses

\section{TYRREL'S CASE.}

(Court of Wards, 1557. Dyer, 155.)

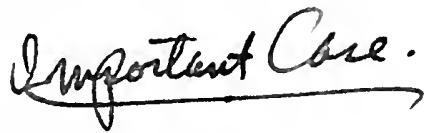

Jane Tyrrel, widow, for the sum of four hundred pounds paid by G. Tyrrel her son and heir apparent, by indenture enrolled in chancery in the 4th year of E. VI, bargained, sold, gave, granted, covenanted, and concluded to the said G. Tyrrel all her manors, lands, tenements, \&c., to have and to hold the said \&c. to the said G. T. and his heir for ever, to the use of the said Jane during her life, without impeachment of waste; and immediately after her decease to the use of the said G. T. and the heirs of his body lawfully begotten; and in default of such issue, to the use of the heirs of the said Jane for ever. Quæere well whether the limitation of those uses upon the habendum are not void and impertinent, because an use cannot be springing, drawn, or reserved out of an use, as appears prima facie? And here it ought to be first an use transferred to the rendee before that any freehold or inheritance in the land can be rested in him by the enrollment, \&c. 
And this case has been doubted in the Common Pleas before now: ideo quære legem. But all the Judges of C. B. and Saunders, Chief Justice, thought that the limitation of uses above is void, \&c. for suppose the statute of Inrollments (cap. 16.) had never been made, but only the statute of Uses, (cap. 10.) in 27. H. VIII, then the case above could not be, because an use cannot be engendered of an use, \&c. See M. 10 \& 11 Eliz. \& fol. ${ }^{70}$

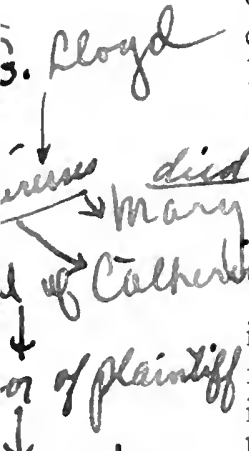

\section{4}

\section{DOE ex dem. LLOYD v. PASSINGHAM.} (Court of King's Bench, 1827. 6 Barn. \& C. 305.)

Ejectment for lands in the county of Merioneth. Plea, the general issue. At the trial before Burrough, J., at the last Summer Assizes for Salop, it appeared that the lessor of the plaintiff claimed as devisee in tail under the will of Catherine Lloyd, who was co-heiress, with her sistẹr Mary, of Giwn Lloyd, who died in 1774. In 1746, by indenture made between himself, G. Lloyd, of the first part, Sarah Hill of the second part, Sir Rowland Hill and John Wynne of the third part, and Sir Watkin Williams Wynne and Edward Lloyd of the fourth part; in consideration of an intended marriage with the said Sarah Hill, and of a sum of $£ 8000$., being the marriage portion of the said Sarah Hill, paid or secured to be paid to him Giwn Lloyd, he, Giwn Lloyd, did grant, release, and confirm unto the said Sir Watkin Williams Wynne and Edward Lloyd in their actual possession then being, by virtue of an indenture of bargain and sale, \&c., and to their heirs and assigns, certan premises therein particularly described, and, amongst others, the premises in question; to have and to hold the said premises with their appurtenances, unto the said Sir Watkin Williams Wynne and Edward Lloyd, their heirs and assigns; to the only proper use and behoof of them the said Sir Watkin Williams Wynne and Edward Lloyd, their heirs and assigns for ever, upon trust, nevertheless, and subject to the several uses, intents, and purposes thereinafter mentioned, that is to say, to the use of the said Giwn Lloyd and his heirs until the said intended marriage should take effect, and from and after the solemnization of the said intended marriage, then to the use and behoof of Giwn Lloyd and Sarah his intended wife, and their assigns, for and during the term of their natural lives, and the longer liver of them, as and for her jointure and in lieu and full satisfaction of dower; and from and after the decease of such survivor to the use of Sir Rowland Hill and John Wynne, their executors, administrators, assigns, for the term of 1000 years, to and for the several intents and purposes thereinafter mentioned; and from and after the expiration or other sooner determination of that estate, to the use

70 See Sambach v. Dalton, Tothill, $18 S$ (1634); Jackson v. Cary, 16 Johns. (N. Y.) 804 (1819) ; Reid $r$ Gordon, 35 Ald. 183 (18i:-); Croxall v. Shererd, 5 Wall. 268,18 L. Ed. 572 (1S66). 
and behoof of the first son of the body of the said Giwn Iloyd on the body of the said Sarah Hill, his intended wife, lawfully to be begotten, and the heirs male of the body of such first son lawfully issuing; and for default of such issue, to the use and behoof of the second son in like manner; and then to the daughters; and for default of such issue, to the use and behoof of the said Giwn Lloyd, his heirs and assigns for ever. And it was thereby declared and agreed by and between all and every the said parties to the said indenture, that the term of 1000 years thereinbefore limited to Sir Rowland Hill and John Wynne, was upon trust that they did and should immediately after the decease of Giwn Lloyd, by sale or mortgane of the whole or any part thereof, raise the swm of $\$ 3000$. to be paid and applied in manner therenafter mentioned. And it was thercby declared and agreed by and between the parties to the said indenture that a sum of $f+000$. of the said sum of $£ 8000$. should immediately after the solemnization of the said intended marriage be paid into the hands of them the said Sir Rowland Hill and John IVynne, "pon trust that the same should be paid, laid out, and applied by them with all convenient speed in the purchase of freehold lands, tenements, or hereditaments in fee simple, in the county of Nerioneth aforesaid or elsewhere in the principality of Wales, or in that part of Great Britain called England, with the approbation of them the said Giwn Lloyd and Sarah Hill, his intended wife, or the survivor of them, testified by any deed or writing under the hands and seals of them the said Giwn Lloyd and Sarah Hill, and the survivor of them, duly executed in the presence of two or more credible witnesses; and that the said lands, tenements, and hereditaments, when so purchased, and every part and parcel thereof, with their appurtenances, should be conveyed to them the said Sir Watkin Willians Wyane and Edward Lleyd, and their heirs, and to the survivor of them and his heirs, to and for the use and behoof of the several persons, and for such estate and estates as the premises thereinbefore mentioned, and thereby granted and released by the said Giwn Lloyd were conveyed, settled, limited, and appointed. And it was thereby also further declared and agreed that in case there should be no issue of the said intended marriage and that the said Sarah Hill should be minded by her last will and testament to give or devise any sum not exceeding $£ 4000$. or the estate thereby intended to be purchased therewith, or any part thereof as aforesaid, to any person or persons whatsoever, it should be lawful to and for her the said Sarah Hill, notwithstanding her coverture, to give and devise the same, or any part thereof, to such person or persons, and to and for such estate and estates, and such uses, intents, and purposes, as she should limit, direct and appoint: and in such case they the said Sir Watkin Williams Wynne and Edward Lloyd should stand seised of all and every the lands, tenements, and hereditaments so to be purchased as aforesaid, to them and their heirs, to and for such uses, intents, and purposes, as she the said Sarah Hill should, by such her last will, 
limit, direct, and appoint; and then and from thenceforth all and every the uses and limitations to the said Giwn Lloyd and his heirs, of and concerning the said lands, tenements, and hereditaments to be purchased as aforesaid, should cease, determine, and be absolutely void, to all intents and purposes whatsoever.

Giwn Lloyd died in 1774, and Sarah his wife in 1782, intestate, and withont having had any issue. Catherine Lloyd, the testatrix, continued in possession of the estate from the death of Sarah Lloyd until the time of her own death, in 1787. For the defendants, it was contended, that the legal estate was vested in Sir W. W. Wymne and Edward Lloyd, by the deed of 1746, and consequently, that neither Giwn Lloyd nor the testatrix had any legal estate; and, therefore, the lessor of the plaintiff could not derive any such estate from her. The learned Judge reserved the point, and the plaintiff having obtained a verdict, a rule nisi for entering a nonsuit was granted in Michaelmas term.

BAYLEY, J. I am of opinion that we ought not to makc the rule absolute for entering a nonsuit, but that there should be a new trial in this case. Considering the length of time that has elapsed since the purposes of the settlement made by Giwn Lloyd were at an end, I think the question as to presuming a reconveyance of the legal estate ought to be submitted to a jury. The first point for our consideration is upon the construction of the settlement: for if it vested the legal estate in the trustees, then the lessor of the plaintiff had not the legal estate unless there had been a reconveyance. The limitation is to Sir W. W. Wynne and E. Lloyd, and to their heirs and assigns, habendum to them their heirs and assigns, to the only proper use and behoof of them their heirs and assigns upon certain trusts. I felt upon first reading it, that this was in a very singular form, and it appeared to me that the words "To the use and behoof of them their heirs and assigns," had been introduced by an accidental mistake, but I now think that they were introduced by design, but through ignorance. It is certainly singular that Giwn Lloyd should part with the legal estate immediately on the execution of the settlement, and that he and his wife should only be equitable tenants for life. It is also singular that the term created for the purpose of raising portions should be a mere equitable term, and that the lands to be purchased with the $£ 4000$. should be limited in such a manner as to leave it doubtful whether or no the cestui que trust would take the legal estate. That would not necessarily be the case, for the direction, that the estate purchased should be limited "for such estate and estates," as the other premises, might mean for equitable estates; and, therefore, this is not absolutely inconsistent with the idea that the trustees were to take the legal estate. And on the other hand, the power which Giwn Lloyd and his wife would have had to defeat all the contingent limitations, if the trustees did not take the legal estate, shows so strong a purpose to be answered by construing the deed according to the strict legal opera- 
tion of the language used, that I think we are not at liberty to put any other construction upon the words than that which they usually bear. Now, ever since I have belonged to the profession of the law, I have invariably understood that an use cannot be limited upon an use. That is admitted to be so in general, but a distinction has been taken where the limitation is to A., to the use of A. in trust for B. and it is said that then $\mathrm{A}$. is in by the common law. That is true: but he is in of the estate clothed with the use, which is not extinguished, but remains in him. In the case of Meredith v. Jones, cited in argitment to show that where an estate is limited to A., to the use of $A$., he is in by the common law, it is said, "For it is not an use divided from the estate, as where it is limited to a stranger, but the use and the estate go together." That case therefore shows, that although the trustees in this case might be in by the common law, yet they were in both of the estate and the use. There are two cases expressly in point. Lady Thetstone v. Bury is a very clear case, and the words used were preciscly the same as those found in the deed in question, and it was there decided, and also in The Attorney General v. Scott, which came before Lord 'Talbot, one of the greatest real property lawyer that ever filled the office of Lord Chancellor, that the legal estate vests in him to whom by the words of the instrument the use is limited. Upon the authority of these two cases, I am of opinion that the use of the estate in gulestion was executed in the trustecs. Then, upon the other question there is certainly some grome for presuming a reconveyance; but, on the one hand, I think the Court would be going a great deal too far were they to make such a presumption, and, on the other, I think the lessor of the plaintiff ought to have an owportunity of submitting that point to a jury. The rule should, therefore, be made absolute for a new trial.

Holroyd, J. I agree with my brother Bayley, that in this case there ought to be a new trial. Upon the first perusal of the deed in question I had no doubt that the legal estate was vested in the trustecs, having always understood that an use cannot be limited upon an use; and althongh I was struck by the ingenuity of the distinction pointed out by Mr. Taunton, yet upon further consideration it appears to me that his argument does not warrant it. The argument is, that as the trustees did not in the first instance take to the use of another, but of themselves, they were in by the common law, and not the statute: that the first use was, therefore, of no effect, and the case was to be considered as if the decd had merely contained the second linitation to uses. But that is not so, for although it be true that the trustees take the seisin by the common law, and not by the statute, yet they take that seisin to the use of themsclics, and not to the use of another, in which case alone the use is executed by the statute. They are, therefore, seised in trust for another, and the lesal estate remains in them. As to the question of intention, even if it were intended that the deed should operate in a different mode from that pointed ont by the law,

\section{wse}

a
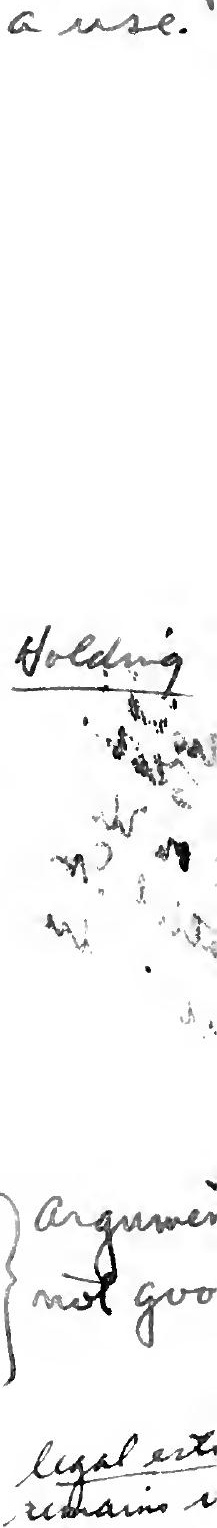

turstes. 
when the legal estate is given to trustees, that intention cannot countervail the law. But the intention appears to me altogether doubtful; the absence of trustees to preserve contingent remainders affording a strong reason for supposing that the parties meant to give the legal estate to the trustees.

LITTLEDALE, J. I am entirely of the same opinion. It is said, that by the construction now put upon the deed the intent of the parties will be defeated. If we were not construing a deed, I should feel disposed to give a liberal effect to the intention, but if all matters of convenience and inconvenience which raise a presumption of intention are to be taken into consideration, as affording rules for the construction of deeds, and are to have the effect of overruling the plain words of such instruments, the law will very soon be thrown into utter confusion. Here, however, there is a balance of inconveniences, and therefore we may come at once to the legal construction of the settlement. I never entertained a doubt that a second series of uses could not be executed. It is true, that certain cases shew these trustees to have taken the estate by the common law, but they took it coupled with the use. The cases cited upon this point are perfectly clear, and they are well collected in a note, by Serjt. Williams, to Tefferson v. Morton, 2 Saund. 11, n. (17). However for the reasons given, I think that there ought not to be a nonsuit, but a new trial.

Rule absolute for a new trial.

\section{URE v. URE.}

(Supreme Court of Illinois, 1900. 185 Ill. 216, 56 N. E. 10S7.)

BogGs, J. The chancellor entered the decree here appealed from on the theory the trust created by the second clause of the will of Margaret Ure, deceased, was a passive or dry trust, and that the Statute of Uses instantly operated to vest the legal title to the real estate in the cestui que trust. Whether such is the true construction of the clause

$?$ is the only question presented by the record. The clause reads as fol- lows:

"Second-After the payment of such funeral expenses and debts, I give, devise and bequeath to my son John Francis Ure all my couvs, bulls and calves, except one cow and my horses Rosy, Jessie and Doll, and the remainder of my real and personal estate equally to my two sons, Robert Arnold Ure and John Francis Ure: Provided, however, that the portion of my estate that I hereby give, devise and bequeath to my son Robert Arnold Ure shall be held by a trustee, and said trustee to be the executor of this my will hereinafter named, to hold and control said property for said Robert Arnold Ure in trust, he, the said Robert Arnold Ure, to have the income, only, from said estate to his own use and benefit as long as he may live, and on his death said estate to revert to his natural heirs," etc.

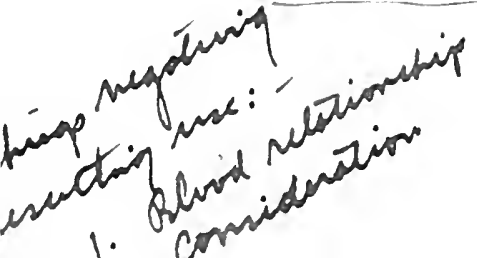


The trust estate, as appears from the will, consisted of both real and personal property. The Statute of Uses has no application to personal property, and the title to that portion of the trust property was not affected by that statute. $27 \mathrm{Am}$. \& Eng. Ency. of Law, p. 111, and cases cited in note $1 ; 3$ Jarman on Wills, p. 51, note 2. Speaking of the rule of construction adopted in some instances when a trust estate consists in part of property the fee whereof necessarily vests in the trustee, it is said in Jarman on Wills, (vol. 3, p. 85, 5 th Am. Ed.): "It seems that where a will is so expressed as to leave it doubtful whether the testator intended the trustee to take the fee or not, the circumstance that there is included in the same devise other property which necessarily vests in the trustee for the whole of the testator's interest affords it ground for giving the will the same construction as to the estate in question."

The income of the estate, both personal and real, is bequeathed to said Robert Arnold Ure during his lifetime and the remainder in fee devised to his "natural heirs." "The trustee is empowered to "hold and control" the property in trust, etc., and these words measure and fix the duties of the trustee. The word "hold," which was a technical word as employed formerly in the tenendum clause of a deed, has now no technical meaning when used in such instrunents. Hotrvier's Law Dic. "Tenendum"; Whecler v. County of 11 ayne, 132 Ill. 599, $2+\mathrm{N}$. E. 625. Among others, the following definitions of the word "hold" are given by $M \mathrm{r}$. Mebster: "To derive title to; to retain in one's keeping; to be in possession of: te occupy: 20 maintain authority over." The word "control" has no legal or tecluical meaning distinct from that given in its popular acceptation. Nebster employs the word "superintendence" as expressive of the meaning of the word "control," and gives the word "control" as one of the synonyms of the word "superintendence." The same lexicographer defines the word "superintendence" as follows: "The act of superintending; care and oversight for the purpose of direction and with authority to direct." The word "manage" is defined to mean "to direct; control ; govern; administer; oversee;" (Anderson's Law Dic.) ; and the words "control" and "manage" have been held to be synonymous. (Youngworth v. Jewell, $15 \mathrm{Nev}$. 48.)

Power to hodd and the duty to control the trust estate involve the custody and possession of the trust property, both real and personal, and such a trust is not merely passive. It is not indispensable to the power and duty of a trustee to r $7 \mathrm{~A}$ the trust property and collect the rent thereon, the devise shall in fxpress terms so empower him. It is enough if the intent to invest $1 \mathrm{~mm}$ with such power can be gathered from the will. 3 Jarman on W/lls (5th Am. Ed.) p. 56 . It was manifestly the intention of the maker of the will here under consideration, the executor, as trustee, shoukd enter into and retain possession of the trust estate during the lifetime of the said Robert Arnold Ure, and should diligently dexote his energy, judgment and discretion to the management and control of the property, to the end that the greatest

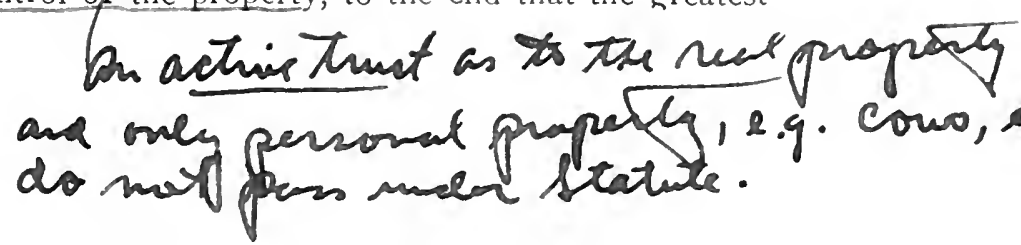


possible income should be secured therefrom. The Statute of Uses does not execute a trust of this character. Meacham v. Steele, 93 Ill. 135; Kirkland v. Cox, 94 111. 400; Kellogg v. Hale, 108 I1l. 164.

The decree must be reversed, and the cause will be remanded for further proceedings in accordance with the views here expressed. Reversed and remanded. ${ }^{71}$

\section{SECTION 3.-UNDER MODERN STATUTES}

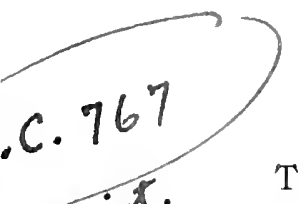

\section{ABBOTT v. HOLIVAY.}

(Supreme Judicial Court of Maine, 1881. 72 Me. 298.)

This is an action on the case for waste. The writ is dated September 28th, 1878 .

The plea is the general issue and brief statement denying the plaintiff's title and claim.

At the trial it was admitted that James Abhott was, on the 30th of April, 1872, and long had been, the husband of the plaintiff; that he died May 5th, 1875; that the defendant is the administrator on his estate; that he owned, on the 30th of April, 1872, and long had owned, the premises described in the writ, a valuable farm in Pittston, upon which was a large timber and wood lot; that he continued to live on the farm with his wife managing and taking the crops thereof until his death, she now surviving him; that in the winter and spring of 1875 , without the consent and against the remonstrance of the plaintiff, he caused to be cut and hauled to market, a quantity of mill logs, cut for that purpose, and not for fencing or repairs.

Since Abbott's death, his administrator has sold the lumber made from the $\log _{\mathrm{s}}$ and received the money therefor.

The plaintiff put in evidence the deed from James Abbott to her, dated April 30th, 1872, embracing the premises described in the writ and upon which the alleged waste was committed, and proved its execution and delivery on the day of its date, and its record in the Kennebec registry on the same day by plaintiff's procurement. It is made part of the case.

71 A tract of land was conveyed to $\mathrm{H}$. upon the following uses and trusts: "This conveyance is made to the said $\mathbf{H}$. as tmustee to hold the said property for the sole use and benefit of $K$., wife of $M$., free from dominion, debts, or liabilities of her present or any future husband, and the rents, profits, proceeds of, or sale or profits of said property, or any portion thereof, shall be held under the same trusts." Was the lesal estate vested in the wife? See Hart v. Bayliss, 97 Temn. $72,36 \mathrm{~S}$. W. 691 (1896) ; Georgia, C. \& N. Ry. Co. v. scott, 38 S. C. 34, 16 S. E. 185, S39 (1892); Sutton v. Aiken, 62 Ga. 733 (1879). 
(Deed)

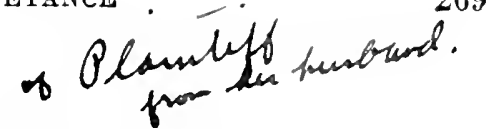

"Know all men by these presents, that I, James Abbott of Gardiner in the county of Kennebec, in consideration of one dollar paid by my wife Clarissa B. Abbott, and for the purpose of providing and securing to my said wife a comfortable support in the event of my decease during her life, the receipt whereof I do hereby acknowledge, do hereby give, grant, bargain, sell and convey, unto the said Clarissa B. Abbott of said Pittston her heirs and assigns forever a certain lot of land situate in said Pittston and bounded.

This deed is not to take effect and operate as a conveyance until my decease, and in case I shall survive my said wife, this deed is not to be operative as a conveyance, it being the sole purpose and object of this deed to make a provision for the support of my said wife if she shall survive me, and if she shall survive me then and in that event only this deed shall be operative to convey to my said wife said premises in fee simple. Neither I, the grantor, nor the said Clarissa B. Abbott, the grantee, shall convey the above promises while we both live without our mutual consent. If I, the grantor, shall abandon or desert my said wife then she shall have the sole use and income and control of said premises during her life.

"To have and to hold the aforegranted and bargained premises, with all the privileges and appurtenances thereof to the said Clarissa B. if she shall survive me, her heirs and assigns, to their use and behoof forever. And I do covenant with the said Clarissa B. her heirs and assigns, that I am lawfully seized in fce of the premises; that they are free of all incumbrances; that I have good right to sell and convey the same to the said Clarissa $B$. if she shall outlive me, to hold as aforesaid at my decease. And that I and my heirs shall and will warramt and defend the same to the said Clarissa B. if she shall survive me, and her heirs and assigns forever, against the lawful claims and demands of all persons.

"In witness whereof, I, the said James Abbott, have hereunto set my hand and seal, this thirtieth day of April in the year of our Lord one thousand eight hundred and seventy-two.

"Signed, sealed, and delivered in presence of

"James Abbott. [Seal.]

"N. M. Whitmore.

"L. Clay."

Duly acknowledged and recorded.

BARROWS, J. The plaintiff's right to maintain this action must depend ultimately upon the construction to be given to the deed or instrument under which she claims title, and upon the force and effect of the terms used therein to define the interest which she acquired by virtue thereof.

Our statutes (R. S. c. 73, \& 1) provide that "a person owning real estate and having a right of entry into it, whether seized of it or not, 
may convey it, or all his interest in it, by a deed to be acknowledged and recorded as heremafter proviced. Detalled regulations as to the mode of exccution and as to the force and effect of conveyances thus made and recorded, follow this general provision in some thirty sections, more or less. Can it be doubted that under such statutes the owner of real estate can convey in the manner prescribed, such part or portion of his estate as he and his grantee may agree, subject only to those restrictions which the law imposes as required by public policy, but relieved from the technical doctrines which arose out of ancient feudal tenures, and all the restrictive effect which they had upon alienations. Why prevent the owner in fee simple from agreeing with his grantee (and setting forth that agreement in his conveyance) as to the time when, and the conditions upon which, the instrument shall be operative to transfer the estate from one to the ather?

In substance our law now says to a party having such an interest in. real estate as is mentioned in R. S. c. 73, you may convey that interest or any part thereof in the manner herein prescribed with such limitations as you see fit, provided you violate no rule of public policy, and place what you do on record so that all may see how the ownership stands.

In the discussion of the effect of the statute of uses and of our own statutes regulating conveyances of real estate in Wyman v. Brown, 50 Me. 139, (a leading case upon the validity of conveyances under which the grantee's right of possession was to accrue not upon delivery of the deed but at some future day,) Walton, J., remarks: "We are also of opinion that effect may be given to such deeds by force of our own statutes, independently of the statute of uses. Our deeds are not framed to convey a use merely, relying upon the statute to annex the legal title to the use. They purport to convey the land itself, and being duly acknowledged and recorded, as our statutes require, operate more like feoffments than like conveyances under the statute of uses." In this connection he quotes Oliver's Conveyancing, touching the operation and properties of our common warranty deed to the effect that in the transfer authorized by the statute in this mode, "the land itself is conveyed as in a feoffment except that livery of seizin is dispensed with upon complying with the requisitions of the statute, acknowledging and recording, substituted instead of it."

And he concludes that deeds executed in accordance with the provisions of our statutes and deriving their validity therefrom may be upheld thereby, as well as under the statute of uses, notwithstanding they purport to convey frecholds to commence at a future day.

In other words the mere technicalities of ancient law are dispensed with upon compliance with statute requirements. The acknowledg-

$\int$ ment and recording are accepted in place of livery of seizin, and it is competent to fix such time in the future as the parties may agree upon as the time when the estate of the grantee shall commence. No more necessity for limiting one estate upon another, or for having an estate 
(of some sort) pass immediately to the grantee in opposition to the expressed intention of the parties.

The feoffment is to be regarded as taking place, and the livery of seizin as occurring at the time fixed in the instrument, and the acknowledgment and recording are to be considered as giving the necessary publicity which was sought in the ancient ceremony. The guestions, did anything pass by the conveyance, if so, what, and when. are to be determined by a fair construction of the language used, without reference to obsolete technicalities. The instrument will be 11 pheld according to its terms, if those terms are definite and intelligible, and 11ot in contravention of the requirements of soumd public policy.

The defendant, while he does not controvert the doctrine of Wyman v. Brown, insists that nothing passed by the deed of James Abbott to his wife, because according to its terms it was left uncertain whether the instrument would ever take effect as a conveyance, that not even a contingent remainder which the plaintiff claims, passed when the deed was made and delivered, that it amounts at most, to a mere executory agreement, and any recognition of its validity is contrary to pullic policy, because it is an attempt to evade the statutes regulating the mak ing and execution of wills. Put the instrument was duly executed by the defendant's testator, a man capable of contracting, and haring an absolute power of disposition over his homestead farm, subject only to the rights of his existing creditors. If was duly recorded so that all the world might know what disposition he had made of a certain interest in it, and what was left in himself. If operative at all, it operated differently from a will. A will is ambulatory, revocalble. Whatever passed to the wife by this instrument became irrevocably hers.

We fail to perceive that any principle of pullic policy, or anything in the statute of wills calls upon us to restrict the power of the owner of property unincumbered by debt, to make gifts of the same, and to qualify those gifts as he pleases, so far as the nature and extent of them are concerned. Public policy in this country has been supposed rather to favor the facilitation of transfers of title, and the alienation of estates, and the exercise of the most ample power over property by its owner that is consistent with good faith and fair dealing. The selfish principle may fairly be supposed to be, in all but exceptional cases, strong enough to prevent too lavish a distribution of a man's property by way of gift.

The learned counsel for defendant speaks of this instrument as "an attempt to make an executory devise," "a mode of devising real estate." It is something more and different, and if the doctrine of Wyman v. Brown is to be maintained, it gives to the grantee a contingent right in the property which (unlike the interest of a devisee in the lifetime of the testator) cannot be taken from her, and may, upon the performance of the condition make her the owner of the premises in fee simple, according to its terms. It is argued that if the court give effect to this mode of transmitting a title to real estate, it will lead to uncertainty as
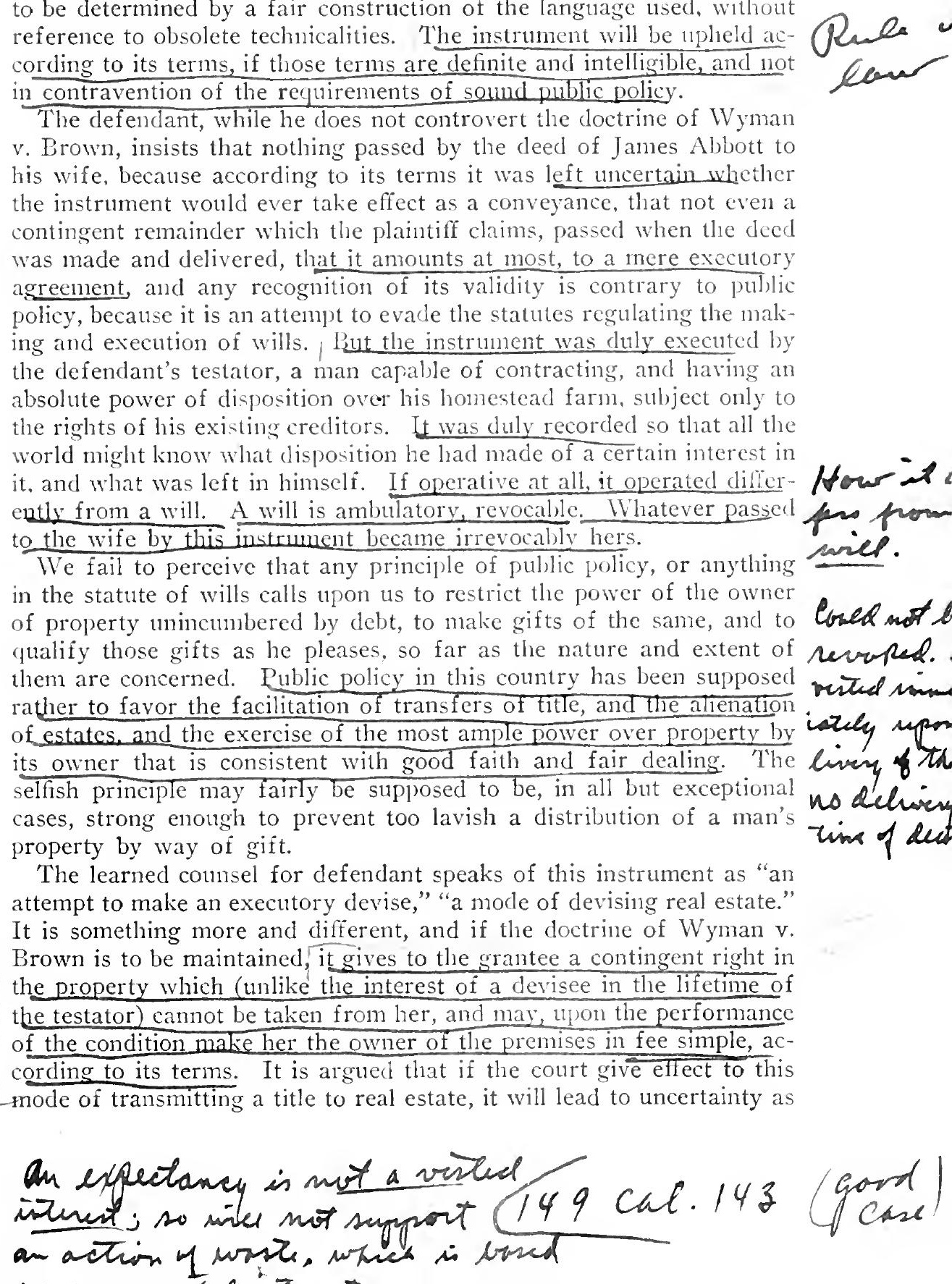
to the rights of the respective parties, and to litigation between the heirs of the grantor and grantee, that "it would tie up estates, embarrass titles, and impair the simplicity of our modes of conveyance," without producing any compensatory benefit. Why these results should follow (when the validity and effect of such conveyances has once been determined) in any greater measure than they are liable to follow any kind of family settlement is not apparent. What we do is precisely this. We uphold a conveyance in conformity with the agreement of the parties therein expressed, that the title of the grantee shall accrue, not upon the delivery of the deed, but upon the happening of a certain event the proof of which is commonly easy) at a future time specified in the recorded conveyance. Why should harm come of it any more than from a lease made to run from a future day certain?

In substance the grantor says to the grantee, I give you this conveyance made and executed in the manner prescribed by our statute, so that you may have an irrevocable assurance that if you outlive me the property therein described shall be yours in fee simple, from and after my decease, in like manner as if you took the same by livery of seizin on that day, under a feoffment from me, the statute provisions for a recorded deed dispensing with that ceremony. Doubtless this is all contrary to the ancient doctrine, which is thus stated in Greenleaf's Cruise, vol. IV, p. *4S: "A feoffment cannot be made to commence in futuro, so that if a person makes a feoffment to commence on a future day, and delivers seizin immediately, the livery is void, and nothing more than an estate at will passes to the feoffee." What was the foundation of this doctrine? It is stated ibidem thus: "This doctrine is founded on two grounds; first, because the object and design of livery of seizin would fail if it were allowed to pass an estate which was to commence in futuro; as it would, in that case, be no evidence of the change of possession; secondly, the freehold would be in abeyance which is never allowed when it can be avoided." But, given the system of recorded conveyances for which our statutes provide, the ceremony of livery of seizin becomes of no importance as an evidence of the change of possession; and we shall find our natural horror of a freehold in abeyance (if it could be demonstrated that such a result would follow from allowing a freehold to take effect in futuro) greatly mitigated by the circlimstance that here and now it is no longer necessary "that the superior lord should know on whom to call for the military services due for the feud," and so, in any event, the defence of the commonwealth will not be weakened; and by the further circumstance that "every stranger who claims a right to any particular lands, may know against whom he ought to bring his pracipe for the recovery of them," by a simple inspection of the public records, and proof of actual possession.

The doctrine of Wyman v. Brown is a good illustration both of the maxim, cessante ratione, cessat etiam lex, and of the changes wrought in the common law by statutory provisions. 
The Virginia doctrine that a feoffment cannot be made to commence in futuro was long ago done away with by statute. Tate's Dig. p. 175. While it does not form part of the decision in Wyman v. Brown, this matter underwent a careful scrutiny, and, upon full consideration, the court agreed that our statute system of registered conveyances brought about the same result here.

We are at liberty, then, to give to the language used by the grantor in a deed, its obvious meaning, without invalidating the deed, to say that it shall operate as the parties intended, and carry an estate to commence in future if they so agree, without the necessity of resorting to any subterfuges under which the estate thus created to commence in futuro may be recognized as existing only by way of remainder or by virtue of some imputed covenant to stand seized.

A single reading of this conveyance of James Abbott to his wife is sufficient to satisfy one that it was no part of the intention or expectation of either, that the wife acquired thercby any interest in the homestead farm during the life of the grantor except as expressly therein declared, to wit, a right to the "use, income and control of said premises during her life," in case the husband deserted her (which he did not do), and besides this, an irrevocable right to the same in fee simple, in casc she survived her husband, her estate to commence at his decease.

The language of the deed differs widely from that of any of the conveyances which have been sustained as passing an cstate in remainder to the grantee with a life-estate in the grantor reserved. If the object of the draftsman had been to exclude the idea that the conveyance should have any force until the time therein appointed, in other words, to have it take effect as a feoffment made at the time fixed in futuro, to convey, as of that date, an estate in fee simple and to have no other operation, it is difficult to see how he could have made that object plainer in words.

"This deed is not to take effect and operate as a conveyance until my decease, and, in case I shatl survive my said wife, this deed is not to be operative as a conveyance. *** If she shall survive me, then, and in that event only, this deed shall be operative to convey to my said wife said prenises in fee simple." Note also the language of the habendum and covenants. A convevance thus framed camot give the rights of a remainderman presently to the grantee, nor so operate forthwith, as a conveyance as to convert thie holding of the grantor from that time forward inte a mere tenancy for life.

Such language bears little resembiance to lhe stipulation in the deed which was under consideration in Drown v. Smith, 52 Me. 142, "but the said (grantee) is not to have or take possession till after my decease; and I do reserve full power and control over said farm during niy natural life."

It differs quite as much from the provision in the case of Wyman v. Brown, to the effect that Mrs. Brown was "to have quiet possession. AIg.Pror. -18 
274

DERIVATIVE TITLES

(Part 2

and the entire income of the premises until her decease." Drown v. Sinith, however, is an authority which relieves us on the question whether stipulations which on the face of them are not consistent with terms previously used importing a present conveyance, will avoid the deed. There is an apparent contradiction in saying, I convey this proparty to you, but this is no conveyance until, \&c., nor unless, \&c. But the modern cases like Drown v. Smith, indicate that if the intent, aking the whole together, is clear and intelligible, the court will give effect to it notwithstanding some apparent repugnance. If a deed can be upheld where, as in Drown v. Smith, the granter reserves to himself "full power and control over said farm during my (his) natural life," on the face of it including the power of disposition, we may give its fair and just effect to one framed, as this is, to convey an estate in fee simple to the grantee, to commence at the decease of the granter, provide the grantee outlives him; and the true effect seems to be that of a feoffment under which the execution and record of the deed operate in the same manner as livery of seizin made at the time of the granto tor's decease. It gives no right of action for waste committed during the granter's life, While this granter lived he could do anything with the homestead farm not inconsistent with the right which he had convexed to his wife to take it from the time of his decease, if she survived him, as the owner thence forward in fee simple.

If the testimony of Lapham and Palmer represents truly the acts of which the plaintiff complains as waste, her suit, were it otherwise well founded, would fail for want of proof of anything which amounts to waste according to the best considered decisions in this country. See Drown v. Smith, upi supra, and cases there cited.

Plaintiff nonsuit. ${ }^{72}$

72 See Miller r. Miller, 91 Kan. 1, 136 Pac. 953, L. R. A. 1915A, 671 (1913).

Had to A ave livery of seisin, at common. Particular

C.C. 1054 (9elimagy)

$101 \quad n \cdot \varepsilon .227$

9 Cal .4/03 


\section{CHAPTER II \\ EXECUTION OF DEEDS}

\section{SECTION 1.-SIGNING}

At common law signing was not essential to a good deed. Blackstone seems to have been of the opinion that the Statute of Frattls made signing necessary. $2 \mathrm{Bl}$. Comm. 305. The general and better view, however, has been that the Statute of Frauds did not, in its requirement of a signature, include instruments under seal. Avetine v. Whisson, 4 M. \& G. 801; Taunton v. Pepler, 6 Madd. 166. See also Cooch v. Goodman, 2 Q. B. 580, 596; Cherry v. Henning, 4 Ex. 631. The statutes of the various states in this country quite uniformly require that a deed effective as a conveyance shall be signed by the conveying party or his agent. The state statutes should be consulted on this point.

\section{SEC'TION 2.-SEALING}

\section{JACKSON ex dem. GOUCH v. WOOD.}

(Supreme Court of New York, 1515. 12 Johns. 73.)

This was an action of ejectment for lot No. 7, in the town of Locke, in the county of Onondaga, and was tried before Mr. Justice Thompson, at the Cayuga circuit, in June, 1813.

The lessors of the plaintiff gave in evidence the exemplification of a patent, dated the 13 th of June, 1791, to John Day, for the lot in question. He then proved that Moses Gouch was the identical person who served, and was known in the New York line of the army by the name of John Day, and that he was the same person to whom the patent was granted by that name. It was also proved, that Moses Gouch, alias dictus John Day, was dead, and that the lessors of the plaintiff were his heirs at law.

The defendant gave in evidence an instrument in writing, endorsed on the original patent, dated the 19th of November, 1792, signed his "John X Day," but without any seal, by which he, John Day, for the mark

consideration of ten pounds, paid to him by Benjamin Prescott, bargained, sold, remised, released and quit-claimed to the said Benjamin 
Prescott, his heirs and assigns, all his right, title, claim, and interest, of, in, and to, the premises granted and described in the patent, to have and to hold the same to the said Benjamin Prescott, and to his heirs and assigns, to his and their only proper use and benefit forever; and to this instrument the names of two witnesses were subscribed.

There never having been any seal to the writing thus endorsed on the patent, it was objected, on the part of the plaintiff, that it amounted to no more than a parol contract, and was not sufficient to pass the land. This point was reserved by the judge, and the defendant gave in eridence sundry mesne conveyances from Benjamin Prescott to himself, all of which had been duly recorded: he also showed a possession for seven or eight years. A verdict was taken for the plaintiff, subject to the opinion of the Court, on a case, as above stated.

PlatT, J., delivered the opinion of the Court.

The single question in this case is, whether an estate in fee can be conveyed otherwise than by deed; that is to say, whether a seal is essential to such conveyance.

The earliest mode of transferring a freehold estate, known in the English common law, was by livery of seisin only. Co. Litt. 49, b, 48, b. But when the art of writing became common among our rude ancestors, the deed of feoffment was introduced, in order to ascertain with more precision the nature and extent of the estate granted, with the various conditions and limitations. This deed, however, was of no validity, unless accompanied by the old ceremony of livery and seisin. 2 Black. Com. 318.

The statute of uses ( $27 \mathrm{Hen}$. VIII) gave rise to the deed of bargain and sale; and, soon afterwards, the conveyance by lease and release was introduced, in order to aroid the necessity of enrolment, required by the statute of 27 Hen. VIII, (2 Black. Con. 343.) By virtue of the statute of uses, which we have adopted, (without the proviso in the English statute requiring the enrolment of deeds,) the deed of bargain and sale, now in use here, is equivalent to the deed of feoffment with livery of seisin, (2 Black. Com. 339, 343,) and has, in practice, superseded the lease and release.

By the common law, estates less than a freehold might be created or assigned, either by deed, by writing without seal, or by parol merely.

By the 29 Car. II, c. 3. (9th and 10th sections of our "act for the prevention of frauds,") it was enacted, "that all leases, estates, interest of freehold, or terms of years, or any uncertain interests in lands, \&c., made or executed by livery and seisin only, or by parol, and not in writing, and signed by the parties so maling and creating the same, shall have the force and effect of leases or estates at will only; excepting leases for three years and less," \&c. ; and, "that no leases, estates, or interests, either of freehold, or terms of years," \&c. "in any lands," \&c. "shall, at any time hereafter, be assigned, granted, or surrendered, unless it be by deed or note in writing signed by the party so assigning, granting, or surrendering the same," \&c. 
Now, it is contended on the part of the defendant, that the common law mode of conveyancing has been so modified by this statute, as to destroy the distinction between an estate of freehold, and an estate less than a freehold, as it regards the mode of alienation; and that either may now be conveyed by "note in writing" without seal, as well as by" deed.

No direct decision appears to have been made on this point; but in the case of Fry v. Philips, 5 Burr. 2827, and in the case of Holliday v. Marshall, 7 Johns. 211, it was decided, that a written assignment of a lease for ninety-nine years was valid, though not sealed; upon the express ground that it was the sale of a chattel-real, for which the statute of frauds requires only a "note in writing"; plainly recognizing the distinction between a term for years, and a freehold estate, as to the mode of conveyance.

According to Sir WVilliam Blackstone, (2 Black. Com. 309, \&c.) sealing was not in general use among our Saxon ancestors. Their custom was, for such as could write, to sign their names, and to affix the sign of the cross; and those who could not write, made their mark in sign of the cross, as is still continued to this day. The Normans used the practice of sealing only, without writing their names; and, at the conquest, they introduced into England waxen seals, instead of the former English mode of writing their names and affixing the sign of the cross, it being then usual for every freeman to have his distinct and particular seal. The neglect of signing, and resting upon the authenticity of seals alone, continued for several ages, during which time it was held, by all the English Courts, that sealing alone was sufficient. But in the process of time, the practice of using particular and appropriate seals, was, in a great measure, disused; and Sir William Blackstone, (2 Black. Com. 310,) seems to consider the statute of 29 Car. II, c. 3, (of which the 9th and 10th sections of our statute of frauds are a copy,) as reviving the ancient Saxon custom of signing, without dispensing with the seal as then in use, under the custom derived from the Normans.

We have the authority of that learned commentiator, unequivocally in favor of the opinion, that a seal is indispensable, in order to convey an estate in fee simple, fee tail, or for life. 2 Black. Com. 297, 312.

Such seems to have been the practical construction, ever since the statute of Car. II in England, and under our statute of frauds in this state; and to decide now, that a seal is unnecessary to pass a fee, would be to introduce a new rule of conveyancing, contrary to the received opinion, and almost universal practice in our community, and dangerous in its retrospective operation. Construing this statute with reference to the pre-existing common law, and the particular evil intended to be remedied, I think the legislature did not intend to dispense with a seal, where it was before required, as in a conveyance of a freehold estate; but the object was to require such deeds to be signed also, which the Courts had decided to be unnecessary. 
I construe this statute as though the form of expression had been thus: "No estate of freehold shall be granted, unless it be by deed signed by the party granting; and no estate less than a freehold (excepting leases for three years, \&c.) shall be granted or surrendered, unless by deed, or note in writing signed by the grantor."

This venerable custom of sealing, is a relic of ancient wisdom, and is not without its real use at this day. There is yet some degree of solemnity in this form of conveyance. A seal attracts attention, and excites caution in illiterate persons, and thereby operates as a security against fraud.

If a man's freehold might be conveyed by a mere note in writing, he might more easily be imposed on, by procuring his signature to such a conveyance, when he really supposed he was signing a receipt, a promissory note, or a mere letter.

The plaintiff is entitled to judgment. Judgment for the plaintiff. ${ }^{1}$

Quite generally the necessity for a seal as requisite to the validity of conveyances has been done away with by statute. $\Lambda$ s to this the statutes of the various states should be consulted. See also Stimson, Am. St. Law, $\S \S 1564,1565$. These statutes vary in form and are found under various heads, as a result of which there has been not a little uncertainty and confusion. See, for instance, Jones v. Morris, 61 Ala. 518; Rondot v. Rogers Tp., 99 Ferl. 202, 39 C. C. A. 462; Jerome v. Ortman, 66 Mich. 668, 33 N. W. 759.

As to what amounts to a sufficient sealing see Lightfoot and Butler's Case, 2 Leon. 21; The Queen v. St. Paul, Covent Garden, 7 Q. B. 232; National Provincial Bank v. Jackson, 33 Ch. D. 1; Warrenv. Lynch, 5 Johns. 239; Pillow v. Roberts, 13 How. 472, 14 L. Ed. 228; Lates v. Railroad Co., 10 Allen, (Mass.) 251; Pease v. Lawson, 33 Mo. 35; Barnard v. Gantz, 140 N. Y. 249, 35 N. E. 430; Lorah v. Nissley, 156 Pa. 329, 27 Atl. 242. ${ }^{2}$

1 See Waren v. Ixnch, 5 Johns. (N. Y.) 239 (1S10), as to the origin, nature, and use of seals.-Iisp.

2 "The ground of this controversy lies in the fact that the deed to Edwards purports to be the deed of Agillon Price, only. The name of Lincy A. Price does not appear in the body of it, nor is there anything in the body of the deed to show that he was a married man. It concludes, "In testimony whereof I have herennto set my hand and seal,' et'c. 'The deed, howerer, is signed by her and her hustand, and acknowledged by her on the twenty-second of July, 185:3, and by him on the fourteenth of September, 1853. The wife, as will he seen, owned the property in her own right, and the fact that she signed her name to the deed, and acknowledged it before a proper officer, does not niake it her grant. The party in whom the title is rested must use appropriate words to convey the estate. Signing, sealing, and acknowledging a deed by the wife, in which her husband is the only grantor, will not convey her estate. Whiteley r. Stewart, 63 Mo. 360 (1876); Agricultural Bank v. Rice, 4 How. 225, 11 I. Ed. 949 (1846); City of Cincinnati v. Newell's Heir's' Lessee, 7 Ohio St. 37 (1857). Whether it would be sufficient to release her dowar in her husband's estate, we do not determine." Bradley r. Missouri Pac. Ry. Co., 91 No. 493, 4 S. W. 427 (1SS6), per Black, J. 


\section{SECTION 3.-ATTESTATION}

At common law attestation by witnesses was not necessary for any purpose in connection with deeds. In the United States not uncommonly the statutes require attestation for some purpose. In Ohio and Connecticut attestation by two witnesses is necessary to make the deed valid as a conveyance, even as between the parties. Langmede $v$. Weaver, 65 Ohio St. 17, 60 N. E. 992; Winsted Bank v. Spencer, 26 Conn. 195. Generally, however, where attestation is called for by the statute it is considered necessary only as a prerequisite to effective recording.

\section{SECTION 4.-ACKNOWLEDGMENT}

This, too, is wholly a requirement of statute, and generally speaking, as in the case of attestation, is not cssential to the validity of the conveyance. In Ohio and Arizona, however, it has been held essential to the validity of the conveyance. Hout v. Hout, 20 Ohio St. 119; Lewis v. Herrera, 10 Ariz. 74, 85 Pac. 245, aff. 208 U. S. 309, 28 Sup. Ct. 412, $52 \mathrm{~L}$. Ed. 505. Quite commonly acknowledgment is made necessary to the validity of conveyances of certain special interests, as homesteads, or conveyances by certain persons, as married women. Aside from these the requirement goes mercly to the effectiveness of the recording or to the matter of proof in offering the instrument in evidence. On this and upon the matter of Attestation as well the statutes and decisions thereunder should be consulted.

\section{SECTION 5.-DELIVERY}

\section{STANTON v. CHAMBERLAIN. \\ (Court of Common Pleas, 25s8. Owen, 95.)}

In an action of debt upon a bond, upon non est factum pleaded, the jury found, that the defendant sealed the bond, and cast it on the table, and the plaintiff came and took up the bond, and carried it away without saying any thing; and if this shall amount to a delivery by the defendant to the plaintiff, was the question. And it was resolved by all the justices, that if the jury had found that he had sealed the bond, 
and cast it on the table towards the plaintiff, to the intent that the plaintiff should take it as his deed, who took the bond and went away, that had been a good delivery; or that the plaintiff, after the sealing and casting on the table, had taken it by the commandment or consent of the defendant; but because it is found that the defendant only sealed it, and cast it on the table, and the plaintiff took it and went away with it, this is not a sufficient delivery, for it may be that he sealed it to the intent to reserve it to himself until other things were agreed, and then if the plaintiff take it, and go away with it without the defendant's consent, that will not make it the defendant's deed. But it was said, that it might be accounted to be the defendant's deed, because it is found that he sealed it, and cast it on the table, and the plaintiff took it, \&c. and it is not found that the defendant said any thing, and therefore because he did not say any thing, it will amount to his consent, Nam qui tacet consentire videtur. But to this it was answered, that it is not found that the defendant was present when the plaintiff took it, and if the defendant had sealed, and cast the bond on the table when the plaintiff was not there, and then the defendant went away, and then the plaintiff came and took it away, then clearly it is not the deed of the defendant. $^{\mathbf{3}}$

\section{BOYD v. SLAYBACK.}

(Supreme Court of California, 18s3. 63 Cal. 493.)

The action was brought against Robert Taggart, a minor, and against O. M. Slayback, as administrator of the estate of Mary B. Taggart, and as guardian of Robert Taggart, to quiet title to certain lands alleged to have been sold to the plaintiff by Mary $B$. Taggart. The plaintiff alleged that some time subsequent to the execution and delivery of the deeds to him, by which the lands were conveyed, they were left at the residence of Mrs. Taggart in a tin box, and that after her death it was discovered that the deeds had been abstracted. The defendant denied the execution and delivery. The deeds were not recorded:

Prir Curian. ${ }^{*} * * *$ The judgment must be reversed for error in the charge to the jury. The court below charged: "A grant, duly executed, is presumed to have been delivered; therefore, if you find from the evidence that Mrs. Taggart actually signed and acknowledged the deeds in question, the law will presume that they were duly delivered, and in order to defeat this presumption, the party disputing the delivery must show, by preponderance of proof, that there was no delivery."

This was error. A deed takes effect only from the time of its delivery. Without delivery of a deed it is void. No title will pass with-

3 See Hughes v. Easten, 4 J. J. Marsh. (Ky.) 572, 20 Am. Dec. 230 (1830); Cannon v. Cannon, 26 N. J. Eq. 316 (1s75).

$*$ Only a portion of the opinion is printed. 
out delivery. Dyson v. Bradshaw, 23 Cal. 528; Fitch v. Bunch, 30 Cal. 208; Barr v. Schiroeder, 32 Cal. 610. It is for the party claining under a deed to prove its delivery. Sometimes slight evidence will be sufficient to support a finding of delivery, but no legal presuniption of delivery arises from the mere fact that the instrument is "signed." The acknowledgment only proves that it was signed.

Judgment reversed and cause remanded for a new trial.

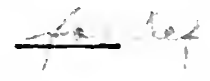

CURRY v. COLBURN.

(Supreme Court of Wisconsin, 1898. 99 Wis. 319, 74 N. W. 778,67 Am. St. Rep. s60.)

BARDEEN, J. The plaintiff brings this action in ejectment to recover possession of a tract of land in the city of Marinette. The answer is a general denial, and a counterclaim substantially to the effect that both parties claim title from one Fairchild, and that the deed under which plaintiff claims title was never in fact delivered to him with intent to pass title. A reply asserts the validity of plaintiff's deed, and that defendants took title with notice of the plaintiff's rights. 'The chief question litigated on the trial was whether the deed from Fairchild to plaintiff had ever been delivered. The court found that such deed was handed by Fairchild to plaintiff merely for examination and inspection, and was rot delivered with the intention of passing the title. As conclusions of law, the court found that defendants were entiled to judgment dismissing the complant and canceling said deed.

There is ample evidence to support the corclusions arrived at by the trial judge, and his findings of fact cannot be disturbed. 'The deed in question was not dated or acknowledged. It was smply handed to plaintiff by Fairchild, at the former's request, to be taken to his lawyer for examination, and the parties were to meet later to comirlui: the bargain. No particular form is necessary to constitute the delivery of the deed. It is sufficient when the deed is executed, and the minds of the parties to it meet, expressly or tacitly, in the purpose to give it present effect. Bogie v. Bogie, 35 Wis. 659. Like every other contract, there must be a meeting of the minds of the contracting parties - the one to sell and convey, and the other to purchase and receive -before the agreement is consummated. Welch v. Sackett, 12 Wis. 243. The question of delivery is largely of intention 1 Devlin, Deeds, $\S 262$. And a deed never becomes operative until it is clelivered with the intent that it shall become effective as a conveyance. Id. Counsel for the plaintiff argue earnestly that, because the deed was handed by Fairchild to the plaintiff, this constituted a full and complete delivery, and that evidence was not admissible to show the actual condition then existing. No donbt, a great deal of discussion and unnecessary refinement may be found in the books, bearing upon this question; but the main principle must predominate, that, to constitute a valid de- 
livery of a deed, the grantor must part with his dominion over it, with intent to pass the title.

The ancient rule that a deed cannot be delivered in escrow to the grantee in no way conflicts with our conclusions. A delivery in escrow contemplates complete loss of control over the deed. Here the incomplete deed was hatıded to the grantee, to take to his lawyer for inspection. By the terms of their agreement of sale, a mortgage was to be made, a party-wall contract was to be executed, and part of the consideration to be paid. There was nothing in the circumstances to show that Fairchild in any way intended to part with his dominion over the deed. On the contrary, they all tend to establish the conclusion arrired at by the trial court. That parol evidence is admissible to show that a written instrument has never been delivered so as to bind the parties thereto is established by the following cases: Gibbons v. Ellis, 83 TIis, 43t, $53 \mathrm{~N}$. IV. 701; Price v. Hudson, 125 Ill. 284, $17 \mathrm{~N}$ E. 817; Brackett v. Barney, 28 N. Y. 333; Jackson v. Roberts, 1 Vend. (N. Y.) 478; Reichart v. Withelm, 83 Iowa, 510, 50 N. IV. 19. In Price v. Hudson the court remark: "It is not competent to control the effect of the deed by parol evidence, when it has once taken effect by delivery, but it is always competent to show that the deed, although in the grantee's hands, has never in fact been delivered, unless the grantor, or those claming through him, are estopped in some way from asserting the nondelivery of the deed."

Not to prolong this discussion, we conclude that the decision of the trial jucge upon the law finds ample support both upon principle and authority.

By THE COURT. The judgment of the circuit court is affirmed. ${ }^{5}$

5 "The question of delivery is a mixed question of law and fact, and it is held thit the delivery of a deed may be made hr acts amone, that is, by doinf sunething and siling nothing; or by words alone, that is, by saying sumething allid doing nothing: or it may be delivered by both acts and words. It must, homerer. he delivered by something ansmering to the one or the oflere, or both, and with the intent therely to give effect to the deed. Roun-

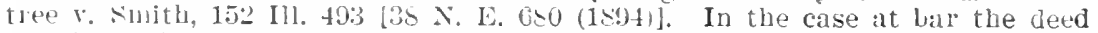
was handed to Charles $\mathrm{S}$. Owen by $\mathrm{Mr}$. Lewis, and after it had been signed and ackinumledged by Mrs. Owen was placed by owen in his private box, where it remaned until after his death. If these were the only facts which appeared in evirluce bearing mpon the question of delivers, it might well be beld that the dered had been delirered. It anpears, however, that the deed was made, not with the intention that it should inmediately take effect and pass the title to said farm to Charles $\mathrm{S}$. Owen, but that it should only take effect in case charles $\mathrm{S}$. Owen survived his wife, and in the event that his wife shomle survire him it mas never to take efiect but was to be destroyed. A desd must take effect immediately upon its execution and delively to the

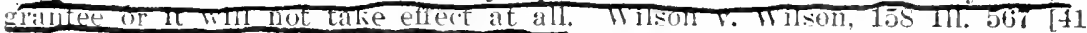

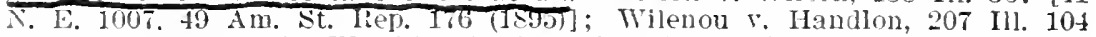
[69 N. L. s9: $(1904)]$. We think it clear tbat the parties to this deed intended it tu operate as a will, and that the possession of the deed by Charles S. Owen did not have the efiect to rest the title to said farm in him. It is urged, however, that the deed was delivered into the hands of Charles $\mathrm{S}$. Owen, and it is said such delivery had the eflect to invest him with the title to the premises regardless of the intention of the parties, on the ground that a deed cannot be transfered from the possession of the grantor to the gran- 


\section{TISHER v. BECKWITH.}

(Supreme Court of Wisconsin, 18i2. 30 Wis. 55, 11 Am. Rep. 546.)

Appeal from the Circuit Court of Waupaca County.

Action against defendants, together with the sheriff and former sheriff of Waupaca county, to restrain said officers from executing a deed of certain mortgaged premises sold under a judgment of foreclosure to the defendants, and to compel the defendants to convey to respondent their title acquired under such sale.

It appeared in evidence that the plaintiff, Tisher, who was in possession of the premises in dispute as a homestead under a patent from the United States, had partially executed but never delivered a deed of the premises to his son Charles H. Tisher. This deed, which was unstamped and bore no consideration or date, was placed by 'Tisher in a trunk and locked up, the key being kept by his wife in a small box in another trunk which was locked. The son kept his papers in the same trunk in which the deed was placed, but had no key. Defendants claimed the premises under a sale by virtue of a julgment of foreclosure of certain mortgages executed by the said Charles H. Tisher. The court found as facts that the pretended deed of Tisher to his son was never fully executed and delivered, but that it was purloined from Tisher without his knowledge or consent, and that the defendants had due notice of the plaintiff's claim to the premises, as

tee without resting title in the grantee. We do not so inderstand the law.

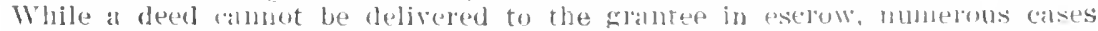

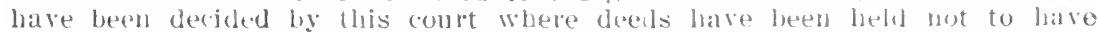

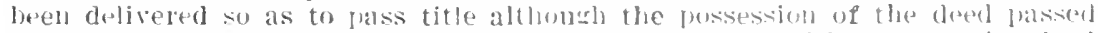
from the grantor to the grantee. In liountree s. sinith, subra, the deen

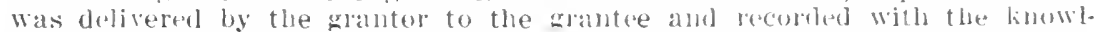
edge and consont of the grantor, and get it was lield that it was not doliv-

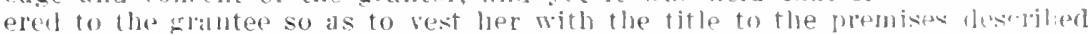

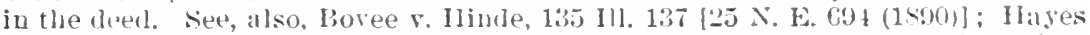

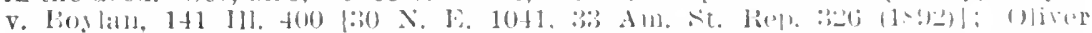

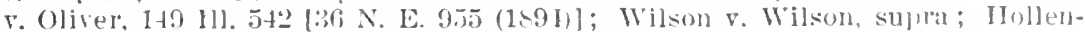

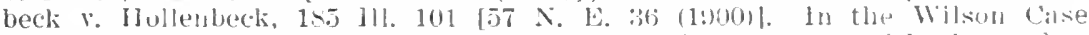
the deed Was flaced in the hamels of one of the glantees with the undel"-

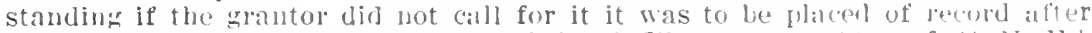

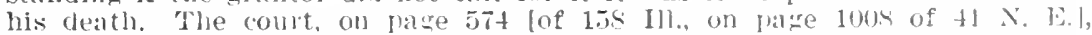
sald: "The mere platring of the deed in the lands of one of the glantees did not, of itself, necessarils constitnte a dovivery. In such a case the inquiry is, what was the intention of the pontes at the time? and lant inter. tion, when ascertaned, must govern.' And in Oliver v. Oliver, sulna, on page 547 Lof 149 Ill., on page 956 of $36 \mathrm{~N}$. E.], it was sail: "The fact that a grantee in a deed may, after the execution of the instrmusnt, talie it into his hands does not, of itself, estalilish a delivery.' And in Ilollembecti $v$. Hollenheck, sujra, on page 103 fof $185 \mathrm{Ill} .$, on page 37 of $57 \mathrm{~N}$. H.]: "The were wacing of a dewdin the hands of the glamee does not conclusively establish a delivery thereof, within the lesal meaning of tndt mord. Delivery is a question of intent, and dejends ujon whetler the birtios at the time meant it to be a delively to take effect at onee." Elliott v, Murray, 225 111.

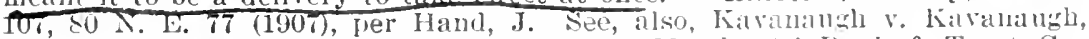
260 111. 179,103 N. E. 65 (1913): Elliott v. Merchants' Bank \& Trust Co., 21 Cal. App. 536, 132 Pac. 250 (1913). 
well as his son's inability to convey. As a conclusion of law the court fotnd that Tisher was the owner in fee of the premises; that the pretended deed to his son was null and void; that the mortgagres executed by the son were null and void, as well as the certificate of sale issued to defendants under the foreclosure sale; that the sheriffs should be enjoined from executing a deed on said certificate that the defendants should be restrained from disposing of the certificate, and that they should release to the plaintiff all claims to the premises in question by virtue of said sale and certificate. Judgment being entered in accordance with such findings defendants appealed.

Dixon, C. J. The fourth finding of fact by the court below is in these words: "That the pretended deed from said plaintiff and his wife to Charles H. Tisher was never fully executed and was never delivered, and that the same was purloined or stolen from said plaintiff without his knowledge, consent or acquiescence." If this finding be correct and sustained by the eridence, it obviously puts an end to all claim of title to the land on the part of the defendants. It has been held by this court that the fraudulent procurement of a deed depositcd as an escrow from the depository by the grantee named therein, will not operate to pass the title, and a subsequent purchaser of such grantee, for valuable consideration without notice, derives no title thereby and will not be protected. Everts v. Agnes and Swift, 4 Wis. 343, 65 Am. Dec. 314; Same v. Same, 6 Wis. 453. It is essential to the validity of a deed that it should be delivered, and such delivery to be valid must be voluntary, thiat is, made with the assent and in pursuance of an intention on the part of the grantor to deliver it, and if not so delivered it conveys no title. A deed purloined or stolen from the grantor, or the possession of which was fraudulently or wrongfully obtained from him without his knowledge, consent or acquiescence, is no more effectual to pass title to the supposed grantee, than if it were a total forgery, and an instrument of the latter kind had been spread upon the record.

The only question which can ever arise to defeat the title of the supposed grantor in such cases, is whether he was guilty of any negligence in having made, signed and acknowledged the instrument, and in suffering it to be kept or deposited in some place where he knew the party named as grantee might, if so disposed, readily and without trouble obtain such wrongful possession of it and so be enabled to deceive and defraud innocent third persons. It might possibly be that a case of that kind could be presented where the negligence of the supposed grantor in this respect was so great, and his inattention and carelessness to the rights of others so marked, that the law would on that account estop him from setting up his title as against a bona fide purchaser for value under such deed. See Everts v. Agnes et al., 6 Wis. 453. There are some facts and circumstances in this case strongly suggestive of such a defense, and were it not for the fact found by the court that the deed was never fully executed, and the 
further fact fully established in evidence that it was unstamped when put away by the plaintiff in the trunk in the manner described by himself and the other witnesses, we might possibly have some hesitation about affirming the judgment of the court below on this ground.

It appears from the plaintiff's own testimony that the trunk was easily accessible to his son, the person named in the instrument as grantee, for he says that his son, who was acting as town clerk at the time, kept his papers there, although he also testifies that the son had no key to the trunk, but that his, plaintiff's, wife kept the liey in a small box in another trunk bclonging to her and which was locked. A deed fully executed and which had been so kept or deposited would seem to furnish some evidence, more or less strong, of negligence on the part of the grantor. It would be unlike the case of a deed executed and deposited in escrow, which this court said was recognized as a-legitimate business transaction. But the finding is that the deed was not fully executed nor was it stamped, and the question is, whether it was negligence so to keep such an instrument, and we are not prepared to say that it was. It occurs to us, as it probably did to the court below,that most men of ordinary care and circumspection would not have regarded this as unsafe or imprudent or careless. An instrument complete in all its parts and lacking nothing to give it validity but delivery to the person named in it as grantee, might excite the cupidity of such person to take wrongful posscssion of it when frequent opportunity for that purpose was afforded, but that an unfinished instrument, one partially executed and not ready for delivery, would present the same temptation would hardly suggest itself to the mind of any ordinarily prudent and cautious man. It would hardly occur to such a man that such an instrument would be purloined or wrongfully taken, when to give it any apparent validity in the hands of the supposed grantee the crime of forgery must also be committed.

It is for these reasons that this court is of opinion that the facts proved were not sufficient to take the case out of the general rule of law above stated, even taking the most liberal view of the facts in favor of the defendants. There are cases, however, the tendency of which would seem to be that the failure of the plaintiff to suspect and treat his son as a lnave, thief, or criminal, could not be attributed to him as negligence. See the able and well considered opinion of the court by Christiancy, J., in Burson v. Huntington, 21 Mich. 415. 4 Am. Rep. 497, a case involving the same question with respect to the delivery of a negotiable promissory note and which, not having been delivered by the maker but stolen or wrongfully taken and put in circulation by the payee, was held void in the hands of a bona fide holder for value. The same case also makes a distinction between a note or other instrument so obtained and one deposited in escrow and afterwards fraudulently delivered by the depositors, holding that in the latter case the maker would be bound as against an innocent holder for value, on the ground of the trust or confidence reposed by him 
in the depository, and upon the principle that, when one of two innocent persons must suffer by the acts of a third, he who has enabled such third person to occasion the loss must sustain it. Upon the same question also of negligence, see Wait v. Pomeroy, 20 Mich. 425, 4 Am. Rep. 395. It only remains, therefore, to be inquired whether the evidence given on the trial was such as to sustain the finding of the court above quoted.

We are of opinion that the preponderance of testimony was decidedly in favor of the finding. If we omit from our consideration entirely the testimony of the plaintiff, which was clear and strong and whose credibility and fairness we discover nothing to impeach, except the mere fact of his interest, the finding was fully sustained by the testimony of the witnesses, Quimby, Wooden and Mrs. Scheppe, who corroborated the plaintiff in almost every particular to which he testified. Opposed to the testimony of these witnesses was only that of the witness Hoxie, who testified merely to certain admissions and conduct of the plaintiff calculated to induce the witness to believe that the plaintiff had conveyed the land to his son. In this, Hoxie was directly contradicted by the plaintiff, and there again the plaintiff was corroborated by the witness Wooden, who was present on the occasion spoken of by Hoxie. In every view in which the testimony presents itself to our minds, we are constrained to say that this finding of the court below was correct, and consequently, that the judgment must be affirmed.

By the Court. Judgment affirmed. ${ }^{\circ}$

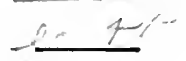

\section{PARROTT v. AVERY.}

(Supreme Judicial Court of Massachusetts, 1893. 159 Mass. 594, 35 N. E. 94. 22 L. R. A. 153, 38 Am. St. Rep. 465.)

Writ of entry, to recover possession of a parcel of land in Great Barrington. Plea, nul disseisin. The case was submitted to the Superior Court, and, after judgment for the demandants, to this court, on appeal, upon agreed facts, in substance as follows.

The tenant claimed title to the demanded premises by virtue of a deed to him of the same from his grandfather, one Miles Avery, deceased, dated, January 21, 1888, the consideration for which was expressed to be "love and affection," which was executed in the presence of a witness, and which was recorded on January 31, 1893; and also under the second clause of the will of Miles Avery, which devised to

6 See Garner v. Risinger, 35 Tex. Civ. App. 378, 81 S. W. 343 (1904), where the grantors prepared a deed and placed it in a drawer of the family organ, where the grantors were accustomed to keep their valuable papers. The grantee, a stepdaughter of one of the grantors and a nember of the household, took the deed without the knowledge of the grantors, and conveyed the property to an innocent purchaser. 
the tenant, among other things, "my chest and its contents except the bank-books."

The deed was duly executed by Miles Avery at or about the time of its date, and is supposed to have been placed by him with other valuable property in a certain chest owned by him, which was the chest bequeathed to the tenant by the second clause of the will. The will, which was dated May 25, 1889, was duly proved and allowed, and the executor of the will, agreeably to its provisions, delivered the chest and its contents, inclucling the deed, which was found in the chest, to the tenant, on January $28,1893$.

Miles Avery retained possession of the demanded premises, and of the chest and its contents, up to the time of his death, which occurred on May 10, 1891.

The demandants claimed title to the premises under the seventh clause of the will, which was as follows: "All the residue and remainder of my estate, both real and personal, not otherwise disposed of, shall be equally divided among all of my grandehildren then living."

If the tenant had title to the demanded premises, judgnent was to be entered in his favor; otherwise, judgment was to be entered for the demandants.

AlLEN, J.† 1 . The agreed facts fail to show a delivery of the deed in the grantor's lifetime. The grantor retained control of the deed and of the land. There was no prior bargain with the grantee, and no indebtedness to him, nor relation of trust towards him. He had no knowledge of the execution of the deed. The only consideration was love and affection. The deed was not recorded during the grantor's lifetime. There was no oral declaration by the grantor that he meant to have it take effect at once. In short, there was nothing tending to show a clelivery of the deed except the bare fact that it was executed in the presence of a witness. The qucstion of delivery is a question of fact, and delivery in the grantor's lifetime must be proved. There must have been an intention that it should operate as a present conveyance of title. A finding of the delivery of the deed would not be warranted on the agreed facts. Stevens v. Stevens, 150 Mass. 557, 23 N. E. 378: Shurtleff v. Francis, 118 Mass. 154; Hawkes v. Pike, 105 Mass. 560 , 7 Am. Rep. 534; Brabrook v. Boston Five Cents Savings Bank, 104 Mass. 228, 232, 6 Am. Rep. 222; Chase v. Breed, 5 Gray, 4t0; Younge v. Guilbeau, 3 Wall. 636, 641, 18 L. Ed. 262; 3 Washb. Real Prop. (5th Ed.) 577 et seq. There were no acts or declarations of the grantor sufficient to show an intent to treat it as delivered. or circumstances such as were found to be sufficient in Lowd v. Brighiam, 154 Mass. 108, 113, 114, 26 N. E. 1004, and cases there cited, and in Regan v. Howe, 121 Mass. 424.

Judgment for demandants affirmed. ${ }^{\text {? }}$

$\dagger$ A portion of the opinion is omitted.

7 See Taylor v. Taylor (R. I.) 90 Atl. 746 (1914), in which the grantor, a short time before her death, called her son, the grantee, to her bedside, and 


\section{DOE ex dem. GARNONS v. KNIGHT.}

(Court of King's Bench, 1826. 5 Barn. \& C. 671.)

This was an ejectment brought to recover possession of certain messuages and lands in the county of Flint. The lessor of the plaintiff claimed the property as mortgagee under a deed purporting to be executed by W. Wynne, deceased. At the trial before Garrow, B., at the summer assizes for the county of Stafford, 1825, the principal question turned on the validity of that deed; and the following appeared to be the facts of the case: Wynne was an attorney residing at Mold in Flintshire, and had acted in that character for Garnons the lessor of the plaintiff, who resided at a distance of about three miles from Mold. Wynne's sister and niece lived in a house adjoining to his own at Mold. On the 12th of April, 1820, about six o'clock in the evening, Wynne called at his sister's house, his niece then being the only person at home, and asked her to witness or sign some parchment. He produced the parchment, placed it on the table, signed his name, and then said, "I deliver this as my act and deed," putting his finger at the same time on the seal; the niece signed her name, and he took it away with him. The deed remained on the table until he took it away. He did not mention to his niece the contents of the deed, or the name of Mr. Garmons. The niece had no authority from Mr. Garnons to receive any thing for him. It was proved by Miss Elizabeth Wynne, the sister of Wynne, that in April, 1820, (but whether before or after the execution of the deed as above mentioned did not distinctly appear,) he brought her a brown paper parcel, and said, "Here, Bess, keep this; it belongs to Mr. Garnons." Nothing further passed at this time; but a few days after he came again, asked for the parcel, and she gave it to him; he returned it back to her again on the 14 th, 15 th, or 16 th of April, saying, "Here, put this by." When she received it the second time, it was less in butk than before. Wynne died in August, 1820. After his funeral, she delivered this parcel to one Barker in the same state in which she received it from her brother. Barker, who was an intimate friend of Wynne, stated, that the latter in July, 1814, sent for him, and told him that he had received upwards of $£ 26,000$. upon Mr. Garnons' account; and after taking credit for sums he had paid, and placed out for Mr. Garnons, he was still indebted to him in more than $£ 13,000$. He then asked the witness, if he, as his (Wynne's) friend, would see Mr. Garnons to explain the circumstances. The witness consented, and Wynne then made a statement of his property; by which it appeared that after payment of his debts, including the $£ 13$,000 ., he would have a surplus for himself and family of $£ 8,000$. at the

gave to him a box and the kex thereto, saying, "Everything in that box is youls." Among the papers in the box was a deed bearing date twelve years eallier, the delivery of which the court was called upon to determine. In the box were also the grantor's will and some insuramce policies which belonged to the grantee's sisters. 
least. He desired the witness to tell Garnons that, although he could not pay him at that time, he would take care to make him perfectly secure for all the monies due from him. Upon this being communicated to Garnons he desired Barker to assure Wynne, that he wotnd not then distress him, or expose his circumstances, but he expected that he would provide him securities for the money he, Wynne, owed him. This was communicated to $\mathrm{Wynne}$, who expressed great gratitude to Garnons, and said, he would take care to make him perfectly secure. After the funeral of Wynne, his will was produced, and with it was a paper in his own hand-writing, containing a statement of his property, and a list of various debts secured by mortgage or bond, and among others, under the title "mortgage," there was stated to be a debt to Mr. Garnons for $£ 10,000$. Miss Wynne soon after delivered to the witness, Barker, a brown paper parcel sealed, but not directed. Lpon this being opened, there was inclosed in it another white paper parcel directed, in the hand-writing of Wynne, "Richard Garnons, Esq." Within it was a mortgage deed, (the same that was witnessed by Wynne's niece, as before stated,) from Wynne to Garnons for $£ 10,000$. There was also within the white parcel, a paper folled in the form of a letter directed in the hand-writing of Wynne to Mr. Carnons. That contained a statement of the account between Wynne and Garnons, and $£ 10,000$., part of the balance due from Wynne to Garnons, was stated to be secured upon Wynne's property. The mortgage deed found in the parcel was then delivered to Garnons. It was a mortgage of all Wynne's real estates.

It was contended on the part of the defendlant that nothing passed by the deed, inasmuch as there had been no sufficient delivery of it to the mortgagee, or to any person on his behalf, to make it valid; and, secondly, because it was fraudulent and void against the creditors of the grantor uncler the statute 13 Eliz. c. 5. 'The learned Judge overruled the objections, and the defendant then proved that Mr. Wynne, in May, 1820, had delivered to him a bond and mortgage of his real estates, to secure money due from $\mathrm{W}^{\mathrm{y}} \mathrm{ynne}$ to him; and that by his will he devised all his estates to the defendant, Knight, in trust to sell and pay his debts. It was further proved, that about the 5th of April a skin of parchment with a $£ 12$. stamp was prepared by Vynne's order, and for a few days he remained in his private room, with the door shut. A clerk entered the room, and found him writing upon a parchment; he afterwards locked the door. There was no draft of the mortgage in the office, and he never mentioned it. The whole of the deed was in Wynne's own handwriting. He had three clerks, and deeds were in the usual course of business executed in the office, and witnessed by himself and his clerks. The learned Judge told the jury, that the first question for their consideration was, whether the mortgage to the lessor of the plaintiff was duly executed by Wyme the deceased; but that if they thought it was originally well executed, the question for their Aig.Prop.-19 
consideration would be, whether the delivery to Mrs. Elizabeth Wynne was a good delivery; and he told them he was of opinion, that if, after it was formally executed, Mr. Wynne had delivered it to a friend of Mr. Garnons, or to his banker for his use, such delivery would have been sufficient to vest in Mr. Garnons the interest intended to be conveyed to him under it; and the question for them to decide was, whether the delivery to Miss Wynne was, under all the circumstances of the case, a departing with the possession of the decd, and of the power and control over it, for the benefit of $\mathrm{Mr}$. Garnons, and to be delivered to him either in Mr. Wynne's lifetime or after his death; or whether it was delivered to Miss Vinne merely for safe custody as the depository, and subject to his future control and disposition. If they were of opinion that it was delivered merely for the latter purpose, they should find for the defendant, otherwise for the plaintiff. A verdict having been found for the plaintiff, Campbell in last Michaelmas term obtained a rule nisi for a new trial.

BAYLIEY, J. ${ }^{8}$ There were two points in this case. One, whether there was an effectual delivery of a mortgage deed, under which the lessor of the plaintiff claimed, so as to make the mortgage operate. The other, whether such mortgage was or was not void against creditors or a subsequent mortgagee. Upon the first point the facts were shortly these. In July, 1814, Mr. Wynne, an attorney, who was seised in fee of the premises in question, made a communication through a friend to the lessor of the plaintiff who was a client, that he (Wynne) had misapplied above $£ 10.000$. of his (Garnons') money. Garnons answered, he relied and expected that Wynne would provide him securities for his money; and Wynne said he would make him perfectly secure, and he should be no loser. On the 12th of April, 1820, Wynne went to his sister's, who, with her niece, lived next door to him, and produced the mortgage in question, ready sealed. He then signed it in the presence of the niece, and used the words: "I deliver this as my act and deed." The niece, by his desire, attested the exccution, and then Mr. Wynne took it away. 'The niece knew not what the deed was, nor was Mr. Garnons' name mentioned. In the same montin of April he delivered a brown paper parcel to his sister, saying, "Here, Bess, keep this; it belongs to Mr. Garnons." He came for it again in a few days, and she gave it him; and he returned it on the $14 \mathrm{th}, 15 \mathrm{th}$, or $16 \mathrm{th}$ of April, saying, "Here, put this by." It was then less in bulk than before, and contained the mortgage in question. Mr. Wynne died the 10th of August following, and after his death the parcel was opened, and the mortgage found. Mr. Garnons knew nothing of the mortgage until after it was so found. My Brother Garrow, who tried the cause, left two questions to the jury; one, whether the mortgage was duly executed; the other, whether the delivery to the sister was a good delivery; and he explained to

8 The argument of counsel and that portion of the opinion relating to counsel's contention that the deed was void under St. 13 Eliz. cc. I and 5, are omitted. 
them, that if the delivery was a departing with the possession, and of the power and control over the deed for the benefit of Mr. Garnons, in order that it might be delivered to him either in Mr. Wynne's lifetime, or after his death, the delivery would be good; but if it was delivered to the sister for safe custody only for Mr. Mynne, and to be subject to his future control and disposition, it was not a good delivery, and they ought to find for the defendant. The jury found for the plaintiff. 'Their opinion, therefore, was, that Mr. Wynne parted with the possession and all power and control over the deed, and that the sister held it for Mr. Garnons, free from the control and disposition of the brother.

It was urged upon the argument, that there was no evidence to warrant this finding, and that the conclusion which the jury drew had no premises upon which it can be supported. Is this objection, however, valid? Why did Mr. Wynne part with the possession to his sister, except to put it out of his own control? Why did he say when he delivered the first parcel, "it belongs to Mr. Garnons," if he did not mean her to understand, that it was to be held for Mr. Garnons" use? And though the sister did return it to her brother when he asked for it, would she not have been justified had she refusel? Might she not have said, "You told me it belonged to Mr. Gamons, and I will part with it to no one but with his concurrence." The finding, thereiore, of the jury, if this be a material point, appears to me well warranted by the evidence, and then there will be two ruestions upon the first point: One, whether when a deed is duly signed and seater, and formally delivered with apt words of delivery, but is retained by the party executing it, that retention will obstruct the operation of the deed; the other, whether if delivery from such party be essential, a delivery to a thirel person reill be sufficient, if such delivery puts the instrument ont of the power and control of the party who executed it though such third person does not pass the deel to the person who is to be benefited by it, until after the death of the party by whom it was executed.

Cpon the first question, whether a deed will operate as a deed though it is never parted with by the person who executed it, there are many authorities to show that it will. In Barlow $v$. I eneage, Prec. Chan. 211, George Heneage executed a deed purporting to convey an estate to trustees, that they might receive the profits, and put them out ior the benefit of his two daughters, and gave bond to the same trustees conditionel to pay to them $£ 1,000$. at a certain day, in trust for his daughters; but he kept both deed and bond in his own power, and received the profits of the estate till he died: he noticed the bond by his will, and gave legacies to his daughters in full satisfaction of $i t$, but the daughters elected to have the benefit of the deed and bond, and filed a bill in equity accordingly. It was urged, that the deed and bond being voluntary, and always kept by the father in his own hands, were to be taken as a cautionary provision only. Lord Keeper Wright said, these were the father's deeds, and he could not derogate from them: and the 
parties having agreed to set the maintenance of the daughters against the profits received by the father from the estate, he decreed upon the bond only; but that decree was, that interest should be paid upon the bond from the time when the condition made the money payable. In Clavering v. Clavering, Prec. Chan. 235, 2 Vern. 473, 1 Bro. Parl. Cas. 122, Sir James Clavering settled an estate upon one son in 1684, and in 1690 made a settlement of the same estate upon another son: he never delivered out or published the settlement of 1684 , but had it in his own power, and it was found after his death amongst his waste papers. A bill was filed under the settlement of 1690 , for relief against the settlement of 1684; but Lord Keeper Wright held, the relief could not be granted, and observed, that though the settlement of 1684 was always in the custody or power of Sir James, that did not give him a power to resume the estate, and he dismissed the bill. In Lady Hudson's Case, cited by Lord Keeper Wright, a father, being displeased with his son, executed a deed giving his wife $£ 100$. per annum in angmentation of her jointure; he kept the settlement in his own power, and on being reconciled to his son, cancelled it. The wife found the deed after his death, and on a trial at law, the deed being proved to have been executed, was adjudged good, though cancelled, and the son having filed a bill in equity to be relieved against the reed, Lord Somers dismissed the bill. In Naldred v. Gilham, 1 Pr. Wms. 577, Mrs. Naldred in 1707 executed a deed, by which she covenanted to stand seised to the use of herself, remainder to a child of three years old, a nephew, in fee. She kept this deed in her possession, and afterwards burnt it and made a new settlement; a copy of this deed having been surreptitiously obtained before the deed was burnt, a bill was filed to establish this copy, and to have the second settlement delivered up and Sir Joseph Jekyl determined, with great clearness, for the plaintiff, and granted a perpetual injunction against the defendant, who claimed under the second settlement. It is true, Lord Chancellor Parker reversed this decree; but it was not on the ground that the deed was not well executed, or that it was not binding because Mrs. Naldred had kept it in her possession, but because it was plain that she intended to keep the estate in her own power; that she designed that there should have been a power of revocation in the settlement; that she thought while she had the deed in her custody, she had also the estate at her command; that, in fact, she had been imposed upon, by the deed's being made an absolute conveyance, which was unreasonable, when it ought to have had a power of revocation, and because the plaintiff, if he had any title, had a title at law, and had, therefore, no business in a court of equity. Lord Parker's decision, therefore, is consistent with the position that a deed, in general, may be valid, though it remains under the control of the party who executes it, not at variance with it; and so it is clearly considered in Boughton v. Boughton, 1 Atkyns, 625. In that case, a voluntary deed had been made, without power of revocation, and the maker kept it by him. Lord Hardwicke considered it as valid, 
and acted upon it; and he distinguished it from Naldred v. Gilham, which he said was not applicable to every case, but depended upon particular circumstances; and he described Lord Macclesfield as having stated, as the ground of his decree, that he would not establish a copy surreptitiously obtained, but would leave the party to his remedy at law, and that the keeping the deed (of which there were two parts) implied an intention of revoking, (or rather of reserving a power to revoke.) Upon these authorities, it seems to me, that where an instrument is formally sealed and delivered, and there is nothing to qualify the delivery but the keeping the deed in the hands of the executing party, nothing to show he did not intend it to operate immediately, that it is a valid and effectual deed, and that delivery to the party who is to take by it, or to any person for his use, is not essential. I do not rely on Doe v. Roberts, 2 Barn. \& A. 367, because there the brother who executed the deed, though he retained the title deeds, parted with the deed which he executed.

But if this point were doubtful, can there be any question but that delivery to a third person, for the use of the party in whose favor a deed is made, where the grantor parts with all control over the deed makes the deed effectual from the instant of such delivery? The law will presume, if nothing appear to the contrary, that a man will accept what is for his benefit (11 East, 623, per Lord Ellenborough); and there is the strongest ground here for presuming Mr. Garnons' assent, because of his declaration that he relied and expected Mr. Wynne would provide him security for his money, and Wynne had given an answer importing that he would. Shepherd, who is particularly strict in requiring that the deed should pass from the posscssion of the grantor, (and more strict than the cases I have stated imply to be necessary,) lays it down that delivery to the grantee will be sufficient, or delivery to any one he has authorized to reccive it, or delivery to a stranger for his use and on his behalf. Shep. 57. And 2 Roll. Abr. (K.) 24, pl. 7, Taw v. Bury, Dyer, 167 b, 1 Anders. 4, and Alford v. Lea, 2 Leon. 111, Cro. Eliz. 54, and 3 Co. 27, are clear authorities, that, on a delivery to a stranger for the use and on the bchalf of the grantee, the deed will operate instanter, and its operation will not be postponed till it is delivered over to or accepted by the grantee. The passage in Rolle's Abridgment is this: "If a man make an obligation to I., and deliver it to B., if I. get the obligation, he shall have action upon it, for it shall be intended that $B$. took the deed for him as his servant. $3 \mathrm{H}$. VI, 27." The point is put arguendo by Paston, Serjt. in 3 H. VI, who adds, "for a servant may do what is for his master's advantage, what is to his disadvantage not." In Taw v. Bury an executor sued upon a bond. The defendant pleaded, that he causes the bond to be written and sealed, and delivered it to Calmady to deliver to the testator as defendant's deed; that Calmady offered to deliver it to testator as defendant's deed, and the testator refused to accept it as such; wherefore Calmady left it with testator as a sched- 
ule, anci not as defendant's deed, and so non est factum. On demurrer on this and another ground, Sir Henry Brown and Dyer, Justices, held, that, first by the delivery of it to Calmady, without speaking of it as the defendant's deed, the deed was good, and was in law the deed of defendant before any delivery over to the testator, and then testator's refusal could not undo it as defendant's deed from the beginning, and they gave judgment for the plaintiff, very much against the opinion of the Chief Justice Sir Anthony Brown, but others of the King's Bench, says Dyer, agreed to that judgment. It was afterwards reversed, however, for a discontinuance in the pleadings. Sir A. Brown's doubt might possibly be grounded on this, that the delivery to Calmady was conditional, if the testator would accept it; and if so, it would not invalidate the position, which alone is material here, that an unconditional delivery to a stranger for the benefit of the grantee will enure immediately to the benefit of the grantee, and will make the deed a perfect deed, without any concurrence by the grantee. And this is further proved by Alford v. Lea, 2 Leon. 110, Cro. Eliz. 54. That was debt upon an arbitration bond; the award directed, that before the feast of Saint Peter both parties should release to each other all actions. Defendant executed a relcase on the eve of the feast, and delivered it to Prim to the use of the plaintiff, but the plaintiff did not know of it until after the feast, and then he disagreed to it, and whether this was a performance of the condition was the question. It was urged that it was not, for the release took no effect till agreement of the releasee. It was answered, it was immediately a release, and defendant could not plead non est factum, or countermand it, and plaintiff might agree to it when he pleased. And it was adjudged to be a good performance of the condition, no place being appointed for delivering it, and the defendant might not be able to find the plaintiff, and they relied on Taw's Case. This, therefore, was a confirmation, at a distance of twentyeight years, of Taw v. Bury; and at a still later period (33 Eliz.) it was again confirmed in the great case of Butler v. Baker, 3 Co. 26 b. Lord Coke explains this point very satisfactorily. "If A. make an obligation to $\mathrm{B}$., and deliver it to $\mathrm{C}$. to the use of $\mathrm{B}$., this is the deed of A. presently. But if C. offer it to B., there B. may refuse it in pais, and thereby the obligation will lose its force; (but, perhaps, in such case, A. in an action brought on this obligation cannot plead non est factum, because it was once his deed,) and therewith agrees Hil. 1 Eliz. Tawe's Case, S. P. Bro. Ab. Doniee, pl. 29 ; 8 Vin. 488. The same law of a gift of goods and chattels, if the deed be delivered to the use of the donee, the goods and chattels are in the donee presently, before notice or agreement; but the donee may make refusal in pais, and by that the property and interest will be divested, and such disagreement need not be in a court of record. Note, reader, by this resolution you will not De led into error by certain opinions delivered by the way and without premeditation, in 7 Ed. IV, 7 \&c., and other books obiter." Upon these authorities we are of opinion that the delivery of this deed by Wynne, 
and putting it into the possession of his sister, made it a good and valid deed at least from the time it was put into the sister's possession. ${ }^{*} * * *$

\section{W. $\pitchfork$ FRYER v. FRYER. W.}

(Supreme Court of Nebraska, 1906. 77 Seb. 29S, $109 \mathrm{~N}$. W. 175, $124 \mathrm{Am}$. St. Rep. S50.)

Albert, C. ${ }^{10}$ This is an appeal from a decree of foreclosure whereby the lien of plaintiff's mortgage is given prierity over the respective judgment liens of the two banks, defendants herein. The mortgage is in the form of an absolute conveyance to the plaintiff by the defendant, William I. Fryer, and his wife of certain real estate in the city of Lincoln, was signed and achnowledged by the grantors on the $22 \mathrm{~d}$ day of April, 1901, and was filed for record on the 2sth day of April, 1902, by William L. Fryer, who had retained it in his possession after it was signed and acknowledged, and after it was recorded, was forwarded te him at Denver, Colorado, where he had taken up his abode. Plaintiff resides in the state of Iowa. On the 18th day of December, 1002, each of the defendant banks brought an action against William I. Fryer, who was the fee owner, and caused a writ of attachment to issue which was levied on the premises covered by the mortgage. In each of these cases judgment was given in favor of the plaintiff therein and an order entered for the sale of the premises for the satisfaction of the julgment. In the present suit the contest is between the plaintiff and the two banks as to the priority of their respective liens, and is now narrowed down to the single question whether there had been a delivery of the mortgage to the plaintiff before the levy of attachments on the property. The two banks join in an appeal, and contend that, while the evidence shows the mortgage was signed, acknowleriged and recorded some time before their attachments were levied, it is insufficient to sustain a finding that it was delivered to the plaintiff before that date.

Appellants' contention seems to be based on the fact that the plaintiff never saw the mortgage nor had actual manual possession of it until after this suit had been pending for some time, and long after the levy of the attachments. But the authorities are uniform that actual manual delivery is not essential to give effect to a deed. In Issitt v. Dewey, 47 Neb. 196, 66 N. IV. 2SS, it was held that, where the grantor places his deed on record for the purpose and with the intent of passing title to the grantee, actual manual delivery and formal acceptance are not essential to the validity of the converance. In the case at bar the evidence is conclusive that at the date of the mortgage

9 See Xenos r. Wickham, 13 C. B. N. S. 381 (1sfi2), 14 C. B. N. S. 495 (1sfi3), L. R. 2 H. L. 296 (1Sti); Blight v. Schenck, 10 I'a. 255,51 Am. Dec. 478 (1519), $10 \mathrm{~A}$ portion of the opiuion is omitted. 
deed the mortgagor, William I. Fryer, was indebted to the plaintiff on two notes, aggregating $\$ 5,000$, for borrowed money, and that at the time such indebtedness was contracted it was agreed between the parties that William I. Fryer should convey the property in suit to the plaintiff as security for the debt, and file the conveyance for record. William I. Fryer testified on behalf of the plaintiff, and, while portions of his testimony would indicate that he had no clear recollection of what he did with the instrument after it was forwarded to him at Denver, toward the close of his testimony he testified positively that it had been forwarded to the plaintiff before the date of a certain payment made by him, which was made September 21, 1902, and almost three months before the attachments were levied. It was after learning of this testimony that plaintiff made search and found the instrument among his papers. His statement, received in evidence as a part of his testimony, accounting for his failure to discover it earlier, is to the effect that it must have been received by another member of his household and placed among his papers during his absence from home. The record further shows that at least two months before the attachments were levied William I. Fryer had importuned the plaintiff to reconvey a portion of the mortgaged premises to the latter's wife, and that plaintiff had refused to do so. The evidence, we think, is amply sufficient to show that the instrument was placed on record by William I. Fryer with the intent and for the purpose of passing the title to the plaintiff, and to render evidence of an actual manual delivery and formal acceptance unnecessary, under the rule announced in Issitt v. Dewey, supra.

The decree of the district court seems amply sustained by the evidence, and we recommend its affirmance.

DUFFIE and JaCkson, CC., concur.

By THE COURT. For the reasons stated in the foregoing opinion, the decree of the district court is affirmed. ${ }^{11}$

11 See Moore v, Hazelton, 9 Allen (Mass.) 102 (1S64), where an insolrent guardian, being largely indebted to his ward's estate, upon the ward's coming of age, executed to the ward, in the presence of an attesting witness, an assignment of a mortgage of realty in a sum less than that due to the ward. This assignment was kept by the guardian until after the institution of proceetlings in insolrency by him, more than a year afterwards, when it was taken by the assignee in insolvencr. The ward, who knew nothing of the assignment until after the insolvency, filed a bill in equity to compel the delivery of the assignment. 


\section{MITCHELL v. RYAN.}

(Supreme Court of Ohio, 185̄t. 3 Ohio St. 377.)

The action is one of ejectment, and is in this court by agreement of parties, on the facts appearing in the notes of Judge Whitman, taken at the trial in the common pleas, and the deposition of Margaret Shannon. From the judge's notes, it appeared that the plaintiff first offered a deed from Owen Shannon to Ellen Shannon, for the land in controversy. This deed, dated April 2, 1838, was left with the recorder of Perry county, April 6th, 1838, and was actually recorded, April 11 th, 1838. It was agreed that Owen Shannon was the common source of title. The marriage of Ellen Shannon to John Mitchell, January 7 th, 1840, was admitted. Her death was also admitted. The possession was admitted always to have been in Owen Shannon, or the defendant Ryan. The defendant offered in evidence a deed from Owen Shannon and wife, to him, Ryan, dated July 27 th, 1847, recorded February 14 th, 1850.

Owen Shannon, the grantor, testified in substance as follows: "Ellen Shannon was my daughter; at the time of the deed to her, she was in the east; she knew nothing of it; no consideration passed, and she never had any knowledge of the conveyance; she was born in 1S23; a year after the execution of the deed, she came to Ohio: she was married in about two years after the conveyance; at this time I was in possession; I continued in possession until I contracter to sell to one Kinney; he took possession and made improvements: left, and gave up the contract; then Patrick Haughran went in under verbal contract with me, and made improvements; he left; I then sold to Timothy Ryan, he paid me two hundred dollars; Ryan never moved on the place; my daughter lived a mile from the place after her marriage; she died last spring or fall."

It was agreed that the taxes were always paid by Shannon, till the sale to Ryan.

Henry Green testified that a short time before the last term of the court, Mitchell had no knowledge of the deed to his wife; Duffy told him; this was just about the time of the death of the wife.

Owen Shannon being recalled, testified that he sent the deed by mail. from McConnellsville to Somerset, to be recorded; it came back in the same way; he kept the original deed till it was lost.

The deposition of Margaret Shannon was in substance as follows: "I am a sister of Ann Ryan, wife of the defendant, and also of Ellen Mitchell, deceased, wife of John Mitchell. Ellen lived in New York before she came to Ohio; she was the last of father's family who came; he sent fifty dollars to bring her out; had no knowledge of her owning any land in Perry county previous to her death; I was with her off and on for two years before her death. she being sick; she had not enough of the necessaries of life; she had nothing that was 
nourishing, but did not complain, because she thought her husband was poor; she and Mitchell, after they left McConnellsville, lived on a farm owned by Mitchell and his father, until it was sold to P. Fagan; they then moved on to Caron's farm, where they lived about a year, and until she died; that farm had cleared land, but they lived in a small $\log$ cabin in the woods; during that time Carons and they fell out, and she wanted to move on to an eighty acre tract adjoining father's farm; she told me that if Fagan would pay his notes according to promise, they would buy a nice little place, if only 40 or 80 acres; I am acquainted with the place in dispute; during the time my sister lived in the neighborhood, Kinney lived on it; next, Joseph Perril, who occupied it at least during one crop; after him was Patrick. Haughran, who raised on it, I think, more than one crop; Ryan then had it; he rented it to Dawson, and afterward to Dew, who now occupies it; it had on it, at the time of my sister's death, two houses and a stable, and a considerable of the land was cleared; never heard her or John Mitchell say anything about owning it; it would have afforded a more comfortable place to live in, than that where she died; Ellen knew all about the sales and the renting of the place by father; I told her all about it; she asked me how much father got of Ryan for it; told her \$200; Ellen had no property with which to purchase land before her coming to Ohio, or previous to her marriage; William, Michael, and Mary Ann, the plaintiffs in this action, were the only children Ellen left."

Thurman, C. J. The decision of this case depends upon the question whether the recorded instrument, purporting to be a deed from Owen Shannon and wife, to Ellen Shannon, was ever, in contemplation of law, delivered.

As the statute provides that copies from the records of deeds, duly certified by the recorder, and under his official seal, "shall be received in all courts and places within this State, as prima facie evidence of the existence of such deeds," it is very clear that the record of a deed is prima facie evidence of its delivery: since, without delivery, it cannot exist as a deed. Swan's St. (New Ed.) p. 310, § 10 . To the same effect are the authorities, Steele v. Lowry, 4 Ohio, 74, 19 Am. Dec. 581; Foster's Lessee v. Dugan, 8 Ohio, 87, 31 Am. Dec. 432; Hammell v. Hammell, 19 Ohio, 18; Jackson v. Perkins, 2 Wend. (N. Y.) 317 ; Gilbert v. N. Am. F. Ins. Co., 23 Wend. (N. Y.) 46, 35 Am. Dec. 543.

It is also clear that this presumption may be rebutted by proof. For the statute makes the record prima facie evidence only, for the obvious reason that it may be the result of accident, mistake, or fraud. And being the act of a mere ministerial officer, there is no reason why it should not be subject to explanation. See the cases above cited and also Chess v. Chess, 1 Pen. \& IV. (Pa.) 32, 21 Am. Dec. 350, and Jackson v. Schoonmaker, 4 Johns. (N. Y.) 163.

It was therefore proper for the defendant to introduce such rebut- 
ting testimony; indeed, it was indispensable for him to do so, as the burthen of proof that a recorded deed was not delivered, rests upon the party attacking it.

He accordingly called Owen Shannon, the grantor, who testified as follows:

"The grantee, Ellen Shannon, was my daughter; at time of deed to her in 1838, 2d April, she was in the east; she knew nothing of it; no consideration passed, and she never had any knowledge of the conveyance; she was born in 1823; she was 15 years old when the deed was executed; she came to Ohio in a year afterward; was married in about two years after the conveyance; at this time I was in possession, and I continued in possession until I contracted to sell the land to Kinney; he took possession, made improvements, left and gave up his contract; then Patrick Haughran went in under a verbal contract with me, and made improvements; he left; I then sold it to Timothy Ryan, the defendant; he paid me $\$ 200$; agreed to; that was the consideration; Ryan never moved on to the place; Ryan agreed to sell to Duffy; the legal title is in Ryan, and he is in possession by Duffy; my daughter (Ellen) lived a mile from the place after her marriage; she died in January, or February, 1852; she never had any notice of the conveyance; I sent the deed by mail from McConnellsville to Somerset to be recorded; it came back the same way; I kept the deed until it was lost."

Other testimony was given by the defendant, tending to prove that the grantee, Ellen, knew of the control over the property exercised by her father, and of his several contracts in relation to it; and that she made no objection, nor asserted any claim; but the same testimony strongly tended to establish that she never had any knowledge of the conveyance; nor did her husband know of it until after her death, and after the sale to Duffy. It was also agreed that Owen Shannon paid the taxes upon the land until he sold to Ryan. Upon this testimony, the first question for our consideration is, with what intent did Owen Shannon send the deed to the recorder to be recorded? Did he thus deliver it for the use of the grantee and to pass the title to her immediately, or had he some other intent?

That a delivery of a deed to a stranger for the use of the grantee, may be a sufficient delivery, is well settled. 1 Shep. 'Touch, 57, 58; Jackson v. Phipps, 12 Johns. N. Y. 421.

But it is said in the Touchstone that if such a delivery be made without a declaration of the use, it seems it is not sufficient. The reason of this is very obvious. If the deed be delivered to the grantee, the natural presumption is that it is for his use, and no words are necessary. But if it be handed to a stranger there is no such natural presumption; and hence, unless there be something besides the mere act of delivery to evidence the intent, it is impossible to say that the grantor designed to part with the title. For the delivery may be by 
mistake, or for mere safekeeping, or for some other cause wholly independent of a purpose to transfer the estate.

But while it is thus apparent that the mere act of delivery to a stranger is insufficient, it is equally clear that there is no precise form of words necessary to declare the intent. Anything that shows that the delivery is for the use of the grantee is enough. For the real question is, does the grantor by his act mean to part with his title? and whatever satisfactorily manifests this design is as good as an explicit declaration. Now it does seem to us that when a man executes and acknowledges a deed and delivers it to the recorder, with unqualified instruction to record it, as was done in the present case, the reasonable presumption, in the absence of any rebutting circumstance, is that he means thereby to transfer his title. ${ }^{12}$ And this presumption is powerfully strengthened when, as in the case before us, the grantee is a minor child of the grantor, and is at a great distance from him, so that the deed cannot be delivered to her in person, and when too the circumstances tend to show that it is a gift, and a reasonable one, for aught that appears for the grantor to make.

It is argued, however, that there are circunstances in proof that rebut the idea that Shannon, when he caused the deed to be recorded, meant to part with his title; and we are referred to his subsequent possession of the instrument, to his subsequent control of the property and contracts to sell it, and to the failure of the grantee, or her husband, to assert any claim to the land before the commencement of this suit.

As to the last circumstance, it is explained by the fact that the grantee died without any knowledge of the deed; nor did her husband know anything about it until just before this suit was commenced. No inference, therefore, can be drawn from their silence. What weight, if any, should be given to the fact that the grantor never com-

\footnotetext{
12 "It is unnecessary to controrert the proposition, howerer, that the record of a deed may be an evidential fact having more or less tendency, ac cording to circumstances, to show that the deed had been delivered to the grantee therein named or to some person for his use. It may, under some circumstances, be prima facie evidence of delivery. But there is no sufficient wariant in reason or precedent for declaring as a rule of law or presumption of fact, that the record of a deed is, under all circumstances, prima facie evidence of deliver.y. On the other hand, experience has shown it to be undoubtedly true that, under some circumstances, the record may have no legitimate tendency nhatever to prove a delivery. The case of Hill $\nabla$. MeNichol, so Me. 220 [13 AtI. 883 (1S8S)], is an apt illustration of this statement." Eqan r. Horrigan, 96 Me. 46, 50, 51, 51 Atl. 246, 248 (1901).

"If the question were a new one, there would perhaps be nothing difficult or impracticable in the conception that the act of leaving a deed with the register for record by the grantor with the intent on his part thereby to rest the title in tle grantee should constitute the register the agent for delivery of the grantee, and that upon the assent of the grantee the trausaction should take effect as a valia delivery. Fut we think the law is otherwise in this state. * * * Barnes v. Barnes, 161 Mass. 3S1, 384, 37 N. L. 379, 380 (1\$9t). Lint see Rev. Law's 1902, Mass, c. 127, 5 .
} 
municated to either of them, the existence of the conveyance, is another matter.

Much stress has sometimes been laid upon the fact of the grantor's possession of a deed after an alleged delivery of it; and it has been said that such subsequent possession is a very pregnant circlimstance to show that the supposed delivery was not absolute. That this may often be the case is undeniable; but where the deed has been recorded, such subsequent possession is evidently entitled to much less consideration than where it has not. An unrecorded deed is the sole evidence of title, and it would be unsafe and altogether unusual to leave it with the grantor after its delivery. But a recorded deed is not the sole evidence. The statute makes the record also proof, and a copy of it is admissible, even though the party offering it has the deed itself in, his possession. Hence, with us, people have been proverbially careless about their deeds after they, are recorded, and often, if not generally, seem to attach more importance to the record than to the original. Add to this that the grantor, Owen Shannon, was the father of the grantee, Ellen; that she was a minor, and away from home several hundred miles when the deed was recorded, and that she remained away for about a year, and it seems to us that but little, if any importance ought to be attached to his subsequent possession of the instrument. He was her natural guardian, and there was nothing strange in his having the custody of what belonged to her, even though it was a deed in which he was the grantor.

Waiving the question, whether the subsequent acts of ownership, exercised by Owen Shannon, in respect to the land, and his failure to communicate the existence of the deed to his daughter, are admissible evidence to prove that it was not his design to transfer the title to her when he caused the instrument to be recorded, we are inclined to the opinion, after a consideration of the whole case, that the testimony rather tends to prove a change of his mind subsequent to the delivery to the recorder, than to establish that it was not then his purpose to convey the estate. If it had been his purpose when he made the delivery, to retain any control over the property, it is reasonable to suppose he would have declared such purpose to some one; if not to the recorder, at least to some nember of his family, or to some friend. He was aware that by causing the deed to be recorded, he would, prima facie, be divested of his title, and it is not very reasonable to suppose that he would make such a prima facie case against himself, without taking some precaution to enable him to rebut it, if he did not mean to do what his act purported.

But this is not all. He was called as a witness, and testified. When he did so, he had the strongest motives to state that he did not mean, by the execution and recording of the deed, to part with his title. For he had subsequently conveyed the land to Ryan with warranty, and if he made that conveyance wilfully and corruptly, knowing that he 
had no title, he committed no less than a penitentiary offense. Yet he uttered not one word to explain the intention with which he sent the deed to the recorder. Nor did the defendant venture, so far as appears, to put a question to him touching his intent. Why this silence of both witness and party? Why this failure to prove what the interest of both required to be proved? Why this neglect to make a successful defense? It seems to us there is but one answer we are authorized to give to these questions, and that is, that the question was not asked, because the answer would have been unfavorable, and, for the same reason, there was no masked statement by the witness. 'This is the ordinary presumption where a party fails to offer proof of what he ought to prove, if it exist. It is almost incredible that, in the case before us, the defendant would fail to ask, and the witness to state, whether it was the intention to convey the land, if that intention had not in fact existed. The very object for which the witness was called was to prove that the deed was never delivered, but instead of asking him directly for what purpose he caused it to be recorded, the defendant contents himself with proving circumstances from which he asks the court to infer the purpose.

We suppose the truth to be, that the deed was sent to the recorder to be recorded in order to vest the title in the grantee, and make the property hers; but, that afterward, the grantor changed this mind, and concluded not to give it to her. And, it is altogether probable, assuming the deed to be a gift, that he supposed he had a right to revole it. This view reconciles his conduct perfectly, without imputing to him any wrong motive at any time, and it is the only view that, upon the testimony, we feel at liberty to take.

And here I would remark, that very clear proof ought to be made, to warrant a court in holding that a man who has executed and acknowledged a deed, and caused it to be recorded, did not mean thereby to part with his title. If such deeds could be overthrown by slight testimony, a door would be opened to the grossest fraud. The testimony should, therefore, do more than make a doubtful case. It should establish clearly, that the delivery for record was not for the use of the grantee.

But it is urged, that even if Owen Shannon did intend to part with the title, yet the delivery was insufficient, because it was never accepted, or assented to by the grantee; and it is said that every sufficient delivery includes such assent or acceptance, for no one can be made a grantee without his consent. ${ }^{13} * * *$ It follows that the plaintiff is entitled to judgment.

${ }_{13}$ The portion of the opinion relating to matter of acceptance, omitted here. Ls printed infra, p. 383. 


\section{MATSON v. JOHNSON.}

(Supreme Court of Washington, 1908. 4S Wash. 256, 93 Pac. 324, 125 Am. St. Rep. 924.)

RUdKin, J. F. Lanston died testate in Kitsap county in this state on the 15th day of June, 1902. During his last illness and a few days before his death, he called in one of his neighbors and directed him to prepare a deed and will in order that he might execute them. A deed was accordingly prepared purporting to convey the property now in controversy to the three minors who are plaintifis in this action. The instrument was signed by the grantor in the presence of two witnesses, but was not acknowledged because there was no officer present authorized by law to take the acknowledgment of deeds. The grantor stated to those present that he would appoint Mr. Johnson as his executor, and would instruct him to have the deed acknowledged and properly executed. The property described in the deed was of the ralue of about $\$ 100$ and was the only real property owned by the grantor. At the time of the execution of this deed and as part of the same transaction, Lanston executed a will making various small bequests which are not material here. The following endorsement was made at the foot of the will by direction of the testator: "Ed Johnson are hereby empowered to appear for the notary publich to have inlaid deed executed." What disposition was made of the will and deed after their execution does not appear, but both instruments were delivered to the executor some time after Lanston's death and were by him filed in the office of the clerk of the superior court, the will under date of June 18th and the deed on Iune 23d, 1902. The deed was not filed for record in the auditor's office until February 1, 1906. At the time of the execution of the deed and will, Lanston was the owner of the real property described in the deed and about $\$ 500$ cash in hank. The will was admitted to probate and Johnson appointed executor tliereof. On the 25th day of November, 1905 , the real property now in controversy was conveyed to the defendants in this action by the executor of the will, pursuant to an order of the superior court made and entered in the estate matter. The present action was instituted by the grantees named in the above deed, through their guardian ad litem, to quiet their title as against the purchasers at the executor's sale, and from a judgment in favor of the defendants, the present appeal is prosecuted.

Three questions have been presented for the consideration of this court: (1) Was the Lanston deed ineffective for lack of an acknowledgment on the part of the grantor; (2) was there a delivery of the deed; and, (3) are the defendants bona fide purchasers.

First. An unacknowledged deed is good as between the parties in this state. Such an instrument conveyed at least an equitable title. Devlin, Deeds (2d Ed.) § 465 ; Edson v. Knox, 8 Wash. 6+2, 36 Pac.

\section{Will me}


698; Carson v. Thompson, 10 Wash. 295, 38 Pac. 1116; Bloomingdale v. Weil, 29 Wash. 611, 70 Pac. 94.

Second. Was there a delivery of the deed? "Actual manual delivery and change of possession are not required in order to constitute an effectual delivery. But whether there has been a valid delivery or not must be decided by determining what was the intention of the grantor, and by regarding the particular circumstances of the case. Where a father had indicated in various ways that certain property should be bestowed at his death upon his infant son, and for that purpose had executed a deed, of which he, however, retained the possession, effect was given to his intention, despite the fact that there had been no manual delivery of the deed." 1 Devlin, Deeds (2d Ed.) § 269.

In Atwood v. Atwood, 15 Wash. 285, 46 Pac. 240, this court said: "In coming to these conclusions we have not lost sight of the able argument and large array of authorities contained in the brief of appellant, to the effect that the delivery of a deed does not necessarily require any formal act on the part of the grantor; that it is often a question of intention; that a deed may become operative while the manual possession is retained by the grantor. But in such cases, before the court can find a delivery, the intention to consummate the transaction so as to fully vest the title in the grantee must be clearly shown, and neither the findings of fact by the referee nor by the superior court, nor the evidence in the case, satisfies us that the grantor in the deed under consideration ever did anything with the intention that by doing it he had so delivered the deed as to make it presently operative."

What was lacking in the Atwood Case, viz., the intention to consummate the transaction so as to fully vest the title in the grantee, was, in our opinion, clearly and unequivocally shown in this case. 'The will and deed were executed at the same time and as part of the same transaction. The real property was omitted from the will, no doubt advisedly, and all the surrounding circumstances show conclusively that the grantor intended to convey his real property to these nimors, that the deed was executed for that purpose; and in our opinion the mere absence of an acknowledgment is not sufficient to defeat his expressed intentions.

Thir- The respondents were not bona fide purchasers, as that term is understood in the law. The rule of caveat emptor applies in all its vigor to sales by administrators or executors in this state, and the purchaser acquires only the interest of the estate. Towner $\mathrm{v}$. Rodegeb, 33 Wash. 153, 74 Pac. 50, 99 Am. St. Rep. 936, and cases cited.

We are therefore of opinion that the appellants have shown a clear title to the lands in controversy, as against the respondents, and the judgment of the court below is accordingly reversed, with directions to enter judgment as prayed in the complaint. 


\section{BURNETT v. BURNETT.}

(Supreme Court of Michigan, 1879. 40 Mich. 361.)

Marston, J. The bill of complaint in this case was filed for the purpose of foreclosing a mortgage alleged to have been executed by defendant and delivered to Calvin T. Burnett now deceased.

Calvin T. Burnett during his lifetime resided in Washtenaw county. He was the owner of a tract of land in Livingston county, upon which the defendant and his sister were living. It is claimed on behalf of the complainant that Calvin T., wishing to divide this tract between defendant and his sister, pursuant to an agreement previously made, had a deed of conveyance of the north half thereof to defendant and one of the south half to his sister prepared at Ann Arbor; that he and his wife, the present complainant, took said deeds and visited their son and daughter where they resided upon said lands; that while there and upon the 18 th day of February, 1873, said deeds were properly executed, and that at the same time two mortgages. one from defendant and one from his sister to said Calvin, were by them respectively executed to secure certain notes, those given by defendant being one for $\$ 4,300$, being the one in controversy, and another for $\$+, 000$. This second note under a separate agreement made at the same time was to be considered as an advance to the defendant towards his share of his father's estate, and to be accounted for in a certain manner.

It is also claimed that the deeds, mortgages and notes were at the time of the execution thereof retained by sail Calvin $T$ who was to have the same recorded, but which was not done. Calvin T. Burnett lied February 6th, 18z7. After his decease the deed to defendant was offered him but he refused to accept the same, and the administratrix, on February 14th, 1877, caused the deed and mortgage to be recorded.

The defendant in his answer admits the execution of the notes and mortgage; that $\$ 500$ of the note in controversy was for personal property which he had purchased from his father; that the deed executed by his father to him of the land was not delivered nor intended to be: that his father was to keep said deed, notes and mortgage, and agreed not to record the same, but would wait and see how defendant managed the property, and if not satisfactory that the papers could be destroyed.

The evidence is conflicting. Mrs. Burnett, the complainant, who was present at the time the papers were executed says: "My husband was to take care of the papers and put them on record at his own expense. He was to see that they were put on record. My husband took then home with him." She farther gives as a reason why they were not at the time placed on record, was that they were to go home by way of Howell and have them recorded, but the sleighing was going off and Arg.Prop. -20 
they got home as quick as they could. She farther testified that her husband three years before his death and again one year before, told her that if the papers were in his possession at the time of his death. to have them recorded, and handed over to the proper parties, Mrs. Burnett's daughter Mrs. Webster, who was present at the time the papers were executed, gives the same version, that Calvin $T$. Burnett was to take the papers, have them recorded, and then send the deeds to the proper persons, the grantees.

The justice of the peace who took the acknowledgment and others who were present and who on other occasions had conversations with Calvin T. fully sustained the position set up in the answer of defendant. Which under all circumstances is the more probable and correct view? It is conceded that Calvin T. Burnett was a good and prompt business man, while defendant was somewhat addicted to the use of intoxicating liquors, and it is now said that it was on this account and to prevent the defendant from squandering the property that the deed and mortgage were not recorded. It is clear from the testimony of Mrs. Burnett and her daughter that there was no formal delivery of this deed to the defendant. There is not the slightest testimony in the case tending to show that he had at any time possession or control of the deed, though for never so short a period. All we have then from which we can find that a sufficient delivery was made is the statement made by the grantor, admitting such a statement to have been made, that he would retain this deed, have it recorded and then send it to the grantee. Had this been done, perhaps no question would have arisen. 'This, however, he did not do, but knowingly retained possession of all the papers up to the time of his decease. This we think falls short of showing a delivery.

It is said, however, that defendant took and remained in possession of the real estate and made payments on the mortgage, and that he is thereby estopped from disputing the validity of the deed. Prior to the execution of this deed defendant was in possession of this land, under a three year's lease from his father. He continued in possession, and the payments made were, we think, as now said by hin, to have been for the personal property which he purchased and in payment of rent of the premises. The retention of all these deeds, notes and mortgages by Calvin ' $T$. Burnett and not placing them on record is consistent and harmonizes with the agreement as testified to by the justice and others, and is inconsistent with the other view. From an examination of the evidence in the light of all the surrounding circumstances, we must come to the conclusion that the deed was not delivered, and that the agreement was in substance as set up by defendant in his answer. It follows, therefore that the decree of the court below must be affirmed with costs.

Campbeli, C. J., and Graves, J., concurred.

COOLEY, J. It appears that the intestate some years ago made an arrangement under which he deeded land to George F. Burnett, his 
son, of which about one-half the estimated value was to be an advancement, and for the remainder the son was to give a ten per cent. mortgage. It is probable from the evidence that the father planned this arrangement alone, but it was carried out by the parties so far as the execution of the papers was concerned, and the mortgage was executed by the son with accompanying notes and delivered to the father. The only question concerning the transaction is, whether the deed was ever delivered.

It does not clearly appear that the deed was ever placed in the son's hands, but I am not satisfied that at the time any of the parties supposed the transaction remained incomplete and unconsumnated. The father who lived at a distance from the place where the papers were executed, took the deed away with him when he returned home, and it was found unrecorded among his papers after his death. His widow testifies that he took it merely for the purpose of putting it upon record, which he was to do at his own expense; and she says an accidental circumstance, which she explains, prevented his going to the register's office on his return home.

The value of the land has depreciated greatly since the transaction took place, and on the death of the father it is found not to be for the interest of the son and daughter to claim under the deeds made to then by the father. And now the son being called upon to pay the mortgage he gave upon the land described in the deed to him, he refuses to do so, and insists that the title was never conveyed to him, because the deed was never formally delivered. The daughter malies no question that the transaction with herself was complete, and as a witness in the case she gives evidence which would make out a transaction equally complete between her father and her brother, this defendant.

There are two facts in this case which to my mind are more conclusive than all the testimony of witnesses as to their understanding of the purpose of the parties in executing such writings. One is that the daughter, although it was greatly for her interest to take the same position that the son takes here, did not understand she was at liberty to do so, but admits that the transaction was what on its face it purported to be. The other is that defendant for two years paid in full the interest on his mortgage, thereby admitting its validity and obligation. And it seems to me exceedingly unsafe to set aside the just inferences from such unequivocal acts on such doubtful and contradictory evidence as we have concerning what took place when the papers were executed. ${ }^{14}$

14 A., the owner of lands, desiring to make provision for his son, directed a lawyer to prepare a deed of such lands. The deed when prepared was signed, sealed, acknowledged, and witnessed, and at reciuest of A. recorded by the lawyer. After the lawyer had receired the deed back from the recorder, $A$. told him "to keep it until called for." The son, without ever learning of the deed, died. Shortly thereafter A. called for the deed and tore his name off. The son's widow now claims the land. Who is entitled thereto? The son had been living on the land with his father. 


\section{WHEELWRIGHT v. WHEELWRIGHT.}

(Supreme Judicial Court of Massachusetts, 1807. 2 Mass. 447, 3 Am. Dec. 66.)

The petitioners set forth that the said Joseph is seised in fee simple of four undivided ninth parts, and the other petitioners of two undivided ninth parts, of thirty-one acres of salt-marsh lying in Wells, in common with the said Aaron Wheelwright, and they pray that their respective parts may be set off to them in severalty.

The respondent pleads in bar that Samuel Wheelwright, grandfather of the respondent, on the 30th day of January, A. D. 1700, being seised in fee of the premises, made his last will in writing, which was afterwards duly proved, and by which he devised the premises to his son, Joseph Wheelwright, father of the respondent, in fee tail general, who entered and was seised, and from whom the premises descended to the respondent, as eldest son and heir in tail to his father,-and traverses the seisin in common with the petitioners, which they, in their replication, affirm, and tender an issue to the country, which is joined by the respondent.

Upon trial of this issue before Thatcher, J., October term, A. D. 1805 , the respondent produced the last will of Samuel Wheelwright, by which it was admitted, for this trial, that the premises were devised in tail to Joseph, son of the testator, and father of the respondent, and also of Joseph W., one of the petitioners, and of the husband of Mary W., another of the petitioners, and grandfather of the remaining petitioners. It was also admitted that the respondent was the heir male of Joseph, his father.

The petitioners produced, in support of their claim, two deeds of the said Joseph, bearing date May 4, 1795, one whereof purported to be a conveyance of four ninth parts to the petitioner Joseph, and the other a conveyance of two ninth parts to the remaining petitioners; and they relied on these deeds to show that they were respectively seised, in fee simple, of the several shares so conveyed. Upon producing these deeds by the petitioners, the respondent called for the evidence of their execution before they should be read. Nathaniel Wells, Esq., was produced as a witness, who testified that, in the year 1795, the petitioner Joseph requested him, by direction from his father, as he said, to write those two deeds. Having written them, on the 4th of May, 1795, the father called upon him, and signed and sealed the two deeds in presence of the witness and his brother, since deceased, and delivered them for the use of the grantees, and that he and his brother subscribed their names as witnesses. That it was the intent of the parties that the grantor should have the use of the premises during his life; and as some of the grantees were minors, and could not secure the use to him, that the deeds were delivered as escrows, as he_expressed it, to be delivered by him to the grantees upon the death of the grantor, which the witness has accordingly done. That the witness 
understood from the grantor that his intent, in executing the deeds, was to prevent the entail from depriving the grantees of the land conveyed.

The counsel for the respondent objected to the reading of the deeds to the jury upon this evidence, upon the ground that there was no proof that the same, or either of them, was duly executed and delivered by the grantor in his lifetime to either of the grantees, or to any person authorized by them, or either of them, to receive the same; and that if they had been duly executed and delivered, they were not made bonâ fide, but merely and for the express purpose of destroying: the entail of said lands.

The judge overruled the objection, permitted the deeds to go in evidence, and directed the jury that they were sufficient and legal evidence to maintain the issue on the part of the petitioners. After a verdict for the petitioners, the respondent's counsel filed exceptions to the above opinion and direction of the judge, which were allowed and signed pursuant to the statute, and at the last July term of the Court, the question of the validity of those exceptions came on to be argued.

Parsons, C. J., (who stated the history of the cause, and proceeded.) The right which the father of the respondent had to convey any of the lands he held in tail must be derived from the statute of March 8, 1792. By that statute it is made lawful for any person of full age, seised in fee tail of any lands, by deed duly executed before two subscribing witnesses, acknowledged before the Supreme Judicial Court, Court of Common Pleas, or a justice of the peace, and registered in the records of the county where the lands are, for a good or valuable consideration, bona fide to convey such lands, or any part thereof, in fee simple, to any person capable of taking and holding such estate; and such deed, so made, executed, acknowledged, and registered, shall bar all estates tail in such lands, and all remainders and reversions expectant thereon.

From inspecting the deeds produced in evidence in this cause, it appears that two subscribing witnesses, to whose credibility no objection is made, have certified that they were signed, sealed, and delivered, in their presence. And it further appears that the grantor, on the same day, acknowledged that each instrument was his deed before a justice of the peace.

One objection made by the respondent is, that. admitting the deeds to have been executed in the form and manner required by the statute in this case, yet these conveyances are not bona fide, being made, not for a valuable consideration, but for the purpose of depriving the heir in tail of his inheritance. The deeds purport to be for a valuable consideration in money, and for love and affection to his issue, which is a good consideration. The statute also provides that the conveyance may be on good consideration. It is therefore very clear that the statute intended that the tenant in tail might bar the heir in tail, by deed conveying the land to his relatives, executed for a good al- 
though not a valuable consideration. This he might do by a common recovery; and this method by deed is substituted by the statute in the place of that common assurance, the effect of which is founded on legal fictions. And it is certain that justice, or parental affection, will of ten induce parents who hold their lands in tail to make provision for the younger branches of their family out of the entail. As the statute has made the estate tail assets for the payment of the debts of the tenant, before and after his decease, a bona fide conveyance was required by the statute, to prevent alienations to defraud creditors, and not to protect the heir in tail. This objection cannot prevail.

The other objection is that, by the statute, the conveyance should be completed, and the estate pass, in the lifetime of the tenant in tail, and that the deed should be sealed, delivered, and acknowledged, by him as his deed; that, in the case at bar, the deeds were delivered by the grantor to Judge WVells, not as his deeds, but as his writings or escrows, to be delivered as his deeds by the judge to the grantees on his, the grantor's death; that they could have no effect until delivered by the judge accordingly; and, as the grantor was dead before the second delivery, they were never his deeds, but are void.

This objection seemed to deserve much consideration. The statute certainly intended that the conveyance of the estate tail should be executed in the lifetime of the tenant; and therefore, if there be no acknowledgment of the deed by him, the defect cannot be supplied by the testimony of the subscribing witnesses after his death, as it may be in conveyances of estates not entailed. The reason is, as common recoveries must be suffered in the lifetime of the tenant in tail, and at a court holden at stated times, and the heir in tail has a chance that the tenant may, after the commencement of the suit, die before the term, so it was intended to leave him the chance of the tenant's dying before acknowledgment, which, as the statute was first drawn, could be made only in some court of record; although, as it was amended, it may now be made before a justice of the peace. There is therefore some chance saved to him, but of much less consequence than it was before the bill was amended.

The law, so far as it relates to the nature of this objection, is very well settled. / If a grantor deliver any writing as his deed to a third person, to be delivered over by him to the grantee, on some future event, it is the grantor's deed presently, and the third person is a trustee of it for the grantee; and if the grantee obtain the writing from the trustee before the event happen, it is the deed of the grantor, and he cannot avoid it by a plea of non est factum, whether generally or specially pleaded. This appears from Perk. 143, 144, and from the case of Bushell v. Pasmore, 6 Mod. 217, 218. But if the grantor make a writing, and seal it, and deliver it to a third person, as his writing or escrow, to be by him delivered to the grantee, upon some future event, as his, the grantor's deed,- -and it be delivered to the grantee accordingly, -it is not the grantor's deed until the second delivery; 
and if the grantee obtain the possession of it before the event happen, yet it is not the grantor's deed, and he may avoid it by pleading non est factum. This appears from Perk. 142, 137, $13 \mathrm{~S}$.

It is generally true that a deed delivered as an escrow, to be delivered over as the deed of the party making it, on a future event, takes its effect from the second delivery, and shall be considered as the deed of the party from that time. Perk. 143, 144.-3 Co. 35, b, 36, a.

Whether the deeds in this case were delivered to Judge Wells as writings to be delivered over as the grantor's deeds on his death, or whether they were delivered as the deeds of the grantor to Judge Wells, in trust for the grantees, to be delivered to them on the grantor's death, is a question of fact, to be determined by the evidence. This evidence results from the testimony of Judge Wells, and from the inspection of the deeds. The deeds appear to have been signed, sealed, and delivered, in the presence of two subscribing witnesses, and to have been acknowledged as the deeds of the grantor before a justice of the peace. The witness swears that the grantor did then sign, seal, and deliver, them for the use of the grantees. Thus far there can be no doubt. But the witness further testifies that, because the grantor was to have the use of the premises during his life, and some of the grantees being minors, the deeds were delivered to him as escrows, to be delivered to the grantees upon the grantor's death. What the witness understood by escrow is not explained. He might consider them as escrows, because he was to have the custody of them until the grantor's death. To aid his memory, he therefore refers us to the memorandum he made, at the time, upon the wrapper of the deeds. In that memorandum they are called the two deeds of the grantor, naming him, to the grantees, naming them, to be kept until the death of the grantor, and then to be delivered to the grantees. Here they are not called the writings, or escrows, but the deeds, of the grantor. The weight of the evidence is certainly very great, if not conclusive, in favor of the deeds having been delivered by the grantor, as his deeds, and deposited with Judge Wells, in trust for the grantees. Upon this ground the deeds were very properly admitted as evidence, and the direction of the judge was correct.

But if the deeds are to be considered as delivered to Judge Wells, not as the deeds, but as the writings, of the grantor, we must not thence conclude that they are void. Although generally an escrow takes its effect from the second delivery, yet there are excepted cases, in which it takes its effect, and is considered the deed of the maker, from the first delivery. The exception is founded on necessity, ut res valeat. Thus Perk. 139, 140. If a feme sole seal a writing, and deliver it as an escrow, to be delivered over on condition, and she afterwards marry, and the writing be then delivered over on performance of the condition, it shall be her deed from the first delivery; otherwise, her marriage would defeat it. In Brook's Reading, on the statute of limitations, p. 150, there is another exception. A. delivers a 
deed, as an escrow, to J. S., to deliver over on condition performed, hefore which $\mathrm{A}$. becomes non compos mentis; the condition is then performed, and the deed delivered over; it is good, for it shall be A.'s deed from the first delivery. Another exception is in 3 Co. 35, b, 36, a. Lessor makes a lease by deed, and delivers it as an escrow, to be delivered over on condition performed, before which lessor dies, and after, it is delivered over on condition performed: the lease shall be the deed of the lessor from the first delivery. There is also a strong exception in 5 Co. 85. If a man deliver a bond as an escrow, to be delivered on condition performed, before which the obligor or obligee dies, and the condition is after performed-here there could be no second delivery, yet is it the deed of the obligor from the first delivery, although it was only inchoate; but it shall be deemed consummate by the performance of the condition.

Therefore, if the deeds in this case were delivered to Judge Wells as escrows, and by him delivered over on the death of the grantor, they must take their effect, and be considered as the deeds of the grantor, from the first delivery, he being dead at the second delivery. And the cases in 3 Co. 36 , a, and 5 Co. 85 , are in point. It may here be observed, that it is not to be presumed that it was the intention of the grantor to deliver these deeds as escrows, to be after delivered as his deeds, on the event of his death; when, from the nature of the event, they could not be considered as his deeds from the second delivery. The presumption is violent that he considered Judge Wells as a trustee of the grantees. But whether the deeds were delivered to him as escrows, or in trust for the grantees, -in either case the verdict must stand, and the first judgment be entered thereon, viz., that partition be made; and let a warrant issue to commissioners to make partition. ${ }^{15}$

\section{RUGGLES v. LAWSON.}

(Supreme Court of New York, 1816. 13 Johns. 285, 7 Am. Dec. 375.)

This was a suit in partition, tried before his honor the Chief Justice, at the Orange circuit, in September, 1814.

The plaintiff, in his petition, set forth, that he was seised, in fee, as tenant in common, of an undivided moiety of the premises in question; and that Daniel Lawson and others, defendants, as heirs at law of Robert Thomson, Jun., deceased, were each seised of an equal and undivided twentieth of the premises, and the widow of Robert Thomson was entitled to her dower in the one third of the said ten twentieths of the premises, of which the heirs of the said Robert Thomson were so seised. Several of the defendants put in pleas of confession, and consented to the partition. Robert Thomson and Nelson Thomson, two of the defendants, pleaded non tenent insimul, and gave no-

15 See Wells v. Wells, 132 Wis. 73,111 N. W. 1111 (1907). 
tice, under the plea, that they would prove, at the trial, that they were entitled, in their own right, to one half of the premises, and that they claimed title to the same, by virtue of a conveyance to them, dated the 15th of November, 1811, from their father, Robert Thomson, (setting forth the deed at length.)

At the trial, it was admitted that the plaintiff was seised, in fee, of an undivided moiety of the premises.

Robert and Nelson Thomson, two of the defendants, gave in evidence the deed set forth in the notice accompanying their plea. The deed was given for natural love and affection of the grantor to his two sons, and for the further consideration of one dollar, and conveyed an undivided moiety of the premises. David Mason, a witness, proved, that, in June, 1814, the grantor, being sick, took from his chest the deed in question, among other deeds to his children, which he delivered to the witness, and, at the same time, directed him, in case he should die before making his will, which he had requested the witness to draw up for him, that he, the witness, would deliver the deeds to his children, respectively; the witness having retired, for a short time, to prepare the will of the grantor, on his return, found him dead; and about a month after his decease, the witness delivered the deeds to the grantees named therein.

A verdict was taken for the plaintiff, subject to the opinion of the Court, on a case which was submitted to the Court without argument.

Per Curiam. The only question in this case relates to the effect and operation of the deed from Robert Thomson, Jun., to his two sons, Robert and Nelson. This deed was duly executed by the grantor, in his lifetime, and delivered to a third person, to be delivered to the grantees, in case the grantor should die before having made and executed his will. The grantor did die without having made any will, and the deed was, after his death, delivered to the grantees. If this deed is to be considered as an escrow, the estate, under the circumstances stated in the case passed to the grantees, upon the delivery after the death of the grantor. It is a well-settled rule with respect to an escrow, that, if either of the parties die before the condition is performed, and, afterwards, the condition is performed, the deed is good, and will take effect from the first delivery. Shep. Touch. 59. It may, however, be questionable whether this deed is to be viewed as an escrow; the grantees had nothing to do, on their part, in order to make the deed absolute, which is usually the case where a deed is delivered as an escrow. The delivery here was, at all events, conditional, and to become absolute, upon an event which has taken place; and, as in the case of an escrow, the deed will take effect from the first delivery. This principle is very fully laid down and illustrated in the cases of Wheelwright v. Wheelwright, 2 Mass. 447, 3 Am. Dec. 66, and Hatch v. Hatch, 9 Mass. 307, $6 \mathrm{Am}$. Dec. 67. The grantees in this deed are, therefore, entitled to a moiety of the premises, and partition must be made accordingly. 


\section{JOHNSON v. JOHNSON.}

(Supreme Court of Rhode Island, 1903. 24 R. I. 571, 54 Atl. 378.)

Tilimanast, J. The only question presented for our decision by the bill, answer and proof in this case is whether the deed under which the respondent claims title to the real estate described in the bill was so deposited or left with the witness Charles P. Moies by the grantor, during her lifetime, as to constitute an absolute delivery thereof for the use and benefit of the grantee.

The material facts in the case are these: On May 9, 1899, Mary Johnson made and executed a quitclaim deed of the premises referred to, to the respondent, Mary A. Johnson, and left it with said Charles P. Moies, with direction that in case anything happened to her (she meaning thereby, as Moies understood it, that in case she should die), he should then deliver the deed to her daughter, said Mary A. Johnson. He did not understand, however, from the instructions given him, that the grantor intended by said acts to place the deed beyond her control, but, on the contrary, he understood that she retained the right to recall the deed at any time, and also that she retained the right to sell and dispose of the property thereafterwards if she saw fit. In short, the substance of Moies understanding, from the instructions given him, was that the deed was left with him subject to the control of the grantor during her life, and that in case of her death, without having disposed of the property, he was to deliver the deed to the grantee named therein.

The grantor continued to exercise dominion over said real estate up to the time of her death, which occurred on the 13th day of November, 1901. She advertised it for sale, and in other ways attempted to effect a sale thereof; she paid the taxes, collected the rents, and paid the interest on the mortgage thereon, and generally treated the estate as her absolute property. After her death said deed was delivered to the grantee by Moies, and by her caused to be recorded in the registry of deeds in Pawtucket. And the complainants now seek by this bill to have said deed set aside and declared void and of no effect, on the ground that no delivery thereof was ever effected by the grantor.

In view of the facts aforesaid, we are of the opinion that said deed was ineffectual to pass any title to the estate.

In order to convey title to real estate, it is necessary that the deed thereof shall be delivered to the grantee or to some one for his use. And the ordinary test of delivery is: Did the grantor by his acts or words, or both, intend to divest himself of the title to the estate described in the deed? If so, the deed is delivered. But if not, there is no delivery, and hence no title passes. See Am. \& Eng. Ency. Law, vol. 9 (2d Ed.) 154-158; Brown v. Brown, 66 Me. 316 . In order to 
constitute a delivery, the grantor must absolutely part with the possession and control of the instrument. Younge v. Guilbeau, 3 Wall. 636, 18 L. Ed. 262; Hawkes v. Pike, 105 Mass. 562, 7 Am. Rep. 554.

That a deed may be effectual to convey title, although delivered to a third person to hold until the grantor's death, and then to deliver it to the grantee, there can be no doubt. But in order to make such a delivery valid, the deed must be left with the depositary without any reservation on the part of the grantor, either express or implied, of the right to recall it or otherwise to control its use. Walter v. Way, 170 Ill. 96, 48 N. E. 421; Foster v. Mansfield, 3 Metc. (Mass.) 412, $37 \mathrm{Am}$. Dec. 154. In other words, in order to make a delivery of a deed valid when it is made to a third person for the benefit of the grantee, such delivery must be an absolute one on the part of the grantor; that is, he must divest himself of any right of future control thereof. And if such control is retained by the grantor, no estate passes.

The law relating to delivery of a deed is well stated in Prutsman v. Baker, 30 Wis. 644, 11 Am. Rep. 592, as follows: "To constitute delivery good for any purpose, the grantor must divest himself of all power and dominion over the deed. To do this he must part with the possession of the deed and all right and authority to control it, either finally and forever, as where it is given over to the grantee himself, or to some person for him, which is called an absolute delivery; or otherwise he must part with all present or temporary right of possession and control until the happening of some future event or the performance of some future condition, upon the happening or not happening, or performance or non-performance of which, his right of possession may returis and his dominion and power over the deed be restored; in which case the delivery is said to be contingent or conditional. An essential, characteristic, and indispensable feature of every delivery, whether absolute or conditional, is that there must be a parting with the possession, and of the power and control over the deed by the grantor for the benefit of the grantee, at the time of delivery. Porter v. Woodhouse, 59 Conn. 568 [22 At1. 299, 13 L. R. A. 64, 21 Am. St. Rep. 131] ; Baker v. Haskell, 47 N. H. 479 [93 Am. Dec. 455]."

In the case at bar the evidence shows that while there was a parting with the manual possession of the deed by the grantor, she did not part with the control thereof; and hence a very essential element of delivery was lacking.

Her intended disposition of the property was evidently of a testamentary character. "In case she died," as Moies testifies, "she wanted the property to go that way." But an instrument which is intended to operate as a will, without being executed in accordance with the provisions of the statute relating thereto (Gen. Laws 1896 , R. I. c. 203), cannot be allowed to have the effect of a will. See Providence Insti-
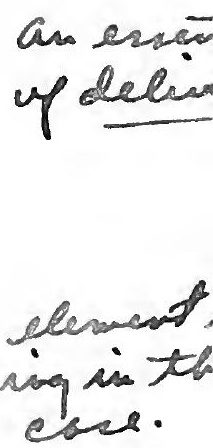
the parties named telling them to put them of record as soon as possible.

"The other Pinal receipt for stock I think is in your bank if so send it to me to the California Hospital and I will endorse and return to you as security for my indebtedness to your bank. I am going to start today and I presume I will be there one or two days before they operate on me so if you mail that other certificate to me I will endorse and return it to you. You will please keep to yourself the names of the parties named in those deeds until you deliver them. After I pass in my checks and take flight for the other world from whence none return.

\section{"Yours, Pat Moore."}

Immediately after mailing this letter Moore went to Los Angeles where the contemplated operation was performed. Towards the end of May he was able to return to his home at Arroyo Grande and to transact various business matters there and in San Luis Obispo, where he went to attend the June session of the board of supervisors, of which he was a member. But his health rapidly declined and on the 18th of June he died without ever having communicated to Tietzen any other instruction, oral or written, than those contained in his letter of May 10th. On June 22d Tietzen delivered the two deeds in question to Mrs. Trott, who filed them for record on the 23d. The sole question in the case is whether these deeds were so delivered as to pass the title to the lands in controversy to the defendant, Mrs. Trott, or whether they remained inoperative for want of delivery.

It was found by the superior court "That at the time said Patrick Moore delivered said deeds to the said P. O. Tietzen as herein found he parted with all dominion over said deeds and each of them and reserved no right to recall or any way control said deeds or either of them. That said deeds were delivered absolutely." Upon this and other sufficient findings judgment was entered in favor of the defendants, and plaintiff appeals from the order denying her motion for a new trial, her principal contention being that the finding here quoted is not sustained by the evidence.

It has been thoroughly established as the law of this state by a series of decisions commencing with Bury v. Young, 98 Cal. 446, 33 Pac. 338, $35 \mathrm{Am}$. St. Rep. 186, that a valid transfer of a fee simple estate, subject to a life estate in the grantor, may be effected by means of a deed delivered by the grantor to a third party with instructions to deliver it to the grantee at his, the grantor's death, provided alwaysand this is the essential condition of the validity of such transfersthat the delivery is absolute so that the deed is placed beyond the pourer of the grantor to recall or control it in any event. The finding of the superior court, it will be seen, fully supports its conclusion in favor of the validity of this transfer to Mrs. Trott and it only remains to inquire whether the evidence in the record sustains the finding.

Moore at the time of his death was over seventy-one years of age.
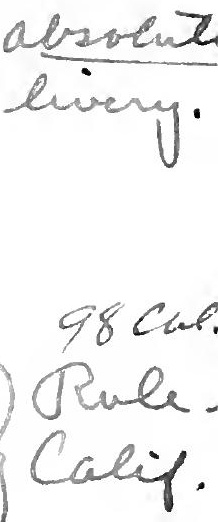
His first wife had died childless and the plaintiff to whom he had been married about two years, was without issue. His relation to the defendant was that of an old and intimate friend of herself and her parents. Annie Gray was a member of his own household, and the other persons named as grantees of different portions of his lands in the deeds placed with Tietzen were intimate and valued friends. Of his long cherished design to make each of them a sharer in the estate he might leave at his death there can be no doubt, and it is equally clear from the evidence that he died in the belief that his purposes in this regard were fully effected by the deeds he had executed and the instructions concerning them contained in his letter to Tietzen. But it is not enough that a man shall desire and intend that a stranger to his blood shall have and enjoy his real property after his death, for unless he complies with the legal requisites of a valid transfer his wishes and intentions are unavailing and his purpose is defeated. If, like Patrick Moore, he is unwilling to make a testamentary disposition which, if unrevoked, will pass the estate at his death, he must deliver his deed absolutely and beyond his power to recall in any contingency, to a custodian whose duty it will be to keep it as long as the grantor lives, and then to deliver it to the grantee. Were these deeds so delivered? If Patrick Moore on his return from Los Angeles had demanded their return could Tietzen have been justified in refusing to return them? If he could not have refused, it matters not that no such demand was made. The test of an effective delivery in such cases is the absolute relinquishment of the right of recall by the grantor in his instructions to the person charged with the duty of making the delivery. The transfer, or attempted transfer, of the estate being entirely gratuitous, the person named as grantee has no right beyond that which is voluntarily conferred and the extent of that right is to be determined in every case where specific instructions are given by what passes between the grantor and his selected agent. The agent is of course bound to do what his instructions require him to do-no more, no less, and when, as in this case, his only instructions are in writing, the effect of the transaction depends upon the true construction of the writing. It is in other words a pure question of law whether there was an absolute delivery or not.

What, then, is the proper construction of Moore's letter? It seems very plain that Tietzen is authorized to deliver the deeds only "in case of my not returning from the California Hospital where I am going for an operation," and the implication that if he does return the deeds are to be at his disposal is clear. But counsel for respondent contends that a different intention is revealed by subsequent clauses of the letter. He relies greatly upon the direction to lock the deeds in Tietzen's safe "and in case I should die to immediately hand them to the parties," etc. We think that this, so far from being inconsistent with our construction of the first part of the letter, is only corroborative of it! If Moore's intention had been to part with the deed absolutely he would 
not have directed their delivery "in case I should die," for he was sure to die at some time. He would more naturally have said when I die. It is apparent that he was not without some hope of obtaining relief more or less permanent from the contemplated operation, and if he had returned from Los Angeles believing himself restored to health and had demanded a return of the deeds from Tietzen we can conceive of no ground upon which the demand could have been resisted. The concluding part of the letter to Tietzen, which counsel agree must be read without any period after the words "until you deliver them," neither aids nor weakens our construction of the first part. The direction to "keep to yourself the names of the parties named in those deeds until you deliver them after I pass in my checks," etc., while they certainly do consist with the idea of that death which is certain to come to every man, were entirely appropriate as referring exclusively to death as the result of the operation about to be performed.

Aside from the letter to Tietzen which, as above stated, contained the only instructions ever given him as to the disposition of the deeds, it was shown by the testimony of numerous witnesses that Moore wished the persons named as grantees in his deeds to have the property therein described, and that his relations to those parties, and his condition and circumstances made them the reasonable and meritorious objects of his bounty. There is, moreover, no reason to doubt that he died believing that his deeds in the hands of 'Tietzen would be sufficient to accomplish his purpose, but his purpose is defeated by the fact that the delivery was not absolute. A technical but inflexible rule of law governing the transfer of real property prevents his intention from being carried out ${ }^{17}$

Counsel for respondent urges with apparent seriousness the proposition that the deeds to Mrs. Trott having been found in her possession there is a presumption of delivery to her at their date, which is not rebutted by the evidence in the case. We think this presumption is not only overtlirown by the evidence, but that the specific findings of the court show that the only delivery was that made by Tietzen after Noore's death.

The order of the superior court denying a new trial is reversed ${ }^{1}$

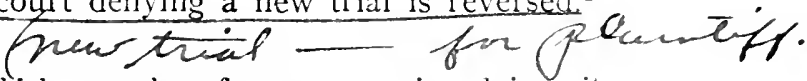

17 A portion of the opinion, in which a number of cases are reviewed, is omit ted.

18 See s. c., 162 Cal. 268, 122 Pac. 462 (1912).

The owner of laud, ill with consumption and believing herself on her deatls bed, prepared a deed of sajd land and gave same to X., with instrmctions thit, "if I recover, I want them back again; and if I do not, you leliver to" the grantees. The grantor died sis weelis later, and $\mathrm{X}$. then turned the deed over to the grantees. Was there an effective delivery? Williams f. Inulner, 10; Wis. 521, 79 N. W. 74 S, 74 Am. St. Rep. 902 (1899); Seeley v. Curts, 180 Ala. 445,61 South. 807 . Ann. Cas. $1915 \mathrm{C}, 3 \mathrm{~S} 1$ (1913).

The owner of land made a deed thereof and leposited same with a trust company, with written instructions "to hold it until a specified date, at which time to return it to the grantor if she is then living, and in the erent of lier desth in the meantime to deliver it to the grantees." "The grantor died prior to the 


\section{OWINGS v. FIRST NATIONAL BANK.}

(Supreme Court of Nebraska, 1914. 97 Neb. 257, 149 N. W. 777.)

REESE, C. J. This is an action brought by plaintiff, Henry Owings, against the First National Bank of Johnson, Nebraska, to recover the sum of $\$ 5,129.67$, the proceeds of the sale of a tract of land, described in the pleadings, but the description of which need not be stated here. The land was formerly owned by Lizzie E. Schmidt, who was later married to Henry Owings. They went to the state of Colorado, and after their marriage there located in the city of Sterling, in that state. Mrs. Owings' health failed, and it became apparent that she was in a precarious condition. On the 2 Sth day of June, 1911, Mrs. Qwings executed a warranty deed to her husband, conveying the land in question to him, and placed it in a trunk in the house, and kept it until the $2 \mathrm{~d}$ day of December, of the same year. At that time it was apparent that she could not recover, and that the date of her dissolution was not far distant, her malady being consumption. She was confined to her bed, and called for the deed to be brought to her. She then obtained pencil and paper and wrote the following instructions: "Sterling, Colorado, Dec. 2, 1911. In case of my death, give this deed to my husband, Henry Owings, to be recorded so my property is his. I am in poor health and no hopes of ever getting well. He is the only provider I have got. Mrs. Lizzie Owings, Sterling, Colo." She handed the deed and the above described memorandum to her husband, requesting him to place them in a local bank at Sterling, which he did, Mrs. Owings died on the 7 th day of January, 1912. The second day after her death, plaintiff called at the bank and received the deed and memorandum of instructions, above copied, as well as some money on deposit, and made preparations for returning to Johnson, Nebraska, with the remains of his deceased wife. Prior to her decease, she, with her husband, had negotiated the sale of the land to one J. George Hahn for the sum of $\$ 5,640$, and on the 11 th day of December, 1911, with plaintiff, executed a warranty deed to the purchaser, which was deposited in the First National Bank of Johnson, in this state. Prior to this time, and on the 2d day of December, 1911, a written contract of sale was made with Hahn for the sale of the land at the price of $\$ 5,640, \$ 400$ of which was paid in cash, the remainder to be paid on the 1st day of March, 1912, or $\$ 2,500$ to be then paid, and the remainder on time at the option of the purchaser. date delivery? Long v. Ryan, 166 Cal. 442, 137 Pac. 29 (1913).

A husband prepared a deed of his lands to his wife, and at the same time the wife prejared a deed of her lands to him. Both deeds were deposited with a third party, with instructions not to returu either deed except upon the writteu order of both, and in case of death of either to deliver the deed of the deceased to the survivor. The wife died first, and her deed was given to the husband. Was it an effective delivery? Dunlap v. Marnell, 95 Nel. $555,145 \mathrm{~N}$. W. 1017 (1914). 
Instead of accepting the time option, Hahn paid into the bank the whole amount, and accepted the deed, with another one executed by plaintiff.

Mrs. Owings left no child, nor father, nor mother, surviving her, but she had two brothers, Henry Schmidt and Charles J. Schmidt, who demanded one-half of the money in the bank as the heirs of Mrs. Owings. The bank refused to pay the money to either claimant, when this action was brought against it by plaintiff for the whole amount. The bank filed the statutory affidavit to the effect that it held no claim on the money, but that it was demanded by the claimants, and asked to be protected. The court ordered the brothers to intervene and set up their claims by a day fixed by the court, which they did, contending that the deed from Mrs. Owings to her husband did not convey any title to him for want of delivery, that the sale of the iand to Hahn was of her property, and by reason of their relationship to her they were entitled to one-half of the fund under the provisions of the statutes of descent in this state. It appears that Henry Schmidt held a note against his sister, Mrs. Owings, for the sum of $\$ 1,019.25$, growing out of the settlement and adjustment of an estate to which the land formerly belonged, and which note Mrs. Owings directed should be paid at the time she handed the deed to plaintiff at Sterling. There is no question as to this sum of money, plaintiff having agreed at the trial that Henry Schmidt should receive it out of the fund. The cause was tried to the court without the intervention of a jury, when a finding and judgment was entered, giving the $\$ 1,019.25$ to Henry Schmidt, and the residue to be paid by the bank to plaintiff. Defendants, interveners, appeal.

The real, and indeed the only, question presented is: Was the deed from Mrs. Owings to plaintiff so delivered to him as to pass the title? The negotiations for the sale to Hahn had so far progressed that the contract of sale to the purchaser was signed on the day the deed was handed to plaintiff for deposit in the Sterling bank, but the contract and conveyance to Hahn were both signed by Mrs. and Mr. Owings. Considerable testimony was taken at the trial showing what occurred at the time the deed was sent to the Sterling bank, as well as declarations made to others by Mrs. Owings after the execution of the deed and before the $2 \mathrm{~d}$ day of December, the day it was sent to the bank. The written memorandum was made by Mrs. Owings while on her sickbed, and she never was "down town" after that date and prior to her death. She never made any effort to countermand those instructions, but, so far as is shown by the record, she was at all times thereafter entirely pleased with what she had done. Had she been able to go to the bank and deposit the deed with oral instructions as written, the case would fall within the rule of Roepke v. Nutzmann, $95 \mathrm{Jeb}$. 589,146 N. W. 939, and we are unable to see-why, under her written instructions to the bank, they would not be of equal force. That case

AIG.Prop.-21 
and Brown v. Westerficld, 47 Neb. 399, 66 N. W. 439, 53 Am. St. Rep. 532, are decisive of this one, and it is not necessary that the law of those cases be further examined.

We are satisfied therewith, and that the judgment of the district court is right and it is affirmed. ${ }^{19}$

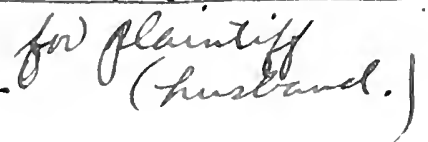

STONE v. DUVALL.

(Supreme Court of Illinois, 1S75. 77 Ill. 475.)

Writ of Error to the Circuit Court of Monroe county; the Hon. Amos Watts, Judge, presiding.

This was a bill in chancery, filed by Washington Duvall and Mary Duvall, his wife, against George Stone, Julia Stone, Pearly Stone and Bissell Davis, heirs at law of Mary Stone, deceased, and William Stone, husband of Mary Stone, to set aside a deed mado-by the complainants to said Mary Stone. The material facts of the case are set forth in the opinion of the court.

WALKER, J. The evidence shows that defendants in error had each been previously married, Washington having a daughter by that former marriage, who was married to William Stone; Mary had a son by her previous marriage, named Allen Agnew. They each owned a small amount of real estate when married, and discord afterwards having arisen between them, it was agreed that they should respectively relinquish or convey their clain to each other's property, so that the survivor would have no interest in the real estate of the other- to cut off the claim of dower by the wife in the property of the husband, and the right of curtesy of the husband in the property of the wife, and to prevent their step children from claiming any interest in the property of their step parents.

In consummating this arrangement, defendants in error went to a justice of the peace, who, under their directions, prepared deeds which they executed and acknowledged. By one of these deeds the land owned by the husband was conveyed in fee to his daughter, Mrs. Mary Stone. By the other, the wife's real estate was conveyed to Allen Agnew. The justice was directed to have the deeds recorded, and to hold them until the death of the parties, and then deliver them to the respective grantees. Subsequently Mrs. Stone died, leaving Tier husband, and the other defendants, her minor children, surviving her.

19 In Loomis v. Loomis, 17 S Mich. 221, 144 N. W. 552 (1913), the grantor, after signing the deed, instructed the scrivener to retain possession thereof, "ind that if anything occurred to her, haplened to her, to detiver this deed to" the grantee. After the grantor's death the s'rivener turied the deed over to the grantee. The scrivener testitied that if the grantor hold alled for the deed during her lifetime, he wondd probuldy have snrrendered it to her. The conrt held there had been an effective delivery, an immediate estate having rested in the grantee, subjert to a life estate in the grautor. See O'Brien v. O'Brien, 19 N. D. $713,125 \mathrm{~N}$. IV. $307(1910)$. 
The deeds were recorded, as required, by the justice of the peace, and held until after Mrs. Stone's death, when Duvall called and took the deed executed to her from the justice. It appears that Stone, with his wife, was in possession of the property conveved to his wife when the deeds were made, and he so continued in possession until after the suit was brought.

Complainants claim that the deed to Mrs. Stone was not made in pursuance of their intentions, and contrary to their directions; that the deed was never delivered to the grantee, or to any one for her, and they asked to have it set aside and cancelled, and the property restored to Duvall, as it was before the deed was made. On a hearing, the court below granted the relief sought, and defendents bring the record to this court on error, and ask a reversal.

The evidence of the justice of the peace seems to be rather indefinite as to what the expressed purpose of the parties was when lie drew the deeds. He is, however, positive that he was directed to prepare deeds to convey the land. He proposed to fix the matter by agreement, will or otherwise, but Duvall declined, saying his wife desired deeds. He, when asked the direct question whether the purpose was not to convey Duvall's interest in his wife's property to her son, and any interest she held in Duvalls property to NIrs. Stone, and whether Duvall did not so inform him, says he believes that was the meaning, but that he could not swear to the exact words. He also says that he was afterwards so informed by Mrs. Duvall. Ile nowhere says that it was understood or intimated that the parties intended or said they desired to retain any interest in the property. By a conveyance in fee, they undeniably would accomplish the purpose of preventing such claims as effectually as by any other mode: and it is strange, if such was the intention, that they did not say that was their only purpose.

Duvall told Stone that he intended to convey the property to his wife, as Stone states in his sworn answer. The deed having been subsequently made in accordance with this declaration, and in pursuance to the advice received from the attorney, a different purpose from that expressed in the deed should be clearly proved, before a court of chancery would interfere to set it aside. The deed itself, in proper form and duly executed, is strong eridence of the grantor's intention, and to overcome it, the evidence should be clear and convincing.

Here we find a man largely advanced in life, the father of a woman having a family of children, and of limited means, and, as it seems, fearful that his wife would, at his death, hold dower in his property, determined to secure the property to his daughter, and it is not out of the usual course of human action for him to make a conveyance to her. He inquired if he could; he said he would, and finally did so convey it. Duvall, himself, testified, and he does not state the purpose of the conveyance, nor the instructions he gave to the justice of the peace. He does not say that the deed did not carry out his pur- 
pose when it was made. He is silent as to the execution of the deed, or what he said to the justice. He does not say there was a mistake, or that the justice did not do precisely what he desired.

It is, however, said there was no consideration paid for the property. He acknowledges, in his deed, that there was, and he, and all others, fail to disprove the acknowledgment of the fact in the deed. The justice says he knew nothing of any consideration being paid, but that does not negative the statement in the deed that it was. Even if it was necessary to prove a pecuniary consideration to sustain the deed, still, the deed, uncontradicted, proves that it was paid. We will not stop to inquire whether natural love and affection, although not expressed in the deed, would not-sustain it, or whether, on his own theory of the case, the getting of the property free from his wife's dower would not be sufficient.

It is manifest that complainants intended to convey some interest in, and title to these premises to Mrs. Stone, but what interest is not shown by the evidence. Whether it was to be a fee subject to a life estate in the grantor, or some other estate, does not appear. Nor do counsel suggest what estate it was. To cancel the deed would be to permit Duvall to change his mind, and to defeat his act deliberately done after consultation and advice taken, and done in accordance with his previously expressed purpose to convey to Mrs. Stone. It would be clearly wrong to abrogate the deed, unless it clearly appeared that an estate less than a fee, and such an estate as terminated with her life, or previous thereto, was intended to be conveyed, but was not by reason of a mistake.

It is urged that the deed was never delivered. It was not, to Mrs. Stone, as she was probably not aware of its existence for a considerable time afterwards, if it ever came to her knowledge. Was the delivery to the justice of the peace, with directions to record and hold it until the death of Duvall, a delivery? It was manifestly not an absolute delivery. The fact that he was directed to hold the deed, and not deliver it till the death of Duvall, renders it absolutely certain that the grantor did not intend that the deed should take effect until that time. This removes all doubt on that question. The deed did not, therefore, operate to give Mrs. Stone any immediate rights or interest in the premises. If she acquired any right, it was that the title should only vest in her at her father's death.

Was this, then, a delivery as an escrow? Kent, Ch. J., in the case of Jackson v. Catlin, 2 Johns. (N. Y.) 248, 3 Am. Dec. 415, says: "A deed is delivered as an escrow when the delivery is conditional, that is, when it is delivered to a third person to keep until something be done by the grantee; and it is of no force until the condition be fulfilled." Sheppard, in his Touchstone, p. 58, gires substantially the same definition, except he does not limit the performance of the act to the grantee, which seems to us to be the more accurate rule. Now this deed was to be delivered on the death of Duvall. That was the ex- 
press condition upon which it was placed in the hands of the justice, and, according to the authority of the case of Jackson v. Catlin, supra, it was delivered as an escrow, and could not take full effect until the thing happened that was conditional to its delivery; and Duvall not having died, the deed has not yet vested the title in full, and can not until that event shall occur.

Sheppard lays it down as the law, that "The delivery is good, for it is said, in this case, that if either of the parties to the deed die before the conditions be performed and the conditions be after performed, that the deed is good; for there was traditio inchoata in the lifetime of the parties; and postea consummata existens, by the performance of the conditions, it taketh its effect by the first delivery, without any new or second delivery; and the second delivery is but the execution and consummation of the first delivery." But in such a case, the delivery only relates back to the first delivery so as to carry out the intention of the grantor, and to vest the title. It would not give the grantee a right to intervening rents and profits. So in this case, the deed is an escrow, that will not take effect until Duvall's death, when it may be delivered to the heirs of the grantec, and it will be held to have taken effect so as to have vested such a title in the mother as to pass the fee to them. Until that time, Duvall will be entitled to the use of the property as though he had a life estate, and the children of Mrs. Stone the remainder.

It, then, follows that the court below erred in rendering the decree, and it is reversed. Decree reversed.20
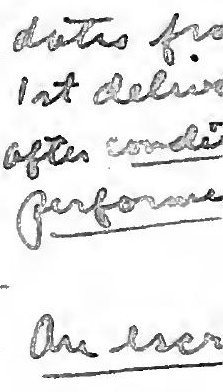

\section{STONEHILL v. HASTINGS.}

(Court of Appeals of New York, 1911. 202 N. Y. 115, 94 N. E. 1068.)

Hiscock, J. This action was brought by the appellants as residuary legatees and representing a deceased residuary legatee of one Margretta Todd to set aside a deed and what has been denominated a life

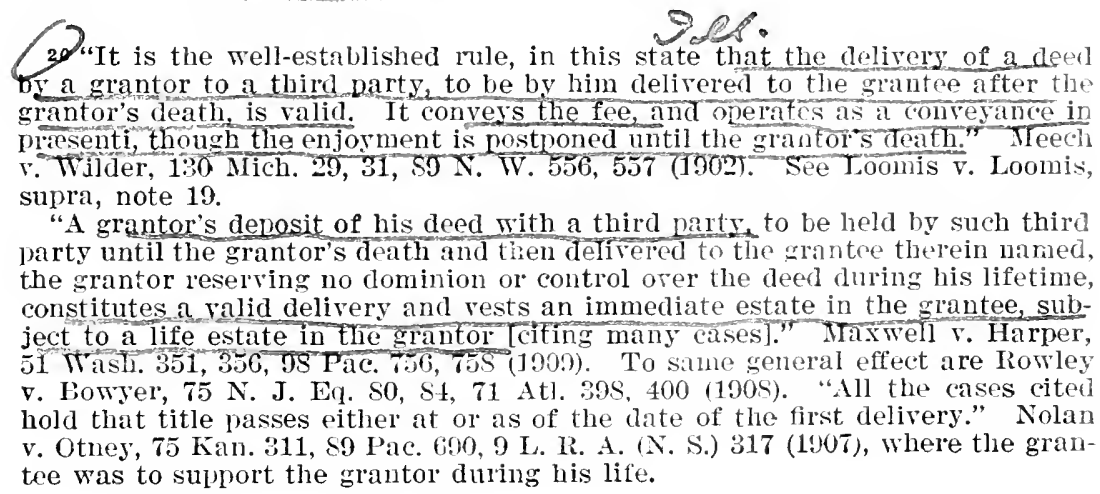


lease of certain real estate situate in the city of New York known as the Von Hoffman Apartment House. The deed ran to a daughter, Rosalie Tousey, subject to the life lease. It was delivered by the grantor to a third person to be by him after her death delivered to the grantee, which was done, and this appeal is concerned with the julgment dismissing the complaint in so far as it attacks said deed. Such attack does not present here any question of fraud or undue influcnce, but involves the question whether the deed was valid and effective under the circumstances of its delivery.

The important findings on which the judgment dismissing the complaint is based and certain significant refusals to find are, in substance, as follows:

Some time before her death, Margretta Todd, being the owner of the premises in question, exccuted a deed of the same to her daughter Rosalie in consideration of natural love and affection, and delivered the same to one Lockwood, "with instructions to hold the same cluring the lifetime of the grantor $* * *$ and upon or after the death of the said Margretta Todd, to deliver the said deed of the said premises to her said daughter." In accorlance with these instructions, communicated to him at the time of the exceution of said deed, Lockwood "did hold the said deed during the lifetime of said Margretta Todd and after her death delivered the same to the said Rosalie Tousey who duly accepted the said cleed." The court refused to find that said deed was deposited with Lockwood by the grantor as her agent, or that she at all times retained control of the aforesaid deed (and lease) and exercised over the said instruments the power to recall them. During the lifetime of the grantor, Lockwood informed the grantee that her mother "had executed and delivered to him a deed conveying the said premises to the said Rosalie Tousey to be delivered to her after the death of her said mother." October 31, 1905, three days after the death of the grantor, Lockwood caused to be recorded in the proper office the deed in question, and notified one Hasings, as attorney for the grantee, of such recording. The grantee at the time was traveling abroad, and after she returned to New York early in December she assumed the direction and management of said premises, expending various sums in re-decoration, repairs, etc., and she made, or caused to be made, a demand upon the Lincoln Trust Company, which had taken possession of the property under circunnstances hereafter to be referred to that the management and control of the premises be relinquished to her "as the said property belonged to her uncler a deed executed" as hereinbefore stated, and thereafter possession was surrendered to her, which she retained until her death, when her title passed to others who are defendants here.

Ifail to see any break in this chain of findings which prevents them from being sufficient in connection with other more formal ones to draw after them the conchusions of law and judgment which have been made to the effect that said deed vested in the grantee a title which

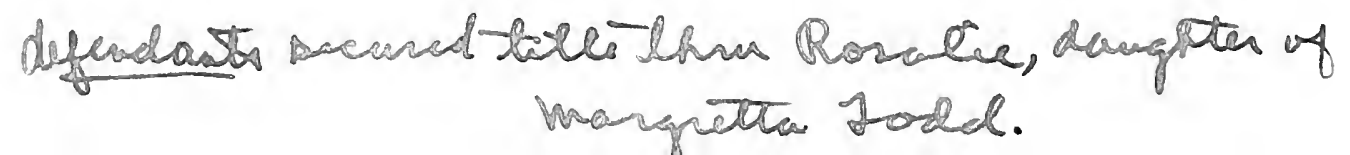


was valid and effective as against the attempt of the appellants to set it aside.

It is urged, however, as against the force of the findings above summarized that other findings were made which are so inconsistent therewith as to lead to a different judgment than that which was rendered. Some of these findings are designated in the decision as findings of fact and some of them which are described as conclusions of law are nevertheless asserted by the appellants to be findings of fact. They are in substance as follows:

That at the time of her death and for many years prior thereto Margretta Todd was the oumer in fee simple of the property in question: that she "retained the active and undisputed control, possession, management and ownership of the said premises down to the date of her death;" that on divers occasions subsequent to the execution of the said deed to her daughter saicl Margretta Todd "had shown much love and affection for her said daughter * * * and harl expressed an intention of executing a deed of the said premises to the said Rosalie Tousey;" "stated as conclusions of law) that the deed was a valid conveyance "to take effect on the death of said Margretta Todd;" that after the death of the said grantor the said Lockwood made a valid delivery of the deed of said premises to Rosalie Tonsey and the said deed was duly accepted by her "and the fee simple of said premises vested in Rosalie Tousey from the time of the death of said Margretta Todd on the 28 th day of October, 1905, and the said_Rosalie Tousey be and is entitled to the rents and profits frefom from said 28 th day of October, 1905."

On these so-called findings of fact the appellants build up the argument that in order to be effective the deed delivered to Lockwood either must have taken effect presently when dclivered to him or else taken effect when delivered to the grantee after the death of the grantor must have related back to the time of its delivery to Lockwood; that on either theory the grantor could not retain ownership of the premises down to the time of her death, and, therefore, the findings which have been last quoted are in conflict with both theories and "compel the conclusion that the deed was intended to take effect not as a present conveyance butas a estary disposition."

The first answer to this argument is that the findings which appellants rely upon and which they claim to be in conflict with those first quoted from, if they are in any conflict, involve statements of law rather than of fact. I suppose that the question as of what time the title would pass from grantor to grantee and at what date the fee simple would vest in the latter upon performance of the various acts set forth in the findings naturally must be one of law.

In the second place, $I$ do not think there is anything in the findings or conclusions as a whole which is intended to be or really is at variance with the judgment which was rendered or which destroys the deed as a valid conveyance. Take as an illustration the findings that 
the deed was to take effect on the death of the grantor and that the "fee simple of said premises vested in Rosalie Tousey *** from the time of the death of said Margretta Todd," and that at the time of her death said grantor was the owner in fee simple of the property, and interpreted in the light of their surroundings they are substantially accurate. The conclusion that the title vested in the grantee from the time of the death of her grantor was part of a conclusion of law made for the purpose of fixing the time from which the grantee should receive the rents and profits, and I do not understand that there is any dispute that she was properly limited in her right to these to the period after her grantor's death. The other conclusions that the deed was to take effect upon the death of the grantor and that the latter died seized of the premises are in accordance with the fact of the final delivery of the deed and the law as established by well-considered cases.

Hathaway v. Payne, 34 N. Y. 92, 113, considered a deed like the present one, which was delivered by the grantor to a third party to be delivered to the grantee after the former's death. Chief Judge Denio wrote for a majority of the court as follows: "They (the authorities) do *** prove that a deed may be delivered to a third person, as this was, with instructions to be finally delivered to the grantee after the death of the grantor. In such a case, the weight of authority is, that no title passes until the final delivery, and that then, and thereafter, the title is, by relation, deemed to have vested as of the time of the first delivery to the third person. If it were an original question, I should suppose that such a transaction was of a testamentary character. * * * But the cases establish the rule as I have stated, and they should not now be disturbed."

The same doctrine was laid down in Rosseau v. Bleau, $131 \mathrm{~N}$. Y. 177,30 N. E. 52, 27 Am. St. Rep. 578. It was there held that an action might not be maintained by the representatives of a deceased person to set aside as fraudulent against creditors a deed not delivered until after the latter's death for the reason that such a deed did not become operative during life and that, therefore, the grantor died so seized that the liens of creditors attached under the statutes relating to real estate of deceased persons.

In this connection appellants' counsel especially relies on the cases of Rochester Sav. Bank v. Bailey, 34 Misc. Rep. 247, 69 N. Y. Supp. 163, affirmed, 70 App. Div. 622, 75 N. Y. Supp. 1131; Burnham v. Burnham, 58 Misc. Rep. 385, 111 N. Y. Supp. 252, affirmed, 132 App. Div. 937, 116 N. Y. Supp. 1132 ; Id., 199 N. Y. 592, 93 N. E. 1117.

In each of these cases it expressly appeared that the grantor retained control of the deed, a condition which not only does not affirmatively appear in this case, but which is negatived by an express refusal to find to that effect.

It is further urged that as evidenced by certain findings, the daughter elected to reject the deed. These findings are to the effect that on 
learning of the death of her mother she cabled to certain representatives to look after her interests, and that those representatives, although knowing of the so-called lease and deed and also of the will, instituted proceedings to have the Lincoln Trust Company appointed temporary administrator and to have it take possession of all of the estate of the decedent, including the real estate in question, which it did. I do not think under the circumstances that this amounted to any binding election to reject the deed. The directions given by the daughter were necessarily general and incomplete and in my opinion did not fairly confer upon her representatives the authority to reject the deed. Inmmediately upon her return she elected to accept the deed and take title under it

Under the circumstances I think the judgment should be affirmed with costs. Judgment affirmed.

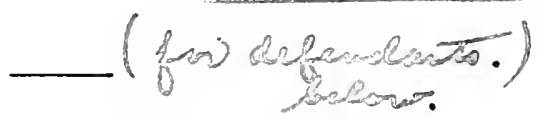

SMILEY v. SMILEY.

(Supreme Court of Indiana, 1SSS. 11. Ind. 25S, 16 N. E. 5S5.)

ElLiotT, Jacob Smiley was married four times. By his first wife, Cadretine, he had four cfiddren, Joseph J., Jonathan H., James and Elizabeth. By his secont trife he had no children. In 1870 he married his third wife, $x$ lary. On the 26th day of September, 1873, he became the owner of the land in controversy. On that day he and his 3 ife executed five deeds, one to his daughter, Elizabeth, one to his son Jonathan H., one to Joseph and Jonathan, one to Joseph, and one to the heirs of James Sniley. At that time James Smiley was living and had four children, Jacob M., Sarah, Willian and Elizabeth. These deeds embraced part, but not all, of the land owned by Jacob Smiley in 1873 . On the 25th day of May, 1875, he executed his will by which he devised to his wife, Mary, during her life or widowhood, part of the land-that in section 11. Item 5th of his will reads as follows: "I have heretofore executed deeds to all my real estate, not above named, to my children and grandchildren for the lands which I wish them each to have, and now place them, the said deeds, in the hands of my executor hereinafter named; which deeds I wish my said executor at my death to deliver to the parties severally named therein, and to whom said deeds are executed." In the 6th item of the will, Joseph J. Smiley was nominated executor.

A few days after the execution of the will, Jacob Smiley placed the deeds in the hands of Joseph I. Smiley, and directed him to retain them until after he, Jacob Smilev, should die, then to deliver them. On the 24 th day of September, 1S75, the third wife, Mary, died. On the 6th day of the following November, Jacob Sniley, on being advised that the deed to the heirs of James Siniley was not valid, executed a deed to his children, Sarah, Jacob M. Milliam and Elizabeth, hnd placer them in the hands of Joseph J. Smiley, and repeated the in-
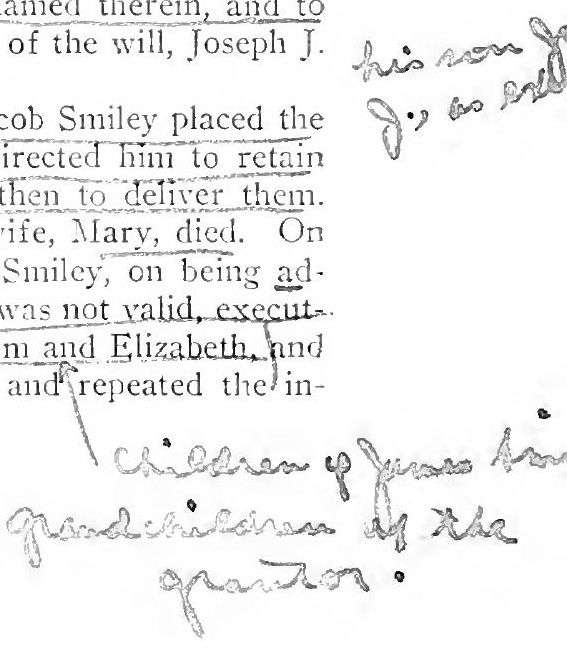
structions formerly given him. On the same day he executed this codicil to his will: "Whereas, my beloved wi 3 departed this life on the 24 th day of September, 1875, I now wish the property bequeathed to her in my will equally divided among all my children." On the 18 th day of December, 1875, Jacob Smiley married the appellee, Agnes Smiley. On the 15 th day of March, 1S77, he died, Teaving no children by his last marriage. On that day Joseph I. Smiley delivered the deeds placed in his hands to the respective grantees therein named. No consideration was paid by any of the grantees. The appellee was advised prior to her marriage that the only estate which Jacob Smiley owned, or in which she would have any clain, was two parcels in section eleven.

The juclgment of the court gave the plaintiff an estate for life in all the land, as well that part described in the deeds placed in the hands of Joseph J. Smiley as that of which no conveyance was made.

The question whether the appellee is entitled to a life-estate in the land embraced in the deeds placed in the hands of Joseph J. Smiley, lepends wion the time those deeds took effect. If they took effect at the time of their conditional delivery to him, then, it is clear, she has no interest in the lands, because her husband was not seized of them at any time during coverture. The case, therefore, turns upon the effect of that conditional delivery. If that delivery was sufficient to vest title in the grantees as of that date, then the appellee can have no claim in the land as against them.

In deciding this question we attach importance to the fact that the appellee was adrised before marriage what land Jacob Smiley owned and in which slie would acquire an interest. She was, at least, put upon inquiry, and if she failed to make inquiry she is not in a situation to aver that she had no notice. Doubtless, marriage is a valid consideration, and if Mrs. Smiley had not been informed as to what lands her husband owned, a diferent question would confront us. We do not, however, decicle that the deeds would not have been valid even if she had not been put upon inquiry, for that is not now necessary. IVe do decide that, as she had notice prior to marriage what land her husband then owned, she can not successfully assert her marital rights in the land embraced in the deeds placed in the hands of Joseph J. Simley.

There was here a conditional delivery for the deeds were placed in the hands of Joseph J. Smiley with explicit instructions to deliver them to the grantees upon the hapipening of a designated event, that of the death of the grantor. In this particular the case differs from that of Jones v. Loveless, 99 Ind. 317. It differs, also, from that case in another particular, and that is this: The party who here assails the deeds had notice that the grantor did not own the lands enbraced in them. This case is, in all material respects, like Owen v. Willians, $11+$ Ind. $179,15 \mathrm{~N}$. F. 678, and the principle there asserted applies to it with griat force. Our conclusion is well sustained by authority. Hockett 
v. Jones, 70 Ind. 227; Crooks v. Crooks, 34 Ohio St. 610; Hatch v. Hatch, 9 Mass. 307, 6 Am. Dec. 67 ; Stephens v. Rinehart, 72 Pa. 434; Morse v. Slason, 13 Vt. 296; Tooley v. Dibble, 2 Hill (N. Y.) $6+1$.

'The trial court erred in its conclusions of law upon the facts stated in the finding.

The appellee has filed a motion to dismiss the appeal as to all of the appellants except William Smiley, and, upon the admissions made in the answer to this motion, the appeal must be dismissed as to all the appellants, except the one named.

It is, therefore, adjudged that, as to all the appellants except IVilliam Smiley, the appeal is dismissed, and that, as to him, the judgment is reversed, with instructions to restate the conclusions of law, and enter judjment in his favor. ${ }^{21}$

\section{RATHMELL v. SHIREY.}

(supreme Comrt of Ohio, 1893 . (e Ohio st. 157, 53 N. E. 109S.)

The cause was tried in the circuit court upon appeal from the court of common pleas. The plaintiff in error prayed for a decree of the court setting asicle a deed for one hundred acres of land made by his testator to the defendant, Thomas Rathmell, in trust for the defendant William C. Shirey and others, and an order for its sale for the payment of debts of his testator, alleging in his petition and amendments thereto the insufficiency of the assets of the testator to pay his debts; that the instrument in question was signed by the testator contemporaneously with the execution of his will and upon no consideration except that expressed, to-wit, love and affection for his son IVilliam and one dollar; that said instrument was not then, nor ever in the lifetime of the testator delivered to said trustee but was delivered as an escrow to one Zeno C. Payne to be by him placed on record and delivered to said trustee after the death of said testator, the testator remaining in possession and control of the premises and paying taxes thereon until liis death, a portion of his debts being contracted after the signing of said instrument and credit being extended to him on account of his apparent ownership of said premises, and that said deed delivered to said trustee after the death of the plaintilf's testator was fraudulently made and that it hinders, delays and defrauds his creditors. The answer admitted the insufficiency of the assets of the testator's estate to pay his debts. On denial by the defendants of the plaintitits allegations as to the fraudulent character and effect of the instrument the cause was tried in the circuit court where upon request the conclusions of fact and law were separately stated as follows:

On the fourth day of December, 1891, Lewis Shirey, then in full

21 Vorheis v. Kitch, 8 Phila. 554 (1S71), ace., the deed there beingan escrow.

See Ladd v. Ladd, $14 \mathrm{Vt}$. 185 (1812), where the widow was held entitled to dower, the grantor having been deemed to have died seised.

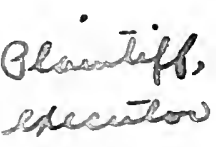


life, was seized of 160 acres of land in Hamilton township, Franklin county, Ohio, upon 60 acres of which there was a mortgage incumbrance of $\$ 1,500$; that on said December 4,1891 , said Shirey executed a trust deed to Thomas Rathmell for the remaining 100 acres thereof for the use of his son, William C. Shirey, for life, remainder to the children of William C. Shirey. That on the same day he executed his will disposing of 60 acres, the remainder of his land; the same being cliarged with the mortgage incumbrance aforesaid to his daughter, Nargaret Thompson. That at the time of the execution of said deed, to-wit, December 4, 1891, he delivered the same to one Zeno C. Payne, his attorney, who made the following indorsement thereon in said Shirey's presence, to-wit: "Deposited with me in escrow to be placed on record at the death of the grantor and delivered to the grantee therein named, Z. C. Payne." At the time of said endorsement said Shrey instructed said Payne to place this deed on record at the time of his death and deliver the same to the grantee therein named. That at the time of the execution of said deed and will in addition to the mortgage inemmbrance of $\$ 1,500$, Shirey was indebted to divers persons in the sum of $\$ 500$, which, in addition to the $\$ 1,500$ mortgage incumbrance, remained unpaid at the time of his death, which occurred in February in 1895. Shirey remained in possession and control of said realty, and paid the taxes thereon during his life time, and contracted subsequently to the execution of said deed other debts to the amount of about $\$ 1,325$, said indebtedness of $\$ 1,325$ remaining unpaid at the time of his death.

Shirey died February, in 1895, leaving defendant, Crissie Shirey, his widow, and said son and datighter surviving him. Said trust deed was, immediately upon Shirey's death, placed on record in the recorder's office of Franklin county, Ohio, and then handed to Thomas Rathmell, the grantee therein named, who, immediately upon Shirey's death and in execution of the trust created by said trust deed, entered into and took possession as such trustee of said 100 acres of land, and is now and has been continuously since the death of said Lewis Shirey in possession thereof. That said 60 acres of land devised to Margaret Thompson by said will have been sold by plaintiff and the proceeds of said sale are not more than sufficient to pay said mortgage indebtedness of $\$ 1,500$, with interest, widow's dower in said 60 acres and costs of sale. No provision for the widow was made either in the deed of trust or in the will At the time of the exccution of said deed the grantor, Shirey, did not retain property clearly and beyond doubt sufficient to pay his existing indebtedness; and of which indebtedness about $\$ 700$ (being unsecured debts) is and remains unpaid, and that unless said 100 acres of land or some part thereof, be sold, the general creditors of said L evis Shirey will receive nothing on their claim, as cost of administration, costs of last sickness and funeral and the mortgage indebtedness of $\$ 1,500$, with interest, and widow's dower and allowance, having consumed the proceeds of said 60 acres of land and all the personal estate of said Lewis Shircy. 'That said Lewis Shirey in the execution 
of said deed acted in perfect good faith and without any intentional fraud. That said Lewis Shirey when contracting said debts subsequent to the execution of said trust deed was guilty of no misrepresentations whatever, credit having been extended to him without any inquiry or investigation by the persons so lending him credit as to how much land or property he then owned, said creditors having knowledge that said Shirey was in the possession and control of 160 acres of land and without knowledge that he had made said trust deed. Upon the foregoing facts the court finds the law to be as follows, to-wit:

First-That said trust deed passed the title to said grantee, Thomas Rathmell, trustee, as of the date of its first delivery, to-wit, December 4,1891 , subject to the dower estate of Crissie Shirey.

Second-There was no intentional fraud in the execution and delivery of said deed, and that the same is valid as to the debts of Lewis Shirey created after December 4, 1891. (Avis of Spessescoss of alese

Third-That said conveyance is void as against the debts existing at the time of its execution.

Fourth-That plaintiff is entitled to sell so much of said 100 acres of land as may be necessary to pay the outstanding debts of Lew is Shirey existing December 4, 1891, with the accrued interest thereon. To each and all of which findings of fact so made by the court as aforesaid, and each and every conclusion of law thereon the plaintiff excepts.

A bill of exceptions was taken embodying all of the evidence, and this petition in error prays for the reversal of the juclgment of the circuit court because its findings of fact are not supported by the evidence and because its conclusions of law were not justified by the facts found.

SHAUCK, J. The case presented permits us to assume, without deciding, that in view of the facts found by the circuit court there was such a delivery of the deed as would give it effect as against the heirs at law of the grantors, and that as to them the deed would, by relation, take effect at the date when the instrument was delivered as an escrow. We have to determine whether it was effective to pass the title to the grantee discharged of debts of the grantor contracted between December, 1891, when the instrument was delivered as an escrow and February, 1895, when upon his death it was delivered to the grantee, as was held by the circuit court.

Delivery being essential to the efficacy of a deed, it is obvious that the title does not actually pass until that which was an escrow becomes a deed by virtue of its defivery as such, or at least, until the satisfaction of the conditions prescribed for its final delivery. Accordingly the general rule is that the title does not pass until the second delivery, or unftif the conditions prescribed therefor are satisfied. It would not be practicable to cite all the cases in which the general rule is so stated. Many of them are collected by Mr. Devlin in a note to section 328 of his work on deeds. To this rule there is a well-recognized exception. The rule and the exception are thus stated by Chancellor Kent: "Generally an escrow takes effect from the second delivery and is to be con-

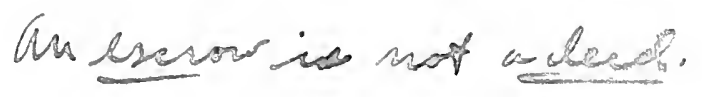


sidered as the deed of the party from that time; but this general rule does not apply when justice requires a resort to fiction. The relation back to the first delivery, so as to give the deed effect from that time, is allowed in cases of necessity, to avoid injury to the operation of the esdeed from events happening. between the first and second delivery. $* * *$ but if the fiction be not required for any such purpose, it is not admitted and the deed operates according to the truth of the case, from the second delivery. It is a general principle of law that in all cases where it becomes necessary for the purposes of justice that the true time when any legal proceeding took place should be ascertained, the fiction of law introduced for the sake of justice is not to prevail against the fact." 4 Com. 454.

Whatever terms may be employed in stating the exception, the relation back to the first delivery is always to accomplish, and never to defeat, justice. Bearing in mind the purpose of this exception and the fact that the deed before us was without any substantial consideration, it is quite apparent that the conclusion of the circuit court that the relation back should be allowed, to cut off the claims of those who gave credit to the testator between the first and second deliveries, and without knowledge of the instrument, is erroneous. That conclusion derives no support from Crooks v. Crooks, 34 Ohio St. 610, or Ball v. Foreman, 37 Ohio St. 132, where the title was held to pass as of the date of the first delivery for purposes clearly within the exception as above stated.

The judgment of the circuit court will be so modified as to order the plaintiff in error to scll so much of the land in controversy as may be necessary for the payment of all the debts of the testator. Judgment accordingly. ${ }^{22}$

\section{WHYDDON'S CASE.}

(Court of Common Pleas, 1596. Cro. Eliz. 520.)

Annuity. The defendant saith, that he delivered the deed of annuity to the plaintiff as an escrow, to be his deed upon a certain condition to be performed, otherwise not: and that the condition was not yet performed. The plaintiff demurred; and, without argument, adjudged

22 Brown v. Austen, 35 Harb. 3-1 (1861), contra.

In Ranken v. Donovan, 46 Alp). Dir. 225, 61 N. Y. Supp. 542 (1S99), 166 N. Y. 626,60 N. E. 1119 (1901), the grantor, after making a deed and puttinir sime into the custoly of a third party, to be delivered to the grantee at death of glantor, made a will purporting to derise the same property to another. IVas the will effective as to that property?

A woman made a deed of certinin linds to her son, and left the deed with a thild party to be handed to the grantee on her death. Iaiter she made a mortsige of the same lands to secure a loan. After the mother's death the mortsasee sought to foreclose the mort gage. The trial court excluded the evidence offered by the son to prove the execution of the deed to him and that the mortgarce hat notice of said deed. Was the court right? See Wittenbrock v. Cass, 110 Cal. 1, 42 I'ac. 300 (1S95). 
for the plaintiff: for the delivery of a deed cannot be averred to be to the party himself as an escrow. Vicle 19 Hen. VIlI, pl. S, 29 Hen. VIII, and Morice's Case, Dyer, 34, b, 35, a, in margin.

\section{HAWKSLAND v. GATCHEL.}

(Court of Queen's Bench, 1601. Cro. Eliz. S:5.)

Debt upon an obligation. The defendant pleads that he delivered that obligation to the plaintiff, as an escrow to be his deed, if he performed such a condition, viz., to permit him to enjoy such corn; and alledgeth, that the condition was not performed, and so not his dect. And hereupon the plaintiff denurs. Clerk, for the plaintiff, argued, that one cannot deliver a deed to the party himself, to be an escrow; and to that purpose cited the 19 llen. VIIl, pl, 43 Ediv. II, pl, 28, where it is said, that this condition cannot be averred upon the delivery to the party himself, in avoidance of the deed, without shewing a deed thereof.

GawDy. There is not any difference, where it is delivered to the party himself as an escrow, and where to a stranger; and the case of 19 Hen. VIII, is so; because the deed was delivered to the party himself first, as his deed upon condition, \&c., in which case the deed is absolute, and takes effect as his deed upon the first delivery; and it cannot be avoided by the condition. But when it is first delivered as an escrow, although it be to the party himself, it is clear that it is not his deed until it be performed. And so is $29 \mathrm{Hen}$. VIll, Dyer, 34 , in Norris and Leigh's Case.

POpHAM accord.; for if, upon the delivery, the words spoken by the obligor purport that it shall not be his deed, it is clear it is not: as where one causeth an obligation to be written and sealed in my name, and brings it unto me, and prays that I would deliver it as my deed, and I say, "Do you such a thing, and take it as my deed, otherwise not ;" it is clear, that it is not niv deed until the thing be performed. So if the obligor saith, "Take it to you, I will not deliver it as my deed;" it is not his deed. Wherefore in the principal case, when the obligation is delivered as an escrow, by express words, it is not possible that it should be his deed, for the words are not sufficient to make it so until the condition be performed. Dut if it be once delivered as his deed, it cannot afterwards be defeated by a condition, if the condition be not in writing; but here the condition is precedent, so as it was not his deed until it were performed, and therefore a conditional delivery may be averred without writing. Wherefore, \&c.

FENAER to the same intent: for although difference hath been taken, that a deed shall not be delivered to the party himself as an escrow, but to a stranger; and the reason hath been alleged, because when it is delivered to the party himself, there cannot be a second delivery. 
whereupon the writing should take his effect as a deed; that seemeth to be no difference: for when it is delivered to the party as an escrow, the words are not sufficient to make it to be his deed, until the condition be performed Wherefore, \&c.

And of that opinion was Chexch. Wherefore it was adjudged for the defendant. Vide Cro. Eliz. 520, Whyddon's Case.

\section{WILLIAMS v. GREEN. \\ (Court of Common Pleas, 1602. Cro. Eliz. SS1.)}

Debt upon a bill. The defendant pleads, that the said bill was delivered to the plaintiff as a schedule, upon condition, that if the plaintiff delivered unto the defendant an horse upon such a day, that then it should be his deed, otherwise not; and that the plaintiff had not delivered the said horse unto him; and so non est factum.-And it was thereupon demurred: and resolved by the whole Court to be no plea; for a deed cannot be delivered to the party himself as an escrow, because then a bare averment without any writing would make void every deed. Wherefore it was adjudged for the plaintiff. See Whyddon's Case, Cro. Eliz. 520.

\section{LONDON FREEHOLD \& LEASEHOLD PROPERTY CO. v. SUFFIELD.}

(Chancery Dirision. [1S97] 2 Ch. 60S.)

This was an action by the plaintiffs, who were mortgagors, against the mortgagees, to set aside a mortgage deed for $\$ 9000$., and arose out of the frauds of one Llewellyn Malcolm Wynne, a solicitor, who had since absconded.

The facts, so far as it is necessary to state them for the purposes of the present report, were as follows. Llewellyn Malcolm Wynne was a solicitor carrying on business in London in partnership with his brother, Campbell Mountague Edward Wynne, under the firm of "Wynne \& Son."

L. M. Wynne was one of the four trustees of the marriage settlement of Sir Frederick Leopold Arthur, and the firm acted as solicitors to the trust. He was also the managing director of the plaintiffs, the London Freehold and Leasehold Property Company, Limited, incorporated in 1883. In May, 1886, Wynne \& Son, who carried on business as bankers as well as solicitors, were appointed managers and bankers of the company at a commission. Wynne $\&$ Son were also solicitors to the company; Wynne \& Son's office was the office of the company, and Wyne \& Son's converancing clerk, Tyler, was the secretary to the company. The company's accounts were kept by L. M. Wynne, 
whose duty it was, as acting banker and manager, to pay the company's money received by him or his firm into the bank of "Wynne \& Son."

Child \& Co. were Wynne \& Son's bankers, and in May, 1892, IVjune $\&$ Son, as the solicitors to the trustees of Arthur's settlement, received a sum of $£ 9000$., part of the trust funds, and paid it into Child's bank to the credit of their own account, pending reinvestment. It appeared that one of the trustees, Mr. Somerset, knew that Wynne \& Son had the money in their hands for reinvestment.

Early in 1893 the directors of the plaintiff company, acting on L. MI. Wynne's advice, proposed to take steps for gradually paying off certain mortgages on properties of the company, bearing interest at 5 per cent., by raising a sum of $t 9000$, at a lower rate of interest. The mode of raising this sum and all the details of the arrangements for the purpose they left to Wynne, in whom the directors placed complete confidence, he telling the board that he had clients who would lend the money. In June, 1893, a mortgage was prepared by counsel on Wynne \& Son's instructions, for $£ 9000$, to the Arthur trustees upon the security of certain leasehold properties of the company consisting of a block of warehouses called "Victoria Warehouses," and two houses in Bury Street, London, being properties comprised in the existing mortgages.

On June 19, Messrs. Worley and Ryder, two of the company's directors, were informed by Wynne \& Son that a meeting of the board would be held on the $22 \mathrm{~d}$. A meeting of the directors was accordingly held on June 22, 1893. An agenda paper for the meeting was prepared by Tyler, and this paper stated that part of the business would be to seal the 19000 . mortgage, and another mortgage. The directors present on the 22d were Wynne, Worley, and Ryder. Tyler, the secretary, was also present. The mortgage for $£ 9000$., engrossed for execution, but with date (except the year) and days for payment left in blank, was produced and discussed, and a statement of the properties comprised in the mortgages which were to be paid off was also produced. The mortgage reserved interest at $51 / 4$ per cent., reducible to $4 \mathrm{I} / 2$ on Dunctulal payment. After explanations by Wynne, it was "resolved that the seal be affixed to the mortgage for $f 9000$. on Victoria Warehouses and Bury Street," and to the other mortgage, and both mortgages were thereupon sealed with the company's seal. Both Worley and Ryder signed the $\$ 9000$. mortgage as directors. Tyler also signed it as secretary. No cash then passed, and the directors were well aware of that fact: nor, as a matter of fact, did the $\$ 9000$. expressed to be advanced to the company ever find its way into the company's coffers at all. The blanks in the mortgage were not filled up at the meeting, but the date of the mortgage, December 29,1893, was sulbsequently filled in by the law stationer when it was sent to be stamped. The blanks left for the days of payment were never filled in. The document thus sealed was then given to or left with Wynne, who, on June 28, 1893, wrote to Arg.Pror. -22 
Colonel Lloyd, one of the Arthur trustees, that the $£ 9000$. had been advanced on that security.

On March 2, 1895, L. M. Wynne absconded, and on March 9 he was adjudicated bankinut. On the 16th his brother was also adjudicated bankrupt, and on the same day a trustee was appointed in the bankruptcies of the property of the firm and of the separate property of L. M. $1 V$ ymne. After the failure of the firm the mortgage of December 29, 1893. was found in a "temporary box" belonging to them in which they kept miscellaneous deeds likely to be wanted for temporary purposes or for stamping. The mortgage had not been entered in the company's register of mortgages, nor was it registered in the Middlesex Registry until May 22, 1897, the day after Kekewich, J., gave judgment in the present action. Alout the same time, and with a view to such registration, one of the Arthur trustees executed the mortgage.

The result of inquiries instituted into Wynne \& Son's affairs after their failure shewed that on June 1, 1893, they had transferred $£ 9000$. from their account with the trustees of Arthur's settlement to the credit of the plaintiff company; the following credit entry, headed "The London Frechold and Leasehold Property Company Mortgage Account" being found in Wynne \& Son's ledger: "By transferred from Sir F. L. Arthur's settlement trustees, amount, advanced on mortgage at $4 \mathrm{~T} / 2$ per cent., £9000." As already stated, the 29000 . never found its way in cash to the company at all, nor was it ever applied in discharge of the existing mortgages, the entry, therefore, being, as the company contended, fictitious and fraudulent. It appeared that Tyler, the clerk to Wynne \& Son and secretary to the company, had access to the ledger; but he, and Vorley and Ryder also, in giving their evilence in the present action, said they knew nothing about any of the entries in Wynne $\&$ Son's books, and never saw or knew of the particular entry in question.

On March 21, 1896, the plaintiff company brought this action against the defendants, the Arthur trustees (including L. M. Nymne) and the trustee in bankruptcy, claiming a declaration that the mortgage of December 29, 1893, was not a valid and effectual security and was not binding on the plaintiffs, and that the same might, if and so far as might be necessary, be set aside and cancelled; delivery-up of the titledeeds relating to the mortgage; and injunction against enforcing the security; and, in case the Court should be of opinion that the mortgage was valid and effectual, a declaration that the plaintiffs were entitled to prove for the $\$ 9000$. as money had and received by L. M. Wymne as their solicitor, either against the joint estate of the firm of Wynne \& Son, or against the separate estate of L. M. Wynne, as they might elect; and all necessary accounts and inquiries. Defences were delivered by all the defendants except Wynne, who, it appeared, had by an order made by North, J., on April 25, 1896-that is, since the issue of the writ-been discharged from the trusts of the Arthur settlement. 
The action came on for trial with witnesses before Kekewich, J., on May $20,1897$.

The witnesses examined were Messrs. Worley and Ryder, two of the directors of the plaintiff company, Mr. Tyler, the late secretary of the company, Mr. C. M. E. Wynne, and Mr. Dalgleish, an accountant who had been auditor of the company, and was its present secretary, having been appointed to that offce in place of Tyler shortly after $W$ ynne \& Son's failure. The effect of their evidence sufficiently appears, for the purpose of this report, from the judgments of Kelewich, J., and the Court of Appeal.

Oct. 30. The judgment of the Court (Lindeey, M. R., and Lord Luni,ow and ChiTTr, L. J J.) was delivered by

LINDLFY, M. R. ${ }^{23}$ 'This is an appeal by the plaintiffs from a decision of Kekewich, I., refusing to set aside a mortgage executed by them for securing $£ 9000$. to Lord Suffield and others, who were the trustees of a settlement called Arthur's settlement.

[His Lordship then reviewed the facts of the case to the effect above stated, observing that the relation of Wynnes Son to the plaintiff company was an all-important element in the case; that as bankers and managers they kept the company's accounts, it being their duty as managers to pay the company's money received by them as managers into their bank; that, moreover, it would be in accorlance with the ordinary course of business for a banker, who had to Day money for one customer to another, to effect sttch payment by book entries, that is, by debiting one customer and crediting another in their respective accounts, it not being necessary that any cash should actually pass from the one customer to the other; also that it was clear from the evidence that the directors of the plaintiff company left all the accounts to Wynne \& Son, and never troubled themselves about any books except the minute-books and the company's pass-book with Wyme \& Son; and that the plaintiffs had fanled to prove that the credit entry of June 1, 1893, was fictitious and fraudulent. His Lordship, after referring to the evidence as to the preparation of the mortgage, its production at the meeting of the company's directors on June - 22, 1893, and its sealing with the company's seal, proceeded:]

The document thus sealed was given to or left with IVynne: but in what capacity is by no means clear. Worley, Ryder, and 'Tyler have all given evidence as to what took place when the $£ 9000$. mortgage was sealed, and it is contended by counsel for the plaintiffs that the mortgage was merely an escrow, and never became a perfected deed. $\sqrt{\mathrm{e} \text { are unable to come to this conclusion. It is, in our opinion, clear }}$ that the deed was sealed and delivered by the company, acting through its directors and secretary, as a deed, i. e., as a perfect instrument; and that it was so executed in order that it might be used as an op rative deed for the purpose of carrying out the contemplated arrange-

23 A portion of the opinion is omitted.

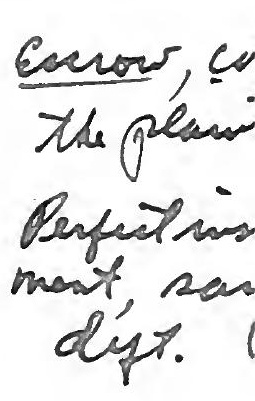


ment by which the several existing mortgages bearing interest at 5 per cent. might be replaced by one mortgage bearing interest at $4 \frac{1}{2}$ per cent. The mortgage was for $\$ 9000$. and interest at $51 / 4$ per cent., reducible to $4 \frac{1}{2}$ on punctual payment. On the face of it, it is a clear mortgage for the money and interest; the subsisting mortgages are not mentioned or referred to. The minute authorizing the sealing of the deed says nothing about any conditional delivery, nor anything shewing that the document was to operate as an escrow. Worley, Ryder, and Tyler all agree that the deed was executed in order to enable Wynne to get the $\$ 9000$., as it was wanted to pay off the other existing mortgages for which it was to be substituted, and Worley says, in order to give the company the right to demand $f 9000$. from the lenders. The real truth is that neither Worley, Ryder, nor Tyler had any distinct idea how the contemplated arrangement was to be carried out. They left the whole matter to Wynne, and entrusted him to carry it out as best he could; but that the deed was executed as a deed and was not an escrow is, in our opinion, clear. This conclusion is fortified by other evidence. [This evidence his Lordship adverted to in detail.] Such is the history of the impeached deed.

Having now stated the material facts of the case, we pass to the law applicable to them. The plaintiff company seek to set aside the £9000. mortgage on the following grounds, namely-first, on the legal ground that the mortgage never was executed as a deed, but was only an escrow; secondly, on the equitable ground that the mortgagees never gave and that the company never got the consideration for which the mortgage was given. As regards the invalidity of the mortgage as a deed, it is urged that, although sealed, the mortgage was handed to IVynne, not as one of the mortgagees nor as solicitor to the mortgagees, but as solicitor to the plaintiff company, to be delivered to the mortgagees or to be kept by him as their solicitor only when the $E 0000$. or at least some of it, reached the plaintiff company or was applied in paying off the other mortgages which the company had arranged to pay off. Kekevich, $I_{2}$, decided this point against the plaintiff company. We take the same view. We are not prepared to go so far as to say that, as IVynne was himself one of the mortgagees and a party to the deed, it could not in point of law be an escrow in his hands. Counsel for the defendants contended that the mere fact that IVynne was himself one of the mortgagees was fatal to the deed being an escrow. They contended that to be an escrow the deed must be delivered to some person not a party taking under it; in short, to a stranger. In support of this contention reliance was placed on Co. Litt. 36 a; Sheppard's Touchstone (7th Ed.) pp. 58, 59; ${ }^{24}$ and

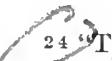

The dehvery of a deed as an escrow is said to be whele one doth make and seal a deed, and detrer it unto a stranger nutil certain conditions be pertormed, and then to be defrered to him to whom the deed is made, to take effeet is his dete And so a man may deliver a deed, and such a delivery is good. Fut in this case two cautions must be heeded: 1. That the form of 
Whyddon's Case, Cro. Eliz. 520. No doubt the language used in the anthorities referred to and reproduced in other works on real property and conveyancing is in favour of this contention. But the language is very general, and we are not at all satisfied that the law is so rigid as to compel the Court to decide that where there are several grantees and one of them is also solicitor of the grantor and of the other grantees, and the deed is delivered to him, evidence is not admissible to shew the character in which and the terms upon which the deed was so delivered. To exclude such evidence appears to us unreasonable; and we do not think we are compelled by authority to exclude it. We hold such evidence to be admissible, and in so doing we believe we are acting in accordance with modern authorities, beginning with Murray v. Earl of Stair, 2 B. \& C. 82, and ending with Watkins v. Nash, L. R. 20 Eq. 262. Upon the evidence, however, to which we have already referred, we come to the conclusion that the mortgage was executed as a complete deed, and that it was given as such to Wynne in order to enable him to carry out the arrangements to which we have before alluded; and to carry them out as he thought proper. ${ }^{25}$

mords used in the delivery of a deed in this manner be ant and proner. 2. That tlie deed be delivered to one that is a stranger to it, and not to the rarty himself to whom it is made. * * * So it nust be delivered to a stranwer; for if I sealmy deed and deliver it to the party hinself to whom it is made as an escrow unon rertain conditions, Se., in this case. Iet the form of the words be what it will, the delivery is absolute, and the doed shall take effect as his reed presentrs and the party is not bound to perform the conditions; for, in tradit.onibus chartarun, non gnod dictum, sed qued factum est. insvicitur. But in the first rascs before, where the deer is theliveren to a stranger, and alt words are used in the delivery thereof, it is of no nore force, until the conditions be performed, than if I had made it, and laid it by me, and not delivered it at all: and therefore in that case, alheit the larty get it into his hands before the conditions be performed, set he can make no use of it at all, neither will it do him any good. But when the conflitims ine performed, and the deed is delivred over, then the deed shan take as nimch effect as if it vicre deTrered inmeditery to the part to whom it is wade and no act of God or man can hinder or prevent this effert then if the party that doth male it be not at twe time of makng Thereof disabled to make it. He therefore, that is trusted witl the keeping and delivering of such a writing, whyt not to deliver it before the conditions be performed: and when the conditions be performed, he onght not to kcep it, but to deliver it to the party. For it may be made a question, whether the deed be perfect, before he hath delivered it over to the party according to the authority giren him. Howbeit it seems the delivery is good for it is said in this case, that if either of the parties to the deed die befure the conditions be performed, and the conditions be after performed that the deed is good; for there was traditio inchoata in the lifetime of the parties; et postea Consummata existens by the performance of the conditions, it taketh its effect by the first delivers, without any new or second delivery and the second delivery is but the execution and consummation of the first delivery." shep. Touch. 58, 59.

25 But see Price r. Pittsburgh, Ft. W. \& C. R. Co., 3t Ill. 13 (1s64), where a deed was left with the solicitor of a corporation, the grimtee, to be beld by him until the performance of a condition. 


\section{IVIPFLER v. IVIPFLER.}

(Supreme Court of Michigan, 190s. 15.3 Mich. 1S, 116 N. T. 544, 16 L. R. A. [N. S.] 941.)

Montgomery, J. Complainant filed a bill for divorce, also praying to have set aside a deed of certain lands made by complainant running to the defendant, and to compel the convevance by defendant to complainant of certain other lands, title to which was taken in defendant's name, the consicleration price having been pad by complamant. The complainant prevailed on all points in the court below and clefendant appealed. The ground for the divorce alleged was extreme cruelty. The circuit judge, who saw the witnesses and noted their appearance upon the stand, was of the opinion that the case of extreme cruelty was made out. We are not disposed, upon the record made, to disturb the circuit judge's finding upon this question.

Upon the question of the right to set asile the deed executed by complainant and placed in defendant's hands, we encounter what we deem a legal obstacle to granting the relief prayed. The equities of the case are undoubtedly very strongly with complainant, and if the rules of law would admit, we should unhesitatingly grant the relief prayed. The property involved represents substantially all the eannins s of the complainant for a lifetime, and the insistance by the defendant upon her legal rights which will result in turning complainant out almost penniless, is most nnconscionable and ineciuitable. IVe have struggled to find authority for relieving complainant in the case, but upon a $\mathrm{f} u l l$ consideration and a re-examination of the question determined by this court in Dyer v. Skadan, $128 \mathrm{Mich} .348,87 \mathrm{~N} . \mathrm{WV} .277,92 \mathrm{Am}$. St. Rep. 461, we are unable to find such authority.

Complainant's testimony is that he prepared signed, acluowledged the deeds in question, and retained them in his possession for several years, but that in the month of August, 1890, when about to take a railway trip to the G. A. R. encampment, which he deemed hazardons on acconnt of a strike of the employees of the road he would travel over, he, before leaving home, handed the deeds to the defendant with instructions that if anything of a fatal nature should befall him, she should have the deeds recorded; that he returned in safety, and several years thereafter found that the defendant had caused the deeds to be recorded during his absence on this trip. The defenclant denies that there was any condition annexed to the delivery of the deeds to her, but asserts that complainant handed her the deeds telling her to record them, and instructing her in what office to have them recorded. But assuming complainant's version to be correct, the transaction constituted a delivery of the deeds to the grantee withont any express reservation of the right to recall them, and with intent that in a certain contingency they should be effective, without any further act on the part of the complainant. 
The case of Dyer v. Skadan reviews the authorities and follows the rule laid down by this court in Dawson v. Hall, 2 Mich. 390, that a delivery of a deed by a grantor to a grantee $C_{\text {in escrow 'or'upon con- }}$ dition is effectual to pass title presently. This question has arisen and is considered and discussed in a vast number of cases. Many cases may be found in which the manual custody of a deed had been entrusted to the grantee temporarily and evidence was admitted to show that no delivery was intended. But these cases when examined and analyzed are found to be, we think, cases in which there was no intent that the deed should take effect ultimately without any further act on the grantor's part if the condition upon which it was delivered should be performed. See a discussion of this subject in Gilbert v. Insurance Co., 23 Wend. ( $\left(Y^{\prime}\right.$.) 43, 35 An. Dec. 543, in which case it was held that leaving the deed in the hands of the grantee to be by him transmitted to a third person to hold in escrow until the happening of a certain event is not a delivery to the grantee so as to vest title in him. But in that case it is manifest that nothing but the bare possession of the deed was vested in the grantee, and it was not to be retained except by a breach of faith. The deed could not presently take effect in the hands of the grantce, nor could it take e.fect without an intervening act by the grantor or his agent. In the present case, no act of the grantor was required which was not performed. It is true the cordition which it is attempted to annex to the delivery has not been fulfilled, but had the death occurred. no other act of the grantor was essential to the passing of title. The case of Gilbertv. insurance Co., it should be stated, was later distinguished and its doctrine questioned by so able a jurist as Judge Selden in Braman v. Bingham, 26 N. Y. 491, in which it was sought to avoid delivery of a deed on the ground that it was deposited with the grantee with instructions to leave it with one of the clerks of the register's office, and it was contended that these facts showed that there was no delivery with intent that title should pass. It was held, however, that it was immaterial whether these facts were properly pleaded; that if the answer, in addition to what it contained, had embraced these facts, it would not, in the opinion of the court, have presented a defense. Referring to Gilbert v. Insurance Co., it was said:

"In that case, the grantee had deposited the deed with the third person in pursuance of the arrangement, the condition had not been performed, and the grantee made no claim under the deed. The case presented merely the question, whether the grantor still retained an insurable interest in the premises described in the deed, the nominal grantee testifying to the terms in which the deed was delivered to him. Limited to its peculiar circumstances, no fault can be found with the decision; but if the grantee had retained the deed, claining that its delivery to him was absolute, and in a contest between him and the grantor parol proof of a conditional delivery had been offered, I think the result would have been different. If I am wrong in this conclu- 
sion, the case discloses an avenue for the overthrow of titles, by parol proof, which was supposed to be closed by the rule to which it would seem to form an exception. *** If a delivery to the grantee can be made subject to one parol condition, I see no ground of principle which can exclude any parol condition. The deed having been delivered to the grantee, I think the parol evidence that the delivery was conditional was properly excluded."

See, also, Foley v. Cowgill, 5 Blackf. (Ind.) 18, 32 Am. Dec. 49; Worrall v. Munn, 5 N. Y. 229, 55 Am. Dec. 330.

But if we assume it to be correct to hold that a deed may be delivered to a grantee as a mere agent or bailee of the grantor to transmit such deed to a third person to hold in escrow, it does not aid the complainant in this case. Nor do we know of any authority which goes to the extent of holding that a deed delivered to a grantee with an intention on the part of the grantor that it shall be subject to a future condition, but with no express provision for recall by the grantor and requiring for its validity no additional act on the part of the grantor or any third person, can be defeated by parol proof of such condition. $^{26} * * *$

The decree must be modified as indicated by this opinion. But the want of equity and good conscience in defendant's attitude in this case is so marked that we are disposed to exercise our discretion and withhold any award of costs. ${ }^{27}$

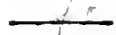

LEE v. RICHMOND.

(Supreme Court of Iowa, 1S94. 90 Iowa, 695, 57 N. W. 613.)

Rominson, J. The defendants, William Richmond and George W. Fulton, for some years carried on a commercial business at Council Bluffs under the name of the Boston Tea Company. James T. Lee, a son of the plaintiff, was employed by them as clerk for about three years. In July, 18s8, and while he was so employed, the defendants caused him to be arrested on a preliminary information which charged him with the crime of embezzlement. While he was under arrest, and before the examination was held, he had an interview with Richmond, in which he admitted that he was guilty of the offense charged, but expressed a desire to settle the matter, and agreed to telegraph

26 The balance of the oninion revierving many cases is omitted.

See accord, Fisher v. Fisher, 23 Cal. App. 310, 137 Pac. 1094 (1913), under a statute.

27 Cf. Alabama Coal \& Coke Co. v. Gulf Coal \& Coke Co., 165 Ala. 304,51 South. $570(1910)$, where $A$. made a deed to $B$. and handed the deed to $\mathrm{X}$., a land purchasing agent of $\mathrm{B}$., to be held, however, in escrow until the payment of the purchase price by $B$. Held no delivery to $B$.

See Blewitt v. Boorum, 142 N. Y. 357, 37 N. E. 119, 40 Am. St. Rep. 600 (1S94), where the conrt limits the doctrine of the principal case to instruments atfecting realty and instruments requiring a seal for validity, intimating, however, that the latter should not come within the rule. 
to his father, who resided at Keokuk, to come to Council Bluffs. On the next day, Saturday, July 14, he learned that his father could not come, and informed Richmond of the fact. On Sunday, the defendants visited him at his home, and spent several hours there. On the same day, Richmond, James T. Lce, and his wife started for the home of the plaintiff, where they arrived Monday. An interview was there had, at which the plaintiff and his wife, the son and his wife, and Richniond were present during all or a part of the time. It resulted in the execution by the plaintiff and his wife to Richmond of a deed for three lots in the town of Atlantic for the specified consideration of two thousand dollars. The deed was given to Richmond, and was recorded in the office of the recorder of Cass county. The plaintiff asks that the deed be canceled, and for general equitable relief. The district court decreed the deed to be void, and that the title to the lots was vested in the plaintiff.

The plaintiff alleges that the deed was executed in consequence of the representations of Richmond, for himself and Fulton, that James T. Lee had embezzled a large sum of money; and they had filed an information against him, in which he was charged with the embezzlement of money and goods to the value of five thousand dollars; that the embezzlement had been confessed by him; that the defendants were his friends, and that for the sum of thrce thousand dollars they would dismiss the information, and restore him to his employment, and he would have no further trouble; that, if the sum of three thousand dollars was not paid at once, the prosecution would be carried on, and he would be sent to the penitentiary. The plaintiff further clains that at that time he and his wife, who is the mother of James T. Lee, were old and feeble; that he was sick; that both were much disturbed and friglitened by what was said to them, and not knowing the facts, and having no knowledge of such matters, they believed what Richmond said to them; that, when the deed was executed, Richmons agreed to submit it to Fulton, and, if it was not satisfactory to him, to return it to plaintiff, but that, if it was satisfactory, the criminal prosecution of his son would be dropped and ended. Some of these claims are denied by the defendants, but the preponderance of the evidence shows the following facts: Until James $T$. Lee and wife and Richmond arrived at the house of the plaintiff, he did not know of the charges against his son. He was then about seventy years of age, had been in poor health for several years, and was confined to the house. He was subject to attacks of nervousness, and had been suffering from one for several days. Riclimond told him that the amount of the embezzlement was six thousand dollars, but the defendants would drop the prosecution for three thousand dollars; that the preliminary hearing was set for the next day, and would be prosecuted, unless a settlement was effected. The son was present, but did not deny the charge of embezzlement which Richmond made. The father and mother were much frightened, and desiring to protect their son, and avoid the scan- 
dal of a criminal prosecution, finally consented to give the deed in question, if it would end the prosecution, and, with notes of the defendants to the amount of about nine hundred dollars, which the son held and proposed to surrender, would effect a complete settlement of the matter in controversy. The deed was delivered under an agreement to that effect, and on condition that, if it was not satisfactory to Fulton, it was to be returned to the plaintiff. The notes held by the son were surrendered to the defendants, but the prosecution of the son was not stopped, although after the case reached the district court, and after an indictment had been returned, it was dismissed on motion of the county attorney for want of sufficient evidence to convict. The deed was retained by the defendants, but they insisted that the plaintiaf should give his promissory notes for the sum of one thousand dollars, which were sent to him repeatedly for his sirnature.

It is said that, if the claims of the plaintiff be well founded, he conveyed his property for the purpose of compromising a criminal prosecution and that, as that object was illegal, the law will leave all parties to the transaction where it finds them. IVe should hesitate long before refusing the plaintiff relicf on that ground, in view of the weakness of his body and mind, the threats made, and the fear he was under when the deed was given. Meech v. Lee, S2 Mich. 274, 46 N. IV. 397. But we prefer to place our conclusion upon the ground that the condition on which the deed was given to Richmond was never complied with, and that the deed was not in law delivered, and, therefore, has not taken effect as a converance. We refer to the condition that the deed and the notes surrendered by the son should be received in $f$ ull settlement of the clains made against the son by the defendants. Conceding that some of the provisions of the agreement were illegal, yet the deed was not to be regarded as delivered, unless the settlement attempted was approred by Fulton, and, as it was not approved by him, there was never, in law, any delivery, and the deed is without effect. Steel v. Niller, 40 lowa, 406: Berkshire v. Peterson, 83 lowa, 198. 48 N. IV. 1035; Head v.. Thompson, it Iowa, 267, 42 N. W. 188; Deere v. Nelson, 73 Iowa, 187, 34 N. W. 809 . The fact that some portions of the agreement were illegal would not operate to annul the conditions and make the delivery complete. Since the deed was never delivered, nothing can be claimed under it. The decree of the district court is in harmony with our conclusions, and is affirmed..$^{28}$

28 Sce. also. Ilaviland v. Haviland, 130 Iowa, 611, 105 N. W. 354,5 L. R. A. (N. S.) 28'1 (1905). 


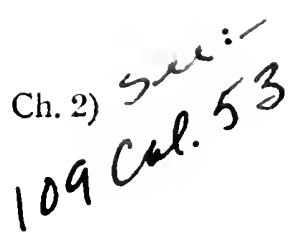

(Supreme Court of Wisconsin, 1555. 4 Wis. 343, 65 Ałn. Dec. 314.)

Everts made a deed of the premises in controversy and deposited same with Zettler with instructions to deliver it to Agnes, the grantee, upon Agnes making certain notes and mortgages. Without having performed the condition Agnes secured possession of the deed and after having same recorded conveyed the premises by deed to Swift. The action was by Everts against Agnes and Swift to set aside and cancel these conveyances. Sivift claimed to have taken as a bona fide purchaser for value. The trial court dismissed the bill as to Swift: and required Agnes specifically to perform his part of the contract with Everts or show cause, etc. Complainant appealed." 9

By the Court, Smitr, J. It is hardly possible to dispose of this case without recapitulating some, and perhaps most of the material allegations and facts involved thercin; yet with the statement of the case which will precede the conclusions to which we have here arrived, and which will fully appear in the report of the case, it is only necessary to recur to them incidentally as the discussion of the principles involved, and of the points argued, shall seem to require.

On the 31 st day of May, A. D. 1851, a written memorandum, very informal and incomplete, was cntered into between the complainant Everts, and the defendant Every Agnes, for the sale of the premises described in the complainant's bill of complaint. Whether or not that written memorandum would be sufficiently definite and certain to authorize or enable a court of equity to decree a specific performance thereof is not alssolutely necessary to inquire. It is, however, worthy of remark, that from that menorandum alone, it would be difficult to settle definitcly the rights of the parties thereto. It is sufficient for the purposes of this case to say, that it comvejed ne title by Everts, nor did Agnes obtain any title thereby; at most an equitable interest in the land, upon the performance of the conditions or stipulations therein contained, on his part to be performed, and that he had, and could have had, no legal rights conveyed by Everts in conformity with the memorandum or otherwise, whatever his equitable rights may have been. It is apparent that the defendant Swift did not purchase any equitable right or title as such, which Agnes may have had by virtue of the contract; but whatever he did purchase, was such interest, title or estate as Agnes had in the premises, by virtue of his record or paper title under the deed of Everts to Agnes, made and recorded as set forth in the pleadings.

It is not necessary, therefore, to inquire what would have been the equitable rights of the defendant Sivift, had the interest of Agnes derived by virtue of the written memorandum or contract before men-

29 This statement is substituted for the one in the report. 
tioned, been assigned to him, and lad he been the purcliaser under the same, and had relied thereon in his answer. But he, Sivift, derives his title solely from the deed of Agnes to him, conveyed through the deed of Everts to Agnes, without any knowledge or consideration of, or reliance upon the written contract or memorandum before mentioned, and bases no claim thereon. So far, therefore, as Swift is concerned, he stands precisely in the same condition as he would have clone, had no written contract ever existed betwcen the partics, Everts and Agnes. It is true that Swift admits in his answer the said agreement, and avers that in pursuance thereof, Everts executed a deed conveying the title, but he sets up no claim under this alleged deed, nor any equitable considerations growing out of the original contract. He claims by virtue of his deed from Agnes and the deed of Everts to Agnes. On them, and them alone does he base his rights and interests, and by them are they to be adjudicated.

For the purposes of this case, it is wholly immaterial whether the defendant Agnes was in a position entitling him to demand a conveyance from Everts or not. Were we to express an opinion upon that subject, perhaps it would not go far to aid either of the defendants. The conveyances under wlich Agnes pretends to claim are voluntary, in contradistinction to those decreed to be executed upon a bill for specific performance. The deed or deeds, therefore, executed by Everts to Agnes, must be considered precisely the same as though no previous contract or menorandum had existed, so far as their operative effect upon the defendant Sivift is concerned.

We regard the making and delivery of the two deeds as but one continuous act, having its consummation in the deposit of the last deed with Zettler. We do not think, as is claimed by the counsel for the defendant, that any title passed by the first decd. It was rather an attempt to convey the premises, which was abandoned for another, and as was supposed, better and more perfect form. The rights of the parties, whatever they are, must therefore depend upon the effect of the last deed, and their respective relations to it.

We think there can be no doubt that the fraudulent means used by Agnes to get possession of the deed from Zettler, the depositary, are such as effectually preclude him from deriving any benefit from it. The testimony on this branch of the case is satisfactory. The deed was left with Zettler as an escrow, with instructions not to be delivered until certain sccurities should be given by Agnes. Until the performance of the condition, it was, and must remain, a mere scroll in writing, of no more efficacy than any other written scroll; but when, upon the performance of the condition, it is delivered to the grantee or his agent, it then becomes a deed to all intents and purposes, and the title passes from the date of the delivery. The delivery to be valid, must be with the assent of the grantor. These are familiar principles and do not require the citation of authorities to sustain them. If the grantee abtain possession of the escrow without performance of 
the condition, he obtains no title thereby, because there has been no delivery wilh the assent of the grantor; which assent is dependent upon compliance with the condition. The assent of the latter is withheld until the condition is performed. The obtaining of it by frand, larceny, or any means short of performance of the condition, is against the assent of the grantor; and as this assent is essential to delivery, and a delivery is essential to the validity of the deed, it is difficult to perceive how Agnes ever obtained any title whatever to the prenises, and of course, equally difficult to perceive how he could convey any, by any conveyance which he might execute to another. The recording of an escrow does not make it a deed. Suppose Zettler had procured the deed to be recorded, and Swift had purchased of Agnes on the faith of the record title, without any delivery of the deed to Agnes, will it be claimed that Swift in such case would have obtained title? How is the case made better by the wrongful possession of the escrow by Agnes, obtained without the consent of Everts, and hence without any delivery to him? It is true, all this might be done and Swift, the purchaser, be quite innocent of any wrong. It is also truc, that either Everts or Swift must suffer by the fraud of Agnes, the latter being unable to make reparation. But which has the prior of superior equity? Everts asks that he shall not be divested of his estate without his consent. Swift asks not only that Everts may be thus divested, but that lie himself, may be invested with it It is quite apparent that the superior equity is with him who had the original title, with which he has never voluntarily parted. Swift has his remedy upon the covenants of his deed from Agnes. But were the equities equally balanced, the legal title must prevail. That the legal title never passed from Everts, we think is clear, both from reason and authority. 2 Blk. Com. -; 4 Kent, Connm. 459; 5 Creenlfs. Cruise, Title, Deed, 45, 46; Jackson v. Catlin, 2 Johns. (N. Y.) 248, 3 Am. Dec. 415; Same v. MIcKee, 8 Johns. (N. Y.) 429, 431; Frost v. Beekman, 1 Johns. Ch. (N. Y.) 296; Jackson v. Rowland, 6 Wend. (N. Y.) 666, 22 Am. Dec. 557 ; Carr v. Hoxie, 5 Mason, 60, Fed. Cas. No. 2,438; Jackson v. Sheldon, 22 Me. 569; Robins v. Bellas, 2 Watts (Pa.) 359; 1 Story's Eq. Juris. par. 75, 76; Somes v. Brewer, 2 Pick. (Mass.) 184, 13 Am. Dec. 406; Worcester v. Eaton, 11 Mass. 375.

But it is contended that Swift is entitled to protection as a bona fide purchaser without notice. This has been a point of some difficulty. We have not been referred to, nor have we been able to find an authority directly in point. We are aware that courts of equity go to great lengths to protect a bona fide purchaser for a valuable consideration without notice. The plaintiff cannot set up the fraul of his grantee in procuring a conveyance, to defeat the title of a subsequent bona fide purchaser. But such, and all the cases referred to, differ from the case at bar, in the important fact that in all of them the conveyance was perfected by the voluntary act, and with the assent of the grantor. He made the sale. He executed and delivered the deed, or caused the 
same to be done. All these acts were perfectly voluntary on his part, and no matter what fraudulent representations may have induced him to do these acts, an innocent third person shall not be made to bear his misfortune, or suffer for his credulity. Cases of this kind are numerous, and the principle on which they all depend is an equitable one. But they all depend, nevertheless, upon the fact, that the party voluntarily parted with his property and executed and delivered the evidences of its alienation. Not so, however, in the case of a forged or stolen deed. The reason is obvious. In the latter case, there is no assent of the alleged grantor. There is no delivery.

It is erroneons to suppose that Everts delivered the deed to Zettler for Agnes, and thus made Zettler his agent, and is therefore bound by his acts. If the depositary of an escrow can be considered the agent of the depositor at all (which we very much doubt), he is only such within the scope of his authority. He is as much the agent of the grantee as of the grantor. He holds the scroll for both, to be delivered on performance of the condition. He is as much bound to deliver the deed on pertormance of the condition, as he is to withhold it until performance. The act of delivery cannot be considered the act of the grantor until the condition be complied with. Without such compliance, there is no assent to the delivery. To obtain the deed or scroll from the depositary without such compliance is as much against the assent of the grantor, as it would be to take it from the desk or drawer where the grantor has deposited it, without his knowledge or consent. It would seem, therefore, that there is a great and fundamental distinction between the case where by frauclulent representations, a person is induced to execute and deliver a deed, and one where the deed or scroll is obtained from a depositary without the knowledge or consent of the depositor, or compliance with the conditions on which the delivery dejends.

It would seem that where a cleed deposited as an ascrow is obtained without performance of the conditions, by operating upon the fears or credulity of the depositary, or by frauclulent collusion with him, or by other unclue means, it bears a closer analogy in principle to the case of a forged or stolen deed, than it does to that of a fraud practiced directly upon the grantor, by means of which he is induced to deliver it. In the latter case, the legal title passes, and a subsequent bona fide purchaser is protected. In the former, no title passes whatever, and a subsequent purchaser is not protected. In the one class of cases, there is the voluntary assent of the grantor; in the other, there is no assent at all.

If this reasoning be correct, the better opinion would seem to be, that the fraudulent procurement of a deed cleposited as an escrow, from the depositary by the grantee named in the deed, would not operate to pass the title, and that a subsequent purchaser for a valuable comsideration without notice, would derive no title and would not be protected. 
But it is contended by the counsel for the complainant, that the defendant Swift does not show himself, by his answer, to be a bona ficle purchaser. If this be so, we are relieved from the necessity of deciding directly the other question. The answer of Swift alleges, "that he paid to Agnes without frand, a good and valuable consideration according to a contract then made between them, and took from Agnes and his wife a conveyance in the usual form of a warranty deed," etc. 'The answer nowhere alleges what the consideration was, how much, if anything, was paid, or when paid though it does state, upon information and belief, that from June, 1851, "the complamant was never heard to set up his claims until after said Swift had obtained and recorded his deed and paid the consideration, all of which occurred on or about the Sth day of October, A. D. 1851."

To entitle a party to the protection which a court of equity extends to a subseguent bona fide purchaser, he nusst n' lie a full statement of all the facts and circumstances of his case, so that the court may be able to do perfect equity between the parties. It is not sulficient to allege that he has purchased for a valuable consideration without notice, but the consideration must have been actually paid before notice. And if a part of the consideration only, has been paid before notice, he will be protected only pro tanto. Hence it is necessary that the actual consicleration be stated, and the amount actually paicl. The mere averment that he is a purchaser for a valuable consideration, and that the consideration is paid, is not sufficient, and no instance, it is beliered, can be found where such a statement in an ansiver has been held sufficient. Story's Eq. par. Gt et seq., and cases there cited; White and T'udor Eq. Ca. 77; Story's Eq. Pl. §§ 28, 805, 852 et sec. ${ }^{30}$

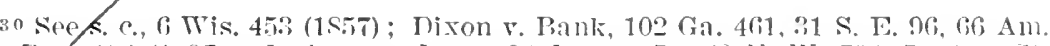

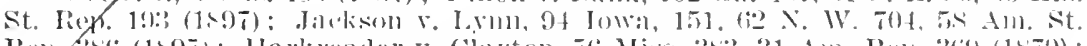

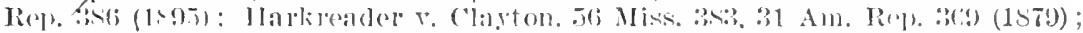

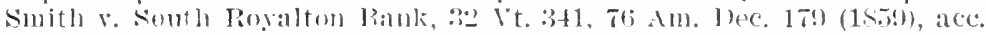

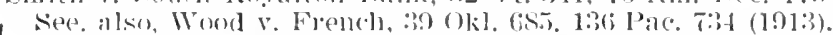

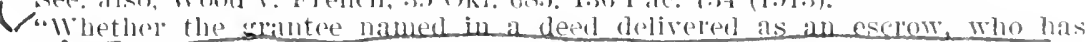

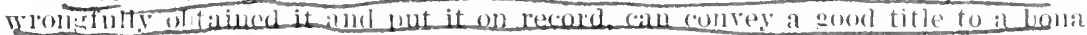

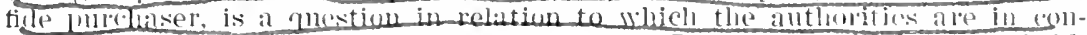

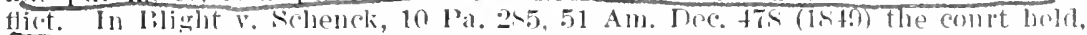

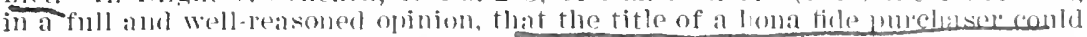

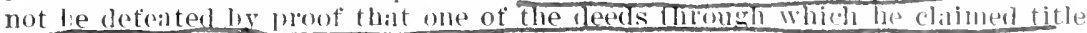

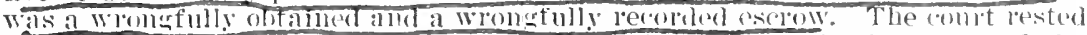
its decision on the finct that the custodian of an escrow is the agent of the grantor as well as the grantee, and if one of two innorent nersoms must suifur

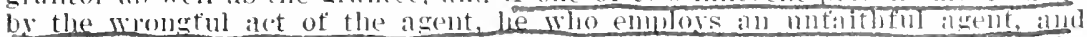
muts it in his power to do the act, must hear the loss thit the gentit hils the potver to deliver the deed, and, if he delivers it "ontrally to his instructions, he will be answerable to his minrijan, and it is, therefore, reasonable that the latter. and not the innocent furchiner slond beal the loss. In brerts $\mathrm{v}$. Agnes, 4 Wis. 34.3, $65 \mathrm{Am}$. Dec, 314 (1.55), the contrary was held. Tut in the Tat-

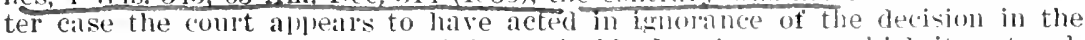
former case, and in ignorance of the equitalle doctrine mon which it rests, although the former decision was made six years lofore the latter. This, as it seenis to us, Was an mufortunite oversingt; for the formen decision is smbuortegdoy reasoning so strong, and, is it seems to us, so sittisfiactory. We camnot re-

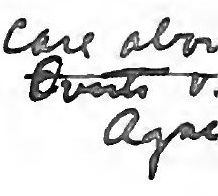




\title{
SCHURTZ v. COLVIN.
}

\author{
(Supreme Court of Ohio, 1896. 55 Ohio St. 274, 45 N. E. 527.)
}

Minshall, J. ${ }^{31}$ There can be no question but that James E. Colvin waived his lien as a vendor by taking a mortgage on the granted premises and other lands of the grantee, to secure the purchase money. Such is the settled law of this state. The court's conclusion of law as to this is correct, and not now questioned by the defendant in error. So that the only question here presented, is as to whether it erred in its second conclusion, that, upon the facts found, the mortgage of James E. Colvin, being subsequent in point of time, is superior in equity to the Schurtz mortgage. Priority is claimed on the ground that at the time the Schurtz mortgage was taken, James E. Colvin held the legal title to his interest in the premises, subject, however, to a legal obligation to convey to James Colvin as purchaser, on his paying the purchase money or securing it to be paid. If the facts found will bear this simple construction, then there can be no question as to the correctness of the court's conclusion of law thereon. In such case the legal title of James $\mathrm{E}$. Colvin would have been notice to the world of his rights in the property; and no one could have acquired an interest in it superior to his by mortgage or otherwise.

The question, however, is whether the facts as found will bear this construction as between James E. Colvin and the Schurtzs. James E. Colvin had by a verbal agreement made in 1884 , sold his interest in the premises to James Colvin, who went into possession under the agreement and was in possession at the time the Schurtz loan was made. Some time before the making of the Schurtz mortgage, James E. Colvin with his co-tenant, Silas H. Colvin, executed a deed for the land to James Colvin, the purchaser, and placed it in the hands of a third person, Howard Colvin, to be delivered when the purchase money was paid or secured by mortgage. Afterward, for the purpose of enabling James Colvin to obtain a loan of money on the land, Howard

sist the conriction that if the attention of the court had been called to it, and the princinles on which it rests, a different conclusion would have been reached; and the subsequent decisions, which have followed the lead of that. Fould hive no existence. *** Escrows are deceptive instruments, They are not what they purport to be. They purport to be instruments which have been delivered, when in fact they have not been delivered. They clothe the grantees with apparent titles which are not real titles. Such deeds are capible of being used to enatle the grantees to obtain credit which otherwise they could not obtain. They are capable of being used to deceive innocent purchasers. And the makers of such instruments can not fail to foresee that they are liable to be so used. And when the maker of such an instrument has voluntarily parted with the possession of it, and delivercd it into the care and leeping of a person of his own selection, it seems to us that be ouglt to be responsible for the use that may in fact be made of it $;$ and that in no other way. can the public be protected against the intoleralle evil of having our public records encumbered with such filse and deceptive instruments." Hubbard v. Greeley, 8t \$e. 210 , 24 Atl. 799, 17 I. R. A. 511 (1S92).

21 The stitement of facts is omitted. 
delivered the deed to him that he might obtain a description of the premises and exhibit it as evidence of his title. The facts found bear this construction and none other. It is true that from the facts found it was not to be regarded as delivered. But the law has always attached much importance to an overt act. It contravenes its spirit to allow that an act may be done with an intention contrary to the act itself. And whilst, as between parties, the intention may be shown, it seldom permits this to be done, where to do so youldwork a fraud on innocent third persons. Here, whilst James Colvin was in possession of the land and of a deed to it by James $E$. Colvin, of whom he had purchased, the Schurtzs, on the faith of these appearances, loaned him $\$ 6,500$, and took a mortgage on the land to secure its payment; and, as the court expressly finds, without any knowledge that the deed had ever been held as an escrow by any one, and that it was taken in good faith without any knowledge that James E. Colvin had or claimed any interest in or lien on the land.

It would seem on the plainest principles of justice, that under these circumstances James E. Colvin, as against the owner of the Schurtz mortgage, should not be heard to say that the deed had not in fact been delivered at the time the mortgage was made, and that his equity is superior to it. He trusted Howard with the deed to be delivered when the conditions had been performed. Howard violated his trust. He delivered it to the grantee that the latter might obtain a loan on the land by exhibiting it as evidence of his title. The loan was so obtained of persons who had no knowledge of the facts and were entirely innocent of any fraud in the matter. Who then should suffer the loss? It may be regarded as one of the settled maxims of the law, that where one of two innocent persons must suffer from the wrongful act of another, he nutust bear the loss who placed it in the power of the person as his agent to commnt the wrong. Or, more tersely, he who trusts most ought to suffer most. And it would seem, that the rights of the parties in this case should be governed by this principle, unless there is some rigid exception established by the decisions, which forbids its application where a deed is delivered in escrow.

Before considering this question, it may be well to note that no importance can be attached to the fact that the deed, on the faith of which the loan was made, had not yet been recorded. A deed on delivery passes title to the land whether recorded or not. It takes effect on delivery. The object of recording a deed is to give notice to third persons, not to perfect it as a muniment of title. Where not recorded it will be treated as a frand against third persons dealing with the land without notice of its existence. Hence, the first deed, if delivered, having been duly executed, passed the title to James Colvin. Recording it would have added nothing to its effect as a deed; and the failure to record it in no way influenced the conduct of any of the parties to the suit.

AIG.PROP. -23 
Th,ere are some cases which seem to hold that, where a deed is delivered as an escrow to a third person to be delivered on the performance of certain conditions, no title passes if delivered without the conditions being performed; and that this is so as aganst an innocent purchaser from the vendee. Everts v. Agnes, $6 \mathrm{~W}$ is. 463, is such a case. The argument there is that no title passes by deed without delivery; that where a deed is delivered by one who holds it as an escrow, contrary to the vendor's instructions, there is no delivery, and consequently an innocent purchaser acquires no title. To the objection that if this be true there is no safety for purchasers, the court said that if it be not true, there is none for vendors. This seems to be a misconception of the real situation of the parties. A vendor may protect himself. He may either retain the deed until the vendee pays the money or select a faithful person to hold and deliver it according to his instructions. If he selects an unfaithful person, he should suffer the loss from a wrongful delivery, rather than an innocent purchaser without knowledge of the facts. In purchasing land, no one, in the absence of anything that might awaken suspicion, is required, by any rule of diligence to inquire of a person with whom he deals, whether his deed had been duly delivered. Where a deed is found in the grantee's hands, a delivery and acceptance is always presumed. Wash. Real Property (5th Ed.) 312, pl. 31. The fact that under any other rule "no purchaser is safe," had a controlling influence with the court in Blight v. Schenck, $10 \mathrm{~Pa}$. 285, 292, $51 \mathrm{Am}$. Dec. 478. In this case the question was whether a deed had been delivered, the defendant being an innocent purchaser from the vendee of the plaintiff. In discussing the case the court used this language: "Here Curtis, who, it is alleged, delivered the deed contrary to his instructions, was the agent of the grantor. If a man employs an incompetent or unfaitlful agent, he is the cause of the loss so far as an innocent purchaser is concerned, and he ought to bear it, except as against the party who may be equally negligent in omitting to inform himself of the extent of the authority or may commit a wrong by acting knowingly contrary thereto." And the case was disposed of on this principle.

The case on which most reliance is placed by the defendant in error, is that of Ogden v. Ogden, 4 Ohio St. 182. The facts are somewhat complicated. It seems to have grown out of an agreement for an exchange of lots between two of the parties, each being the equitable owner of his lot. The deed for the lot of one of them, David Ogden, was to be delivered by the legal owner to the other on his performing certain conditions, and was delivered to a third person to be delivered on the performance of the conditions. It was delivered without the conditions being performed; and was then mortgaged by the grantee to the defendants, Watson and Strol, who claimed to be innocent purchasers for value. But it was charged in the bill that they took their mortgages with notice and to cheat and defraud the complainant; and it does not distinctly appcar whether this was true or 
not. From the reasoning of the court it would seem that the deed had been obtained from the party holding it in some surreptitious manner. It is first conceded "that if David reposed confidence in Gilbert, and he violated that confidence and delivered the deed, and loss is to fall on either David or the mortgagees, that David should sustain that loss, and not the innocent mortgagees." Instances are then given in which the rule would be otherwise-an innocent purchaser from the bailee of a horse, or of stolen property, or from one who had either stolen or surreptitiously obtained his deed. There is no room for doubt in either of these cases. But the court then observes that, "If the owner of land makes a deed purporting to convey his land to any one, and such person by fraud or otherwise procures the owner to deliver the deed to him, a bona fide purchaser from such fraudulent grantee without notice of the fraud, might acquire title to the land." This, we think, is equally clear; but, unless the deed in the case had been stolen or surreptitiously obtained, or the mortgagees were guilty of the fraud charged, then, on the reasoning of the court, the decree should have been in their favor. If the case is to be understood as holding differently, then it is not in accord with the later decision in Resor v. Railroad Company, 17 Ohio St. 139. Here the owner of a tract of land contracted to sell it to the company, but refused to deliver the deed until paid. An agreement was then made by which the deed was placed in the hands of the president, but it was not to be considered delivered until payment had been complied with, and the company went into possession. The president wrongfully placed the deed on record, and the company then mortgaged its entire property to secure an issue of bonds. The court held the bond-owners to be innocent purchasers, and that the plaintiff was estopped from setting up his claim as against them. It might be claimed that the delivery by Resor was to the purchaser, the company; and that a deed cannot be delivered as an escrow to the vendee. The latter statement is true. But as a matter of fact it was delivered to the president of the company and not to the company itself. There is no reason why the president could not have held it as an escrow, and under the agreement, must be regarded as having so held it. Railroad Co. v. Iliff, 13 Ohio St. 235; Watkins v. Nash, L. R. 20 Eq. 262; Insurance Co. v. Cole, 4 Fla. 359. The plaintiff trusted the president to hold the deed, and it was his wrongful act that disappointed him.

The supreme court of Indiana in a well-considered case, Quick v. Milligan, 108 Ind. 419, 9 N. E. 392, 58 Am. Rep. 49, the facts of which are very similar to the case before us, held that where a deed is delivered to a third person to be delivered the grantee, who is already in possession of the land, on payment of the purchase money, and is delivered without the condition being performed that the vendor is estopped as against an innocent purchaser to set up his title. See, also, and to the same effect, the following cases: Bailey v. Crim, 9 
Biss. 95, Fed. Cas. No. 734; Haven v. Kramer, 41 Iowa, 382; Blight v. Schenck, 10 Pa. $285^{.22}$

It is the general, if not universal, rule of the courts, to protect the innocent purchaser of property for value, against such vices in the title of their vendors, as result from fraud practiced by them in acquiring the property. For in all such cases the party complaining is found to have been guilty of some negligence in his dealings, or to have trusted some agent who has disappointed his confidence and is more to blame for the consequences than the innocent purchaser, so that his equity is inferior to that of such purchaser. Hence, it is, that the innocent purchaser for value from a fraudulent grantee, is always protected in his title as against the efutity of the wronged grantor. In Hoffman v. Strolecker, 7 Watts (Pa.) 86,32 Am. Dec. 740, where a sale has been made under execution upon a satisfied judgment, the satisfaction not appearing of record, an innocent purchaser of the person who purchased at the sale was protected in his title, although the purchaser at the sale had knowledge of the facts, and acquired no title. A similar holding had been made by the same court in Price v. Junkin, 4 TVatts (Pa.) 85, 28 Am. Dec. 685, and in Fetterman v. Murphy, 4 Watts (Pa.) 424, 28 Am. Dec. 729. In the case of Price v. Junkin it is said "An innocent purchaser of the legal title, without notice of trust or fraud is peculiarly protected in equity, and chancery never lends its aid to enforce a claim for the land against him."

Most of the cases cited and relied on by the defendant are not in point. Where the grantee wrongfully procures the holder of a deed as an escrow to deliver it to him, he acquires no title, or at least a voidable one; but this is a very different case from where a third person without notice, afterward and while the grantee is in possession, deals with him in good faith as owner. Again, it may be conceded that the delivery of a deed by one who simply holds it as a depositary, transfers no title; but if he holds it as an escrow, with power to deliver it on certain conditions, a delivery, though wrongful, is not in excess of his authority for, in such case, the act is within his authority and binds the principal as against an innocent party. And so a deed held in escrow, delivered after the death of the principal, passes no title. It will readily appear, from reasons already given, that such cases are without application to the case under review. Here it will be conceded that as between the grantor and the grantee the latter took no title, because delivered by Hoivard contrary to his instruction. But the plaintiff relies on the fact that, as found, he had no knowledge that the deed had ever been held as an escrow and, in good faith, loaned his money and took a mortgage on the land to secure it; and that the defendant is therefore estopped from setting up his legal title as against him.

82 See, also, Mass v. Shields, 117 Ga. 814, 45 S. E. 68 (1903). 
But it is claimed that, as the plaintiff relies on an estoppel, he should have pleaded it. This rule, however, only applies where the party has had an opportunity to do so. In this case he had none until the evidence had been introduced. The defendant, in his answer and cross-petition, set up that the deed from hin had been placed in escrow and wrongfully delivered to the grantee and that the plaintiff harl knowledge of the facts. The plaintiff then averred his want of any knowledge or belief as to the facts stated by the defendant and denicil them. The court, however, found that the deed had been deliveres to Howard Colvin to be held as an escrow and was by him wrongfully delivered to the grantee; but also found that the plaintiff was ignorant of the facts, and an innocent purchaser for value willont notice. 'The object of pleading is to inform the opposite party of the fucts 'upon which the pleader relies as the ground of his claim or defence. And here, when the plaintiff denied knowledge of the facts as pleaded by the defendant, he fairly advised the defendant that he relied on an estoppel, on the ground of want of notice, should the facts as pleader be made to appear in the evidence; for, that he was a purchaser for value appeared from his petition, which was taken as truc as it was not controverted. Hence the claim of the plaintiff could in no way surprise the defendant dinless he was ignorant of the law. The first opportunity the plainflf hal to plead an estoppel as against James $\mathrm{E}$. Colvin, was when the facts were fully made to appear in evidence; and he is not therefore precluded from doing so on the facts as found by the court.

Judgment reversed and judgment on the facts for plaintiff in error. $^{33}$

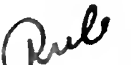
Holaing ithat contractis

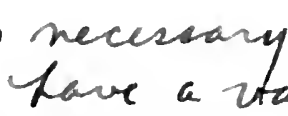

(Supreme Court of Wisconsin, 1877. 42 Wis. 437, 24 Am. Ren. 427.)

Appeal from the Circuit Court for Racine County.

The case, stated most favorably to the plaintiff, is briefly as follows: The plaintiff and Thomas entered into a parol agreement' for the sale by the latter to the former of certain land, at a stipulated price, to be secured and paid as hereinafter mentioned. In accordance with such parol agreement, the plaintiff paid Thomas a small sum on account of the purchase money, and the latter signed, sealed and duly acknowledged a deed of the premises to the plaintiff (which was in the usual form of a warranty deed), and delivered the same to Judge

33. Where the custodian has improperly handed the deed over to the grantee the grantor may have same canceled. Anderson $v$. Goodwin, 125 Ga. 66:3, 51 S. E. 679 (1906); Bales v. Roberts, 1 S9 Mo. 49. S7 S. W. 914 (1905). And the registration of such a deed may be enjoined. Matteson .v. Smith, 61 Neb. 761, 86 N. W. 472 (1901). 
Hand, his codefendant, with directions to deliver it to the plaintiff if the latter should, two days later, deposit with Hand his notes for a certain sum (part of the price of the land), and a mortgage executed by him on the same land to secure the payment of such notes, and at the same time pay to Hand, for the use of Thomas, the balance of isthe agreed price. These proceedings were all in accordance with such verbal agreement. At the appointed time, the plaintiff deposited

$\checkmark$ with Hand the notes, mortgage and money as agreed, and demanded the deed of the land; but, acting in obedience to instructions from Thomas, Hand refused to deliver the deed. At the same time, Thomas tendered to the plaintiff the money which the latter paid him when the verbal agreement was made, and, on the refusal of the plaintiff to receive it, left the same with Judge Hand for the plaintiff.

This action was brought to compel Judge Hand to deliver to the plaintiff the deed thus deposited with him by Thomas. The circuit court gave judgment for the plaintiff, that the defendant Hand deliver such deed to him, and that Thomas pay the costs of the action. From this judgment Thomas appealed.

T The court concluded that the judgment should be reversed. A petition for rehearing having been granted, the case was reargued, and the following opinion handed down.]

Lyon, J. The controlling question in this case is, whether it is essential to the plaintiff's right of action that there was a valid executory contract between the parties for the purchase and sale of the land described in the deed of the defendant deposited with Judge Hand. If this question be answered in the affirmative, the plaintiff cannot recover; for it is certain that no note or memorandum of the alleged agreement under which the plaintiff claims, expressing the consideration thereof, was reduced to writing and subscribed by the defendant. Rev. St. 1858 , c. 106, § S.

The learned counsel for the plaintiff has met this question squarely, and, in his elaborate and most able arguments on the motion for a rehearing and on the rehearing of the cause, has maintained the proposition that "it is not true that a person must be under a previous binding cxecutory contract to convey the lands described in the deed to the grantee, in order to place a deed thereof, delivered to a third person on condition for the grantee, beyond the control of the grantor."

Undoubtedly there is a class of cases in which this proposition is true. These are the cases where the deed has been delivered by the grantor to a third person with instructions to deliver the same to the grantee on the happening of a future certain event-as the death of the grantor or some other person,- and such conditional delivery is assented to by the grantee. In such a case, if the grantor reserves no control over the deed, he cannot after such delivery recall it, but the grantee is entitled to it upon the happening of the event, although there is no valid executory contract to support it. The reason of this is, that the first delivery of the deed passes to the grantee the title to 
the land, and thus relieves him of the obligation to make title through any contract other than that expressed in the deed itself.

But by atl of the authorities a deed so deposited with a third person to be delirered to the grantee on the happening of some event in the future which may or may not happen, does not pass title to the land described in it to the grantee until such event occurs, and then only from that time, or perhaps from the actual delivery of the deed to the grantee after the event has occurred. There may be exceptional cases, as where a man delivers his deed in escrow and dies before the conditions of the deposit are fulfilled. In such cases, it has been said that from necessity after the conditions are fulfilled the deed must take effect by relation as of the time of the first delivery. This, however, is not one of the exceptional cases; and it must be conceded, we think, that the deposit of the deed with Judge Hand by the defendant with the assent of the plaintiff did not transfer title to the plaintiff.

Because such deposit did not divest the plaintiff of his title to the land, there is no executed contract for sale; and hence, it scems almost too plain to be questioned or doubted that, before the plaintiff can pbtain the delivery of the deed and the title to the land, after the defendant has recalled the deed and repudiated the whole transaction, he must show that the defendant has made a valid and binding agreement to sell and convey the land. And such an agreement can be evidenced only by a written note or memorandum thercof, expressing the consideration and subscribed by the defendant.

In many of the cases cited, there was no valid executory contract for the sale of the land, but the grantor permitted the deed to be delivered by the depositary to the grantee upon performance of the parol conditions of the deposit. Undoubtedly, the final delivery to the grantee in such cases operated to pass the title; as it would in the present case had the defendant seen fit to allow his void parol agreement to be thus consummated. In other cases cited, there was a compliance with the statute of frauds. Everts v. Agnes, 4 Wis. $3+3$, $65 \mathrm{Am}$. Dec. 314, is one of them. But we have not discovered a single case in which it has been held that one who has deposited a deed of land with a third person with directions to deliver it to the grantee on the happening of a given event, but who has made no valicl executory contract to convey the land, may not revole the dircctions to the depositary and recall the deed at any time before the conditions of the deposit have becn complied with; provided those conditions are such that the title does not pass at once to the grantee upon delivery of the deed to the depositary

The case of Welch v. Sackett, 12 Wis. 243; Brandeis v. Neustadtl, 13 Wis. 142, and Prutsman v. Baker, 30 Wis. 644, 11 Am. Rep. 592, as well as that of Thomas v. Sowards, 25 Wis. 631, contain much doctrine in perfect accord.with the views here expressed. The latter of these cases, as was observed in the first opinion filed herein, is
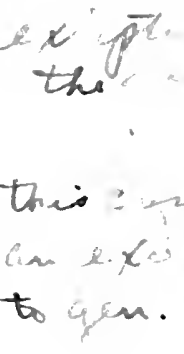


\section{HULL v. SANGAMON RIVER DRAINAGE DIST.}

(Supreme Court of Illinois, 1906. 219 Ill. 454, 76 N. E. 701.)

CARTIVRIght, C. J. ${ }^{35}$ This is an appeal from orders of the county court of McLean county odsanizing the Sangamon River drainage district, in said county, and confirming an assessment of benefits against appellants lands by the commissioners of said district. The proceeding was commenced by filing a petition for the organization of the district under what is commonly known $\overrightarrow{\mathrm{as}}$ the "Levee Act." 2 Starr \& C. Ann. St. 1896, p. 1500 , c. 42 , par. 29. Commissioners were appointed by the court, and they examined the lands proposed to be drained, and over and upon which the work was proposed to be constructed, and made a report, as required by section 9 of the act (paragraph 37), recommending the organization of the district. Appellant filed objections to the report, and his objections were overruled.

It is first contended that the court erred in overruling the objections and in not dismissing the petition, for the reason that it was not signed by a majority of the adult owners of the land within the district and who represented one-third in area of the lands to be reclaimed or benefited. The petition was signed in the summer of 1903, and the hearing was in the fall of that year, and Mark Banks, one of the signers, was counted by the court as the owner of 160 acres of land. He had previonsly signed and acknowledged a deed of the land to Farrison Frink and Sheridan J. Frink, and had deposited the deed in the First National Bank of Bloomington, to be clelivered on payment of the purchase price on or before February 15, 1904, and in case of such payment he was to deliver possession on or before March 1, 1904. The leed placed in escrow conveyed nothing until the conditions for its delivery were performed on Febrtary 15, 1904, when it was delivered to the grantees. Leiter v. Pike, 127 I11. 237, 20 N. E. 23. "The title did not pass out of Mark Banks until the deed took effect and the grantees became the owner of the land, and he was properly counted as an owner. **** $*$

The judgment is reversed, and the cause remanded. Reversed and remanded. 3

35 A portion of the opinion is omitted.

3e silnose the grantee in an escrow deed, after performance of the coulithons, in order to save the pronerty from tax sale, pays the taxes which wer ansessed against the property after the deposit of the deet with the thind purty but before the nerformance of the condition. IIas he any remedy against the grantor? Nohr r. Joslin, 16ie Iowa, 3-1, 1'2 N. W. 9S1 (1913).

As to the deposit of a deed in escrow working a "change in interest in the property insured," and so aroiding an insurance poliey on the property described in the deed, see Pomeroy $x^{\circ}$. Fina Ins. Co., so Kan. 214, 120 Pac. 34t, 38 L. R. A. (N. s.) 142, Ann. Cas. 191:C. $170(1912)$.

See, also, Furness r. Willians, 11 Mll. 230 (1S.9); Hoyt v. MeLagan, 87 Iowa. 746,55 N. W. 18 (1893). 


\section{FARLEY v. PALMER.}

\section{(Supreme Court of Ohio, 1570. 20 Ohio St. 223.)}

By THE Court. Farley, the plaintiff, seeks to reverse the judrment of the court below, decreeing the specific execution of his written contract"made with Palmer and wife for the purchase of her land. At the time of making the contract a deed was exectited by Palmer and wife and placed in the hands of a third person, and by the terms of the contract this deed was to be delivered to Farley upon his paying the stipulated purchase-money. Upon Farley's refusal to pay the money and receive the deed at the time agreed upon, Palmer and wife brought their action for a specific execution. And now it is contended that Fiarley was not bound by the contract, on the alleged ground that as Mrs. Palmer, being a married woman, was not bound, there was no mutuality of obligation. We think otherwise. Mrs. Palmer was bound. She had no power to revoke the deed. The person holding the deed was the agent of both parties, and his delivery, according to the terms of the contract, without her consent, or even after her death, would have been good. Indeed, the authorities show, that upon fulfilment of the condition by Farley the title would have vested in him, ipso facto, without further delivery. The contract was executed on the part of Mrs. Palmer - the title had passed from her-subject only to the performance of the condlition on the part of Farley.

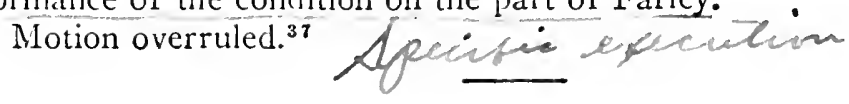

\section{HALL v. HARRIS.}

(Supreme Court of North Carolina, 1848. 40 N. C. 303.)

Cause removed from the Court of Equity of Montgomery County, at the Spring Term, 1848.

The facts in this case are fully stated in a case between the same parties, Hall v. Harris, 38 N. C. 289 , and so much of them as is necessary to the understanding of the decision now made is set forth in the opinion of the Court here delivered.

Pearson, J. When this case was before this Court at June Term 1844 , it was decided, that an execution does not bind equitable interests and rights of redemption from its teste, as in ordinary cases, but from

37 What if the grantor dies hefore the condition is nerformed? See Guild v. Althouse, 71 Kan. 604, 81 Paç. 172 (1905); Nolan v. Otney, 75 Kan. 311, 89 Par. (:!0, !) L. R. A. (N. S.)::17 (1907).

What if the depositary refuses to deliver the deed to the grantee after the conditions have been performed? See Tombler v. Sinnpter. 97 Ark. 4S0, $134 \mathrm{~S}$.

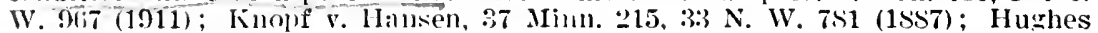
v. Thistlewood. 40 Kan. 23:, 16 I'ac. 6i29 (1ss's, where the retention of the deed by the depositary was by direction of the glantor; Regin r. Huwe, 1:1 Mass. 424 (15it), where the grantor had procured the deed from the depositary on the statement that he intended to hand it to the grantee. 
the time of "execution served;" and it was declared that the plaintiff would be entitled to a decree, provided the deed, under which he claimed, took effect before the execution, under which the defendant Harris claimed, was issued. 38 N. C. 239.

We are satisfied, that the view then taken of the case was correct. The rights of the parties depend upon that single question.

'The execution issued on the 7 th of March, 1840 . The plaintiff alleges that the deed took effect on the $2 \mathrm{~d}$ of March, 1840 . The facts are, that on the $2 \mathrm{~d}$ of March the plaintiff and the defendant Morgan made an agreement, by which the plaintiff was to give Morgan $\$ 725$, for the land, to be paid, a part in cash, and the balance in notes and specific articles, as soon as the plaintiff was able, which he expected would be in a few days, and Morgan was to make a deed to the plaintiff, and hand it to Col. Hardy Morgan, to be by him handed to the plaintiff, when he paid the price. Accordingly on that day the plaintiff paid to Morgan a wagon and some leather, which was taken at the price of $\$ 57.50$ and Morgan signed and sealed the deed, and handed it to Col. Morgan to be handed to the plaintiff, when he paid the balance of the price. The deed was witnessed by Col. Morgan and one Sanders, and is dated on the $2 \mathrm{~d}$ of March. Afterwards on the tenth of March, the plaintiff paid to Morgan the balance of the $\$ 725$, with the exception of $\$ 152$, for which Morgan accepted his note, and the decl was then handed to the plaintiff by $\mathrm{Col}$. Morgan.

The question upon these facts is, whether the deed takes effect fron the $2 \mathrm{l}$ or from the 10 th of March? We are of opinion, that it takes effect from the $2 \mathrm{~d}$, at which time, according to the agrecment, it was signed, sealed, and delivered to Col. Morgan, to be delivered to the plaintiff, when he should pay the price. 'The effect of the agrecment was to give the plaintiff the equitable estate in the land, and to give Morgan a right to the price. The purpose, for which the deed was delivered to a third person, instead of being delivered directly to the plaintiff, was merely to secure the payment of the price. When that was paid, the plaintiff had a right to the deed. The purpose, for which it was put into the hands of a third person, being accomplished, the plaintiff then held it in the same manner, as he would have held it, if it had been delivered to him in the first instance. This was the intention, and we can see no good reason why the parties should not be allowed to effect their end in this way.

It is true, the plaintiff was not absolutely bound to pay the balance of the price. Perhaps, he had it in his power to avail himself of the statute of frauds, and it would seem from the testimony, that, at one time, he contemplated doing so, on account of some doubt as to the title; but he complied with the condition and paid the price. His rights cannot be affected by the fact, that he might have avoided it. If the vendor had died, after the delivery to the third person, and before the payment, the vendee upon making the payment, would have been entitled to the deed; and it must have taken cffect from the first delivery; 
otherwise, it could not take effect at all. The intention was, that it should be the deed of the vendor from the time it was delivered to the third person, provided the condition was complied with. If this intention is bona fide and not a contrivance to interfere with the right of creditors, of which there is no allegation in this case, it must be allowed to take effect.

A distinction is taken in the old books, between a case, when a paper, being signed and sealed, is handed to a third person, with these words; "take this paper and hand it to A. B. as my deed, upon condition" \&c., and a case where these words are used, take "this deed and hand it to A. B. upon condition," \&c. In the latter case it takes effect presently; while in the former, it is held, in most cases, not to take effect, until the second delivery. Touchstone, 58, 59.

The distinction, upon which this "diversity" is made, would seem too nice for practical purposes, to be a mere play upon words. ${ }^{38}$ The intention of the parties, whether one set of words be used or the other, is to make it a deed presently, but to lodge it in the hand of a third person, as a security for the performance of some act. If it was not to be a deed presently, provided the condition be afterwards performed, the maker would hold it himself, and the agency of the third person would be useless. Indeed the idea, that the third person is a mere agent to deliver the paper as a deed, if particular words be used, "escrow" for instance, even by the old cases, has many exceptions, and the deed is allowed, in such cases, to take effect. As if the maker dies, as in the case above put; or becomes non compos mentis; or, being a feme sole, marries; or if the vendor should create any incumbrance, as by making a lease; in all such cases, when the paper was handed to the third person to be delicered as a deed upon condition \&c., it is allowed to take effect from the first delivery, in order to effectuate the intention of the parties. In ather words, when it can make no difference, the deed takes effect from the second delivery, but if it does make a difference, then the deed takes effect from the first delivery. This entirely yields the question. The last exception cited above, as to the relation of the deed, in cases of "escrow" to avoid a lease, takes in the case under consideration; for it is the same, whether the incumbrance, to be avoided, proceeds from the act of the party, or from the effect of an execution, as the object is to make the deed effectual and to carry out the intention. State v. Pool, 27 N. C. 105.

But, in truth, the distinction cannot be acted upon-it is merely verbal, and whether one set of words would be used, or the other, would be the result of mere accident. The law does not depend upon the accidental use of mere words "trusted to the slippery memory of witnesses." It depends upon the act, that a paper, signed and sealed, is put out of the possession of the maker. It must be confessed, (and with reverence I say it,) that many of the dicta to be found in the old

38 State Bank' v. Evans, 15 N. J. Law, 155, 2 S Am. Dec. 400 (1835) acc. 
books, in reference to deeds, are too "subtle and cunning" for practical use, and have either been passed over in silence, or wholly explained away.

We are satisfied from principle and from a consideration of the authorities, that when a paper is signed and sealed and handed to a third person to be handed to another upon a condition, which is afterwards complied with, the paper becomes a deed by the act of parting with the possession, and takes effect presently, without reference to the precise words used, unless it clearly appears to be the intention, that it should not then become a deed, and this intention would be defeated by treating it as a deed from that time, as, if, no fraud being suggested, the paper is handed to the third person, before the parties have, concluded the bargain and fixed upon the terms; which cannot well be supposed ever to be the case; for in ordinary transactions, the preparation of deeds of conveyance, which is attended with trouble and expense, usually comes after the agreement to sell.

There must be a decree for the plaintiff, with costs against the defendant Harris.

- Per Curial. Decree accordingly. ${ }^{39}$

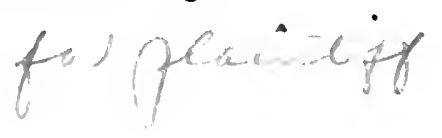

\section{MAY v. EMERSON.}

(Supreme Court of Oregon. 190S. 52 Or. 262, 96 Pac. 454, 1065, 16 Ann. Cas. 1129.)

This is an action of ejectment, commenced on October 23, 1907, to recover the possession of lots 35 and 36 , in block 11, Stewart's second addition to Baker City. The answer admits that defendant is in possession, and alleges that he is the owner of the lots in fee simple; and as a second defense alleges possession under a contract of purchase, as disclosed in the stipulation of facts, which includes the following: That on February 24, 1906, defendant purchased the lots from Dugan and wife, the price to be paid in monthly installments, continuing over a period of more than a year; that a deed was executed by Dugan and wife, and deposited in escrow with M. S. Hughes, to whom payments

39 Whitfield v. Harris, 48 Miss. 710 (1873); Dettmer v. Behrens, 106 Iowa, $585,76 \mathrm{~N}$. IV. $\$ 53,68 \mathrm{Am}$. Nt. Rep. 326 (1S9S). acc.

In Vorheis F. Fitch, \& Phila. (Pa.) 5.5t (1S71), the wife of the grantor who had become such between the denositing of the deed in escrow and the performance of the condition was held not entitled to dower.

In Lewis v. Prather, 21 S. W. 53S, 14 Ky. Law Rep. 749 (1S93), it was held that a deed made by the grantor after the deposit of the escrow deed but be. iore the performance of the condition to a purchaser who knew of the esclow deed was ineffective as against the first grantee upon the performance of the condition. Leiter v. Pike, 127 Ill. 257,20 N. E. 23 (1S89), acc. See Cannon v. Handley, 72 Cal. 133, 13 Pac. 315 (1SS7); Conneau v. Geis, 73 Cal. 176, 14 Pac. 580,2 Am. St. Rep. 785 (18S7) ; McDonald v. Huff, 77 Cal. 279, 19 Pac. 499 (1SSS). 
were to be made, and was to be delivered by Hughes when the payments were completed; that defendant was to have possession from the date of the purchase; that on April 12, 1906, after the purchase and before the delivery of the escrow deed, plaintiff, in an action of debt ) against Dugan and wife, attached the said lots, which action resulted in judgment against them on Apri1 25, 1906; that an execution sale of said lots was had on June 12,1906, and confirmation thereof was had on June 22, 1906, and a sheriff's deed issued to the plaintiff on June 27, 1907; that plaintiff, at the time of the attachment, had knowledge of the contract of sale and escrow deed, and on July 15, 1906, notified the defendant of said judgment and execution sale, and demanded that payment of the purchase price be made to him; that defendant paid all the installments of the said purchase price to Hughes, according to the agreement, and received the deed from him on or about September 14, 1907. From these facts the trial court found that plaintiff acquired the title to the property free from any equity of the defendant, and rendered judgment accordingly, and the defendant appeals.

EAKIN, J. (after stating the facts as above). 1. The first matter for consideration is the effect of plaintiff's judgment lien and execution sale upon defendant's prior possession, under his purchase and escrow deed from Dugan and wife, defendant contending that when the conditions under which the escrow deed was deposited with Hughes were fulfilled, the deed related back to, or took effect from, the date of such deposit, and thus cut off the lien of plaintiff's judgment. The sale by Dugan to the defendant, and the deposit of the deed with Hughes, created in the defendant an equitable interest in the property, such that, upon full payment of the purchase price according to the escrow agreement, the title would vest at once in the grantee, but pending the completion of the purchase by the full payment of the price, the legal title to the property remained in the vendor and was therefore subject to attachment, or the lien of a judgment against the vendor to the extent of his interest therein. Such lien, obtained with notice of the escrow agreement, is subject to the equity of the vendee. The delivery of the deed to the vendee being essential to pass the title, the escrow agreement only becomes effectual for that purpose upon the fulfillment of its conditions. The general rule is that the title passes to the vendee from the second delivery. Devlin, Deeds, par. 328; Prutsman v. Baker, $30 \mathrm{~W}$ is. 644, $11 \mathrm{Am}$. Rep. 592. There are exceptions to this rule, as stated in 4 Kent's Commentaries, 454. "Generally an escrow takes effect from the second delivery, and is to be considered as the deed of the party from that time; but this general rule does not apply when justice requires a resort to fiction. The relation back to the first delivery, so as to give the deed effect from that time, is allowed, in cases of necessity, to avoid injury to the operation of the deed from events happening between the first and second delivery. *** But if the fiction be not reguired for any such purpose, it is not adnitted, and the deed operates, according to the truth of the case, from the 
second delivery." Rathmell v. Shirey, 60 Ohio St. 187, 197, 53 N. E. 1098, 1099; Devlin, Deeds, par. 328. In Prutsman v. Baker, 30 Wis. 644, 11 Am. Rep. 592, it is said: "This relation back to the first delivery is permitted, however, only in cases of necessity, and where no injustice will be done, to avoid injury to the operation of the leed from events happening between the first and second delivery; as if the grantor, being a feme sole, should marry, or whether a fene sole or not, should die or be attainted, after the first and before the second delivery, and so become incapable of making a deed at the time of second delivery, the deed will be considered as taking effect from the first delivery, in order to accomplish the intent of the grantor, which would otherwise be defeated by the intervening incapacity. But subject only to this fiction of relation, in cases like those above supposed and others of the kind, and which is only allowed to prevail in furtherance of justice, and where no injury will arise to the rights of third parties, the instrument has no effect as a deed, and no title passes until the second delivery; and it has accordingly been held that, if in the meantine the estate should be levied upon by a creditor of the grantor, he would hold by virtue of such levy, in preference to the grantee in the deed:" W'asliburn, Real Prop. \$ 2181; Rathmell v. Shirey, 60 Ohio St. 187, 53 N. L. 109S; Jackson v. Rowland, 6 IVend. (AN. Y) 667, 22 Am. Dec. 557.

2. The second delivery cannot take effect by relation when the grantor is able to make, and the grantee able to receive, such second delivery absolutely. Jackson v. Rowland, 6 Wend. (N. Y.) 667, 22 Am. Dec. 557. It is held in Whitfield v. Harris, 48 . Miss. 710, that this fiction of relation will apply to ward off the intervening liens of creditors; and Chinn v. Butts, 3 Dana ( $K y$.) $5+7$, holds to the same effect. But the weight of authority is the other way. 11 Am. \& Eng. Enc. Law (2d Ed.) 348, says: "But it seems to be the prevailing rule that, in the interval of time between the first and second delivery, title remains in the grantor, subjcct to the claims of his creditors, and that this doctrine of relation cannot be applied for the purpose of defeating such intervening claims." This text is supported by the authorities above cited, and also by Wolcott v. Johns, 7 Colo. App. 360, 44 Pac. 675; Taft v. Taft, 59 Nich. 185, 26 N. W. 426, 60 Am. Rep. 291 ; Hoyt v. McLagan, 87 Iowa, 746,55 N. W. 18.

3. $\mathrm{t}$ is beyond controversy that the title remains in the vendor until the actual delivery of the deed. The vendor still has not only the legal title, but also an interest in the property as security for the payment of the purchase price; and this interest should be and is available to a creditor through the lien of his judgment, which lays hold of such legal title, and thereafter payments made to the vendor by the vendee are at his peril: Tomlinson v. Blackburn, 37 N. C. 509 . If the purchase price is fully paid, although the deed is not actually delivered, the vendor having but the naked legal title, the judgment creditor can acquire no more: Stannis v. Nicholson, 2 Or. 332; Riddle v. 
Miller, 19 Or. 468, 23 Pac. 807; Riddle's Appeal (Pa.) 7 Atl. 232; Uhl v. May, 5 Neb. 157; Elwell v. Hitchcock, 41 Kan. 130, 21 Pac. 109. Reversed. ${ }^{40}$

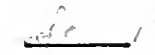

\section{$\because$ SCOTT. v. STONE.}

(Supreme Court of Kansas, 1906. 72 Kan. 545, 84 Pac. 117.)

Graves, J. This was an action to recover damages for a breach of the covenants of a warranty deed. The transaction was evidenced by a contract of sale, dated April 8, 1902, which specified the subsequent steps to be taken by each party in completing the conveyance. The defendants in error were grantors, and the plaintiff in error grantee.

The contract of sale, together with $\$ 1000$ cash paid by the grantee upon the purchase-price of the land, was placed in escrow with an E1 Dorado bank to await the performance of the subsequent requirements of each party. It was stipulated that the grantors should furnish an abstract of title and execute a warranty deed to the land, and place them in the bank with the contract, there to remain until August 1, 1902, when the grantee should pay the remainder of the purchasemoney and receive the deed and abstract of title. These conditions were performed by each party, and the deed and abstract of title were duly delivered to the grantee as stipulated.

At the date of the contract of sale the land was in the possession of tenants. The cultivated portion was occupied by one Arnall, and the pasture-lands by one Pirtle. Arnall paid his rent to the grantee, and Pirtle paid to the grantors. The grantee began this action to recover damages as a substitute for the Pirtle rent.

The case was tried to a jury. The controversy on the trial was whether, if a recovery could be had at all, it should be for rent accruing from the date of the contract of sale, or from the date when the grantee actually received the deed, to November 1, 1902, when the Pirtle lease expired. The case was presented to the jury upon both theories, and the anount returned in the verdict indicated that it was intended to cover the longer period. The court, on a motion for a new trial, decided that the finding should have been for the shorter period, and thereupon offered to deny the motion if the plaintiff wonld accept an amount stated, being the value of the rent after August 1, 1902; if not, the court indicated that it would grant a new trial. The plaintiff declined the offer and the motion was allowed. * * *

We might let the case rest here, but, as a new trial is necessary and the legal questions involved are controlling, we deem it best to decide them now, and thereby save the parties the delay and expense of further litigation in this court. The trial court erred in hold-

40 See Lord's Oregon Laws, § 301. 
ing that the grantee could recover rent only from the date he actually received the deed-August 2, 1902. Where land is sold by a transaction involving a contract of sale containing stipulations for the subsequent performance of specified acts by each of the parties, pending which performance the contract is placed in escrow, and afterward in compliance with such escrow the grantor executes and delivers his deed, to be also held in escrow with the contract and delivered to the grantee when payment has been made by him as stipulated, and all the provisions of the escrow are performed and the deed delivered to the grantee accordingly, such delivery completes the conveyance, and the deed relates back to the date of the contract of sale and is not limited to the date when actual delivery is made to the grantee.

This doctrine of relation is of ancient origin, and has always been applied, both at law and in equity, to meet the requirements of justice, to protect purchasers, and to effectuate the intent of the parties to contracts. 18 Vin. Abr. 286-293; 2 Greenl. Cruise on Real Prop. 441; 24 A. \& E. Encycl. of L. 275; Welch v. Dutton et al., 79 Ill. 465 ; Young v. Guy, 87 N. Y. 457; Sutherland v. Goodnow et al., 108 I11. 528, 48 Am. Rep. 560; Nellis v. Lathrop, 22 Wend. (N. Y.) 121, 34 Am. Dec. 285; Thompson v. Spencer, 50 Cal. 532; Cummings $r$. Newell, 86 Minn. 130, 90 N. W. 311; Davis v. Clark, 58 Kan. 100, 48 Pac. 563.

It has been held that whether by this rule of relation the operation of the deed will be carried back to the date of the contract of sale, to the execution of the deed, or only to its actual delivery to the grantee, will depend upon the intent of the parties as shown by the transaction. 1 Devlin, Deeds (2dEd.) § 262. But whatever test may be applied to this case, the result will be the same. It is necessary to protect the grantee in the enjoyment of the property which he las bought and paid for, and it is necessary to carry out the manifest intention of the parties that this deed should relate back to the date of the contract of sale.

The grantors purchased the land in controversy less than a week before the sale in question. The grantec paid interest on the purchase-price from the date of the contract. A vendor, in the absence of express stipulations therefor, cannot receive intcrest on the purchaseprice and the rents also. 29 A. \& E. Encycl. of L. 708: Siemers v. Hunt, 28 Tex. Civ. App. 44, 65 S. IV. 62, 66 S. WV. 115. The grantors knew when they executed the contract of sale, and on May 6, 1902, when they placed their deed with full covenants of warranty in escrow, to be delivered August 1, 1902, that tenants were on the land, but no reservation or suggestion was made that they expected the rent. If must be presumed that they intended to convey by their deed every right which its covenants covered.

Placing a deed in escrow practically withdraws the land from the market, and renders the grantor powerless to convey or encumber it, AIG.Prop. - 24 
so far as the vendee is concerned. After the grantee had paid the purchase-money in full, as agreed, including interest thereon from the date of the contract of sale, it would be manifestly unjust to deprive him of the rent conveyed by the covenants of his deed. We conclude that under the facts and circumstances shown in this case the plaintiff is entitled to receive rents from the date of the contract of sale, April \&, 1902.

The order of the court granting a new trial is affirmed, with direction that on the further trial the views herein expressed be followed. All the Justices concurring. ${ }^{11}$

\section{BAKER v. SNAVELY.}

(Supreme Court of Kansas, 1911. S4 Kan. 179, 114 Pac. 370.)

SuIth, J. William Weisiger was the record owner of the lots in question. On the 6th day of November, 1901, one Clarence Ford obtained a tax deed to the lots, and his right thereto was conveyed to John Baker, who subsequently, and on the 5 th day of October, 1905, brought this action in the district court of Finney county to quiet his title to the lots against Weisiger and wife and others. Service was made by publication. On the 21 st day of November, 1905, judgment was rendered in favor of the plaintiff quieting his title.

On March 3, 1906, Weisiger and wife filed their motion and affidavit to open the judgment, and also filed an answer to the petition of Baker, in which they made a general denial of the allegations of the petition, and, for a second defense, alleged that the tax deed upon which the plaintiff based his title was null and void. On April 21, 1905, the motion to open the judgment was allowed.

September 22, 1906, the Weisigers filed a motion to make S. C. Thompson a party defendant, which motion was sustained November 30, 1906, and summons served on Thompson on December 2, 1906. Permission was also given the IVeisigers, on November 30, 1906, to file an amended answer and cross-petition, in which, in addition to the allegations of the former answer, they alleged that defendant Thompson purchased the property in controversy, on or about the 31 st day of March, 1906, from Noah B. Matkins, to whom the plaintiff, Join Baker, on the same day had conveyed the property; that both transfers were made with the full knowledge of the interest of the Weisigers in the property, and were made for the purpose of defrauding them out of their interest therein, and that such transfers were null and void as against them.

41 Cf. Olirer v. Mowat, 34 U. C. Q. R. 472 (1S74), where the grantor, between the time the deed was handed to the depositary and the performance of the condition, was allowed to distrain for rent. 
On August 23, 1907, by leave of court and with the consent of the Weisigers, Thompson filed an answer in which he admitted that he claimed an interest in the property, and made a general denial to the allegations of the cross-petition, alleging, in substance, that he purchased the premises from Noah B. Matkins on the 10th of January, 1906; that Matkins executed a warranty deed conveying the premises to him; that at that time he was actually occupying the premises, and has ever since continued in the possession thereof; that he purchased the property in good faith, after taking legal advice that the title to the premises was in Noah B. Matkins, and after being advised by comnsel that the title to the property had been quieted in the action of John Baker against Mary H. Snavely et al.; that he made a payment on the property, and took it subject to a mortgage for $\$ 1650$, which he had since paid off and discharged; that at the time of the purchase he had no notice of any claims by defendant William Weisiger, and bought the property in good faith; that the tax deed in question was recorded in the office of the register of deeds, of Finney county on the 7 th of November, 1901, that five years had expired after the recording of the deed prior to any pleading filed by defendant Weisiger against this defendant; and that the action, as to him, was barred by the five-year statute of limitation.

Trial was had before Charles E. Lobdell, judge pro tem., and the following findings of fact and conclusions of law were made:

\section{"Findings of Fact.}

"(1) That the defendlant, Weisiger, is the owner of the fee or patent title to the property in controversy, unless such title is extinguished by the tax deed to Baker or by the judgment heretofore rendered in this case and subsequent conveyances which are clamed to have been accepted in good faith and in faith of such judgment.

"(2) That on November 21, 1905, the plaintiff, John Baker, obtained julgment in this court and in this cause quieting title in him to the land in controversy against the defendants, Weisigers.

"(3) That on November 28, 1905, John Laker executed a sufficient deed of general warranty to the property in controversy to Noah $D$. Matkins and placed the same in escrow for future delivery with G. L. Miller.

"(4) That on March 3, 1906, the defendants, William Weisiger and wife, filed in this court their motion, in proper form, to open up the judgment thereinbefore rendered in favor of Baker as recited in finding No. 2.

"(5) That thereafter, and on April 21, 1906, by the consideration of this court such decree and judgment was fully set aside and opened up.

"(6) That on Miarch 31, 1906, the deed from Baker to Matkins was, by Miller, delivered to Matkins. 
"( 7$)$ That on February 19, 1906, Noah B. Matkins, a single man, executed a sufficient warranty deed to the property in controversy to the defendant S. C. Thompson, which deed was placed in escrow with G. L. Miller, as was the deed from Baker to Matkins.

"(8) That on the same date that the deed from Baker to Matkins was delivered by Miller the deed from Matkins to Thompson was by Miller delivered to Thompson.

"(9) That Thompson took possession of the property in controversy on January 6, 1906, and has been continuously in possession since that time.

"(10) That the title of Baker at the time of his judgment rested upon the tax deed introduced in evidence.

"(11) That a part of the consideration for the tax deed on which Baker's title rested was what was known as 'current university tax,' levied for the year 1596.

"(12) That the so-called redemption notice for the lots in controversy, published by the county treasurer of Finney county, contained in the amount stated as necessary to the redemption of said lots the sum of thirty-five cents as costs for advertising, and included it for each of the three years embraced in the notice necessary to redecm, and that the treasurer's fee of twenty-five cents was also included in the notice for each year."

"Conclusions of Law.

"(1) That the tax deed to Baker is voidable and should be set aside because of the facts stated in findings 11 and 12 .

"(2) That the creation of the escrow with reference to the deeds from Baker to Matkins and Matkins to Thompson was not in law delivery of the deeds.

"(3) That the delivery of such deeds, which actually took place on March 31, 1906, can not be made to relate back so as to relieve Thompson and Matkins of the effect of the notice to open up judgment, which motion was filed before the escrow was terminated.

"(4) That at the time of the delivery of their deeds to them Matkins and Thompson had constructive notice, which was binding upon them, of the motion then filed and pending in this cause to open up and vacate the judgment, and that neither of them was a purchaser in good faith and in faith of such judgment."

The contention of the appellees is that the deed from Baker and wife to Matkins did not become a conveyance of the property until the actual delivery thereof on the 31st of March, 1906, that the deed from Matkins to Thompson did not become an actual conveyance until the same date, and that Thompson had constructive notice of the pendency of the action before the deed was delivered to him.

Upon the other hand, the appellant contends that both the deed from Baker to Matkins and the deed from Matkins to him were executed long before the motion to reopen the judgment was filed, on 
March 3, 1906; that the considerations therefore were paid in part at the time of the execution of the contracts, and the remainder in fuli when the deeds were delivered, on March 31, 1906; that they were in escrow with Miller from the time of their execution until their actual delivery, and that when the actual delivery was made, on March 31, 1906, the delivery dated back to the time of the original contracts and partial payments. These adverse contentions constitute the only substantial question in the case.

Whether a deed executed and placed in escrow relates back to the time of the contract and execution thereof, so as to vest the grantee with the full title from that time, or whether it becomes such conveyance only upon the full performance of the conditions, seems to depend upon which of the two theories will promote justice under all the circumstances of the individual case.

"This doctrine of relation (from the time of the second delivery to the time of the delivery in escrow) is of ancient origin, and has always been applied, both at law and in equity, to meet the requirements of justice, to protect purchasers, and to effectuate the intent of the parties to contracts." Scott v. Stone, 72 Kan. 545, 548, S+ Pac. 117, 118, citing numerous cases.

'The syllabus in that case states the rule strongly, without exception, and holds that, under the circumstances of that case, the delivery dated back to the time of making the contract. The same doctrine was upheld in Davis v. Clark, 58 Kan. 100, 48 Pac. 563. In each of those cases justice clearly required that the conveyance be held as of the date of the delivery in escrow and not as of the date of the second delivery.

In a case similar to this, Hill v. Miller, 84 Kan. 196, 198, 113 Pac. 1043 , as between the rights of a purchaser from a tax-deed holder and the holder of the patent title, who had brought an action to set aside a decree quieting the title, it was said:

"At all events he (the purchaser) was not protected by the statute unless he bought and paid for the land prior to January 18,1908 , the date when the proceeding was begun to set aside the decree quieting title"

No finding is made by the court in this case in regard to any payment made by the appellant prior to the delivery of the deed from the party holding it in escrow, which was twenty-eight days after the filing of the motion to set aside the judgment. Nor does the appellant disclose in his evidence how much he paid toward the purchase price, at or prior to the time of the execution of the deed. The evidence is that he made a payment. According to the evidence, he purchased seventeen lots for $\$ 3500$, nearly $\$ 206$ per lot, and assumed the payment of a mortgage for $\$ 1650$, which he afterward paid, leaving $\$ 1850$, upon which "a payment" was made at the time of purchase, and the remainder March 31; 1906. The three lots involved in this action would, at the price, amount to about $\$ 618$, leaving over $\$ 1200$, less such payment 
as he may have made, and the amount of which he does not disclose, to protect himself against any failure of title. He was bound to take notice, at the time he actually received his deed and made final payment, of the proceeding to vacate the judgment quieting the title, and, as he has failed to show that he was unable to protect himself from any loss, if the title to the lots should eventually be shown to be in the appellees, there is no reason for holding that the second delivery of the deed related back to the time it was delivered in escrow.

On the other hand, the invalidity of the tax deed is not contested, and the appellees' equities in the case are very strong. We think the court correctly decided the case. We have not considered various other assignments of error, as it seems to be conceded that the case must turn upon this one question. The judgment is affirmed. ${ }^{\mathbf{2}}$

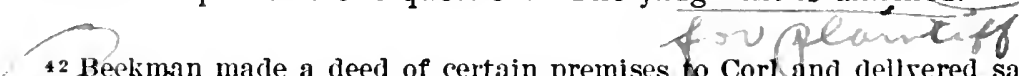

42 Beekman made a deed of certain premises to Corl and dellrered same to Westerlo as an escrow, to be delivered over to Coll ilun the hatter's execution of a mortgane on the Iremises to lietininn and the delosit of the same with Westerlo. Corl made a deed of the lands to Frost. Corl then exreuted the noitgage to beeliman, and uron delivering same to Vesterlo received the lleed to the fremises. Nieither Beeliman nor Frost had any actual notice. IBeliman having alvertised the fremlses for sale moder the provisions of the mortgage, Frost sued to enjoin such action. The opinion of Mr. Chancellor lieut in part is as follows:

"Ilis (ase has led to the discussion of sereral tmportant questions. (1) The first in order is, whether the deed from lieeliman to Corl was duly delivereal, and at what time, so as to pass the estate. The deed must he talien to have been duly delivered from the time it was handed to Corl hy Westerlo, with whom it had been dejosited as an escrow. * * * Every deed talies effect from the delivery; and the reasonalile inference from the fridnsiction, is to consicler the deed as operating only rrom the time of the performance of the condiffon, and the actual delivery to the grantee. This is the general rule as stated by Pelinis (sect. 1:38, ant it is only to be controverted wholl justice reinires a resort to tiction. In lintler and lialier's case, 3 ( $0.35,1$, 36 , a (15!1), it Was resolved, and the law hal, indeed, been so mnderstoon lonin before. (lisn. tit. Non est Factum, ,1. 5,) that a deed delivered as an escrow, aud aftermards to the grantee, shall relate back to the first delivery, when that relation is necessily to gite effect to the dred, as if the grintor, being a feme sole, shonlla marly. or if the glantor, whether a felle sole or not, sliould die between the tirest and second delivery; but thit, in other cases, as where it would avoid a lease, it small not have that relation, but sliall operate acoording to the truth of the case from the second delivery. The tiction of carrying the deed back ly mation is resorted to from necessity, to prevent injury, and to uphold the deed; or, as it is expressed in the case from Coke, in such case for necesity, and ut res magis raleat quam pereat, to this intent, by fiction of law, it sliall be a deed ab initio, and yet in truth it was not his deed until the second lelivery. In that case it was likewise resolved that, as to eollateral acts, there should be no such relation at all. In the present case, there is no neressity for resolting to this tiction of relation, as between the parties to the lill. It would operate unjustly upon the defendant, for it woutd be lefeating his unortgase altogether, so lar as respected the tist deed from Corl to Frost, which Was recorded in July, 1s05. If the question was between Coll and the persoms to whom be sold, the deed onsht to relate back, so as to give effect to his intermediate srints, and prevent bin from defeating them. This is the amomt of the doctrine in Jackison v. Bull, 1 Jolns. Cas. (.. Y.) SI (1799). liut here is a struggle between innocent persons, to aroid a loss. and we ought not to resort to fiction to help one aganst the ofher. The transaction minst lue left to lest upon ifs simple and naked truth." Frost v. Beeliman, 1 Johus. Ch. (N. Y.) 288 $\left(151 \frac{11}{1}\right)$.

See Ames, Cases on Trusts (2d Ed.) 287-289. 


\section{THOMPSON v. LEACII.}

(Courts of Common Pleas, King's Bench, Iouse of Lords, 1c91. 2 Tent. 19S.)

In an ejectment by Thomas Thompson against Sir Simon Leach and divers other defendants, upon the demise of Charles Leach, of the manor of Bulkworthy, and divers messuages, lands and tenements.

Upon not guilty pleaded, a special verdict was found to this effect,

That Nicholas Leach was seised in fee of the said manors, lands and tenements in the declaration; and by his last will in writing, bearing date the 9th day of December, in the 19th year of the reign of the late King Charles the Second, devised the premises to his brother Simon Leach for life, rcmainder to the first son of the body of the said Simon, and the heirs males of the body of such first son, and in like manner to the second, third son, \&c. and for want of issue of the said Sinon Leach, the remainder to Sir Simon Leach and the heirs males of his body; and for default of such issue, to the right heirs of Nicholas the testator for ever; and that the said Nicholas died seised of the premises, and after his decease the said Simon Leach entred and became seised for life, with remainders over, as aforesaid; and being so seised made a deed, bearing date the 23 l of Angust, in the 25 th year of the reign of the said King Charles, sealed and delivered to the use of the said Sir Simon Leach (but he was not present) which deed the verdict sets forth in hæc verba; and by it he granted and surrendered to the said Sir Simon Leach, his heirs and assigns, the said manor and premises, the reversion and reversions, remainder and remamders of the same; to have and to hold the same to the said Sir Simon Leach and his heirs, to the use of him and his heirs: and they find that the said Charles Leach, lessor of the plaintiff, the first son of the sail Sir Simon Leach was born the first of November, in the 25 th year of the reign of the said King Charles, and not before; and that Simon Leach, from the time of his sealing the deed to the 25 th of May, in the 30th year of the said King Charles, continued possessed of the premises, and that then, and not before, Sir Simon Leach accepted and agreed to the said surrender, and entred into the premises; and that afterwards the said Simon Leach, brother of the said Nicholas the testator, died, and the said Charles Leach his son, after his decease entred into the premises, and demised them to the plaintiff, who by virtue thereof entred and became possessed, and so continued till the said Sir Simon Leach and the other defendants, by his command, ejected him. But whether upon the whole matter, the said Simon Leach did surrender the said manor and premises to the said Sir Simon Leach, before the said Charles Leach was born; and if he did not surrender before the birth of the said Charles Leach, then they find the defendants guilty; and if he did surrender them before the birth, then they find for the defendants. 
And Pollexfen, Chief Justice, Poweli and Rokeby, were of opinion that here was no surrender till such time as Sir Simon Leach had notice of the deed of surrender, and agreed to it, and so the remainder was vested in Charles the son; and it was not defeated by the agreement of Sir Simon, after his birth, to the surrender.

But VeNTRIs differed, and his argument was as followeth:

Upon this record the case is no more than thus; Simon Leach, tenant for life, remainder to his first son, remainder in tail to Sir Simon Leach. Simon Leach before the birth of that son, by deed, sealed and delivered to the use of Sir Simon, but in his absence and withont his notice) surrenders his estate to Sir Simon, and continues the possession until after the birth of his son; and then Sir Simon Leach agrees to the surrender, whether this surrender shall be taken as a good and effectual surrender before the son born?

There are two points which have been spoken to in this case at the Bar.

First, whether by the sealing of the deed of surrender the estate immediately passed to Sir Simon Leach? for then the contingent remainder could not vest in the after-born son, there being no estate left in Simon Leach his father to support it?

Secondly, whether after the assent of Sir Simon Leach, tho' it were 3 given after the birth of the son, doth not so relate as to make it a sur- render from the sealing of the deed, and thereby defeat the remainder which before such assent was vested in the son?

I think these points include all that is material in the case, and I shall speak to the second point, because I would rid it out of the case. For as to that point I conceive, that if it be adnitted, that the estate for life continued in Simon Leach till the assent of Sir Simon, that the remainder being vested in Charles the second son before such assent, there can be no relation that shall devest it.

I do not go upon the general rule, that relations shall not do wrong to strangers. 'Tis true, relations are fictions in law, which are always accompanied with equity.

But 'tis as true, that there is sometimes loss and damage to third persons consequent upon them; but then tis what the law calls damnum absque injuria ${ }_{2}$ which is a known and stated difference in the law, as my. brother Pemberton urged it. But I think there needs nothing of that to be considered in this point

But the reason which I go upon is, that the relation here, let it be never so strong, cannot hurt or disturb the remainder in Charles Leach in this case; for that the remainder is in him by a title antecedent and paramount to the deed of surrender, to which the assent of Sir Simon Leach relates, so that it plainly over-reaches the relation.

If an estate in remainder, or otherwise, ariseth to one upon a contingency or a power reserved upon a fine or feoffment to uses, when the estate is once raised or vested it relates to the fine or feoffment, as if it were immediately limited thereupon, 1 Co., 133, 156. So this remain- 
der when vested in Charles, he is in immediately by the will, and out of danger of his remainder being devested by any act done since, as the surrender is.

I will put one case, I think full to this matter, and so dismiss this point.

It cannot be denied, but that there is as strong a relation upon a disagreement to an estate, as upon an agreement, where the estate was conveyed without the notice of him that afterwards agrees or disagrees; if the husband discontinues the wife's estate, and then the discontinuee conveyes the estate back to the wife in the absence of the husband, who (as soon as he knows of it) disagrees to the estate, this shall not take away the remitter which the law wrought upon the first taking the estate from the discontinuee. And so is Litt. cap. Remitter. Co. 1 Inst. 356 b. The true reason is, because she is in of a title paramount to the conveyance to which the disagreement relates, tho' that indeed was the foundation of the remitter, which by the disagreement might seem to be avoided. This therefore I take to be a stronger case than that at the Bar: so that if there were no surrender before the birth of Charles the son, there can be none after by any construction of Taw, for that would be in avoidance of an estate settled by a title antecedent to such surrender, whereas relations are to avoid mesne acts; and I believe there can be no case put upon relations that go any further, and it would be against all reason if it should be otherwise.

But as to the first point, I am of opinion, that upon the making of the deed of surrender, the frecliold and estate of Simon Leach diif immediately vest in Sir Simon, before he had notice, or gave any express consent to it; and so it was a surrender before Charles was born, and then the contingent remainder could never vest in him, there being no particular estate to support it.

A surrencler is a particular sort of conveyance that works by the common law. And it has been agreed, and I think I can nake it plainly appear, that conveyances at the common law do immediately (upon the execution of them on the grantor's part) devest the estate out of him, and put it in the party to whom such conveyance is made, though. in his absence, or without his notice, till some disagreennent to such estate appears. I speak of conveyances at the common law; for I shall say nothing of conveyances that work upon the Statute of Uses, or of conveyances by custom, as surrenders of copyholds, or the like, as being guided by the particular penning of statutes, and by custom and usage, and matters altogether foreign to the case in question.

In conveyances that are by the common law, sometimes a deed is sufficient (and in surrenders sometimes words without a deed) without further circumstance or ceremony; and sometimes a further act is requisite to give them effect, as livery of seisin, attornment, and sometimes entry of the party, as in case of exchanges; and as well in those conveyances that require a deed only, as those which require some further act to perfect them, so soon as they are executed on the grantor's 
part, they immediately pass the estate. In case of a deed of feoffment to divers persons, and livery made to one feoffee in the absence of the rest, the estate vests in them all till dissent, 2 Leon. 23, Mutton's Case. And so 223 , an estate made to a feme covert by livery, rests in her before any agreement of the husband, Co. 1 Inst. 356a. So of a grant of a reversion after attornment of the lessee, passeth the freehold by the deed, Co. 1 Inst. 49a; Litt. sect. 66. In case of a lease, the lessee hath right inmediately to have the tenements by force of the lease. So in the case of limitation of remainders and of devises, (which tho' a conveyance introduced by the statute, yet operates according to the common law) the freehold passeth to the devisee before notice or assent, I do not cite authorities, which are plentiful enough in these matters, because they that have argued for the plaintiff have in a manner agreed, that in conveyances at the common law, generally the estate passeth to the party, till he devests it by some disagreement.

But tis objected, that in case of surrenders, an express assent of the surrendrce is a circumstance requisite; as attornment to a grant of a reversion, livery to a feoffment, or execution by entry, in case of an exchange.

To which I answer, that an assent is not only a circumstance, but 'tis essential to all conveyances; for they are contracts, actus contra actum, which necessarily suppose the assent of all parties: but this is not at all to be compared with such collateral acts or circumstances, that by the positive law are made the effectual parts of a conveyance ; as attornment, livery, or the like; for the assent of the party that takes, is implied in all conveyances, and this is by intendment of law, which is as strong as the expression of the party, till the contrary appears; stabit p'sumptio donec probetur in contrarinm.

But to make this thing clear, my Lord Coke in his first Institutes, fol. 50, where he gives instances of conveyances that work without livery, or further circumstance or ceremony, puts the cases of lease and release, confirmation, devise and surrenders, amongst the rest; whereas if an express assent of the surrendree were a circumstance to make it effectual, sure he would have mentioned it and not marshall'd it with such conveyances, as I have shewn before need no such assent, nor any thing further than a deed.

The case of exchanges has been put as an instance of a conveyance at law, that doth not work immediately; but that can't be compared to the case in question, but stands upon its particular reasons; for there must be a mutual express consent, because in exchanges there must be a reciprocal grant, as appears by Littleton.

Having, I hope, made out (and much more might have been added, but that I find it has been agreed) that conveyances work immediately upon the execution of them on the part of him that makes them, I will now endeavor to shew the reasons, why they do so immediately vest the estate in the party without any express consent; and to shew that these reasons do hold as strongly in case of surrenders, as of any 
other conveyances at law; and they consider the inconveniences and ill consequences that have been objected, would ensue, if surrenclers should operate without an express consent; and to shew, that the same are to be objected as to all other conveyances, and that very odd consequences and inconveniences would follow, if surrenders should not operate without an express consent of the surrendree; and then shall endeavour to answer the arguments that have been made on the other side, from the putting of cases of surrenders in the books, which are generally mentioned to be with mutual assent, and from the manner of pleading of surrenders.

The reasons why conveyances do devest the estate out of the grantor before any express assent or perhaps notice of the grantee, I conceive to be these three:

First because there is a strong intendment of law, that for a man to take an estate it is for his benefit, and no man can be supposed to be unwilling to that which is for his advantage, 1 Rep. 44. Where an act is done for a man's benefit an agreement is implied, till there be a disagreement. This does not only hold in conveyances, but in the gift of goods, 3 Co. 26. A grant of goods vests the property in the grantec before notice. So of things in action; a bond is sealed and delivered to a man's use, who dies before notice, his exccutors may bring an action. Dyer, 167. An estate made to a feme covert vests in her inmediately, till the husband disagrees. So in my Lord Hobart, 204, in Swain and Holman's Case. Now is there not the same presumption and appearance of benefit to him in reversion in case of a surrender? Is it not a palpable advantage to him to determine the particular estate, and to reduce his estate into possession? And therefore, why should not his assent be implied, as well as in other conveyances?

Secondly, a second reason is, because it would seem incongruous and absurd, that when a conveyance is compleatly executed on the grantor's part, yet notwithstanding the estate should continue in him. The words of my Lord Coke (1 Inst. 227a.) are, that it cannot stand with any reason, that a freehold should remain in a man against his own livery when there is a person able to take it. There needs only a capacity to take, his will to take is intended. Why should it not seem as unreasonable, that the estate should remain in Simon Leach, against his own deed of surrender? For in case of a surrender, a deed, and sometimes words without a deed, are as effectual as a livery in case of a feoffment.

Thirdly, the third and principal reason, as I take it, why the law will not suffer the operation of a conveyance to be in suspence, and to expect the agreement of the party to whom 'twas made, is to prevent the uncertainty of the freehold. This I take to be the great reason why a freehold cannot be granted in futuro, because that it would be very hard and inconvenient that a man should be driven to bring his præcipe or real action first against the grantor, and after he had proceeded in it a considerable time, it should abate by the transferring the freehold 
to a stranger, by reason of his agreement to some conveyance made before the writ brought; for otherwise there is nothing in the nature of the thing against conveying a freehold in futuro; for a rent de novo may be so granted; because that being newly created, there can be no precedent right to bring any real action for it. Palmer, 29, 30.

Now in this case, suppose a pracipe had been brought against Sinion Leach, this should have proceeded, and he could not have pleaded in abatement till Sir Simon Leach had asscnted; and after a long progres: in the stit he might have pleaded, that Sir Simon I-each assented puis darrein continuance, and defeated all. So that the same inconvenience, as to the bringing of real actions, holds in surrenders, as in other conveyances.

And to shew that it is not a slight matter, but what the law much considers, and is very careful to have the freehold fixed, and will never suffer it to be in abeyance, or under such uncertainty, as a stranger that demands right should not know where to fix his action.

A multitude of cases might be cited; but I will cite only a case put 1 Hen. VI, 2 a, because it seens something of a singular nature, lord and villain, mortgagor and mortgagee, may be both made tenants.

But it will be said here, that if a precipe had becn brought against Sir Simon Leach, might not he have pleaded this disagreement, and so abated the writ by nontenure?

'Tis true; but that inconvenience had been no more than in all other cases, a plea of non-tenure; and it must have abated immediately; for he could not have abated it by any dissent after he had answered to the writ. Whereas I have shewn it in the other case, it may be after a long progress in the suit.

Again, it's very improbable that he should dissent; whereas on the other side, an assent is the likeliest thing in the world; so the mischief to the demandant is not near so great, nor the hundredth part so probable.

Now I come to consider those inconveniences that have been urged that would ensue, if a surrender should work immediately.

It has been said, that a tenant for life might make such deed of surrender, and continue in possession, and suffer a recovery; and this might destroy a great many recoveries, and overthrow marriage-settlements, and defeat charges and securities upon his estate after such deed of surrender.

These, and a great many more such like mischiefs, may be instanced in surrenders; but they hold no less in any other conveyances, whereby a man may (as hath been shewed before) devest himself of the estate, and yet continue the possession; and in this case the assent of the surrendree, tho' he doth not enter, would (as it is urged of all hands) vest the estate in him, Hutton, 95; Br. tit. Surrender, 50; tho' he cannot have trespass before entry, and that assent might be kept as private, and let in all the mischiefs before mentioned as if no such assent were necessary. 
And this I think sufficient to answer to the inconveniences objected on that side.

Now let us see what inconveniences and odd consequences would follow, in case a surrender could not operate till the express assent of the surrendree, then no surrender could be to an infant at least, when uncler the age of discretion; for if it be a necessary circminstance, it cannot be dispensed with no more than livery or attornment. So tho' an infant of a year old is capable to take an estate, because for his benefit he could not take a particular estate, upon which he had a reversion immediately expectant, becanse it must enure by surrender. If there be jointenants in reversion, a surrender to one of them enures to both, 1 Inst. 192, 214 a, so there, as to one moiety, it operates without assent or notice.

Suppose tenant for life should make livery upon a grant of his estate to him in reversion and two others, and the livery is made to the other two in the $\mathrm{ab}$ ience, and without the notice of him in reversion, should the livery not work inmediately for a thircl part of the estate? and if it doth, it must enure as a surrender for a thirel part. So is Bro. tit. Surrender, and 3 Co. 76 .

If tenant for life should by lease and release convey the lands held by him for life, together with other lands to him in reversion who knows nothing of the sealing of the decel: should this pass the other lands presently, and the lands held for life not till after an expresassent, because as to those lands it must work as a surrender? I'lainly an express assent is not necessary. For if the grantee enters, this is sufficient

I come in the last place to answer those arguments that lave been made from the manner of putting the case of surrenders in the books, and the form of pleading surrenders. Co. 1 Inst. 3.37 b.

First, a surrender is a yielding up of the estate, which lrowns by mutual agreement between them. Tenant for life, by agreement of him in reversion, surrenders to him; he hath a freehold before he enters. And so Perlins, in putting the case of a surrender, mentions an agreement; and divers other books have been cited to the same purpose.

To all which I answer:

No doubt but an agreement is necessary. But the question is, whether an agreement is not intended where a deed of surrender is made in the absence of him in the reversion? whether the law shall not suppose an assent, till a disagreement appears?

Indeed, if he were present, he must agree or disagree immediately and so 'tis in all other conveyances. The cases put in Perkins, sect. 607, 608,609 , are all of surrenders made to the lessor in person; for thus he puts them: the lessee comes to the lessor, and the lessee saith to the lessor, I surrender, saith he, if the lessor doth not agree, 'tis void; car il ne poit surrender a luy maugre son dents. And that is certainly so in surrenders, and all other conveyances; for a man cannoi have an estate put into him in spight of his teeth. 
But I cannot find any of the books cited that come to this point, that where a deed of surrender is executed without the notice of him in reversion, that it shall pass nothing till he consents; so that it cannot be said, that there is any express authority in the case.

Now, as to the form of pleading of a surrender, it has been objected, that a surrender is always pleaded with acceptance; and many cases have been cited of such pleadings, Rastal's Entries, 176, 177 ; Fitzh. tit. Barre, 262, which are cases in actions of debt for rent, and the defendant in bar pleads, that he surrendered before the rent grew due, and shews, that the plaintiff accepted the surrender: so in waste brought, a surrender pleaded with the agreement of the plaintiff.

These and the like cases have been very materially, and I think fully answered at the Bar by my Brother Pemberton; that those actions being in disaffirmance of the surrender, and implying a disagreement, the defendant had no way to bar and avoid such disagreement, but by shewing an express agreement before.

The case of Peto and Pemberton in 3 Cro. 101, that has been so often cited, is of the same sort: in a replevin the avowry was for a rentcharge; in bar of which 'tis pleaded, that the plaintiff demised the land out of which the rent issued, to the avowant. The avowant replies, that he surrendered dimissionem præd. to which the plaintiff agreed. This is the same with pleading in bar to an action of debt for rent: but when the action is in pursuance of the surrender, then it is not pleaded.

So is Rast. Entries, 136. The lessee brought an action of covenant against the lessor, for entering upon him, and ousting of him. The defendant pleads a surrender in bar, and that without any agreement or acceptance.

In Fitzherbert, tit. Debt, 149, where the case is in an action of debt for rent, the defendant pleaded in bar, that he surrendered, by force of which the plaintiff became seised: there is no mention of pleading any agreement, notwithstanding that the action was in disaffirmance of the surrender.

Therefore as to the argument which has been drawn against the form of pleading, I say, that if an agreement be necessary to be pleaded: then, I say,

First, that 'tis answered by an implied assent, as well as an express assent. I would put the case; suppose a lessee for life should make a lease for years, reserving rent; and in debt for the rent the lessee should plead, that the plaintiff before the rent grew due surrendered to him in reversion, and he accepted it, and issue is upon the acceptance; and at the trial it is proved, that the plaintiff had executed a deed of surrender (as in this case) to him in reversion in his absence; would not this turn the proof upon the plaintiff, that he in reversion disagreed to this surrender? for surely his agreement is prima facie presumed, and then the rule is, stabit præsumptio donec probetur in contraritin. 
Again, I say it appears by the cases cited that it is not always pleaded and when pleaded 'tis upon a special reason, as I have shewn before, $i$. e. to conclude the party from disagreeing; and it would be very hard to prove in reason, that an agreement (admitting an express assent to be necessàry) must be pleaded; for if it were a necessary circumstance to the conveyance, why then 'tis implied in pleading sursumreddidit; for it cannot be a surrender without it.

In pleading of a feoffment it is enough to say feoffavit, for that implies livery; for it cannot be a feoffment without it.

Now why should not sursumreddidit inply all necessary requisites, as well as fcoffavit? and therefore I do not see that any grcat argument can be drawn from the pleading. For,

1. It is not always to be pleaded.

- 2. It cannot be made out to be necessary so to plead it; for if assent be a necessary requisite, then tis inplied by saying sursumreddidit, as livery is in feoffavit; and then to add the words of express consent is as superfluous, as to shew livery after saying feofiavit.

And again, if it were always necessary, it is sufficiently answered by an assent intended in law: for presumptions of law stand as strong till the contrary appears, as an express declaration of the party.

Nots. A writ of error was brought in the King's Bench upon this judgment and it was there affirmed by the unanimous consent of the whole Court.

Memorand. Anno quarto Villielmi \& Mariae: this case was brought by writ of error into the House of Lords, and the judgment was there reversed upon the reasons in the aforesaid argument. ${ }^{* 3}$

43 See Standing v. Bowring, L. R. 31 Ch. D. $2 S 2$ (1S85) ; Mallott v. Wilson, [190:31 2 Cl1. 49 t.

- Tt is true. that judges have sajd, with more solemnity than I think the occasion warmated, that no one can have an estate thrmst ulon him arininst his Will, and that, consequently a deliery of a deer to a stringer, tor the use of the grantee, is of no effect, until assented to hy the hitter. Ilow much weight this algminent is entitled to, may be jugred of by the filet that estat tos a re erory day thrust upon people ly last will and testament; and it would certainly somd somewhat norel to sily that the derises were of no effect until assented to ly the derisees. It a filther should die testalte, derising an estalte to his dinughter, and the latter shontr afterind die wiflont a knowledge of the will, it wonld hamlly be contended that the derise liecame roid for want of ac ceptance, ind that the hoils of the derisee hinst lose the estife. Neither will it be denied that equitable estafes are every day thrust hoon people li, deeds, or assignments, macle in trust for their lenefit, nor will it he sald that such beneticiaries take nothing unt il they assent. Aild to these the pstates that are thrilst mon people ly the statute of descellt, and we begin to estinate the valne of the argument, that a man shiall not be made a property holder arainst his nill. and that courts should he astute to shield him from such a wrong. It is certianly true, as a gelledal rule, that acceptance, by the grantee, is necessiry to constitute a good delivery, for a man may refuse even a ifft Int that such acceptance need not he manmal is equally true, and it is also certain that simple assent to the consevance, given even before its execution, is a sufficient acceptance. Thus, whele a vendee nad fully bind for the lind and was entitled to a converance, and his venclor, withont his knowlerlye, executed the deed and delivered it to a stranger, not of the vendee's appointment, for the use of the latter, it was held that the delivery was sulticient, and the deed took effert 


\section{WELCH v. SACKETT.}

\section{(Supreme Court of Wisconsin, 1S60. 12 Wis. 243.)}

Dixon, C. J. ${ }^{44} * * *$ The question which was considered by far the most important, and upon which the counsel bestowed the most attention, citing nearly all the English and American authorities, calls for the determination, in a case where a mortgage of personal property from a debtor to a creditor is executed in the absence and without the knowledge of the latter, and delivered to a stranger for his use, of the time at which the title to the property mortgaged vests in the

immediately, although the rendee was wholly ignorant of what was done, Churcti Gilman, 15 Wend. (N. Y.) 656 [30 Am. Dec. 82 (1S36)]. "So patents for the public lands are held to take effect as soon as issued, though they may never come to the grantee s hands, and were issued witliout any specific application for them. But the cases go still further, and, upon the soundest reasons, hold that where a grant is plainly beneficial to the grantee, his accentance of it is to be presumed in the absence of proof to the contrary. It is argued, however, that this is only a rule of evidence, and that where the proofs show that the grantee has never had any knowledge of the conveyance the presumption is rebutted. If this argument were limited to cases iu which an acceptance of the grant would impose some obligntion upon the grantee, I am not prelsared to say that I would object to it, althourh the obligation might fall far short of the value of the grant. But where the grant is a pure, ưlqualitied gift, I think the true rule is that the presumntion of acceptance can be rebutted only by lroof of dissent; and it matters not that the grantee never knew of the conveyance, for as his issent is presumed from its beneficial cliaracter, the presumption can be oreithrown only by proof that he did know of and rejected it. If this is not so, how cau a deed be made to an infantof such tender years as to be incapable of assent? Is it the law, that if a fither make a deed or gift to his infant child, and deliver it to the recorder to be recorded for the use of the child, and to vest the estate in it, the deed is of no effect until the child grow to year's of intelligence and give its consent? May the estate, in the meantime, be taken for the subsequently contracted debts of the father, or will the statute of limitations begin to run in faror of a trespasser, upon the idea that the title remains in the adult? Or, will the conreyance entirely fail, if either grantor or grantee die before the latter assent? I do not so understand the law. In such a case tlie acceptance of the grantee is a presunption of law, arising fow the leneficial nature of tre grant, and not a incre prestmiption of an actual acceptance. And for the same reason that the raw manes the presunption, it does notmow it to be disproved by any thing short of actuil dissent. I am fully aware that these rien's mar seent opposed to many tecided cases, but they are fully sustained by others that stand, in our judenent, upon a more solid foundation of reason. The strictness of the ancient doetrine, in respect to the delivery of deeds, has graduilly worn aura until a doctrine nore consistent with reason and the hatits of the present generation now prevails. Snider v. Lackenour, 37 N. C. 360 [35 Añ. Dec. $685(18+2)$; Elnington v. Cưrre, 40 N. C. $21(18+7)$ Church v. Gilman, 15 Wend. (N. Y.) 656 [30 Am. Dec. $\$ 2$ (1836)]; Tate v. Tate, 21 N. C. 26 (1834) ; Morrow v. Alexander, 24 N. C. 392 (1S42). It remains to be considered, whether the deed in question was of that beneficial nature to the grantee, as to give rise to the presumption of which I have spoken. Upon its face it purports to be for a pecuniary consideration paid to the grantor. Prima facie, therefore, it was neither a gift nor advancement. But the proof satisfies us that the grantor never received, or expected any pecuniars consideration for it. If he intended that his daughter should have the land, he intended it as a gift. I have already said that npon the testimony we feel bound to say that he did intend to convey it to her, and we must therefore consider the deed as a gift. Ap-

44 The statement of facts and portions of the opinion are onitted. 
mortgagee, as between him and another creditor of the mortgagor who acquired an interest in it by attachment between the time of the delivery to the stranger and the time when the mortgagee actually received notice of and accepted it. Whilst it must be admitted that there is some conflict in the adjudications upon this subject, still both natural reason and the weight of authority tend to the same conclusion, which is, that the title in such case only vests from the time there is an acceptance in fact on the part of the mortgagee. On principle I think it may be laid down as an indubitable proposition in such case, that the title does not vest in fact until the mortgagee has actually assented to the conveyance; and consequently, that until such assent it remains in the mortgagor. While all the courts acknowledge the correctness of principles which lead unerringly to this result, and clearly and positively exclude any other, it is somewhat strange that any should have been found to adopt a conclusion directly opposed to it. All agree that it is necessary to the validity of every deed or conveyance, that there be a grantee who is not only willing, but who does in fact accept it. It is a contract, a parting with property on the part of the grantor, and an acceptance of it by the grantee. Like every other contract, there must be a meeting of the minds of the contracting parties, the one to sell and convey, and the other to purchase and receive, before the agreement is consummated. If there be anything in legal principles, or in common sense, it is an unpardonable absurdity to say, that a contract can be completed in the absence and utter ignorance of one of the contracting parties; that he can or does, under such circumstances, assent to, or agree to become bound by it. The idea that a contract could be thus made, and that title to property could pass into a party without his knowledge or consent, and out of him without any motion or act of his signifying his willingness, but merely by his refusal to receive it at all, had its origin at a period in the history of the common law, when the legal mind, instead of being governed in its conclusions by a steady application of the clear and rational principles of the law to plain matter of fact, and by arguments to be drawn therefrom, was too frequently influenced by a mysterious and fanciful logic, that depended for its support upon artfully devised fictions and falsehoods, which for the most part were as repugnant to reason as they were unnecessary to the proper administration of justice.

The discovery that such things could be done, is, I believe, attributa-

plying, then, the princinles we have recognized, the title rested in Ellen Shannon when Owen Shamnon cansed the rleed to be recorded. She was seized of it during ber internaliase with the lessor of the plaintiff, there was issne of the marriage, and she died before the commencement of this suit. According to the decision in Porland's Isessee r. Marshall, 2 Ohio st. 308 (1853), the leslor of the plaintiff hecame temant by the rurtesy, even if the lands were adcersels held dnring the corerture. It follows that the plaintiff is entitled to julgment." Mitrhell v. Ryan, supra. p. 29T. See, also. Derry Bank v. Tebster, 41 . ח. $264(1862)$, where the deed contained a provision placing a burden upon the srantee.

Aig.Prop.-25 
ble to the inventive skill of Justice Ventris, as exhibited in the case of Thompson v. Leach, 2 Vent. 198, decided about the year 1690; at least several courts and judges since that time, with many compliments, have agreed in giving him the credit of having proved something on this subject which none of them could understand. The substance of his proposition is, that a deed of lands made to a party, without his knowledge or consent, and placed in the hands of a third person for his use, is a medium for the transmission of the title to the grantee, and takes effect so as to vest it in him, the instant the deed is parted with by the grantor, and if the grantee, upon receiving knowledge of it, rejects it, such rejection has the effect of revesting the title in the

$\checkmark$ grantor by a species of remitter. Inasmuch as this is the only attempt at sustaining it by argument to be found in the books, the more recent cases having, without discussion, gone off almost entirely on the strength of the authorities, I propose to examine some of the positions assumed by him, upon which his argument mainly depends, and from which, I think, its fallacy and the incorrectness of his conclusions will be clearly made to appear. He admits, what is universally conceded to be an indispensable element of every grant, namely, that it should be accepted by the grantee, and says, "that an assent is not only a circumstance, but it is essential to all conreyances; for they are contracts, actus contra actum, which necessarily suppose the assent of all parties;" but avoids the difficulty into which the admission of this well settled principle brings him, by saying, "that because there is a strong intendment of law, that for a man to take an estate is for hus benefit, and no man can be supposed to be unwilling to that which is for his advantage," therefore the law will presume that the grantee has accepted a conveyance before a knowledge of its execution and delivery has come to him. Upon the foundation of this hypothesis, misnamed by him a presumption of law, the falsity and unreasonableness of which are so self-evident that reasoning can hardly make them plainer, he proceeds to the erection of his superstructure. Assent or acceptance on the part of the grantee or other party to a deed or other instrument, by means of which the title to property, whether real or personal, is to be transferred to him, or by which he is in any other manner to become bound, is a fact, the truth of which is to be established by competent evidence, before such deed or other instrument can be adjudged to have a legal existence. Like every other fact, it may be established by direct evidence, or its existence may be inferred or presumed from other facts already in proof. But I deny that the existence of one fact is to be inferred or presumed from the existence of others, when the connection between the former and the latter is such that according to the course of nature it plainly appears that the former cannot exist. In other words, I deny that the existence of any fact may be shown by proving others which conclusively show its nonexistence, or that the legitimate mode of establishing the truth of a matter is by indubitably proving its falsehood. Justice does not re- 
quire, nor does the law tolerate such an absurdity. The learned justice says, that where a deed is executed by the grantor and delivered to a stranger for the use of the grantee, without the previous advice, direction or authority of the grantee, and without his knowledge, the law will presume that the grantee assents to it, the moment it is delivered to the stranger. Assent is an act of the mind-that intelligent power in man by which he conceives, reasons and judges, and of which it is a primary, invariable and most familiar law that it cannot act with reference to external objects, until, through the medium of the senses, it is impressed with or knows their existence. Hence, without such impression or knowledge, there can be no assent, no actus contra actum, and to presume it in opposition to the facts, is to presume that which is impossible; which the law, the rules and precepts of which are in conformity with the unchanging truths of nature, will never do.

"A presumption," says Mr. Starkie, "may be defined to be an inference as to the existence of one fact, from the existence of some other fact, founded upon a previous experience of their connection. To constitute such a presumption, it is necessary that there be a previous experience of the connection between the known and inferred facts, of such a nature that as soon as the existence of the one is established, admitted or assumed, the inference as to the existence of the other immediately arises, independently of any reasoning upon the subject." Presumptions thus defined, he says are either legal and artificial or natural, and may be divided into three classes. 1st. Legal presumptions made by the law itself, or presumptions of mere law. 2d. Legal presumptions made by a jury, or presumptions of law and fact. $3 \mathrm{~d}$. Mere natural presumptions, or presumptions of mere fact. The definition which he so clearly and accurately gives, although applied by him to all presumptions, is perhaps more strictly applicable to the latter class. The assent to a deed or other instrument by the grantee or other party, being a matter of mere fact, it is obvious that to the latter class also would belong a presumption in relation to such assent, in a case where such presumption could properly be indulged. But, whether the presumption be assigned to the one or the other of these classes, the position of the learned justice is equally untenable; for in no instance, not even the most artificial and arbitrary, does the law indulge in presumptions which are directly contradicted by the facts on which they are predicated. The known facts, though often insufficient of their own natural force and efficacy, to generate in the mind a conviction or belief of those which are inferred, are always, to say the least, not inconsistent with or opposed to them. If for example we take the case instanced by Mr. Starkie, of the presumption of the satisfaction of a bond after the lapse of twenty years, without payment of interest or other acknowledgment of its existence, while if a single day less than the twenty years has elapsed, such presumption does 
not arise, we find it to be extremely arbitrary and technical. No natural reason can be given why the lapse of the last day should operate to produce in our minds a conviction or belief of payment, while the lapse of all the days and years preceding it does not so operate. Such is not its effect. But as from common experience of the affairs of men, there arises in the mind, after the lapse of many years without payment of interest or other acknowledgment, a strong probability that a debt has been satisfied, and as the law loves certainty and industriously avoids doubts, it has from these motives arbitrarily fixed a period of time at the expiration of which this probability shall ripen into and take effect as a presumption of law, and at which the rights and position of the parties in reference to such debt, flowing from the mere lapse of time, unaccompanied by other circumstances, shall become determined and certain. This presumption, which is in so many respects artificial, is in no respect inconsistent with the fact from which it is said to arise. On the contrary, though not conclusively sustained, it is strongly corroborated by the fact; since experience teaches that it is very improbable that the holder of the bond would, unless it were satisfied, permit such a space of time to elapse without receiving the interest or obtaining from the maker some other evidence of its nonpayment. The same is true of that most purely artificial presumption, that a bond or other specialty was executed upon a good consideration, which is so peremptory and absolute in its nature that it cannot be rebutted by evidence; whilst the consideration of another instrument, executed and delivered under precisely the same circumstances, and in the same words, but not under seal, may be freely inquired into and impeached; yet there the conclusion that it was made upon a good consideration is entircly consistent with the facts from which it is drawn; for there is much reason for supposing that without a good consideration, it would not have been sealed and delivered. IVithout multiplying illustrations, I think it will be found that in no instance (unless the present case is to form an exception) does the law infer the existence of facts in clear and direct opposition to those upon which the inference rests. It does not do so here. Reason rebels against it, and neither justice nor equity demands it. The only result of dropping the absurdity will be that, as in the present case, in a contest between two equally meritorious parties, the title to the property of which a conveyance was sought to be made, will be adjudged to be in him whom reason designates as the true owner.

The mistake of the learned justice consisted in his carrying the presumption of law so far as to say that it presumes that a person has consented to that of which he knows nothing, which is an impossibility; instead of saying, what was more truly said by the more logical and cautious courts and judges of his time, and by Lord Ellenborough, in Stirling v. Vaughn, 11 East, 623, namely, that, if nothing appears to the contrary, the law presumes that he will accept that which is for his 
benefit, when he is informed of it, which assent, in the absence of intervening rights or equities, will have relation back to the time of delivery for his use, and malie his title good as from that date. After a brief argument of this sort, he proceeds to say, "that very odd consequences and inconveniences would follow, if surrenders should be ineffectual till an express consent of the surrenderee," and that most disastrous effects upon estates and conveyancing in England would ensue, unless her courts adopted and upheld his absurdity. It is said that one error surely gives rise to another and a greater. This saying was never more aptly and forcibly illustrated, than by the fantastic feats which the learned justice makes the common law, the sober common sense of ages, perform by way of getting the title back again in the grantor in case the grantee refuses to accept the conveyance. He says that after, by this kind of one-sided contract, it has got into him without his knowledge, it remains with him without his consent until he absolutely rejects and spurns the offer, and that then, by some magical power of the law, such rejection, without deed or other writing, becomes an instrument of conveyance, by which the legal title to land is conveyed from one who has it to one who has it not, against the express wishes of the latter and in despite of his own deed, the highest and most solemn act known to the law, by which he could rid him. self of it. It is not surprising that the learned and logical Chief Jus. tice Gibson, in Read v. Robinson, 6 Watts \& S. (Y'a.) 329, while commenting upon what he calls "the masterly argument of Justice Ventris, in Thompson v. Leach," says, that "the difficulty is to comprehend how the remitter can take effect without displacing intermediate interests springing from the rejected deed;" and then, as if in despair of ever comprehending it, he dismisses the subject from his mind by saying, "but the authorities conclusively prove that it may." All agree that neither the grantor nor the stranger who consents to receive and hold the deed, can, by their acts, bind the grantee, and that the latter may, on receiving notice of it, repudiate it altogether. If the title vests in the grantee at once, it must, of course, vest according to the terms of the conveyance, and in the case of an absolute conveyance, he would have an absolute title. If, after delivery to the stranger, and before notice to the grantee, a creditor of the latter should fasten upon the property by execution or attachment, no reason can be given why he could not hold it. If it is the property of the grantee, it follows, as of course, that the creditor would have this right, and that he would at once acquire a lien to the extent of liis demand. Suppose, after this is done, that the grantee, on receiving notice, refuses to accept the conveyance, what becomes of the property? Does the refusal unbind and set the property free from the seizure of the creditors, and remit the title at once back to the grantor? Or does the intendment of Jus. tice Ventris step in, in behalf of the creditor as well, and say, because the grant is presumed beneficial to the grantee, and he might, at some 
future period, accept it, that therefore he shall be deemed to have accepted it before the seizure, and at a time when he was utterly ignorant of it, and thus enable the creditor to withhold the property from the grantor, by which means it would happen that although it was neither bought nor sold, the grantor would, without consideration, lose it, and the grantee enjoy the full benefit of it on the same terms? Knowing of no rational or satisfactory answers which can be given to these and various similar questions which will readily suggest themselves to the reader, I leave them to be replied to by those who maintain that the title to property, real or personal, may, without words written or spoken, or other act of transfer, be thus mysteriously passed and repassed between parties by contract. I deny that it may be.

It seems to me very plain, that it does not pass in fact until the grantee has actually consented to receive it; and, as of course, that it remains with the grantor, who is unable, without such consent, to vest it in the grantes. No other conclusion is consistent with the doctrine that a grant is a contract, and that the assent of the grantee is necessary to give it validity. The justice assumed the question in controversy by saying that the execution and delivery of the deed to the stranger passed the title out of the grantor, and then he was under the necessity of resorting to these further absurdities, in order to account for it; for he says, "that it is not a slight matter, but what the law much considers, and is very careful to have the freehold fixed," and not "under such uncertainty, as a stranger that demands right should not know where to fix his action." If he had considered that the operation of the deed was suspended, or that it did not take effect until the grantee had assented, he would have been saved the trouble of drawing so largely on his imagination to show where the title was, and how it was thereafter to be controlled. It is a matter of no small moment, and of just pride to the bench of England, that Justice Ventris, at the time he wrote his wonderful argument, dissented, and that the other members of the Court of Common Pleas, viz.: Pollexfen, Chief Justice, and Powell and Rokeby, Associates, were of opinion in the case, "that there was no surrender till such time as the surrenderee had notice of the deed of surrender and had agreed to it," and that it was so adjudged by that court; and that the case was afterwards taken by writ of error to the King's Bench, of which Lord Holt was at the time Chief Justice, and the judgment of the Common Pleas "was there affrmed by the unanimous consent of the whole court." It was afterwards brought by error into the House of Lords, where, - as it is said, upon the reasons contained in Justice Ventris' argument, the judgment pronounced in both superior courts was reversed. Thus

$\ell$ - we have on the one side the legal learning, and almost the unanimous opinion of the courts, and on the other the judgment of reversal of the House of Lords, the great majority of whom knew very little, and cared less, about the correct settlement of legal principles. 
The argument is of a piece with that kind of reasoning once employed to prove that titles to estates were "in abeyance," "in nubibus," and "in gremio legis," the folly of which is so thoroughly exposed and exploded by the severe and searching logic of Mr. Fearne, in his admirable treatise on Remainders. See pages 360 to 364 , inclusive. It was held, in case of a lease to one person for life, remainder to the right heirs of another still living, that no estate remained in the grantor; and because there was no heir, for the reason that no one can be heir during the life of his ancestor, but only after his death, and because the tenant took only a life estate, the remainder was said to be in abeyance, in the clouds, or in the bosom of the law. These opinions were founded upon the very same assumption as that of Justice Ventris, namely: That the remainder passed out of the donor at the time of livery, and consequently that no estate remained in him thereafter; and because the title must always be somewhere, the advocates of the doctrine sent it to the clouds; "though," says Mr. Fearne, "by some sort of compromise between common sense and the supposition of an estate passing out of a man, when there is no person in rerum natura, no object beside hard and hardly intelligible words, for the reception of it at the time of the livery, they are compelled to admit such a species of interest to remain in the grantor, as upon the determination of the estate beiore the contingent remainider can take place, entitles the grantor, or his heirs, to enter and reassume the estate."

The questions are so closely allied, and the substrata of the two follies are so exactly alike, that Mr. Fearne's reasoning is fully in point. And it is certainly refreshing, after a perplexing and vain effort to understand that which never was and never will be intelligible, to take up an author, who, like Mr. Fearne, treats the subject upon the principles of common sense. He intimates a conviction, that instead of the titles to estates being in the clouds, there is a much stronger probability of caput inter nubilia condit, of the head of the inventor of the fiction having becn buried or hidden in them. He says: "I cannot but think it a more arduous undertaking, to account for the operation of a feoffment or conveyance, in annililating an estate of inheritance, or transferring it to the clouds, and afterwards regenerating or recalling it at the beck of some contingent event, than to reconcile to the principles as well of common law as of common sense, a suspension of the complete, absolute operation of such feoffment or conveyance, in regard to the inheritance, till the intended channel for the reception of such inheritance comes into existence." The same is true of the delivery of a deed to a third person for the use of the grantee, without his knowledge or previous direction. It is far more compatible with common law and common sense, to say that its operation is suspended until the happening of the event indispensable in the law to its validity, namely an acceptance by the grantee, than to

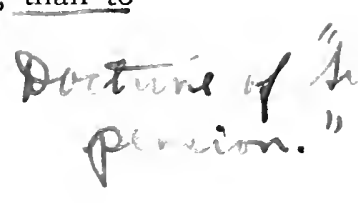


make the law perform the wonderful exploits of vesting and recalling the title contrary to its best settled and soundest principles. I am of opinion therefore, that the defendants in error took no interest in the goods in question by virtue of their mortgages, until after the plaintiff in error had seized them upon process of attachment, and consequently, that they cannot maintain their action.

Nuch was said in this case about the manner in which the mortgages were delivered. There can be no doubt that so far as the mortgagor was concerned, the delivery was good. They were placed by him in the hands of a stranger, to be by him delivered to the mortgagees, and thus passed beyond his reach and control, unless the mortgagees, within a reasonable time after notice, should refuse their assent. This made the delivery, as to the mortgagor, valid and binding, which is all I understand the author of the Touchstone to mean, when he says that a deed "may be delivered to any stranger for and in behalf and to the use of him to whom it is made." But a delivery by the donor to a third person, for the use of the donee, and an acceptance by the latter, are two very different things. By the former, the donor signifies his willingness to part with the property, whilst by the latter the donee makes known his assent to receiving it, and botl must concur before the title is changed or affected. It was formerly, and may perhaps by some be still supposed, that there can be no delivery without at the same time an acceptance; that they are correlative, inseparable parts of the same transaction, and must both occur at the same instant of time; and hence, in part, the fiction of relation, by which in case of a delivery by the grantor to a stranger, the subsequent acceptance by the grantee was carried back in legal contemplation to the time when the grantor gave the deed to the stranger, in order to save the logic of the law and to preserve "the eternal fitness of things." It seems to me that every case in which it has been adjudged that there may be a delivery to a stranger, and that a subsequent ratification by the grantee will make the instrument effectual for the purposes intended, falsifies this notion and proves that in every such case there may be, what there is in fact, a delivery by the grantor at one time to a third party, and an acceptance by the grantee from such third party at a subsequent and different time. Such is the common sense of the transaction; and it is better and more rationally disposed of without than with the aid of the fiction. But if the fiction must be employed then the maxim, in fictione legis semper subsistit equitas, applies, and it will not be allowed to operate when it infringes or violates the rights of strangers. It is only resorted to in furtherance of justice and to prevent injury. In this case the plaintiff in error is a stranger to the mortgages. He represents the rights and interests of the creditors of the mortgagor, who in good faith sued out and levied their attachments upon the goods, thereby lawfully acquiring a lien upon them; and it cannot be said to be in furtherance of justice, 
to postpone their demands thus legally secured, to those of the mortgage creditors, which are in no sense more equitable or just. The struggle is between innocent persons, to prevent loss, and the fiction ought not to be resorted to for the purpose of helping one as against the other. The transaction must be left to stand upon its simple and naked truth. * * *

The judgment of the circuit court is reversed, and a new trial awarded. ${ }^{45}$

45 Hibberd v. Smith, 67 Cal. 547.4 Pac. 473, 8 Pac. 46, 56 Am. Rep. 726 (185.5): Hulick v. Scovil, 4 Gilman, 159 (1S47); Woodhury v. Fisher. 20 Ind. 357. 83 Am. Dec. 925 (1863); Day v. Griffith. 15 Iowa, 104 (1863); Bell v. Farmers' Bank, 11 Bush (Ky.) 34, 21 Am. Rep. 205 (1S75); Parmelee v. Simpson, 5 Wall. $81,1 \mathrm{~s}$ L. Ed. 542 (1S66), acc. See Watson $v$. Hillman, 57 Mich. 607, $24 \mathrm{~N}$. W. (66:3 (1855): Meigs v. Dexter, 172 Mass. 217, 52 2. E. 75 (1S9S). Buffum v. Green. 5 N. H. 71, 20 Am. Dec. $562(1829)$; Wilt v. Franklin, 1 Bin. (Pa.) 502, $2 \mathrm{Am}$. Dec. $474(1809)$; Merrills v. Switt, 18 Conn. $257,46 \mathrm{Am}$. Dec. 315 (1S47), contra. See Jones v. Swayze, 42 N. J. Law, 279 (1880). 


\section{CHAPTER III}

\section{THE PROPERTY ${ }^{1}$ CONVEYED}

\section{SECTION 1.-BOUNDARIES}

\section{HARRIS v. WOODARD.}

(Supreme Court of North Carolina, 1902. 130 N. C. 5S0, 41 S. E. 790.)

Action by J. W. Harris and others against the Woodard \& Goodridge Company, heard by Judge Walter $\mathrm{H}$. Neal and a jury, at February Term, 1902, of the Superior Court of Granville County. From a judgment for the plaintiff, the defendant appealed.

CLARK, J. The plaintiffs, holders of a second mortgage, seek to enjoin sale under a prior mortgage executed by the mortgagor to defendants, because the description in the latter is too vague and indefnite to pass title to the defendants. Said description is as follows? "A certain piece or tract of land, grist mill and all fixtures thereunto, and one store-house, 28 by 100 feet long, lying and being in Brassfield township, Granville County, N. C., and adjoining the lands of Anderson Breedlove, J. C. Usry and Dora Harris, said lot to contain three acres." There are forty acres in the tract on which the store and grist mill are located. There is nothing to segregate this three acres out of the forty, nothing to indicate a beginning, nor where or in what direction the lines are to be run-nothing whatever beyond the inference-for it is not expressly stated that the grist mill and store-house are to be located somewhere upon the said three acres when laid off.

As was said by Gaston, J., in Massey v. Belisle, 24 N. C. 170, "every deed of conveyance must set forth a subject-matter, either certain in itself or capable of being reduced to a certainty by recurrence to something extrinsic to which the deed refers." Here there is no subject-matter which is either definite in itself or capable of being reduced to a certainty by recurrence to something to which the deed refers. No beginning point, nor directions are given, nor distances. and there is nothing which authorizes anyone to lay off the lines of any particular three acres out of the forty in the tract, which tract is bounded by the parties named. The reference to them renders

1 The word, of course, is not used here in its narrow, technical sense of a right, but in its broader, more popular sense of the external object over which rights are exercised. 
the forty-acre tract certain, but is no aid in rendering it possible to select three acres out of said tract. This is not like the "twenty-nine acres to be cut off of the north end" of a tract which was bounded by straight, well-defined lines, and whose selection required merely a knowledge of surveying, as in Stewart v. Salmonds, 74 N. C. 518 , nor a similar description in Webb v. Cummings, 127 N. C. 41, 37 S. E. 154.

The statute, Laws 1891, chap. 465, applies only where there is a description which can be aided by parol, but not when, as in this case, there is no description. Hemphill v. Annis, 119 N. C. 514,26 S. E. 152; Lowe v. Harris, 112 N. C. 472,17 S. E. 539, 22 L. R. A. 379. In Lowe v. Harris there were the words "his land," which the minority of the Court insisted could be helped out by parol evidence, but here there is only an uncertain, indefinite, undefined and undefinable three acres out of a tract of forty, and the Court properly held that this was too indefinite to be a conveyance of any three acres, and the mortgage was, therefore, void as to the land.

No error. ${ }^{2}$
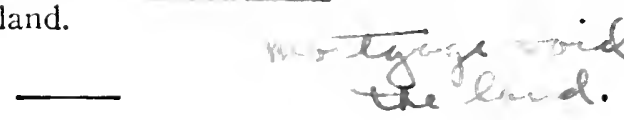

\section{LEGO v. MEDLEY.}

(Supreme Court of Wisconsin, 1891. 79 W'is. 211, 48 N. W. 375, 24 Am. St. Rep. 706.)

TAYLOR, J. The questions arising in this case grow out of a foreclosure action brought by the plaintiff and appellant against the respondent and the other persons named to foreclose a mortgage. The mortgage sought to be foreclosed was given to the appellant by Richard P. Medley, dated October 16,1888 , to secure the payment of $\$ 500$ and the interest thereon. The property mortgaged was described in the mortgage as the W. $1 / 2$ of the S. W. $1 / 4$ of section 9 , township $30 \mathrm{~N}$., of range $6 \mathrm{~W}$., in Chippewa county, IVis. None of the defendants in the action appeared in the case or defended the action, except the respondent Rose Medley. She answered that she was the mother of the mortgagor, Richard P. Medley, and that on the 9th day of April, 1884, she was the owner in fee-simple of the W. $1 / 2$ of the S. W. $1 / 4$ of said section 9 , the property described in said mortgage, and on said 9th day of April, 1884, for love and affection for her said son, she conveyed to him, by an ordinary warranty deed, so much of said W. $1 \%$ of said section 9 as is described in said deed, and no more. The following is the description contained in said deed from her to her said son, viz.: "The west half

2 Cathey v. Buchanan Lumber Co., 151 N. C. 592, 66 S. F. 580 (1909) ; King v. Ruckman, 20 N. J. Eq. 316 (1869); Le Frauc v. Richmond, 5 Sawy. 601, Fed. Cas. No. \$,209 (1s64), acc.

In Gaston $r$. Weir, 84 Ala. 193, 4 South. 258 (1857), the description in question was "forty-seven and one-fourth acres of the west part of the north half of the northwest fourth of section 1." It was held that the land could be located. See, also, Tierney v. Brown, 65 Miss. 56:3, 5 South. $104,7 \mathrm{Am}$. St. Rep. 679 (1888) ; Osteen v. Wynn, 131 Ga. 209, 62 S. E. 37, 127 Am. St. Kiep. 212 (1908).

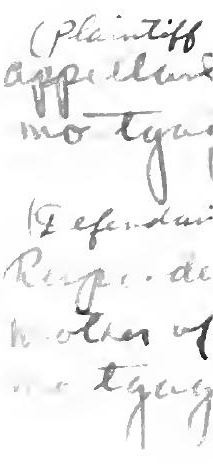


of the southwest quarter of section nine (9), township thirty (30), range six (6), except one acre from the southeast corner of the southwest quarter of the southwest quarter of said section, town, and range, together with the buildings thereon."

This deed was duly recorded in the proper register's office on the 10 ih of April, 1884. She also set forth in her answer that at the time of and ever since the execution of said deed to her said son she was, and since has been, in the actual possession of said acre of land, and the buildings thereon, and is still in the possession of the same; and she further alleges in her complaint that the acre of land, with the buildings thereon, excepted in her said decd, and which she has always occupied and still occupies, is bounded as follows: "Beginning at the boundary line of the highway which runs along the south side of said southwest quarter of the southwest quarter of section nine (9) aforesaid, on the line of division between the soutliwest quarter of the southwest quarter, and the southeast quarter of southwest quarter, of section nine (9) aforesaid; thence west along the boundary line of said lighway seventeen rods and three quarters; thence north, at right angles to the boundary line of said highway, nine rods; thence east to the boundary line between the southwest quarter of the southwest quarter and the southeast quarter of the southwest quarter of section nine (9) aforesaid, seventeen rods and three quarters; thence south, along the boundary line between the southwest quarter of the southwest quarter, and the southeast quarter of the southwest quarter, of section nine (9) aforesaid, to the place of beginning; that said acre of land so measured belongs to this defendant, and that she is the owner thereof, and in the actual possession of same, and has been at all times since the making of said deed to the defendant Richard P. Medley, and of the dwelling-house and buildings situated thereon, and was in such possession at the time of making of the mortgage of the plaintiff herein, and that the said Richard P. Medley had no right or title in or to said land or buildings, and no power or authority to sell or mortgage same; that the plaintiff in this action has no right or power or permission to sell or convey said land and premises, or to excrcise any rights of ownerslip in or to same." There was no demurrer to the answer.

On the trial the plaintiff offered in evidence his note and nortgage, and made the computations of the amount due thereon, and in addition to such evidence he did in open court "release all claims whatever to one acre from the southeast corner of the southwest quarter of the southwest quarter of section nine (9), town thirty (30), range six (6), in Chippewa county, Wisconsin, and the buildings thereon, and consents that whatever judgment is rendered in the actions shall so declare," and rested his case; and thereupon Rose Medley was called as a witness in her own behalf. The plaintiff then objected to any evidence under the answer of defendant Rose Medley, upon the ground that the same does not constitute any defense whatever. And 
the counsel for the plaintiff then said: "I want to say that, meaning to release one acre in the corner square and bounded by four equal sides." The court overruled the objection to the evidence offered, and the defendant gave her testimony in the action. The court, under objections on the part of the plaintiff, permitted the defendant to show that one acre, in the southeast corner of the eighty acres described in her deed to her son, in the form of a square with four equal sides, would not include her dwelling-house.

After hearing the evidence, the court made the following findings of fact and conclusions of law: The 1st, $2 \mathrm{nd}$ and 3rd findings relate to the mortgage, and the amount due thereon. The court then makes the following findings:

"(4) That the said defendant Richard P. Medley derived his title to the mortgaged premises from defendant Rose Medley, under a deed executed by said Rose Medley several years prior to the execution of said mortgage, and also recorded in the office of the register of deeds, Chippewa county, Wis., prior to the execution of said mortgage; that in said conveyance said lands are described as follows: "The west half of the southwest quarter of section nine (9), town thirty (30), range six (6), except one acre from the southeast corner of the southwest quarter of the southwest quarter of said section, town, and range, together with the buildings thereon; that at the the time of the making of said conveyance there was a dwelling-house, and some outbuildings used in connection therewith, located near the southeast corner, and the said Rose Medley was in the actual possession of said tract of land, and residing in said dwelling-house; that during all the time after the making of said conveyance, up to the present, said Rose Medley has continued to reside in said dwelling-house, and used said outbuildings in connection therewith.

"(5) That at the time of making of said conveyance to Richard P. Medley there was, and ever since has been, a strip of land two rods wide off from the south side of said described land, constituting part of the public lighway, and that said land, as used and occupied by said Rose Medley, was bounded on the south side by said highway.

"(6) That a square acre laid off from the sontheast corner of said land would not include the said dwelling-house; and that an oblong square acre laid off from said corner, having for its southern boundary the center of said highway, would include said dwelling-house, but would not include all the other buildings referred to as used in connection therewith; but an acre so laid off from said comer, excluding the highway, that is, taking for the corner the point where the east boundary of said land intersects with the highway, would include all of said buildings; said acre would be sixteen rods long on the south boundary, and ten rods wide on the east boundary."

And as conclusions of law the court finds as follows:

"(1) That said conveyance from Rose Medley to Richard P. Medley should be construed with reference to the circumstances attend- 
ing the transaction, the situation of the parties, state of the property, the location of said dwelling-house, and other buildings, and the existence of the highway; and, having regard for these circumstances, the court holds that it was the evident intention of the parties, by the langrage used in said conveyance, that the acre excepted should be laid off from the southeast corner of said west half of the southwest quarter in said section nine (9), excluding the highway, so as to include said dwelling-house and said outbuildings used in connection thercwith as the same were located at the time of the execution of said conveyance, which said acre, as near as can be determined from the testimony, is bounded as follows: Beginning at a point where the east boundary line of the southwest quarter of the southwest quarter of section nine (9), town thirty (30), range six (6), intersects with the highway on the south side of said land; thence west along the said highway sixteen rods; thence, at right angles, north ten rods, to the said east boundary line of said land; thence at right angles south to the place of beginning.

"(2) That plaintiff is entitled to judgment as prayed for in the complaint, except that said judgment should provide only for a sale of the west half of the southwest quarter of said section nine (9), excepting one acre from the southeast corner thereof, described as aforesaid."

The plaintiff excepted to the conclusions of law, but took no exceptions to the findings of fact. The learned counsel for the appellant assigns two errors: First, that it was. error to permit the defendant Rose Medley to introduce any evidence under her answer, on the ground that it does not state facts constituting a defense to the plaintiff's action, or to any part thereof; second, that the court erred in permitting parol evidence to aid in construing the deed given by the said defendant to her son. He also assigns as error the allowance of costs to the respondent.

The first objection, that the answer does not constitute a defense to the plaintiff's action, or any part thereof, cannot be sustained under the rule established by this court in Wickes v. Lake, $25 \mathrm{~W}$ is. 71 ; Roche v. Knight, 21 Wis. 324; Newton v. Marshall, 62 Wis. 8, 17, 21 N. IV. 803. These cases hold that when the plaintiff, in a foreclosure action, makes any person defendant, alleging "that he claims to have some interest or lien upon the mortgaged premises or some part thereof, which licn, if any, has accrued subsequently to the time of said mortgage," such defendant may by his answer set up a paramount claim to the mortgaged premises, or to some part thereof, and that such right may be tried and adjudged in the foreclosure action. This rule is certainly the correct rule, and the only way the plaintiff can avoid the trial of the right of the defendant so brought into court by him, as to his paramount title, is to discontinue his case as to such defendant so that he may not be prejudiced by the judgment to be entered in the foreclosure action. See Hekla F. Ins. Co. v. Morrison, 56 Wis. 133, 136, 
14 N. W. 12. As the plaintiff did not offer to discontinue his action as to the respondent after she had filed her answer setting up her paramount title, he cannot now object to the trial of her right. He in fact admitted her right, and offered to take judgment recognizing her right to the acre excepted in her deed, but insisted that the excepted acre should be in the form of a square. He therefore waived his objection to her asserting a right paramount to his mortgage, and insisted in binding her to take the excepted acre in the shape which he claimed was given to her by the law under her deed.

The learned counsel also insist that the court erred in permitting respondent to introduce parol evidence of the situation of her buildings in the southeast corner of said west half of the southwest quarter, mentioned in her deed to her son, for the purpose of locating the acre of land so excepted from her deed; the claim being that the exception in the deed is the exception of an acre in the southeast corner in the form of a square, and that parol evidence is inadmissible to show that any other form was intended by the parties. The rule contended for by the learned counsel is undoubtedly the correct rule when there is nothing else in the deed which calls for a different form. But the rule does not apply to a case when the exception is of a certain quantity of land, and the exception, from the tract described in the conveyance, refers to other objects than mere locality. It is not denied by the learned counsel that, if the exception had been of one acre in the southeast corner of the tract conveyed, including the grantor's dwelling-house situated thereon, that evidence would not be admissible to show that one acre in a square form would not cover the dwelling-house, and that in such case the bounds of the acre should be so located as to include the dwelling-house, if this could be done, and still locate the acre on the southeast corner of the tract conveyed. The surroundings and the objects on the ground would control the shape of the acre, which, in the absence of such surroundings and objects called for in the deed, the law would construe to mean a square acre. In such case there is no mistake in the description, which, if corrected at all, must be corrected in an action brought for that purpose. It is a mere question of the location of the tract excepted in the conveyance.

But the learned counsel insists that an acre in a square form will cover all the material calls for boundary mentioned in the deed, because the evidence shows that an acre, in a square form, will include some of the buildings of the defendant situate in the southeast corner of the land described in the deed. That fact we do not think meets the call for the buildings evidently intended by the parties to the deed. Such acre would not include the defendant's dwelling-house, which was evidently far the most valuable building situate on the southeast corner of the land described in the deed; and that fact, with the other evidence introduced, raises a fair presumption that that build- 
ing, of all others, was the one intended by the parties as one of the ouildings which they intended the excepted acre should include.

It is true that the description of the excepted acre in the conveyance from the mother to the son is not as particular and specific as it should have been, but, under the evidence showing that at the time the conveyance was made the grantor owned an adjoining eighty acres, and that her dwelling-house and outhouses were situate on the eighty acres conveyed to her son, that these houses constituted her home at the time, and that after the execution of the deed she remained in the occupation of her dwelling and outhouses as she had done before claiming to own the same, strongly tend to show that such dwellinghouse and other buildings were situate on the acre excepted in the convevance to her son; and as an acre of land can be laid off in the southeast corner of the tract described in the conveyance in a convenient and useful form, so as to include the buildings, it seems to us that the court properly directed that it should be so laid off and bounded. The words in the description are general, and not specific, and, in the absence of anything indicating a different boundary, the law would determine that the acre should be a square; but, when there is anything in the description which would not be complied with by making the acre a square, then the question as to what was intended by the parties by the words used is to be determined by the surrounding circumstances. In such case there is a latent ambiguity on the face of the deed when applied to the facts existing at the time the conveyance was executed, and the intent of the parties in such case becomes a question of fact, and not one of law, to be determined alone by the mere words used in the conveyance.

The rule applicable to this case is well stated in Dunn v. English, 23 N. J. Law, 126, 128. In that case the court say: "The construction of the grant must be favorable, and as near the mind and intention of the parties as the rules of law will admit, and to ascertain this intention parol evidence may be resorted to, not to contradict or vary the words of the grant, but to show from the situation and condition of the subjectmatter what meaning the parties attached to the words used, especially in matters of description." The rule above stated was recognized and approved by this court in the opinion of the late learned Chief Justice Ryan in the case of Lyman v. Babcock, 40 Wis. 512. See, also, Ganson v. Madigan, 15 IVis. 14t, S2 Am. Dec. 659; Prentiss v. Brewer, 17 Wis. 635, S6 Am. Dec. 730; Rockwell v. Mut. L. Ins. Co., 21 Wis. 548; and Sawyer v. Dodge Co. Mut. Ins. Co., 37 WVis. 503. This rule is peculiarly applicable to the case at bar. The parol evidence was offered to show what the intention of the parties was as to the land excepted from the deed from the mother to the son. It does not contradict the language used in the deed, but tends to explain its meaning as intended by the parties at the time. The fact that the respondent lived, at the time the conveyance to her son was made, in the southeas corner of the eighty acres described in the deed, that she had no other 
home, and owned a farm adjoining, explains what was intended by the use of the words in the deed, "together with the buildings thereon," and it overcomes the general presumption that, without any explanation, an acre, in the southeast corner of the land conveyed, must be construed to mean a square acre. We think there was no error in permitting the introduction of the parol evidence allowed on the trial. $^{3} * * *$

By THE CourT. The judgment of the circuit court is affirmed.

\section{MOREHEAD v. HALL.}

(Supreme Court of North Carolina, 1900. 126 N. C. 213, 35 S. E. 42S.)

MONTGOMERY, J. This is an action for the recovery of the possession of a tract of land. On the trial the plaintiff introduced a chain of paper-title, beginning with a grant to John Benthall, dated October 30,1765 , and concluding with a deed from Joseph A. Perry to John M. Morehead, the plaintiffs being his heirs-at-law, dated July 17. 1856 , and testimony going to show that the locus in quo was covered by the descriptions in the conveyances, and that David B. Hall, onc of the defendants, was in possession of the land at and before the conmencement of the action.

There was no objection entered to any of the evidence, and at its conclusion, as stated in the case on appeal, "the defendants jointly demurred to the evidence, and moved to dismiss the action under the Act of 1897." The motion was allowed, and the plaintiffs appealed.

In each of the muniments of title, the whole of the land described in the complaint was conveyed, except that in one of the deeds, the one from Mary Bell and others, the heirs-at-law of David Bell, to $\mathrm{H}$. G. Cutler, the land was described as "a certain piece of land in the fork of Newport, on the north side of the Southwest branch, adjoining the lands of William C. Wallace, deceased, and others, it being one-half of a tract of land given by Malachi Bell, Sr., to his son David Bell, as will more fully appear by reference to the will of Malachi Bell to David Bell, containing 200 acres more or less."

The counsel of the defendants contended here, as to the construction of that deed, first, that nothing was conveyed therein because of a totally defective description of a particular portion of the 200-acre tract, which was attempted to be conveyed; and second, that even conceding that there was conveyed in the deed a one-half undivided interest in the 200-acre tract, yet the plaintiffs could recover no part of the land, for the reason that they did not show on the trial whe were the owners of the other half of the tract in order that a judgment might be rendered for them, and the plaintiffs as tenants in common.

3 The portion of the opinion relating to the matter of costs is onitted. AIg.Prop.—26 
We think that the contention in neither of its forms can be sustained. We are without a decision on the first point in our Reports, nor have we been able, after a diligent research, to find much in the Reports of the courts of other States, and so we are left to adopt a construction of the deed, as best we may, from the light of reason.

We are of the opinion that there was conveyed in the deed a one-half undivided interest in the 200 acres. Some confusion, it is true, has arisen out of the use of the words "a certain piece of land," but there was no attempt to describe that "certain piece" by metes and bounds, or by any other definite description. If such an attempt, that is, an attempt to convey a specific number of acres, by survey or by metes and bounds, had been made, and the boundaries and description had been fatally defective, then nothing would have been conveyed, for such an attempted description would have shown in its own terms that an undivided interest had not been attempted to be conveyed. The deed on its face conveys only a part, one-half of a well-described tract, and makes no pretense to describe the particular part conveyed, and we see no reason why the deed should not be construed as conveying a one-half undivided interest in the land. 'That view is supported by the opinion in Grogan v. Vache, 45 Cal. 610. But in Gibbs v. Swift, 12 Cush. (Mass.) 393; Jackson v. Livingston, 7 Wend. (N. Y.) 136 , and L. I. Railroad Co. v. Conklin, 29 N. Y. $572,{ }^{4}$ a contrary doctrine is held, that is, that even if there was an attempt to convey a given part of a larger tract of land, and the deed should fail to locate the quantity by a sufficient description, yet, upon the delivery of the deed, the grantee would become the owner, tenant in common with his grantor. We adopt the other construction because we think it the more reasonable, and more in conformity with the trend of our decisions on the questions of boundary and description. Either construction, however, is against the defendants' contention. ${ }^{5}$

New trial.

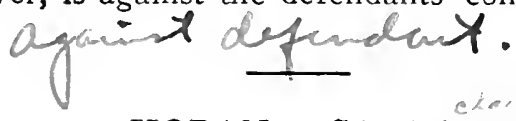

HOBAN v. CABLE,

(Supreme Court of Michigan, 1894. $102 \mathrm{Mich} .206,60 \mathrm{~N}$. W. 466.)

Montgomery, $J{ }^{6}$ This is an action of ejectment. The trial was had before a jury, and a verdict rendered for the plaintiff. The defendant brings error. The assignments of error are numerous, but have been carefully grouped by the appellant's counsel, so that the questions may be dealt with under a few heads. The diagram on the following page will furnish an aid to an understanding of the points involved.

The record contains the substance of all the testimony, from which it appears that plaintiff derived title from the heirs of Laurie McLeod, to whom a conveyance was made by Eliza R. McLeod, in 1862, Eliza

\footnotetext{
4 So also in Cullen v. Sprigg, \$3 Cal. 56, 23 Pac. 222 (1S90).

${ }^{5}$ The balance of the opinion relating to other points is omitted.

${ }^{6}$ Portions of the opinion relating to other matters are omitted.
} 

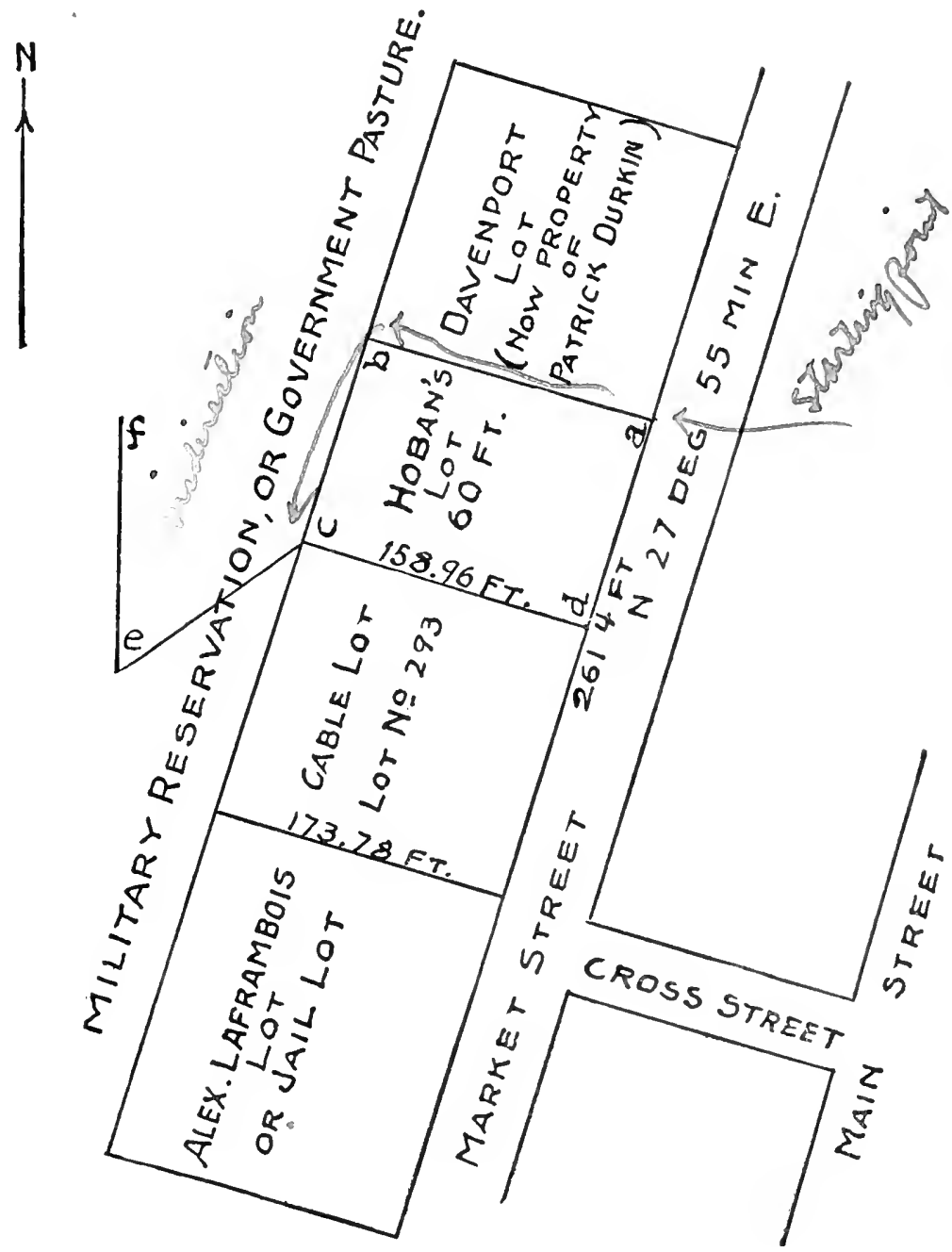

R. McLeod being then in possession, and the apparent owner. The defendant claims title by adverse possession, and also claims that by a subsequent conveyance to him by Eliza R. McLeod of lot No. 293 the title passed to him, and in this connection contends that the deed to Laurie McLeod contained no sufficient description of any property, and that the record of the deed was, therefore, no notice to him of any right in Laurie McLeod.

As the deed to Laurie McLeod was first recorded, and as defendant claims it in fact read when executed, the description of the land was as follows:

"Beginning on Market street, between the lot hereby intended to be conveyed and a lot confirmed by the government of the United States 
to Ambrose R. Davenport; thence north, 62 degrees 15 minutes west, 158.96 feet; thence south, 31 degrees west, 60 feet; thence south, 62 degrees 15 minutes west, 158.96 feet, to Market street; thence along said street north, 27 degrees 55 minutes east, to the place of beginning."

Was this a sufficient description, or must the deed be treated as a nullity? The starting point is definite. The first line, to point "b," is also certain, as is the line between points " $\mathrm{b}$ " and "c." But, if the direction of the next line is followed as given in the instrument, the terminus is at "e," and the line named in the succeeding portion of the description would end at "f." But the course given after reaching point " $\mathrm{c}$ " is not the only means of identification adopted. That line is described as terminating at Market street. If we exclude the words indicative of the direction of the line, and carry the line in the most direct course to Market street, we have not only a line answering to the other terms of the deed, but one which, with its extension, incloses something, which is, by the terms of the deed, "a lot intended to be conveyed," and which, to answer the terms of the portion of the description relating to the starting point, must lie next to "a lot confirmed by the government of the United States to Ambrose R. Davenport." To make this clearer, the deed contains the statement that from the terminus of the third line named in the description the boundary shall extend along Market street to the place of beginning. We think the intent of the grantor is clear, and that the deed is not a nullity for want of a sufficient description. See Anderson v. Baughman, 7 Mich. 69, 74 Am. Dec. 699 ; Cooper v. Bigly, 13 Mich. 463; Dwight v. Tyler, 49 Mich. 614, 14 N. W. 567.

A number of defendant's points depend upon this, and it becomes unnecessary to treat in detail some of his assignments of error. The deed being valid to convey the land, the-record was notice to subsequent purchascrs.

One of the conveyances under which plaintiff claims contained a description as follows:

"A lot 60 feet wide on Market street and 128.90 feet deep, being the north end of lot 293 in the village of Mackinac."

This is claimed to be insufficient, but we think there is no mistaking the land intended to be conveyed. * **

We think no error to the prejudice of defendant was committed.

The judgment will be affirmed, with costs, and the case remanded. ${ }^{7}$

7 See Newbold r. Condon, 104 Md. 100, 64 Atl. 356 (1906) ; Whitaker r. Posten, 120 Temn. 067,110 s. W. 1019 (190s); Peoria Gas \& Electric Co. v. Dunbar; $2: 34$ Ill. $50 \div, 5$ N. E. 229 (1908): Nicolin r. Schmeiderhan, 37 Minn. 63, 39 న. W. 23: (1-s); Mellor v. Walmesley, [1904] ¿2 Ch. 525.

A deed contilned the following calls: "Beginning on the soutleast bank of Toe river, two lods below the mill house, and runs west, nolth, east, and sonth. to the berinning, so as to include the mill and site and two acres of land. it feing and incluting the land sold as the excess of the homestead of A. Wisemin." The land contained in the calls given did not include the sarmill, nor 


\section{WHITEHEAD v. RAGAN.}

(Supreme Court of Missouri, 1891. 106 Mo. 231, 17 S. W. 307.)

MACFARLANE, J. The contest in this case is over the location of the division line between lots 1 and 4 of Kritzer and Ragan's subdivision of a part of the east half of the northwest quarter of section 21 , toynship 49 , range 33 .

About the year 1870 defendant, Mary Ragan, and one Virginia Kritzer, being the owners of the whole tract, had it subdivided into seven lots numbered from 1 to 7 . A plat of the subdivision was made and recorded. The dimensions of each lot and the area were marked on the plat. Lot 1 is designated on the plat as a parallelogran, eleven and thirteen hundredths chains north and south, five and thirty-four hundredths chains east and west, containing five and ninety-four hundredths acres. This lot lay in the northwest corner of the tract. Lot 4 lay south of and adjoining lot 1 , but extending six and sixty-six hundredths chains further east. The north and south line on the west side of lot 4 as marked on the plat was eight and seventeen hundredths chains, and the lot contained twelve and ninety-two hundredths acres.

On the first day of September, 1870 , defendant conveyed, by quitclaim deed, to Virginia Kritzer, all her interest in lots 1,5 and 6, reciting in the deed that lot 1 contained five and ninety-four hundredths acres, "as will appear by reference to the recorded plat of said subdivision." March 17, 1885, Virginia Kritzer and husband conveyed to Larkin and Blackmar, by warranty deed lot 1 under the following description: "Lot number 1 in Kritzer and Ragan's subdivision of the east half of the northwest quarter of section 21, township 49, range 33 , containing five and ninety-four hundred ths acres more or less, including thirty feet roadway."

April 22, 1886, Larkin and Blackmar conveyed, by warranty deed, to plaintiff Whitehead, "lot I in Kritzer and Ragan's subdivision in east half of the northwest quarter, section 21 , township 49 , range 35 , in Jackson county, Missouri." When he purchased he was not shown the corners of the lot, but was referred to the plat for quantity, courses and distances.

At the time of plaintiff's purchase, lots 1 and 4 were included in one inclesure. Soon thereafter defendant built an east and west fence, as she claimed, on the north line of lot 4 for the purpose of a separate inclosure of that lot. Plaintiff claims that this fence is about thirty-five feet toe far north and included that quantity of lot 1 , to recover which this suit is prosecuted.

the gristmill, nor the mill site. But if the first call, "west," were to be read "enst," the description would indude the sammill, gristmill, and mill site The coult heta "west" shonld he rear as "east." Wiseman V. Cleen, 127 N. C. 2Ss,

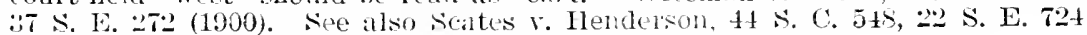
(1895); Rushton r. Hallett, s Ttal, 277, 30 Fac. 1014 (1892),

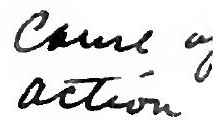


An accurate measurement of the north and south line of plaintiff's lot 1 , commencing at defendant's fence, shows an unquestioned shortage of thirty-four and fifty-eight hundredths feet as compared with the whole length of the lot as shown on the plat. All the foregoing facts were shown by plaintiff, and are not disputed.

Defenclant offered evidence which tended to prove that, when the subdivision was made, stones were planted to mark the four corners of lot 1; that, after she conveyed her interest in lot 1 to Kritzer in 1870 , the line between the stones planted for the southwest and southeast corners of lot 1 was adopted by them as the true division line between lots 1 and 4, and was so recognized and used until plaintiff purchased lot 1; that the north and sonth lines of the subdivision on the west side were fifty-one feet shorter than was shown by the plat; and that the division fence was on the line so marked, held and recognized.

'The circuit court, upon this evidence, directed a verdict for plaintiff, thus holding that the courses and distances, indicated upon the plat, should prevail over the lines actually surveyed and corners established.

1. When an authentic plat of a subdivided tract of land is referred to in a deed conveying a subdivision of such tract, the plat itself, in legal construction, becomes as much a part of the deed as if it had been fully incorporated in it. Dolde v. Vodicka, 49 No. 100; 2 Devlin on Deeds, $\$ 1022$.

11. While the deeds, under which plaintiff claims title to lot 1 in the subdivision, must be construed as describing the land conveyed as being of the full length shown by the plat, it does not follow that the particulars of the description contained in the plat are conclusive of the correctness of such description. The plat is only intended to be a representation of the actual survey as made upon the land itself. It is in the nature of a certified copy of an instrument which will be controlled by the original. So it is held, "where there are no express calls that determine a line with certainty, evidence aliunde is admissible to show where the line was actually run to which the deed refers, or to which it must have reference; and its location so fixed, by extrinsic evidence, will control the courses and distances named in the deed or in the survey. The right to prove the true line of the survey to which the deed refers, and which it follows, does not depend upon the rules applicable to ambiguities in written instruments. *** It is not a question of construction but a question of fact." Kronenberger $v$. Hoffner, 44 Mo. 185. So in Dolde v. Vodicha, 49 Mo. 98, the court says: "Had this (lot) been so staked out in the original survey, there would be no difficulty, for the division of the lines of the lots would then have been actually located, and the location must govern."

It is a well-settled rule of construction that known and fixed monuments will control though they conflict with the courses and distances called for in the deed. Myers v. St. Louis, 82 Mo. 373; Orrick v. Bower, 29 Mo. 210; Gray v. Temple, 35 Mo. 494; 3 Wash. Real Prop. 
(4th $\mathrm{Ed}$.) 405. While natural monuments are regarded of higher value in determining boundaries than artificial ones, the latter will also control courses and distances. "The order of applying descriptions of boundaries is, first, to natural objects; second, to artificial marks; third, to courses and distances given in the deed." 3 Wash. Real Prop. (4th E. d.) 405 .

If the line between lots 1 and 4 was located, upon the land when surveyed and subdivided, and can now be ascertained and determined, that line will constitute the true division line between the lots though it conflicts with the description given in the plat.

Where the boundary line was actually located was a question for the jury, the evidence tending to prove a conflict between the calls in the deeds and plat, and the survey as located on the land. The court committed error in directing a verdict for plaintiff, and in refusing to submit the issue of fact to the jury.

Reversed and remanded. All concur. ${ }^{8}$
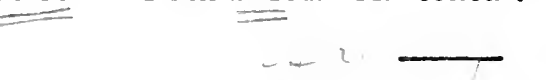

\section{LERNED v. MORRILL.}

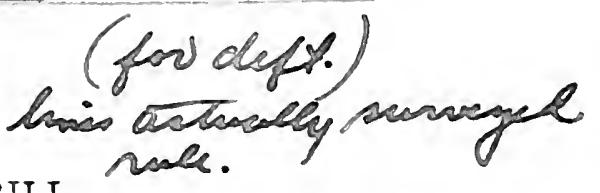

(Supreme Court of New IIampshire, 180. 2 N. H. 197.)

This was a writ of entry, in which the demandant counted upon his own seisin within twenty years and upon a disseisin by the tenant.

The cause was tried here at April term, 1819, upon the general issue, when a verdict was taken for the demandant, subject to the opinion of the court, upon the following facts.

The tenant by deed dated March 8,1806 , conveyed to the demandant a tract of land described in the deed as follows: "Being the westerly part of lot No. 2, and containing 80 acres, beginning at the north-west corner on Boscawen line; then south by Lerned's land to Contoocook river to a poplar tree, thence by said river to a stake and stones, thence northwardly a parallel line with the side line of said lot to a stake and stones on Boscawen line, thence on said Boscawen line to the bound first mentioned." The stakes and stones mentioned in the deed were not erected at the time of making the deed; but about eighteen months afterwards, the parties went upon the premises with a surveyor and chain-men to run out and locate the land, and they erected the stakes and stones at the north-east and south-east corners of the premises. The parties first measured the whole lot, divided it in the middle, and then measured off ten acres from the east half and adjoining the west half, and set up stakes and stones at the north-east and south-east corners of the land so measured off, and run the line from one stake and stones to the other and set up stakes and stones at every tally. The tenant immediately cleared his land up to the line and built

8 See in accord City of Decatur v. Niedermeyer, 168 I11. 68, 4S N. E. 72 (1897); Olson v. Seattle, 30 Wash. 657,71 Pac. 201 (1!i03). 
a fence upon it. The demandant also built a hoard fence on the line, and the parties occupied and improved the land on each side of that line till 1817. It was proved that the tenant said the demandant bought ten acres more than half the lot. In the fall of 1817 , the defendant surveyed the lot and finding that the demandant had more than eighty acres, removed the fence, and went into possession of all but eighty acres, and this action is brought to recover the land, of which the tenant thus took possession.

PFr Curiam. The question presented to us in this case for decision, has long been settled, and must now be considered as entirely at rest. Where land has been conveyed by deed, and the description of the land in the deed has reference to monuments, not actually in existence at the time, but to be erected by the parties at a subsequent period: when the partics have ance been upon the land and deliberatcly erected tue monuments, they will be as much bound by them, as if they had been erected before the deed was made. In this case, there was a reference Ain the deed to monuments not actually existing at the time, but the parties soon after went upon the land with a surveyor, run it out, erected monuments, and built their fences accordingly; and this is not all. They respectively occupied the land according to the line thus established, for nearly ten years. And there is now no evidence in this case of any mistake or misapprehension in establishing the line. There is no pretence that the tenant could lawfully remove monuments thus deliberately erected and so long acquiesced in.

His claim to the demanded premises, for ought that appears in this case, is without any foundation whatever, and there must be judgment for the demandant. ${ }^{8}$

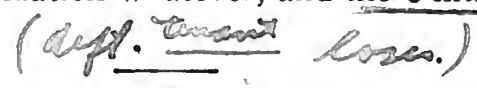

\section{BURKHOLDER v. MARKLIY.}

- (Supreme Court of Pennsylvania, 1SS1. 9S Pa. 37.)

Error to the Court of Common Pleas of Lancaster county; of May Term, 1881, No. 74.

Trespass vi et armis, quare clausum fregit, by Jacob Markley against M. J. Burkholder, for entering on the plaintiff's land and tearing down a fence. Plea not guilty, and liberum tenementum.

On the trial, before Livingston, P. J., the following facts appeared: The plaintiff and the defendant were owners of adjoining tracts of land, the location of the division line between which was the subject of this dispute. Both clanined title by mesne conveyances from Samuel Moyer. The descriptions in all the deeds, under which both parties claimed contained, inter alia, the following courses and distances: "Thence by other land of said Samuel Moyer, north, seventy-five degrees west, three perches and four-tenths, to a post, thence by the same

9 Makepeace v. Bancroft, 12 Mass. 469 (1815), acc. Cf. Cleaveland v. Flagry, 4 Cnsh. (Mass.) 76 (1S49); Miles v. Parrows, 122 Mass. 579 (1S77). 
north nineteen degrees east, izenty-three perches and five-tenths, to a stonc in said road," etc. The part in italics is the division line in lispute. This was a straight line upon or near to which a fence was erected prior to the time of the conveyances from Moyer, and which had remained standing until a portion of it was torn down by the defendant. It was not, however, alleged in the narr. to be a line fence.

Upon a recent survey of the Burkholder tract, it was found that the line as described in the deeds runs through the conner of a shed anneed to a hoter bunding on the land of Burliholder, both of which buildings had been erected by Moyer.

The defendant offered to prove by Isaac Gingrich, his predecessor in title and the immediate grantee from Moyer of the defendant's tract, that by the agreement of purchase between himself and Moye the hotel and shed were wholly upon the tract purchased by him and the boundary line in question was fixed upon the round by Moyer and himself from twelve to eighteen inches ontside the said shed so that the water falling from the roof of the shed would fall upon Gingrich's (now defendant's) land; that the end of the said line, as then rum by the surveyor on the ground, was marked by a stake and not a stone; and that the line, as subsequently described in the deeds, differs from that line as so fixed and marked on the ground. Objected to; objection sustained and offer rejected; exception.

The defendant also offered in evidence the deposition of Samuel Moyer and the court, upon objection, ruled out the portions of it which corroborated the facts stated in the above offer.

Verdict, guilty; damages assessed at $\$ 25$, and judgment thereon. The defendant took this writ of error, assiguing for error the rejection of said offer, and of the portions of the deposition.

Trunkey, J. Samuel Moyer, by deed dated April 10th, 1865, conveyed part of a tract of land to Isaac Gingrich, whose title has been vested in Burkholder. On the 10th of May following, Moyer conveyed another part of said tract to David Ober, which part is now vested in Markley. The line between these parcels, being the one in dispute, is described in the deeds as ruming from a post north nineteen degrees east, twenty-three perches and five-tenths, to a stone in the road. Both parties agree that this is a straight line. 'They also agree that a shed, built before Moyer conveyed, is still standing where it did at the time of the conveyances. Markley claims that the line, ascertained from the courses and distances set out in the deeds, passes through that shed so that a portion of it is on his land. Burliholder claims that after Moyer had orally agreed to sell to Gingrich, and before he made the deed to hin, there was an actual survey, that the line ran from a post direct to a stake, not less than twelve nor more than eighteen inches from the shed, and that the land was sold and bought by the parties with reference to said line. If Burkholder's claim be true, then, so far as the courses and distances in the deeds show a line differing from that, they must yield. 
The lines run and marked on the ground are the true survey and when they can be found will control the calls for a natural or other fixed boundary; and also constitute the boundaries in the grant where they differ from those produced by the courses and distances stated in the patent. This well-settled rule in cases of lands granted by the commonwealth, applies to grants by individuals. Blasdell v. Bissell, $6 \mathrm{~Pa}$. 258; Craft v. Yeaney, $66 \mathrm{~Pa}$. 210. In Craft v. Yeaney the testimony of the original grantor was received, the court below saying, "while it is true the deed cannot be changed, or construed, or affected by parol, it is competent to prove outside the deed that the calls in the deed are not on the ground, or that a line or boundary called for in the deed is in a different place from that contracted for by the parties, or that what is called the eastern line of warrant No. 4019 is not at the place sold and bought to." And that was held not to be errer.

Where a deed was for fifty acres of land, the quantity intended by both parties, described by existing lines on three sides, and called for a south "line to be run so far south from the north line, and parallel therewith, as to include fifty acres of land," it was held competent to prove that the line agreed upon by the parties as the south line was a fence, though it differed from the one produced by the description in the deed. The grantee objected to the deed because she did not know that fifty acres would run to the fence, but the grantor assured her that fifty acres would reach the fence, that the deed embraced it, and she accepted the deed. It was said to be of no consequence whether the grantor was aware that he was making a misrepresentation, if by it the grantee did what she would not have done and was injured. Bartle v. Vosbury, 3 Grant, Cas. 277. That decision rests on the principle that a line on the ground, fixed by the parties as the one sold and bought to controls calts or distances stated in the deed, wherever there is fraud or mistake. The cases enforcing and illustrating the application of this principle are numerous; it would be idle to cite additional.

It may frequently occur that the location of a line, which was agreed upon, cannot be determined for want of evidence. In such case the location is settled by the deed. The lines produced by the calls, courses and distances in the deed, are taken as correct, unless there be proof of a different line on the ground, which the grantor and grantee fixed as the true ane.

At the trial of this case considerable evidence was rightly received, tending to show that the parties fixed a line at the time of the sale, and its location on the ground. Other pertinent and material evidence for the same purpose was rejected, and for this the judgment must be reversed. We are of opinion that all of the offers of testimony, set forth in the several assignments of error, should have been admitted. Judgment reversed, and venire facias de novo awarded. ${ }^{10}$

10 See Emery v. Fowler, 38 Me. 99 (1854): Paxter v. Wilson, 95 N. C. 137 (1886); Kashman v. Parsons, 70 Conn. 295, 39 Atl. 179 (1S98). 


\section{HALL v. EATON.}

(Supreme Judicial Court of Massachusetts, 1S85. 139 Mass. 217, 29 N. E. 660.)

Writ of Entry to recover a lot of land in the city of Worcester. Plea, nul disseisin. Trial in the Superior Court, without a jury, before Blodgett, J., who allowed a bill of exceptions, in substance as follows:

The land in dispute was a triangular tract on the northerly side of Dix Street, marked on a plan used at the trial, a copy of which is printed in the margin, as "Demanded Premises." It appeared that all the land lying next northerly of Dix Street and between Wachusett Street on the east and Goulding Street on the west was formerly owned by Henry Goulding, and was divided into lots and sold by his executors. The tenants' lot was at the corner of Dix Street and IVachusett Street, and the demandant's lot was part of the lot next westerly, and the question was as to the westerly boundary of the tenants' lot and the easterly boundary of the demandant's lot, under the following deeds:

On February 20,1869, Goulding's executors conveyed the corner lot Tenas fo to Blackmer and Kelley, (under whom the tenants derive their title;) by the following description: "A certain lot of land situated in the city of Worcester, on the westerly side of Wachusett Street and northerly side of Dix Street bounded and described as follows, to wit: beginning at the southeasterly corner of the lot conveyed, and at the intersection of said streets; thence running northerly by Wachusett Strect one hundred and thirty-four feet, to land of the heirs of Henry Coulding; thence running westerly by land of the heirs of said Goulding, sixty feet; thence running southerly by land of said heirs at right angles to said Dix Street one hundred and twenty-five feet to Dix Street; thence running easterly by Dix Street sixty-one feet more or less to the first-mentioned bound, containing 7770 feet more or less."

On October \&, 1869, said executors conveyed the residue of the land

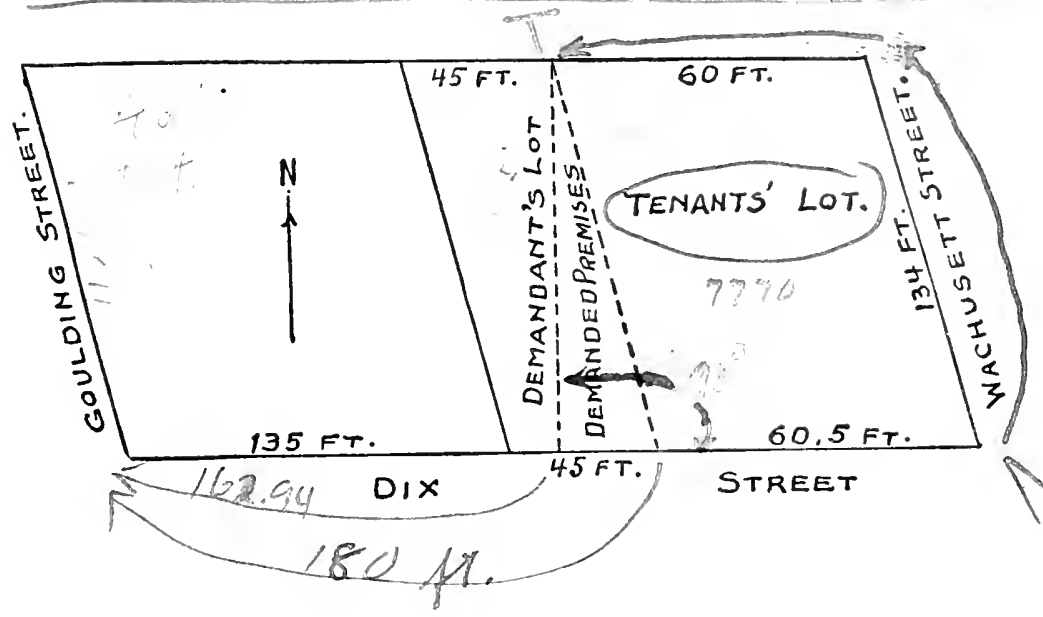


between the tenants' lot and Goulding 'Street to one Ling by a deed which contained the following description: "Lot of land on the northerly side of Dix Street, bounded as follows: beginning at the southeasterly corner of the lot at a corner of land of Kelley and Blackmer hand running westerly on Dix Street one humdred and eighty feet to a new street about to be made; thence turning and running not herly on said new street one hundred and twelve and a half feet, to land belonging to the estate of the late Henry Goulding; thence turning and running easterly on said Goulding estate one hundred and eighty feet, to land of Kelley and Blackmer; thence turning and running southerly on land of said Kelley and Blaclimer one hundred and twcinty-five feet, to the place of beginning on said Dix Street.

It was agreed that the new street referred to was Goulding Street, and the corner of Goulding Street and Dix Street was a known and fixed bound.

On May S, 1S71, King conveyed to the demandant a part of said lot, forty-five feet wide on Dix Street, bounded as follows: "beginning at the southeasterly corner thereof at corner of land of Kelley and Blackmer, and at a point one hundred and eighty feet distant from the easterly line of Goulding Street, thence northerly on land of Kelley and Blackmer one hundred and twenty-five feet, to land of the estate of Henry Goulding; thence westerly on said land of Goulding forty-five feet; thence southerly and parallel with the first-described line one hundred and twenty-five feet more or less, to said Dix Street; thence easterly on Dix Street forty-five feet, to the place of beginning."

The corner of Dix Street and Wachusett Street was a known and fixed bound, and the northerly line of Dix Street was a known and fixed line.

If the third line described in the deed of the executors to Blackmer and Kelley is drawn at right angles to Dix Street, it strikes a point on Dix Street eighty feet and fifty-two one-fiundredths of a foot from IVachusett Street, and one hundred and sixty-one feet and ninety-four one-hundredths of a foot from Goulding Street. In such case, the tenants line on Dix Street is eighty feet and fifty-two one-hundredths of a foot in length, and is shown by the westerly dotted line, and their lot contains 9101 square feet.

If the third line described in said deed to Blacknier and Kelley is drawn so as to strike Dix Street one hundred and eighty fcet easterly from Goulding Street, the tenants' line on Dix Street is sixty feet and a half in length, and their lot contains exactly 7770 square feet.

The demandant offered evidence tending to show that, before the several lots were sold by the executors of Henry Goulding, they prepared a plan of them, which was produced at the trial ; and it was testified by one of the exechifors, that the lots were sold by said plan. but there were no monuments at the corners of the lots when the deeds were given, and there was no evidence that Blackmer and Kelley saw the planbefore they took their deed Said plan showed the tenants lot 
to have a line of only sixty feet and a half on Dix Street, and showed that the westerly line did not make a right angle with Dix Street.

The demandant also offered evidence tending to show that, in the year 1876 , he erected a fence between his said lot and the tenants' lot (Kelley, who had bought Blackner's interest, then being the owner of the tenants' lot,) and by Kelley's consent it was placed on the line a claimed by the demandant, and remained there several years, and untif removed by the tenants a short time before this suit was brought.

The demandant asked the judge to rule that it was a question of fact. on all the evidence, whether the tenants' westerly line was to be drawn at right angles to Dix Street, and asked a finding in fact that it was to be drawn at an angle to said Dix Street, so as to strike said street sixty and a half feet from Wachusett Street. The judge ruled, as matter of law, that the said line was to be drawn at a right angle to Dix Street, without regard to the evidence outside of the deeds; and found for the tenants. The demandant alleged exceptions.

W. Altex, J. The courses of the lines on Vachusett Street and Dix Street are fixed on the land, and fix the angle contained by them. There is nothing on the land to fix the course of the second or of the third line, for it does not appear that the line of the land of the heirs of Henry Goulding mentioned is fixed. The description in the deed gives the length of the first, second, and third lines, which there is nothing to control, and the angle contained by the third and fourth lines. There is no diffeculty in locating this description upon the land, and it makes the length of the fourth line eighty feet and fifty-two onehundredths of a foot, and the contents of the lot 9101 square feet. The description in the deed gives the length of the fourth line as "sixtyone feet more or less," and the contents of the lot as "7770 feet more or less." This discrepancy of one third in the length of the front line of the lot, and one fifth in its contents, could not have becn intended, although the length and dimensions are only approximately given, and it is obvious that there is a mistake, either in the angle given, or in the length of the fourth line

We do not regard the statement of the quantity of the land as very material. It is the computation of the contents of the figure described in the deed, but which cannot be produced on the land. The fact that to give exactly the quantity of land mentioned when the other particulars of the description are applied to the land, the third line nuust intersect the fourth at an obtuse angle, and the fourth line must be sixty feet and a half in length, goes to show, what is otherwise sufficiently apparent, that no such discrepancy in the length was intended. There was a mistake either in the angle given or in the length of the fourth line: they cannot both be applied to the land, though either of them may be, and the question is which must be rejected.

The question to be determined is the intention shown in the language of the deed, in the light of the situation of the land and the circumstances of the transaction, and sometimes $w$ ith the aid of declarations

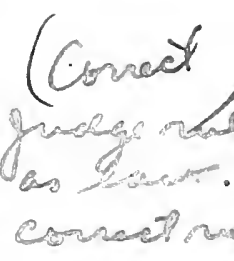


and conduct of the parties in relation to the subject-matter. The rule that monuments, in a description in a deed, control courses and distances, is founded on the consideration that that construction is more likely to express the intention of the parties. The intention to run a line to a fixed object is more obvious, and the parties are less likely to be mistaken in regard to it than in running a given distance or by a given course. But, where the circumstances show that the controlling intention was otherwise, the rule is not applied. Davis v. Rainsford, 17 Mass. 207; Parks v. Loonis, 6 Gray, 467 ; Murdock v. Chapman, 9 Gray, 156. So far as the question is as to the relative effect to be given to a course and a distance, neither has in itself any advantage over the other as showing a governing intent. Whether the one in a given case shall outweigh the other, as showing the intention of the parties, must (lejend upon the circumstances existing at the time.

The angle formed by Dix Street and Wachusett Street is an acute angle; the lot was a corner lot, the front on Dix Street. In laying it out, it would be natural either to have the third line in the description parallel to Wachusett Street, or at a right angle with Dix Street. The latter is for the advantage of the purchasers. The deed shows that the parties had that, and not the other, in mind. Not only is the third line not said to be parallel with Wachusett Street, but it appears that if was not intended to be. The parties understood that the angle at the corner of the streets was an acute angle, and that making the other angle on Dix Strect a right angle, would require the line on that street to be longer than the rear line, and they said that the angle should be a right angle, and therefore that the line should be longer. It was not merely giving a course to the third line, but it was expressly fixing the shape of the lot. The length of the fourth line was left indefinite, and to be determined by the angle which was fixed. It is true that the given angle requires a longer line than was supposed; but the angle and the shape of the lot, and not the length of the line, appear to have been the controlling considerations. See Noble v. Googins, 99 Mass. 231.

It is contended by the plaintiff, that it is a case of latent ambiguity, which may be explained by parol evidence. If the difference were between a given course of the third line and measurement of the fourth, it might present such a case, but neither is given. The course of the third line was not run, but it was to intersect Dix Street at a right angle; the fourth line was not measured, but its length was estimated, and apparently estimated as the distance between the point where the third line must meet Dix Street to form a right angle with it and the first corner. A mistake was made in the estimate of the distance. It would seem that the angle was so material a particular in the description of the lot, that the expressed intention in regard to it could not be made doubtful by a mistake in the estimate of the length of the fourth line, which was determined by it; but it is not necessary to decide this. As. the case stood at the trial, and upon the evidence offered, the court 
properly ruled that as matter of law, the third line was to be at a right angle with Dix Street, without regard to the evidence outside the deed.

The plaintiff relied upon evidence that the executors of Goulding, before the lot was sold, made a plan of this and other lots, by which it appeared that the fourth line was sixty feet and a half in length, and that the angle formed by the third line and Dix Street was an obtuse angle. This plan is not referred to in the deed, and was not seen by the purchasers. The only effect of this evidence would be to show that the grantors knew that the lot described in the deed did not correspond with the one on the plan, and did not inform the grantees.

Eight months after the conveyance to Blackmer and Kelley, the executors conveyed to one King the adjoining lot on Dix Street, extending westerly to a way to be laid out, called Goulding street, bounding easterly on the land of Blackmer and Kelley and the line on Dix Street, and the rear lines being each one hundred and eighty feet in length. This evidence may tend to show that the executors intended that the third line of the Blackmer and Kelley lot should be parallel with Goulding Street, but such intention was not known to Blackmer and Kelley, and was not expressed or indicated in the deed to them. The demandant also relied upon evidence that King afterwards conveyed to the demandant a lot adjoining Blackmer and Kelley, described as beginning at a corner of their land on Dix Street one hundred and eighty feet from Goulding Street,and that several years after, and seven years after the conveyance to Blackmer and Kelley, and after Kelley had acquired Blackmer's interest, the demandant put up a fence between his lot and Kelley's, and, with Kelley's consent, put it on the line now claimed by the demandant, where it remained for several years.

We do not see that any of this evidence is competent to control the construction indicated by the deed itself. It is not sufficient to show a practical construction of the deed by the parties to it, nor an admission by the tenants grantor which can bind the tenants, nor a mutual agreement as to the boundary, and occupation accordinglv. See Liverpool Wharf v. Prescott, 7 Allen, 494; Miles v. Barrows, 122 Mass. 579; Lovejoy v. Lovett, 124 Mass. 270. Whether evidence of the construction of the deed by the acts of the parties by locating the third line on the land, or fixing the point of its intersection with Dix Street by a monument or otherwise, would present a question for the jury, we need not consider, because the evidence offered was not sufficient to show such acts, and the question presented was one of law upon the construction of the deed.

A majority of the court are of opinion that the ruling excepted to was correct.

Exceptions overruled.
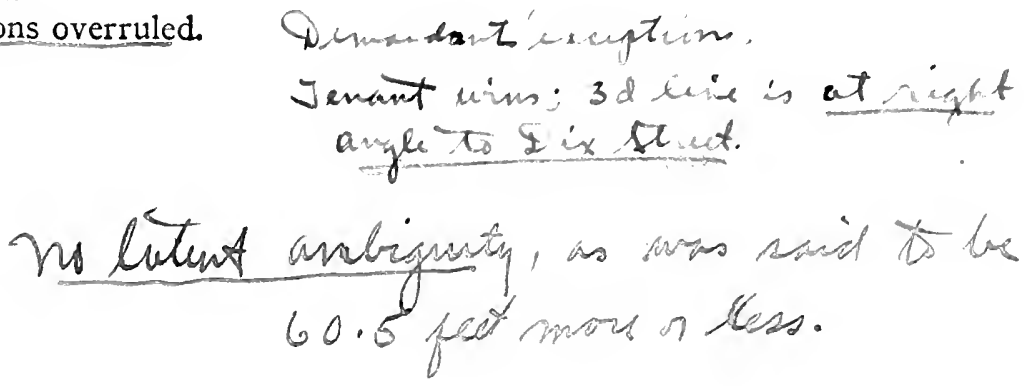


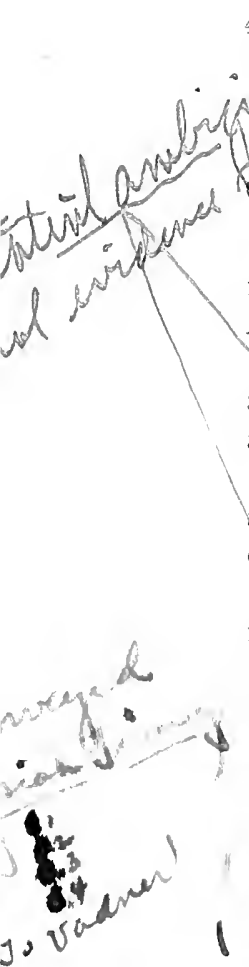

\section{TEMPLE v. BENSON.}

(supreme Judicial Court of Massachusetts, 1912. 213 Mass. 12S, 100 N. E. 63.)

Tetition, filed in the Land Court on September S, 1910, for the registration of the title to certain land on East Quincy Street in Norih Adams.

In the Land Court the case was heard by Davis, J. 'The only issue at the trial was the position of the southerly line of the petitioner's land as shown on the slietch on the next page.

In $18-0$ one Sylvester A. Kemp owned land which included the locus and land immediately east and sotith of it shown on the plan as land of the respondent, and conveyed to one Josiah Tinney the locus and the lot east of it by a deed with the following description: "Situate near the North Village of North Adams, bounded and described as follorns, to wit: Commencing on the south side of East Quincy Street, so called, at the point of its intersection with Mechanic Street now Summit Avenue), so called; thence south 12 degrees west on the west side of a contemplated street, six rods to a stake and stones; thence westerly eight rods to land of J. M. Ganedy; thence northerly on lands of J. M. Canedy and Mrs. Porter bseven rods to East Quincy Street; thence easterly on the sonth side of said street, about eight and onefourth rods, to the place of beginning."

The same premises were conveyed by four mesne conveyances to one Samuel Vadner, who received them in 1855, all the deeds containing the same description as that given above.

In 1887 Kemp conveyed to the respondent land south of that previously described, by a deed containing the following description: "Beginning on the west side of Summit Avenue, at the southeast corner of land of Samuel Vadner, ruming westerly on the south line of said Vadner's land, eight rods to land of Charles Tower (formerly of L.M. Canedy); thence southerly on said Tower's land, sixty fcet; thence, easterly cight rods to Sumnit Avenue, thence northerly on the west side of Summit Avenue, sixty feet to the place of beginning."

On June 1, 1890, Vadner conveyed to the respondent the lot east of the locus by a deed with the following description: "Commencing at the northeast corner of lands of said Benson, on the west side of Summit Avenue; thence running northerly on the west line of Summit Avenue, about six rods to East Quincy Street; thence westerly on East Quncy Street, sixty feet to stake and stones; thence southerly on line parallel with the first mentioned line, about six rods,-to land of said grantee; thence easterly on land of said Benson, sixty fect to place of beginning,"

In 1894 Vadner conveyed the locus to the petitioner by a deed containing the following description: "Beginning on the sonth side of Tast Quincy Street, so called, at a point of its intersection with Mechanic Street (now Summit Avenue), so called; thence south twelve 


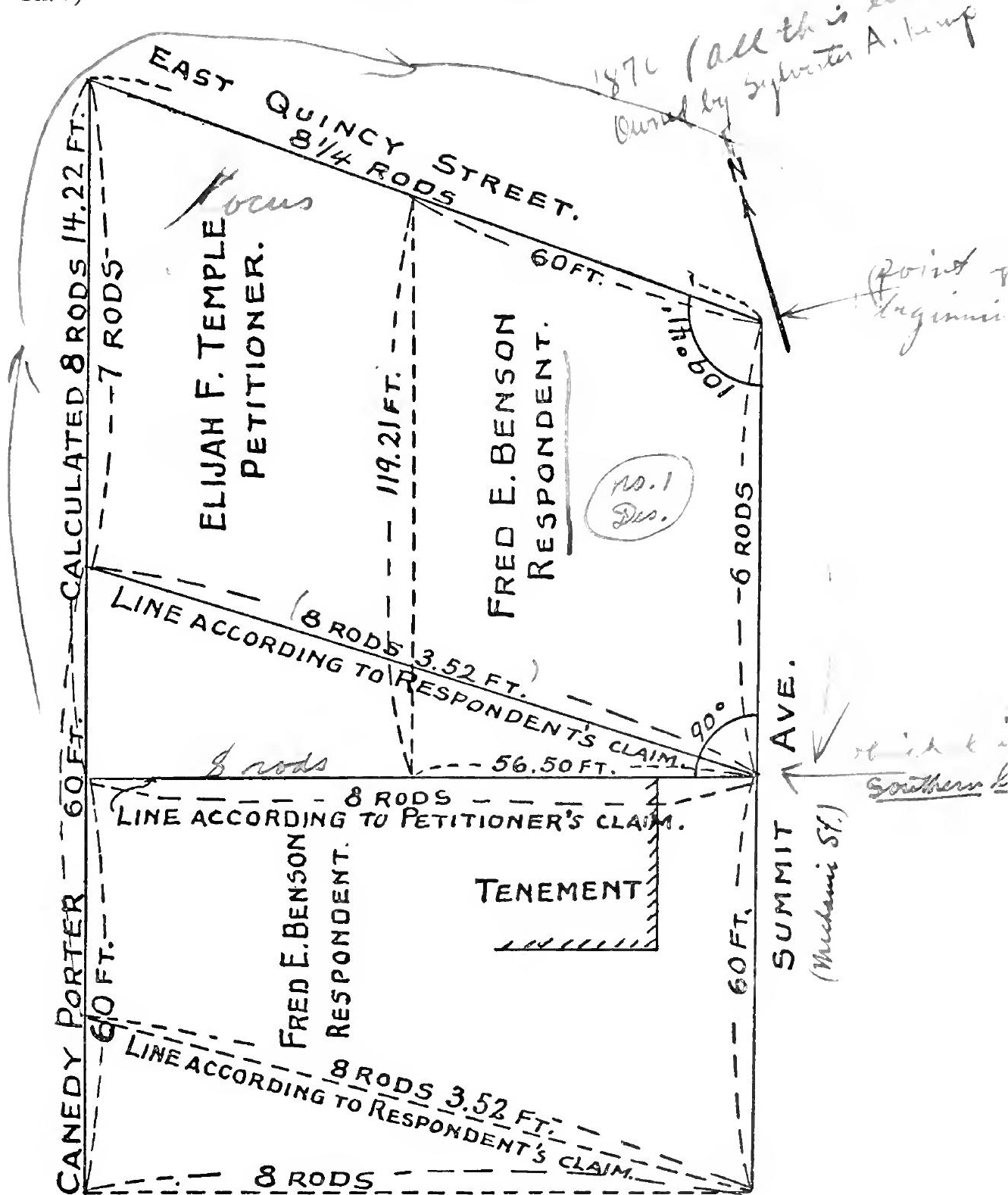

LINEACCORDING TOPETITIONER'S CLAIM.

degrees west, on the west side of a contemplated street, six rods to a stake and stones; thence westerly eight rods, to land formerly owned by J. M. Canedy; thence northerly on said land and land of Mrs. Porter, seven rods to said East Quincy Street; thence easterly on the south AIG.PRop. -27 
side of said street, about eight and ore-fourth rods to place of beginning, except what I have sold pertaining to this lot of land to Fred E. Benson, of said North Adams, with deed dated June 1st, $1890 . "$

In 1870 neither East Quincy Street nor Summit Avenue was a public street. Kemp had opened East Quincy Street as a private way. After 1879 both streets were public streets, East Quincy Street being two rods wide. The bill of exceptions states: "The point of intersection of Eası Quincy Street, and Mechanic Street, or Summit Avenue, in July, 1870, was agreed to as the point marked on the annexed sketch, at the northeast corner of the lot at the intersection of East Quincy Street and Mechanic Street and has never been changed and is the point of intersection of the south line of East Quincy Street and west line of Summit Avenue, as laid out by the City of North Adams, in 1879."

The westerly boundary line of the locus was fixed by a stone wall which was parallel to Summit Avenue.

The petitioner contended that the southerly line of East Quincy Street as laid out by North Adams was in a different location from the southerly line of East Quincy Street as it was understood to be before that time. The respondent contended that that line had not been changed. Both parties offered evidence in support of their contentions.

The judge ruled as follows, subject to an exception by the respondent: "The description in the petitioner's deed cannot as a physical matter be literally applied in all its details to the ground. If the westerly end of the southerly line be taken as contended for by the respondent at a point on the Canedy land distant exactly seven rods from the southerly line of East Quincy Street, then the southerly line will exceed eight rods in length. If on the other hand the westerly end of said southerly line be taken at a point on the Canedy land distant exactly eight rods from its point of departure, on the westerly line of Summit Avenue, then the westerly line on land of Canedy and Porter will exceed seven rods in length. * * * I rule that the deed is ambiguolus."

Subject to an exception by the respondent, the judge admitted in evidence, "so far as it tended to show the location of East Quincy Street," a deed by Kemp to one Frost dated in 1872. According to the description in the deed, the north line of East Quincy Street extended over the east side of Summit Avenue and ran south 79 degrees east. and the street was three rods wide through the land of Porter.

Subject to a further exception by the respondent, the judge allowed Tinney, called by the petitioner, to testify, "that at the time he bought his Tand, previously described, from Kemp and before the deed was drawn, he went on the ground with Kemp; that they began at the northeast corner of the lot he was to buy, at the corner of Summit Avenue and East Quincy Street, and measured south on Summit Avenue, six rods; that from there they turned a right angle, because Kemp stated he wanted 'to measure at right angles so that all the lots would come 
square,' and measured eight rods to the old stone wall on Canedy land; that they then measured down the line of Canedy land seven rods and stopped there, in order, Kemp said, to leave room for a street, Kemp stating he might throw the street to the north or to the south, and that he would deed by the street so that if the street went to the nor th Tinney would be the gainer; that the measurements stopped about one rod short of the nearest wheel track, and that two or three days later the deed was drawn, executed and delivered."

The judge found for the petitioner; and the respondent alleged exceptions.

Braley, J. The petitioner by mesne conveyances and the respondent by direct grant derive title to their respective lands which are contiguous on the south from a common grantor Sylvester A. Kemp, and as the duly recorded deed from him to Joseph Tinney under whom the petitioner claims, antedates his deed to the respondent, it follows upon comparison of the descriptions, that when the position of the disputed southerly line of the petitioner's lot has been ascertaned the northerly line of the respondent's lot also will have been defined, and the controversy determined.

It is a familiar rule in the construction of deeds, that, where the land conveyed is described by courses and distances and also by monuments which are certain or capable of being made certain, the monuments govern, and the measurements if they do not correspond must yield. Howe v. Bass, 2 Mass. 380, 3 Am. Dec. 59; Pernam v. Wead, 6 Mass. 131 ; Mann v. Dunham, 5 Gray, 511, 514; George v. Wood, 7 Allen, 14; Morse v. Rogers, 118 Mass. 572, 578; Percival v. Chase, 182 Mass. 371,65 N. E. 8C0. In its application natural or permanent objects, such as streams or rivers and the shore of the sea, or highways or other lands, or artificial land marks or signs such as fences, walls, a line, a building, or a stake and stones, are to be treated as monuments or boundaries. Storer v. Freeman, 6 Mass. 435, 4 Am. Dec. 155; King v. King, 7 Mass. 496; Flagg v. Thurston, 13 Pick. 145; Whitman v. Boston \& Maine Railroad, 3 Allen, 133; Paine v. Woods, 108 Mass. 160; Boston v. Richardson, 13 Allen, 146; Needham v. Judson, 101 Mass. 155; Pernam v. IVead, 6 Mass. 131 ; Smith v. Smith, 110 Mass. 302; Charlestown v. Tufts, 111 Mass. 348; Frost v. Angier, 127 Mass. 212. And their identity may be established by extrinsic evidence. White v. Bliss, 8 Cush. 510, 512. The only exception recognized is, where, by strict adherence to monuments, the construction is plainly inconsistent with the intention of the parties as expressed by all the terms of the grant. Davis v. Rainsford, 17 Mass. 207; Murdock v. Chapman, 9 Gray, 156; George v. Wood, 7 Allen, 14.

The petitioner had the burden of proving himself entitled to registration of the premises as described in the application. Bigelow Carpet Co. v. Wiggin, 209 Mass. 542,95 N. E. 938.

On the face of the deed no uncertainty as to the distances or the location of the monuments or boundaries is disclosed, yet upon applying 
the description to the land it became apparent that the southerly line must run at a right angle westerly from the stakes and stones in the west side of Summit Avenue "to land formerly owned by J. M. Canedy" or the call for a distance of eight rods cannot be satisfied. But if, as claimed by the respondent, this line should run from the stake and stones to the Canedy land, the abuttal or boundary on the west, at a point distant seven rods from the south side of East Quincy Street, the boundary on the north, it would exceed eight rods, and the area of the petitioner's land called for by his deed would fall correspondingly short, as is clearly shown by the first sketch or plan forming part of the exceptions.

The parties agreed that, as marked on the plan, the starting point of the lot was the northeast corner at the intersection of East Quincy Street with Summit Avenue, which never had been changed, and the respondent's exception to the admission of the deed of Kemp to Pattie D. Frost would seem to have become immaterial. It was, however, properly admitted. At the date of the deed to Frost East Quincy Street, althongh a private way opened by the grantor was a boundary common to the land conveyed to her as well as to the tract, a part of which was later deeded to the respondent, and grants of adjacent premises even between strangers are admissible where the location of the land for which registration is sought is in dispute. Sparhawk v. Bullard, 1 Metc. 95, 100; Devine v. Wyman, 131 Nass. 73.

The northerly boundary and point of beginning being certain, the easterly boundary was the west side of the avenue, measuring six rods to a stake and stones. The termini and length of the first course were thus fixed, and the stake and stones from which the second or southerly course starts locates and controls the easterly end. No further description is given, and the presumption is that this course, whatever the interior angle may be, ran straight to the land on the west, although it conld not be deflected by parol evidence to a point north of the Canedy land. Allen v. Kingsbury, 16 Pick. 235; Jenks v. Morgan, 6 Gray, 448; Hovey v. Sawyer, 5 Allen, 554, 555. Henshaw v. Mullens, 121 Mass. 143. The angle of departure however is not given, and, as the southerly line claimed by each party is not irregular, but when projected extended directly from landmark to landmark, a material discrepancy in the measurement of the third or westerly course would be caused whichever position is taken. A latent ambiguity, as the judge properly ruled, had been developed which could be removed only by proof of extrinsic facts. Frost v. Spaulding, 19 Pick. 445, $31 \mathrm{Am}$. Dec. 150; Stone v. Clark, 1 Metc. 378, 35 Am. Dec. 370; Stevenson v. Erskine, 99 Mass. 367 ; Miles v. Barrows, 122 Mass. 579; Graves v. Broughton, 185 Mass. 174, 69 N. E. 1083; Haskell v. Friend, 196 Mass. 198, 81 N. E. 962 ; Weeks v. Brooks, 205 Mass. 458, 462, 463, 92 N. E. 45. Compare Hall v. Eaton, 139 Mass. 217, 29 N. E. 660.

It appears from the chain of title that Kemp, when the owner of the entire tract shown by the plan, first conveyed the portion lying north- 
erly of the respondent's land to Joseph Tinney, and the declarations of Kemp to Tinney made while measuring the land, and contemporaneous with the giving of the deed, "that from there," meaning the stake and stones, "they turned a right angle because Kemp stated he wanted to measure at right angles so that all the lots would come square, and measured eight rods to the old stone wall on the Canedy land," was clearly admissible. Abbott v. Walker, 204 Mass. 71, 73, 90 N. E. 405, 26 L.R. A. (N. S.) 814 ; Blake v. Everett, 1 Allen, 24S; Davis v. Sherman, 7 Gray, 291. The subsequent conveyance of Kemp to the respondent also shows a rectangular lot, and the description is confirmatory of the grantor's previously expressed purpose in fixing the shape of the lots, that the respondent's northerly line should run at a right angle with the westerty side of Summit Avenue, and not at an acute angle as the respondent contends.

The adverse finding of fact of which the respondent complains, that the southerly line should be established as contended for by the petitioner, having been warranted by the evidence, is conclusive, and the decision that the petitioner had the right to have his title confirmed and registered as described in the application shows no error of law. American Malting Co. v. Souther Brewing Co., 19+ Mass. 89, 80 N. E. 526; Rev. Laws, c. 128, § 37.

Exceptions overruled.

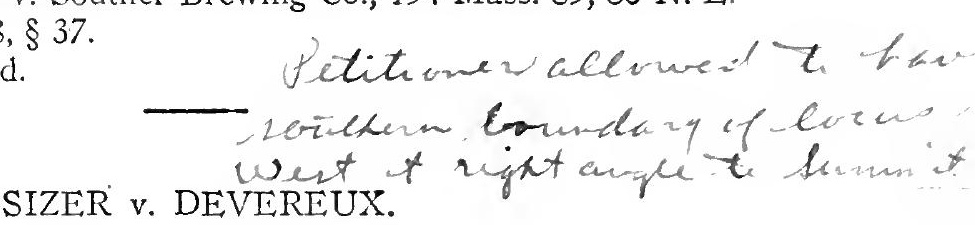

(Supreme Court of New York, 1853. 16 Larb. 160.)

This action was brought to recover an undivided fourteenth part of so much of the land covered by the Devereux block in the city of Utica, as lies within the original lines of Hotel street. On the trial, at the Oneida circuit, in October, 1851, before Justice Gridley, the defendant's counsel, at the close of the testimony on both sides, moved for a nonsuit. The justice granted it; remarking, among other things, that as it appeared by the map referred to in the description of the lands conveyed by the original deeds of 94 and 95 , that those lots lay upon the easterly line of Hotel street, a conveyance of the lots by the description and reference contained in the deed, gave to the grantee the land lying between the lots and the middle of the street. The plaintiffs excepted, and on a bill of exceptions, moved for a new trial.

Gridley, J. Mrs. Sizer, one of the plaintiffs, is one of the heirs at law of John Mappa, deceased; and she seeks to recover in this action, for her share as such, the one-fourteenth part of a piece of land covered by a part of the building known as the Devereux block; and being a part of Hotel street, in the city of Utica. The defendant owns the premises situated on both sides of the street opposite the piece of land in question. The plaintiff, however, insists that her ancestor never 
parted with the legal title to the site of the street; and that she, as his heir, is entitled to recover in this action her interest in it. Several questions were discussed on the argument, which we do not propose to examine. The case, we think, may be disposed of, without reference to them.

Hotel street, in the city of Utica, was laid out as a public highway, and recorded in the office of the town clerk of the town of Whitestown, on the sixth day of April, 1801. Previous to the laying out of this highway, the proprietors of the tract had procured a survey to be made, and a map to be constructed, by Calvin Guiteau, and filed with the clerk of the court in which a space was laid off, for Hotel street; and lots were laid out upon it ; from which map sales were made to purchasers, and the lots were described in the deeds by reference to that map and survey. The premises in question consisted of parts of village lots 94 and 95, as designated on the map; and were respectively described as follows, in two deeds executed by the original proprietors, which title has descended through several mesne conveyances to the defendant, as was admitted on the trial. The deed conveying lot 94, bears date on the twenty-eighth day of April, 1803, in which the premises conveyed are described in the following manner: "All that certain piece or parcel of land situate, lying and being in the village of Utica, county of Oneida, and state of New York, known and distinguished by a survey made thereof by Calvin Guiteau, in the vear one thousand seven hundred and ninety-eight, and on a map of said land filed in the clerk's office of the county, by lot 94 . Beginning at the S. E. corner of No. 93, and runs from thence north fifty-three degrees and fourteen minutes, W. fifty-seven feet. Thence S. 36 degrees 15 minutes, W. sixty feet. Thence south fifty-three degrees fifteen seconds, East twenty-nine feet, to the Genesee road. Then No. sixty degrees East along the side of the same, to the place of beginning." Lot No. 95 was convered by deed, bearing date September $24 \mathrm{th}, 1802$, in which the premises were described as "All that certain lot or piece of ground situated in the village of Utica, and county of Oneida, known by a survey made thereof by Calvin Guiteau, in the year one thousand seven hundred and ninetyeight, by lot No. 95. Beginning at the S. E. corner of 94, runs thence north 53 degrees 45 minutes $W$. twenty-nine feet; thence S. thirty-six degrees 15 minutes west, sixty-four feet, to the Genesee road; thence along the side of the same $\mathrm{N}$. sixty degrees $\mathrm{E}$. to the place of beginning." It will be observed that though Genesee street is named in these deeds, and the boundary of the lands described is stated to run along the side of the Genesee road, yet Hotel street is not named in either of them; but the boundary of the lots is described as running a certain course for a certain distance, referring to the survey and map on file; which, on inspection, show these lots bounded on the space laid out as Hotel street; which descriptions are, by the settled constructions, to be read as though the boundary had been described as running "to Hotel street, and along the said street," on the given courses, and for 
the given distances. This is a significant distinction, and as we shall see by and by, is quite decisive of the rights of the parties in this cause.

We are to inquire what is the legal construction of deeds which describe the boundaries, adjacent to Hotel street, by courses and distances merely. Does such a description convey the land to the center of Hotel street, or does it convey the land only up to the eastern side of it? We believe the uniform construction of words, such as are employed in this description is, that the conveyance extends to the center of the highway. Such words as are used to describe the premises on the side next Hotel street, not only have never been construed to limit the grant to the side of the street, but have been uniformly regarded by the courts as a conveyance to the center of the street. The general rule on this subject is laid down in Kent's Commentaries, (3 vol. 432,) in these words: "The law with respect to public highways and to fresh water rivers, is the same. The owners of the land on each side go to the center of the road." The language of the court in Jackson v. Hathaway, 15 John. $454,8 \mathrm{Am}$. Dec. 263, and the same is re-affirmed in the court for the correction of errors, in Child v. Starr, 4 Hill, 369, is as follows: "Where a farm is bounded along a highway, or upon a highway, or is described as running to a highway, there is reason to intend that the parties meant the middie of the highway." Ch. Kent says, (supra,) "The idea of an intention in a grantor to withlhold his interest in a road to the middle of it, after parting with all his right to the adjoining land, is never to be presumed; it would be contrary to universal practice." Nevertheless a grant may be so worded as to exclude the highway from the terms of the conveyance. And it was held in Child v. Starr, 4 Hill, 369 , and 5 Denio, 600, that where land is described as running to the side of a road, or to the bank of a river, and then along the side of the road or bank the road or bank is excluded by the terms of the grant. We see, therefore, that when premises are described as running "to a road, and along a road," the grant includes the road to the center; whereas, if the boundary were to the side of the road, and along the side of the road, the road is excluded, by the terms of the conveyance. The description of the lots in question, on the side of Genesce street, running to the side of the street, and along the side of the street, conveys no part of that street. That was a turnpike road; and the proprietors did not own it, and had no right to convey it; and hence the significant phraseology of the deed. The fact was not so, however, with respect to Hotel street. The proprietors owned the soil of that street, and they adopt a description which by the established construction of the words carries the grantee to the center of that street. The boundary on the side of Hotel street is equivalent to a description in words of premises running "to Hotel street and along Hotel street." It is fixed by courses and distances, without naming Hotel street at all. And in just such a case as this, the very point was decided by the supreme court of Connecticut, in the case of Champlin v. Pendleton, 13 Conn. 23, 25, 27. The question was, wheth-
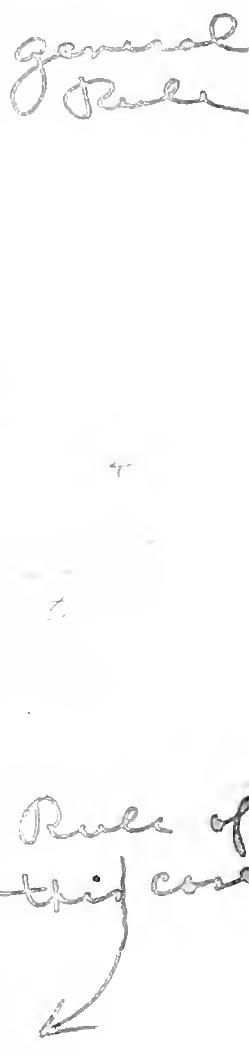
er a line not described as running on a street, but which was proved on the trial to run on a street, in fact, was to be construed as carrying the grant to the middle of such street, and the court held that it should be so construed. The court, after saying that the general principle was, that a description which carried the boundary "to a street, and along a street," embraced the street, to the center of it, proceeded to lay down the doctrine that where it turns out in the evidence that the courses and distances given in a deed do, in fact, carry the boundary to a street, and along that street, it is the same in law as though it were expressed in words.

Applying that principle to the case at bar, we see that the courses and distances given in the deeds do, in fact, carry the boundary to Hotel street, and along Hotel street. It follows therefore that it is in law the same as though the boundary were described to run "to Hotel street, and along Hotel street," in words. The consequence is, that by the settled construction of the words and phrases used in describing the premises adjacent to Hotel street, the grant is carried to the center of that street

There is another view of this question that leads to the same conclusion and is equally conclusive in favor of the defendant. The description refers to the map made by Calvin Guiteau and on file in the office of the clerk of the county. That map is in evidence, and exhibits the premises in question as lying adjacent to Hotel street. This map therefore is, by legal intendment, a description of the premises as bounded on Hotel street, and demands a construction precisely the same as though the description was so written out in words. This principle is stated and illustrated in the case of Varick v. Smith, 9 Paige, 550, 553, where the premises, which consisted of two separate pieces of land, were described, the one as "lot No. 7 laid down and delineated on a map filed, \&c., as adjacent and extending to the Oswego river;" and the other as "blocks No. 78, 90, 99, 103 of the village of West Oswego as the same have been surveyed and designated on the map of the said village filed in the office of the secretary of state." The vice chancellor, in his opinion, in discussing this point, uses the following language: "An exemplified copy of the said map has been given in evidence, which exhibits these blocks as adjoining the river, which I consider as equivalent to a description that in terms bounds them on the river." This position of the vice chancellor was denied by the counsel of the defendant, on the argument of the appeal. But the chancellor affirmed the doctrine asserted by the vice chancellor, and said: "The patent for No. 7 refers for its location to the map of the township of Hannibal, filed in the surveyor general's office, and upon that map the lot is bounded generally on the Oswego or Onondaga rivers. This is the same, therefore, as if the patent had in terms bounded the land granted by the river, without restriction or limitation, which would legally have carried the grant to the center of the stream." "The patent for the blocks in West Oswego also refers in the same 
manner, to a map on file in the office of the secretary of state, which map bounds these blocks on the river, without restriction." This case is therefore a direct and conclusive authority in favor of the principle on which the question in this case turns.

There is only one objection to this result, which remains to be considered; and that is the fact that the distance given in the deeds would only carry the grant to the side of Hotel street, instead of carrying it to the center. This objection, it will be seen, is founded on the idea that whenever it appears by the express words of the grant, or by a map which exhibits the premises as running to the road, the road itself is excluded. This we have already seen to be an error. The road or street is in the nature of a monument, and overrides and controls the courses and distances; and by a fixed and settled construction premises described as running to a road are carried by the conveyance itself to the center of the highway. The case of Herring v. Fisher, $3 \mathrm{~N}$. Y. Super. Ct. 344, 348, illustrates and answers the objection founded on both these grounds. The deed in that case stated the premises as beginning at a certain road and running along the road. Oakley, Ch. J., after laying down the general rule to which we have adverted, proceeds to remark that "if the deed of lot No. 9 had in express terms declared the boundary to begin at the side of the road, still by virtue of the following words 'running along the road,' the line must be held to run along the center of the roal. The plaintiff, however, contends that there are two circumstances that tend to indicate an intention to exclude the road. It refers to the nap; and by the map the road is laid down coloredred, and the land appears to run up to the road and not to the center of it; and secondly, that the distance given of the line of the prenises running to the road, would exclude the road. But as to the latter circumstance it is of little moment. 'The distances can never be safely relied on as affording the means of correctly locating the land; and they are resorted to only when other means fail, as courses and monuments. But the propriety of this rule is strongly illustrated in the present instance. Two of the lines of lot No. 9 are incorrectly given." "As to the map we do not consider it can affect the construction of the deed. It is not usual, when a nuap is made of a farm bounded by a road, to include any part of the road within the lines. The principal object of the map is to show the extent of the beneficial ownership of the proprietor, and of his right to exclusive occupancy. When a map has a road forming one of the sides of a farm, in judgment of law it includes one-half the road though the line marled on the map would seem to exclude it. A map in this respect is like a deed." See also the same principle put forth in Hammond v. McLachlan, 3 N. Y. Super. Ct. 323. This seems to dispose of the objections we have been considering. There are other questions-as, whether ejectment, being a possessory action, will lie for part of a street, and also the questions arising on the dedication of the road to the public, 
and the implied exclusion of all right of the plaintiff to take possession of it if he should recover it. But we do not deem it necessary to discuss these questions.

New trial denied. ${ }^{11}$

\section{BANGOR HOUSE PROPRIETARY v. BROWN.}

(Supreme Judicial Court of Maine, 1551. 33 Me. 309.)

Trespass for tapping the plaintiff's aqueduct and drawing water therefrom.

In 1829 , the proprietors of a tract of land, in the city of Bangor, caused one Bradley to draw a plan of it and to designate streets and building-lots thereon. They then recorded the plan in the registry of deeds.

Soon after the plan was made, one of said streets, now called Centre strcet, was built by said proprietors, but it has not been kept in repair, and only one part of it is used as a street.

The lot No. 17, bounded southerly on Centre street, "as laid down in said plan," was conveyed in 1832, by the proprietors to Elliott Valentine. A part of No. 17 , and bounded on the street, is now owned by the defendant under that conveyance, and his divelling house stands upon it. A portion of Centre street, remote from the defendant's house, and

11 See Com'rs for Land Tax $r$. Railway Co., [1913] A. C. 364, 379, where the land conveyed was desimated as colored pink on a nap, the said colored portion extending only to the side of the high:way.

"Incler the rule established by this court, as well as of other courts cited helow, the important fact in the conreyance which raises the presumption of an intent to convey the bed of a navigable stream, or the street or highway, in front of the land conveyed, is that the side of the street or highway, or the bank of the navigable stream, is in fact the bolmdary on the side of the lands described in the deed next to such street or stream, or that such side of the street or bank of the stream is included within the boundaries nentioned in the deed on the side next thereto, althoush the line of the tract as described in the deed mas extend bejond the side of the street or bank of the river into the street or river. The tact that the line of the tract of land convered as lescribed in the deed is a straight line from point to point, by course and distance, on the side next the river or street, and that no mention is made of the river or street, does not, of itself, overcome the presumption of an intent to convey to the center of the river or street, if such line be in fact substantially concident with the side of the street or the bank of the river, and extends to or into such river or street," Norcross $\nabla$. Griffiths, 65 Wis. 599, 610, 27 N. W. 606,56 Am. Rep. 642 (1586), per Taylor, J. The case involved the boundary on a stream, the description by metes and bounds extending to the stream, but not mentioning it. Railway Co. v. Platt, 53 Ohio St. 254, 41 N. E. 243, 29 L. R. A. 52 (1895), acc.

As to boundaries on railroad rights of way, see Center Bridge Co. v. Wheeler, S6 Conu. 585, 86 Atl. 11 (1913); Maynard v. Weelss, 41 Vt. 617 (1S6S).

As to boundaries on canals, see Goodyear v. Shanahan, 43 Conn. 201 (1875); Lawson v. Mowry, $52 \mathrm{~W}$ is. 219,9 N. W. 280 (1S81).

As to boundaries on natural ponds, see School Trustees v. Schroll, 120 Ill. 509,12 N. E. 243,60 Am. Rep. 575 (1SS7); Hardin v. Jordan, 140 U. S. 371,11 sinp. Ct. Sos, s98, 35 I. I. 428 (1S91). See, also, Lowell v. Robinson, 16 Me. $357,33 \mathrm{Am}$. Dec. 671 (1839), where the pond was formed by a mill dam. CH. Boardman v. Scott, 102 Ga. 404,30 S. 1. 9s2, 51 L. R. A. 178 (1S97). 
that portion only, has been laid out and accepted by the city, as a public street.

In 1834, the plaintiffs laid an aqueduct, running along in Centre street, at the depth of six feet below the surface, to the cellar of their hotel,

The evidence proved that the defendant cut the aqueduct pipe, lying within the northern half of the street, and in front of his own house.

The defendant contended, that as his premises were bounded upon the street, his title extencled to the centre of it, and gave him a right to tap, and even to remove the aqueduct. The Judge ruled that the defense was not made out, and the defendant excepted.

SHEPley, C. J. An aqueduct, owned by the plaintiffs appears to have passed through a street, formerly called Centre street, in front of the defendant's dwelling house, nearer to it than the centre of the strect, and about six feet below the surface of the earth.

A lot of land numbered seventeen, a part of which constitutes the defendlant's house lot, was conveyed by the owners to Elliott Valentine, on September 28, 1832, bounded "sontherly on Centre street, there measuring 120 feet," "as the same is laid down on a plan drawn by Zebulon Bradley, in December, 1829." The title of the defendant is derived from Valentine.

The owners of land, including this lot, caused Bradley to draw a plan thereof in December, 1829, and to designate upon it building lots and streets. They soon afterwards caused Centre street to be prepared for use as a street or way.

As the law has been established in this State, when land conveyed is bounded on a highway, it extends to the centre of the highway; where it is bounded on a street or way existing only by designation on a plan, or as marked upon the earth, it does not extend to the centre of such way.

The occasion of such difference in effect may be ascertained. The owner of land, who has caused it to be surveyed and designated as containing lots and streets, may not be able to dispose of the lots as he anticipated, and he may appropriate the land to other uses; or he may change the arrangement of his lots and streets to promote his own interest, or the public convenience in case the streets should become highways. He does not by the conveyance of a lot bounded on such a way hold out any intimation to the purchaser, that he is entitled to the use of a highway to be kept in repair, not at his own, but at the public expense, for the common use of all. While he does by an implied cavenant assure to him the use of such designated way in the condition in which it may be found, or made at his own expense. By a repurchase of that title, the former owner would be entitled to close up such way, as he would also by obtaining a release of the right of way.

There is no indication in such cases of an intention on the part of the grantor to dispose of any more of his estate than is included by the description, with a right of way for its convenient use.

$$
\begin{aligned}
& \text { 51Cal. } 19470 \\
& \text { C.C.831-1112 } \\
& 52 \text { cse.den.186. }
\end{aligned}
$$


When a lot conveyed is bounded on a highway expected to be permanent, the intention to have it extend to the centre of it is inferred, (among other reasons noticed by this Court in former cases,) from the consideration that the vendor does not convey or assure to the vendee a right of way, the law affording him in common with others a more permanent and safe public way, to be kept in repair at the -public expense. The vendor not being burdened by an implied covenant, that the vendee shall have a right of way, has no occasion to retain the fee of the highway for that purpose. Hence arises one motive inducing him to convey all the rights, which he can convey to land covered by the lighway.

In argument for the defendant it is insisted, that Centre street at the time of the conveyance had become a highway by dedication of the owners of the land.

It might be sufficient to observe, that such a position does not appear to have been presented at the trial, for decision by the jury or for instruction by the Court.

Without insisting upon this, the testimony presented in the bill of exceptions does not sustain the position.

If an owner of land should cause it to be surveyed into lots and streets, and a plan thereof to be made, and should also cause the streets to be made convenient for use, and continue to keep the land enclosed as his own property, it would not be contended, that a dedication of it to the public could be inferred from these acts. There must be some act of the owner, from which it can be clearly inferred, that he intended to surrender it for public use, and not for the use of certain persons only. The simple facts, that a person pursued such a course respecting his land, and that he opened a way for the use of a purchaser of a lot, would not, alone considered, authorize an inference that it was dedicated to the public for common use. There should be some evidence, that it was generally used with his knowledge, as public convenience might require, to authorize such a conclusion. Nor could the owner compel the public to accept and adopt such streets as highways. There should be evidence that they had been commonly used to authorize an inference, that they had been accepted as public ways.

In this case, there is not only no evidence that Centre street at the time of the conveyance of the defendant's lot to Valentine had been used as a public way, but there is evidence, that it was not kept in repair, and that part of it only is used as a street.

Exceptions overruled, and judgment on the verdict. ${ }^{2}$ (for pesistiff)

12 Hopkinson v. McKnight, 31 N. J. Law, 422 (1S66); Robinson r. Mvers, 67 Pa. 9 (1871); I'lumer r. Johnston, 63 Mich. 165, 173, 29 N. W. 6S7 (18s6), dictum, acc. Johnson v. Arnold, 91 Ga. 659, is s. E. 370 (1893); Stark \& Wales v. Cottin, 105 Mass. 32S (1S70); Bissell v. New York Cent. R. Co., 23 N. Y. 61 (1S61); Jarstadt v. Morgan, 48 Wis. 245,4 N. W. 27 (1879) ; Paine v. Consumers Forwarding \& Storage Co., 71 Fed. 626, 19 C. C. A. 99 (1S95), contra. 


\section{SACCONE v. WEST END TRUST CO.}

(Supreme Court of Pennsylvania, 1909. 224 Pa. 554, 73 Atl. 971, 24 L. R. A. [N. S.] 539.)

Case stated in ejectment to determine title to the bed of an alley in the ninth ward of the city of Philadelphia. Before Audenried, J.

The following plan shows the situation of the alley:

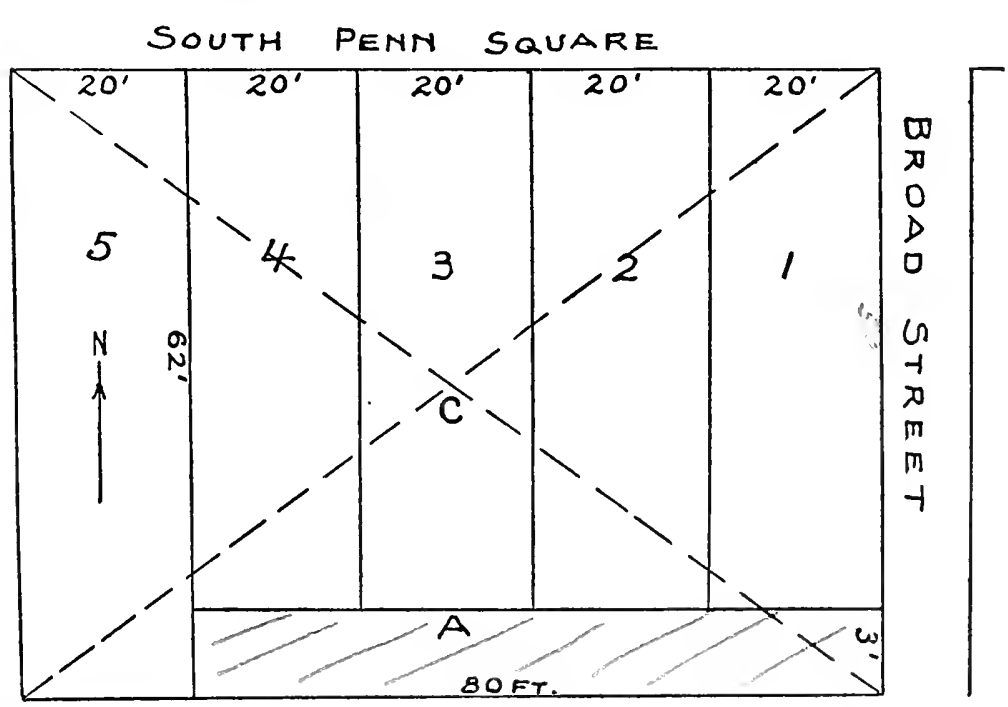

The facts are stated in the opinion of the Supreme Court.

Error assigned was in entering judgment for defendants on the case stated,

POTTER, J. This was an amicable action of ejectment, brought to recover possession of a strip of ground, three feet in width and eighty feet in depth, situated on the west side of Broad street, fifty-nine feet south of its intersection with South Penn square, in the city of Philadelphia. The parties agreed upon a case stated, which disclosed the following facts: On April 21, 1832, Robert A. Caldcleugh conveyed to various grantees, five lots of ground situated on South Penn square west of Broad street, each twenty feet in width, the corner lot and the three lots nearest to it being fifty-nine feet in depth and the westernmost lot sixty-two feet deep. Each of the first four lots was described in the deeds as extending "to a three feet wide alley laid out and opened by the said Robert A. Caldcleugh for the accommodation of this and other lots adjoining thereto and leading westward from the said Broad street to the depth of eighty feet." Each of the five deeds contained a grant of "the free use and privilege of the said three feet wide alley as and for a passageway and water course in common with the owners and occupiers of the said adjoining lots."

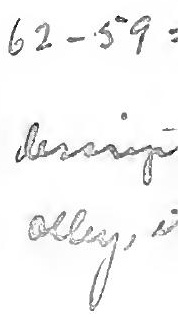


From the date of the deeds each of the owners of the lots continued to have, use and enjoy the free and uninterrupted use and privilege of the alley as and for a passageway and water course in common with the owners and occupiers of the other four lots.

On Novenber 11, 1St6, Robert O'Neill acquired title to the premises adjoining the alley on the south and on June 25, 1S48, Caldeleugh conveyed to $\mathrm{O}^{\circ} \mathrm{N}$ eill the soil of the alley in fee, subject to the uses and privileges granted to the owners of the lots adjoining. On August 9, $18+9$, O'Neill conveyed to one IVickersham the premises south of the alley "together with the free and common use and privilege of the aforesaid three feet wide alley as and for a passageway and water course into and from Broad street at all times forever."

Subsequently, by various conveyances, three of the lots next the comer originally granted by Caldcleugh became vested in the West End Trust Company and the other tivo lots, as well as the premises south of the alley, granted by O'Neill to Wickershan, became vested in the Girard Trust Company. Both companies made use of the soil of the alley in connection with buildings erected on their respective premises, and on October 6, 1905, they entered into an agreement with each other, "that the said alley be and the same is hereby abandoned and vacated." 'The plaintifis are the heirs at law of Robert O'Neill, grantee of Caldelewgh by the deed of Jume 26, 1848, and the defendants are the West End 'Trust Company and the Girard Trust Company.

Upon the facts stated, the court below held that each of the grantees of Caldclengh, under the four deeds of April 21, 1832, took a fee simple title to so much of the ground in dispute as lay immediately in the rear of the lot he bought, subject to an easement in the owners of the other lots, and that Calcleleng parted with all his interest at that time, and 110 title to the soil of the alley passed by the deed of Caldcleugh to $\mathrm{O}$ Neill on June 26, $18+5$. Judgment was entered on the case stated for the defendants, and the plaintiffs have appealed.

If the alley in question had been a public highway, the grantees of land bounded thereby would without doubt have taken the fee to the center of the highway, if the grantor owned such fee, and had used no language in his deed indicating an intention to retain the fee in the highway. In one of our latest cases bearing on this question, Willock v. Beaver Valley R. R. Co., 222 Pa. 590, 595, 72 Atl. 237, 23S, our Brother Elkin said: "If the plan of lots in the present case had been laid out by an individual in precisely the same manner as the commonwealth had done, and lots had been sold with streets as boundaries, the title to the fee to the center of the streets would have passed to the purchaser. This is the rule of our cases, from Paul v. Carver, 26 Pa. 223 [69 Am. Dec. 413], to Neely v. Philadelphia, $212 \mathrm{~Pa} .551$ [61 At1. 1096]."

We can see no reason why the same rule should not apply to land which is conveyed as bounded by a private way. The doctrine was 
substantially adopted by this court, in Ellis v. Academy of Music, 120 Pa. 608, 623, 15 Atl. 494, 496 (6 Am. St. Rep. 739), where it was said: "Nor did the court err in charging that parties who are entitled to a free use of an alley, have the same right in it that the public has in its highways, and that if the way in this case were vacated, the soil would belong to the plaintiff and defendant as tenants in common. By the several grants to these parties, their properties were not only bounded on the alley in controversy, but it was made appurtenant to those properties. Nothing, therefore, was left in the owner, and if the fee did not vest in these grantees, it is hard to tell where it is. The case is very much like that of Holmes v. Bellingham, reported in 7 C. B. (N. S.) 329, in which Cockburn, C. J., says: "The direction conplained of is, that the learned judge told the jury that there was a presumption in the case of a private way or occupation road between two properties, that the soil of the road belongs usque ad medium to the owners of the adjoining property on either side. That proposition, subject to tine qualification which I shall presently mention, and which I take it, was necessarily involved in what afterwards fell from the learned judge, is, in my opinion, a correct one. The same principle which applies to a public road, and which is the foundation of the doctrine, seems to me to apply with equal force to the case of a private road.' As the doctrine here stated seems to be reasonable and sound, we cannot understand why we should not adopt it. It seems to be admitted that, were the alley public, its vacation would vest in each of the parties the unincumbered one-half of the fee in severalty, and why this should not apply to a private way, where, just as in the case of a public way, by the grant it was made appurtenant to the several properties, we cannot understand." The reference above to the plaintiff and defendant as being tenants in common of the soil in the alley in case it was vacated, was probably a slip of the pen, as later in the opinion it is stated that vacation would vest in each of the parties onehalf of the fee in severalty.

In Rice v. Clear Spring Coal Co., $186 \mathrm{~Pa}$. 49, 40 Atl. 149, the rule which was approved by this court was thus stated: "When the boundary given in a deed has physical extent, as a road, street, or other monument having width, courts will so interpret the language of the description, in the absence of any apparent contrary intent, as to carry the fee of the land to the center line of such monument." And in Schmoele v. Betz, 212 Pa. 32, 61 Atl. 525, 108 Am. St. Rep. 845, a case which involved the use of a private alley, the doctrine was again cited with approval, that, in case of vacation, the rule which applies to a public highway is to be applied as between parties entitled to the use of a private alley. 13

13 See Fisher v. Smith, 9 Gray, 441 (1S:7): MeKenzie r. Gleason, 184 Mass. 452, 69 N. E. $1076,100 \mathrm{Am}$. St. Rep. 566 (1004): Freenan v. Sayre, 48 N. J. Law, 37,2 Atl. 650 (1Ss6): Stockwell v. Fitzgerald, 70 Vt. 468,41 Atl. $50+(1895)$ (semble); Wiess v. (xoodhue, 46 Tex. Civ. App. 142, 102 S. W. 793 (1907), hold- 
In some of our cases, the language used appears to sustain the contention of appellants, that there is a distinction between a call for a public highway as a boundary, and a private street or alley, so designated. But we think upon examination that these decisions were not intencled to go further, than to hold that where land is conveyed as bounded by an unopened street, the grantee takes the fee only to the side line of the street, with an easement over its bed. Thus in Cole v. Philadelphia, 199 Pa. 46t, 49 Atl. 308, the deed called for a street which was unopened, and it was held that the call for an unopened street as a boundary only conveyed the title to the side of the street and not to the middle thereof. In Clymer v. Roberts, $220 \mathrm{~Pa} .162,69$ Atl. $5+8$, the deed called for "the middle line of Howard street fifty feet wide; thence along the middle line of said Howard street." Howard street was at the time an unopened street, but it was held that the purpose of making the boundary to be the middle line of the street was to vest the fce in the grantee as far as the center line, notwithstanding the fact that the street was at the time unopened. In Robinson v. Myers, $67 \mathrm{~Pa}$. 9, where the rule with regard to unopened streets seems to have been first laid down, this distinction is expressly made. Justice Williams, after stating the doctrine of Paul v. Carver, $26 \mathrm{~Pa} .223$, 67 Am. Dec. 413, and Cox v. Freedley, 33 Pa. 124, 75 Am. Dec. 584, said, with reference to the case then before him: "But in this case there was no alley or street by which the lots were bounded. The recorded plan which is to be taken as a part of the defendant's title shows that the ground in question is a lot, and not a street. And it is admitted that no alley was ever laid out over the lot, or ever used by the public or by private individuals. There is then no ground or reason for the application of the rule laid down in Paul v. Carver, to this case." The case of Van O'Linda v. Lothrop, 38 Mass. (21 Pick.) 292, 32 Am. Dec. 261, cited in Robinson v. Myers, and also by Justice Mercur in Spackman v. Steidel, $88 \mathrm{~Pa} .453$, relied on by appellants, was also a question of an unopened street. Morton, J., said (21 Pick. 296, 32 Am. Dec. 261): "The street did not then exist in actual use, but only in contemplation." The decision there seems to have gone upon the

ing same rule applies where boundary is upon a prirate way as in the cases inrolying public ways. In Gould $\mathrm{r}$. Masner, 196 Mass. $270,82 \mathrm{~N}$. L. $107(1907)$, the lot was described as situated "on" a way fire feet wide; despite the fact that the way was on the margin of the grantor's land, only half of it passed under the deed. Two justices, howerer, dissented on the ground that the entire way should have passed. See Albert v. 'Thomas, 73 MId. 181, 20 Atl. 912 (1890).

As to what will be sufficient to orercome the presumption that at least half of the way shall pass, see Stealns v. Mullen, 4 Gray (Mass.) 151 (1855); Codman v. Erans, 1 Allen (MIass.) 443 (1S61) ; Crocker v. Cotting, 166 Mass. 1S3, 44 N. I. 214,33 L. I. A. $245(1896)$; Mott r. Mott, 68 N. Y. $246(1877)$.

That in case of bondaries upon wrivate ways the same rule as in the case of public ways is not applicable, see Seery v. Waterbury, S2 Conn. $56 \pi, 74 \mathrm{Atl}$. 908 . 25 L. R. A. (N. S.) 6\$1, 18 Ann. Cas. 73 (1909); Ames r. Hilton, 70 Me. 36 (1879); Winslow r. Reed, s9 Me. 67, 35 Atl. 1017 (1896).

See also Taylor v. Armstrong, 24 Ark. 102 (18(i3); In re Robbins, 34 Minn. 99, $21 \mathrm{~N}$. W. 356, 57 Am. Rep. 40 (18s5); Ilealey r. Babbitt, 14 R. I. 533 (18s1). 
ground that the deeds showed an intention by the grantor to exclude the fee of the street from the grant.

In the present case the language of the deeds from Caldcleugh, as set forth in the case stated, shows that at the time of the conveyances the alley was already "laid out and opened by the said Robert A. Caldcleugh ;" and it further appears from the case stated that after the conveyances were made the owners of the lots continued the use of the alley, and it was not abandoned or vacated until October 6. 1905, a psriod of over seventy-three years. So that the facts of this case distinguish it clearly from Robinson v. Myers, supra, and the subsequent cases relating to unopened streets and highways. When Justice Mercur, in delivering the opinion of this court, in Spackman v. Steidel, $88 \mathrm{~Pa} .453$, said: "Where the street called for a boundary is not a public highway, nor dedicated to public use the grantee does not take title in fee to the center of it, but by implication acquires an easement or right of way only over the lands," and then cites the cases which we have above referred to (Van O'Linda v. Lothrop, and Robinson v. Myers), we think it is apparent that he had in mind cases where the deed called for a street that was unopened, as the two cases which he cites had reference to such unopened streets.

The authorities are uniformly to the effect that the question of whether the grant includes the fee to the bed of the highway, is one of intention. The grantor in the present case did not expressly except from his conveyances the fee of the alley in the rear of the lots conveyed, and it is hardly reasonable to suppose that he intended to reserve a strip at the end of the four lots, three feet wide and cighty feet long, which he was subjecting to easements which, so long as claimed by the grantees, would prevent him from making any beneficial use of the fee in the strip. We think it is apparent that Caldcleugh in 1832 intended to part with his entire interest in the property, and that the alley was laid out and opened as stated in his deeds "for the accommodation of this and other lots adjoining thereto." It will be recalled that the westernmost lot, No. 5, was described as being sixtytwo feet in depth, and that Caldcleugh did not reserve the three feet at the rear of that lot. If he had intended to reserve to himself the fee in the alley, he would naturally have reserved the same space in the rear of lot No, 5. But he evidently conveyed that lot to its full depth because, as it was at the head of the alley, access could be had thereto without any such reservation. Neither the language of the deeds nor the situation of the ground, nor the circumstances connected with the conveyances, indicate any intention on the part of Caldcleugh to retain the fee to the bed of the alley, when he made the conveyances in 1832.

The assignments of error are overruled, and the judgment is affirmed. AIG.PROP. -28 


\section{GEDDES COARSE SALT CO. v. NIAGARA, LOCKPOR'T \& ONTARIO POWER CO.}

(Court of Appeals of New York, 1913. 207 N. Y. 500, 101 N. E. 456.)

Hiscock, J. This action was brought as one of ejectment to compel the appellant to remove wires used for conducting high power electric currents and strung above the boundaries of a highway, as shown upon a map which will be referred to. The facts which define the controversy are as follows:

In 1902 the state issued to the respondent letters patent whereby it granted and conveyed to it certain lands theretofore constituting part of the Onondaga Salt Springs Reservation and amongst which was one parcel, alone involved in this action, described as "Subdivision No. 17 (of Farm Lots 45 and 46) containing $1342-100$ acres," as said subdivision was laid down on a map of the farm lots in question made by one Greene, deputy surveyor in August, 1849, and during said month filed in the office of the secretary of state. Said map showed said subdivision 17 as abutting at its southerly boundary on a road four rods wide, and which road in turn had for its southerly boundary the blue line of the enlarged Erie canal then in process of construction, the distance from this blue line to the base line of the canal as finally constructed and used being upwards of thirty feet. For some time before the grant in question said road apparently was not used by the public in the portion bounding subdivision 17 aforesaid, but at least some part of it seems to have been occupied by a storehouse belonging to the respondent. The letters patent and the map to which reference has been made gave the area of subdivision 17 and other parcels then being conveyed and such statement of such area is satisfied without incorporating in the grant any portion of the highway. Under these circumstances the question has arisen whether the respondent acquired title to all or to part of said highway as subdivision 17 abutted on the same, and this question by consent was disposed of by the trial court as a question of law, it holding that the respondent acquired title to the bed of the entire highway.

The general rule is that a conveyance by reference to a map which shows the premises being conveyed as abutting upon a highway, as between the grantor and grantee, conveys to the latter title to the fee of the highway to the center line thereof. This is the rule as against the state as well as against a private grantor, and it applies even though at the time of the conveyance the highway as shown upon the map has not been accepted and used by the public as such, and although the grant by its terms or by reference to a map gives an area of the premises being conveyed which is satisfied without resort to the land included in the highway, Bissell v. N. Y. C. R. R. Co., 23 N. Y. 61; Matter of Ladue, 118 N. Y. 213, 23 N. E. 465; Trowbridge v. Ehrich, 191 N. Y. 361, 84 N. E. 297 ; Paige v. Schenectady Ry. Co., 178 N. 
Y. 102, 111, 70 N. E. 213; Van Winkle v. Van Winkle, 184 N. Y. 193, 204, 77 N. E. 33.

I see no reason for attempting to build up an exception to this general rule upon the facts presented in this case, but think that the respondent's title extended to the center of the highway opposite said subdivision 17 , as shown upon the map.

The respondent, however, is not satisfied with this but insists that under its grant it took tite to the fee of the entire highway and thus it has so far been held.

The theory upon which it bases this contention is that the state was not the owner of or interested in land on the southerly side of this highway in such manner as would justify the presumption that it intended to retain title to the fee of such southerly half of said highway. The cases especially relied on in support of this theory are those of Haberman v. Baker, 128 N. Y. 253, 28 N. E. 370, 13 L. R. A. 611, and Johnson v. Grenell, 188 N. Y. 407, 81 N. E. 161, 13 L. R. A. (N. S.) 551. Each of these cases involved the principle so far as applicable to this discussion that where a highway has been constructed upon the margin of the grantor's land his subsequent grant of the abutting land should be deemed to include the fee in the whole roadbed because it will not be assumed that he intended to retain the fee to onehalf of the roadbed under such circumstances.

In the Grenell Case the grantor being the owner of an island in the St. Lawrence river constructed on its shore a road extending to the waters of the river, and thereafter made a conveyance of land abutting on said roadway, and it was said by Judge Gray in writing for the court that "there is no sufficient reason apparent to infer an intention by the grantor, when parting with her title to the only land adjoining the road, to reserve any interest in the fee of the road itself. Manifestly, from the facts, an inducement to the purchaser of the lot was its being shown, and stated, to lie upon the shore of the island and the enjoyment of the riparian advantages conferred a distinct value. The ordinary presumption is that, in the absence of contradictory terms, the grantor does not intend to retain the fee of the soil in the street." 188 N. Y. 410, 81 N. E. 161, 13 L. R. A. (N. S.) 551.

I do not regard the facts presented in those cases as so parallel with the ones arising here as to compel or justify the adoption of the respondent's contention. The state is the owner of the canal and as already stated between the base line of the canal and the blue line which bounds the highway on the south there is a strip of land of considerable width. Under these circumstances it does not follow as a conclusion of law that when the state made its conveyance to respondent it had no interest in retaining the fee to the southerly half of the roadway or that such retention would secure a useless and barren right. On the contrary, it seems to me that the ownership of this extra strip of thirty-three feet adjoining the canal lands may be a right of much value and convenience. Thus again I feel that we should follow the
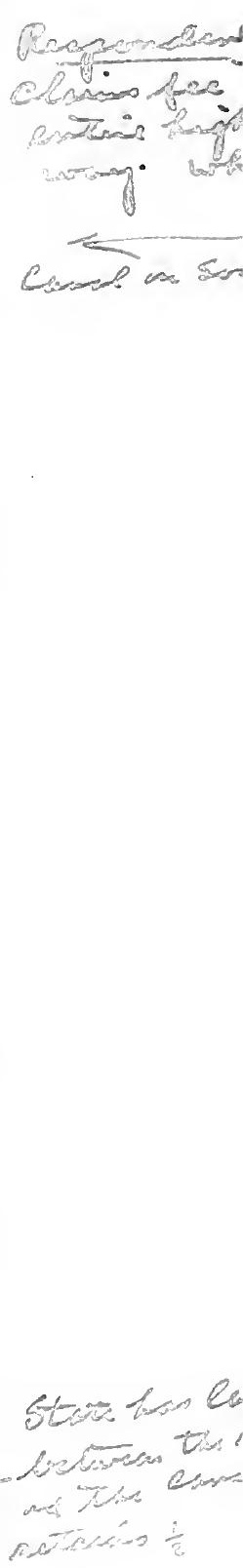
general rule prevailing in the case of grants of land abutting on highways and that no sufficient reason exists for awarding to respondent the title to the fee of the entire roadway instead of one-half thereof.

These views lead to the conclusion that the judgment appealed from should be so modified as to determine that respondent acquired title to the northerly half of the highway on which its said premises abut according to said Greene map, and that it have ejectment against appellant as to said premises, and as modified affirmed, without costs to either party on this appeal.

Cullex, C. J., and Gray, Willard Barthett, Cuddeback, and Hogan, JJ., concur. MII.LER, J., not sitting.

Judgment accordingly. ${ }^{14}$

\section{CHICAGO \& E. I. R. CO. v. WILLARD.}

(Supreme Court of Illinois, 1910. 245 Ill. 391, 92 N. E. 271.)

HAND, J. This was an action of ejectment brought by the appellant in the circuit court of Williamson county against the appellees to recover a strip of land described as commencing at the north-west corner of the south-west quarter of the north-west quarter of section 19 , township 8 , range 3 east, running thence south 275 feet, thence east 16 feet, thence north 275 feet, thence west 16 feet to the place of beginning, in Williamson county, Illinois: The general issue was filed, and upon a trial, at the close of the plaintiff's evidence, the jury, under the direction of the court, returned a verdict in favor of the defendants, upon which verdict the court rendered judgment, and the record has been brought to this court by appeal, for review.

The parties claimed title from a common source. It appears from the record that on April 24, 1894, Felix G. Henderson was the owner in fee of the south-west quarter of the north-west quarter of said section 19; that the Chicago, Paducah and Memphis Railroad Company had located its right of way across said tract of land; that on that day Henderson conveyed a 100-foot strip across said tract, and the forty-acre tract lying immediately south of said tract, to said railroad company by the following description: "I hereby sell and convey to the said Chicago, Paducah and Memphis Railroad Company a strip 100 feet wide across my land, to-wit: Where the line of said railroad is now surveyed and located on the west side of the S.W.N.IV.qr. and the N.W.S.W.qr. Sec. 19, Town 8, South, Range 3, East of the third

14 See Banks v. Ogden, 2 Wall. 57, 17 L. Ed. S1S (1S64); Scholl v. Emerich, $36 \mathrm{~Pa}$. Super. Ct, 404 (190S).

A., the owner of lands bounded on the east by a river with a highway running along the river bank, the east side of the highway being the west water line of the river, made a deed of a portion of said lands to B., describing the part conveyed as being "bounded on the east by the highway." By accretion a considerable tract of valuable land has been formed on the east side of the highway. The new land is claimed both by A. and B. 'To whom does it belong? 
P.M., subject to public road as it now runs, being 50 feet on each side of line as now located " that on the west line of section 19 there was located a highway 40 feet wide; that 20 feet of said highway was upon the Henderson land; that the west line of the right of way strip conveyed by Henderson to the railroad company was situated $16 \mathrm{feet}$ from the section line; that in 1897 the Chicago, Paducah and Memphis Railroad Company conveyed all its property, including the right of way purchased from Henderson, to the appellant; that on March 23, 1897 , the appellant purchased a strip of land 20 feet wide and 788 feet long adjoining the strip in controversy, and other lands on the west, and the old 40-foot highway on the section line was abandoned and a new highway 50 feet wide and parallel to and 40 feet west of the section line was laid out in lieu of the old highway; that in 1905 Felix G. Henderson conveyed to A. L. Willard the 16-foot strip in controversy, and Green Hindman is in possession of the same as the tenant of Willard.

It is the contention of the appellant that the title to said 16-foot strip lying between the section line and the west line of appellant's right of way passed by the deed from Henderson to the Chicago, Paducah and Memphis Railroad Company and from that railroad company to the appellant, subject to the right of the public to use the same as a highway, and that the appellant is the owner in fee of said strip, and that the highway having been abandoned, it is entitled to the possession of said premises. The appellees contend that the deed from Henderson to the Chicago, Paducah and Memphis Railroad Company only conveyed a 100-foot strip, and that the title to said 16-foot strip remained in Henderson until it was transferred by him to Villard, and that the appellant has no interest in said strip, and that Willard, by his tenant, is law fully in possession of the same.

It has repeatedly been announced as the law of this State, that where the fee to the center of a public street or highway is in the adjoining owner, the fee to the center of the street or highway will pass to a grantee of the premises abutting upon the street or highway untess there are words in the deed which limit the operation of the deed to the margin of the street or highway. Hamilton v. Chicago, Burlington \& Quincy R. Co., 124 I11. 235, 15 N. E. 854; Thomsen v. MIcCormick, 136 I11. 135,26 N. E. 373 ; Henderson v. Hatterman, 146 Ill. 555, 34 N. E. 1041; Clark v. McCormick, 174 I1l. 164, 51 N. E. 215 ; Davenport. \& Rock Island Bridge Ry. Co. v. Johnson, 188 Ill. 472, 59 N. E. 497 ; Huff v. Hastings Express Co., 195 I1l. 257, 63 N. E. 105; Eisendrath \& Co. v. City of Chicago, 192 Ill. 320, 61 N. E. 419; Brewster v. Cahill, 199 Ill. 309, 65 N. E. 233. The question therefore in this case is, was the grant limited to the 100 -foot strip in the deed from Henderson to the Chicago Paducah and Memphis Railroad Company? We think an examination of the deed shows that it was. The deed does not in terms describe the premises conveyed as abutting upon the highway. On the contrary, it conveys "a strip 100 feet wide across 
my land," that is, "50 feet on each side of line as now located." At the time the deed was executed the railroad company was limited to a right of way strip 100 feet wide. The west line of the 100 -foot strip was $16 \mathrm{ft}$. east of the section line, and the east four f.eet of the 40foot highway was thereby conveyed to the railroad company by the Henderson deed. We think it probable the words "subject to public road as it now runs," were inserted in the deed to cover the part of the highway which was included in the 100-foot strip. The grantor in the deed manifestly intended to convey to the railroad company a strip 100 feet wide across his land, and no more, for right of way purposes. The strip conveyed was not described as being on, upon or along the highway, but the west margin of the strip was four feet in the highway. We therefore conclude that the title to said 16-foot strip remained in Henderson until he conveyed the same to Willard, and that, the appellant having failed to show title in itself to said premises, the court properly instructed the jury to return a verdict for appellees.

The judgment of the trial court will be affirmed. Judgment affirmed.

\section{LOW v. TIBBETTS.}

(Aupreme Julicial Court of Maine, 1SS1. 72 Ne. 92, 39 Am. Rep. 303.)

On Report. Trespass for hauling certain loads of stone upon the locus which is within the limits of a town way, and the plaintiff claimed to own the fee. The question presented, called for the construction. of a deed from the plaintiff to the defendant, dated June 26, 1857. The description is given in the opinion.

At the trial, the presiding justice was of the opinion that the fee was in the defendant, and a nonsuit was ordered "which is to be set aside, if such construction of the deed was erroneous."

Barrows, J. The question is, whether the fee in the locus (which is a strip about twelve rods in length, by forty-four feet in width, being a section of a duly located street in the village of Spring Vale, running along the bank of Mousam river, cutting a lot formerly owned by the plantiff very unequally, and leaving the largest part of it on the side farthest from the river, and a little irregularly shaped land between street and river) is in the plaintiff, or in the defendant.

After the street was built, plaintiff conveyed his lot to defendant, describing first the more important part, as "situate in the village of Spring Vale * * * beginning on the north easterly side of the new road leading from the Province Mills Bridge to the cotton mill, and at the southerly corner of the lot as now fenced belonging to school district number one, $* * *$ and running (course given) by said road *** to a stake," and thence around the rear of the lot, "to 
the place begun at; also the land now owned by said Low between said read and Mlousam river."

The well settled doctrine in this State is, that a grant of land bounded on a highway, carries the fee in the highway to the centre of it, if the grantor owns to the centre, unless the terms of the conveyance clearly and distinctly exclude it, so as to control the ordinary presumption. Oxton v. Groves, 68 Me. 372, 28 Am. Rep. 75. Here the principal piece is bounded by the road as a monument or abuttal. So is the land lying opposite "between the road and the river."

Is there enough in the language used, to exclude the street from the conveyance? The mere mention in the description of a fixed point on the side of the road as the place of beginning or end of one or more of the lot lines, does not seem to be of itself sufficient. Cottle v. Young, 59 Me. 105, 109; Johnson v. Anderson, 18 Me. 76; nor will similar language, with reference to monuments standing on or near the bank of a stream, in lines beginning or ending at such stream, prevent the grantee from holding ad medium filum aqux: Pike v. Monroe, 35 Me. 309, 58 Am. Dec. 751; Robinson v. White, 42 Me. 210, 21S; Cold Spring Iron Works v. Tolland, 9 Cush. (Mass.) 495, 496. The case of Sibley v. Holden, 10 Pick. (Mass.) 249, $20 \mathrm{Am}$. Dec. 521, cited by plaintiff, was commented on by this court, in Bucknam v. Bucknam, 12 Me. 465, and that of Tyler v. Hammond, 11 Picis. (Mass.) 193, in Johnson v. Anderson, 18 Me. 78; and the apparent force of these decisions is somewhat restricted and explained, by the learned court which pronounced them, in Newhall v. Ireson, 8 Cush. (Mass.) 598, 54 Am. Dec. 790, and Phillips v. Bowers, 7 Gray (Mass.) 24; although it is apparent from the last case and from Smith v. Slocomb, 9 Gray (Mass.) 36, 69 Am. Dec. 274, that the Massachusetts court lays less stress upon the ordinary presumption, and requires less distinctness in the terms of the deed to obviate it, than we have done in the cases above cited from the 18th, 591h, and 68th of our own reports. See also, Perkins' note to Sibley v. Holden, in the second edition of Pickering's Reports, vol. 10, p. 251.

Had the plaintiff run his first line "by the north easterly side line of said road," instead of "by said road," and conveyed the land "lying between the southwesterly side line of said road and Mousam river," instead of that "lying between said road and Mousam river," a different question would have been presented.

In the absence of the very few words which were necessary to make plain an intention on the part of the plaintiff to reserve the fee in the land covered by the street to himself, we think the ordinary presumption and construction must prevail.

Nonsuit confirmed. ${ }^{15}$

15 In Sibley v. Holden, 10 Pick. (Mass.) 249, 20 Am. Dec. 521 (1S30), referred to above, the court said: "From this description, we are all of opinion, that the line must begin on the side of the road, and at that point exclude the road; then the question is, whether when the description leturus to the road again, 


\section{SALTER v. JONAS.}

(Court of Errors and Appeals of New Jersey, 1877. 39 N. J. Law, 469, 23 Am. Rep. 229.)

In Error to the Supreme Court.

This was an action of ejectment for a small strip of land, being one* half of what had been a public street, in front of a lot of land which the plaintiff had conveyed to a certain person, and which lot had come, by divers mesne conveyances, to the defendants. The plaintiff's deed conveyed the premises by the following description, viz:

"All that certain lot or parcel of land, situate, lying and being in the township of Bergen, in the county of Hudson and state of New sersey, butted and bounded as follows: Beginning at a stake standing at the junction of the easterly line of Rowland street with the northerly line of Johnson street, as laid down on the map of said Salter's premises, and running thence (1) along the northerly line of Johnson street south, twenty-three degrees forty minutes, east, fifty (50) feet, to a stake; thence (2) north, sixty six degrees east, one hundred (100) feet, to a stake, thence (3) north, twenty-three degrees and forty minutes west, fifty (50) feet, to a stake in the said easterly line of Rowland street; thence (4) along the same south, sixty-six degrees west, one hundred (100) feet, to the beginning."

After Rowland street had been used for some time, it became useless, in consequence of another street having been opened, and the defendants had proceeded, thereupon, to take in and enclose to the middle line of the street in front of the lot above described.

At the trial in the Hudson Circuit, the court instructed the jury that the defendant's deed covered the land in the street which was in dispute, and there was a verdict accordingly. $\gamma / 20$ ?

The opinion of the court was delivered by

BEAsLEY, C. J. This case, as it stands before this court, presents, in a distinct form, the question whether in a conveyance of lands which, in point of fact, abut upon a street or highway, anything short of express words of exclusion will prevent the title from extending to the medium filum of such street or highway, the grantor, at the date

it shall be taken to mean the side or the center of the road. If construed to be the center, then the remaining line wonld neithel be by the side of the road nor the center, but by a diagonal line from a point in the centel to a point on the side. This wonld not only he obscure and inconsistent witl ans supnosed intent of the parties, but repugnant to the last clause in the description, which is, 'by said road to the place of beginning.' As one point in this line is fised by the descrintion to the side of the road, we are satistied that, by a just and necessary construction, the other point must be taken to be at the side of the road, and therefore that the soil of the road was not included." cf., how ever, Mchenzie v. Gleason, 184 Mass. 452,69 N. E. 1076, 100 Am. St. Rep. 566 (1904).

See In re Parkway, 209 N. Y. 344, 103 N. F. 508 (1913), where the beginning point was "at the northwesterly corner of Walnut street and Second avenue." 
of such conveyance, being the owner of such street or highway to that extent.

This is a subject with respect to which the views of judges are much at variance. The general opinion appears to be that there is so strong a presumption of an intention to convey the soil of the highway when the premises granted actually border upon it, that very plain indications of a contrary purpose are requisite to exclude it. Under the operation of such a test, the present deed would not embrace the land in dispute, for the descriptive words cannot be extended from their intrinsic force, so as to have so wide a reach.' The words here used will not, if interpreted in their familiar sense, and standing by themselves, admit of being taken as delineatory of any part of the street. The only point for consideration, therefore, is whether, when the terms used have this restrictive force, they are to lose that force in the presence of the great presumption to the contrary, which is inherent in the position of affairs where a lot thus located is granted.

There are, undoubtedly, decisions which tend very strongly to this point, and others which apparently reach it. The leading cases are carefully collected, and the general subject judiciously handled in the notes of Mr. Wallace, appended to the case of Dovaston v. Payne, 2 Smith's Lead. Cas. (7th Ed.) 160. In this series stands prominently the case of Paul v. Carver, decided by the Supreme Court of Pennsylvania, $26 \mathrm{~Pa} .223,67 \mathrm{Am}$. Dec. $413 .{ }^{13}$ In that instance, the description carried the lot conveyed by so many feet to a designated street; "thence southeasterly along the northerly side of said street," and the street thus referred to was afterwards vacated, and it was held that half of it passed with the lot that was thus bounded by its northerly side. This result was justified on the broad ground "that the paramount intent of the parties, as disclosed from the whole scope of the conveyance, and the nature of the property granted, should be the controlling rule." A number of decisions, bearing a similar aspect, are cited in this opinion, which also displays, with much clearness, the impolicy of the opposite view. The conmentator, with reference to this case, and other decisions, thus sums up the result: "The rule, therefore, which the Pennsylvania courts regard as the true one, and which, perhaps, on the whole is the wisest one, would seem to be that nothing short of an intention expressed in ipsis verbis, to 'exclude' the soil of the highway, can exclude it."

And this doctrine, although it cannot be said to be sustained by the greatest number of decisions, is, I think, the one that ought to be adopted in this state. In our practice in the conveyance of lots bounded by streets, the prevailing belief is, that the street to its centre is conveyed with the lot. Among the mass of the people it is undoubtedly supposed that the street belongs, as an appurtenance, to the contiguouts property, and that the title to the latter carries with it a title to the former. This 
belief is so natural that it would not be easily eradicated. As a general practice, it would seem preposterous to sever the ownership to these several particles of property. Under ordinary circumstances, the thread of land constituting the street is of great value to the contiguous lots, and it is of no value separated from them. It would rarely occur that the vendee of a city lot would be willing to take it separated in ownership from the street, and it would as rarely occur that a vendor would desire to make such severance. In my own experience, I have never known such an intention to exist, and it is safe to say that whenever it does exist, the conditions of the case are peculiar.

And it is the very general notion that these two parcels of property are inseparably united, and pass as a whole by force of an ordinary convevance, that accounts for the absence of any settled formula in general use for the description of city lots in a transfer of their title. Upon an examination of such conveyances, it would, I am satisfied, be disclosed that the utmost laxity in this respect prevails. The property conveyed is indiscriminately described as going to the street and running along it, or as going to one side of such street and thence running along such side. Such discriminations are not intentional, the purpose being to convey all the interest that the seller has in the property and in its belongings, and the mode of accomplishing this purpose is not the subject of attention, the street lot, as I have said, being regarded as a mere adjunct of the property sold, and worthless for any other use. This being undeniably the practice and general understanding, to give a close and literal meaning to the descriptive terms employed in such instances would serve no useful purpose, but its tendency would be to defeat the object in view, and to call into life a vexatious litigation. The particular words should, in such transactions, be controlled and limited by the manifest intention which is unmistakably displayed in the nature of the affair and the situation of the parties. When the conditions of the case are altered, as if the vendor should, in a given case, have an apparent interest to reserve to himself the parcel of street in question, a different rule of interpretation might become proper. So if the abutting street referred to in a conveyance should be such only in contemplation, and should be contingent on the will of the vendor, the rule now adopted might not, and probably would not, be applicable. But where the street is an existing highway, or has been dedicated as such by the vendor, or in case, by the effect of his conveyance, he imposes on himself the obligation to devote the street to the public use, the rule then becomes the criterion by which the sense of the deed is to be ascertained.

The only case in our books that I deem entirely apposite to the present inquiry, is that of Hinchman et al, v. Paterson Horse Railroad Co., 17 N. J. Eq. 75, 86 Am. Dec. 252. The extreme fitness of this decision, as an authority at this time, does not appear upon reading the report of it; but I have looked at the original papers on file, and have found that in some of the deeds in that proceeding, the descriptions of 
the boundaries of the lots are not distinguishable from the one now under our view. Those lots were described as beginning at a fixed. point on a designated side of the street, and thence along such designated side, \&c., as in the present instance. The descriptive words, therefore, were clear, and if they were not overruled by the predominant presumption of intent arising out of the nature of the act done, it was impossible to hold that any part of the street passed to the vendee. But Chancellor Green did hold that the parcel in the street passed, saying: "It is objected, by the defendant's answer, that the complainant's titles do not extend to the middle of the street, because the lots, as described, are bounded by the sides of the streets. But the established inference of law is, that a conveyance of land, bounded on a public highway, carries with it the fee to the centre of the road, as part and parcel of the grant."

I do not know how this decision is to be sanctioned, except upon the ground already marked out. I regard the case as directly in point, and it is unnecessary to say that it is of the highest authority.

The result to which I have come is, therefore, that this conveyance embraces the parcel of land in the street, for the reason that there are no express words of exclusion of such parcel.

The consequence is, the judgment of the court below should be affirmed, witl costs. ${ }^{17}$

17 See Burk v. Squiers, 22 Tt. 484 (1550), contra, Redfield, .J.. dissenting.

"Coming, then, to the case in hand, I find nothing to exclude the bed of the

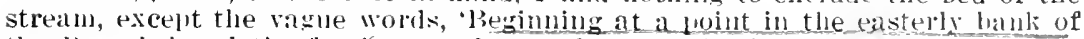
the l'assaic, and the further words, 'to the easterly line of the l'asaic river

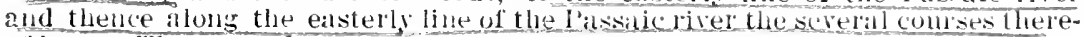
of' ets. These words are no more indicative of an intention to exilule the streilu than were the corresjunding Woils in sitter r. fomas to exctude tle stleet. lin both the easterly line is declared in terins to he the houndary. But, looling at the surmunding circumstances, I find no nore reason for giving them an exclusive effect in the one ase than in the other." simmons r. City

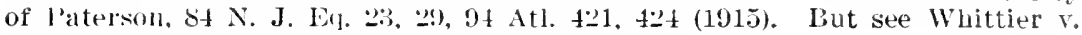
Montuelier Ice Co. (Vt.) @6 Atl. 3is (1916j), contla.

"The defendants contend that the clause in the deed from Baldwin to Reeres and from Reeves to the phintiff, 'thence northeasterly on the river slore, linlits and restricts the glant to the bisul or shore of the river. In Woolman $v$. Syencer, 54 N. H. 507 (157t) this guestion was considered in respect to lind bounded by a highwas, and it was there held that the expressions on the hishway' and 'by the side of the highway' were identical in meaning and effect;

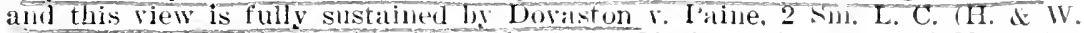

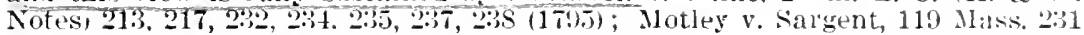

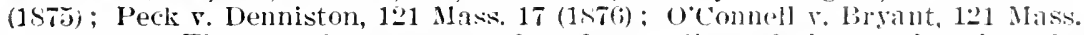
557 (157\%). The rule is a wesumed understanding of the parties that the grantor does not retain a narrow stuip of land under a st leam or other hisliway, because the title of it left in lim would generally be of little use, except for a purpose of annoyince and litigation." Sleeper v. I.aconia, 60 N. H. 201, 49 Am. Rep. 311 (1580). Starr Y. Child, 20 Wend. (N. Y.) 149 (1838), ace.; Bronson, J., disisenting. In the Comt for the Correction of Errors, Starr v. Child was reversed by a vote of 11 to $10.4 \mathrm{Hill}, 369$ (15.2). 


\section{TROWBRIDGE v. EHRICH.}

(Court of Appeals of New York, 190S. 191 N. Y. 361, S.1 N. E. 297.)

HAIGHT, J. This action was brought to determine the title to a Eriangular piece of land lying at the intersection of Westchester and Stebbins avenues, bounded on the west by Stebbins avenue, on the southeast by Westchester avenue, which intersects Stebbins avenue diagonally, and on the north by the southerly line of three lots owned by the defendants Ehrich, Spaeth and the Hudson Realty Company. The property in question was formerly owned by the plaintiff and was located in the twenty-third ward of the city of New York. In the year 1882 she caused a map of her property to be made and filed in the office of the register, showing the location of the streets existing and proposed, with which her property was bounded and intersected. This map corresponded with a prior map filed in 1878 by the park commissioncrs of the city showing the proposed location of streets in that part of the city, which the commission designed to have opened as streets of the city and upon which Dongan street, as mapped, intersected Westchester avenue and extended in a straight line to Stebbins avenue, covering the triangular parcel in dispute. Thereafter and in the year 1882 the plaintiff conveyed to Bertha Eck a parcel of land designated, on the map filed by her in the office of the register No. 892, as lot number one in block 513 on said map and particularly described as follows: Beginning at a point where the northerly line of One Hundred and SixtyThird street intersects the easterly line of Stebbins avenue; rumning thence easterly along the northerly line of One Hundred and SixtyThird street 30 feet; thence northerly and parallel with Stebbins avenue 128.71 feet; thence westerly and parallel with One Hundred and Sixty-Third street 30 feet and thence southerly and along the easterly line of Stebbins avenue 128.71 feet to the point or place of beginning. One Hundred and Sixty-Third street had not been opened through to Stebbins avenue. Had it been, its lines would nearly have corresponded with those given upon the map filed by the park commissioners as Dongan street, which was followed by the plaintiff in tre map fled by her. We, therefore, conclude that the plaintiff, in her reference to One Hundred and Sixty-Third street had reference to the northerly line of the street as given upon the map filed by her. The defendant Ehrich, through subsequent mesne conveyances from Bertha Eck, has become the owner of the lands so deeded ta her.

The trial court has found that the defendant Ehrich has become the owner in fee of that portion of the premises described as Dongan street in front of those specifically described in the deed. We readily concede the correctness of the contention that where an owner of real estate files a map of his premises in the office of the register, upon which is laid out streets and avenues, either existing or proposed, and deeds with reference to such streets and avenues, running to such 
streets and along such streets it will be construed to have been the intention of the grantor to convey to the center of such streets or avenues. But this case is distinguishable. The plaintiff has been careful to commence her description of the property conveyed at the intersection of the northerly line of One Hundred and Sixty-Third street with the easterly line of Stebbins avenue. The commencing point, therefore, is at the external line of the street and continues easterly along the northerly line of the street. Had she commenced at the intersection of the two streets and thence ran along the street it would have been apparent that she intended to convey to the center of the street, but as we have seen, she has placed the boundary at the northerly line, thus indicating an intention not to include the fee of the proposed street. It is true that she has executed this deed in accordance with the provisions of the map filed by her, upon which she designated this space as a street and by reason thereof the grantee acquired an easement in it of light, air and access, but not the fee.

The trial court, in determining that the grantee acquired the fee as well as the easement in the street, relies upon the cases of Matter of Ladue, 118 N.Y. 213,23 N. E. 465, and Hennessy v. Nurdock, 137 N. Y. 317, 33 N. E. 330, but in neither of those cases were the boundaries given of the property conveyed limited to the exterior lines of the street, and that is the distinguishing feature between those cases and this. It is said that she had no reason for reserving the fee to this particular parcel, It is quite apparent to us that she had a reason; a map had been filed by the officers of the city, by which it was proposed to take this identical parcel for the purposes of a street; when so taken she would be entitled to compensation from the city for the value thereof. She, therefore, in executing this deed saw fit to limit the fee conveyed to the exterior boundary of the street, but by conveying the land with reference to the street she necessarily included the easements of light, air and access.

On the 12th day of October, 1886, the plaintiff conveyed to Mathew Farrell another parcel of land embraced in the map filed by her as lots numbers 3,4 and 5 of block 513 , beginning at a point formed by the intersection of the northerly side of IVestchester avenue with the westerly side of Rogers place; running thence along the westerly side of Rogers place 33.82 feet; thence westerly and at right angles to Rogers place 176 feet; thence southerly and parallel with Stebbins avenue 128.71 feet; thence easterly at right angles to Stebbins avenue 40 feet and thence northerly along the northerly side of IVestchester avenue 166.93 feet to the point of beginning. The third course, running southerly and parallel with Stebbins avente 128.71 feet, in fact carried the line to the street marked upon her map, and thence easterly at right angles to Stebbins avenue 40 feet in fact carried the line alcng sucli street This was equivalent to a designation of the street in the running of the line, as to and along the same. Van WVinkle v. V'an IVinkle, $18+$ N. Y. 193, 204, 77/N. E. 33; Hennessy v. Murdock, 137 N. Y. 317 , 
323, 33 N. E. 330; Sizer v. Devereux, 16 Barb. 160; Champlin v. Pendleton, 13 Conn. 23. It will be observed that, by the description given in this deed, the exterior lines of the streets are also followed; but by a subsequent clause she states that the conveyance is to include all the right, title and interest which she has to that portion of Westchester avenue and Rogers place "lying in front of and adjacent to said lots to the center of said avenue and place, as laid down on said map, thus indicating an intent to convey to the center of the streets.

Again, on the $23 \mathrm{~d}$ day of August, in the year 1890, the plaintiff conveyed to James $G$. Patten and William $H$. Sutcliff another parcel of land described upon the map filed by her as lot number 2 in block 513 , beginning at a point on the northerly side of Westchester avenue, distant 30 feet easterly from the corner formed by the intersection of said northerly side of IVestchester arenue with the easterly side of Stebbins avenue; running thence northerly parallel with said Stebbins avenue $128.71 \mathrm{feet}$; thence easterly and at right angles with said Stebbins avenue 30 feet; thence southerly and again parallel with Stebbins avenue 128.71 feet to said northerly side of Westchester avenue, and thence westerly along said northerly side of Westchester avenue 30 feet to the place of beginning. In this deed she has designated the street which she marked upon her map as Westchester avenue, which in her first deed she called Qne Hundred and Sixty-Third street. By a subsequent clause of her deed she provides that it includes all of her right, title and interest "Of, in and to that portion of Westchester avenue lying in front of and adjacent to said lots to the center of said avenue," thus indicating an intent to convey a fee to the center of the avenue. The defendant Spaeth, by subsequent mesne conveyances, has acquired the title of Patten and Sutcliff and the defendant, the Hudson Realty Company, has accluired the title of Farrell.

Our conclusion, therefore, is that the judgment appealed from should be morlified in so far as lot number 1 is concerned, owned by the defendant Ehrich, so as to limit his title in the lands in controversy to the easements of light, air and access, with the right to have such lands kept open and used as a street, and that as so modified, the judgment should be affirmed as to him and the other respondents, with costs to the respondents Spaeth and the Hudson Realty Company, but without. costs to either party as to the respondent Elrich.

Cullen, Ch. J., and Gray, Vann, W'erner, Willard Bartlett and Chase, JJ., concur.

Judgment accordingly. 


\section{DODD v. WITT.}

(Supreme Judicial Court of Massachusetts, 1855. 139 Mass. 63, 29 N. E. 4 th. 52 Am. Rep. 700.)

Writ of entry to recover a parcel of land in North Adams. Plea, nul disseisin. Trial in the Superior Court, before Gardner, J., who directed a verdict for the demandant, and reported the case for the determination of this court. The facts appear in the opinion.

Ficl,D, J. The demanded premises are a strip two rods wide on the westerly end of the lot described in the demandant's deed. 'The demandant derives title from Reuben Whitman, who in May, 1866, conveyed the premises to Thomas H. Lidford by a description as follows: "Commencing on the road at the southeast corner of the land that I gave D. H. Raymond a bond to convey; thence west $22 \mathrm{deg} .30 \mathrm{~min}$. $\mathrm{N}$. ten rods; thence south 22 degrees 30 minutes west four rods; thence east 22 degrees 30 minutes S. ten rods; thence sovith on the road to the place of beginning." The descriptions in the mesne conveyances are substantially the same. The road was four rods wide, and Reuben Whitman when he executed his deed owned the fee of it. The deed therefore conveyed the land to the centre line of the highway. Peck v. Denniston, 121 Mass. 17; O'Connell v. Bryant, 121 Mass. 557.

The tenants contended, that, by the construction of the deed, the side lines of the demanded premises extended ten rods from the centre line of the highway, or eight rods from the westerly side of the highway: or, if this were not the true construction, that there was an ambiguity in the description; and they offered "John Lidford, father of said Thomas H. Lidford, as a witness to prove that at the time of the execution of the above-mentioned deed from Reuben Whitman to Thomas H. Lidford, the said witness was present; and that said IVlhitman measured on the west line of the road above mentioned westerly eight rods, and fixed a monument at the northwest corner of the lot; thence southerly four rods to the southwest corner, and fixed a monument; thence southerly eight rods to the west side of the highway; thence on the highway to the place of beginning; that his son Thomas H. Lidford and himself built a fence across the west end of said lot from corner to corner, as indicated by the monuments thus erected, at the time of said deed to Lidford, which fence remained until after the demandant went into possession under his deed; that the land included within said measurement was all that Thomas $\mathrm{H}$. Lidford purchased as he understood it at the time, except that he was told by Whitman that his grant really extended to the centre of the highway, which he was told was four rods wide." "The court excluded this testimony, and ruled "that there was no ambiguity in the deeds offered by the plaintiff; that the monument called for 'on the road' was by the side of the road, and not the centre of the road;" and directed the jury
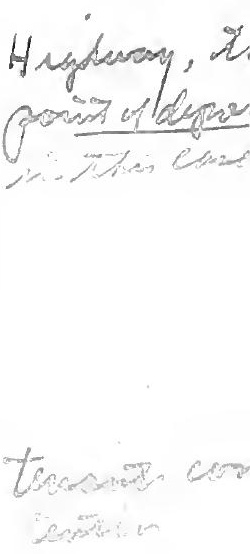
to render a verdict for the demandant. This is a ruling that, by the construction of the deed, the lines extended ten rods from the westerly side of the road.

In Peck v. Denniston, ubi supra, Chief Justice Gray says: "The general rule is well settled that a boundary on a way, public or private, includes the soil to the centre of the way, if owned by the grantor, and that the way, thus referred to and understood, is a monument which controls courses and distances, unless the deed by explicit statement or necessary implication requires a different construction. Newhall v. Ireson, 8 Cush. 595, [54 Am. Dec. 790]; Fisher v. Smith, 9 Gray, 441 ; Boston v. Richardson, 13 Allen, 146; White v. Godfrey, 97 Mass. 472; Motley v. Sargent, 119 Mass. 231."

Not one of these cases, however, considers the construction to be given to a deed in which a highway is a point of departure for a measured line.

In Newhall v. Ireson, ubi supra, the line was "running northerly seven poles to the county road, and from thence upon the road twentytwo poles to the first-mentioned bound." The seven rods terminated on the north at an old wall, which formerly constituted the southerly boundary of the road. The court held that the line ran to the centre of the road, although this was more than seven rods.

The rule is stated in Motley v. Sargent, ubi supra, as follows: "It $\mathrm{S}$ is a general rule of construction that where there is a boundary upon a fixed monument which has width, as a way, stream, or wall, even if the measurements run only to the side of it, the title to the land conveyed passes to the line which would be indicated by the middle of the monument."

The rule is then well established when the road is the terminus ad quem, but there is little authority when it is the terminus a quo, and there is no monument at the other end of the line.

A majority of the court is of opinion, that it is a common method of measurement in the country, where the boundary is a stream or way, to measure from the bank of the stream or the side of the way; and that there is a reasonable presumption that the measurements were made in this way, unless something appears affirmatively in the deed to show that they began at the centre line of the stream or way. The ruling of the court, in the construction of the deed, was therefore prima facie correct, as there was no monument to determine the other end of the line. But this presumption can be controlled by evidence that the parties at the time of the conveyance established monuments of the boundaries. Without determining whether, in this case, there can be said to be a latent ambiguity in the deed, (see Hoar v. Goulding, 116 Mass. 132), or merely an indefiniteness in the description, we are of opinion that the acts of the parties contemporaneous with the delivery of the deed in fixing the monuments, and the subsequent fencing of the lot and the occupation in accordance therewith, are admiss - 
ble in evidence upon the construction to be given to the deed. Blaney v. Rice, 20 Pick. 62, 32 Am. Dec. 204; Stewart v. Patrick, 68 N. Y. 450; Hamm v. San Francisco (C. C.) 17 Fed. 119.

\section{New trial.}

\section{SECTION 2.-EXCEPTIONS AND RESERVATIONS}

\section{DORRELL, v. COLLINS.}

(Court of Queen's Bench, 1582. Cro. Eliz. 6.)

Ejectione firmæ. Upon not guilty, the jury found that the master and scholars of the college of Sinkford were seised in the time of Hen. $\mathrm{S}$ of the manor of Hodley, of which the place, \&c. is parcel, and let all their lands in Lambehurst (except the manor of Hodley, in Kent and Sussex) to J. S. for years: and they further find, that the master and scholars had no other lands in Lambehurst than the said manor. The question was, if the manor passeth by the lease? And all the Court held, that it being found they had no other land than the manor, the exception is yoid, because it goeth to the whole thing demised; otherwise of an exception of part ***18 as

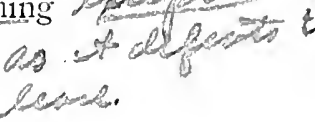

\section{WHITAKE:R v. BROWN.}

(Supreme Court of Pemsylvania, 1S63. $46 \mathrm{~Pa}$. 197.)

Error to the District Court of Allegheny county.

This was an action of trespass vi et armis, by Anthony Whitaker against William $\mathrm{H}$. Brown, to recover damages for breaking and entering the plaintiff's close, and for digging, mining, and carrying away thirty-nine thousand six hundred and twenty-five bushels of bituminous coal, and converting and disposing of the same to his own use.

After the plaintiff had offered all his evidence, the defendant's counsel moved the court to enter a peremptory nonsuit under the Act of Assembly, which was done, and this was the error assigned here.

The facts of the case are sufficiently stated in the opinion of the court.

Woodward, J. On the 14th of March 1853, Boyle Irwin and wife conveyed by warranty deed, six and a half acres of land in Allegheny

18 The remainder of the case is omitted.

Cf. Foster v. Runk, 109 Pa. 291, 58 Am. Rep. 720 (1885) ; Adams v. Warner, $23 \mathrm{Vt} .895$ (1851).

A conveyance is made of a tract of land, describing same "excepting one acre with the buildings thereon." What would be the result thereof?

AIg.Prop. -29 
county, to Anthony Whitaker in fee, "he, the said Boyle Irwin, saving and reserving nevertheless for his own use, the coal contained in the said piece or parcel of land, together with free ingress and egress by wagonroad to haul the coal therefrom as wanted." Boyle Irwin is dead, and his rights in the coal, if descendible, are vested in his heirs, under mhom the defendant justifies his entry to take coals.

It is argued that the above clause of the deed constituted a strict and technical reservation, which, having no words of perpetuity, died with Irwin, and therefore that Whitaker now has a several and exclusive title to all the coal in the land convered to him. On the other hand, the argument is, that it was not a reservation but an exception, and therefore that no title to the cont passed to Whitaker by the deed. Fhe question is, whether the words of the deed constituted a reservation or an exception.

Althoigl they were apt words to constitute a reservation. yet so far as they affect the coal, they must oferate as an exception, because the coal was a corporeal hereditament, in esse at the date of the deed, part of the land itself, and therefore not the subject of a reservation. Says Lord Coke. "note a diversity between an exception (which is ever of part of the thing granted and of a thing in esse) and a reservation, which is always of a thing not in esse, but newly created, or reserved out of the land or tenement demised." And his criticism upon the word reserve is as follows: "Reserve cometh of the Latin word reservo; that is, to provide for store, as when a man departeth with his land, he reserveth or provideth for himself a rent for his own livelihood. And sometimes it hath the force of saving or excepting." 2 Thomas's Coke Litt., star page 412. And so in Sheppard's Touchstone we read that "a reservation is a clause of a deed, whereby the feoffor, donor, lessor, grantor, \&.c., doth reserve some new thing to limself ont of that which he granted before This doth differ from an exception which is ever a part of the thing granted, and of a thing in esse at the time; but this is of a thing newly created, or reserved ont of a thing demised that was not in esse before, so that this doth always reserve that which was not before, or abridge the tenor of that which was before. ${ }^{19}$ If one grant land jielding for rent money, corn, a horse. spurs, a rose, or any such tling this is a good reservation: but if the reservation be of the grass, or of the vesture of the land, or of a common or other profit to be taken

19 See Emerson r. Mooner, 50 N. II. 315 (1S70), which determined the extent

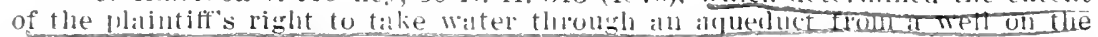
defondant's land. The luabitit had dus a well on the land which later cane

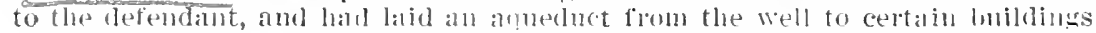

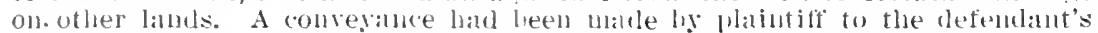

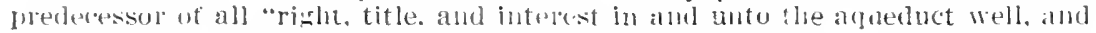

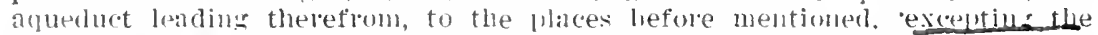

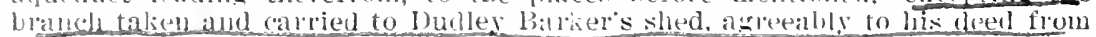

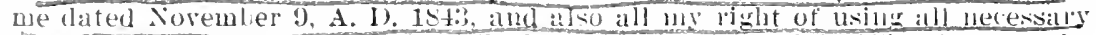

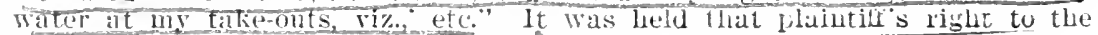
nuter was not liwited to his lifetime. 
out of the land, then these reservations are void." Touchstone, p. 80, et seq. Void, I take it the meaning is, as reservations, but capable of support as exceptions. In the case of The Earl of Cardigan $v$. Armitage, 2 B. \& C. 197, the words of the deed were "except and always reserved," and they were applied, among other things, to all the coals in the land granted, together with right of way to take them. Bayle, J., treated this as an exception of the coals which were part of the thing granted, part of the land, and in esse at the time, and because they were never out of the grantor, would have remained to him and his hcirs, even without the word heirs, which happened in that instance to be addled. In respect to the right of way, he quoted the rule from the Touchstone, that when anything is excepted, all things that are depending on it, and necessary for obtaining it, are excepted also.

This case is very much in point-indeed it is a direct authority for the ruling below, and it has been recognised and followed in subsequent cases. Fancy v. Scott, 2 Man. \& Ryl. 335; Douglass v. Lock, 4 Nev. \& Man. $\$ 26$.

In cur own case of Shoenberger v. Lyon, 7 Watts \& S. (Pa.) 184, the words "excepting and reserving" were construed an exception, but were set aside on the principle that every saving in a deed as large as the grant, is void.

Thus it appears, upon sufficient authority, that words of reservation may operate by way of exception, and to have any effect, must do so when the subject of the reservation is not something newly created, as a rent or other interest strictly incorporeal, but is a thing corporate and in esse when the grant is made. That the coal in question was land is not to be doubted, since the case of Caldwell v. Fulton, $31 \mathrm{~Pa}$. 475, $72 \mathrm{Am}$. Dec. 760 . As such, it would have passed under Irwin's deed to Whitaker, had it not been excepted out of the grant. At the date of the deed, Irwin held it in fee simple, and because it did not pass by the conveyance, he continued to hold it in fee. The word heirs was not necessary in the reservation, for an estate of inheritance existed alrearly in Irwin, and, unimpaired by the conveyance, it descended to his heirs at his death. And so also the right of way, expressly annexed to the estate in the coal, was saved by the exception, and descended to the heirs. The law would have given it if the partics had not expressly reserved it.

But what was the extent of the coal reservation? It is an undoubted rule that an exception in a deed is to be construed most strongly against the grantor, and most favourably to the grantee. And upon this principle it is claimed, that it was only a special and temporary use of the coal that was reserved to Irwin himself, a right to use the coal during his life, but which ceased at his death. We cannot so read the clause. "The coal contained in said piece or parcel of land" was the subject of the reservation. If that means less than the whole, how much less? what proportion of the coal was reserved? Words 
not larger than these were construed to mean the whole of a coal right in Caldwell v. Fulton, and we confess we should not know by what rule to restrict these words if we felt called upon to impose a restriction where the parties imposed none. Do the words "for his own use" amount to a restriction? Sometimes the use is limited in point of duration, as while the grantee is temant of a particular messuage, or so long as he manufactures a specific production; but here it is as general and absolute as so few words could make it. "For his own use," means, in such a reservation, the same dominion and proprietorship over the coal that he would have had if he had made no deed for the land. He held it for his own use in all the forms that it was capable of being used at the date of his deed-he held it just as absolutely after his deed was delivered.

The judgment is affirmed. ${ }^{20}$

\section{KISTER v. REESER.}

(Supreme Court of Pennsylvania, 1ss1. 9s Pa. 1, 42 Am. Rep. 608.)

Trespass quare clausum fregit, by Isaac Kister against George Reeser et al. On the trial, before Fisher, P. J., the following facts appeared:

By indenture dated September 30th, 1865, IVilliam Reeser and wife granted and conveyed to Henry $\mathrm{H}$. Drorbaugh and his heirs a tract of land containing about nineteen acres, part of a larger tract of land owned by the said William Reeser in fee. This deed contained the following clause: "The said Willian Reeser doth reserve a road ten feet wide along the line of Joseph Burger, to be shut at each end by a bar or gate." Burger's land formed one of the boundaries of the tract granted.

By indenture dated November 13th, 1867, Drorbaugh and wife granted and conveyed the said tract to Isaac Frazer and his heirs. This deed contained the following recital: "This being the same tract of land that William Reeser deeded to Henry H. Drorbangh by deed dated the thirtieth day of September A. D. one thousand eight hundred and sixty-five, wherein said William Reeser reserves a road ten feet in width along the line of Joseph Burger's land, to be shut at each end with a bar or gate."

By indenture dated December 9th, 1867, Frazer and wife granted and conveyed the same tract to Isaac Kister and his heirs. This deed also contained the last-mentioned recital.

20 In Fancy $r$. Scott, 2 Mann. \& R. 335 (1S2S), there was a declaration in trespass for brealing and entering the plaintiff's close, spoiling the grass, and digging peat and turt. The defendant in his plea, set up that he had leased the said close to the plaintiff reselving all pits, guarries, and mines, etc. To this plea there was a demurrer. In sustaining the denurrer Bayley, J., said, "The pleas are clearly bad. A landlord cannot reserve a component part of the land dewised or granted, as he has done here." 
William Reeser died in March, 1872. Prior to his death the said William Reeser, by indenture dated March 3d, 1872, granted and conveyed to his son, George Reeser. Sr., one of the defendants, another portion of the said large tract of land. This deed contains no mention. of the privilege of the said road reserved by the said William Reeser in his deed to Drorbaugh. George Reeser, Sr., however, clainns under the said reservation the use of a ten-feet-wide way over the land of Isaac Kister along the line of Joseph Burger.

In April, 1880, Isaac Kister placed a permanent fence at each end of the line of reservation mentioned in the deed of WVilliam Reeser to Drorbaugh. A short time afterwards George Reeser, Sr., and the other defendants, broke down the said fences, entered upon Kister's land, and drove a wagon across the same. For this alleged trespass Isaac Kister brought this suit.

The plaintiff requested the Court to charge, substantially, that the right to a road reserved by William Reeser in his deed to Drorbaugh not having been reserved to the heirs and assigns of William Reeser, ceased and determined on the death of William Reeser in March. 1872, and that such reservation was no justification of the trespass committed by the defendant. The Court declined so to charge.

The defendants submitted, inter alia, the following point:

2. That under the legal effect of the reservation in said deed from William Reeser to Drorbaugh, the portion of land ten feet wide along the line of Joseph Burger, for the use of a road, is excepted out of the grant, and remained as it was before for the purposes of a road; that the evident purpose of said reservation was to furnish egress and regress from the other lands of the grantor to and from the public roge leading to Goldsboro', and the defendant, being the owner of those other lands, had a legal right to pass in and out to said public road, over the said land reserved in said deed, and committed no trespass in doing so.

Answer. Under the reservation in the deed of William Reeser and wife to Henry H. Drorbaugh for nineteen acres and thirty-five perches, dated September 30th, 1865, the defendant had a legal right to pass over the road reserved in said deed, and did not commit a trespass by entering as he did the premises of the plaintiff.

The Court further instructed the jury that the plaintiff was not entitled to recover, and directed them to find for the defendants.

Verdict accordingly for the defendants, and judgment thereon. The plaintiff took this writ of error, assigning for error the answers to points as above, and the instruction to find for the defendants.

Trunkey, J. William Reeser, by deed dated September 30th, 1865, conveyed to Drorbaugh part of a tract of land which he then owned, and Drorbaugh's title has been vested in the plaintiff. The deed contains this clause: "The said William Reeser doth reserve a road ten feet wide along the line of Joseph Burger, to be shut at each end with a bar or gate." Prior to the conveyance there was neither a public 
nor private road over the land. The owner in fee of land may travel over it when and where he pleases, and it would be vain to speak of his right of way withim his lines. William Reeser died in 1872 . The court properly treated the question as one of law; for, aside from the conceded facts, there was no evidence to affect the construction of the deed or clause of reservation. If that clause is an exception of land ten feet wide, next to Burger's line, the plaintiff was not entitled to recover. But if it is a reservation of a way over said land, the defendants were trespassers. The land was granted in fee and a road reserved next Burger's line. This was to be shut at each end, and, subject to the grantor's use for a road, the grantee could enjoy it for all purposes. 'The word road has never been defined to mean land; it is difficult to find a defmition which does not include the sense of way, though the latter word is more generic, referring to many things besides roads. Road is generally applied to highway, street, or lane, often to a pathway, or private way, yet strictly it means only one parlicular kind of way. Its sense in this deed is very clear. Taking the entire clause, with reference to the grant, it means the reservation of a way. This is as plain as if the word way were in place of roal. Lawyer and layman alike would understand the word road in this clause in the same sense as it is used in the statutes providing for grant of "private roads." A private road obtained by proceedings under those statutes, is a mere way, the owner of the way having no interest in the land.

A private way is an incorporeal hereditament of a real nature, entirely different from a common highway; it is "the right of going over another man's ground." Where land is granted and the right of way reserved, that right becomes a new thing, derived from the land; and although, before the deed, the grantor had the right of way over the land whenever he chose to exercise it, yet when he conveyed the land the reservation was a thing separated fron the right of the grantee in the land: State v. Wilson, 42 Me. 9. A reservation is the creation of a right or interest which had no prior existence as such in a thing or part of a thing granted. It is distinguished from an exception in that it is of a new right or interest. An exception is always of part of the thing granted, it is of the whole of the part cxcepted. A reservation may be of a right or interest in the particular part which it affects. These terms are often used in the same sense, the technical distinction being disregarded. Though apt words of reservation be used they will be construed as an exception, if such was the design of the parties. Thus, when a deed in fee of land was made, the grantor "saving and reserving, nevertheless, for his own use the coal contained in the said piece or parcel of land, together with free ingress and egress by wagonroad to hanl the coal therefrom as wanted," it was held that the saving clause operated as an exception of the coal. The coal was land and the reservation of that part of the land excepted it from the grant. It was a thing corporate, existed when the grant was made, and differed 
from something newly created, as a rent or other interest strictly incorporeal: Whitaker v. Brown, 46 Pa. 197. Here, the saving clause created the way over part of the land granted, a right strictly incorporeal, and is not an exception of part of the land contained in the grant.

Judgment reversed, and venire facias de noro awarded. ${ }^{21}$

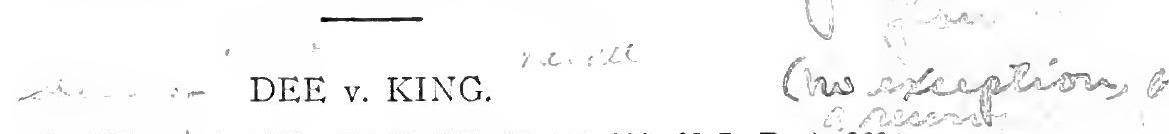

(Supreme Court of Vermont, 1905. 77 Vt. 230, 59 Atl. Se?, 6S L. R. A. SCo.)

Watson, J. When this case was here before (73 Vt. 375, $50 \mathrm{Atl}$. 1109 ,) the (ecree was reversed pro forma and the cause remanded for additional findings of fact by the special master, as to the time when, with reference to March 16, 1882, Jared Dee asked and obtained permission of the defendant to cross his three-acre piece of land on the east side of the Central Vermont Railroad. On the hearing before the master for this purpose, the orator introduced no further evidence. The defendant testified in his own behalf, and from his testimony the fact is found that Jared Dee first asked and obtained of the defendant permission to cross that land in January 1882. The orator seasonably objected and excepted to the defendant's testifying to any conversation had between him and Jared Dee on this point, because Jared Dee was dead.

The defendant was called and used as a witness by the orator at the first hearing, upon the question, among other things, whether Jared Dee passed through and over the three-acre piece, his habit and custom in so doing, to what extent, under what circumstances, and for what purpose. The orator made the defendant a general witness upon that question, and he thereby waived the statutory incompetency of the

21 "It is to be observed that a right of mas cannot, in strictness, be made the subject either of exception or reservation. It is neither lincel of the thing granted. nor is it issuline ont of the thing granted; the former hoind escentinl to an excention, and the latter to a reservation. A right of way reserved (using that worl in a somewhat popular semse) to a lessor, as in the present taise, is, in strictness of law, an easment newly cleated by wa of grint from the grantee or lessee, in the same manner as a light of sporting or fishing. Which his been litely much consitered in the mses of Doe hem. boniats ". Lack, 2A. \& E. 705 (18:35), and Wickham v. Hawker. 7 M. \& W. 6? (1St(t). It is not, indeed, stated in this case thit the lease was executed hy the lessee, which would be essential in order to establish the ensement climed ly the lesisors as in the nature of a grant from the lessee; but we presmme thit in fal the deed was, according to the ordinary practice, executed by both fillties. lessee as well as lessors." Ratilway Co. v. Walker, 2 A. \& L. (…‥ 940, 96it (1st2), per 'Tindal, C. J. But Cf. May v. Belleville, [1905] 르 Ch. 60J.

It has lieen held that, even though the stitute has Inde muncessary the use of the word "heirs" to create a fees sinte, a reservition of a riefit in ree refuites

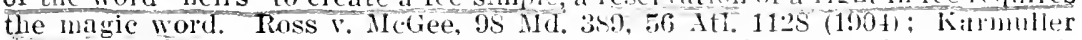
F. Krotz, 18 lowa, 352 (1S65); Ruhnke v. Aubert, 5s O1. 6, 113 l'ac. 3́s (1911), contra.

Cf. Lathrop v. Elsner, 93 Mich. 599,53 N. IV. 791 (1892). 
defendant as a witness. Paine v. McDowell, 71 Vt. 28, 41 Atl. 1042; Ainsworth v. Stone, 73 Vt. 101, 50 Atl. 805, - and he could not afterwards complain because the defendant gave testimony in his own behalf more fully upon the same subject matter.

Jared Dee having obtained permission of the defendant to cross the three-acre piece within fifteen years next after March 16, 1867, the orator can have no prescriptive way over it. A right of way over this land is neither set forth nor claimed by the orator in his bill; yet in one aspect of the case whether he has such a way is material.

The only right of way claimed by the orator over the defendant's land so far as appears by the bill, is over the one-half acre piece on the west side of the Central Vermont Railroad, as reserved by Jared Dee in his deed October 7, 1862, conveying that land to Villiam W. Pettingill. In that deed inmediately following the description of the land conveyed is the clause "reserving the privilege of a pass from the highway past the house to the railroad in my usual place of crossing." the defendant contends that these words are only a reservation of a personal privilege to Jared Dee which could not pass to his heirs or assigns because no words of inheritance or assignment were used in connection therewith; while the orator contends that the clause has the force of an exception, and that the servient estate thereby created passed to the stibsequent owners of the dominant estate without such words of limitation being used. Nuch depends upon the construction given in this regard, in the disposition of the case. Lord Coke says that "reserving" sometimes has the force of saving or excepting, "so as sometime it serveth to reserve a new thing, viz. a rent, and sometime to except part of the thing in esse that is granted." Co. Litt. 143 , a. Sheppard says that "a reservation is a clause of a deed whereby the feoffor, donor, lessor, grantor, etc., doth reserve some new thing to himiself out of that which he granted before. And this doth, most commonly, and properly, succeed the tenendum, * * * This part of the deed doth differ from an exception, which is ever of part of the thing granted, and of a thing in esse at the time, but this is of a thing newly created or reserved out of a thing demised that was not in esse before, so that this clause doth always reserve that which was not before, or abridge the tenure of that which was before." Shepp. Touch. 80. Again the same author says, that an exception clause most commonly and properly succeeds the setting down of the things granted; that the thing excepted is exempted and does not pass by the grant. Page 77. The same principles were largely laid down by this Court in Roberts v. Robertson, 53 Vt. 690, 38 Am. Rep. 710. There the deed given by the plaintiff contained a specific description of the land conveyed, and a clatuse "reserving lots * * * 32, 33," etc. Under this clatuse the plaintiff claimed title to the two lots above named. The court, after stating the offices of an exception and of a reservation the same as abore, said these terms, as used in deeds, are often treated as symonymous and that words creating an exception are to have that 
effect, although the word reservation is used. It was held that the clause should be construed as an exception.

In England it has been held that a right of way cannot in strictness be made the subject of either an exception or a reservation; for it is neither parcel of the thing granted, an essential to an exception, nor is it issuing out of the thing granted, an essential to a reservation. Doe v. Lock, 2 Ad. \& E. 705 ; Durham, etc., R. R. Co. v. Walker, 2 Q. B. 945. But there, as in this country, quasi easements are recosnized in law, such as a visible and reasonably necessary drain or way used by the owner of land over one portion of it to the convenient enjoyment of another portion, and there has never been any separate ownership of the quasi dominant and the quasi servient tenements. As such easement, a drain is classed as continuous, because it may be used continuously without the intervention of man; and a right of way as noncontinuous because to its use the act of man is essential at each time of enjoyment. In Barnes v. Loach (1S79) 4 Q. B. D. 494, it was said regarding such easements of an apparent and continuous character, that if the owner aliens the quasi dominant part to one person and the quasi servient to another, the respective alienees, in the absence of express stipulation, will take the land burdened or benefited, as the case may be, by the qualities which the previous owner had a right to attach to them. And in Brown v. Alabaster (1888) 37 Ch. D. 490, it was said that although a right of way by an artificially formed path over one part of the owner's land for the benefit of the other portion, could not be brought within the definition of a continuous easement, it might be governed by the same rules as are apparent and continuous easements.

Cases involving quasi easements have been before this Court. In Harwood v. Benton \& Jones, 32 Vt. 724, the owner of a water privilege, dam, and mill, also owned land surrounding and bordering upon the mill pond and mill, which he subjected to the use and convenience of the mill privilege and mills. A part of these adjacent lands thus subjected was conveyed without any stipulation in the deed that any servient condition attached thereto. The condition of the estate had been continuous, was obvious, and of a character showing that it was designed to continue as it had been. The Court said this was a palpable and impressed condition, made upon the property by the voluntary act of the owner. It was held that, without any stipulation in the deed upon that subject, the law was that the grantee took the land purchased by him, in that impressed condition, with a continuance of the servitude of that parcel to the convenience and beneficial use of the mill. It was there laid down as an unquestioned proposition that "upon the severance of a heritage, a grant will be implied of all those continuous and apparent easements which have in fact been used by the owner during the unity, though they have had no legal existence as easements;" and that the doctrine was equally well settled that the law will imply a reservation of like easements in favor of the part of the inheritance retained by the grantor. In Goodall v. Gorlfrey, $53 \mathrm{Vt} .219,38 \mathrm{Am}$. Rep. 
671 , a "visible, defined way in use for the obvious convenience of the whole building" "as in question, consequent on a division of the property among the representatives of the deceased owner, and the same principles of law were applied. And in Willey, Adnx., v. Thwing, 68 't. 128, 34 Atl. 428. applying the same doctrines, a right of way was upheld under an implied reservation.

In this country it is commonly held that a way may be the subject of a reservation, and in many cases courts of high standing have held that it may properly be the subject of an exception in a grant. While it is true that an owner of land cannot have an easement in his own estate in fee, he may as before seen have a quasi easement over one portion in the character of a visible, travelled way reasonably necessary to the convenient enjoyment of another portion, and when such a way exists, there would seem to be no substantial legal reason why it may not be treated as a thing in being, and as a part of the estate included in the description of the grant be made an exception in a deed of the land over which the way is, when such appears to have been the intention of the parties. That this is the principle upon which a clause reserving a way is construed as an exception appears from Chappell v. N. Y., N. H. \& H. R. R. Co., 62 Conn. 195, 2+ Atl. 997, 17 L. R. A. 4:0, which is more particularly referred to later. There the Court saicl: "Then too the right to cross was, in a certain sense, a right existing in the grantors at the date of the deed. It was a part of their full dominion over the strip abont to be convered by the deed.and wot a right to be, in effect, conferred upon them by the grantees. It was something which the 'reservation' in effect 'excepted' out of the operation of the grant."

The distinction between a reservation and an exception of a way is best understood by an examination of cases involving clauses very similar to the one here under consideration, yet so unlilie as to reculuire different constructions in this regard. In Ashcroft v. Eastern R. R. Co., $126 \mathrm{Alass} .195,30 \mathrm{Am}$. Rep. 672, the clause was "reserving to myself the right of passing and re-passing, and repairing my aqueduct logs forever, through a culvert * * * to be built and kept in repair by saicl company; which culvert shall cross the railroal at right angles," etc. It was helcl that the provision that the grantee should builcl and keep in repair the culiert was an essential part of the grant, and clearly indicated that the intention of the parties was to confer upon the grantor a new right not before vested in him, which, therefore, could not be the subject of an exception. In Claflin v. Boston \& Albany R. Co., 157 Mlass. 489, 32 N. E. 659, 20 L. R. A. 638, the clause was "reserving to ourselves the right of a passage way to be constructed and kept in repair by ourselves." 'There was no evidence of an existing way across the land. It was held to be a reservation and not an exception." ${ }^{22}$ In Chappell v. N. Y., N. H. \& H. R. R. Co. before

22 Hut see Failey r. Aqamam Nat. Pank, 190 Mass. 20, 66 N. E. 449. 3 L. R. 1. (N. S.) 9S, 11: Am. St. Itep. $296(1906)$, where there was inrolved the con- 
eited, John IV. and Lenjamin F. Drown, in 1851, owned a piece of land in New London fronting on the river Thames and lying between that river and Bank street. On the river front was a wharf and docks. Between the wharf and Bank street was about one and one-half acres of land used by the Browns in carrying on a coal and wharfage business. The wharf was valuable. In that year the Browns conveyed, for railroad purposes, a strip of this land, twenty-five feet wide, running through the land and separating the wharf from the land lying westerly of the strip conveyed, and rendering it inaccessible except by crossing the strip. This right of crossing was indispensable to the Browns and all who might thereafter own the premises then owned by them. The deed thus conveying this strip eontained the clause "And we reserve to ourselves the privilege of crossing and re-crossing said piece of land described, or any part thereof within said bounds." The way at the time of the date of the deed was an existing one plainly visible, necessary, and in almost constant use. The clause was construed to be an excention. In Bridger v. Pierson, 45 N. Y. 601, the defenclant conveyed land to the plaintiff and inmediately following the description the deed contained the clause "reserving always a right of way as now used on the west sicle of the abore described premises * * * from the public highway to a picce of land now owned by" R. It was held to be an exception. In White v. N. Y. \& N. E. R. R. Co., 156 Mass. 181,30 N. E. 612 , the action was tort for the obstruction of a private way claimed by the plaintiff over the location of the defendant's railroad, under a clause in a deed which read "reserving the passway at grade over said railroad where now marle." This way had existed as a clefined roadway or cart track, and had been used in passing to and from a highway to and from parts of the lot north of the tracks before the railroad was located, and before the deed referred to was given. The clause was held to be an exception. These are but a few of the many decisions in different jurisdictions which might be referred to upon this question, but more are unnecessary.

'The language of the clause under consideration cannot be said to be unequivocal. We therefore look at the surrounding circumstances existing when the deed containing it was macle, the situation of the parties, and the subject matter of the instrument; and in the light thereof the elause should be construed according to the intent of the parties. At the time of making this deed Jared Dee was the owner of

struction of the following provision in a deed from Moore to Ifenry: "A passagewall is to be liept oblen and for use in common between the two bouses ten feet in width, fire teet of sild passageway to be fuldisled br sad llemis and fice feet hy me from lind ling e:1st of the land here converel." "There wis no massacenaly in existence at the time of the deet. Menry hater conveyed the same land to the defendint, who in tum consered it by deed with full corenants for title to the plaintiff. The case arose npon a daim for damares for breach of the covenimt against incmmbrances. The phint iff was allowed to recover despite the fact that loole had dicel hefore the deed to the nainititit.

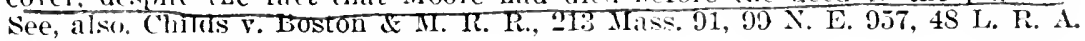
(N. S.) $378(1912)$. 
land on the opposite side of the railroad, consisting of a three-acre piece of tillage land, and a hill lot adjoining it on the north, chiefly valuable for its sugar works, for its pasturage, and as a wood and timber lot. The last named lot is traversed its entire length from north to south and about a third of its width from west to east by a considerable hill, more or less ledgy and making it extremely inconvenient to cross from the grantor's own land north of the Fairbanks land, but easily reached by the now disputed right of way across the one-half acre piece, and over the three-acre piece of tillage land. The greater portion of Jared Dee's sugar orchard, timber, and wood was on top and east of this hill. There was no way to or out of the hill lot except over the hill on Jared Dee's own land west of the Fairbanks land, or out through the three-acre piece and the one-half acre piece onto the public highway leading westerly to Jared Dee's house. For more than ten years next prior to the time when Jared Dee gave the deed to Pettingill, the Dees had passed over the one-half acre piece and through the three-acre piece almost exclusively for all purposes whenever they went to or from the hill lot, whether with team, on foot, or in any other manner, except when they got wood on the west side of the lot they went from the highway across the Fairbanks farm west of the railroad, thence over the railroad at the "middle crossing" onto the hill lot. And on rare occasions they used still another route further north wholly over Dee's land. It appears from the deed itself that in crossing the one-half acre picce they had a particular place of travelling then known to both the grantor and the grantee, for the words used in the deed in describing it are "from the highway past the house to the railroad in my usual place of crossing." Thus showing the intention of the parties to be that the grantor should retain the right to pass through this land over a visible travelled way then in existence, and that no new way was thereby being created for his benefit.

Clearly under the law and in the light of the foregoing circumstances, the clause must be construed, not as a reservation, but as an exception. When given this construction, technical words of limitation are not applicable, for the part excepted remained in the grantor as of his former title, because not granted. Cardigan v. Armitage, 2 Barn. \& C. 197 ; Chappell v. N. Y., N. H. \& H. R. R. Co., before cited; Winthrop v. Fairbanks, $41 \mathrm{Me}$. 307. We think the parties intended that by this provision the grantor should permanently retain from the grant for the benefit of his land east of the railroad, the way over the onehalf acre piece, which he had been accustomed to use in crossing that land to and from the land first named. The way, thus retained became an easement over the half-acre piece of land and an appurtenant to the other land; and with the latter it would pass by descent or assignment.

Subsequent to conveying the one-half acre lot to Pettingill, Jared Dee sold and conveyed the three-acre piece, which through mesne conveyances has become the property of the defendant. But this cannot 
affect the easement as an appurtenant to the hill lot; for a right of way appurtenant to land attaches to every part of it, even though it may go into the possession of several persons. Lansing v. Wiswall, 5 Denio (N. Y.) 213; Underwood v. Carney, 1 Cush. (Mass.) 285.

The master finds that if upon the facts reported the orator has a right of way or a right to cross over defendant's land to the hill lot, then the orator has suffered damage by reason of the acts of the defendant complained of in the bill, to the amount of sixty-five dollars. The orator can recover only such damages as he has suifered by acts of the defendant in obstructing the way across the one-half acre piece, considering the fact that the orator had no right of way over or right to cross the defendant's three-acre piece. "Upon this basis the damages have not been assessed. The report should therefore be recommitted for that purpose, and upon such damages being reported, a decree should be rendered that the injunction be made perpetual, and that the defendant pay to the orator the damages found with costs in this Court. The costs in the court below should be there determined.

The decree dismissing the bill with costs to the defendant is reversed and cause remanded with mandate. ${ }^{23}$

\section{SMITH'S EX'R v. JONES.}

(Supreme Court of Vermont, 1912. 86 Vt. 25S, St Atl. S66.)

Case for obstructing a private way. Plea, the general issue. Trial by court on an agreed statement of facts at the September Term, 1911, Franklin County, Waterman, J., presiding. Judgment for the plaintiff. The defendant excepted. The opinion states the case.

Munson, J. The plaintiff sues as executor of Francis Smith to recover damages for the obstruction of a private way which crosses the defendant's land, called the Pratt farm, to a wood lot immediately adjoining, which belongs to Smith's estate and is in the possession of the executor. In $1867 \mathrm{Smith}$, then the owner of both parcels. conveyed the farm to a grantor of the defendant by a deed which contained the following clause: "Reserving the right at reasonable times and in a reasonable way to cross said land below the road to my wood lot." There is no similar clause in the succeeding deeds, but each of these contains a reference to the deed immediately preceding. Since the conveyance of Francis Smith the owners of the wood lot have had no other means of reaching it than the claimed right of way. The parties submit the question whether this easement ceased with the life of Francis Smith, or inures to the benefit of his heirs and estate.

There is nothing in the agreed statement to show that at the date

23 See Smith .. Furbish, 68 N. H. 123, 44 Atl. 398, 47 I. R. A. 226 (1891); York Haven Water \& Power Co. v. Iork Haven Paper Co., 201 Fed. 270, 119 C. C. A. 508 (1912). 
of the Francis Smith deed there was a defined and visible way across the grantor's farm to his wood lot. So the way mentioned in the deed must be taken to be a new way, not in being previous to the execution of the deed. If there had been an existing road, the provision in question could be construed as an exception, and thus accomplish a retention of a right of way. Dee v. King, 77 Vt. 230, 59 Atl. 839, 68 L. R. A. 860 . The terms "reservation" and "exception" are often used as synonymous when the thing to be secured to the grantor is a part of the granted premises, and when so used they are to be construed accordingly. 2 Wash. Real Prop. *645. If given their technical meaning, an exception is something withheld from a grant which otherwise would pass as a part of it, while a reservation is some newly created right which the grantee impliedly conveys to the grantor. Ashcroft v. Eastern R. R. Co., 126 Mass. 196, 30 Am. Rep. 672; Bailey v. Agawam Nat. Bank, 190 Mass. 20, 76 N. E. 449, 3 L. R. A. (N. S.) 98, 112 Am. St. Rep. 296. The extreme technicality of the latter conception is apparent. It would be easier and nearer the truth to say that a reservation is an interest which the grantor creates and excepts or reserves from lis grant. Then the interest classed as a reservation would remain in the grantor, and an easement in fee would arise without the use of the word "heirs."

It is still the rule of the common law that an easement in fee cannot be created by way of a reservation without words of inheritance. But it has been held that terms of reservation may be construed as constituting an exception when this is necessary to effectuate the purpose of the parties. It seems to be considered that the parties may use the term in a sense different from its technical meaning, and that their intent, if ascertainable from the subject of the grant and the surrounding circumstances, sliould control rather than the legal implication. 'The primary and natural meaning of the word is inconsistent with the effect given it in the law of this subject. To reserve. is to keep in reserve, to retain, to keep back, not to deliver or make over. Its meaning in law, as given by Webster's New International, is "to withhold from the operation of a grant or agreement." Unless saved by the rule of construction above stated, this inconsistent technical meaning of a word in common use and a forced implication therefrom will determine whether an easement, essential to the use and value of an estate, shall end with the life of the then owner or go with the estate in perpetuity.

After Smith conveyed the Pratt farm his wood lot was entirely surrounded by the lands of others. There is nothing to indicate that he had any personal interest in securing a right of way distinct from his interest as owner of the lot. His interest as owner required that he secure a right of way available after his death. The value of the lot to Smith as its then owner, irrespective of use, depended upon the perpetuity of the means of reaching it. In ordinary circumstances there is no ground for supposing that a grantor intends to limit a 
right of this nature to the uncertain period of his life, and thereby materially lessen the value of his land as property in the market or as an asset of his estate. The purpose of reserving a right of way to that part of the property retained by the grantor is manifest to the grantee, even though there is no definite and visible way impressed upon the soi]; and the purpose is one that points directly to an intention on the part of the grantor to reserve a right co-extensive in duration with his estate in the land. The purpose and umderstanding of the parties in creating an easement of this nature are so nearly universal, that those using terms of reservation may properly be held to have intended an easement in fee, when there are no circumstances or restrictive words inclicating a contrary intention.

Judgment affirmed.

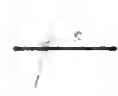

\section{IIAVERIIILL SAVINGS BANK v. GRIFFIN.}

(Supreme Judicial Court of Massacliusetts, 1903. 1S4 Mass. 419, GS N. E. S89.)

Dill in equity, filed August 17, 1901, to restrain the defendant from using and maintaining a drain from certain land on the east sicle of Auburn Street, in Haverhill, owned by the defendant, through land on the south side of Sixth Avenue in that city owned by the plaintilf, and praying that the plantiff be authorized to close the portion of the drain upon its land.

In the Superior Court Stevens, J., made a decree granting the relief prayed for; and the defendant appealed. At the request of the defendant the judge reported the material facts found by lim, in accordance with R. L. c. $159, \S 23$.

The report was in substance as follows: The defendant is the owner of the land described as hers in the bill, bouncled on the north by the land of the plaintiff also described in the bill. Both parcels of land were owned on and before November, 185.5, by one Algernon P. Nichols, who had died before the filing of the bill. The land owned by the defendant was conveyed to her by Nichols by a warranty deed in common form dated November 4, 1885 . The land owned by the plaintiff was conveyed to one IVarren Iloyt by Nichols, by a warranty deed in common form dated July 12, 1586 . In this deed the plaintiff's land was described as bouncled on the south by land of Caroline Griffin about one hundred and seven feet more or less, and contained the following clause: "And reserving to the lot next southerly owned by Griffin the right to enter a drain into a private sewer now on said land." ) The plaintiff accuired its title through a mortgage given by lloyt to the plaintiff and foreclosed by the plaintiff. The mortgage did not contain any words relating to the drain. After the conveyance to the defendant, a drain was constructed by her from the lot owned by her into and through the Nichols land, afterwards conveyed to 
Hoyt. This drain connected with the sewer on Hoyt's land, and fromi the autumn of 1885 was in continuous use draining the defendant's lot.

The deed from Nichols to Hoyt containing the clause above quoted was as follows, omitting the portion after the habendum clause which contained the ordinary corenants of a warranty deed:

"Know all men by these presents that I, Algernon P. Nichols, of Haverhill in the County of Essex and Commonwealth of Massachusetts, in consideration of two thousand dollars paid by Warren Hoyt, of said Haverlill, the receipt whereof is hereby ackinowledged, do hereby give grant bargain sell and convey unto the said Warren Hoyt a certain parcel of land in said Haverhill on the southerly side of Sixth street and bounded on the North by said St. one hundred and ten feet more or less, on the east by land of the Children's Aid Society, about one hundred feet more or less, on the south by land land of Caroline Griffin about one hundred and seven feet more or less, and on the West by Auburn street about one hundred feet. Saving and reserving neyertheless to myself and my heirs and assigns forever for the use of said Children's Aid Society a right to pass and repass upon and over a strip of land four feet ( $4 \mathrm{ft}$.) wide and seventy-five feet long, extending southerly from Sixth St. and next to land of said Society, so as to make a passage way for the exclusive benefit-the adjoining estates twelve feet wide including the eight feet in width which I reserved for such use in my deed to said Society, and reserving to the lot next southerly owned by Griffin the right to enter a drain into a private sewer now on said land. To have and to hold the granted premises with all the privileges and appurtenances thereto belonging to the said Hoyt and his heirs and assigns to their own use and behoof forever."

BRALEY, J. At the time the defendant obtained title to her land the drain was not in existence and the deed under which she holds is silent as to any right to lay and maintain such a drain through the land of the plaintiff. Neither does it appear that this alleged right whereby the defendant would be entilled to connect her premises with the public sewer, can be said to arise by implication. See in this connection Bumstead v. Cook, 169 Mass. 410, 48 N. E. 767, 61 Am. St. Rep. 293.

The case falls within the well recognized general rule that where an easement is not set out in the instrument under which the party claiming the privilege holds title, it must be shown to be actually in existence and connected with the estate conveyed in order to pass as appurtenant by implication. Philbrick v. Ewing, 97 Mass. 133; Bass v. Eidwards, 126 Mass. 445, 449.

In order therefore to maintain her claim she is necessarily obliged to rely on the clause in the deed to the plaintiff's grantor which is in these words, "and reserving to the lot next southerly owned by Griffin the right to enter a drain into a private sewer now on said land," and 
the rights of the parties must be determined on the construction to be given to this clause.

At the date of this deed so far as the facts appear by the record no such right had been granted to or prescriptively acquired by the defendant, and which might be preserved for her use by the language used, on the ground that thereby an exception was created and hence the easement claimed was excepted from the grant. But they must be construed as an attempt to vest in the grantor a new interest or right that did not before exist and therefore constitute a reservation rather than an exception. Wood v. Boyd, 145 Mass. 176, 13 N. E. 476; White v. New York \& New England Railroad, 156 Mass. 181. 30 N. E. 612.

As the defendant was not a party but a stranger to the deed she could gain no rights under the reservation which enured solely to the grantor, and for this reason she did not acquire an easement under it. Murphy v. Lee, 144 Mass. 371, 374, 11 N. E. 550.

It follows that the decree entered in the Superior Court was right and should be affirmed. Decree affirmed. ${ }^{24}$

24 Ce. Lipsky v. Heller, 199 Mass. 310, 85 N. E. 453 (190S); Martin v. Cook, 102 Mich. 267, 60 N. W. 679 (1\$94); Corning v. Troy Iron \& Nail Factory, 40 N. Y. 191 (1869) ; Bartlett v. Barrows, 22 R. I. 642, 49 Atl. 31 (1001); Wail r. Wall, 126 N. C. 405,35 S. E. 811 (1900).

AIG.ProP. -30 
CHAPTER IV

\title{
CREATION OF EASEMENTS BY IMPLICATION 1
}

\author{
COPPY v. I. DE B.
}

\author{
(1496. Y. B. 11 Hen. VII, 25, pl. 6.)
}

Villiam Coppy brought an action on the case against J. de B., and counted that according to the custom of London, where there were two tenements adjoining, and one had a gutter rumning over the tenement of the other, the other cannot stop it, though it be on his own

1 The ordinary way of crentine easements and profits of course is lw ginnt, which accololing to the common liw, weidut lig al sealed instriment. The prohlenss of difliculty that arise in commection with such expless grints are in gren-

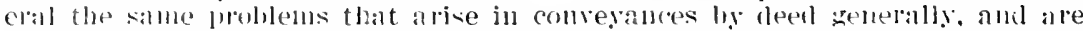
sutliciently treated muler other heads. Ilowerer in the matter of the sutficiency of the words in the grant to serve to create de nuro an easement there arise oscasionilli guestions of sileciol tifliculfy.

"Ilith the "ndurtenances" does not sirve to create an easement de novo, even where the absement clamed had a de facto existence prior to the comreyance. Whalley v. Thompson. 1 lios. \& P. 371 (17)

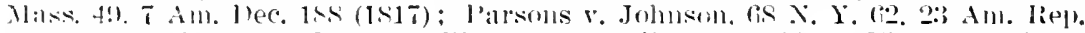

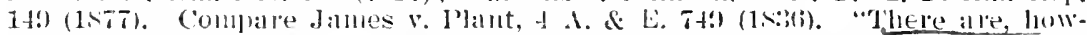

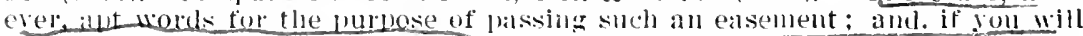

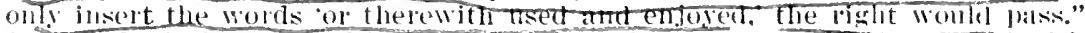

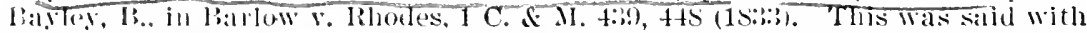

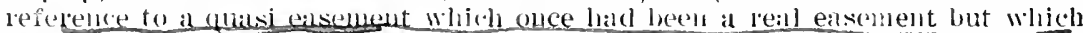

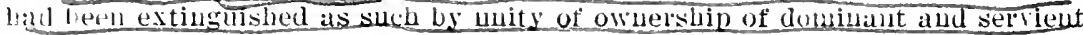
tellellolits.

"Thenthe owner of a piece of land has a right of way over adjacent laml, so that he may maintain at any time an action for an ol stivetion. if afterwarts by inhelitane or burelalse both pieces of lallul come to one and the same own-

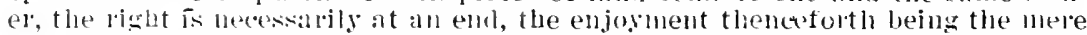
exercise of a riaht of property on his uwn land. But it, at a later period the

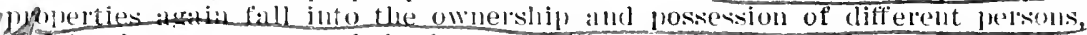

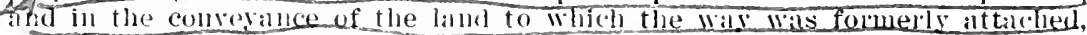

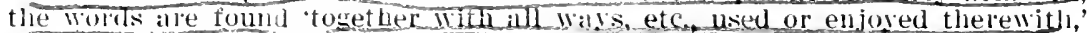

- the effect of these worts is fo jerive the right that formerly esisted, and inhich hats been not extinguished. but onl suspended. Put since it does not allerar here that at any anteredent time there existed a risht orer one of these prieces

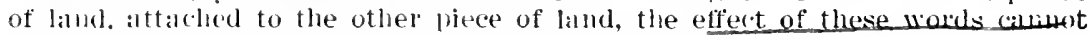
malie or lerive a right of wall that never iofore existed." Relly, C. 13., in Linngley r. llammont. T. R. 3 Fx. 161, 168 (18tis). Contil the cases of Watts v. Kelson. I. R. 6 Ch. Apt. 160 (1S70, and Kily r. Oxley, I. R. 10 Q. B. 360 (15i5), it seems to have heen considered that gencral words of the sort referred to woulel onerate to create an alsement only where there had once been a trine eisement "hich. thongh extinguished in taw hy unity of onnership had been continuen is it de tacto easpment in connection with the use of the quasi dom-

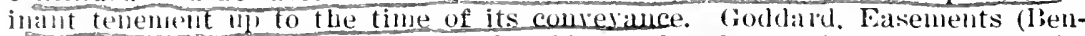
netts En 10? In Ka! r. Oxley, Backlsum, J., after reviewing some of the earlise calces liniting the dortrine as ahore stated. states what would seem to be the proper riow: "It camnot make any difference in law, whether the right of way was only de facto used and enjoged, or whether it was originally created before the unity of possession, and then ceased to exist as a matter of right, 
land; and counted how he had a tenement and the defendant another tenement adjoining.

Rede [ for the defenclant]: "TVe say that since the time of memory one A. was seised of both tenements, and enfeoffed the plaintiff of the one and defendant of the other."

Wood [for the plaintiff]: "'This is not a good plea, for the defendant seeks to defeat the custom by reason of an unity of possession since the time of memory; and that he cannot do in this case, for such a custom, that one shall have a gutter running in another man's land is a custom solemnly binding the land, and this is not extinct by unity of possession; as if the lord purchase lands held in gavellind, [still] both sons of the lord shall inherit, just the same as if the land had remained in the possession of the tenant, because [the custom of ] gavelkind is solemnly binding on the land."

TownsuE.ND. "If a man purchase land of which he has the rent, the rent is gone by the unity of possession, because a man cannot have a rent from himself; but if a man has a tenement from which a gutter runs into the tenement of another, although he purchase the other tenement, the gutter romains, and is as necessary as it was before."

Rele: "Hle who was the owner of the two tenements night have destroyed the gutter; and that if he had done so, and then made several feoffments of the two tenements, the gutter con'd not have reviver.".

Davero: "If that were so, you might have pleaded such destruction specially, and it would have raised a good issue."

l'owssurs: "Amend your plea, for we will not argue with you any longer."

Whereupon Rede pleaded new matter.

\section{RODBINS v. BARNES.thes the pening. (Court of Common I'leas, 1616. Ilobart, 191.)}

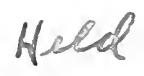

Robhins brought a quod permittat against Barnes, prosternere quandam domum, \&c., and connts, that he was seised of an ancient liouse and yard; and whereas in the east part of the said house there is, and time out of mind hath been, a window of such length and breatth; the defendant hath erected a certain house of such length and breadth upon his own frechold so near the said east part of the said house, that it overhangs the same and stoppeth his light, \&c. The defendant pleads, that one Richard Allen was seised of the plaintift's house and

so that in the one ase it would he created as a right de noro, in the other

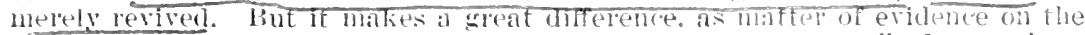
guesion, whether the way was med and engoyed as alpurtenallt." It wals there lucld that the right to nse a way which lad had no existence jrior to any uint

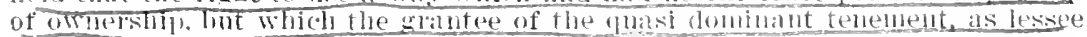
thereof, hidd heen lising in conmertion with lis ocompincer passed as an easement under general wolds of the chidracter under consideration.

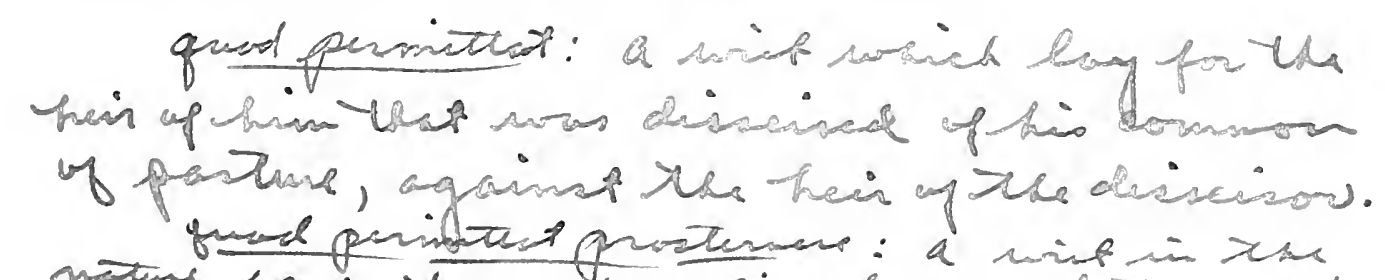


yard, and was also seised of a certain house, standing in the place where the said house of the defendant now standeth, which did overhang the house of the now plaintiff, in tam amplis modo and forma, as the said now house of the said defendant doth. And he saith, that he pulled down that house, because it was ruinous, and built this house in the place of it. The plaintifif maintains his count and traverseth, that the old house superpendebat, \&c., in tam amplis modo \& forma prout, \&c. And the jury found for the plaintiff. And now it was said in arrest of judgment, that this was an unperfect issue; for there ought no more of the new house to be prostrated, than did indeed overhang more than the former house did, which was granted by the Court, if it had been wisely pleaded. For it was agreed by the Court, that though one of these houses had been built overhanging the other wrongfully before they came both into one hand; yet after when they came both into the hand of Allen, that wrong now was purged; so that if the houses camie afterwards into several hands, - yet neither party could complain of a wrong before: so that in this case it was plain, that the plaintiff could have no cause of action, but for the increase of the overhanging. Yet because he had not expressed and distinctly linited that in his plea, but took issue generally as before, which was found against him, the Court must now give judgment according to the complaint as true, because they can take no other knowledge; for the jury hath not found that the former house overhanged so much, and not the rest; yet out of their discretion they gave the plaintiff judgment for the whole, and execution for damages and costs presently; but staid execution, as to the abating of the house till it might be viewed what was overhanging de novo; because the Court was informed, that in truth it was but a small matter. If I have an ancient house and lights, and I purchase the next house or ground, where yet no nuisance is done to my former house; now it is clear, that my privilege, against that I have purchased, ceaseth; for I may use mine own as I will. Now then suppose I would lease my former house, I may build upon the latter, or if I lease my latter, he may build against me, as it may seem.

But note, there is a great difference between interests and profits, as rents, commons, \&c., and bare easements, such as are lights, air, gutters, stillicidia and the like; for though while they are in one hand they may be stopped, or foredone, because a man cannot be said to wrong himself, yet if they be divided, things of that nature (still in being) do revive, because they are of no less use of themselves in one hand than in divers, being equally (rebus stantibus in the same use and occupation) necessary for the several houses to which they belong, but clearly, if even such things be foredone or altered, while they are in one hand, and so being the houses be again divided, they cannot be restored by law, but must be taken as they were at the time of the conveyance. 


\section{PALMER v. FLETCHER.}

(Court of King's Bench, 1663. 1 Lev. 122.)

Case was brought for stopping of his lights. The case was, a man erected a house on his own lands, and after sells the house to one, and the lands adjoining to another, who by putting piles of timber on the land, obstructed the lights of the house; and it was resolved, that although it be a new messuage, yet no person who claims the land by purchase under the builder, can obstruct the lights any more than the builder himself could, who cannot derogate from his own grant by TWYSDEN and WYNDHA T, Justices, HYDE being absent, and KELYNGE doubting. For the lights are a necessary and essential part of the house. And Keny NGE said, Suppose the land had been sold first, and the house after, the vendee of the land might stop the lights; TWYSDE: to the contrary said, Whether the land be sold first or afterward, the vendee of the land cannot stop the lights of the house in the hands of the vendor or his assignees; and cited a case to be so adjudged; but all agreed, that a stranger having lands adjoining to a messuage newly erected, may stop the lights, for the building of any man on his lands, cannot hinder his neighbour from doing what he will with his orvn lands; otherwise if the messuage be ancient, so that he has gained a right in the lights by prescription. And afterwards in Mich. $\overline{16}$ Car. II, B. R. a like judgment was given between the same parties, for erecting a building on another part of the lands purchased, whereby the lights of another new messuage were obstructed.

\section{PINNINGTON v. GALLAND.}

(Court of Exchequer, 1555. 9 Exch. 1.)

This was an action on the case for the disturbance of a right of way, which came on to be tried before Coleridge, J., at Nottingham Summer Assizes, 1852, when a verdict was found for the plaintiff, damages 40s., subject to the following special case: ${ }^{2} * * *$

Martin, B. This is a special case, which was argued before us during the last Term; and the question is, whether the plaintiff, as occupier of two closes called the Rye Holme closes, is entitled to a right of way over certain lands of the defendant.

The material circumstances are these: In the year 1839 a property consisting of five closes belonged to a $\mathrm{Mr}$. Dickinson. Two of them were the Rye Holme closes, and they were separated by two of the others from the only available highway, the Town-street of Suttonupon-Trent. From the year 1823 the road over which the plaintiff

2 A portion of the statement of facts is omitted.

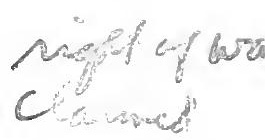


now claims the right of way was that which was used by MIr. Dickinson's tenant for the occupation of the Rye Holme closes. From a plan, which forms part of the case, the road appears to be the shortest and most direct access from the highway to the closes; and it having been used for so many years by the tenant who occupied the entire property, we think we may safely conclude that it was, and is, the most convenient road.

In 1839 the property was sold by Mr. Dickinson in three lots. A Mr. Mloss purchased the Rye Holme closes, a Mr. Newboult purchased one of the other closes, and a Mr. Dearle purchased the remainder of the property, which includes that now belonging to the defendant, and over which the way in question goes. The deeds of convevance to the three purchasers, although bearing different dates, were all executed on the same day, the Sth of April, 1S40, and it cannot now be ascertained in what order of priority they were executed. No special grant or reservation of any particular way is contained in any of them ; but in the conveyance to Mr. Moss, whose tenant the plantiff is, there is comprised the usual words, "together with (inter alia) all ways, -ads, paths, passages, rights, casements, advantages, and appurtenances whatsoever to the said closes belonging or in any way appertaining." Mr. Dearle executed the deed of conveyance to him.

For several years after the execution of the conveyances the occupier of the Rye Holne closes continued to use the road in question; but in $1 S+3$ the defendant, who had purchased from III. Dearle pit of the land conveyed thus by Mr. Dickinson, and over which the way in question goes, disputed the plaintiff's right to use it. Attempts were made for arrangement, which falled, and we are now required to decile the point; and we are of opinion that the plaintiff, as occupier of the Rye llolme closes, is entitled to the right of way claimed.

lt is impossible to ascertain the priority of the execution of the two conveyances (that to the third purchaser may be put out of consideration), and the plaintiff having to establish his right, is bound to show that, whichever was the first executed, he nevertheless is entitled to the right of way.

First, assume that the conveyance to Mr. Moss was executed before that to Jir. Dearle. In this case there would clearly be the right of way. It is the very case put by Mr. Serjt. IVilliams in his note to Pomfret v. Ricroft, 1 IVms. Saund. 323, viz., "where a man, having a close surrounded with his land, grants the close to another in fee, for life, or for years, the grantee shall have a way over the grantor's land, as incident to the grant, for without it he cannot have any benefit from the grant, and the way would be the most direct and convenient, which we think we may properly assume the one in question in the present case to be. This is founded upon the legal maxim, "Quando aliquis aliquid concedit, concedere videtur et id sine quo res concessa uti non potest," which, though it be clearly bad Latin, is, we think, good law. 
Secondly, assume that the conveyance to Mr. Dearle was executed the first. In this case the Rye Holme closes were for a short priud of time the property of $\mathrm{Mr}$. Dickinson, after the property in the land conveyed to M/r. Dearle had passed out of him. There is no doubt. apparently, a greater difficulty in holding the right of way to exist in this case than in the other; but, according to the same very great authority, the law is the same, for the note proceeds thus: "So it is when lie grants the land and resarves the close to himself; and he cites several authorities which fully bear him out: Clarke v. Cogze, Cro. Jac. 170; Staple v. Heydon, 6 Mod. 1; Chichester v. Lcthbridge, Willes, 72 , note. It no donbt scems extraordinary that a man should have a right which certainly derogates from his own grant; but the law is distinctly laid down to be so, and probably for the reason given in Dutton v. Taylor, 2 Lutw. 148, that it was for the public good, as otherwise the close surrounded would not le capable of cultivation.

According to this law, therefore, the right of way would accuse to Mr. Dickinson upon the execution of the conveyance to Mr. Dearle, and it would clearly pass to Mr. Nloss under his conveciance, for it would be a way appurtenant to the Rye Holme closes, and would pass under the words "all ways to the closes belonging or appertaining," and, indeed, probably without them. The plaintiff has vested in him, as Mr. Moss's tenant, all his rights of way; and, for the above reason, we think that he is entitled to the judgment of the Court.

There is a statement in the case respecting another road described in the plan as from $C$ to $D$, which the defendant contends was the plaintiff's proper way. But it is perfectly clear, that, whatever may be the rights of the occupiers or owners of the two closes further to the east, called Maples and Catliffe closes, and which were sold a:d conveyed by Mr. Dickinson before the sales to Mir. Mloss and Mr. Dearle, Mr. Moss or the plaintiff his tenant, upon the statement in the present case, has no right to the use of it; and except by one or other of the roads, the case states that the plaintiff could not get to the Rye Holme closes without being a trespasser upon land other than Mr. Dickinson's.

Judgment for the plaintiff."

3 See Daries $\nabla$. Sear, I, I. 7 Eq. 427 (1Sf, ), where at the time of conreyance it was not necessary to use the granted land as moms of alcoss to re-

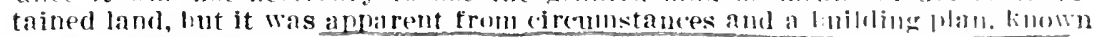
to the grautee that certain building operations, when colupleted, Would cut off all other weaus of access.

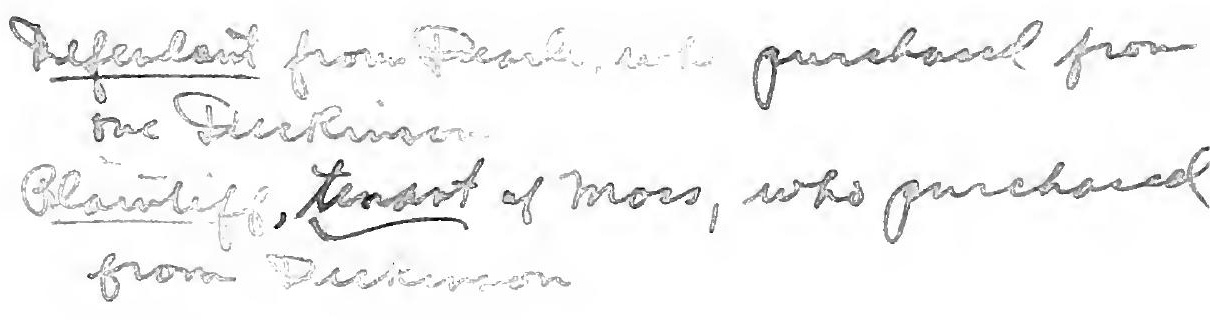


learned Judge directed a verdict for the plaintiff, reserving leave to the defendant to move to enter a verdict for him.

WATSON, B. This was an action for stopping a drain that ran under both the plaintiff's and defendant's houses, taking the water from both. The cause was tried at Liverpool, before Baron Bramwell, when a verdict was entered for the plaintiff, and a motion was made to enter a verdict for defendant in pursuance of leave reserved at the trial.

The plaintiff's and defendant's houses adjoined each other. They had formerly been one house, and were converted into two houses by the owner of the whole property. Subsequently the defendant's house was conveyed to him, and after that conveyance the plaintiff took a conveyance of his house. At the time of the respective conveyances the drain ran under the plaintiff's house and then under the defendant's house, and discharged itself into the common sewer. Water from the eaves of the defendant's house fell on the plaintiff's house, and then ran into the drain on plaintiff's premises, and thence through the drain into the common sewer. The plaintiff's house was drained through this drain. It was proved that by the expenditure of $f 6$., the plaintiff might stop the drain and drain directly from his own land into the common sewer. It was not proved that the defendant, at the time of his purchase, knew of the position of the drains.

Under these circumstances we are of opinion, upon reason and upon authority, that the plaintiff is entitled to our judgment. We think that the owners of the plaintiff's house are, by implied grant, entitled to have the use of this drain for the purpose of conveying the water from his house, as it was used at the time of the defendant's purchase. It seems in accordance with reason, that where the owner of two or more adjoining houses sells and conveys one of the houses to a purchaser, that such house in his hands should be entitled to the benefit of all the drains from his house, and subject to all the drains then necessarily used for the enjoyment of the adjoining house, and that without express reservation or grant, inasmuch as he purchases the house such as it is. If that were not so, the inconveniences and nuisances in towns would be very great. Where the owner of several adjoining houses conveyed them separately, it would enable the vendee of any one house to stop up the system of drainage made for the benefit and necessary occupation of the whole. The authorities are strong on this subject. In Nicholas v. Chamberlain, Cro. Jac. 121, it was held by all the Court that, "if one erects a house and builds a conduit thereto in another part of his land, and conveys water by pipes to his house, and afterwards sells the house with the appurtenances, excepting the land, or sells the land to another, reserving to himself the house, the conduit and pipes pass with the house, because it is necessary and quasi appendant thereto, and he shall have liberty by law to dig in the land for amending the pipes or making them new as the case requires. So if a lessee for years of a house and land erect a con-

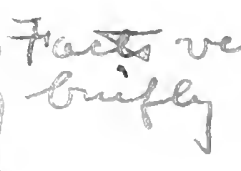

$$
\text { (1) }
$$


duit upon the land, and after the term the lessor occupies them together for a time, and afterwards sells the house with the appurtenances, to one, and the land to another, the vendee shall have the conduit and the pipes, and liberty to amend them." Shury v. Pigott, Popham, 166, s. c. 3 Lulst. 339, and the case of Coppy v. I. de B., 11 Hen. VII, 25, pł. 6, support this view of the case, that where a gutter exists at the time of the unity of seisin of adjoining houses it remains when they are aliened by separate conveyances, as an easement of necessity.

It was contended, on the part of the defendant, that this pipe was not of necessity, as the plaintiff might have obtained another outlet for the drainage of his house at the expense of 26 . We think that the amount to be expended in the alteration of the drainage, or in the constructing a new system of drainage, is not to be taken into consicteration, for the meaning of the word "necessity" in the cases above cited and in Pinnington v. Galland, 9 Exch. 1, is to be understood the necessity at the time of the convevance, and as matters then stood without alteration; and whether or not at the time of the conveyance there was any other outlet for the drainage water, and matters as they then stood, must be looked at for the necessity of the drainage.

It was urged that there could be no implied agreement unless the easement was apparent and continuous. The defendant stated he was not aware of this drain at the time of the conveyance to him; but it is clear that he must have known or onght to have known that some drainage then existed, and if he had incuired he would have known of this drain; therefore it cannot be said that such a drain could not have been supposed to have existed; and we agree with the observation of Mr. Gale (Gale on Easements, p. 53, 2d Ed.) that by "apparent signs" must be understood not only those which must necessarily be seen, but those which may be seen or known on a careful inspection by a person ordinarily conversant with the subject.

We think that it was the defendant's own fault that he did not ascertiin what easements the owner of the adjoining house exercised at the time of his purchase; and therefore we think the rule must be discharged.

Kule discharged.

POLDEN v. BASTARD.

(Court of Queen's Bench, 1SG3. 4 Best \& S. 2चs.;

The declaration stated that the defendant broke and entered the close of the plaintiff, situate at \&c., and there broke epen a door and cut down and destroyed a wooden fence, and took and carried away large quantities of water belonging to the plaintiff.

First plea, except as to cutting down and destroying the wooden fence, that before the committing of the acts complained of, and before the plaintiff had any estate or interest of or in the close in which \& 8 ., 
Rachel Polden Bonnel was seised in fee, as well of and in the close in which \&c. and of a pump and well therein, as of and in a certain dwelling house, outhouse and garden, and, being so seised, duly made and published her last will and testament \&c.; and by the said will devised to Clementina Polden, and her heirs and assigns for ever, the house, outhouse and garden, together with a way on foot from the house, outhouse and land unto, into, through, and over the close of the plainitit to the pump and well, for the purpose of the said Clementina Iolden, her heirs and assigns, having, taking and fetching and for her and them to have, take, and fetch, water from the pump and well, and so back again frcm the pump and well in, through, over and along the close of the plaintiff minto and into the house, outhouse and garden of Rachel Polden Bonnel, at all times of the year \&..; and Racliel Polden bonnel being so seised afterwards died without revoling her will; and thereupon Clementina Polden became seised in fee of the house, outhouse and garden, with the appurtenances, together with the right and easement by the will given and devised to her; and Clementina Polden, beng so seised, by deed duly bargained, sold, granted and assigned to the defendant the louse, outhouse and garden, with the appurtenances, together with the right and easement, and she ceased to have any estate or interest therein, and the defendant became and was seised in fee of and in the house, outhouse and garden, with the appurtenances, and the right and easement, and at the times of the committing the acts complained of continued so seised, and one James Dennis was in occupation thereof, as tenant thereof, together with the right and easement to the defendant, the reversion of the same belonging to the defendant; and the trespasses complained of, to which this plea is pleaded, were a use and exercise by the defendant of the way, right, and easenent, the said water being water in the pump and well. The plea proceeded to justify the breaking of the door in the use and exercise of the right and easement of having, taking, and fetching water from the pump and well, and for the protection of the defendant's reversionary right.

There were other pleas justifying on the grounds respectively of a prescriptive right of way, of a right of way for twenty years and of a right of way for forty years, on foot through the close of the plamtif to the pump and well, for the purpose of having, taking and fetching water therefrom. Also pleas justifying the trespass to the fence, because it obstructed the defendant's right to light and air.

Issues were joined on all the pleas.

On the trial, before WVilliams, J., at the Dorsetshire Summer Assizes in 1862, it appeared that, on the 26th May, 1834, Rachel Polden Bonnel, being the owner in fee of three cottages, made her will, by which she devised as follows: "I give to my nephew R. B. Polden, all that my frechold cottage and garden at Charlton Marshall, now occupied by IV. Wills, to him and his heirs and assigns for ever. To my nephew IV. Polden" (the plaintiff) "I give the house I now live in, with the out-

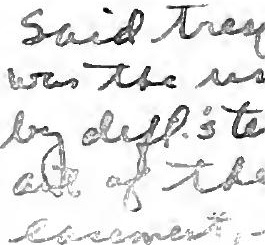


house and garden and orchard, in my own occupation, to him and his heirs and assigns forever. Also the sum of $£ 10$. I give to my niece Clementina Polden the house and outhouse and garden as now in the occupation of Thomas Answood. junior, to her and her heirs and assigns for ever." The house in the occupation of the devisor had a pump belonging to it, which stood under a shed at the back of an outhouse belonging to the house occupied by Answood; there was no fence between his house and the land on which the shed stood; he $O C$ cypied that house for two years as tenant from year to year of the devisor by a parol letting, and was accustomed with her knowledge to go to the pump and draw water from it for his use; there was no other pump or well on his premises, but there was a river within 150 yards and a road to it. The devisor died in 1S48, and in September, 1849 , Clementina Polden, who survived her, conveyed the cottage devised to her to the defendant in fee.

The jury found a verdict for the defendant on the pleas as to the right te light and air, and the learned Judge directed a verdict to be entered for the defendant on the pleas as to the enjoyment of the pump and well, reserving leave to move to enter a verdict for the plaintiff for 40 s. on those pleas.

In the following Michaclmas Term, Collier obtained a rule accordingly, on the ground that the right to the use of the pump did not pass under the will of Rachel Polden Bonnel to Clementina Polden under whom the defendant claimed.

WIGHTMAN, J. I am of opinion that this rule should be made absolute. Mr. Kingdon has been unable to furnish us with any case which goes to the extent of saying that such words as are used in this devise create an easement. Pyer v. Carter, 1 H. \& N. 916, is open to the distinction that the easement there was continuous. If the will had contained words shewing that the cottage was intended to be devised "as usually enjoyed before," it might have been contended that the right to use the pump, which had been enjoyed by the tenant of the cottage for two years, would pass, though not properly an easement. But there are no such words; the devise is simply of "the house and outhouse and garden as now in the occupation of Thomas Answood." The circumstances of the present case shew that the pump was not used by fim in the exercise of a right to use it as an easement.

Crompton, J. I also think that my brother Williams was right in lolding that an easement was not created by the terms of this devise. The distinction between easements which are in their nature continuous and apparent, such as drains, \&c., and other easements, such as ordinary rights of way, and that in question here, is well pointed out in Gale on Easements (3d Ed., by Willes) pp. 76, 77; the former pass with the devise or conveyance of a house as appurtenant thereto, and will pass without general words; but that does not apply to things not continuous in their nature, -in order to pass them there must be the creation de novo of a new easement. I adhere to what 
I am reported to have said in Worthington v. Gimson, 29 L. J. C. B. $116,120,6$ Jur. N. S. 1053, 105t, which was approved by this Court in. Pearson v. Spencer, 1 B. \& S. 571, 583. This is not a contintous easement, nor an easement belonging to the cottage but a mere enjoyment for two years by the tenant of the privilege of using the P1Mnp. If this had been an old easement attached to the cottage it would pass by the words "appertaining or belonging;" but to create a new easement which did not exist before the will must have devised the cottage "with the pump therewith enjoyed." It is said that the words "as now in the occupation of "Thomas Inswood" are equivalent to that; but I am of opinion that they are not.

Blackiurn, J. I am of the same opinion. So long as the defendant's cottage and the plaintiff's garden with the pirmp in it belonged to the devisor, who was seised in fee, there could be no easement. When the two cottages were severed, whether by will or grant of the owner, an easement might exist, but there must be words in the will or grant to create it. If this had been a continuous easement, as a flow of water to the cottage, or a drain carrying water from it, the principle which has been called the principle of dispusition of the owner of two tenements would apply. But this right of way to go to and return from a pump is no such continuous easement as would dass upon that principle; and therefore it is necessary to shew words sufficient to express an intention by the devisor to create this easement de novo, and annex it to the cottage devised. There are no such words: there only is a devise of the cottage itself, "as now in the occulpation of Thomas Answood;" and he had enjoyed merely a license to go to the punip.

Rule absolute. ${ }^{4}$

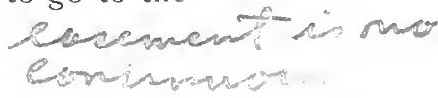

4 In Pearson 5 . Spencer, 3 B. \& S. 761 (1\&f3), an owner of a farm dicided it by his will into two portions, derising them to $A$ and $B$. respectively. The portion of B. was landocked. The devisor, during his life, hasl used a way in a cerfain direcion over the property devised to $\mathrm{A}$. in order to reach the portion devised to $B$. It was claimed br $B$. that he accuired ns implicition an easement of a way orer the land of $A$. In the devisor's accustomed line of travel. The court held that such an easement had been acquired, not is it wiy of necessity for this mas a particular way, but on the basis of the general implication. Erle, C. J., said: "It falls under that class of implied grants where there is no necessity for the right claimed, but where the tenenient is so constructed as that parts of it involve a necessary dejendence, in oider to its enjorment in the state it is in when derised, npon the aljoining temement. There are rights which are implied, and we think that the farm derised to the party under whom the defendant clains could not be enjored without defendence on the plaintiff's land of a right of way over it in the customary inanner."

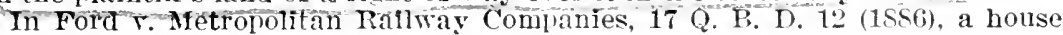
was divided into a front and back block; and A. was lessee of three rooms on the first floor in the back block. The lease did not expressly grant auy mode of access. Access to the rooms demised to $A$. Was gained from the street by passing through a hall or vestibule, and then up some stairs. The front block was taken under eminent domain proceedings, and $\mathrm{A}$. claimed compensation. The court held that $A$. Was entitled to compensation, if for no other reison, for interference with his easement through the hall though strictly speakin if was not a way of necessity. Bowen, L. J., said: "Now, it seems to me, that the access to the demised premises falls distinctly within the class of rights 


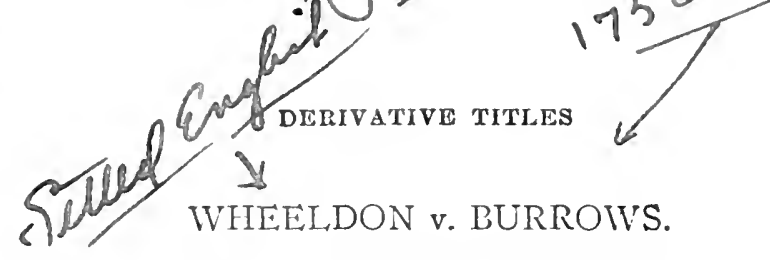

(Part 2

(Court of Appeal in Chancery, 1S79. I. R. 12 Ch. D. 31.)

Trisiger, L. J. ${ }^{5}$ The material facts of this case are short and simple. Prior to the month of November, 1875, a person of the name of Samuel Tetley was the owner of certain property in Derby, which included a piece of vacant land having a frontage to the street, and a silk manufactory and certain workshops at the rear of and abutting upon that vacant land, having in one of the workshops certain windows which opened upon that land. Owning this property, Tetley was minded to sell it, and appears to have put it up in several lots for sale by auction; and in respect of some of the lots, including a lot which Was afterwards sold to the defendant, the sale by auction was abortive. However, an agreement was made at the auction to sell one of the lots to the plaintiff's husband, and that lot was conveyed to him upon the 6 th day of January, 1S\% 6 , with these general worils, "together with all walls, fences, sewers, gutters, drains, ways, passages, lights, watercourscs," and the other general words, "easements and appurtenances Whatsoever to the sald piece of land and hereditaments belonging or in anywise appertaining." The conveyance contains no reservation in express tems of any right to the grantor in respect of his other land. On the 18th of February, a contract was made by which Tetley contracted to sell to the defendant the silk manufactory and the workshop which had the windows opening upon the land previously sold and conveyed to the plaintiff's husband. This action arises from a claim on the part of the defendant to have as of right the light enter into those windows, or, to put it in another way, to prevent the plaintiff from obstructing these windows by building on her land. Upon the matter conning before the Vice-Chancellor, he held that no right in respect of the windows was reserverl, either impliedly or expressly, under the conveyance of January, 1876; and, consequently, that the defendant, as privy in estate with the grantor of the land which was the subject of the conveyance, was entitled to no right of light through those windows; in other words, he decided that the plaintiff was entitled to build upon her land, although the result of that building might be to obstruct these lights. I am of opinion, both upon principle and upon authority, that the Vice-Chancellor decided rightly.

We have had a considerable number of cases cited to us, and out of

alluded to in Wheeldon r. Burrows (1579), $12 \mathrm{Ch} . \mathrm{N}, 31$. By the grant of part of a tenement it is now well known that there will pass to the grantee all

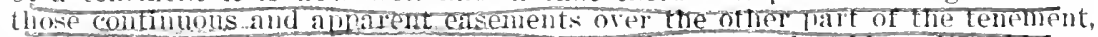
which are necessiry to the enjoynent of the part granted and have been nitherto ined Tremintl."

Anil see Brown v. Alahaster, L. R. 27 Ch. D. 490 (1SS7). where a right of way through a walled-in passingeway, with gates opening binto the sane from the quisi doninant estate. Was claimed to have been created by implied grant upon conrerance of the guasi dominant estate.

The statement of facts is omitted. 
them I think that two propositions may be stated as what I may call the general rules governiug cases of this kind. The first of these rules is, that on the grant by the owner of a tenement of part of that tenement as it is then used and enjoyed, there will pass to the grantee all those continuous and apparent easements by which, of course, I mean quasi easements), or, in other words, all those casements which are necessary to the reasonable enjoyment of the erty granted, and which have been and are at the time of the grant used by the owners of the entirety for the benefit of the part granted.

The second proposition is that, if the grantor intends to rescrve any right over the tenement granted, it is lis duty to reserve it expressly in the grant. Those are the general rules governing cases of this kind, but the second of those rules is subject to certain exceptions. One of those exceptions is the well-known excention which athaches to cases of what are called ways of necessity; and I do not dispute for a moment that there may be, and probably are, certain other exceptions, to which I shall refer before I close my observations upon this ease.

Both of the general rules which I have mentioned are founded upon a maxim which is as well established by authority as it is consonant to reason and common sense, viz., that a grantor shall not derosate from his grant. It has been argued before us that there is no distinction between what has been called an implied grant and what is attempted to be established under the name of an implied reservation; and that such a distinction between the implied grant and the implied rescrvation is a mere modern invention, and one which runs contrary, not only to the seneral practice upon which land las been bought and sold for a considerable time, but also to authorities which are said to be clear and distinct upon the matter. Su far, however, from that distinction being one which was laid down for the first time by and which is to be attributed to Lord Westbury in Suffield v. Brown, 4 D. J. \& S. 185 , it appears to me that it has existed almost as fir back as we can trace the law upon the subject; and I think it right, as the case is one of considerable importance, not merely as regards the parties, but as regards vendors and purchasers of land generally, that I should go with some little particularity into what I may term the leading cases upon the subject.

The first case to which I refer is Palmer v. Flctcher, 1 T.cv. 122, where the first proposition which I have stated as a general rule was laid down or decided. The other proposition was mooterl, but lhere was a difference of opinion amongst the members of the Court upon it, and it was not decided. [His Lordship then read the report.] It appears therefore that upon the proposition that if a man wishes to derogate from his grant or to reserve any right to himself he should state so in the grant itself, there was a difference of opinion in the Court, and that point was not decided.

The next case of importance is Nicholas v. Chamberlain, Cro. Jac. 
$121 .^{\circ}$ [His Lordship then read the report, calling attention to the words "necessary et quasi appendant thereto."] Now if that determination is held to mean that in all cases this doctrine of implied reservation stands upon exactly the same footing as the doctrine of implied grant, I think it will be found that over and over again that has been overruled. But it is clear, as I have already suggested, that to the second rule under. which a man is prevented from derogating from his grant there are certain exceptions, one of those being in regard to easements which have been called of necessity; and if Nicholas $v$. Chamberlain only decides that point it appears to me to be quite right. That Nicholas v. Chamberlain was not meant to decide more than what I have suggested is, I think, shewn by the next case, Tenant v. Goldwin, 2 Ld. Raym. 10S9, 1093. There Lord Holt, in delivering the judgment of the Court, deals, with that very point which had been mooted in Palmer v. Fletcher, 1 Lev. 122.; and he says, "As to the case of Palmer v. Fletcher, if, indeed, the builder of the house sells the house with the lights and appurtenances, he cannot build upon the remainder of the ground so near as to stop the lights of the house; and as he cannot do it, so neither can his vendee. But if he had sold the vacant piece of ground, and kept the house without reserving the benefit of the lights, the vendee might build against his house. But in the other case, where he sells the house, the vacant piece of ground is by that grant charged with the lights." I think it will be found that, putting aside the case of Pyer v. Carter, 1 H. \& N. 916, there has been no distinct decision which in any way affects the principle laid down in those clear and distinct terms by Lord Holt.

The next case to which I will refer is Swanshorough v. Coventry, 9 Bing. 305, which has been cited on both branches of the argument addressed to us by Sir Henry Jackson. That was a case of a sale by auction of different lots to different persons at the same time, and it was argued (and I particularly direct attention to this) that such a case must stand upon exactly the same footing as if the land in respect of which the easement was claimed had been conveyed first; consequently the case would be one in which a grant of the easement would be implied. Now observe what that admits, and the argument so dealt with upon that footing. It admits that priority in time of the conveyance was a material point for consideration, because, if it had not been admitted, then the Court might have gone to the general question, not whether the conveyances were at the same time, not whether one preceded the other by a few minutes, or a few days, or by a few years,

6 The case is reported in Cro. Jac. 121 (1606), as follows: "Trespass. It was held by the court upon demurrer, That if one erect a house, and build a conduit thereto in another part of his land, and convey water by pipes to the louse, and afterward sell the house with the appurtenances, excepting the land. of sell the land to another, reserving to himself the house, the conduit and pipes pass with the house; because it is necessary, et quasi appendant thereto; and he shall have liberty by law to dig in the land for amending the pipes, or making them new, as the case may require," etc. 
but whether upon the severance of the property there was this (if I may use the expression) continuous and apparent easement in respect of which a reservation might be claimed, or an implication of a grant might be made. Lord Chief Justice Tindal deals with the matter, as it appears to me, upon the supposition that the general maxim is that a man who conveys property cannot derogate from his grant by reserving to himself impliedly any continuous apparent easements; he says (Id. 309), "It is well established by the decided cases that where the same person possesses a house, having the actual use and enjoyment of certain lights, and also possesses the adjoining land and sells the house to another person, although the lights be new he cannot, nor can any one who claims under him, build upon the adjoining land so as to obstruct or interrupt the enjoyment of those lights. The principle is laid down by Twysden and Wyndham, JJ., in the case of Palmer v. Fletcher, 1 Lev. 122, 'that no man shall derogate from his own srant.' 'The same law was adhered to in the case of Cox v. Matthews, 1 Ventr. 237, by Chief Justice Holt in Rosewell v. Pryor, 6 Mod. 116, and lastly, in the later case of Compton v. Richards, 1 Price, 27. And in the present case, the sales to the plaintiff and the defendant being sales by the same vendor and taking place at one and the same time, we think the rights of the parties are brought within the application of this general rule of law." It appears to me, therefore, that this is a decision which fortifies the previous decision of Lord Holt.

I now come to Pyer v. Carter, $1 \mathrm{H}$ \& N.216, which seems to break the hitherto unbroken current of authority upon this point, and there can be no doubt that Sir Henry Jackson is justified in saying that if that case is right this appeal ought to be allowed. That was a case of a somewhat special character. A house was conveyed to the defendant by a person who was the owner of that house, and also of the house which was subsequently conveyed to the plaintiff; and there had been during the unity of the ownership the enjoyment of the easement of a spout which extended from the defendant's prenises over the plaintiff's premises, and by which water was conveyed on to the latter. But it is material to observe that the water when it came on to what were subsequently the plaintiff's premises was conveyed into a drain on the plaintiff's premises, which drain passed through the defendant's premises, and in that way went out into the common sewer. Subsequently the house over which, this easement existed was conveyed to the plaintiff, and upon an obstruction of the drains in the defendant's house, which, be it observed, immediately caused a flooding of the plaintiff's house by the very water coming from the defendant's house the plaintiff brought his action, and it was held there that the plaintiff was entithed to maintain his action, and that upon the original conveyance to the defendant there was a reservation to the grantor of the right to carry away this water which came from the defendant's premises by the medium of the drain which also went through his premises. AIG.PROP.-31 
Though those circumstances were special in their character, there is no doubt that the principles laid down by the Court of Exchequer were as wide as possibly could be. That Court laid down that there was no distinction between implied reservation and implied grant; and this, as it appears to ne, broke the hitherto mbroken current of authority upon this subject.

Now, although it is possible that the actual decision in Pyer v. Carter, 1 H. \& N. 916, was not exactly overruled, the principles there laid down were clearly and distinctly overruied by the same Court in White v. Bass, 7 H. \& N. 722, the facts of which case were these: A man was the owner of certain land and of a certain house which had windows through which the light, not as an easement but as a matter of enjoyment had come for sume time. He let the land (reserving the house) to trustecs, subject to certain covenants by which they were to build in a particular manner upon the land, and if those covenants had been complied with, and they had built in the specific manner, there would have been no obstruction to the lights of the house which the grantor or the lessor reserved. Therefore, if we were entitled in these cases to go back to matters which existed before the time of the conveyance, we should have found liere, as clearly as could be shown, an intination on the part of the lessor that if building was to be permitted on the adjoining land, it was only to be permitted under such conditions as would prevent the lights of the house being obstructed. But that being originally the position of matters it was followed by a conveyance of the reversion in the land to the trustees, and subsequently to that conveyance the house was conveyed to another person, and buildings having been put upon the land occupied by the trustees contrary to the terms of the original covenant, and of such a kind as obstructed the lights of the house, an action was brought by the person to whom the house was conveyed. In that action it was decided that the defendant held his land unfettered by the original covenant, and unfettered by any implied reservation, and that he was entitled to build in such a way as he thought proper on his land, although the effect of what he did might be to obstruct the lights of the plaintiff. In giving judgment Lord Chief Baron Pollock says this (7 H. \& N. 730): "My brother Petersdorff has cited no authority for the precise matter which he has urged before us, and I think that in construing a converance of land we must collect what the parties intended from the language they have used. It seems to me that we cannot look into the lease of the $2 \mathrm{~d}$ of October, 1855 , for it is merged in the fee, a conveyance of the reversion having been made to the lessees, and we must look to that conveyance alone in order to ascertain the rights of the parties. In that conveyance there is no covenant by the purchasers not to build on the land so as to obstruct the light and air coming to the windews of the plaintiff's house, nor indeed any limitation of the right to use the land." Now, no case can be more clear and distinct upon the point which we have to decide to-day, and the case is admitted by Sir Henry 
Jackson to be such, but he suggested that we ought to overrulc it as being an exception to the general current of authority. So far from that being the case, Pyer v. Carter, 1 H. \& N. 916, appears to me to have been the exception, and not White v. Bass, 7 H. \& N. 722.

The latter case was followed by Sufficld v. Brown, 4 D. J. \& S. 185. A good deal has been said about that case; and the principles upon which this Court ought to act in dealing with decisions of Courts of coordinate authority have been also discussed. I think I may say for myself (and I believe I am expressing the views of the other members of the Court) that we ought not to lay down as an absolute rule that decisions of Lord Chancellors, at all events sitting alone, are to be taken as decisions of the Court of Appeal, and absolutely binding on this Court so as to prevent us from even looking into the grounds or considering the case which was before the particular Lord Chancellor. But no doubt the greatest weight ought to be given to such decisions, and unless they are shewn to be manifestly wrong or manifestly contrary to the general current of authority on the point decided, it appears to me that we ought not to take upon ourselves to ovcrrule them.

That being so, let us look a little morc narrowly into that case. First, we have to see what was decided - and by that I do not mean what was absolutely necessary to be decided, but what really the Lord Chancellor took upon himself to decide, and, although he might have deciled the case upon other grounds, put as his ratio decidendi. Upon that point there can be no doubt. We have only to read the close of his judgment to see that he put it entircly upon this principle, which I have stated as the second of the general rules applicalile to cases of this kind, that a man cannot derogate from his own grant, and that as a general rule no implication can be made of a reservation of an eascment to the grantor, although there may be an implication of a grant to the grantee. The Lord Chancellor closes his judgment by saying (having dealt with some of the authorities as to continuous and apparent easements): "But this is irrclevant to my decision, whicin is founded on the plain and simple rule that the grantor, or any person claiming under him, shall not derogate from the absolute sale and grant which he has made." Although, thereforc, it is perfectly true that, looking to the special circumstances of that case, it might have been decided upon those special circumstances so as even to admit the proposition for which Sir Henry Jackson contends, it is equally clear that the Lord Chancellor did not so decide the case, but decided it upon a distinct negative of that proposition. If we were to stop here, it seems to me that, looking to the fact that this was not a case in which this point in question was mooted for the first time, but that the point had been mooted and decided as early as the third year of the reign of Queen Anne, we should not be justificd in doing anything but follow the principles enunciated by Lord IVestbury.

But Suffield v. Brown, 4 D. J. \& S. 185, has been confirmed by an equally high authority, for in Crossley \& Sons v. Lightowler, Law 
Rep. 2 Ch. 478, Lord Chelmsford as Lord Chancellor had to deal with a similar question, and he there says: "Lord Westbury, however, in the case of Suffield v. Brown, refused to accept the case of Pyer v. Carter, 1 H. \& N.916, as an anthority, and said, It seems to be more reasonable and just to hold that if the grantor intends to reserve any right over the property granted it is his duty to reserve it expressly in the grant rather than to limit and cut down the operation of a plain grant (which is not pretended to be otherwise than in conformity with the contract between the parties) by the fiction of an implied reservation, I entirely agree with this view. It appears to me to be an immaterial circumstance that the easement should be apparent and continuous, for non constat that the grantor does not intend to relinquish it unless he shews the contrary by expressly reserving it. The argument of the defendants would make, in every case of this kind, an implied reservation by law; and yet the law will not reserve anything out of a grant in favour of a grantor except in case of necessity."

Now the only case in the Court of Appeal which is suggested as being contrary to this high authority of two Lord Chancellors, is Watts v. Kelson, Law Rep. 5 Ch. 166, 174, and no doubt there are observations of Lord Justice Mellish to the effect that the order of conveyance in point of date is immaterial, that Pyer v. Carter, 1 II. \& N. 916, is good sense and good law, and that most of the Common Law Judges have not approved of Lord Westbury's observations. But, putting aside for the moment that this was a mere dictum of the Lord Justice during the argument, I must observe that this is not exactly so, as in White v. Bass, $7 \mathrm{H}$. $\mathrm{I}_{\mathrm{r}}$ 722, the Judges of the Court of Exchequer liad distinctly, as regards the reasoning of Pyer v. Carter, overruled that case. No doubt, also, Lord Justice James says, "I an satisfied with the decision in Pyer v. Carter." But in the considered judgment of the Court, when if it had been intended to say that Suffield v. Brown, 4 D. J. \& S. 185, was not law, one would have thought there would have been something distinct upon the point, there is not one word to the effect of that which had been said by the Lords Justices during the argunent. All that is said about it is this, Lord Justice Mellish, who delivered the judgment, after referring to Nicholas v. Chamberlain, Cro. Jac. 121, said, "This case has always been cited with approval, and is identical not only in principle but in its actual facts with the case now before us. It was expressly approved of by Lord Westbury in Suffield v. Brown, 4 D. J. \& S. 185, where, though he objected to the decision in Pyer v. Carter, 1 H. \& N. 916, in which it was held that a right to an existent continuous apparent easement was impliedly reserved in the conveyance by the owner of two houses in the alleged servient houses, yet lie seenis to agree that the right to such an easement would pass by implicd grant where the dominant tenement is conveyel first;" and that is what the Court of Appeal had to decide in Watts v. Kelson, Law Rep. 6 Ch. 166. Therefore Watts v. Kelson is no authority to justify us in overruling Suffield v. Brown, still less 
for overruling it, supported as it is by the case of Crossley \& Sons v. Lightowler, Law Rep. 2 Ch. 478. Thus, then, as it appears to me, stand the principal authorities on the general rules of law which I stated at the commencement of this judgment.

Other cases which have been cited during the argument illustrate the exceptions to the second of those general rules. As I have already said, there is an undoubted exception in cases where the easenent is what is called a way of necessity. Thus in Pinnington v. Galland, 9 Ex. 1, 12, which was a case for disturbance of a right of way, there were five closes, tivo of them called the Holme Closes, which were separated by the others from the only available highway, and which were conveyed subsequently in point of time to the conveyance of the remaining closes through which this way de facto ran. In deciding that the way still existed, Baron Martin appears to me to have put the case entirely upon the exception to which I am referring. He says this: "Secondly, assume that the conveyance to Mr. Dearle was cxecuted the first. In this case the Rye Holme closes were for a short period of time the property of Mr. Dickinson after the property in the land conveyed to Mr. Dearle had passed out of him. 'There is no cluubt apparently a greater difficulty in holling the right of way to cxist in this case than in the other; but according to the same very great authority the law is the same, for the note $1 \mathrm{Wm}$. Samnd. 323, n., proceeds thus: 'So it is when he grants the land and rescrves the close to himself; ' and he cites several authorities which fully bear hin out: Clark $v$. Cogee, Cro. Jac. 1\%0; Staple v. Heydon, 6 Mod. 1; Chichester v. Lethbridge, Willes, 72, n. It 110 loubt seens extraorlimary that a man should have a right which certainly derogates from his own grant: but the law is distinctly laid down to be so, and probalily for the reason given in Dutton v. Taylor, Lutw. 1487, that it was for the public grooul, as otherwise the close surrounded would not be capable of cultivation."

Now those last words clearly shew that the whole foundation of the judgment in the case of Pinnington v. Galland, $9 \mathrm{Ex} .1,12$, was that the way claimed in the case was a way of necessity, and it is equally clear, as it seems to me, that Baron Martin and the Court whose jurloment he delivered in no way disputed the general maxims to which i have referred. The case of Davies v. Sear, Iraw Rep. 7 Eq. 427, 431, also appears to me to have been decided on the same basis. There a man, a builder, liad got a lease of land for the purpose of building upon that land, and he proposed to build upon it in such a way as that through an archway, which was, at all events, standing to such an extent as to shew that it was intended to be used for a passage-that through that archway should be the only means of communication with certain stables which were to be erected. That being the position of things, a portion of the land was sold to a third person, and the question arose whether it was open to that person to build upon his land in such a way as to obstruct this one only way into the stable. The Master of the Rolls (Lord Romilly) held that it was not. And why? He 
founded his opinion upon the basis of this exception to which I an referring. He says: "The question is, whether the defendant has a right to shut up the archway, and to intercept all access to Erskine Mews through this passage. This depends upon whether this easement is reserved by implication on the assignment of the house to the defendant; and this depends upon whether the easement is apparent, and also is a way of necessity."

These cases in no way support the proposition for which the appellant in this case contends; but, on the contrary, support the propositions that in the case of a grant you may imply a grant of such continuons and apparent easements or such easements as are necessary to the reasonable enjoyment of the property conveyed, and have in fact been enjoyed during the unity of ownership, but that, with the exception which I have referred to of leasements of necessity? you cannot imply a similar reservation in favour of the grantor of land.

Upon the question whether there is any other exception, I must refer both to Pyer v. Carter, 1 H. \& N. 916, and to Richards v. Rose, 9 Ex. 218 , and, although it is quite unnecessary for us to decide the point, it seems to me that there is a possible way in which these cases can be supported without in any way departing from the general maxims upon which we base our judgment in this case. I have already pointed to the special circumstances in Pyer v. Carter, and I cannot see that there is anything unreasonable in supposing that in such a case, where the defendant under his grant is to take this easement, which had been enjoyed during the unity of ownership, of pouring lis water upon the grantor's land, he should also be held to take it subject to the reciprocal and mutual easement by which that very same water was carried into the drain on that land and then back through the land of the person from whose land the water came. It seems to me to be consistent with reason and common sense that these reciprocal easements should be implied; and, although it is not necessary to decide the point, it seems to me worthy of consideration in any after case, if the question whether Pyer v. Carter is right or wrong comes for discussion, to consider that point. Richards v. Rose, although not identically open to exactly the same reasoning as would apply to Pyer v. Carter, still appears to me to be open to analogous reasoning. Two houses had existed for some time, each supporting the other. Is there anything unreasonable-is there not, on the contrary, something very reasonable-to suppose in that case that the man who takes a grant of the house first and takes it with the right of support from that adjoining house, should also give to that adjoining house a reciprocal right of support from his own?

One other point remains, and that I shall dispose of in a very few words. It is said that, even supposing the maxims which I have stated to be correct, this case is an exception which comes within the rule laid down in Swansborough v. Coventry, 9 Bing. 305, and Compton v. Richards, 1 Price, 27, namely, that, although the land and houses were not in fact conveyed at the same time, they were conveyances made as 
part and parcel of one intended sale by auction. It seems to me that that proposition cannot be supported for one moment. We start here with an absolute conveyance in January, 1876. What right have we to look back to any previous contract or to any previous arrangenent between the parties? If it had been the case of an ordinary contract, and there had been parol negotiations, it is well-established law that you cannot look to those parol negotiations in order to put any construction upon the document which the parties entered into for the purpose of avoiding any dispute as to what miglnt be their intentions in the bargain made between them. The same rule of law applies, and even more strongly in the case of a conveyance, which alone must regulate the rights of the parties. In the cases which have been cited the conveyances were founded upon transactions which in Equity were equivalent to conveyances between the parties at the time when the transactions were entered into, and those transactions were entered into at the same moment of time and as part and parcel of one transaction. There niay be, and there is, according to Swansborough $r$ Coventry, 2 bing, 305 , another exception to the rule which I have mentioned; but here the sale by auction was abortive as regards the defentant's property. There was a conveyance in January of the plaintift's property without any reservation, and there was no contract of purchase on the part of the defendant until nore than a month after that conveyance had been complete. I belicte I am expressing the view of the other members of the Court when I say that it appears to the Court that under such circumstances there is no exception to the general rulc. For these reasons, therefore, the appeal should he rlismissed.

JAuEs, L. J. The Lord Justice has been kind enough to express the judgment of the Court. I only want to say sonething in addition, that in the case of Nicholas v. Chamberlain. Cro. Jac. 121, the Court seems to have really proceeded on the ground that it was not an incorporeal easement, but that the whole of the conduit through which the water ran was a corporeal part of the house, just as in any old city there are cellars projecting under other houses. They thought it was not merely the right to the passage of water, but that the conduit itself passed as part of the house, just like a flue passing through another man's house. 'The appeal is dismissed with costs.

BAGGAILAY, L. J., concurred.

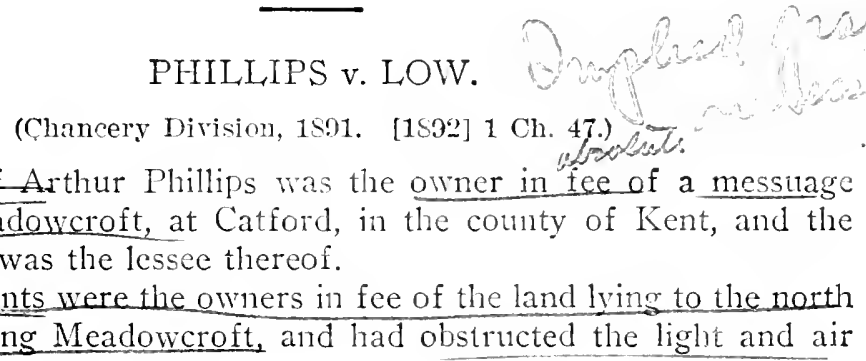


coming thereto by erecting a building, and placing hoardings on the land close to the messuage.

The messuage and land formerly both belonged to one J. J. Stainton, who dicd possessed thereof in the year 1875, he having previously built the messuage as a washhouse, stables, billiard room, and observatory, and it was the access of light and air to a door and windors in such messuage which the defendants had obstructed.

At the time the messuage was built and down to the time of the death of J. J. Stainton the only building standing on the land to the north of the messuage was a cottage called Laurel Lodge,-surrounded by a garden occupied by one G. T. Williams, and not interfering in any way with any light or air coming to the messuage.

J. J. Stainton made his will dated the 30th of June, 1875, and thereby devised to G. T. Williams the cottage called Lantel Lodge, together with the land thereto adjoining wp to the boundary of Meadorvcroft, and clevised all the residue of his frechold property to trustees upon trust for sale.

The plaintiff Phillips became entitled to Mcadowcroft under an exercise of the trust for sale contained in the said will. The defendants purchased Lawel Lodse and the adjoining land from G. T. Thillams.

The plaintiff Buck resided in one part of Mcadowcroft, and carried on business as a coachbuilder on the other part thereof.

In Augirst, 1590, the defendants commenced to build a lodge on the north side of Meadowcroft within a few inches thereof which almost entircly obstructed the light and air coming to the door and windows in such messuage.

Complants were made by the plaintiffs to the defendants that they were not entitled to build the lodge, and the defendants insisting that they had such right, the writ in this action was issued on the 26 th of January, 1891, and on the 29th of January the defendants commenced to erect, and shortly afterwards completed a hoarding painted black within six inches of most of the windows and openings in Meadowcroft.

A motion was made in this action for an injunction to restrain the obstruction to the access of light and air as aforesaid, whereupon the defendants undertook without prejudice to remove the hoarding and the motion was ordered to stand till the trial.

The plaintiffs claimed that the defendants might be restrained from obstructing or interfering with the access of light and air coming to Meadowcroft, and that they might be ordered to remove the building already erected by them, or to pay to the plaintiffs damages for obstructing and interfering with the access of such light and air.

The action now came on for trial.

CHI'Tr, J. Nothing turns on the particular language of the willthat is achitted. "The circumstance that the devise of the defendants" tenement is expressed to be made free of incumbrances, that it is a specific devise in form, and that the plaintiffs' tenement is comprised 
in a residuary devise of messuages, are all immaterial, and rightly admisted to be so. The term "incumbrance" does not affect the question of light; and a devise of land, though in form residuary, is specific. Lancefield v. Iggulden, Law Rep. 10 Ch. 136.

The question, then, may be stated in this simple form: A man being seised in fee in possession of a house with windows, and of an adjoining field over which the Tight required for the windows passes, devises the house to one and the field to another; does the right to the light over the field pass to the devisee of the house, or is the devisee of the field entitled to block up the windows?

If the owner of the house and field by deed for value grants the house but retains the ficld, it is settled law that a right to the light rcquired for the enjoyment of the house passes to the grantce. Why? The reason stated in Palmer v. Fletcher, 1 Lev. 122, the leading case on the subject, is that "the lights are a pecessary and essential part of the house." In other words, what is conveyed is not a mere brick or stone building with apertures called windows, but a house with windows enjoying light. 'This is the broad, substantial reason which commends itself at once to the common sense of mankind. Worked out somewhat more technically, the conveyance operates as an implied grant of the light. Blocking up the windows by the giantor is regarded as an attempt on his part to derogate from his grant-a form of expression which assumes that the right to light has passed to the grantee. The implication does not necessarily arise upon a mere perusal of the deed itself. Generally the situation and ownership of the adjoining field is not disclosed; but the implication of grant arises prima facie so soon as the facts are ascertained that the light required for the windows passed over the field, and that the grantor was owneof the field at the time of the grant. On these facts being linown, and in the absence of any other special circumstances, the law imputes to the partics an intention that the easement of light should pass with the louse by virtue of the grant. As I have recently stated with more fulness my opinion in regard to the subject of the implied grant in the case of Bcddington v. Atlee, 35 Ch. D. 317, I refrain from repeating what I there said. When all the surrounding circumstances which may legitimately be inquired into are made known, the result may be different-the prima facie implication or inference may be wholly displaced or considerably modified, as was held in the case of the Birmingham, Dudley and District Banking Company v. Ross, 38 Ch. D. 295. Where the implication arises, the easement which passes is an easement created de novo.

The principle of the decision in Palmer v. Fletcher, 1 Lev. 122, applies where the house and the land are sold and conveyed to two different grantees contemporaneously, as stated by the late Master of the Rolls (Sir G. Jessel), in his judgments in Rigby v. Bennett, 21 Ch. D. 559, 567, and Allen v. Taylor, 16 Ch. D. 355.

It was argued for the defendants that the principle applies only 
applies to the present case. The house devised to the persons through whom the plaintiffs claim contained windows so constructed as to involve a necessary dependence, in order to its enjoyment of light, wpon the adjoining tenement. Light is an apparcnt continuons easennent, Gale on Easements (4th Ed.) p. 22. The case of Polden v. Bastard, Law Rep. 1. Q. B. 156, which related merely to the eascment or quasi easement of a way which is a discontinuous easement, is not in point.

It was part of the argument for the defendants, that the basis of the doctrine laid down in Palmer v. Fletcher, 1 Lev. 122, and developed by subsequent authorities, was contract, or implied contract on the part of the person retaining or taking the field that he would not obstruct the lights, and that where there was no contract, the doctrine was inapplicable, and consequently that as there was no contract between a testator and his devisees, there was no ground for applying the doctrine to the case of a will. In support of this contention, certain expressions of the Lord Justices in their judgments in the case of the Birmingliam, Dudley and District Banking Company v. Ross, 38 Ch. D. 295, were cited. It is unnecessary to deal with them at length. It is sufficient to say, that in my opinion the Lords Justices did not intend to alter the law as to implied grants, and that my decision in this case is not affected by anything which fell from them; and further, assuming that where there is a deed between parties, the doctrine ought to be explained theoretically as resting on contract as its basis. I see no difficulty in applying by analogy, in the case of a will, an obligation, or condition, or duty (whichever may be the right term) on the part of the devisec, or imposed on him by the testator, not to obstruct the access of light to the house devised to another. I prefer, however, ta rest my judgment on the broad principles already stated. ${ }^{\top}$

RAY v. HAZELDINE.

(Chancery Division. [1904] 2 Ch. 17.)

Prior to the date of the indenture next hereinafter mentioned, the defendant was the owner in fee simple of two adjacent houses in Cheadle Hulme, Cheshire. By an indenture dated October 18, 1895, the defendant conveyed one of these houses to the plaintifi's husband in fee simple, and this house was subsequently conveyed by him to the

7 Milner's Safe Co. v. Great Northern \& City R. Co., [1907] 1 Ch. 208; Gorton-Pew Fisheries Co. $\nabla$. Tolman, 210 Mass. 402.97 N. E. 54. 38 L. R. A. (N. s.) SS2 (1912), acc. So, also, in Mason r. Ilorton, 67 Vt. 266, 31 Atl. 291, 4S Am. St. Rep. 817 (1S94); Johmson v. Gomld, 60 W. Va. S4, 53 S. E. 79S (190t), where the severance was brought abont by partition anong heirs of the common owner.

In Maynard $\nabla$. Esher, $17 \mathrm{~Pa} .222$ (1851), the projerties were sold separately at the same publie sale. It appeared that the deed of the quasi servient tenement had been made just prior to the deed of the quasi dominant tenement. An instruction to the jury that under such circumstances the conveyances should be deemed as made simultaneously was held erroneous. 
laintiff. In the western wall of the house retained by the defendant there were two windows overlooking a yard forming part of the plaintiff's premises. Neither of the windows was an ancient light, nor was any right to light in respect of either of the windows reserved in favour of the defendant by the indenture of October 1S, 1595 .

The plaintiff recently commenced to erect a wall in her yard close to these windows, so as completely to block the access of light thereto; but the defendant knocked down the wall from his own premises, and it was again erected and knocked down.

The plaintiff brought this action for a declaration that she was entitled to build on her premises so as to obstruct the light to the two windows in question, and for an injunction to restrain the defendant from throwing down the wall, and for damages.

The defendant pleaded that the access of light to these two windows was absolutely necessary for the enjoyment and use for habitation of the part of his house which was lighted by these windows. Of these two windows one lighted a pantry and the oiner lighted a landing inmediately over the pantry. The evidence shewed that the landing could be lighted by making a skylight in the roof, and that the pantry could be lighted by making a window into the scullery which adjoined the pantry, thus obtaining a borrowed light through the scullery; but it was admitted in cross-examination by the plaintiff's surveyor that the blocking up of the existing window would render the pantry useless as a pantry.

KEKEWICH, J. If a vendor of land desires to reserve any right in the nature of an easement for the benefit of his adjacent land which he is not parting with, he must do it by express words in the deed of conveyance. That is settled law, and expresses the result of the decision in Wheelcion v. Burrows, 12 Ch. D. 31, where the Court of Appeal affirmed the decision of Bacon, V.C. That is the general rule, but the rule is subject to certain exceptions. One of them is the well-known exception of an easement of necessity-that is to say, where the enjoyment of the alleged right over the adjoining land is necessary to the property which is not conveyed, then the Court will consider the easement as impliedly reserved, though it has not been reversed by express words. Such easement, or right in the character of an easement, may be a right to the access of light to a particular window. In a large majority of cases a window which lights a room is deemed necessary to the lighting of that room and is, on the whole, essential to the comfortable enjoyment of that room, but it does not follow that the right io access of light to that window is an easement of necessity. Where are you to draw the line? Supposing the blocking up of the window largely interferes with the comfort and enjoyment of the room, is the grantee of the adjacent land entitled to block it up, or does the exception stand? It seems to me that the line to be drawn is pointed out by Stirling, L. J., in Union Lighterage Co. v. London Graving Dock Co., [1902] $2 \mathrm{Cl}$. 557, 572. His Lordship makes a distinction between an 
easement of necessity and an easement necessary to the reasonable enjovment of property. After referring to the two rules laid down in Wheeldon v. Burrows, 12 Ch. D. 31, 49, and the excepticns thereto he says: "The appellants did not dispute that there is no express reservation in the conveyance to the plaintiffs, but they contended that the easement claimed by the defendants is an 'easement of necessity' within the recognised exception to the second rule. Now, in the passages cited the expressions 'ways of necessity' and 'easements of necessity' are used in contrast with the other expressions, "easements which are necessary to the reasonable enjoyment of the property granted,' and 'easements * * * necessary to the reasonable enjoyment of the property conveyed,' and the word 'necessity' in the former expressions has plainly a narrower meaning than the word 'nceessary' in the latter. In my opinion an easement of necessity, such as is referred to, means an easement without which the property retained cannot be used at all, and not one merely necessary to the reasonable enjoyment of that property." Then, after pointing out that the lights in Wheeldon $v$. Burrows, 12 Ch. D. 31, 49, were reasonably necessary to the enjoyment of the workshop, he says: "So here it may be that the tie-rods which pass through the plaintiffs' property are reasonably necessary to the enjoyment of the defendants' dock in its present condition; but the dock is capable of use without them, and I think that there cannot be implied any reservation in respect of them." That seens to me to draw the distinction between what is absolutely necessary and what is reasonably required for the enjoyment of the land and building as it stands. In my judgment this is a window to which the access of light cannot be reserved by implication upon the ground that the light is necessary to the pantry. It cannot be that there is any necessity by reason of its being used as a pantry, since it can be used for other purposes. It cannot be said that a special use of light attaches to it as a pantry, and to say, as the defendant does, that access of light to that window is rescrved to him by necessity is giving to the word "necessity" a meaning which it does not properly bear in this connection.

[His Lordship made a declaration that the plaintiff was entitled to build on her hereditaments in such a manner as to obstruct the lights of the two windows in question. $]^{8}$

8 As to the creation of the easement of licht and air by implication in the United States, see Kennedy r. Burnap, 120 Cil 48252 I'ac. 843,40 L. R. A. 476 (1S9S); Keating v. Syllinger, 146 Ill. $481,3-1$ N. E. 505,22 I. R. A. 544.37 Am. St. Rep. 175 (1S93); Keats v. IIugo, 115 MIss. 20.t, 15 Am. Rep. So (1s74); Mullen $r$. Stricker, 19 Ohio St. 135, 2 Ain. Rep. 379 (1Sf9). concluding that such easement camnot be so created. Janes r. Tenkins, 31 idd. 1, 6 An. Rep. 300 (1871); Greer v. Van Meter, 54 N. J. Eq. 270, 33 Ati. 794 (1896), contra.

"As to light and air, I am free to say that I do not believe the rule, as applied to our situation and cipcunstances, i sound one, Which holds that unde any circumstances this right can by impication be burdened upon an adjoining estate, as to prevent the onmer thereot rrom ruilding upon or improvins it as he pleases. I would reverse the ruie and hold that he whe claims that ten, twenty or thirty feet adjoining him (which in cities may be very valuable, stall remain vacant and unimproved, should found such claim upon an express 


\section{BRIGHAM v. SMITH.}

(Supreme Judicial Court of Massachusetts, 15.5. 4 Gray 297, fit Am. Dec. 76.)

Action of tort for trespassing on a close to which the plaintiff claimed title under a deed of warranty from William Sherman. The defenclant justified under a way of necessity attached to adjoining land, belonging, at the time of said deed, to Sherman, from whom the defendant also derived title. At the trial in the court of common pleas, it appeared that Sherman, at the time of the first deed, retained no other way to his remaining lot except over the land granted. But Perkins, J., ruled that the defendant could not justify under a way of necessity over land which he had conveyed by deed of warranty. 'The jury returned a verdict for the plaintiff, and the defendant alleged exceptions.

Thomas, J. If A. conveys land to B., to which B. can have access only by passing over other land of A., a way of necessity passes by the grant. If A. conveys land to B., leaving other land of $A$. to which he can have access only by passing over the land granted, a way of necessity is reserved in the grat. These points are settled, as well in the cases cited for the plaintiff, as those cited for the defendant.

Is the rule affected by the fact that the grantor conveyed by deed of warranty? We think not. If the way were expressly reserved in the deed, the covenants must apply to the premises granted, that is, an estate with a right of way rescrved or carved out of the fee. In the present case, the law does for the parties the same thing, and the covenants apply to an estate, with this way of necessity reserved.

\section{Exceptions sustaingd. ( fos a fe.)}

grant or covenant." Dillon, C. J., in Morrison v. Marquardt, 24 Iowa, 35, 60,

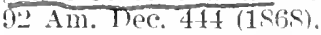

In Rennyson's Appeal, 9+ Pa. 147. 39 Am. Rep. 777 (1Ssio), the court said that the easenent of light and air wonld not arise by implication unless there was "real necessity:" See, too, Robinson r. Cl:1pp, 65 Conn. 360, 32 At1. 939, 20 I. R. A. 552 (1505): Dorle ₹. Lork, G+ N. Y. 432,21 Am. Rep. 629 (1876).

In Manning $v$. N. J. Short Line R. R. Co., 80 N. J. Law, 349, 78 Atl. 200, 32 I. R. A. (N. S.) 155 (1910), the plaintiff in a proceeding for an award in conremuation nroceedings wherehy the defendant had taken a strip of land for murposes of a right of was, claimed the award should include compensation for lateral support for the right of way burdened artificially by the railioad for lililroad purposes, it being contended that upon the acquisition of the right of was the company acquired by implication an easement of such lateral sup1rort.

" "It is not the necessity which creates the right of way, but the fair construction of the acts of the parties. To necessity will justify an entry upon inother s land. If a man can be supposed to hold land without any right of acress to it, a grant of it would not convey to the grantee ans right to pass "ver the adjoining land, howerer necessary it might be to the enjoyment of the thing granted. He would acquire nothing more than his grantor held. The necessities of the parties would add notming to tt. Dutton v. Tarler, 2 Lutw. 1457. But the true principle is, that nothing will pass, as incident to the grant, "xcept it be necessary to the enjorment of the princiual thing granted. Hence the grinfiee of a close surrounded by the grantor's land, is entitled onis be a convenient way over the grantor's land, and will have no right te nass over it

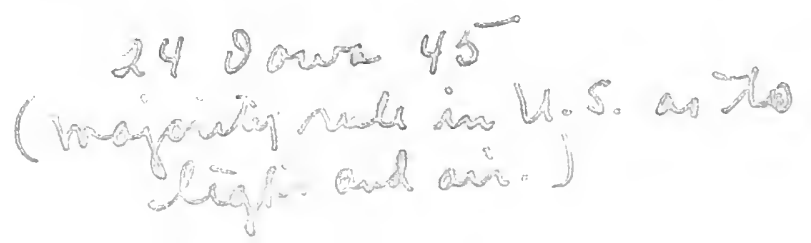




\section{DABNEY v. CHILD.}

(Supreme Court of Mississippi, 1909. 95 Miss. 585, 4S South. S97.)

Dabney, appellant, was complainant in the court bulow. Child, appellee, was defendant there. From a decree in defendant's favor the complainant appealed to the supreme court. The facts are sufficiently stated in the opinion of the court.

MAYEs, I., delivered the opinion of the court.

The complanont in this case executed to Child a warranty deed to one acre of land in section 6 , township 15 , range 5 E., in Warren county, and the deed contains no reservation of any easement what-

wherever he pleases. He may select a suitable ronte for his way, but in doing it he must regard the interest and convenience of the owner of the laid, and when he has done it, he will be confined to the sime way and mat $y$ not elunges its course according to his wishes or caprite. Fussell r. Jackson (18-1) "2 l'ick.

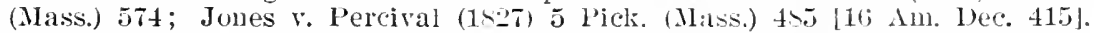
Although generully a man can acquire, as incident to a grant, only one richit of Was to the same close, yet the same principle of necessits which rilise's thes implication of one may extend it to two or more. Where at man should grant a tract of land surrounded by his own, so diviled into parts by an imlinssiblete mountain, river or other barier, as that there could be no palssing from one part to the other, he would by necessary inmlication convey al right of way tw each separate part, because withont his some portion of the thing aranted would be entirely useless to the orintee. Put these imglications of grants are looked noon with jealonsty and construed with strictness. It is only the necessity of the case which will carry one wity; and corminly the necessity must be not less strong to carry two. It is not preteuded that the hluft ateross the defenclants' land is impassable; but only that it is 'exceenlinery difticult to pass it, and that it would be much more convenient to the defendants to pass" orelo the plaintift"s laud. Here is no snch neressity as will raise an implication of a grant of different ways from different palts of the defendant's lot. Conrenience, even great conrenience is not sulficint. If the defentants, when they purchated, had desired a separate wy for this small section of their lot, they should have stipulated for it and had it expressly inserted in their deed." Mor-

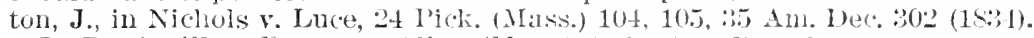

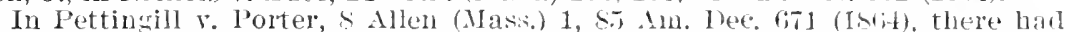
been an instruction as follows: "The deed under which the plaintiff reliment eonveyed whatever was necessary to the beneficinl enjoyment of the estate sranted, and in the power of the grantor to convey; that it was not mongh

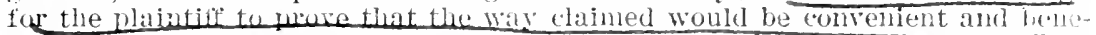

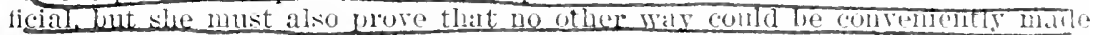

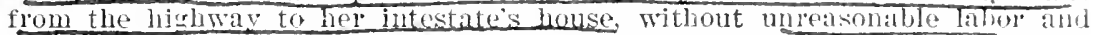
expense; that uneasonable labor and expense means excessive ind dismoprtionate to the value of the property purehased; and that it mas a question for the jury, on all the evilence, whether such new was could be made without such unreasontble latior and expense." Feld a correct instruction. Tu sime effect is Crotty r. New Rirer is locahontas Consol. Coal Co., T2 W. Va. 6s, Ts S. E. 233,46 L. R. A. (N. S.) $156(1913)$.

In Hildreth r. Googins, 91 He. $227,89 \mathrm{Atl} .550$ (1598), where in order to get to the land as incident to which the way of necessity was claimed it was neces. sary to go either over other lands of the grantor or over a portion of the ocem, it was held, there being no evidence offered is to the unarajididity of the ocean as a bighway and means of iccess, that there was no way of necessity oy's. the grantor's other lands. See, also, staples r. Cornwan, D2 N. Y. Supp. 1009 (1906).

As to ways of necessity where there are other rossible meaus of access, see, generally, Corea v. Higuera, 153 Cal. 451, 95 Pac. S\$2, 17 L. R. A. (N. S.) 1018 (1908). 
cver. The object of this suit is to have the court declare that when this conveyance was made there was an implied reservation in the deed that complainant should have a right of way to his own premises over the land conveyed, on the idea that it is a way of necessity.

The complainant has not brought himself within that rule of law which would warrant the court in declaring that there was any way of necessity reserved by implication in the deed, since the bill itself shows that the way sought to be established is no more than a way of convenience, and in no sense one of necessity, since Child has already given him another way by which he has free access to and from his premises. One of the charges in the bill is that complainant is allowed "to pass to and from his land over land belonging to Child north of the one acre, but that this is by sufferance of said Child, and which, it avers, the complainant has no right to, but enjoys merely at defendant's will, and alleges that he has a right of way over the strip, which Child denies, and refuses to allow him to cross for this purpose, and that he sceks herein to have this court decree him this right." It is thus seen that the complainant already has a way_of necessity open to him, over which he may go to the very land in question, and there can exist no right to clam another and different way as a way of necessity, even though the route now used may be at the sufferance of Child. If the appellant desires a private and permanent right of way, Code $1906, \S 4411$, provides an adequate remedy whereby he may have a private way laid out.

In 11 Cyc. p. 1171, a clear statement of the law in regard to implied reservations in deeds is made, supported by a great many authorities, and we quote the statement with approval. It is there said: "If the grantor intends to reserve any right over the tenement granted, it is his duty to reserve it expressly in the grant. To say that a grantor reserves to hinnself in entirety that which may be beneficial to him, but which may be most injurious to his grantee, is quite contrary to the principle upon which an implied grant depends, which is that a granior shall not derogate from or render less effectual his grant, or render that which he has granted less beneficial to his grantee. Accordingly, where there is a grant of land, with full covenants of warranty, without express reservation of easemnents, the best-considered cases hold that there can be no reservation by implication, unless the easement is strictly one of necessity; for the operation of a plain yrant, not pretended to be otherwise than in conformity with the contract between the parties, ought not to be limited and cut down by the fiction of an implied reservation."

TVe do not think that the case of Pleas v. Thomas, 75 Miss. 495, 22 South. 820 , is at all in point under the facts of this case. In the case just referred to the way claimed was one of necessity, well marked out, and had been in use for a considerable space of time. Not so here. The way is not one of necessity, and it is not shown that it was ever in use as a right of way. The court said in Pleas v. Thomas: 
"The principles of law governing the case are not doubtful, but their application to peculiar facts is difficult and delicate." We repeat the same here; but we do not think that appeilant has shown any such facts as would authorize us to declare that there is an implied reservation of a way of necessity in the deed of conveyance, when no necessity exists. (Implied reservations, as against the express covenants of a deed, are not favored by the courts, and are to be limited to ways of strict necessity. The fact that the land was practically given to Child by Dabney in no way alters the principle. ${ }^{10}$

\section{SEIBERT v. LEVAN.}

(Stnpreme Court of Pennsylvania, 1StS. S Pa. 3S3, 49 Am. Dec. 525.)

In error from the Common Pleas of Berks county.

The facts of this case are fully set forth in the charge of the court below; and, as no other exceptions were argued in this court, either upon the argument in $18+7$, or upon the reargument in 1818, but those taken to the charge, it will be sufficient to present the case to the profession, as it was presented to this court by the court below. Upon the trial there, Jones, P. J., charged the jury as follows:

"This is an action on the case for obstructing a certain race through which the water flowed to the plaintiff's clover-mill.

"In 1830, George D. B. Keim was seised of a tract of land in this county through which flowed a stream of water, formed by the confinence of springs arising on the land, and of a stream of water flowing into it from land situated above it. The stream thus formed, flowed in its natural channel, through the lower part of the meadow on Kein's land, into the tract below, and was used by him at the proper season - of the year for the purpose of irrigating the meadow, by means of a ditch on the higher part of the mezciow, and so much of it as was not consumed, flowed back again into the natural channel, by which it entered the farm adjoining below, the property of John Esterly.

10 Land was leased and tomether therewith a right of way orer other lind: of the lessor. Tniler its powers of eminent domant il rimpad company erected an embankment across the lessee's right of way in such manner as to make impossible the further use of said way. The lesser had no other means of access unless he had a right to nass orer the other lands of his lessor. in some other lize. ILid he have such right? See Cornell-Andrers smelting Co. r. Boston \& P. R. Corn., 202 Mass. 585, s9 N. E. 118 (190!).

A strip of land cuttine across the grantor's farm mas convered in fee to a railroad company, with no reservition escent, as a part of the consideration. thit the grante should malie a good crossing or roaclivar. Gas was later discorered on the part of the farm separated from the grantor's house by the railroad. The grantor claimed the right to put in a pipe line lending from the yells through the right of way to the liouse. The conpany oujected, on the ground that such rimet was not included in the reserration. Is there ally gronnd upon which the right so to locate the pipe line may be supported? See Chl v. Ohio River R. Co., 47 W. Va. $59,3 \pm$ S. E. $93 \pm$ (1S99).

AIg.Prop.-32 
"Ey his deed of the 23d March, 1830, John Esterly conveyed to Sem, in fee, the said farm adjoining him below, containing about two hundred acres. Keim, having thus become the owner of both farms, in the same year erected on the lower farm a mill for cleaning cloverseed, \&c., and for the purpose of supplying this mill with water, constructed a long ditch or race, principally on the upper farm, with a pond or dam near the mill (which pond was also on the upper farm), through which the water of the stream before mentioned was conducted out of its natural channel for the purposes of the mill at such times as it was thought necessary to put the mill in operation.

"On the 31st December, 18+1, Keim conveyed that tract of land, on which the race and dam were, to Messrs. Muhlenburg \& Schwartz, whose deed was recorded on the 9th April following. Oni the 6th August, 18+2, Keim mortgaged that tract of land on which the mill was, to Jacob Bechtel and others. On the 22d October, 1842, Muhlenberg \& Schwartz, entered into articles of agreement with the defendants, acting as the agents of their mother; whereby they covenanted to convey to her a certain portion of the tract purchased by them of $\mathrm{Keim}$, on which portion were the race and dam in question; and, in pursuance of those articles, they executed their deed to her on the 29th April, 1843. By virtue of a levarifacias, on a judgment confessed by Keim upon the scire facias issued on the mortgage given by him to Bechtel and others, that tract still held by Kem, and on which was the mill, was sold by the sheriff to the plaintiff, who received the sheriff's deed therefor, on 5th November, $18+4$.

\& "In neither of those deeds to Muhlenberg \& Schwartz, or from them, is any mention whatever made of this race and dam; nor is there any reservation to Keim and his heirs or assigns of any right whatever to have the water flow through that race to the mill, or to enter upon the land now of the Levans, for the purpose of repairing, cleaning, or doing anything else to this race and dam. By the first of those deeds, the land passed absolutely, and without any restriction or reservation whaterer in farour of $K$ cim, to his grantecs, who acquired the most cutive and perfect dominion ozer it, the largest and most comprehensive knoin to our lai's. IThateier may have been the relations and understanding between Keim and his immediate grantees, with regard to this land, Mrs. Lezan, in purchasing of them, was not required to go further than their recorded deed in fee; which aras equally notice to Keim's mortgagees of the lower tract, and to the purchasers from Keim's grantees of the upper tract, of the extent of the rights of these last. That decd reserving no right to this raceno right to have the auters flow through it to the mill-no such right remained in Keim, or in those claiming under him, by any subsequent concelance or encumbrance of that lozeer tract. Mrs. Levan took the upter tract from Mullenberg. \& Schacarts, as their deed conveyed it to them, as fully and as amply, as free and as e.tempt from all reservations in favour of the owner of the lower tract, as they had held it: 
and consequently she had a right to fill up that race, or divert its a aters, at her own mere zeill and pleasure; and for the doing of this, no action can be maintained against her, or those claiming under her.

"The plaintiff has submitted to us six points, agreeably to which, we are requested to charge you. We will take them up in their order:

"1. It is true that the rights of the plaintiff, who purchased at sheriff's sale, under the mortgage by Keim to Bechtel and others, are the same as those of Keim, on the 6th of August, 1842, which was the date of the mortgage. Whatever right, title, or interest, Keim had in the lower tract on that day, was bound by this mortgage, which became the measure of the right, title, and interest of the sheriff's vendee, under proceedings upon it. If Keim had then a right to the flow of water through that race, as appurtenant to the mill, or by virtue of any previous reservation or grant, such right would, we take it, have been bound by the mortgage, and would have passed to the sheriff's vendee of the mortgaged premises. But, before that day, Kcin had conveyed the upper tract, on which were the race and dam, in $f e c$, without any rescriation of such right, and on that day he had no such right that he conld bind by mortgage. Ho had no right to the flocing of the water in that race; no right to cuter upon that upper tract to clcan or repair the race, or for any purpose whatever, save only by the syffarance of Mulhlenberg and Schartar.

2. The plaintiff is not entitled to recover under the sheriff's deerl, and that whether the defendants did or did not give notice, as they allege: The right in this case does not in any manner depend upon the fact of the defendants having given notice at the sheriff's sale, that they etaimed this race.

"3. However necessary and incident to this mill, this race may be, and notwithstanding it was occupied by the servants or tenants of Keim, and by the plaintiff, for fifteen years before suit brought, still, if Keim conveyed away the land, on which it is, in fee, when he had a right to do so, and made no reservation of it, all right to the easement here claimed was lost by him and by those claiming it under him.

4. The mortgage and sheriff's deed given in evidence, do not contey the race in controversy as incident and appurtenant to the mill. If Keim had mortgaged the lower tract on which the mill is, before he conveyed the upper tract in fee, that might alter the case. But he could not have claimed incidents or appurtenances to his own land, in land by him conveyed to another in fee, without having reserved them in his deed to that other.

The cases of ways of necessity, cited from Cro. Jac. 170, and 2 Lutwyche, 1487, held to exist in favour of grantors, are of doubtful authority. The necessity here is self-created, and such a necessity could not be, in the words of Sergeant Villiams, either in law or reason any justification of a trespass committed on another's lands; Pomfret v. Pycraft, 2 Wms. Saund. 323, n. 6; and if it could not afford 
a justification for a trespass, supposing Seibert to be a defendant here, of course it can afford him no foundation for a right to recover, being a plontifif.

5. Muhlenberg and Schwartz's consent to Keim and his tenants isfing the dam and race after his deed to them and up to the date of his mortgage to Bechtel and others, as Keim had occupied and used it before his deed to Muhlenberg and Schwartz, does not entitle the 1aintiff to recover. They might have permitted this use or not, as they pleased; it might have been even an adverse use, but whether fermissive or adverse, it can give no right as against the Levans. 'They are not bound by the mere permission, express or implied, of Nuhlenberg and Schwartz, nor are they bound by any adverse use short of twenty-one years. The moment the Levans came in they had a right to do with this land, whereon the race and dam are, what they pleased.

16. We cannot say, that, under all the circumstances in this case, the law will imply a reservation of the right to the race by Keim when he conveyed to Muhlenberg and Schwartz. We cannot distinguish this case in principle from Collam v. Hocker, 1 Rawle, 10S. And having that as a rule laid down to us by the highest tribunal in. the state, it is our and your duty to conform implicitly to its authority.

"Your verdict should be for the defendants."

Verdict and judgment for defendants, whereupon this writ of error was sued out, and in this court those parts of the clarge printed in italics, as well as the answers to the second and subsequent points of the plaintiff, were assigned for error.

Gibson, C. J. We have before us a case in which the proprietor of two adjoining tracts of land, through which ran a water-course to his mill on the lower one, part of which was the natural bed of a small stream, and part of it a trench from a neighbouring creek, conveyed the upper tract expressly, without reserving the water-right, to a party who has obstructed the trench and cut off the supply of water from the creek. Such a watercourse is analogous to a way of necessity, which is not extinguished by unity of seisin, the only difference being that in the latter the right has not been created during the unity, but existed antecedently to it. But the time, not of creating the right, but of parting with the land to which it was attached, is the material circumstance. When the owner of a way sells the land through which it leads to a market, or a ville, or a church, he retains the way without an express reservation of it; and why? Pecause, as appears in Jordan v. Atwood, Owen, 121, and the several cases collected in Woolrych on Ways, 71 , the law presumes he would not have parted with a part of the property to the ruin of the rest of it; and the presumption is practically founded in justice and truth. Is not a water-course as necessary to a mi1ll as a way is to a ville or a church? Yet when the land is sold, the easement is retained on the principle of implied reservation. A right 
of way and a right of water-course, being alike subject to the general law of easements, are not distinguishable from each other in any essential particular. But we are not driven to analogies from association, however intimate; for it will be seen that there are several decisions, in cases of water-right, directly on the point before us.

The three principal ones adduced on the part of the defendant are Burr v. Mills, 21 Wend. (N. Y.) 292; Preble v. Reed, 17 Me. (5 Shep.) 175; and Hayes v. Bowman, 1 Rand. ( $\mathrm{Va}$.) 420. In the first of them, a small part of the tract above, which was sold by the owner of the mill, was covered by the pool of the dam; and in an action for the damage, Mr. Justice Cowen, delivering the opinion of the court, said: "It can make no difference that there was then a dam built which flowed this land. If a man convey land which is covered with his millpond, without any reservation, he loses his right to flow it. There is no room for implied reservation. A man makes a lane across one farm to another, which he is accustomed to use as a way; he then conveys the former, without (expressly) reserving a right of way; it is clearly gone. A man cannot, after he has absolutely conveyed away his land, still retain the use of it for any purpose, without an express reservation. The flowing, or the way, is but a mode of use; and a grantor might as well claim to plough and crop his land." An argument, by an analogy, to a right of water-course from a right of way, which, we have seen, may be retained without being expressly reserved, is merely a petitio principii; and the doctrine of the entire paragraph, being as applicable to natural as to artificial water-courses, would justify the filling up of a natural pond, used as a reservoir; which is surely not the law. Nor does the claim of a water-course of necessity bear any resemblance to a claim to plough and crop another's land, which would merely be an idle and extravagant pretension. He admitted that the land would have remained subject to the easement, had the owner of it retained it and sold the mill ; for which distinction, he cited Nicholas v. Chamberlain, Cro. Jac. 121; which clearly proves the particular position, but as clearly disproves his conclusion from it, as well as the whole doctrine predicated by him; for it was held by all the court, "that if one erects a house and builds a conduit thereto in another part of his land, and conveys water by pipes to the house, and afterwards sells the house, with the appurtenances, or sells the land to another, reserving to himself the house, the conduit and pipes pass with the house." As the reservation of the house is not an express reservation of the pipes, it must be an implied one; and as we have seen that a vendee may set up an implied grant of a thing lying out of the limits of his conveyance, on the ground of necessity, we may infer that a vendor may, on the same ground, set up an implied reservation of something within them.

It is not by force of the word appurtenances that a water-course, like the present, would pass by the grant of a mill, but by force of the 
principle that the grant of a thing includes all the means in the grantor's power to attain it; for the means shall pass inclusive without the words "cum pertinentis," or words equivalent to them: Touchstone, 89. The grant of the means, therefore, is an implied one, for it is certainly not expressed; and there is no imaginable reason why there should not be an implied reservation where the land is sold and the mill is retained. But to return to the defendant's cases. 'The second of them, Preble v. Reed, is a decision of the same stamp, in which the same doctrine is asserted without a reason or an authority given for it, excepting an instruction reported to have been given on a supposed state of facts in Hathorn v. Stinson, 10 Me. (1 Fairf.) 224, 25 Am. Dec. 228, which secms, it was said, to have met the approbation of the whole colirt. In the third of them, Hayes v. Bowman, it was barely held that a man who had granted a part of his land divided from the rest of it by a river, and expressly to the middle of the stream, had not a right to erect a dam from shore to shore for the better enjoyment of his mill-seat; but the court did not determine what would have been the law of the case had a dam been erected before the land was sold. The decision is a sound one, but it does not touch the point before us.

The preceding cases make up the sum of what has been adduced as authority for the defendant; and we will now turn to the authorities on the part of the plaintiff. Besides Nicholas v. Chamberlain, which is full to the point, we have Sury v. Pigott, Palmer, 444, more fully reported in Popham, 166, and more intelligibly stated in Noy, 184. It seems from the last, that the case was this: A., seised of IVhiteacre, with a house, curtilage, and hop-yard through which ran a stream to a pond in the curtilage for watering cattle, enfeoffed P., of the hop-yard above, and leased the house and curtilage to S. P. stopped the stream; and S. brought an action on the case for it; and the court held that the right of water-course had not been extinguished by the unity of seisin. Yet there, as here, the defendant obtained title to the ground above by the earlier grant. It was said by Dodderidge, that if "a man having a mill and water-course over his tand, sells a portion of the land over which the water-course runs; in such case, by necessity, the water-course remaineth to the vendor, and the vendee cannot stop it:" and Crew, Chief Justice, said that it had been adjudged accordingly in Day and Drake's Case, 3 Jac. 1, in the King's Bench. The opinion of Chief Justice Popham in Lady Brown's case was also cited by him, in which it was held that if one "hath a stream of water which runneth in a leaden pipe, and he buys the land where the pipe is, and he cuts the pipe and destroys it, the water-course is extinct because he thereby declares his intention and purpose that he does not wish to enjoy them together"; the inference from which is, that if he had sold the land without cutting the pipes, the easement would have remained, and he instanced the case of a dye-house with water running to it, in which it was held that a purchase and subsequent sale of the 
land on which the water was current, by the owner of the dye-house, did not extinguish the easement.

These are ancient cases, but they seem to have been deeply considered, and founded in the soundest maxims of the laws. It is admitted that the owner of adjoining tracts traversed by a natural water-course, is as much entitled to the use of the water, having sold the lipper one as if he had not owned it. The vendee would be entitled to a reasonable use of it, returning it, when it had served his purpose, to its former channel, so as to make it enter the tract below at the point where it entered it at the time of the sale; and what difference could there be, whether the channel to lead it to that point were made by water or by the hand of man? There is no particular charm in a gully cut by natural agents. While the grantor was lord of the whole, he might assign a permanent channel to the stream, and as regards himself or those to claim under him, impress it with any character he should see proper. There is no peculiar sanctity in the natural bed of a stream, which is perpetually changing its course from accidental causes. Had the connexion with the natural water-course leading from the springs to the mill, been made by a flood tearing its way through the bank of the creek, it would not have been pretended that the grantee, having purchased with the fact before his eyes, would have been at liberty to destroy it. But that it would have been entitled to no consideration as a dispensation of Providence, is shown by the undoubted right he would have to mend a breach made after his purchase. It is true the rule is, that water shall flow ubi currere solebat et consuevit; but that regards the duty of returning it, and not the nature of the channel. It was said by Dodderidge, in Sury v. Pigott, that as water descends it is always current, et aut invenit aut facit viam; and he asked, "Shall such a thing be extinguished which hath its being from creation?" And Crew said, "A water-course is a thing natural, and therefore by unity it shall not be discharged," but that these things were said of the element without reference to the nature of its channel, is evident from Nicholas v. Chamberlain, and Lady Brown's case, in which the easement was not lost though the water was conveyed through leaden pipes. The sum of the matter in regard to disposition by the act of an owner of two tenements, is thus condensed in Gale and Whatley's Law of Easements, 52: "It is true that, strictly speaking, a man cannot subject one part of his property to another by an easement, for no man can have an easement in his own property, but he obtains the same object by the exercise of another right, the general right of property; but lie has not the less thereby altered the quality of the two parts of his heritage; and if, after the annexation of peculiar qualities, he alien one part of his heritage, it seems but reasonable, if the alterations thus made are palpable and manifest, that a purchaser should take the land burthened or benefited, as the case may be, by the qualities which the previous owner had undoubtedly the right to attach to it." The ease-7 ment in the case at bar was palpable and permanent; and the defend- 
ant was not at liberty to listurb it. As the exceptions to cridence have not been separately argued, it is mnecessary to examine them in detail.

Judgment reversed, and a venire facias de novo awarded. ${ }^{11}$

Rucirs and Coulitis, JJ., dissented.
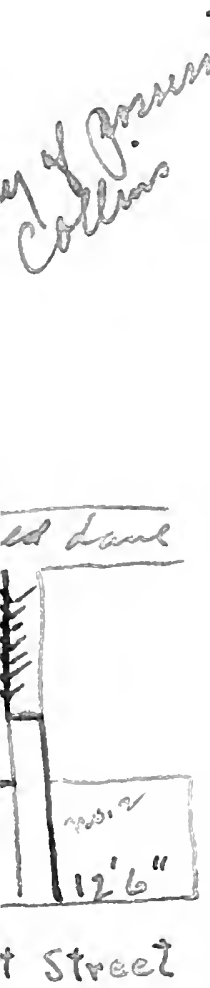

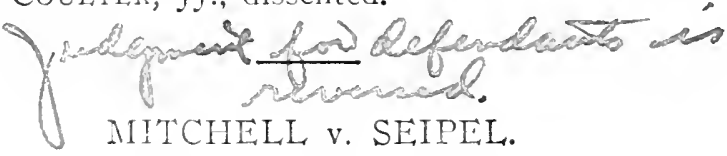

(Court of Apneals of Marylaud, 1570. $53 \mathrm{Md} .251,36 \mathrm{Am}$. Rep. 404.) -

Millet, J. ${ }^{12}$ This action was brought in December, 1878, by the appellee against the appellant to recover damages for closing and obstructing an alley between two houses then separately owned by the respective parties. The case presents an important and interesting question respecting the law of easements.

The facts necessary to be stated, and about which there is no dispute are these: In the year 1839, Daniel Collins became the owner under a lease for ninety-nine years renewable forever of a lot of ground in the City of Baltimore, fronting thirty feet on Thest strect, and extending back eighty feet to Gould lane, a public alley twonty feet wide. The lot was then vacant, but soon after his purchase Collins erected thereon two brick houses fronting on Vest street. These houses were built a bout the same time, the first having a front of fifteen feet. and the second a front in the lower story of twelve feet and six inches, and in the upper stories of fifteen feet, thus learing an alley of two feet and six inches between them, covered by the joists which supported the second floor of the second house. These joists projected over the alley and into the adjoining wall of the first house. The alley thus corered was open to the street, and extended back between the houses about thirty feet. At its inner terminus two gates were placed, which opened respectively into the rear prenises and yards of each house, and it was used by the occupants of each as a common passageway to and from the street. Each hotnse had, as usual, a front door opening upon the street, and from the end of the alley a fence was built which extended back to Gould lane, and divided the lot into two parts, giving to each a width of fifteen feet. During his life, Collins continued the owner of the whole property and occupied one of the houses. After his death his widow became the owner under his will, and so continued until the year 1865 , when by an order

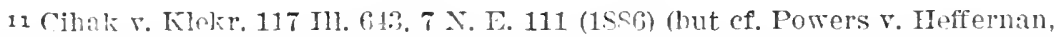

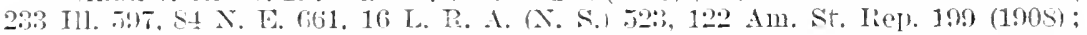

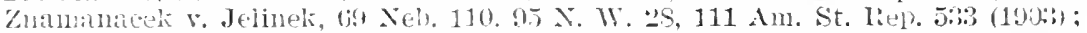

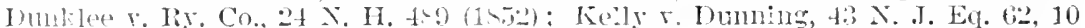

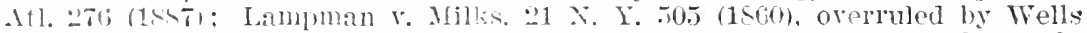

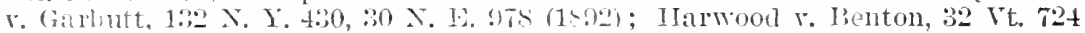

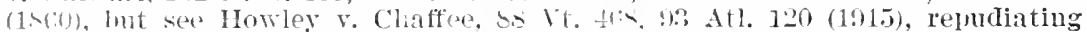
Hichm in Ilarwood case: Pennett v. Pooth, 70 W. Ya. 264, 73 S. E. 909, 89 L.

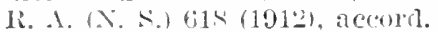

12 The statenient of facts and a portion of the opinion are ourtted. 
of the Orphan's Court, and in pursuance of a power contained in the will, the cxecutor of Collins sold and conveyed the entire property to George ' $\Gamma$. Waters.

While the unity of possession thus continued, it is very clear no easement in respect to this alley existed. A party cannot have an easement in his own land, inasmuch as all the uses of an easement are fully comprehended in his general right of ownership. Oliver v. Hook, $47 \mathrm{Md}$. 308. But this unity of ownership was severed on the Sth of June, 1865 , by Waters the owner, who on that day sold and conveyed the second house and lot to George W. Chandler, from whom the defendant throligh several mesne conveyances derived his title to the same. This conveyance was an absolute and unqualified grant, describing the property by metes and bounds, which included the whole of this alley, and contained no reservation of the right to use the same for the benefit of the house and lot retained by the grantor. Waters retained ownership of the first house and lot until the 29th of July, 1868, when he sold and conveyed the same to the plaintifi by a similar grant, which emoraced no part of the alley. The defendant obtained his title to the second house and lot, (as before stated by mesne conveyances from Chandler, the first grantee thereof,) in October, 1874, and shortly before this suit was brought, prevented the plaintiff from using the alley, by placing upon it buildings and other obstructions. There is no pretence that the plaintiff had acquired a prescriptive right to use the alley, nor is the case complicated by any easements of crainage or sewerage. There are no pipes or drains, either underground or otherwise, from one house to the other, and thence to a common outlet, nor loes the surface drainage pass through the alley. 'The proof shows that the natural flow of surface water, and that from the hychants on both prenises is in the opposite direction, towards and to Gould lane. The alley was therefore simply a convenient passage way. Without doubt it was open and apparent, and was made and designed by Collins, for the common use and benefit of both houses, and was in fact so used by the occupants of both, until obstructed by the defendant, but it is equally clear that Collins and those who succeeded him in the ownership of both could have closed it, and re-arranged the pramises at pleasure. The real question in the case then is: Does the lat attach to the unqualified grant in 1865 , from Waters to Chandler, of the second house and lot, by metes and bonnds, which include the whole of this alley, an implied reservation of the use of it for the benefit of the house and premises retained by the grantor? Upon this point, our investigations have led us to an examination of the large number of authorities cited by counsel, as well as many others, and upon no question have we found so great a contrariety of judicial opinions and dicta, if not of actual decisions. ***

In short, after a careful examination of the numerous authorities in this country to which our attention has been called, we have found but one prominent decision by a Court of last resort, in which the doc- 
trine of implied reservation in a case analogous to the one before us has been sustained, where the racts were such as fairly to present the question for determination. That is the case of Seibert v. Levan, 8 I'a. 383, $49 \mathrm{Am}$. Dec. 525, in which the opinion of the Conrt sustaining the doctrine was delivered by Gibson, Ch. J., in his usual forcible and vigurous style. Two, however, of the five Judges dissented, and in the conrse of his opinion the Chief Justice was obliged to set aside the opposing authorities of Burr v. Mills, 21 Wend. (N. Y.) 292, and I'reble r. Reed, 17 Me. 175. Against this case nuay be placed the decision in Carbrey v. Millis, 7 Allen (Mass.) 364, 83 Am. Dec. 688, (where also the facts presented the question,) in which it was said by the Supreme Court of Massachusetts: "But where there is a grant of land by metes and bounds without express reservation. and with full corenants of warranty against encumbrances, we think there is no just reason for holding that there can be any reservation by implication, unless the easement is strictly one of necessity. Where the easement is only one of existing use and great convenience, but for which a substitute can be furnished by reasonable labor and expense, the grantor may certainly cut himself off from it by his deed, if such is the intention of the parties. And it is difficult to see how such an intention could be more clearly and distinctly intimated than by such a deed and warranty." In a subsequent case in the same State, (Randall v. McLaughlin, 10 Allen [Mass.] 366, notice is taken of the fact that the authority of Pyer $v$. Carter [1 H. \& N. 916] had then recently been wholly denied by the Chancellor of England, in the opinion given in Suffield v. Brown [4 De G., J. \& S. 185], which, says the Court, "contains an elaborate review of the whole doctrine, resulting in conclusions substantially like those to which we came in Carbrey v. Willis."

But the decision of our predecessors in MicTavish v. Carroll, 7 Md. 352, $61 \mathrm{Am}$. Dec. 353, has been pressed upon our attention by the appeilee's counsel. 'That was a case peculiar in its facts and circumstances. A father who owned a large tract of land on which there was a mill, mill-dam, race and roadway for repairing it, conveyed by a voluntary deed of gift, the portion on which the dam, race and road were situated, to his daughter without reservation, and subsequently by a like deed, conveyed the portion on which the mill was located to his son, and in both deeds reserved a life estate to himself. The Court held that the grantee of the portion on which the mill was situated, was entitled to the use of the dam, race and road upon the principle of legal necessity, but also adverted to the fact as distinguishing that case from the authorities there cited, that the two deeds gave the grantees the right of possession at the same time, viz.; upon the death of the grantor, he having reserved to himself a life estate in both parcels of land. There was in fact, therefore, no antecedence of title of one grantee to the other, and in view of the authorities to which we have referred, the decision of that case might well have been rested on that point alone. But it was in other respects materially different from the present case, 
and cannot control its decision. Neither in that case nor in that of Oliver v. Hook, 47 Md. 301, were the views of Gale on Easements, adopted further than in reference to implied grants, and in the latter case, it was heid upon abundant authority, that even the doctrine of implied grants had no application to the case of an ordinary, open and unenclosed way, not being at the time of the grant an existing easement.

Finding then no binding decision of this Court, and no decided preponderance of authority in this country, to prevent us from following the law as it has recently been settled by the decisions in England, and being satisned the distinction so clearly drawn in those decisions between what has been called an implied grant, and what has been attempted to be established under the name of an implied reservation, is not only founded in reason, but has existed almost as far back as the law upon the subject can be traced, we shall apply it to the case before us.

It remains then to ascertain whether this alley is a way of necessity, so as to fall within the exception to the second profosition stated in Wheeldon v. Burrows. Among the cases coming under this exception, reference may be made to Pinnington v. Galland, 9 Excheq. 1, and Davies v. Sear, Law Rep. 7 Eq. 427. In those cases the ways in question were ways of necessity, and the decisions went upon that ground. But we are all clearly of opinion this alley is not such a way. Te adopt as entirely applicable to the present case, what was said in Docld v. Burchell, 1 Hurl. \& Colt, 113, by Wilde, B., viz., "It appears at the time of the grant in respect of which the right of way is claimed, there was a way from the house into the garden, and that way now exists. But it is said the way now claimed is more convenient than the other. Then comes the question whether the plaintiff can claim it as a way of necessity, on account of its great superiority over the other way. It seems to me that it would be most dangerous to hold, that where a deed is silent as to any reservation of a way, the one that is more convenient to use than another way, must exist as a way of necessity. There is no foundation whatever for such a doctrine." When the deed of $1: 65$ from Vaters to Chandler was executed, access to the yard and kitchen of the house retained by the grantor could be had, not only thitough the front door of the house, but from Gould lane in the rear. Such public lanes or alleys are to be found in almost every part of the City of Baltimore, and were made for the very purpose of affording access to yards and kitchens which could not otherwise be reached save through the front doors of the houses. Most of the dwellings in that city have such alleys in the rear, and no entrance from the front except a door which opens into a hall or front room. It is true the proof shows there 'was a brick stable on the plaintiff's lot fronting on Gould lane, but it was built by the plaintiff himself, and not until after the year 1872. If this obstructed access from Gould lane, it was the plainriff's own fault. He certainly could not by his own act, without con- 
sent and against the rights of the defendant, convert this alley from a way of convenience to a way of necessity. Whether it is a way of necessity or not, must depend upon the state of things existing at the date of the deed of 1865 , and not with reference to the changes subsequently made by the plaintiff on his own premises. At that time the alley was, as it is now, useful and convenient, but it was not what the law regards as a way of necessity.

But it has been further argued, there ought to be an implied reservation of this alley, because that part of the house granted by the deed of 1865 , which is above the alley, is supported by the wall of the house retained by the grantor. The contention on this point is, that the alley and this support afforded the granted house make a case of reciprocal easements. But we do not see how the fact, that there may be an implied grant of this easennent or right of support, can be held to take from the grantee the ground used for the alley, which was expressly granted to him without reservation. The two are not necessarily or inseparably connected. The case is not like that of Richards v. Rose, 9 Excheq., 218, where a block of houses on a plot of ground were so built together by the same owner as necessarily to require mutual support. In that case it was held that there was, either by a presumed grant or by a presumed reservation, a right to such mutual support, so that the owner who sells one of the houses as against himself grants such right, and on his own part also reserves the right, and consequently the same mutual dependence, of one house upon its neighbor's still remains. This furnishes another instance of an easement of necessity within the exception to the general rule forbidding implied reservations. The present case, however, is quite different. It does not come up to that case, nor does it touch the cases or the law of party walls, nor even that of an alley situated and constructed in the manner described in the case of Dowling v. Hennings, 20 Md. 179, 83 Am. Dec. 545 .

It follows that there was error in granting the instruction given by the Court, and for this the judgment must be reversed. The Court, however, was clearly right in excluding, at the instance of the defendant, the agreement, under seal, between Chandler and Vaters, of the Sth of June, 1865, which professes to grant the common use of this alley. That instrument was never recorded, and was not embodied in or referred to by the deed of the same date. It can have no effect in determining the construction or operation of that deed, nor can it in any wise affect the rights of the parties to this suit. It, therefore, plainly appears, from the record before us, that the plaintiff has no ground of action, on account of the obstruction complained of, and it hence becomes the duty of this Court not to award a new trial. Judgment reversed, and new trial refused.

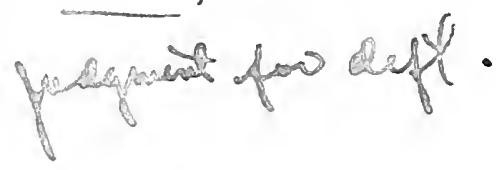




\section{MANCUSO v. RIDDLEMOSER CO. OF BALTIMIORE CITI.}

(Court of Appeals of Maryland, 1911. 117 Ma. 53, 82 Atl. 1051, Ann. Cas. $191+\lambda, \&+$.

URNER, J. ${ }^{13}$ The appellee corporation is the owner of a six-story industrial building in Baltimore City, fronting on the south side of Fayette street and abutting in the rear on an alley known as Bank lane. On July 27th, 1908, the company leased to the appellants a wareroom on the first floor of the building together with a part of the basement lying immediately north of the alley and south of a designated wall. The lease was for a term of two years. Sometime during the first year the tenants, in consideration of a reduction in the rent, surrendered to the landlord the north half, approximately, of the basement area covered by the lease, and the new division line was indicated by a wire screen partition then constructed. On February 11 th, 1910 , the parties executed a new agreement for the leasing to the appellants of the room and cellar space they then occupied for the term of five years, beginning September 1st, 1910, with an option to the lessee to renew for successive terms. In each of the leases it was stipulated that the premises should be used only as a barber shop and bathing establishment and for certain incidental purposes, and there was a covenant that the landlord should supply all hot and cold water and all electric current and heat reasonably required by the tenants in the prosecution of their business. The section of basement leased to the appellants appears to have been mainly used by them for access to a toilet and for the storage of empty boxes. In the basement retained by the landlord, and partially under the wareroom tenanted by the appellants, is located the steam and electric plant by which the appellee's building is supplied with heat, light and power. There are numerous lessees who are dependent upon this service. The entire second floor is occupied by a business college, and the floors above by various manufacturing industries, while the first floor accommodates several business enterprises in addition to that conducted by the appellants.

At the rear of the basement leased to the appellants is a doorway five feet wide opening into Bank lane. It is equipped with outer doors of iron, with inner doors of glass, and with intermediate doors of wire screen. Until a short time before the filing of the present bill this doorway had been used continuously by the employees of the appellee in going to and from the steam and electric plant and in moving supplies and repairs, and the iron and glass doors had been kept open in order to aid ventilation and reduce the temperature. There were openings provided for the same purposes through the wall and screen partition located between the plant and the rear portion of the basement. It appears without dispute that the temperature of the base-

13 A portion of the opinion is omittad. 
ment, with the Bank lane doors open, is usually about one hundred and eight degrees in winter and sometimes as high as one hundred and forty-five degrees in summer, and that when these doors are closed, at any season of the year, the thermometer rises about forty degrees. This is shown by the evidence to be considerably above the temperature at which the men can remain at work and the machinery be operated with safety. The testimony is that when the heat reaches one hundred and forty-five or one hundred and fifty degrees there is danger that the wiring and insulation on the electric generators will be destroyed. 'This would necessarily cause a stoppage of the plant and of all the machinery which it supplies with power and would require heavy expenditures for repairs. It is proven also that in the event of a sudden discharge of steam, which may result from the bursting of a pipe or the blowing out of a gasket, the only way of escape for the employees in the basement would be through the door opening on Bank lane. There is a narrow passage leading by the boiler and fire pit to a stairway in the front of the building, but an accident of the character described, which has already once occurred, would cut off this means of exit.

The conditions we have indicated were existing and apparent when the appellants entered into possession under their first lease. They knew that the employees in charge of the steam and electric plant were daily using and depending upon the alley doorway for ingress and egress. They must have been aware also that the system of ventilation which the appellees had provided for the basement of their building could not be effective if the door in question were kept closed. They made no objection for nearly three years to the use of the doorway by the appellees for the purposes we have mentioned, and it was . not until after this long period of acquiescence that they loched the door and asserted that its exclusive control belonged to them under their lease. They assumed this attitude for the first time early in March, 1911, and when they then closed and fastened the door the temperature of the basement rose to about one hundred and forty degrees, and according to the testimony of the engineer in charge "it absolutely got dangerous to run the machines, and it was dangerous not only to the machines but to the help, and you simply suffocated in there, and if anything were to happen you were caught like rats in a trap and couldn't get out." After this condition had existed for about two weeks the City Inspector of Buildings notified both the appellants and appellees "to keep free and open the rear exits of the heating plant in the building, as it appears they are now locked and bolted. It is a menace to the men operating the plant and must be done immediately." This was followed a few days later by the present bill for an injunction to restrain the appellants from keeping the doontway closed. A preliminary writ was granted, and upon final hearing the injunction was made perpetual.

In support of their position the appellants rely upon the fact that 

the lease under which they hold contains no express reservation to the agpelless they invoke the well settled principle that easement by implied reservation will not be sustained except in cases of strict necessity. Jay $v$. Tichael, 92 Md. 210, 48 Atl. 61 ; Burns v. Gallagher, 62 MId. 472; 入iitchell v. Seipel, 53 Md. 269, 36 Am. Rep. 404. It is insisted that the conditions shown by the record are not such as to make the present case an exception to the general rule. The contention is that the use by the appellee of the doorway in controversy is not necessary, within the meaning of the rule stated, because it is possible that other means of access and ventilation may be provided through other portions of the basement. The evidence, however, does not support this theory. It is shown by the proof that no adequate provision could be made in substitution for the use of the opening into the alley without injuriously encroaching upon the rights of other tenants in possession of adjacent sub-divisions of the basement under prior leases. When the appellants acquired their leasehold interest, the doorway on Bank lane was the only way under the control of the appellees by which a draft of air could be obtained for the area occupied by the steam and electric plant and by which a safe exit could be secured for the engineer and fireman. This doorway was then, and thereafter continued to be, in actual and necessary use for these vitally important purposes. Under such circumstances it is clear that a reservation to the appellee of the right to such user must have been understood and intended by both the parties to the lease. In the decisions we have cited it was held that: "It is only in cases of strictest necessity, and where it would not be reasonable to suppose that the parties intended the contrary, that the principle of implied reservation can be invoked." In the case before us it would be altogether unreasonable to suppose that there was any intention on the part of the lessor company or of the lessees that the former should surrender the only available means of insuring the safety of the employees in charge of the plant in the basement and of obtaining the ventilation required for its satisfactory operation. In our judgment, under the conditions presented in this case, the use of the rear doorway in connection with the steam and electric plant must be held to be one of strict and absolute necessity.

Decree affirmed, with costs.

\section{BROVN v. FULLER.}

(Supreme Court of Michigan, 1911. 165 Mich. 162, 1:00 N. T. 621, 33 L. R. A. [N. S.] 459, Ann. Cas. 1912C, 853.)

Complainant and defendants were, respectively, owners of adjoining lots facing Burdick street, in the city of Kalamazoo. Upon complainant's lot, which was 22 feet wide and about 230 feet deep, extending to Farmer's alley, there had stoorl for many years a three-

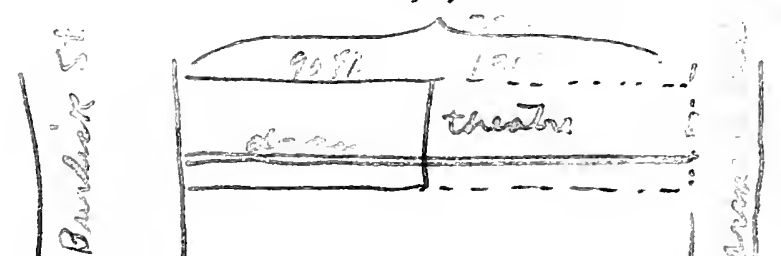


story brick block, running east from Burdick street about 90 feet. To the east and in the rear of said brick building, a one-story building extended eastward to the alley, about 130 feet. The sewage from the brick block was conducted under the one-story building to a lateral sewer in Farmer's alley. The roof drainage of the block was carried onto the roof of the one-story building and thence to the alley. Defendants desired to erect a theater, and, their own lot not affording suffcient area for their purpose, negotiated with complainant for the purchase of the rear or easterly 130 feet of her lot. On November 9, 1908, a warranty deed of said parcel with full covenants against incumbrances was executed by complainant to defendants for the consideration of $\$ 5,000$. This deed contains the following agreement:

"It is understood and agreed between the parties hereto, as a part of the consideration of this deed, that the second parties are to build a wall on the west side of the land above conveyed, about 16 inches thick and about 40 feet in height, and that the party of the first part is to own said wall jointly with the second parties, and it is to be used as a party wall. The center of the said wall to be on the west line of the land above conveyed."

Defendants, after said purchase was completed, proceeded to tear down the one-story building which stood on the lot conveyed, and commenced excavation for the basement under the proposed theater. In excavating, the sewer from complainant's block was uncovered, and as defendants desired to make a basement nine feet deep, which was three or four feet deeper than the sewer, the sewer was cut, and the excavation proceeded. In the negotiations complainant did not advise defendants of the existence of the sewer, and the record does not show that they or either of them knew it was there.

After the sewer was cut, complainant filed her bill of complaint, praying for a mandatory injunction compelling defendants to restore the sewer connection and roof drain-pipe, and for a permanent injunction restraining defendants from breaking or interfering with the sewer and from interfering with the passage of the roof drainage over said lot. A preliminary mandatory injunction was granted ex parte which the court refused, on motion, to vacate. This injunction was granted on January 5, 1909. The cause came on to be heard on the merits October 17, 1909. In the meantime, defendants had completed the theater building, and, in obedience to the mandate of the court, had taken care of the complainant's servage and roof drainage, at considerable expense. Upon final hearing, the preliminary injunction was made permanent. The decree further provides that the expense of maintenance and repairs of the sewerage connection and the storm pipe shall be borne equally by the parties. From this decree defendants appeal.

BROOKE, I. (after stating the facts). The sole question for determination here is whether or not there is an implied reservation of an pasement orer the land sold by complainant to defendants. It is said 
that in reaching the conclusion he did, the learned circuit judge relied upon the case of Smith v. Dresselhouse, 152 Mich. 451, $116 \mathrm{~N}$. W. 387. An examination of the facts in that case will at once demonstrate that it differs vitally and fundamentally from the case here considered. There the owner of two adjoining tenements, located upon either side of a river, upon each of which stood a mill, sold one of the tenements to the complainant in that case, and, as appurtenant to the tenement conveyed, sold the water rights. The owner and his grantees continued to operate the mill on the other side of the river, using the water for that purpose. Complainant filed his bill to enjoin the use of the water. This court held that, as to the water, complainant was a tenant in common with the owner of the adjoining tenement on the opposite bank of the stream. Mr. Justice Ostrander, in stating the general rule, there said:

"It is a general rule of the law of easements that where the owner of two tenements sells one of them, the purchaser takes the portion sold with all the benefits and burdens which appear at the time of the sale to belong to it as between it and the property which the vendor retains."

The matter under consideration was a grant, not a reservation, and in discussing the effect of the grant he further said:

"We should not expect that a grant of the land on one side of the river only, the grantor retaining the land and mill on the other side, and using the water there appurtenant, conveyed an exclusive right to the entire water power. The terms of the grant to complainant are express and seem to be unambiguous. The land is described by metes and bounds. One boundary is the center of the main channel of the river. The mill tract and the mill are within the boundaries. It is the mill privilege and water power 'there situate,' i. e., appurtenant to the land conveyed, which is deeded, with the right to flow lands and to 'use and make use of the water power there situated." '

Assuming, therefore, that the rule was correctly stated, the case was determined, not by any application of the rule, but by a construction of the terms of the grant. Nor is it applicable to the case under consideration. Here, the sewer was under ground. It was not apparent, and defendants are not shown to have had any knowledge of its existence under the land purchased by them. But, if they had such knowledge, that fact would not be controlling, because complainant knew that the use to which this property was to be devoted would uncover the sewer and, as it existed, destroy it.

Even if it could be said that a grantor under any circumstances could by implication reserve the right to continue an underground sewer in the premises granted, which we do not determine, it would not aid complainant. Here, it is sought by implication to reserve the right to have the existing sewer destroyed and rebuilt in the air through the basement of the tenement to be erected upon the demised lands. SimAIG.PROP. -33 
ply to state such a proposition would seem to be a sufficient answer.

The rule applicable to implied reservations of easements is stated in 14 Cyc. p. 1171, as follows:

"As regards implied reservations of easements, the matter stands on principle in a position very different from implied grants. If the grantor intends to reserve any right over the tenement granted, it is his duty to reserve it expressly in the grant. To say that a grantor reserves to himself in entirety that which may be beneficial to him, but which may be most injurious to his grantee, is quite contrary to the principle upon which an implied grant depends, which is that a grantor shall not derogate from or render less effectual his grant or render that which he has granted less beneficial to his grantee. (Accordingly, - where there is a grant of land with full covenants of warranty without express reservation of easements, the best considered cases hold that there can be no reservation by implication, unless the easement is strictly one of necessity." )

Tases are cited from many jurisdictions in support of this statement of principle, and we think it is in accord with the weight of modern authority. The great weight of authority touching the question, with reference to subterranean drainage, is to the effect that, if the owner of the land under which there is such a drain conveys a part of it with full covenants of warranty without reference to the drain, no easement is reserved.

The grantor and his privies, under such circumstances, are estopped to claim any interest in the premises so granted. To permit such a claim would be to allow the grantor to derogate from the terms of his grant which, by every applicable principle, is forbidden. The authorities upon the subject are collected and discussed in $10 \mathrm{Am}$. \& Eng. Enc. Law (2d Ed.) p. 42 . See, also, 14 Cyc. p. 1169, and cases there cited, and Farnham on Waters \& Water Rights, vol. 3, pp. 2454, 2455 .

In the recent case of Covell v. Bright, 157 Mich. 419, 122 N. IV. 101, which upon principle much resembles the case at bar, we said:

"To entitle the complainant to a decree, the burden was upon him to establish that the servitude was apparent, continuous, and strictly necessary to the enjoyment of his lands" citing cases.

In New Jersey, a different doctrine for a long time obtained, based upon the ruling in the celebrated case of Pyer v. Carter, 1 Hurlst. \& N. 916, and those cases which followed the rule there laid down. Pyer $v$. Carter has frequently been severely criticised, and was finally distinctly overruled in England. The case of Toothe v. Bryce, $50 \mathrm{~N}$. J. Eq. 589, 25 Att. 182, contains a review of the English and American cases, questions the soundness of the doctrine announced by that court in its earlier decisions, and seems to recognize the distinction between an implied grant of an easement and an implied reservation.

While it is apparent from the record that it will be somewhat ex- 
pensive to dispose of the sewage from complainant's building otherwise than over detendants' land, it by no means appears that it is impossible to do so. There is not made out, therefore, a case of strict necessity.

The case presents this alternative: Either complainant at some, perhaps considerable, expense to herself, must take care of her own sewage and storm waters, or the defendants who purchased and paid for a tenement warranted to be free from all incumbrances, must take that tenement charged in perpetuity with an incumbrance of a very serious character and one which is liable, through the breaking or stoppage of the drain, to cause serious annoyance and damage.

Why should defendants be compelled to accept this burden? Why should they be charged in perpetuity with the duty of defraying onehalf of the expense of maintaining complainant's sewer as well as the cost of its original construction? So far as the record discloses, they have done no act which was not fully warranted by the terms of the grant to them. They have sought to make use of the granted tenement in a lawful manner and in a manner and for a purpose known by complainant before the sale.

Touching the disposition of the storm waters, it is clear that, by the sale of the one-story building upon which it had theretofore been carried to the alley, with the knowledge that said building was to be immediately demolished, complainant must have known that such drainage would be interrupted. The very terms of her written contract show this, because she stipulated for the erection of a brick wall between the premises granted and those retained. This wall was to be 16 inches thick and about 40 feet in height. It is obvious that she could not have contemplated the carrying of her roof waters over that wall. At that moment it was apparent that some new arrangement must be made to care for this water. Defendants did not contract to build a new drain and carry it across their own property to the alley, nor did they agree to construct a new sewer, and we linow of no principle of equity which would compel them to do so.

The decree of the court below is reversed, and the bill of complaint is dismissed, and, inasmuth as the record discloses that defendants have expended certain sums of money in obedience to the mandate of the court in caring for complainant's sewage and water, the record will be remanded for the purpose of ascertaining the exact amount of such expenditure which, when ascertained, shall be decreed to be a debt due from complainant to defendants for the collection of which execution may issue.

Ostrander, C. J., and Hooker, Máluvay, Blair, and Stone, JJ., concurred with BROOKE, J.

BIRD, J. (dissenting). I am of the opinion that the trial court reached a right conclusion upon the law and facts in this case and that it ought to be affirmed by this court.

In the case of Smith v. Dressclhouse, 152 Mich. 451, 116 N. W. 387,

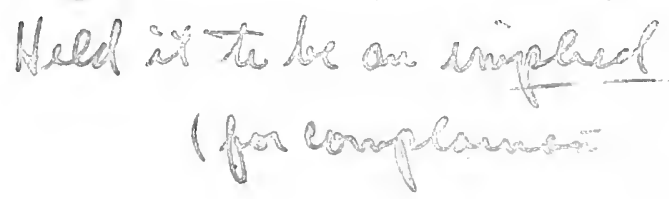


Mr. Justice Ostrander, discussing the doctrine of implied reservations, quoted, with approval, the following general rule of easements:

"It is a general rule of the law of easements that where the owner of two tenements sells one of them, the purchaser takes the portion sold with all the benefits and burdens which appear at the time of the sale to belong to it as between it and the property which the vendor retains. Seymour v. Lewis, 13 N. J. Eq. 439, 78 Am. Dec. 108. Every grant of a thing naturally imports a grant of it as it actually exists. United States v. Appleton, 1 Sumn. 502, Fed. Cas. No. 14,463."

Mr. Justice Selden, in speaking of this rule, said:

"This is not a rule for the benefit of purchasers only, but is entirely reciprocal. Hence, if, instead of a benefit conferred, a burden has been imposed upon the portion sold, the purchaser, provided the niarks of this burden are open and visible, takes the property with the servitude upon it." Lampman v. Milks, 21 N. Y. 505.

If we are to take the foregoing rule as our guide in determining this case, I am very firm in the conviction that defendants took the deed of the premises burdened with the sewer. In arriving at this conclusion, the distinction made by Mr. Justice Brooke, in his opinion, between implied grants and implied reservations, has not been overlooked. Although there is a difference of opinion in the cases as to the degree of necessity required to create them, the better rule seems to be, and the one supported by the weight of anthority is, that a reasonable necessity is sufficient to raise an implied grant; whereas, a strict necessity is necessary to raise an implied reservation. This court has adopted the strict necessity rule in Covell v. Bright, 157 Mich. 419, 122 N. W. 101. The question therefore arises whether the circumstances of this case are such as to bring it within the rule of strict necessity. A study of the record has persuaded me that they do. To establish her case it was necessary for complainant to show that the easement claimed was apparent, continuous, and strictly necessary.

"Tas the easement apparent? "Apparent easements" have been defined to be those the existence of which appears from the construction or condition of one of the tenements so as to be capable of being seen or known on inspection. $10 \mathrm{Am}$. \& Eng. Enc. Law (2d Ed.) p. 405. To this class of easements belongs the bed of a running stream, an overhanging roof, a pipe for carrying water, a drain, or a sewer. Fetters v. Humphreys, 18 N. J. Eq. 262. And the mere fact that a drain or aqueduct, as the case may be, is concealed from casual vision, does not prevent it from being "apparent" in the sense in which that word is used in that connection. Larsen v. Peterson, 53 N. J. Eq. S8, 30 Atl. 1094.

Defendant testified that he did not know that the sewer extended through the premises conveyed to him. If he had no actual knowledge, he did have constructive knowledge of that fact. He had owned for upwards of 25 years premises side by side with the premises in question, with like improvements. He knew there was a sewer which served 
complainant's premises because he had the front portion of them under lease nearly two years before he purchased the rear portion, and at the time there were five water-closets in the portion he had under lease. He knew that the sewer from his own premises was discharged into the Farmer's alley sewer, and must have known that there was no other sewer into which it could be discharged and, if he did, it would not be unreasonable to assume that he knew the same thing was true of complainant's premises. On one occasion, prior to his purchase, a portion of the floor in the rear part was taken up, which disclosed the sewer, and defendant was present at that time. Defendant had, before purchasing the property, talked and planned with complainant's husband about building a theater where he has since erected one, and, in doing so, undoubtedly considered the question of plumbing among other questions of construction and arrangement. A knowledge of these facts was sufficient in the law to put defendant upon inquiry and to charge him with notice that the sewer traversed that portion of the premises purchased by him.

Is the easement continuous? The sewer had been in existence for $? 20$ years, was of a permanent nature, was in use at the time, and was susceptible of being used and enjoyed without making an entry on defendant's premises, except for the purpose of repair. These facts would clearly bring it within the definition of a "continuous easement." Larsen v. Peterson, supra.

Is the easement strictly necessary to the enjoyment of complainant's premises? The sewer in Farmer's alley is the only one available for her use. The city engineer testified that one might be constructed to De Visser alley, but that it would be impracticable for the reason that, where it would discharge into that sewer, it would be only 18 inches underground. The topography of that part of the city is such that no other sewer can be constructed which will serve these premises without a prohibitive expense. A cesspool was suggested by complainant; but the city authorities would not permit it. She then made an effort to buy the right of her neighbor on the north to go through the partition wall and connect with his sewer, which also discharges into the Farmer's alley sewer; but to this her neighbor would not consent. We have then a situation where complainant must be permitted to use the sewer which has served her premises for 20 years, if her building is to have any sewer service. If this situation, which nature has so fashioned that the sewage can be directed only in the direction of Farmer's alley, does not bring it within the rule of strict necessity, it would, indeed, be difficult to suggest one. If greater exigency than here exists is. required before the strict necessity rule can apply, there would be little use for the existence of the rule, as its use would be so infrequent as to render it useless.

In my opinion, the trial court found his way to a very equitable adjustment of the entire matter, and I think his decree should be affirmed.

MOORE, J., concurred with BIRD, J. 


\section{BUSS v. DYER.}

(Supreme Judicial Court of Massachusetts, 1878. 125 Mass. 2S7.)

Tort for tearing down, refusing to rebuild and preventing the plaintiff from rebuilding, a climney, in which the plaintiff claimed an easement. Writ dated March 16, 1875. Trial in the Superior Court, before Pitman, J., who allowed a bill of exceptions in substance as follows:

The plaintiff introduced evidence tending to prove that previously to July 12, 1844, John E. Thayer and Nathaniel Thayer built a block of five wooden houses on land owned by them on Meridian Street, East Boston; that these houses were then or afterwards numbered from 61 to 69 on said street, inclusive; that the chimney in question, at the time the block was built, was placed between the houses numbered 63 and 65 , but wholly upon the premises of No. 65 , for the use of both houses, and was constructed with connections or stove-holes for each house; that on July 12,184t, the Thayers conveyed by simultaneous deeds (which contained covenants against all incumbrances made or suffered by them) the premises No. 63 to Oliver Lewis, and the premises No. 65 to Martin Lewis, both deeds describing the premises by metes and bounds; that by mesne conveyances the plaintiff became, on $11 \mathrm{arch} 5$, 1873 , the owner of the premises No. 63 ; that on November 14, 1874, the chimney in question was torn down by the defendant, (to whom the house No. 65 was conveyed on October 7,1874 , by the heirs of Martin Lewis,) and was never rebuilt; and that the defendant prevented the plaintiff from rebuilding, and refused to allow him to rebuild it. In none of the deeds or mesne conveyances above referred to was any specific mention made of any right to use the chimney in question, though in each the premises were conveved with "all rights, easements, privileges and appurtenances to the said land belonging." The plaintiff claimed no right to use the chimney by prescription.

For the purpose of showing that a right to use the chimney passed by the deed from the Thayers to Oliver Lewis, by implication, as an appurtenance to the house on the premises so conveyed, the plaintiff introduced evidence tending to show that, at the time Oliver Lewis became the owner of the premises No. 63, a suitable chimney, which would be a substitute for the chimney in question, could not be built wholly upon his premises at a reasonable cost and expense; but this was contradicted by the defendant. As bearing upon this question, evidence was introduced by both parties to show what would be the cost and expense of building such a chimney at the time of the trial and at the time when the chimney was torn down.

For the purpose of showing that the right to use the chimney in question had not been lost or extinguished, the plaintiff introduced evidence to prove that the chimney and the houses of himself and the defendant were in good condition up to the time when the chimney was 
torn down; that they had not been destroyed by the elements or mere lapse of time; and that they were not in such a condition that they needed to be rebuilt from the bottom; and the defendant introduced evidence to prove the contrary, and that the plaintiff could have built a suitable chimney upon his own estate as a substitute for the one torn down at a very small cost, especially soon after the chimney had been torn down.

The plaintiff asked the judge to rule as follows: "If the plaintiff acquired a right to use the chimney in question under the deed from the Thayers to Oliver Lewis, such right so acquired was not lost or terminated until both the chimney and the houses of the plaintiff and defendant were destroyed by the elements or mere lapse of time, or were in such a condition that they had to be rebuilt from the botton."

The judge refused so to rule; but instructed the jury that if such a right was acquired by the plaintiff through the deed from the Thayers to Oiiver Lewis, yet if the chimney at the time it was torn down was unsafe and needed to be rebuilt from the bottom, the defendant had a right to tear it down, and the plaintiff could not recover. No instructions were given as to whether or not the condition of the houses of the plaintiff and defendant, or either of them, had anything to do with the duration of the alleged easement, or right to use the chimney in question, and the instructions given were objected to only on the ground of that onission. The jury were fully instructed on the other questions of law in the case; and, among other things, were instructed that no servitude, as claimed, could be created by implication of law unless there was a reasonable necessity therefor; and that if the plaintiff, with reasonable labor and expense, could have built a suitable chimney on his own estate, he could not claim a right to use that upon the defendant's premises.

The jury were further instructed to answer the following questions, and that if the second question was answered in the affirmative they need not answer the third question, but should return a verdict for the defendant: "1. Did the houses now occupied by the parties respectively exist upon the estates at the time of the deeds from the Messrs. Thayer? 2. Could the plaintiff at a reasonable cost have built a suitable chimney upon his own estate, as a substitute for the one he claimed to use on the estate of the defendant? 3 . Was the chimney in question so defective and unsafe as to require the defendant to take it down?" The jury answered the first and second questions in the affirmative; and returned a verdict for the defendant. The plaintiff alleged exceptions.

Soule, J. The deed of the Thayers, under which the plaintiff claims, was made and delivered when they were owners of the premises of the defendant. It makes no mention of any rights in the chimney on the adjoining premises. Their deed of the defendant's premises, given at the same time, contains covenants against incumbrances made or suffered by the grantors, and of warranty against all persons clain- 
ing under them. Each deed describes the lot of land conveyed by metes and bounds, without mentioning any buildings. The grantors having built the houses and the chimney, and being owners of both parcels, these covenants are as strong an expression of intention to convey the defendant's premises free of the easement claimed by the plaintiff as covenants of general warranty would have been. The words, "and all rights, easements, privileges and appurtenances to the said land belonging," in the deed of the plaintiff's premises, are of no effect to carry the easement in question, because no easement existed, while the fee of ototh parcels was held by the same owners. Ammidown v. Granite Bank, 8 Allen, 285. Moreover, the title conveyed by that deed is not older than the title conveyed by the deed of the defendant's premises, which covenants against any incumbrance created by the grantors. If therefore, an eascment to use the chimney was created in favor of the premises, of the plaintiff, it was created by implication, as being absolutely necessary to the enjoyment of the estate.

We are aware that it has been held in some English cases, that a deed of premises carries the right to continue to enjoy, as easements, all privileges or conveniences in and upon adjoining lands of the grantor, which were apparent, and had been used by the grantor in connection with the premises before the conveyance; that the conveyance is a conveyance of the premiscs "as they are." A leading case to this effect is Pyer v. Carter, 1 H. \& N. 916. Similar doctrine has been held in New York. Lampman v. Milks, 21 N. Y. 505. We do not regard this as a correct view of the law.

It is a well established and familiar rule that deeds are to be construed as meaning what the language employed in them imports, and that extrinsic evidence may not be adduced to contradict or affect them. And it would seem that nothing could be clearer in its meaning than a deed of a lot of land, described by metes and bounds, with covenants of warranty against incumbrances. The great exception to the application of this rule to the construction of deeds is in the case of vajs of necessity, where, by a fiction of law, there is an implied reservation or grant to neet a special emergency, on grounds of public policy, as it has been said, in order that no land should be left inaccessible for purposes of cultivation. This fiction has been extended to cases of easements of a different character, where the fact has been established that the easement was necessary to the enjoyment of the estate in favor of which it was claimed. (

In this Commonwealth, grants by implication are limited to cases of strict necessity. Carbrey v. Willis, 7 Allen, 364, 83 Am. Dec. 685, and cases cited; Randall v. McLatughlin, 10 Allen, 366. The case of Pyer v. Carter was denied by Lord Chancellor Westbury in Suffield v. Brown, 4 De G., J. \& S. 185, which has been since recognized as containing the correct doctrine. Crossley v. Lightowler, L. R. 2 Ch. 478; Watts v. Kelson, L. R. 6 Ch. 166.

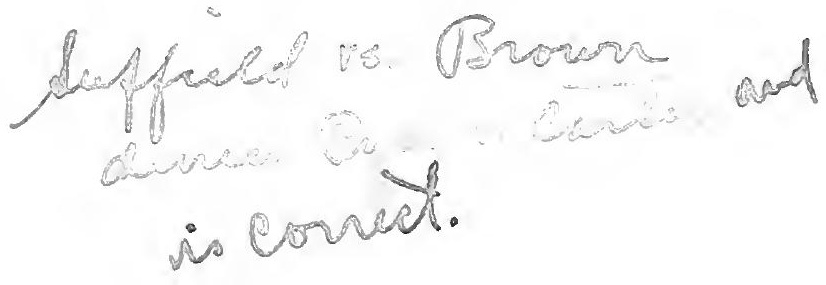


The case seems to have been tried in the Superior Court on the assumption by both parties that the obstacles, if any, to the erection of a chimney on the plaintiff's premises, were the same when the Thayers conveyed as when the chimney in question was taken down, and the question to the jury, and the instructions, appear to have been framed in accordance with that assumption, and without any objection or stggestion to the contrary by the plaintiff. We cannot, therefore, consider the objection now made, for the first time, that the question of necessity was to be determined by the state of things existing when the conveyance was made by the Thayers.

In this view of the case, it appears that the jury found that the unse of the chimney was not necessary to the enjoyment of the premises owned by the plaintiff. This being so, no easement in the chimney was reserved by implication in the deed to the defendant srantor, and the defendant, in destroying the chimney, merely exercised a right of ownership.

It is unnecessary, therefore, to consider the question raised by the refusal to give the instruction asked for by the plaintiff. On the facts found by the jury, no easement in favor of the premises of the plaintiff having been created, the ruling as to how such easement could be determined, if it existed, became immaterial.

Exceptions overruled. ${ }^{14}$

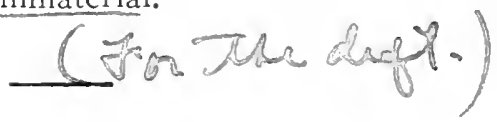

TOOTHE v. BRYCE.

(Court of Chancery of New Jersẹ, 1§02. 50 N. J. Eq. 5\$9, 25 Atl. 182.)

On order to show cause why an injunction should not issue.

Heard upon bill and answer and accompanying afficlavits.

The complainant, by his bill, seeks to establish and protect his right to the benefit of a flow of water to his premises from the defendant's premises, throtigh two several pipes laid underground and forced up by two hydraulic rams, situate, with the spring that drives them on the defendant s premises.

The facts as they appear in the pleadings and affidavits, or are admitted by the parties, for the purposes of this motion only, are as follows: Before and on the 13th of April, 1892, the defendant was the owner of a tract containing about forty-five acres, which comprised both tenements, situate in Madison, Morris county, New Jersey, and on that day entered into a written contract with the complainant, by

14 Stillwell v. Foster, s0 Mle, 333, 1t Atl. 731 (15s5), acc. In Bussmeyer v. Jablonsk $y, 2+1$ IIo. 681,145 S. W. 772,39 L. R. A. (N. S.) 549 , Ann. Cas. $1913 \mathrm{C}$, 1104 (1912), the court held that an eisement there claimed has not been created by implied grant, no showing that there was any "reasonalle" necessity therefor having been nate, though the eridence protabty estatlislied that the riglt chimed was a conrenience. So, also, in Sandford r. Boss, 76 ×. H. 476, S4 Atl. 936,42 L. R. A. (N. S.) 620 (1012). 
which the defendant, in consideration of $\$ 13,000$, agreed to sell and convey to complainant, and complainant agreed to purchase and pay that price for the tract in question, consisting of forty-five acres and twenty-three one-hundredths of an acre, excepting thereout a house and barn and lot whereon they stood, containing one acre, the deed of conveyance to be delivered and the purchase-money paid on the 13th day of May, at eleven o clock in the morning, at a specified place in New York City.

At the date of the contract there were upon the whole tract two dwellings, two barns, and a green or hot-house, a spring of waier and tivo hydraulic rams driven by its waters, with a pipe leading from each, one to the green-house and one to one of the barns. One divelling and one barn and the green-house were on the part contracted to be conveyed; the other dwelling and barn, the spring and rams were on the lot of one acre reserved. Included in the sale were a lot of hot-house plants in the hot-house.

At and before the date of the contract the water was flowing continnously at both the barn and green-house, in the latter of which were the hot-house plants. The water was discharged at the barn into an open trough from which the cattle and horses drank, and at the greenhouse into a tank from which it was used in watering the plants. This flow was observed by the complainant, and he knew it was due to the action of a ram (he supposed there was but one) on the lot reserved, and such flow formed, in complainant's mind, a feature of value in the premises. The pipes and flow of water to the barn ind existed for several years, but that to the green-house had been in use for less than two years. The ram which supplied it had been in place and use for many years, and carried the water in a pipe along the road in front of the premises in question to a property adjoining it on the other side, which property was sold by the defendant in 1890 to another party, and the flow of water to it was cut off and the pipe turned from the road up to this green-house, and was in use there from that time on.

The corporate authorities of Madison have recently erected waterworks for the use of the town and its inhabitants, but no main has as yet been laid in the street in front of these premises.

The negotiations for the purchase and sale were carried on between the complainant in person and an agent of the defendant, and nothing was said by either in their course about the flow of water. Such flow continued up to the date of the delivery of the deed. Before ten o'clock on the morning of that day defendant directed his employee in charge of the premises to stop the operation of the rams, and then proceeded by train to New York to deliver the deed, which was done about eleven o'clock. The man in charge stopped the ram supplying the barn at once, but left the one supplying the green-house running until three o'clock in the afternoon. So that in point of fact the water was probably not running to the barn at the moment the deed was delivered, but was running to the green-house. No notice was given 
to the complainant at the delivery of the deed that the flow of the water had been stopped, nor was any mention made of it by either party. The deed contained the usual verbiage as to appurtenances, ineluding "ways, waters, privileges," \&c.

The springs driving the rams are about fifteen feet lower than the barn and green-house, so that the water would not run naturally to either. The difference in height between the spring and the rams does not appear.

'The parties agreed that the court should act upon its personal knowledge of the peculiarities of hydraulic rams, which, so far as necessary for present purposes, are as follows: By the use of this machine the power due to the fall from a given height of a given quantity of water is utilized to lift a comparatively small fraction thereof to a height greater than the source or head. The effect of the machine is precisely the same as would be that of a water wheel driving an ordinary pump. The advantage of the use of the ram is its extreme simplicity and durability. It works automatically and in theory should run without stopping or touch by the hand of man until its parts were actually worn out. It is, however, liable to stop and requires the hand of man to start it again. 'This liability is due to several causes, none of which are of any importance, and all can be guarded against by proper care in setting it and in preventing substances other than water from passing through it, except one, viz., a necessary part of the machine is a chamber of confined air which acts as a cushion. This air comes in contact with and is liable to be absorbed by the water and exhausted, and when the air-chamber becomes filled with water the ram works defectively and is liable to stop. The tendency of the air to be exhausted varies with the character of the water and the height or head to which it is lifted. If the water is lifted to a great height there is a corresponding pressure of the water upon the air and the absorption of the air by the water is increased thereby, but with a small height to lift against, like fifteen, twenty or thirty feet, rams may run for weeks and months without stopping. The process of recharging the airchamber with air is very simple and may be done by any person in a few minutes. An hydraulic ram, properly set, may run for one or more years without any repair, and the operation of repair or renewal is very simple.

Pitney, V. C. The complainant rests his right to the continued flow of the water upon the fact that such flow was apparent and continuous at the time of the purchase, and constituted a valuable adjunct to the premises, rendering their use more beneficial and valuable.

Against the case thus made defendant makes three points--first, that the use of the water in the way described was not necessary to the enjoyment of the premises; second, that it was not in actual use at the moment when the title passed; third, that it was not in its nature continuous, since the water did not run by gravity, but by machinery, which required the intervention of the hand of man, upon the land of the grantor, the defendant. 
I. As to the element of necessity. I think some inaccuracy of thought and expression has arisen in the discussion by bench and bar of this doctrine of the creation of an easement by implication upon the severance of a tenement, as to the importance of the element of necessity, by failing to distinguish between that class of cases where it has been held or claimed that an easement is reserved by implication in favor of that portion of the tenement which is retained by the grantor in and upon that portion conveyed, and that other class of cases where it has been held that an easement was granted in favor of the part conveyed in and upon the part reserved. In the former class of cases the grantor is usually claiming an easement in direct derogation of his own grant, while in the latter it is well held to be in accordance with, and to flow naturally by implication from, his grant.

In fact it has been suggested that the grant in such cases is not by implication, but that the quasi-easement passes with the quasi-dominant tenement as, in substance, a part of the thing conveyed, and without any regard to the element of necessity. On the other hand, in the case of a reservation, it has been held that there can be no implied reservation of an easement in the land granted when the grantor has conveyed, as he generally does, all his right, title and interest therein, except such an easement as is absolutely necessary to any enjoyment of it whatever, as in the case of a way of necessity. Gale \& W. Easem. *72; Godd. Easem. (Am. Ed.) 266, 267 ; Nichols v. Luce, 24 Pick. (Ma'ss.) 102, 35 Am. Dec. 302; Oliver v. Pitman, 98 Mass. 46; Washb. Easem. *163, *164, and cases.

To permit the grantor to claim such reservation is to permit him to derogate from his own grant. So rigid was this rule held that in the older cases the reservation of a right of way to and from the close retained by the grantor out of the conveyance of the land surrounding it was put on the ground of the interest that the public had that the close so surrounded should not be unised and unproductive. 'The conveyances in conmon use in this country contain an express convevance of all the right, title and interest of the grantor in and to the premises conveyed, and it is difficult to perceive on what ground short of absolute necessity any easement could be reserved.

This distinction between a grant and a reservation by implication seems to be founded in logic and, as will appear further on, is now thoroughly established in the English tribunals, and it seems to me to furnish the true test as to the value and importance of the element of necessity in the establishment of easements upon the division of tenements.

My examination of the authorities has led me to the conclusion that where the right to the easement is based upon the ground that it passes, as in substance, a valuable adjunct to the land conveyed, the element of necessity is not a requisite, and to use the word "necessary" in connection with it is to misuse it. In saying this, I may say that I am, in appearance at least, going contrary to what has 
been said and decided in many cases; but I think that an examiination of them will show that in most, if not all, of those instances where the case was that of an implied grant of an easement in connection with the conveyance of a quasi-dominant tenement, the so-calle i "necessity" upon which the judges relied was, in fact, no necessity at all, but a mere beneficial and valuable convenience, and that this elevation of a mere convenience to the level of a necessity was the result of an attempt to obliterate the distinction between an implied grant and an implied reservation, before referred to, and to place implied reservations and implied grants upon the same footing, and to hold that upon the severance of a tenement one part of which had been subjected to a quasi-servitude, which was continuous and apparent, in favor of the other, the easement would be preserved, whether it be by grant, when the dominant tenement is conveyed, or by reservation, when the servient tenement is conveyed; and as the latter could only occur where the element of necessity was present, it was held that such element must also be present in the former case. ${ }^{15} * * *$

These cases in our own state have probably established the doctrine here-certainly in this court-that in these cases of apparent and continuous easements, upon the severance of the tenement, a reservation of a quasi-easement will take place on the conveyance of the servient part wherever it would pass by way of grant on the conveyance of the dominant part, and that in each case the element of necessity is a requisite. But for myself, I desire to repeat, by way of protest, that my examination of the authorities has led me to the conclusion that this doctrine of mutuality is not founded on solid ground and is mischievous in its tendencies, and also that it is a misapplication of the word "necessary" or "necessity" to apply it to such a case, and leads to uncertainty and confusion in attempting to define different degrees of the element, when, in fact, strictly speaking, it is not capable of being graded.

It seems to me that the proper inquiry in such cases is whether the apparent and continuous easement in question forms a part of the tenement and is beneficial to and adds to its value for use, and will continue to do so in the future. If it is, then the grantee is, upon plain principles, entitled to have it continued. He is entitled to enjoy the thing as it was when he bought it, with all its apparent appurtenances, if those apparent appurtenances are apparently permanent, and are useful and add to its value.

In the case in hand, I think there can be no doubt that the flow of the water at the barn or stable and at the green-house are valuable additions to the property, increase its beneficial use, and also that it is necessary in the sense in which that word has been used in that connection, and is defined by Vice-Chancellor Van Fleet in Kelly

15 A portion of the opinion, in which the court reviews many English and American cases, is omitted. 
v. Dunning, 43 N. J. Eq. 62, 10 Atl. 276; and I adopt the language of Lord-Justice Mellish in Watts v. Kelson, L. R. 6 Ch. App. 166, above quoted, as applicable to this case.

It would be no answer to say, if it were true, that the complainant may procure water to supply these places from the public waterworks at a comparatively trifling expense. That expense, though trifling, is continuous, and it was the relief from its burden which formed the element of value in the water which was actually flowing.

II. The second objection made presents little difficulty. Complainant is clearly entitled to have the premises in the condition which they were at the time he made the contract-April 13th, 1892. His right to them vested at that date. As the contract was positive and binding on both parties-defendant being bound to convey and the complainant to purchase and pay the price-the familiar rule in equity is that from that time on, the premises in question belonged to the complainant, subject to the lien of the purchase price, and that the purchase price belonged to the defendant. It would be monstrous, indeed, to hold that the defendant might, at the very moment that the deed was being delivered in. New Xork, by his agent in Madison destroy an apparent and continuous easement and deprive the complainant of the benefit of it.

Nor can the defendant, as the case now stands, deny the right of his agent to sign the contract for him as his agent. The execution of the deed in pursiance of it was in ratification and adoption of the previous contract, with all its burdens as well as its benefit.

III. The third question presents more difficulty. IVas the easement in its nature continuous, considering the fact that the water did not run by gravity, in the ordinary sense of the term, but was forced up by a machine driven by the power of the fall of a greater quantity, and that it would be necessary for the complainant to enter on the servient tenement from time to time to readjust, repair and renew this machine?

All cases of this character deal with artificial structures, situate in whole or in part on the servient tenement, which are liable to fall into disorder and decay, and all the adjudged cases hold that the owner of the dominant tenement may enter upon the servient tenement for the purpose of repairing and renewing those artificial structures. It was so declared in Nicholas v. Chamberlain, and Mr. Gale quite properly calls this right of reparation and maintenance a "secondary easement” (Gale \& W. Easem. *323; Washb. Easem. *24, *25), which is appurtenant to the primary or actual easement.

If, in the case in hand, the water ran by gravity in an artificial shannel, complainant would have the right to enter from time to time upon defendant's land, and repair and renew such part of it as was there situate. So if the water-supposing it to be practicable -were raised by a dam instead of a ram to the height necessary to 
make it flow to the barn and green-house, the right of reparation and renewal of this dam would be included, and, in such a case as this, the head or power would be employed to carry it.

These secondary easements, however, are not the easement which passes with the conveyance by implied grant because apparent and continuous. They are, as before remarked, merely incidents thereto, and, because of their non-continuous and desultory character, the principal easement is none the less continuous.

In this connection, what is said by Mr. Gale in his treatise is not without import $(* 50)$ :

"An easement is a quality superadded to the usual rights, and, as it were, passing the ordinary bounds of property; and, with the exception of those easements the enjoyment of which depends upon an actual interference of man at each time of enjoyment, as of a right of way, it is attended with a permanent alteration of the two heritages affected by it, showing that one is benefited and the other burdened by the easement in question."

His idea of a non-continuous easement is one whose enjoyment depends upon an actual interference of man at each time of enjoyment as in Polden v. Bastard, supra [4 Best. \& S. 257, L. R. (1 Q. B.) 156]. And it seems to me that that is the correct test, and that the mere fast that a machine is used which is substantially self-acting, and does not require the constant attention of man, does not make it non-continuous, any more than the propulsion of the water by a dam through an artificial channel would have that effect. It is said that the owner of the servient tenement will be subjected to the servitude of a more frequent entrance upon his land for the purpose of adjusting and repairing the ram than he would in case of an artificial ditch or pipe or dam. But I think the difference is one of degree and not of character, and it is hardly necessary to say that a mere difference of degree will not alter the case.

I will advise that an injunction issue.

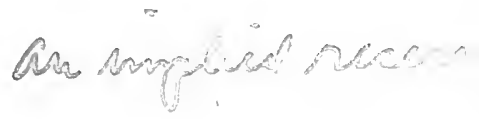

\section{LIQUID CARBONIC CO. v. WALLACE.}

(Supreme Court of Pennsylvania, 1908. 219 Pa. 457, 6S Atl. 1021, 26 L R. A. [N. S.] 327.)

Bill in equity for an injunction. Before Shafer, $J$.

The facts are stated in the opinion of the Supreme Court.

Error assigned was decree awarding an injunction.

Mitchisl, C. J. The legal principle governing this case is thus expressed in Grace M. E. Church v. Dobbins, 153 Pa. 294, 25 At1. 1120, 34 Am. St. Rep. 706: "Where an owner of land subjects part of it to an open, visible, permanent and continuous servitude or easement in favor of another part, and then aliens either, the purchaser takes 
subject to the burden or the benefit, as the case may be." See, also, Manbeck v. Jones, 190 Pa. 171, 42 Atl. 536.

The facts are not in material dispute. In 1890 Wallace, one of appellants, became the owner of a large lot of ground in the twentieth ward of the city of Pittsburg. It was bounded by three streets and the Pennsylvania Railroad, but being hilly and uneven, access to parts of it was difficult or very inconvenient. Wallace began to grade it, and in the course of so doing roads were worn here and there over the property by the hauling incident to grading, the principal road so worn or constructed being in substantially the same position as that over which the plaintiff now claims a right of way. In 1891, Wallace conveyed to the plaintiff a portion of said tract, bounded by the Pennsylvania Railroad, two streets and other lands of Wallace afterwards conveyed to the Duquesne Reduction Company. At the time of sale by Wallace to plaintiff the said road was used upon the ground and appellants admit that stone quarried upon other land of Wallace and sold to the plaintiff was hauled down over it. Appellee used it in the erection of its buildings and claims that it was in general use by the owners of the adjacent properties for access, and it appeared that it had continued in such use until 1906, when appellants built a fence across it and plaintiff filed this bill.

The court found that it was the only wagon road on the lot, and that access from the streets by which the appellee's lot was bounded was impracticable for loaded wagons at most points, and very inconvenient for any other purpose.

The learned court below refused to find the road a way of necessity, because there were other ways of access and egress however inconvenient, citing McDonald v. Lindall, 3 Rawle, 492.

The court, however, found that "the road was apparent on the ground and there was nothing on the ground to indicate that it was not intended to be permanent." "He therefore found that the right to the use of the road passed by implication as an easement, appurtenant to the grant.

The argument of the appellant rests mainly on the view that the road having had its origin in temporary convenience to the owner of the larger lot was never intended to be permanent; and that the intention was an essential element in the creation of a servitude. The principle in general may be conceded, and so long as the ownership of the dominant and servient lands remains in the same party the application of the principle may be determined by his actual personal intent. But on a severance a question of conflicting rights arises and the intent which lies at the basis of the creation of a servitude is no longer the grantor's actual and perhaps undisclosed intent, but the mutual intent of the parties as gathered from their acts and the circumstances, as well as from their words. This principle was well expressed in Hopewell Mills v. Savings Bank, 150 Mass. 519, 23 N. E. 327, 6 L. R. A. 249, 15 Am. St. Rep. 235 (cited though in a different connectioin 
in Bank v. North, $160 \mathrm{~Pa} .303,28$ Atl. 694). "The intention to be sought is not the undisclosed purpose of the actor, but the intention implied and manifested by his act. It is an intention which settles, not merely his own rights, but the rights of others who have or may acquire interests in the property. They cannot know his secret purpose, and their rights depend, not upon that, but upon the inferences to be drawn from what is external and visible."

The facts as found by the court in the present case were that Wallace was at the time of the sale "the owner of the land over which the way is claimed and of the land to which it is now claimed to be appurtenant. Before the grant, Wallace had laid out and opened upon the ground the road in question, and it was the only road by which it was practicable to have access to the land. The road was apparent on the ground, and there was nothing upon the ground to indicate that it was not intended to be permanent." The natural inference from these facts would be that the road was intended to be permanent. That inference the grantee was entitled to draw without regard to the grantor's actualbut undisclosed intent, and it therefore became the law of the case.

Decree affirmed at the costs of appellant. ${ }^{18}$

\section{ADAMS v. GORDON.}

(Supreme Court of Illinois, 1914. 265 Ill. 87, 106 N. E. 517.)

Appellant filed her bill in chancery in the circuit court of Lake county, Illinois, against appellee, for an injunction to restrain him from interfering with her in the exercise of her rights which she claimed in

16 In Martin v. Murphy, 221 Ill. 632, 77 N. E. 1126 (1906), and German Sasing \& Loin Co. v. Gordon, 54 Or. 147, 102 Pac. 736, 26 L. R. A. (N. S.) 331 (1909), quasi easements of passage evidencel by board walks and in part bo fences, were held to be turned into real easements by inplication upon sever-

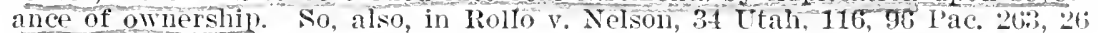
L. R.A. (N. S.) RIJ (1908), where the quasi easement was evidenced by a cement walk. See Polden v. Fastard, and note thereto, supra.

In Baker v. Rice, 56 Ohio St. 463, 47 N. L. 653 (1897), the court had to determine whether an easement of a way had been created by implication, the deeds severing the common ownership having been delivered simultaneously. The way was "plainly obvious and apparent." The court held the easement: was created by implication. Minshall, J., said: "But it is claimed, that only such easements as are termed 'continuous' will pass by implication in a grant, and thit such as are termed 'discontinuons' will not. This is a distinction of the civil law, and has been incorporated in the law of some of the states, particularly Maine and Massachusetts. The former are such as operate without the intervention of man. such as drains and sewers; the latter require the interrention of man in their use, such as wars. The distinction is somewhat arbitrars and is not uniformly adopted, as will appear from the cases cited. The better rule and the one now more generally adopted, is not to consider the particular Find of easement, but whether it is aplarent, flesigned to be permanent, and is reasonably necessary to the use of tire lremises sranted."

Mol'gan v. Menth, 60 Mich. 238,27 N. W. 509 (18S6), contra. Arg.Prop.-34 
the nature of an easement in certain water facilities and a way thereto, situated on the lands of appellee. A demurrer was sustained to the bill, and appellant electing to abide by her bill, a decree was entered dismissing the bill for want of equity. She prayed and perfected an appeal to the Appellate Court for the Second District, which has transferred the cause to this court pursuant to the statute, for the reason that a freehold is involved.

It appears from the allegations of the bill that prior to November 29, 1911, appellee was the owner of a tract of about one hundred or more acres of land situated on what is known as Deerpath avenue, in the vicinity of Lake Forest, Illinois. November 29, 1911, he entered into a contract with John F. Tracy for the sale of a portion of this land, in which he contracted, among other things, that the purchaser should have the right to the use of the well located on his adjacent property, together with the pump, gasoline engine and tank situated thereon, until such time as public water mains should be installed in Deerpath avenue, with the right to use a path; not exceeding eight feet in width, from a gate on the west line of the property leading in a direct line to the well, the purchaser to maintain the well, pump, engine and tank at his own expense and furnish water for the use of appellee without charge or expense to him, and should said Tracy fail to so maintain and furnish water, his right to the use of the well and pump might be terminated by the vendor and all obligations under the contract canceled. On the same day the contract was made appellee conveyed the land described in the contract to said Tracy by warranty deed, in which no reference whatever is made to the provision in the contract in relation to the use of water facilities as above set forth. At the time the contract was made between appellee and Tracy appellant was a tenant on the property under a lease expiring on Noveunber 30, 1911. January 4, 1912, Tracy conveyed the land purchased by him to appellant by warranty deed in all respects the same as the deed he had received from appellee, the deed making no mention whatever of the easement contained in the contract between appellee and Tracy.

Appellant alleges the omission of this matter was due to the mistake of the scrivener in drafting the deed, but she does not ask that the deed be reformed. For some years the water facilities located on appellee's land have been used by him and his tenants, including appellant, for the purpose of supplying the premises now owned by her with water for domestic purposes and to supply water for the stables, lawns and gardens thereon, said water facilities being absolutely necessary and essential to the full enjoyment of her premises. Appellant charges that one of the important factors inducing her to purchase the premises was the fact that she should have the right to the free and unobstructed use of the water facilities mentioned in the contract between said Tracy and appellee. The pump, pump house, tank and engine are located on appellee's premises about one hundred feet from the west line of appellant's property, and the water is conveyed from there to her premises 
and buildings by means of an underground pipe leading from the tank on appellee's property to the house, stable, lawn and garden on appellant's premises. The pipe is visible on appellee's land between the point where it leaves the tank and enters the ground, and also visible on appellant's premises where it emerges from the ground and connects with the faucets, plugs, flush-boxes and hydrants on her land A view of the premises at the time of the purchase by Tracy and of her purchase from Tracy would have disclosed that the fancets, plugs, Hushboxes and hydrant on her property were connected with the tank on appellee's land, and that the pump, pump house, engine and tank situated thereon were used as the means of supplying these premises with water, and that the water facilities thus proviled were highly beneficial to her property. No public water mains have been installed or constructed in Deerpath avenue leading to this property, and it is indispensable to its use and enjoyment by appellant that she have the advantage of water facilities provided for it, situated on appellee's land.

After appellant became a purchaser appellee permitted her to contimue to use the water facilities for some time withont protest and from time to time to make the necessary repairs thereon. Shorty before filing the bill he demanded of her the payment of $\$ 50$ which he claimed was due on a former tenancy by her, and when she refused to pay, on the ground that it was without any foundation, appellee refused to allow her servants to make repairs, on the engine used for puniping water into the tank, locked the door to the pump house, slut the water off, forbade appellant or her servants to use the well or the pathway thereto and blockaded the same by installing posts and wires across the pathway, and threatened violence to appellant and her servants if they attempted to obtain water from the well or to use the pathway leading thereto. The bill prayed for an injunction enjoining the appellee from interfering with appellant's rights in the premises and in the use of the water, pump house, engine and tank and other water facilities as above set forth, and for general relief. A general demurrer was sustained to the bill, setting forth the above facts. Appellant elected to abide by her bill and a decree was entered dismissing the bill for want of equity. 'This appeal followed.

The errors assigned are, (1) that the court erred in sustaining the demurrer to the bill; and (2) that the court erred in dismissing appellant's bill for want of equity.

CrAIG, J. ${ }^{17}$ Appellant by her bill asserts and seeks to establish and maintain a right in the nature of a perpetual easement in the adjoining lands of the appellee in the use and maintenance of certain water $\mathrm{fa}$ cilities located thereon, by means of which her house, barn, garden and premises are supplied with water. This right, if it exists, is an easement appurtenant to an estate in fee, and a bill filed for the purpose of establishing such an easement involves a freeliold, and the case

17 A portion of the opinion is omitted. 
was therefore properly transferred to this court. Tinker v. Forbes, 136 Ill. 221, 26 N. E. 503 ; Foote v. Marggraf, 233 Ill. 48, 84 N. E. 42 ; Foote v. Yarlott, 238 Ill. 54, 87 N. E. 62; Espenscheid v. Bauer, 235 I11. 172,85 N. E. 230.

Appellant insists that she is entitled to the benefits of the contract of November 29, 1911, between Tracy and appellee, and also that the water facilities on appellee's land constitute an open and visible easement appurtenant to her premises, which passed by the deed of conveyance of the land from appellee to Tracy and from Tracy to her. Appellee insists that no rights passed to appellant under the contract with Tracy, for the reasons it was never executed by Tracy, that it was a personal contract, and that it became merged into and extinguished by the deed subsequently made conveying the land to Tracy. The appellee further insists that in order for an easement to pass as appurtenant to land, it must be open, visible and continuous and such as does not require the interference by man. We do not deem it necessary to pass upon each one of these contentions separately, but the substance of each and all of these contentions will be given full consideration.

The object in construing and interpreting an instrument is to ascertain and make it speak the true intention and meaning of the parties at the time it was made, and where any doubt exists as to its sense and meaning, resort may be had to the circumstances surrounding its execution, for the purpose of ascertaining the subject matter and the standpoint of the parties in relation thereto. Without this knowledge it would be impossible to fully understand the meaning of an instrument or the effect to be given to the words of which it is composed. Goodwillie Co. v. Commonwealth Electric Co., 241 Ill. 42, 89 N. E. 272. This knowledge is almost as indispensable as that of the language in which the instrument is written, and a reference to the actual condition of things at the time as they appeared to the parties themselves will often afford the court great help in construing such language and arriving at the true intent and meaning of the agreement they have made. By referring to the situation of the parties and a condition of the premises at the time appellant became a purchaser of the same, we find she had been a tenant thercof for some years, the length of time not being stated in the bill, and during all of that time had used and enjoyed all of the privileges which she now claims as an easement appurtenant to her premises. In purchasing the property she had a right to assume and expect she was buying it in its then condition and would have the right to use and enjoy all of those necessary conveniences which had been placed thereon by the owner and were used in connection therewith and were recognized by the owner as being appurtenant to the premises and passing with a lease under which she had enjoyed the same as a tenant.

The rule is, where the owner of lands divides his property into two parts and disposes of one part, he by implication includes in his grant 
all such easements in the remaining part as were necessary for the reasonable enjoyment of the part which he grants in the form in which it was at the time he transferred the property, the general rule of law being, that when a party grants a thing, he by implication grants whatever is incident to it and necessary to its beneficial enjoyment. Newell v. Sass, 142 Ill. 104, 31 N. E. 176; Keegan v. Kinnare, 123 Ill. 280, $1+$ N. E. 14; Foote v. Yarlott, supra; Feitler v. Dobbins, 263 I1l. 78, 104 N. E. 1088; Martin v. Murphy, 221 Ill. 632, 77 N. E. 1126; Hankins v. Hendricks, 247 Ill. 517, 93 N. E. 428; Powers v. Heffernan, 233 I11. 597, 84 N. E. 661, 16 L. R. A. (N. S.) 523, 122 Am. St. Rep. 199. And it is not necessary that the easement claimed by the grantee be absolutely necessary to the use and enjoyment of the property; "it is sufficient if it is highly convenient and beneficial therefor." (Newell v. Sass, supra; Powers v. Heffernan, supra.) Where an owner sells a portion of his land he is presumed to intend that the purchaser shall take it in its then condition. (14 Cyc. 1166.) This intention is to be sought, not in the undisclosed purpose of the vendor, but in what is manifest and implied from his acts. Liquid Carbolic Co. v. Wallace, $219 \mathrm{~Pa}$. 457, 68 Atl. 1021, 26 L. R. A. (N. S.) 327 ; Hopewell Mills v. Saving 3 Bank, 150 Mass. 519, 23 N. E. 327, 6 L. R. A. 249, 15 Am. St. Rep. 235. In Feitler v. Dobbins, supra, the rule is stated as follows: "The law applicable to the situation here is, that where the owner of entire premises arranges for ways, light, etc., for the benefit of the different parts or portions of the premises, and afterwards the premises are severed and the title vested in separate owners, each grant will carry with it, without being specifically mentioned, the rights and burdens and advantages imposed by the owner prior to such severance. The doctrine is founded upon the principle that the conveyance of a thing imports a grant of it as it actually exists at the time the conveyance is made, unless a contrary intention is manifested in the grant. This doctrine has often been applied by this court. Morrison v. King, 62 Ill. 30; Clarke v. Gaffeney, 116 I11. 362 [6 N. E. 689] ; Newell v. Sass, 142 111. 104 [31 N. E. 176]; Hankins v. Hendricks, 247 Ill. 517 [93 N. E. 428]." The following are a few of the cases which will illustrate how that doctrine has been applied by the courts in analogous cases:

In Larsen v. Peterson, 53 N. J. Eq. 88, 30 Atl. 1094, it was held that a water pipe leading from a driven well in a yard to a sink in the kitchen of a dwelling house, there ending in a pump by which water could be habitually drawn from the well to the kitchen for domestic purposes, would pass by a conveyance of the dwelling house, alone, by the owner of both house and yard, although the well and water pipe were both hidden from view, and that the same result would follow a simultaneous conveyance of the house to one person and the yard and well to another, if the latter took with notice of the connection between the well and pump. In this connection see, also, 14 Cyc. 1183, where the rule is stated to be as follows: "If the owner of land devises a system of pipes or conduits through which water is conveyed from a 
spring on one portion of his premises to another portion for the benefit of the latter and then alienates the portion to which the water is thus conveyed. the right to receive water through such pipes or conduits over the land conveyed will pass to the grantee by general words."

In Ingals v. Plamondon, 75 I11. 118, a furnace flue projected eight incies through a party wall. The owner of the two lots divided by the wall sold one of them and afterwards sold the other. A question arose between the first and the second grantees as to the right to maintain the fue. The flue was shown to be necessary to the maintenance of the furnace and its existence apparent to the second vendee when the premises were purchased, and the easement was upheld as appurtenant to the premises.

In Powers v. Heffernan, supra, it was held that where the owner of a building, upon erecting a new building on an adjoining iot, uses the stairway and hall of the old building for many years as the only means of access to the second floor of the new building, an easement attaches in favor of the new building upon a sale of the old building, although the only reservation in the deed is the right to one-half the party wall between the two buildings. This holding is based on the principle that where the owner of a building. while he was seized of the entire titie, made ccrtain arrangements with reference to access, heat, light and air which are highly beneficial and convenient to the use and enjoyment of the property and enhance its value, sells a portion of the builsing he sells it in its then condition, and each portion of the severed premises is subject to the burdens or advantages thereby imposed or conferred upon the other by the owner.

In Foote v. Yarlott, supra, we held that whcre the owner of a flatbuilding executed two trust deeds for the north and south halves of the building, respectively, and afterward installed a heating plant so as to heat the whole building, the heating plant being located on the north half, an easement was created in favor of the south half in the beneficial use and enjoyment of that part of the heating plant located in the north half, which right could be asserted by anyone who might become the owner of the south half under the trust deed. It was there said: "After the trust deeds were executed, and before the extension of the time of payment, the owner of the property put in the steam heating plant, with its pipes and radiators, to heat the entire building. While it was designed for the benefit of every part of the building, that portion where the steam heat was generated was on the north half. If the plant had been in the building at the time of the making of the trust deeds an easement for the enjoyment of the heating plant by anyone who should become owner of the south twenty feet upon foreclosure would have passed although not expressly stated, on the principle that when a party grants a thing he grants everything pertaining to it necessary to its enjoyment. The owner could not create any charge or easement on the north half, after the execution of the trust deeds, to the detriment of the owner of that half, but the natural conclusion 
would be that the installing of the heating plant subject to the right of the owner of the south half to the beneficial use of the same plant constituted an addition to the security as to the north half, and so far as appears that is true. The owner installed the heating plant, which increased the value of both parcels and which was necessary for the convenient and comfortable enjoyment of both, in such a way that the portion of the plant designed to generate the steam heat was on the north half, and the advantages and burdens of the arrangement attached to the property. Even nore libcral principles ought to be applied in such a case than in case of the implied reservation sustained in Powers v. Heffernan, 233 Ill. 597,84 N. E. 661, 16 L. R. A. (N. S.) 523, 122 Am. St. Rep. 199. In our opinion the trust deed includes the easement of the beneficial use of that part of the heating plant locater on the north twenty feet, and the owner of said north twenty feet must permit such beneficial use by anyone who may become the owner of the south twenty feet under the trust deed."

$\mathrm{No}$ distinction, in principle exists or can be made in the application of the law of easements, between easement of heat, light and air ur of ingress and egress, and the right to the use and enjoyment of the water rights and facilities shown in the case at bar. Nor can it well be said that an easement in the beneficial use and enjoyment of the heatirg plant in Foote v. Yarlott, supra, was more open, visible and continuous, and susceptible of being operated, used and enjoyed without the interference of man, than the water facilities, pump and engine are in the case at bar. The aid of man to put them in operation and keep them in repair is equally necessary and essential in both cases. The above cases so conclusively answer appellee's contentions upon this question as to render a further discussion of them at this time wholly unnecessary. $* * *$

For the reasons given, the decree will be reversed and the cause remanded to the circuit court of Lake county, with directions to overrule the demurrer, and for further proceedings in accordance with the views herein expressed. Reversed and remanded, with directions.

\section{BUTTERIVORTH v. CRAWFORD.}

(Court of Appeals of New York, 1S71. 46 N. Y. 349, 7 Am. Ren. 352.)

Appeal from judgment of the General Term of the Court of Common Pleas, for the city and county of New York, affirming judgment entered upon the report of a referee.

The facts of this case, as found by the referee, are as follows: Henry Vulkening in 1864 owned two houses adjoining each other on the north side of Forty-Sixth street, in the city of New York, known as Nos. 83 and 85 West Forty-Sixth street. While such owner, he dug 
and formed a vault, extending partly into the yard of each house, and constructed a drain from such vault, running through the lot of house No. 85, to the sewer in Forty-Sixth street. He then built a division fence between the yards of the two houses, extending from the rear of the houses to the rear of the lots, which fence was upon the division line, and crossed the vault in the center. He constructed an outhouse on either side of such division fence, over the vault for said house respectively, the roof of such outhouse extending a few inches above the fence.

After constructing such vault and outhouses, on the 11 th day of December, 1865 , he conveyed the house and lot No. 85 West FortySixth street, to the defendant in this action, by full covenant warrantee deed.

The defendant, immediately on the receipt of such deed, took possession of the said premises. Thereafter, on the 26th day of Janufary, 1866, Vulkening conveyed said house, known as No. 83 West Forty-Sixth street to the plaintiff.

In the summer of 1866, the defendant built a privy on his premises No. 85 West Forty-Sixth street, about twelve feet further towards the rear of his lot, and extended the drain to the vault of such privy, and then cut off the connection between that portion of the vault on the plaintiff's lot and the said drain.

The defendant upon the trial offered to show, that there was nothing in the appearance of the premises at the time he bought, to give notice that the privy was drained through his lot. This was refused by the referee, and the defendant's counsel excepted.

The defendant's counsel also offered to prove, that the defendant had no notice when he bought, that the privy was drained through his lot. This was refused by the referee, and the defendant's counsel duly excepted.

The referee, as conclusions of law, decided: That the defendant had no right to cut off or obstruct the communication, from that part of the vault on the plaintiff's lot, through the drain on the defendant's premises to the sewer in the street.

That the plaintiff was entitled to judgment, restraining the defendant from eomtinuing such obstruction, and requiring the defendant to open such drain, and to restore the same to the condition it was in at the time of the said conveyance to the plaintiff.

RAPALLO, J. We have come to the conclusion that the drain in controversy did not constitute an apparent servitude or easement, and that consequently the case does not present the question so fully argued before us, whether when a dominant and servient tenement are owned by the same person, and he makes a conveyance of the servient tenement first, with covenants of warranty, and against incumbrances, and without the express reservation of any easement, such conveyance will preclude him or his assigns from afterward asserting in favor of 
the dominant tenement, which he retains, the benefit of the easement in the premises so conveyed. We therefore refrain from expressing an opinion upon that point.

All the authorities cited on the argument, by the learned counsel for the respective parties, concur in holding that the rule of law which creates an easement on the severance of two tenements or heritages, by the sale of one of them, is confined to cases where an apparent sign of servitude exists on the part of one of them in favor of the other; or as expressed in some of the authorities, where the marks of the burden are open and visible.

Unless therefore the servitude be open and visible, or at least, unless there be some apparent mark or sign, which would indicate its existence to one reasonably familiar with the subject, on an inspection of the premises, the rule has no application.

There was nothing in the situation or appearance of the premises to indicate that there was any drain from the privies in question. Drains are not a necessary accompaniment of privies constructed as these were. In cities, municipal regulations provide for their being cleansed by licensed public scavengers, and this practice is frequently brought to the notice of the inhabitants in a very obvious manner. No evidence was introduced to show that drains from them were usual in the locality in question. But had such evidence been given, it does not appear that there was any thing to indicate that the privy of the neighboring house was drained through the lot sold to the defendant.

In the case of Pyer v. Carter, 1 Hurl. \& Nor. 916, which was much relied upon on the argument, and in the opinion of the learned court below, the dominant and servient tenement had originally been one house. This house had been divided into two parts. The drainage was of the water which fell upon the roof, and it may well be, that the situation and arrangement of the building were such as to indicate that some drain necessarily existed as an appurtenant to the house, and that upon the division of the house into two parts, that drain became common, and afforded drainage for both of the parts through one of them.

Such seems to have been the fact; for the court says, in rendering judgment, that "the defendant must have known, or ought to have known, that some drainage existed, and if he had inquired, would have known of this drain."

That decision recognizes the necessity of establishing that the servitude is apparent, or that there is an apparent mark or sign of it, and seems to be based on the fact that the situation and construction of the premises afforded such a sign.

In Washburn on Easements (2d ed.), p. 68, the learned author, after reviewing the cases on this subject, states that he considers the doctrine of Pyer v. Carter confined to cases where a drain is necessary 
to both houses, and the owner malies a common drain for both; and this arrangement is apparent and obvious to an observer.

If Pyer v. Carter goes farther than that, or, at all events, if it app)lies to cases where there is no apparent mark or sign of the drain, it is not in accordance with the current of the authorities.

The bearing of that case upon the question, whether the alleged easement was one of necessity, upon the point as to the order in which the tenements were sold, and upon the other questions, which were argued before us with so much learning and ability, need not now be considered, as we lo not propose at this time to decide those questions; and for the same reason we forbcar reviewing the numerous other authorities to which we have been referred, basing our decision upon the single ground that the servitude claimed was not apparent.

The judgment should be reversed and a new trial granted, with costs to abide the event. All concur.

Judgment accordingly.

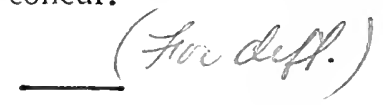

\section{WEEKS v. NEIV. YORK, W. \& B. RY. CO.}

(Court of Appeals of New York, 1912. 207 N. Y. 190, 100 N. E. 719.)

Appeal from a judsment of the Appellate Division of the Supreme Court in the second judicial department, entered June 13, 1911, affirming a judgment in favor of defendant entered upon a dismissal of the complaint by the court on trial at Special Term.

The nature of the action and the facts, so far as material, are stated in the opinion.

Cunsr:, J. On July 30, 1906, the plaintiff purchased two lots of land in New Rochelle which were in part described in the deed as follows: "known and distinguished as lots numbers fifty-seven and fifty-eiglit ( 57 and 58 ) on a certain map entitled 'Map of Property Belonging to IV. Chalmers, J. C. IVilson and Others, New Rochelle, N. I',' (lated December, 1904, made by Horace Crosby, C. E. filed in the V'estchester County Register's office, which lots are more particularly bounded and described as follows: Beginning at a point on the westerly sille of Cedar street as shown on said map (detailed description onitted), to the said westerly side of Cedar street and running thence southeasterly along the said westerly side of Celar street, cighty-one and one one-hundredths (81.01) feet to the point or place of beginning."

The defendants subsequently became the owners of all the other lots fronting on the so-called street, north of Orchard street in said city, and they conmenced the erection of an embankment across said socalled street, north of Orchard street, so as to obstruct the plaintiff"s riglit of access to her said lots. 
This action was commenced and the complaint alleges in detail the plaintiff's ownership in fee of said lots, and the acts of the defendants, including an allegation, "That said railway company, its agents or employees, have caused to be erected across said Cedar street, same being a public street, and are now erecting said embankment so as to completely obstruct the right of access of this plaintiff through said Cedar street to her said property." The complaint denands judgment: "(1) That the defendants be enjoined and restrained from in any way interfering with the free use of said Cedar street by this plaintiff. That defendants be compelled to remove from said Cedar street all obstructions now erected thereon interfering with the free access of plaintiff to her premises through said street."

The plaintiff's failure to recover a judgment protecting her right of access to said lots has apparently resulted from the extraordinary attitude of her counsel in insisting that the so-called strect is a public street or highway when he was wholly unable to sustain such position. The court did, however, find the following facts:

"Second. That in or about the month of December, 1904, IV. Chalmers, Frederick A. Steele and J. C. Wilson, at that time the owners of the so-called Maple Park tract in New Rochelle, duly filed a map of said tract, surveyed by Horace Crosby, in the office of the Register of Westchester county.

"Ihird. That the description of the premises in the decd of Chalmers et al. to plaintiff, bounds same as abutting on Cedar street as indicated on the map filed by said Chalmers et al. in December, 1904, the abutting lot being described in said deed and on said $\mathrm{m}^{\sim} \mathrm{p}$ as lot number 58."

"Sixth. That the defendant the City and County Contract Company is owner in fee of all the land or right of way over which the line of the defendant New York, Westchester \& Boston Railway Company has been constructed, or is about to be constructed in the said Maple Park Tract, and more particularly is owner in fee of the lots 11,12 , 13 and 14, and that part of Cedar street over which the line of the defendant, New York, IVestchester \& Boston Railway Company passes, and also of all of Cedar street north of Orchard street, except that portion opposite lot 58 to the center of said Cedar street.

"Seventh. That defendants have caused to be placed on Cedar street aforesaid near Orchard street, obstructions consisting of stone, which completely block access over Cedar street northerly from said Orchard street, and placed said stone there before the commencement of this action."

"Tenth. That plaintiff by the obstruction of stone aforesaid, is deprived of all access to her premises, lots 57 and 58 , over said Cedar street from Orchard street, and has been so deprived before the commencement of this action."

"Twelf th. That plaintiff after delivery of deed to her of lots 57 and 
58 , used Cedar street more or less each year since, for going to and coming from said premises, to and from Orchard street.

"Thirteenth. That plaintiff has not at any time consented to the closing of Cedar street by defendants or their agents.

"Fourteenth. That at the time of delivery of deed, Exhibit 1, to plaintiff, Chalmers et al. the owners of the entire tract, still owned all the lots abutting on Cedar street north of Orchard street, and did not convey the balance of said lots until after plaintiff owned and had possession of lot 58 under the said deed and said deed was filed of record."

The plaintiff requested the court to find, as conclusions of law: "14. That the proof shows that plaintiff is entitled to some relief and that the court should therefore have given judgment for plaintiff." "17. That plaintiff is entitled to a judgment directing defendants to remove all obstructions from Cedar street and enjoining defendants from further obstructing the said street and interfering with plaintiff's free access over Cedar street to her property described in the complaint." The court refused to find the conclusions of law requested by the plaintiff, but did find that the complaint states facts sufficient to constitute a cause of action, and that the plaintiff has no adequate remedy at law. It also found that that part of Cedar street north of Orchard street is not and never has been a public street, and that the defendants are entitled to judgment dismissing the plaintiff's complaint upon the merits, and judgment was entered accordingly.

The facts found show that the plaintiff had a private easement over the so-called Cedar street. Her rights as the owner of such easement, as between herself and the defendants, are similar to the rights of an abutter upon a public street or highway.

In Lord v. Atkins, 138 N. Y. 184, 191, 33 N. E. 1035, 1037, the court say: "It is well settled that when the owner of land lays it out into distinct lots, with intersecting streets or avenues, and sells the lots with reference to such streets, his grantees or successors cannot afterwards be deprived of the benefit of having such streets kept open. When, in such a case, a lot is sold bounded by a street, the purchaser and his grantees have an easement in the street for the purposes of access, which is a property right." See, also, Reis v. City of New York, 188 N. Y. 58,80 N. E. 573; India Wharf Brewing Co. v. B. W. \& W. Co., 173 N. Y. 167, 65 N. E. 985 ; Story v. N. Y. Elev. R. R. Co., 90 N. Y. 122, 165, 43 Am. Rep. 146; Bissell v. N. Y. C. R. R. Co., 23 N. Y. 61; Gerard on Title to Real Estate, 551, 821; Jones on Easements, § 430: Elliot on Roads and Streets, §§ 18, 144.

Upon a trial before a court or referee an exception to a general finding of law, holding that one party is entitled to recover against the other, raises the question as to whether, upon all the facts found, the successful party was entitled to judgment. Hemmingway $v_{0}$ Poucher, 98 N. Y. 281. 
The plaintiff, upon her pleadings and upon the facts found, was entitled to a judgment recognizing her private easement and granting her some relief on account of the invasion of her rights.

The judgment should be reversed and a new trial granted, with costs to abide the event.

Cullen, Ch. J., and Gray, Werner, Willard Bartlett, HisCOCK and Collin, JJ., concur.

Judgment reversed, etc. ${ }^{18}$

\section{CITY OF BATTLE CREEK v. GOGUAC RESORT ASS'N.}

(Supreme Court of Michigan, 1914. 181 Mich. 241, 149 N. W. 441.)

Bill by the city of Battle Creek against the Goguac Resort Association Limited, and others for an injunction. From a decree for complainant, defendants appeal.

Bird, J. The complainant, as well as the defendant association, are riparian owners on Lake Goguac. This lake is near the city of Battle Creek, and covers 360 acres, and is fed by subterranean springs. Complainant purchased a parcel of land bordering on the lake in 1886, and commenced to take therefrom its water supply in 1887. From that time on, its consumption of the water increased, until it reached upwards of 3,000,000 gallons per day at the time this suit was filed. The defendant association is the owner of lands bordering on the lake adjoining those of complainants. It maintains a summer resort and bathing beach during the summer months. Complainant has for some time objected to the bathing at the resort, on the theory that it polluted and rendered the water unfit for the use of its inhabitants. Its protests were not heeded by the association, nor by the other defendants who own and manage it. In order to enforce what it conceived to be its rights, this bill was filed to perpetually restrain the defendants from operating their bathing beach. The chancellor who heard the case granted the relief prayed, and the defendants have appealed. The

18 What would be the situation if the deed made no mention of streets, but referred for description to a plat which showed contemplated streets touching the property conreyed?

Land is sold and conveyed, reference heing made for description to a plat showing a great nany proposed new streets, onls one of which, howerer, touches the property conveyed. In which of such contemplated streets, if any, does the purchaser acqui re rights? What rights, if any, does he acunire? See_Danjelson v. Sykes, 157 Cal, 6\$6, 109 rac. 87,28 L. R. A. (N. S.) 1024 (1910); Harrington $v$. City of Manchester, 76 N. H. 347, S2 Atl. 716 (1912).

What would be the situation if lots are sold and convered after reference to a plat which shows contemplated streets, but no reference is made to such plat in the deed, nor is there any reference in the deed to the proposed streets? See Prper v. Whitman, 32 R. I. 510, S0 Atl. 6, 35 L. R. A. (N. S.) 938 (1911): Danielson v. Sykes, supra.

What if the grantor does not own the land on whiclr the contemplated streets are to be laid out? 
most serious question raised by defendants is that the complainant has no such right to the use of the water as entitled it to the relief granted.

Both complainant and defendants are riparian owners, and as such, in common with others, they own the bed of the lake, and by virtue of such ownership both have a right to a reasonable use of its waters for domestic, agricultural, and mechanical purposes. Clute v. Fisher, 65 Mich. 48, 31 N.W. 614; 40 Cyc. p. 635. Unless the complainant can show that it has some right other than that which arises by reason of riparian ownership, it has no greater right in the waters than have the defendants. As a riparian owner, the complainant has no right to divert the water for the purpose of selling it to the inhabitants of Battle Creek. Stock v. City of Hillsdale, 155 Mich. 375, 119 N. IV. 43.5; Smith v. City of Rochester, 92 N. Y. 463, 44 Am. Rep. 393; Ulbricht v. Water Co., 86 Ala. 587, 6 South. 78, 4 L. R. A. 572, 11 Am. St. Rep. 72; Lord v. Water Co., 135 Pa. 122, 19 Atl. 1007, 8 L. R. A. 202, 20 Am. St. Rep. S64; Sparks Manfg. Co. v. Town of Newton, 57 N. J. Eq. 367, 41 Atl. 385.

The question therefore gets around to this: Whether one riparian owner is entitled to equitable relief as against another riparian owner, to aid him in diverting the water to uses other than for riparian purposes. If this were a suit by complainant to protect its right to some reasonable use of the water incidental to its riparian ownership, it would present a different question, but when it seeks relief of this character to facilitate its business of unlawfully diverting the water, it prays for relief to wlich it is not entitled as a mere riparian owner. But counsel argue that the complainant's right is something more than a riparian right, and point to a legislative act whereby the city was authorized to go beyond its corporate limits to acquire water rights and, when acquired, to protect such rights against pollution. Act No. 428, Local Acts of 1837. We are unable to see how this act has any force in these proceedings. That act authorized the complainant to go beyond its corporate limits and accuire water rights by purchase or condemnation, which right it did not then have until the act was passed. Houghton Common Council v. Mining Co., 57 Mich. $547,24 \mathrm{~N}$. IV. 820. In pursuance of this act, the city purchased a small parcel of land on the shore. The city has never exercised its authority under this act, except to become a riparian owner. If in pursuance of this act complainant had acquired all the water rights at Goguac Lake, either by purchase or condemnation, it would then be in a position to insist upon what it is now insisting upon. The act does not attempt to enlarge the riparian rights of the complainant at the expense of the other riparian owners, and indeed the legislature would have no authority to confer such rights upon the city without compensation being made therefor.

Another claim made by complainant is that it has acquired the right by prescription to take its water supply from the lake. Defend- 
ants' riparian rights began in 1885 , before complainant's did. When complainant purchased, it was with the view of putting down wells; later it installed an intake. As the use of the water by the city increased, the lake was lowered to such an extent that defendants filed a bill to restrain complainant from lowering the water and interfering with their riparian rights. The city recognized the rights of the defendants and other riparian owners by diverting Minges brook into the lake, which action brought the lake back to its normal level, since which time it has been so maintained. After diverting Minges brook into the lake, the chancery suit was discontinued by stipulation. The record shows no such adverse use of the water as would ripen into a prescriptive right; but, even if we assume to the contrary, the right acquired would be no more than the right to take the water subject to the use which the defendants and their predecessors in title have made of it since the resort was established in 1885 . The prime object of the city in filing this bill was not to establish its own right to use the water as it has been using it, but to restrain defendants from making the use of it which they have made since 18S5. If this relief is to be granted, it should be based upon some right. The city has shown no prescriptive right, and as a riparian owner it would be entitled to no such relief. Were the city attempting to establish its right to take the water as it has done in the past, other questions might arise which are not important on this record.

In view of the conclusion reached upon this question, it will be unnecessary to consider the other questions raised. The decree of the trial court will be reversed, and the bill dismissed, with costs to defendants.

Stone. Ostrander, and Moore, JJ., concurred with Birn, J.

BrookE, J. I find myself unable to agree with the conclusions of my Brother BIRD in this case. In addition to the facts stated by him in his opinion, it should be noted that the complainant city of Battle Creek purchased the land upon which it located its water-works from one Surby, who was at that time and for many years had been conducting a summer resort in a small way upon the banks of the lake. He sold to the city a portion of his land with the knowledge that the city intended to erect a pumping station thereon and to supply its citizens with drinking water from the lake. His resort business at that time was insignificant, though the record tends to show that bathing by his patrons was indulged in to some extent. Surby not only stood by and saw the city expend a large amount of money in the establishment of its plant, but actually sold the land to the city to be used for that purpose. Some time after the city had placed in operation its waterworks, the defendant resort association purchased from Surby his adjacent lands, and rebuilt the buildings and added many attractions in order to induce large patronage; among these was the establishment of a bathing beach with dressing rooms and other necessary 
accommodations for its patrons. It further appears that at the time the city established its pumping station upon the shores of the lake, the lake had no visible inlet or outlet, but was supposed to be fed by springs. The use of the water by the complainant city had a tendency to reduce the mean level in the lake, and after some years the recession of the waters became so marked as to cause much complaint from other riparian owners, whereupon the city secured the right to divert a small stream called Minges brook from its natural course into the southerly end of the lake, since which time it has been able, through a proper manipulation of the waters of such brook, to maintain the lake at its normal level, although in the meantime the daily consumption of the city has reached somiething like $3,000,000$ gallons. It will thus be seen that the taking of the water from the lake by the complainant inflicts no injury upon the defendant or other riparian owners. It further appears that since the establishment of said plant the city limits of the city of Battle Creek have been extended so that they now embrace the entire site of the waterworks plant upon the banks of the lake as well as a further very considerable frontage, apparently used as a public park.

My Brother BIRD's opinion proceeds upon the theory that the use complainant is making of the waters of this lake is both unreasonable and unlawful. Under the circumstances disclosed by this record, I find myself unable to agree with him on either proposition. No person has a property right in water. The right is usufructuary only, and the modern authorities all tend to establish the principle that one riparian owner may not restrain the use of the water by another riparian owner for nonriparian purposes, unless such use results in injury to the first. The very recent case of Stratton v. Mt. Hermon Boys' School, 216 Mass. 83, 103 N. E. 87, 49 L. R. A. (N. S.) 57, Ann. Cas. 1915A, 768, is instructive upon this point. There the defendant, a riparian owner, took the water from a running stream and diverted it to nonriparian lands upon a different watershed, for use upon lands wholly separated from its riparian lands. The case contains a very full review of all the authorities. It is there said:

"The question in such a case is not whether the diversion, being for a legitimate use, is in quantity such as is reasonable, having regard to all the circumstances, as it is in cases of distinctly riparian uses, but only whether it causes actual damage to the person complaining. $* * *$ That there can be no recovery for a diversion of water for a proper use, so small in quantity and of such character that it occasions no injury to the present or future use of the lower riparian land is recognized in other jurisdictions"-citing cases.

I am further of the opinion that the complainant is entitled to the relief prayed upon the ground of estoppel. As before pointed out, the parties held title as riparian owners from a common grantor, Surby. It is to my mind entirely clear that Surby, having sold a part 
of the land belonging to him upon the shore of the lake for the purpose of enabling the city to establish a system of waterworks for the supplying of drinking water to its inhabitants, would not be heard to say that he had the right to make such use of the waters upon his adjoining lands as would render waters taken by the city unfit for the contemplated use. When the resort association purchased from Surby, it purchased with constructive knowledge that the city had bought from its grantor, and with actual knowledge of the fact that the city was then taking its supply of drinking water from the lake by means of its plant, plainly visible. Under the circumstances I am of opinion that Surby's grantee is under exactly the same disability that would attach to Surby had he attempted to render his grant valueless by a pollution of the waters immediately after the grant was made.

I am further unable to agree with the proposition that the use which the defendant resort association is making of the waters of the lake is, under the circumstances, either reasonable or lawful. In the case of People v. Hulbert, 131 Mich. 156, 91 N. W. 211, 64 L. R. A. 265, $100 \mathrm{Am}$. St. Rep. 588, the court held, though with some apparent difficulty, that Mr. Hulbert, a riparian owner, cotild not be punished for bathing in this lake, although his act was in violation of a legislative enactment. Act No. 428, Local Acts 1887. Whatever may be said of the propriety of this decision, and its soundness is questioned by complainant, it is apparent that the court was mindful of the possibility of future developments when it very carefully limited the effects of the decision to the single point then in issue. Mr. Justice Moore, in concluding his opinion, said:

"In what we have said we do not mean to intimate that an upper proprietor may convert his property into a summer resort, and invite large numbers of people to his premises for purposes of bathing, and give them the right possessed only by the riparian owner and his family. We are undertaking to decide only the case which is presented here."

This court thus clearly foreshadowed its probable action if such a case arose. It is unnecessary to predicate complainant's right to relief upon the fact that the health of 30,000 people is endangered by defendants' unlawful acts. The city as a riparian owner, with but a single resident upon the land who used or was entitled to use the wraters of the lake for drinking purposes, would have the absolute right to enjoin his neighbor from making such use of the water as would render it unfit for drinking purposes.

Defendants filed a cross-bill, in which it asks that complainant be restrained from diverting any of the waters of the lake through its pipes. Even if complainant's use of the water was wrongful, injunctive relief would be denied. Stock v. City of Hillsdale, 155 Mich. 375, 119 N. W. 435.

AIg.Prop. 35 
I am of opinion that the decree of the circuit court should be affirmed, with costs to complainant.

McAlvaY, C. J., and KuHN and STEERE, JJ., concurred with BROOKE, J. ${ }^{19}$

19 See Tahor $r$. Bradley, 18 N. Y. 109, 79 Am. Dec. $49 \mathrm{~S}$ (1S5S), where a right to flood remaining lands of the grantor was clinimed to have passed ly implied grant upon conveynce of a tract of land with mill and millam thereon. The land conveyed was described by metes and bounds, with no mention of the uill or dam. It appeared that the grantor had no knowledge of the existence of the mill and dam. and of course no knowleflge of the flooding.

See, also, Pwllbach Colliery Co. v. Woodman, [1015] A. C. 634, where property was leased with power to carry on thereon tlue trade of miners. Uther fremises were leased by the same landowner to a butcher. The colliery contpany erected on the premises demiscd to it a screning anmaratus, the operation of which resulted in the deposit of dust upon the butclier's buildings. It was coutended, inter alia, bs the colliery compling, in an ar tion against it fur ninsance, that the grant of the privilege to carry on the trade of miners anthorjzed the commission of a nuisance as against the lessor and those claiming nuder lim. 


\section{CHAPTER V \\ ESTATES CREATED

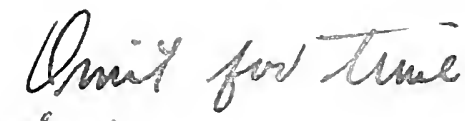 \\ SECTION 1.-ESTATES IN FEE SIMPLE}

\section{LITTLETON'S TENURES.}

Tenant in fee simple is he which hath lands or tenements to hold to him and his heirs for ever. And it is called in Latin, feodum simplex, for feodum is the same that inheritance is, and simplex is as much as to say, lawful or pure. And so feodun simplex signifies a lawful or pure inheritance. Quia feodum idem est quo hæreditas, et simplex idem est quod legitimum vel purum. Et sic feodum simplex idem est quod hæreditas legitima, vel hæreditas pura. For if a man would purchase lands or tenements in fee simple, it behooveth him to have these words in his purchase, to have and to hold to him and to his heirs: for these words (his heirs) make the estate of inheritance. ${ }^{1}$ For if a man purchase lands by these words, To have and to hold to him for ever; or by these words, To have and to hold to him and his assigns for ever; in these two cases he hath but an estate for term of life, for that there lack these words (his heirs), which words only make an estate of inheritance in all feoffments and grants. ${ }^{2}$

\section{Section 1.}

1 In many states the necessity of using the word "heirs" has been done array either expressly or indirectly by statute. Tlie state statutes should be consulted. Section 51 of the comeyancing Act (St. $4+-45$ Vict. c. 41 ) provides that in deeds executed after lecember 31 , 1S\$1, it shall be sufficient, in the limitation of an estate in fee simple to use the works "in fee simple," without the word "lieirs." In re Ethel and Mitchell's and Butler"s Contract, [1901]1 Ch. $94 \overline{5}$, held the words "in fee" not suflicient muler the statute.

Even at common law there were exceptions to the rule requiring the word "heirs." See 2 Bl. Comm. *108, *109.

2 "The grant to $A$. and his heirs' and a grant to $\Lambda$. for life and after his decease to his heirs,' according to the primitive force and effect of the expres. sions, were manitestly identical, inssumch as they both conferred life estates uron A., and upon the jersons desimnatel as his heirs in succession. They were still construed as identical, notwithstanding the change in the position and interest of the lieir consequent unon the enlarged power of alienation in the aucestor; the limitation to the heirs,' in both cases, ceased to confer directly any estate unon the persons answering to that designation, and was referred to the estate of the ancestor, which, though expressed to be in the first place for life, it enlarged to an estate of inberitance, so that the heir took only by descent. This is the origin and simplest form of the rule in Shelley's Case, an ancient rule of great imprortance in construing the limitations of estates, which will be noticed more fully hereatier." Ifake, Law of Property in Land [Randall's Ed.] 24. See 29 I. R. A. (N. S.) 963 et seq. 


\section{MCCULLOCK v. HOLMES.}

(Supreme Court of Missouri, 1S92. 111 MIo. 445, 19 S. W. 1096.)

BARCLAY, J. This is an action of ejectment involving the title to a piece of land in Lincoln county.

The facts are admitted.

The case turns upon the effect to be given to the following clause in a deed from Oliver Holmes (the common source of title) and his wife to Azra A. Holmes, dated, April 11, 1855, and duly recorded about the same time, viz.:

"To have and to hold * * * unto him the said Azra A. Holmes for and during his natural life and then to his two children, Laura Eliza and Mary Emily Holmes, and their heirs and assigns forever, and if either of said children shall die without issue in the lifetime of their father, then all of said lands is to go to the survivor."

The chronology of the principal facts, affecting the controversy, is as follows:

First. Mary Emily Holmes died without issue, some years before Azra A. Holmes.

Second. Azra died in April, 1888.

Third. He left his widow, the defendant in possession, and his daughter, Laura Eliza, one of the plaintiffs, who has intermarried with Mr. McCullock, the other plaintiff.

The fact that the limitation above quoted appears only in the "habendum" clause of the conveyance to Azra A. Holmes does not deprive it of its legal force or effect. All parts of the deed should be considered in gathering its meaning, and the true intent it designs to express, throughout, should be effectuated.

In the premises of this deed "A. A. Holmes" is named as grantee, while in the habendum the extent of his estate is defined, and the remainder now in consideration carved out.

All parts of an instrument are to be construed as consistent with each other, if such construction be possible.

Where land is conveyed to an individual, without adding to his name, as grantee, the word "heirs" or other words of inheritance, the fee thereby passes to him under the law of Missouri, "unless the intent to pass a less estate shall expressly appear or be necessarily implied in the terms of the grant." Rev. St. 1889, § 8834. The intent to pass a less estate is very evident in the present case, and is lawfully expressed. Farrar v. Christy's Adm'rs (1857) 24 Mo. 453 ; Spyve v. Topham (1802) 3 East, 115.

Even under the strictest common-law rules of conveyancing, a stranger to those mentioned in the premises of a deed might be introduced in the habendum as a grantee in remainder. 1 Wood on Conveyancing (6 Eng. Ed.) Habendum (B), p. 336.

The limitation in the case at bar is not uncertain or obscure. Azra. 
took a life estate in possession. During its currency, one of the possible remaindermen died. The other, the present plaintiff, survived Azra. She is plainly entitled to the estate, the contingency having been resolved in her favor. The trial court so held. Its judgment is affirmed. Sherwood, C. J., and Black and Brace, JJ., concur. ${ }^{3}$

3 In Palmer v. Cook, 159 Ill. 300, 42 N. E. 796, 50 Am. St. Rep. 165 (1S96) lands were conveyed by one Thomas Stewart to his two children. Following the description of the property was the following clause: "And I, Thomat Stewart, as for myself, retain possession and reserve the use, profits and full control during my life; and further, in case either of the grantees dies without an heir, her interest to revert to the survivor." The court said: "This deed effected an absolute fee simple conveyance by the nist clatuse of the deed and rested the estate. By the last clause an attempt is male to monnt a fet? upon a fee, which can only be done by executory derise. Sinith v. Kimbell, $15 \%$ Ill. $368,3 S$ N. E. 1029 (1594) ; Fowler v. Black, $1: 36$ Ill. $30 ; 3.26$ N. E. 596,11 L. R. A. 670 (1891); Griswold v. Hicks, 132 1ll. 494, 24 N. E. 63,22 Am. St. Rep. $549(1,90)$. It is a further principle of construction of deeds, that if the terms used vest a fee in the tirst taker, other parts of the instrument showing an intention to give a less estate will not control. Carpenter v. Tan Olinder, 127 Ill. 42, 19 N. E. S6S, 2 L. R. A. 45., 11 Am. St. Rep. 22 (1Ss?). Under the statute, the conveyance being to the grantee and her heirs and assigns, the terms have, in law, a definite meaning. By the use of terms of a lefinite legal meaning the intention can be determined from the lansuage used. If that language means a certain thing and nothing else, then the only reasonable construction is that what was intended was expessed in the language used. The language used did not create an estate in joint tenancy nor il life estate. Under these principles this deed reserved to the grantor a life estate and rested a fee in the grantees, and the clause, 'and further, in case either of the grantees dies without an heir, her interest to revert to the survivor' must be held to be inolerative, as a limitation of the fee."

In Cover v. James, 217 Ill. 309,75 N. E. 190 (1905), lands were convered to two of the grantor's children, with the following provision immediately following the description of the prenises: "In case of the death of either A. Ford Cover or bessie Cover, the other to have the whole of said property without litigation." A. Ford Cover died before Bessie Cover, and the question was whether the heirs of said A. Ford Cover took any interest. The court, inter alia, said: "Section 13 of chapter' 30 of Hurd's Revised Statutes of 1903, page 441 , provides that 'every estate in lands which shall be granted, conveyed or derised, although other words heretofore necessary to transfer an estate of inheritance be not added, shall be deemed a fee simple estate of inheritance, if a less estate be not limited by express words or do not alluear to have been granted, couveyed or devised by construction or operation of law.' Here the deed does expressly state that in case of the death of either of the grantees the survivor shall have the whole of the property, thus clearly limiting the estate granted to both jointly for life, with the right of survirorship. It is in. sisted, however, by counsel for appellees that this last provision cannot be given effect because it does not appear in the granting clause of the deed, or, as is said, does appear in the habendum, and reliance is placed upon the case of Palmer v. Cook, 159 Ill. 300, 42 N. E. 796, 50 Am. St. Rep. 165 (1S96). In that case a deed somewhat similar to the one now before the court was construed as conveying the fee simple title to the grantees, and it was held that the expréssion, 'in case either of the grantees dies without an heir her interest to revert to the survivor,' was an attempt to mount a fee upon a fee, and was therefore void. The granting clause of that deed was held to convey the fee simple title under the provisions of section 9 of chapter 30 , supra. If a fee simple title was in fact granted, it is clear that that estate could not be limited or qualified by the subsequent language. Merely because the deed was substantially in the form prescribed by section 9, however, a fee simple title was not necessarily conveyed. That section prescribes the form of the deed, and provides that every deed substantially in that form shall be deemed and held to be a conveyance in fee simple to the grantee, etc.; but it must be construed in 


\section{CARLLEE v. ELLSBERRY.}

(Supreme Court of Arkansas, 1907. S2 Ark, 209, 101 S. W. 407, 12 L. I. A. [N. S.] 9.9, 11S Am. St. Rep. 60.)

BATTLE, $\mathrm{J}$ : This case involves the construction of so much of a deed executed by John T. Hamblett and wife to Georgena Ellsberry as is in the following words:

"Know all men by these presents, That we, J. T. Hamblett and Cordelia P. Hamblett, his wife, for and in consideration of the sum of one dollar to us in hand paid, and for the love and affiection we have

connection with section 13. supra, under which, if a less estate he limited by explness worls or alphalr to hare been granted, conveyed or derised hy construction or operation of lal w, the conveyance, not using words beretofore necessary to transfer an estate of inheritance, shall not he leened to convey a fee simple estate. * * * That the position of comnsel for appellee and the decision of the cont below do violence to his expressod intention must be conceded.

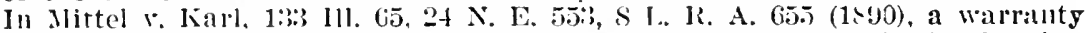
deed by John Mlittel conreged premises to Maria Johst and Mlichel .Jobst. her husband, and the surviror of them, in her or his own right.' In construing thit deed, atter holding that the words 'the survirol of them.' ete., could not

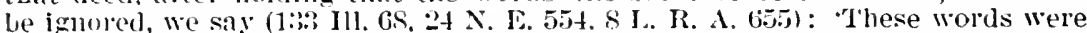
pliced in the deerl log the contracting parties for a purpose. and they camot arbitralily he rejacted. In the construction of written contracts it is the duty of the conrt to ascertain the intention of the parties, and the intention, when ascertained, nust control; but in arriving at the intention, effect must be given to each clinse, word or term emplosed by the party, rejecting none as meiningless or surplusige-citing Lchndort $v$. Colle, 122 Ill. $317,1: \mathrm{N}$. L. 505 (15s7). And after discussing the question as to whether that deed conveyed an estate in joint tellancy, we further saill (133: 111, 70, 24 N. E. 555. S I. R. A. (55): We think the linguage of the deed, when properly moderstood. Will admit of but one construction, ann that is, that the premises were convesed to Maria and Michacl Jolist for life, with a contingent remainder in fee to the smvivor: liy the lallsuage of the grant. to "Alichael Jolst and Iraria Jobst, and the surviror of theml, in his or her own right," it was doulit less intended that the one who should die first should take only a life estate in the premises, with the remainder in fee to the surviror and his heirs.' The authorities cited in suplort of this position, as well as the reasoning of the learned judge who wrote the opinion, fully sulpolted it. It is there further sald: "There is no way in which it can be beld that Jolst and his wife took the fee as tenants in common withont rejecting the clause in the deed providing that the survivor should talie the fee, and we are aware of no rule of construction under which that can le done. As is said in Riggin v. Love, i2 1ll. jn:? (1Sit) a construction which requires us to reject an entire clanuse of the deed is not to he admitted excelnt from unaleidable necessity: lut the intention of the parties, as mantfesterl by the language emblosed in the deed, should. so far as marcticible. he carried into effect.' So in this case, whether the father understood the difference between the estates in joint temancy and tenancy in common or not. be manifestly did understand what his desire was, that is, that the surviror. of his children, the grantees, should hare the entire estate; and under the rule annomed in Mittel $\therefore$. Karl there is no difficulty in giving effect to that intention. We think the court below was in error in holding that A. Ford Cover and bessie Cover took the estate as tenants in common and in sustaining the demurrer to the bill of the alpellant, Bessie Cover. Cnder the views here exmessed it is cleall that the complainants in the cross-libll were entitled to no relief under the sime, and whether, technically, the motion to strike it from the

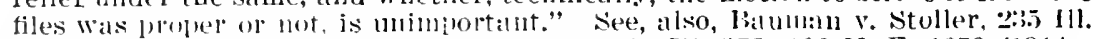
450, s5 N. E. 657 (1900s); Buck r. Garlier, $2(31$ III. 378, 103 N. E. 1059 (1914); Grares $:$ Wheeler, 1so Ala. 412, 61 South. 341 (1913), acc. 
for our daughter, Georgena Ellsberry, we hereby convey, sell, give and bequeath to the said Georgena Ellsberry, and unto her heirs and assigns forever, the following lands lying and being situate in the county of IVoodruff and State of Arlansas, to-wit: Lots numbered twelve (12), thirteen, (13) and fourteen (14) in block number fourteen (14) in the town of Augusta, to have and to hold the same unto the said Georgena Ellsberry and unto her heirs and assigns forever, with all the appurtenances thereto belonging. Provided, however, that sho:ld the said Georgena Ellsberry die without issue and before her husband, $\mathrm{W} \mathrm{m}$. M. Ellsberry then the property herein conveyed is to revert unto the said Wm. M. Ellsberry."

The granting clause of the deed conveys the lands described to the grantee in fee simple. The habendum defines the estate the grantee is to take to be the iee simple, with a proviso limiting the estate in certain contingencies to a life estate. The proviso or condition is repugnant to the granting clause. Which prevails?

In Maker v. Lazell, 83 Me. 562, 22 Atl. 474, 23 Am. St. Rep. 795, the court said: "There is one rule pertaining to the construction of deeds, as ancient, general and rigorous as any other. It is the rule that a grantor cannot destroy his own grant, however much he may modify it or load it with conditions, - the rule that, having once granted an estate in his deed, no subsequent clause, even in the sane deed, can operate to nullify it. 11 Bac. Abr. 665; Shep. Touch. 79, 102. We do not find that this rule has ever been disregarded, or even seriously questioned, by courts. We find it often stated, approved, and sometimes made a rule of decision. In Duke of Marlborough v. Lord Godolphin, 2 Ves. Sr. 74, Lord Chancellor Hardwicke, 'in whose judgments equity shone resplendent,' declared that the courts either of law or equity should not adopt such a construction of an instrument of devise as would defeat the interests given. In Cholmondeley v. Clinton, 2 Jac. \& Walk. 84, which was a case most elaborately. argued and considered, it was said by the court that where a limitation in a deed is perfect and complete, it cannot be controlled by intention collected from other parts of the same deed." To support this rule of construction, the court cites and comments upon the following cases: Budd v. Brooke, 3 Gill (Md.) 198, $43^{\circ}$ Am. Dec. 321; Ackerman v. Vreeland, 14 N. J. Eq. 23; Wilder v. Davenport, 58 Vt. 642, 5 Atl. 753; Cutler v. Tufts (Mass.) 3 Pick. 272; Wilcoxson v. Sprague, 51 Cal. 640; Green Bay \& Mississippi Canal Co. v. Hewett, 55 Wis. 96, 12 N. W. 382, 42 Am. Rep. 701.

In Green Bay \& Mississippi Canal Co. v. Hewett, 55 Wis. 96, $12 \mathrm{~N}$. W. 382, 42 Am. Rep. 701, Mr. Justice Lyon, delivering the opinion of the court, said: "Which of these two conflicting clauses in the deed of 1873 should prevail? This question must be determined by rules of law *** governing the construction of deeds. One of these rules is that a deed is always construed most strongly against the grantor. 4 Greenl. Cruise, Real Prop. p. 352, tit. 32, ch. 20, § 13. Another 
is that where there are two clauses in a deed, and the latter is contradictory to the former, the former shall stand. This is an application of the ancient rule or maxim that 'the first deed and the last will shall operate. * * * If the subsequent clause in the deed of 1873 is regarded as a habendum, then we have this rule laid down by Cruise in the title above cited (chapter $21, \S \S 75,76$ ): "Vhere the habendum is repugnant and contrary to the premises, it is void, and the grantee will take the estate given in the premises. This is a consequence of the rule already stated, that deeds shall be construed most strongly against the grantor; therefore he shall not be allowed to contradict or retract, by any subsequent words, the gift or grant made in the premises. Thus, if lands are given in the premises of a deed to A. and his heirs, habendum to A. for life, the habendum is void, because it is utterly repugnant to and irreconcilable with the premises." " $4 * * *$

The conveyance in fee simple carries with it the power to dispose of the estate by deed or will. The power of alienation is an inseparable incident of such an estate. So the deed in question conveyed to Mrs. Ellsberry the estate in fee simple with the power to dispose of it. The limitation of it to a life estate was repugnant to the granting clause, and was void.

Reversed and remanded, for proceedings consistent with this opinion. ${ }^{5}$

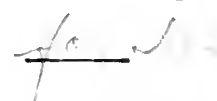

FIRST UNIVERSALIST SOCIETY v. BOLAND.

(Supreme Judicial Court of Massachusetts, 1892. 155 Mass. 171, 29 N. E. 524, 15 L. R. A. 231.)

Bill in equity, filed, in the Superior Court, for the specific performance of an agreement by the plaintiff to sell and by the defendant to purchase land. The case was submitted to the Superior Court, and,

4 A portion of the opinion, in which the court reviews a number of cases, is omitted.

5 Prindle v. Orphans Home, 15\% Iowa, 234, 133 N. W. 106 (1911), acc.

but see Wilson v. Terry, 130 IIich. 73, S9 N. W. 560 (1902); Jacolis $\nabla$. All Persons, etc., 12 Cal. App. 163, 106 Pac. 896 (1909); Midgett $\nabla$. Meekins, $160 \mathrm{~N}$. C. 42, 75 s. E. 728 (191:); Johnson v. Barden, 86 Vt. 19, 83 Atl. 721 , Ann. Cas. $1915 \mathrm{~A}, 1213$ (1912) ; Wood v. Losne, 167 Iowa, 486, 149 N. W. 613 (1914) ; Kenner r. State (Ark.) 150 S. W. 192 (1915).

Lands were conveyed to $X$., "his heirs and assigns forerer, subject to the limitations hereinafter expressed as to part thereof," etc. In the habendum the estate of the grantee as to one-half was limited "to his own use, benefit, and behoof during his natural life, and at his decease *** to descend to and the title thereof vested in the children" of said $\mathrm{X}$. by him lawfully begotten. The question was as to the estate acquired by X. Tyler v. Moore, 42 I'a. $374(186 \%)$.

Bf leed lands were conveyed to 11. " "her children and assigns forever," with habendum to M., "ler heirs and assigus forever." Held that M. took a fee simple, and not as tenant in common with her children. Rines $\nabla$. Mansfield, 96 Mo. 394, 9 s. W. 795 (1SSS). Cf. Kal'hner v. Hoy, $151 \mathrm{~Pa} .383,25$ Atl. 20 (1892); Morton v. Babb, 251 Ill. 488, 96 N. E. 279 (1911).

As to the propriety of declaring trusts in the habendum, see Nightingale $\mathbf{v}$. Hidlen, 7 R. I. 115 (1862). 
after judgment for the plaintiff, to this court, on appeal, on an agreed statement of facts, and was as follows:

On April 9, 1842, Joseph D. Clark and twenty-five or thirty other persons formed the plaintiff society, with a constitution which adopted as the basis of its religious faith the profession of belief accepted by the General Convention of the Universalists at its session at Winchester, New Hampshire, in 1803, and provided for three trustees to be the executive power of the society and to see that all votes of the society were carried out. On April 3,1854, Clark for the expressed consideration of nine hundred dollars conveyed the land in question by a deed containing the usual covenants to the plaintiff society, "to have and to hold to the said First Universalist Society and their assigns, so long as said real estate shall by said society or its assigns be devoted to the uses, interests, and support of those doctrines of the Christian religion embraced in the Confession of Faith adopted by the General Convention of Universalists held at Winchester, New Hampshire, in the year eighteen hundred and three. And when said real estate shall by said society or its assigns be diverted from the uses, interests, and support aforesaid to any other interests, uses, or purposes than as aforesaid, then the title of said society or its assigns in the same shall forever cease, and be forever vested in the following named persons, and such persons shall be the legal representatives of any of such persons at the time the same so vests as aforesaid in the following undivided parts and proportions, to wit: to Stephen M. Whipple $140 / 1000$, Alanson Cady $140 / 1000$, John F. Arnold 11 $\dot{4} / 1000$, Joseph D. Clark ${ }^{70} / 1000$. [Here followed the names of thirty-seven others after each of which was placed a fraction in thousandths.] To have and to hold the above granted premises, with the privileges and appurtenances thereto belonging, to the said grantees, their heirs and assigns, to them and their use and behoof forever, as aforesaid."

On December 16, 1885, Clark executed and delivered to the plaintiff society a quitclaim deed of the same premises, "intending hereby to vest in said society absolutely and in fee simple the title to said premises free and discharged of all the conditions, restrictions, and restraints as to the uses, interests, and purposes for which said premises are to be used and enjoyed by said society, as set forth in my said deed of April 3, 1854, and to enable said society to sell, lease, or otherwise use and dispose of said premises to all intents and purposes as if no restraints or contingent interests had been created by my said deed or referred to therein."

Upon the land so conveyed to the plaintiff a church was erected, which from the time of its erection to the present time has.been occupied and used for religious worship by the plaintiff society, without any change in the profession of faith mentioned in the deed of April 3,1854 , or in its constitution. The agreement in question was made by the parties on April 20,1891, but the defendant, upon the tender of a deed to hin from the plaintiff, refused to carry it out, on the ground, 
among others, that the plaintiff society never was seised in fee simple, but at most obtained only a qualified or conditional fee, and could not convey a good and clear title.

The partics having ascertained that between April 3, 1854, and December 16, 1885, Clark had gone into bankruptcy, the plaintiff waived any rights which it might have under the deed of December 16, 1885, and relied for its title upon the deed dated April 3, 1854.

A I.LEN. J. The limitation over, which is contained in the deed of Clark to the plaintiff in 1854 , is void for remoteness. Wells v. Heath, 10 Gray, 17, 25, 26; Brattle Square Church v. Grant, 3 Gray, 142, 152, $63 \mathrm{Am}$. Dec. 725. The fact that the grantor designated himself as one of the persons amongst many others to take under this limitation, does not have the effect to make the limitation valid. He was to take with the rest, and stand upon the same footing with them.

Where there is an invalid limitation over, the general rule is that the preceding estate is to stand, unaffected by the void limitation. The estate bccomes rested in the first taker, according to the terms in which it was granted or devised. Brattle Square Church v. Grant, 3 Gray, 142, 156, 157, 63 Am. Dec. 725; Sears v. Russell, S Gray, 86, 100; Fosdick v. Fosdick, 6 Allen, 41, 43; Lovering v. Worthington, 106 Mass. S6, SS; Lewis on Perpetuity, 657. There may be instances in which a void limitation might be referred to for the purpose of giving a construction to the language used in making the prior gift, provided any aid could be gained thereby. In the present case, we dc not see that any such aid can be gained. The estate given to the first taker does not depend at all upon the validity or invalidity of the limitation over, and the construction of the language used is not aided by a reference thereto.

The grant to the plaintiff was to have and to hold, etc., "so long as said real estate shall by said society or its assigns be devoted to the uses, interests, and support of those doctrines of the Christian religion," as specified. "And when said real estate shall by said society or its assigns be diverted from the uses, interests, and support aforesaid to any other interests, uses, or purposes than as aforesaid, then the title of said society or its assigns in the same shall forever cease, and be forever vested in the following named persons," etc. These words do not grant an absolute fee, nor an estate on condition, but an estate which is to continue till the happening of a certain event, and then to cease. That event may happen at any time, or it may never happen. Because the estate may last forever, it is a fee. Because it may end on the happening of the event, it is what is usually called a determinable or qualified fee. The grant was not upon a condition subsequent, and no re-entry would be necessary; but by the terms of the grant the estate was to continue so long as the real estate should be devoted to the specified uses, and when it should no longer be so devoted, then the estate would cease and determine by its own limitation. Numerous illustrations of words proper to 
create such qualified or determinable fees are to be found in the books, one of which, as old as Walsingham's Case, 2 Plowd. 557, is "as long as the church of St. Paul shall stand." Brattle Square Church v. Grant, 3 Gray, 142, 147, 63 Am. Dec. 725; Easterbrooks v. 'lillinghast, 5 Gray, 17; Ashley v. Warner, 11 Gray, 43; Attorney General v. Merrimack Manuf. Co., 14 Gray, 585, 612; Fifty Associates v. Howland, 11 Metc. 99, 102; Owen v. Field, 102 Mass. 90, 105; 1 Washb. Real Prop. (3d Ed.) 79; 2 Washb. Real Prop. (3d Ed.) 20, 21 ; 4 Kent, Com. 126, 127, 132, note; 2 Crabb, Real Prop. $\$ \$ 2135,2136.2$ Flint. Real Prop. 230, 232; Shep. Touchst. 121, 125.

A question or doubt, however, has arisen, though not urged by counsel in this case, whether after all there is now any such estate as a qualified or determinable fee, or whether this form of estate was done away with by the statute Quia Emptores. See Gray, Rule against Perpetuities, $\S \S 31-40$, where the question is discussed and authorities are cited. We have considered this question, and whatever may be the true solution of it in England, where the doctrine of tenure still has some significance, we think the existence of such an estate as a qualified or determinable fee must be recognized in this country; and such is the general consensus of opinion of courts and text writers. Jamaica Pond Aqueduct v. Chandler, 9 Allen, 159, 16S; L.conard v. Burr, 18 N. Y. 95; Gillespie v. Broas, 23 Barb. (N. Y.) 370; State v. Brown, 27 N. J. Law, 13; Henderson v. Hunter, 59 Pa. 335; IViggins Ferry Co. v. Ohio \& Mlississippi Railway, 94 Ill. 83, 93; 1 Washb. Real Prop. (3d Ed.) 76-78; 4 Kent, Com. 9, 10, 129. See, also, of English works in addition to citations ahove, Shep. Touchst. 101 ; 2 Bl. Com. 109, 154, 155; 1 Cruise Dig. tit. 1, $\S \S 72-76 ; 2$ Flint. Real Prop. 136-133; 1 Prest. Est. 431, 441; Challis, Rea1 Prop. 197-20s.

Since the estate of the plaintiff may determine, and since there is no valid limitation over, it follows that there is a possibility of reverter in the original grantor, Clar $\mathrm{x}$. This is similar to, though not quite identical with, the possibility of reverter which remains in the grantor of land upon a condition subsequent. The exact nature and incidents of this right need not now be discussed, but it represents whatever is not conveyed by the deed, and it is the possibility that the land may revert to the grantor or his heirs when the granted estate determines. Challis, Real Prop. 31, 63-65, 153, 174, 198, 200, 212; 1 Prest. Est. 431, 471; Newis v. Lark, 2 Plowd. 403, 413; Shep. Touchst. 120; 2 Washb. Real Prop. (3d Ed.) 20, 579: 4 Kent, Com. 10; Smith v. Harrington, 4 Allen, 566, 567 ; Attorney General v. Merrimack Manuf. Co., 14 Gray, 586, 612; Brattle Square Church v. Grant, 3 Gray, 142, 147-150, 63 Am. Dec. 725; Owen v. Field, 102 Mass. 90, 105, 105; Gillespie v. Broas, 23 Parb. (N. Y.) 370; Gray, Rule against Perpetuities, $\$ \S 33,34,39$, and cases cited.

Clark's possibility of reverter is not invalid for remoteness. It has been expressly held by this cuurt, that such possibility of reverter 
upon breach of a condition subsequent is not within the rule against perpetuities. Tobey v. Moore, 130 Mass. 448; French v. Old South Society, 106 Mass. 479. If there is any distinction in this respect between such possibility of reverter and that which arises upon the determination of a qualified fee, it would seem to be in favor of the latter. But they should be governed by the same rule. If one is not held void for remoteness, the other should not be. The very many cases cited in Gray, Rule against Perpetuities, $\S \S 305-312$, show conclusively that the general understanding of courts and of the profession in America has been that the rule as to remoteness does not apply; though the learned author thinks this view erroneous in principle.

We have no occasion to consider whether the possibility of reverter would or would not pass to an assignee in bankruptcy or insolvency, because the plaintiff expressly waived any right it might have under the second deed from Clark, and we have not, therefore, felt at liberty to consider the second deed, and have been confined to the construction and effect of the first deed. See Ricc v. Boston \& -Worcester Railroad, 12 Allen, 141. This being so, the plaintiff's title must be deemed imperfect, and the entry must be: Biil dismissed.

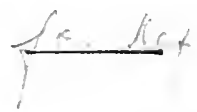

SECTION 2.-ESTATES IN FEE TAIL'

\section{STATUTE DE DONIS CONDITIONALIBUS.}

First, concerning lands that many times are given upon condition, that is, to wit, where any giveth his land to any man and his wife, and to the heirs begotten of the bodies of the same man and his wife, with such condition expressed that if the same man and his wife die without heir of their bodies between them begotten, the land so given shall revert to the giver or his heir; in case also where one giveth lands in free marriage, which gift hath a condition annexed, though it be not expressed in the deed of gift, which is this, that if the husband and wife die without heir of their bodies begotten, the land so given shall revert to the giver or his heir; in case also where one giveth land to another and the heirs of his body issuing, it seemed very hard and yet seemeth to the givers and their heirs, that their will being expressed in the gift was not heretofore nor yet is observed. In all the cases aforesaid after issue begotten and born between them, to whom the lands were given under such condition, heretofore such feoffees had power to aliene the land so given, and to disinherit their issue of the land, contrary to the minds of the givers, and contrary to the form expressed in the gift. And further, when the issue of such 
feoffee is failing, the land so given ought to return to the giver or his heir by form of gift expressed in the deed, though the issue, if any were, had died; yet by the deed and feoffment of them, to whom land was so given upon condition, the donors have heretofore been barred of their reversion of the same tenements which was directly repugnant to the form of the gift: wherefore our lord the king, perceiving how necessary and expedient it should be to provide remedy in the aforesaid cases, hath ordained, that the will of the giver according to the form in the deed of gift manifestly expressed shall be from henceforth observed, so that they to whom the land was given under such condition sháll have no power to aliene the land so given, but that it shall remain unto the issue of then to whom it was given after their death, or shall revert unto the giver or his heirs if issue fail, either by reason that there is no issue at all, or if any issue be, it fail by death, the heir of such issue failing. Neither shall the second husband of any such woman from henceforth have anything in the land so given upon condition after the death of his wife, by the law of England, nor the issue of the second husband and wife shall succeed in the inheritance, but immediately after the death of the husband and wife, to whom the land was so given, it shall come to their issue or return unto the giver or his heir as before is said. And forasmuch as in a new case new remedy must be provided this manner of writ shall be granted to the party that will purchase it. * * * The writ whereby the giver shall recover when issue faileth is common enough in the chancery. And it is to wit that this statute shall hold place touching alienation of land contrary to the form of gift hereafter to be made, and shall not extend to gifts made before. And if a fine be levied hereafter upon such lands it shall be void in the law, neither shall the heirs or such as the reversion belongeth unto, though they be of full age, within England, and out of prison, need to make their claim.

Westm. II, c. 1, 13 Edw. I, A. D. 1285.

\section{LITTLETON'S TENURES.}

Tenant in fee tail is by force of the statute of W. 2, cap. 1, for before the said statute, all inheritances were fee simple; for all the gifts which be specified in that statute were fee simple conditional at the common law, as appeareth by the rehearsal of the same statute. And now by this statute, tenant in tail is in two manners, that is to say, tenant in tail general, and tenant in tail special.

Section 13. 


\section{COKE UPON LITTLETON.}

"Before the said statute all inheritances were fee simple." Here - fee simple is taken in his large sense, including as well conditional or qualified, as absolute, to distinguish them from estates in tail since the said statute. Before which statute of donis conditionalibus, if land had been given to a man, and to the heirs males of his body, the having of an issue female had been no performance of the condition; but if he had issue male, and died, and the issue male had inherited, yet he had not had a fee simple absolute; for if he had died without issue male, the donor should have entered as in his reverter. By having of issue, the condition was performed for three purposes: First, to alien: Secondly, to forfeit: Thirdly, to charge with rent, common, or the like. But the course of descent was not altered by having issue; for if the donee had issue and died, and the land had descended to his issue, yet if that issue had died (without any alienation made) without issue, his collateral heir should not have inherited, because he was not within the form of the gift, viz. heir of the body of the donee. Lands were given before the statute in frank-marriage, and the donees had issue and lied, and after the issue died without issue; it was adjudged, that his collateral issue shall not inherit, but the donor shall re-enter. So note, that the heir in tail had no fee simple absolute at. the common law, though there were divers descents.

If lands had been given to a man and to his heirs males of his body, and he had issue two sons, and the eldest had issue a daughter, the daughter was not inheritable to the fee simple, but the younger son per formam doni. And so if land had been given at the common law to a man and the heirs females of his body, and he had issue a son and a daughter, and died, the daughter should have inherited this fee simple at the common law; for the statute of donis conditionalibus createth no estate tail, but of such an estate as was fee simple at the common law, and it is descendable in such form as it was at the common law. If the donee in tail had issue before the statute, and the issue had died without issue, the alienation of the donee at the common law, having no issue at that time, had not barred the donor.

If donee in tail at the common law had aliened before any issue had, and after had issue, this alienation had barred the issue because he claimed a fee simple; yet if that issue had died without issue, the donor might re-enter, for that he aliened before any issue, at what time he had no power to alien to bar the possibility of the donor.

In gifts in tail these words (heirs) are as necessary, as in feoffments and grants; for seeing every estate tail was a fee simple at the common law, and at the conmon law no fee simple could be in feoffments and grants without these words (heirs), and that an estate in tail is but a cut or restrained fee, it followeth, that in gifts in a man's lifetime no estate can be created without these words (heirs), unless it 
be in case of frank-marriage, as hereafter shall be shewed. And where Littleton saith (heirs), yet heir in the singular number in a special case may create an estate tail, as appeareth by 39 Ass. p. 20. hereafter mentioned. And yet if a man give lands to A. et hæredibus de corpore suo, the remainder to $B$. in forma prædicta, this is a good estate tail to B. for that in forma prædicta do include the other. If a man letteth lands to $\mathrm{A}$. for iife, the remainder to $\mathrm{B}$. in tail, the remainder to $\mathrm{C}$. in forma prædicta, this remainder is void for the uncertainty. But if the remainder had been, the remainder to $\mathrm{C}$. in eadem forma, this had been a good estate tail; for idem semper proximo antecedenti refertur. If a man give lands or tenements to a man, et semini suo, or exitibus vel prolibus de corpore suo, to a man, and to his seed, or to the issues or children of his body, he hath but an estate for life; for albeit that the statute provideth. that voluntas donatoris secundum forman in charta doni sui manifeste expressan de caetero observetur, yet that will and intent must agree with the rules of law. And of this opicion was our author himself, as it appeared in his learned reading aforementioned upon this statute, where he holdeth, if a man giveth land to a man et exitibus de corpore suo legitime procreatis, or semini suo, he hath but an estate for life, for that there wanteth words of inheritance.

"Of his body." These words are not so strictly required but that they may be expressed by words that amount to as much: for the example that the statute of IV. 2 putteth hath not these words (de corpore) but these words (hæredibus) viz.: Cum aliquis dat terram suam alicui viro et ejus uxori et hredibus de ipsis viro et muliere procreatis. If lands be given to $B$. et hæredibus quos idem $B$. de prima uxore sua legitime procrearet, this is a good estate in especial tail (albeit he hath no wife at that time) without these words (de corpore). So it is if lands be given to a man, and to his heirs, which he shall beget of his wife, or to a man et hæredibus de carne sua, or to a man et hærediibus de se. In all these cases these be good estates in tail, and yet these words de corpore are omitted.

It is holden by some opinions, that if there be grandfather, father and son, and lands are given to the grandfather, and to his heirs begotten by the father, the father dieth, the grandfather dieth, the son is in as heir to the grandfather begotten upon the body of his father. and the wife of the grandfather in that case shall be endowed. But certain it is, that in some cases one shall have the land per formam doni that is not issue of the body of the donee, which see Section 30.

"Begotten." This word may in many cases be omitted or expressed by the like, and yet the estate in tail is good: as hæredibus de carne, hæredibus de se, hæred' quos sibi contigerit, \&c. as is aforesaid; and where the word of Littleton is, ingendered or begotten, procreatis, yet if the word be procreandis, or quos procreaverit, the estate in tail is good; and as procreatis shall extend to the issues begotten afterwards, so procreandis shall extend to the issues begotten before.

Co. Litt. 19a, 20a, b. 


\section{EWING v. NESBITT.}

(Supreme Court of Kansas, 1913. SS Kan. 708, 129 Pac. 1131.)

Burch, J. In the year 1893 John Ewing made his will. The fourth paragraph reads as follows:

"Fourth: I will and bequeath to my daughter, Mary A. Nesbitt, née Ewing, and to the heirs of her body, the south half (1/2) of the northwest quarter $(1 / 4)$ of section No. twenty-one (21), township thirteen (13), of range twenty-four (24), in Johnson county, Kansas."

Devises using the same language were made to the testator's other children, four in number. Besides these the will contained four other devises, which were expressly stated to be "free and clear of all entailment," thus clearly indicating the intention of the testator to create estates tail by the phraseology employed in paragraph 4 and those like it. In 1895 John Ewing died, leaving as his heirs the five children who were the beneficiaries of his will. The will was duly probated, the estate was administered and closed, and Mary A. Nesbitt entered into possession of the tract of land devised to her. In the year 1909 she died without having borne children and was survived by her husband, William J. Nesbitt, who continued in possession of the land. Soon after Mary A. Nesbitt's death her brothers and sisters commenced an action of ejectment, and for rents and profits, against William J. Nesbitt, claiming to be owners in fee simple. He answered claiming a one-fifth interest in the land and praying for partition. Judgment was rendered for the defendant and the plaintiffs appeal.

The will contained a residuary clause in which the testator gave to his children surviving him, share and share alike, "all other property, goods, chattels, moneys, stocks, credits, and effects" of which he might die seized. The defendant claims that his wife was the donee of an estate tail; that the donor retained a reversionary interest in fee simple expectant upon the estate tail; that if, by virtue of the residiary clause of the will, this reversion was not disposed of it descended, upon the death of the donor, to his heirs, one of whom was his daughter, Mary A. Nesbitt; and that upon her death the defendant, as her surviving husband, took her share of the fee, which was one-fifth... If, however, the residuary clatuse of the will was effectual to devise the reversion to the testator's children, Mary A. Nesbitt took a one-fifth interest which, upon her death, descended to the defendant. Under either theory the defendant's claim to a one-fifth interest in the land is valid if the law of this state recognizes estates tail as they existed under the common law of England at the time of the colonization of this country.

Under the early common law a grant to a man and the heirs of his body was a grant of a fee on condition that he had heirs of his body. The fee so granted was designated a conditional fee. If the donee 
had no heirs of his body, the condition was not performed and the land reverted to the donor. If heirs of the donee's body were born, the condition was regarded as performed and the donee was at liberty to make a conveyance which would bar him, his issue, and the donor's reversion. He could likewise charge the land with rents and encumbrances which would bind his issue, and the estate was forfeitable for his treason. If the condition were performed but the donee made no conveyance, the land descended, upon his death, to the specified issue, who were at liberty to convey. If they made no conveyance the land reverted to the donor. If the condition were performed but the issue died, and the donee then died without having made a conveyance, the land reverted to the donor. In order to bar the possibility of reverter to the donor and to restore the descent to its ordinary course under the common law, donees of conditional fees were in the habit of making conveyances as soon as issue was born and taking back warranty deeds. To stop this practice, which evaded the condition and defeated the intention of the donor, the nobility of the realm, who were desirous of perpetuating family possessions, procured the passage of the statute of Westminster II, known as the statute "de donis conditionalibus." $13 \mathrm{Edw}$. I, c. 1, June 28, 1285. This statute took away the power of alienation and declared that the will of the donor, plainly expressed, should be observed, and that tenements given to a man and the heirs of his body should go to his issue, if there were any, and if not should revert to the donor. The judges interpreted this statute to mean that the donee no longer took a conditional fee capable of being disposed of as soon as issue was born, but that he took a particular estate, denominated an estate tail, and that instead of a possibility of reverter only remaining in the donor, he had a reversion in fee simple expectant upon the failure of issue. Some of the social consequences of this statute are thus described by Blackstone:

"Children grew disobedient when they knew they could not be set aside; farmers were ousted of their leases made by tenants in tail; for if such leases had been valid, then under colour of long leases the issue might have been virtually disinherited; creditors were defrauded of their debts; for, if a tenant in tail could have charged his estate with their payment, he might also have defeated his issue, by mortgaging it for as much as it was worth; innumerable latent entails were produced to deprive purchasers of the lands they had fairly bought; of suits in consequence of which our ancient books are full: and treasons were encouraged, as estates-tail were not liable to forefeiture, longer than for the tenant's life. So that they were justly branded, as the source of new contentions, and mischiefs unknown to the common law; and almost universally considered as the common grievance of the realm." 2 Commentaries, *116.

Notwithstanding these mischiefs, the statute forms one of the funAig.Prop.-36 
damental institutes of the land law of England which three and a quarter centuries later was transplanted in the New World.

Before the settlement at Jamestown, in the fourth year of James I $(1607)$, a number of statutes had been passed whereby the privileges attending estates tail were much abridged They were made forfeitable for treason. 26 Henry VIII, c. 13. Certain leases by the tenant in tail not prejudicial to the issue were allowed to be good in law. 32 Henry VIlI, c. 28. The statute of fines (4 Henry VII, c. 24) was construed to permit the tenant in tail and his heirs to be barred by levying a fine (32 Henry VIII, c. 36). Such estates were chargeable with the payment of certain debts due the king (33 Henry VIII, c. 39), and by construction of the statute, 43 Eliz. c. 4, an appointment to charitable uses by a tenant in tail was held to be good, 2 Bl. Com. 117 et seq. The most serious blow, however, to the evils fostered by estates tail under the statute de donis was struck by a bold piece of judicial legislation. In Taltatum's case, reported in Year Book, 12 Edlw. IV, 19 (1472), the judges, upon consultation, held that a common recovery suffered by a tenant in tail accomplished the complete destruction of the estate tail. This mode of barring estates tail is thus described in 1 Washburn on Real Property (6th Ed.) § 186:

"This was a fictitious suit brought in the name of the person who was to purchase the estate, against the tenant in tail who was willing to convey. The tenant, instead of resisting this claim himself, under the pretence that he had acquired his title of some third person who had warranted it, vouched in, or, by a process from the court, called his third person, technically the vouchee, to come in and defend the title. The vouchee came in as one of the drannatis persona of this judicial farce, and then without saying a word disappeared and was defaulted. It was a principle of the feudal law adopted thence by the common law, that if a man conveyed lands with a warranty, and the grantee lost his estate by eviction by one having a better title, he should give his warrantee lands of equal value by way of recompense. And as it would be too barefaced to cut off the rights of reversion as well as of the issue in tail, by a judgment between the tenant and a stranger, it was gravely adjudged, 1 st, that the claimant should have the land as having the better title to it; and $2 \mathrm{~d}$, that the tenant should have judgment against his vouchee to recover lands of equal value on the ground that he was warrantor, and thus, theoretically, nobody was harmed. If the issue in tail or the reversioner, or remainder-man, lost that specific estate, he was to have one of equal value through this judgment in favor of the tenant in tail, whereas in fact the vouchee was an irresponsible man, and it was never expected that he was anything more than a dummy in the game. The result of this, which Blackstone calls 'a kind of pia fraus to elude the statute De Donis,' was that the lands passed from the tenant in tail to the claimant in fee simple, free from the clains of reversioner, remainder-man, or 
issue in tail, and he either paid the tenant for it as a purchaser, or conveyed it back to him again in fee-simple."

The precedent of fictitious suits as means of acquiring or conveying property was found in the Roman law, and the practice of resorting to them was supposedly introduced in England by the clergy to evade the statute of mortmain. Spence's Equitable Jurisdiction of the Court of Chancery, p. 141, note. The solemn piece of jugrlery already described later became more involved.

"Complex, however, as the proceedings above related may appear, the ordinary forms of a common recovery in later times were more complicated still; for it was found expedient not to bring the collusive action against the tenant in tail himself, but that he should come in as one vouched to warranty. The lands were, therefore, in the first place conveyed, by a deed called the recovery deed, to a person against whom the action was to be brought, and who was called the tenant to the pracipe or writ. The proceedings then took place in the Court of Common Pleas, which had an exclusive jurisdiction in all real actions. A regular writ was issued against the tenant to the precipe by another person, called the demandant; the tenant in tail was then rouched to warranty by the tenant to the precipe. The tenant in tail, on being vouched, then vouched to warranty in the same way the crier of the Court, who was called the common vouchee. The demandant then craved leave to imparl or confer with the last vouchee in private, which was granted by the Court; and the vouchee, having thus got out of Court, did not return; in consequence of which judgment ivas given in the manner before mentioned, on which a regular writ was chirected to the sheriff to put the demandant into possession." Williams on Real Property (1/th Ed.) p. 108.

In all cases there was an agreement or understanding that the person who acquired an estate tail by means of a common recovery should pay for it, or convey it to the original tenant in tail in fee simple, or dispose of it as such tenant might direct. The result was that estates tail and all remainders over and the reversion were effectually barred As Blackstone said, by long acquiescence and use, these recoveries came to be looked upon as a legal mode of conveyance by which a tenant in tail might dispose of his land. 2 Com. *117. This right of conveyance became, in contemplation of the law, an inherent and inseparable incident of an estate tail and covenants and conditions attempting to restrain the exercise of the right were held to be void. 1 Washburn on Real Property (6th Ed.) \& 18S. The same purpose was accomplished by the equally fictitious proceeding of fine.

In volume 4 of his Commentaries (14th Ed.) p. *14, Chancellor Kent said :

"Estates tail were introduced into this country with the other parts of the English jurisprudence, and they subsisted in full force before our Revolution, subject equally to the power of being barred by a fine or common recovery." 
These estates are now very generally changed by legislation into fee simples, or reversionary estates in fee simple, or may be converted into fee simples by ordinary conveyance, 2 Bl. Com. 119 (Cooley's note). In the pages following the above quotation from Kent much of this legislation is referred to.

The territorial legislature of 1855 passed an elaborate act relating to conveyances. Stat. of Kan. Terr. 1855, ch. 26. Section 5 of this act reads as follows:

"Ihat from and after the passage of this act, where any conveyance or devise shall be made whereby the grantee or devisee shall become seized in law or equity of such estate, in any lands or tenements, as under the statute of the thirteenth of Edward the first, (called the statute of entails) would have been held an estate in fee tail, every such conveyance or devise shall vest an estate for life only in such grantee or devisee, who shall possess and have the same power over and right in such premises, and no other, as a tenant for life thereof would have hy law; and upon the death of such grantee or devisee, the said lands and tenements shall go and be vested in the children of such grantee or devisee, equally to be divided between them as tenants in common, in fee; and if there be only one child, then to that one, in fee; and if any child be dead, the part which would have come to him or her shall go to his or her issue : and if there be no issue, then to his or her heirs."

This, of course, constituted a deliberate legislative modification of the common law relating to estates tail. In 1859 the territorial legislature completely revised the act of 1855 relating to conveyances, making radical changes in its substance and content. Laws 1859, ch. 30. The subject matter of the section quoted was entirely omitted and nothing whatever was substituted for it either in the revision or in any other statute. The result was that section 5 was repealed by implication, and since the legislature had its attention specially directed to estates tail by that section the purpose evidently was to restore the common law on the subject. This intention is made more apparent by the passage of the following act at the same session:

"The common law of England and all statutes and acts of Parliament in aid thereof, made prior to the fourth year of James the First, and which are of a general nature, not local to that kingdom and not repugnant to or inconsistent with the constitution of the United States and the act entitled 'An act to organize the Territory of Nebraska and Kansas,' or any statute law which may from time to time be made or passed by this or any subsequent Legislative Assembly of the Territory of Kansas, shall be the rule of action and decision in this Territory, any law, custom or usage to the contrary notwithstanding." Laws 1859 , ch. $121, \S 1$.

The constitution adopted in July, 1859, under which the state was admitted to the Union on Jantrary 31, 1861, contains nothing which bears upon the stubject either directly or remotely, and the legislature has not since dealt with it. Nothing is to be found in the acts relating 
to conveyances, descents and distributions, or wills, incompatible with the existence of such estates, and in their unfettered form such estates are not out of harmony with the conditions and wants of the people of Kansas. On the other hand, they exactly meet the requirements of testators in the situation of John Ewing. He desired to give his daughter an estate for life, in order to secure to her a home and some measure of comfort and welfare while she lived. After that he desired that the remainder should go to her children in fee. But he did not desire that his son-in-law should take the whole gift should she die childless, to be enjoyed by him and perhaps a strange second wife and their children. The court knows of no reason in law, morals, or public policy why these sentiments should not be respected, and they were clearly and fully expressed by the language of the will, interpreted by the common law. The overweening propensity to perpetuate family name and family property which made estates tail so obnoxious in the middle ages is fairly curbed by the right of a tenant in tail to convert his tenancy into a fee simple, and is not a menace to the general welfare of the people of this state; and it will be remembered that this right became one of the characteristics of the estate. Fines and recoveries, however, are not adapted to any of our needs, are inconsistent with the code of civil procedure and consequently can not be resorted to, as portions of the common law, in aid of the general statutes of this state. Gen. Stat. 1909, § 9850. The effect of these indirect, fictitious and operose proceedings was merely that of a deed of record, and the same end may now be accomplished by an ordinary conveyance. The fiction and the form alone are obsolete. The substance of the proceeding-a conveyance-and the essential character of the estate tail-the right to convert the estate into a fee simple by a conveyance-are preserved. If, therefore, Mary A. Nesbitt had chosen, in her lifetime, to make a conveyance of the land devised to her, she would thereby have barred herself, her issue, born and unborn, and her father's reversion.

While the mere possibility of a reverter such as attended conditional gifts under the ancient common law is not a subject of disposal by will, reversions in fee under the statute de donis may be devised. The result is that Mary A. Nesbitt was given by the will an estate tail in the land in controversy. She also took by virtue of the residuary clause of the will, one-fifth of the reversion in fee expectant upon her death without issue. Upon her death this interest passed to her husband, the defendant.

The judgment of the district court is affirmed. ${ }^{8}$

6 Estates in fee tail are recognized in Delaware as still subsisting. In Hazzard r. Hazzard (Del. Super.) 94 Atl. 905 (1915), it was held that upon a levy and sale under an execution against a tenant in tail the purchaser acquired a fee simple; the statute (Rer. Code Del. 1915, \$ 4365) providing that such purchaser should acquire such estate as the judgment debtor might conrey. By section 3235 , Rer. Code 1915 , it is provided that a person having an estate tail shall have power to alien the lands in fee simple or for other less estate by deed. See, however, the same case rerersed in 97 Atl. $2: 39$ (1916). 


\section{DUNGAN v. KLINE.}

(Supreme Court of Ohio, 1910. 81 Glio St. 371, 90 N. E. 93S.)

On October 27, 1906. Etta Kline commenced an action in the court of common pleas of Pickaway county against the plaintiff in error, Harrict Dungan and others, asking for the partition ot certain real estate in her petition described. Thereafter, to-wit, on November 22, 1906, Adolph G. Wilson also brought suit in said court of common pleas against said Harriet Dungan and others, asking partition of the same lands. On motion these cases were consolidated and tried as one case. The lands of which partition was asked consisted of three tracts, two of which, by the will of Titus Dungan, had been devised to "Elizabeth Wilson and the heirs of her body," and the other tract had been devised to said "Elizabeth Wilson and the heirs of her body" by one Mary Ann Kirkendall. 'The devisors Titus Dungan and Mary Ann Kirkendall both died prior to June 18, 18S3, and the will of each had been cluly admitted to probate prior to that time. The devisee Elizabeth IVilson had seven children, among whom were two sons, IVilliam T. and George H. Wilson. IVilliam T. Wilson died on January 16, 1887, his mother Elizabeth Wilson surviving him. She died October 27, 1906. On July 4, 1S7S, during the lifetime of his mother, IVilliam ' $\mathrm{T}$. Wilson deeded to one George Dungan an undivided one-seventh interest in the premises which had been devised to Elizabeth Wilson and the heirs of her body, and thereafter said George Dungan deeded the same to the plaintiff in error, Harriet Dungan. On June 1S, 1S83, George $\mathrm{H}$. Wilson, his mother being then in full life, also deeded an undivided one-seventh interest in said lands to George Dungan, which interest was subsequently deeded by said George Dungan to one John Schleyer and by the latter to Harriet Dungan, the plaintiff in error. George I. Wilson died in October, 1896, ten years prior to the death of his mother Elizabeth Wilson. The deeds of William T. and George $\mathrm{H}$. Wilson, although containing no covenants of general warranty, contained recitals that would perhaps estop each of them, if living, from asserting title to the property therein described.

The controversy in this case is between the children of William $T$. and George $\mathrm{H}$. Wilson on the one side, and Harriet Dungan the plaintiff in error on the other side. The children of William $\mathrm{T}$. and George H. Wilson claim to be the owners of, and entitled to such interest in the real estate to be partitioned, as would have descended to their fathers William ' $T$. and George $\mathrm{H}$. Wilson respectively, if they had survived their mother Elizabeth Wilson, the first donee in tail. Harriet Dungan, plaintiff in error, claims title to the same premises under and by virtue of the alleged conveyances made as aforesaid by said William ' $\mathrm{T}$. and George $\mathrm{H}$. Wilson in their lifetime, and she further contends that the children of the said William T. and George $\mathrm{H}$. Wilson, because of the recitals in said conveyances, are now estopped from claiming any interest in or title to the prenises sought to be par- 
titioned. In both the court of common pleas and the circuit courtto which latter court the case was taken on appeal-this claim of Harriet Dungan was determined against her. She now prosecutes error to this court asking a reversal of the judgment of the circuit court.

CrEw, J. If the estate tail devised to Elizabeth Wilson was not alienable by the issue in tail during her life, subject to her tenancy therein, then the grants made by William T. Wilson and George $\mathrm{H}$. Wilson, who both died before their mother, were wholly void and no estoppel thereunder can be invoked against their children. Therefore the decision of this case, upon the facts as presented by the record herein, depends primarily upon whether or not William T. and George $\mathrm{H}$. Wilson during the lifetime of their mother, were severally seized of a fee simple estate in the premises which they respectively assumed to convey to George Dungan. That under the wills of Titus Dungan and Mary Ann Kirkendall, Elizabeth Wilson, as devisee, took an estate tail in the premises in controversy, is conceded, and the contention of Harriet Dungan, plaintiff in error, is, that under the devises therein made to Elizabeth Wilson and the heirs of her body, that William ' $\mathrm{T}$. and George H. Wilson as her clildren, upon the death of saicl testators, each inmediately, by force of the provisions of Section 4200, Re= vised Statutes, became entitled to and vested with an absolute estate in fee simple to a one-seventh part of the premises so devised to their mother, Elizabeth IVilson, as first donee in tail. On the other hand, it is claimed by the children of WVilliam T. and George H. Wilson, all of whom are defendants in error herein, that their fathers, during the lifetime of Elizabeth Wilson, had no estate or interest in said prenises which they of right could alienate or convey, that until the death of said Elizabeth Wilson, the interest of WVilliam T. and George H. Wilson in said premises was that of a mere possibility or expectancy which could ripen into title and become a vested estate or interest, only in the event that they surviverl their mother, Elizabeth Wilson, the first donee in tail. In both the court of common pleas and in the circuit court, the contention of Harriet Dungan was held to be erroneous and was determined against her, and in this we think there was no error.

Section 4200, Revised Statutes, provides as follows: "No estate in fee simple, fee tail, or any lesser estate, in lands or tenements, lying within this state, shall be given or granted, by deed or will, to any person or persons but such as are in being, or to the immediate issue or descendants of such as are in being at the time of making such deed or will; and all estates given in tail shall be and remain an absolute estate in fee simple to the issue of the first donee in tail." Counsel for plaintiff in error, in discussing the effect of this statute, say in their brief : "The first part of the section, preceding the semi-colon, permits the granting of a limited estate tail and it forbids the granting of the same to persons who are in fact more remote than the immediate issue of persons in being at the time said grant is made." This claim, ignoring

7 Part of the opinion is omitted. 
as it does the word "descendants" found in the statute, is in part at least clearly erroneous. It will be observed that by the language of the first clause of this section the entailment by deed or will, is not restricted to persons in being, or to the immediate issue of such as are in being, but the limitation is, to persons in being, "or to the immediate issue or descendants of such as are in beirg at the time of making such deed or will." * * *

That, during the life of Elizabeth Wilson, first donee in tail, her children William T. and George $\mathrm{H}$. Wilson had no estate or interest in the premises devised to her which they of right could alien or convex, while not heretofore directly decided by this court has, we think, by necessary implication, been so determined in several cases. In Pollock v. Speidel, 17 Ohio St. 448, in discussing the scope and effect of the act of 1811 (now section 4200, Revised Statutes), Scott, J., says: "The statute recognizes the first donee in tail as holding an estate for life only, as tenant in tail; and does not convert the estate into a fee simple till it reaches the hands of his issue." While it would seem to be, and was, incorrect to speak of the first donee in tail as holding an estate for life, as tenant in tail, this apparent inaccuracy of statement is sufficiently, and we think correctly explained in Harkness v. Corning, 24 Ohio St. 428, where the court say: "A somewhat similar expression is used by the learned judge delivering the opinion of this court in Pollock v. Speidel, 17 Ohio St. 447. The controversy in that case was between the issue of the donee and the defendant, claiming under a conveyance from the donee, and the question was as to the quantity of interest conveyed. The judge said the 'statute recognizes the first donee in tail as holding an estate for life only, as tenant in tail.' The idea intended to be expressed was that the donee, holding only as tenant in tail, could not convey an estate that would endure beyond his own life. To give to the expression the meaning clained by plaintiff's counsel, that the donee took a mere life estate, would render the opinion not only inconsistent with itself but with the fourth proposition of the syllabus." This case of Harkness v. Corning, supra, is also decisive of the proposition, that the statute does not become operative until the estate passes by the first donee in tail and reaches the issue of such donee, when, as said in the opinion (24 Ohio St. at page 426), on the determination of the interest of such donee and of such rights as the law annexes to his interest while held by him, the statute then enlarges the estate tail in the hands of such issue into an absolute estate in fee simple.

When the case of Pollock v. Speidel, supra, was a second time before this court, 27 Ohio St. 86, the court, in considering and discussing the effect of the last paragraph of the statute which reads, "and all estates given in tail shall be and remain an absolute estate in fee simple to the issue of the first donee in tail," say that the issue of a tenant in tail "has no legal rights in the premises during the tenant's life. The issue takes, if at all, by descent as heir of the body, and the maxim is 'nemo est hreres viventis." "The action was one in ejectment, and was 
brought by the children of one James Pollock, who was the son of John Pollock, Jr., first donee in tail, against the defendant to recover possession of certain real estate of which they claimed to be seized in fee simple as heirs of said James Pollock. The defendant denied the title of plaintiffs and alleged title in himself under a conveyance from said James Pollock by deed of general warranty executed June 30, 1831. While it does not positively and affirmatively appear at what time John Pollock, Jr., the first donee in tail died, and the court in the opinion so state, yet it does appear from the agreed statement of facts therein: "III. That John Pollock, Jr., left some five children besides James Pollock, the grantee in the deed dated June 30, 1831." We therefore conclude that the fair and reasonable inference is, and that the fact was, that John Pollock, Jr., the father of James, died before he did, and as, upon the death of his father, James as issue in tail would thereupon take, by force of the statute an absolute estate in fee simple, with full power of alienation, he would of course, as would also his heirs, be estopped by his deed of June 30,1831, which was a deed of general warranty, and this would be so, as said by the court in that case, even though John Pollock the first donee in tail was living at the time of its execution. Upon no other theory, than that James survived his father, can the decision in this case be reconciled with other decisions of this court, or be supported and upheld.

Our statute of entailments, Section 4200, substantially in its present form, was copied from the statute of Connecticut, and the precise question we are now considering was decided by the supreme court of that state in Dart v. Dart, 7 Conn. 250, where it is said by Peters, J.: "2. What estate passed from the plaintiff, by his deed to the releasees? By the common law, a release is a secondary conveyance, and is a discharge of a man's right in land or tenements to another, who hath some former estate in possession. Shep. Touch. 318, 2 B1. Com., 328. But in this state, a release is considered as a primary conveyance, and passes all the right of the releasor to the releasee, provided no other person be in possession adversely; and operates as a conveyance without warranty. $1 \mathrm{Sw}$. Dig. 133. But if he have no right, nothing passes, not even a chose in action. What estate, then, had the issue of the first donee in tail, during his life? My answer is, none. The plaintiff cottld, therefore, convey none. Such issue is only an heir apparent or presumptive. His title is the bare possibility, or mere chance, of beconing eventually the heir in tail ; for the maxim is, "nemo est hares viventis." And it is a well settled rule, that a mere possibility can not be released or conveyed; and the reason thereof is, that a release supposes a right in being. Shep. Touch. 319; Bac. Abr. tit. Release, H."

It follows from the foregoing, we think, that the judgment of the circuit court in the present case was right and should be affirmed. Judgment affirmed. ${ }^{8}$

$s$ In many states statutes relative to estates tail have been passed. See 1 Stimson, Am. St. Law, § 1313; Brewster on Conveyancing, § 143 . In Mich- 


\section{SECTION 3.-LIFE ESTATES}

\section{Conventional}

\section{LITTLETON`S TENURES.}

Tenant for tcrm of life is, where a man letteth lands or tenements to anuther for term of the life of the lessee, or for term of the life of another man. In this case the lessee is tenant for term of life. But by conminon speech he which holdeth for term of his own life, is called tenant for term of his life, and he which holdeth for term of another's life, is called tenant for tem of another man's life (tenant pur terme d'autre vie.)

Section 56.

\section{COKE UPON LITTLETON.}

"Or for term of the life of another man." Now it is to be understood, that if the lessee in that case dieth living cesty que vie (that is he for whose life the lease was ma(le), he that first entereth shall hold the land during that other man's life, and he that so entereth is within Littleton's words, viz. tenant pur autre vie, and it shall be punished for waste as tenant pur auter vie, and subject to the payment of the rent reserved, and is in law called an occupant, because his title is by his first occupation. ${ }^{2}$ And so if tenant for his own life grant over his estate to another, if the grantee dieth there shall be an occupant. In like manner it is of an estate created by law; for if tenant by the curtesy or tenant in dower grant over his or her estate, and the grantee dieth, there shall be an occupant. But against the king there shall be no occupant, because nullum tempus occurrit regi. And therefore no man shall gain the king's land by priority of entry. There can be no occupant of anything that lieth in grant, and that cannot pass without deed, because every occupant must claim by a que estate and aver the life of cesty que vie. It were good to prevent the uncertainty of the estate of the occupant to add these words (to have and to hold to him

igan the statute is as follors: "All estates tail are aholished, and erery estate which would be adjudged a fee tail, according to the lims of the territory of Michigan, as it existed before the second day of March, one thousand eight lundred and twenty-one, shall for all purquses be adjudged a fee simple; and if no valid r'mainder be limited thercon, shall be a fee simple alsolute." Ilowell"s Aun. Nt. 1912, $\$ 10625$. There are many states in which the statutes are substintially as above, omitting the italicizerl portion; tle part in it:ulics, thougl not so common, is found in sereral statutes.

o See 1 Stimson's Am. St. Law, § 1335; Howell's Ann. Mich. St. 1912, \& 106is'; St. 7 Will. IV \& 1 Vict. c. 26 . ss. 3,6 ; St. 60 \& 61 lict. c. 65. part 1. 
and his heirs during tl.e life of cesty que vie) and this shall prevent the occupant, and yet the lessee may assign it to whom he will; or if he hath already an estate for another man's life without these words, then it were good for him to assign his estate to divers men and their heirs during the life of cesty que vie. ***

You have perceived, that our author divides tenant for life into two branches, viz., into tenant for term of his own life, and into tenant for term of another mar's life; to this may be added a third, viz., into an estate both for term of his own life, and for term of another man's life.

As if a lease may be made to A. to have to him for term of his own life, and the lives of $\mathrm{B}$. and $\mathrm{C}$. for the lessee in this case hath but one freehold, which hath this limitation, during his own life, and during the lives of two others.

If a man grant an estate to a woman dum sola fuit, or durante viduitate, or quandiu se bene gesserit, or to a man and a woman during the coverture, or as long as the grantee divell in such a house, or so long as he pay $\mathrm{xl}$. \& c. or until the grantee be promoted to a benefice, or for any like uncertain time, which time, as Bracton saith, is tempus indeterminatum: in all these cases, if it be of lands or tenements, the lessee hath in judgment of law an estate for life determinable, if livery be made; and if it be of rents, advowsons, or any other thing that lie in grant, he hath a like estate for life by the delivery of the deed, and in count or pleading he shall allege the lease, and conclude, that by forc c thereof he was seised generally for term of his life.

If a man make lease of a manor, that at the time of the lease made is worth $£ 20$. per annum, to another until $£ 100$. be paid, in this case because the annual profits of the manor are uncertain, he hath an estate for life, if livery be made determinable upon the levying of the $f 100$. But if a man grant a rent of $£ 20$. per annum until $£ 100$. be paid, there he hath an estate for five years, for there it is certain, and depends upon no uncertainty. And yet in some cases a man shall have an uncertain interest in lands or tenements, and yet neither an estate for life, for years, or at will. As if a man by his will in writing, devise his lands to his executors for payment of debts, and until his debts be paid ; in this case the executors have but a chattel, and an uncertain interest in the land until his debts be paid; for if they should have it for their lives, then by their death their estate should cease, and the debts unpaid; but being a chattel, it shall go to the executors of executors for the payment of his debts; and so note a diversity between a devise and a conveyance at the common law in his life time. And tenant by statute merchant, by statute staple, and by elegit, have uncertain interests in lands or tenements, and yet they have but chattels, and no freehold, whose estates are created by divers acts of parliament, whereof more shall be said hereafter. And so have guardians in chivalry which hold over for single or double value uncertain interests, and yet but chattels. 
If one grant lands or tenements, reversions, remainders, rents, advowsons, commons, or the like, and express or limit no estate, the lessee or grantee (due ceremonies requisite by law being performed) hath an estate for life. The same law is of a declaration of a use. A man may have an estate for term of life determinable at will; as if the king doth grant an office to one at will and grant a rent to him for the exercise of his office for term of his life, this is determinable upon the determination of the office.

A., tenant in fee simple, makes a lease of lands to B. to have and to hold to B. for term of life, without mentioning for whose life it shall be, it shall be deemed for term of the life of the lessee, for it shall be taken most strongly against the lessor, and as hath been said an estate for a man's own life is higher than for the life of another. But if tenant in tail make such a lease without expressing for whose life, this shall be taken but for the life of the lessor, for two reasons.

First, when the construction of any act is left to the law, the law which abhorreth injury and wrong, will never so construe it as it shall work a wrong; and in this case, if by construction it should be for the life of the lessee, then should the estate tail be discontinued, and a new reversion gained by wrong; but if it be construed for the life of the tenant in tail, then no wrong is wrought. And it is a general rule, that whensoever the words of a deed, or of the parties without deed, may lave a double intendment, and the one standeth with law and right, and the other is wrongful and against law, the intendment that standeth with law shall be taken.

Secondly, the law more respecteth a lesser estate by right, than a larger estate by wrong; as if tenant for life in remainder disseise tenant for life, now he hath a fee simple, but if tenant for life die, now is his wrongful estate in fee by judgment in law changed to a rightful estate for life.

Co. Litt. $41 b, 42$ a, b.

\section{LITTLETON'S TENURES.}

And it is to be understood, that there is feoffor and feoffee, donor and donee, lessor and lessee. Feoffor is properly where a man infeoffs another in any lands or tenements in fee simple, he which maketh the enfeoffment is called the feoffor, and he to whom the feoffment is made is called the feoffee. And the donor is properly where a man giveth certain lands or tenements to another in tail, he which maketh the gift is called the donor, and he to whom the gift is made is called the donee. And the lessor is properly where a man letteth to another lands or tenements for term of life, or for term of years, or to hold at will, he which maketh the lease is called lessor, and he to whom the lease is made is called lessee. And every one which hath an estate in any lands or tenements for term of his own or another man's life, 
is called tenant of freehold, and none other of a lesser estate can have a freehold; but they of a greater estate have a freehold; for he in fee simple hath a freehold, and tenant in tail hath a freehold, \&c.

Section 57.

\author{
ROSSE'S CASE. \\ (Court of Common Pleas, 1600. 5 Co. 13.)
}

Between Peter Rosse and Aldwick in an ejectione firmæ, which began Pasch. 37 Eliz. Rot. 499, the case was such; a lease is made to A. and his assigns, habendum to him during his life, and the lives of $\mathrm{B}$. and $\mathrm{C}$. and if this limitation during the life of $\mathrm{B}$. and $\mathrm{C}$. were void or not, was the question. And it was adjudged, that the limitation was good; for where it was objected that when a man hath two estates in him, the greater shall drown the less, and that an estate for his own life is higher than for the life of another; and therefore an estate for his own life, and for the lives of others cannot stand together. To that it was answered and resolved that in the case at Bar, the lessee had but one estate, which hath this limitation, scil. during his life, and the lives of two others, and he hath but one freehold, and therefore there cannot be any drowning of estates in the case, but he hath an estate of freehold to continue during these three lives, and the survivor of them. ${ }^{10}$

\title{
In re AMOS.
}

\section{CARRIER v. PRICE.}

(Court of Chancers. [1891] 3 Ch. 159.)

Originating summons by the executors of the will of James Amos, asking for the determination by the Court of questions arising in the administration of his estate.

By his will, dated the 20th of October, 1888, the testator appointed Robert Carrier and J. N. Clark to be his executors. And he gave, devised, and bequeathed unto Thomas Price a leasehold house known as 27, Bath Terrace, "the conditions to be as follows: that the property be left to him for his life and for the life of his heir, after which it becomes the property of the Boiler Makers and Iron Ship Builders Society." There followed similar gifts in precisely similar terms, and subject to exactly similar conditions, of two other (freehold) houses to Henry Poole and Thomas Henry Williams respectively. The will continued thus, "that each of the above keep the property held by them in good repair, and shall pay to the trustees the sum of $4 \mathrm{~s}$. per week, 
until the whole of the mortgage be paid. And that the further sum of $£ 36$ s. 8d. each per annum be paid by them to be disposed of as follows: viz., $£ 5$ per annum to the Boiler Makers Benevolent Fund, and $£ 5$ per annum to the executors. Should either of the parties refuse or fail to comply with the foregoing conditions they shall forfeit all rights to the property, and the executors shall cause the same to be handed over to the Boiler Makers Society forthwith."

The attesting witnesses to the will were the two executors.

The Defendants to the summons were the three devisees, Price, Poole, and Williams; the Boiler Makers and Iron Ship Builders Society; and the Boiler Makers Benevolent Fund; and Elizabeth Reece, the wife of J. H. Reece, who was the heiress-at-law and one of the next of kin of the testator.

The Boiler Makers Society was registered under the Trade Union Acts, 1871 and 1876. It was governed by an executive council. The rules provided for the payment by members of monthly contributions for the purpose of forming a fund for providing weekly pay for the members during sickness, super-annuation allowances, and other pecuniary benefits. There were also provisions relating to strikcs and trade disputes. Rule 39 provided for the formation of a Benevolent Fund for the benefit of the widows and children of members. This fund was under the control of the executive council.

The summons asked that a construction might be put upon the devises, bequests, and directions in the will contained of and concerning the three houses given to Price, Poole, and Williams respectively, and that the effect of the gift of $£ 5$ per annum to the Boiler Mlakers Benevolent Fund and $£ 5$ per annum to the executors might be determined.

NorTh, J. ${ }^{11} * * *$ The only remaining question is, what interest do the tenants for life take? I confess I do not understand what the testator had in his mind; and I can only construe his language as I find it. In my opinion, the property is given to each devisce or legatee for a limited interest, which is described as "for his life and for the life of his heir." For the devisee's own life the gift is clearly good. The question is, whether the interest which he takes comes to an end upon his death, the interest for the life of his heir being too vague to be recognized. I do not see any reason in point of law which prevents the gift from being good. There is no hiatus of any kind; the gift to the devisee for his life would necessarily come to an end at his death. But at the very moment of his death the person who is his heir is ascertained, and there is nothing discontinuous in the limitation which prevents it from being good. I see no ground for saying that the heir takes beneficially. In my opinion, it is a limitation to a tenant for two lives, the lives being his own and that of his heir in each case. I think that is the meaning of the testator's words, and I can sce nothing in law to prevent their taking effect.

11 Part of the opinion is omitted. 
The two annual payments to the executors and to the Penevolent Fund are void. The payment of these sums is a condition subsequent, and, as the person who takes the land cannot legally pay them, he is not liable to forfeit his land by reason of his not doing that which he cannot legally do.

\section{THOMPSON v. DAXTER.}

(Supreme Court of Minnesota, 1009. 107 Minn. 122, 110 N. W. 797, 21 I. R. A [N. S.] 5T5.)

Brown, J. Proceedings in forcible entry and unlawful detainer, instituted in justice court, where defendant had judgment. Plaintiff appealed to the district court, where a like result followed. From the judgment of that court she appealed to this court.

The action involves the right to the possession of certain residence property in the city of Albert Lea, and was submitted to the court below upon the pleadings and a stipulation of facts. It appears that plaintiff is the owner of the premises; that she acquired title thereto by purchase from a former owner, who had theretofore entered into a contract by which he leased and denised the premises to defendant at an agreed monthly rent of twenty-two dollars; and plaintiff's title is subject to all rights that became vested in defendant thereby. The lease, after reciting the rental of the premises and other usual conditions, contained upon the subject of the term of the tenancy, the following stipulation: "To have and to hold the above-rented premises unto the said party of the second part (the tenant) his heirs, executors, administrators, and assigns, for and during the full term of while he shall wish to live in Albert Lea, from and after the first day of December, 1904." The only question involved uncler the stipulation is the construction of this provision of the lease. Defendant has at all times paid the rent as it became due; but, if plaintiff has the right to terminate the tenancy and eject him, proper notice for that purpose has been given. Appellant contends that the lease created either a tenancy at will, at sufferance, or from month to month, and that plaintiff could terminate the same at any time by proper notice. The trial court held, in harmony with defendant's contention, that the contract created a life estate in defendant, terminable only at his death or removal from Albert Lea. Appellant assigns this conclusion as error.

A determination of the question presented involves a construction of the lease and a brief examination of some of the principles of law applicable to tenancies at will, at sufferance, from month to month, and life estates. Deeds, leases, or other instruments affecting the title to real property are construed, guided by the law applicable to the particular subject, precisely as other contracts are construed, and effect given the intention of the parties. Lawton v. Joesting, 96 Minn. 163, 
104 N. W. 830; Whetstone v. Hunt, 78 Ark. 230, 93 S. W. 979, 8 Ann. Cas. 443, and extended note. The contract before us, though somewhat peculiar and unusual as to the term of the tenancy intended to be created, is nevertheless clear and free from ambiguity. It granted the demised premises to defendant "while he shall wish to live in Albert Lea." The legal effect of this language is, therefore, the only question in the case.

Tenancies at will may be created by express words, or they may arise by implication of law. Where created by express contract, the writing necessarily so indicates, and reserves the right of termination to either party, as where the lease provides that the tenant shall occupy the premises so long as agreeable to both parties. Richardson v. Langridge, 4 Taunt. 128; Say v. Stoddard, 27 Ohio St. 478. Such tenancies arise by implication of law where no definite time is stated in the contract, or where the tenant enters into possession under an agreement to execute a contract for a specific term and he subsequently refuses to do so, or one who enters under a void lease, or where he holds over pending negotiations for a new lease. The chief characteristics of this form of tenancy are (1) uncertainty respecting the term, and (2) the right of either party to terminate it by proper notice; and these features must exist, whether the tenancy be created by the express language of the contract or by implication of law. An accurate definition is given in 1 Wood, Landlord \& Tenant, 43 , in the following language: "A tenant at will is one who enters into the possession of the lands or tenements of another, lawfully, but for no definite term or purpose, but whose possession is subject to termination by the landlord at any time he sees fit to put an end to it. He is called a tenant at will "because he hath no certain or sure estate, for the lessor may put him out at what time it pleaseth him.' "

A tenancy at sufferance arises where the tenant wrongfully holds over after the expiration of his term, differing from the tenancy at will, where the possession is by the permission of the landlord. 4 Kent, Com. 117; Edwards v. Hale, 9 Allen (Mass.) 462. He has a naked possession without right, and, independent of statute, is not entitled to notice to quit. 1 Wood, Landlord \& Tenant, § \&. It also arises where a mortgagor holds over after the expiration of the period of redemption on foreclosure. Stedman v. Gassett, $18 \mathrm{Vt}$. 346 . In fact, this relation exists in all cases where a person who enters lawfully into the possession wrongfully holds possession after his estate or right has ended. Kinsley v. Ames, 2 Metc. (Mass.) 29; Jackson v. McLeod, 12 Johns. (N. Y.) 182; 2 Blackstone, 150; 1 Wood, Landlord \& Tenant, 7 .

A tenancy from month to month or year to year arises where no definite time is agreed upon and the rent is fixed at so much per year or month, as the case may be, and is terminable at the expiration of any period for which rent has been paid. Finch v. Moore, 50 Minn. 116, 52 N. W. 384. This form of tenancy can never exist where 
the lease or contract prescribes a fixed time. The mere fact that rent is payable monthly does not alone determine the character of the tenancy. The monthly or yearly payments and an intention to limit the term to a month or year must in all cases concur to create this species of tenancy.

From these general principles of the law of tenancy it is quite clear that the lease under consideration does not come within either class mentioned. Its language does not expressly define it as a tenancy at will, and no such relation arises by implication, for the reason that the term is not indefinite, within the meaning of the law on this subject, nor is the right to terminate the lease reserved to the lessor. Indefiniteness or uncertainty as to the term of the lease is illustrated by instances where one occupies land by the naked permission of the owner (Hull v. Wood, 14 Mees. \& W. 681; Williams v. Deriar, 31 Mo. 13; Larned v. Hudson, 60 N. Y. 102), or a person who holds under a void deed (Stamper v. Griffin, 20 Ga. 312, 65 Am. Dec. 628; Executors v. Houston, $16 \mathrm{Ala} .111)$, or where he enters under an agreement for a lease not yet executed (Emmons v. Scudder, 115 Mass. 367), or under a lease until the premises are sold (Lea v. Hernandez, 10 'Tex. 137; Ela v. Bankes, 37 Wis. 89), and under various circumstances where no time is specifically agreed upon. In the lease under consideration the tenancy is linited by the time defendant shall continue to dwell in Albert Lea, and this limitation takes the case out of the class of tenancies at will. It is equally clear that a tenancy at sufferance was not created by the contract. There has been no wrongful or unlawful holding over after the expiration of the term. Nor does the rule of tenancy from month to month apply for the reasons already pointed out.

We therefore turn to the question, the turning point in the court below, whether the instrument created a life estate in defendant within the principles of law applicable to that branch of land titles. It is thoroughly settled that a life estate may be created by a deed, lease, or devise, either with or without a stipulation for the payment of rent. This class of tenancies differs in many essential respects from tenancies at will, or from year to year, or at sufferance; the principal distinction being that the former confers a freehold upon the tenant, and the latter a mere chattel interest. The lease under consideration embodies all the essentials of a life tenancy. It contains the usual words of inheritance, necessary at common law, running to defendant, "his heirs, executors, administrators, and assigns," and grants the right of occupancy for the term stated therein.

Life estates or life tenancies are clearly defined in the books, and the lease here involved brings it within this class of estates. 1 Taylor, Landlord \& Tenant, $\S \S 52,53$, states the rule as follows: "An estate for life may be created either by express limitation or by a grant in general terms. If made to a man for the term of his own life, or AIG.ProP.-37 
for that of another person, he is called a tenant for life. But the estate may also be created by a general grant, without defining any specific interest, as where a grant is made to a man, or to a man and his assigns without any limitation in point of time, it will be considered as an estate for life, and for the life of the grantee only. *** Where a grant is made, subject to be defeated by a particular event, and there is no limitation in point of time, it will be ab initio a grant. of an estate for life, as much as if no such event had been contemplated. 'Thus, if a grant be made to a man so long as he shall inhabit a certain place, or to a woman during her widowhood, as there is no certainty that the cstate will be terminated by the change of habitation or by the marriage, respectively, of the lessees, the estate is as much an estate for life, until the prescribed event takes place, as if it had been so granted in express terms."

The author's statement of the law is sustained by the other writers on the subject (4 Kent, Com. 27; 2 Blackstone, 121), and by the adjudicated cases. In Warner v. Tanner, 38 Ohio St. 118, a life estate was held to be created by a lease for a yearly rent extending during the time the lessee should continue to occupy the premises for a particular purpose. In Mickie v. Woods' Ex'r, 5 Rand. (Va.) 571, 574, the grant was to continue so long as the tenant should pay the stipulated rent. It was held a life estate. A grant "so long as the waters of the Delaware shall run" was held in Foster v. Joice, 3 Wash. C. C. 498, Fed. Cas. No. 4,974, to create a life estate. In Hurd v. Cushing, 24 Mass. (7 Pick.) 169, the premises were leased at a fixed yearly rent for the term "so long as the salt works" to be located thereon should continue in operation. It was held a life estate. In Thonas v. Thomas, 17 N. J. Eq. 356, it was held that a right given by a will to occupy at a specified annual rent certain premises so long as the devisee "may desire to occupy the same as a drug store" amounted to an estate for life. See also to the same effect, 16 Cyc. 614; Maverick v. Gibbs, 3 McCord (S. C.) 315; People v. Gillis, 24 Wend. (N. Y.) 201 ; Roseboom v. Van Vechten, 5 Denio (N. Y.) 414; Ely v. Randall, 68 Minn. 177, 70 N. W. 980.

The lease in the case at bar comes within the rule of these anthorities, and the trial court properly held that it vested in defendant a life estate, terminable only at his death or his removal from Albert Lea.

$$
\text { Judgment affirmed. }{ }^{12}
$$

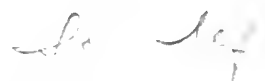

12 Beauchamp v. Runnels, 35 Tex. Civ. App. 212, 79 S. W. 1105 (1904), contra. By act of I'arliament the fee of certain lands was vested in a board of deputies, which was anthorized to allot portions of the lands to persons to hold same so Jong as they should be willing, and pay a specified annual rent, and conform to the orders and regulations to be made from time to time by the deputics. The serenteenth section of the act empowered the deputies to disnose. by absolute sale, any portion of the premises, freed from any claim by any resident allottee. By the twenty-second section $\mathrm{n}$ o sale was to be effected without the consent of the majority of the allottees in regular meeting as- 


\section{LEGAL}

\section{(A) In Tail After Possibility of Issue E.rtinct}

\section{LITTTLETON'S TENURES.}

Tenant in fee tail after possibility of issue extinct is, where tenements are given to a man and to his wife in especial tail, if one of them die without issue, the survivor is tenant in tail after possibility of issue extinct. And if they have issue, and the one died, albeit that during the life of the issue, the survivor shall not be said tenant in tail after possibility of issue extinct; yet if the issue die without issue, so as there be not any issue alive which may inherit by force of the tail, then the surviving party of the donees is tenant in tail after possibility of issue extinct.

Also, if tenements be given to a man and to his heirs which he shall beget on the body of his wife, in this case the wife hath nothing in the tenements, and the husband is seised as donee in especial tail. And in this case, if the wife die without issue of her body begotten by he1 husband, then the husband is tenant in tail after possibility of issue extinct.

And note, that none can be tenant in tail after the possibility of issue extinct, but one of the donees, or the donee in especial tail. For the donee in general tail cannot be said to be tenant in tail after possibility of issue extinct: because always during his life, he may by possibility have issue which may inherit by force of the same entail. And so in the same manner the issue, which is heir to the donees in especial tail, cannot be tenant in tail after possibility of issue extinct, for the reason abovesaid.

And note, that tenant in tail after possibility of issue extinct shall not be punished of waste, for the inheritance that once was in him, $10 \mathrm{H}$. 6. 1. But he in the reversion may enter if he alien in fee, $45 \mathrm{E}$. 3. 22 .

\section{Sections 32, 33, 34.}

sembled. Under a statute allowing only freelolders to vote at a certain elec tion, was an allottee of such lituds entitled to rote?

Under a devise "to M." of "my" cottage and all it contains at Nahant-to use for the term of five years or longer," what estate did M. take?

Land was leased at a certain rent "for such time as the lessee, his heirs and assigns, may occupy the same for a sawmill yard." There was a provision that possession should be yielded to the lessor, "his beils or assigns, at the time of the expiration of the occupation of said premises for sawmill purposes." What estate did the lessee have? See Gilmore v. Hamilton, 83 Ind. 196 (1SS2). 


\section{(B) Husband's Interest in Wife's Realty}

\section{LITTLETON'S TENURES.}

Tenant by the curtesy of England is, where a man taketh a wife seised in fee simple or in fee tail, general, or seised as heir in tail especial, and hath issue by the same wife male or female born alive (oyes ou vife,) albeit the issue after dieth or liveth, yet if the wife dies, the husband shall hold the land during his life by the law of England. And he is called tenant by the curtesy of England, because this is used in no other realm but in England only.

And some have said, that he shall not be tenant by the curtesy, unless the child, which he hath by his wife, be heard cry; for by the cry it is proved, that the child was born alive. Therefore Quiere. Section $3 j$.

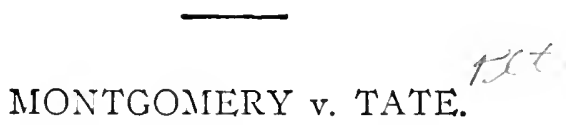

(Supreme Court of Indiana, 1559. 12 Ind. 615.)

WORDEN, J. This was an action by the appellee against the appellant, to recover the possession of a certain piece of land described in the complaint. There are two paragraphs in the complaint, one claiming a fee simple, and the other a life estate in the land.

Answer in denial. Trial by jury; verdict and judgment for plaintiff, over a motion for a new trial.

By a bill of exceptions it appears, that on the trial the plaintiff proved, prima facie, a title to the land in herself, either in fee simple or for life; but whether her evidence established, prima facie, a fee simple interest in her, or a life estate merely, it is wholly unnecessary to determine for the purposes of this case; therefore we shall express no opinion in reference to it.

After the plaintiff became seized of the premises, she intermarried with one John B. Tate, who is still living, and the husband of the plaintiff. Afterwards, in September, 1840, Bates and Abrams recovered a judgment in the Fayette Circuit Court against IVilliam 'Tully and the said John B. Tate, for the sum of 177 dollars, 60 cents, besides costs of suit, on which an execution was afterwards issued, which was levied upon the property in controversy, as the property of said John B. Tate, "for and during the natural life of Ursula Tate, wife of said John B. Tate," and the property, on a venditioni exponas, was afterwards sold, according to law, to satisfy the judgment and costs.

James Miller and Sanford P. White became the purchasers at the sheriff's sale, and received his deed for the premises, conveying 
to them the interest of said John B. Tate therein during the lifetime of his wife, Ursula Tate. This took place in 1842. Niller and White afterwards conveyed to Elisha Vance, and Vance to the defendant, Montgomery.

On these facts, the Court charged the jury, "that if they believed the evidence, it would be their duty to find for the plaintilf."

The defendant asked several charges, to the effect that if the jury believed the propositions relied upon by defendant in support of his title (substantially those contended in the evidence), it would be their duty to find for the defendant. These were refused, and the defendant excepted to the ruling of the Court in giving and refusing the charges.

At common law, by the marriage of Ursula with John B. Tate, he became entitled to an estate in her lands during their joint lives. This estate is as absolute and perfect in him during that period, as if acquired by conveyance, or in any other mode. It is sulbject to sale on execution against him, and may be conveyed by him. Vide 2 Kent's Con. 131; Butterfield v. Peall, 3 Ind. 203; Junction Railroad Co. v. Harris, 9 Ind. 184, 68 Am. Dec. 618.

But it is contended that the law of 1838 (R. S. 1838 , p. $276, \S 1$ ), in force at the time of the sale in question, subjecting property to sale on execution, does not authorize such estates to be sold on execution. It provicles, "that the personal and real estate of every individual," \&ce, "including his, her, or their goods, chattels, lands, tenements and hereditaments, be and the same are hereby made subject to execution," \&c.

The counsel say that, "Nowhere do they find any law authorizing the selling of the wife's interest in land for the debts of her husband." No interest of the wife is sold; for the entire estate in the land is, by the marriage, vested in the husband during their joint lives. During their joint lives she has no estate in the lands. Such estate being vested in the husband, it is very clearly within the terms of the statute, and subject to sale on execution against hinl.

Subsequent legislation has, perhaps, changed this rule. See Acts of 1847, p. 45 , and 1 R. S. p. $321, \S 5$. But these acts can liave 110 influence on the case at bar, as the sale here took place before either of them was enacted.

A contingency may arise that will abridge the term conveyed by the sheriff's deed, to a less period than that of the life of said Ursula. The death of said John B. leaving her surviving him, would, perhaps, terminate the estate conveyed; but this does not at all vitiate the deed. It would be good for whatever interest he had in the premises, not extending beyond the lifetime of said Ursula.

Both husband and wife being still alive, the term conveyed by the sheriff's deed is not yet expired, and the defendant's title to premises derived from such sale, still subsists. 
The ruling of the Court was wrong, and the judgment must be reversed.

The judgment is reversed with costs. Cause remanded for a new trial. $^{13}$
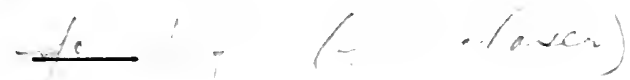

\section{MATTOCKS v. STEARNS.}

(Supreme Court of Vermont, 1S:37. 9 vt. 526.)

This was an action of ejectment for about seven eighths of an acre of land in the village of Danville.

Plea, severally, not guilty, and issue to the jury. On trial the plaintiffs introduced a deed from Josiah Bellows to Caleb Wheaton, dated 10th May, 1828, containing the land in question. He also introduced, a lery of execution upon the same land in his favor, against John Stearns, one of the defendants, dated August 5th, 1834. He then introduced cvidence, tending to prove, that Caleb Wheaton was the father of John Stearns' wife, the other defendant, and that he died seized and possessed of the premises sued for, and that his estate was nearly settled and the debts all paid, and that he left a wife and two children living, to wit: Mirs. Stearns and Zalmon Wheaton.

The plaintiff further introduced evidence tending to show, that John Stearns had absconded to Canadla, about two years ago, and a short time before the levy, and that his wife and children lived on and took care of the premises.

The plaintiff then produced two written notices, one to Mrs. Stearns, and one to C. Davis, defendants' counsel, requiring them to produce a deed, from said Zalmon Wheaton to Mrs. Stearns, of the premises, and no deed being produced by defendants and no copy of any deed being offered by the plaintiff, he offered Zalmon Wheaton as a witness to prove the contents of a deed, executed by him; which testimony was objccted to by the defendants but was admitted by the court, and said Zalmon was sworn, and testified that he, on the 5th October, 1832, executed a quit claim deed of the premises to his sister, Mrs. Stearns, and that she, at the same time, executed a quit claim deed to the witness of some other real estate left by their father, and that there was no distribution of the real estate among the heirs by decree of the probate court, and that the widow of Caleb. Wheaton had relinquished her right of dower, in consideration of a support, guarantied by the witness. Here the plaintiff rested his case. It was

13 "We are still living under the common-law rule which gives the husband a freehold estate for the joint lives of himself and his wife in her lands which she held at the time of her marriage, except such as she held to her sole and separate use. In this land, therefore, the petitionee has such a freehold interest. In that sense and to that extent it is his estate. He is entitled to the rents and rrofits thereof." Hubbard v. Hubbard, 77 Vt. 73, 76, 5S Atl. 969, 67 I. R. A. 969,107 Am. St. Rep. 749, 2 Ann. Cas. 315 (1904), per Stafford, J. See, also, Ballantine \& Sons r. Fenn, SS Vt. 166, 170, 92 Atl. 3 (1914). 
admitted the defendants had issue born alive. The defendants requested the court to instruct the jury, that upon this evidence the plaintiff was not entitled to recover against both defendants, or either. But the court instructed the jury, that if they believed the said testimony, the plaintiff was entitled to recover possession of the premises, and costs, against both defendants; to which decision of the court, in admitting parol evidence, in relation to the deed to Mrs. Stearns, and to the said instructions to the jury, the defendants excepted.

REDFILLD, J. ${ }^{14} * * *$ The freehold title of the wife being made out, and the plaintiff's levy being admitted to be formal, and it being also admitted, that the defendants had issue born alive, it only remains to inquire whether the defendant, John Stearns, had such an estate in the land, as was liable to be levied upon by his creditors.

The statute provides that, "any estate, held by the debtor in his own right in fee, or for his own life, or the life of another, paying no rents therefore," shall be subject to be levied upon.

We see no difficulty in considering this an estate, which the debtor held in his own right. The title was, indeed, derived throngh the right of his wife, but, by virtue of the marriage, he, as husband, acquires certain rights, among which, the use of the freehold estate of inheritance of the wife, during the coverture, is one. After issue born alive, this estate is enlarged and extends not only during the coverture, but till the death of the husband, except in one event, which will be named hereafter. This, in England, after the death of the wife, was denominated an estate by the curtesy, but is strictly an estate, which the husband holds in his own right, whether before or after the death of the wife. He may bring trespass or ejectment in his own name, for any injury to the usufruct during the continuance of his estate.

The next inquiry is, whether this is an estate for the life of the debtor. It is undoubtedly true, that this estate might be determined by a divorce, a vinculo, before the death of either husband or wife. But this is a contingency of so remote expectation, as not to enter into the ordinary calculations of the duration of the relation of married life. It is one of those extreme cases, which, like earthquakes and tempests in the natural world, or like public executions in the history of individual existence, do, indeed, sometimes occur, but which no one feels bound to expect or to provide against.

14 Only a portion of the opinion is given here.

In Canby v. Porter, 12 Ohio, 79 (1813), the plaintiff in ejectment claimed under an execution sale upon a judgment against the defentant. The lind in question was owned in fee by defendant's wife. Issue had been born. In upholding plaintiff's contention the court said: "We have been furnished with no argument by the defendant: but the plaintiff's right to recover seems plain. For the interest of the husband is a legal estate; it is a frechold during the joint lires of himself and wife, with a freehold in remainder to himself for life, as tenant by the curtesy, and a remainder to the wife and her heirs, in fee. It is a certain and determinate interest, whose value may be casily ascertained by reference to well-known rules. It is, in every sense, his 'land,' within the meaning of the statute, and liable to respond for his debts." 
This, then, is an estate for the life of the debtor, depending upon this remote contingency, which no honest or prudent man could anticipate in his own case, and which the law cannot regard until it occurs. And should the contingency happen, and thus the estate of the levying creditor be determined, it is no detriment to the debtor, nor has he any just cause of complaint. His debt is paid, and the loss and risk, if any, fall upon the creditor.

but if this were a contingency still less remote, it would not change the character of the estate.

An estate to a woman durante viduitate, or dum sola, or to a man, so long as he shall dwell in a particular house, are all estates for life, although each particular class of those estates is liable to be determined any hour, and that during the life time of the person, by the term of whose existence the estate is otherwise to be measured. 1 Cruise's Digest, 77. 1 Institutes, 42 , a. * * *

The judgment of the County Court is affirmed.

\section{FOSTER v. MARSHALL.}

(Sunerfor Court of Judicature of New Inmpshire, 1551. 22 N. II. 401.)

Writ of entry. The facts in this case are sufficiently stated in the opinion of the Court.

BELL, J. The principal question arising in this case, is as to the effect of the Statute of Limitations upon the demandant's right of action. It appeared that the demanded premises were set off by a committee of partition, appointed by the Court of Probate, to Mary Foster, formerly Mary Eastman, the mother of the demandant, as her share of the estate of her father, Samuel Eastman, deceased, on the 14th of May, 1814. Mary Foster was then the wife of Frederick Foster, by whom she then had one or more children. Frederick Foster died in 1834, and his wife in 1836 . They had six children, whose rights are said to be now vested in the plaintiff.

The defendant proved, that in 1817 , one Morrill was in possession, claiming to be the owner of the demanded premises. He conveyed the same by deed, dated July 3,1817 , to one Marshall, who entered and occupied, claiming title, till April 30th, 1847, when he conveyed to the tenant, who has since remained in possession. The tenant claims that he has a perfect title by thirty years undisturbed and peaceable possession. The demandant alleges that his right is not barred, because at the time when the disseisin occurred, in 1817, Mrs. Foster was a feme covert, and up to 1834 her husband had an estate for life in the premises and she had no right of entry until his decease, and consequently no right of action till then, and that since that time twenty years have not elapsed.

Under the Statute of Limitations, which was in force in this State before the Revised Statutes, it must be considered settled, that the 
statute did not affect the right of a remainderman or reversioner, during the continuance of the particular estate; and that neither the acts nor the laches of the tenant of the particular estate could affect the party entitled in remainder. Wells v. Prince, 9 Mass. 503; Wallingford v. Hearl, 15 Mlass. 471; 'Tilson v. Thompson, 10 Pick. (Mass.) 359 .

No right of entry or action accrued to, or vested in the heirs of the wife during the continuance of an estate by the curtesy. Jackson v. Schoonmaker, 4 Johns. (N. Y.) 390.

But the party entitled is not barred, until the usual period of limitation after the termination of the life estate. Heath v. White, 5 Conn. 228; Witham v. Perkins, 2 Greenl. (Ne.) 400.

If, then, the husband had, in this case, an estate by the curtesy, or any interest in the land which would entitle his wife, who survived, to be regarded as seised only in remainder or reversion, she and her heirs would have the full period of twenty years after the death of the husband, to commence their action.

To constitute a tenancy by the curtesy, the death of the wife is one of the four things required. The estate of the husband is initiate upon the birth of issue. It is consummate on the death of the wife. 4 Kent's Comm. 29; Co. Litt. 30, a.

By the intermarriage, the husband acquires a frechold interest, during the joint lives of himself and his wife, in all such freehold property of inheritance, as she was seised of at the time of marriage, and a like interest vests in him in such as she may become seised of during the coverture. The husband acquires jointly with the wife, a seisin in fee in the wife's freehold estates of inheritance, the husband and wife being seised in fee in right of the wife. Gilb. Ten. 108; Co. Litt. 67, a; Palyblank v. Hawkins, 1 Saund. Rep. 253, n.; s. c. Doug. 350 .

This interest may be defeated by the act of the wife alone; as if, at common law, the wife is attainted of felony, the lord by escheat could enter and eject the husband. 4 Hawk. P. C. 78; Co. Litt. 40, a : Vin. Ab. Curtesy, A; Co. Litt. 351, a.

After the birth of issue the husband is entitled to an estate for his own life, and in his own right, as tenant by the curtesy initiate. Co. Litt. 351, a, 30, a, 124, b; Schermerhorn v. Miller, 2 Cow. (N. Y.) 439. He then becomes sole tenant to the lord, and is alone entitled to do homage for the land, and to receive homage from the tenants of it, which until issue born must be done by husband and wife. 2 Black. Comm. 126; Litt. §90; Co. Litt. 67, a, 30, a.

Then he may forfeit his estate for life by a felony, which, until issue born, he could not do, because his wife was the tenant. 2 Black. Conm. 126; Roper, Hus. \& Wife, 47.

If the husband, after the birth of issue, make a feoffment in fee, and then the wife dies, the feoffee shall hold the land during the husband's 
life; because by the birth of issue, he was entitled to curtesy, which beneficial interest passed by the feoffment. Co. Litt. 30, a.

If such feoffment is made before issue born, the husband's right to curtesy is gone, even though the feoffment be conditional and be afterwards avoided. And if in such case the husband and wife be divorced a vinculo matrimonii, the wife may enter immediately. Guneley's Case, 8 Co. Rep. 73.

The husband's estate after issue born, will not be defeated by the attainder of the wife, for his tenancy continues, he being sole tenant. 1 Hale, P. C. 359; Co. Litt. 351, a, 40, a; Bro. Ab. Forf. 78.

The obrious conclusion from these views of the nature of the interest of a tenant by the curtesy initiate is, that such tenant is seised of a freehold estate in his own right, and the interest of his wife is a mere reversionary interest, depending upon the life estate of the husband. The necessary result of this is, that the wife cannot be prejudiced by any neglect of the luusband, and of course she may bring her action, or one may be brought by her heirs, at any time within twenty years after the decease of the husband, when his estate by the curtesy, whether initiate, or consummate, ceases, and her right of action, or that of her heirs, accrues. In this respect there is no distinction between curtesy initiate and curtesy consummate. Melvin v. Locks \& Canals, 16 Pick. (Mass.) 140.

So far as we are aware, this principle has never been questioned, where the inheritance of the wife has been conveyed to a third person, either by the deed of the husband alone, or by a deed executed by husband and wife, which from some defect did not bind the interest of the wife. Miller v. Shackleford, 3 Dana (Ky.) 289; Culler v. Metzer, 13 Serg. \& R. (Pa.) 356, 15 Am. Dec. 604; Fagan v. Walker, 27 N. C. 634; McCorry v. King, 3 Humph. 267, 39 Am. Dec. 165; Mellus v. Snowman, 21 Me. 201; Meraman v. Caldwell, 8 B. Mon. (Ky.) 32, 46 Am. Dec. 537; Gill v. Fauntleroy, \& B. Mon. (Ky.) 177; Melvin v. Locks \& Canals, 16 Pick. (Mass.) 140. But it has been held, (Melvin v. Locks \& Canals, 16 Pick. (Mass.) 161; Kittredge v. Locks \& Canals, 17 Pick. (Mass.) 246, 28 Am. Dec. 296,) that where a disseizin has been committed upon the wife's estate, the disseizin is done alike to the husband and wife; that a joint right of entry and of action accrues to both for the recovery of it, and that if such remedy is not prosecuted within twenty years, it is barred.

This is true where the husband has acquired no estate by the curtesy, and is seized merely in the right of the wife of her estate. Such are the cases of Guion v. Anderson, 8 Humph. (Tenn.) 298; Mellus v. Snowman, 21 Me. 201.

And if the husband is tenant by curtesy, as he and his wife are seized of the fee in right of the wife, the action must be brought by husband and wife, and a joint seizin in fee alleged in them in her right. Anon., Buls. 21. Their joint right of action is barred by the 
lapse of twenty years after it accrues. But it by no means follows, that the reversionary right of the wife, accruing in possession after the estate of her husband has ceased, is also barred. It is well settled, that the same party may have several and successive estates in the same property, and several rights of entry by virtue of those estates, and one of those rights may be barred without the others being affected. Hunt v. Burn, 2 Salk. 422; Wells v. Prince, 9 Mass. 508; Stevens v. Winship, 1 Pick. (Mass.) 318, 11 Am. Dec. 178; Tilson v. Thompson, 10 Pick. (Mass.) 359.

And every reason, which can exist in favor of the right of any reversioner, applies equally in this case, namely, that a reversioner has as such, no right of entry and no right of action during the particular estate, and consequently is not barred until twenty years after his own right of entry accrued. 2 Sugd. V. \& P. 353; 3 Steph. N. P. 2920, n. 10; Wells v. Prince, 9 Mass. 508; Stevens v. Winship, 1 Pick. (Mass.) 318; Wallingford v. Hearl, 15 Mass. 471; Tilson v. Thompson, 10 Pick. (Mass.) 359; Jackson v. Schoomaker, 4 Johns. (N. Y.) 390, before cited. Besides, the wife by reason of her disability can make no entry to revest her estate during the coverture. Litt. p. 403 ; Co. Litt. 246, a. Coke says, in express terms, "after coverture, she (the wife,) cannot enter without her husband."

In Jackson v. Johnson, 5 Cow. (N. Y.) 74, 15 Am. Dec. 433, and Heath v. White, 5 Conn. 22S, this question arose, and was decided in accordance with our views, and we think upon sounder principles than the cases in Massachusetts, to which we have referred.

We have compared the provisions of the Revised Statutes with the older Statutes, and do not perceive, that there is, as to the point in question, any difference in their effect. Under neither would the plaintiff propose to claim any advantage from the proviso. His ground is not that the ancestor was a married woman, when her right accrued; but that her marriage and the birth of one or more children had vested a life estate in her husband, and that the disseizin was done to him, and that no right of action accrued to her in virtue of the reversionary interest, under which her heirs now claim, until she became a widow, and the husband's estate had terminated; and that the action is brought within twenty years after that event. This appears to us a correct view of the case, and of the law; and the verdict must therefore be set aside, and a

New trial granted. 


\section{BORLAND'S LESSEE et al. v. MARSHALL.}

\section{HUNTER'S LESSEE v. DURRELL.}

(Supreme Court of Ohio, 185:3. 2 Ohio St. 308.)

Both these cases depend on the same question. They are writs of error to the court of common pleas of Hamilton county, and are part uf the series to which belong the cases of Buchanan v. Roy's Lessee, 2 Ohio St. 251, and Fowler's Lessee v. Whiteman, 2 Ohio St. 270.

In the case of Borland's Lessee v. Marshall, it was proved by the plaintiffs, that Isabella Hill, a sister of Timothy Trimble, deceased, acquired title to one-seventh of one-half of the land in controversy, by the decease of her brother in 1810. 'That Isabella died leaving issue, of whom Isabella, wife of Charles Borland, was one, and that on the death of her mother, in 1837, Isabella Borland acquired title, by descent, to one-fourth of one-seventh of one-half of the land. That Isabella, the younger, was married to Charles Borland in 1819, and that she died intestate in 1845 , leaving two children as her heirs at law, who are the lessors of the plaintiff in this case. These facts they prove by Charles Borland, the husband of Isabella, and the father of the children.

It was also proved, or admitted by the plaintiffs, that at the date of the adverse possession of Mr. Longworth, the lands were wild and unsettled.

In the case of Hunter's Lessee v. Durrell, it was proved by the plaintiffs, that Elizabeth Trimble, a sister of Timothy Trimble, was married, in 1790, to Samuel Hunter, by whom she had lawful issue. That Elizabeth Hunter died about the year 1838, leaving issue, who are the lessors of the plaintiffs, and that her husband and the father of the plaintiffs was living when this suit was brought. The lands were wild, and all the lessors of the plaintiffs were non-residents of the State of Ohio.

The plaintiffs then rested their cause, and a motion was made by the defendant in each suit for non-suit on the grom that, by the plaintiff's own showing, a freehold estate was outstanding in Messrs. Borland and Hunter, respectively, as tenants by the curtesy, and that no recovery could be had on the demises of the present plaintiffs during the existence of the estates by the curtesy. These motions the court allowed, and directed judgment of nonsuit, which were accordingly entered.

The plaintiffs in each case took a bill of exceptions to the action of the court in granting the judgment of nonsuit, and to review that action of the court upon these motions these writs of error are prosecuted.

Thurman, J. The decision of this cause depends upon the answer that shall be given to the following question: Is a man entitled to 
curtesy in lands, the title to which descended to his wife during coverture, but which were in the actual possession of an adverse claimant from the time her title accrued until her death? It is very clear that, by the strict rule of the common law, he is not; and for the reason that neither the wife, nor the husband in her right, was, at any time during coverture, actually seized of the premises. Four things, according to the common law, are necessary to create an estate by the curtesy, viz: marriage, seizin of the wife, issue, and death of the wife. Co. Lit. 30a. "And where the wife's title is derived by inheritance, or any other mode requiring an entry to perfect it, the seizin must be in deed, and not merely in law. Co. Lit. 29a; Jackson v. Johnson, 5 Cow. (N. Y.) 98, 15 Am. Dec. 433.

But it is contended, that in Ohio seizin is unnecessary; and this leads us to inquire: 1 . What is the reason of the common-law rule requiring seizin? 2. Does the reason exist in this state. 3. If it does not, is the maxim applicable, "cessante ratione, cessat ipsa lex," the reason ceasing, the law itself ceases?

The books generally, and with but few exceptions, give but one reason for the rule making seizin indispensable to curtesy, namely, that as, by the common law, livery of seizin was necessary to the transfer of a freehold estate by deed, and an entry necessary to perfect the title to such an estate, of an heir or devisee, it followed that unless the wife, or the husband in her right, was actually seized, her issue could never, as her heirs, inherit the lands; for, owing to the want of actual seizin, she never acquired an inheritable estate. But unless she had an estate of inheritance there could be no curtesy, as it was indispensable to the existence of curtesy that the mother be seized of an estate which might descend to her heirs, and "the tenancy by curtesy is an excrescence out of the inheritance." 3 Bac. Abr. 11 (Bouvier's edition).

Thus, Littleton says (section 52): "And memorandum that, in every case where a man taketh a wife seized of such an estate of tenements, etc., as the issue which he hath by his wife, may by possibility inherit the same tenements of such an estate as the wife hath, as heire to the wife; in this case, after the decease of the wife, he shall have the same tenements by the curtesie of England, but otherwise not."

Commenting on the above expression, "as heire to the wife," Coke says: "This doth implie a secret of law, for except the wife be actually seized the heire shall not (as hath been sáid) make himself heire to the wife; and this is the reason that a man shall not be tenant by the curtesie of a seisin in law." Co. Lit. 40a.

And, in illustration of the law that the wife must have an estate inheritable by her issue, the following case is put: "If lands be given to a woman and to the heires males of her body, she taketh a husband and hath issue a daughter and dieth, he shall not be tenant by the curtesie; because the daughter by no possibility could inherit the mother's estate in the land; and therefore where Littleton saith, issue 
by his wife male or female, it is to be understood, which by possibility may inherit as heir to her mother of such estate." Co. Lit. 29b.

Blackstone puts the same case, and adds: "And this seems to be the principal reason why the husband can not be tenant by the curtesy of any lands of which the wife was not actually seized, because, in order to entitle himself to such an estate, he must have begotten issue that may be heir to the wife; but no one, by the standing rule of law, can be heir to the ancestor of any land, whereof the ancestor was not actually seized." 2 Bla. Com. 128.

In a subsequent passage, he suggests an additional reason. It is as follows: "A seizin in law of the husband will be as effectual as a seizin in deed, in order to render the wife dowable: for it is not in the wife's power to bring the husband's title to an actual seizin, as it is in the husband's power to do with regard to the wife's lands: which is one reason why he shall not be tenant by the curtesy, but of such lands whereof the wife, or he himself in her right, was actually seized in deed." 2 Bla. Com. 132. The only authority referred to by Blackstone, in support of the above, is Co. Lit. 31, where the diversity between dower and curtesy is noticed, but no such reason as Blackstone gives for denying curtesy is stated, although it may be inferred.

What Coke says is as follows: "For a woman shall be endowed of a seizin in law. As where lands or tenements descend to the husband, before entry he hath but a seizin in law, and yet the wife shall be endowed, albeit it be not reduced to an actual possession, for it lieth not in the power of the wife to bring it to an actual seizin, as the husband may do of his wife's land when he is to be tenant by the curtesy, which is worthy the observation."

As before observed, it is only by inference that this passage supports Blackstone's remark. It is to some extent fortified, however, by the following language in 7 Viner's Abr. 149, namely: "Feme shall be endowed of a seizin and possession in law, without seizin in deed, quod nota; for otherwise it is of tenant by the curtesy, and the reason scems to be, inasmuch as the baron may enter in jure uxoris, but the feme can not compel her baron to enter into his own land."

On the other hand, the following extract from 3 Bac. Abr. 12, is certainly opposed to the existence of this reason, as the idea is rejected that the allowing or disallowing curtesy is dependent on the ability or inability, industry or negligence, of the husband. "But now of such inheritances, whereof there can not possibly be a seizin in fact, a seizin in law is sufficient; and therefore if a man seized of an advowson or rent in fee, hath issue a daughter, who is married and hath issue, and he dieth seized, and the wife dieth likewise before the rent becomes due, or the church becones void, this seizin in law in the wife shall be sufficient to entitle her husband to be tenant by the curtesy, because, say the books, he could not possibly attain any other seizin, as indeed he could not; and then it would be unreasonable he should suffer for what no industry of his could prevent. But the true reason 
is, that the wife hath these inheritances which lie in grant, and not in livery, when the right first descends upon her; for she hath a thing in grant when she hath a right to it, and nobody else interposes to prevent it."

In Davis v. Mason, 1 Pet. 507, 7 L. Ed. 239, the foundation of the rule is thus stated in the opinion of the court: "As it relates to the tenure by curtesy, the necessity of entry grew out of the rule, which invariably existed, that an entry must be made in order to vest a freehold (Co. Lit. 51), and out of that member of the definition of the tenure by curtesy which requires that it should be inheritable by the issue. When a descent was cast, the entry of the mother was necessary, or the heir made title direct from the grandfather, or other person last seized."

A careful examination of the authorities makes it quite apparent that this is a correct statement of the principal, if not the only, reason of the rule. No other reason is found in the books, except the suggestion before referred to, that curtesy is refused where there was no actual seizin, because the husband might, by diligence, have obtained such seizin. But this idea, as we have seen, is not universally admitted.

Our next inquiry is, Do these reasons, or either of them, exist in Ohio?

That livery of seizin has never been essential, in Ohio, to the creation of a freehold estate, nor an entry necessary to perfect the title of an heir or devisee, is well known to every lawyer. The most common instrument of conveyance is a deed of bargain and sale, which, without the aid of a statute of uses, transfers both the legal and equitable estate. Nay, further, a mere deed of quitclaim, or release, is sufficient, even where the releasee has no prior interest in the land. But our departure from the English law does not stop here; for an adverse possession does not prevent the transfer of title, either by deed, descent, or devise. Whatever title is held by the grantor, ancestor, or testator, may be thus transferred, notwithstanding the lands are adversely held by another. Holt v. Hemphill, 3 Ohio, 232; Helfenstine v. Garrard, 7 Ohio, 275, pt. 1, Hall v. Ashby, 9 Ohio, 96, 34 Am. Dec. 42t. It might seem, from what was said in Holt v. Hemphill, that an adverse possession would be fatal to a deed; but that such possession in no wise affects it, was expressly decided in Hall v. Ashby.

As, then, a freehold estate is created in Ohio without entry, it is manifest that the principal, if not the only reason, of the rule requiring actual seizin to give curtesy does not exist in this state.

But allowing that the minor reason before stated did exist in England, does it exist here? Ought a husband to be denied curtesy in Ohio upon the ground that he might have entered upon the land during coverture, and that if he did not, he was guilty of a fault that deservedly bars his right? There may have been much reason for saying so in England, when the rule requiring seizin was established; for, by the failure of the husband to enter, the wife and her issue 
might lose the estate, which it was plainly his duty to prevent, if possible. Liut in Ohio her title is as perfect before as after entry; and. in general, it would be nothing less than absurd to make a man's right depend upon whether he had gone for a moment upon the land and "broken a twig," or "turned a sod," or "read a deed." There is, however, one case, and perhaps but one, in which, if curtesy exists, the heirs of the wife might be prejudiced by a failure of the husband to obtain possession, namely, when by such failure the bar of the statute of limitations becomes perfect against them. But this would probably occur so rarely as to furnish but a slight foundation for the rule we are consirlering. Nor is it the only case in which a remainderman, or reversioner, may be powerless to preserve his estate. If $\mathrm{A}$, the owner in fee of lands in the adverse posession of $B$, devise or convey them to $\mathrm{C}$ for life, with remainder to $\mathrm{D}$, it is manifest that, as the statute of limitations began to run against $\mathrm{A}$, and therefore continucs to run against $C$ and $D$, the latter may lose his estate through the neglect or failure of $\mathrm{C}$ to obtain possession. So, when the statute begins to run against a feme sole, and she afterward marry, she may lose her land by the neglect or inability of her husband to recover it.

These possible cases of hardship it is the province of legislation to guard against, and not of the courts. Were we to say that there shall be no curtesy where the possession was held adversely during the coverture, because to give it might, by possibility, result in the loss of the estate to the heir, it is very probable that, in guarding against hardships on the one side, we would open the door to quite as much, or more, hardship on the other. For it is very far from being true that the failure to obtain posession during the coverture, is always attributable to the hutsband's neglect. He may have freely spent his time, labor, and money to recover the land, and yet, without any fault of his, be unable to succeed in the lifetime of the wife. Decide as we may, and doubtless there will he room for cases of hardship to arise; but, as was truly said by Duncan, J., in Stoolfoos v. Jenkins, \& Serg. \& R. (Pa.) 173: "Courts can not usurp legislative functions, or new-model the law according to their own ideas of natural justice, or redress hardships in each particular instance." And it is never to be forgotten that all wise laws are framed with a regard to what is likely to occur, rather than to that which is only possible.

On the whole, the conclusion to which we have arrived is, that neither of the reasons given for making actual seizin indispensable to curtesy, affords any sufficient foundation for the rule in Ohio. It remains to be considered whether the reason of the rule having ceased, or rather never having existed in this state, the rule itself exists here. Tenancy by the curtesy has always been known to our law and is recognized by our statutes. We can not deny its existence; but may we not deny the necessity of a requisite, that properly enongh formed a place in the common law, but has no reason to support it in our jurisprudence? We are naterially aided in this inquiry by the American deci- 
sions upon the subject of curtesy. These decisions may be reduced into three classes:

1. Those in which there being no adverse possession, the husbant and wife were held to be constructively seized in deed, and such constructive seizin deemed sufficient.

2. Those in which there was an adverse possession; but a recovery in ejectment, on the demise of the husband and wife or the husband alone, took place during the coverture; and in which there was held to be curtesy, although no acttial possession followed the recovery.

3. Those in which an adverse possession was decided to be no bar to curtesy.

Of the first class, Jackson v. Sellick, 8 Johns. (N. Y.) 262. and Davic v. Mason, 1 Pet. 506, 7 L. Ed. 239, may properly, perhaps, be called the leading cases. Nany others might be cited, for the general current of American atuthority certainly admits curtesy in this class of cases.

Of the second class, Ellsworth v. Cook, 8 Paige (N. Y.) 643, is the leading case.

To the third class, belong Bush v. Bradley, 4 Day (Conn.) 298, approved in Chew v. Comm'rs of Southward, 5 Rawle (Pa.) 160, etc.

Now, a careful scrutiny of these cases will show that, in nearly all of them, the decisions were arrived at by an application of the maxin. "cessante ratione, cessat ipsa lex." It was so expressly declared in Davis v. Mason. That case respected lands in Kentucky. After giving. in the passage hereinbefore quoted, the reason of the rule requiring seizin, the judge, who delivered the opinion of the court, went on to say: "But in Kentucky, we understand, the livery of seizin is unheard of. Freeholds are acquired by patent, or by deed, or by descent. without any further ceremonies; and in tracing pedigree. the proof of entry, as successive descents are cast, is never considered as necessary to a recovery, or in any mode affecting the course of descent. If a right of entry therefore exists, it ought by analogy to be sufficient to sustain the tenure acquired by the husband, where no adverse possession exists; as it is laid down in the books relative to a seizin in law, 'he has the thing, if he has a right to have it.' Such was not the ancient law; but the reason of it has ceased. It has been shown, that in the most remote periods exceptions had been introduced on the same ground; and in the most modern, the rule has been relaxed upon the same consilleration. We ought not to be behind the British courts in the liberality of our views, on the subject of this tenure."

So in Jackson v. Sellick the court said: "We must take the rule (requiring seizin) with such a construction as the peculiar state of new lands in this country require."

Both these cases seem to proceed on the ground that the wife, thongh not actually, was yet constructively seized in deed. Hence the allusion, in each case, to the fact that there was no adverse possession to rebut the presumption. The question whether an adverse possession would

AIG.PROP. - 38 
be fatal to the claim to curtesy was not presented. The cases in effect decide, not that seizin in deed is indispensable, but that, if there must be seizin, a constructive seizin is sufficient. But in Bush v. Bradley, the question was directly raised. The premises, during the whole period of the coverture, were adversely held by a third person. Yet the husband was adjudged to be tenant by the curtesy. The real estate law of Connecticut was, in all respects material to the present inquiry, the same as that of Ohio; and the court held that, as the reason of the rule requiring seizin did not exist, seizin was unnecessary, and that the symmetry of the law required this decision. To the same effect is the following langtrage of the court in Stoolfoos v. Jenkins, S S. \& R. 175: "The actual seizin of the husband during coverture is necessary to entitle him, as tenant by the curtesy, by the common law; though such actual seizin by the husband is not necessary by our law, if there be a potential seizin, or right of seizin. This has been decided to be sufficient in this state." This ruling, as well as the case of Bush v. Bradley, was approved in the case in 5 Ravle, 160, before cited, the court holding that it was sufficient to entitle the luusband to curtesy, that the wife owned the land and had a right "to demand and recover the immediate possession thereof." 15

In the light of these decisions, and the considerations upon which they rest, we cain hardly err in holding that the reason, or reasons, of the rule requiring seizin in deed, having no existence in Ohio, the rule itself does not exist. And, certainly, the symmetry of our law demands this. It would be strange indeed, and only lead to confusion and perplexity, if, while every other tenancy may be created in this state without entry, or regard to the fact of adverse possession, a tenancy by the curtesy could not. Nor does a rule strongly commend itself to the good sense of men that makes the existence of the estate depend upon an almost, or quite, imaginary distinction between seizin in law and constructive seizin in deed. The constructive seizin relied on in Jackson v. Sellick, Davis v. Mason, and Ellsworth v. Cook, was in substance nothing but a seizin in law. It is a mere fiction to say that a man is actually possessed of that which is in no one's possession, and it is plainly untrue to say so when the thing is in the possession of another. The reasoning of the courts in all these cases, if carried to its legitimate result, makes seizin in deed, either actual or constructive, wholly unnecessary; and this result is not in conflict with the principles of the common law. For even at common law, a seizin in law is sufficient to give curtesy in all inheritances created without entry. 3 Bac. Abr. 12 ; Jackison v. Johnson, 5 Cow. (N. Y.) 98, 15 Am. Dec. 433; Ellsworth v. Cook, S Paige (N. Y.) 643. It is therefore a mere application of a common-law principle to say that a seizin in law is sufficient in Ohio, where in no case is an entry necessary to create an inheritance. In the case before us, Mrs. Borland was seized in law, for "seizin in law is a right to lands and tenements, though the owner is by wrong disseized

15 Buchanan v. Duncan, 40 Pa. $\$ 2$ (1S61), acc. 
of them." 6 Jacob's Law Dic. 41. Her husband, there being issue born, became tenant by the curtesy, and as he was yet in life when the ejectment was brought by her heirs, the common pleas did right to nonsuit them.

The decision of this case also decides the case of Doe ex dem. Hunter et al. v. Durrell; the only difference in the cases being that there was an adverse possession in the one and not in the other. ${ }^{16}$

\section{WATSON v. WATSON.}

(Supreme Court of Errors of Connecticut, 1S39. 13 Conn. S3.)

This was an action of ejectment; tried at Hartford, September term, 1838, before Bissell, J.

In the life-time of Ann Watson, and until her death, the demanded premises were owned by her in fee; and the plaintifts are her children and heirs at law, by John Watson, to whom she was lawfully married, and who is still living. The plaintiffs clained, that John IVatson had not an estate by the curtesy in the premises; and to establish this point, they offered in evidence the following writing, under his hand and seal, dated the 23rd of February, 1837, after the death of his wife: "Know all men, by these presents, that I, John Watson, do hereby publish, declare and make known, to all whom it may concern, and especially the heirs and children of my late wife, Ann Watson, that I have not, at any time hitherto, and now do not claim, demand, possess, or in any manner or to any extent whatever, have, or pretend to have, any right, title or interest in three pieces of land (describing the premises) but do now fully, absolutely and without any reservation, disclaim and reject any and all right, title and interest in the same, which I might or could have had, by operation of law or otherwise, by reason of my surviving my said wife, or any title to said premises which she had during her

16 See De Grey v. Richardson, 3 Atk. 469 (17 17 ).

Lands are conveyed to $\mathrm{A}$. for life, vemainder in fee to B., a roman. B. marries, issue is born, and $B$. dies, all during the lifetime of A. Is B.'s husban!l entitled to an estate by the curtesy? See Todd r. Oviatt, 58 Conn. 17t, 20 Atl. 440, 7 I. R. A. 699 (1S49); Redus v. Ifayden, 49 Miss. (114 (1ऽ70); Doziel r. Toalson, 180 Mo. 546, 79 s. W. 420, 103 Am. St. Rep. 5s6 (1904); Fel.mson r. Tweedy, 43 N. Y. 543 (1S71); Watkins v. Thonton, 11 Ohio St. 867 (1sC0).

As to the rights of the hushand of a trustee or cestui que trust. see Kenneson's Cases on Trusts, 223 et sen.; Ogden r. Omalen, 60 Ark. 70, 2s S. W. 79;, $46 \mathrm{Am}$. St. Rep. 151 (1594); Carson v. Fuhs, 131 Pa. 256, 18 Atl. 1017 (1590).

Lands are conveyed to a woluan and the heirs of her body; she marries, has issue which dies, and then she dies withont issue, learing hel husband surviving. Is her husband entitled to curtesy? See I'aine's Case, S Co. 34 (15s7).

An estate is devised to a woman in fee, with limitation orer, in case she dies under the age of twenty-one, without issue; slue maries, has issue which dies, and then she dies under twenty-one, learing her husband surviving. Is he entitled to curtesy? See Fuckworth v. Thirkell, 3 Bos. \& P. 652, note (17 \&5). See, also, Buchannan $r$. Sheffer, 2 Teates (Pa.) 374 (179s): Weller r. Weller, 28 Barb. (N. Y.) $5 S S$ (1S5S); Hatfield v. Sneden, 54 N. Y. $2 S 0$ (1S73); Withers r. Jenkins, 14 S. C. 597 (1SSO). 
life." This writing was signed and sealed by John Watson, attested by two witnesses, acknowledged before a justice of the peace, and recorded in the town records. It was admitted by the plaintiffs, that John Watson was tenant by the curtesy of the demanded premises, and that they could not recover in this action, unless by operation of this writing, he had no such estate. The defendant objected to the admission of it in evidence to the jury; and the court rejected it ; and a verdict passed for the defendant. The plaintiffs thereupon moved for a new trial.

WAITE, J. The object of a disclaimer, is, to prevent an estate passing from the grantor to the grantee. It is a formal mode of expressing the grantee's dissent to the conveyance before the title has become vested in him. In some cases, it may be highly proper; as where a deed is made conveying an estate to one for life, with a remainder to another in fee. Here, in the absence of all evidence to the contrary, the law would presume the assent of the grantee in remainder, upon delivery of the deed to the grantee for life, for the benefit of both. But if the remainder-man chooses not to take the estate, he may disclaim, and thereby remove all presumption of assent. So, where a deed is executed to several persons, and delivered to one for the benefit of all, if one dissents, he may disclaim, and furnish evidence that his share still remains in the grantor. 'Treadwell et al. v. Bulkley et al., 4 Day, 395.

But if the grantee once assents, and the title thereby becomes vested in him, he cannot, by any disclaimer, revest the estate in the grantor. For if he could, the disclaimer wonld have the effect of a deed, which it cannot have; the object of the latter being to transfer property, of the former to prevent a transfer.

But in a case of descent, the heir cannot, by any disclaimer, prevent the estate from passing to him. It vests in him inmmediately upon the leath of the ancestor; and no act of his is required to perfect his title. He cannot, by any act, cause the estate to remain in the ancestor; for the latter is incapable of holding it, after his death. Nor can he, by a disclamer, transfer the estate to any other person, as the heir of the ancestor: for, as has already been observed, the object of a disclaimer is not to convey, but to prevent a conveyance. He is, therefore, in the same situation, upon the death of the ancestor, as a purchaser, who has assented to the conveyance. In both cases, a transfer can only be made, by some instrument adapted to the conveyance of real estate.

A devisee, however, stands in the same situation as a purchaser. If he dissents, the estate passes to the heir, in the same manner as if no will had been made. It is entirely optional with him to take or refuse the estate devised. Townson v. 'Tickell et al., 3 Barn. \& Ald. 31.

In the present case, the disclaimer was made by one who was entitled to the property as tenant by the curtesy. Is he, in this respect, like a grantee, or an heir? This species of estate has sometimes been classed witls those acquired by purchase. But it is rather an estate thrown upon the tenant by operation of law. Co. Litt. 18b. It partakes more 
of the character of an estate acquired by descent than by purchase. Inmediately upon the death of the wife, the estate vests in him. Like the heir, he cannot, by refusing to take it, cause it to remain in the wife; nor can he, by a disclaimer, transfer it to others. The estate thus vested in him, becomes immediately liable for his debts; and he cannot, by any refusal to take the property, defeat the claims of his creditors.

The disclaimer offered in evidence could have no effect in shewing a title in the plaintiffs; and was properly rejected by the court.

We are, therefore, satisfied, that no new trial should be granted.

In this opinion the other Judges concurred.

New trial not to be granted. ${ }^{17}$

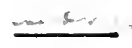

\section{(C) Wife's Interest in Husband's Realty}

\section{LITTLETON'S TENURES.}

Tenant in dower is, where a man is seised of certain lands or tenements in fee simple, fee tail general, or as heir in special tail, and taketh a wife, and dieth, the wife after the decease of her husband shall be endowed of the third part of such lands and tenements as were her husband's at any time during the coverture, to have and to hold to the same wife in severalty by metes and bounds for term of her life, whether she hath issue by her husband or no, and of what age soever the wife be, so as she be past the age of nine years at the time of the death of her husband, (for she must be above nine years old at the time of the decease of her husband,) otherwise she shall not be endowed.

Section 36.

\section{BROUGHTON v. RANDALL.}

(Court of Queen's Bench, 1596. Cro. Iiliz. 502.)

Error of a judgment in Wales in dower. * * *

Note here, the title of the feme to recover dower was, that the father and son were joint-tenants to them and the heirs of the son; and they were both hanged in one cart; but because the son (as was deposed by witnesses) survived, as appeared by some tokens, viz., his shaking his legs, his feme therempon demanded dower. And upon this issue nunques seisie dower, this matter was found for the demandant. ${ }^{18}$

17 See In re Starbuck's Estate, 137 App. Div, 866,122 N. Y. Sulp. 581 (1910); Id., 201 N. Y. 531,94 N. E. $109 S^{\prime}(1911)$; Crenshaw v. Moore, infra, p. 616.

"Curtesy is abolished or modified, in many states, by statutes which must be consulted." 4 Kent's Comm. *29, note.

$18 \mathrm{~A}$ part of the report relating to another point is omitted. 


\section{HOLBROOK v. FINNEY.}

(Supreme Judicial Court of Massachusetts, 1S08. 4 Mass. 566, 3 Am. Dec. 243.)

This was an action for dower in several parcels of land which Hannah Holbrook demands on the seizin of her deceased husband Ezra Finney during the coverture.

The cause came before the court on a case stated by the parties, in which it is agreed that John Finney, the father of Ezra and of three other sons, was seized of the premises in fee, and on the 13 th of March, 1786, by his deed of that date, in consideration of $£ 400$. conveyed the premises with other parcels of land to his said four sons in equal proportion in fee simple, the demandant then being the wife of Ezra; that immediately and by a deed of even date with the deed from John, the four sons mortgaged the same lands to their father in fee, to secure to him the payment of the said sum of $E 400$. with interest, and also a maintenance during his life; that these deeds were duly acknowledged on the same day, and registered the day after; that in December in the same year Ezra, the husband of the demandant, died; that in 1787 the mortgagee foreclosed the mortgage, the conditions thereof having been broken; that in 1790 , by virtue of the levying of an execution to satisfy a judgment recovered against John Finney the father by the present tenant, he became seized in fee of the premises described in the writ; and that the execution of the said deeds was in pursuance of a previous agreement to the same effect made between the parties.

Upon these facts it was submitted to the court whether the demandant was entitled to recover her dower.

PARsoxs, C. J. [After reciting the substance of the case as agreed by the parties:] The question before the court upon these facts, is whether Ezra Finney the husband was, during the coverture, so seized of the premises, that the demandant has a right to her dower. He was not so seized, unless from the operation of the deed from his father to himself and his three brothers.

The tenant has made two objections. 1. That this conveyance was of an estate to jointenants, of which the demandant's husband was not the survivor. 2. That her husband had that instantaneous seizin only, which will not entitle her to dower.

It is settled that if an estate be devised to two or more equally to be. divided, they are tenants in common. The same construction is applied to a devise to two or more share and share alike. Show. Parl. Cas. 210. Also the words equally to be divided in a covenant to stand seized, or in the surrender of a copy-hold, or in a deed appointing uses, create a tenancy in common. 2 Vent. 365, 6; 1 Salk. 391; 1 Wils. 341, 2. This construction has been adopted, because the words in equal shares, or equally to be divided, import a division in futuro.

The words in this deed are in equal proportion; and it is said that 
they do not imply a future division, but are applied only to the respective interests in the thing conveyed. On this ground they nust be considered as wholly inoperative; for without them, the grantees would have taken an equal interest in the lands granted. To give them operation, may they not be considered as equivalent to the words in equal purparties or shares, and thus contemplate a future partition?

But it is not necessary now to decide this point, for by the statute of 1785 , c. 61 , passed three days after the execution of these deeds, it is enacted that all estates which had been, or which should be aliened to two or more persons, shall be deemed to be tenancies in common, unless it be manifestly the intent of the alienor that they should be held as joint estates; with a saving to the survivor of any estate in jointenancy before created and already vested in him. This statute has a retrospective effect, and comprehends this conveyance; and there seems to be no constitutional objection to the power of the legislature to alter a tenure, by substituting another tentire more beneficial to all the tenants.

If this objection had been pressed, it would have been unnecessary to consider it, as the statute of 1783 , c. 52 , in force when the deeds were executed, although repealed by the last cited statute, had abolished the principle of survivorship among jointenants, and had cnacted, that on the death of a jointenant, the joint estate, of which he was seized, should descend to his heirs. In consequence of these provisions, the wife of a jointenant is dowable, as on the death of her husband there could be no survivor, who would be in by a title paramount to her claim of dower. ${ }^{19}$

The demandant must therefore recover, unless the second objection should prevail. It certainly is law that where the husband is seized but for an instant, of this seizin his wife shall not be endowed. The seizin for an instant is where the husband by the same act, or by the same conveyance, by which he acquires the seizin, parts with it. Thus if tenant for life make a feoffnent in fee his wife shall not be endowed, for by making the same feoffment which passed the fee, he acquired a fee. 2 Cro. 615. And if a joint-tenant make a feoffment, his wife shall not be endowed, for by the feoffment he was seized of a several estate but for an instant, which he acquired and parted with by the feoffment. So if a feoffment be to $\mathrm{B}$. and his heirs to the use of $\mathrm{C}$. and his heirs, the wife of $B$. shall not be endowed, for he was but an instrument; and the same feoffment, which gave him the seizin, by the statute of uses transferred it to $\mathrm{C}$. Nor shall the wife of the conusee of a fine be endowed, when by the same fine the estate is rendered back to the contsor. 2 Co. 77 , a.

Let us now compare the present conveyances with these principles, for the previous agreement may be laid out of the case. If the deeds

1 o Davis v. Logan, 9 Dana (Ky.) 185 (18:9), acc. State statutes not uncommonly have abolished the survivorship feature of joint tenancies. 
pursne it. it is meeless: and if they do not, we must he governed wholly by the construction of the deeds. The mortgage back to the father, from the terms of $i t$, is of even date with the conveyance from him. They are therefore to be consiclered as parts of the same contract, and as taking effect at the same instant. The conveyance from the father took effect when he delivered his deed; the mortgare back took effect when the mortgage deed was delivered; but both being of even date yere delivered at the same time. The mortgagors were therefore seized but for an instant, taking an absolute estate in fee, and instantaneously rendering back a conditional estate in fee. These two instruments must therefore be considered as parts of one and the same contract between the parties; in the same manner as a deed of defeazance forms with the deel to be defeated but one contract, although engrossed on several shects; and no interval of time intervened between the taking, and the rendering back of the fee.

But if the husband had continued seized for any portion of time, however short, his wife would have been entitled to clower; as if the conveyance back had been made posterior in point of time, or by a deed distinct from the first grant. There is the case of Nash v. Preston reported in Cro. Car. 190, illustrating and supporting these principles. In that case I. S. scized in fee bargains and sells the land to the husband for $£ 120$. in consideration that the bargainee shall redemise it to the bargainor and his wife for twenty years, rendering a nominal rent, with a conclition that if the bargainor at the end of twenty years paid back the $£ 120$. the bargain and sale should be void. The bargainee accordingly redemised it and dies. His wife shall have dower because the land by the bargain and sale was vested in the husband. But it would have been otherwise if the land was in, and was out of the husband by one act. In the case at bar, the execution of the two deeds, they being of even date, was done at the same instant, and constitutes but one act.

The demandant therefore cannot support her claim, as her husband was never so seized as to entitle her to dower. According to the terms of the agreement submitting the case to the court, the demandant must become nonsuit.

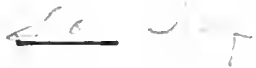

\section{SHOEMIAKER v. WALKER.}

(Supreme Court of Pennsylvania, 1S14. 2 Serg. \& R. 554.)

Case stated for the opinion of the Court. By the last will and testament of Phobe Shoemaker, deceased, dated the 2d August, 17SS, and by a deed of trust from Benjamin Shoemaker and Elizabeth his wife, to John Reynell, bearing date the 31st October, A. D. 1765, Charles Shoemaker, "was vested with, and entitled to the remainder of one-eighth of all the real estate in the said deed mentioned after 
the life estate thereby given to his mother, Elizabeth Shoemaker, shall have expired," \&c.

On the 4th June, 1792. Charles Shoemaker, by deed in consideration of a debt of above 4,000 pounds sterling to Hathrip \& Co. and to secure the same, also of 20 shillings, granted, \&c. to John Whitesides "all his estate, right, title, interest, claim and demand, of, into, and out of all the residue of the remainder of the said one-eighth of the real estate above-mentioned, as well as all and every the real estate of him, the said Charles Shoemaker, wheresoever the same may be, and whether it be in possession, reversion, or remainder."

The demandant was married to Charles Shoemaker on the $7 \mathrm{th}$ January, A. D. 179S.

Elizabeth Shoemaker, the mother of Charles, died the 23d April, 1798 .

Charles Shoemaker died the 4th April, 1807, leaving a widow and children.

John Whitesides, in the life-time of Elizabeth Shoemaker, viz. on the - day of - granted and conveyed the estate in question to the defendant.

The question submitted to the decision of the Court is, whether the widow is entitled to her dower in the estate so devised to Charles Shoemaker? If the Court shall be of opinion in the affirmative, then judgment to be entered for the demandant for an amount to be ascertained by the counsel. Otherwise, judgment to be for the defendant.

Tilghman, C. J. In this case two questions are made. 1. Whether a widow is entitled to dower of a trust estate. 2. Whether she is entitled to dower of an estate, the remainder of which in fee was vested in her husband, dependent on an estate for life in a third person, which said remainder her husband had aliened during the coverture. 1. In England a woman is not dowerable of a trust estate although a husband may be tenant by the curtesy. This is the more remarkable, as dower is the favourite of the common law. A woman has her dower where the husband had only a seisin in law, but a man cannot be a tenant by the curtesy unless there was a seisin in fact. lo $_{0}$ good reason has been assigned for excluding the wife of her dower in a trust estate. It rests upon usage, which though not now approved cannot be altered by any authority less than the parliament. In Pennsylvania the usage has been more reasonable and more analogous to the general principles of dower. The husband and wife are placed on an equal footing. He has his tenancy by the curtesy, and she has her dower. I do not know that the question has ever been brought to a decision in this Court. The reason of this I take to be, that it has never been doubted. I have frecuently heard it taken for granted, but never seriously questioned. I do not understand that the learned counsel who now makes the point, supposes the law to be in his favour. But he wishes it to be settled by a solemn decision. It is best that it should be so. My opinion is, that 
by the usage and law of Pennsylvania a woman is dowable of a trust estate. $^{20}$

2. By the common law there can be no dower, unless the husband is seised in fact or in law of the freehold, as well as the estate of inheritance, during the coverture. This is not questioned by the counsel for the demandant. But he supposed, that in this state the law might be different, in consequence of some provisions in our intestate acts. He has, however, very candidly and very properly declared, that upon examining the act of assembly he finds, that its provisions are not applicable to a case where the husband had aliened his whole interest by deed. That is the present case. The demandant, therefore, is not entitled to a recovery of dower.

YeAtes, J., and BrackenRIDGe, J., concurred.

\section{BATES v. BATES.}

\section{(Court of Common Pleas, 1697. 1 Ld. Raym. 326.)}

Dower. The tenant pleads, that the husband ne unques fuit seisie que dower. Upon which issue being joined, the jury find, thet Ralph Bates, husband of the demandant was seised of the lands now deinanded for life, remainder to A. and B. trustees for ninety-nine years, remainder to the heirs of the body of Ralph Bates, \&c. et si, \&c. And it was argued for the demandant, that the husband died seised of an estate tail executed; for the intervening estate being for years, ought not to be regarded. That the feoffment of the husband would have discontinued the intail, which proves that he was seised of it. See 2 Bulstr. 29, 30; Cro. Car. 233, 234; 1 Roll. Abr. 632; 8 Vin. 516, b, pl. 2, and that his warranty would have been lineal to a son, which proves that the son is in by descent. E contra it was argued for the tenant, that dower was allowed by the law for the support of the wife and her children; and therefore where by such allowance the wife and her children cannot be supported, no dower can be allowed, for lex non facit inutilia. Then dower in these cases, where the mesne term might be for a thousand years, would be so remote, that it would be of no avail to the wife. And as to the objection, that the heir was in by descent; it was answered, that that signifies nothing, because if the intervening estate had been for life, the heir had been in by descent, and yet in such case without doubt the wife is not dowable.

This case was thrice argued at Bar, and at the first argument the Court doubted, because the estate tail is so disjoined by the intervening lease, and though it be vested, it is not executed; and perhaps (they said) the feoffment of the husband would not have discontinued the intail. At the second argument TrFBY, Chief Justice, was of opinion

$20 \mathrm{As}$ to the rights of the widow of a trustee or cestui que trust, see Kenneson, Cases on Trusts, $2: 3$ et seq. 
for the demandant, because at the instant of the death of the husband there was but an estate for years in the trustees, and the estate tail was in the husband; and (by him) the instant should be divided in favour of dower, as Cro. Eliz. 503, Broughton v. Randall. But upon the third argument judgment was given for the demandant upon this reason, because the husband had a frechold and inheritance in him, and the intervening estate, being only for years, ought not to be regarded. For at common law such a term was a precarious thing, the freeholder might have destroyed it at his pleasure by a feigned recovery. A descent, which tolls an entry, does not disturb a term; and if tenant for life conmits waste, such an intervening term will not obstruct the action of waste, as an intervening estate of freehold would do. And therefore all the Court was of opinion, that such intervening term would not hinder dower, as it would have done if it had been an estate for life, ${ }^{21}$ according to the opinion of Perkins, 336, the only authority in the books for that resolution. Judgment was given for the, denıandant.

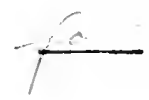

\section{EDWARDS v. BIBB.}

(Supreme Court of Alabama, 1875. 54 Ala. 475.)

\section{Appeal from Limestone County Court.}

Heard before Hon. R. S. Watkins.

This was a bill in equity, filed by Ann C. Edwards and her husband, against Mary P. Bibb individually, and as administratrix of the estate of David Porter Bibb, deceased, and certain of his heirs at law, seeking to have dower allotted to her in certain lands in their possession.

The complainant, Ann C., in the year 1857, intermarried with one Thomas Bibb, Jr., and continued to live with him as his wife until his deatll, and afterwards intermarried with her present husband and co-complainant, Julian T. Edwards. Her claim of dower in said lands arose in this wise: Prior to the year 1S40, Thomas Bibb, Sr., (the father of Thomas Bibb, Jr., complainant's first husband,) was seized of a valuable tract of land in Limestone county, the lands in question, known as the "Belmina estate."

Thomas Bibb, Sr., died on the 23d day of April, 1840, leaving a last will and testament, which was duly admitted to probate in that county. The will, among other provisions not necessary to be here noticed, devised said Belmina estate, with the exception of a small portion, (which he had conveyed to one Jackson,) to testator's wife, Parmelia Bibb, during her natural life, and at her death "unto my eldest son, Thomas Bibb, and lis lawful male issue, and in case my said

21 What would be the situation if the interrening frechold were a contingent estate? 
son Thomas should die, leaving no lawful male issue, or leaving such male issue, the same should become extinct, before he or they shall arrive at the age of twenty-one years, and likewise leaving no male issue, then, and in that case, my will and desire is, that said estate, with the property named and devised to my said wife, shall become the property of my son, David Porter Bibb, to descend to the lawful male issue of him my said son Porter."

This clause of the will was once before construed in this court, in an ejectment suit brought to recover the lands, in which dower is sought, from the heirs of David Porter Bibb. See Edwards and Wife v. Libb et al., 43 Ala. 666.

About the year 1855 , said Parmelia departed this life, after taking possession of the lands devised to her for life, and thereupon said Thonas Bibb, Jr., entered and took possession, and so remained until his death in 1861, leaving a daughter, the fruit of his marriage with complainant, but never having had any male issue. He left a will from which his widow duly dissented, and which in the view the court took of this case need not be further noticed. In 1865 the said David Porter Bibb entered into possession and so remained until his death in the latter part of that year, intestate. The appellees, Nary P. Bibb, his widow and administratrix, and his heirs at law, were in possession of said lands at the time of the filing of said bill, and had made partition among themselves.

The chancellor dismissed the bill on demurrer, and hence this appeal.

[For subsequent opinion, see Bibb v. Libb, 79 Ala. 437.]

Stone, J. ${ }^{22}$ In the case of Edwards \& IVife v. Bibb et al., 43 Ala. 666 , the question considered and decided was, whether under the will of Thomas Libb, Sr., 'Thomas Bibb, Jr., took an absolute title in fee to the property therein described as a portion of the Belmina estate, or dicl it pass to David Porter Libb on the death of Thomas Bibb, Jr., "leaving no lawful male issue." Thomas Bibb, Jr., had died "leaving no law ful male issue." It was then ruled that the words of the will constituted a valid "executory devise" of the estate over to David Porter Bibl). An application for a rehearing in that cause was overruled, and the rlecision became final, settling for all time the rights of the parties to that suit to the property involved therein.

'The present is an application by the widow of Thomas Bibb, Jr., for dower in the same lands, the title to which, it was determined in that suit, passed from Thomas Bibb, Jr., and his heirs, by his death, "leaving no lawful male issue." We are asked to review the decision pronounced in that cause. ***

It results from what we have said above, that under the will of Thomas Bibb, Sr., Thomas Bibb, Jr., took an estate, determinable on his dying "leaving no male issue"; and that inasmuch as he did so die, the

22 A portion of the opinion is omitted. 
executory devise over to David Porter Bibb took effect at the death of the former. We shall, consequently, in the discussion of the remaining questions presented by this record, deal with the subject as if there were no words of entailment in the devise we are considering.

Under this will thus construed, Thomas Bibb, Jr., either took a fee simple, having another fee engrafted upon it by way of executory devise, to come into being on the happening of an event therein provided for as a conditional limitation, or he took only a life estate, and at his death, his lawful male issue, if he had left such, would have taken as purchasers. If the latter be the true construction of the devise, no one will contend that Thomas Bibb's widow would be dowable of the lands. Supposing, then, that the estate of Thomas Bibb was a defeasible fee, the question comes up, is his widow entitled to dower, the estate of her husband having expired with his life?

Few questions of the law have been more discussed, or have given rise to more perplexing distinctions than that of the widow's right to dlower in lands, the title to which passed out of her husband contemporancously with his death, by force of some limitation, reversion or remainder. The case in hand is one of remainder, which has taken effect. The question is thus stated by a very accurate writer: "Is the widow entitled to clower after the estate of her husband has determined, before its natural expiration, by the happening of an event particularly mentioned in the instrument creating it, but without disturbing or overreaching his prior seisin?"

The case of Buckworth v. Thirkell, is one of the first cases on this question. 3 Bos. \& Pul. 652, note. That case came before Lord Nansfield, one of England's greatest jurists, and it was determined that the husband was entitled to curtesy. The rule in regard to dower is the same on this question as that in regard to curtesy.

The case of Buckworth v. Thirkell has not had the good fortune of commanding universal assent. Mr. Butler, in his note to Coke upon l.ittleton, page 141, while conceding that upon the termination of an estate tail by the failure of issue, the right of curtesy or dower will attach as a prolongation of the estate, yet contended that when a fee simple is determined by a valid executory devise, neither curtesy or dower ensules. Other writers contend for the same distinction. See very full discussions of this question in Park on Dower, page 157 et seq.; 1 Scrib. on Dower, 284 et seq. To follow them through the shadowy mazes of their disquisitions would tend rather to bewilder than instruct. The human mind is not wont to rest satisfied with distinctions when it can find no substantial differences to rest them on.

Speaking of dower, as affected by conditional limitations, Chancellor Kent says: "The estate of the husband is, in a more emphatical degree, overreached and defeated by the taking effect of the limitation over, than in the case of collateral limitation;" and, he 
adds, "the ablest writers on property law are evidently against the authority of Buckworth v. Thirkell, and against the right of the dowress when the fee of the husband is determined by executory devise, or shifting use." 4 Kent's Com. 50.

Mr. Jacob, in his learned note published in the appendix to 2 Bright on H. \& W. p. 468, says: "Upon the introduction of conditional limitations by way of use and executory devises, it became a question whether dower or curtesy should cease when the estate was determined by either of these modes. Upon principle, it would seem that the decision of this question ought to be guided by analogy to the general rule of the common law, and not by analogy to the excepted case of an estate tail. * * * The conditional limitation destroying the estate, defeats the whole of that which is expressly granted. It would be singular, if that which is inclucled in the grant by implication only, could be preserved." He adds, "The supposed rule, (speaking of Mr. Preston's attempt to justify the rule laid down in Buckworth v. Thirkell,) rests on very doubtful grounds."

In New York, it was decided by Chancellor Walworth that where an estate in fee was terminated by the happening of a conditional limitation, and the executory devisees took as purchasers, the widow of the first devisee could not have dower. See Adams v. Beekman, 1 Paige (N. Y.) 631.

In the case of Weller v. Weller, 28 Barb. (N. Y.) 58S, the same question arose as in Adams v. Beekman, supra. The court said, "The widow takes her estate through the husband, and not from him like one who inherits; for he can do no act which will divest her right. And when the estate of the husband is determined by the happening of an event which defeats its further continuance, the estate in dower must be determined with it. It is a part of the same estate of freehold and inheritance of which the husband was seized, and, to the extent of it, so much abstracted from what would otherwise descend to the heirs at law. *** The wife's right to dower ceased with the estate out of which it could only proceed. This conclusion conflicts with Lord Mansfield's judgment in Buckworth v. Thirkell. It is the rule, however, given by Mr. Cruise in his treatise on the law of real property, and is the rule now sustained by Mr. Park with singular ability in his work on the law of dower."

Washburn, in his work on Real Property, vol. 1, p. 212, says: "There is a class of cases where, what at first sight might seem to be an inconsistent doctrine is applied. Thus, in the familiar case of tenant in tail dying without issue, although the estate, as one of inheritance, is determined, and the remainder over upon such a contingency takes effect, yet, it having been an estate of inheritance in the tenant, his widow, if he dies, will be entitled to dower, it being by implication of law annexed to such an estate as an incidental part of it, a portion of the quantity of enjoyment designated by the terms of the limitation itself. And the doctrine is broadly laid down by writers upon the sub- 
ject, that wherever the husband is seized during coverture of such an estate, as is in its nature subject to the attachment of dower, the right of dower will not be defeated by the determination of that estate by its regular and natural limitation." $\mathrm{He}$ adds: "This class of cases has given rise to much ingenious speculation and grave diversity of opinion, where the estate of the husband is one of inheritance, but ceases at his death by what is called a conditional limitation."

The case of Buckworth v. Thirkell was followed in Moody and Wife v. King, 2 Bing. 447; and in this country, in the cases of Milledge v. Lamar, 4 Desatıs. (S. C.) 617 ; Evans v. Evans, 9 Pa. 190, and Northcut v. Whipp, 12 B. Mon. (Ky.) 65. In a later case in South Carolina, Wright v. Herron, 6 Rich. Eq. 339, the court of errors was equally divided, and no decision was pronounced. This case presented the same question as the one presented in Buckworth v. Thirkell.

In the case of Evans v. Evans, supra, the opinion of the supreme court of Pennsylvania was pronounced by Chief Justice Gibson-one of the ablest jurists that ever sat on that bench. It will be seen that he was laboring to break down the imaginary distinction attempted to be drawn by Mr. Butler and others between the cases of remainderover, made and provided to take effect after the termination of an estate tail by failure of issue, and the termination of an estate in fee simple by failure of heirs, with a valid limitation over by way of executory devise. He says: "I can not apprehend the reason of his [Mr. Butter's] distinction between a fee limited to continue to a particular period at its creation, which curtesy or dower may survive, and the devise of a fee simple, or a fee tail, absolute or conditional, which, by subsequent words, is made deterninable upon some particular event, at the happening of which curtesy or dower will also cease." $\mathrm{He}$ propounds, and in effect answers, the following pertinent inquiry, "How to reconcile to any system of reason, technical or natural, the existence of a derivative estate, after the extinction of that from which it was derived, was for him [Mr. Butler] to show; and he has not done it."

Any attempt to maintain a distinction between the claim of dower or curtesy, when the inheritance in an estate tail has failed, and a limitation over has taken effect, per formam doni, and the same result when an estate in fee has been determined by the happening of the event upon which a conditional limitation over was made to take effect, by the terms of the instrument creating the title, is too artificial and technical to command our assent. Dower is a derivative estate; it is derived from the estate of the husband. It is the creature of the law, not of contract. While the husband lives, there is no estate in dower. It is an interest, carved out of, or abstracted from the inheritance; or out of the estate of the husband's alienee, if the widow survives, and has not delinquished her dower. The husband, by any conveyance made, or recovery suffered by him, cannot bar, or impair her right. 
When, however, by the very terms of the conveyance or devise, legal in form and purpose, the estate of the husband expires with him, cutting off per formam doni, the heritable quality of his estate, and the title passes to another as purchaser by a valid limitation over, the primitive estate is gone, and there is nothing left from which dower can be derived. We do not declare what would be the result, if the case were one of mere reversion to the devisor or grantor. It will be time enough to consider that question when it arises.

Decree affirmed.

Chief Justice BrICKELL, having been of counsel, not sitting. ${ }^{23}$

\section{ELLIS v. KYGER.}

(Supreme Court of Missouri, 1SS6. 90 Mo. 600, 3 S. W. 23.)

Black, J. This is a suit for the assignment of dower. One of the plaintiffs, Polly Ellis, and her former husband, Isaac Jacobs, on the thirteenth of November, 1859, conveyed to Frederick Billum, in trust for the Pacific railroad, a parcel of land twelve hundred and sixtyseven feet in length by an average width of five hundred feet. The deed recites that it is made "upon the condition that if the Pacific Railroad Company shall not construct the said railroad through said tract, or if, when constructed, they shall not establish a freight and passenger station upon said tract, then the conveyance shall be null and void, but otherwise to remain in full force and effect." Isaac Jacobs died in 1863. The railroad was completed to a point beyond the tract of land in question in 1865 . There was evidence, the bill of exceptions recites, tending to show that the company failed to perform the conditions in the deed, and evidence to the contrary effect. In 1869, Asa Whitehead procured deeds from some of the heirs of Jacobs, and in that year built a house upon the lots in question, which was destroyed by fire. Neither Jacobs in his lifetime, nor his heirs, ever entered or made any effort to recover the property for condition broken. In 1878, Coventry, Cockrell and Zoll, who had acquired the title of Whitehead and the other heirs of Jacobs, quit-claimed a part of the premises described in the deed to the trustee of the railroad company, and the company at the same time quit-claimed the residue to them, from whom defendant acquired his title.

The trial court gave an instruction that, upon the evidence the plaintiffs could not recover. That the conditions in the deed for the construction of the railroad through the land therein described, and the establishment of a freight and passenger depot thereon, were conditions subsequent, is too clear to call for the citation of authorities. The trustee became seised of the premises, though the estate in lim continued defeasible until the conditions were performed,

23 See notes to Lessee of Borland v. Marshall, supra, 588 . 
waived, released, or barred by the statute of limitations, or by estop. pel. As no time was fixed within which the conditions were to be performed, the law would allow the company a reasonable time. $2 \mathrm{Wash}$. Real Prop. (4th Ed.) 1. Since the railroad was completed to a point beyond the land in question, in 1865 , a reasonable time has long since elapsed; and we must assume, under the instructions given, that the company has failed to perform the stipulations in the deed to the trustee.

It is wcll settled that an action of ejectment may be maintained by the grantor or his heirs for condition broken, without any entry or demand of possession. Austin v. Cambridgeport Parish, 21 Pick. (Mass.) 215; Plumb v. Tubbs, 41 N. Y. 442; Cowell v. Spring Co., 100 U. S. 55, 25 L. Ed. 547. Our statute with respect to actions of ejectment leads to the same conclusion. R. S., 1879, $\S \S 2240-47$. But it is equally well settled that non-performance of the condition alone does not divest the estate. Performance of the condition may be waived; and the estate continues in the grantee after the breach until he, who has a right to insist upon performance, elects to declare a forfeiture. The estate continues with its original incidents until entry or some act equivalent to it. 4 Kent, $127 ; 2$ Wash. Real Prop. (4th Ed.) 12; 1 Smith's Lead. Cas. (8th Ed.) 130; Memphis \& C. R. Co. v. Neighbors, 51 Miss. 412; Kenner v. Contract Co., 9 Bush (Ky.) 202 : Knight v. Railroad, 70 Mo. 231. The grantee in the deed of trust, therefore, continued to be the owner of the premises at and after the death of Jacobs, who was not seised at any time after the delivery of the deed. A widow is entitled to be endowed in all the lands of which her husband, or any person to his use, was seised of an estate of inheritance at any time during the marriage, to which she shall not have relinquished her dower. R. S. $1879, \S 2186$. As the plaintiff here relinquished her dower by deed duly acknowledged, and her husband did not enter for condition broken, and was, therefore, not seised of the premises in dispute at any time after the delivery of the deed, it would seem to follow that the plaintiff is not entitled to dower. Washburn says, it is enough that the husband had a seisin in law, with the right to an immediate corporal seisin. If it was not so, it might often be in the husband's power, by neglecting to take such seisin, to deprive his wife of her right to dower. 1 Wash. Real Prop. (4th Ed.) 215: But here the husband made no entry, nor was he seised in law. The same author in the same connection says, if, at common law, the husband had not, during coverture, anything more than a mere right of entry or of action to obtain seisin, it would not be sufficient to entitle his widow to dower. The mere right of entry upon lands was not sufficient to give dower. 1 Scrib. on Dower, 243. If the husband dies before entry, in a case of forfeiture for condition broken, his wife is not dowerable, because he had no seisin, either in fact or law. 4 Kent (13th Ed.) 38. In Thompson v. Thompson, 46 N. C. 431, the court said. AIG.PRop. -39 
by way of illustration: "So where one makes a feoffment upon condition, and dies after condition broken, but without revesting his estate by entry, and afterwards the heir enters and revests the estate, the widow is not entitled to dower."

It results from what has been said, both upon principle and authority, that the plaintiff is not entitled to dower in the premises in question. The result would be the same had the heirs of Isaac Jacobs, and not their grantees only, entered for breach of the condition in the deed to Billum.

It is further insisted by the appellants that the defendant is estopped from denying plaintiff's right to dower. This contention is based upon the fact that the defendant's grantors acquired possession and claim of title, at least, from Whitehead, who made claim and took possession alone under his deeds from the heirs of Isaac Jacobs. The authorities all show that the right to enter for condition broken descended to the heirs of Jacobs, the right not having been exercised by him in his lifetime. But though this be true, it does not follow that the widow would, for that reason, be entitled to dower. We have seen that she would not be entitled to dower because her husband was not seised, either in fact or law. There is, therefore, nothing inconsistent between a claim under them, and the claim that the widow should not be endowed.

It is urged that the general common law rule, which confined the right to take advantage of the non-performance of a condition subsequent annexed to an estate in fee to the grantor or his heirs, has been modified by our statutes with respect to conveyances. We do not stop to consider this question, for it cannot affect the result before reached in this case.

The judgment is, therefore, affirmed. All concur.

\section{WALLIS v. DOE ex dem. SMITH'S HEIRS.}

(High Court of Errors and Appeals of Mississippi, 1844. 2 Smedes \& M. 220.)

Appeal from the circuit court of Holmes county.

This was an action of ejectment, brought by the heirs at law of Chafin Smith, to the October term, 1839, of the circuit court of Holmes county, to recover a tract of land lying in that county. The declaration and notice were served on Joseph Wallis, who, at the July special term, 1840, appeared, and caused himself to be made defendant, confessed the lease, entry, and ouster, \&c., and pleaded not guilty. On the trial it was proved that the plaintiffs were the heirs at law of Chafin Smith, who in his life-time was admitted to have had title to the land in dispute, that he lived upon it, and, at the time of his death, it was his homestead; that Joseph Wallis purchased it, at sheriff's sale, under an execution against Jane Smith, who was the widow of said Chafin Smith, and claimed it by virtue of said purchase; that at the time of the 
commencement of the suit, the land was in possession of one Martin, who held and claimed it as his own; that Joseph Wallis sold it to said Martin, but none of the witnesses knew of any written contract between them, or conveyance to Martin.

The defendant's counsel then read to the jury the execution, sheriff's return thereon, and the deed under which he purchased and claimed. It was admitted that the widow was still living.

No further evidence being offered by either party, the defendant's counsel moved the court to instruct the jury.

1st. That if they believed, from the evidence, that Jane Smith was the widow of Chafin Smith, and that he owned and lived upon the lands in dispute, at the time of his death, and that the same have been purchased by the defendant, under executions against her, and that she is still living, that unless they are satisfied, from the evidence, that her dower in his lands has been assigned to her, they must find for thrdefendant.

2d. That the widow of a decedent is, by law, entitled to the possession of the tract of land constituting the homestead of her husband, at the time of his death, until her dower in his lands is assigned to her.

$3 \mathrm{~d}$. That unless the jury believe, from the evidence, that the defendant was in possession, at the time of the service of the declaration in this cause, they must find for the defendant.

4th. That the deed of the sheriff convey's only such title as Jane Smith herself could lawfully have made.

All of which the court refused to give, and, at the request of the plaintiff's counsel, instructed the jury, "That if they believe, from the testimony, the defendant, either in his own person, or by another claiming under him, was in possession of the land, at the time of bringing the suit, it is sufficient proof of possession, to entitle the plaintiff to recover, so far as possession is concerned." To all of which the defendant's counsel excepted. The jury found for the plaintiffs, and the court rendered judgment accordingly. The defendant's counsel then moved for a new trial; his motion was overruled, and he appealed to this court. The errors assigned are, the refusal of the court below to give the instructions asked by the defendant, and giving that asked for by the plaintiffs.

Clayton, J. This was an action of ejectment, brought by the defendants in error as the heirs of their ancestor, to recover a tract of land in Holmes county. Two errors are assigned for reversing the judgment.

It is first objected that the land was the homestead or place of residence of Smith, the ancestor, at the time of his death, that he left a widow who, under the statute, is entitled to the premises until her dower is assigned to her, and that the plaintiff in error claims under the widow as the purchaser of her interest at execution sale.

At common law the widow had a right to remain in the mansionhouse of her deceased husband for forty days after his death, within 
which time it was the duty of the heir to assign her dower. But before strch assignment she could not maintain ejectment for it. Adams on Ejectment, 65; 1 Th. Coke, 601; 2 C. \& P. 430. She has no vested estate for life in any particular part, until after allotment. 4 Kent, 62. The right of quarantine, or the right to remain in possession of the mansion-house, is by our statute extended, so as to enable her to retain it free from molestation and rent, until her dower is assigned. H. \& H. 353. Under a similar statute in New Jersey it has been decided, that an action of ejectment will not lie against her, unless her dower had been previously assigned. Den v. Dodd, 6 N. J. Law, 367. This decision is against the weight of English and American authorities, in states in which no such statute exists; but it may be a just construction, and applicable to our own statute. ${ }^{24}$ But be this as it may, this right of enjoyment of the mansion-house, we regard as a mere personal privilege, one which cannot be transferred to a third person; and that such third person claiming under her may be put out by the heir, and driven to the remedy to recover the dower. Until assignment the widow has no estate in the lands, and her claim is a mere charge or incumbrance upon them. We think therefore, that this defence cannot be sustained. See 4 Kent, $61 . .^{25} * * *$

Judgment is therefore reversed and a new trial granted.

\section{FLYNN v. FI,YNN.}

(Supreme Judicial Court of Massachusetts, 1898. 171 Mass. 312,50 N. E. 650 , 42 L. R. A. 9S, 68 Am. St. Rep. 427.)

LATHRor, J. The land in which the plaintiff had an inchoate right of dower was taken by the city of Boston by right of eminent domain, for the purposes of a schoolhouse, the city acting by virtue of and in accordance with the provisions of the St. of 1895 , c. 408 . This act, in sec. 2, gives the board of street commissioners of Boston, at the request of the school committee, power to "take by purchase or otherwise such lands for school purposes as said school committee, with the approval of the mayor, shall designate, and to take any lands under the right of eminent domain." The board is also required to "sign, and cause to be recorded in the registry of deeds for the county of Suffolk, a statement containing a description thereof as certain as is required in a common conveyance of land and stating that the same are taken for school purposes; and upon the recording of any such statement the lands described therein shall be taken in fee for said city." We assume that all the formalities required have been complied with, and that the city now owns the land in fee.

24 See Callalian v. Nelson, 12S Ala. 671, 29 South. 555 (1900).

25 The balance of the opinion, in which the court concluded that the portion of the charge regarding the sufficiency of the proof of possession to entitle the plaintiff to recover was er'oneous, is omitted. 
The question then is whether an inchoate right of dower is such an interest in land that, when the land is taken by the right of eminent domain, the wife may apply to a court of equity to have in some way the benefit of such interest. We are not aware that this right has ever before been asserted in this Commonwealth, and this is the first time that the question has been presented for our decision.

It is declared by the Pub. Sts. c. $124, \S 3$, as follows: "A wife shall be entit 1 to her dower at common law in the lands of her deceased husband." This chapter makes many provisions in regard to dower, but there is none which relates to the question before us.

At common law, "a woman is entitled to dower out of all the lands whercof her husband was seised in fee simple, at any time during the coverture." 1 Greenl. Cruise, 175.

There is no doubt that the inchoate right of dower is an encumbrance upon land. Shearer v. Ranger, 22 Pick. 447. The release of such a right of dower is a good consideration for a promise. Bullard v. Briggs, 7 Pick. 533, 19 Am. Dec. 292; Holmes v. Winchester, 133 Mass. 140; Nichols v. Nichols, 136 Mass. 256. It is a contingent right. which the wife during coverture may have the assistance of the court to establish or protect. Burns v. Lynde, 6 Allen. 305 ; Davis v. Wetherell, 13 Allen, 60, 90 Am. Dec. 177; Madigan v. Walsh, 22 Wis. 501. Clifford v. Kampfe, 147 N. Y. 383, 42 N. E. 1; Buzick v. Buzick, 44 Iowa, 259, $24 \mathrm{Am}$. Rep. 740 . So, too, a wife having an inchoate right of dower may maintain a bill in equity to redeem land from a mortgage in which she has joined with her husband to release dower. Davis v. Wetherell, 13 Allen, 60; Lamb v. Montague, 112 Mass. 352. Sec Pub. Sts. c. $124, \S 5$. But if the mortgage contains a power of sale, and the wife has joined in the deed with her husband in release of her dower, a sale of the land in pursuance of the power bars all claim and possibility of dower. Pub. Sts. c. 181, § 19.

While a wife may, under Pub. Sts. c. $124, \S 6$, bar her right of dower by releasing the same in a deed executed by her husband, or by a subsequent deed executed either separately or jointly with her husband, yet she cannot convey her inchoate right of dower to a person to whom her husband has not conveyed the land. Such a deed is void. Mason v. Mason, 140 Mass. 63, 3 N. E. 19. See also Reiff v. Horst, 55 MId. 42. In Mason v. Mason, it was said by Mr. Justice Devens: "While the inchoate right of dower is a vested right of value, dependent on the contingency of survivorship, it is not that separate property which passes by conveyance, but a right which one entitled thereto may, under certain circumstances, release. It is of a peculiar character, and, before assignment, the wife has no seisin." While the word "vested" is used in this case, it would seem that the word "contingent," which was used by Chief Justice Parker in Bullard v. Briggs, 7 Pick. 533, 539, 19 Am. Dec. 292, would more accurately describe the nature of the estate. After an assignment of dower is made, the widow acquires no new freehold, her seisin being deemed in contemplation of law a con- 
tinuation of her husband's seisin. Windham v. Portland, 4 Mass. 384, 388.

Even after the death of the husband, a creditor cannot at law attach the right of the widow to have her dower assigned to her, or take the same on execution. McMahon v. Gray, 150 Mass. 289, 22 N. E. 923, 5 L. R. A. 748, 15 Am. St. Rep. 202. Until dower has been assigned to her, a widow has no estate in the land of her deceased husband. Smith v. Shaw, 150 Mass. 297, 22 N. E. 924 ; State v. Wincroft, 76 N. C. 38. Nor can she object to a partition of the land among the tenants in common. Motley v. Blake, 12 Mass. 230; Ward v. Gardner, 112 Mass. 42.

There can be no doubt that the inchoate right of the wife is always subject to any encumbrance or infirmity in the husband's title existing at the time he became seised; and we are also of opinion that it is subject to any incident attached to it by law. The land may be sold on a petition for partition, if the husband is a tenant in common. Pub. Sts. c. $178, \S 65$. When this happens, it has been held in a well considered case in Indiana that the wife is not a necessary party to the partition proceedings, and is not entitled to share in the fund derived from the sale. Haggerty v. Wagner, 148 Ind. 625, 48 N. E. 366, 39 L. R. A. 384.

Land may be sold for taxes, and if there is a surplus it is to be paid "to the owner of the estate." Pub. Sts. c. 12, § 35; St. 1888, c. $390, \S$ 40. In a case arising under a New York statute, which directed that any surplus arising on a tax sale "shall be held for the use of and paid over to the person legally entitled upon his establishing his right thereto," it was held that the owner of the land was entitled to the surplus. People v. Palmer, 10 App. Div. 395, 41 N. Y. Supp. 760. It was also held in this case that the interest which the wife of the owner had in the land by virtue of her inchoate right of dower, although a valuable interest, was not an "estate" in the land which would give her a right to redeem from the tax sale, under a statute giving a right to redeem to "any person or persons having an estate in, or any mortgagee of" any land sold for taxes.

It is also an incident of land that it is liable to be taken by the right of eminent domain, and we are of opinion that when it is so taken in the lifetime of the husband, the wife is not entitled, on account of her inchoate right of dower, to have any portion of the money received for the land either paid to her directly, or set aside for her benefit on the contingency of her surviving her husband. If the land had not been taken, the husband could have done what he pleased with it during his life. He might have sold it for its full value, yet the wife could not interfere, or deprive him of the use of any part of the purchase money. In case the husband survived the wife, the purchaser would have a good title, which the heirs of the wife could not interfere with. If the chief value of the estate should consist of a building on the land, which was insured by the husband, and the building should be destroyed by fire, 
no one would contend that the wife had any interest in the insurance money, or that a court of equity would compel a part of the money to be set aside for her benefit unless the husband would agree to rebuild the house. Again, if a parcel of land should be washed away by the negligent maintaining of a dam, and the owner of the land should recover as damages the full value of the land, would not the money so received be his to do with as he pleased?

The only case in support of the doctrine contended for by the petitioner which has been decided by a court of last resort is that of Wheeler v. Kirtiand, 27 N. J. Eq. 534, decided in 1875 by the Court of Errors and Appeals in New Jersey. It laid down a new doctrine, which has not since been recognized except by a court of inferior jurisdiction, and which we are of opinion is opposed to sound principles.

The case of Wheeler v. Kirtland was partly decided on the ground that the rule laid down in Moore v. New York, 8 N. Y. 110, 59 Am. Dec. 473 , had been repudiated or morlified in later decisions in that State, citing In re Central Park Extension, 16 Abb. Prac. 56; 68, and Simar v. Canaday, 53 N. Y. 298, 13 Am. Rep. 523. In Moore v. New York, 8 N. Y. 110, 59 Am. Dec. 473, lands in which the wife had an inchoate right of dower were taken by the right of eminent domain. After the husband's death, his wife claimed dower in them. The statute under which the land was taken anthorized commissioners to make "a just estimate of the damage to the respective owners, lessees, parties, and persons respectively entitled unto or interested in the hands." It was said by Gardiner, J.: "The question is whether the possibility of dower accruing to the wife after marriage, but before the death of the husband, is an interest in law, within the purview of this statute. * * * Such a possibility may be released, but it is not, it is believed, the subject of grant or assigmment, nor is it in any sense an interest in real estate."

It was held in In re Central Park Extension, $16 \mathrm{Abb}$. Prac. 56, 69, on the authority of Moore v. New York, that the inchoate right of dower was not an interest in real estate, Judge Ingraham, however, added, after quoting the remarks of Gardiner, J.: "It might have been added to that case, that the right was transferred from the land to the money received for the land by the husband, if the wife survived him."

The case of Simar v. Canaday, 53 N. Y. 298, 13 Am. Rep. 523, merely decides that, if a husband is induced to part with his land by fraud, his wife has such an interest that she can join with him in an action against the fraudulent purchaser.

The rule laid down in Moore v. New York, so far from being repudiated or nodified in that State by later decisions, has been recognized and affirmed by the Court of Appeals, Witthaus v. Schack, 105 N. Y. 332, 11 N. E. 649, where it is said by Ruger, C. J.: "The settled theory of the law as to the nature of an inchoate right of dower is that it is not an estate or interest in land at all, but is a contingent claim arising not out of contract, but as an institution of law, constituting 
a mere chose in action incapable of transfer by grant or conveyance, but susceptible only during its inchoate state of extinguishment. By force of the statute this is effected by the act of the wife in joining with her husband in the execution of a deed of the land. Such deed, so far as the wife is concerned, operates as a release or satisfaction of the interest and not as a conveyance, and removes an encumbrance instead of transferring an interest." See also Hammond v. Pennock, 61 N. Y. $145,158$.

The only case which has been brought to our attention that has followed Wheeler v. Kirtland is In re New York \& Brooklyn Bridge, 75 Hun, 558, 27 N. Y. Supp. 597, and S9 Hun, 219, 34 N. Y. Supp. 1002. But the view taken of the nature of the inchoate right of dower in this case does not seem to be in conformity with the cases above cited from the higher courts of New York.

In the cases of Bonner v. Peterson, 44 Ill. 253, and In re Hall's Estate, L. R. 9 Eq. 179, cited by the plaintiff, the husband had died, and the widow's right of dower was no longer inchoate when the land was taken.

For the reasons before stated, we are of opinion that the bill should be dismissed. So ordered. ${ }^{26}$

\section{CRENSHAW v. MOORE.}

(Sunreme Court of Tennessee, 1911. 124 Tenn. 52S, 137 S. W. 924.)

LANSDEN, I. William R. Moore died in Shelby county testate, and his widow, Mrs. Charlotte Blood Moore, dissented from his will. Such proceedings were had in the county court of Shelby county that she was assigned a year's support, to the value of $\$ 20,000$, and dower of one-third of his real estate. The complainant brought this suit to collect from her an inheritance or succession tax on both her year's support and dower, under the act of 1893 (Shannon's Code, section 724), as amended by chapter 479 of the Acts of 1909 .

The act of 1893 imposed a tax upon "all estates, real, personal, and mixed, of every kind whatsoever, situated within this State, whether

26 Cf. French r. Tord, 69 Me. 537 (1579); Borongh of York r. Welsh. 117 Pa. 174, 11 Atl. 290 (1S\$7). See Benton v. City of St. Louis, 217 Mo. 6S7, 118 S. W. 41 S, 129 Am. St. Rep. 561 (1908).

In Brown $\nabla$. Brown, S2 N. J. Eq. 40, SS Atl. 1 S6 (1913), the court entertained a bill in equity br a wife to protect her inchonte dower in certain lands held bs the defendant in trust for her hushand against a possible conreyance to an innocent purchiser. See, too, Brown v. Brown, 94 S. C. 492, 78 S. E. 147 (1913), where it was held that under some circumstances a court of equity would interfere to protect a wife's inchoate dower against waste. But see Rumsey r. Sullivan, 166 App. Dir. 246,150 N. Y. Sulp. 287 (1914).

In Whiting V. Whiting (Me.) 96 Atl. 500 (1916), the plaintiff, who had been induced by fraudulent representations of her husband to join in a deed of his land, was held entitled to maintain a bill in equity against him to have him declared a trustee of a certain portion of the purchase price for her benefit. The plaintifl's only interest in the land was her contingent interest provided for by the statute in place of the common-law dower. 
the person or persons dying seized thereof be domiciled within or out of this State, passing from any person who may die seized or possessed of such estates, either by will or under the intestate laws of this State, or any part of such estate or estates, or interest therein, transferred by deed, grant, bargain, gift, or sale, made in contemplation of death, or intended to take effect in possession or enjoyment after the death of the grantor or bargainor," passing to collateral kindred of the owner; and section 20, ch. 479, Acts of 1909, provided "that inheritances not taxed under the present laws shall pay a tax as follows: All inheritances of $\$ 5,000$ and over, but less than $\$ 20.000$, a tax of one per centum of their value. All inheritances of $\$ 20,000$ and over, a tax of one and one-fourth per centum of their value, to be collected by the county clerk of each county."

This is a privilege tax imposed on the right of acquiring property by succession. State v. Alston, 94 Tenn. 674, 30 S. IV. 750, 28 L. R. A. 178; Knox v. Emerson, 123 Tenn. 409, 131 S. W. 972. Likewise it is a special tax, and the rule is that laws imposing such taxes are to be construed strictly against the government, and favorably to the taxpayer. English v. Crenshaw, 120 Tenn. 531, 110 S. IV. 210, 17 L. R. A. (N. S.) 753, 127 Am. St. Rep. 1025.

The widow's year's support is given her by statutory provision, which is found in sections 4020 and 4021 of Shannon's Code. It is inconceivable that the legislature intended to levy the tax in question upon this bounty of the widow, given her by the law out of her husband's personal estate. She does not succeed to the husband's title to the property set apart to her as a year's support, but acquires it adversely to his administrator by virtue of the statute. By the act of separation of the personalty assigned to her by the commissioners, and the subsequent confirmation of their report by the court, the title to the specific property thus set apart becomes absolutely rested in the widow. The obvious intention of the legislature in passing this statute was to provide a temporary support for her and her family immediately on the death of her husband. It is an extension by law of her right of support out of the personal estate of her husband for one year after his death, and is founded in a sound public policy, which has for its purpose a conservation of the family upon the death of the husband. The widow does not succeed to the right of the husband, nor does she take the property under the intestate laws of this State. It is a special provision made for her in the law for the support of herself and her family. Bayless v. Bayless, 4 Cold. 363; Railway Co. v. Kennedy, 90 Tenn. 185, i6 S. W. 113.

Nor do we think that the widow's dower is subject to this tax. By the common law, if a husband acquire an estate which is subject to descend to his heirs, the wife, at the same time the husband acquires his title, has vested in her the right of dower; and although the husband aliened the estate, the wife's dower would attach. By the acts of 1784 and 1823, carried into Shannon's Code at section 4139, the widow 
is dowable in one-third part of all the lands of which her husband died seized and possessed, or of which he was equitable owner. In all other respects, the widow's right of dower in this State is the same as it was at common law. It has the same qualities as the commonlaw right of dower, but its quantity was cut down by the statutes referred to. This right originates with the marriage. It is an incunbrance upon the title of the heir at law, and is superior to the claims of the husband's creditors. Its origin is so ancient that neither Coke nor Blackstone can trace it, and it is as "widespread as the Christian religion and enters into the contract of marriage among all Christians."

"By a fiction of law, the estate in dower relates to the marriage. It is adjudged in Fulwood's Case, 4 Co. 65 , that the widow shall hold her dower discharged from all judgments, leases, mortgages, or other incumbrances made by her husband after the marriage, because her title, being consummated by his death, has relation to the time of the marriage, and, of course, is prior to all other titles. She claims by and through her husband, has the oldest title, is under him for the valuable consideration of marriage, the best respected in the law, and cannot be disturbed by any other claiming under the husband." Combs v. Young, 4 Yerg. 226, 26 Am. Dec. 225.

The preamble to the act of $178+$, which was the first passed in this State reducing the quantity of the widow's dower estate, recites, in substance, that the dower allotted by law in lands for widows, in the then unimproved state of the country, was a very inadequate provision for the support of such widows; that it was only just and reasonable that those who, by their prudence, economy, and industry had contributed to raise up an estate to their husbands, should be entitled to share in it-thus showing that the legislature recognized that the widow's dower under this act had the same origin and was of the same quality as her dower existing at common law.

So, it is seen that, whether it be considered that the widow holds her dower in the nature of a purchaser from her husband by virtue of the marriage contract, or whether it be merely a provision of the law made for her benefit, it cannot be considered that her right is in succéssion to that of her husband upon his death, or that the husband bestows it upon her in contemplation of death. While it is true that her right to dower is not consummated until the death of the husband, and that it is carved out of only such realty as he owned at his death, it does not follow from this premise that the widow succeeds to his title by the intestate laws. She derives it by virtue of the marriage, and in her right as wife to be consummated in severalty to her upon the death of her husband. Boyer v. Boyer, 1 Cold. 14.

The sunreme court of Illinois, in Billings v. People, 189 Ill. 472 , 59 N. E. 798,59 L. R. A. 807, upon a construction of the inheritance tax law of that State, together with the laws governing the descent and distribution of the property of persons dying intestate reached a different conclusion from that reached by us. The reasoning of that 
court is predicated chiefly upon a construction of the statutes of that State, which are essentially different from those of this State. It is stated, however, that, while the husband cannot deprive his wife of her inchoate right of dower, the State may, and that she does not hold by contract, but holds by laws which the State may change. Without undertaking to meet all of the arguments set forth in support of this very able opinion, we are content to hold that, under a proper construction of the statute in question, the legislature did not intend to tax the widow's dower as an inheritance from the estate of her husband, or a succession to his rights therein. As stated heretofore, she does not inherit from her husband, but derives her right by virtue of her marriage, which is consummated upon her husband's death, and becomes an incumbrance upon the inheritance of the heirs at law, and is, to that extent, an interest adverse to the inheritance from the husband. For the same reason she does not succeed to the rights of the husband. Her dower is intended for her support and maintenance, and an intention to tax it will not be imputed to the legislature, except where the language employed makes it plainly imperative to do so.

Billings v. People, supra, is the only case cited by counsel which discusses the question at issue in any way, and no case is cited discussing the liability of the widow's year's support for the tax involved here. But, upon reason, we are content to hold that neither the year's support nor dower is subject to the tax. It results that the decree of the court below is affirmed, with costs. ${ }^{27}$

\section{INGRAM v. MORRIS.}

(Superior Court of Delaware, 1S44. 4 Har. 111.)

Summons in dower. Plea, that the land was sold on a judgment against the husband, which was a lien thereon at the time of the marriage. Replication and issue.

It was admitted that Samuel Ingram was seized of an estate of inheritance in the premises at the time of the marriage. The judgment upon which the land was sold bore date on the same day of the marriage, and there was no evidence which, in point of time, preceded the other. Yet the title of the widow of Samuel Ingram to dower depended on this question; for if the judgment was a subsisting judgment at the time of the marriage, the sale of the land which was afterwards made in execution of that judgment discharged the land of

27 See In re Estate of Sanford, 91 Neb. 752, 137 N. W. $\$ 64$ (1912); In re Bullen's Estate (Utah) 151 Pac. 5:3: (1915), acc. See, also, In le Estate of Strahan, 93 Neb. $8 * 8,142$ N. W. 678 (1913), enlarged statutory sulstitute for dower; Kohny v. Dunbar, 21 Idaho, 25S, 1:21 Pac. 544. 39 I. R. A. (N. S.) 1107, Aun. Cas. 19130,492 (1912), community property ; In re Thompson's Estate, 85 Misc. Rep. 291, 147 N. Y. Supp. 157 (1914), tenancy by entireties. 
dower, if the marriage took place before the judgment was entered, the wife's right to dower attached and could not be divested by a judgment subsequently entered.

Ridgely, for the claimant, argued that the claim of dower was a favored claim; and, in the absence of evidence, the jury would imply in favor of dower. He showed that the judgment was entered on a bond, dated many months before, and argued that the delay of entering the judgment should be considered to the prejudice of the party claiming under it; that the burthen of proof was on the defendant, who pleaded an affirmative plea in derogation of this favored right. Jenkins' Rep. 274; Parke on Dower, 2.

Wootten, contra, argued from the fact of the entry of judgment on the day of the marriage, that the inference should be made that it was entered before the marriage, for the very purpose of binding the land so as to prevent the right of dower; that the common usage of the country was, for marriage to take place in the evening, after the usual hour of doing business in the public offices; and that if the marriage and entry of judgment were at the same moment the wife would not be dowable, for his seizin otherwise than as subject to dower, would be only momentary. And such a seizin gives no right to dower. 1 Johns. Dig. 518; Stow v. Tifft, 15 Johns. (N. Y.) 458, 8 Am. Dec. 266.

The jury rendered a verdict for the demandant.

\section{GRADY v. McCORKLE.}

(Supreme Court of Missouri, 1S74. 57 Mo. 172, 17 Am. Rep. 676.)

WAGNER, J., delivered the opinion of the court.

This was a suit commenced in the Circuit Court of Howard county, against the defendants, the widow and heirs of Leonard Grady, deceased, for the assignment of dower in certain real estate. From the record it appears, that in the year 1859, William Grady, the plaintiff's husband, was seized of the land in controversy, and agreed with his son, Leonard Grady, that if he would go on the land and improve it, he would convey the same to him by deed, by way of advancement, and charge him with its value at the time he took possession.

Uncler this agreement Leonard took possession of the land and made improvements on the same, and continued to reside on and cultivate it up to the time of his death.

William Grady died without having conveyed the land according to the agreement, and without having fixed any price thereon, to be charged as an advancement.

In the year 1865, after the death of William and Leonard, the father and son, the widow and heirs at law of Leonard, who are the defendants in the present case, filed their petition in the Circuit Court 
against the plaintiff and the heirs of William, setting out the facts as above stated, and praying the court to decree that the land should be held by them as the widow and heirs of Leonard, as if the same had been conveyed to him by William in his life time, and to fix a valuation thereon, at which they should be charged for the same.

In this proceeding plaintiff was duly served with process, but made no answer. The court made a decree in accordance with the prayer of the petition, declaring that the land "described be, and the same is hereby vested in the plaintiffs, to be held by them as if the same had been conveyed by said William Grady in his life time, to the said Leonard Grady, and that the title of defendants, as the widow and heirs of William Grady be divested."

The court below held that this decree barred the plaintiff, the widow of William Grady, from having any dower in the premises, and this is the only question in the case.

The statute provides that "every widow shall be endowed of the third part of all the lands whereof her husband, or any other person to his use, was seized of an estate of inheritance, at any time during the marriage, to which she shall not have relinquished her right of dower, in the manner prescribed by law, to hold and enjoy during her natural life." 1 Wagn. Stat. p. 538, § 1.

The right of dower attaches whenever there is a seizin by the husband during the marriage, and unless it is relinquished by the wife in the manner prescribed by law, it becomes absolnte at the husband's death. After the right of dower has once attached, it is not in the power of the husband alone to defeat it by any act in the nature of an alienation or charge. It is a right in law, fixed from the moment the facts of marriage and seizin concur, and becomes a title paramount to that of any person claiming under the husband by subsequent act. Co. Litt. 32a.

The alienation of the husband, therefore, whether voluntary, as by deed or will, or involuntary, by proceedings against him or otherwise, will confer no title on the alienee, as against the wife in respect of her dower.

It is a necessary consequence of this rule, that all charges or derivative interest created by the husband, subsequent to the attachment of the wife's right, are voidable as to that part of the land which is recovered in dower. As the husband cannot defeat his wife's dower by any alienation of the land by himself alone, so neither can he bind her by any modification of the nature of the seizin, nor by any merger or extinguishment produced by his own act without her concurrence. Scribn. Dower, 577.

In conformity with these principles, it has been held that if a woman, after she becomes a widow, is made a party to a suit to foreclose a mortgage executed by the husband alone, and no allegation be made in the petition in reference to her claim for dower, the decree will not be considered as affecting her dower estate. Lewis v. Smith, 9 N. 
Y. 502, $61 \mathrm{Am}$. Dec. 706; Thompson v. Reeve, 12 Mo. 157; Crenshaw v. Creek, 52 Mo. 98; Freem. Judg. § 303.

Neither the petition nor the decree in the case of Leonard Grady's widow and heirs v. William Grady's widow and heirs, made any mention of the subject of dower, nor was it at all litigated or drawn in question. The whole object, extent and scope of that proceeding was to have the agreement and undertaking of IVilliam Grady specifically performed. The rights against the widow and heirs were precisely the same as they would have been against William Grady, had he been alive and made a party to the suit. But a suit against him would not have affected his wife's right to dower, without any concurring act on her part. The decree divested his title out of the widow and heirs, and vested it in the widow and heirs of his son. Nothing more was attempted ard nothing more was done.

The question of the plaintiff's right of dower was neither raised nor decided, and was not made a subject of adjudication in the suit for specific performance. The plaintiff did not answer, and although she was perhaps properly made a party, my conclusion is, that she is not barred from claiming her dower interest in the land-she having done nothing to relinquish the same.

Wherefore the judgment must be reversed and the cause remanded; the other judges concur. ${ }^{28}$

\section{CATLIN v. IVARE.}

(Supreme Judicial Court of Massachusetts, 1\$12. 9 Nass. 218, 6 Am. Dec. 56.)

This was a writ of dower, to which the tenant pleaded in bar: 1st That the demandant's husband Joseph Catlin was never seized, \&c. on which issue was joined. 2d That the said Joseph, being seized in his demesne as of fee, on the 28th day of March, 1793, by his deed of that date duly acknowledged, \&c. for a valuable consideration, bargained and sold the same land, in which the demandant claims her dower, to one David Horton in fee simple; and that the said Abigail, by the consent of her husband, for the consideration in the said deed expressed, and also of one dollar paid her by the said David, assented and agreed to the same deed of the said Joseph, and then and there by her act and consent, signified by her affixing her seal to the said deed, and subscribing her mark thereto, she being unable to write her name, barred herself of all right of dower in the same premises and every part thereof: by virtue whereof the said David became seized in fee of the same premises, free and exempt from all claim, demand or right of dower of the said Abigail therein.

28 Cf. Phillins v. Phillips, 30 Colo. 516, 71 Pac. 363 (1903) ; Ligare ₹. Semple, 32 Mich. 438 (1S75). But see Bennett r. Harms, 51 Wis. 251, 8 N. W. 222 (1Ss1). 
The demandant replied, that she did not by her act and consent signified, \&c. bar herself, \&c. and tendered an issue to the country, which was joined by the tenant.

The several issues thus joined were tried at the last April term of this court in this county, before Sedgwick, J., from whose report it appears, that the seisin of the demandant's husband and her coverture were agreed, as alleged in the writ.

The tenant produced the deed of Joseph Catlin to David Horton, mentioned in the pleadings. It purported a conveyance in fee of the land, in which dower is demanded, and to it, after the name and seal of her husband, were set the demandant's seal and mark. But her name was not otherwise mentioned in the deed, nor were there any words therein purporting or implying a release of her right of dower. The deed was acknowledged by the husband, and recorded; but there was no acknowledgment by the wife.

On the part of the tenant it was insisted at the trial, that the latter issue was proved on his behalf. But the judge directed a verdict on both issues in favour of the demandant; referring to the decision of the court, the question whether that direction was right.

It was also referred to the court to determine any question which might arise from the finding of the jury, respecting the improved value of the land: the improvements having arisen from ditching the land, making walls, and erecting and improving buildings.

The jury returned a verdict conformably to the directions of the judge; assessed the demandants' damages at 49 dollars 50 cents; and certified that the improvements made upon the demanded premises, since the conveyance thereof by Joseph Catlin, were at the rate of fifty per cent.

Curia. Two objections, made to the deed read in evidence at the trial of this cause, have been replied to by the counsel for the tenant.

As to the second, the want of an acknowledgment by the wife, we think an acknowledgment unnecessary in the case. One party to a deed acknowledging it gives notoriety to it, and that is the whole that is necessary. Though a deed be acknowledged and recorded, yet on the issue of non est factum the execution of the deed is still to be proved, as if it had not been acknowledged. Neither was an acknowledgment by the wife necessary in order to make the deed binding on her. She must know her own acts, and is bound by such, as the law authorizes her to execute.

The other objection to this deed has much more weight in it, and is indeed fatal to the defence of the action. A deed cannot bind a party sealing it, unless it contains words expressive of an intention to be bound. In this case, whatever may be conceived of the intention of the demandant in signing and sealing the deed, there are no words implying her intention to release her claim of dower in the lands conveyed which must have been, to give it that operation. It was merely 
the deed of the husband, and the wife is not by it barred of her right to dower. ${ }^{29}$

As to the question referred to us, respecting the increased value of the lands, in which the demandant claims her dower, as they have arisen from the labours and expense of the purchaser, it is our opinion that she is entitled to her third part of the land, in the condition it was in at the time of the alienation by her husband. Had the heir of the husband been the tenant, and the improvements been made by him after the land descended, it would have been otherwise; for it was his folly not to assign the dower to the widow, before he made the improvements. ${ }^{30}$

Judgment on the verdict.

\section{ROBINSON v. BATES.}

(Supreme Judicial Court of Massachusetts, 1S41. 3 Metc. 40.)

Writ of Dower, wherein the demandant claimed her dower in land in Webster, in the seizin and possession of the tenant, and counted upon the seizin of her late husband, William Robinson. The action was tried, on the general issue, before Wilde, J., who reported the case as follows:

The demandant proved her marriage with said William in 1792 , his seizin of the demanded premises from the time of said marriage until 1816; the death of said William in 1837; and a demand of dower, made upon the tenant on the 11th of March, $18+0$.

The tenant then introduced a judgment recovered in this court, at

29 Cox v. Wells. 7 Blackf. (Ind.) 410, 43 Am. Dec. 95 (1S45); Lothrop r. Foster, 51 Me. 36 (186:): MeFarland r. Feliger, 7 Ohio, 194, pt. 1, 28 Am. Hec. 632 (1835), ace. Johnson v. Montgomery, 51 Ill. 1S5 (1S69), semble contra. See Learned v. Cutler, 18 Pick. (Mass.) 9 (1\$86).

As to the ability of the husband and wife to make an effective conveyance of the wife's inclionte dower alone, see Darenport v. Grilliams, 133 Ind. 142. 31 ․ E. 790, 22 L. R. A. 244 (1592). See, also, Hart r. Burch, 130 I1l. 429.22 N. E. 831,6 L. R. A. 371 (1889); Mason v. Mason, 140 Mass. (i3, 3 N. E. 19 (1855). 30 "Nol is the widow's riglat in lands which have been alienated by the husband alone limited to the value of such lands at the date of such converance. It is to be admitted that anthurity may be found for such rule, but the orerwhelming reight is to the contrary. It is, of course, equitable in such cases that the widow shall not be permitted to profit by an increase in value due to improvements and betterments madc or created by the labor and money of the srantee, who has expended them in good faith, believing he had a perfect title: hut in all increase arising from the general growth, proslerits, and development of the country, or from any other source than the labor and expense of the grantee, sle is entitled to share." Butler v. Butler, 151 Iowa, 583 , 5S\&, $132 \mathrm{~N}$. W. 63 (1911), per Wearer, J. It was accordingly held in that case that the court had no jurisdiction to fix a value upon the inchoate dower of a wife who had not joined in a deed of her husband and decree that upon a deposit of such sum liy the grantee, to abide the determination of survisorship, the land should be held free of such dower.

Occasionally the rule is linid down as above quoted, but omitting any reference to the good faith of the grantee. In re 'Tomlinson, 9 Del. Ch. 446, S1 Atl. 4198,555 (1911). See Park on Dower, *256 et ser. 
September term, 1828, by one Morris Larned against said William Robinson, and a levy, in due form, in October, 1828, of the execution which issued on said judgment, upon the demanded premises: Also a judgment, at the October term, 1830, of this court, in a writ of entry brought by said Larned to recover the demanded premises of William Robinson, Junior, and Sylvanus Robinson, then tenants in possession thereof, and the writ of habere facias, issued on said judgment, with the return of an officer thereon, stating the delivery of seizin to said Larned in November 1831: Also a deed of said premises, afterwards made to the tenant by said Morris Larned, dated November 30th, 1831, and duly acknowledged and recorded.

The tenant then offered to prove, that in December, 1816, said William Robinson, by his deed, duly executed and recorded, for the consideration of $\$ 4,000$, conveyed the premises in question to one John Jacobs, Junior, and that the demandant joined him in said deed, and released her dower in said premises. The demandant's counsel objected to the admission of this evidence, because the tenant did not claim under this conveyance. But the evidence was admitted, upon the tenant's counsel intimating that they expected to prove this conveyance fraudulent and void as to creditors, and that, if so, it would, by St. 1805 , c. $90, \S 5$, bar the demandant of her dower. The tenant also proved a conveyance of the demanded premises by said Jacobs to the aforesaid IWilliam Robinson, Junior, and Sylvanus Robinson, by deed duly executed, and recorded in February, 1822.

The tenant then offered to introduce the abovementioned judgment of Morris Larned against William Robinson, to prove that the aforesaid conveyance from said Robinson to Jacobs, in December, 1816, in which the demandant joined and released her dower, was frandulent and void as to creditors, and that therefore the demandant was barred of her dower, by force of the statute aforesaid. The demandant objected to the admission of that judgment for this purpose, because it was between different parties, and not binding on her; and because it had no tendency, in itself to prove fraud in said deed to Jacobs; there being no proof on what ground the verdict and judgment in that case was rendered.

The judge ruled that said judgment could not be admitted for the purpose for which it was offered. To this ruling the tenant excepted. A verdict was taken for the demandant, which was to be set aside and a new trial granted, if the court, should be of opinion that the record of said judgment was admissible for said purpose.

TYILDE, J. The demandant having made out a prima facie case, entitling her to dower, the general question is, whether the defence set up by the tenant is sufficient in law to bar her claim. He relies. on a deed of the premises in question from William Robinson, the demandant's late husband, to one John Jacobs, Junior, in which AIg.Prop. -40 
deed the demandant joined, and thereby released to the said Jacobs her right of dower in the premises.

It is admitted, that the tenant has no title under Jacobs; but his counsel contends that he has, by the common law, a right to plead in bar, and under St. 1836, c. 273 , abolishing special pleadings, to give in evidence under the general issue, a conveyance by the demandant to a third person under whom he does not claim; and he relies on the case of Wolcott v. Knight, 6 Mass. 418, and sundry other cases, in which this principle is laid down. "For," it is said, "although the tenant may have no title, still if the demandant has no right to recover, he cannot be permitted to draw into question the seizin of the tenant, whether he acquired it by right or by wrong." Stearns on Real Actions, 226.

It has been argued by the counsel for the tenant, that this principle is applicable to a case of dower, where the demandant had relinquished her inchoate right of dower by joining her husband in a conveyance to a stranger. But the contrary doctrine is laid down in Pixley v. Bennett, 11 Mass. 298. And that case, we think, was rightly decided.

The tenant's counsel contended, that as the demandant had once released her claim, she was for ever estopped to demand dower, whoever may be in possession of the land. But it is very clear that a stranger cannot be bound by, nor take advantage of, an estoppel. An estoppel, to be binding, must be reciprocal, and parties and privies only are bound thereby.

Whether the demandant's deed may by law operate as a release, or in any way, except by way of estoppel, is a question which it is not necessary to decide; because, if it may operate so as to pass the right to the grantee, this action may well be maintained for his benefit, or for the benefit of his assigns; as they cannot maintain an action in their own names, to enforce their right against the tenant.

But there is another answer to this objection to the demandant's title, which is entirely satisfactory and conclusive. The tenant, at the trial, offered to prove that the conveyance to Jacobs, was fraudulent and void as to the creditors of the grantor, and that, on that ground, he had recovered judgment for the possession of the premises against the assignees of the said Jacobs. Now we are of opinion that the tenant, having avoided the deed to Jacobs, cannot now be allowed to set it up as a bar to the demandant's claim. In Stinson v. Sumner, 9 Nass. 143, $6 \mathrm{Am}$. Dec. 49, it was decided that where a wife releases her claim of dower, by joining her husband in a conveyance, and the purchaser recovers back the purchase money on account of the grantor's defect of title to the land, the release of the wife thereby becomes inoperative, and does not bar her right of dower after her husband's decease. The principle, on which that decision is founded, applies conclusively to the present case. The tenant has avoided the deed of the husband, and defeated the estate on which the demand- 
ant's release of dower was intended to operate. By law, therefore, and in justice, she was thereby restored to her former rights.

The other ground of defence depends on the construction to be given to St. 1805 , c. 90 , sec. 5, which provides "that all the lands, tenements, and hereditaments of which the intestate died seized, and also all such estate which he had fraudulently conveyed, with intent to defraud his creditors, shall be liable for the payment of his debts, and may be recovered and applied thereto, saving to the widow her dower therein; except in the estate so fraudulently conveyed, to which she had legally relinquished her right of dower." The execution, under which the tenant claims title, was extended on the premises in the lifetime of the demandant's husband, and is not therefore within the letter or the meaning of the statute, which is expressly limited to the lands, tenements, and hereditaments of an intestate, and to the proceedings after his death. If the demandant's dower is subject to forfeiture, it must be applied to the equal benefit of all the creditors, and the tenant has gained no priority or title under the execution, in respect to the claim of the demandant. Wildridge v. Patterson, 15 Mass. 148. Where a statute in clear terms is limited to a certain class of cases, the limitation is not to be extended by construction, especially if it would thereby subject an estate to forfeiture.

\section{Judgment on the verdict. ${ }^{31}$}

31 See Huntzicker v. Crocker, 135 Wis. 38,115 N. W. 340, 15 Ann. Cas. 444 (1908); In re lingafelter, 181 Fed. 24,104 C. C. A. 2S, 32 L. R. A. (N. S.) 103 (1910), where the convesance was set aside in binkinutcy proted ings betaluse preferential. But compare IIiller v. Wilson, 15 Ohio, 10 (1846).

Statutony Provisions as to Dower.-In practically all of the states there are statutes relative to dower. These statntes vary in their terms and siolve, and shonld be consulted by the student. In many states the statutes provide for a dower almost, if not wholly, identical with the common-law dower. In almost an equal mumber of states it is declared by statute that dower is abolished, and provision is made, usually in the chanter on bescents, wherely, upon the death of the bushand, the wilow shall take a specitiel interest in his realty. Inder these latter statutes a nice question may arise as to the nature of the widow's title; that is, whether the common-law principles relative to dower have any applicability, or whether it is to he treaterl purely as a case of inlieritance. In Fletcher v. Ilomes, 32 Ind. 457,510 (1870), the court said: "It seems clear, therefore, that the right of the widow, under the statute, to a third of the lands of her deceased husband, is not as dowress, but it rests ill her, at his death, as an heir, by descent. The estate thus given is much larger than that of dower. It is a fee simple, and not merely an estate for life. It differs in many other respects from dower; it entitles the wife, without assigmment, to immediate nossession, as a tenant in common with the other heir's. and sle may convey it at pleasure. On the other hand, it has some of the incidents of dower. 'The widow is made a favored heir, and the interest which descends to her is exempt from liability for the payment of the debts of the estate. And so, by section twenty-seven, she is not only entitled to a third of all the lands of which her husband may die seized in fee simple, and of all in which he has an equitable interest at the time of his death; but also of all of which he may have been seized in fee simple at any time during the coverture, in the conveyance of which she did not join in due form of law," etc.

How about such interest being subject to the inheritance tas? See In ro Estate of Strahan, 93 Neb. 82S, 142 N. W. 678 (1913). 


\section{SECTION 4.--ESTATES FOR YEARS}

\section{LITTLETON'S TENURES.}

Tenant for term of years is where a man letteth (lou home lessa) lands or tenements to another for term of certain years, after the number of years that is accorded between the lesser and the lessee. And when the lessee entreth by force of the lease, then is he tenant for term of years.

Section 58.

\section{COKE UPON LITTLETON.}

Words to make a lease be, demise, grant, to farm let, betake; and whatsoever word amounteth to a grant, may serve to make a lease. In the king's case this word Committo doth amount sometime to a grant, as when he saith Commissimus W. de B. officium seneschalsiæ, \&c. quamdiu nobic placuerit, and by that word also he may make a lease: and therefore a fortiori a common person by that word may do the same.

"Of certain years." For regularly in every lease for years the term must have a certain beginning and a certain end; and herewith agreeth Bracton, terminus annorum certus debet esse et determinatus. And Littleton, is here to be understood, first, that the years must be certain when the lease is to take effect in interest or possession. For before it takes effect in possession or interest, it may depend upon an incertainty, viz. upon a possible contingent before it begin in possession or interest, or upon a limitation or condition subsequent. Secondly, albeit there appear no certainty of years in the lease, yet if by reference to a certainty it may be made certain it sulficeth, Quia id certum est quod certum reddi potest. For example of the first. If A. seised of lands in fee grant to B. that when B. pays to A. 20 shillings, that from thenceforth he shall have and occupy the land for 21 years, and after $B$. pays the 20 shillings, this is a good lease for 21 years from thenceforth. For the second, if A. leaseth his land to $B$. for so many years as $B$. hath in the manor of Dale, and $B$. hath then a term in the manor of Dale for 10 years, this is a good lease by $\mathrm{A}$. to $\mathrm{B}$. of the land of $\mathrm{A}$. for 10 years. If the parson of $\mathrm{D}$. make a lease of his glebe for so many years as he shall be parson there, this cannot be made certain by any means, for nothing is more uncertain than the time of death, Terminus vitæ est incertus, et licet nihil certius sit morte, nihil tamen incertius est hora mortis. But if he make a lease for three years, and so from three years to three years, so long as he shall be parson, this is a good lease for six years, if he 
continue parson so long, first for three years, and after that for three years; and for the residue uncertain.

If a man maketh a lease to I. S. for so many years as I. N. shall name, this at the beginning is uncertain; but when I. N. hath named the years, then it is a good lease for so many years.

A man maketh a lease for 21 years if $\mathrm{I}$. S. live so long; this is a good lease for years, and yet is certain in incertainty, for the life of I. S. is incertain. See many excellent cases concerning this matter put in the said case of the Bishop of Bath and Wells. By the ancient law of England for many respects a man could not have made a lease above 40 years at the most for then it was said that by long leases many were prejudiced, and many times men disherited, but that ancient law is antiquated.

"And when the lessee entreth by force of the lease, then is he tenant for term of years." And true it is, that to many purposes he is not tenant for years until he enter; as a release made to him is not good to him to increase his estate, before entry; but he may release the rent reserved before entry, in respect of the privity. Neither can the lessor grant away the reversion by the name of the reversion, before entry. But the lessee before entry hath an interest, interesse termini, grantable to another. And albeit the lessor die before the lessee enters, yet the lessee may enter into the lands, as our author himself holdeth in this Chapter. And so if the lessee dieth before he entered, yet his executors or administrators may enter, because he presently by the lease hath an interest in him; and if it be made to two, and one die before entry, his interest shall survive.

Co. Litt. 45b, 46a, b.

\section{LIT'TLETON'S TENURES.}

And it is to be understood, that in a lease for years, by deed or without deed, there needs no livery of seisin to be made to the lessee, but he may enter when he will by force of the same lease.

Section 59.

\section{HARE et al. v. CELEY.}

(Court of Common P'leas, 15Ss. Cro. Eliz. 143.)

Trespass for breaking their close called Church-field, and metes and bounds it. The jury find a special verdict, that the place where was sixteen acres lying in a field called Churcli-field, and meted it by other metes and bounds that were mentioned in the new assignment, of which Hare was seised in fee, and eas exposuit to the other three to sow at halves, scil. that he should find one half of the seed, and the other three the other half, and should manure the land; and 
that Hare should have one moiety of the grain there growing when it was reaped, and the others the other moiety; and after the land was sown, A. entered by the command of the defendant, and spoiled a great part of the corn. Upon which entry and spoiling, the action was brought.-First matter, If Church-field being found to be a great field, in which divers men had interest, if the sixteen acres in it may be called Church-field? And as to this the Court spake little.-Second matter, If this exposing the land to half be not a lease of the land, so as the action was to be brought in the name of Hare and the three? - 'Third, admitting it was a lease, if Hare be not tenant in common with them of the corn; for the moiety of that which was sown, was his?

The Court held it no lcase of the land, but otherwise if it be for two or three crops: and therefore, as to the breaking of the close, Hare only was to bring the action; and as to the spoiling the corn, they ought to join being tenants in common. But in that they joined in the action for breaking the close, whereas he ought to have brought it alone, it was adjudged the writ should abate.

\section{CASWELL v. DISTRICH.}

(Supreme Court of New Tork, 1836. 15 Wend. 379.)

Error from the Monroe common pleas. The plaintiff as executrix of D. Caswell, brought an action of assumpsit against Districh for the rent of certain premises. The defendant pleaded the general issue. On the trial, the plaintiff produced a written agreement between her testator and the defendant to the effect; that the testator had agreed to let the defendant have his farm for one year, and that Districh had agreed to sow oats and give the testator one third in the half bushel ; corn, one third in the basket; to sow three lots (particularly described) into wheat, and give the testator one third in the half bushel - the meadow, three cocks out of five, and the rest half delivered in the barn. The plaintiff proved the quantities of grain raised by the defendant, and rested. The defendant insisted that the instrument produced was an agreement to work the land on shares, and not a lease securing rent; that the parties therefore were tenants in common in the crops, and an action for the rent of the premises would not lie. Whereupon he moved for a nonsuit, which was granted by the court. The plaintiff sued out a writ of error.

Nelson, J. The agreement between the parties was a letting of the premises upon shares, and, technically speaking, was not a lease. Bradish v. Schenck, \& Johns. 151; Foote v. Colvin, 3 Johns. 216, 3 Am. Dec. 478; Whipple v. Foot, 2 Johns. 421, 3 Am. Dec. 442; De Mott v. Hagerman, 8 Cow. 220, 18 Am. Dec. 443. There is nothing which indicates that the stipulation for a portion of the crops was 
by way of rent; but the contrary. The shares were of the specific crops raised upon the farm. It is very material to the landlord, and no injury to the tenant, that this view of the contract should be maintained, unless otherwise clearly expressed, for then the landlord has an interest to the extent of his share in the crops. If it is deemed rent, the whole interest belongs to the tenant until a division. Where a farm is let for a year upon shares, the landlord looks to his interest in the crops as his security, and thereby is enabled to accommodate tenants, who otherwise would not be trusted for the rent.

This case is clearly distinguishable from that of Stewart v. Dougherty, 9 Johns. 108. There the court, from the correspondence between the phraseology of the instrument and the terms usual in leases in the reservation of rent, came to the conclusion that the.proportion of the crops specified in the agreement was intended as payment of rent in kind, and that therefore the whole interest belonged to the tenant. If my conclusion be correct, then the parties were tenants in common in the crops, and as the plaintiff stood in the place of her testator, she was not entitled to sustain her action, and the common pleas did right to grant a nonsuit.

Judgment affirmed..$^{32}$

\section{STEEL v. FRICK.}

(Supreme Court of Pennsylrania, 1S67. 56 Га. 172.)

Error to the Court of Common Pleas of Westmoreland county; No. 90, to October term, 1866.

This was an action of covenant, commenced April 6th, 1863, by David $Z$. Frick against James Steel, and was founded on an article of agreement dated January Sth, 1862, by which "Steel agrees to let the said Frick farm his part of the Warden farm, now in the occupancy of James D. Porter, for the term of one year, commencing on the 1st day of April next-the said Frick to put one field in corn, and work it sufficiently well, and to put the cornstalk field out in oats in the spring in good time and order, and to sow so much of the land in wheat and rye in the fall as the said Steel may wish, or as is fit to be sowed, and to haul out all the manure and put it on the ground before sowing, and to keep up the fences in good repair, and to sow so much of the land with timothy and cloverseed as it not intended to be

32 See Putnam v. Wise, 1 Hill (N. Y.) 2:4, 37 Am. Dec. 309 (1S41).

In Taylor v. Donahoe, 125 Wis. 513,103 N. W. $10 ! 99$ (1905), the arrangement entered into was held to have created a relationship of mister and servant and that, therefore, the ownership of the crops was wholly in the landowner, the clopper acquiring an interest therein only after division by the landowner. So, also, in Kelly r. limmertield, 117 Wis. 620,94 N. W. 6-19, 9s Am. St. Rep. 951 (190:3), where the landowner sued the croller in replevin to recover the half of the crop ly bim harvested and appropriated; and in Farrow v. Wooley, 138 Ala. 267, 36 South. :3St $\left(190^{\circ}\right)$. 
ploughed immediately again, and to deliver the said Steel the one-half of all the oats, corn, wheat and rye at market, when wanted or ready for delivery. All to be done in a sufficient manner as farming should be done, and to pay all the taxes assessed or to be assessed for the year 1862-the said Frick is to have all the hay he makes, and all the pasture during said year on said land."

The "Warden farm" contained in the whole about 159 acres, and belonged to Steel and one David Williams. In an action of partition by Williams against Stcel, to February Term, 1852, judgment quod partitio fiat was rendered May 12th, 1862, and a writ de part. fac. issued to August Term 1862.

The evidence was, that Frick went to the holise on the premises on the 1st of April, 1862, with all his goods. Porter had the house locked and would not let Frick in; he had to haul his goods away and put them into a barn about two miles off, and his family into an almost untenantable house at another place. There was evidence that Frick was not prevented from farming the land, but made no attempt to do so; also, that upon Frick's informing Steel that he could not get possession, Steel said he would give him a house and land off his own farm, more than he was to get there; that Steel thought the offer was a good one, but that he did not wish to leave the neighborhood.

The court (Buffington, P. J.) charged:

"Steel and Williams were the owners of this land as tenants in common. Steel leased his part to the plaintiff, Frick, from 1st April, 1862 to 1st April, 1863. This is not a contract to lease to him the whole of the land, but only his part. The name of Porter is introduced, not to define the amount of interest leased, but the description of the tract, his interest in which was leased. Steel had no right to the entire possession, but Williams had as good a right to his part of the tract. [Steel, however, did agree to lease to him his part of the land. That was a covenant to enable him to get and hold the possession, and enjoy the undivided half or all the interest Steel had, including not only the farm land, but the barn, house and other buildings necessary to the enjoyment of the farm.] If he made a contract which he could not comply with, it was his fault, or his misfortune; and if the contract was a fair one, Frick had a right to the possession, and was prevented from enjoying the premises according to the spirit of the agreement, and he could not enjoy it, either by the act of Steel, or his want of right or power to give possession, then the tenant would be entitled to recover whatever damages he sustained.

"[If the jury believe Frick was thus deprived of the possession, either by the act or want of power in Stcel to give possession, Frick is entitled to recover.] It is no excuse that he could not give a possession."

There was a verdict for the defendant for $\$ 315.91$ damages.

The defendant took a writ of error, and assigned for error the parts of the charge included in brackets. 
Thompson, $J$. If the agreement between the plaintiff and defendant in this case, is to be regarded as a lease of the premises, it would pass the possession of the buildings on it to the lessee. It would necessarily be a covenant for quiet enjoyment. The instrument is very inartificial, but we think it contains all the elements of a lease.

It sets out by a stipulation, that "Steel agrees to let Frick farm his part of the Warden farm, now in the possession of James D. Porter." This is a letting to farm by equivalent words to these, "To farm let," which are operative terms in leases. The premises mentioned were well understood, at least no dispute exists on the ground of description. After this preliminary stipulation, then follows "for the term of one year." It may as well be said here, that this and what follows is nothing like a contract for cropping. After stipulating about the mode in which the farming was to be done, and that the lessee should haul out all the manure to the fields, and keep the fences in good repair, then follows the reservation of rent, which was to be "the one-half of all the oats, corn, wheat and rye, to be delivered to Steel at market when wanted, or ready for delivery, and the payment of all the taxes for the year 1862, Frick to have all the hay and the pasture of the land during the year."

A cropper is one hired to work land and to be compensated by a share of the produce. Such a contract gives hin no legal possession of the premises, further than as a hireling. The legal possession remains in the hirer or landlord, and hence the remedy by distress is not applicable to him: Fry v. Jones, 2 Rawle, 11; Adans v. McKesson, $53 \mathrm{~Pa}$. 81, $91 \mathrm{Am}$. Dec. 183. That the above contract is not a hiring to work land merely, is evident. The lessee was to farm the lessor's share or portion of the Warden farm for the term of one year-to do it in a sufficient manner as farming should be done, and to pay all taxes. This left the mode of farming to the lessee, as it is not stipulated to be done in a particular way, and necessarily gave him the possession and control to do the farming in his own way, unlike the relation of a mere hireling-still more unlike cropping, as the stipulation that the lessee was to pay the taxes. One hired to crop would hardly be expected to pay taxes. But it is further apparent in this, that Frick was to have the possession of the premises for the specified term, on the stipulation that he was bound to haul out the manure, and keep the fences in repair. These stipulations clearly look to a possession of the premises by the lessee; so, too, is the stipulation for all the pasturage during the year. If then the contract means, as we think it does, that the possession was to be in Frick, this evinces the intention to create a tenancy.

That the rent was reserved, payable in kind by a share of the grain, does not militate against the idea of a lease. In Fry v. Jones, on the demise of a grist-mill, the lessee to render one-third of the toll as rent, it was held by this court that the lessor might distrain for rent. The principle to be applied in that case was illustrated by the learned judge, 
by the case of farm-letting. "We have almost always," says Rogers, J., "adopted the mode of renting for a share of the produce of the farm, which is preferred by tenant and landlord;" and he follows this remark by concluding that a distress was the remedy in such a letting. An implication of a doubt in Warren v. Forney, 13 Serg. \& R. 52, whether the right of distress is incident to a lease, may possibly arise from the remark of Tilghman, C. J., in refusing to express any opinion on the point, although he said he did not consider it legitimately belonging to it; but Fry v. Jones was decided five years subsequently, and both by illustration and the announcement of the very principle settled the doctrine that it is. So in Jones v. Gundrim, 3 Vatts \& S. 531 , rent payable in hire was held to be liable to distress, and the case of Jones v. Fry was relied on as authority for it. The same doctrine is very distinctly announced in Rinehart v. Olwine, 5 Watts \& S. 157. We consider the doctrine settled, and that in this case there was a letting for a term, with a reservation of rent sufficiently certain to permit of a distress. This being so, the agreement for tenure was broken on the failure of the plaintiff to get possession, being kept out by a person in possession under the defendant. The declarations of the defendant, and his offer to give the plaintiff a house and land in another place, was some evidence of the understanding as to the possession.

Upon the whole, we see no error on the part of the court in construing the instrument in question a lease, and in charging as it did on the subject-matter complained of. Judgment affrmed. ${ }^{33}$

\section{SEC'TION 5.-ESTATES AT IVILL AND FROM YEAR TO YEAR}

\section{LITTLETON'S TENURES.}

Tenant at will is, where lands or tenements are let by one man to another, to have and to hold to him at the will of the lessor, by force of which lease the lessee is in possession. In this case the lessee is called tenant at will, because he hath no certain nor sure estate, for the lessor may put him out at what time it pleaseth him.

Section 68.

33 In Warner 5 . Abher, 112 Mass. 355 (1S73), the arrangement for cropping was held to anount to a lease.

$A$. leased premises to $B$. for three sears, with the privilege of five, upon shares, $B$. to to all the work, find all the seed, and to deliver to A. one-third the crops. The film was to be crolped in a way specified. and $B$. was to have the use of certain farm implements of A., and was to take good care of same. Could B. assign his interest to $\mathrm{X}$ ? Randall $\mathrm{v}$. Chulb, 46 Mich. 311, $9 \mathrm{~N}$. W. $4: 9,41 \mathrm{Am}$. Rep. 165 (1Ss1); Meyer v. Livesley, 45 Or. 4S7, 7s Pac. 670, 106 Aim. St. Rep. 667 (1904). 


\section{COKE UPON LITTLETON.}

"Tenant at will is, where lands or tenements are let by one man to another, to have and to hold to him at the will of the lessor, \&c." It is regularly true, that every lease at will must in law be at the will of both parties, and therefore when the lease is made, to have and to hold at the will of the lessor, the law implieth it to be at the will of the lessee also; for it cannot be only at the will of the lessor, but it must be at the will of the lessee also. And so it is when the lease is made to have and to hold at the will of the lessee, this must be also at the will of the lessor; and so are all the books that seem prima facie to differ, clearly reconciled.

"The lessor may put him out." There is an express ouster, and implied ouster; an express, as when the lessor commeth upon the land, and expressly forewarneth the lessee to occupy the ground no longer; an implied, as if the lessor without the consent of the lessee enter into the land, and cut down a tree, this is a determination of the will, for that it should otherwise be a wrong in him, unless the trees were excepted, and then it is no determination of the will, for then the act is lawful albeit the will doth continue. If a man leaseth a manor at will whereunto a common is appendant, if the lessor put in his beasts to use the common, this is a determination of the will. The lessor may by actual entry into the ground determine his will in the absence of the lessee but by words spoken from the ground the will is not determined until the lessee hath notice. No more than the discharge of a factor, attorney, or such like, in their absence, is sufficient in law until they have notice thereof.

Co. Litt. $5 \overline{5} \mathrm{a}, \mathrm{b}$.

\section{LITTLETON'S TENURES.}

Also, if a man make a deed of feoffment to another of certain lands, and delivereth to him the deed, but not livery of seisin; in this case he, to whom the deed is made, may enter into the land, and hold and occupy it at the will of him which made the deed, because it is proved by the words of the deed, that it is his will that the other should have the land; but he which made the deed may put hin out when it pleas eth him.

Section 70. 


\section{COKE UPON LITTLETON.}

There is a great diversity between a tenant at will and a tenant at sufferance; for tenant at will is always by right, and tenant at sufferance entreth by a lawful lease, and holdeth over by wrong. A tenant at sufferance is he that at the first came in by lawful demise, and after his estate ended continueth in possession and wrongfully holdeth over. As tenant pur terme d'auter vie continueth in possession after the decease of Ce' que vie, or tenant for years holdeth over his term; the lessor cannot have an action of trespass before entry.

Co. Litt. $57 \mathrm{~b}$.

\section{LEIGH'TON v. THEED.}

(Court of King's Bench, 1701. 2 Salk. 413.)

If $\mathrm{H}$. holds land at will, rendering rent quarterly, the lessor may determine his will when he pleases; but if he determines it within a quarter, he shall lose the rent which should have been paid for that quarter in which he determines it. So the lessee may determine it when he pleases, but then he must pay the quarter's rent. Per Holi, C. J.

\section{TURNER v. MEYMOTT.}

(Exchequer Chamber, 1S23. 1 Bing. 158.)

Trespass for breaking and entering plaintiff's house. At the trial before the Lord Chief Baron, Guilford Summer assizes, 1822, it appeared that the plaintiff had been tenant of the house to the defendant, from week to week; that he had received a regular notice to quit, but onitted to deliver up possession, whereupon, the defendant, at a time when nobody was in the house broke open the door with a crowbar, and other forcible applications, and restmed possession. Some little furniture was still in the house. The Chief Baron having said that the law would not allow the defendant thus forcibly to reinstate himself, the jury found a verdict for the plaintiff, whereupon,

Taddy, Serjt., obtained a rule nisi for a new trial, and

Pell, Serjt., now showed cause against the rule. The question is, whether when a tenant refuses to deliver possession after a regular notice to quit, the landlord may make a forcible re-entry: but it cannot be permitted he should take the law into his own hands, and do that by violence which is usually accomplished by an action of ejectment. It is contrary to the first principles of lav, that he should become judge in his own cause, and substitute his own strength for the ordinary civil process. If there had been resistance, and death had 
ensued, the crime of murder would have been committed; and it makes no difference that nobody was in the house, for the defendant could not ascertain that till he entered, and the plaintiff might have come up while the violence was in progress. Some furniture being in the house, this was not a case of vacant possession. 'The statute of 11 G. II, which gives the landlord double value where the tenant holds over, shows what is the appropriate remedy in such cases; but that statute would be useless, if the landlord might thus take the law into his own hands. It might be urged, that if the landlord had proceeded irregularly he would be liable in an indictment for a forcible entry, but his subsequent liability would not justify the previous wrong. In Taunton v. Costar, 7 T. R. 431, the entry made by the landlord's putting his cattle on the ground was entirely peaceable, and to that there could be no objection; so that Lord Kenyon's observation, "that if he dispossessed the tenant with a strong hand, he would be liable for a forcible entry, but there could be no doubt of his right to enter on the land at the expiration of the term," was uncalled for by the case before him, and leads to the absurdity, that, in certain cases, a landlord may enter, and yet he shall be punished for the entry. Pell also referred to Davies v. Connop, 1 Price, 53.

Dallas, C. J. The high respect which I entertain for my lord chief. baron, has alone made me hesitate a single moment, and even now, perhaps, as the cause is to go down to be tried again, I ought not to express an opinion. The question is, whether a landlord has a right to enter in the manner the defendant did under the circumstances of this case, in which the tenant held over after his right to possession had ceased, and the landlord's right to enter had accrued. It must be admitted he had a right to take possession in some way; the case of Taunton v. Costar is in point, to show that he night enter peaceably and that no ejectment was necessary. If he had used force, that is an offence of itself; but an offence against the public for which, if he has done wrong, he may be indicted.

PARK, J. I am of the same opinion. The declaration states that the defendant broke and entered the house of the plaintiff, but the fact was not so; the plaintiff had gone out, and the house was not his, but his landlord's, who had a right to break his own door; as no person was within, there could be no danger to any man's life. Lord Kenyon says, in Taunton v. Costar, "it is clear the landlord could have justified in a plea of liberum tenementum. There can be no doubt of his right to enter upon the land at the expiration of the term;" and that decision, in my judgment, goes the whole length of the present.

BURRoUgh, J. I was once concerned at the cock-pit in a case similar to the present, where I used the same arguments as have now been urged by my brother Pell, but Lord Kenyon and Lord Alvanley who were there, entertained no doubt, and said the landlord might enter. The rule for a new trial in this case nutst be made absolute. 
HILLARY v. GAY.

(Court of Exchequer, 1\$33. 6 Car. \& P. 2S4.)

Trespass for breaking and entering a room of the plaintiff, being parcel of a dwelling-house. There were also counts for expulsion, and for taking the plaintifi's goods. Plea-General issue.

It appeared that the house at which the trespass occurred belonged to the defendant, who had let it to a person named Jury, who had under-let a part of it to the plaintiff. It further appeared that Jury was under notice to quit at Midsummer, 1833, but that the plaintiff did not quit at that time, the defendant having distrained his goods in the month of August, 1833, for the rent due up to Midsummer: it was also proved that the plaintiff had said that he would not leave till he could suit himself, which would be within a fortnight; however, it appeared that after that fortnight the plaintiff did not leave; and the defendant procured a number of Irishmen to go to the house, and after getting the plaintiff to go away, by sending a boy to tell him that his master wanted him, the Irishmen entered the plaintiff's room, and turned his wife out into the street, and put the plaintiff's furniture out at the window.

Thesiger, for the defendant.-I submit that this was no trespass in the defendant; he was the landlord, and the tenancy had expired, and he had therefore a right to resume the possession. In the case of Turner v. Meymott, 7 Moo. 574, it was held that where a tenancy had determined, the landlord was not a trespasser if he broke into the house.

Lord Lyxdiurst, C. B. There the tenant had gone away and had not left his family in possession. The tenant was in that case out of possession; and no one was in possession. Where that is so, the landlord may enter if the term is at an end.

Thesiger.-In the case of Taylor v. Cole, 2 T. R. 292, it was held that the breaking was the gist of the action, and that the expulsion was merely aggravation.

Lord Lyndhurst, C. B. How do your say the tenancy was put an end to?

Thesiger.-The tenancy terminated on Midsummer-day.

Lord Lyndhurst, C. B. You distrain after that.

Ball.-There was also a disclaimer by the plaintiff.

A witness for the defendant stated, that he called on the plaintiff in July or August, 1833, and told him that it was an injury to his landlord that he should stay in the house contrary to his agreement; and that the defendant replied, that he would not go, as it was a comfortable thing to pay no rent, and that he would not leave for Mr. Gay, or Mr. Jury either.

LORD LYNDHURST, C. B. (in summing up.) Even if the plaintiff had promised to leave at a particular day, the conduct of the defend- 
ant is unjustifiable. There is no proof of any distinct promise of the plaintiff to go away at any particular time; but even if he had so promised, I am of opinion that the conduct of the defendant cannot be justified. If the defendant had a right to the possession, he should have obtained that possession by legal means.

Verdict for the plaintiff-Damages $£ 50 .{ }^{3 *}$

\section{POLLEN AND WIFE v. BREWER.}

\section{(Court of Common Pleas, 1S59. 7 C. B. [N. S.] 371.)}

The first count of the declaration charged an assault on the female plaintiff, the second (which was abandoned at the trial) the like with an allegation of loss of service, \&c., the third an assault upon the male plaintiff, the fourth breaking and entering the plaintiff's dwelling-house and forcibly expelling him and his wife and family, and the fifth was trover.

The defendant pleaded not guilty.

34 In Newton v. Ilarland, 1 M. \& G. 644 (1S.0), the plaintiff. who had heen forcilly ejocted by the defembant from premises to the possession of which the defendant was then entilled, sued for assault and hattery. Tindal, C. J., said : "This case involves a puestion of great importance and one of very general application, namely. Whether, after a tenaney has been determined by a notice to quit, the landord may enter on the prentises whilst the tenant still remains in possession. and atter requesting bim to depant and give up the possession, and his refusing so to do. may turn him ont of possussion by force. using as much force and no more than is necessary for that purpose. * * * The point above stated must be necessalily determined hefore this case is ultinately decidred. It appears, however, to me that sach question cannot, mon the mesent finding of the jury, he prolerly brousht helore us. * * * For if the landlord, in making his entry upon the tenant. has been suilty either of a breach of a positive statute, or of an offence aginst the common law, it appears to me that surh violation of the law in making the entry canses the jossession therely obtained to lie illegal, and that the allogation in the plea that one of the defondants was lawfully in possession at the time the assalt was committed is neratived."

Hosangnet. I.. said: "sone things are clear. If a tenant hold over the land after the expiration of his term, he canmot treat the lessom: who enters peaceably, as a trespasser; and the lessor, in such case, may just ify his own entry upon the land by rintue of his title to the possession. *** On the otluer hand, the lessor, who is out of possession, rannot mantain an artion of trespass against a tenant holding over. Ile must tiust acpulire a law ful pussession before he can naintain such action. Int if the lessor enter won the land to take possession, he mas treat as trespassers all those who afterwalds come upon it (Hey v. Moorhouse, 6 New Cases, 52, 8 Seott, 156 [1S:901), or who, having manfully taken possession. wrongfully contime upon the land, as in the case of Butcher v. Butcher, 7 Ib. \& C. 402 (15:7), where the defendant had come into possession of the land by intrusiom, and the riahtful owner, haring entered, was held entitled to maintain an action of trespass against him. The lessor may even break and entel a house, provided it lie enpty, which has heeu occulied and held over by his tenant, thongh lle teinnt maly hare lett some of his property therein. Turner v. Meymott, 1 ling. 1Ri (15:3). lint no case has yet leen decided in which the lessor has been hels to be justified in expelling by force from a dwelling house a person who, having lawiully come into possession of it, has merely continued to hold yossession after the expiration of his title." 
The cause was tried before Williams, J., at the sittings at Westminster after last Term. The plaintiff swore, that, in May, 1858, he entered into a negotiation with the defendant for an assignment of a lease of certain premises which the defendant held, that the defendant agreed to let him into possession, and gave him the key, and that shortly afterwards the defendant went to the premises with two men, and assaulted the plaintiff and his wife, and turned them and their children and furniture into the street.

The defendant denied that he had ever agreed to let the premises to the plaintiff, but stated that he gave him the key for the purpose of enabling his agent to inspect the premises. He also denied the alleged assaults, and proved that, the plaintiff having refused to redeliver possession of the premises to him on demand, he entered and expelled him.

The jury, however, found that there was a tenancy of some sort, and that the alleged assaults were committed; and they found for the plaintiffs on the first count 20 s. damages, on the third count 40 s., and on the fourth count $£ 25$. The learned judge reserved leave to the defendant to move to reduce the damages by the last-mentioned sum, if the court should think there was any evidence of a determination of the tenancy.

ERLE, C. J. I am of opinion that this rule must be made absolute to reduce the verdict by $£ 25$., the amount of damages found upon the fourth count. It is clear that the plaintiff had at the utmost only the interest of a tenant at will. I incline to think that the defendant never intended to create even that limited interest: but the jury have found it. The defendant, having a right to determine the plaintiff's possession at any moment, sent to demand the key, telling the plaintiff at the same time (by letter) that he was in against his will. I am of opinion that either of these was a sufficient intimation to the plaintiff that he was no longer tenant at will, and that his continuance of the possession was without a shadow of right, and therefore that the defendant was justified in treating him as a trespasser and removing him from the premises. There was abundant evidence that, at the time of the expulsion, the plaintiff was on the premises without any right. I therefore think the rule must be made absolute.

Willians, J. I also think there was sufficient evidence of a determination of the will, and consequently that the plaintiffs are not entithed to recover damages for the expulsion.

CROWDER, J. I am of the same opinion. I do not see what more the defendant could do than he did to determine what the jury have found to be a tenancy at will. It is said that there was no proper determination of the tenancy, because the demand of possession or the key, was accompanied by an assertion that there never was any tenancy at al!. I do not, however, see how that can cut down the evidence of determination. The defendant demands the key, then a correspondence ensues, and then he makes an entry. This was a clear in- 
timation to the plaintiff of his election to determine any right he might have.

BYLES, J. I also am clearly of opinion that the rule to reduce the damages should be made absolute. I have nothing to add to what has fallen from the rest of the court.

Rule absolute.

\section{CURTIS v. GALVIN.}

(Supreme Judicial Court of Massachusetts, 1861. 1 Allen, 215.)

Tort for entering the plaintiff's dwelling-house, and removing his furniture and ejecting his family therefrom. The defendants praved, in justification, that the defendant Galvin, being the owner of the premises, conveyed them by deed to the other defendant Carney, and that, eight days before the acts complained of, Carney informed the plaintiff thereof, and gave him notice to quit. At the trial in the superior court Rockwell, J., directed a nonsuit, and the plaintiff alleged exceptions. The facts appear more fully in the opinion.

BIGELOW, C. J. It appears by the testimony of the plaintiff that, in October 1858, prior to the alleged trespass, the premises from which he was ejected belonged to Galvin. Inasmuch as he offered no evidence of any right to their occupation created by an instrument in writing, he could have no greater title or interest therein than an estate at will. Rev. St. c. 59, §29. On the facts stated in the exceptions, this is the most favorable view which can be taken of his right to the possession and enjoyment of the premises, prior to the conveyance to the defendant Carney. But, on a familar and well settled rule of law, this tenancy at will was determined, and the plaintiff became a tenant by sufferance only, by the conveyance from Galvin to Carney, the other defendant, on the 9th of said October. Howard v. Merriam, 5 Cush. 563, 574; McFarland v. Chase, 7 Gray, 462.

The evidence offered by the plaintiff to impeach this conveyance, and to show that it was colorable, and was in fact made for the purpose of enabling the said Galvin to eject the plaintiff from the premises, was rightly rejected. The deed was a valid one as between the parties. It passed the title to the premises. The grantor had no power to compel the grantee to surrender the estate conveyed to him. It violated the legal rights of no person. It is true that a creditor of the grantor, who could show that he was thereby hindered, delayed and defrauded of the collection of his debt, or a subsequent purchaser without notice, who could prove that the deed was made with intent to defraud him, might impeach the conveyance, and set it aside on the well settled principles of the common law as declared in Sts. 13 Eliz. c. 5, sec. 2, and 27 Eliz. c. 4, sec. 2 . But in such case the deed is valid between the parties; and, with this exception, we know of no Ata.Prop. -41 
rule of law which restrains the owner in fee from the free and unfettered alienation of his estate. It is only an exercise of a legal right, which works no injury to any one, least of all to a person who holds under the grantor. He tock his estate or interest in the premises subject to all the legal rights of the owner therein, and must be presumed to have known them, and to have assented thereto. 'To him, therefore, the maxim volenti non fit injuria is applicable. The determination of an estate at will, by an alienation by the owner of the reversion, is one of the legal incidents of such an estate, to which the right of the lessee therein is subject, and by which it may be as effectually terminated as by a notice to quit given according to the reguisitions of the statute. Indeed it is difficult to see upon what ground a deed can be held void, as being colorable or fraudulent, which is made in the exercise of a legal right, and which has no effect on the rights of a third party, who seeks to set it aside, other than that which was necessarily incident to the estate which he held in the premises. The dictum of the court in Howard v. Merriam, ubi supra, cited by the counsel for the plaintiff, was not essential to the decision of that case, and cannot be supported on principle or authority.

It follows that, after the conveyance of the demised premises, the plaintiff became tenant by sufferance only, and could not maintain this action of tort in the nature of trespass quare clatusum against the defendant Carney, who was the grantee in the deed; nor against the other defendant, who acted under his authority in attempting to eject the plaintiff from the premises. At the time of action brought, it was not the plaintiff's close. A tenant by sufferance holds possession wrongfully. Co. Litt. $57 \mathrm{~b}, 27 \mathrm{ia}$. The defendants had a full right of entry. Meader v. Stone, 7 Metc. 147.

Exceptions overruled.

\section{SAY v. STODDARD. \\ (Supreme Court of Ohio, 1S75. 27 Ohin St. 47S.)}

Error to the Superior Court of Montgomery County.

The nlaintiff in error was plaintiff in the court below, where his amended petition was demurred to, on the ground that it did not state facts sufficient to constitute a cause of action. This demurrer was sustained, and plaintiff not desiring farther to amend, judgment was entered for defendant. The action of the court in sustaining the demur- rer is here assigned for error. The petition was substantially as follows:

That, on August 27th, 1869, James Celey leased a dwelling-house in the city of Dayton, in the county of Montgomery, with the lot whereon said house is situate. Said written lease being as follows, to wit:

"Henry Stoddard, Sr., has rented to James Celey his Fowler House, on lot No. 4, on the east side of St. Clair street, between Water and 
First streets, in Dayton, at a rent of thirteen dollars a month, for so long as the parties shall mutually agree to continue the renting under this agreement. Said Celey being in the employment and service of Stoddard \& Co., in their mill; they are to pay the rent monthly or half monthly, as may be most convenient, out of Celey's wages. Either party may put an end to this renting by giving the other party four days' notice, in writing, that this renting is to cease at the expiration of four days from the service of such notice on the other party. Said Celey agrees to use and treat the premises in a proper tenant-like manner while he occupies. The rent to commence August 27. 1869.

"[Signed]

“[Stamp.]

"Paid up to Oct. 1, 1869."

That James Celey, on the 27th day of August, 1S69, with Henry Stoddard, Sr.'s, consent, took lawful and peaceable possession of the premises, under said lease, and continued in possession thereof till the 7 th day of December, 1869, when he moved out of said premises.

That while said Celey was in possession of said premises, and before he moved out, he did, on the 1st day of December, 1869, rent two rooms of said house to the plaintiff, George Say, for six dollars par month-Say paying to Celey, on the day of renting, four dollars rent on the month of December, 1869; that on said 1st day of December, 1869, Say, with his wife, moved into the said two rooms of said house, while Celey, with his family, occupied the other room, with small kitchen, immediately in the rear of and adjoining the two rooms occu pied by Say. Said Celey continuing to occupy the rooms in the rear of Say's, till the 7th day of December, 1869, when he, Celey, moved out of the premises; Celey owing, on back rent, seven dollars for month of November 1869; George Say and his wife continued in possession of his two rooms from December 1st till December 15th, 1869, when, on December 15th, 1869, E. Fowler Stoddard, the defendant, the son of Henry Stoddlard, Sr., with screw-driver, hatchet and ax, went, on said 15th day of December, 1869, to the front door of the room fronting on St. Clair street, Say and his wife being in their rooms at the same time; that E. Fowler Stoddard, with his instruments aforesaid, and without the consent of Say or his wife, and against their remonstrance, proceeded to get possession of said rooms, occupied at the time by Say and his wife, by taking hold of the knob of the front door, leading into the front room, which was fastened by a lock. The door being opened by defendant, the plaintiff, Say, warning him not to come in. That the defendant, on said 15th day of December, 1869, and while Say (who was 69 years old in March, 1871) and his wife were in their rooms, did enter their rooms, and did remove, take off, and carry away five doors and five windows-being all the doors and windows belonging to the rooms occupied by the plaintiff, George Say, and his wife; and also being all the doors and windows of the rooms occupied by Celey 
and his family, till he moved, December 7, 1869, excepting one door in rear room of house. And in removing one of the doors in the room, immediately in the rear of and adjoining the front room, in order to get at the door to take it off the hinges the defendant did move a cupboard of plaintiff, so he could get at the door with his screw-driver. After the doors and windows were taken away by defendant, the plaintiff hung up at the door, strips of carpet. The day, on which the doors and windows were taken down and carried away by defendant, was cold and chilly, and remained cold till plaintiff left said premises, which was on the 20th day of December, 1869. Plaintiff being compelled to leave the premises by reason of defendant's acts, as aforesaid. Snow had fallen while plaintiff was in possession of rooms, and during the time the doors and windows were out.

No written notice to leave said premises was ever served by anyone -on either Say or Celey.

Neither did Celey ever serve a written notice on Stoddard, Sr., or defendant, that he, Celey, would leave the premises.

Said Henry Stoddard, Sr., died on November 1, 1869, testate, leaving the said defendant one of his executors and devisee under the will of said decedent. Said plaintiff says that by reason of the acts of the defendant herein set forth, said plaintiff has sustained damage five thousand dollars, for which he asks judgment.

Scotr, Chief Judge. The contract of lease between Stoddard, Sr., and Celey, set out in the petition in the court below, created, by its express terms, a tenancy at will.

True, the rent was to be $\$ 13.00$ a month, and was to be paid by Stoddard \& Co. out of Celey's wages, monthly, or half monthly, as might be most convenient. But the renting was to continue for "so long as the parties shall mutually agree to continue the renting under this agreement." And, again: "Either party may put an end to said renting by giving the other party four days' notice, in writing, that this renting is to cease at the expiration of four days from the service of such notice on the other party." It is clear, from this language, that the tenant was to hold at the will of the lessor, though while the tenancy continued the rent was to be paid monthly or half monthly. ${ }^{36}$ The character of the tenancy is not affected by the fact that four days' notice of its determination, is provided for in the contract; for in a general tenancy at will, reasonable notice must be given by the party whose will determines it, to the other party; and the contract here fixes the length of that notice. It is said by Blackstone: "An estate at will is where lands and tenements are let by one man to another, to have and to hold at the will of the lessor, and the tenant by force of this lease obtains possession." 2 Bl. Com. 145; Litt. $\S 68$. Such tenant has no certain indefeasible estate, nothing that can be assigned by him to any other, because the lessor may determine his will, and put him out whenever he pleases. 2 Bl. Com. 145; Taylor's Landl. and Ten. 48.

\footnotetext{
35 Richardson v. Langredge, 4 Taunt. 128 (1811), acc.
} 
Tenancy at will may be determined by implication of law. Such implication will arise on the death of either of the parties. So, if a tenaint at will assigns over his estate to another, who enters on the land he is a disseisor, and the landlord may have an action of trespass against him. Greenl. Cruise on R. Pr. 244; Taylor's Landl. and 'Ten. 43 '.

So, also, a desertion of the premises by the lessee, puts an end to a tenancy at will. For he thereby discontinues his lawful possession and terminates his relation to his lessor, which is only of a personal character, and he ceases to have any interest in the premises which he can transfer or control.

The plaintiff shows, by his petition, that Stoddard, the lessor, died November 1, 1869, leaving the defendant his devisee of the premises. Celey, the lessee, continued in possession till December 1st, when he undertook to sublet a part of the premises to the plaintiif. It is not alleged that the defendant assented to this continuance of possession, or subletting. On the 7 th of December, the lessee, Celey, removed wholly from the premises; and, eight days afterward, the grievances occurred of which the plaintiff complains. As against the defendant, the plaintiff acquired no rights by his contract with Celey, for the latter had none which he cotld transfer. The facts stated do not show that the relation of landlord and tenant was ever created between the parties to this suit. There was neither privity of estate, nor of contract between them. And the acts complained of were but the lawful exercise of the rights incident to the defendant's ownership of the premises, and are not charged to have been attended with any unnecessary interference either with the plaintiff's person or property.

We think the court below properly sustained the demurrer to the plaintiff's petition, and its judgment is affirmed.

\section{READER v. PURDY.}

(Supreme Court of Illinois, 1S66. 41 Ill. 279.)

Appeal from Kane; Isaac G. Wilson, J.

Erastus S. Purdy, in the fall of 1858, built a house on a lot in Aurora, which he obtained of Otis on a parol contract, went into possession of the same with his family, and occupied the same as a homestead from that time until the spring following the assault and battery for which this suit is brought. In 1861, Reader, whose wife was sister to Purdy's wife, obtained from Otis the legal title of the premises on which Purdy and wife lived, and brought an action of ejectment for the possession of the same. On the first trial of the ejectment suit, the jury rendered a verdict in favor of Purdy, and a new trial was granted to Reader; and between the time of the first trial and that of the second trial of the ejectment suit, to-wit: in October, 1862, Reader, Baker and Barker, in the absence of Purdy from home, got admission into the house, and then proceeded to put Mrs. Purdy and the 
furmiture out of the house hy force. Mrs. Purdy, who is described as a weak litte woman, weighing ninety-six pounds, fought for her possession with great energy. She locked one of the doors and gave the key to lier laughter, from whom it was taken, then went at the assailants with hot water, a stick of wood and a bayonet belonging to her lusband, who had been a soldier in the army, and, insomuch that one of the assailants was obliged to hold ber by the wrists, to enable the other two to get out the furniture. finally, after all the furniture had been gert out of the house, except that in her bed-room, she succeded in nailing a bard across the door and barring the assailants out. By this time the city marshal and others arrived, and the attempt to dispossess her, which had occupied from nine to twelve oclock in the moming, was abandencel. 'The second trial of the ejectment suit occmrer in May, 1863, and the record therein was introduced in evidence on the trials of these canses, as showing that at the time of the assault the title to the property of which Purly's family were in the ocempancy was in the defendint Reader. No new trial was ever granted or appeal taken in the ejectment suit. 'lhe comrt instructed the jury:

1. 'That in trespass all are principals, he who stands by advising, etc., as well as he who (loes the act.

2. 'That if defomants obtaned admission to the premises theretofore ocompied by plaintiffs, with intent to remove plaintills by force, then defendants were trespassers from the beginning.

3. 'The fact that the defendant Reader was the owner, and entutled to the possession of the premises occupied by the plaintiff, is no justification for the assault and battery upon the plaintifl's wife, if any such is proven, and no justification of his attempts to take possession of the premises ocempicel by the plaintiff by force, and no justification for the removal of plaintif's property therefrom by force, if any such foree is proven; proviled that the plaintilt and his family were in the guiet possession of the said premises at the time of such assault and force; neither can that fatet be regarded by the jury in mitigation of any actual damages caused the plaintiff by such assault and force.

ine other instructions present nothing essentially different. The jury found a verdict for the plaintiffs in the suit of Purdy and wife, for $\$ 500$, and in the suit of l'urely for $\$ 450$.

Lawklinel, I. These two cases, althongh separately tried, depend upon the same facts and present similar questions, and it will be unore convenient to dispose of both in one opinion.

In Octolser, 1862, Reader, claming to be the owner of a house occupied by lurdy aud his wife, entered it, accompanied by the other appellauts, for the purpose of taking possession. Purly was not at heme. Mrs. l'urly refused to leave, whereupon Reader commenced putting the fumiture out of doors. She resisted this, and he seized lee and hek her by the wrists, while baker, one of the co-rlefendants, comtimmel to remove the furniture. 'This was somewhat damaged, and sonie slight injury was done to the wrists of Mrs. Purdy by the force 
applied in holding her. The appellants finally abandoned their attempt to take possession and withdrew.

'liwo actions of trespass have been bronght, one by l'urly alone, and one by Purdy and wife joindly. The declatation in the suit hrought hy

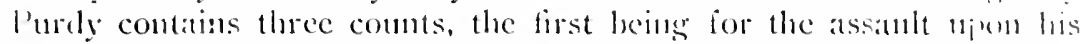
wife, the second for the injury to the persomal property, and the thirel for hreaking his close and carrying off his iurniture. 'The declatation in the suit of burly and wife contains two comnts, both of which atre for the assault 11 pon the wife. 'Jlhere were pleats of not guily, and an agrecment that all defenses might he mate under them. A verdict for the plaintiff of $\$ 450$ in one case, and $\$ 5(0)$ in the other was returned hy the jury, and a judgment was rendered upon it from which the defendiunts appealed.

It is insisted by the appellants that Reader, being the owner of the premises, had a right to enter, and to use such force ats might lie necessary to overcome any resistance, and that he camnot he mate liable

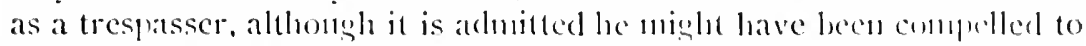
restore to P'urdy, through an action of forchle cutry and letaincr, the possession thus forcilly taken. The court helow instructed otherwise, and this ruling of the court is assigned for crror.

We should not consider the question one of musch difficulty, were it not for the contrarlictory decisions in regard to it, and we must alluit that the current of anthoritics, up to a compranatively recent period, is adverse to what we are convinecel must be derelared to be the law of this State. litut the rule camnot he satid to lave becu firmly or atuthoritatively settled even in England, for lirskine, J., observes in Newton v.

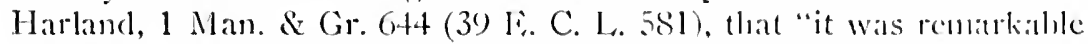
a question so likely to arise, should never have been directly brought before any court in bane until that case." 'This was in the year listo, and all the cases prior to that time, in which it was held that the owner in fee could enter with a strong hatnd, without rendering himsclf lialle to an action of trespass, seem to have been merely at nisi prius, like the of -quoted case of 'Taunton v. Costar, 7 'T. R. 431. Still this was the general language of the books. But the point had never received such an adjudication as to pass into established and incontrovertible law, and a contrary rule was held by Lord I yudlumst in llilary v. Gay, 6 C. \& 13. 284 (25 E. C. L. 39S). But in Newton v. II:arlancl, already referred to, the court of Common Pleats gave the efuestion matture consideration, and finally held, after two argunnents, that a landlord who should enter and expel by force a tentunt holding over after expiration of his term, would render himself liable to ans action for dannages. But the later case of Meriton v. Commls, 67 li.. C. 1. 78s, secms to recognize the opposite rule, and we must, therefore, regatrd a question which one would expect to find among the most firmly settled in the law as still among the controverted prints of Westminster Ilall.

In our own country there is the sanfe contlict of anthorities. In New York it has been muiformly held, that, under a plea of liberum 
tenementum, the landlord, who has only used such force as might be necessary to expel a tenant holding over, would be protected against an action for damages. Hyatt v. Wood, 4 Johns. (N. Y.) 150, 4 Am. Dec. 258, and Ives v. Ives, 13 Johns. (N. Y.) 235. In Jackson v. Farmer, 9 Wend. (N. Y.) 201, the court, while recognizing the rule as law, characterize it as "harsh, and tending to the public disturbance and individual conflict." Kent, in his Commentaries, states the principle in the same manner, but in the later editicns of the work, reference is made by the learned editor in a note, to the case of Newton v. Harland, above quoted, as laying down "the most sound and salutary doctrine."

In Tribble v. Frame, 7 J. J. Marsh, (Ky.) 599, 23 Am. Dec. 439, the court held, that, notwithstanding the Kentucky statute of forcible entry and detainer, the owner of the fee, having a right of entry, may use stich force as may be necessary to overcome resistance, and protect himself against an action of trespass, under a plea of liberum tenementum. On the other hand, the Supreme Court of Massachusetts has held, that, although trespass quare clausum may not lie, yet, in an action of trespass for assault and battery, the landlord must respond in damages, if he has used force to dispossess a tenant holding over. The court say, "he may make use of force to defend his lawful possession but, being dispossessed, he has no right to recover possession by force, and by a breach of the peace." Sampson v. Henry, 11 Pick. (Mass.) 379. See also Ellis v. Page, 1 Pick. (Mass.) 43; Sampson v. Henry, 13 Pick. (Mass.) 36; Meader v. Stone, 7 Metc. (Mass.) 147, and Moore v. Boyd, 24 Me. 242. But, by far the most able and exhaustive discussion that this question has received, was in the case of Dustin v. Cowdry, $23 \mathrm{Vt}$. 635, in which Mr. Justice Redfield, delivering the opinion of the court, shows, by a train of reasoning which compels conviction, that, in cases of this character, the action of trespass will lie. And he also says: "Whether the action should be trespass quare clausum, or assault and battery, is immaterial, as under this declaration, if the defendant had pleaded soil and freehold, as some of the cases hold, the plaintiff might have new assigned the trespass to the person of the plaintiff, and a jury, under proper instructions, would have given much the same damages, and upon the same evidence, in whatever form the declaration is drawn." The case of Mussey v. Scott, 32 Vt. 82, cited as inconsistent with this case does not in fact conflict with it. It only holds that trespass quare clausum will not lie in behalf of a tenant for an entry not within the statute of forcible entry and detainer.

In this conflict of authorities we must adopt that rule which, in our judgment, rests upon the sounder reason. We cannot hesitate, and were it not for the adverse decision of courts, which all lawyers regard with profound respect, we should not deem the question obscured by a reasonable doubt. The reasoning upon which we rest our conclusion lies in the briefest compass, and is hardly more than a simple syllogism. The statute of forcible entry and detainer, not in terms, but by necessary construction, forbids a forcible entry, even by the owner, upon 
the actual possession of another. Such entry is, therefore, unlaw ful. If unlawful, it is a trespass, and an action for the trespass must necessarily lie. It is urged that the only remedy is that given by the statute. -an action for the recovery of the possession. But the law could not expel him who has entered if his entry was a lawful entry, and if not lawful all the consequences of an unlawful act must attach to it. The law is not so far beneath the dignity of a scientific and harmonious system that its tribunals must hold in one form of action a particular act to be so illegal that inmediate restitution must be made at the costs of the transgressor, and in another form of action that the same act was perfectly legal, and only the exercise of an acknowledged right.

It is urged that the owner of real estate has a right to enter upon and enjoy his own property. Undoubtedly, if he can do so without a forcible disturbance of the possession of another; but the peace and good order of society require that he shall not be permitted to enter against the will of the occupant, and hence the common law right to use all necessary force has been taken away. He may be wrongfully kept out of possession, but he cannot be permitted to take the law into his own hands and redress his own wrongs. The remedy must be sought through those peaceful agencies which a civilized community provides for all its members. A contrary rule befits only that condition of society in which the principle is recognized that

He may take who has the power,

And he may lieep who can.

If the right to use force be once admitted, it must necessarily follow as a logical sequence, that so much may be used as shall be necessary to overcome resistance, even to the taking of human life. The wisdom of confining men to peaceful remedies for the recovery of a lost possession is well expressed by Blackstone, book 4, p. 148: "An eighth offense," he says, "against the public peace, is that of a forcible entry and detainer, which is committed by violently taking or keeping possession of lands and tenements with menaces, force and arms, and without the authority of law. This was formerly allowable to every person disseized or turned out of possession, unless his entry wás taken away or barred by his own neglect or other circumstances, which were explained more at length in a former book. But this being found very prejudicial to the public peace, it was thought necessary, by several statutes, to restrain all persons from the use of such violent methods, even of doing themselves justice, and much more if they have no justice in their clain. So that the entry now allowed by law is a peaceable one; that forbidden, is such as is carricd on with force, violence and unusual weapons." In this State, it has been constantly held that any entry is forcible, within the meaning of this law, that is made against the will of the occupant.

We state, then, after a full examination of this subject, that in our opinion the statutes of forcible entry and detainer should be construed as taking away the previous conmon law right of forcible entry by 
the owner, and that such entry must be, therefore, held illegal in all forms of action.

There are, however, some minor points upon which both of these judgments must be reversed. In the suit brought by the husband alone, the court refused to instruct the jury that the plaintiff could not recover for any damages to the real estate. This instruction should have been given. Although the occupant may maintain trespass against the owner for a forcible entry, yet he can only recover such damages as have directly accrued to him from injuries done to his person or property, through the wrongful invasion of his possession, and such exemplary damages as the jury may think proper to give. But a person having no title to the premises, clearly cannot recover damages for any injury done to them by him who has title. It would be a startling doctrine to hold that the wrongful occupier of land could make the owner thereof to respond to him in damages for timber that the owner might cut upon the premises. This point was decided by this court in Hoots v. Graham, 23 Ill. 82, to the decision in which case we fully adhere.

In the case brought by Purdy, the court, after telling the jury they could give exemplary damages, gave the following instruction for the plaintiff :

"In estimating the amount of exemplary damages, if they find any, the jury have a right to take into consideration the unlawful purpose for which defendants were together, if any is proven; the force and violence with which they attempted to carry out that unlawful purpose, the wantonness of the attack upon the premises, family and property of the plaintiff, if the proof show any such, and the willfulness of the defendants in doing the acts, if the evidence show any such."

The suit brought by Purdy and wife had been already tried, and in that suit the jury had been instructed they might give exemplary damages, and they had undoubtedly given them. The record of that suit was in evidence on the trial of the second suit. The court refused the instructions asked by the defendant, and properly, in the form they were drawn, except as to the one already considered. Neither is there anything in itsclf wrong in the foregoing instruction, and yet it is of such a character, that the court, in order to secure a fair consideration of the case by the jury, and having refused all the instructions drawn by the defendant, should, of its own motion, have modified the somewhat augmentative effect of this one by telling the jury that they were also, in estimating the exemplary damages, to consider the fact that the jury in the other suit had been anthorized to give exemplary damages, and to take into consideration on that question the amount of the verdict in the other case. We must hold, that, in strict law, exemplary damages are recoverable in both cases, because the suits are brought in different rig!ts. In the suit by Purdy and wife, if Purdy fails to collect the jullgment in his lifetime, on his death it would go to the wife surviving liim, and not to his personal representatives. But, apart from that contingency, the fruits of both judgments go into his pocket. It 
would, therefore, be highly proper that the jury, in considering the question of punitive damages, should have taken into consicleration not only the circumstances of aggravation enumerated in the instruction, but also the fact, that these same circumstances, and the same transaction, had been submitted to another jury, in a suit prosecuted in reality for the benefit of the same plaintiff, and, so far as related to the single question of the amount of vindictive damages, the amount of the former verdict would have been a proper subject of regard.

The jury were also told in the third instruction for the plaintiff, at the suit of Purdy, that the fact, that the defendant was the owner and entitled to the possession of the premises occupied by the plaintiff could not be regarded by the jury in mitigation of any actual damages caused to the plaintiff by the assault and force. This is undoubtedly true so far as actual damage was concerned, but it would not be true in regard to exemplary damages, unless we are prepared to say, that it is as inexcusable for a person to attempt to recover his own property by force as it would be to attempt to rob another of property to which the assailant had no claim. This would not be contended, and while, therefore, the third instruction was strict law, yet, in connection with the other instructions in regard to exemplary damages, and unexplained by anything in behalf of the defendant, we think the jury would be likely to be misled. This is more especially true in regard to the suit of Purdy and wife, for in the third instruction for the plaintiff in that suit, the jury are told the same thing as to damages, but the word actual is left o11. These instructions should have been so modified, that the jury would clearly understand on the question of vindictive damages, they woukd have a right to regard the fact, that the defendant was the owner and entitled to the possession of the property, a fact proven in the case.

This last objection applies equally to the instructions in both cases. The others above considered apply only to the suit of Purdy. There is, however, another fatal objection to the judgment in favor of Purdy and wife. Both counts in that declaration are for injuries done to the person of the wife. A suit could not have been maintained in their joint names for injuries done to the property of Purdy. Yet the court, against the objections of defendants, allowed the plaintiff to give in evidence the injury done to the furniture. This was wholly inadmissible, except so far as might be necessary to explain the assault on the person of the wife, and, in a case of this character, notwithstanding the instruction given for the defendants, this evidence would have a strong tendency to improperly prejudice them in the minds of the jury.

In order to prevent misapprehension we would say, in conclusion, that, for a mere entry by the landlord upon the possession of his tenant holding over, unaccompanied by any trespass upon either the person or personal property of the occupant, only nominal damages could be recovered, because the plaintiff has no legal right to the possession. The gravamen of actions of this character is the trespass to the person, and goods and chattels of the tenant. If, for example, a tenant of a 
house should remove his family and furniture at the end of the term, but refuse, without reason, to surrender the key to his landlord, and still claim the possession, the landlord might, nevertheless, force the door of his vacant house, without incurring a liability to more than nominal damages. He would be liable to an action of forcible entry and detainer, and to an action of trespass, in which nominal damages would be recovered, because the entry would be unlawful, but to nothing more. But for an entry, while the house is still occupied by the family and furniture of the tenant, and for forcibly thrusting them into the street, or attempting to do so, he would be liable to such damage as a jury might deem the case to recuire. A landlord, however, would have the right to enter upon the possession of his tenant for certain purposes, as to demand rent or to make necessary repairs, and we must be understood as confining the action of trespass quare clausum by the tenant against the landlord, even for the recovery of nominal damages, to those cases, where an action of forcible entry and detainer would lie under our statute. By the application of this principle much of the apparent conflict in the authorities can be explained.

The judgment in both of these cases must be reversed and the case remanded. Reversed and remanded. ${ }^{36}$

\section{LOIV v. ELIVELL.}

(Supreme Judicial Court of MLassachusetts, 1876. 121 Mass. 309, 23 Am. Rep. 272.)

Tort for an assault in forcibly ejecting the plaintiff from her dwelling house.

At the trial in the Superior Court; before Brigham, C. J., it appeared that the plaintiff was the wife of John C. Low, who had hired a house of Josiah Low, the owner thereof, under an oral lease, and had occupied the same for two years under that tenancy; and that in March, 1873, Josiah Low made a lease of the house under seal to Zeno P. Elwell, and both of them in writing gave notice to John C. Low of this lease, and to quit the premises.

The plaintiff testified that on April 15, 1873, she was occupying the house with her husband and family, consisting of her son, eleven years of age, and a hired servant, and that, while her husband was absent from home, the following events took place: "About ten o'clock in the morning, I saw a furniture wagon stop in front of the house. The doors were all fastened. Elwell and his wife came to the back door, and tried it. Mrs. Elwell came and knocked on the window and said, 'Let me in.' I said she must not cross the threshold. She said she

36 Whitney v. Bromn, 75 Kan. 67S, 90 Pac. 277, 11 L. R. A. (N. S.) 468, 12 Ann. Cas. 7 (is (1907); Entelman v. Hagood, 95 (:a. 390. 22 S. L. 545 (1S95); Noel r. McCrory, 7 Cold. (Tenn.) 623 (1S6S), dictum; Dustin . Cowdry, 23 Vt. 631 (1851), acc. 
should come in, she had a deed of the place. They went away, and I heard a noise at the front door. I was combing my hair: I opened the door into the front entry, and found the front door open, the bolt lying on the floor, and Elwell and his wife standing on the step, he having an iron bar in his hand. The door had been bolted by me before that time. I forbade their crossing the threshold, but they canie in. Elwell said, 'You forbid my crossing the threshold. I own this house, and want you to go out.' I told him not to lay his hands on me. They then proceeded to take out the furniture, carpets, etc., and to bring in their own. My boy was by my side. The hired man was near me, and Elwell took him by the collar and put him out. There were six men with them in the street. They were not at the door at the time it was broken, and did not do anything except remove furniture. Mr. Josiah Low was one of them. The others were neighbors and men who had brought the defendants' furniture from Gloucester. I remained in the house, most of the time in ny bedroom, until about half past two o'clock in the afternoon. All my furniture had been removed, except a box on which I was sitting. Elwell came to me and removed me by force from the box, and carried it out. Afterwards he came to me and directed me to leave the house, which I refused to do. He then took me by the shoulders and ran me out of the house, from my bedroom, through the sitting-room, into the street. My boy followed me. Elwell said, in his wife's presence, that he was acting under her directions." It was admitted that she was jointly liable with him for whatever was done, if either was liable; and that, if they had the right to remove the plaintiff by force, at the time she was removed, no more force was used than was reasonably necessary in either instance.

The case was reported, by consent of parties, before verdict, to this court; the parties agreeing that if, upon these facts, the defendants could not justify the acts admitted to have been done by them, the case was to stand merely for an assessment of damages; if otherwise, the plaintiff should become nonsuit.

The case was argued in November 1875, and was afterwards submitted on briefs to the whole court.

GraY, C. J. A tenant holding over after the expiration of his tenancy is a mere tenant at sufferance, having no right of possession against his landlord. If the landlord forcibly enters and expels him, the landlord may be indicted for the forcible entry. But he is not liable to an action of tort for damages, either for his entry upon the premises, or for an assault in expelling the tenant, provided he uses no more force than is necessary. The tenant cannot maintain an action in the nature of trespass quare clausum fregit, because the title and the lawful right to the possession are in the landlord, and the tenant, as against him, has no right of occupation whatever. He cannot maintain an action, in the nature of trespass to his person, for a subsequent expulsion with no more force than necessary to accomplish 
the purpose; because the landlord, having obtained possession by an act which, though subject to be punished by the public as a breach of the peace, is not one of which the tenant has any right to complain, has, as against the tenant, the right of possession of the premises; and the landlord, not being liable to the tenant in an action of tort for the principal act of entry upon the land, cannot be liable to an action for the incidental act of expulsion, which the landlord, merely because of the tenant's own unlawful resistance, has been obliged to resort to in order to make his entry effectual. To hold otherwise would enable a person, occupying land utterly without right, to keep out the lawful owner until the end of a suit by the latter to recover the possession to which he is legal'y entitled.

This view of the law, notwithstanding some inconsistent opinions, is in accordance with the current of recent decisions in England and in this Commonwealth.

In Turner v. Meymott, 7 Moore, 574, s. c. 1 Bing. 158, it was decided that a tenant whose term had expired could not maintain trespass against his landlord for forcibly breaking and entering the house in his absence. In Hillary v. Gay, 6 C. \& P. 284, indeed, Lord Lyndhurst at nisi prius, while recognizing the authority of that decision, ruled that if the landlord, after the expiration of the tenancy, by force put the tenant's wife and furniture into the street, he was liable to an action of trespass quare clausum fregit. And in Newton v. Harland, 1 Man. \& Gr. 644, s. c. 1 Scott, N. R. 474, a majority of the Court of Common Pleas, overruling decisions of Baron Parke and Baron Alderson at nisi prius, held that under such circumstances the landlord was liable to an action of trespass for assault and battery.

But in Harvey v. Brydges, 14 M. \& W. 437, Baron Parke stated his opinion, upon the point raised in Newton v. Harland, as follows: "Where a breach of the peace is committed by a freeholder, who, in order to get into possession of his land, assaults a person wrongfully holding possession of it against his will, although the freeholder may be responsible to the public in the shape of an indictment for a forcible entry, he is not liable to the other party. I cannot see how it is possible to doubt that it is a perfectly good justification to say that the plaintiff was in possession of the land against the will of the defendant, who was owner, and that he entered upon it accordingly; even though, in so doing, a breach of the peace was committed." Baron Alderson concurred, and said that he retained the opinion that he expressed in Newton v. Harland, notwithstanding the decision of the majority of the Court of Common Pleas to the contrary. The opinion thus deliberately adhered to and positively declared by those two eminent judges, though not required by the adjudication in $\mathrm{Har}$ vey $v$. Brydges, is of much weight. In Davis v. Burrell, $10 \mathrm{C} . \mathrm{B}$. 821,825 , Mr. Justice Cresswell said, that the doctrine of Newton v. Harland had been very much questioned. And it was finally overruled 
in Blades v: Higgs, 10 C. B. (N. S.) 713, where, in an action for an assault by forcibly taking the defendant's property from the plaintiff's hands, using no more force than was necessary, Chief Justice Erle, delivering the unanimous judgment of the court, approved the statement of Baron Parke, above quoted, and added: "In our opinion, all that is so said of the right of property in land applies in principle to a right of property in a chattel and supports the present justification. If the owner was compellable by law to seek redress by action for a violation of his right of property, the remedy would be often worse than the mischief, and the law would aggravate the injury, instead of redressing it." See also Lows v. Telford, 1 App. Cas. 414, $426 .{ }^{37}$

In Commonwealth v. Haley, 4 Allen, 318, the case was upon an indictment for forcible entry, and no opinion was required or expressed as to the landlord's liability to a civil action.

The judgment in Sampson v. Henry, 11 Pick. 379, turned upon a question of pleading. The declaration, which was in trespass for an assault and battery, alleged that the defendant assaulted the plaintiff, and with a deadly weapon struck him many heavy and dangerous blows. The pleas of justification merely averred that the defendant was seised and had the right of possession of a dwelling-house, that the plaintiff was unlawfully in possession thereof and forcibly opposed the defendant's entry, and that the clefenclant used no more force than was necessary to enable him to enter and to overcome the plaintiff's resistance; but did not deny the use of the dangerous weapon and the degree of violence alleged in the declaration; and were therefore held bad, in accordance with Gregory v. Hill, 8 T. R. 299, there cited. The remarks of Mr. Justice Wilce, denying the right of a party dispossessed to recover possession by force and by a breach of the peace, would, if construed by themselves, and extended beyond the case before him, allow the tenant to maintain an action of trespass against the landlord for entering the divelling-house, in direct opposition to the judgment delivered by the same learned judge, in another case, between the same parties, argued at the same term and decided a year after. Sampson v. Henry, 13 Pick. 36.

In the latter case, which was an action for breaking and enterine the plaintiff's close, and for an assault and battery upon him, the court held that the plea of liberum tenementum was a good justification of the charge of breaking and entering the house, but not of the personal assault and battery. That decision, so far as it held that the landlord was not liable to an action of trespass quare clausum fregit by a tenant at sufferance for a forcible entry, has been repeatedly

37 In Edwick v. Hawkes, 18 Ch. D. 199 (1SS1), Fry, J., approved of the doctrine of Newton v. Harland, and allowed damages for injuries done to the plaintiff"s wife on account of a forcible entry. The judge said that persons who have a right of entry on land must enter "in a peaceable and easy manner, and if they cannot do so they must resort to the courts." 
affirmed. Meader v. Stone, 7 Metc. 147; Miner v. Stevens, 1 Cush. 482, 485; Mason v. Holt, 1 Allen, 45; Curtis v. Galvin, 1 Allen, 215; Moore v. Mason, 1 Alien, 406. And, so far as it allowed the plaintiff to recover, in such an action damages for the incidental injury to him or to his personal property, it has been overruled. Eames v. Prentice, 8 Cush. 337; Curtis v. Gaivin, ubi supra.

It has also been adjudged that a landlord, who, having peaceably entered after the termination of the tenancy, proceeds, against the tenant's opposition, to take out the windows of the house, or to forcibly eject the tenant, is not liable to an action for an assault, if he uses no more force than is necessary for the purpose. Mugford v. Richardson, 6 Allen, 76, 83 Am. Dec. 617; Winter v. Stevens, 9 Allen, 526. For the reasons already stated, we are all of opinion that a person who has ceased to be a tenant, or to have any lawful occupancy, has no greater right of action when the force exerted against his person is contemporancous with the landlord's forcible entry upon the premises.

Our conclusion is supported by the American cases of the greatest weight. Jackson v. Farmer, 9 Wend. (N. Y.) 201; Overdeer v. Lewis, 1 Watts \& S. (Pa.) 90, 37 Am. Dec. 440; Kellam v. Janson, 17 Pa. 467; Stearns v. Sampson, 59 Me. 568, 8 Am. Rep. 442; Sterling v. Warden, 51 N. H. 217, 12 Am. Rep. S0. The opposing decisions are so critically and satisfactorily examined in an elaborate article upon this subject in 4 Am. Law Rev. 429, that it would be superfluous to refer to them particularly.

The tenancy of the plaintiff's husband under an oral lease was but a tenancy at will, which, by the written lease from his landlord to the defendant, and reasonable notice thereof, was determined, and he became a mere tenant at sufferance. Pratt v. Farrar, 10 Allen, 519. It being admitted that, if the defendants had the right to remove the plaintiffs by force, no more force was used than was reasonably necessary, this action cannot be maintained.

Plaintiff nonsuit. ${ }^{38}$

38 Viuson v. Flynn, 64 Ark. 453, 43 S. W. 146, 46 S. W. 1S6, 39 L. R. A. 415 (1S97): Allen v. Keily, 17 R. I. 731, 24 Atl. 776,16 L. R. A. 795,33 Am. St. Rep. 905 (189:), acc. See, also, Hugnins r. Fridges, 29 Pa. Super. Ct. R. S2 (1905); Rush r. Aiken Mfg. Co., 5́S S. C. 145,36 S. E. 497, 79 An. St. Rep. 836 (1900), repudiating views earlier expressed in Sharp v. Kinsman, 18 S. C. $10 S$ (1SS2).

in smith v. Detroit I. \& B. Ass'n. 115 Mich. $310,73 \mathrm{~N}$. W. 395 (1597), the landlord. in the tenant's temporary alsence after the expiration of the term, entered upon the premises and broke into the house, removed the furniture to an outbuilding, and then folcibly prerented the return of the tenant. It was held that the tenant had no cause of action. Bliss r. Johnson, 73 N. Y. 529 (1S7S); Mussey v. Scott, 32 Vt. 82 (1S59); Davis v. Burrell, 10 C. B. 821 (1S51), acc. Willer v. IHouse, $4 S$ Ill, 279 (186s); Mason v. Hawes, 52 Conn. 12, 52 Am. Rep. 55: (18\$1), contla.

Occasionally it has been declared that, hile there is no basis for an action by the forcibly ejected tenant in trespass quare clausam, there may be a recovery for trespass to the person or goods, even though there may have been 


\section{LAY'TON v. FIELD.}

(Court of King's Bench, 1701. 3 Salk. 222.)

Per Holt, Ch. Just. Where a lease is made at will, the lessee, after a quarter of a year is commenced, may determine his will, but then he must pay that quarter's rent; and if the lessor determine his will after the commencement of a quarter, he shall lose his rent for that quarter; but if a lease be made from year to year, quamdiu ambabus partibus placuerit; in such case, after a year is commenced, neither the lessor nor the lessee can determine their wills for that year, because they have willed the estate certain for so long time.

\section{BRAYTHWAYTE v. HITCHCOCK.}

\section{(Court of Exchequer, 1842. 10 Mees. \& W. 494.)}

Debt for rent. The first count of the declaration stated a demise, on the 26th of October, 1840, from the plaintiff to William Hitchcock, of a messuage and premises, to hold for one year from the 25 th of December then last, and so on from year to year if the plaintiff and the said William Hitchcock should respectively please, at the annual rent of $£ 140$., payable quarterly on \&c.: that, during the said tenancy, to wit, on the 17 th July, 1841, all the estate and interest of the said W. Hitchcock in the said messuage and premises came to and vested in the defendant, by assignment from the said W. Hitchcock: and alleged as a breach the nonpayment by the defendant of $£ 35$., a quarter's rent due at Christmas, 1841. There was also a count on an account stated.

The defendant pleaded, first, nunquam indebitatus; secondly (to the first count,) a denial of the demise of W. Hitchcock: and thirdly (to the first count,) a denial that the estate and interest of W. Hitchcock vested in him the defendant: on which issues were joined.

At the trial before Lord Abinger, C. B., at the Middlesex sittings after last term, the plaintiff put in evidence an agreement, dated the 17 th December, 1840 , and signed by the plaintiff only, whereby the plaintiff agreed to execute a lease of a cottage, \&c. to W. Hitchcock, for seven years, at a yearly rent of $£ 140$., payable quarterly. It was proved that no lease had been executed in pursuance of the agree-

no excessive force. See Levy r. Mcclintock, 141 Mo. App. 593, 125 S. W. 546 (1909): Stearns v. Sampon, 59 \e. 568, S Am. Rep. 412 (1si1), semble.

As to what amounts to a forcible entry under the forcible entry and detainer statutes, see smith r. Detroit I. \& B. Ass'n, supra.

On the right of a forcibly ejected wroncful possessor to proceed under the forcible entry and detainer statutes arainst the ejector, who was entitled to possession, see Yage v. Dwight, 170 Mass. 29, 48 N. E. 850,39 I. R. A. 418 (1597).

AIG.PROP. -42 
ment, but that $\mathrm{W}$. Hitchcock had entered into possession of the cottage shortly after the date of the agreement, and had paid two quarters' rent up to Midsummer, 1841 , at the rate of $£ 140$. a year. The plaintiff then proved a notice to the defendant to produce a deed of assignment, bearing date the 17 th July, 1841, of the cottage, from W. Hitchcock to the defendant; and on its nonproduction, called a witness, who produced a paper which he said was a true copy of the original assignment, which he had read and compared with it. It was objected that this copy could not be read in evidence for want of a stamp; but the Lord Chief Baron overruled the objection, and the copy was read: from which it appeared, that by the deed of assignment, which was executed both by IV. Hitchcock and the defendant, after reciting the agreement of the 17 th December, 1840 , and that no lease had been executed in pursuance thereof, IV. Hitchcock assigned to the defendant, his executors, \&c., all the said agreement, and all benefit and advantage thereof, and all his estate, title, and interest therein, to hold to the defendant, his executors, \&c., absolutely, subject nevertheless to a proviso for redemption. It was contended for the defendant, that there was no sufficient evidence of a demise whereby a tenancy from year to year was created, as alleged in the declaration. The Lord Chief Baron overruled the objection, and the plaintiff had a verdict for $f 35$., leave being reserved to the defendant to move to enter a nonsuit, if the Court should be of opinion that there was no sufficient evidence of the assignment.

Erle now moved accordingly for a rule to enter a nonsuit, and also for a new trial, on the ground that

Secondly, under the agreement recited in the deed, W. Hitchcock was a mere tenant at will, no lease having been executed, and there was not sufficient evidence from which to infer a demise from year to year, as alleged in the declaration. He had therefore no assignable interest in the premises. He referred to Brashier v. Jackson, 6 M. \& IV. 549.

LORD AbINGER, C. B. ${ }^{3 \theta}$ I think the evidence was sufficient to show a tenancy from year to year, under the agreement which was duly executed by the plaintiff; the cases which have been decided on this point go fully at length. Here there is the additional fact of an admission under the defendant's hand, in the deed of assignment, that an agreement for the lease was executed by the plaintiff. But the plaintiff's case does not rest solely on the agreement to let; there is the fact of William Hitchcock having been in the possession of the cottage for more than a year, and having paid two quarters' rent under the agreement. William Hitchcock had therefore an assignable interest, which passed to the defendant under the deed proved at the trial. As to the other point, I think the provisions of the Stamp Acts relate only to such copies as are evidence per se, and that the word "copy"

39 Part of the statement is omitted. 
there means an authenticated copy, receivable as evidence in the first instance. Here the copy was evidence, only because the party who produced it had compared it with the original, and swore to the contents of it, word for word.

PARKE, B. I am of the same opinion. Although the law is clearly settled, that where there has been an agreement for a lease, and an occupation without payment of rent, the occupier is a mere tenant at will; yet it has been held that if he subsequently pays rent under that agreement he thereby becomes tenant from year to year. Payment of rent, indeed, must be understood to mean a payment with reference to a yearly holding; for in Richardson v. Langridge, 4 Taunt, 128, a party who had paid rent under an agreement of this description, but had not paid it with reference to a year, or any aliquot part of a year, was held nevertheless to be a tenant at will only. In the present case, there was a distinct proof of the payment of rent for two quarters of a year. There is the additional fact of an occupation for more than a year; but in the case of Cox v. Bent, 5 Bing. 185, 2 II. \& P. 281, where a party, under an agreement for a lease, had occupied for more than a year, the Court held that a tenancy from year to year existed, not on the ground of the occupation, but because the party had during that occupation paid a half-year's rent. I think, therefore, the fact of such a payment was the stronger evidence in this case, and that William Hitchcock may be taken to have been a yearly tenant. Then, as to the question whether there has been a due assignment of such his interest. I think it is clear that there has; bechuse, although the deed in its commencement recites only the agreement, the operative part of it convers and assigns "all that the hereinbefore recited agreement of the 17 th of December, 1840, and all benefit and advantage thereof, and all that and those the said messuage or tenement and premises at $\delta c$., and all the right, title, interest, property. claim, and demand whatsoever, at law or in equity, of him the said William Hitchcock in the said premises," \&c. On the other point I quite agree with my Lord Chief Baron that no stamp was requisite, inasmuch as, though the document might in form have been read as a copy of the original, it was in truth read only as a memorandum to refresh the memory of the witness, who had compared it with the deed. ${ }^{* 0}$

40 Cf. Doe ex dem. Bastow v. Cox, 11 Q. B. 122 (1S17): Sag v. Stoddard, supra. p. 642. 


\section{DOE d. THOMSON v. AMEY.}

(Court of Queen's Bench, 18t0. 12 Adol. \& El. 476.)

Ejectment, on the several demises of Elizabeth Thomson and others, to recover possession of a farm occupied by the defendant.

On the trial, at the Cambridge Spring assizes, 1839, before Tindal, C. J., it appeared that on 29th July, 1835, articles of agreement had been entered into between Miss Thomson, the lessor of the plaintiff, and the defendant, whereby Miss Thomson, for and on behalf of herself and others, devisees in trust under the will of her father, in consideration of the rent and covenants thereinafter mentioned to be paid and performed by the defendant, agreed with the defendant, so far as she lawfully could or might, that she and all other necessary. parties should and would grant a lease of the farm to defendant, excepting out of the said lease agreed to be made all trees, mines \&c., with liberty of ingress and egress for the intended lessors, for fourteen years, from 11 th October then next, at a rent of $£ 346$., payable quarterly. And it was thereby agreed, that there should be contained in the lease covenants to repair, the said "intended lessors" finding rough timber; that defendant should not assign without license; that defendant should use the premises agreed to be demised in a husbandlike and proper manner according to the best system of husbandry practised in that part of the country; that defendant should, during the said term, scour ditches and drains, and make and renew hedges; that defendant would not destroy any trees, nor grow two successive crops of white corn or grain on any of the arable land without summer tilting, or taking a green fallow crop; nor sell or suffer to be taken off the premises any of the hay or straw grown, or manure made thereon, but should spend them on the premises. And it was further agreed that the lease should contain a proviso empowering the intended lessors to enter on the premises as of their former estate in case defendant should fail in observing any of the covenants or agreements therein contained; and all other usual and proper covenants in leases of a like nature. It was also agreed that defendant should execute a counterpart of the lease, and defray the expense of the articles of agreement.

The defendant entered into possession at the time fixed for the commencement of the term, and continued to hold and pay the rent until action brought; but no further lease was ever made or executed.

Before the commencement of the action, notice of several breaches of agreement was served on the defendant by the lessor of the plaintiff. One of these, namely, that defendant had taken successive crops of white corn on the same land without summer tilting or green fallow, was satisfactorily proved on the trial, and the plaintiff had a verdict, subject to a motion for a nonsuit on the grounds hereafter stated.

In the following term, B. Andrews obtained a rule nisi in pursuance of the leave reserved. 
Lord Denman, C. J. In this case the defendant was let into possession under an agreement, which gave the parties a right to go into equity to compel the execution of it by making out a formal lease. Under such circumstances it has long been the uniform opinion of Westminster Hall, that the tenant in possession holds upon the terms of the intended lease. One of these terms was, that the lessee should not take successive crops of corn, and that the lessor should have power to re-enter on the breach of such agreement. This agreement and proviso apply to the yearly tenancy of the defendant. It has been argued, that the terms of the lease cannot be applied to the parol tenancy, inasmuch as some of them, such as the agreement for repairs, are not usually considered as applicable to such tenancy. Whether the obligation to repair can be enforced under such circumstances, at least as to substantial repairs, may perhaps be questionable; but at all events, the agreement as to cropping the land is one which is consistent with a yearly tenancy.

PatTeson, J. In Mann v. Lovejoy, Ry. \& M. N. P. C. 355, though the facts differed from those of the present case, yet, in principle, the ruling of Abbott, C. J., is in favour of the plaintiff. It is said, that a covenant respecting the rotation of crops cannot be engrafted on a yearly tenancy, but I see no reason why it should not. The tenant in possession under such circumstances is bound to cultivate the land, as if he were going to continue in possession as long as the lease itself would have lasted. It is argued, that the tenancy arises by operation of law upon the payment of rent, and that the law implies no particular mode of cropping, nor any condition of re-entry. But the terms upon which the tenant holds are in truth a conclusion of law from the facts of the case, and the terms of the articles of agreement; and I see no reason why a condition of re-entry should not be as applicable to this tenancy as the other terms expressed in the articles.

Williams, J. It is admitted, that, if this were a case of holding over, the terms of the written agreement would apply. In principle, there is no distinction between that case and the case of a tenant who enters and pays rent upon the faith of an executory agreement for a lease.

Rule discharged.41

41 See Doe d. Tilt $\nabla$. Stratton, 4 Bing. 446 (1828). In Doe d. Rigge v. Bell, 5 Term Rep. 471 (1793), the court, Lord Kenyon, C. J., said: "Though the agreement be void by the Statute of Frauds as to the duration of the lease, it must rergulate the terms on which the tenancy subsists in other respects, as to the rent, the time of the year when the tenant is to quit, etc. So where a tenant holds orer after the expiration of his term, without having entered into any new contract, he holds upon the former terms. Now, in this case, it was agreed, that the defendant should quit at Candlemas; and though the agreement is void as to the number of years for which the defendant was to hold, if the lessor choose to determine the tenancy before the expiration of the seven years, he can only put an end to it at Candlemas." 


\section{COUDERT v. COHN.}

(Court of Appeals of New York, 1590. 11S N. Y. 309, 23 N. E. 295, 7 L. R. A. (9, 16 Am. St. Rep. T(j1.)

BradeEY, J. The action was brought to recover rent of premises described in a written lease made by the agent of the plaintiffs' intestate to the defendants in January, 18S4, for the term of two years and five months, commencing on the first day of March, 18S4, and ending on the first day of August, 18\$6, at the yearly rent of $\$ 3,000$, payable in equal monthly payments, on the last business day of each month. The authority of the agent to make the lease not being in writing it was void. $2 \mathrm{R}$. S. (1st E.d.) p. 13t, $\S 6$. The defendants went into possession on the first of March, 1SSt, and continued to occupy and pay rent up to August, 1SS5, when they left the premises and sought to surrender the possession up to the plaintiff's intestate, who declined to accept it. He recovered for the amount of rent at the rate mentioned in the lease from the first of August, to the first of March following. While the cases are not entirely in harmony on the subject, the doctrine now in this state is such that the defendants on going into possession of the premises and paying rent, became, by reason of the invalidity of the demise, tenants from year to year, and in such case the continuance of occupancy into the second year rendered them chargeable with the rent until its close. They could then only terminate their tenancy at the end of the current year. Reeder v. Sayre, 70 N. Y. 180, 26 Am. Rep. 567; Laughran v. Smith, 75 N. Y. 205.

The question presented is: When did the rental year arising out of such relation commence and terminate? It is contended by the defendant's counsel that inasmuch as the end of the term designated by the terms of the lease was the first of August, 1886, that was the time when the yearly tenancy in contemplation of law terminated, and, therefore, the surrender was properly made on the first of August, 1885. It is urged that this view is in harmony with the recognized principle that, although the lease was invalid the agreement contained in it regulated the terms of the tenancy in all respects, except as to the duration of the term, and Doe v. Bell, 5 D. \& E. 471, is cited. There a farm was, in January, 1790, let by a parole lease, void by the statute of frauds, for seven years, the lessee to enter upon the land when the former tenant left, on Lady-day, and into the house on the 25 th of May following, and was to quit at Candlemas. He entered accordingly and paid rent. A notice was served upon the tenant September 22d, 1792, to quit on Lady-day. In ejectment brought against him it was claimed, on the part of the lessee, that his holding was from Candlemas, and, therefore, the notice was ineffectual to terminate the tenancy. Lord Kenyon, in deciding the case, said and held that "it was agreed that the defendant should quit at Candlemas, and 
though the agreement is void as to the number of years for which the defendant was to hold, if the lessor choose to determine the tenancy before the expiration of the seven years, he can only put an end to it at Candlemas." That case has in several instances been cited by the courts of this state upon the question of the force remaining in the terms of the agreement embraced in a void lease. And in Schuyler v. Leggett, 2 Cow. 663, it was remarked by Chief Justice Savage, in citing it, that such an agreement "must regulate the terms on which the tenancy subsists in other respects; as the rent, the time of year when the tenant must quit, etc." And the citation was repeated to the same effect by the Chief Justice in People v. Rickert, 8 Cow. 230.

The question here did not arise in either of those two cases, nor can they be treated as authority that the time for termination of a tenancy from year to year, in any year other than that of the designated expiration of term, is governed by such designation in a void lease for more than one year rather than by the time of entry. The effect sought to be given in the present case to the case of Doe v. Bell is not supported by English authority. In Berrey v. Lindley, 3 M. \& G. 496, the tenant entered into possession of premises under an agreement void by the statute of frauds, by the terms of which he was to hold five years and a half from Michaelmas. Several years after his entry, and after expiration of the period mentioned in the agreement, the lessee gave notice to his landlord to terminate the tenancy at Michaelmas. It was there contended on the part of the latter, and Doe v. Bell was cited in support of the proposition, that the time designated in the agreement for the termination of the tenancy governed in that respect. But the court decided otherwise, and held that the notice was effectual to terminate the tenancy. The views of the court there were to the effect, that, although the tenancy was from year to year, the tenant might without notice have quit at the expiration of the period contemplated in the agreement, but having remained in possession and paid rent subsequently to that time, he must be considered a tenant from year to year with reference to the time of the original entry.

The same principle in respect to holding over a term was announced in Doe v. Dobell, 1 A. \& E. (N. R.) 806, where it was said that "in all cases the current year refers to the time of entry unless the parties stipulate to the contrary."

The doctrine of the English cases seems to be that a party entering under a lease, void by the statute of frauds, for a term, as expressed in it, of more than one year, and paying rent is treated as a tenant from year to year from the time of his entry, subject only to the right to terminate the tenancy without notice at the end of the specified term. And to that extend and for that purpose only, the terms of agreement, in such case, regulate the time to quit. This right is held to be reciprocal. Doe v. Stratton, 4 Bing. 446. That proposition is 
not without sensible reason, for its support. The lease for more than one year, unless made in the manner provided by the statute, cannot be effectual to vest the term in the lessee, yet in othcr respects the rights of the parties may be determined by its terms, so far as they are consistent with its failure, to create any estate or interest in the land or any duration of term for occupancy by the lessee. And that principle is properly applicable to such leases. Porter v. Bleiler, 17 Barb. 154; Reeder v. Sayre, 70 N. Y. 184, 26 Am. Rep. 567 ; Laughran v. Smith, 75 N. Y. 205, 209.

This view does not aid the defendants. They became tenants from year to year as from the time of their entry; and although by virtue of the terms of the agreement, in that respect, in the lease, they may have been at liberty to quit on the first of August, 1886, if they had remained until then, such time in that, or the year previous, could not be treated as the end of any year of the tenancy. The defendants having entered upon the second year from the time of the original entry, it was not within their power to terminate their relation or liability as tenants until the end of the then current year, which did not terminate until the first of March, was reached.

The conclusion, from these views, necessarily follows that the judgment should be affirmed. All concur, except Brown, J., not sitting. Judgment affirmed. ${ }^{\mathbf{2}}$

\section{CLAYTON v. BLAKEY.}

(Court of King's Bench, 1795. 8 Term Rep. 3.)

This was an action against a tenant for double rent, for holding over after the expiration of his term, and a regular notice to quit. The first cotunt of the declaration stated a holding under a certain term, determinable on the 12th of May then past; and other counts stated a holding from year to year, determinable at the same period. It appeared in evidence, that the defendant had held the premises for two or three years, under a parol demise for twenty-one years from the day mentioned, to which the notice to quit referred; and the Statute of Frauds directing that any lease for more than three years, not reduced into writing, shall operate only as a tenancy at will, it was contended, at the trial of the last assizes for Northumberland, that the holding should have been stated according to the legal operation of it, as a tenancy at will; and as there was no count adapted to that statement, that the plaintiff ought to be nonsuited. Rooke, J., however, considering that it amounted to a tenancy from year to year, over-ruled the objection, and the plaintiff obtained a verdict.

Wood now moved to set aside the verdict, on the ground of a misdirection, relying upon the positive words of the stature

42 See Adams v. City of Cohoes, 127 N. Y. 175, 28 N. E. 25 (1S91); Larkin v. Avery, 2:3 Comn. 304 (1854). 
L_ORD KenYon, C. J. The direction was right; for such a holding now operates as a tenancy from year to year. The meaning of the statute was, that such an agreement should not operate as a term; but what was then considered as a tenancy at will, has since been properly construed to enure as a tenancy from year to year.

Per Curiam. Rule refused. ${ }^{43}$

\section{GRISWOLD v. BRANFORD.}

(Supreme Court of Errors of Connecticut, 1908. 80 Conn. 453, 68 Atl. 987.)

Action to recover rent, brought to and tried by the Court of Common Pleas in New Haven County, Bennett, J. Facts found and judgment rendered for the plaintiff for $\$ 420$, and appeal by the defendant. No error.

The plaintiff sought to recover the agreed rent of certain premises for the year beginning October 1st, 1899. He set up a parol lease for that term, and alleged that the defendant entered into possession under it, continued in possession through the term, and had paid no rent. The defendant pleaded a general denial and the statute of limitations.

Prior to October 1st, 1897, the parties entered into a parol agreement whereby the plaintiff undertook to lease and the defendant to hire the premises for the term of two years from said October 1st, at an annual rental of $\$ 300$ payable annually at the end of each year. The defendant thereupon went into occupation on said day and continued in such occupation throughout the two-year period, and paid the agreed rent at the end of each year as stipulated. Before the period had expired a new parol agreement, embodying precisely the same terms and for the same time was made, and the defendant continued its possession confessedly until January 1st, 1900, and as the plaintiff claims, until May, 1901. The premises were hired and used for the purposes of the Town Court. On December 31st, 1899, the selectmen gave written notices to the plaintiff and the officers of the court that

43 "It is true the Revised Statutes, c. $60 . \S 21$, declare that all interests 01 " estates in lands, created without any instrument in writing, shall have the force and effect of estates at will only; yet we think that this estate, when once created, may, lilie any other estate at will, by subsequent events, be chang. ed into a tenancy from year to year. In the case before us the lessee entered into possession, and the possession was continued from year to year, until July, 18t4, and the rents semi-annually paid by the lessee and accepted by the landiord. From these facts a new agreement mar well be presumed, and the estate. which was originally created by the statute as an estate only at wiil, expands into a holding from year to year." Barlow v. Wainwright, 2.2 Vt. 88 , 52 Am. Dec. 79 (1S49). Ellis v. Paige, 1 Pick. (Mass.) 43 (1S22), contra.

See Richardson v. Giffard, 1 A. \& E. 52 (1834), where a tenant who liad gone into possession under an agreement for a lease for three years at an annual rent, but which agreenent was not executed as required by the Statute of Frauds, was held liable on an undertaking in such agreement to keep the prem. ises in repair. 
on and after January 1st, 1900, its sessicns would be held in the town hall, and that, as was the fact, suitable accommodations had been provicled there. On January 1st the defendant removed from the plaintiff's building substantially all of its furniture, but the judge of the court continued to hold its sessions there until May 1st, 1901. No rent was paid after October 1st, 1899. The action was begun September 28th, 1906. Judgment was rendered for $\$ 300$ as the rent for one year from October 1st, 1899, with interest thereon from October 1st, 1900.

PRintice, J. Prior to October 1st, 1897, these parties entered into a parol agreement whereby the plaintiff undertook to lease the premises in question to the defendant for the period of two years from and after said October 1st, for an annual rent of $\$ 300$ payable at the end of each year. The defendant thereupon, on said date, entered into possession of the prenises and thereafter remained in possession thereof until January 1st, 1900, if not later. The amount of rent in said parol agreement stipulated to be paid, was paid as agreed for each of the two years succeeding October 1st, 1S97. Beyond question, therefore, the defendant became a tenant from year to year, and remained such tenant down to October 1st, 1899. The recited facts disclose a lease not actionable by the statute of frauds, an entry into possession under it, and the payment and acceptance of the stipulated annual rent, thus satisfying even more exacting conditions than those contended for by the defendant as necessary to create by implication of law a tenancy from year to year, and more exacting ones than our law requires. Lockwood v. Lockwood, 22 Conn. 425, 433; Larkin v. Avery, 23 Conn. 304, 316 ; Corbett v. Cochrane, 67 Conn. 570, 577, 35 Atl. 509. When, therefore, the defendant, with the acquiescence of the plaintiff, remained in possession after October 1st, 1899, as it confessedly did, a tenancy for a new year commencing on that date was created, unless a new and different situation arose from the second parol agreement and the conduct of the parties under it. 1 Washburn on Real Property, $\S 797 ; 4$ Kent's Conm. 115; 1 Taylor on Landlord \& Tenant, $\S 55$. If this ineffective agreement and subsequent conduct was barren of legal results, the accountability of the defendant to the plaintiff for the amount of rent for which judgment in this case was rendered, and for that amount covering the precise period described in the complaint, follows. And judgment for that amount might, under those conditions, have been rendered upon the present complaint, although it avers a lease by parol for one year, made on or about October 1st, 1899. The facts do not, indeed, show a technical lease of any kind, or that the parol lease was one for the expressed period of one year from that date, but they do disclose a tenancy with an obligation to pay an agreed rental of $\$ 300$, and that the tenancy was one for the year in question, all as the result of the acts of the parties. Larkin v. Avery, 23 Conn. 304, 316. Acts and contracts may be stated according to their legal effect, and immaterial variances are not to be regarded. Practice Book, 1908, p. 244, $\S 144$; page $245, \S 149$. 
The defendant is thus placed in the position where, as one of the conditions of any successful defense he may interpose, he must establish a new tenancy beginning October 1st, 1899. Counsel appear to have been unmindful of the full significance of the pre-existing relation of the parties as bearing upon both the incidental question as to whether the defendant's continued possession was under a new tenancy sufficiently established, or under a mere continuance of the term of the old one, and upon the ultimate question of the plaintiff's right to recover the $\$ 300$ rental for which judgment was obtained. The plaintiff's counsel approaches the question at issue as though the parol agreement of 1899 was the first significant fact in the record, and upon the assumption that the possession after October, 1899, was so clearly referable to it that there would be attached to that possession the same importance as would have been attached to an original entry. The defendant's counse! likewise looks to the events of 1899 as determining the relations of the parties, but urges that there is a distinction not to be lost sight of between an entry and a continuance in possession as evidencing a holding under a tenancy having its origin in an agreement ineffective in itself.

Approaching the question at issue in the manner thus indicated, the plaintiff claims that the defendant's possession after October 1st, 1899, following the new parol agreement, created a new and independent status. This status, he says, was that of a tenancy from year to year. The practical result of this claim is that while the origin of the tenancy after October 1st, 1899, is found in the events of that year, the character and incidents of the tenancy are precisely the same as would have resulted from the defendant's occupancy had there been no attempt to make a renewal lease. The defendant's position with respect to the question of the creation of a new tenancy referable to the new agreement is not definitely stated, although the inference to be drawn from the distinction he makes between a continued occupancy and a new entry would seem to indicate that it was that no such new tenancy came into existence. His main contention, however, is that whatever new tenancy may have been created by the events of 1899 , it was one at will and not one from year to year.

We have already observed that a successful defense involves the establishment by the defendant of two propositions, to wit: (1) That the defendant's possession after October 1st, 1899, was under a new tenancy of some sort, and (2) that this tenancy was, to say the least, not one from year to year. If it be assumed, as the plaintiff claims and the defense requires, that a new and independent tenancy originated in the events of 1899 , the question remains as to its character. The defendant urges that it was one at will, since no rent was paid for any occupancy or period after October 1st, 1899. His contention is that the payment of rent must concur with possession by the lessee under a term lease in violation of the statute of frauds, in order that a tenancy from year to year be created by implication of law, and that 
without such payment the tenancy will be regarded as one at will. Whatever the rule may be elsewhere, such is not the law of this jurisdiction. Tenancies from year to year by implication are the results of judicial legislation as a measure of equity and sound policy. 1 Washburn on Real Property, $\S 797$. In this State the long-established rule is that when parties make an oral lease of lands reserving rent, which lease is non-actionable by reason of the statute of frauds, and the lessee thereafter enters into possession under the lease, there results a tenancy which under ordinary conditions at least will by implication of law be regarded as one from year to year. Larkin v. Avery, 23 Conn. 304 ; Corbett v. Cochrane, 67 Conn. 570, 35 Atl. 509.

This rule has an especial appropriateness in this State where parol leases for a term not exceeding one year under which possession is taken are not invalid by our statute of frauds. The same result would of course logically follow, where the lessee remained in a possession previously acquired, if the circumstances were such as to sufficiently disclose that his continued possession was referable to the ineffective lease, and therefore under it, as an agreement made, although not enforceable in and of itself. Andrew v. Babcock, 63 Conn. 109, 121, 26 Atl. 715. Section 4043 of the General Statutes 1902 first enacted, in substance, in 1866, prescribes that a holding-over possession, standing by itself, shall not be regarded as evidence of any agreement of a further lease. It does not, however, prevent a tenancy from being established by other recognized means. One of these means, recognized long before the legislation of 1866, was that of supplementing proof of the agreement non-enforceable under the statute of frauds, with proof of the acts of the parties disclosing a recognition by them of a tenancy in fact under it. 1 Swift's Digest, s. p. 91 ; Lockwood v. Lockwood, 22 Conn. 425; Larkin v. Avery, 23 Conn. 304. The only significance which can reasonably attach to a mere payment and receipt of rent, is to be found in a recognition of a tenancy of some sort under the invalid lease, and our own courts have well said that, however satisfactory such a recognition might be, there might well be one sufficiently disclosed in other ways. In some jurisdictions, rent payments of annual sums or aliquot parts thereof have been, by reason of their indication of the intention of the parties, regarded as essential to the conversion of what by force of statute or judicial construction are prima facie tenancies at will into tenancies from year to year. Such is not the law of this State.

The defendant having, for the reasons stated, failed in his contention that the tenancy after October 1st, 1899, was other than one from year to year, the judgment appealed from was properly rendered.

Upon our conclusions the defense that the statute of limitations had run against the plaintiff's claim is confessedly not well made.

There is no error. In this opinion the other judges concurred. 


\section{LYONS v. PHILADELPHIA \& R. R. CO.}

(Supreme Court of Pennsylrania, 1904. 209 Pa. 550, 58 Atl. 924.)

Appeal from report of viewers.

From the record it appeared that plaintiffs who were liquor dealers, entered into a verbal undertaking with Rieker, the then owner, the terms of which were that they agreed to pay twenty-five cents for each barrel of beer more than the regular price elsewhere, as rental. The rental was "payable just as the becr bill was payable-paid at all tirnes, * * * along different periods,-running account, * * * sometimes every week they got a check." The understanding was that the plaintiffs "had a right to remain on that lot as long as you [they] wanted," or, as the owner's son testifies, they "could have stayed as long as they felt."

The tenants erected buildings on the premises which were used for bottling, storage, liquor-room and offices, - and also a stable, wagon shed, coal shed and outbuildings and machinery necessary to the conduct of their business.

The defendant company being desirous to enter upon the lands for railroad uses, presented a bond in the usual form, which was approved May 16, 1901, and thereafter viewers were appointed for the purposes stated.

The defendant gave notice to the plaintiffs December 20, 1901, that it desired possession of the lot March 1, 1902, and stated the notice was given to allow them time to arrange their affairs, but did not take actual possession of the premises until June 4, 1902.

The plaintiffs disregarded the notice, and the railroad company proceeded to the demolition of the buildings. The court gave binding instructions for defendant.

Per Curiam. The appellants were tenants at will of Rieker. The agreement under which they went into possession was altogether indefinite as to the tine it was to last; they were to "remain as long as they wanted." The rent was not fixed either as to amount or time of payment, but was determined by the number of barrels of beer they should purchase fron their lessor, and was payable "just as the beer bill was payable." A clearer case of tenancy at will would be hard to discover. Under such circumstances the mere fact that the tenancy ran along for more than a year did not change its character or convert it into a tenancy from year to year. "Where the duration of the term is left uncertain * * * the lessee holds ab initio as a tenant at will. And the mere payment of rent will not change the tenancy into one from year to year, unless there are other circumstances to show an intention to do so, as for instance an agreement to pay rent by the quarter, or some other aliquot part of the year:" $18 \mathrm{Am}$. \& Eng. Ency. of Law (2d Ed.) tit Landlord \& Tenant, p. 183. But "the mere payment of a periodical rent, however, will not necessarily have the effect of chang:ng the ten- 
ancy at will into a periodical tenancy and parol evidence may be admitted for the purpose of showing the character of the payment:" 18 Am. \& Eng. Ency. of Law (2d Ed.), p. 186. It was on this last principle that the issues in McDowell v. Simpson, 3 Watts, 129, 27 Am. Dec. 338, and Dunn v. Rothermel, 112 Pa. 272, 3 Atl. 800, were sent to the jury to determine whether the leases were at will or from year to year. In both cases the rent was paid yearly, and the expression of Justice Kennedy, in the former, so much relied on by appellants, that "if the tenants were suffered to hold under it for upwards of a year, paying the rent as it became due, and the plaintiff receiving it without objection, the lease instead of continuing to be a lease strictly at will would thereby become a lease from year to year," must be read in connection with the facts of the case.

Being tenants at will, the termination of the lessor's estate, even though by involuntary alienation under eminent domain determined the appellants' lease, and made them technically tenants at sufferance of the railroad company. The difference, however, is not practically of any importance. All they were entitled to in either case was notice and a reasonable time to remove their goods and fixtures. This they received, but failed to avail themselves of, and the learned judge below was justified in treating their conduct as an abandonment.

The filing of the bond by the railroad company did not change the nature of the tenancy, nor the rights of the appellants except so far as it substituted the company as lessor in place of Rieker. The bond was security for such damages as the appellants "shall be entitled to receive for the entering by the said company upon the said lands, and establishing and constructing the said additional tracks and structures thereon." If the company had entered immediately and demolished the buildings in the construction of its tracks, it would have been liable just as its predecessor, Rieker, would have been, for the damages caused by want of reasonable opportunity to appellants to remove their property, but such opportunity having been given, there were no damages, and the verdict was rightly directed for defendant.

Judgment affirmed.4

\section{RIGHT d. FLOWER v. DARBY et al.}

\section{(Court of King's Pench, 17S6. 1 Term Rep. 159.)}

Ejectment tried at the last assizes at Salisbury, before Hotham, Baron, when a verdict was found for the plaintiff, subject to the opinion of the Court of King's Bench on the following case:

That the lessor of the plaintiff was seised in fee of the premises in question. 'That on the 11th day of May, 1781, the defendant Darby took the premises, which are a house in Salisbury, and occupied them

44 See Doe d. Tomes r. Chamberlain, 5 M. \& W. 14 (1S39); Sheldon v. Davey, 4 Vt. $637(1570)$, acc. 
as a public-house from that time under a parol demise at $t 10$. per annum; the rent to commence from Midsummer then next following. The defendant Darby let part of the premises to the defendant Bristow. That on the 26th March, 1785, the defendant Darby was served with a notice to quit on the 29th of September following.

The question is, whether the lessor of the plaintiff is entitled to recover?

Lord Mansfiet.d, C. J. When a lease is determinable on a certain event, or at a particular period, no notice to quit is necessary, because both parties are equally apprized of the determination of the term.

If there be a lease for a year, and by consent of both parties the tenant continue in possession afterwards, the law implies a tacit renovation of the contract. They are supposed to have renewed the old agreement, which was to hold for a year. But then it is necessary fur the sake of convenience, that, if either party should be inclined to change his mind, he should give the other half a year's notice before the expiration of the next or any following year: now this is a notice to quit in the middle of the year, and therefore not binding, as it is contrary to the agreement.

As to the case of lodgings, that depends on a particular contract, and is an exception to the general rule. The agreement between the parties may be for a month or less time, and there to be sure much shorter notice would be sufficient, where the tenant has held over the time agreed upon, than in the other case. The whole question depends upon the nature of the first contract.

Ashinurst, J. There is no distinction in reason between houses and lands, as to the time of giving notice to quit. It is necessary that both should be governed by one rule. There may be cases, where the same hardship would be felt in determining that the rule did not extend to houses as well as lands; as in the case of a lodging-house in London, being let to a tenant at Lady-Day to hold as in the present case: if the landlord should give notice to quit at Michaelmas, he would by that means deprive the lessee of the most beneficial part of the term, since it is notorious that the winter is by far the most profitable season of the year for those who let lodgings.

BULler, J. It is taken for granted by the counsel for the plaintiff, that the rule of law, which construes what was formerly a tenancy at will of lands into a tenancy from year to year, does not apply to the case of houses, but there is no ground for that distinction. 'The reason of it is, that the agreement is a letting for a year at an annual rent; then if the parties consent to go on after that time, it is a letting from year to year. This reason extends equally to the present case; an annual rent is here reserved; and upon such a holding it lias been determined that half a year's notice to quit is necessary. This doctrine was laid down as early as in the reign of Henry the Eighth. [13 H. VIII, 15 b.] The moment the year began, the defendant had a right to hold to the end of that year; therefore there should 
have been half a year's notice to quit before the end of the term. This gives rise to another objection in this case, upon the distinction between six months and half a year. The case in the Year-Books requires half a year's notice; but here there is less than half a year's notice, and therefore it is bad on that ground also.

Judgment for the defendant.

\section{HERTER v. MULLEN.}

(Court of Appeals of New York, 1899. 159 N. Y. 28, 53 N. E. 700, 44 I. R. A. 703, 70 Am. St. Rep. 517.)

Martin, J. This action was to recover seven months' rent of a dwelling house situated upon Madison avenue, in the city of New York. There was a lease between the parties, by which the defendants rented the premises from May 1, 1894, for the period of one year, the rent payable in monthly installments in advance. The rent for that term has been paid. By this action the plaintiff seeks to recover rent for a portion of the succeeding year, on the ground that the defendants held over after the expiration of their term, and thus became liable for the rent of the premises for that time. The facts are undisputed. The defendants alleged as a defense to the action the making of the contract or lease with the plaintiff; that in the month of February, 1895 , before the expiration of their term, they notified the plaintiff that they would not retain the premises for another year, and that after such notice the plaintiff and his agents were permitted to show the premises, and to place the usual notice "To Let" upon them, which remained during the balance of the term.

The defendants then specially alleged that on May 1, 1895, the defendants were prevented from yielding up the possession of the premises by the act of God in afflicting their mother, who was a member of their family, with a disease which, at that time, previously, and subsequently, including May 15th, confined her to her bed so that it would have endangered her life to take her from the house; that for that reason, and no other, of which the plaintiff had full knowledge and notice, the defendants were obliged to and did occupy a small portion of the premises until May 15th; that all their property, furniture, and belongings and their family were removed from the premises, and every part thereof, on May 1, 1895, except from the sick room in which their mother was confined, and that they were forbidden by the physician in charge to remove her until May 15th, when she was at once removed.

Upon the trial it was admitted that upon the 1st of February, 1895, the defendants notified the plaintiff that on the 1st of May they would give up and surrender the possession of the premises. That they were occupied under the lease was admitted, also the rate of rent, and the fact that the defendants, from necessity, held over after the expira- 
tion of the lease some 15 days. The plaintiff then admitted the facts set up in the answer as to the impossibility of the defendants' surrendering possession at the expiration of the year, so that the question presented is whether, notwithstanding the facts alleged in the answer, the plaintiff was entitled, as a matter of law, to recover rent for the succeeding year, upon the ground that the defendants held over after the expiration of their term.

The admission of the plaintiff amounts to a concession that, by reason of the sickness of the defendants' mother, it was impossible for them to surrender up the possession of the premises to the plaintiff; that, so far as it was possible, they did so; and hence, that their retention was wholly involuntary. If there was any doubt as to the question of impossibility, it should have been submitted to the jury, and the defendants' exception to the direction of a verdict was well taken. Thus, in a word, the question is whether that impossibility justified the defendants' action, or whether, although it was impossible to surrender the entire premises, the holding of a small part for a few days imposed upon them a liability for rent for the succeeding year. It is well settled that, where a tenant voluntarily holds over after the expiration of his term, he may be held as upon an agreement to hold for a year upon the terms of the prior lease. Conway v. Starkweather, 1 Denio, 114; Board v. Clark, 33 N. Y. 251; Haynes v. Aldrich, 133 N. Y. 287, 289, 31 N. E. 94, 28 Am. St. Rep. 636. The basis of this liability is often said to be an implied agreement upon the part of the tenant to hold for another year. While I doubt, as I always have, the propriety of calling this class of obligations implied contracts, but think they are to be regarded as duties which the law imposes, yet, whether they be denominated implied contracts or duties created by law, in either case the right arises upon' an implication of law, and in no sense upon an express or absolute contract.

It is also well settled that, where a duty or charge is created by law, and the performance is prevented by inequitable accident or the act of God, without fault of the party sought to be charged, he will be excused, but where a person absolutely, and by express contract, binds himself to do a particular thing, which is not at the time inmossible or unlawful, he will not be excused, unless through the fault of the other party. The reason given for the latter portion of this rule is that he might have provided by his contract against inevitable accident or the act of God. Harmony v. Bingham, 12 N. Y. 99: 62 Am. Dec. 142; Tompkins v. Dudley, 25 N. Y. 272, 82 Am. Dec. 349; Dexter v. Norton, 47 N. Y. 62, 7 Am. Rep. 415. Thus the most that can be said of the obligation that arises from the relation of landlord and tenant and follows by a general lease is that the tenant is cliarged with the duty of vacating the premises at the end of his term. If he fails, it is a breach of his duty, and ordinarily the law implies or creates a liability on his part for anArG.PROP. -43 
other year's rent. This being a duty implied or created by law, and not by an express or absolute agreement, it falls within the first part of the foregoing rule, and hence it is obvious that, if the tenant's removal was rendered impossible by inevitable accident or the act of God, he is excused for his omission to surrender the premises, at least so far as it creates a liability for a year's rent which is implied by law. The reason for the distinction between the effect of impossibility of performance, occasioned by inevitable accident or the act of God, upon an obligation created by express contract and upon an obligation which the law implies, has been held to rest "upon the unwillingness of the law to at once create, impose, and exact the performance of an obligation forbidden or rendered impracticable by the interposition of Providence." School Dist. v. Dauchy, 25 Conn. 530, 68 Am. Dec. 371 .

Under the principle of the authorities relating to this subject, I think it is clear that, as the obligation sought to be enforced was one created by law, and not by the agrcement of the parties, impossibility of performance was a valid excuse, and the defendants cannot be held for the rent for the subsequent year. Moreover, the same resuit may be reached upon another ground. There are many cases where the courts have implied a condition in a contract to the effect that a party is relieved from its terms where its performance has, without his fault, become impossible. The principle upon which those cases are based is that, when the contract was made, the parties contemplated that the condition which subsequently existed might arise, and render performance impossible, and that the implied condition is to be construed as a part of the existing contract, and thus relieves the party from liability in case that condition arises. Dexter v. Norton, 47 N. Y. 62, 7 Am. Rep. 415; Lorillard v. Clyde, 142 N. Y. 45̄6, 462, 37 N. E. 489, 24 L. R. A. 113; Stewart v. Stone, 127 N. Y. 507, 28 N. E. 595, 14 L. R. A. 215; Spalding v. Rosa, 71 N. Y. 40, 44, 27 Am. Rep. 7 ; Taylor v. Caldwell, 3 Lest. \& S. 826; Robinson v. Davison, L. R. 6 Excl. 269; Kcin v. Tupper, 52 N. Y. 550, 555; Dolan v. Rodgers, 149 N. Y. 489, 492, 44 N. E. 167.

To lold in this case that this agreement was made upon an implied condition that the defendants should not be required to racate the premises at the expiration of their term in the event that it was rendered impossible by inevitable accident or the act of God is quite within the principle of the authorities cited. But, be this as it may, it is manifest that the charge or liability which the plaintiff seeks to enforce was created by law, and not by agreement, and that, as its performance was prevented without the defendants' fault, they were excused from the onerous liability which the plaintiff now seeks to enforce. It may well be, and doubtless is, true that the plaintiff may recover for the time the premises were occupied by the defendants, or if, by reason of their failure to surrender up the premises, additional damages follow, that they may be recovered in a proper ac- 
tion so that all damages caused by the defendants' misfortune would be borne by them, but that he cannot recover the rent for the subsequent year upon the implied contract or duty imposed by law seems to me clear.

These considerations lead me to the conclusion that the judgment in this action should be reversed, and a new trial ordered, with costs to abide the event. ${ }^{45}$

\section{GOLDSBOROUGH v. GABLE.}

(Supreme Court of Ininois, 1892. 140 Ill. 269,29 N. E. 722, 15 T. R. A. 294.)

Scholfield, J. Appellant brought covenant against appellee for rent. Upon the trial in the circuit court, appellant read in evidence a deed, executed by himself to appellee, leasing certain real estate in Peoria from March 1S, 1SS3, until March 1S, 1S84, for \$\$40, payable in installments of $\$ 70$ on the $1 S t h$ day of each month; occupation of the premises, after the execution of the deed, by appellee until the 1Sth of October, 1SSS; the payment of the stipulated rent for the term described in the deed; the failure of appellee to surrender possession of the premises at the expiration of the term, and his continued occupancy thereof; payment of the same rent for the first montl after the expiration of the term, as provided by the deed to be paid by the month during the term; and the payment of other sums for rent from time to time throughout the period that appellee occupied the premises; amounting, however, in the aggregate, to a less sum than the total amount of rent due at the rate provided to be paid by the deed.

Appellee was permitted to introduce evidence, over the objection of appellant, tending to prove that, after the expiration of the term described in the deed, and after he had paid appellant one month's rent for the occupation of the premises at the rate provided to be paid in the deed, namely, on the 2Sth of May, 1SS4, he commenced negotiating with appellant to reduce the rent for the premises; that the negotiation was protracted until the 9th of July following, when it was agreed between appellant and appellee that the rent for the premises should be reduced to $\$ 50$ in lieu of $\$ 70$ per month, as it had been theretofore; and the court refused to instruct the jury, at the instance of the appellant, that, even if they believed such agreement had been proved, it was "invalid, and could not be enforced," but, on the contrary, the court instructed the jury that, if they believed from the evidence that such agreement had been proved, it was valid, and the

45 The concurring opinion by $\mathrm{O}^{\circ} \mathrm{Brien}, \mathrm{J}$., and the dissenting opinion by Gray, J., are omitted. l'arker, C. J., and Haight, J., concurred with O'Brien and Martin, JJ., in voting for reversal. Bartlett and Vann, JJ., concurred with Gray, J.

See Doe v. Crago, 6 C. B. 90 (1Sts); Oakley v. Monck, 3 H. \& C. 706 (1S65); Dougal v. McCarthy, [1S93] 1 Q. E. 736. 
plaintiff was thereafter entitled to recover only $\$ 50$ per month for the rent of the premises.

In our opinion, the court erred in these several rulings. There was no evidence given on behalf of appellee tending to prove that he had surrendered the premises to appellant before the making of the agreement of July 9, 1884, or that he had offered to do so, and refused to execute the terms of the lease, or that there was any reason why he could then have surrendered the premises and refused to execute the terms of the deed. Appellee having remained in possession after the expiration of the term described in the deed, without any new contract with appellant in respect thereto, it was optional with appellant to treat him as a trespasser, or to waive the wrong of holding over, and treat him as a tenant; and, by accepting the payment of the month's rent thereafter from appellee, appellant made his election, and appellee then became a tenant of the premises under appellant, from year to year, upon the same terms and subject to the same rent, etc., as is provided to be paid in the original deed. Prickett v. Ritter, 16 I11. 96; Hunt v. Morton, 18 I1l. 75; McKinney v. Peck, 28 Ill. 174; Cloth Co. v. Gardner, 99 Ill. 151; Webster v. Nichols, $10+$ I1l. 160.

The only respect wherein the agreement of the 9th of July, 1884, whereof evidence was permitted to be given to the jury, purported to change this tenancy from year to year, is in the amount of the monthly payment of rent to be made. Appellee, by that agreement, is required to do nothing which he was not already obligated to do as tenant from year to year, and appellant's duties are in no wise lessened or changed thereby. It simply purports to obligate appellee to pay and appellant to receive $\$ 50$, where they were already obligated, the one to pay and the other to receive $\$ 70$. There is thereby neither in fact nor in presumption of law injury or loss to appellee, or gain or benefit to appellant. It follows that it is an agreement, as clearly as one can be, without any consideration to support it,- - a mere nudum pactum; and so it is binding upon neither of the parties, and is insusceptible of Leing enforced in this suit. Titsworth v. Hyde, 54 Ill. 386; Seybolt v. Railroad Co., 95 N. Y. 562, 47 Am. Rep. 75 ; Davenport v. Society, 33 Wis. 387; Johnson's Adm'r v. Sellers, 33 Ala. 265; Gordon v. Gordon, 56 N. H. 170. See, also, 3 Amer. \& Eng. Enc. Law, 390, 391, and notes.

It is impossible to say that the agreement was made as an adjustment of a dispute in regard to a doubtful right, for appellee's own testimony shows that there was no fact in dispute between him and appellant. His testimony is only that he claimed that the rent should be reduced, and that appellant resisted the claim at first, but finally yielded to the extent shown by the agreement. It cannot be held that appellant is in any way estopped by the agreement, since it is not shown that appellee has in consequence of it, done that which he would otherwise not have done, whereby he will be injured if the agreement be not carried out; nor can it be held that the agreement has the effect 
of an executed gift as to the difference between the $\$ 50$ and the $\$ 70$ per month, because there was executed no receipt or release for the amount, and there was no proof of any action of the parties equivalent thereto.

The judgments of the appellate and circuit courts are reversed, and the cause is remanded to the circuit court for a new trial.

\section{KING v. DURKEE-ATWOOD CO.}

(Supreme Court of Minnesota, 1914. 126 Minn. 452, 148 N. W. 297, L. R. A. $1915 \mathrm{~A}, 235$.

Bunn, J. Defendant was a tenant of plaintiff under a lease from month to month, the leased premises being a store in Minneapolis and a flat above it. The rent was payable monthly in advance. April 4, 1913, defendant caused to be served on plaintiff a notice of the termination of the tenancy of May 31st. Defendant did not, howvever, vacate the premises on the date named, but continued in possession until June 30th, when it ceased to occupy the premises for any purpose, and delivered the keys to plaintiff. The holding over was with the knowledge and consent of plaintiff, though there appears to have been no agreement as to the terms upon which the tenant held over. Apparently it was understood that the tenant was to move to new quarters as soon as they were ready, and that it was not the intention of defendant to continue its occupancy of the leased premises beyond the month of June.

This action was brought to recover the rent of the store for the months of June, July, and August, and of the flat for the months of June and July. Plaintiff was unable to rent the store in July or August, but occupied the flat the latter month. Defendant admitted its liability for the month of June, during which it occupied the premises, but claimed that it was not liable for the July and August rent. The trial was to a jury. The court instructed that the tenant's holding over after May 31st made the notice a nullity, that the case was as if no notice had been given, and that defendant was liable for the July and August rent. The verdict was in accord with this instruction. Defendant moved for a new trial, and appealed from an order denying such motion.

The decision here depends upon whether the instruction of the court to the jury, above referred to, is a correct statement of the law as applied to the facts in the case.

1. If the notice was rendered a nullity by the tenant's holding over, it must be on the ground of waiver. It is clear, in this state at least, that a notice by the landlord to a tenant to quit may be waived by the landlord, and that such notice is thenceforth inoperative. Arcade Invest. Co. v. Gieriet, 99 Minn. 277, 109 N. W. 250. See note to Wisner v. Richards, Ann. Cas. 1912D, 160. 
It is doubtless true that a tenant may withdraw or waive a notice to quit given by him. And if he does waive it, it is plainly correct that the situation is as if no notice had been given. Clearly, notice was necessary in order to terminate this tenancy at will or from month to month. Rev. Laws 1905, \$ 3332.

Did the tenant, by holding over after the tıme named in the notice, waive or withdraw such notice? There are some statements in textbooks, and at least one reported case, that lends support to the view that such holding over is only presumptive evidence of waiver, and does not operate as a matter of law to continue the tenancy. In Cyc. the law is thus stated: "No continuance of the tenancy is necessarily implied from the mere fact of a tenant continuing in possession after the expiration of a notice to quit given by such tenant. It is for the jury to decide whether or not the tenant, by remaining in possession, intends to waive the notice and continue the tenancy." 24 Cyc. 1336.

But one case is cited as authority for the text, and that is Jones v. Sheares, 4 Ad. \& El. 832, 6 Nev. \& M. 428, 2 H. \& IV. 43, 5 L. J. K. B. (N. S.) 153. This case was determined by the court of King's Bench in 1836. The lessee of the coal under certain lands gave a notice, as under the lease he had a right to do, that at the end of two years he would deliver possession and end the term. He continued for two months after the two years to work the coal, and it was claimed by the lessor that the notice was thereby waived. 'The lessee insisted that the working was not carried on with any view of continuing the tenancy, that the coal mined was taken from the pillars which supported the roof, and that this was customary on leaving a mine. It was held that the question whether the lessee intended to waive the nutice and continue the tenancy was for the jury. Mr. Tiffany states that a tenant holding over after the time named in his notice of intention to quit is liable in use and occupation as a tenant holding over, but that such retention of possession does not necessarily operate as a waiver or withdrawal of the notice, so as to effect a continuance of the former tenancy. 2 Tiffany, Landl. \& T. 1464.

But the decided weight of authority is that a tenant who holds over after the expiration of his term may be held liable as tenant for a further period without reference to his actual wishes on the subject, and necessarily without reference to his intention to become a tenant for a further term. 2 Tiffany, $\$ 209$, and cases cited. It would seem to be immaterial whether the term expires because of the termination of the period named in the lease, or by a notice to quit, given where the lease requires it or where the tenancy is at will. Graham v. Dempsey, 169 Pa. 460, 32 Atl. 408; Conway v. Starkweather, 1 Denio (N. Y.) 113; Schuyler v. Smith, 51 N. Y. 309, 10 Am. Rep. 609. See, also, Smith v. Bell, 44 Minn. 524, 47 N. IV. 263. The doctrine is that the landlord has the option to hold the tenant for another period, or to treat him as a trespasser or a tenant at sufferance. He may eject the tenant or 
resort to summary proceedings to recover possession. But if he sues for the rent, or demands it, he elects to hold the tenant for another period, and the tenant has nothing to say about it. The rule is perhaps a harsh one, but it is too well settled generally and by our own decisions to justify departing from it. Smith v. Bell, supra; 3 Notes to Minn. Rep. 427.

The length of the term for which the tenant will be held depends, in the absence of statute, on the character of his prior tenancy. In the case of a prior tenancy from month to month, such as was the tenancy in the case at bar, the tenant, on the election of the landlord to so treat him, becomes or remains a tenant from month to month. Smith v. Bell, supra. And this would be so as to urban property in case of a holding over without any new agreement after the termination of a lease for a definite timé. Laws 1901, chap. 31; Rev. Laws 1905, § 3333; Gen. St. 1913, § 6812; Backus v. Sternberg, 59 Minn. 403, 61 N. W. 335; Quade v. Fitzloff, 93 Minn. 115, 100 N. W. 660; Slafter v. Siddall, 97 Minn. 291, 105 N. IV. 30S. See note in 25 L. R. A. (N. S.) 857 ; also, in 28 Am. St. Rep. 639.

We are forced to the conclusion that defendant, by holding over after the time specified for the termination of the tenancy, waived the notice given by it. The trial court was therefore correct in instructing the jury that the notice was a nullity, and that defendant would be held just the same as though such notice had never been given.

2. It follows that notice was necessary in order to terminate this tenancy. It is admitted that no such notice was given. Defendant relies on the statute, before cited (Gen. St. 1913, § 6\$12), in support of its claim that it is liable only for one month's rent. But the cases of Stees v. Bergmeier, 91 Minn. 513, 98 N. W. 648, Quade v. Fitzloff, and Slafter v. Siddall, supra, are conclusive that this statute affords defendant no relief. It was enacted to do away with the harsh rule whereby, at the option of the landlord, a tenant under a lease for a definite term who remained in possession after the termination of his lease was bound for another term on the same conditions. If the statute applies at all to a holding over after the termination by notice of a tenancy at will or from month to month, it cannot be construed as making a new tenancy for a single month. In Slafter v. Siddall, the lease was for a year, and the tenant held over without any new agreement. The statute was applied, and it was held that the tenancy was from month to month. Clearly, when the original tenancy is one from month to month, and the tenant has the right to give a month's notice and relieve himself from further liability, the statute was not intended to, and does not, convert such tenancy into one for a month only. Indeed, when we have said that the notice was a nullity, it is equivalent to saying that the tenancy at will was not terminated. It remained in force until the tenant quit after the expiration of the time named in a new notice. 
It follows that the trial court was correct in holding that the tenancy had not terminated, and that defendant was liable for the July and August rent. Order affirmed. ${ }^{46}$

\section{ARBENZ v. EXLEY, WATKINS \& CO.}

(Supreme Court of Appeals of West Virginia, 1905. 57 W. Va. 580, 50 S. E. 813 , 4 Ann. Cas. 6:5.)

Brainon, P. John Arbenz, Sr., made a written lease, but not under seal, to Exley, Watkins \& Co., leasing for a term of five years and three months a brick building, including the vacant parts of certain lots, in the City of Wheeling, the term commencing January 1, 1896, and ending March 31, 1902, for the annual rent of $\$ 700.00$, commencing April 1, 1896, payable in monthly instalments. The lessees took possession on the first week of January, and occupied the premises, paying rent monthly. On September 15, 1898, a fire totally destroyed said building. The lessees paid rent for that September and also for October, but with the rent of October sent a letter, October 31, 189S, to Arbenz, informing him that they "hereby" vacate the premises and surrender them to him.

In November, 1898, Arbenz sued out a distress warrant against said lessees for rent from November 1, 1898, to October 31, 1899, and the same having been levied, a forthcoming bond was given, and in the proceedings upon it in the circuit court of Ohio county a verdict was rendered for the plaintiff for $\$ 502.54$, after deducting for failure to repair an engine, and judgment given thereon, and the defendants took a writ of error. The defendants filed a plea denying grounds of attachment, and denying all liability for the rent claimed.

The judgment below was affirmed by this Court. Those matters will appear in 52 W. Va. 476, 44 S. E. 149, 61 L. R. A. 957. On August 1, 1903, Arbenz brought assumpsit against Exley, Watkins \& Co. to recover rent accruing later than that recovered in the proceeding above mentioned-to recover rent for the period beginning November 1, 1899, and ending December 31, 1902, a period of 38 months, at $\$ 700.00$ per year, and the suit resulted in a verdict for only $\$ 148.15$, that is, for the two months of November and December, 1899, the court holding

46 See Mason r. Wierengo's Estate, 113 Mich. 151, 71 N. W. $4 \& 9,67$ Am. St. Rep. 461 (1897); Providence County Sar. Bank v. Hall, 16 R. I. 154, 13 Atl. $122(1888)$, acc.

The $\mathrm{X}$. Company was lessee of certain premises at an annual rental under a lease expiring October 1,1911 . In July, 1910, a receiver was appointed to take charge of the business of the company. The receirer at once took possession and paid the rental in monthly installments until April, 1912, when be vacated the premises. In an action for rent accruing after such vacation, on the theory that the holding over had created a tenancy from year to year, the court held that after October 1,1911 , the receirer was merely a tenant at will. Dietrich r. O'Irien, 122 Md. 482, \&9 Atl. 717 (1914). See, also, Blumenberg v. Myres, 32 Cal. 93, $91 \mathrm{Am}$. Dec. 560 (1867) ; Pusey r. Presbyterian Hospital of Omaha, 70 Neb. 353,97 N. W. 475,113 Am. St. Rep. 788 (1903). 
that no recovery could be had after the current year ending that date, on the theory that the tenancy from year to year then closed. The theory against the right to recover is, that a few days after the fire the defendants wrote Arbenz the following letter: "Oct. 31st, 1898. Mr. John Arbenz, City-Dear Sir: We beg to advise that we have vacated, the premises known as west building on 20th street, destroyed by fire Sept. 15th, last, and hereby surrender possession of same. Yours truly, Exley, Watkins \& Co."

On the former writ of error we held that for want of a seal to the lease the term of years named in it was not created, but that it created an estate from year to year, and that said letter did not operatc as a notice to quit, to end the tenancy so as to preclude recovery of rent up to November 1, 1899, the rent in litigation in the former proceeding. We did not go further, as no later rent was involved in that case. The question presented in the second suit is, Did the tenancy end 31st December, 1899? Did that letter close the tenancy and stop the rent at that date, the close of the current year 1899? For the defendants the contention is, that the letter, accompanied by actual vacation of the premises, and coupled with the fact that in the circuit court in April, 1899, Exley, Watkins \& Co. made defense in the former proceeding denying liability for rent, operated as a notice to quit and closed the tenancy 31st December, 1899.

Take the letter. The question rests mainly on it. It states the facts that the lessees had vacated, and then surrendered possession. It does not notify that at the end of a current year in future the tenant would quit, but states present acts or past, vacation and surrender. The common law, for centuries, has required, in order that lessor and lessee, under a tenancy from year to year, may close the tenancy of his own motion, that a notice to quit should be given six months before the end of the current year. 'That period or time of notice must be prior to the close of a year. The Code 1899, chapter 93, section 5, provides that "a tenancy from year to year may be terminated by either party giving notice in writing to the other, prior to the end of any year, for three months, of his intention to terminate the same." That provision recognizes as still continuing the common law estate of tenancy from year to year and the process of terminating it by notice to quit, and changed it only in requiring written notice and fixing a shorter time of notice. Hence it seems that we must appeal to the common law and its mode of notice to test the efficiency of the letter as notice to quit. It does not notify of a future act of quitting, but relies on past vacation and present surrender of possession for the effect of the letter. It does not name a day or time in future when the tenancy is to end. The profession has always regarded this as a requisite in a notice to quit, I think, 2 Taylor, Landlord \& 'Ten. § 476, says: "Form of.-The notice may be given to quit on a particular day; or, in general terms, at the end of the current year of the tenancy, which will expire next after the service of the notice; or, in one month after the next 
rent-day. The latter form of expression is generally used where the landlord is ignorant of the period when the tenancy commenced; and it is preferable even when the commencement of the tenancy is known, as it provides against any misapprehension of the exact day when the tenant entered." 1 Washburn Real Prop. $\$ \$ 10$ says: "Notice. The Time.-Whether a longer or shorter time of notice is required, it must, in order to be binding, clearly indicate the time when the tenancy is to expire, and, of course, must be given a sufficient number of days before the time so indicated."

The particular question before us is, whether that letter is bad as a notice to quit because (1) it is a quitting at its date, not notice of a future quitting at the end of a year, and (2) because it fails to state a time for quitting. Under the above and many other authorities we are driven to say that it did not end the tenancy at any time. Currier v. Barker, 2 Gray (Mass.) 224, and Steward v. Harding, Id., 335 ; Hanchet v. Whitney, 1 Vt. 311 ; Hunter v. Frost, 47 Minn. 1, 49 N. IV. 327 ; Grace v. Michand, 50 Minn. 139, 52 N. W. 390; Phœnixville v. Walters, $147 \mathrm{~Pa}$. 501, 23 Atl. 776; People v. Gcdney, $15 \mathrm{Hun}$ (N. Y.) 475; Prescott v. Elm, 7 Cush. (Mass.) 346; Berncr v. Gebhardt, 87 Mo. App. 409; Huntington v. Parkhurst, 87 Mich. 38, 49 N. W. 597, 24 Am. St. Rep. 146; Finklestein v. Herson, 55 N. J. Law, 217, 26 Atl. 6SS; Waters v. IVilliamson, 59 N. J. Law, 337, 36 Atl. 665; Godard v. S. Carolina Railroad, 2 Rich. (S. C.) 346; Huyser v. Chase, 13 Mich. 98; Rollins v. Moody, 72 Me. 13j. The text-book writers scem to so regard the law. I quoted from some above. Tiedcman on Real Estate, $\$ 218$, says that "the notice must not only be given for a certain length of time before the estate is to end, but the estate can only be determined at the expiration of the time during which the tenant may lawfully hold, i. e. at the end of the rental period; it can only be determined at the end of the year, quarter or month, according as the tenancy is respectively a yearly, quarterly or monthly tenancy. The notice must be sufficiently clear in its terms as to the time when the tenancy is to expire." 3 Minor's Inst. part 1, 2+1. "The notice * * * must end with the period at which the tenancy commences." 2 Kerr, R. Prop. 1310. 1 Lomax, Dig. 164; 1 Greenleaf's Cruise, R. Prop. 248, $\$ 26$. Chitty on Contracts (11th Ed.) 485, speaking of English common law, says, "The notice must be framed with reasonable certainty as to the time of quitting." In Currier v. Barker, 2 Gray (Mass.) 227 , it was held that a present demand or notice to quit was insufficient, and the rule is stated as follows:- "The notice to quit is technical, and is well understood. It fixes a time at which a tenant is bound to quit, and the landlord has a right to enter at a time at which the rent terminates. The rights of both parties are fixed by it, and are dependent on it. Should the landlord decline to enter, and the tenant quit according to notice, the tenant could no longer be holden for rent, although he had given no notice to the landlord: The lease is determined' by such notice, properly given by either party. It is manifest, 
therefore, that when such consequences depend upon the notice to be given, the notice should fix with reasonable exactness the time at which these consequences may begin to take effect. See, also, Walker $v$. Sharpe, 14 Allen (Mass.) 45."

Of course, much force is to be given to the harmonious construction of the many cases by the text writers. Still, I have had a question whether the cases mean only that period of time before the termination must expire on the day of the close of the year, or that the notice must designate the time when the tenant intends to quit. Such seems to be the law. The only question is, Does it fit this case? It does seem of great force to say, that the only object of notice is to manifest an intent of one party to end the tenancy, and to inform the other party of that intent, and that the letter in this case did that. Arbenz surely knew that his tenants designed to end the tenancy, because he knew that they had quit the premises and surrendered possession. IVhat more could formal notice do? True, it coild not go to end the tenancy 31 st December, 1898, because from the letter to that date was not three months. But could it not end the tenancy at close of 1899? Now, if the tenants had on the date of the letter given notice that they would qurit 31st December, 1899, who would say that it would not be sufficient? Did not that letter disclose intent to quit? By law it could not operate to close the tenancy 31st December, 1898, because the time would be too short. Would it not operate then as soon as the law would let it, just as a formal notice at the date of the letter would have done, that is, December 31, 1899? Arbenz had notice of his tenants' intention to quit. Why could not that notice operate at the earliest date the law would allow it to operate? In addition, if anything more could in reason be demanded to disclose the intention of the tenants to stop the tenancy and to inform Arbenz of such intention, we add that the tenants in April, 1899, in court defended the claim of Arbenz to rent prior to November, 1899. Their defense was that the building was destroyed and they had sent that letter and abandoned possession. But here comes in the answer that the statute, reiterating conmon law prevalent for centuries, tells how the tenant must end his tenancy, that is, by written notice. It is dangerous for us to insert an exception by saying that if the landlord had knowledge of the tenant's intention, it stands for notice. It may not be improper to say that I have given labored investigation of this case, as other members of the Court have, and I have been impressed with the weight of the line of defense just stated, and have struggled to find a justification for adopting it, as the payment of the whole rent by the defendants, without any return, works a hardship, which all the members of the Court appreciate; but I am compelled to say that to decide against the plaintiffs would be to fly in the face of practically a unanimity of anthorities through several hundred years in all quarters where the common law rules. As applied generaliy the rule is right; as applied in this case, it works hardship; but we cannot bend a fixed rule to suit a hard case. 
Counsel says that the statute only requires three months notice before end of year, and that the written notice need not specify time of quitting, and that to say so is to read such a requirement into the statute. We answer that the statute only recognizes as the law already the requirement of notice to terminate a tenancy from year to year, and it has not changed the common law requisites of the notice. We have cited to us the Georgia case of Roberson v. Simons, 109 Ga. 360, 34 S. E. 604, in which the opinion says that while mere abandonment of premises at the end of the year "might perhaps" be sufficient to bring home notice to the landlord of the tenant's intention to terminate the tenancy, "so as to prevent the landlord recovering rent beyond the year immediately succeeding such abandonment." This is mere opinion. It was not at all in judgment-a thought in the mind, not maturely considered for actual judgment. Betz v. Maxwell, 48 Kan. 143, 29 Pac. 147, seems to support the defense in saying that as the landlord from abandonment of possession knew of the intention to quit, formal notice was useless. This seems to be answered by the quotation above from Currier v. Barker. And it runs counter to the principle which all authorities assert, that mere abandonment will not dispense with notice, but the tenancy and liability for rent go on. "The tenant's liability for rent continues till he puts an end to the estate by notice, whether he continues to occupy the premises or not." 1 Washb, R. Prop. $\S 807$. So far is this so, that the landlord may, at his choice, relet and recover the difference, or let the premises stand vacant. Merrill v. Willis, 51 Neb. 162, 70 N. W. 914; 6 Ballard, R. Prop. $\$ 462$; Schuisler v. Ames, 16 Ala. 73, 50 Am. Dec. 168; Adams v. Colloes, 127 N. Y. 175,28 N. E. 25 , is strongly relied on. The judge writing the opinion does say that knowledge of intention to quit brought home to the landlord will dispense with formal notice. - In the vast mass of New York decisions it is readily noticed there are multitudinous conflicts. This case is in conflict with other decisions in New York itself. It seems that the New York statutes entered into the case.

We do not go on the theory that the former decision is res judicata to fix right to recover the rent involved in the present case. That case was for rent for a certain period of time-this for another. That case is res judicata to establish that it was a tenancy from year to year, but did not say how long. A case may settle principle, but not be res judicata as to matters not immediately involved.

We are compelled to reverse the judgment and render judgment for the plaintiff for his demand. Reversed. 


\section{SECTION 6.-CONCURRENT ESTATES}

\section{CHALLIS, REAL PROPERTY.}

An estate, whether in possession or in remainder, admits of being so limited that several distinct individuals may be entitled to concurrent and simultaneous interests. Moreover, several persons may take the same estate concurrently by descent; either at the common law, in the case of a descent to several sisters, or the representatives of several sisters; or by a descent in gavelkind among several brothers, or their representatives; or by other special custom, among several brothers and sisters, or their representatives. The several individuals so entitled will, according to the nature of the relation subsisting between their interests, be (1) joint tenants, (2) tenants in common, (3) parceners, also styled coparceners, or (4) tenants by entireties.

Littleton's definition of joint tenancy is founded upon the mode in which an estate is limited to joint tenants. If lands are limited to several persons by name, habendum to them for life, or lives, those persons are joint tenants during that life or those lives. Litt. sect. 277. They have an estate pur autre vie in joint tenancy. Similarly, if lands are limited to several persons by name, habendum to them and their heirs, those persons are joint tenants in fee simple.

Joint tenancy is equally applicable to fees (excepts fees in general tail, as mentioned in the next following paragraph), to estates of mere freehold, and to chattel interests. Litt. sect. 281.

An estate in general tail cannot be limited in joint tenancy, because (except under the circumstances which would make the estate an estate in special tail) there cannot be a single heir of the bodies of the donees; and the right of the several heirs in tail of the several donees to inherit, secundum formam doni, which is expressly conferred upon heirs in tail by the statute De Donis, would be repugnant to the right of the surviving joint tenants, upon the death of one, to enjoy the whole estate, which is the most prominent characteristic of joint tenancy.

The distinguishing characteristic of joint tenancy is styled jus accrescendi, or the right by survivorship. Upon the death of one out of several joint tenants, the survivors hold the whole estate, and nothing passes to the representatives in title (whether real or personal) of the deceased tenant. Litt. sect. 280.

But the practical advantage of the jus accrescendi is not necessarily equal for each of the joint tenants; for two men may have a joint estate for the life of one of them; in which case, if that one who is cestui que vie should die in the lifetime of the other, the estate 
is determined, whereas, if the other should die in the lifetime of cestui que vie, the latter has the whole estate and becomes thenceforward sole tenant for his own life. Co. Litt. 181b. It still remains true, that each upon the death of the other takes the whole estate; but in the one case, the whole estate which he takes is reduced to nothing.

The right by survivorship is liable to be defeated by any act which severs the joint tenancy and turns it to a tenancy in common.

Joint tenants must claim an equal interest by the same title and in the same right. Co. Litt. 189a; Ibid. 299b. Therefore they can only take by purchase. And under limitations at the common law, they must all take simultaneously. But in limitations by way of use, if the use is declared jointly to several persons, some of whom are not yet ascertained or not yet in being, such last-mentioned persons, if and wlien they are ascertained or come into being, will be joint tenants with the others; and the same rule holds good, when the interests arise by devise. Co. Litt. 1S8a; and Harg, n. 13 thereon; 2 Prest. Abst. 56. The identity of the interest and title of joint tenants is commonly analysed into the "fourfold unity" of interest, title, time and possession. 2 Bl. Con1. 180-184. This analysis has perhaps attracted attention rather by reason of its captivating appearance of symmetry and exactness, than by reason of its practical utility. It means only, that each joint tenant stands, in all respects, in exactly the same position as each of the others; and that anything which creates a distinction either severs the joint tenancy or prevents it from arising. Blackstone seems not to have adverted to the fact, that the "unity of time" is not, under the learning of uses and devises, an indispensable requisite.

Joint tenants are said to be seised per my et per tout; which expression properly refers to two only, two being taken as a type or pattern for two or more. In one sense each has nothing, and in another sense each has the whole, nihil per se separatim et totum conjunctim. Co. Litt. 186a. In another sense, each has an equal aliquot share; namely, for purposes of alienation, whether total or partial, and for purposes of forfeiture. Ibid. Each can alienate his aliquot share, and can thereby sever the joint tenancy and turn it to a tenancy in common. Herein joint tenants differ from tenants by entireties, who are seised per tout only, and not per my; and of whom, accordingly, neither can prejudice the right by survivorship of the other to succeed to the whole in severalty. $2 \mathrm{Bl}$. Com. 182.

The following point is practically important. When two or more persons are joint tenants for their lives, whether by express limitation or by implication of law, and although the limitation be expressly to the survivor of them, then, on a severance of the joint tenancy, the share of each will afterwards be held for his own life only. Co. Litt. 191a; 2 Prest. Abst. 63. This is because the words in italics are mere surplusage, which express nothing which the law would not without them have implied. Hence it appears, observes Lord Coke. 
that a severance of the joint tenancy of a lease for lives is beneficial to the lessor.

In the limitation of a fee simple in joint tenancy, the words above placed in italics, instead of erring from mere superfluity, are highly pernicious. They turn the limitation to a joint freehold for lives, with a contingent remainder in fee simple to the survivor. Butl. n. 1 on Co. Litt. 191a.

At the common law, one or more joint tenants could not be compelled by the other or others to make partition. Litt. sect. 290. Voluntary partition between them can be made only by deed. Co. Litt. 169a; Ibicl. 187a. By the statutes 31 Hen. VIII, c. 1, and 32 Hen. VIII, c. 32 , the same right of partition as appertained at common law to coparceners, is given both to joint tenants and to tenants in common. ${ }^{47}$

A tenancy in common, though it is an ownership only of an undivided share, is, for all practical purposes, a sole and several tenancy or ownership; and each tenant in common stands, towards his own undivided share, in the same relation that, if he were sole owner of the whole, he would bear towards the whole. And accordingly, one tenant in common must convey his share to another, by some assurance which is proper to convey an undivided hereditament; and he cannot so convey by release. 2 Prest. Abst. 77.

A title by tenancy in common may be claimed by prescription. Lit*. sect. 310. This proves the severalty of the interest.

Tenancy in common may arise in any of the following ways:

(1) By express limitation.

At the common law a gift or limitation contained in the premises of a deed, which standing by itself would have created a joint tenancy, might be turned to a tenancy in common by express words in the habendum; such as, habendum the one moiety to the one and the other moiety to the other of them. Co. Litt. 183b.

In modern assurances, which are commonly made under the Statute of Uses, tenancy in common is limited in the habendum, by declaring the use "as to one equal undivided moiety," or other fractional part, to one of the persons, with similar declarations in favour of the others respectively.

(2) By the severance of a joint tenancy. Litt. sect. 292.

(3) Similarly, by severance, through alienation, without partition, of the interests of coparceners. Litt. sect. 30 .

(4) By construction of law.

47 "It is true that, in this court [Chancery] jointenancies are not faromred, because they are a kind of estates that do not make provision for posterity, neither do I take it that courts of law do at this day favour them; although Lord Coke says that jointenancy is favoured because the law is against the division of tenures, but as tenures are many of them taken away, and in a great measure abolished, that reason ceases, and courts of law incline the same way with this court." Hawes v. Hawes, 1 W'ils. I6i (17t7), per J,ord Haldwicke. See, also, Rigden v. Vallier, 2 Ves. 252, 25S (1751). But see Godrard v. Lewis, 25 T. L. R. 813 (1909). 
(i) If a (contingent) remainder be limited to the heirs of two living persons, not being husband and wife, which remainder must therefore vest in interest at different times, the respective heirs will take as tenants in common. Windham's Case, 5 Rep. 7, at p. 8a, resolution 3; Roe v. Quartley, 1 T. R. 630.

(ii) Under a limitation, in the form of an estate tail, to two persons neither married nor capable of lawful marriage, or to three or more persons, they will take in common. Windham's Case, ubi supra, resolution 4.

Other instances might be specified; but in the present state of the law, they are not material in practice.

There is nothing in the nature or origin of tenancy in common to import any necessity that the shares taken by the different tenants must be equal; because they hold by several, or different, titles, not by a joint title. Litt. sect. 292. Their shares will, accordingly, be unequal, whenever the circunstances under which their titles arose were such as to institute any diversity between them. On an express limitation, unequal shares may be expressly limited; and then the shares will be unequal from the commencement of the tenancy. When the origin of a tenancy in common is by the severance of a joint tenancy, or by a change in the title of coparceners, the shares will in their inception be equal; but inequality may be subsequently introduced, by more than one of such equal shares becoming united in the same hands.

Parceners, or coparceners, are two or more persons who togetler constitute a single heir; as the daughters, where there is no heir male, in respect to common law lands, and the sons, in respect to gavelkind lands. Litt. sect. 241, 265. As to gavelkind, see more at large Rob. Gav. 138 et seq. The same rule holds of sisters, aunts, and other groups of female kinsmen in the same degree, there being no prior heir male. Litt. sect. 242. But with respect to gavelkind lands, it is to be observed that, though by the custom of Kent the rule of coparcenary extends to collateral descents (Rob. Gav. 115), this is not necessarily true of gavelkind lands situated elsewhere; and a custom to that effect must be proved as a special custom (Co. Litt. $140 \mathrm{a}, \mathrm{b})$. The rule of representation holds good in descents in coparcenary; so that the issue of a person who, if living at the time of the descent, would have been a parcener, will take in coparcenary along with the other like persons. But such issue, as respects the amount of their share, take per stirpes and not per capita. Co. Litt. 164b.

Parceners hold a position intermediate between joint tenants and tenants in common. Like joint tenants, they have among them only one single freehold, so long as no partition is made. Like tenants in common, they have among themselves no jus accrescendi; but upon the death of one parcener, a descent takes place of her aliquot share. And one parcener may at common law convey to another by 
an assurance proper to convey a several estate, as a feoffment. Co. Litt. 164a. But such conveyance might also be made by release. Co. Litt. 9b.

A female who, having no sisters, stands in the position of heir, is of course styled the heir and not a parcener. Litt. sect. 242.

One parcener was, even at the common law, entitled as against the others to a compulsory partition. Litt. sect. 241. The intrinsic union between the shares of parceners is shown by the fact that, on a partition, nothing was held to pass from one parcener to another, and therefore a partition between them was no purchase to make an alteration in the course of descent.

Voluntary partition might be made between parceners by mere parol agreement, or by drawing lots, or by reference to the award of arbitrators agreed upon beforehand by all the parties. Litt. sects. 243, 244, 246.

The Court of Chancery from very early times exercised jurisdiction in respect to partition, when land holden of the King in capite descends upon parceners, one or more of them being under age. Fitzh. N. B. 256, F; Ibid. 260, B. This jurisdiction, being incident to the tenure, and a consequence only of the necessity for livery of the lands out of the King's hand, was practically abolished by $12 \mathrm{Car}$. II, c. 24. Suits for partition were also frequently instituted and en. tertained under the court's equitable jurisdiction, when this had grown into general recognition; and under this jurisdiction a decree for partition was regarded as a matter of right, upon proof of title. 2 Com. Dig. 762.

At the common law, upon the death of one parcener, her whole share descended to her issue.

Tenancy by entireties, occurs, at the common law, when a gift or conveyance, which, if made to two strangers, would create a joint tenancy, is made to a husband and wife during the coverture. Litt. sect. 291, and Lord Coke's comment; 2 Prest. Abst. 39. See Co. Litt. 326a: "Where the husband and wife are jointly seised to them and their heires of an estate made during the coverture."

The peculiarities of this kind of tenancy arise out of the identity which the common law imagines to exist between husband and wife. Litt. sect. 291. It is equally applicable to estates in fee simple, in fee tail, for the lives of the parties, and pur autre vie. 2 Prest. Abst. 39.

It constitutes the most intimate union of ownership known to the law. A husband, being tenant by entireties of freeholds with his wife, cannot by any alienation bar her right by survivorship in any part. Co. Litt. 326a; Doe v. Parratt, 5 T. R. 652, at p. 654. They are accordingly said to hold per tout et non per my. $2 \mathrm{Bl}$. Com. 182. The same rule formerly applied also to forfeiture. Co. Litt. 187a.

Arg.Prop. -44 
Husband and wife might be tenants by entireties, as between themselves, of an undivided share; and might, as regards the owners of the other undivided shares, be either tenants in common or joint tenants. 3d Ed. by Sweet, pp. 364, 365, 366, 367, 368, 369, 370, 373, $37 \bar{j}, 376,377$.

\section{MUSTAIN v. GARDNER.}

(Supreme Court of Illinois, 1903. 203 Ill. 2St, 67 N. E. 7i9.)

Bogcs, J. The appellants are the heirs-at-law of one Ola I. Mustain, who departed this life on the 11 th day of December, 1900. They filed a bill in equity in the circuit court of McDonough county against Sarah A. Gardner and Charles H. Gardner, her husband, for the partition of lots 3 and 4 in block 5, in Davis' addition to the village of Blandinsville. The title to the said lots was in one John T. Mustain at the time of his death. He left a will containing but two clauses, which are as follows:

"First-It is my will that my funeral expenses and all of my just debts be fully paid.

"Second-To my beloved daughter, Ola I., and my beloved wife, Sarah A. Mustain, jointly, I give, devise and bequeath lots three (3) and four (4), in block five (5), in Davis' second addition to the late town (now village) of Blandinsville, to them and to their heirs and assigns forever."

The chancellor construed the second clause of the will to devise the premises to the devisees therein named as joint tenants, and held that upon the death of the said Ola I. Mustain the title thereto inured as an entirety to the said Sarah A. Gardner, née Mustain, as the surviving joint tenant, and sustained a demurrer to the bill and dismissed the case.

The only question presented by this record is whether the devisees took as joint tenants or as tenants in common. Joint tenancies are looked upon with disfavor in this State. For this reason section 5 of the act concerning conveyances (1 Starr. \& Cur. Stat. 1896, p. 916,) was adopted. The section reads as follows: "No estate in joint tenancy in any lands, tenements or hereditaments, shall be held or claimed under any grant, devise or conveyance whatsoever, heretofore or hereafter made, other than to executors and trustees, unless the premises therein mentioned shall expressly be thereby declared to pass, not in tenancy in common, but in joint tenancy; and every such estate, other than to executors and trustees, (unless otherwise expressly declared as aforesaid,) shall be deemed to be in tenancy in common." 48 The devise does not expressly declare that the estate thereby created

48 "American statutes on the subject are of three classes: (a) Those rerersing the common law lule that an estate glanted or derised to two or more persons is presumed to create a joint tenancy rither than a tenancy in common; (b) those destroying survivorship; (c) those expressly abolishing joint tenancy." 
and devised is an estate in joint tenancy and not an estate in common. But such a declaration is not indispensable. It is enough if it shall appear from the phraseology of the devise that the testator understood the nature and incidents of the two estates, and the language employed be such as to clearly and explicitly show that the premises are not to pass in tenancy in common. Slater v. Gruger, 165 I1l. 329, $46 \mathrm{~N}$. E. 235. In the absence of an affirmative declaration that the estate devised is in joint tenancy, an estate in tenancy in common will be devised, unless it clearly and explicitly appears from the language employed that the testator understood the nature and incidents of the different estates and intended to create a joint tenancy. The quality of survivorship is the distinguishing feature of a joint tenancy, and where the grant or devise expressly imparts that quality to the estate, as did the deed under consideration in Slater v. Gruger, supra, it will be deemed effectual to create a joint tenancy, though the negation indicated by the statute be omitted.

The devise under consideration does not, in terms, negative the presumption which arises from the statute that it was the intention of the testator to create an estate in tenancy in common, and does not, in terms, declare it to be the intent to create a joint tenancy; nor do we find anything in the language of the devise to indicate that the testator understood the nature and incidents of the different estates, or either of them, and desired that an estate having the peculiar characteristic of survivorship should pass by the devise. The word "jointly," found in the devise, cannot be accepted as sufficient to show, clearly and explicitly, that the testator intended that the estate devised should possess the attribute of survivorship. Tenants in common or coparceners hold the estate "jointly" mntil a severance is effected. Davis v. Smith, 4 Har. (Del.) 6S; Billingslea v. Baldwin, 23 Md. 115. It is entirely consistent with the use made by the testator of this word "jointly" to construe it as indicating only an intent to devise the estate to both devisees, and as it cannot be construed to declare, explicitly and clearly, the intent that the estate, as an entirety, should inure to the survivor of the devisees, it cannot avail to take the devise out of the operation of the statute. The statute must be given effect and the estate devised declared to be an estate in tenancy in common.

The decree is reversed and the cause remanded to the circuit court. with directions to that court to overrule the demurrer to the bill and require the defendants to plead, answer or demur thereto. Reversed and remanded, with directions. ${ }^{49}$

Bremster on Conrerancing, $\S 151$. The student should consult the statutes and dercisions of his state.

In Obio the court early refuser to reconnize joint tenancies as at common

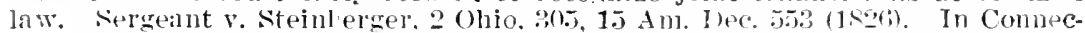
ticut the court refused to allow the right of survivorship. Whittlesey v. Fuller, 11 ('omn. 337 (1ડ:36).

49 Overheiser v. Lackes, 207 N. Y. 229,100 N. E. 739, Ann. Cas. 1914C, 229 (191:3): Joran v. Beale, 106 Miss. 30.5, (i3 South. 64t (1919), acc. Case r. Owen. $1: 39$ Ind. 22, :38 N. E. 395, 47 Am. St. Rep. ㅁ5:3 (1694), contr' 


\section{THORNBURG v. WIGGINS.}

(Supreme Court of Indiana, 1893. 135 Ind. 178, 34 N. E. 999, 22 L. R. A. 42, 41 Am. St. Rep. 422.)

DAILIY, J. This was an action instituted in the court below, in two paragraphs, in the first of which appellees allege, in substance, that on and before December 15, 1884, one Lemuel Wiggins was the owner of a certain tract of real estate therein described, containing eighty acres; that on said day said Lemuel and his wife, Mary, executed and delivered to the appellees a warranty deed, conveying to them the fee-simple of said real estate; that at the time of said conveyance the appellees were, ever since have been, and now are, husband and wife; that said deed conveyed to the appellees the title to said real estate which they took and accepted, ever since have held, and now hold by entireties and not otherwise; that appellees hold their title to said real estate by said deed of Lemuel Wiggins, and not otherwise; that on the 24th "day of April, 1877, Isaac R. Howard and Isaac N. Gaston, who were defendants below, recovered a judgment in the Randolph Circuit Court for the sum of $\$ 403.70$ and costs, against one John 'T. Burrough's and the appellee, Daniel S. Wiggins, as partners, doing business under the firm name of Burroughs and Wiggins; that on May 12, 1886, said Howard and Gaston caused an execution to be issued on said judgment and placed in the hands of the appellant, Thornburg, as sheriff of said county, and directed him to levy the same on said real estate, and that said sheriff did, on the 25 th day of May, 18S6, levy said execution on said real estate, or on the one-half interest in value thereof, taken as the property of said appellant, Daniel S. Wiggins, to satisfy said writ; that pursuant to the levy thereof said sheriff proceeded by the direction of said Howard and Gaston to advertise said real estate for sale under said execution and levy to make said debt, and did, on the 8th day of June, advertise the same for sale on the $3 \mathrm{~d}$ day of July, 1886, and will, on said day, sell the same, unless restrained and enjoined from so doing by the court; that said Daniel S. Wiggins has no interest in said premises, subject to sale thereon; that the appellees hold the title thereto as tenants by entireties, and not otherwise; that the sale of said tract on said execution would cast a cloud on the appellee's title," etc.

The second paragraph is the same as the first, in substantial averments, except that in this paragraph the appellees set out as a part thereof a copy of the deed under which they claim title to said real estate as such tenants by entireties.

The granting clause of the deed is as follows: "This indenture witnesseth, that Lemuel Wiggins and Mary Wiggins, his wife of Randolph county, in the State of Indiana, convey and warrant to Daniel S. Wiggins and Laura Belle Wiggins, his wife, in joint tenancy," etc. Appellants separately and severally demurred to each paragraph of 
the complaint, and their demurrers were overruled by the court, to which the appellants excepted, and, refusing to answer the complaint, judgment was rendered in favor of appellees on said demurrers.

Appellants appeal, assigning as errors the overruling of said demurrers, and urge that the appellees under the deed took as joint tenants, and hence that the husband's interest is subject to levy and sale upon execution. A joint tenancy is an estate held by two or more persons jointly, so that during the lives of all they are equally entitled to the enjoyment of the land, or its equivalent in rents and profits, but, upon the death of one his share vests in the survivor or survivors until there be but one survivor, when the estate becomes one in severalty in him and descends to his heirs upon his death. It must always arise by purchase, and can not be created by descent. Such estates may be created in fee, for life, for years, or even in remainder. But the estate held by each tenant must be alike. Joint tenancy may be destroyed by anything which destroys the unity of title. Our law aims to prevent their creation and they can not arise, except by the instrument providing for such tenancy. Griffin v. Lynch, 16 Ind. 396.

The 9th Am. and Eng. Ency. of Law, 850, says: "Husband and wife are, at common law, one person, so that when realty or personalty vests in them both equally $* * *$ they take as one person, they take but one estate as a corporation would take. In the case of realty, they are seized not per my et per tout, as joint tenants are, but simply per tout; both are seized of the whole, and each being seized of the entirety, they are called tenants by the entirety, and the estate is an estate by entireties. $* * *$ Estates by entireties may be created by will, by instrument of gift or purchase, and even by inheritance. Each tenant is seized of the whole, the estate is inseverable-can not be partitioned; neither husband nor wife can alone affect the inheritance, the survivor's right to the whole."

This tenancy has been spoken of as "that peculiar estate which arises upon the conveyance of lands to two persons who are, at the time, husband and wife, commonly called estates by entirety." As to the general features of estates by entireties there is little room for controversy, and there is none between counsel. Our statute re-enacts the common law. Arnold v. Arnold, 30 Ind. 305; Davis v. Clark, 26 Ind. 424, 89 Am. Dec. 471.

Strictly speaking, estates by entireties are not joint tenancies, Chandler v. Cheney, 37 Ind. 391; Hulett v. Inlow, 57 Ind. 412, 26 Am. Rep. 64; the husband and wife being seized not of moieties, but both seized of the entirety per tout and not per my. Jones v. Chandler, 40 Ind. 588; Davis v. Clark, supra; Arnold v. Arnold, supra.

It has been said by this court in some of the earlier decisions that no particular words are necessary. A conveyance which would make two persons joint tenants will make a husband and wife tenants by the entirety. It is not even necessary that they be described as such or their marital relation referred to. Morrison v. Seybold, 92 Ind. 298; 
Hadlock v. Gray, 104 Ind. 596, 4 N. E. 167; Dodge v. Kinzy, 101 Ind. 102; Hulett v. Inlow, supra; Chandler v. Cheney, supra.

But the court has said that the general rule may be defeated by the expression of conditions, limitations and stipulations, in the conveyance, which clearly indicate the creation of a different estate. Hadlock v. Gray, supra; Edwards v. Beall, 75 Ind. 401.

Having its origin in the fiction or common law unity of husband and wife, the courts of some States have held that married women's acts, extending their rights, destroyed estates by entirety, but this court holds otherwise. Carver v. Smith, 90 Ind. 222. 46 Am. Rep. 210.50

And the greater weight of authority is in its favor. Our decisions hold that neither, alone, can alienate such estate. Jones v. Chandler, supra; Morrison v. Seybold, supra.

There can be no partition. Chandler v. Cheney, supra.

A mortgage executed by the husband alone is void. Jones v. Chandler, supra.

And the same is true of a mortgage executed by both to secure a debt of the husband. Dodge v. Kinzy, supra.

And the wife can not validate it by agreement with the purchaser to indemnify in case of loss arising on account of it. State cx rel., v. Kennett, 114 Ind. 160,16 N. E. 173.

A judgment against one of them is no lien upon it. Barren Creek Ditching Co. v. Beck, 99 Ind. 247; McConnell v. Martin, 52 Ind. 434 ; Orthwein v. Thomas (I11.) 13 N. E. 564.

Upon the death of one, the survivor takes the whole in fee. Arnold v. Arnold, supra.

The deceased leaves no estate to pay debts. Simpson v. Pearson, Admr., 31 lnd. 1, 99 Am. Dec. 577.

And, during their joint lives, there can be no sale of any part on execution against either. Carver v. Smith, supra; Dodge v. Kinzy, supra; Hulett v. Inlow, supra; Chandler v. Chency, supra; Davis v. Clark, supra; McConnell v. Martin, supra; Cox's Adm'r v. Wood, 20 Ind. 54.

The statutes extending the rights of married women have no effect whatever upon estates by entirety. Carver v. Smith, supra.

Such estate is, in no sense, either the husband's or the wife's separate property. The husband may make a valid conveyance of his interest to his wife, because it is with her consent. Enyeart v. Kepler, 118 Ind. 34.

50 Roulston v. Hall, 66 Ark. 305,50 S. Wr. 690, 74 Am. St. Rep. 97 (1599); Hiles v. Fisher, 14 N. Y. 300,30 X. E. 397,30 I. R. A. 30., 4:; Anl. St. Rep. 762 (1895); Bramberly's Estate, 156 Pa. 628, 27 Atl. 405. 22 J. R. A. 594. 36 Aw. st. Rep. 64 (1S98), ace. Wilson v. Wilson. 43 Minn. $39 s, 45$ N. W. 710 (1s90), dictum; Swan v. Walden, 156 Cal. 195, 103 I’ac. 9:31, 134 Am. st. Rep. 115, 20 Ann. Cas. 194 (1909), dictum, contra.

In some states, irrespective of statute, the courts have beld there was no tenancy by the entirety. Whittlesey v. Fuller, 11 Conn. 337 (1s36); lierner v. Icuonald, 60 Nel, 663, st N. W. 92. \&3 An. St. Rel. 500 (1900); Faruters' \& Merchants' Nat. Bank v. Wallace, 45 Ohio St. 152, 12 N. E. 439 (1SS7). 
The rule that husband and wife take, by entireties was enacted in this territory in 1807, nine years before Indiana was vested with statehood, and has been repeated in each succeeding revision of our statutes. It has thus been the law of real property, with us, for eightysix years.

Section 2922, R. S. 18S1, provides that "all conveyances and devises of lands, or of any interest therein, made to two or more persons, except as provided in the next following section, shall be construed to create estates in common and not in joint tenancy, unless it shall be expressed therein that the grantees or devisees shall hold the same in joint tenancy and to the survivor of them, or it shall manifestly appear, from the tenor of the instrument, that it was intended to create an estate in joint tenancy."

Section 2923 provides that the preceding section shall not apply to conveyances made to husband and wife. ${ }^{51}$

Under a statute of the State of Michigan, similar in all its essential qualities to our own, the court held that "where lands are conveyed, in fee, to husband and wife, they do not take as tenants in common." Fisher v. Provin, 25 Mich. 347.

They take by entireties; whatever would defeat the title of one. would defeat the title of the other. Manwaring v. Powell, $40 \mathrm{Mich}$. 371 .

They hold neither as tenants in common nor as ordinary joint tenants. The survivor takes the whole. During the lives of both, neither has an absolute inheritable interest, neither can be said to own an undivided half. Enna Ins. Co. v. Resh, 40 Mich. 241; Allen v. Allen, $47 \mathrm{Mich}, 74,10 \mathrm{~N}$. W. 113.

While the rule of entireties was predicated upon a fiction, the legislative intent, in this State, has always been to preserve this estate, and has continued the peculiar statute for this purpose. Estates by entireties have been preserved as between husband and wife, although joint tenancies between unmarried persons have been abolished, so as to provide a mode by which a safe and suitable provision could be made for married women. Carver v. Smith, supra.

"Where a rule of property has existed for seventy years and is sustained by a strong and uniform line of judicial decisions, there is but little room for the court to exercise its judgment on the reasons on which the rule was founded. Such a rule of property will be over-

51 In Marburg v. Cole, 49 Md. 402, 33 Am. Rep. 266 (1878), a statute providing that no instrument of conveyance shall be construed to create a joint tenancy unless it is expressly provided that the property shall he so held, was not considered to affect the creation of tenancies by the entireties, for they are not joint tenancies.

But where the statute provided that "convesances to two or more in their own right create a tenancy in common, unless a contrary interest is expressed" it was lield that a converance to two who were husbind and wite created a tenancy in common. Lader v. Dyer, 106 Iowa, 715,77 N. W. 469, 68 Am. St. Rel. 332 (159S). 
ruled only for the most cogent reasons and upon the strongest convictions of its incorrectness. It is evident that the Legislature of 1881 did not intend to repeal the statutes establishing tenancies by entireties. They simply intended to enlarge, in some particulars, the separate power of the wife, which existed already under the acts of 1852 and the year following. * * * 'It did not abolish estates by entireties as between husband and wife, but provided that when a joint deed was made to husband and wife, they should hold by entireties, and not as joint tenants or tenants in common.'" Carver v. Smith, supra.

In Chandler v. Cheney, supra, the court says: "It was a well settled rule at common law, that the same form of words, which, if the grantees were unmarried, would have constituted them joint tenants, will, they being husband and wife, make them tenants by entirety. The rule has been changed by our statute above quoted."

The whole trend of authorities, however, is in the direction of preserving such tenancies, where the grantees sustain the relation of husband and wife, unless from the language employed in the deed it is manifest that a different purpose was intended.

Where a contrary intention is clearly expressed in the deed, a different rule obtains.

"A husband and wife may take real estate as joint tenants or tenants in common, if the instrument creating the title use apt words for the purpose." 1 Preston on Estates, 132; 2 Blackstone's Com., Sharswood's note; 4 Kent's Com. side page 363; 1 Bishop on Married Women; Freeman on Co-Tenancy, section 72; Fladung v. Rose, 58 Md. 13, 24.

"And in case of devise and conveyances to husband and wife together, though it has been said that they can take only as tenants by entireties, the prevailing rule is that, if the instrument expressly so provides, they may take as joint tenants or tenants in common." Stewart on Husband and Wife, sections 307-310; Tiedeman on Real Property, section 244.

"And as by common law it was competent to make husband and wife tenants in common by proper words in the deed or devise," etc. Hoffman v. Stigers, 28 Iowa, 310; Brown v. Brown, 133 Ind. 476, 32 N. E. 1128,33 N. E. 615.

So it seems that husband and wife may, by express words, be made tenants in common by gift to them during coverture." McDermott v. French, 15 N. J. Eq. 80.

In Hadlock v. Gray, 104 Ind. 596, 599, 4 N. E. 167, 168, a conveyance had been made to Isaac Cannon and Mary Cannon, who were husband and wife, during their natural lives, and the court says: "The language employed in the deed under examination plainly declares that Isaac and Mary Cannon are not to take as tenants by entirety. This result would follow from the provisions destroying the 
survivorship, for this is the grand and essential characteristic of such a tenancy. *** The whole force of the language employed is opposed to the theory that the deed creates an estate in fee in the husband and wife."

The court further says: "It is true that where real property is conveyed to husband and wife jointly and there are no limiting words in the deed, they will take the estate as tenants in entirety. $* * *$ But while the general rule is as we have stated it, there may be conditions, limitations, and stipulations in the deed conveying the property, which will defeat the operation of the rule. The denial of this proposition involves the affirmation of the proposition that a grantor is powerless to limit or define the estate which he grants, and this would conflict with the fundamental principle that a grantor may for himself, determine what estate he will grant. To deny this right would be to deny to parties the right to make their own contracts. It seems quite clear, upon principle, that a grantor and his grantees may limit and define the estate granted by the one and accepted by the other, although the grantees be husband and wife."

The court then adopts the language of Washburn, supra, and Tiedeman, supra.

In Edwards v. Beall, supra, the court hold that when lands are granted husband and wife, as tenants in common, they will hold by moieties, as other distinct and individual persons would do.

If, as contended by appellees, the rule prevail that the same words which, if the grantees were unmarried, would have constituted them joint tenants, will, they being husband and wife, make them tenants by entireties, then it would result as a logical conclusion that husband and wife cannot be joint tenants. Because, by this rule, words, however apt or appropriate to create a joint tenancy, would, in a conveyance to husband and wife, result in an estate by entireties-joint tenancy would be superseded or put in abeyance by the estate created by law-tenancy by entirety. .

The result of such reasoning would be to destroy the contractual power of the parties where this relationship between the grantees is shown to exist. Any other process of reasoning would carry the rule too far, and we must hold it modified to the extent here indicated. Husband and wife, notwithstanding tenancies by entirety exist as they did under the common law, may take and hold lands for life, in joint tenancy, or in common, if appropriate language be expressed in the deed or will creating it, and we know of no more apt terms to create a joint tenancy in the grantees in this estate than the expression "convey and warrant to Daniel S. Wiggins and Laura Beple Wiggins in joint tenancy."

These words appear in the granting clause of the deed conveying the land in question, and the estate accepted and held by the grantees is thereby limited, and they hold not by entireties but in joint ten- 
ancy. A joint tenant's interest in property is subject to execution. Freeman on Ex. 125.

Judgment reversed, with instructions to the circuit court to sustain the demurrer to each paragraph of the complaint. ${ }^{62}$

\section{PEGG v. PEGG.}

(Supreme Court of Michigan, 1911. 165 Mich. 228, 130 N. W. 617, 33 L. R. A. [N. S.] 166, Ann. Cas. 191:C, 925.)

BIRD, J. The bill of complaint in this cause calls for the construction of a deed made by Davis Pegg to Mary C. Pegg, the complainant. Davis Pegg was the husband of complainant, and in the year 1897 he conveyed to her, by warranty deed in the usual form, an undivided one-half interest in and to the following described premises:

"The west half (IV. 1/2) of the southeast quarter (S. E. 1/4) of section three (3), and the west half (IV. 1/2) of the northeast quarter ( $N$. E. 1/4) of section ten (10), in Grand Traverse county."

In the deed, between the granting and the habendum clauses, is inserted the following clause:

"The objection and purpose of this deed is to convey to said second party such an interest in said land that the parties hereto will have an estate in entirety, and that the same shall survive and vest in the survivor as a full and complete estate."

The deed was recorded in 1901, and in 1902 Davis Pegg died. Complainant is in possession of the premises, and claims title thereto on the theory that she and her husband owned the premises as tenants by entirety, and, she being the survivor, she takes the whole. It is claimed by the defendants, who are brothers and children of deceased brothers of Davis Pegg, that Davis Pegg and complainant were the owners of the premises as tenants in common, and that upon his decease an undivided one-half of the premises descended to them. The defenclants demurred to the bill, and the trial court made an order overruling it, and they have appealed from that order.

Davis Pegg conveyed an undivided one-half interest in said premises to complainant. He retained an undivided one-lialf interest therein. After this was done they had distinct titles, and were therefore tenants in common. The tille remained that way until Davis Pegg died. The question is, then: What became of his undivided half? Ordinarily it would descend to his heirs, the defendants; and it did

52 See Hetzel v. Iincoln, 216 Pa. 60, 64 Atl. 866 (1906), where the conreyance was to a man and woman, by name, "jointly," the grantees being in fact husband and wite.

In Morris v. McCarty, 158 Mass. 11, 32 N. E. 93S (1S9?), lands were convered to A. and B., wife of A., "as tenants by the entirety aud not as tenints in counnon." A. and B. were not in fact husband and wite. The case arose unon a writ of entry by the heirs of $\mathbf{B}$. against $\mathbf{A}$. to recover an undivided one-half of the premises. 
so descend, unless the clause which was inserted carried it in a different direction. Complainant contends that it did not so descend, because she and her husband owned the premises as tenants by the entirety, and were made such by said deed, and that now, as survivor of her husband, she is entitled to the whole of said premises.

In order to own the whole, as survivor, she would have to be seised of the whole before his death. Whatever vested in her as survivor must have been owned by both her and her husband before his death, and each must have been seised of the whole. As neither one was seised of the whole, but both held by distinct titles, they could not have been tenants by the entirety. Neither were they tenants by entirety of the undivided half conveyed to her, because Davis Pegg reserved no interest in the undivided half he conveyed to complainant. The deed as a.whole cannot be construed as creating a tenancy by entirety, because the law was not followed in creating it. At the common law, the unities of time, title, interest, and possession had to be observed in creating such an estate. Blackstone's Commentaries, book 2, p. 1S2; 1 Washburn on Real Property (6th Ed.) p. 529. See suggestion in Bassett v. Budlong, 77 Mich. 338, 43 N. W. 984, 18 Am. St. Rep. 404.

The common law has remained unchanged in this respect and is now in force. In the attempt to create an estate by entirety, in the case under consideration, neither the unity of time nor title was observed. 'The estate was not created by one and the same act, neither did it. vest in them at one and the same time. If the clause inserted can be said to be a part of the habendum of the deed, as is argued, then that part of the habendum must fail, on the ground that it seeks to enlarge an estate in common, which is granted, into an estate of entirety, without complying with the rules of law for the creation of such an estate. By reason of these considerations, the deed must be read as though the clause had been omitted. The deed created a tenancy in common between complainant and her husband, and upon his decease his undivided one-half of the premises descended to his heirs.

The order of the trial court, overruling defendants' demurrer, will be vacated and set aside, and an order entered sustaining the demurrer.

Ostrander, C. J., and Hooker, Moore, and McAlvay, JJ., concurred in the result. ${ }^{53}$

33 William Wright, the omner of premises, executed a deed thereof containing the following: "Retween William Wright, of the township of North Plains in Ionia county and state of Michigan, of the first part, and Willam Wriglit and Elizabeth Wright [his wifel jointly, the survivor to have full ownership, of the same place, of the serond part." William diel, and later Elizabetli. What were the rights of the heirs of each? Wright v. Kllall, 1s:3 Mich. 656, 150 N. W. 315 (19)5). See. also, Michigan State Rink of Eaton Rapils 1 . Kelp (Mich.) 155 N. IV. 50:2 (1915); In re Klatzl's Estate (N. Y.) 110 N. L. 181 (1915) 
VAN HORNE v. FONDA.

(Court of Chancery of New York, 1821. 5 Johns. Ch. 388.)

The Chancelior. ${ }^{54}$ The bill seeks to call the defendant to an account, as executor of the estate of Jellis Fonda, deceased, and, also, as executor of the estate of Henry V. Fonda, deceased, and, generally, to make him account as trustee, acting for and on behalf of the plaintiffs, in the management and disposition of the estate, real and personal, of Henry V. Fonda.

The defendant admits himself to have been the acting executor of the estate of his father, Jellis F., and is ready to account for the personal estate, and the rents and profits of the real estate which he may have received. The great contest in the case is as to the character in which he acted, and the responsibilities which he has incurred, in respect to the estate, real and personal, of his brother Henry V. F. * * *

2. The bill charges that the defendant received, in March, 1799, from the government of this state $\$ 6,500$, as a compensation for the extinguishment of the right derived from Jellis F. to 2.000 acres of land in the Royal Grant, and that the plaintiffs are entitled to a moiety of that sum, with interest. The defendant admits that the sum received was $\$ 6,250$, but he claims title to the whole of it; and contends, in the first place, that his father, Jellis F., was only entitled, in his lifetime, to 1,000 acres, inasmuch as Brant Johnson, who sold him the 2,000 acres, owned only a moiety of it, and that the other moiety belonged to William Johnson, a brother of B. Johnson. He contends, in the second place, that his brother Henry, by his deed of the $3 \mathrm{~d}$ of Nay, 1794, conveyed to him in fee, and absolutely, without any reservation or trust, his interest in the 1,000 acres, for the consideration of $£ 100$., and which consideration was paid by a deed from the defendant to Henry, of the date of the 24th of April, 1794, of two lots in the Royal Grant, and containing the like consideration.

It is to be observed, as we proceed, that the defendant and his brother Henry were joint and equal residuary devisees of their father, Jellis Fonda.

There is reason to believe that the deed of the 24th of April, was not given as the consideration of the deed of the $3 \mathrm{~d}$ of May following. The want of concurrence in dates raises that presumption, especially as that want of concurrence is left without any explanation. In the next place, it is in proof, by the testimony of Simon Veeder, who took the acknowledgment of the deed of the $3 \mathrm{~d}$ of May, and delivered the deed over to the defendant on the same day, that Henry observed, at the time, that the deed to Jellis F., his father, was deficient. The certificate of acknowledgment bears date the 31st day of May, 1794, but ted.

54 The statement of facts is omitted. Portions of the opinion also are omit- 
the certificate of acknowledgment of the prior deed of the 24th of April, bears date the 2 d day of August, 1794, and both the acknowledgments were made before the same judge. The defendant was present when the acknowledgment of the deed of the $3 \mathrm{~d}$ of May was taken; and when the deed was handed to him, he observed that the consideration mentioned in the deed was not the value of the property, but he took the deed in order to save something for the children of his brother, as his brother was pretty much involved in trouble.

These observations of the parties, made at the time of the execution of the deed, are evidence that the deed was not taken as an absolute purchase of the right of Henry to the 1,000 acres; and they are evidence that it was taken in trust, and, probably, with a view to facilitate a compromise with the state, according to the charge in the bill. The testimony of Evert Yates and James Lansing shows that the deed of the $3 \mathrm{~d}$ of May was not considered by the defendant as an absolute purchase of the right of Henry, and paid for, by the prior deed of the 24th of April. When the executors of Henry met, soon after his death, the defendant told John Fonda, who asserted Henry's interest in the money received upon the compromise, that Henry had no such interest, for his father's title was incomplete, and he had since purchased up the Indian title of William Johnson, and considered it a speculation of his own. Here was no suggestion that he had actually bought in the right of Henry, a reply that would naturally have suggested itself, if such had been the fact.

It is also admitted, by the answer, that the title of Jellis $F$. to the 2,000 acres, had been conveyed by him, in his lifetime, to Abrahan G. Lansing; and that as the title proved partly defective, the defendant and his brother Henry, as the representatives of their father, had conveyed to Lansing, in 1793, other lands to the amount of 2,650 acres, derived to them from their father, in lieu of the 2,000 acres: and that Lansing had then released his right to the 2,000 acres, to the defendant and Henry. The 2,000 acres were thus received back into the funds of the estate, as a substitute for the 2,650 acres which had been transferred; and the two brothers became equally entitled, as tenants in common and residuary devisees of Jellis $F$., to all the right and interest, in law and equity, of their ancestor to the 2,000 acres. The defendant, afterwards, on the 29th of May, 1795, purchased of Moses Johnson, the heir of William Johnson, for $\$ 600$, his right and title to 1,000 acres, being part and parcel of 2,000 acres originally purchased by Jellis F. from Brant Johnson. The question, then, is, whether the defendant did not make that purchase for the joint benefit of himself and his brother Henry. If the deed of the $3 \mathrm{~d}$ May, 1794, was given to the defendant, in trust for the purpose of facilitating the acquisition of a good title, then the purchase from Moses Jolnnson was in trust for their joint benefit. The defendant has not interposed and pleaded the statute of frauds against setting up a trust by parol, in opposition to the deed of the 3d of May, 1794; and we are left at lib- 
erty to judge of the truth and effect of the parol proof. I am strongly inclined to believe, that the deed was taken in trust, and that the subsequent purchase from Moses Johnson was made in trust, and that Henry was equally interested in the settlement made with the state, in March, 1799; and that his representatives are entitled to a moiety of the payment received from the state, (which payment amounted to $\$ 6,500$,) after allowing to the defendant, the payment he made to Moses J., and a just indemnity for his expenses in procuring the satisfaction from the state.

In some cases, says Littleton, (sec. 307,) a release to one joint tenant shall aid the joint tenant to whom it was not made, as well as him to whom it was made. I will not say, however, that one tenant in common may not, in any case, purchase in an outstanding title for his exclusive benefit. But when two devisees are in possession, uncler an imperfect title, derived from their common ancestor, there would seem, naturally and equitably, to arise an obligation between them, resulting from their joint claim and community of interests, that one of them should not affect the claim, to the prejudice of the other. It is like an expense laid out upon a common subject, by one of the owners, in which case all are entitled to the common benefit, on bearing a due proportion of the expense. It is not consistent with good faith, nor with the duty which the connection of the parties, as claimants of a common subject, created, that one of them should be able, without the consent of the other, to buy in an outstanding title, and appropriate the whole subject to himself, and thus undermine and oust his companion. It would be repugnant to a sense of refined and accurate justice. It would be immoral, because it would be against the reciprocal obligation to do nothing to the prejudice of each other's equal claim, which the relationship of the parties, as joint devisees, created. Community of interest produces a community of duty, and there is no real difference, on the ground of policy and justice, whether one co-tenant buys up an outstanding incumbrance, or an adverse title, to disseise and expel his co-tenant. It cannot be tolerated, when applied to a common subject, in which the parties had equal concern, and which created a mutual obligation, to deal candidly and benevolently with each other, and to cause no harm to their joint interest. I have no doubt, therefore, that in a case like the present, and assuming what the evidence warrants us to assume, that the deed of May, 1794, was taken by the defendant for trust purposes, that the purchase from Moses Johnson ought, in equity, to enure for the common benefit, subject to an equal contribution to the expense. ${ }^{\text {ss }}$

55 See Matthews r. Bliss, 22 Pick. (Mass.) 48 (1S39) ; Kennedy v. De Trafford, [1897] A. C. 1So, where under a power of sale in a mortgage the mortgaged premises were sold to one of the two tenants in common who had mortgaged the premises. Lord Hersehell said: "But then it is said that the mere fact that Kennedy was co-owner with Dodson of this property creates such a rela. tionship between them that the one co-owner could not take this property and bold it for himself, but that the other co-owner is entitled on equitable grounds 


\section{ELSTON v. PIGGOTT.}

(Supreme Court of Indiana, 1Ss: 94 Ind. 14.)

ElliotT, J. ${ }^{58} * * *$ The question which next demands consideration may be thus stated: Is one who brings a partition suit, holding, at the time, a deed from an assignee in bankruptcy conveying two-thirds of the land, and holding, also, a certificate issued won a sale on a decree of foreclosure embracing all the land, estopped by a decree rendered in the partition suit, awarding to him two-thirds of the land and to the defendant one-third from asserting the title subsequently acquired by a deed executed pursuant to the certificate of sale.

'The right conferred on the holder of the certificate of sale was not a title to the land; it merely invested him with a lien on the land, which might ripen into a title by the failure of the debtors to redeem the land within the time prescribed by law. State ex rel. v. Sherill, 3t [ncl. 57 ; Davis v. Langsdale, 41 Ind. 399; Hasselman v. Lowe, 70 Ind. 414; Felton v. Smith, 84 Ind. 485; Wilhite v. Hamrick, 92 Ind. 594. When the partition suit was commenced, the plaintiff in that suit was not the owner of all the land, but was the owner of two-thirds, which was properly set off to him. The title which he acquired to all the land was a subsequent one.

It is settled that a decree in partition operates only upon the title held at the time the suit was instituted, and has, ordinarily, no effect upon a title subsequently acquired. Niller v. Noble, 86 Ind. 527; Crane v. Kinnmer, 77 Ind. 215 ; Avery v. Akins, 74 Ind. 283, see page 290; Arnold v. Butterbaugh, 92 Ind. 403.

A decree in partition does not create title; it merely severs possession and awards to each tenant his share in severalty. Kenney v. Phillipy, 91 Ind. 511 ; Niller v. Noble, supra; Utterback v. Terhune, 75 Ind. 363; Teter v. Clayton, 71 Ind. 237; Avery v. Akins, supra.

It results from these settled rules that the decree in partition does not estop the appellant from asserting the title acquired under the deed issued on the decree of foreclosure.

The title which a plaintiff is ordinarily required to set forth in the

to hare it declared that the benefit of one half of that purchase should be his. My Lords, no authority has been cited in suplort of such a proposition. * * * The only anthority, if it can he so called, which has been vited is the case be. fore Chancellor Kent [1:an IIolne v. Fonda. 5 Johns. Ch. (X. Y.) 3xS (1N:21)]: but he commences his olservations by salying that he is not woing to lay down a gelleral rule which would be applicable to such a case as this. lle deals with

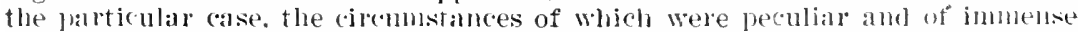
complication, and he certainly does not lay down any rule or dectrine of law

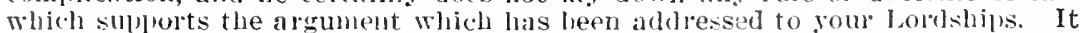
is not necessary to enter into the details of that case. It is enongh to say that, even if it is to be taken as enunciating a rule of law which would be as applicable in this combly as in America, it cloes not enunciate any rule of law which Nonld be sutficient for the aprellant in this case."

Cf. Huluues v. Holmes, 129 Mich. 412, 69 N. W. 47, 95 Am. St. Rep. 444 (190:). 56 Parts of the opinion are omitted. 
complaint in partition is such as will enable him to secure the decree of partition demanded in his complaint. It is not incumbent upon him to make an issue settling all questions of title, or all rights of lien holders, although it is proper for him to do so. If the appellees had desired to settle all questions in the partition suit, they might, doubtless, have done so, by tendering proper issues; but they chose to go to trial on the single question of the right of Elston to a decree of partition, awarding him two-thirds of the land, and tendered no issue as to his right as the holder of the certificate, issued upon the sale made on the decree of foreclosure. Nothing more was embraced in the issues in the partition suit than Elston's right to the two-thirds of the land, and this was all that was adjudicated. It was, indeed, all that could have been properly adjudicated under the issues, for only a claim to two-thirds of the land was then asserted.

The application of these legal principles secures a just result in the present instance. Mrs. Piggott had joined her husband in executing the mortgage sued on in the United States court, was a party to the suit to foreclose that mortgage, and was, of course, chargeable with knowledge that the decree covered all the land, that it was unsatisfied when the partition suit was brought, and that the time for redemption had not then expired. She could not, therefore, have any reason for inferring that Elston was asserting a title founded on the decree, since that would have been a title to the whole, and not merely two-thirds, of the land. She had full knowledge of the extent of the title he asserted, and must have known that it embraced only her husband's interest, and was founded on the sale made by the assignee of her husband, under the order of the Federal court in the bankruptcy proceedings.

The question which is next encountered may be thus stated: Does the fact that the appellant, at the time he acquired the certificate of sale issued on the decree of foreclosure rendered on the mortgage executed by Albert Piggott, the husband, and Martha J. Piggott, the wife, held a conveyance for two-thirds of the land from the assignee in bankruptcy of Albert, the husband, executed after the sale on the decree, preclude him, the appellant, from asserting against Martha J., the wife, the title founded on the deed executed upon the foreclosure sale?

Appellee's counsel contend that the appellant is precluded from asserting title under the foreclosure sale, because he was, as they affirm, a tenant in common with Martha J. Piggott, and could not, therefore, buy in an outstanding lien and build a title on it. The general rule unquestionably is, that one tenant in common can not, by purchasing an outstanding lien, acquire a title which will evict his co-tenant. This rule, however, is subject to many exceptions and obtains only where the relation of tenants in common exists in strictness, and where the relation is such as to require mutual trust and confidence. It is impossible to perceive how one who buys at a sale made by an assignee 
in bankruptcy of the husband's interest becomes charged in such a case as that embraced in our general question, with duties of trust and confidence to the wife of the bankrupt. The title is not a common one; the interests are not reciprocal, and there is no fiduciary relationship created. The title is secured by virtue of a judicial sale, and not by the same instrument, nor from the same source, as that from which the wife's claim is derived. There is, we repeat, nothing in such a case to create relations of trust and confidence, and, therefore, the reason of the rule applicable to ordinary cases fails, and the time-honored doctrine is, that where the reason of the rule ceases so does the rule itself. An examination of the cases will show that we are right in stating that the reason of the rule is that the relationship is one imposing trust and confidence and requiring the tenants not to assume positions of hostility. Mr. Freeman says:

"If their interests accrue at different times, and under different instruments, and neither has superior means of information respecting the state of the title, then either, unless he employs his cotenancy to secure an advantage, may acquire and assert a superior outstanding title, especially where the cotenants are not in joint possession of the premises." Freeman, Cotenancy \& Part. § 155; Roberts v. Thorn, 25 Tex. 728, 78 Am. Dec. 552; Rippetoe v. Dwyer, 49 Tex. 498; King v. Rowan, 10 Heisk. (Tenn.) 675; Matthews v. Bliss, 22 Pick. (Mass.) 48; Frentz v. Klotsch, 28 Wis. 312; Reinboth v. Zerbe, etc., Co., $29 \mathrm{~Pa}$. 139; Brittin v. Handy, 20 Ark. 381, 73 Am. Dec. 497.

It is not to be forgotten that the wife was bound both by the decree and the mortgage, and the case is, therefore, altogether different from one where the lien is created by the act of the law, as for taces, or where the encumbrance was created by a former owner through whom both parties claim title. In such cases the burden is a common one. In the present case the burden rests alone on one of the tenants. This is so by virtue of her own act creating it, and by force of the decree directing the execution of the lien by sale of the property. Here, then, we find an essential element not found in cases to which the general rule is ordinarily applied.

The wife, as against the mortgagee, owned a mere equity of redemption. Kissel v. Eaton, 64 Ind. 248; Haggerty v. Byrne, 75 Ind. 499; Eiceman v. Finch, 79 Ind. 511; Baker v. McCune, 82 Ind. 585; Vermillion v. Nelson, 87 Ind. 194. This equity of redemption had been barred by the decree of foreclosure, so that nothing remained except the statutory right of redemption. Eiceman v. Finch, supra. This right was one to be exercised pursuant to law, and the failure to exercise it made the title absolute upon the execution of the sheriff's deed. Something more than a mere mortgage lien was, therefore, bought by the appellant, and he did not buy it by virtue of his position as a cotenant, nor did his cotenancy give him superior means of knowledge. No one could have had greater knowledge than Mrs. Piggott, AIG.Prop. -45 
by whom the mortgage was executed, and against whom the decree of foreclosure was rendered. Here, again, emerges an element pushing the case outside of the general rule.

There was, as already intimated, no obligation resting on the appellant to discharge the lien, for that obligation rested on the nortgagors. This obligation did not arise from the relationship of the parties, because the burden was not a common one, nor was there trust or confidence. There was, therefore, nothing which, in law or equity, imposed a duty on the appellant to pay off the mortgage and then sue for contribution. As no duty rested on him, and as he did not avail himself of knowledge or opportunity supplied by his cotenancy, he was as free to buy as anybody else. The failure to redeem ensured the loss of the property to MIrs. Pisgott, and whether the judgment plaintiff or his assignee, the appellant, gets the title, can really make no difference to her, for the loss is in either case precisely the same. Her opportunities for knowledge and for action were just the same against the appellant as against his assignor; she had just as much right to redeem from the one as from the other.

We are well satisfied that this case is not within the general rule forbidding one tenant in common from buying an outstanding lien and building title upon it, and that the case assumed in our question is the one made by the record. ${ }^{57} * * *$

\section{HURLEY v. HURLEY.}

(Supreme Judicial Court of Massachusetts, 1859.148 Mass. 444, 19 N. E. $\mathbf{5 1 5}$, 2 L. R. A. 172.)

Holmes, J. This is a petition for partition. In 1870 the petitioner, Thomas Hurley, inlherited one undivided half of the premises from his mother, subject to his father's tenancy by the curtesy. On November 14,1879 , the father died, and the other half, which had belonged to him under a separate conveyance, descended to the petitioner and the respondents, two sons of the father by a later wife. On September 8, 1879, before the father's death, the premises were sold for taxes to one Capen. On December 6, 1880, the respondent Daniel $T$. Hurley paid Capen the amount necessary to redeem the premises, and took a release from him. At that time the respond-

5 i Bracken r. Cooper. S0 Ill. 221 (1S-5), contra.

In Kirlipatrick r. Mathiot, 4 Watts \& $\mathrm{S}$. (T'a.) 2.51 (1S42), one tenant in common prrcinased the land from the connty in which title had been rested by reason of fallure to pay taxes, after the time allowed fol redemption had gone by. The tenant in common so purchasing was held entitled to said land as against another tenant in common who oftered to contribute to the redemption cost. But compare Oliver r. Hedlerly, 32 Minn. 455, 21 N. W. 478 (1SS4), whele the cotemant who murbased from the purchaser at foreclosure sale, after the time for redemption had gone by, had made arrangements for such trans. artion with the mort rigee before the forectosure. 
ent's mother was in possession. In the spring of 18S2, Daniel $\mathrm{I}$. Hurley took possession; the petitioner has never ofiered to repay any part of the sum paid to Capen; and the question raised by the exceptions is whether Capen's deed to him is a bar to this petition.

There has been some uncertainty as to the extent and grounds of the principle that a purchase of a tax title by one tenant in conmon inures for the benefit of all. Frentz v. Klotsch, 28 Wis. 312, 318; Insurance Co. v. Bulte, 45 Mich. 113, 120, 7 N. W. 707; Rothwell v. Dewees, 2 Black, 613, 618, 17 L. Ed. 309. Some cases dwell principally on the existence of a fiduciary relation, (Lloyd v. Lynch, $2 S$ Pa. 419, 424, 70 Am. Dec. 137; Van Horne v. Fonda, 5 Johns. Ch. (N. Y.) 388, 407; Flinn v. McKinley, 44 Iowa, 68; Weare v. Van Meter, 42 Iowa, 128, 20 Am. Rep. 616; Venable v. Beauchamp, 3 Dana (Ky.) 321, 324, 28 Am. Dec. 74;) while others put the proposition in the narrower form, that a tenant in common cannot take advantage of a title created by his own default as against his co-tenant, (Choteau v. Jones, 11 Ill. 300, 322, $50 \mathrm{Am}$. Dec. 460; Voris v. Thomas, 12 Ill. 442; Dubois v. Campau, 2t Mich. 360, 368; Lacey v. Davis, 4 Mich. 140, 152, 66 Am. Dec. 52t; Downer v. Smith, 38 Vt. 46t, 468. See Piatt v. St. Clair, 6 Ohio, 227; Bernal v. Lynch, 36 Cal. 135, 146; Carithers v. Weaver, 7 Kan. 110.) Undoubtedly, as is said by Dixon, C. J., dissenting, in Smith v. Lewis, 20 Wis. 350, 356, it will be found in most of the cases that the party setting up the tax title was under an obligation to pay the taxes.

It has been held that a tenant in common could purchase a tax title from a stranger after the period of redemption had expired, and hold it for his own benefit, (Reinboth v. Improvement Co., 29 Pa. St. 139; Keele v. Cunningham, 2 Heisk. (Tenn.) 288; Watkins v. Eaton, 30 Me. 529, 536, 50 Am. Dec. 637; Coleman v. Coleman, 3 Dana (Ky.) 398, 403, 28 Am. Dec. 86;) and in this commonwealth it is decided that he may take an assignment of a paramount mortgage, and rely on it to defeat a petition for partition, (Blodgett v. Hildreth, 8 Allen, 186.) On the other hand, it has been held that a purchase of a tax certificate before the period of redemption has expired, by one who is not a tenant in common at the time, will inure to the benefit of the other tenants in common, if he becomes such before he gets the tax deed. Flinn v. McKinley, 44 Iowa, 68; Tice v. Derby, 59 Iowa, 312, 314, 13 N. W. 301. Compare Sneed v. Atherton, 6 Dana, 276, 279, $32 \mathrm{Am}$. Dec. 70.

There are strong grounds for saying that there were no special fiduciary relations between the petitioner and the defendant in this case. Their titles were in part derived from different sources. Frentz v. Klotsch, 28 Wis. 312, 318. According to the bill of exceptions, the defendant was not in possession when he took the tax deed, (Wright $v$. Sperry, 21 Wis. 331, 337,) and he had no interest in the premises when the tax was assessed, or until after they were sold, while the petitioner owned ine-half, subject to his father's tenancy by the cur- 
tesy. It is at least consistent with the facts stated to assume that the petitioner was not relying on the respondent in any way. See Matthews v. Bliss, 22 Pick. 48, 52. Again, it would be pressing the notion of default very far to say that, although the defendant was a stranger to the estate at the time of the sale, yet, since he might have redeemed, he could not found a title on his failure to do so. But it is unnecessary to decide what would have been the effect if the defendant had taken a conveyance of the tax title to a third person, and had given the transaction the form of an assignment; for, whether the defendant had a right to take an assignment or not, he certainly had $a_{4}$ right to redeem and pay off the incumbrance. Pub. St. c. 12, § 49. See Coughlin v. Gray, 131 Mass. 56, 58; Langley v. Chapin, 134 Nass. 82; Coxe v. Wolcott, $27 \mathrm{~Pa} .154$. Which of the two transactions took place may be a question for the jury, under some circumstances. Coxe v. Wolcott, ubi supra. But, as was said in Watkins v. Eaton, 30 Me. 529, 534, 50 Am. Dec. 637, a case very similar in principle to the one at bar, "when a part owner obtains a conveyance of his own share, and the share or shares of co-tenants, by payment of the precise amount required to redeem them, he must be presumed, in the absence of all rebutting testimony, to have done so in the exercise of a legal right; and in such case the whole so conveyed will be redeemed from the sale." See Sherwin v. Bank, 137 Mass. 444, 449. It is plain, on the face of the deed accepted by the defendant Daniel T. Hurley, that he redeemed the premises in the exercise of his legal right so to do; and it follows that the lien of the tax sale was discharged, in such a sense that it could not ripen into a legal title as against his co-tenants, except upon their refusal or neglect to pay their share. Watkins v. Eaton and Weare v. Van Meter, ubi supra.

Then the question arises whether, as the respondent has paid the tax, and has not taken the steps to assert and preserve his lien prescribed by Pub. St. c. $12, \S \S 63,64,65$, his rights are not gone altogether. But we think that it would be too harsh a construction of those sections to hold that they apply to a redemption of the premises after a sale, when the tenant takes a deed which is put on record. We interpret the statute as intended to apply to a payment in the first instance, when, unless a certificate is filed as provided, there will be nothing in the registry to show the tenant's claim, and when no other statutory mode of divesting the title of his co-tenants has been set in motion.

We are of opinion that, although the tax is legally paid, as we have said, yet the respondent Daniel Hurley is entitled to have the lien kept alive for his benefit until the petitioner shall have paid his share. Until that time, the petitioner has no right to the possession of any part of the land, in equity or at law. Watkins v. Eaton, 30 Me. 529, 535, 50 Am. Dec. 637. See McCabe v. Swap, 14 Allen, 1SS, 191; Gibson v. Crehore, 3 Pick. 475, 5 Pick. 146, 150; Popkin v. Bumstead, 8 Mass. 491, 5 Am. Dec. 113. Therefore the petition was rightly dis- 
missed. Pub. St. c. 178, § 3; Blodgett v. Hildreth, ubi supra; Bradley v. Fuller, 23 Pick. 1, 8; Hunnewell v. Taylor, 6 Cush. 472; Coughlin v. Gray, 131 Mass. 57 : Husband v. Aldrich, 135 Mass. 317, 318. Exceptions overruled.

\section{JACKSON v. BAIRD.}

(Supreme Court of North Carolina, 1908. 148 N. C. 29, 61 S. E. 632, 19 L. R. A. [N. S.] 591.)

Brown, J. It is admitted that Robert Baird was the owner of the land in controversy, and that he executed a deed in trust to secure $\$ 150$ to S. H. Reid, trustee. After Robert Baird's death the land was sold by the trustee, who conveyed it to Mrs. Julia D. Shuford for a consideration of $\$ 286$ by deed dated May 26, 1898. George Shutford and his wife, the aforesaid Julia, conveyed the land to defendant Laura Baird, wife of defendant John Baird, by deed dated May 28, 1898. The trustee's deed to Mrs. Shuford, although dated May 26th, recites that the sale took place on May 28th. It appears that Julia Baird joined in the execution of the note and deed in trust along with Robert Baird. The plaintiffs allege that the debt was contracted for 'John Baird's benefit. The defendants deny this, and aver that John Baird signed as surety for his father, Robert Baird. The evidence offered upon this point is very meager and tends to prove that the money borrowed was used in building a house upon the tract of land in controversy, which belonged to Robert Baird.

This case was presented to this court upon the theory that there is evidence that Shuford bought in the property in trust for Baird, and that consequently, as Baird is a tenant in common with plaintiffs, the title he acquired, whether legal or equitable, must inure to the joint benefit of all. We do not think there is any evidence whatever of a fraudulent combination between Shuford and Baird to effect a secret sale of the property or to suppress bidding, although the testimony of Judge Shuford may possibly be susceptible of the construction that he intended the property for Baird, and that he was acting in his interest. The contention of plaintiffs that John Baird could not acquire the exclusive title at the sale is founded upon a misapprehension of the law. The general rule is well settled that one co-tenant cannot purchase an outstanding title or incumbrance affecting the common estate for his own exclusive benefit and assert such right against his co-tenants; but that rule does not apply under the facts of this case. The title which was acquired by Shuford, assuming that he acquired it for Baird, was not an outstanding title adverse to the title of Robert Baird. It was the title of Robert Baird himself, the common ancestor under whom all claimed, and the sale was being made under a deed executed by such ancestor and to pay his debts, which was an incumbrance on the land when it descended to plaintiffs and their coheir. 
It is held in the state that one co-tenant lawfully may purchase his co-tenants' share of the common property under execution sale to pay the debt of such co-tenant. Likewise, it is held that one of the cotenants may purchase the entire property at a sale to pay the common ancestor's debt. Baird v. Baird's Heirs, 21 N. C. 536, $31 \mathrm{Am}$. Dec. 399. In that case Chief Justice Ruffin says: "It is a very common case that one brother buys at sheriff's sale the undivided estate of another brother in descended lands, either for the debt of the ancestor, or that of the brother himself contracted after the father's death; and we believe the legality of such a purchase has never been questioned." Again: "It is not the duty of one heir, or of one tenant in common as such, to pay the debts of another tenant in common, *** nor to refrain from buying to his own disadvantage, more than it is the duty of any other person, wholly unconnected with them." So it is said by Judge Gaston that "a tenant in common, as such, is not a trustee for his companion." Saunders v. Gatlin, 21 N. C. 92.

It is likewise held in England that there is no fiduciary relation existing between tenants in common, as such, and that a tenant in common of property previously mortgaged, who purchased the eritire property at the mortgage sale, was entitled to hold it for his sole benefit. This is an interesting case, decided by the House of Lords and Privy Council, in which an elaborate opinion is delivered by Lord Herschell and concurred in by the other Lord Justices. See, also, 17 Am. \& Eng. 676, and cases cited; also, Freeman, Co-Tenancy, $\$ \S 162-165$; Blodgett v. Hildreth, 90 Mass. (8 Allen) 186; Sutton v. Jenkins (at this term) 147 ‥ C. 11,60 S. E. 643.

When the land in controversy descended upon these plaintiffs and upon their coheir, John Baird, it was incumbered with the mortgage to Reid made by their ancestor. When that mortgage was foreclosed in the manner allowed by law, any one of the heirs had a right to purchase the entire estate to protect his own interest, and he would acquire the title discharged of any trust to his coheirs. There is no evidence that John Baird agreed to purchase for the benefit of the other heirs, or endeavored to suppress bidding, or practiced any other fraud upon his co-tenants. So far as the record discloses, the sale appears to have been fairly made by the trustee, and it was open to the plaintiffs or any of them to attend and purchase if they so desired.

We think therefore the judgment of nonsuit should be affirmed. 


\section{PICO v. COLUMBET.}

(Supreme Court of Califoruia, 1859. 12 Cal. 41!, $73 \mathrm{Am}$. Vec. 550.)

This was an action by one tenant in common against his co-tenant, who is in the sole possession of the premises, to recover a share of the profits of the estate.

In the Court below, the defendant demurred to the complaint of the plaintiff, upon the ground that "it does not state facts sufficient to constitute a cause of action." The demurrer was overruled. Defendant excepted, and subsequently answered. This Court has considered the question of the sufficiency of the complaint, the substance of which is set out in the opinion of the Court. The judgment of the Court below is, that the bill be dismissed, and defendant have judsment for his costs. Plaintiff appealed to this Court.

FiELD, J., delivered the opinion of the Court-Terry, C. J., and BALDWIN, J., concurring.

This action is brought by one tenant in common against his cotenant, who is in the sole possession of the entire premises, to recover a share of the profits received from the estate. The case was argued upon the demurrer to the complaint, which, by stipulation of the parties, was admitted to have been taken on the ground that the complaint does not state facts sufficient to constitute a cause of action. The complaint avers a tenancy in common between the parties; the sole and exclusive possession of the premises by the defendant; the receipt by him of the rents, issues, and profits thereof; a demand by the plaintiff of an account of the same, and the payment of his share; the defendant's refusal; and that the rents, issues, and profits amount to $\$ \$ 4,000$. These arerments, and not the form in which the prayer for judgment is couched, must determine the character of the pleading. The complaint is designated a bill in equity, but the designation does not make it such. There are no special circumstanees alleged which withdraw the case from the ordinary remedies at law, and require the interposition of equity. The action is a common law action of account, and, viewed in this light, the complaint is fatally defective. It does not aver that the defendant occupied the premises upon any agreement with the plaintiff, as receiver or bailiff of his share of the rents and profits. It is essential to a recovery that this circumstance exist, and equally essential to the complaint that it be alleged. By the common law, one tenant in common has no remedy against the other who exclusively occipies the premises and receives the entire profits, unless he is ousted of possession when ejectment may be brought, or unless the other is acting as bailiff of his interest by agreement, when the action of account will lie. The reason of the doctrine is obvious. Each tenant is entitled to the occupation of the premises; neither can exclude the other; and if the sole occupation by one cotenant could render him liable to the other, it would be in the power 
of the latter, by voluntarily remaining out of possession, to keep out his companion also, except upon the condition of the payment of rent. The enjoyment of the absolute legal right of one co-tenant would thus often be dependent upon the caprice or indolence of the other. 1 Co. Lit. 200; 5 Bac. Ab. 367; Willes, 209.

The statutes of 4 and 5 Anne, 16, gave a right of action to one joint tenant, or tenant in common, against the other as bailiff, who received more than his proportional share of the profits. At common law, the bailiff was answerable, not only for his actual receipts, but for what he might have made from the property without willful neglect, (Co. Lit. 172, a. Willes, 210;) but as bailiff under the statute of Anne, he was responsible only for what he received beyond his proportionate share. That statute only applied to cases where one tenant in common received from a third person money, or something else, to which both co-tenants were entitled by reason of their co-tenancy, and retained more than his just share according to the proportion of his interest. This was held in Henderson v. Eason, Exch. 9 Eng. Law and Eq. 337. In that case, it was decided that if one of two tenants in common solely occupies land, farms it at his own cost, and takes the produce for his own benefit, his co-tenant cannot maintain an action of account against him as bailiff for having received more than his share and proportion.

The statute of Anne has never been adopted in this State, nor have we any similar statute. The case at bar must therefore be determined upon the principles of the common law. By them, as we have observed, the action cannot be maintained against the occupying tenant unless he is by agreement a manager or agent of his co-tenant. The occupation by him, so long as he does not exclude his co-tenant, is but the exercise of a legal right. His cultivation and improvements are made at his own risk; if they result in loss, he cannot call upon his co-tenant for contribution, and if they produce a profit, his cotenant is not entitled to share in them. The co-tenant can at any moment enter into equal enjoyment of his possession: his neglect to do so may be regarded as an assent to the sole occupation of the other.

On this point, the observations of Baron Parke in Henderson v. Eason are pertinent, although that case arose under the statute of Anne: "There are obviously many cases," says the Justice, "in which a tenant in common may occupy and enjoy the land or other subject of tenancy in common solely, and have all the advantage to be derived from it, and yet it would be most unjust to make him pay anything. For instance, if a dwelling-house or room is solely occupicd by one tenant in common without ousting the other, or a chattel is used by one tenant in common, and nothing is received, it would be most inequitable to hold that by a simple act of occupation or user, without any agreement, he should be liable to pay a rent, or anything in the nature of a compensation, to his co-tenant for that occupation, to which, to the full extent to which he enjoyed, he had a perfect right. It ap- 
pears impossible to hold such a case to be within the statute, and an opinion to that effect was expressed by Lord Cottenham in MicMahon v. Burchell. Such cases are clearly out of the operation of the statute. Again, there are many cases where profits are made and are actually taken by one co-tenant, yet it is impossible to say that he has received more than comes to his just share. For instance, if one tenant employs his capital and industry in cultivating the whole of the piece of land, the subject of the tenancy, in a mode in which the money and labor expended greatly exceeds the value of the rent or compensation for the mere occupation of the land, in raising hops, for example, which is a very hazardous adventure, and he takes the whole of the crops, is he to be accountable for any of the profits in such a case, where it is clear, if the speculation had been a losing one altogether, he could not have called for a moiety of the loss, as he would have been enabled to do had it been so cultivated by the mutual agreement of the co-tenants? The risk of the cultivation, and the profits and the loss, are his own, and what is just with respect to the very uncertain and expensive crop of hops, is also just with respect to all the produce of the land, the fructus industriales, which are raised by the capital and industry of the occupier, and cannot exist without it. In taking all the produce, he cannot be said to receive more than his just share and proportion to which he is entitled as tenant in common, as he receives in truth the remuneration for his own labor and capital, to which a tenant has no right."

The American cases are to the same effect. In Sargent v. Parsons, 12 Mass. 149, the Court said: "The action of account is maintainable only against a bailiff; and a bailiff can only be one who is appointed such, or who is made such by the law, which latter instance applies only to a guardian, who is bailiff of his ward, and who is liable, not only for rents and profits actually received, but also for those which he might have received by a proper management of the estate. One tenant in common may, by contract, make another his bailiff or receiver; and if he does, he may bring him to account in this form of action; and probably, also, to avoid a process considered in some degree troublesome, might sue him in indebitatus assumpsit as on a promise to account. But this must be for rents and profits actually received beyond his share; for, by the common law, no remedy is given for a mere sole use and occupation by one of the tenants; for it is in the power of each tenant at any time to occupy; and the not doing it by one would look like an assent that the other should occupy the whole."

In Woolever v. Knapp, 18 Barb. (N. Y.) 265, the defendant had enjoyed the sole possession of a farm for five years, the rent and occupation of which was worth two hundred dollars a year. The plaintiffs were his cotenants, and brought their action of account. The Court decided that the action could not be sustained, holding that one tenant in common who possesses the entire premises, without any agreement 
with his co-tenants as to his possession, or any demand on their part to be allowed to enjoy the same with him, is not liable to account in an action for their use and occupation. See, also, Nelson's Heirs v. Clay's I. eirs, 7 J. J. Marsh. (Ky.) 139, 23 Am. Dec. 387.

We have treated this case as an action of account at law, but to the ame result we should come if the proceeding were in equity. There is no equity in the claim asserted by the plaintiff to share in profits resulting from the labor and money of the defendant, when he has expended neither, and has never claimed possession, and never been liaHe for contribution in cases of loss. There would be no equity in giving to the plaintiff, who would neither work himself, or subject himself to any expenditures or risks, a share in the fruits of another's labor, investments, and risks.

The cases to which our attention has been called, in which equity has sustained an account in favor of one tenant in common, out of possession, against his co-tenant in possession, for the rents and profits, are, with some exceptions in the Court of Appeals of South Carolina, those in which the account was a collateral incident to a claim for partition, and the rents and profits claimed were due from the defendant as a tenant of the plaintiff's interest, or were received by him when they belonged to both parties, or were the proceeds of their joint labor and expenditures. Thus, in Pope v. Haskins, 16 Ala. 321, the defendant had leased of the complainant his undivided one-third interest in a lot belonging to the parties as tenants in common, and upon the expiration of the lease had rented out the lot to a third party, and received the entire profits, and the bill was filed to obtain an account of the rents and profits, and for a partition of the property.

In Hannan v. Osborn, 4 Paige (N. Y.) 336, the bill was filed for the partition and sale of a lot of land, and an account of the rents and profits, and the account directed was of the rents and profits received by any of the parties, not of the profits made in the use and occupation of the premises.

In Turner v. Morgan, \& Ves. 143, the bill prayed partition of a house at Portsmouth, and an account of the rent, under the following circumstances: The house was decreed to three persons, equally to be divided. The plaintiff purchased two-thirds. The defendant was tenant of the house under a lease of $\left(f_{22}\right)$ twenty-two pounds a year, and refusing to raise the rent, the plaintiff brought ejectment for his two-thirds. The ejectment was defeated, the defendant purchasing the remaining third. Upon this, the bill was filed. The Chancellor allowed a partition. No question appears to have been made upon the right of the plaintiff to an account, the defendant having been tenant under the lease; and the Chancellor observed, in relation to the account, that there was a possible distinction between the time during which the defendant was tenant, and the time since he became owner, but that justice would be answered by inquiring what would have been a reasonable rent in each year the account was sought. 
The doctrine laid down by the Court of Appeals of South Carolina, as to the liability of one co-tenant to another, is believed to be peculiar to that Court. In Hancock v. Day, McMul. Eq. (S. C.) 69, $36 \mathrm{Am}$. Dec. 293, Thompson v. Bostick, McMul. Eq. (S. C.) 75, and Holt v. Robertson, McMul. Eq. (S. C.) 475, it was held that as between tenants in common, the occupying tenant is liable for rent of so much of the premises as was capable of producing rent at the time lie took possession, but not liable for that which was rendered capable by his labor. The reasons upon which these decisions rest do not commend themselves to our judgment, and are insufficient to overcome the force of the English, Massachusetts, New York, and Kentucky authorities.

The demurrer should have been sustained; but as the same result was obtained by a judgment rendered for the defendant on the merits of the case, it will be sufficient to direct the afrirmance of the judgment. ${ }^{58}$

58 See Gage v. Gage, 66 N. II. $2 \S 2.29$ Atl. 545, 28 L. R. A. $\$ 29$ (1S90), semble contra.

The Stat. 4 Anne, c. $16 . \$ 27$, has been deemed in some states a part of the common law, as, for example, in Massaclunsetts and Marrland. Munroe $v$. Lulse, 1 Metc. 459 (1S40): Flack v. Gosnell, 76 Md. SS, 24 Atl. 414, 16 L. R. A. $547,35 \mathrm{Am}$. St. Rep. 413 (1892). In many states there are statutes in varying terms giving to one co-owner a remedy along the general lines of the statute of Anne, against another co-owner. See 1 Stim. Am. St. Law, $\$ 1378$.

By chapter 2 , \$ 1 (1)aragraph 27 of Jones \& A. Ann. St. of Illinois, 1913), it is provided: "That where one or more joint tenants, tenants in common or" coparceners in real estate, or any interest therein, shall take and use the profits or benefits thereof, in greater proportion than his, her or their interest, such person or persons, his, her or their executors and administrator's, shall account therefor to his or their co-tenant, jointly or sererally."

Section 10956 of Howell's Michigan Statutes provides that: "One joint tenant or tenant in common, and his executors or administrators, may maintain an action for money had and received, against lis cotenant, for receiving more than his just proportion of the rents or profits of the estate owned by them as joint tenants or tenants in common."

As to whether the rents and profits have been "received" so as to nermit use of the remedy under Stat. 4 Anme, c. 16 , or similar statute, see Hender'son v. Eason, 17 Q. B. 701 (1551); Sargent v. Parsons, 12 Mass. 1.19 (1815) ; Woolever r. Knapp, is Barb. (N. Y.) 265 (1S54); Cheney v. liicks, 1Si Ill. 171, 58 N. L. 234 (1900); Howard v. Throckmorton, 59 Cal. 79 (18s1).

In West v. Weyer, 46 Ohio St. 66, is N. E. 537, 15 Am. St. Rep. 552 (1Sss), under a statute which provided that "one tenant in common, or coparcerrer, may" recover from another his share of the rents and profits received by such tenant in common or coparcener from the estate, according to the justice and equity of the case," it was held that a cotenant in possession of the entire common property could be required to account for his co-owner"s share of the reasonable worth of such occupation, though there had been no onster. See Thompson v. Bostick, McMul. Eq. (S. C.) 75 (1S40); Early v. Friend, 16 Grat. (Va.) 21. is Am. Dec. 649 (1S60); Hasden v. Merrill, 44 Vt. 336, 8 Am. Rep. 372 (1S72) ace. 


\section{CALVERT v. ALDRICH.}

(Supreme Judicial Court of Massachusetts, 1S6S. 99 Mass. 74, 96 Am. Dec. 693.)

Contract. The defendant filed a declaration in set-off on an account annexed for two fifths of the cost of repairs of a machine shop in Lowell: and the only question in dispute in the case was the liability of the plaintiff for any portion of such cost.

At the trial in the superior court, before Reed, J., these facts appeared: Calvert and Aldrich owned the machine shop and the machinery therein in the proportion of two fifths and three fifths respectively, as tenants in common; and Aldrich, having agreed to pay to Calvert a yearly rent for such occupation of Calvert's two fifths, was in occupation thereof when the building caught fire, and the roof, windows and one of the floors were so burnt that the machinery was exposed to injury by the weather. Calvert at this time was in Europe, but had an agent in Lowell, to whom Aldrich immediately represented the importance of repairing the building. The agent confessed such importance, but replied that he had no authority from Calvert to sanction any repairs, and wrote to Calvert for instructions, who replied, declining to make any repairs upon the building. This letter the agent showed to Aldrich, who meanwhile had caused the building to be repaired. After the return of Calvert, Aldrich showed him the repairs and stated to him the expenses thereof, and asked him to contribute his proportion of the same. But Calvert, not disputing that the expenses were reasonable, contended that he was not liable for any portion of them, and refused to contribute.

On these facts the judge ruled that the defendant could not recover on his account in set-off, and ordered judgment for the plaintiff; and the defendant alleged exceptions.

Foster, J. The issue in this action is on an account of one cotenant in common against another to recover from the defendant in set-off part of the cost of certain needful repairs made by the plaintiff in set-off upon the common property. It is not founded upon any contract between the parties, but upon a supposed legal obligation which, if its existence were established, the law would imply a promise to fulfill.

The doctrine of the common law on this subject is stated by Lord Coke as follows: "If two tenants in common or joint tenants be of an house or mill, and it fall in decay, and the one is willing to repair the same, and the other will not, he that is willing shall have a writ de reparatione faciendâ, and the writ saith ad reparationem et sustentationem ejusdem domûs teneantur, whereby it appeareth that owners are in that case bound pro bono publico to maintain houses and mills which are for habitation and use of men." Co. Lit. 200b; Id. 54b. And in another place he says: "If there be two joint tenants of a wood or arable land, the one has no remedy against the other to make inclo- 
sure or reparations for safeguard of the wood or corn," but if there be two joint tenants of a house, the one shall have his writ de reparatione faciendâ against the other. This is said to be because of "the preeminence and privilege which the law gives to houses which are for men's habitation." Bowles's Case, 11 Co. 82.

In Carver v. Miller, 4 Mass. 561, it was doubted by Chief Justice Parsons whether these maxims of the conmon law, as applied to mills, are in force here, especially since the provincial statute of 7 Anne, c. 1, revised by St. 1795 , c. 74 .

In Loring v. Bacon, 4 Mass. 575, the plaintiff was seised in fee of a room and the cellar under it, and the defendant of the chamber over head and of the remainder of the house; the roof was out of repair; the defendant, being seasonably requested, refused to join in repairing it; and thereupon the plaintiff made the necessary repairs, and brought assumpsit to recover from the defendant his proportion of their cost. This, it will be observed, was not a case of tenancy in common, but of distinct dwelling-houses, one over the other. Chief Justice Parsons said: "If there is a legal obligation to contribute to these repairs, the law will imply a promise. We have no statute nor any usage on the subject, and must apply to the common law to guide us." "Upon a very full research into the principles and maxims of the common law, we cannot find that any remedy is provided for the plaintiff." It was not absolutely decided that an action on the case would not lie, but the intimations of the court on the subject were such that no further attempt appears to have been made. The relations between tenants in common were not actually involved in this case, and the remarks touching the writ de reparatione were only incidental and by way of illustration.

Doane v. Badger, 12 Mass. 65, was an action on the case. The plaintiff had a right to use a well and pump on the defendant's land; and the defendant had removed the pump and built over the well, thereby depriving the plaintiff of the use of the water. The judge before whom the case was tried had instructed the jury that the defendant, by the terms of a deed under which he claimed, was bound to keep the well and pump in repair, although they were out of repair when he purchased, and, without any previous notice or request, was liable in damages for the injury the plaintiff had sustained by his neglect to make repairs. The court held that no such evidence was admissible under the declaration, the cause of action stated being a misfeasance, and the proof offered being of a nonfeasance only; also, that a notice and request were indispensable before any action could be maintained. Mr. Iustice Jackson in delivering the opinion made some general observations, unnecessary to the decision of the cause, the correctness of which requires a particular examination. He said that the action on the case seems to be a substitute for the old writ de reparatione faciendâ between tenants in common, and could not be brought until after a request and refusal to join in making the repairs. He added: "From 
the form of the writ in the register, it seems that the plaintiff, before bringing the action, had repaired the house, and was to recover the defendant's proportion of the expense of those repairs. The writ concludes, 'in ipsius dispendium non modicum et gravamen.' It is clear that until he have made the repairs he cannot in any form of action recover anything more than for his loss as of rent, \&c., while the house remains in decay. For if he should recover the sum necessary to make the repairs. there would be no certainty that he would apply the money to that purpose." Mumford v. Brown, 6 Cow. 475, $16 \mathrm{Am}$. Iec. 4+0, a per curiam opinion of the supreme court of New York, and Coffin v. Heath, 6 Metc. SO, both contain obiter dicta to the same effect, apparently founded upon Doane v. Badger, without further rescarch into the ancient law.

If it were true that the writ de reparatione was brought by one cotenant, after he had made repairs, to recover of his cotenant a due proportion of the expense thereof, there would certainly be much reason for holding an action on the case to be a modern substitute for the obsolete writ de reparatione. But all the Latin forms of the writ in the Kegister, 153, show that it was brought before the repairs were made, to compel them to be made under the order of court. Indeed, this is implied in the very style by which the writ is entitled, de reparatione faciendâ, viz.: of repairs to be made; the future participle faciendâ being incapable of any other meaning. This also appears in Fitzherbert. N. B. 127, where the writ between cotenants of a mill is translated; the words, in ipsius dispendium non modicum et gravamen, (quoted by Judge Jackson,) being correctly rendered, "to the great damage and grievance of him," the said plaintiff. Fitzherbert says: "The writ lieth in divers cases; one is, where there are three tenants in common or joint or pro indiviso of a mill or a house, \& c., which falls to decay, and one will repair but the other will not repair the same; he shall have this writ against them." In the case of a rumous house which endangers the plaintiff's adjoining house, and in that of a bridge over which the plaintiff has a passage, which the defendant ought to repair, but which he suffers to fall to decay, the words of the precept, are, "Command A. that," \&c., "he, together with B. and C., his partners, cause to be repaired." The cases in the Year Books referred to in the margin of Fitzherbert confirm the construction which we regard as the only one of which the forms in that author are susceptible namely, that the writ de reparatione was a process to compel repairs to be made under the order of court. There is nothing in them to indicate that an action for damages is maintainable by one tenant in common against another because the defendant will not join with the plaintiff in repairing the common property. In a note to the form in the case of a bridge, It is said in Fitzherbert: "In this writ the party recovers his damages, and it shall be awarded that the defendant repair, and that he be distrained to do it. So in this writ he shall have the view contra, if it be cut an action on the case for not repairino. for thers to shall recover 
lut clamages." There is no doubt that an action on the case is maintainable to recover damages in cases where the defendant is alone bound to make repairs for the benefit of the plaintifi without contribution on the part of the latter, and has neglected and refused to do so. Sec Tenant v. Goldwin, 6 Mod. 311, s. c. 2 Ld. Raym. 10S9; I Salk. 21,360 .

The difficulty in the way of avarding damages in faror of one tenant in common against his cotenant for neglecting to repair is, that buth parties are equally bound to make the repairs, and neither is more in default than the other for a failure to do so. Lpon a review of all the authorities, we can find no instance in England or this country in which, between cotenants, an action at law of any kind has been sustained, either for contribution or damages, after one has made needful repairs in which the other refused to join. We are satisfied that the law was correctly stated in Converse v. Ferre, 11 Mass. 325, by Chief Justice Parker, who said: "At common law no action lies by one tenant in common, who has expended more than his share in repairing the common property, against the deficient tenants, and for this reason our legislature has provided a remedy applicable to mills." The writ de reparatione facienda brought before the court the question of the reasonableness of the repairs proposed, before the expenditures were incurred. It seems to have been seldom resorted to; perhaps beciluse a division of the common estate would usually be obtained where the owners were unable to agree as to the necessity or expecliency of repairs. Between tenants in common, partition is the natural and usually the adequate remedy in every case of controversy. This is the probable explanation of the iew authoritics in the books, and of the obscurity in which we have found the rhole subject involved. But if we have fallen into any error in our exanination of the original doctrines of the common law of England, it is at least safe to conclude that no action between tenants in common for neglecting or refusing to repair the common property, or to recover contribution for repairs made thereon by one without the consent of the other, has been adopted among the common law remedies in Massachusetts.

This restitt is in accordance with the rulings at the trial. Exceptions overruled. 50

59 "The weneral doctrine is that one tenant in common can compol his cotenant to share in the expense of necessary repairs to the common property. by refuesting him so to do. If the cotenant refuse to join in making such repairs, he may, after such reruest and refusil, make them and recover of the cotenant for his pronortionate share. Eut he camnot, without the consent of his cotenant, make permanent improvements upou the common property at the expense of the tenants in common. If he desires to improve his share of the common properts beyond what his cotenants will consint to, he must resort to a petition for partition, so that he can own his share in severalty. 4 Kent, Com. 420 to $423(* 370,371)$; 1 Wash. R. P. 420, 421 ; Kirller r. Rixford, 16 Vt. 169 , 42 Am. Dec. 504 (1844)." Farrand v. Gleason, 56 vt. 6.3.3, 693 (1584). See Warr v. Ward, 40 W. Va. 611, 21 s. E. 746,29 J. R. A. 449, 52 Am. St. Rep. 911 (1595).

"A tenant in conmon cannot, in the absence of an agreement or understand- 


\section{PICKERING v. PICKERING.}

(Supreme Court of New Hampshire, 18S5. 63 N. H. 468, 3 AtI. 744.)

Bill in equity, for an accounting between tenants in common. The defendant claimed to be allowed for necessary repairs made by hin upon the premises without notice to the plaintiff.

LixGHAM, J. The plaintiff seeks for an accounting, and to charge the defendant for the rents and income of lands and buildings thereon. The parties are tenants in common. The defendant has had the possession and income of the property since December 27,1883 , and has in that time expended $\$ 370$ in necessary repairs that materially increased the value of the buildings and the income, and claims to be allowed for the same in the accounting. The plaintiff had no notice of the repairs, and was not requested to join in making them.

If we are to consider it settled at common law that one tenant in common cannot recover of his cotenant a contribution for necessary repairs, where there is no agreement or request or notice to join in making them, or excuse for a notice not being given to join (Stevens v. Thompson, 17 N. H. 103, 111, Wiggin v. Wiggin, 43 N. H. 561, 568, 80 Am. Dec. 192), because both parties, until this is done are equally in fault, one having as much reason to complain as the other (Mumford v. Brown, 6 Cow. $475-477,16$ Am. Dec. 440, Kidder v. Rixford, 16 Vt. 169-172, 42 Am. Dec. 504, 4 Kent Com. 371, Doane v. Badger, 12 Mass. 65-70, Calvert v. Aldrich, 99 Mass. 78, 96 Am. Dec. 693), it does not follow that in this proceeding for an equitable accounting for the income, a part of which is produced by the repairs, the defendant may not be allowed for them. There is a wide difference bctween a right of action at common law to recover a contribution for repairs, and a right to have them allowed out of the income, which exists in part through their having been made. In the first case, the party makes them at his will on the common property without the consent or knowledge of his cotenant, while in the last the cotenant recognizes the existence of the repairs, that they have materially increased the income, but demands the incrcase and refuses to allow for the repairs. The objection, that no privity, no joint knowledge, no authority existed, is in equity and good conscience waived when the entire income is demanded. It is not unlike the ratification of the acts of an assumed agent; it relates back to the time of making the repairs, and makes the

ing with his cotenant to that effect, make improrements upon the commnn ploperty at the expense, in any part, of his cotenant, so as to enable him to recorer any portion of the cost or ralue of the immrovements, either in an ac. tion brought by him for that jurpose, or by way of set-off in an action brought aganst him by his cotenant. We are not spaking of repairs, nor of what misht be done ulum a lartition." Walter $r$. Freenwool, 29 Minn. 8т. 90, $12 \AA$. W. $145(1582)$. But see Nelson v. Leale, 25 Miss. 199 (1S52); Ruffners v. Lewis, 7 Leigh (Ta.) 720,30 Am. Dec. $5 i ̈ 3$ (1Sï6). 
plaintiff a privy from the beginning. He cannot claim the repairs and the income, and equitably ignore the expense of making them.

In Moore v. Cable, 1 Johns. Ch. (N. Y.) 385, a bill for the redemption of a mortgage, it was decided that the mortgagee should not be charged for rents and profits arising exclusively from repairs made by him.

In Jackson v. Loomis, 4 Cow. (N. Y.) 168, 15 Am. Dec. 347, an action of trespass for mesne profits against a bona fide purchaser, it was held that he should be allowed against the plaintiff, in mitigation of damages, the value of permanent improvements, made in good faith, to the extent of the rents and profits claimed by the plaintiff. Green v. Biddle, 8 Wheat. 1, 5 L. Ed. 547.

In Rathbun v. Colton, 15 Pick. (Mass.) 472, 485, it was decided that when the rent of a trust estate is increased in consequence of improvements made by the trustee, the beneficiary may be put to his election, either to allow the trustee the expense of such improvements, or be deprived of the increase of rent obtained by means thereof; that the question was not whether the trustee has a right to make a charge for the improvements, but whether the plaintiffs were entitled to receive any benefit for them, they refusing to contribute their share towards the expense.

It seems, however, that courts of equity have not confined the doctrine of compensation for repairs and improvements to cases of agreement or of joint purchases, but have extended it to other cases where the party making the repairs and improvements has acted in good faith, innocently, and there has been a substantial benefit conferred on the owner, so that in equity and right he ought to pay for the same. 2 Story, Eq. Jur. $\S \S 1236,799 b$; Coffin v. Heath, 6 Metc. (Mass.) 76, SO. And in 2 Story, Eq. Pl. $\S 799 b, n .1$, it is said: "In cases where the true owner of an estate, after a recovery thereof at law from a bona fide possessor for a valuable consideration, without notice seeks an account in equity as plaintiff against such possessor for the rents and profits, it is the constant habit of courts of equity to allow such possessor (as defendant) to deduct therefrom the full amount of all meliorations and improvements which he has beneficially made upon the estate, and thus to recoup them from the rents and profits. *** So, if the true owner of an estate holds only an equitable title thereto, and seeks the aid of a court of equity to enforce that title, the court will administer that aid only upon the terms of making compensation to such bona fide possessor for the amount of his meliorations and improvements of the estate beneficial to the owner." This is on the old, established maxim in equity jurisprudence, that he who seeks equity must do equity. Hannan v. Osborn, 4 Paige (N. Y.) 336; Dech's Appeal, 57 Pa. 468, 472; Peyton v. Smith, 2 Dev. \& Bat. Eq. 325, 349; ifibbert v. Cooke, I Sim. \& S. 552.

The sum of $\$ 370$ for the repairs may be deducted from the income,

AIg.Prop. -46 
if it amounts to that sum; if not, then to cancel the income, whatever it may be.

The claim for insurance should be disallowed. It does not appear that it was procured for the plaintiff, or in her interest, or with her knowledge, or that she has ever received or accepted any benefit arising from it.

Case discharged.

Bi,ODGETT, J., did not sit; the others concurred.

\section{Appeal of KELSEY.}

(Supreme Court of Pennsylvainia, 1ss6. 113 Pa. 119, 5 Atl. 447, 57 Am.

Fien. 414.)

Mr. Chief Justice Mercur delivered the opinion of the Court, May 31 st, 1886.

This bill was to compel partition of lands in which the appellees held the undivided five ninths. The Court decreed partition, and awarded to the appellants four ninths of the land. Their complaint now is the refusal of the Court to allot to them a proportionate value of the permanent improvements erected on the land by the appellees. It may be conceded that there may be cases of partition in which the improvements should be held to enure to the benefit of all the co-tenants. It is well intimated such might be the case where one co-tenant undertakes to improve the whole estate as by erecting a building covering the whole of a city lot. Here, however the improvements appear to have been such only as were reasonably necessary for the proper enjoyment of the land by the co-tenant who made them. While the title was in the wife of the appellee yet he was tenant by curtesy initiate, and therefore in making the improvements, presumably for himself and his wife, he cannot be treated as a mere stranger or volunteer. While a tenant in common is liable to his co-tenant for repairs absolutely necessary to buildings already erected and in being. which fall into decay; yet he is not liable to his co-tenant for new and permanent buildings which the latter erects thereon: Beaty v. Borkwell, 91 Pa. 438; Crest v. Jack, 3 Watts, 238, 27 Am. Dec. 353; Dech's Appeal, $57 \mathrm{~Pa}$. 467. Hence, although the appellees owned the larger share of the land they were powerless to compel the appellants to contribute towards the improvements. The appellees must either forego the proper use and enjoyment of their estate or else incur the necessary expense to make it productive. They chose to do the latter. The appellants paid nothing towards the improvements, and their estate was not injured by the erection thereof. This is a procceding in equity. Due regard must be had to the equitable rights of each party. Under the facts of this case it would not be a just ap- 
plication of the rules in equity to give to the appellants any share of the value of the permanent improvements made by the aypellees only. Decree affirmed, and appeal dismissed at the costs of the appellants. ${ }^{60}$

\section{GRISWOLD v. JOHNSON.}

(Supreme Court of Errors of Connecticut, 1824. 5 Conn. 363.)

This was an action of ejectment; tried at New London, October term, 1823, before Peters, J.

The plaintiff claimed title, by virtue of a deed from Charles Griswold, administrator de bonis non with the will annexed of Dyar Throop, deceased. In support of the title of Dyar Throop, the plaintiff produced the will of his father, Rev. Benjamin Throop, deceased, containing the following devise: "To my two sons, Dyar and Benjamin, I give and bequeath to them, and their heirs and assigns, that part of my farm which lies Easterly of Wolf-swamp brook to be equally divided between them for quantity and quality; and that my son Dyar have the part next the brook; upon the consideration that they bear their proportion with my other son, William, in paying what debts and legacies my personal estate will not answer, if any there be." That part of the farm, which lay Easterly of Wolf-swamp brook, was a tract of about thirty-seven acres: and the administrator's deed to the plaintiff contained about seventeen acres of that part of such tract lying next adjoining the brook, including the demanded prem,ses, and described the land, which it purported to convey by metes and bounds. The plaintiff claimed, and adduced evidence to prove, that such land was one half in quantity and quality of the tract of thirty-seven acres. He also clamed, that Dyar Throop took such land, under the devise, as estate in severalty. The judge instructed the jury, that Dyar and Ber jamin, under the devise, took the tract lying Easterly of the brook, as enants in common; and that the deed, as it embraced but a part of such common estate, describing it by metes and bounds, was void, and conveyed no title whatever to the plaintiff.

The defendant claimed, and adduced evidence to prove, that Dyar refused to take any of the land under the devise. The plaintiff insisted, that admitting such refusal, Dyar's part thereupon became intestate estate, and he became vested with an interest therein, as tenant in common with the other heirs of the testator; and that the ad-

60 See Louvalle v. Menard, 1 Gilman (6 Ill.) 39, 41 Am. Dec. 161 (1844); Martindale v. Alexander, 26 Ind. 104, 89 Am. Der. 45 S (1S66); Burns v. Palker (Tex. Cir. App.) 137 S. W. 705 (1911); Nelson`s Heir's r. Clay's Heirs, 7 J. J. Iarsh. (Ky.) 139, $23 \mathrm{Am}$. Dec. $35 \mathrm{~T}$ (1S32); Cosuritt v. Foss, 152 N. Y. 104, 46 N. E. 307,36 I. R. A. 753,57 Am. St. Rep. 500 (1597); Howald r. Morrissey, 71 Misc. Rep. 267,130 ․ I. Supp. 822 (1911); Moore v. Williamson, 10 Rich. Eq. (S. C.) $323,73 \mathrm{Am}$. Dec. 93 (155s). 
ministrator's deed to the plaintiff, whether it contained the whole or a part of the common estate, conveyed the whole of Dyar's common interest in the land described in that deed. The judge instructed the jury, that if the deed embraced any quantity of the common estate less than the whole, describing it by metes and bounds, such conveyance was in law null and roid.

The jury returned a verdict for the defendant; and the plaintiff moved for a new trial, for a misdirection.

Hosmer, C. J. The plaintiff claims title by the deed from Charles Griswold, the administrator de bonis non, with the will annexed, of Dyar Throop, deceased. The Rev. Benjamin Throop made his last will, derising to his sons, Dyar and Benjamin, a tract of land, of which the premises demanded is part, in manner following: "To my two sons, Dyar and Benjamin, I give and bequeath to them, their heirs and assigns, that part of my farm which lies Easterly of Wolf-swamp brook, to be equally divided between them for quantity and quality, and that my son Dyar have the part next the brook." The above tract contained thirty-seven acres, and the aforesaid administrator duly authorized by the court of probate, gave to the plaintiff a deed of seventeen acres thereof, by metes and bounds, of that part of said land, which lies next adjoining the brook aforesaid. The plaintiff insists, that Dyar Throop, under the aforesaid devise, took the land described in the above deed, as an estate in severalty; while the defendant urges, that the said Dyar and Benjamin had title to the aforesaid land, east of the brook, as tenants in common. The court charged the jury in conformity with the defendant's claim; and that if the said deed embraced any quantity of said common estate, less than the whole, by metes and bounds, such conveyance in law was null and void.

Whether the charge of the court was correct, depends on the answer which the law gives to two questions, namely: Was the estate in question devised in common to Dyar and Benjamin; and if so, was the deed invalid.

1. Tenants in common are such as hold by unity of possession, because none knoweth his own severalty, and they occupy promiscuously. Co. Litt. sec. 292; 2 Bla. Comm. 191. The infallible criterion of this species of estate, is, that no one knoweth his own severalty; and hence the possession of the estate necessarily is in common until a legal partition be made. But of an estate in severalty the criterion is, that a man knows, what he has the exclusive right of possessing; and his possession is sole, because no person has a right to occupy with him. If an estate is given to a plurality of persons, without any restrictive, cxclusive and explanatory words; from the nature of the case, they are tenants in common. 2 Bla. Comm. 192, 180. If the grant superadds, that the property "is to be equally divided" between them, the estate is held in common, because these words are inapplicable to a several estate. 2 Bla. Comm. 192. Now, in the case under discus- 
sion, the devise to Dyar and Benjamin of a tract of land, constituted a tenancy in common on the preceding principles; and this more particularly is evinced, by the words "to be equally divided between them, for quantity and quality;" an expression indicating a future division of the property devised. The expression that "Dyar to have the part next the brook," construing the devise in all its parts together, and not disjointly, denotes merely this; that when a future division of the property shall be made, Dyar shall have his portion assigned him in the place specified. It, however, has no possible effect on the tenancy in common necessarily arising from the unity of possession; nor can it operate to produce such estate, unless by exchanging the former words, instead of giving them their legal construction. The claim, that Dyar had devised to him an interest in severalty, is not a little extravagant, inasmuch as the wisdom of the wisest would be baffled in the ascertainment of the bounds of this supposed several estate. The question, what is its quantity, its form, its location, no one except a competent judiciary can resolve. No bounds are mentioned; no lines are prescribed; no quantity is given. A court can take cognizance of the case; and, in a legal mode, well understood, determine the quantity, by the quality of the land, and, on principles of justice, assign a distinct location to each of the devisees; but there is no competency to the performance of either of these acts, by an individual.

2. The deed of this common estate, by metes and bounds, the one tenant in common thus attempting to make a partition of the property, without any co-operation of the other, is, undoubtedly void. The point is at rest, and not to be questioned. Hinman v. Leavenworth, 2 Conn. 244, n.; Starr v. Leavitt, 2 Conn. 243, 7 Am. Dec. 268; Mitchell v. Hazen, 4 Conn. 495, 10 Am. Dec. 169; Bartlet v. Harlow, 12 Mass. 348. 7 Am. Dec. 76; Porter v. Hill, 9 Mass. 34, 6 Am. Dec. 22.

The determination of the Judge below was correct, and no new trial is to be granted. ${ }^{61}$

\section{CRESSEY v. CRESSEY.}

(Supreme Judiciảl Court of Massachusetts, 1913. 215 Mass. 65, 102 N. E. 314.)

Petition for partition, filed in the Superior Court on March 17, 1911. the petitioner alleging that he and the respondents Job $\mathrm{H}$. Cressey. Anna E. Emerson and Charles A. Newhall were tenants in common of certain premises on Park Street in Lynn, their undivided shares being as follows: petitioner, eight twenty-eighths, Job H. Cressey, seven twenty-eighths, Anna E. Emerson, seven twenty-eighths, and Dorman, trustee for Charles A. Newhall, six twenty-eighths; and that Arthur I. Newhall, Sarah Effie Newhall, Anna E. Emerson and Charles A. Newhall claimed to own undivided interests other than as alleged.

61 Sinith v. Benson, 9 Vt. 138, 31 Am. Dec. 614 (1837), acc. See Marshall v. Trumbull, 28 Conn. 18:, 73 Am. Dee. 667 (1859). 
The case was heard by McLaughlin, J., without a jury. The material facts found by him are stated in the opinion. He ruled that the partition should be made in the proportions set out in the petition, made an interlocutory judgment accordingly, and reported the case for determination by this court.

RugG, C. J. This is a petition for partition of land on Park Street in Lynn. The question at issue is the shares to which the several owners are entitled. The material facts are that in 1899 William M. Newhall died intestate, seized of several parcels of real estate, among them being the Park Street land which is the subject of this petition, leaving no wilow and seven children. Title to all these parcels descended to his seven children as tenants in common. In 1903 on a judgment recovered against one of these children, Sarah E. Newhall, all her right, title and interest in this Park Street land described by metes and bounds was sold, and by mesne conveyances the right acquired thereby is now held by Charles A. Newhall. In March, 1904, William F. Newhall, one of the seven children, died unmarried and intestate, leaving as his heirs his six surviving brothers and sisters. Thereafter judgment was recovered against Sarah E. Newhall and Harriet A. Newhall, on execution in which all their right, title, and interest in the Park Street land on July 27, 1904, described by metes and bounds, was sold, and by mesne conveyances all right under this deed has come to the petitioner. In November, 1905, commissioners were appointed by the Probate Court to make partition of the several parcels of real estate left by William M. Newhall at his decease among his six surviving children as tenants in common, the share of each being set out in the warrant as one sixth. In making partition the commissioners reported that the Park Street land, which they had appraised at $\$ 8,000$, was equal to four shares, and, as in their judgment it could not be divided advantageously, they set it off to Anna E. Emerson, Sarah E. Newhall. Harrict A. Newhall and Nary I. Cressey, to each one fourth. This report was confirmed in March, 1906. Between March 1906, and March, 1910, Mary I. Cressey deceased leaving her share to Job H. Cressey, one of the respondents. In March, 1910, Harriet A. Newhall deceased, ummarried, intestate, leaving her four surviving hrothers and sisters as her heirs at law, namely Anna E. Emerson, Sarah E. Newhall, Charles A. Newhall and Arthur I. Newhall.

The levy of the two executions against Sarah E. Newhall was not upon the share held by her as tenant in common in the entire real estate inherited by her from her father. It did not follow the provisions of R. L. c. 17S, sec. 13, 14. As has been pointed out, each was a levy apon all her title in only one of the several parcels held as tenants in common, which one was described by metes and bounds. The levy and sale upon execution of real estate of a debtor operates as a conveyance of the title which the debtor was capable of conveying. One of screral tenants in common cannot as against his cotenants make a sale by metes and bounds of a portion of the common land. Bartlet $v$. 
Harlow, 12 Mass. 348, 7 Am. Dec. 76; Benjamin v. American Tele. phone \& Telegraph Co., 196 Mass. 454, 82 N. E. 681, 13 Ann. Cas. 306. Sale on execution, which is in the nature of a statutory conveyance, stands upon the same basis as a conveyance by the owner.

The case at bar is governed by Brown v. Bailey, 1 Metc. 25t, in which at page 257 Chief Justice Shaw said, respecting facts precisely similar to those presented in the case at bar, "such conveyance or levy, therefore, is good against the grantor and all claiming under him. If then the other cotenants release, or if upon a partition, their full shares are set off in other parts of the common estate, and the part conveyed or levied on is assigned to the party whose share has thus been conveyed or levied on by metes and bounds, such partition operates by way of estoppel and release, because no one has any longer a right to contest its validity." The principle that a conveyance by metes and bounds, whether by personal deed or statutory transfer, by one tenant in common of a portion of the common estate, although of no effect against the consent of his cotenants, operates after partition by way of estoppel to transfer the title, has been affirmed repeatedly. De Witt v. Harvey, 4 Gray, 486, 491; Barnes v. Boardman, 157 Mass. 479, 32 N. E. 670; Barnes v. Lynch, 151 Mass. 510, 512, 24 N. E. 783,21 Am. St. Rep. 470; Frost v. Courtis, 172 Mass. 401, 404, 52 N. E. 515.

The application of this principle results in something like a wager or chance. The grantee gets nothing unless on partition the share of the grantor should happen to include the parcel described by metes and bounds in the deed. The grantor loses by estoppel and release all his interest in the parcel so described if it should happen to be set off to him.

By the partition, the interest of Sarah E. Newhall in the entire estate inherited by her both from her father and her brother, consisting of several parcels, was converted into a one fourth interest in the Park Street property. Of this one fourth she acquired six out of seven parts by inheritance of the one seventh of her father's estate. This share, or six twenty-eighths, is held by the first levy of execution, which was made before the death of the brother, from whom she inherited. The one sixth of one seventh which she inherited from him, constituting one out of seven parts of the one fourth of the Park Street property, or one twenty-eighth, passed under the second levy, under which also passed the entire share of Harriet. The ruling of the Superior Court as to who are the cotenants and their respective shares was right.

Interlocutory judgment affirmed. ${ }^{62}$

62 Cf. Rising r. Stamard, 17 IIass. $2 \$ 2$ (1\$21). Cf. also Butler v. Rors, $2 \overline{5}$ Mich. 53, 12 Am Rep. 218 (1572).

See Empric r. Alvarado, 90 Cal. 444. 27 Pac. 8jo (1S91): Young v. Ldwards, 33 S. C. 404,11 S. N. 1066,10 L. R. A. 5., 26 Am. St. Rep. 689 (1s.00); Pellow v. Arctic Iron Co., 164 Mich. 87, $12 \mathrm{~S}$ N. W. $91 \mathrm{~S}, 47$ L. R. A. (N. S.) 573, Ann. Cas. 1912B, 827 (1910). 


\section{LESSEE OF IVHITE v. SAYRE.}

(Sulreme Court of Ohio, 1s25. 2 Ohio, 110.)

This was an ejectment, and came before the court upon a case agreed, adjourned from Greene county. The facts material to be reportell, are these:

The defendant was in possession of a tract of land which had been the property of his former wife, by whose death it had descended in parcenary to her eight brothers and sisters; with one of the latter the defendant had again intermarried. By a judicial proceeding in the court of common pleas, partition had been made and a separate part assigned to each by metes and bounds. The lessor of the plaintift purchased the separate right allotted to three of the heirs, and took separate deeds from each for so much land specifically described. Error was afterward brought in the Supreme Court, upon the procecdings in partition, and they were reversed.

The declaration contained several demises; among others, a separate one for one undivided eighth part of each of the tracts contained in his three deeds; and whether he could recover upon these deeds and demises, was the question submitted to the court.

Hitcicock, J. It is well settled that where one joint tenant, or tenant in common, has ejected, or withheld the possession from his co-tenant, the person so ejected or held out of possession, may maintain his ejectment against the ejector or person in possession. To determine the case under consideration, then, it is only necessary to ascertain whether the lessor of the plaintiff took anything under the thrce several deeds referred to in the agreed case, or, in other words, whether he had any interest in the premises in dispute. The grantors were three of the heirs of the deceased wife of John Sayre, Jr. By the death of their sister, the interest in the one hundred and fiftyfive acres of land was vested in them and their brothers and sisters as coparceners, or tenants in common. It is to be observed, that when these deeds were executed, partition had been made of the one hundred and fifty acres of land, by judgment of the court of common pleas, in pursuance of the statute in such case made and provided. The three parcels which were conveyed to White had been, by this judgment, aparted and set off to the grantors in severalty. Under the then existing circumstances, they conveyed nothing more than they had a legal right to convey. So long as this judgment remained in force, the title of the lessor of the plaintiff to the lands to him conveyed, was perfect. This judgment, however, was subsequently reversed; and it is necessary to ascertain how far the deeds, which were before operative, were affected by this reversal. That the reversal must in part, at least, defeat the operation or validity of those deeds, there can be no doubt. The judgment being reversed, the parties in interest could be no more affected by it than if no judgment had bee: 
rendered. Under these circumstances, the decision of this case must depend upon the solution of these several questions: 1. Can one of two or more joint tenants, coparceners, or tenants in common, convey his interest in the estate thus held? 2. If he can convey his interest or estate in the whole property thus held, can he convey it in a part merely? 3. Is a deed, or grant, which purports to convey an estate in severalty, when the grantor has, in fact, only an estate in joint tenancy, coparcenary, or in common, void; or does it convey the whole interest of the grantor in the premises purporting to be conveyed?

1. Can one of two or more joint tenants, coparceners, or tenants in common, convey his interest in the estate thus held?

This is a question about which it is presumed there can be no dispute. Such conveyances are frequently made, and their validity is not questioned. In fact, this is one of the most common modes resorted to for destroying a joint tenancy. One joint tenant aliens and conveys his estate to a third person, by which means the joint tenancy is severed and turned into a tenancy in common.

2. If one joint tenant, etc., can convey his interest or estate in the whole property thus held, can he convey it in a part merely?

The determination of this question is attended with considerable difficulty. This difficulty, however, arises, not so much from any apparent inconsistency, or inpropriety in such grant, as from a possible inconvenience which might result to the tenant who retains his estate. One tenant in common may grant his entire interest or estate in a particular species of property, a tract of land for instance, or he may grant one-half as a smaller proportion of his interest in the same entire property. If this be correct, no good reason is perceived why he may not grant his entire interest in a particular part. A. and B. are seized of a section of land as tenants in common. It is well established, that A. may grant his entire interest, or estate, in the section, and the conveyance will be valid. Upon what principle, then, can it be said, that if he convey his entire interest in a particular quarter of such section, such conveyance shall be void? Certainly A. and B. tenants in common, as aforesaid, might with propriety unite and convey a particular quarter of the section, and a complete title in the grantee would be vested. Would not the title of the grantee be equaily valid, if the tenants in common should by separate deeds convey to him their individual interest in that particular quarter? This question, it is believed, must be answered in the affirmative, and if so, it proves conclusively that one tenant in common may transfer to a third person his entire interest in a part of the property held in common. Otherwise we run into this absurdity, that a deed properly executed, by one individual, which is an entire thing, and purports to convey a specific property, must depend for its validity upon the execution of a similar instrument by a third person, who is in no way party to the first. The principal reason assigned why one tenant in common shall 
not be allowed to convey, as before stated is, that by so doing, he may do a great injury to his co-tenant, by compclling him in case of partition, to take his proportion of the estate in small parcels, very much Lo his disadvantage. If such evils would result, they ought if possible to be aroided. It does not follow, however, that because one of two tenants in common can convey his estate in a part of the property so held, therefore the rights of his co-tenant are affected. This co-tenant will still have the same interest in every part, and in the whole of the property. He can still compel partition, and may have his share of the property set off to him in severalty, in the same manner he could have done had no conveyance been made. Such, at least, as at present adrised, is the opinion of the court, and if in this we are mistaken, the objection is not of sufficient force to induce us to adopt any other principle, as applicable to this case, than as before stated.

3. Is a deed, or grant, which purports to convey an estate in severalty, when the grantor has in fact only an estate in joint tenancy, coparcenary, or in common, void; or does it convey the whole interest of the grantor in the premises purporting to be conveyed?

Every deed is to be so construed as, if possible, to give effect to the intention of the parties. It is to be construed most strongly against the grantor. If the intention of the parties, apparent upon the face of the instrument, cannot be carried into effect, this object should be attained as far as is possible. Taking these principles into consideration, and adopting them as correct, it follows, that where an individual mndertakes to convey to another a greater interest in the thing conveyed than what he possesses, the grantee may take that which was in his grantor. A. conveys to B. one hundred acres of land by metes and bounds. It is afterward ascertained that $\mathrm{C}$. has title to fifty of the one hundred acres included within the boundaries. IVill it be said that B. can take nothing by this deed? On the contrary, all the lands within the prescribed boundaries, to which A. had title, are, by the conveyance, rested in B. So far as the deed can have effect, so far it ought. The circumstance that the grantor has attempted to convey more land than he was possessed of, shall not prevent the deed from conveying that of which he was possessed. Upon the same principle, if $A$. and $C$. had been tenants in common of the same one hundred acres of land, and $\mathrm{A}$. had attempted to convey the whole in severalty to B. so far as A. had any interest, that interest would, by the conveyance, have bcen vested in B. Thus far the deed would take effect. Lnder it B. would become tenant in common with C. in the same manner he would have done had the conveyance from $\mathrm{A}$. been for an undivided moiety of the land.

These principles being applied to the case under consideration, it will be seen that the grantors of the lessor of the plaintiff, although they had not a several estate in the parcels of land by them to him conveyed, yet had an interest as coparceners, or tenants in common with others. That by the deeds of conveyance, this interest, what- 
ever it might be, was vested in the lessor of the plaintiff; and he being kept out of possession by the defendants, the action is well brought, and the plaintiff is entitled to a judgment. Let judgment, therefore, be entered accordingly. ${ }^{63}$

\section{SECTION 7.-REVERSIONS AND REMAINDERS}

\section{LEAKE, LAW OF PROPERTY IN LAND.}

If tenant in fee simple convey the land to a person for a particular estate only, as for an estate tail, or for term of life, or of years, there remains in him and his heirs an estate expectant, as to the possession, upon the determination of the particular estate. This estate is called the reversion, because the land then reverts or returns in possession to him or to his heirs. ***

In like manner, if the tenant of a particular estate convey the land for a less estate, he has a reversion left in himself. * * *

The grant of a particular cstate, leaving a reversion in the grantor, creates a tentre between the tenant of the particular estate and the reversioner. This tenure is not within the statute of Quia Eimptores, for that statute extends only to alienations in fee simple, preventing any new tenure arising upon such alienations. Hence rent reserved upon such a grant of a particular estate is of the nature of rent service, and is attended at common law with the remedy of distress. And a grant of the reversion impliedly carries with it all the incidents of the tenure. as the rent service, if any, unless there be an express exception of such incidents in the grant.

If tenant in fee simple convey a particular estate in the land to one person, and at the same time another estate, to commence in possession immediately upon the expiration of the particular estate, to another person, the latter estate is called, relatively to the prior particular estate, a remainder. Thus, if tenant in fee simple grant to A. for life, and after the determination of that estate to B. for life, the estate of $B$. is a remainder relatively to the estate of A. So, if the grant be made to A. for life, and after the determination of that estate to B. and to his heirs, $\mathrm{B}$. has a remainder in fee. In the former example there is a reversion in fee in the grantor; in the latter the whole fee is disposed of and there is no reversion. In like manner, several remainders may be created successively in the same land, either leaving a reversion or with an ultimate remainder in fee.

63 The dissenting opinion of Furnet, J., is omitted.

See Matter of Prentiss, 7 Ohio, 120, it. 2, $30 \mathrm{Am}$. Dec. 202 (1836); Barn-

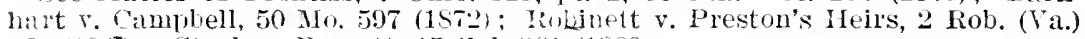
ZTS (1St) ; Stark v. Barrett, 15 Cal. :3(j1 (1860). 
If a grant be made to A. for life, and after the lapse of a day after his death to $\mathrm{B}$. for life or in fee, the limitation to $\mathrm{B}$. is not a remainder, because it does not commence in possession immediately on the determination of the particular estate; it is a limitation of a freehold estate to commence in futuro, which in a common law conveyance is void, and the reversion of A.'s estate remains in the grantor.

Also a limitation which is to take effect in defeasance of a preceding estate, without waiting for the regular determination of that estate according to the terms of its limitation, is not a remainder; and such a limitation is void at common law. But the preceding particular estate may be made determinable by a conditional limitation, and the estate limited to take effect in possession immediately upon its determination, whether that happen under the conditional limitation or by the expiration of the full term of limitation, is a remainder.

The particular estate and the remainder must be created at the same time by one conveyance or instrument; for if the particular estate be first created, leaving the reversion in the grantor, any subsequent disposition can be effected only by grant or assignment of the reversion; which is not thereby changed into a remainder, but still retains its character of a reversion, to which the tenure of the particular estate is incident.

A remainder which is certain as to the owner and absolute as to his estate or interest is a vested remainder; the remainderman is presently invested with a portion of the seisin or freehold, the whole fee being divided into a particular estate and remainder or remainders.

But a remainder may be linited to a person not yet ascertained, or to a certain person upon a condition precedent which may not happen until after the determination of the particular estate; and whilst such uncertainty lasts, as to the person or the interest, it is described as a contingent remainder. A contingent remainder becomes changed into a vested remainder by the owner becoming certain or the condition happening during the continuance of the particular estate.

According to Fearne: "A contingent remainder is a remainder limited so as to depend on an event or condition which may never happen or be performed, or which may not happen or be performed till after the determination of the preceding estate." And, as he afterwards explains: "It is not the uncertainty of ever taking effect in possession that makes a remainder contingent; for to that every remainder for life or in tail is and must be liable; as the remainderman may die or die without issue before the death of the tenant for life." The present capacity of taking effect in possession, if the possession were to become vacant, and not the certainty that the possession will become vacant, before the estate linited in remainder determines, universally distinguishes a vested remainder from one that is contingent.

The principle of the common law that the seisin of the freehold can never be in abeyance, but must always be vested in some determinate person inposed two rules upon the limitation and operation of con- 
tingent remainders: The first of which rules was that a contingent remainder of freehold must always have a particular vested estate of freehold to support it.

The other rule resulting from the principle above stated is: That a contingent remainder must formerly have become vested during the continuance of the particular estate or at the instant of its determination. If not then vested, it failed altogether, and the next limitation took immediate effect.

The limitation of a contingent remainder for life or in tail, as it conveys no estate, but only a possibility of an estate in a future event, does not interfere with the limitation of a vested estate of freehold in remainder; and upon the contingent remainder becoming vested during the continuance of the particular estate, the vested remainder will be postponed in interest.

Where there is a contingent limitation in fee absolute, no estate limited afterwards can be vested; but two or more several contingent remainders in fee may be limited as substitutes or alternatives one for the other, so that one only take effect, and each subsequent limitation be substituted for a former if it should fail of effect; and the inheritance in the meantime, if not otherwise disposed of, remains in the grantor and his heirs, or in the heirs of the testator until the contingency happens to take it out of them. Upon a devise of a contingent remainder in fee, the fee subject to the contingency will pass as a vested remainder under the will by a specific or residuary devise.

Randall's Ed., pp. 228, 229, 230, 231, 233, 234, 236, 237, 243, 244. 


\title{
CHAPTER VI
}

\section{COVENANTS FOR TITLE}

\author{
NOKE v. AIVDER. \\ (Queen's Bench. 1595. Cro. Lliz. 373, 436.)
}

Covenant. Wherein he shews that one John King made a lease for years to $A$. the defendant, who by deed granted it to Abel, and covenanted with him, that he and his assignees should peaceably enjoy it without interruption. Abel grants it to J. S. who grants the term to the plaintiff, who being ousted by a stranger, brings this action; and after issue joined upon a collateral matter, and after verdict for the plaintiff, it was alleged in arrest of judgment, that this action lay not for the second assignee, unless he could shew the deed of the first covenant, and of the assignment, and of every mean assignment; for without deed none can be assignee to take advantage of any covenant, which cannot commence without deed: and to that purpose cited Old Act, 102, and 19 Edw. II. "Corenant," 25. And if one be infeoffed with warranty to him his heirs and assignees, and the feoffee makes a feoffment over without deed, the assignee shall not take adrantage of this warranty, because he hath not any deed of assignment. But if he had the deed, it should be otherwise; and to that purpose vide 13 Edw. III. "Vouch." 17. 3 Edw. III. "MIonstrans de Fayts" 37. 11 Edw. IV. Ibid. 164. 15 Edw. II. Ibid. H. 13 Hen. VII. 13. \& 14. 22 Ass. plea SS. But Pormam held, that he shall have advantage without the deed of assignment; for there is a difference where a covenant is annexed to a thing, which of its nature cannot pass at the first without deed, and where not. For in the first case, the assignee ought to be in by deed, otherwise he shall not have advantage of the covenant; and therefore he denied the case of the feoffee with warranty; for the second feoffee shall have benefit of the warranty, although he doth not shew the deed of assignment, but shews the deed of the warranty; and so is the better opinion of the books. And to that opinion the other justices inclined. Sed adjournatur. Vide 3 Co. 63.

It was now moved again. And all the JUSTICES agreed, that the assignee shall have an action of covenant without shewing any deed of the assignment; for it is a covenant which runs with the estate; and the estate being passed without deed, the assignee shall have the bencfit of the covenant also; and the executor of the baron, who is as-ignee in law, who comes in without decd, shall have the benefit of such a corenant, as appears $30 \mathrm{Edw}$. 3. in Symkins Simonds' case. Ind Poptiam and FENNER held. that a feoffee shall vouch by a war- 
ranty made to his feoffor, without shewing any deed of assignnent; for the deed of assignment is not requisite, nor is it to any purpose to shew it; for it appears by the books, that being shewn, it is not traversable by the rouchee. And as a warranty or covenant is not grantable, nor to be assigned over without the estate; so when the estate passeth, although it be by parole, the warranty and covenant ensue it; and the assignee of the estate shall have the benefit thereof. Coke Attorney General (who was of counsel with the defendant) said, that the law was clear as you have taken it, yet the declaration is ill; for he declares, quod cum Johannes King, 10 Eliz. let that to the defendant for years, virtute cujus he was possessed, and granted it to Abel by indenture with the covenant, who in 15 Eliz. assigned it to the plaintiff: and further alledgeth, that long time before that the said J. K. had any thing, one Robert King was scised in fee, viz. 7 Eliz. and so seised, died seised in 15 Eliz. and it descended to Thomas King, who entered upon the plaintiff and ousted him; so he doth not shew that John King who made the lease had any thing; for Robert King was thereof then seised. And then when John King let to the defendant, and he granted his term by indenture, nothing passed but by estoppel; then the lessee by estoppel cannot assign any thing over, and then the plaintiff is not an assignee to maintain this action. But admitting that $J$. $K$. had at the time of the lease made by him, a lease for a greater number of years, and that Robert King had the freehold, and thereof died seised, and so all night be true which is pleaded; then the entry of Thomas King upon the defendant is not lawful. So quacumque via data, this action cannot be maintained. And this point for the case of estoppel was adjudged in this Court, in the case of Armiger v. Purcas, in a writ of error.

And all the Cour'T held here, that it was clear upon the matter shewn. that the action lay not: for the plaintiff ought to have shewn an estate by descent in J. King, at the time of the lease and assignment made, or an estate whereby he night make a lease, and that this was afterwards determined; and so confess and avoid the estate in the lessor, otherwise this action of corenant lieth not: and it never lies upon the assignment of an estate by estoppel. Wherefore they were of opinion to have then given judgment against the plaintiff; but afterward they would advise until the next term.

Note. This was continued until Trin. 41. Eliz. and then being noved again, all the justices resolved, that the assignee of a lease by estoppel, shall not take adrantage of any covenant; but that it shall not be intended a lease by estonpel, but a lawful lease. But no sufficient title being shewn to avoid it, it is then as an entry by a stranger without title, which is not any breach. Wherefore it was adjudged for the defendant. ${ }^{1}$

1 In an action of corenant for nomparmont of lent ly the assionee of the lessor against the lessee the plaintilf in his dechration alleg'd selsin in fee in the lessor at the time of making the indenture of lease, the execution of saitl 


\section{BEDDOE'S EX'R v. WADSWORTH.}

(Supreme Court of New York, 1S39. 21 Wend. 120.)

Demurrer to declaration. This was an action on covenants of warranty and for quiet enjoyment, contained in a deed of land, dated July 7 th, 1797, executed by the defendant to John Johnston. Each count (there being six in all) averred that afterwards, viz. on the same day, the defendant by Johnston's direction, and with his consent, surrendered possession of the land to the testator, John Beddoe, who continued in possession until Johnston, on the 16th August, 1802, by indenture, in consideration of one dollar, therein expressed as in hand paid by Beddoe, did "remise, release, and forever quit claim unto the said John

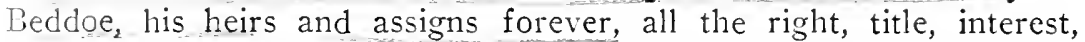
claim or demand, which the said John Johnston, \&c. had in or to the said tract, \&c. to have and to hold the said tract, \&c. unto the said John Beddoe, his heirs and assigns forever, to his and their own proper use, benefit and behoof, \&c." Each count stated an eviction from part of the premises, while in possession of persons claiming under John Beddoe, the plaintiff's testator, and during the lifetime of the testator. The eviction was alleged to have been in virtue of a title in one Rachel Malin. All the counts except the sixth stated this title to be paramount to the defendant's; and all except the fifth averred that the plaintiff, as executor, had thereby incurred damages and costs. The fifth count averred that the testator in his lifetime, and the plaintiff since his death, had been obliged to pay them.

The first and second counts averred that the defendant's deed to Johnston was given to and received by Johnston for and in behalf of Beddoe, the testator, and for his benefit.

All the counts except the third, concluded as for a breach of the covenant for quiet enjoyment only; the third was for a breach of the covenant of warranty only. But the deed as set forth in each count in fact contained covenants of seisin, of warranty, for quiet enjoyment, and further assurance. The defendant demurred to each count.

CowEs, J. If the covenants of warranty and for quiet enjoyment passed by the quitclaim deed from Johnston to the plaintiff's testator, the right of action sought to be shown by the declaration seems to be clear in all the counts except the sixth. This count is defective in not averring that the eviction was by a title paramount to that of the defendant. Webb v. Alexander, 7 Wend. 281; Luddington v. Pulver, 6 Wend. 404 to 406; Greenby v. Wilcocks, 2 Johns. 1, 3 Am. Dec. 379;

ind enture, the assimment hy the lessor, and the breach. To a plea alleging that frior to the maling of said lease the lessor lad conresed the premises in fine aml that thereafter the lessor has no interest therein, there was a demurrer. 'The demurrer' was sustained. Palmer v. Lkins, 2 Ld. Raym. 1550 (172s). Sre cuthbertson $v$. Irving, 4 H. \& N. 471 (1559) acc.

Nolie $\because$. dwder was approved in Neslit v. Montgomery, 1 N. C. 181 (1S00), ant in Martin v. Gordon, 24 Ga. 593 (155s). 
Ellis v. Welch, 6 Mass. 246, 4 Am. Dec. 122; per Savage, Ch. J., in Rickert v. Snyder, 9 Wend. 421, 422; 4 Kent's Comm. 479, 3d Ed. Non constat but Rachel Malin may have proceeded to eviction upon a right derived from Jolnston or the testator himself. In the other five counts, however, there is enough to show that during the life time of Beddoe the testator, he either became personally liable on covenants to his grantees as to a part of the premises from which they were evicted by a title superior to the defendants, or suffered an injury in an eviction of lis tenant by a like superior title. Then it is averred either that the plaintiff was compelled to pay damages and costs as executor, or, according to the fifth count, the testator in his life time was obliged to pay a part, and the plaintiff another part after his death. In either case, the right of action pertained to the testator personally. The covenant was broken by the eviction, and the whole damages were due Hosmer, Ch. J., in Mitchell v. Warner, 5 Conn. 504 to 506, the right to which passed on his death, not to his heir, but to his personal representative. Hamilton v. Wilson, 4 Johns. 72, 4 Am. Dec. 253. A covenant real ceases to be such when broken, and no longer runs with the land. It would not go to the heir by death, for the same reason that it could no longer follow the land into the hands of a devisee or grantee. See Markland v. Crump, 18 N. C. 94, 101, 27 Am. Dec. 230; Kingdorn v. Nottle, 1 . Maule \& Sel. 355; s. c., 4 Maule \& Sel. 53.

This view of the case disposes of all the minor objections raised by the demurrers. There must be judgment for the defendant on the sixth count, and for the plaintiff on all the others, unless either the first or second point taken by the defendant's counsel is sustainable. These are each applicable to the remaining five counts.

The first point is, that it appears from five of the counts, that when the defendant conveyed to Johnston, he, the defendant, had no title; and as no estate therefore passed to the plaintiff's testator, the covenants were not assigned; that covenants pass only as incidents to an estate; and if there be none, the covenants cannot be said to be annexed to an estate, much less to pass with it. The point seems to suppose that these covenants can never be transferred where there is a total want of right in the original covenantor, though his deed transfer the actual possession. It seizes on the phrase in 4 Kent's Comm. 471, note b, 3d Ed., and other books, "that they cannot be separated from the land and transferred without, but they go with the land as being annexed to the estate, and bind the parties in respect to privity of estate." No New York case was produced which denies that they pass where the possession merely goes from one to another by deed, and there is afterwards a total failure of title; but there are several to the contrary. Withy v. Mumford, 5 Cow. 137; Garlock v. Closs, 5 Cow. 143, n. And see Markland v. Crump, 18 N. C. 94, 27 Am. Dec. 230; Booth v. Starr, 1 Conn. 244, 248, 6 Am. Dec. 233. AIG.Prop. 47 
Nor, when we take the word estate in its most comprehensive meaning, can it be said there is none in such a case to which the covenant may attach. It is said by Blackstone to signify the condition or circumstance in which the owner stands with respect to his property, 2 Black. Comm. 103, and a mere naked possession is an imperfect degree of title, which may ripen into a fee by neglect of the real owner. Id. 195, 6 . It is, in short, an inchoate ownership or estate with which the covenants run to secure it against a title paramount; and in that sense is assignable within the restriction insisted upon. It is said in seyeral cases that the covenants of warranty and quiet enjoyment refer emphatically to the possession and not to the title. Waldron v. McCarty, 3 Johns, 471, 473, per Spencer, J.; Kortz v. Carpenter, 5 Johns. 120. The meaning is, that however defective the title may be, these covenants are not broken till the possession is disturbed. When the latter event transpires, an action lies to recover damages for the failure both of possession and title according to the extent of such failure.

The case of Bartholomew v. Candee, 14 Pick. (Mass.) 167, was mainly relied upon in support of the ground taken by the first point. All that case decides is, that a covenant no longer runs with the land after it is broken. The declaration was by the grantee of one Thorp, to whom the defendant had conveyed in fee with covenants of seizin and warranty; and breaches were assigned upon both. The defendant pleaded and the jury found, that before the defendant conveyed to Thorp, he had conveyed to one Sparks, who entered and died actually seized, leaving the land to his children, who were still actually seized when the defendant conveyed to Thorp. Mr. Justice Wilde arrives at the conclusion that the covenant of seizin was broken before the deed from Thorp to the plaintiff; and adds: "This point being established, it is perfectly well settled that no action will lie on this contract in the name of the assignee. By the breach of the covenant of seizin, an action accrued to the grantee, which being a mere chose in action, was not assignable." He does not notice the covenant of warranty, but seems to consider the claim under that as standing on the same ground; which I think might well lie under the pleas as found by the jury. The fair import of these was, that neither Thorp nor the plaintiff ever had possession; so that, according to some cases, the covenant of warranty was also immediately broken; Duvall v. Craig, 2 Wheat. 45, 61, 62, 4 L. Ed. 180; Randolph v. Meek, Mart. \& Y. (Tenn.) 58; and according to our own it never could have any effect. No possession ever having been taken under the deed, there could be no actual eviction, which is said to be essential to a recovery upon a covenant of warranty. Webb v. Alexander, 7 Wend. 281 to 284 , and the cases there cited; Jackson, ex dem. Montresor, v. Rice, 3 Wend. 180, 182, $20 \mathrm{Am}$. Dec. 683, per Savage, Ch. J.; Vanderkarr v. Vanderkarr, 11 Johns. 122. See a very full collection and consideration of the cases to this point, both as it respects the covenant of warranty and for quict enjoyment, by Hosmer, Ch. J., in Mitchell v. Warner, 5 Conn. 
521 to 526. That an unbroken covenant of warranty shall run with the possession of the land, was not questioned by counscl or court in Bartholomew v. Candee, nor was it in a subsequent and similar case, Wheelock v. Thayer, 16 Pick. (Mass.) 6S, also relied upon.

I have looked through the other cases cited by the counsel for the defendant, and they all go to the point, either that a covenant broken ceases to be assignable, or that covenants in gross are not so. These positions are indisputably settled; and we have adopted the first, in order to show that this action was properly brought by John_Beddoc's executor instead of his heir. I do not except from this remark the case of Andrew v. Pearce, 4 Bos. \& Pull. 158. It is true that was an action on covenants both that the defendant had authority to demise and for quiet enjoyment. The title failed before the plaintiff took an assignment; he entered and was ousted; and it was held that he could not recover, because the mere failure of the title broke the covenants. Mansfield, Ch. J., said expressly, the assignor had only a right of action left, which he could not assign. It would seem by this case that, in England, a simple failure of title, without eviction, would be a breach of the covenant for quiet enjoyment. With us the doctrine is clearly otherwise. Kortz v. Carpenter, 5 Johns. 120; Norman v. Wells, 17 Wend. 160, and the cases there cited. And see Mitchell v. Warner, 5 Conn. 497, 522, and the very full reference there to the New York cases. In Andrew v. Pearce, the lease was treated as totally gone, by a failure of the title; whereas there was still a continuing possession, till the plaintiff was ousted, and then and not till then, according to our cases, was the covenant for quilet enjoyment broken. There is a difference in more respects than one between our own and the English cases as to what shall constitute a breach of the covenants of title, so as to take away their assignable quality. Even a corenant of seizin, made and broken in the same breath, is there held to run with the land, till actual damages are sustained by the breach. Kingdorn v. Nottle, 1 Maule \& Sel. 355; 4 Maule \& Sel. 53. Kent's Comm. $471,2,3 \mathrm{~d}$ Ed., says the reason assigned for the decision is too refined to be sound. The case is followed by Backus' Adm'r v. McCoy, 3 Ohio 211, 17 Am. Dec. 585; but severely criticised in $\lambda$ Iitchell v. Warner, 5 Conn. 497 to 505; Kent's Comm. ut supra, note a.

But secondly, if the covenant be in its own nature available to the assignee as a protection against the total failure of the defendant's title, and if it be assignable by a grant of the land, it is insisted that none of the counts in the declaration show that such a grant was made from Johnston to the plaintiff's testator. All the counts stop with averring that Johnston, for the consideration of one dollar, remised, released and forever quit-claimed to the testator in fee. Technically, these are but words of release; and as no previous lease from Johnston to the testator is shown, it is supposed that the granting words are inoperative. This objection supposes that the words used cannot carry the estate except as part of a conveyance by lease and 
release; and that, in order to give them effect, a lease should be shown, either by its production and proof, in the usual way, or its recital in the release; and this formal strictness would seem still to prevail in England. Doe, ex dem. Pember, v. Wagstaff, 7 Carr. \& Payne, 477. In Bennett v. Irwin, 3 Johns. 365, 366, Van Ness, J., said, a mere release or quit-claim, unless the releasee is in possession, is void. But the declaration, in the case at bar, shows that the grantee was in possession. Even this strictness was, however, totally exploded, by the case of Jackson, ex dem. Salisbury, v. Fish, 10 Johns. 456, the operative words as set forth in the declaration being held of themselves sufficient to raise and execute a use under the statute. The conveyance was there held good as a bargain and sale. Had that case occurred to counsel, we should doubtless have been saved the examination of this objection; for we do not remember its being denied on the argument that words which are sufficient to pass a fee in conveyancing are equally sufficient in pleading by way of averment.

The demurrers are overruled as to all the counts except the sixth, and the judgment must be given for the plaintiff.

The demurrer to the sixth count is well taken, and judgment must be given for the defendant as to that count, with leave to both parties to amend. ${ }^{2}$

\section{SOLBERG v. ROBINSON.}

(Supreme Court of South Dakota, 1914. 34 S. D. 55, 147 N. W. 87.)

Polder, J. On the 27 th day of January, 1906, one C. C. Robinson and wife executed and delivered to W. J. and J. L. Smith a certain warranty deed. purporting to convey to said Smiths, with other property, a quarter section of land in Hughes County. On the 9th day of January, 1907, said Smiths executed and delivered to plaintiffs a warranty deed, purporting to convey said land to plaintiffs, but neither the Robinsons nor the Smiths were ever in the actual possession of the

2 See Dickinson v. Hoomes' Adm'r, S Grat. (Va.) 406 (1852) ; Slater v. Raw'son, 1 Mete. (Mass.) 450 (1840), s. e. 6 Metc. (Mass.) 439 (18-13), ace.

See, also, Dickson r. Desire's Adm'r, 23 Mo. 1.1, 66 Am. Dec. 661 (1856); Backus' Adm'rs r. MeCoy, 3 Ohío, 211, 17 Am. Dec. 585 (1827).

A., the ormer of premises, lived thereon with her husband, he pasing the taxes and looking after repairs, etc. Both jomed in a deed conveying the premises to $\Gamma$. the deed containing corengnts by them that she was seized, also for quiet enjoyment and general warrant. $\mathbf{X}$. convesed to $\mathbf{Y}$., who, after eviction, sued $A$. and $B$. on the corenants. Should there be a recovery?

That should be the result where the sponse sought to be held liable by the assisnee of the covenantee had an inchoate dower interest in the premises? See H. T. \& C. Co. F. Whitehouse (Utah) 154 Pac. 950 (1916).

A converance with marranty is made by one not in possession; the corenantee coes into possession and convers to the plaintiff, who is ericted. Should the covinintor be held liable on the covenant? See Wead v. Larkin, 54 Inl. 489 , 5 Am. Rep. 149 (1570); Tillotson v. Prichard, $60 \mathrm{Vt} .9 \pm, 14$ Atl. 302,6 Am. st. Rep. $0 \div(1857)$. 
land. Thereafter, one Vesey commenced an action against plaintiffs for the purpose of quieting title to said premises and to enjoin plaintiffs in this action from asserting further claim thereto. Said action was defended by plaintiffs but, on the trial, it developed that, from a time long prior to the attempted conveyance from the Robinsons to the Smiths and down to the time of the trial, said Vesey was the absolute owner in fee of the land in question; that, while Robinson's title appeared to come through Vesey, the deed which purported to divest him of his title proved to be a forgery and he had judgment as prayed for. Upon appeal to this court, said judgment was affirmed. Vesey v. Solberg, 27 S. D. 618, 132 N. IV. 254.

In the deed from Robinson to the Smiths, Robinson and wife covenanted /vith the Smiths: "Their heirs and assigns that they are well seized in fee of the lands and premises a foresaid and have good right to sell and convey the same in manner and form aforesaid," and that "the above bargained and granted lands and premises in quiet and peaceable possession of the said parties of the second part, their heirs and assigns, and against all persons lawfully claiming or to claim the whole or any part thereof the said parties of the first part will warrant and forever defend." The deed from the Smiths to plaintiffs contained covenants of similar import.

After the affirmance of the judgment quieting title to the said premises in Vesey, plaintiffs commenced this action against the defendant as administrator of the estate of the said C. C. Robinson, who had died in the meantime, for the purpose of recovering on the abore quoted covenants in the Robinson deed of January 27, 1906. During all of this time, the land in question was vacant and unoccupied. The Smiths were named as defendants in the summons, but only one of them was ever served, and as to him, the action was dismissed. Plaintiff seeks to recover the amount Robinson had received for the land with interest, together with the expenses necessarily incuried in defending the Vesey case in the circuit court, upon appeal to this court and upon motion for rehearing, including attorney's fees for conducting all of these proceedings. Plaintiffs had judgment in the circuit court for $\$ 1183.98$. From this judgment and the order denying a new trial, defendant appeals.

(1) It is contended by appellant that, as Robinson had neither possession nor right of possession at the time he executed the deed to the Sniths, the covenants sued upon were broken as soon as made and, therefore, did not run with the land nor inure to the benefit of his remote grantees. As to the covenant of seizin, this contention is undoubtedly correct. Our statute, section 1139, Civ. Code, enumerates certain covenants as those which run with the land, but no mention is made of the covenant of seizin, and this covenant does not run with the land: Gale v. Frazier, 4 Dak. 196, 30 N. W. 138.

Under a statute like ours it would appear that it is only the immediate grantee of the covenantor who can recover on this covenant. Plain-
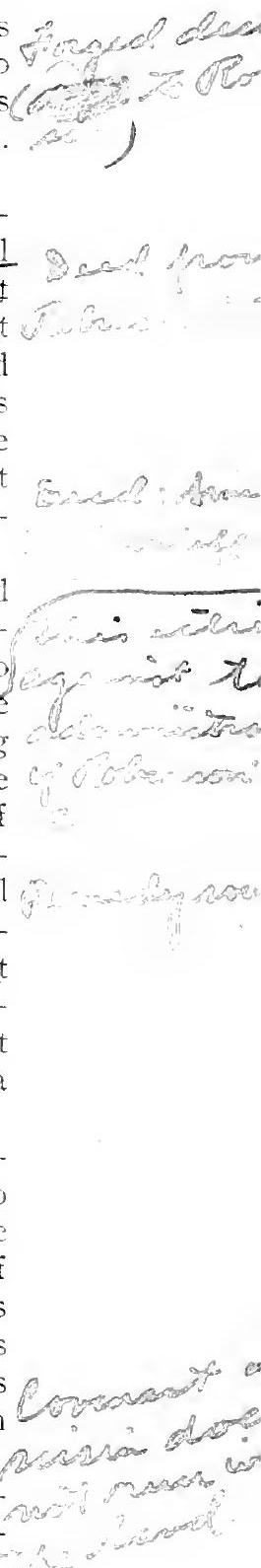
tiffs could have recovered from the Smiths upon the breach of this covenant, and they, in turn, could have recovered from defendant, provided they brought their action within the period of the statute of limitations. 3 Wash. Real Property (5th Ed.) 504. But there was no such privity of contract between plaintiffs and defendant's intestate as would entitle them to recover against defendant.

(2) The other covenant set out in plaintiff's complaint (that of quiet enjoyment) presents a different proposition. By express statute, this covenant does run with the land: Civ. Code, $\S 1139$. This covenant is made for the benefit of remote as well as immediate grantees, and, unless there is something in the facts connected with this case to relieve appellant from liability on the covenant, the plaintiff is entitled to recover, and the judgment should be affirmed. This is conceded by appellant, but, to avoid liability, he contends that, because his intestate had no estate whatever in the premises at the time of making the covenant, and because his intestate's grantee did not go into possession of the land, there was nothing to which the covenant could attach to carry it to the covenantor's remote grantees. He also contends that, the covenantor having neither possession nor right of possession at the time he made the covenant, a constructive eviction took place at once and that the covenant immediately ripened into a cause of action in favor of his covenantee that neither ran with the land nor passed to his covenantee's grantee, and that, in any event, more than six years had elapsed since the breach of the covenant and plaintiffs' action is barred by the six years statute of limitations. In other words, that, in this particular case, the effect of both covenants is exactly the same, and plaintiffs are not entitled to recover on either. If appellant's position is correct, the covenant for quiet enjoyment contained in the Robinson deed conld never, under the facts in this case, become the basis for a recovery by anyone except his immediate grantee. Although the deed purporting to divest Vesey of his title was a forgery and conveyed no title in fact, it appeared upon its face to be a valid conveyance and the apparent chain of title from Vesey to plaintiffs was perfect. For aught plaintiffs knew, or could know until Vesey asserted his title, they were the absolute owners of the fee and could have gone into the physical possession of the land at any time.

Supposing plaintiffs had taken possession and afterward had learned the facts relative to the title to the land, and, before they had been disturbed by Vesey, had brought this stit against defendant for breach of the covenant for quiet enjoyment, he could have said: "You have not been disturbed in your rightful possession of the land and you may never be disturbed. While your deed may not be good, it is yet color of title, and if you are not disturbed by Vesey within the time for bringing an action for that purpose, your present title, although defective, will ripen into a title that can never be disturbed by anyone. In other words, you have no cause of action until you have been actually ousted by a decree of court." This would be a complete defense 
to plaintiff's demand, or the most they could recover would be nomiral damages only.

That the proposition that covenants found in deeds purporting. to convey title to land do not run with the land unless the covenantor was possessed of some estate in the land to which the covenant could attach is supported by many, if not the great weight of, judicial decisions is not questioned. Notable among the more recent decisions to this effect is Bull v. Beiseker, 16 N. D. 290,113 N. W. 870, and reported with an extended note, in 14 L. R. A. (N. S.) 514; Mygatt v. Coe, 147 N. Y. 456, 42 N. E. 17, a New York case; and Wallace v. Pereles, 109 Wis. 316, 85 N. W. 371, 53 L. R. A. 644, 83 Am. St. Rep. 898.

In Bull v. Beiseker, supra, the court said: "The action was brought and the complaint framed upon the mistaken theory that the covenants contained in defendant's deed to Johnson were covenants running with the land, and therefore passed to Washburn by the deed from Johnson to him. This probably would be true if any title or possession was transferred by such conveyances; but, under the facts alleged in the complaint, neither title nor possession, actual or constructive, passed under the deeds, and hence there was nothing for the covenants to run with There was a constructive eviction of the grantee immediately upon the execution and delivery of the deed to Johnson; and a cause of action for breach of the covenants in such deed at once arose in his favor against the Beisekers to recover damages therefor; and the deed from Johnson to Washburn did not operate to assign to the latter such cause of action."

And in Wallace v. Perles, supra, the Wisconsin court said: "We therefore hold that where the record shows that the grantor had no title and no possession, and there is no proof that the grantee took possession, the covenants of the grantor are personal to the grantee, and are not transmitted to subsequent grantees by a mere conveyance of the land."

And, again, in Mygatt v. Coe, supra, we find: "It must be regarded as the law of this case that privity of estate is essential to carry covenants of warranty and quiet enjoyment to subsequent grantees in order to support a right of action by them against the original covenantor, when there is an eviction by paramount title."

These cases are fully supported by very many, if not all, of the preceding decisions on the same subject.

The covenants usually found in deeds of conveyance of real property, are the subject of legislative enactment in many of the states. Our statute, section 1138, Rev. Civ. Code, reads as follows: "Every covenant contained in a grant of an estate in real property, which is made for the direct benefit of the property, or some part of it then in existence runs with the land." Section 1139: "The last section includes covenants of warranty, for quiet enjoyment, or for further assurance, on the part of a grantor * * *."

But these statutes do not seem to have changed the rule that, in 
order that the covenant will run with the land so as to inure to the benefit of a remote grantee, the covenantee must have received some estate in the land to which the covenant could attach.

It seems to be generally held that, where the covenantor delivers the possession of the land to his grantee and he, in turn, puts his grantee in possession, this constitutes a privity of estate sufficient to carry the covenant with the land. And it may be taken as true that the reason for the rule originated at a time when physical possession of land was the chief muniment of title thereto. But this reason no longer exists. A person who has a grant of land from the owner of the fee becomes the absolute owner thereof and is entitled to all the benefits that can be derived therefrom, even though neither of them was ever in the actual possession thereof. This being the case, why should it be necessary that actual, as distinguished from constructive, possession should be delivered in order to carry a covenant with the land when the covenantor was without title? It is for the purpose of protecting the covenantee and his grantees in their right of possession of the land, and to protect them against defective title thereto that the covenant is made. The right of quiet enjoyment of a piece of land is its most valuable attribute, and a covenant from a grantor that his grantee shall be protected in the quiet enjoyment thereof adds materially to the value of the land itself, and a material portion of the consideration paid for the grant may be, and as a rule is, paid because of the covenantee's expectation of the right of quiet enjoyment of the demised premises. If a perfect title is passed to the grantee then he need never avail himself of the covenant in his deed, while, on the other hand, if it should develop that the covenantor had no estate whateyer in the premises attempted to be conveyed, the grantee conld not, except as against his immediate covenantor, avail himself of the covenant This, at least, is the logical conclusion to be drawn from the decisions holding that a remote grantee cannot recover upon a covenant unless the covenantor had some estate in the land when the covenant was made.

Some cases, notably Kimball v. Bryant, 25 Minn. 496, and Iowa Loan \& Trust Co. v. Fullen, 114 Mo. App. 633, 91 S. W. 58, hold that, although a covenantor must have some estate in land at the time of making the grant to which covenants can attach in order to enable a remote grantee to recover on a breach of the covenant, yet, nevertheless, such grantee, however remote, who is holding under said grant at the time of the assertion of, and eviction under, the paramount title, may recover the damages occasioned by the lack of title. This is upon the ground that the covenant was broken as soon as made and at once ripened into a chose in action in favor of the covenantee, and that the transfer of the land by successive warranty deeds passed this cause of action along through the successive grantees until such time as an actual eviction by paramount title took place, when the party who suffered damage by reason thereof might enforce the cause 
of action that accrued in favor of the first grantee against the original covenantor. Against this doctrine, this court is already committed. Hill v. City, 33 S. D. 324, 145 N. W. 570 . We believe plaintiffs should recover; but we think they should recover as upon the covenant itself, rather than upon successive assignments of a cause of action that had accrued in favor of some prior grantee. Under the theory adopted by the Missouri and Minnesota courts, unless the eviction take place and the action be commenced within the period prescribed by the statute of limitations for bringing such action, then the right to recover will be barred by the statute, and the party who is holding under the grant at the time of the eviction and the one who suffers the real damage cannot reach the covenantor at all. Iowa L. \& T. Co. v. Fullen, supra.

(3) But, again, since it is held that a delivery of the possession of the disputed premises is necessary in order that the covenant of a grantor without title may inure to the benefit of his remote grantees, then the constructive possession of the grantee ought to be sufficient to carry the covenant. In this case, while the Smiths acquired no title to the land by virtue of their deed from the Robinsons, still they had the apparent title even as against Vesey himself. The county records showed that they had a perfect chain of title, and, therefore, the Smiths and their grantees (plaintiffs in this action), as against the defendant should be held to have had constructive possession of the granted premises, and that plaintiffs are entitled to recover against the defendant because of the eviction by Vesey. This, of course, involves the doctrine of estoppel by deed; and we believe this to be a proper case for the application of this doctrine.

The rule of estoppel by deed is stated in 16 Cyc. 686, as follows: "A person who assumes to convey an estate by deed is estopped, as against the grantee, to assert anything in derogation of the deed. $\mathrm{He}$ will not be heard, for the purpose of defeating the title of the grantee, to say that at the time of the conveyance he had no title, or that none passed by the deed; nor can he deny to the deed its full operation anc effect as a conveyance."

Where a grantor represents himself as the owner of the fee to a piece of land and agrees that he will protect his grantee and assigns in their peaceful possession thereof, and it afterward develops that he was not the owner of the fee and cannot defend his grantees in their possession of the land, and they call upon him to respond in damages, why should he not be estopped from saying that he did not have, and convey the constructive possession of the land as he represented he had and for which he had received a valuable consideration, and that, therefore, his covenant did not pass beyond his immediate grantee and that he is not liable to the party who has suffered by his broken covenant? And why should the rule just quoted not apply?

True, no case has been called to our attention where a covenantor has been held to be estopped by his deed from claining that he had no
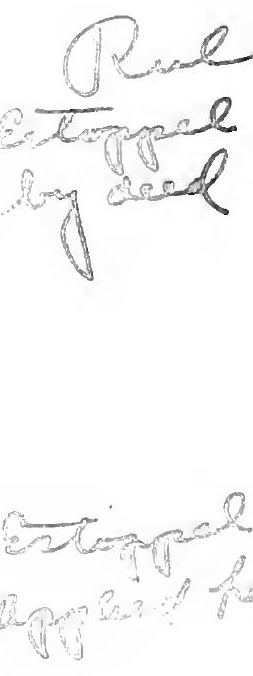
estate in the land, attempted to be conveyed, at the time he made the covenant, and thereby escape liability to a remote grantee who had been evicted; but neither has any reason been suggested why this should not be done; and we hold that the defendant is estopped by the covenants in his intestate's deed from denying that his intestate possessed any estate in the land in question at the time the deed was made; and that respondent is entitled to recover upon the broken covenant. ${ }^{3}$.

The judgment should be modified in regard to the amount of interest allowed respondents as herein indicated, and as so modified it is affirmed.

\section{ANDREW v. PEARCE.}

(Court of Common Pleas, 1S05. 1 Bos. \& P. N. R. 158.)

Covenant. The declaration stated, that by indenture, dated the 25 th of February, 1764, P. Best, the Defendant's testator, demised to one John Garland and his assigns a certain messuage and tenement, commonly known by the name of Lower Bofindle, in the county of Cornwall, for the term of 99 years, at the yearly rent of $f 4$. per annum, covenanting that he, the said P. Best, at the time of the grant and demise, had in himself good, right, and lawful and absolute authority to grant and demise the said premises; and also for the quiet enjoyment of the said John Garland, his executors, administrators, and assigns, during the said term, without the let, hindrance, molestation, or denial of him the said P. B., his heirs and assigns, and of all and every other person whatsoever; that, by virtue of the said demise, the said John Garland, on the 25th of February, 1764, entered into the said premises and became possessed thereof, and that afterwards, viz. by deed of the 22d of June, 1791, he assigned to one John Bennett, his executors, administrators, and assigns the said demised premises for the residue of his, the said John Garland's, term therein; that John Bennett accordingly entered, and afterwards, viz., by deed of the $2 \mathrm{~d}$ of November, 1801, assigned to the Plaintiff, his executors, administrators, and assigns the said premises for the remainder of the said term then to come and unexpired; that the plaintiff accordingly entered and was possessed thereof until ejected therefrom.

The declaration then alleged, "that the said P. Best deceased, at the time of making the said indenture of lease, had not, nor had he, at any other time whatsoever, any right, or title to the said demised premises, with the appurtenances, or any party thereof, in him, the said $P$. Best deceased, in his life time, or any authority whatsoever, whereby or by virtue whereof, he, the said P. Best deceased, might or could lease or demise the said demised premises, or any part thereof, with the

${ }^{3}$ A portion of the opinion dealing with matters of damages is omitted. 
appurtenances, or any part thereof, to the said John Garland, to hold the same, or any part thereof, to him the said John Garland, his executors, administrators, or assigns, from the said 24th day of February, 1764, for, and during, and unto the full end and term of 99 years from thence next ensuing, and fully to be complete and ended; and that after the maliing of the said demise by the said P. Best, deceased, and after the said Plaintiff became such assignee of the said demised premises as aforesaid, and during the continuance of the said term, to wit, on the 1st day of January, in the year of our Lord 1802, at Bodmin aforesaid, in the county of Cornwall aforesaid, the said Thomas Pearce became and was lawfully and rightfully entitled to have and enjoy the immediate possession of the said demised premises, with the appurtenances, under and by virtue of a title thereto, in opposition to the said title of the said Plaintiff to the possession thereof; and the said Thomas Pearce being lawfully and rightfully entitled to the said immediate possession of the said demised premises, with the appurtenances of the said Thomas Pearce, afterwards and while the said Plaintiff so was in possession of the said demised premises, with the appurtenances, and before the expiration of the said term of 99 years thereof demised by the said P. Best deceased as aforesaid, to wit, on, \&c." proceeding to state an ejectment for the premises by 'T'. Pearce, and judgment against the present Plaintiff, and writ of possession in consequence; and concluded that the said P. Best, deceased, in his life time, and the said T. Pearce, executor as aforesaid, since his death had not kept their covenant with the Plaintiff since he became assignee of the covenant made by the said P. Best, in his life time, with the said John Garland and his assigns.

The Defendant pleaded, "that the said P. Best, mentioned in the said declaration, at the time of making the said indenture of demise therein mentioned, and from thence until and at the time of his death hereinafter mentioned, was seised in his demesne as of fee tail male of and in the said tenements, with the appurtenances, mentioned in the said declaration and in the said indenture of demise, that is to say, to him and the heirs male of his body lawfully issuing, and being so seised thereof, he, the said P. Best, afterwards and before the making of the said supposed indenture of assignment between the said John Bennett and the said Plaintiff, also mentioned in the said declaration (to wit), on the 4th day of June in the year of our Lord 1794, at, \&c., died so seised of such his estate of and in the said tenement with the appurtenances without heir male of his body lawfully issuing; and so the said Defendant says that before the making of the said indenture of assignment between the said John Bennett and the said Plaintiff (to wit) on the said 4th day of June in the said year of our Lord 1794, upon the death of the said P. Best, the said term of years in the said tenements, with the appurtenances, granted by the said indenture of demise mentioned in the said declaration, and the estate and interest of the said John Bennett in the same tenements, ceased, and became and 
were wholly void, ended, and determined." To this plea the Plaintiff demurred, and the Defendant joined in denaurrer.

Sir James Mansfieid, Ch. J. This is an action of covenant, and the declaration states that Peter Best in 1764 demised the premises in question for 99 years to John Garland, and covenanted that he had good right to make such demise, and that Garland shonld quietly enjoy the premises during the said term; that Garland in 1791 assigned to Bennett, and Bennett in 1801 assigned to the Plaintiff, who was ejected by Thomas Pearce under a title superior to that of Peter Best. The plea states that Peter Best, at the time of the demise, was seised of the premises in tail male, and before the assignment by Bennett to the Plaintiff, died so seised without heirs male of his body, whereupon the term of years ceased and determined. Upon these pleadings, it is clear that Peter Best had no power to make a demise of these premises to continue for 99 years if he should die without issue male; but that it was a gocd lease so long as he should live, and he might have lived till the end of 99 years. On this demurrer every fact is admitted; it is clear therefore that at the time when Bennett assigned to Andrew, Bennett had no interest in the premises; the lease is stated to have become absolutely void by the death of Peter Best without heir male. The lease then having become absolutely void, what could be the operation of the assignment by Bennett to Andrew? He could neither assign the lease nor any interest under it because the lease was gone. What right of any sort had Bennett? If any thing, it could only be a right of action on the covenant, and that could not be assigned by law. As the person who made the assignment had no interest in the premises, the assignment itself could have no operation. Consequently there is no ground upon which the present action can be maintained, and therefore judgment must be given for the Defendant.

Judgment for the Defendant.

\section{IVILLIAMS v. BURRELL.}

(Court of Common Pleas. 1StJ. 1 C. B. 402.)

Tindal, C. J.4 The material facts out of which the questions sent to us by his honour the Master of the Rolls have arisen, are very few. George O'Brien, Earl of Egremont, being tenant for life, with a leasing power, by indenture of lease, bearing date the 24th of March, 1805, demised to John Williams, the plaintiff, for ninety-nine years, if three persons therein-named should so long live; which lease, upon the death of the tenant for life was held to be void as against the remainder-man, by the judgment of a court of law, on the ground that it was not made in due conformity with the leasing power. This lease contained in it a clause in the following terms; viz. "And the said earl, for himself, his

4 A portion of the opinion only is printel here. 
heirs and assigns, the said demised premises, with the appurtenances unto the said John IVilliams, his executors, administrators, and assigns, under the rent, covenants, conditions, exceptions, and agreements before expressed, against all persons whatsoever lawfully claiming the same, shall and will during the said term warrant and defend." And upon this state of facts the question is, whether the original lessee can maintain covenant against the executors of the tenant for life, upon the clause of warranty above set forth,

And a second question is then put to us, namely, whether in the case of another lease granted precisely under the same circumstances, and in the same form, the executors of the assignee of the original lessee can maintain such action.

As to the question arising on the second lease, we think that the executor of the assignee of the lessee has the same right of suing on this covenant as the original lessee.

In Spencer's Case, 5 Co. Rep. 16a, fourth resolution, it was held that a covenant in law for title would pass with the estate; and there is neither principle nor authority to shew that an express covenant, either for title or quiet enjoyment, will not equally pass, and be available for the assignee of the lessee, or the executor of such assignee.

And, although in Andrew v. Pearce, 1 New Rep. 158, it was held that no action was maintainable upon the covenant for quiet enjoyment by the assignee of the lessee against the executor of the lessor; yet that was expressly on the ground that the lease had become absolutely void by the death of the lessor before the assignment made to the plaintiff; a fact which does not occur in the present case.

\section{BEARDSLEY v. KNIGHT.}

(Supreme Court of Vermont, 1832. 4 Vt. 471.)

This was an action of covenant, and the declaration contained two counts. The first alleged that the defendant and one Elijah Hyde, deceased, on the 3d day of March, 1808, for the consideration of eighteen hundred dollars, by deed of that date, duly executed, acknowledged and recorded, according to law, conveyed to Ebenezer Hatch, his heirs and assigns, the undivided half of a certain piece or farm of land, lying in the town and county of Grand-Isle, to wit, the first division lots drawn to the rights of Thomas Tolman, Samuel Herrick, and John Wood; and that the said Knight and Hyde, in and by said

5 See Lewis r. Cook, 35 N. C. 193 (1851), which was as follows: A. and his wife joined in a deed to $B$. of the wife's land, $W$ hich, because of a defect in execution, operated only as a converance of A.'s life estate. B. conveyed to $X$. "and his heirs" by deed with covenant of marranty. By levy of execution and sale thereunder the land came to $\mathrm{P}$., who went into possession, and continned therein until after the death of $A$., when he was evicted by the heirs of Mrs. A. P. then sued D., the administrator of B., for breach of the covenant of warlanty. A nonsuit of P. was held elroneous. 
deed, covenanted to and with the said Hatch, his heirs and assigns, that they would warrant and defend the premises against all lawful claims and demands whatsoever; that afterwards Hatch by deed dated November 20,1812 , for a valuable consideration, quit-claimed the south half of said premises to the plaintiff, including the south part of the aforesaid lot drawn to the right of John Wood; by virtue of which the plaintiff entered into possession, and became seized and possessed of the premises, as assignee of the said Hatch; that Reuben Clapp, administrator of one Alexander Gordon, afterwards, on the 26th day of January, 1822, sued out a writ of ejectment against the plaintiff, demanding the seizin and possession of thirty six acres of the east corner of said lot, drawn to the right of John Wood; and such proceedings were had in said action, that in January, 1828, the said Clapp recovered judgment in said action against said Beardsley for the seizin and possession of the premises demanded, with one cent damages, and his cost, taxed at $\$ 112.52$; and afterwards took out a writ of possession, and by virtue thereof he entered upon, and took possession of, the demanded premises, and dispossessed said Beardsley of the same; and averring that the title on which the said Clapp recovered was elder and better than the title derived from said Knight and Hyde by said Hatch, and independent of the same.

In the second count the conveyance by Knight and Hyde to Hatch, was set out as in the first. It was then alleged that, on the Sth day of July, 1807, Knight and Hyde conveyed the undivided half of the premises, to the plaintiff, by virtue of which conveyance the plaintiff entered into possession; and after the execution of the deed by Knight and Hyde to Hatch, as before mentioned, Hatch also went into possession of an undivided half of the premises; whereby the plaintiff and Hatch were seized as tenants in common, and so continued, until the 20th day of November, 1812, when they made partition of the premises, by which the plaintiff became seized and possessed of the south half thereof in severalty, and of thirty six acres on the south part of the lot drawn to the right of John Wood, and so continued seized and possessed, until the eviction by Clapp, as mentioned in the first count.

The plaintiff claimed to recover of the defendant the value of the thirty six acres from which he had been evicted by Clapp, and all the cost and charges to which he had been subjected in defending the said action of ejectment.

The defendant pleaded that he had kept and performed his covenants according to the form and effect of the said indenture of said covenant. On which plea, issue was joined. On the trial in the county court, the plaintiff insisted the burden of proof lay on the defendant to make good his plea. But the court decided that the plea was a general denial of all the material allegations in the declaration, and put the plaintiff on proof of every material fact alleged. The plaintiff then offered in evidence the deed set forth in his declaration from Knight 
to Hatch, which was read without objection; and the deed from Hatch to himself, dated the 20th of November, A. D. 1812, acknowledged on the same day, and recorded on the 9th day of October, 1813. This leed had no seal affixed to the signature of the grantor, excepting a scroll or circle made with a pen, and the word "seal" written within it. The defendant objected to its admission, and insisted that it was not sealed, and, therefore, could not be given in evidence to the jury.

The plaintiff insisted that it was sealed, and offered, in connection with it, parol evidence to prove, that he went into possession of the premises therein described, under it, in 1812, and continued in possession under it till 1829, when he was evicted as set forth in his declaration, and that whether the deed was sealed or not, was a question of fact for the jury. The court determined that the deed was not sealed, and that whether it was sealed or not, was a question of law for the court to try, and not the jury; and, therefore, excluded it. The plaintiff then offered a quit-claim deed from Knight and Hyde to himself, dated in 1807, of one equal undivided half of the same premises included in the deed from Knight and Hyde to Hatch; and tendered evidence to prove that the plaintiff, under his deed from Knight and Hyde, and Hatch, under his deed from the same, occupied said premises from 1807 to 1812 , as tenants in common; that in 1812, Hatch and the plaintiff made a division of the premises, and continued ever after to occupy and enjoy the same in severalty under said division; that by said division the land mentioned in the declaration was set apart to the plaintiff; and that he held and occupied the premises as his own, under said division, from 1812 till the time of the eviction, mentioned in the declaration. Which deed and parol evidence were objected to, and excluded by the court, who directed the jury to return a verdict for the defendant; which they accordingly did. To the several decisions of the court the plaintiff excepted, and the cause was ordered to the Supreme Court.

Willians, J. The plaintiff has declared against the defendant in covenant. The declaration contains two counts. The defendant pleads performance, and tenders an issue which is joined. It was considered by the county court that this plea put the plaintiff on proof of every material fact in his declaration. The plaintiff contends, that, under this issue, his derivative title was not denied, nor the character in which he sued. But if the plea required the plaintiff to shew a breach of the covenant declared on, and this was not questioned, he must, to shew such breach, prove an eviction of some one holding under Hatch; and this made it necessary to prove a conveyance from Hatch to himself. The plaintiff does not sue as assignee, nor in the right of another, as an executor, or administrator, or assignee of a bankrupt, in which case his character as assignee would not be denied under the plea. But he sues as on a covenant made with him, and coming to him with the land, by virtue of a deed from Hatch. The eviction of the plaintiff would be no breach of the defendant's covenant with Hatch, unless 
plaintiff claimed title to the land through Hatch. Hence it was incumbent on the plaintiff to show a conveyance from Hatch, and this brings in question the validity of the instrument which was offered as Hatch's. deed to plaintiff. It seems that it was objected to, and excluded as not having been sealed. ${ }^{6} * * *$

The instrument, therefore, offered in evidence as the deed of Hatch, was not a deed or conveyance of land, as it wanted one of the essential requisites to constitute it a deed. The paper from Hatch to the plaintiff, having been rightly excluded by the court, there is no other ground on which the plaintiff can recover of the defendant on the covenants contained in the defendant's deed to Hatch. The argument that the plaintiff was in possession, and, therefore, might avail himself of the covenant as running with the land, is wholly destitute of foundation. His possession, as against Hatch, may have been adverse, so that he was acquiring a title by the statute of limitations as against him; but if so, it would be, at least, singular, if he could acquire a title as against Hatch by a trespass, and, at the same time, by the same trespass, acquire a right to Hatch's claim against the defendant on the covenants in his deed. Although a deed from Hatch to the plaintiff might under some circumstances be presumed, yet, as presumptions are made to quict men in possession, I do not know that it has ever been contended before, that they would create a right of action on the deed presumed. A deed might be presumed to give a legal origin to a possession; but an instrument not under seal cannot be presumed to be a deed for the purpose of giving an action of covenant thereon, or an action of covenant on a deed farther back in the chain of title. It seems that the plaintiff had a quit-claim deed from the defendant and Hyde, dated Sth July, 1807, of one undivided moiety of the land in dispute. If he was not in possession under that deed, he was in without title, and can have no claim upon the defendant if he has not kept his covenant with Hatch, for the other moiety of the same premises.

It is said the evidence on the second count was excluded by the court. This count appears to be decidedly bad; and although the court may have erred in excluding the testimony altogether, and the regular course might have been to have admitted the testimony, leaving the defendant to move in arrest, or bring his writ of error, yet this court would not, on that account, grant a new trial, when we should be under obligation to arrest the judgment thereon on account of the insufficicncy of the declaration. But it will be observed that notwithstanding the pleader in framing the declaration avoided any distinct reference to the instrument which purported to be a deed from Hatch to the plaintiff, which was excluded as not being sealed, yet, to avail himself of the covenant made with Hatch, and entitle himself to shew the eriction as a breach of that covenant injurious to him, he declares that

6 The portion of the opinion in which the court considered the sufficiency of the deed from Hatch to the plaintiff is omitted. 
he was possessed of the part of which he was evicted, as assignee of Hatch. To support this count, therefore, it was necessary for him to show a legal assignment from Hatch, and if he failed to introduce a regular deed from Hatch to himself, the counit would fail for want of proof. This count, therefore, as well as the other, depended upon the validity of Hatch's conveyance to the plaintiff; and that being excluded, all other testimony was irrelevant, and was properly rejected. If neither Hatch nor his grantee were evicted from the premises, the plaintiff has not become liable on his covenant to Hatch. If the plaintiff was evicted from his undivided part, he is without remedy at law, as his title to an undivided moiety was nothing more than a quit-claim deed from the defendant and Hyde, on which he has not set up any clain; and his title to the other moiety was under a writing from Hatch which the Court consider as no legal conveyance.

On every view which we have been able to take of the case, we can see no remedy for the plaintiff at law; and the judgment of the county court must be affirmed. Judgment affirmed. ${ }^{7}$

\section{ST. CLAIR v. WILLIAMS.}

(Supreme Court of Ohio, 1836. 7 Ohio, 110, pt. 2, 30 Am. Dec. 194.)

This is an action of covenant reserved from the county of Hamilton.

Williams, the defendant, conveyed a tract of land, with warranty, to Davis, in 1816. Davis afterward conveyed the same land to St. Clair, who died seized in 1820, leaving the plaintiff his willow, to whom the premises were set off as dower. She has been evicted by a recovery in ejectment, under a paranount title, and she brings this action against Williams, upon the warranty in his deed to Davis, claiming that it passed with the land to her.

LANE, J. The question arising in this case is, whether the right of action upon a covenant of warranty annexed to a conveyance in fee, passes to one who holds but an estate for life in the land. It is no subject of doubt that an assignee is entitled to the benefits of all covenants running with the land. Backus' Adm'rs v. MicCoy, 3 Ohio, 219, 17 Am. Dec. 585; King v. Kerr's Adm'rs, 5 Ohio, 156, 22 Am. Dec. 777. Nor is it doubted where a covenant running with the land is divisible in its nature, as if the entire interest of separate parts of land pass to different individuals, that a right of action accrues to each party, to recover his proportion of the warranty. Van Horne v. Crain, 1 Paige (N. Y.) 455; Astor v. Miller, 2 Paige (N. Y.) 78; Touchstone, 199; Co. Lit. 385, 386. lint a plain distinction is made between the holder of a part of the land, and the holder of a part of the estate;

7 See Deason r. Findley, 145 Ala. 407, 40 South. 220 (1906), acc. AIG.PROP. -48 
the former may vouch as assignee, or bring warrantia chartæ; the latter has the benefit of the warranty by aid prayer, or by the voucher of him who holds the remainder. Co. Lit. 385, a; 4 Dane, 51; Wood's Conveyancing, 373. The same distinction is carried into the modern action of covenant. The assignee, upon whom is cast the benefit or the obligation of covenants, is he who holds the whole estate or term. Doug. 183; 1 East, 502. These principles settle the present suit. The plaintiff could not vouch as assignee, nor have warrantia cliartæ under the ancient law, nor can she sustain an action of covenant, because she does not hold the whole estate. The right of action on the warranty passes to the heirs, and her remedy is by a new assignment of dower. Judgment for defendant. ${ }^{8}$

\section{LEWES v. RIDGE.}

(Court of Common Pleas, 1601. Cro. Eliz. 863.)

Covenant. The defendant, being seised of land in fee, let it for life, remainder for life, rendering rent. He afterwards acknowledged a statute; and after that by indenture bargained and sold the reversion; and covenanted with the bargainee, his heirs, and assigns, that it should be discharged within two years of all statutes, charges and incumbrances, excepting the estates for life. The statute is extended, and thereupon this reversion and rent was extended. The bargainee grants this reversion to the plaintiff, who, for not discharging of this statute, brings covenant. And all this matter being disclosed by the count, it was thereupon demurred. The question principally moved was, whether the plaintiff, as assignee, shall have benefit of this covenant made to the bargainee by the common law, or by the $32 \mathrm{Hen}$. VIII, c. 34? But because the covenant was broken before the plaintiff's purchase, the land being then in extent, and so a thing in action, which could not be transferred over, it was adjudged for the defendant that the action was not maintainable against him.

And here THE COURT held clearly, that the 32 Hen. VIII, c. 34, doth not extend to covenants upon estates in fee or in tail, but only upon leases made for life or for years, and therefore this assignee was out of the statute: But for the other matter principally it was adjudged ut supra. ${ }^{9}$

8 See McClure's Ex'rs v. Gamble, 27 Pa. 288 (1856); White $\nabla$. Whitney, 3 Mete. (Mass.) S1 (1S41).

${ }^{9}$ In Lucy v. Levington, 2 Lev. 26 (1671), the executor of the grantee sued the grantor for breach of a covenant for quiet enjoyment, broken during the lifetime of the grantee. Held, the action was properly brought by the executor. 


\section{KINGDON v. NOTTLE.}

\section{(Court of King's Bench, 1513. 1 Maule \& S. 355.)}

This action was brought by the plaintiff, as executrix of Richard Kingdon; and the declaration stated, that by indentures of lease and release of the 11th and 12th of May, 1780, the defendant conveyed to R. Kingdon in fee a 4th part of certain lands therein particularly described, with a proviso for redemption upon payment of $£ 450$; and that the defendant covenanted for himself, his heirs, executors, and administrators, with $R$. Kingdon, that he the defendant was at the time of the execution of the indenture seized of and in the premises of a good and indefeasible estate of inheritance in fee simple: and that he had good right to convey the same to $\mathrm{R}$. Kingdon and his heirs: and farther, that the defendant would from time to time, upon every reasonable request of $R$. Kingdon, his heirs or assigns, but at the defendant's costs, execute any farther conveyance for the purpose of assuring and confirming the premises to $\mathrm{R}$. Kingdon, his heirs and assigns; and then the following breaches were assigned: first, that the defendant was not seized in fee at the time of the execution of the indenture: secondly, that the defendant had not at that time good right to convey: lastly, that the plaintiff, as executrix after the death of $\mathrm{R}$. Kingdon, made a reasonable request to the defendant to execute an indenture between the defendant of the first part, the plaintiff of the second part, and Samuel Anstice of the third part, intended to be a release of the premises for suffering a common recovery for the better assuring and confirming the premises to the uses mentioned in the deed; and tendered the same to the defendant for execution, but the defendant refused to execute.

The defendant demurred to the first and second breaches, assigning for causes that they are assigned too generally, and are not sufficiently precise and certain, and that it does not appear that R. Kingdon sustained or could have sustained any damage by the said breaches of covenant, or either of them, nor that he was at any time interrupted or disturbed in his enjoyment of the premises conveyed to him by the defendant; nor that the said Elizabeth has or claims any interest in the premises, or that she is heir at law, or assignee of the same, or any part thereof. He demurred also to the last breach, assigning for causes, that it does not appear that the said Elizabeth hath or claims to have any interest in the premises, as assignee or otherwise, of R. Kingdon, nor to what person, or for whose use the deed of release was intended to enure, or why or for what reason Samuel Anstice was made a party thereto, nor that the said deed of release was a reasonable conveyance or assurance in that behalf: and also for that the said last mentioned breach of covenant cannot by law be joined in the same declaration with the other breaches of covenant in the said declaration assigned: and also for that the said declaration as to the said breach 
of covenant lastly assigned is in various other respects insufficient, informal, and defective. Joinder.

Lord Elfenborougi, C. J. This is a case in which a person may have formed his opinion from what is to be found in a book of very excellent authority, I allude to Comyn's Digest, in which it is laid down generally that if a man covenant with B. upon a grant or conveyance of the inheritance, his executor may have covenant for damages upon a breach committed in the lifetime of his testator. But when that position comes to be compared with Lucy v. Levington, which is the authority there cited in support of it, it will be found not to be borne out by that case in its generality; for in that case there was an eviction in the life-time of the testator, and therefore the damages in respect of such eviction, for which the action was then brought, were properly the subject of suit and recovery by the executor; and nothing descended to the heir. But in this case there is no other damage than such as arises from a breach of the defendant's covenant that he had a good title, and there is a difficulty in admitting that the executrix can recover at all, without also allowing her to recover to the full amount of the damages for such defect of title; and in that case a recovery by her would bar the heir; for I apprehend the heir could not afterwards maintain another action upon the same breach. Had the breach here been assigned specially with a view to compensation for a damage sustained in the life-time of the testator, and so as to have left a subject of suit entire to the heir, this action might have gone clear of the difficulty, because then it would not operate as a bar to the heir; but framed as it now is, it seems to me that it would operate as a bar to his action.

It is certainly a new point; and if I thought, that more authorities could be found than what have been cited, which, however, from the industry of the gentlemen who have argued the case, is not very probable, I should have paused. But what has been cited from Co. Litt., and the other authorities, that the executor of a person who died seized of a rent could not maintain an action to recover the arrears incurred in the life-time of his testator, inasmuch as he could not represent his testator as to any contracts relating to the freehold and inheritance, is in a great degree an authority to show that in the present case the executrix does not stand in a situation to take advantage of this breach of covenant. Therefore on the principle of what is here laid down, and in the absence of any damage to the testator, which, if recovered, would properly form a part of his personal assets, I do not know how to say that this action is maintainable.

LE Blanc, J. This action is brought by the executrix to increase the personal estate of the testator. The difficulty arises from its being assigned as a breach of covenant in the life-time of the testator. The breach assigned is in not having a good title. But how is that breach shown to liave been a damage to the testator. It is not alleged that the estate was thereby prejudiced during the life-time of the testator; and 
if after his decease any damage accrued, that would be a matter which concerns the heir. The distinction which attends real and personal covenants with respect to the course in which they go to the representatives of the person with whom the covenants are made, is a clear one; real covenants run with the land, and either go to the assignee of the land, or descend to the heir, and must be taken advantage of by him alone; but personal covenants must be sued for by the executor. Now this is a covenant on which after one breach has been assigned and a recovery had thereon, the party cannot again recover. It is not like a covenant for not repairing, for a breach of which damages may be recovered now, and again hereafter, and so toties quoties; although even in that case there is always a difficulty in apportioning the damages. But here no breach from which a damage accrued to the testator is stated at all. Yet the action is brought to increase the personal estate, which belongs to the executor; when the estate itself, such as it is, has come to the heir.

BAYley, J. The testator might have sued in his life-time; but having forborne to sue, the covenant real and the right of suit thereon, devolved with the estate upon the heir. If this were not so, and the executrix was permitted to take advantage of this breach of covenant, she would be recovering damages to be afterwards distributed as personal assets, for that which is really a damage to the heir alone; and yet such recovery would be a complete bar to any action which the heir might bring. The case of Lucy v. Levington struck me as a strong authority for the defendant: because in that case it appears there was an actual damage accruing to the testator by the eviction. whereby he was deprived of the rents and profits during his life, and of course the personal estate was so far damnified. There, as I have before observed, if the executor could not have sued, no other person could, because the testator having been evicted, there could be no heir of the land, and that was given as a reason why the action was holden to be maintainable.

Per Curiam. Judgment for defendant.

\section{KINGDON v. NOTTLE.}

\section{(Court of King's Bench, 1815. 4 Maule \& S. 53.)}

Covenant by the plaintiff as devisee of Richard Kingdon; and the plaintiff declares that by indentures of lease and release of the 11th and 12th of May, 1780, the defendant conveyed to R. Kingdon in fee a fourth part of certain lands therein particularly described, with a proviso for redemption upon payment of $£ 450$; and that the defendant covenanted for himself, his heirs, executors, and administrators, with R. Kingdon, that he the defendant was at the time of the execution of the indenture seized of and in the premises of a good and indefeasible 
estate of inheritance in fee-simple; and that he had good right to convey the same to $R$. Kingdon and his heirs; and then the plaintiff avers that R. Kingdon, on the 3d of May; 1791, duly made his will, \&c. and thereby devised the same premises to her in fee, and died seised, and that she (the plaintiff) entered into the premises, and became and was and continuaily hath been possessed thereof, and seized of and entitled to all such estate and interest of and in the same as R. $\mathrm{King}$ don had in his lifetime, and at the time of his death, and assigns for breach, 1st, That the defendant, at the time of the execution of the indenture, was not seized, \&c.; 2dly, That he had not good right to convey to R. Kingdon and his heirs, \&c. And so the plaintiff says, that by reason thereof the prenises are of much less value, to wit, less by $£ 2000$. to the plaintiff than they otherwise would be, and that she hath not been able to sell, and hath been prevented and hindered from selling the same, for so large a price or so beneficially and advantageously as she otherwise might have done. And so she saith that the defendant hath not kept his covenant so made with $\mathrm{R}$. Kingdon, but to keep the same with R. Kingdon in his lifetime, and the plaintiff, since his death, hath wholly refused.

Demurrer assigning for cause, 1st, That it appears by the declaration that the supposed breaches of covenant therein assigned were committed in the lifetime of R. K., before the plaintiff had any estate or interest in the premises; and also, that it does not appear by the declaration that $\mathrm{R}$. K. was at any time disturbed or interrupted in the enjoyment of the premises by the defendant or any other person, or sustained or could have sustained any damage by the same supposed breaches of covenant or either of them, and also for that it is not alleged that the plaintiff hath at any time since the death of $\mathrm{R}$. K. been interrupted or disturbed in the enjoyment of the premises, or any part thereof, or hath sustained any damage from the supposed breaches of covenant or either of them; and also that it does not appear that any person hath refused to purchase the premises on account of the supposed breaches of covenant, and also that the allegations that the premises are of much less value than they otherwise would be, and that the plaintiff hath not been able to sell, and hath been prevented and hindered from selling the same for so large a price or so beneficially and advantageously as she otherwise might have done, are too general, and do not give the defendant sufficient notice of the supposed damage.

Lord Ellenborough, C. J. The rule with respect to the executor's right to sue upon breaches of contract made with the testator was considered in the former case of Kingdon v. Nottle as subject to some qualification; and in a still more recent case, [Chamberlain v. Williamson, 2 M. \& S. 408,] it was considered that he could only recover in respect of such breach as was a damage to the personal estate. But here the covenant passes with the land to the devisee, and has been broken in the time of the devisee, for so long as the defendant has 
not a good title, there is a continuing breach and it is not like a covenant to do an act of solitary performance, which, not being done, the covenant is broken once for all, but is in the nature of a covenant to do a thing toties quoties, as the exigency of the case may require. Here, according to the letter, there was a breach in the testator's lifetime; but according to the spirit, the substantial breach is in the time of the devisee, for she has thereby lost the fruit of the covenant in not being able to dispose of the estate.

LE BLANC, J. If the covenant is to cease with the breach of it, then if it be broken, and the covenantee die immediately after, the covenant will be gone; and yet the injury arising from the breach would accrue altogether to the devisee.

DAMPIER, J. This is a covenant which runs with the land; but if it may be broken but once, and ceases eo instanti that it is broken, how can it be a covenant which runs with the land?

PER Curiam. Judgment for the plaintiff. ${ }^{10}$

\section{MITCHELL v. WARNER.}

(Supreme Court of Errors of Connecticut, 1825. 5 Conn. 497.)

This was an action on the covenants of warranty in a deed of land. The plaintiff declared, that the defendant, Curtis Warner, on the 30th of May, 1817, for the consideration of $\$ 1500$, by his deed duly executed, granted and sold to George Welton a certain piece of land in said deed described as lying in Roxbury, on Jack's brook, ,containing two acres, with a dwelling-house, clothier's works, \&c. standing thereon, bounded South on Roswell Warner's land, \&c.; that in and by said deed, the defendant did for himself, his heirs, executors and administrators, covenant with said Welton, his heirs and assigns, that at and until the ensealing of said deed, he was well seised of the premises as a good indefeasible estate in fee-simple, and that he had good right to bargain and sell the same, in the manner and form as was in said deed by him before written, and that the same was free from all incumbrances; that the defendant, in and by said deed, did covenant and bind himself and his heirs forever to warrant and defend said granted and bargained premises to the said Welton, his heirs and assigns, against all claims and demands whatsoever; that on the 7 th of March, 1822, Welton and the defendant, by quit-claim deed, by them executed, for a valuable consideration, released to the plaintiff the same land, buildings and privileges, which the defendant had conveyed to Welton, by the first mentioned deed, and the plaintiff became

10 Acc.: King $\nabla$. Jones, 5 Taunt. 418 (1814), where the covenan't sued on by the heir of the grantee was for furtber assurance. The grantee in his lifetime had called upon the covenantor to levy a tine, which request had been denied. 825,

But see Spoor v. Green, L. R., 9 Ex. 99 (1874); Turner v. Moon, [1901] 2 Ch. 
vested with such right and title thereto as Welton had acquired, and was the assignee of all the covenants in the defendant's deed to Welton, and had good right to take benefit thereof.

Breaches of these corenants were then assigned as follows: That at the time when the defendant made and executed his deed to Welton, he, the defendant, was not well seised of the premises, as a good indefeasible estate in fee-simple, and had not good right to bargain and sell the same, in manner and form as stated and set forth in said deed, and the same was not free from all incumbrances; that the defendant has not kept and performed his covenant to warrant and defend the premises to the plaintiff, but has broken the same, for that long before and on the 30th day of May, 1817, and at the time when the defendant made, executed and delivered his deed to Welton, one Roswell Warner was well seised and possessed, in his own right in fee-simple, of the right and privilege of turning the water of Jack's brook in said deed mentioned, (and which brook or stream of water runs through and upon said land, and was, at the time of the conveyance by the defendant to Welton, and ever since has been, of great use in carrying on the business of a clothier's shop in said deed described, also of great value and use in carrying a carding-machine and other water works, "which the plaintiff has, since he took the deed from Welton and the defendant, erected on said land, and by said stream,) from a certain dam, which had been previously erected across said brook upon said land, on to the meadow of said Roswell Warner below, so much thereof as should be necessary for the purposes of watering the same; that on the 1st of April, 1822, said Roswell Warner, by virtue of such right and privilege, entered upon said land, and diverted the water from said stream, at said dam, and turned it upon his said meadow, to water the same, and has ever since used said stream for that purpose; by means whereof, the plaintiff has wholly lost the bencfit of said stream, and the use of said clothier's shop, carding machine and other water-works thereon; and so the said Roswell Warner had disseised and dispossessed the plaintiff of said water-works and of the benefit of said stream.

The defendant pleaded, that at the time of executing said deed to IVclton, he, the defendant, was well seised of the premises in said deed described, and had good right to convey the same, as in said deed set forth; that the premises were free from all incumbrances whatsoever; and that the defendant has warranted and defended the premises to the plaintiff against all claims and demands, according to the form and effect of said deed, and of the several covenants therein contained. On this plca issue was joined.

On the trial of the cause at Litchfield, February term, 1824, before Hosmer, Ch. J., the plaintiff, after proving the deeds mentioned in the declaration, adduced evidence to prove the right of Roswell Warner to turn the water of Jack's brook on to his own land, and the exercise of that right to the plaintiff's damage, which constituted the only 
breaches relied upon of the covenants in the defendant's deed to Welton. To the competency, as well as to the relevancy of this evidence, the defendant objected. The Chief Justice, in his charge to the jury, cxpressed the following opinion:

"First, as to the covenant of seisin. The facts adduced in evidence did not prove it to have been broken; the right claimed to exist in Roswell Warner being an incorporeal hereditament only, and like a right of way or of turbary, not any part of the freehold, but perfectly compatible with the covenant of seisin, on which the plaintiff has declared.

"Secondly, as to the covenant against incumbrances. The declaration having alleged, by way of breach, that the premises granted 'were not free from all incumbrances,' and nothing more, under this negative averment, without any specification of the nature of the incumbrance complained of, the proof offered was inadmissible. It should have been definitely set forth, to appraise the defendant of its nature, and give him the requisite information to prepare himself for a defence. Further; the actual exercise of the right of turning water from Jack's brook, by Roswell Warner, was not an incumbrance warranted against; but the incumbrance consisted in the incorporeal hereditament, viz. the right of turning the water; the covenant, from its nature, being broken instantaneously, on the delivery of the deed, or not at all. And if the exercise of the right were an incumbrance, it was not alleged to be so in breach of the covenant aforesaid.

"Thirdly, as to the covenant of warranty. The facts stated, by the plaintiff, if proved, did not amount to an eviction in breach of the aforesaid covenant; but if they were established, by the evidence, the jury must find for the plaintiff, and leave the defendant to his legal remedy, the facts appearing on the record.

"Fourthly, as to the damages. As no breach of the covenant of warranty was alleged, but of a disturbance only, the jury must give the plaintiff reasonable damages for the actual injury."

The jury returned a verdict for the plaintiff, with twenty dollars damages. The defendant then mored in arrest of judgment, for the insufficiency of the declaration; and the court arrested judgnent on that ground. To obtain a reversal of the latter decision, the plaintiff brought a writ of error. He also moved for a new trial, on the ground of a misdirection.

Hosmer, Ch. J. The case made by this motion, presents two questions for determination.

The first is, whether the plaintiff, claiming to be the assignee of the covenant of seisin, can maintain an action on that covenant.

This covenant, from its nature, is broken instantaneously on the delivery of the deed, or it is never broken. It runs in the words of the present tense, and asserts, that the grantor is well seised. Now, if he is well seised according to his covenant, the agreement is fulfilled; and if he is not well seised, the covenant is false, and immediately 
broken. It follows from this, that it is a personal covenant, which, most clearly, never runs with the land, and that the grantee, in whose time the breach existed, can alone sue upon it; for, after a breach the cause of action can never be assigned. It would be the assignment of a chose in action, which the common law will not permit. That the covenant of seisin, if false, is broken as soon as it is made, appears from Shep. Touch. 170; from Bickford v. Page, 2 Mass. 460; from Marston v. Hobbs, 2 Mass. 437, 3 Am. Dec. 61; from Bennett v. Irwin, 3 Johns. (N. Y.) 365; from Abbott v. Allen, 14 Johns. (N. Y.) 253; from Greenby et al. v. Wilcocks, 2 Johns. (N. Y.) 1, 3 Am. Dec. 379; from Pollard et al. v. Dwight et al., 4 Cranch, 430, 2 L. Ed. 666; from 1 Swift's Dig. 370; and from Mitchell v. Hazen, 4 Conn. 495, 10 Am. Dec. 169. From its nature, it does not run with the land, as none but real covenants do; and these are alivays suspended on some act posterior to the delivery of the deed. Hence, as I have said before, having been broken, the covenant has become a chose in action, and therefore cannot be assigned. 1 Swift's Dig. 370. In Bickford v. Page, 2 Mass. 455, it was said by the court: "This covenant being broken before the release, was, at that time, a mere chose in action, and unassignable." The court, in the case of Greenby \& al. v. Wilcocks, 2 Johns. (N. Y.) 1, 3 Am. Dec. 379, determined, that the assignee of a covenant of seisin conld not recover. The opinion was delivered by Spencer, J., in which he says: "Choses in action are incapable of assignment at the common law; and what distinguishes these covenants, broken the instant they were made, from an ordinary chose in action? The covenants, it is true, are such as run with the land; but here the substratum fails, for there was no land whereof the defendant was seised, and of consequence, none that he could alien: the covenants are, therefore, naked ones, uncoupled with a right to the soil."

The same point was adjudged as far back as the reign of Queen Elizabeth, in Lewes v. Ridge, Cro. Eliz. S63; and the case, so far as I can find, has never been overruled. The principle settled in that case, was this; that an assignee shall not have an action upon a breach of covenant before his own time. The same principle was recognized in Marston v. Hobbs, 2 Mass. 439, 3 Am. Dec. 61; in the determination of which case, it was said by Parsons, Ch. J., when delivering the opinion of the court; that "no estate passed, to which these covenants (i. e. of seisin and right to convey) could be annexed, because in fact broken before any assignment could be made, they were choses in action, and not assignable." In Com. Dig. tit. Covenant, B. 3, it is asserted, that "covenant does not lie by an assignee, for a breach done before his time." It cannot rum with the land; for nothing having been conveyed, what land is there for it to run with? To the same effect is Lucy v. Levington, 2 Lev. 26, s. c. 1 Vent. 175, in which it was decided, that for a breach of the covenant of quiet enjoyment in the testator's time, the executor was authorized to recover; and of his 
opinion was that eminent judge Sir Matthew Hale. Similar doctrine is to be found in the Digest of Baron Comyns, tit. Covenant, B. 1.

In relation to principles so well established, one or two modern decisions in Westminster-Hall in opposition to them, however they might there be regarded, ought not here to be considered as of any authority. Such decisions have been cited. The first of them is the case of Kingdon, Ex'r v. Nottle, 1 Mau. \& Selw. 355. The defendant had conveyed to Richard Kingdon, the testator, certain property, and covenanted that he was seised of it, and had good right to convey. It was averred as a breach, that he was not seised of the premises; and the court adjudged, that the executor could not sue on the covenant, without shewing special damage to the testator, but that the heir might. It was said by Lord Ellenborough, that "the covenant, it was true, was broken, but that there was no damage sustained in the testator's life-time." To this observation of that learned and able judge I cannot subscribe. The covenant being broken the instant it was made, the damage, most obviously, was the whole consideration paid; and $I$ am at a loss to conceive what other or further damage could arise.

In the surrounding states, as well as in our own, it is unquestionably established, that the damage is the consideration paid; and that tilis is immediate on the delivery of the deed. This, then, is the first objection to the determination, that whatever may be the law of Westminster-Hall, the damage, in the case alluded to, is justly considered as not nominal, but real, and indeed all that the party can experience. It is the whole consideration paid. This principle alone shews, that the determination in Kingdon v. Nottle is inapplicable to us; and it likewise authorizes the assertion, that Lord Ellenborough and his associates, had they resided in Connecticut, and there pronounced their opinion, would have decided the case before them differently from what they have.

To the determination in Kingdon v. Nottle there is a sound objection. It is opposed to principles, uniformly, and for centuries, established in Westninster-Hall. It was said by Lord Ellenborough, in the case alluded to, that "if the executor could recover nominal damages, it would preclude the heir, who is the party actually damnified, from recovering at all!" The force of this reasoning depends entirely on the assertion that the heir is "the party actually damnified;" and if this is an incorrect position, the argument wholly fails. Now, it is not true, that the heir is the party damnified. The damage arises entirely by the breach of the covenant in the life-time of the testator; and the testator is the only person, who receives damage. Thus were all the determinations before the last mentioned decision. To this effect was Lewis v. Ridge, Lucy v. Levinton, and the law as laid down in Comyn's Digest; and not a case or Dictum was there to the contrary. Indeed, the admission of Lord Ellenborough, that the covenant was broken in the life-time of the testator, most conclusively 
shews, that the heir was not damnified. His own damage must result from his title to the land, and not from the covenant broken, to which he was no party. Now, as to the land, the heir never had title; nor had his ancestor. The complaint is, that the grantor was not seised, and had conveyed no title. How, then, is it possible, that the heir should inherit land, to which his ancestor had no title? If, then, he had no title to the estate supposed to be conveyed, and he was no party to the covenant, and the breach happened before his ancestor's death, what is the ground of his claim? In my opinion, none. On the other hand, as the covenant was broken in the testator's life-time, and the damage restilting from the breach was due to him; after his death, his executor, standing in his place, had the right of suit. For the principle is incontrovertible, that where the testator can maintain covenant in his life-time, on a cause of action then existing, his executor may support the same action after his death. 1 Swift's Dig. 371; Toll. Ex. 158, 432.

Another writ of covenant was brought by Kingdon, as devisee, against Nottle, 4 Mau. \& Selw. 53, upon the covenant of seisin before mentioned, on the ground that the covenant run with the land, and that the breach happened to the devisee. Consistently with the former determination, the court decided in favour of the plaintiff. It required some ingenuity to sustain an action on a covenant, for a breach happening in the time of the testator, before the devisee (the plaintiff) could have any interest in the covenant; and more especially, as no special damages were laid. For it was not stated in the case, that the plaintiff was, at any time, interrupted or disturbed in the enjoyment of the premises; or that he sustained any damages, by the breach of the covenant, in the testator's life-time. Accordingly, this point was met, by Lord Ellenborough, who said: "The covenant passes with the land to the devisee, and has been broken in the time of the devisee; for so long as the defendant has not a good title, there is a continuing breach, and it is not like a covenant to do an act of solitary performance, but it is in the nature of a covenant to do a thing toties quoties, as the exigency of the case may require."

From this opinion I am compelled to dissent in omnibus. First, I affirm, that the novel idea attending the breach in the testator's lifetime, by calling it "a continting breach," and therefore a breach to the heir or devisee at a subsequent time, is an ingenious suggestion, but of no substantial import. Every breach of a contract is a continuing breach, until it is in some manner healed; but the great question is, to whom does it continue as a breach? The only answer is, to the person, who had title to the contract, when it was broken. It remains, as it was, a breach to the same person, who first had a cause of action upon it. If it be anything more, it is not a continuing breach, but a new existence. In the next place, I assert, that it is like a covenant to do an act of solitary performance; and for this plain reason, that it is, in its nature, a covenant for a solitary act, and not a successive 
one. If the covenant is broken, that is, if the grantor was not seised, it is infracted to the core; and a second supposed breach is as futile as the imaginary unbroken existence of a thing dashed in pieces. It has no analogy to a covenant to do a future act, at different times, which may undergo repeated breaches. It has no futurition; and cannot be partly broken and partly sound; but the grantor is seised, or not seised; and therefore, the covenant is inviolate, or violated wholly. Not further to pursue the subject, I remark, that, in my judgment, the case of Kingdon v. Nottle may justly be said to authorize the assignment of a chose in action by devise; a supposition as unfounded as it is novel.

I, therefore, conclude, that the determinations in the above mentioned cases of Kingdon v. Nottle, are against the ancient, uniform and established law of Westminster-Hall; against well settled principles and decided cases in the surrounding states; and that the judges pronouncing them, would have been of an opinion different from the one expressed, had they recognized the principle here well established, that the breach of the covenant of seisin is, in its nature, total, and the measure of damages the whole consideration money paid for the land. As a consequence, I am of opinion that the plaintiff cannot sustain his action on the covenant of seisin.

2. The next question relates to the covenant of freedom from incumbrances.

The deed of the defendant to George Welton contains a covenant of this description; and the plaintiff claims title to the covenant, and a right to recover for a breach of it, by virtue of a deed of quit-claim from the defendant and Welton. Without a further statement of fact, it is sufficient to remark, that the plaintiff has no right to recover for the breach of this covenant; and if he had, no breach of it is assigned.

First, he has no title to the covenant of freedom from incumbrances, nor right to recover for the breach of it. His only claim is founded on the principle, that this covenant runs with the land. In opposition to this claim, I observe, that the covenant above-mentioned was personal, and not a real covenant; that it was broken in the testator's life-time, and could not run with the land,-a peculiarity attending real covenants only; and of consequence, that George Welton is the only person who can sue on this unassignable contract.

This covenant is classed, by the late Chief Justice Swift, (in the first volume of his Digest, p. 370,) with the covenant of seisin and of good right to convey; and in relation to them all, he correctly says: "These covenants must be all broken at the time of executing the deed. or they never can be; for if at that time, the grantor is not well seised of the premises, as an indefeasible estate, or if he had no right to sell, or if any incumbrance existed, then the covenants are broken. But if the grantor is seised, has right to sell, or there are no incumbrances at the time of making the deed, then these covenants can never 
be broken; for no subsequent act can be done, by the grantor, which will amount to a breach of them; as he can do no act, that will affect or incumber the estate. These covenants, of course, cannot be real covenants; for being broken at the instant of their creation, they are choses in action, and cannot be assigned. The distinguishing feature of the real corenant, is, that it may be broken at a future time; and it is this quality, which renders it assignable; but it must be assigned before it is broken; for when once broken, the right to recover damages, is a chose in action, which cannot be assigned."

With these observations, I entirely concur. The fundamental question, on which the whole doctrine depends, is, when is the covenant of freedom from incumbrances broken? It is a covenant for a fact, existing or said to exist, not in futuro, but in præsenti; at the moment when the deed is delivered. The phraseology of the covenant is, that the premises are free from incumbrances; not that they shall in future be free; just like the expression the grantor is seised, and has good right to convey. ${ }^{11}$ If the covenant be true, it can never be broken; if it be false, it is broken immediately, in which event it is a chose in action, and cannot be assigned. The doctrine contended for was adjudged, by the supreme judiciary of Massachusetts, in Prescott v. Trueman, 4 Mass. 627, $3 \mathrm{Am}$. Dec. 246, and by the supreme court of New York, in Delavergne v. Norris, 7 Johns. (N. Y.) 358, 5 Am. Dec. $281 .{ }^{12}$

Secondly, no breach of the covenant in question has, by the plaintiff, been assigned. The averment is merely this-that the estate "is not free from all incumbrances." It is sufficient to say, that the law requires the incumbrance to be specially named and set forth; or the defendant will always be taken by surprise. Incumbrances, in their nature, are numerous. A mortgage, a way, a right to dig turf, to pasture cattle, or to have dower assigned, and in short, an easement of any kind, is an incumbrance, because it is a load or weight on the land, and must lessen its value. Prescott v. Trueman, 4 Mass. 630, 3 Am. Dec. 246. It is opposed to the fundamental principles of pleading, (which are to inform the court, the jury, and, above all, the party, by the altercations in writing) to authorize a general allegation that there are incumbrances, without declaring what they are. The point is settled, by first principles, and he is too clear for controversy. In Marston v. Hobbs, 2 Mass. 433, 3 Am. Dec. 61, it was said, by Chief Justice Parsons, that the breach of the covenant against incumbrances, like that for quiet enjoyment, must be specially assigned, shewing its nature, and the interruption complained of. The same point was ad-

11 See Ilall r. Dean, 13 Johns. (N. Y.) 105 (1816) ; Post r. Campau, 42 Nich. 90,3 N. W. 272 (1879). But see Guerin v. Smith, 62 Mich. 369, 2S N. W. 006 (1S১6).

12 ('. Dehority v. Wright, 101 Ind. 3S2 (1SS5); Worler r. Hineman, 6 Ind.

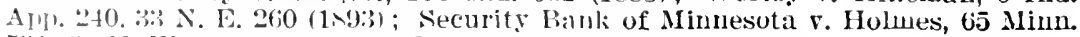
5.31 , 6s $\mathrm{N}$. W. 113,60 Am. st. Rep. 495) (1N!)(6).

See Iichard v. Bent, 59 Ill. 38, 14 Am. Rep. 1 (1ST1), contra. 
judged, by the same court, Bickford v. Page, 2 Mass. 455; and in De Forest v. Leete, 16 Johns. (N. Y.) 122, it was said, by the supreme court of New York, that under a general assignment of a breach of the covenant against incumbrances, the plaintiff cannot give evidence of his having bought in an incumbrance, because it was not specifically alleged in the declaration; and for the admission of such evidence, a new trial was granted.

The charge of the judge to the jury, in this case, is free from exception. The covenant in question, as was said by him, is broken instantaneously, if ever; and under the negative averment is not free from incumbrances, the jury were correctly instructed, that proof of a particular incumbrance was inadmissible, because it should have been set forth specifically, to apprize the defendant of its nature, and give him the means of preparation for his defence.

Peters, Brainard and Bristol, JJ., were of the same opinion.

New trial not to be granted. ${ }^{13}$

\section{SCHOFIELD v. IOWA HOMESTEAD CO.}

(Suprene Court of lowa, 1S71. 32 lowa, 317, 7 An. Rep. 197.)

Action upon the covenants of a deed for lands. Trial to the court without a jury, and judgment for plaintiff. Defendant appeals.

BECK, J. I. The counsel of the respective parties agree that the action is based upon the covenant of seizin, which is sufficiently expressed in the deed. As a defense, the answer alleges that, prior to the commencement of the action, plaintiff, for value, sold and conveyed a part of the lands to another, and that the covenant declared on passed with the land, so far as the contract covered the same, to the purchaser from plaintiff, and that recovery in this action for the land so conveyed is barred. To this defense a demurrer was sustained. The question thus presented for our determination is this: Does the covenant of seizin run with the land?

Ve are fully aware of the discord of authorities upon this question, and that a great majority of the American cases hold the covenant to be in præsenti, and that it is broken, if at all, when the deed is delivered, and that the claim for damages thereby becomes personal in its nature to the grantee, and is not transferred by a conveyance to a subsequent grantee. But in England the rule prevails that the covenant runs with the land, and recovery for a breach thereof may be had by the assignee of the grantee in the deed. Kingdon v. Nottle, 1 Maule \& Selw. 355; 4 Maule \& Selw. 53; King v. Jones, 5 Taunt. 418; 4 Maule \& Selw. 186; 1 Smith's Lead. Cases, Am. notes to Spencer's Case, p. 150; 4 Kent's Conı. 472; 1 Washburn on Real Prop. 649.

13 See Collier v. Gamble, 10 Mo. 467 (1847); Cole r. Kimball, 52 Vt. (ia9 (18s0) ; Peter's v. Powman, 98 U. S. 56, 59, 25 L. Ed. 91 (187s) ; Clark v. Swift, 3 Metc. (Mass.) 390 (1S41). 
The English doctrine has been adopted, and the rule in Kingdon $v$. Nottle, followed by the supreme courts of Ohio and Indiana, ${ }^{14}$ with the modification, however, in Ohio, that when the grantor has neither title nor possession, and is therefore unable to transfer either by his deed, the covenant is broken as soon as made, and becomes a mere right of action which is not transferred by a subsequent conveyance of the land. Backus' Adn'rs v. McCoy, 3 Ohio, 211, 17 Am. Dec. 585; Foote v. Burnet, 10 Ohio, 317, 36 Am. Dec. 90; Devore v. Sunderland, 17 Ohio, 52, 49 Am. Dec. 442; Martin v. Baker, 5 Blackf. (Ind.) 232.

A similar rule, applicable to covenants against incumbrances, formerly prevailed in Massachusetts, but has been abandoned. Wyman v. Ballard, 12 Mass. 304; Sprague v. Baker, 17 Mass. 586.

A like doctrine is recognized in South Carolina. Brisbane v. McCrady's Ex'rs, 1 Nott \& McCord, 10t, 9 Am. Dec. 676.

The English rule is commended to us by reason and justice, and Chancellor Kent, while condemning the reasons upon which it is supported in Kingdon v. Nottle, admits that the American doctrine is supported upon a "technical scruple," and assigns the most conclusive reasons in support of the opposite English rule, 4 Kent, 472.

The object of all covenants in conveyances of lands, relating to their title or their enjoyment, is to secure indemnity to the party entitled to the premises in case he is deprived of them. The subsequent vendee, in the language of Kent, "is the most interested and the most fit person to claim the indemnity secured by them (the covenants), for the compensation belongs to him as the last purchaser and first sufferer."

The American rule will operate oppressively in all cases where the land has been subsequently conveyed by the grantee, either toward the grantor or subsequent purchaser. If the purchaser is evicted he ought to receive the indemnity secured by the covenant, for he is not only, as is said by Kent, the first sufferer, but the only sufferer in every instance, except when he has not paid for the land. When the grantee, under the deed containing the covenant, has sold and received pay for the land, it would be gross injustice to permit him to recover, for he would not in that case sustain damages. But under the rule, to which we are now objecting, the grantee may recorer on the covenant of seizin and, if there be a covenant of warranty in the deed, the subsequent grantee may also recover upon that contract against the first grantor. But if there be no covenant of warranty, we would have the equally strange case of a party, the first grantee, recovering damages when he is entitled to none, and the party really injured unable to recover. Other instances of unjust and unreasonable results could be mentioned.

The "technical scruple," as it is called by Kent, upon which the 
American doctrine is based, is this: The covenant is broken the instant the conveyance is delivered; it then becomes a chose in action held by the grantor in the deed. Brady v. Spurck, 27 Ill. 478; King v. Adm'x of Gilson, 32 Ill. 348, 83 Am. Dec. 269. But how can this be a reason in support of the doctrine under the laws of this State which permit the assignment of all choses in action? What legal principle would be violated by holding that the deed from the first grantee operates as an assignment of this chose in action?

Deeds under the laws of this State have been reduced to forms of great simplicity. Intricate technicalities have been pruned away, and they are now as brief and simple in form as a promissory note. All choses in action, as I have just remarked, may be assigned and transferred. The covenant of seizin (if it be held that such a covenant exists in a deed of the form authorized by the laws of this State), as we have seen, is intended to secure indemnity for the deprivation of the title and enjoyment of the lands conveyed. Why not brush away the "technical scruples" gathered about the covenant of seizin, as we have the like technical and cumbrous forms of the instrument itself, and enforce it for the benefit of the party who is really injured by its breach, even though, in so doing, we find it necessary to hold that a chose in action is assigned and transferred by the operation of the deed?

To my mind, the position reached by this course of argument is impregnable, and I cannot be driven from it by the great weight of authorities in support of the contrary doctrine.

We conclude that plaintiff was not entitled to recover for the land conveyed by him, and that the court erred in rendering judgment for the full amount of the consideration paid, as shown by the deed.

II. The plaintiff's counsel argues that, admitting the covenant runs with the land, being entire, a conveyance of a portion of the premises vests no right of action in the grantee. But this position is in conflict with the authorities. It is held that covenants running with the land are susceptible of division, so that if the land be conveyed in parcels to several persons, each may maintain an action upon the covenant to recover for the land in which he has an interest. Kane v. Sanger, 14 Johns. (N. Y.) 89; Dickinson v. Hoomes' Adm'r, 8 Grat. (Va.) 353.

This rule is based upon sound reason, and accords with the analogies of the law. ${ }^{15} * * *$

On account of the error in holding that the covenant sued upon does not run with the land, the judgment of the circuit court is reversed. ${ }^{10}$

15 A portion of the opinion relating to the burden of proof is omitted.

16 See Hall v. I'laine, 14 Ohio St. 417 (1S(;:) : Geiszler r. De Graaf, $166 \mathrm{~N}$. Y. 339, 59 N. E. 993,82 Am. St. Rel. (i.) (1901): In re Hanlin, 133 Wis. 140,113 N. W. 411, 17 I. R. A. (N. S.) 1189, 126 Am. St. Rep. 938 (1907); Brooks v. Mohl, AIG.Prop. - 19 


\section{MARKLAND v. CRUMP.}

(Sunreme Court of North Carolina, 15:34. 1S N. C. 94, 27 Am. Dec. 230.)

This was an action to recover damages for the breach of a covenant of quiet enjoyment contained in a cleed whereby the defendant conveyed land to the intestate of the plaintiff. The breaches assigned, were: 1st. The eviction of the intestate by paramount title. 2nd. The eriction of the bargainee of the intestate.

The plaintiff having made out a prima facie case, for the defence it was proved that the interest of the intestate in the land, had, before the eviction, been sold under a fi. fa. against the intestate, to one Marc11m, and that the latter was the person who had really been evicted.

Upon this fact being admitted, his honour, Judge Sewell, at Rowan, on the last Circuit, ruled that the plaintiff, to entitle himself to a verdict, should "show a disturbance, either of his intestate, or of some person holding under him, as his tenant, whose possession was that of the intestate. That the plaintiff as administrator, could not recover for a disturbance, when the person disturbed could claim the benefit of the covenant, in the deed to the intestate. That the covenant declared on, either ran with the land to the assignee, or it did not. If the former, the assignee being the person disturbed, was entitled to its benefit-that but one action could be maintained for the disturbance, and to allow that action to be brought by one whose interest had passed away, and who had received the full value of the land, for a disturbance which in no way molested him, and this to the prejudice of the person really injured, who had lost both the lands and his money, was not consistent either with reason or justice. That if on the other hand, the covenant did not run with the land, and extend to the assignee--the purchaser under the fi. fa. then it had not been broken by the eviction of the latter."

In subinission to this opinion, the plaintiff suffered a non-suit, and appealed.

RufFin, C. J. The opinion delivered in the Superior Court, is that entertained by this Court; and very much upon the reasons expressed by his honour. For it would seem to be a first principle, that in an action sounding in damages, none can be recovered, if none have been sustained by the plaintiff.

Marcum, the purchaser at sheriff's sale, has been regarded by the plaintiff's counsel, as a purchaser with warranty; because, under the statute, he can have recourse to Tucker, the defendant in the execution. The Court supposes it clear, that he is an assignee, who, by reason of

10 Jimn. 401,116 N. W. 931, 17 L. R. A. (N. S.) 1195, 124 Am. St. Rep. 629 $11 ! 11)$

lint sue Zent v. l'icken, 54 Iowa. 595.6 x. W. 750 (18S0); Backus' Adu'rs v.

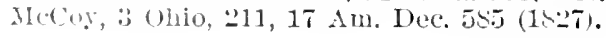


the privity of estate, is entitled to the benefit of, and bound by all covenants running with the land. Spencer's Case, 6th Resolution, 5 Rep. 17. But whether such recourse against Tucker, would amount to such a warranty, or ought to be construed to have the same effect, the Court does not deen it necessary to determine. Because we think, an express warranty from Tuclier to Marcum, would not, upon the eviction of the latter, give an action to Tucker against Crump, on his covenant of warranty, nor be a bar to that of Marcum against Crump on the same covenant.

In support of the proposition to the contrary, the counsel for the plaintiff has been able to adduce no case, in which that was the point adjudged. In Kane v. Sanger, 14 Johns. (N. Y.) 89, Chief Justice SPENCER states the general rule to be, that where covenants run with the land, if it be conveyed before a breach of the covenant, the assignee only can sue upon the subsequent breach; but if the assignor be himself bound in his deed, to indemnify the assignee against such breach, there the assignor only can bring the action. This is certainly a very explicit declaration of the opinion of a most respectable Judge. But it is not entitled to the authority of an adjudication; because it was not necessary to the decision of the case, and is only a dictum. There the plaintiff, who was the assignor, had immediately taken back the legal estate, by way of mortgage in fee; and therefore his assignee could not, under any circumstances, have had an action; for at the time of the breach, he was not the assignee, but the plaintiff was reinrested with the estate by force of the mortgage. Upon this ground the plaintiff had judgment. As it was held, that in the case proved, the effect of the plaintiff's warranty could not be a bar to the action, it became immaterial to determine what the effect would have been, if the estate had remained in the assignee, until his eviction.

To English case is referred to by the Chief Justice, and but one in this country, that of Bickford v. Paige, 2 Mass. 460. This last case does not seem to us to admit of such an interpretation. Chief Justice Parsons says, that "the assignee alone can sue, unless the nature of the assignment be such, that the assignor is holden to indemnify the assignee against a breach of the covenants by the original vendor; which is founded on the principle, that no man can maintain an action to recover damages, who has suffered none." This is a very clear opinion, that an assignee without a covenant from his immediate vendor, may sue on a remote covenant; and that he alone can sue in such a case; and that for the very best of reasons-because no body else is injured. But it affords no inference, that an assignee with warranty may not also sue on a remote covenant, but only, that in such case, he is not the only person, who can have remedy for a breach. In the context, it nu1st mean, that the assignee who is ericted, may sue the remote corenantor for the damages sustained by him; but that this case is not like the former in which he alone could have the action; because in this case, another, besides the assignee, may sus- 
tain damages, namely, his assignor upon his engagement to indemnify. As without such engagement the assignor could not sue, because he could not be injured; so where he paid the damages to the assignee upon such an engagement, the assignor could sue, because he then had suffered. But because the assignor can bring an action after suffering, it does not follow that he can bring his action upon the eviction of his assignee, and before satisfying the assignee, and to the exclusion of the assignee himself.

This construction of the language of Chief Justice Parsons is that adopted by the Court in Withy v. Mumford, 5 Cow. (N. Y.) 137, in which the doctrine laid down in Kane v. Sanger, is pointedly denied, under such circumstances as to destroy its authority; even in the Courts of New York. For had the point been necessary to a decision in Kane v. Sanger, it is adjudged directly to the contrary in Withy v. Mumford, in which it was held, that the assignee, who is evicted, may sue any one or more of the covenantors, whether immediate or remote; and that an assignor, who has himself corenanted, cannot sue a prior covenantor, until he has himself satisfied the evicted assignee; but that upon doing that, he can.

This Court is at loss for a reason upon which the first rule laid down in the Supreme Court of New York can be sustained, or the second can be impeached. If there be a reason, it must be peculiar to covenants and conveyances of land. None such is perceived; and to us, the position contended for seems to be inconvenient, unjust, and contrary to analogy. It multiplies suits, by requiring each assignee to sue his own vendor only. It may defeat the evicted person of his damages, by enabling his insolvent assignor to recover the money from the only person among those liable, who is able to pay it; and he may refuse to pay it over. Covenants which run with land, were always exceptions to the maxim of the common law, that choses in action could not be assigned. They cannot be separated from the land, and transferred; but with the land they could, as being annexed to the estate in possession, and bound the parties in respect to the privity of estate. In other instances of assignments tolerated by law, the assignee having for the time being the right, is alone entitled to an action on the contract, and may have his action against any of the parties bound, either mediately or immediately. Negotiable mercantile instruments, afiord a similar example. The holder may sue, not only his own endorser, but also any one whose name is on the paper. Lut an endorser cannot have an action against any party prior to himself, until he shall have taken up the paper from the last holler, and thus become the holder to his own use. The good sense of this principle scems to make it necessarily applicable to all cases of successive engagements of indemnity.

It is admitted that, if the grantee with warranty, convey without warranty, the last grantee may sue directly on the covenant of the first grantor. It is not seen why the interposing a second warranty should, 
nor how it can, restrict the assignee to a remedy on the last covenant. In each case, the first covenant came to him, as being annexed to the estate; and thus belonging to him, he, and not another, ought to have the action on it, until he gets satisfaction. When that is made, the person who makes it is then the injured person, and may have his action to make himself whole. It is for the benefit of all parties, that each claimant should have a direct recourse on the person ultimately responsible, if he be able to respond.

An argument was drawn for the plaintiff, from the doctrine of Buckhurst's Case, 1 Co. Rep. 1, that a vendor who warrants, is entitled to keep the title papers, which contain covenants to which he may resort for his indemnity. The inference sought is, that if he has a right to the deed, it must be because he alone can bring an action on the covenants in them, or that such possession gives him the exclusive right of action. In our opinion, that consequence cannot be deduced. It affords no better ground for his action for a breach subsequent to his assignment, than for such action before any breach, in anticipation of one. The possession of the title deeds may indeed put the assignee to a difficulty in framing his declaration, making profert, and giving evidence of a deed not in his own possession, which he must encounter, and get over as well as he can. Indeed, it may be, that he may be excused from a profert, if the record shows that he is not entitled to the deeds. But these obstacles merely arise out of the rules of pleading and evidence, as between the assignee and covenantor sued; and have no reference to the rights of an intermediate owner, who has parted from his title. The first feoffor can make direct satisfaction to the person evicted, or take a release from him.

That an assignee may sue the remote covenantor, the case of Middlemore v. Goodall, Cro. Car. 503, is a direct authority. It is true that the plaintiff there did not state in his declaration, that his conveyance was with warranty; so that the effect of such a covenant is not precisely shown by that case. But it is equally true, that it does not appear that the deed to the plaintiff did not contain such a covenant. Now every declaration must give a complete cause of action, and if the law be, that an assignee with warranty cannot sue on any prior covenant, the declaration ought to aver that the plaintiff is an assignee without one. Nothing of that kind is found in that case, nor in the precedents. They are silent as to the covenants contained in all the deeds, under which the plaintiff claims, except the particular covenants on which the suit is brought, and only sets forth the operative parts of the deed, as conveying the estate to the plaintiff. Nor has any case, or precedent been found, of a plea, that the conveyance from the plaintiff's vendor, or from some assignor between himself and the defendant, did contain covenants, although the case. of such covenants, posterior to that of the defendant in the action, must frequently have occurred. 
But a still broader ground was asserted in the argument; which is, that even if the assignee Marcum could sue, yet the plaintiff, as administrator of Tucker, the defendant's bargainee, could.also have his action: the two actions resting on different grounds; the former on privity of estate, and the latter on privity of contract.

For this no direct authority has been cited, and we suppose there can be none. For it is a proposition of simple justice to the covenantor, that both actions cannot be maintained. It has however been likened to the case of the action of covenant by a lessor against an assignee of the lessee, and also against the lessee himself; both of which will certainly lie. That, however, is but the ordinary case of a creditor having a right to look to two persons severally for the same debt, from one only of whom, is he allowed to collect it. This would be the anomalous one, of two persons having each the distinct right to recover and collect from a debtor, the same money, although he ought to pay it but once.

The present case is really correlative, not to that of a lessor claiming from the lessee and his assignee the rent due him, but to that of a lessor who has assigned his reversion and sues the lessee on the corenants in the lease for rent arising after the assignment. That such an action cannot be sustained upon the privity of contract has been settled ever since Lord Coke's time. Walker's Case, 3 Rep. 22. It is there laid down "that if the lessor grants over his reversion, now the contract runneth with the estate, and therefore the grantor shall not have any action of debt for rent due after his assignment, but the grantee shall have it; for the privity of contract follows the estate, and is not annexed to the person but in respect of the estate." The explanation of the difference he proceeds afterwards to give, and it is most reasonable. "The lessee himself," he says, "shall not prerent by his own act such remedy which the lessor hath against him; but when the lessor grants over the reversion, there, against his own grant he cannot have remedy, because he has granted to another the reversion, to which the rent is incident." It is thus seen, that to an action by the lessor against the lessee or his assignee, it is a full answer, that the plaintiff had assigned before the rent accruted.

The same principle embraces the present case. Tucker, the defendant's grantee, cannot have the action, because he conveyed to Marcum, before the breach, the estate to which the covenant was incident, and the original privity of contract will not support the action, but in respect of the privity of estate continuing, or of the loss of the estate and damages thence arising to the plaintiff.

Indced, if privity of contract alone was sufficient without reference to the estate, the present plaintiff might recover as well if his intestate had conveyed without, as with warranty; for the covenants inserted in the deed do not make it more or less an assignment of the land. Iet the very cases cited admit the assignee's sole right to sue, 
if there had not been a warranty by his vendor; for if he had not the right there would be no redress.

But there are other cases from which it is clear that mere privity of contract will not suffice to sustain an action; but the plaintiff must show a damage arising to himself in particular, from the breach alleged. Those of Kingdon v. Nottle, 1 Maule \& Selw. 355, and 4 Maule \& Selw. 53, are clear examples. The defendant conveyed to the testator with a covenant of seisin; and the first action was brought by the plaintiff as executrix, upon the idea that such a covenant was broken as soon as entered into, and therefore that, as in other cases of a breach in the testator's time, she ought to sue in that character. But it was held otherwise on denurrer, because although the warranty was broken in the testator's time, yet the declaration did not show a special damage to him in his life-time, and the heir or devisee took the estate such as it was, and was entitled to the benefit of the covenant; and therefore the executrix could not sue, and claim the damages as personalty, since the testator had not so treated the breach of covenant. Lord Ellenborough said there would be a difficulty in admitting the executrix to recover at all, that is, upon the declaration as framed, without allowing her to recover the full amount of damages for the defect of title; and in that case, the heir would be barred by her recovery; for the heir could not maintain another action for the same breach and the same damages. All the Judges, indeed, put it pointedly, that the recovery by the executrix would be a bar to the heir, and leave no subject of a suit for the devisee, although the estate such as it was, came to him, and the damage was actually to him. Accordingly when the same plaintiff, in the last case, sued as devisee, there was judgment for her.

These cases are contrary to several in this country in one respect; which is, that upon a covenant of seisin the assignee of the land cannot have an action, since the breach is necessarily before the assignment. Greenby v. Wilcocks, 2 Johns. (N. Y.) 4, 3 Am. Dec. 379, and Bickford v. Paige, 2 Mass. 460. That difference does not affect the question before us; and the case of Kingdon v. Nottle is a clear authority for this principle, that whenever a person is in the land in privity of estate with the covenantor, eviction or defect of title is not necessarily to the damage of one who has merely a privity of contract; but that such latter person must particularly show his damage, before he can sue on the contract. It further establishes, that the action of the person who has only a privity of contract will not lie, because a recovery in it would be a bar to the person who had the privity of estate, to whom the injury is immediate, and who therefore has the first right to satisfaction.

Upon the whole, therefore, the Court is of opinion, both upon authority and reason, that a purchaser with warranty from his vendor may sue upon a covenant of warranty to his vendor; and as a con- 
sequence, that the latter cannot sue, until he shall have sustained damage by making satisfaction upon his own covenant.

This is the more proper here, since the rule established in this state for measuring the damages; because the plaintiff's intestate ought not to recover his purcliase money, but only what Marcum recovered from him; that is to say, the purchase money and interest paid by Marcum. IVilliams v. Beeman, 13 N. C. 483.

The observations on the first point supersede the necessity of examining the question, whether an estate passed by the defendant's deed or not. The declaration is not framed on a covenant to convey, as if this were such an agreement and not a conveyance; but on this as a covenant of warranty of an estate conveyed. The gravamen is the eviction of Marcum, the assignee, and the damages arising therefrom; and not a refusal to make an assurance. Now the eviction of the intestate's assignee can never, per se, be an injury to the plaintiff; but to the assignee alone, until he shall have called on the plaintiff to make him whole. When that shall be done, the plaintiff can state a case in his declaration, on which a special damage to his intestate, or to himself as administrator, can be seen and assessed to him.

Per Curiam. Judgment affirmed. ${ }^{17}$

\section{WILSON v. TAYLOR'S EX'RS.}

(Supreme Court of Ohio, 1859. 9 Ohio St. 595.)

This is an action of covenant. Reserved in the district court of Licking county. The case stands upon demurrer to rejoinder.

The material allegations of the declaration are substantially these: That 'Taylor (the defendant's testator) conveyed the land, which is the strbject of the covenant sued on, to Wilson, the plaintiff; that Wilson conveyed to Thomas Legget; that Legget conveyed to William Weis, who went into possession; that all these conveyances contained like covenants of general warranty against all incumbrances and claims of all persons whomsoever; that at the time Taylor made his deed and covenants to Wilson, one Rebecca Houston, then wife of John Houston, Taylor's grantor, had in the land a contingent right of dower, which became absolute; and that in Taylor's lifetime she filed her petition against Weis, and procured dower in the land to be assigned to her; and that Weis, thus evicted of part of the land, brought an action upon the covenant made by the plaintiff, Wilson, to Legget, and recovered a judgment against the plaintiff for $\$ 284.43$, and costs of suit, which he was compelled to pay. To make himself whole again, Wilson brought this action on the covenant made by Taylor to him.

Taylor's executors plead, in substance, in bar of the action, that

17 See I3ooth v. Starr, 1 Conn. 244, 6 Am. Dec. 233 (1S14); Kramer v. Carter, 130 Mass. 301 (1s\$1) aec. 
Weis had brought an action against Taylor on the same covenant upon which the plaintiff, Wilson, sues, and had recovered judgment against Taylor for its breach for $\$ 280.23$, which he had fully paid.

Wilson replies that Weis had recovered judgment for $\$ 414.43$ against Legget on the covenant made by him directly to Weis, as well as the judgment against the plaintiff, Vilson, of $\$ 284.43$, mentioned in the declaration, and the judgment of $\$ 280.23$ against Taylor, mentioned in the plea; that these judgments recovered by Weis were on the successive coyenants made by Taylor, Wilson, and Legget; and that the recovery of dower and consequent eviction was the common and only breach of all and each of the covenants; and that the amount of the judgment against Legget, to wit, \$414.43, was the true amount of damages sustained and proved by Weis; that of the damages, Taylor paid only $\$ 148.08$, and that the plaintiff, Wilson, paid $\$ 172.46$, and costs and expenses.

To this Taylor's executors rejoin, setting up the same defense made by their plea. To this rejoinder Wilson demurs.

BrinkerhofF, C. J. The covenant in this case sued on, was a covenant running with the land; and Weis, the last grantee, having been evicted from part of the land embraced within the successive covenants of warranty, brought several actions simultaneously against each of the successive covenantors, and recovered several judgments against each. This, it seems to be settled, he might properly do. King v. Kerr's Adm'rs, 5 Ohio, 155, 22 Am. Dec. 777; Foote v. Burnet, 10 Ohio, 317, $36 \mathrm{Am}$. Dec. 90, and notes. But though he might have his several actions, either simultaneously or successively, against all his covenantors, whether immediate or mediate, yet it is equally well settled, that he could have but one satisfaction.

It seems that, for some unexplained reason, judgnent in these several actions, thus simultaneously brought against the successive covenantors, were taken for very different amounts, varying from about $\$ 280$ to about $\$ 414$. And Taylor, the first covenantor, having paid and satisfied the judgment against him, and which was among the smallest in amount, the question presented by the demurrer is, whether this satisfaction of the judgment against him is a bar to an action over against him by the plaintiff, who was an intermediate covenantee, after payment by the latter of a judgment recovered at the same time?

The question seems to be one of first impression, and our minds are not free from difficulty in regard to it; but, on the whole, we are unanimously of opinion that the plea is good. As before remarked, Weis, the last covenantee, and who suffered damage by reason of partial eviction, was entitled to his several action against all the prior covenantors. Not only was his right of action perfect against all, but the same rule of damages would apply as to all; and, although he could have but one satisfaction, yet he was clearly entitled to recover the full amount of his damages against each. If he failed to make the proper showing in order to recover the full amouni of his damages 
against each, it was his own fault; and having collected and received the amount recovered against the first covenantor, who occupied the position in law of a guarantor of all the subsequent grantees, it seems to us that Weis' claim under all the covenants must be held satisfied; and that all enforcement of the judgments against the other intermediate covenantors was wrongful, and in violation of the principle that he could have but one satisfaction. Taylor ought not to be subjected to different actions, and liable to several recoveries for the same breach of the same covenant.

It follows from this that the plaintiff has mistaken his remedy. He ought, after the satisfaction by Taylor of the judgment against him, to have either resorted to a court of equity to restrain the collection of the judgment against himself, or, if circumstances forbade that, to have sued to recover back the money he had paid on the judgment against him, as for money had and received by IVeis wrongfully, and which in conscience he ought not to retain.

Demurrer overruled, and cause remanded. ${ }^{\mathbf{1 8}}$

is Release of Covenantor. See Middlemore v. Goodale, Cro. Car. 50:; (1639); Chase v. Weston, 12 N. H. 413 (1St1); Susquehamna \& W. Val. Rail. load \& Coal Co. v. Quick, 61 Pa. 328 (1S69).

The cases above given under the heading "covenants for title" have been selected with a view eslecially to the derelorment and presentation of the mrollems arising out of the rmning of such covenants with the "land," probably the most diflicult phase of the general subject. On this and other phases of the subject, the student should further consult Rawle on Covenants for Title. 


\section{CHAPTER VII}

\section{ESTOPPEL BY DEED}

\section{LI'T'TLETON'S TENURES.}

Also these words which are commonly put in such releases, scilicet (quæ quovismodo in futurum habere potero) are as roid in law; for no right passeth by a release, but the right which the releasor hath at the time of the release made. For if there be father and son, and the father be disseised, and the son (living his father) releaseth by his deed to the disseisor all the right which he hath or may have in the same tenements without clause of warrantie, \&c., and after the father dieth, \&c., the son may lawfully enter upon the possession of the disseisor, for that he had no right in the land in his father's life (pur ceo que il navoit droit en la terre en la vie son pier) but the right descended to him after the release made by the death of his father, \&c.

Section 446.

\section{COKE UPON LITTLETON.}

Note, a man may have a present right, though it cannot take effect in possession, but in futuro.

As he that hath a right to a reversion or remainder, and such a right he that hath it may presently release. But here in the case which Littleton puts, where the son release in the life of his father; this release is void, because he hath no right at all at the time of the release made, but all the right was at that time in the father; but after the decease of the father, the son shall enter into the land against his own release.

"Without clause of warrantie." For if there be a warrantie annexed to the release, then the son shall be barred. For albeit the release cannot bar the right for the cause aforesaid, yet the warrantie may rebut, and bar him and his heirs of a future right which was not in him at that time; and the reason (which in all cases is to be sought out) wherefore a warrantie being a covenant real should bar a future riglit, is for avoiding of circuity of action (which is not favoured in law); as he that made the warrantie should recover the land against the ter-tenant, and be by force of the warrantie to have as much in value against the same person. § 265 a. 


\section{JACKSON ex dem. MCCRACKIN v. WRIGH'T.}

(Supreme Court of New York, 1817. 14 Johns. 193.)

This was an action of ejectment, brought to recover 200 acres of land, on the west side of lot No. 60, in the town of Sterling. The cause was tried before Mr. Justice Yates, at the Cayuga circuit, in 1816.

Peter Boise, by deed poll, dated the 5th of July, 1794, and which was recorded on the 12th of June, 1807, wherein he is described as late private in the first New York regiment, in consideration of forty pounds, granted, bargained, sold, and quit-claimed to the lessor of the plaintiff, in fee, "all that military right, or parcel of land, granted to him as bounty lands, for his services in the regiment aforesaid, during the late war." The deed contained no covenants or warranty.

On the $2 \mathrm{~d}$ of April, 1806, an act was passed by the legislature of this state (Laws 1806, c. 95), entitled, "An act, for the relief of Peter Boise, and others," by which it was enacted, "that it shall and may be lawful for the commissioners of the land office, and they are hereby required to grant letters patent to Peter Boise late a soldier in the first New York regiment, commanded by Colonel Goose Van Schaick, in the line of the army of the United States, and his heirs and assigns forever, for the quantity of two hundred acres of land, in the tract set apart for the use of the line of this state, serving in the army of the United States, as a gratuity for his services and sufferings in the late revolutionary war: provided, that the grant shall be to the said Peter Boise; during his life only, and afterwards to his heirs in fee." In pursuance of this act, letters patent, bearing date the 20 th of November, 1806, for the premises in question were issued to Peter Boise, under the great seal of the state.

The judge ruled, that the act of the Legislature above mentioned, was a private act, and that the deed from Boise to the lessor of the plaintiff, being prior in date to the patent, did not entitle him to recover. A verdict was accordingly rendered for the defendant.

The plaintiff moved for a new trial, and the case was submitted to the court without argument.

Spencer, J. The decision of the judge at the circuit, was correct, on two grounds: ${ }^{1}$

2. The deed from Boise to MeCrackin is a bargain and sale, and quit claim, and he had then no title to convey in the premises; and no title, not then in esse, would pass, unless there was a warranty in the deed; in which last case, it would operate as an estoppel, for avoiding circuity of action. (Co. Lit. sect. 446, 265, a and b; Bennett v. Irwin, 3 Johns. 365$.

\section{Motion denied.}

1 The court's opinion covering the first ground is omitted. 
BAYLEY v. McCOY.

(Supreme Court of Oregon, 18s0. S Or. 259.)

PRIM, J. This was an action to recover damages for an alleged breach of certain covenants in a deed. On May 23, 1870, John H. Kendall and wife, for a valuable consideration, sold a certain lot in the town of Corvallis, Benton county, Oregon, to James R. Bayley, and then and there made, executed, and delivered to him their deed for the same, as follows: "That the party of the first part, for and in consideration of the sum of eight hundred dollars to them in hand paid, * * * have bargained, sold, and conveyed, unto the said party of the second part, the following described premises, to wit: All of their right, title, and interest in and to lot number one in block number eleven, in the city of Corvallis, Benton county, and state of Oregon, to have and to hold the said premises, with their appurtenances, unto the said James R. Bayley, his heirs and assigns forever. And the said John H. Kendall does hereby covenant to and with the said James R. Bayley, his heirs and assigns, that $I$ am the owner in fee simple of said premises; that they are free from all incumbrances, and that I will warrant and defend the same from all lawful claims whatscever." That at the time when said deed was made, the said Kendall was not the owner of any portion of said lot except the south half thereof, and neither he nor his heirs have warranted or defended the said premises to the said Bayley, but on the contrary, at the time when said deed was made and delivered to him, the north half of said lot was seised and possessed by the Corvallis Lodge, No. 14, Ancient Free and Accepted Masons, of Benton county, Oregon, by virtue of an older and better title. Said Kendall having died prior to the commencement of this action intestate, it was brought against appellant as the administratrix of his estate.

The answer of appellant, after denying certain allegations of the complaint, sets up as a separate defense: That at the time when said Kendall made the deed mentioned in the complaint in this cause, he did not sell or convey to the respondent all of said lot number one in block number eleven, but that he sold only the right, title, and interest he then had in said lot, which was the south half of said lot; that at the time of making said deed, the said Kendall was the owner in fee simple of the south half of said lot. That said south half was all that said Kendall attempted to convey to respondent by said deed, and was all that had been bargained for by him at the time, and was all that said covenant of title related to, and was so understood at the time of said purchase. A demurrer was interposed to this part of the answer, which was sustained by the court, and judgment rendered against the appellant, from which he appeals. The order and judgment of the court sustaining the demurrer to this portion of the answer, is the principal and main ground of error complained of here. 
It was claimed on the argument, that the deed only purports to conrey such right, title, and interest as the grantor then had in said lot one, and no more, and the corenants, although more general, should be heid to have reference only to such right and title as the grantor then had in said lot, whatever that might be. This doctrine appears to be maintained by the decisions of Massachusetts and one or two other states; but the modern decisions of the most of the state courts, and of the supreme court of the United States, maintain a contrary doctrine. They hold that "whatever may be the form or nature of the converance used to pass real property, if the grantor sets forth on the face of the instrument by way of recital or averment, that he is seised or possessed of a particular estate in the premises, and which estate the deed purports to convey; or what is the same thing, if the seisin or possession of a particular estate is affirmed in the deed, either in express terms or by necessary implication, the grantor and all persons in privity with him shall be estopped from ever afterwards denying that he was so seised and possessed at the time he made the conveyance." Van Rensselaer v. Kearney, 11 How. 325, 13 L. Ed. 703; Fairbanks v. Williamson, 7 Greenl. (Me.) 96; Jackson ex dem. MIunroe v. Parkhurst, 9 Wend. (N. Y.) 209. In Taggart v. Risley, 4 Or. 235, this court adopted that doctrine, and that case we think is decisive of this one.

Mr. Rawle, in his work on Covenants, in commenting on this subject, says: "When, however, it has distinctly appeared in such conyeyance, either by a recital, an admission, a covenant, or otherwise, that the parties actually intended to convey and receive reciprocally a certain estate, they have been held to be estopped from denying the operation of the deed, according to this intent." Rawle on Covenants, $38 S$; Jackson v. TValdron, 13 Wend. (N.Y.) 178. By reference to the deed, it will be seen that Kendall and wife "bargained, sold, and conveyed * * * the following described premises, to wit: All their right, title, and interest in and to lot number one in block number eleven." And there it is asserted by way of covenant, "that he was owner in fee simple of said premises, and that he would warrant and defend the sane from any lawful claims whatsoever." The word "premises" evidently refers to the whole of lot number one, described in the deed, and not to one half of it, as is contended by the appellant. We think that the appellant is estopped by the recitals and covenants of this deed from averring and proving the matters sought to be set forth in the answer as a defense to this action.

There being no error in the record, the judgment of the court below is affirmed.

Kistry, C. J. (dissenting). I do not concur in the opinion of the court, and will briefly give the reasons for my dissent. It is conceded that the deed of J. H. Kendall and wife to J.R. Bayley conveyed to the latter only the right, title, and interest which they had in lot one in block eleven, and not the lot itself; but the court holds that the cove- 
nant of Kendall and wife that they were the owners in fee simple of the premises, is a covenant that they were the owners of the entire lot. I do not so understand it. The deed conveyed only the interest which the grantors then had in the lot. The habendum limits the estate then granted to the interest which they then had in the prennises, and the warranty is that they were the owners of the premises. I do not consider that the word premises, as here expressed, means the entire lot, but only the interest which the grantors then sold. If they had covenanted that they were the owners of lot number one, then there would have been no doubt of their liability in this action. I think this position is supported by the decision of the supreme court of Massachusetts in the case of Sumner v. Williams, 8 Mass. 162, 5 Am. Dec. 83, and is not in conflict with the case of Taggart v. Risley, decided by this court in 4 Or. 235.

\section{HANNON v. CHRISTOPHER.}

(Court of Chancery of New Jersey, 18s1. 34 N. J. Eq. 459.)

VAN FLEET, V. C. The defendant seeks to have an injunction, which has been granted against the further prosecution of an action of ejectment, dissolved. The facts on which the motion must be decided are undisputed. They show that Mary Vermilya died seized in fee of the lands in dispute, in 1824, leaving a will, in which she made the following devise: "And also I give and devise all my real estate, whatsoever and wheresoever, unto my niece, Mary Ann Jarvis, my mother, Sarah Vermilya, and my brother, Thomas Vermilya, to the survivor of them, and to the heirs and assigns of such survivor."

The lands in dispute passed by this devise. The devisees died in the following order: First, Saraf Vermilya, March 30th, 1834; -second, Mary Ann Jarvis, January 29th, 1846, and, lastly, Thomas Vermilya, in September, 1853. Mary Ann Jarvis married Thomas S. Christopher January 9, 1840, and had by him two children, viz., the defendant (Thomas V. J. Cliristopher) and James J. V. Christopher. 'I Thomas Vermilya, shortly after the death of his mother, Sarah Vermilya, and on the 10th of October, 1834, conveyed the lands in dispute to Mary Ann Jarvis, by deed containing the following recitals: "Whereas, Mary Vermilya, late of the city of New York, deceased, was in her lifetime seized in fee simple of and in certain lots of land, hereinafter particularly described; and whereas, the said Mary Vermilya did, in and by her will, by her duly made to pass real estate, bearing date September 2d, 1824, give and devise all her real estate, whatsoever and wheresoever, unto her niece, Mary Ann Jarvis, her mother, Sarah Vermilya, and her brother, Thomas Vermilya, to the survivor of them, and to the heirs and assigns of such survivor; and whereas, Sarah Vermilya, my mother, is now dead, and the said property is now vested in me, the said Thomas Vermilya, and Mary Ann 
Jarvis, in fee simple, and $I$, the said Thomas Vermilya, being desirous of vesting the whole in my niece, Miary Ann Jarvis, now this indenture witnesseth," \&c.

The deed then, in consideration of the sum of $\$ 100$, grants, bargains and sells unto Miary Ann Jarvis, and to her heirs and assigns, all the grantor's estate, right, title and interest whatsoever, under the will of Mary Vermilya or otherwise, of, in and to the lands therein described. The deed is without covenants, but the habendum declares that the grantee, and her heirs and assigns, shall have and hold the lands, to her and their use, absolutely, forever.

On the 6th of September, 1844, Mary Ann Jarvis, together with her husband, Thomas S. Christopher, by deed containing covenants of general warranty, conveyed the lands in dispute to John Arbuckle. Since then, in virtue of several mesne conveyances, they have become rested in the complainant. No dispute is raised respecting the regularity of the complainant's title; the objection to her case goes deeper; it is denied that the source from which she derived her title could grant a fee.

Thomas Vermilya, the survivor of the three devisees, died, as already stated, in September, 1853. He left a will, by which he gave his whole estate to the defendant (Thomas V.J. Christopher) and to the defendant's brother, James J. V. Christopher, and to the defendant's father, Thomas S. Christopher. The defendant's father and brother both subsequently died intestate, and without leaving any other relative as near in blood as he; consequently, the whole estate of which Thomas Vermilya was seized at the time of his death is now vested in the defendant. The defendant, under a claim that the deed from Thomas Vermilya to Mary Ann Jarvis passed only a life estate, and that the fee is now. vested in him, has brought an action of ejectment against one of the complainant's tenants. That suit has been enjoined at the instance of the complainant, and the question now before the court is, whether or not, on the facts first narrated, the defendant is entitled to have that injunction dissolved. The main topic of dcbate presented by the case is, whether or not the deed of 1834 , made by Thomas to Mary Ann, should be adjudged to have created an estoppel, which should debar Thomas, and those standing in his rights, from asserting a claim to the estate subsequently cast upon him by the death of Mary Ann. At the time Thomas made that deed, it is admitted he was seized of only a life estate, with a possibility that the contingent remainder in fee might vest in him as survivor.

The legal construction of the devise is, in my judgment, entirely clear. The thrce devisees took a joint estate for life, with contingent. remainder in fee to the survivor. Under our system of real property law, neither words of inheritance nor perpetuity are necessary to pass a fee by will. By the common law they were, but a devise to $A$ and his assigns forcver, or to $\mathrm{A}$ and his heir, would pass a fee. 4 Com. Dig. 161, tit. "Estate by Derise," n. (4). So a devise to one et sanguini 
suo would pass an estate of like quantity. Gilbert on Dev. 19. By a statute passed in 1784, it is enacted that all devises in which the words heirs and assigns, or heirs and assigns forever, are omitted and no expressions are contained whereby it shall appear that such devise was intended to convey an estate for life only, shall be construed, deemed and adjudged, in all courts of law and equity, to convey an estate in fee simple in as full a manner as if the lands had been given to the devisee, and to his heirs and assigns forever. Rev. p. 300, § 13. Hence, as the law stands, a devise to A, simpliciter, in which nothing appears indicating a purpose to give him only a life estate, wiil create a fee. In view of the provisions of this statute, it is clear that if the devise in this case had been to the three, and to the survivor, without more, the survivor would have taken the fee, and such, obviously, in view of the terms of this devise, must have been the construction it would have received according to the common law, and in the absence of a statute like that just cited. A devise to two, and the survivor of them, and the heirs of such survivor, gives them a joint estate for life only, with contingent remainder in fee to the survivor. 2 Fiearne on Rem. 66, § 187 a; Vick v. Edwards, 3 P. IVms. 372.

Thomas Vermilya, then, according to the legal construction of this devise, became seized of the fee of the lands in dispute on the death of his niece, Mary Ann Christopher. The defendant stands in his place, with no greater rights or higher equity. He is simply the donee of Thomas, and the case must be decided in the same manner that it would be if Thomas were the person seeking to dissolve this injunction. The recitals of the deed made by Thonias to Mary Ann show, beyond all question, that the estate about which they were dealing, and which Thomas intended to convey, and Mary Ann expected to get, was the fee. It is incontrovertible that the decisive and controlling representation of the deed is that in which it is said, that "the said property is now vested in me, Thomas Vermilya, and my niece, Mary Ann Jarvis, in fee simple." 'They manifestly dealt on the basis that they were the owners, absolutely, of as great and as perfect an estate as it is possible to hold in lands.

Do the recitals of this deed create an estoppel against Thomas?

There is an apparent conflict in the adjudications upon the question whether a deed of bargain and sale, without warranty of title, but containing recitals showing that the parties evidently dealt under a belief that the grantor was seized of a greater estate in the lands than he actually had at the time of its execution, will bind or transfer, by estoppel, a contingent subsequently acquired estate. Some seem to hold that a grant in this form is utterly inefficacious to pass an estate not yet vested, and can only operate as a conclusion between the parties and their privies on an estate vested at the time of its execution; while others, resting upon a much more liberal and just basis, hold that whether a contingent or an after-acquired interest will pass by estopAIG.PROP. -50

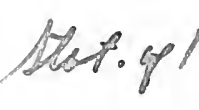


Fel, as the result of a conveyance in this form, depends entirely upon whether it was the intention of the parties to convey it, and that whenever it clearly appears that such was their intention, it is the duty of the court to adjudge an estoppel, in order that the deed may be carried into effect according to the minds of the parties. No review of the learning on this subject will be attempted. The limits of a judicial opinion are neither sufficient nor adapted to such an undertaking. The cases will be found collected in the American notes to the Duchess of Kingston's Case, 2 Smith's L. C. 623 et seq.

In my opinion, the latter view is the correct one. It commends itself to my sense of justice as being in entire accord with certain fundamental doctrines of the law, and it is obviously better adapted to promote and further justice than its opposite. It appears to be a natural deduction from, if not an actual exemplification of, that great principle which declares that in searching for the meaning of an instrument, that interpretation shall prevail which is "as near the minds and apparent intent of the parties as it possibly may be, and the law will permit." Shep. Touch. ch. V, p. S5. And "if it cannot operate in one form, it shall operate in that which, by law, will effectuate the intention of the parties." Goodtitle v. Bailey, Cowp. 597.

The most accurate and lucid statement of the essentials of such an estoppel that has come under my observation, is that given by $\mathrm{Mr}$. Justice Nelson, in pronouncing the opinion of the supreme court of the United States, in the case of Van Rensselaer v. Kearney, 11 How. 297, 301 (13 L. Ed. 703) in which he says: "That if the deed bears on its face evidence that the grantor intended to convey, and the grantee expected to become invested with an estate of a particular description or quality, and that the bargain proceeded upon that footing between the parties, then, although it may not contain any covenants of itle, in the technical sense of the term, still, the legal operation and effect of the instrument will be as binding ipon the grantor and those claming under him, in respect to the estate thus described, as if a formal covenant to that effect had been inserted, at least so far as to estop them from ever afterward denying that he was seized of the particular estate at the time of the conveyance."

Then, after a careful examination of several previous adjudications, both by the courts of England and of this country, he further says: "The principle deducible from the authorities seems to be that whatever may be the form and nature of the conveyance to pass real property, if the grantor sets forth on the face of the instrument, by way of recital or averment, that he is seized or possessed of a particular estate in the premises, and which estate the deed purports to convey,

* * the grantor, and all persons in privity with him, shall be estopped from ever afterwards denying that he was so seized and possessed at the time he made the conveyance. The estoppel works upon the cstate, and binds an after-accuircd title as between the parties and privies. The reason is, that the estate thus affirmed to be in the party 
at the time of the conveyance, must necessarily have influenced the grantee in making the purchase, and hence the grantor and those in privity with him, in good faith and fair dealing, should be forever thereafter precluded from gainsaying it."

The rule thus established was subsequently affirmed in French v. Spencer, 21 How. 228, 16 L. Ed. 97, Chancellor Walworth, prior to the decision of Van Rensselaer $v$. Kearney, had enunciated the same doctrine, substantially, in giving his opinion, as a judge of the court of errors of New York, in Jackson v. Waldron, 13 Wend. (N. Y.) 178; and his formula of the rule was subsequently quoted and approved in Fitzhugh v. Tyler, 9 B. Mon. (Ky.) 559. The learned editor of the American notes to the Duchess of Kingston's case, states that the fair result of the more recent cases would seem to be, that whenever the terms of the deed, or of the covenants which it contains, clearly show that it was meant to convey an absolute and indefeasible title, and not merely that which the grantor has at the time, it will bind and pass every estate or interest which may vest in him subsequent to its execution, whether the warranty which it contains be general or special, and although it may contain no warranty whatever. 2 Smith's L. C. 636. In the language of Mr. Justice Nelson, it is clear that this doctrine is founded upon the highest principles of morality, and recommends itself to the justice and common sense of every one.

But for the presence of another fact in the recitals of this deed, viz., a correct recital of the terms of the devise, I think it might very properly be declared, at this point, without further consideration, that the defendant is estopped. The presence of this fact maies the recitals, in their legal essentials, flatly contradictory. The grantor says that he and his grantee hold the lands in fee; but in stating the facts from which this conclusion is deduced, he shows, at least to the professional mind, that his deduction is entirely unwarranted. Now, it cannot be doubted that it was originally held that there could be no estoppel by deed where the truth appeared on the face of the instrument. 4 Com. Dig. 205, tit. "Estoppel" (E 2); Sinclair v. Jackson, 8 Cow. (N. Y.) 543; Pelletreau v. Tackson, 11 Wend. (N. Y.) 111; Jefferys v. Bucknell, 2 Barn. \& Ad. 278; Wolling v. Camp, 19 N. J. Law, 148. But this rule, like all other legal rules, was formulated for the doing of justice, and when it cannot be used for that purpose, but its enforcement will lead to injustice or wrong, it should be disregarded. Equity recognizes no rule as binding which will constrain it to do injustice.

Recently this rule has been repudiated by three of the superior courts of England-chancery, exchequer chamber and queen's bench. In the court of chancery, Lord Chelmsford declared that the appearance of the truth on the face of the deed constituted a reason rather why the party should be held to be estopped, than that he should be permitted to gainsay or disprove what he had previously admitted or alleged. I quote his words: "It appears to me that the circumstance 
of the truth of the case appearing upon the deed, is a reason why the agreement of the parties, which it embodies, should be carried out, either by giving effect to their intentions in the manner which they have prescribed, or, by way of estoppel, to prevent their denying the right to do the acts which they have authorized to be done." Jolly $v$. Arbuthnot, 4 De G. \& J. 224.

And Chief Baron Kelly, in giving his opinion in Morton v. Woods, L. R. (4 2. B.) 293, said that if there were any decisions or dicta which held that where the truth appears there can be no estoppel, that doctrine must now be considered overruled; and he thought it had been rightly overruled. The same case, when before the court of queen's bench was decided in the same way. L. R. (3 Q. B.) 658.

Now it cannot be denied that the truth appears on the face of the deed under consideration, but it is also entirely clear that the parties dealt with each other as though it did not appear there. It must also be admitted that what is false, as well as what is true, is declared on the face of this instrument, and that the parties dealt with each other, obviously, understanding that truth and falsehood, in this instance, were consistent. The truth was obscurely stated, and the falsehood plainly, and they dealt, consequently, on the basis of the falsehood. In this condition of affairs, I think it would be a manifest misapplication of legal principles to say that the truth bars the estoppel. The true rule upon this subject I take to be this: Whether the appearance of the truth on the face of the instrument will defeat an estoppel or not, must altogether depend upon the fact whether it is so expressed that it can be readily seen and understood by the person who ought to be influenced by it, or in manner so technical or obscure that, although it must be admitted it appears in the instrument, yet it is certain it was not seen nor understood by the person who should have been influenced by it, but that he dealt with the party sought to be estopped as though the words on which the estoppel is founded expressed the whole truth.

The great purpose, lying at the foundation of the law of estoppel, is to prevent fraud, either actual or legal. Estoppels are to be used as hields, not as swords. A simple reading of the recitals of this deed can leave no doubt on the mind of any person as to the basis on which the parties dealt. They were dealing with the fee. Thomas intended to grant to Mary Ann the fee simple absolute, and she expected to get it. That was the estate for which she paid her money, and that was the estate Thomas intended to convey to her. Now, if Thomas were here insisting that inasmuch as his deed told both the truth and a falsehood, it was equitable and just that he should be allowed to recover the lands in dispute, in spite of the fact that he had received full compensation for them many years ago, his conduct, according to my notions of legal ethics, would constitute a fraud of the most offensive character. Thomas's donee, in legal principle if not in morals, stands just exactly where Thomas would, if he, instead of the defendant, were now asking for a dissolution of this injunction. My conclusion 
is that it should be adjudged that the defendant is estopped by the deed of 1834.

But another ground for equitable relief remains to be considered. The complainant contends that, even if it be admitted that Thomas had no interest in the lands, at the date of his conveyance, upon which a deed of bargain and sale could operate, by way of estoppel or otherwise, still, inasmuch as it distinctly appears on the face of his deed that it was intended to convey any future interest which he might acquire, and was not intended to be limited to the interest which he then had, equity will enforce the deed as an executory agreement to convey the subsequently-acquired interest. This contention is founded on the most obvious principles of justice, and is supported by very high authority. The adjudications supporting it will be found collected in 2 Smith's L. C. $641 ; 2$ Story's Eq. Jur. $\S 1040 \mathrm{c}$; and 2 Spence's Eq. Jur. 852. Chief Justice Tilghman, in Mclvilliams v. Nisly, 2 Serg. \& R. (Pa.) 509, 515 (7 Am. Dec. 654), said: "Equity will enforce a covenant to convey an estate whenever it shall be acquired by the covenantor, and the case is not the less strong where there is an absolite conveyance."

This ground of relief is, unquestionably, a matter of which a court of equity only can take cognizance. While I am decided in my opinion that the deed of Thomas to Mary Ann contains matter which creates an estoppel against Thomas and all who may claim under him as heirs or devisees;, still, so far as I am aware, the question whether a deed in this form will create an estoppel or not is, as a matter of law, undecided in this state. To compel the complainant, therefore, to litigate the question of estoppel in the court where the action of ejectment is pending, is to send her to a tribunal which it is clear is incompetent to give her one measure of relief to which she seems entitled. If the injunction should be dissolved, and it should then turn out that the court in which the action of ejectment is pending should be of opinion that the deed created no estoppel, the complainant would be compelled either to yield possession of the land, or return here in order that her additional claim to relief might be determined.

For these reasons I think the defendant's motion should be denied. ${ }^{2}$

2 A., in possession of lands as derisee of his father, win in his lifetime was equitable owner thereof, executed a n!ortgage of those lands to B., reciting therein that he, A., was legally or equitably entitled to the premises, and also corenanting that he was lawfully or equitably seised thereof. Later A. acquirecl the legal estate and mortgaged the premises to $C$., who took without notice of B.'s rights. In ejectment by A. against C. it was contended on behalf of $A$. that $C$. was estopped to set up the legal estate. It was held that there was no such estoppel. Right d. Jefferys v. Bucknell, 2 B. \& Ad. 278 (1831).
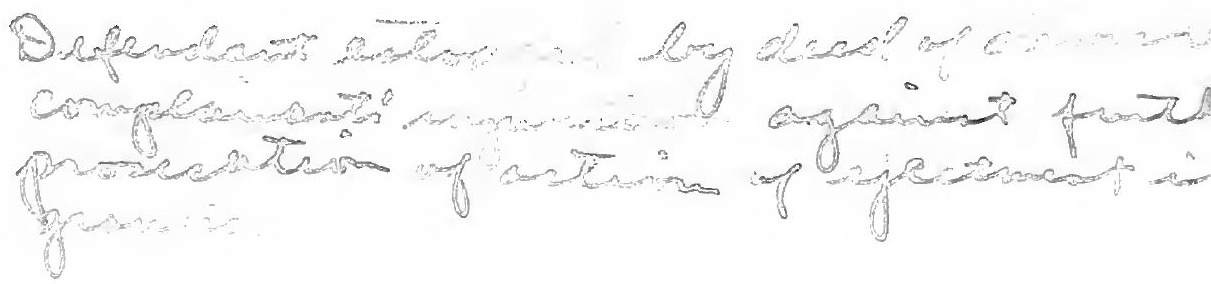


\section{AYER v. PHIL.ADELPHIA \& B. FACE BRICK CO.}

(Supreme Judicial Court of Massachusetts, 1592, 1s93. 157 Mass. $57,31 \mathrm{~N}$. E. $717,159$ Mass. 84,34 N. E. 177.$)$

This is a writ of entry to foreclose a mortgage. The case on the agreed facts, so far as it needs to be stated, is this. One Waterman made a first mortgage, and later a second mortgage. The first was foreclosed and the land subsequently was reconveyed to him. Then the holder of the second mortgage conveyed to a third person, who convered to the demandant. The tenant is a grantee under Water-

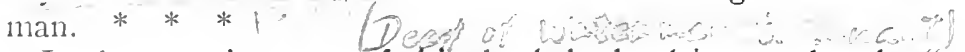

In the granting part of this deed the land is stated to be "conveyed subject to" a certain right of drainage, a certain easement, "and the mortgage hereinafter named." The covenants are as follows: "And $I$, the said grantor, for myself and my heirs, executors, and administrators, do covenant with the said grantees and their heirs and assigns, that I am lawfully seised in fee simple of the aforegranted premises; that they are free from all encumbrances, except a certain mortgage given by me to the Boston Five Cents Savings Bank, dated March 1, $1 \bar{S} 72$, to secure the sum of forty thousand dollars, the right of drainage and the easement aforesaid; that I have good right to sell and convey the same to the said grantees, and their heirs and assigns forever, as aforesaid; and that I will, and my heirs, executors, and administrators shall, warrant and defend the same to the said grantees and their heirs and assigns forever, against the lawful claims and demands of all persons, except the right of drainage and the easement a foresaid." * * *

Holmis, J. ${ }^{3}$ When this case was before us the first time, 157 Mass. $57,31 \mathrm{~N}$. E. 717, it was assumed by the tenant that the only question was whether the covenant of warranty in the second mortgage should be construed as warranting against the first mortgage. ${ }^{4}$ (No attempt was made to deny that, if it was so construed, the title afterwards acq11ired by the mortgagor would enure to the benefit of the second mortsagce under the established American doctrine.) The tenant now desires to reopen the agreed facts for the purpose of showing that after a breach of the covenant in the second mortgage, and before he repurchased the land, the mortgagor went into bankruptcy and got his discharge. The judge below ruled that the discharge was immaterial, and for that reason alone declined to reopen the agreed statement, and the case comes before us upon an exception to that ruling.

The tenant's counsel frankly avow their own opinion that the dis-

3 'The statement of facts is taken from the olinion reported in 157 Mass. 57, 81 న. E. 717 .

(4) $t$ ws held that the covenant of warranty in the second mortgage should be su construed. Welbon V. Welbon, 109 Mich, 356, 67 N. W. 335 (1596); Smith

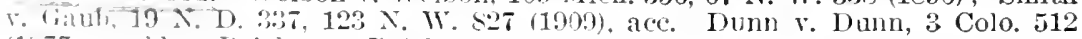
(1sio) semble; Irirker v. Bricker, 11 Ohio St. 240 (1S60), contra. 
charge in bankruptcy makes no difference. But they say that the inuring of an after acquired title by virtue of a covenant of warranty must be due either to a representation or to a promise contained in the covenant, and that if it is due to the former, which they deem the correct doctrine, then they are entitled to judgment on the agreed statement of facts as it stands, on the ground that there can be no estoppel by an instrument when the truth appears on the face of it, and that in this case the deed showed that the grantor was conveying land subject to a mortgage. If, however, contrary to their opinion, the title inures by reason of the promise in the covenant, or to prevent circuity of action, then they say the provision is discharged by the discharge in bankruptcy.

However anomalous what we have called the American doctrine may be, as argued by Mr. Rawle and others (Rawle on Covenants (5th Ed.) $\S 247$ et seq.), it is settled in this State as well as elsewhere. It is settled also that a discharge in bankruptcy has no effect on this operation of the covenant of warranty in an ordinary deed where the warranty is coextensive with the grant. Bush v. Person, 18 How. 82, 15 L. Ed. 273; Russ v. Alpaugh, 118 Mass. 369, 376, 19 Am. Rep. 464. Gibbs v. 'Thayer, 6 Cush. 30 ; Cole v. Raymond, 9 Gray, 217 ; Rawle on Covenants, (5th Ed.) $\S 251$. It would be to introduce further technicality into an artificial doctrine if a different rule should be applied where the conveyance is of land subject to a mortgage against which the grantor covenants to warrant and defend. No reason has been offered for such a distinction, nor do we perceive any.

But it is said that the operation of the covenant must be rested on some general principle, and cannot be left to stand simply as an unjustified peculiarity of a particular transaction without analogies elsewhere in the law, and that this general principle can be found only in the doctrine of estoppel by representation, if it is held, as the cases cited and many others show, that the estoppel does not depend on personal liability for damages. Rawle on Covenants, (5th Ed.) § 251.

If the American rule is an anomaly, it gains no strength by being referred to a principle which does not justify it in fact and by sound reasoning. The title may be said to enure by way of estoppel when explaining the reason why a discharge in bankruptcy does not affect this operation of the warranty; but if so, the existence of the estoppel does not rest on the prevention of fraud or on the fact of a representation actually believed to be true. It is a technical effect of a technical representation, the extent of which is determined by the scope of the words devoted to making it. A subsequent title would inure to the grantee when the grant was of an unencumbered fee although the parties agreed by parol that there was a mortgage outstanding; Chamberlain v. Meeder, 16 N. H. 381, 384; see Jenkins v. Collard, 145 U. S. 546, 5,60, 12 Sup. Ct. 868, 36 L. Ed. 812, and this shows that the estoppel is determined by the scope of the conventional assertion, not by any question of fraud or of actual belief. 
But the scope of the conventional assertion is determined by the scope of the warranty which contains it. Usually the warranty is of what is granted, and therefore the scope of it is determined by the scope of the description. But this is not necessarily so; and when the warranty says that the grantor is to be taken as assuring you that he owns and will defend you in the unencumbered fee, it does not matter that by the same deed he avows the assertion not to be the fact. The warranty is intended to fix the extent of responsibility assumed, and by that the grantor makes himsclf answerable for the fact being true. In short, if a man by a deed says, I hereby estop myself to deny a fact, it does not matter that he recites as a preliminary that the fact is not true. The difference between a warranty and an ordinary statement in a deed is, that the operation and effect of the latter depends on the whole context of the deed, whereas the warranty is put in for the express purpose of estopping the grantor to the extent of its words. The reason "why the estoppel should operate, is, that such was the obvious intention of the parties." Blake v. Tucker, 12 Vt. 39, 45.

If a general covenant of warranty following a conveyance of only the grantor's right, titte, and interest were made in such a form that it was construed as more extensive than the conveyance, there would be an estoppel coextensive with the covenant. See Blanchard v. Brooks, 12 Pick. 47, 65, 67; Bigelow, Estoppel (5th Ed.) 403. So in the case of a deed by an heir presumptive of his expectancy with a covenant of warranty. In this case, of course, there is no pretence that the grantor has a title coextensive with his warranty. Trull v. Eastment, 3 Metc. 121, 124, 37 Am. Dec. 126. In Lincoln v. Emerson, 108 Mass. 87 , a first mortgage was mentioned in the covenant against encumbrances in a second mortgage, but was not excepted from the covenant of warranty. The title of the mortgagor under a foreclosure of the first mortgage was held to inure to an assignee of the second mortgage. Here the deed disclosed the truth, and for the purposes of the tenant's argument it cannot matter what part of the deed discloses the truth. unless it should be suggested that a covenant of warranty cannot be made more extensive than the grant, which was held not to be the law in our former decision. See also Calvert v. Sebright, 15 Beav. 156, $160.0^{5}$

The question remains whether the tenant stands better as a purchaser without actual notice, assiming that he had not actual notice of the second mortgage.

5 See Drury v. Holden, 121 Ill. 130, 13 N. E. 547 (1SS7), where immediately following the description of the lots conveyed there was the following clatuse: "Subject to the following incumbrances on said described premises: One for the principal sum of $\$ 10,600$, and the other for the principal sum of $\$ 6,500$." The deed cont aned full covenants of waranty and against incumbrances, there

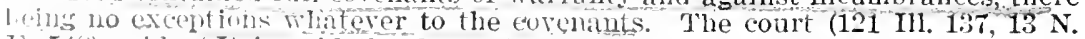
1. 5.5) sail: "It is sild the deed * * * contained full corenants of warlanty, to which there was no excention: that therely Drury's grantor covenantwd that he rould warrant and defend the lots conveyed against the holders of all incumbrances. The covenants extentod only to what was convesed, and 
"It has been the settled law of this Commonwealth for nearly forty years, that, under a deed with covenants of warranty from one capable of executing it, a title afterwards acquired by the grantor inures by way of estoppel to the grantee, not only as against the grantor, but also as against one holding by descent or grant from him after acquiring the new title. Somes v. Skinner, 3 Pick. 52. White v. Patten, 24 Tick. 324. Russ v. Alpaugh, 118 Mass. 369, 376, 19 Am. Rep. 464. We are aware that this rule, especially as' applied to subsequent graitees, while followed in some States, has been criticised in others. See Rawle on Covenants (4th Ed.) 427 et seq. But it has been too long established and acted on in Massachusetts to be changed, except by legislation." Knight v. Thayer, 125 Mass. 25, 27. See Powers v. Patten, 71 Me. 583, 587, 589; McCusker v. McEvey, 9 R. I. 528, 11 Am. Rep. 295 ; 'Tefft v. Munson, 57 N. Y. 97.

It is urged for the tenant that this rule should not be extended. But if it is a bad rule, that is no reason for making a bad exception to it. As the title would have inured as against a subsequent purchaser from the mortgagor had his deed made no mention of the mortgage, and as by our decision his covenant of warranty operates by way of estoppel notwithstanding the mention of the mortgage, no intelligible reason can be stated why the estoppel should bind a purchaser without actual notice in the former case, and not bind him in the latter.

Upon the whole case, we are of opinion that the demandant is entitled to judgment. Our conclusion is in accord with the decision in a very similar case in Minnesota. Sandwich Manuf. Co. v. Zellmer, $4 \mathrm{~S}$ Minn. 408, 51 N. W. 379.

Exceptions overruled.

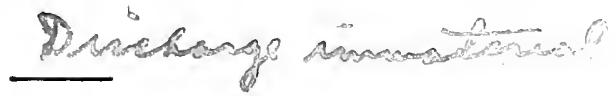

\section{DOE ex dem. CHRISTMAS v. OLIVER.}

(Court of King's Bench, 1529. 10 B. \& C. 181.)

BAYLEY, J. ${ }^{6}$ This case depended upon the effect of a fine levied by a contingent remainder-man in fee. Ann Mary the wife of Joseph Brooks Stephenson was entitled to an estate in fee upon the contingency of her surviving Christian, the widow of Theophilus Holmes; and she and her husband conveyed the premises to Thomas Chandless for ninety-nine years, and levied a fine to support that conveyance. Christian, the widow, died leaving Mrs. Stephenson living, so that the contingency upon which the limitation of the fee to Mrs. Stephenson depended, happened, and this ejectment was brought by the assignees of the executors of Thomas Chandless, in whom the term for

that was not the lots absolutely, but the lots subject to the incumbrance. The real covenant was that, otherwise than as subject to the incumbrances named, the lots were free from all incumbrances, and that the ratoutor would warrant and defend the title." See, also, Koch v. Hustis, 113 Wis. 604, S9 N. W. $\sin (1902)$.

: The statement of facts is omitted. 
ninety-nine years was vested. It was conceded upon the argument that the fine was binding upon MIr. and Mrs. Stephenson, and all who clamed under them by estoppel; but it was insisted that such fine operated by way of estoppel only; that it therefore only bound parties and privies, not strangers; that the defendant, not being proved to come in under Mr. and Mrs. Stephenson, was to be deemed not a privy, but a stranger; and that as to him, the estate was to be considered as still remaining in Mr. and Mrs. Stephenson. To support this position, the defendant relied upon the latter part of the judgment delivered by me in Doe dem. Brune v. Martyn, \& B. \& C. 497 ; and that part of the judgment certainly countenances the defendant's argument here. The reasoning, however, in that case, is founded upon the supposition that a fine by a contingent remainderman operates by estoppel, and by estoppel only; its operation by estoppel, which is indisputable, was sufficient for the purpose of that decision, whether it operated by estoppel only, or whether it had a further operation, was quite immaterial in that case; and the point did not there require that investigation, which the discussion in this case has made necessary. We have, therefore, given the point the further consideration it required, and are satisfied upon the authorities, that a fine by a contingent remainder-man, though it operates by estoppel, does not operate by estoppel only, but that it has an ulterior operation when the contingency happens; that the estate which then becomes vested feeds the estoppel; and that the fine operates upon that estate, as though that estate had been vested in the cognizors at the time the fine was levied.

In Rawlins's Case, 4 Co. 52, Cartwright demised land, not his, to Weston for six years; Rawlins, who owned the land, demised it to Cartwright for twenty-one years; and Cartwright re-demised it to Rawlins for ten; and it was resolved that the lease by Cartwright, when he had nothing in the land, was good against him by conclusion; and when Rawlins re-demised to him, then was his interest bound by the conclusion; and when Cartwright re-demised to Rawlins, now was Rawlins conclucled also. Rawlins, indeed, is bound as privy, because lhe comes in under Cartwright; but the purpose for which I cite this case is, to shew that as soon as Cartwright gets the land, his interest in it is bound. In Weale v. Lower, Poll. 54, (A. D. 1672,) Thomas, a contingent remainder-man in fee, leased to Grills for 500 years, and levied a fine to Grills for 500 years, and died. The contingency hapjened, and the remainder vested in the heir of Thomas, and whether this lease was good against the heir of Thomas was the question. It was debated before Hale, C. J., and his opinion was, that the fine did uperate at first by conclusion, and passed no interest, but bound the licir of Thomas; that the estate which came to the heir when the contingency happened fed the estoppel; and then the estate by estoppel irecame an estate in interest, and of the same effect as if the continfency har happened before the fine was levied; and he cited Rawlins's (ace, 4 Coke, 53, in which it was held, that if a man leased land in 
which he had nothing, and afterwards bought the land, stich lease would be good against him by conclusion, but nothing in interest till he bought the land; but that as soon as he bought the land, it would hecome a lease in interest. The case was again argued before the Lord Chancellor, Lord C. J. Hale, Wild, Ellis, and Windham, justices, and they all agreed that the fine at first enured by estoppel; but that when the remainder came to the conusor's heir, he should claim in nature of a descent, and therefore sliould be bound by the estoppel; and then the estoppel was turned into an interest, and the cognizee had then an estate in the land. In Trevivan v. Lawrence, 6 Mod. 258, Ld. Raym. 1051, Lord Holt cites 39 Ass. 18, and speaks of an estoppel as running upon the land, and altering the interest of it,-as creating an interest in or working upon the estate of the land, and as running with the land to whoever takes it. In Vick v. Edwards, 3 P. Wms. 372 (1735), Lord Talbot must have considered a fine by a contingent remainder-man as having the double operation of estopping the conusors till the contingency happened, and then of passing the estate. In that case, lands were devised to A. and B. and the survivor of them, and the heirs of such survivor, in trust to sell: the master reported that they could not nake a good title, because the fee would vest in neither till one died. On exceptions to the master's report, Lord Tallot held, that a fine by the trustees would pass a good title to the purchaser by estoppel; for though the fee were in abeyance, it was certain one of the two trustees 1111st be the survivor, and entitled to the future interest; consequently, his heirs claiming under him would be estopped by reason of the fine of the ancestor to say, quod partes finis nihil habuerunt, though he that levied the fine had at the time no right or title to the contingent fee. And the next day he cited Weale v. Lower. Now, whether Lord Talbot were right in treating the fee as in abeyance, and the limitation to the survivor and his heirs as a contingent remainder or not, it is evident he did so consider them; and he must have had the impression that the fine would have operated not by estoppel only, but by way of passing the estate to the purchaser, because, unless it had the latter operation as well as the former, it could not pass a good title to the purchaser.

In Fearne, c. 6, $\S 5$ (Edit. 1820) p. 365, it is said, "we are to remember, however, that a contingent remainder may, before it vests, be passed by fine by way of estoppel, so as to bind the interest which shall afterwards accrue by the contingency;" and after stating the facts in Weale v. Lower, he says, it was agreed that the contingent remainder descended to the conusor's heir; and though the fine operated at first by conclusion, and passed no interest, yet the estoppel bound the heir; and that upon the contingency, the estate by estoppel became an estate in interest, of the same effect as if the contingency had happened before the fine was levied.

Upon these anthorities we are of opinion that the fine in this case had a double operation,--that it bound Mr. and Mrs. Stephenson by 
estoppel or conclusion so long as the contingency continued; but that when the contingency happened, the estate which devolved upon Mrs. Stephenson fed the estoppel; the estate created by the fine, by way of estoppel, ceased to be an estate by estoppel only, and became an interest, and gave Mr. Chandless, and those having right under him, exactly what he would have had had the contingency happened before the fine was levied.

Postea to the plaintiff. ${ }^{7}$

\section{PERKINS v. COLEMAN.}

(Court of Appeals of Kentucks, 1890. $90 \mathrm{Ky} .611,14 \mathrm{~S}$. W. 640.)

BENNETT, J., delivered the opinion of the court.

N. G. Terry owned an undivided interest in the land in controversy, and conveyed the whole of it to Horace Dunham by deed of general warranty. Thereafter Terry inherited that part of the land that he did not own, and this action of ejectment is brought by Terry's heirs to recover the possession of that part of the land thus inherited from the appellee. He resists the right of the appellants to recover the said land upon the ground that the title that Terry inherited was transferred to his vendee by estoppel. The appellants contend that the doc-

7 "By the common law there were only two classes of converances which were held to operate upon the after-acguired title-those by feoffiment, by fine, or ly common reeosers, and this from their solemnity and publicity, and those by indentire of lease from the implied covenants arising upon such indentiures. Clark v. Paker, 14 Cal. 612, 627, $76 \mathrm{Am}$. Dec. 449 (1S60), per Field, C. J. See, also, Burtners v. Keran, 24 (Grat. (Va.) 42 (1873).

In Sturgeon v. Wingtield, $15 \mathrm{M}$. \& W. 224 (1816), where the lessee sued the assignee of the lessol for hreach of covenant made by the lessor, the defenses were (1) that there had heen no denise to the plaintiff, and (2) that no reversion har come to the defendant. The lessor at the time of making the lease han no interest in the premises, but later acquired an interest. The conrt, by l'arke, B., said, "On the first issue, the rerdict clearly must be entered for the phintili, that there was such a demise to him as is stated in the declaration. Then, as to the second point, all the reversion of Hogarth, which was a reversion hy estoplel, passel from him to the defendant. This estoppel, was fed by the llemise for one hundred years from the Broderer's Company to Hogarth, the lessor, and thereby the lease from him to the plaintifi became good in point of interest."

IIhat would be the result where from the face of the lease it appears that the lessor bas no interest?

"A. lessee for life of B., makes a lease for rears by deed indented, and after pulchises the reversion in fee; B. dies; A. sllall avoid his own lease, for he may fonfess and a void the lease which took effect in point of interest and de. teinilined by the death of B." Co. Litt. $47 \mathrm{~b}$.

"helit for rent on an indenture of lease for forty years. The defendant pleaclecl that a vear before the plaintiff made a lease for forty years to A., virtute cujus A. cintered and was possessed; and that though the defendant did aftelwits enter, yet he was accountable to the said A. On demurrer Carthew alrorlet. that the serond lease was void for the first thirty-nine years, and so was the reservition, and that here was no estoppel, because the last of the for-

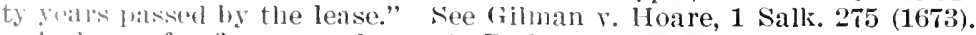

A., lisee for five years, leases to $B$. for twenty-five years, and later acquires the revision th ree. What, if any, difect does such acquisition of the fee have "iol Th's position? 
trine of estoppel does not protect strangers to the transaction; but only the parties and privies are bound thereby; and as the appellee is neither party nor privy, he can not avail himself of the estoppel that would bar the appellants' right as against Dunham or his privies.

It is true that where the estoppel merely affects the consciences of the parties, and not the title, it does not operate on strangers to the transaction; but where it "works an interest in the land" conveyed, "it runs with it, and is a title." Where it clearly appears from the writing that the vendor has conveyed, or agrees to convey, a good and sufficient title, and not merely his present interest in the land, the agreement runs with the land, and repeats itself every day; and if the vendor, at the time of the conveyance, has not title to the land, but subsequently acquires the title, it, "eo instante," inures to the bencfit of the vendee and his privies. In other words, it is immediately transferred by the law of estoppel to the vendee and his privies, because by the contract, which daily repeats itself, the vendor's title, whenever acquired, is transferred to the vendee and his privies; consequently, a stranger to the transaction, in an action of ejectment by the vendor against him, where he must recover upon the strength of his title, and not upon the weakness of his adversary, may show that he has thus parted with his title.

7 The judgment is affirmed.

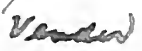

\section{JORDAN v. CHAMBERS.}

(Supreme Court of Pennsylvania, 1910. $226 \mathrm{~Pa} .573,75$ Atl. 956, $134 \mathrm{Am}$. St. Rep. 10s1.)

Ejectment for land in Jefferson township. Before Kennedy, P. J. The facts are stated in the opinion of the Supreme Court. ${ }^{8}$

Verdict and judgment for plaintiff. Defendant appealed.

Brown, J. The title to the land involved in this ejectment passed out of the commonwealth in 1817, and Mary Robb acquired title to it by deed dated September 15, 1832. After her death it was sold in 1837 by her administrator, the father of the appellant, under an order of the orphans' court for the payment of debts, and the title which the appellant claims, passed to him through sundry conveyances, starting with the deed from Mary Robb's administrator to Hugh Toner and ending with that of the sheriff of Allegheny county to himself. Though an unbroken chain of title by deed was shown in the appellant, the proof submitted by the appellee, whose claim to title by adverse possession was sustained by the jury, was that from 1837 to 1897 , a period of sixty years, possession of the land had never been taken by the grantee of Mary Robb's administrator nor by any subsequent grantee claiming under Toner.

8 The charge to the jury and certain renuests are omitted.

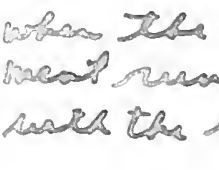


The adverse possession tpon which the appellee relied and recovered started in 1865. In that year-twenty-seven years after the sale by Mary Robb's administrator-Jane Robb, the widow of Oliver Robb, (500) a son of Nary Robb, was in possession of the farm, living on it and claiming it as her own. There was ne title in her out of Mary Robb. By her last will and testament, admitted to probate October 12, 1869, Tane Robb derised the farm to her son Robert. On August 16, 1870, he executed a general warranty deed for the coal underlying the property to Thomas J. Keenan, Malcolm Hay and Robert Woods. In 1874 his interest in the farm, excepting the coal, was sold at sheriff's sale, and, by various conveyances, it finally became vested in Herman Handel, to whom Thomas J. Keenan executed a deed for the onethird interest in the coal which Robert Robb had undertaken to convey 10 him in 1870. Upon the death of Herman Handel the property passed to the appellee in 1897, under proceedings in partition in the orphans' court of Allegheny county. Under instructions free from error as to the measure of proof required from the appellee to sustain the title claimed to have been acquired by her by adverse possession, the jury, with ample evidence before them, found her title to be good.

It is most earnestly contended that, as the title to two-thirds of the coal is still outstanding in Malcolm Hay and Robert Woods, or their representatives, under the deed of 1870 from Robert Robb, a general verdict in favor of the plaintiff for the land, including the coal, onght not to be sustained. While at first blush this may seem plausible, it is clear, upon reflection, that it cannot avail the appellant. When Robert Robb conveyed the coal in 1870 he had no interest in it nor in the surface above it. In 1S65-five years before-Jane Robb, his mother, hecame the adverse occupant of the property, and for five years after her death he continued the adverse possession as her devisee, but during those ten years neither she nor he acquired any right in the propcrty as against the real owner or owners, and against them nothing could have been acquired by adverse possession until the full statutory period of twenty-one years adverse possession had expired. During all those twenty-one years the trespassers could at any time have bcen driven from the land by the holders of the paper title. During that period there was no title at all in Jane Robb or in anyone claiming under her as the adverse occupier of the premises. In 1886, and not before, title by adverse possession became rooted in the land, but its roots went no deeper than 1886. "If, according to Lord Mansficld, the right of possession is taken away from the former owner, and according to Chief Justice Tilghman, it is acquired by the disseisor's (scupancy for the statutory period, Judge Gibson was strictly accurate When he said, in Graffus v. Tottenham, 1 Watts \& S. 494, 37 Am. 1) 4 . 472, that the effect of the statute was to transfer to the adverse couldant the title against which it has run. He added, 'the title of the nrimal owner is unaffected and untrammelled till the last moment, and when it is rested in the adverse occupant, by the completion of 
the statutory bar, the transfer has relation to nothing which preceded it ; the instant of conception is the instant of birth." "Woodward, J., in Schall et al. v. Williams Valley Railroad Co., 35 Pa. 191. By the deed from Robb to Keenan, Hay and Woods there was no sererance of the coal. There conld not have been, for the deed conveyed nothing to them. Neither these grantees nor any one ciaining under them at any time before or since the acquisition of the title by adverse possession in 1886 have made any attempt to sever the coal from the surface.

In 18S6, when title by adverse possession vested in Handel, then in possession of the sirface, not only it, but what was beneath it, vested in him; but when the title so vested in him he was in the same position as Robb would have been in 18S6, if still in adverse possession of the property, claiming ownership in it by such possession. Having undertaken to convey the coal when he had no title to it, if confronted by his conveyance of the same at the time of his acquisition of title ly adverse possession, he would have been estopped, as against his grantees, from denying their equitable ownership in the coal and could have been compelled to convey to them. "It is not to be doubted that a vendor who undertakes to sell a full title for a valuable consideration, when he has less than a fee simple, but afterwards acquires the fee, holds it in trust for his vendee, and will be decreed to convey it to his use." Clark v. Martin, 49 Pa. 299. In Chew v. Barnet, 11 Serg. \& R. 389, Judge James IVilson conveyed to Chew before he had title to the property. A conveyance was subsequently made to him by his vendors under articles of agreement with him. To secure the purchase moncy he executed a mortgage upon the property upon which it was subsequently sold at sheriff's sale. When Chew, in an action of ejectment, sought to recover the property from the sheriff's vendees, it was held that their title was paramount to his, and it was said by Gibson, I.: "What is the nature of the estate which Mr. Chew acquired by the conveyance from Judge Wilson? When that conveyance was executed, the legal tille was in Jeremiah Parker, by patents from the commonwealth; and Judge Wilson having nothing but an equitable title under the articles, could convey nothing more; his deed, therefore, passed to Mr. Chew only an equitable title. But it is said, the subsequent conveyance from Jeremiah Parker to Judge Wilson inured to the benefit of Mr. Chew. It did so; but only in equity, and to entitle him to call for a conveyance from Judge Wilson; and not as vesting the title in him, of itself, as contended, by estoppel. The facts presented constitute the ordinary case of a conveyance before the grantor has acquired the title; in which the conveyance operates as an agreement to convey, which, when the title has been subsequently acquired, may be enforced in chancery."

Where one conveys with a general warranty land which he does not own at the time, but afterwards acquires the ownership of it, the principle of estoppel is that such acquisition inures to the renefit of the 
grantee, because the grantor is estopped to deny, against the terms of his warranty, that he had the title in question. Burtners v. Keran, 24 Grat. (Va.) 42. But the estoppel of the grantor, who subsequently acquires title for what he had undertaken to previously sell, inures only to the benefit of his grantee, who can compel a proper conveyance after the acquisition of title by the grantor. Those who were not privics or parties to the original conveyance can take no advantage of estoppel arising from it. Allen v. Allen, $45 \mathrm{~Pa}$. 468. Estoppels may be by deed, but estoppels by deed avail only in favor of parties and privies. Sunderlin v. Struthers, $47 \mathrm{~Pa}$. 411. To this appellant the estoppel of the appellee as against Robert Robb's conveyance of the coal is unavailing, for he was no party or privy to it. The situation as it existed at the time this ejectment was brought was a title in the appellee for herself absolutely to the surface and one-third of the coal, and as trustee for Hay and Woods, or those claiming under them, for an equitable title to two-thirds. But this outstanding equitable title to a portion of the coal was of no avail to the appellant as against the appellee, the holder of the legal title to the surface and of the coal, entitled under that title to possession of both.

In 1902 an ejectment was brought for this land by Rebecca J. Bennett et al., claiming by descent from Mary Robb. The original defendant in the action was the present appellant, but the appellee and others, as claimants, were made co-defendants. The jury were sworn as against all the defendants, and the verdict having been rendered in their favor, the further contention of the appellant is that his title is res adjudicata, in view of that verdict. All that need be said as to this is that the verdict was in favor of all the defendants, but settled no title in dispute among themselves. Whether Chambers could assert title as against his codefendants, or any of them, remained, as the court properly said in overruling a motion for a new trial, to be settled in a controversy likely to arise between them. This is that controversy.

Nothing in the assignments of error calls for further discussion. They are all overruled and the judgment is affirmed. ${ }^{\circ}$

${ }^{9} \mathrm{~A}$. made a deed of premises to $\mathrm{B}$., with general covenant of warranty; the next sear a deed of the sime premises was made by $X$. to $A$. who thereupon went into jossession and continued therein for the period of the statute of limitations. In an action of ejectment by a grantee of $B$., it was held that A. was entitled to judgment. Chatham v. Lansford, 149 N. C. 363, 63 S. E. 81,25 L. R. A. (N. S.) 129 (190S). 


\section{JARVIS v. AIKENS.}

(Supreme Court of Vermont, 1853. 25 Vt. 635.)

Appeal from the Court of Chancery. The bill was brought by the orator to foreclose a mortgage, dated the 19th day of July, 1845, and to foreclose the equity of redemption, of Daniel Aikens and those claiming under him, of three pieces or parcels of land in Barnard, described in said bill and mortgage, as follows: one piece of about one hundred acres, called the "Paul Ellis Farm." One other piece of land containing about one hundred acres known as the "Lease Lot." And also a piece of land containing about fifty acres. The bill was in the usual form.

Henry Murphy answering says, that he claims title to a certain part of the mortgaged premises described in the orator's bill as the "Lease Lot." And further says, that he will insist in defence to said action, that on the 20th day of November, 1848, the said "Lease Lot,". belonged to the Society for the Propagation of the Gospel, \&c., subject to such interest as the orator might have by virtue of the mortgage deed from said Aikens to him, mentioned in-said bilt of complaint, which interest extended only to the unexpired portion of the lease formerly made by said Society to one Abial Frye, dated January 1 st, 1836 , for the term of thirty years thereafter. That on said 20th day of November, 1848, said Society executed a durable lease of said land to the said Aikens, and that on the 27th day of November, 1848, the said Daniel Aikens conveyed to this defendant by deed of warranty the same premises, subject to the payment of a yearly rent to said Society, in consideration of $\$ 300$, paid by this defendant.

That on the first day of January, 1836, said Society were the exclusive owners of the premises, and did lease the same to said Frye for thirty years for a certain reserved rent; that said Frye gave a mortgage deed to one Willard Caryl, and said Caryl afterwards quit-claimed to one A. Howe and others, all of whom quit-claimed their interest to the said Aikens.

That afterwards, and previous to the time of the execution of the orator's deed by the said Aikens, said Aikens contracted in writing for the sale of the same to one William Dutton, and that he took possession under said contract; that afterwards while said Frye and said Dutton were both in possession, said Society commenced their ejectment suit for the possession of the premises, in the Windsor County Court, and at the November Term of said court, in 1846, did recover the possession of the same.

Catherine Murphy answering, sets forth the same facts, and says that said Henry Murphy, before the bringing of the orator's bill, executed and delivered to her a deed of the said premises, which deed AIg.Prop.-51 
is now in full force, by the reasons of which, this defendant claims the premises aforesaid.

Daniel Aikens did not answer.

Testimony having been taken upon the matters in issue between the orator and said Sarah A. Goddard, the cause, December Term, 1852, was heard on the bill and answers of said Henry and Catherine Murphy: and on the bill, pleadings and evidence, as to said Sarah; and at said term, the Court of Chancery decreed that as to said Henry and Catherine Murphy, and said Sarah A. Goddard, and the several parts of the premises aforesaid by them, respectively claimed, being the "Paul Ellis Farm," so called in the bill, and the "Lease Lot," so called in the bill, stand dismissed out of said bill; and foreclosure on the other prenises.

BEXXETT, J. ${ }^{10}$ This case comes up by an appeal from the Court of Chancery. The bill is brought to foreclose the equity of redemption, of Daniel Aikens and those claiming under him, in certain parcels of lands, described in the bill of complaint, and in the mortgage deed from said Aikens to the orator, bearing date the 19th day of July, 1845 , and recorded the same day.

The more important question is, in relation to the "Lease L.ot" so called. Though it may be true that this lot was, in 1836, leased by the Society for the Propasation of the Gospel in Foreign Parts, to Abial Frye for a period of thirty years; and he mortgaged it to IVilliam Caryl; and though the premises may have come by quit-claim to Daniel Aikens, yet it is clear, that without resort to what shall be the effect of the recovery in ejectment, by the Society against Frye and Dutton, the present plaintiff cannot rely upon any title which Aikens had to this lot under the Frye lease. The title which Caryl had from Frye was but a mortgage, and there is nothing in the case to show, that Caryl's debt against Frye is outstanding, or that it passed into the hands of Aikens. His title is stated to be by quit-claim deed. As our courts have decided, that a mortgagee cannot maintain ejectment after the mortgage debt has been paid, and that to rebut the presumption of payment, the mortgage notes should be procluced, or accounted for otherwise; it would seem to follow, that so far, at least, there was no title in Aikens for him to convey; but it is claimed that Aikens, after he had executed his mortgage to the plaintiff, took a durable lease of this lot from the propagation Society, and that this after title, inured to the benefit of Jarvis.

It appears, that the date of the Society's lease to Aikens was the 20 th day of November, 1848, and recorded the same day; and that on the 27 th day of November. 1848, Aikens conveyed, by a deed of warranty, the lot to Henry Murphy; and after this, Murphy conveyed by a deed of warranty, to Catherine Murphy; and the question is, which title shall prevail.

10 The farts of the statement of farts and of the opinion relating to the "l'aul lillis Farm" are omitter?. 
It is not seriously claimed by the counsel for Catherine Murphy, but what the subsequent title acquired by Aikens, would inure to the benefit of Jarvis, so as to estop Aikens and his heirs from claiming title against him and his assignees; but it is said that the principle should not be applied, as between the purchaser and a subsequent purchaser from the grantor, and that to so apply it, would be at war with our registry system. This is a point of some importance, and well deserves consideration. We need cite no authorities to show, that Aikens himself would be estopped from setting up title against Jarvis, because he might sue Aikens on his covenants, if he was not estopped; and the law abhors circuity of action; but it is said, if Jarvis can claim the premises, as against Aikens, to save circuity of action, yet as against Murphy no such reason exists, and the only question is, which shall be compelled to resort to the covenants in Aikens' deeds, Jarvis, or Murphy? In Trevivan v. Lawrence et al., 1 Salk. 276, it was held that the parties, and all claiming under them, were bound by an estoppel, and the court put the case, as between the purchaser and a subsequent purchaser from the grantor. In the same case, reported in 6 Mod. 258, and Ld. Ray. 1051, Lord Holt cites 39 Ass. 18, and speaks of an estoppel, as running upon the land, and altering the interest of it -as creating an interest in, or working upon the estate in the land, and as running with the land to whoever takes it. 'The covenants in Aikens' deeed to Jarvis, may well be said to have a double operation, first as an estoppel, and secondly to pass the estate, the instant that Aikens became the owner.

The covenants bound Aikens, as an estoppel, until he took his durable lease from the Society, and then the estate, which devolved upon him, fed the estoppel, and the estate created by the covenants in Aikens' deed by way of estoppel, ceased to be an estate by estoppel only, and became an interest, and gave the orator precisely what he would have had, in case the durable lease had been executed to Aikens before his mortgage deed to the orator. The estoppel, when it runs with the land, operates upon the title, so as actually to alter the interest in it, in the hands of the heir, or assigns of the person bound by the estoppel, as well as in the hands of such person himself. It was said, by Lane, J., in the case of Douglass v. Scott, 5 Ohio, 198 "that the obligation created by estoppel, not only binds the party making it, but all persons privy to him; the legal representatives of the party, those who stand in his situation by act of law, and all who take his estate by contract, stand in his stead, and are subjected to all the consequences, which accrue to him. It adheres to the land, is transmitted with the estate, it becomes a muniment of title, and all who afterwards acquire the title, take it subject to the burden, which the existence of the fact imposes upon it." We think this view is in accordance with the adjudged cases. See Rawlins' Case, 4 Coke, 52: Weale v. L_, Pollexfen, 60; Christmas et al. v. Oliver, 10 Barn. \& Cres. 181: Coke. Littleton, 352 (a); Wark v. IVillard, 13 N. H. 389: 
White v. Patten, 24 Pick. (Mass.) 324; Dudley v. Cadwell, 19 Conn. 227; Bank of Utica v. Mersereau, 3 Barb. Ch. (N. Y.) 567, 49 Am. Dec. 189. In this view of the case, our registry system can have no control of the question. There was no title in Aikens, when he deeded to Henry Murphy, it had before passed to Jarvis, and was vested in him. In the case from 24 Pick. (MIass.) 324, the point was specially made by counsel, that this doctrine was in conflict with their registry system; but the court did not regard the objection. The same objection has been made in other cases, but without effect.

We see no reason, why this doctrine should not be extended to a mortgage deed with the usual covenants, as well as to an absolute deed, and indeed in the case of 24 Pick. 324, the claimant's title was under a mortgage deed.

Though it may be true, that before the lease was executed by the Society to Aikens, Henry Murphy paid sixty dollars to the Society towards rent, which was in arrear, and which was to be a part of the consideration which he was to pay to Aikens for his deed; but this cannot create a resulting trust in Murphy, to any portion of the land, which can avail against the legal title of Jarvis. It was in fact money paid by Murphy to the use of Aikens. Nothing can be made out of this, that can aid Murphy in this controversy.

We think then, that the decree of the Chancellor should be reversed, as to Henry and Catherine Murphy with costs; and a decree of foreclosure pass against them as to the "Lease Lot," and in other respects affirmed. ${ }^{11}$

\section{RESSER v. CARNEY.}

(Supreme Court of limesota, 1593. 52 Minn. 397, 54 N. W. \$9.)

Appeal by plaintiffs, William C. Resser and Charles Davison, from a judgment of the District Court of Ramsey County, Kelley, J., entered March 15, 1892, that they take nothing by the action and for costs.

Dickinson, J. Action for breach of covenant of seisin contained in a deed of conveyance executed by the defendant to the plaintiffs in February, 1882. Whaterer title the defendant had to convey, and whatever title may have subsequently inured to the plaintiffs as his grantees, was derived from the United States through the Northern Pacific Railroad Company; the land being within the indemnity limit of the land grant to that corporation. The chain of conveyances to which attention is directed is as follows:

In 1879 the Northern Pacific Railroad Company conveyed to Paine,

11 A. conveyed premises to B., and later convered the same premises to C., with covenant of warranty "against all persons claiming by, through, or under A." B. afterwards reconvesed to A., and D., a creditor of A., levied upon the land as the land of $A$. Mad $A$. a leviable interest? See Wheeler v. Young, infra, $P$. sc2, and cases there referred to. 
and in 1880 Paine conveyed to Kindred, and the latter to the defendant, Carney, all such conveyances being by warranty deed. February 28,1882 , Carney conveyed, by warranty deed containing a covenant of seisin, to the plaintiffs. This action is for a breach of the covenant contained in that deed. Of the purchase price, $\$ 4,480$, there was paid the sum of $\$ 2,480$. On the same day the plaintiffs executed to their grantor, the defendant, a mortgage on the same land to secure the unpaid part of the purchase price. Subsequently, and in the same year, 1882, the plaintiffs conveyed to other parties, who in 1887 , prior to the commencement of this action, reconveyed to the plaintiffs. In July, 1886, the mortgage given by the plaintiffs was foreclosed under the power therein contained, the defendant purchasing the property at the foreclosure sale, and no redemption was made therefrom.

The premises have always been vacant and unoccupied. This action was commenced in November, 1887. In April, 1891, the United States executed a patent conveying the land to the Northern Pacific Railroad Company, in which patent it was recited that the land had been selected by an agent of the railroad company, "as shown by his original list of selections, certified under date of March 19, 1883, and April 9, 1883, by the register and receiver at Fargo, State of Dakota.' It does not otherwise appear when this selection was approved by the secretary of the interior.

The selection of indemnity lands, which was to be made "under the direction of the secretary of the interior," (13 St. at Large, p. 367, c. $217, \S 3$,) did not become effectual, nor did the title pass from the United States, at least until the selection was approved, or in some way sanctioned by the secretary of the interior; and hence, so far as appears in this case, not until the issuing of the patent, in April, 1891, which evidences such approval. Musser v. McRae, 38 Minn. 409, 38 N. IV. 103; Id., 44 Minn. 343, 46 N. W. 673; United States v. Missouri, K. \& T. Ry. Co., 141 U. S. 358, 12 Sup. Ct. 13, 35 L. Ed. 766. Hence it will be observed that at the time of the conveyance from the defendant to the plaintiffs, February, 1882, the title was still in the United States, and that it was not until some nine years thereafter, nor until more than three years after the commencement of this action, that the title was conveyed to the railroad company. Not until then could such title have been transmitted, or have inured by operation of law, to the grantees of that company, immediate or remote. In other words, the covenant of seisin appears to have been wholly broken when it was made, so that the plaintiffs had a right of action to recover the purchase money paid; and not until after this action was commenced was the defendant in a position, so far as appears, to invoke the application of the principle that a title acquired by a grantor after a conveyance by him, with covenants, inures to the benefit of his covenantee. The question here presented is whether that principle

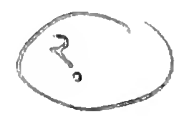


is to be applied, under such circumstances, to defeat a recovery on the covenant broken. Otherwise expressed, the question is whether the title acquired during the pendency of the action for breach of covenant was actually transferred to and vested in the plaintiffs by operation of law, so that they were compclled to and did actually acquire it, even without their consent and against their will. If so, that fact would probably be available to the defendant in defense of such an action, or at least in mitigation of damages.

Upon the question thus presented, the law cannot be said to be settled. In support, wholly or to some extent, of the proposition that a title acquired by the grantor subsequent to the conveyance by him inures by operation of law to his grantee, even though he is unwilling then to accept it, and hence will mitigate the damages recoverable for breach of covenant, or wholly defeat an action for damages, according to the circumstances of the case, may be cited Baxter v. Bradbury, 20 Me. 260. 37 Am. Dec. 49; King v. Gilson's Adm'x, 32 Ill. 348, 83 An. Rep. 269; Reese v. Smith, 12 Mo. 344; Morrison v. Underwood, 20 N. H. 369; Knowles v. Kennedy, S2 Pa. 445; Farmers' Bank v. Glenn, 68 N. C. 35 ; Cornell v. Jackson, 3 Cush. (Mass.) 505; Boulter v. Hamilton, 15 U. C. C. P. 125 , citing doe - v. Webster, 2 U. C. Q. B. 225. See, also, Knight v. Thayer, 125 Mass. 25. In some of these cases, however, it may be noticed that the plaintiff was in possession of the granted lands under his deed.

On the contrary, the doctrine is well supported by authority that a grantee to whom no title passed by the deed of convevance, who acquired no possession, and no right of possession, may recover the purchase money paid, with interest, in an action for a breach of the covenant of seisin, even though the grantor may have acquired a title during the pendency of such an action, or, perhaps, even prior to its commencement; that the grantee is not to be compelled to accept the after-acquired title in satisfaction of the already broken covenant of seisin, or in mitigation of damages recoverable for the breach. Blanchard v. Ellis, 1 Gray (Mass.) 195, 61 Am. Dec. 417; Tucker v. Clarke, 2 Sandf. Ch. (N. Y.) 95; Bingham v. Weiderwax, 1 N. Y. 509; Nichol v. Alexander, 28 Wis. 118; McInnis v. Lyman, 62 Wis. 191, 22 N. W. 405; Burton v. Reeds, 20 Ind. 87, 93; Rawle, Cov. $\$ \S 179-182,256-258,264,265$; Bigelow, Estop. 440; Sedg. \& W. Tr. Title Land, $\S 850$. While in some of the cases last cited there had been an eviction of the covenantee after he had been in possession, that would not distinguish such cases from that now before us. The inability of the plaintiffs to enter into possession of this vacant land without committing a trespass, by reason of the paramount title being in another, would have the same effect, as respects the right of action for a breach of the covenants contained in the deed, as would an eviction if possession had been acquired. Fritz v. Pusey, 31 Mlinn. 368, 18 N. IV. 94; Shattuck v. Lamb, 65 N. Y. 499, 22 Am. Rep. 656. 
To our minds the authorities last cited present the vicw of the law most consistent with reason and with familiar legal principles, as well as the rule most conducive to justice, in its practical application.

It is certain, if the defendant's deed conveyed no title, that the plaintiffs had a legal right, when this action was commenced, to recover the purchase price paid for a.title. They elected to pursue that remedy, and still insist upon the legal right. We cannot understand how that perfect, absolute legal right of action, and especially after an action has been already instituted, is defeated; how the right, at the election of the grantee, to enforce his action for the breach of the covenant is taken away or lost by any proper application of the principle that an after-acquired title inures to the benefit of the grantee, by force of his covenants, and upon principles embraced within the general doctrine of estoppel. We do not concur in the proposition that the principle just referred to is effectual to actually transfer and vest in the covenantee an estate acquired by the covenantor subsequent to his conveyance. See, in addition to the authorities above cited, Buckingham v. Hanna, 2 Ohio St. 551; Burtners v. Keran, 2+ Grat. (Va.) 42, 67; Chew v. Barnet, 11 Serg. \& R. (Pa.) 399, 391. Indeed, that the estate is thus actually transferred to the covenantee, without resting in the covenantor, to whom the after-acquired title is in terms conveyed, is inconsistent with the idea of an estoppel binding the latter and those in privity with him; and yet it is not to be doubted that the doctrine which we are considering really rests upon the ground of estoppel. It is founded on equitable principles, and affords to a grantee with covenants a remedy of an equitable nature with respect io a title acquired by the grantor after he had assumed to convey the same; and donbtless courts of law, at this day, recognize and apply the principle of estoppel, in such cases, as courts of equity are wont to do. 'They will treat the after-acquired title as though it had been conveyed, when ecruity would decree that a conveyance be made. Rawle, Cov. $\$ 258$.

But this equitable right is one in favor of the covenantee, resting upon the estoppel of the covenantor to assert, as against him, a title to the property. If the grantee acquires nothing by the deed to him, and has and asserts a legal cause of action for covenant broken, no principle of estoppel operates against him, to compel him, perhaps years afterwards, as in this case, to accept, in satisfaction of that legal cause of action, wholly or partially, a title which his covenantor may then procure. The latter, whose covenant has been wholly broken, has no right to elect, as against the covenantee, and to his prejudice, whether he will respond in damages for the breach by repaying the purchase money, or buy in the paramount title, when the value of the property may have greatly depreciated, and compel the plaintiff to accept that title. The right of election is, and should be, with the other party. He had the benefit of the estoppel, but it is not to be imposed 11pen him as a burden, at the will of the party who alone is subject

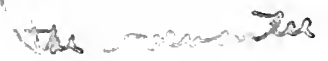


to the estoppel. He may elect to pursue the action at law, and recover the consideration paid for a title which was not conveyed to him. At least, he may so elect, as the plaintiffs did in this case, at any time before the acquisition of the title by the covenantor.

The case of Burke v. Beveridge, 15 Minn. 205, (Gil. 160,) did not require a consideration of the question now before us. The decision necessarily rested upon another ground; and while, in the opinion of the court, Baxter v. Bradbury, supra, is referred to with approval, we do not. accept the dictum as expressing the law on this subject.

The respondent adopts the memorandum or opinion of the learned judge who tried the cause, in place of a brief, for the purposes of this appeal. We infer that the respondent relies upon the proposition, upon which the court based its decision, that, by reason of the foreclosure of the purchase-money mortgage, the purchase by the defendant at the foreclosure sale, and the nonredemption therefrom, the plaintiffs' right of action for breach of the covenant of seisin has been extinguished; that it passed from the plaintifts back to the defentlant, the vendor, when by the foreclosure the plaintiffs were divested, and the defendant reinvested, with whatever estate or interest was conreyed by the deed. Kimball v. Bryant, 25 Minn. 496, is cited in this connection. This contention must rest upon the familiar legal proposition that. a right of action by a grantee upon covenants which run with the land does not remain in him after he has transferred the estate, but passes with it. But we do not deem the proposition applicable to the case here presented.

It will be kept in mind that the mortgage was executed by the vendees to the rendor contemporaneously with the conveyance made to the former by the latter, and for the purpose, merely, of securing the payment of a part of the purchase price.

Ve may state, without discussing the proposition, that the vendees were not estopped or precluded, by the covenants in their mortgage to the vendor, from recovering for a breach of the similar covenants contained in the deed of the latter to them. Sumner v. Barnard, 12 Metc.. (Mass.) 459; Brown v. Staples, 28 Me. 497, 48 Am. Dec. 504; Smith v. Cannell, 32 MIe. 123; Haynes v. Stevens, 11 N. H. 28; Connor v. Eddy, 25 Mo. 72; Rawle, Cov. (5th Ed.) § 266.

In Kimball v. Bryant, supra, it was considered that, if the grantee uncler a deed of conveyance with a covenant of seisin conveys the same land to another, it may be presumed, "unless there be something to show a contrary intention," that, although the covenant was broken when it was given, he intends to confer on his grantee the benefit of the covenant, so far as necessary for his protection; to transfer his right to sue for the breach, so far as his grantee sustains injury by reason of it. But in a case like that under consideration the circumstances do "show a contrary intention:" When the plaintiffs purchased the prop- 
erty, and took a deed with covenants embracing that of seisin, the presunption is irresistible and conclusive that the covenant was intended by both parties to the deed to be effectual as an obligatory assurance of title, giving an immediate right of action to the plaintiffs if the coventant should be found to have been broken. It would be unreasonable to suppose that when the purchasers gave back to their vendor a mortgage of the land, merely to secure the payment of a part of the purchase price, it was the intention of the parties that the purchasers should thereby divest therinselves of, or relinquish, in favor of their covenantor, the benefits of the covenant, which in the very same transaction they had just taken from him for their own protection. It could not have been intended that the mortgage should, in effect, embrace and hypothecate to the vendor his own covenant assuring to his vendees the title which he then assumed to convey. As between the parties to such a transaction, the mortgage back to the vendor is to be deemed as reconveying, subject to the condition of defeasance, only such estate as is conveyed by the mortgagee to the mortgagors. It was not effectual as between these parties, to discharge the vendor from his obligation upon the covenant of seisin, which, being then broken, gave to the mortgagors an inmediate right of action. The general rule that the right of action upon covenants which run with the land passes with the estate, and does not remain in a covenantee after the estate has been transferred, is not applicable Smith v. Cannell, 32 Me. 123; Haynes v. Stevens, 11 N. H. 28; Randall v. Lower, 98 Ind. 255; Rawle, Cov. 266; Bigelow, Estop. (5th Ed.) 411-413.

Hence the plaintiffs, upon the case here presented, were entitled to recover for breach of covenant. Judgment reversed. ${ }^{12}$

12 On the subject-matter of the chapter generally, see Rawle on Covenants for Title, c. 11, and Bigelow on Estoppel (6th Ed.) c. 11. 


\section{CHAPTER VIII}

\section{PRIORITIES}

\section{SECTION 1.-FRAUDULENT CONVEYANCES}

\section{ST. 27 ELIZ. c. 4 (15S5).}

Sec. 1. Forasmuch as not only the Queen's most excellent Majesty, but also divers of her Ilighness's good and loving subjects, and bodies politic and corporate, after conveyances obtained or to be obtained and purchases made or to be made, of lands, tenements, leases, estates, and liereditaments, for money or other good considerations, may have, incur, and receive great loss and prejudice by reason of fraudulent and covinous conveyances, estates, gifts, grants, charges, and limitations of uses heretofore made or hereafter to be made, of, in, or out of lands, tenements, or hereditaments so purchased or to be purchased; which said gifts, grants, charges, estates, uses, and conveyances were, or hereafter shall be, meant or intended by the parties that so make the same to be fraudulent and covinous, of purpose and intent to deceive such as have purchased or shall purchase the same; or else, by the secret intent of the parties, the same be to their own proper use, and at their free disposition, co'ored nevertheless by a feigned countenance and show of words and sentences, as though the same were made bona fide, for goorl causes, and upon just and lawful considerations:

Sec. 2. For remedy of which inconveniences, and for the avoiding of such fraudulent, feigned, and covinous conveyances, gifts, grants, charges, uses, and estaies, and for the maintenance of upright and just dealing in the purchasing of lands, tenements, and hereditaments: Lie it ordained and enacted, by the authority of this present Parliament, that all and every conveyance, grant, charge, lease, estate, incumbrance, and limitation of use or uses, of, in, or out of any lands, tenements, or other hereditaments whatsoever, had or made any time heretofore sithence the beginning of the Queen's Majesty's reign that now is, or at any time hereafter to be had or made, for the intent and of purpose to defraud and deceive such person or persons, bodies politic or corporate, as have purchased or shall afterward purchase in fee simple, fee tail, for life, lives, or years, the same lands, tenements, and hereditaments, or any part or parcel thereof, so formerly conveyed, granted, leased, charged, incumbered, or limited in use, or to defraud and deceive such as have or shall purchase any rent, profit, or commodity in or out of the same, or any part thereof, shall be deemed 
and taken, only as against that person or persons, bodies politic and corporate, his and their heirs, successors, executors, administrators, and assigus, and against all and every other person or persons lawfully having or claiming by, from, or under them, or any of them, which have purchased or shall hereafter so purchase for money or other good consideration, the same lands, tenements, or hereditaments, or any part or parcel thereof, or any rent, prosit, ö commodity, in or out of the same, to be utterly void, frustrate, and of none effect; any pretence, color, feigned consideration, or expressing of any use or uses to the contrary notwithstanding.

Sec. 3. And be it further enacted by the authority aforesaid, that all and every the parties to such feigned, covinous, and fraudulent gifts, grants, leases, chirges, or conveyances before expressed, or being privy and knowing of the same or any of them, which after the twentieth day of April next coming shall wittingly and willingly put in use, avow, maintain, justify, or defend the same or any of them, as true, sinuple, and done, had, or made bona fide, or upon good consideration, to the disturbance or hindrance of the said purchaser or purchasers, lessees, or grantees, or of or to the disturbance or hindrance of their heirs, successors, executors, administrators, or assigns, or such as have or shall lawfully claim anything by, from, or under them or any of them, shall incur the penalty and forfeiture of one year's value of the said lands, tenements, and hereditaments so purchased or charged; the one moiety whereof to be to the Queen's Majesty, her heirs and successors, and the other moiety to the party or parties grieved by such feigned and fraudulent gift, grant, lease, conveyance, incumbrance, or limitation of use, to be recovered in any of the Queen's courts of record by an action of debt, bill, plaint, or information, wherein no essoin, protection, or wager of law shall be arhnitted for the defendant or defendants; and also, being thereof lawfully convicted, shall suffer imprisonment for one-half year without bail or mainprise.

Sec. 4. Provided also, and be it enacted by the authority aforesaid. that this Act, or anything therein contained, shall not extend or be construcd to impeach, defeat, make void or frustrate any conveyance, assignment of lease, assurance, grant, charge, lease, estate, interest, or limitation of use or uses, of, in, to, or out of, lanks, tenements, or hereditaments heretofore at any time had or nuade, or hereafter to be had or made, upon or for good consideration and bona fide to any person or persons, bodies politic or corporate; anything before mentioned to the contrary hereof notwithstanding.

Sec. 5. And be it further enacted by the authority aforesaid, that if any person or persons have heretofore, sithence the beginning of the Queen's Majesty's reign that now is, made or hereafter shall make any conveyance, gift, grant, demise, charge, limitation of use or uses, or assurance of, in, or out of any lands, tenements, or hereditaments, with any clause, provision, article, or condition of revocation, deter- 
mination, or alteration, at his or their will or pleasure, of such conveyance, assurance, grants, limitations of uses or estates of, in, or out of the said lands, tenements, or hereditaments, or of, in, or out of any part or parcel of them, contained or mentioned in any writing; deed, or indenture of such assurance, conveyance, grant, or gift; and after such conveyance, grant, gift, demise, charge, limitation to uses, or assurance so made or had, shall or do bargain, sell, demise, grant, convey, or charge the same lands, tenements, or hereditaments, or any part or parcel thereof, to any person or persons, bodies politic and corporate, for money or other good consideration paid or given (the said first conveyance, assurance, gift, grant, demise, charge, or limitation, not by him or them revoled, made void, or altered, according to the power and authority, reserved or expressed unto him or them in and by the said secret conveyance, assurance, gift, or grant) that then the said former conveyance, assurance, gift, demise, and grant, as touching the said lands, tenements, and hereditaments, so after bargained, sold, conveyed, demised, or charged against the said bargainees, vendees, lessees, grantees, and every of them, their heirs, successors, executors, administrators, and assigns, and against all and every person and persons which have, shall, or may lawfully claim anything by, from, or under them or any of them, shall be deemed, taken, and adjudged to be void, frustrate, and of none effect, by virtue and force of this present Act.

Sec. 6. Provided, nevertheless, that no lawful mortgage made or to be made bona fide, and without frand or covin, upon good consideration, shall be impeached or impaired by force of this Act, but shall stand in the like force and effect as the same should have done, if this Act had never been had nor made; anything in this Act to the contrary in any wise, notwithstanding. ${ }^{2}$

\section{DOE ex dem. OTLEY v. MANNING.}

(Court of King's Bench, 1S07. 9 East, 59.)

In ejectment for certain messuages and premises at St. Mary Magdalen, Bermondsey, in Surry; a verdict was found for the defendants, subject to the opinion of the Court on the following case. Thomas Clendon, being seised in fee of the premises in question, by his will of the 6th of March, 1750, duly executed and attested, demised the premises (amongst others) to his nephew William Clendon for life; remainder to trustees during IV. C.'s life to preserve contingent remainders; remainder to the first and other sons of W. C. successively in tail male;

1 As to character of American legislation, see Figelow on Fraudnlent Conreyances (Knowlton's Ed.) p. 6:2 et ser.

P'ure chattels are not within the statute. Bill v. Cureton, 2 My. \& K. 503 (18:15.) 
remainder to the testator's nephew, Owen Manning, for life; remainder to trustees during $O$. M.'s life to support contingent remainders; remainder to the first and other sons of $O$. $M$. successively in tail male; remainder to his own right heirs for ever; and gave the usual powers of leasing, in possession, at rack rents, for 21 years; and also power to each of the devisees, when in actual possession, to settle upon such person as he should marry, for her jointure, premises of the yearly value of $£ 80$. for every $£ 1000$. he should receive with such wife. The testator died seised of the premises in 1751; and Wm. Clendon, lis nephew, died in March, 1764, without issue, whereby the estate descended to O. Manning, the next tenant for life, in remainder. By indenture of bargain and sale of the 25th of Nov. 1782, duly enrolled in C: B., between Owen Manning and George Owen Manning, his eldest son, of the 1st part, T. Green of the $2 \mathrm{~d}$ part, and P. Willson of the $3 \mathrm{~d}$ part, Owen Manning and George, his son, sold and conveyed the premises to Green in fee, to the intent that he might become tenant thereof, for the purpose of suffering a recovery, to the use of O. Manning and his assigns for life; remainder to the said G. O. Manning in fee; and a recovery was accordingly suffered in Hil. term 23 Geo. III. On the 15th of March, 1783, G. O. Manning died intestate, and without issue; whereby the reversion in fee descended to John Manning his brother and heir at law. By indentures of lease and release of the 11 th and 12th of April, 1783, between Owen Manning, who was then in possession, of the first part, the said John Manning of the second part, and $\mathrm{W}$. Gill and $\mathrm{H}$. S. Giil of the third part; reciting the former indenture of bargain and sale, and the recovery, and the death of $\mathrm{G}$. O. Manning, and that divers other messuages, \&c., having in like manner descended to the said John Manning, he was desirous of making some settlement and provision for the benefit of his mother, in case she should survive Owen Manning, and of his sisters and younger brother; it was witnessed, that in consideration of the natural love and affection which John Manning bore towards Catharine Manning his mother, and Jane, Catharine Matilda, Ann, and Matilda Manning, his sisters, and Charles Manning, his brother, and for making provision for them for their respective lives, and of 10s. \&c.; Owen Manning and John Manning conveyed to W. and H. S. Gill in fee, amongst others, all the said premises, habendum, \&c., to the use of Owen Manning for life, sans waste; remainder to the use of the trustees, during the life of $O$. M., in trust to preserve contingent remainders; remainder to the use of Cath. Manning for life, sans waste; remainder to the trustees and their heirs, upon trust, during the lives of Jane, Catharine Matilda, Ann, Matilda, and Charles Manning, and the survivor of them, to receive the rents, \&c., and pay the same equally amongst his said sisters and brother, and to the survivor of them; remainder to John Manning in fee; with the like power of leasing as is contained in Clendon's will; and a power for Owen Manning, during his life, and Catharine his mother, during her life, with the privity and consent of John Manning 
and the trustees, or the survivor, his heirs or assigns, testified as therein mentioned; and for John Manning, after his father's and mother's decease, with the like privity of the trustees, or the survivor, his heirs or assigns, testified as aforesaid; to execute like leases for 99 years. Owen Manning died the 9th of Sept., 1801. By indentures of lease and release of the 16 th and 17 th of May, 1805, between John Manning of the first part, R. Otley of the second part, and H. Otley of the third part; reciting the indenture of bargain and sale of the 25th of Nov., 1782, and the deaths of George Owen Manning and Owen Manning, and that John Manning had contracted with R. Otley for the absolute sale of the premises; it was witnessed, that in consideration of $£ 1800$. to John Manning paid, he conveyed to R. and H. Otley in fee all the said premises for which this ejectment was brought, being part of the premises in the last-mentioned deed; habendum to such uses as R. Otley should appoint; and in the mean time, and subject thereto, to the use of R. Otley in fee. The consideration for the conveyance to the lessor of the plaintiff was paid thus; by a book debt from John Manning to the lessor of plaintiff $f+17.2 \mathrm{~s} .9 \mathrm{~d}$. By cash at sundry times $£ 1382.17 \mathrm{~s} .3 \mathrm{l}$. The book debt was contracted, and $£ 150$. of the consideration money paid, at the date of the purchase contract, and $£ 387$. 5s. 6d. at a subsequent period, but before the execution of the conveyance of 1805, and before the lessor of the plaintiff had notice of the deed of 1783 . The residue of the consideration was paid, and the deeds executed, subsequent to such notice. John Manning did not divest himself of all his property by the conveyance of the 12 th of April, 1783. There was no fraud in the last-mentioned conveyance, unless fraud is to be implied by construction or operation of law. The question for the opinion of the Court was, IVhether the lessor of the plaintiff was entitled to recover against the defendant Manning? If the Court should be of opinion that he was, a new trial was to be had, or an issue granted, as the Court should direct, between the plaintiff and the defendant Goom, to try the validity of his lease. If the verdict on such new trial or issue should be found against Goom, a verdict was to be entered against both the defendants. But if the Court should be of opinion that the lessor of the plaintiff was not entitled to recover against the defendant Manning, the verdict taken for the defendants was to stand. * * * *

Lord ElLExborough, C. J., ${ }^{2}$ after stating the facts-On this case, as it is found that there was no fraud in fact in the conveyance of the 12 th of April, 1783, the only point for the consideration of the Court is, whether a voluntary conveyance, without any valuable consideration, he not according to the legal construction of the stat. 27 Eliz. c. 4. fraudulent against a subsequent purchaser for a valuable consideration; or, in other words, whether in such case the law do not presume fraud, without admitting such presumption to be contradicted. The

2 Part of the statement is omitted. 
cases in which the construction of the statute of the 27 of Eliz. has comc on to be considered have been numerous; and in several of those which arose nearest the time of passing the statute the Judges seem to have thought that a voluntary settlement was only prima facie fraudulent against a ptrchaser, according to the language of the Court in Sir Ralph Bovy's Case, Ventris, 193; where it is said, (Lord Hale being Chicf Justice) "that though every voluntary conveyance carries an evidence of fraud; yet it is not upon that account only always to be reckoned fraudulent, or to be avoided by a purchaser for a valuable consideration." And in Jenkins v. Kemishe or Kemis, which is to be found in Hardress, 398, and in 1 Lev. 150, in Lavender v. Blackstone, in 2 Lev. 146, and in Garth v. Mois, 1 Keb. 486, the same doctrine is distinctly laid down; and in Style, 446, it is stated to have been said on a trial at bar (Lord Rolle being then Chief Justice), "that a voluntary convevance upon consideration of natural affection hath no badge of fraucl, unless he who makes it be indebted at the time, or in treaty for the sale of the lands;" which case Chief Baron Gilbert adopts, and supports by reasoning of his own, in his Law of Evidence, 235, p. 201, in the edition of 1801. And in addition to these printed cases, Sir Robert Eyre, then Chicf Justice of C. P., according to a MS. note formerly belonging to Mr. Justice Clive, in a case of Standon v. Charlwood, tried before him at the London Sittings after Trinity term, 1752, laid it clown, that a voluntary settlement, made upon marriage by Sir Richard Andercon, was not fraudulent quia voluntary; but the question was, Whether it was not made with an intent to defraud; and the jury so found it. And with this doctrine other of the cases which were cited by the counsel for the plaintiff may well agree, in which it is stated, "that conveyances were decided, on evidence given at the bar, to be frauchlent ;" or, "that a jury were directed on evidence;" though it must be recollected, that these cases are not so strong as those I have alluded to, as they are not inconsistent with the possibility of juries having been directed, what ought to be their conclusion in point of law, from the facts given in evidence, if the jury should find them to be true; for fraud and covin is always a question of law; it is the judgment of law on facts and intents. In a more modern case, where the question was upon the stat. 13 Eliz., that of Cadogan v. Kennett, in Cowper, 434, Lord Mansfield said, obiter, "the stat. 27 Eliz. c. 4, does not go to voluntary conveyances, merely as being voluntary; but to such as are fraudulent." And in a late case, of Doe v. Routledge, in the same book, p. 705, where the question arose on the statute now under consideration, Lord Mansfield, in considering one point in the case, whether the settlement there, under all its circumstances, were fraudulent and covinous, stated, "that in the statute there was not a word that impeached voluntary settlements, merely as being voluntary, but as fraudulent and covinous;" and noticed the $3 \mathrm{~d}$ section, which subjects parties to such fraudulent grants, who should attempt to defend them, to forfeiture and imprisonment, as if such practices were 
a crime; in which light no person making a mere voluntary settlement, by way of provision for his family, was ever considered to stand.

This section furnishes most unquestionably a very strong argument in favour of that construction; and had these cases not been opposed by many others of great weight and authority, there would have been but little doubt in our minds as to this construction being the right one; but we have to deal with a class of cases full as numerous, decided by Judges of the greatest eminence, which have given this statute a different construction, and have held that a conveyance without a valuable consideration is by the statute made void, as fraudulent, against a subsequent purchaser for such consideration. The earliest case in which this is distinctly laid down is WVodie's Case, cited by Tanfield in Colville v. Parker, Cro. Jac. 158, as far back as East, 5th of Jac. I, where it was adjudged, "that an assignment of a lease of lands by one quasi in jointure to his wife, he taking the profits, and afterwards selling it without notice, was within the statute; though not made in trust to be revoked, nor with any clause or revocation; because it was a voluntary conveyance at first, and shall be intended fraudulent at the beginning." In this case, though the person making the conveyance continued in possession and took the profits, it will be observed that there was no badge of fraud; as such possession accompanied and followed the deed; but the Judges might very well apprehend that subsequent purchasers might be continually defrauded by such secret conveyances, if they should be held good; and that when the question was between one, who had paid a valuable consideration for an estate, and another. who had given nothing, it was a just presumption of law, that such voluntary conveyance, founded only in considerations of affection and regard, if coupled with a subsequent sale, was meant to defraud those, who should afterwards become purchasers for a valuable consideration; and that a different construction would have so narrowed the operation of the statute as to leave the persons meant to be protected by it subject to almost all the mischiefs intended to be guarded against; and it certainly is more fit, upon the whole, that a voluntary grantee should be disappointed, than that a fair purchaser should be defrauded. In Prodgers v. Langham, 1 Sid. 133, a conveyance made by a man in trust for his daughter till marriage, for her maintenance, and then in trust to raise a portion for her, was held to be a voluntary conveyance in its origin, and void by the stat. 27 of Eliz. against purchasers for valuable consideration; this was in the 15 th of Car. II. In White v. Hussey, Precelents in Chancery, 14, in the beginning of King William's reign, in the case of a conveyance, where the fraud, if any, was only from its being voluntary, the commissioners of the great seal were all of opinion that they might decree a conveyance fraudulent merely from being voluntary, and that, without any trial at law. In Gardiner v. Painter, Cas. temp. King, C. P. 65, Lord King said, it could never be a question, whether a voluntary settlement be good against purchasers. This was in the year 1726; and in the next year, 
in Tonkins v. Ennis, 1 Eq. Cas. Abr. 334, a voluntary settlement was considered as being made void against a purchaser by the stat. 27 of Eliz. And this could only have been so held from such settlement being in point of law considered as fraudulent. In White v. Sanson, 3 Atk. 412, though Lord Hardwicke is stated to have said, that he had heard it said in that court, that there are reasonable voluntary conveyances, which that Court will not interfere to disturb, upon the construction of these statutes; yet, according to the same case, he said, "he hardly knew an instance where a voluntary conveyance had not been held fraudulent against a subsequent purchaser." And in Lord Townsend v. Windham, 2 Ves. 10, he said, "on the 27 th of Eliz. every voluntary conveyance made, where afterwards there is a subsequent conveyance made for valuable consideration; though no fraud in that voluntary conveyance, nor the person making it at all indebted; yet the determinations are, that such mere voluntary conveyance is void at law by the subsequent purchase for valuable consideration." In Roe v. Milton, 2 Wils. 356, Lord Ch. J. Wilmot stated the question to be, Whether there were a good and valuable consideration to support the limitation therein to Thomas Hammerton, the father of the lessor of the plaintiff; or whether the limitation were merely voluntary under the stat. 27 of Eliz., and bad against a purchaser for valuable consideration? And the Court held it good; as the mother giving up her charge of an annuity on the whole of the estate, and taking it on a part, was considered as a valuable consideration. And Lord C. J. De Grey, in Goodright v. Moses, in 2 Sir W. Black. Rep. 1019, laid it down, "that the deed in question was only a voluntary conveyance within the true meaning of the stat. 27 th of Eliz.; being founded only on a good, and not on a valuable consideration; and therefore could not be set up against a bona fide purchaser."

And the observation on this case made by the counsel for the defendant, that it seemed that Lord C. J. De Grey had been misled by a case in 2 Vern. 326, which he referred to; and which was said not to have been decided, and on which he was supposed to have relied; does not weaken the authority of the case in Blackstone; for Lord C. J. De Grey referred to it, not to support the opinion of the Court on the point now before us; but to shew that a lessee for years was a purchaser for a valuable consideration. Lord Mansfield himself (whose opinion in Doe v. Routledge, and whose dictum in Cadogan v. Kennett, have been much relied on,) held in the case of Chapman v. Emery, Cowp. 280, that a voluntary conveyance after marriage by a man on his wife and children was void by the stat. 27 th of Eliz. against a subsequent mortgagee, whom he held to be a purchaser. And with respect to the case of Doe v. Routledge, it may be observed that Lord Mansfield seems to have supported his opinion by cases, which were not considered as cases of voluntary settlements; but as cases where the settlements had for their foundation valuable considerations; such AIg.Prop. -52 
was the case of Newstead and Searles, in 1 Atk. 268, which he mentioned by name; for Lord Hardwicke in that case stated "the question to be, Whether the articles of the 30th of April, 1709, were for a valuable consideration, and binding, or ought to be considered as voluntary and fraudulent, with respect to subsequent creditors and purchasers?" And afterwards he said, "I think the settlement no voluntary agreement, but a binding one; the statutes of the 13th and 27 th of Eliz. that make conveyances fraudulent, are voluntary conveyances macle against purchasers for a valuable consideration, or bona ficle creditors; but it would be difficult to shew that such a limitation, as in the present case, has been held fraudulent and void against subsequent purchasers and creditors. The present is a stronger case; for here are reciprocal considerations both on the part of the husband and wife, by the provisions under the articles for the second marriage."

And 1 believe, if it were necessary to go into the examination, it would be found that in most, if not in all of the cases cited by the defendant, there were reciprocal considerations; some benefit acquired by the persons making the settlement, which might fall under the denomination of a valuable consideration; though perhaps other persons derived a benefit from the settlement. who were not the principal objects of it. As in Jenkins v. Keymys, where the consideration of a marriage and a marriage portion was held to run through all the estates raised by the settlement on the marriage; though the marriage was not concerned in thein. And it must be further recollected, with respect to Doe v. Roitledge, that upon the strength of the voluntary settlement in that case a marriage was had; which was noticed by Lord Mansfield. And according to the case of Prodgers v. Langham, 1 Sid. 133 , a voluntary conveyance, fraudulent against a subsequent purchaser, was held to be made good by a subsequent marriage. And it will be further recollected, that in Doe v. Routledge there was no bona ficle purchaser. Subsequently to the case of Chapman v. Emery, the cases of Evelyn v. Templar, 2 Bro, Chan. Cas. 148, and Doe ex dem. Bothell r. Martyr, 1 Bos. \& Pull. New Reports, 332, have been determined; in the last of which it was laid down, "that it cannot now be held that a prior voluntary conveyance shall defeat a conveyance to a purchaser for a valuable consideration, without overturning the settled and decicled law." And in the first of them (i. e.) Evelyn v. Templar, it was said by Lord Thmrlow, that so many estates stand upon the rule, that it cannot be shaken. And so late as Mich. term, 1804, in the case of Doe d. Lewis v. Hopkins, the Court of Exchequer held; where after marriage a man covenanted to stand seised of an estate to the use of himself for life, remainder to the use of his wife for life, remainder to the heirs of the body of the wife begotten by the husband; that such settlement was roid, as being voluntary against a lessee of the husband for 31 years; the son of the settlor claining the estate after his father's death against the lessee. To the authority of these cases may be added the case of Nunn v. Willsmore, S Term Rep. 52S, where Lord Kenyon 
said, "if this deed were either actually fraudulent, or voluntary, from whence the law infers fraud, the conseguence insisted on by the plaintiff would follow; and I admit that if this deed were a voluntary deed, the law says it is fraudulent." Thus stand the authorities on both sides of the question; and the weight, number, and uniformity of those which establish the point contended for on behalf of the piaintiff, do in our opinion very much preponderate; and as many estates depend upon the rule, it ought not, we conceive, to be shaken. It appears from the MS. note I have cited, formerly belonging to Mr. Just. Clive, that Mr. Horsman, in the year 1713, advised the making a mortgage of the estate settled in strict settlement by $\operatorname{Sir} \mathrm{R}$. Anderson after his marriage; thinking it voluntary and fraudulent as against a purchaser, and the like advice as that which he gave nearly a century ago, probably had been given before; and that it has been given since, and acted on, we cannot doubt; as Lord Thurlow was not likely to have expressed himself, as he did in Evelyn v. Templar, unless he had known that such had frequently been the case. Feeling ourselves pressed with these authorities and considerations, we think ourselves bound to give judgment for the plaintiff. Much property has, no doubt, been purchased, and many conveyances settled upon the ground of its having been so repeatedly held, that a voluntary conveyance is fraudulent, as such, within the stat. 27th of Eliz.; and it is no new thing for the Court to hold itself concluded in matters respecting real property by former decision upon questions, in respect of which, if it were res integra, they probably would have come to very different conclusions. And if the adhering to such determinations is likely to be attended with inconvenience, it is a matter fit to be remedied by the Legislature, which is able to prevent the mischief in future, and to obviate all the inconvenient consequences which are likely to result from it, as to purchases already macie. And we cannot but say, as at present advised, and considering the construction put on the statute, that it would have been better if the statute had avoided conveyances only against purchasers for a valuable consideration without notice of the prior conveyance. Our opinion being with the plaintiff, the consequence is, that there must either be a new trial, or an issue between the plaintiff and the defendant Goom to try the validity of his lease. ${ }^{3}$

3 A., heing seised in fee, covenanted to stind sejsed to use of himself for life, remainder ultimately to use of $P$. in fee. A. diell. leaving a will by which the same premises were devised in fee to C. who conveged them to $\mathrm{X}$., a purchaser for value. In ejectment log B. against $X$., the defense was on the statute 27 Eli\%, 1lold, the statnte did not aroid the deed to 5 . Doe d. Newman

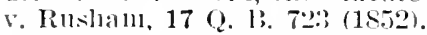

In l'ary v. Carwalden, 2- Dick. 544 (177S), it was held that equity at the suit of a inmehaser for value, would decree a specific performance of a contract of sile made after a rolmutary converance of the same mremises. But where the suit for specitic performance is hy the vendor, held otherwise in Smith v. Garland, 2 Mer. 12.2 (1S17). See, also. Clatke v. Willutt, L. R. 7 Exch. 313 (1872). where the rendex, who had contracted to pulchise the prenises atter the rendor had mate a voluntary conveyance thereof, sued to recover bates deposits which he had made. 


\section{COOKE v. KELL.}

(Court of Appeals of Maryland, 1858. 13 Md. 469.)

Ejectment for a lot of ground, forty-one feet front and one hundred and fifty-nine deep, on York street, in the city of Baltimore, being lot No. 17, and part of "Todd's Range," brought on the 29th of August, 1850 , by the appellant against the appellees. Plea, Non cul.

The plaintiff, on the whole evidence, asked an instruction to the jury in substance as follows:

That by the deed of the 14th of May, 1792, Joseph Bankson conveyed to grantees therein named, the property therein described, in fee, subject to the life estate in and to the same, of the grantor and his wife and of the survivor of them, and if the jury find from the evidence, that said Joseph Bankson died in 1806, and his widow in 1843, that the right of action to recover possession of said lot of ground, theretipon first accrued to the grantees in said deed named, and their representatives, and that the deed of 1795, from said Bankson to Diffenderffer, was not sufficient to aroid said conveyance of 1792, although they may find, that the said deed of 1795, was for full value, and that of 1792, voluntary, and for no other consideration than that stated therein, provided the jury shall further find, that said last mentioned deed was duly acknowledged and recorded in the records of Baltimore county court, on the 14th of May, 1792.

The defendants, on the same evidence, asked two instructions to the jury, in substance as follows:

1st. If the jury find, that the deed from Joseph Bankson, of the 14th of May, 1792, was a voluntary conveyance, and for no other consideration than that stated in it, that then the sale by him in 1795, of the same property to Diffenderffer, and the execution of the deed therefor to Diffenderffer, of the 17th of February, 1795, if the jury shall find such sale and deed, and that the same was for a valuable consideration, and without actual notice by Diffenderffer of said deed of the 14th of May, 1792, is presumptive evidence, that said deed of the 14th of May, 1792, was fraudulent and void.

2nd. If the jury shall find, that the said deed of the 14th of May, 1792, was only for the consideration therein stated, and shall also find that the grantor, Bankson, had antecedently thereto conveyed away all his other property, and was at the time of the execution of said deed of the 14th of May, 1792, the owner and possessor of no other property, and if they shall find, that his wife, who had a life estate under that deed, joined by a relinquishment of dower in the deed to Diffenderffer, of the 17 th of February, 1795, with knowledge that the same conveyed the title to the grantee, and that she lived till 1843, and that the three children, the grantees in said deed of 1792 , were then infants and unable to maintain themselves, and that said Bankson never had any property afterwards, other than the purchase money 
received from Diffenderffer, from the said sale to him of said lot, or what he may have procured by means thereof, and that neither said Bankson, nor his wife, or any one else, ever communicated to Diffenderffer the existence of said deed of 1792, and that neither he (Diffenderffer) nor Thomas Kell, under whom the defendants claim, ever had actual knowledge of the same until long after the deed to said Kell by Henry Dorsey, of 1833, offered in evidence by the defendants, (if the jury find such deed, and that the same was for full value,) and the jury shall also find, that said Diffenderffer, and those claiming under him, held said property from 1795 , to the present time, adversarily under said deed to Diffenderffer of 1795 , and that said Cooke never did set up title to the same under the said deed of 1792 , that then the jury may find that said deed of the 14th of May, 1792, was not bona fide but fraudulent and void.

The court (Frick, J.) refused the plaintiff's prayer, and granted those of the defendant. To this ruling the plaintiff excepted, and the verdict and judgment being in favor of the defendant, appealed.

LE Grand, C. J. This case has been discussed at the bar with great fullness of illustration, and the views of the respective counsel, presented with clearness and cogency of reasoning.

To our minds-looking to past and distinctly recognized adjudications-the questions we are called upon to decide are confined within a narrow space. The action is one of ejectment, and the principal facts of the case may be thus stated:

On the 14th day of May, 1792, a certain Joseph Bankson, by deed, conveyed (reserving to himself and wife, and to the survivor of them, a life estate therein) a certain lot of ground and the improvements thereon, to his three children, Harriet Giles Bankson, Joseph Bankson and Elizabeth Bankson, their heirs and assigns forever, as tenants in common. The consideration for this conveyance was natural love and affection, and the nominal sum of five shillings. On the 17th day of February, 1795, the aforesaid Joseph Bankson conveyed the same property to Daniel Diffenderffer, for a valuable consideration, the wife of Bankson releasing her dower. Diffenderffer immediately took possession, and remained in it until his death in 1809 or 1810, devising the property to his wife, who continued in it until her death, which occurred in 1832 or 1833, after which, it was sold by a trustee appointed for the purpose, and the title of Diffenderffer and wife, by legally executed and acknowledged mesne conveyances, and lastly, by a deed from Henry Dorsey, became vested in Thomas Kell, who paid for it $\$ 7000$, and who remained in possession of it until his death in 1846. The lessor of the plaintiff claims title under the voluntary deed of 1792, and the defendants under the deed of 1795, for a valuable consideration to Diffenderffer, and through the intermediate conveyances down to Thomas Kell, and through and from him down to themselves. The deeds of 1792 and 1795 , were both placed on record in the proper office on the days of their dates. The widow of Joseph 
Bankson survived her husband until 1843. Elizabeth Bankson, (who intermarried with a certain John S. Cooke, since dead,) is the only child of the grantor, being a grantee in the deed of 1792, now living, the other two children having died without leaving issue. There was testimony given on the part of the defendants, for the purpose of showing that the elder Bankson was apparently in needy circumstances, and that, at the time of the exccution of the deed in 1795 to Diffenderffer, it did not appear, from the public records, he had any other property than that mentioned in that conveyance, and also, that until a very short time before the institution of this action, no claim on the part of the grantees in the deed of 1792, was heard of by the witnesses. This is substantially the evidence in the cause. The plaintiff offered one prayer to the court, which was rejected, and the defendants two, which were granted.

The defendants contend, that under a proper construction of the statute of 27 th Elizabeth, entitled, "An act against covinous and fraudulent conveyances," and the circumstances of this case, the decd of 1792, under which the lessor of the plaintiff claims title, is void and of no avail as against the defendants, who claim under the deed of 1795 , which was for valuable consideration; that as to them, it is void and fraudulent, there being no evidence of notice of the deed of 1792, and that it was executed with a fraudulent intent in fact.

On the other hand the plaintiff insists, that neither in law, nor in fact, was there any frand in the execution of the deed of 1792, and that it is all sufficient to entitle her to recover in this action.

The first inquiry for our determination is: What is the received and binding interpretation of the statute of 27 th Elizabeth, ch. 4, in this State? On this, principally depends, the decision of this case. Until the year 1807, when was decided the case of Doe v. Manning, 9 East, 59, there was much contrariety of opinion in England-and doubtless, also in this country -as to the true meaning of the statute; since then, however, the opinion of Lord Ellenborough, has, in England, put to rest all judicial doubts on the subject. Were that opinion law in this State, there would be an end to the plaintiff's title under the voluntary deed of 1792. But it is not the law. In the case of IVarren and Others' Lessee v. Richardson and wife et al., decided in the year 1837, the Court of Appeals relied upon and adopted the decision of the Supreme Court of the United States, in the case of Catheart $v$. Robinson, 5 Pet. 280, S L. Ed. 120, and in the case of the Mayor and City Council of Balto. v. Williams, $6 \mathrm{Md}$. 235, this court again construed the statute of $27 \mathrm{th}$. Elizabeth, and again adopted the construction placed upon it by the Supreme Court. Fully concurring in the correctness of those decisions, we are relieved from all inquiry as to what may be the law elsewhere. The principal difference between the doctrine of Doe v. Manning, and that of Catheart v. Robinson, consists in this: By the former, and mere execution of a voluntary deed raises the presumption-which cannot be rebutted-of fraud 
as against subsequent purchasers for value, whilst by the other, the rule is, in the language of Chief Justice Marshall: "A subsequent sale without notice, by a person who had made a settlement not on valuable consideration, was presumptive evidence of fraud, which threw on those claiming under such settlement, the burthen of proving that it was made bona fide." This quotation from the opinion of Chief Justice Marshall, contains, to the fullest extent contended for by the counsel of the defendants, their interpretation of the statute. It does not assert the doctrine, in any sense, that a voluntary deed is void simply because it is voluntary; it merely-as against subsequent purchasers for value-makes it presumptive evidence of fraud, where there has been no notice to stbsequent purchascrs, and casts, in such a case, upon those claiming under it, the burthen of disproving the presumption. When the subsequent purchaser has notice, no such presumption arises, and as was said in 6 MId. 265: "To hold that, with notice to the purchaser, the settlement is stibject to the presumption of fraud, simply in consequence of the subsequent conveyance for value, we think is not required by the language of the statute, and is inconsistent with correct moral feeling."

This being so, the question then is: Had Diffenderffer notice of the voluntary deed of 1792? There is no evidence in the record showing that he had, in point of fact, notice of its existence; on that head there is perfect silence. Whether or not, then, he had such notice as will bind him, and those claiming under him, must depend upon the effect of our registration laws. The deed of 1792 was placed on record the day of its execution, and, of course, open to inspection in 1795 , when the second deed was made.

In the case of Warren v. Richardson, already referred to, decided by the late Court of Appeals, and reported in 6 MI. 272, the Reporter, in a note, has drawn the inference from the decision of the court upon the prayers offered, and from the facts appearing in the record of that case, and from the fact, that the Court of Appeals, upon the reversal of the judgment awarded a procedendo, "that the notice which will bind the subsequent purchaser, need not be actual, but that constructive notice furnished by the recording of the voluntary deed under our registry laws, is sufficient." In this, we think, he was correct. There was no evidence, that the subsequent purchasers in that case had any actual notice of the prior voluntary deed. If, then, the fact of the registry of the deed did not affect them with notice, we are unable to perceive for what purpose a new trial was directed under a procedendo? IVe think the court could not otherwise than have decided, that the registry of the deed affected the subsequent purchasers with notice, and thereby shifted the onus upon them to show, if they could, that the deed was fraudulent in fact, and for the purpose of enabling them to do this, ordered a new trial. If the registry of the deed did not have, in the opinion of the court, this effect, then, the defendants stood in the attitude of subsequent purchasers 
for value, without notice, and the question of law raised by the prayers, became a mere abstract proposition, the decision of which, either way, would have been of no avail to the voluntary grantees under the deed.

But, be this as it may, the interpretation we have sanctioned is fully sustained by express decisions. In the case of Beal v. Warren and another, 2 Gray, 450, the Supreme Court of Massachusetts, when speaking of a voluntary deed, under the statute of 27 th Elizabeth, say: "No question is made whether the second grantee had actual notice of the first conveyance, though, from the relation of the parties, and from the fact, that there was no attempt to show actual fraud, such notice may reasonably be inferred. Nor would this be, in the absence of fraud, material; for the registration of the conveyance would be constructive notice, and sufficient notice, to all subsequent purchasers." In the case of O'Neill v. Cole, $4 \mathrm{Md}$. 123, the court, referring to a deed, executed by a female, a short time before her marriage, and which was contested by her surviving husband after her death, remark that, "If the appellant, (the husband,) had reason to suppose that his late wife, before their marriage, had been imposed upon, or induced to execute a conveyance of which she did not know the contents and meaning, it was quite proper for him to resist the attempt of the appellee to possess himself of the property. In this we think he has failed; and if, failing in this, he seeks to make out a case of fraud in law upon his marital rights, there is no reason why he should not be bound by the notice, which our recording acts impute to others when seeking to vacate conveyances, or when claiming against them." In the same case, the Chancellor had previously said, 3 MId. Ch. 174, that, "It is the settled American doctrine, that the registration of a conveyance, operates as constructive notice upon all subsequent purchasers of any estate legal or equitable in the same property." And as was said by a majority of the court, in the case of Williams et al. v. Banks et al., $11 \mathrm{Md}$. 250: "It seems to us a contradiction in terms, to say, that a person is defrauded by an instrument, when he deals with a perfect knowledge of its existence and of its effect. If our registration laws have any operation, they certainly do, as they were designed, give notice to all the world, so that there may be no deceit practiced upon any one. If registration laws do not give notice to the community which will bind it, then they are of no use whatever, for, without registration, deeds would be binding inter partes." This language was applied as well to deeds under the 13th, as to those under the 27 th of Elizabeth.

These authorities are all sufficient, in this state at least, to show that registration is constructive notice, and all sufficient to bind subsequent purchasers in the absence of actual fraud.

The prayer of the plaintiff was defective, only in the omission, to require the jury to find the existence of the deed of 1792 .

The first prayer of the defendants was erroneous, in ignoring the 
effect of the registration, and requiring actual notice. We do not think the facts, if found, enumerated in their second prayer, sufficient to have authorized the jury to find the deed of 1792 was not bona fide, but fraudulent and void. All those facts might be found, and, nevertheless, the deed might be bona fide and valid. There must be some pointed evidence to establish fraud in fact. We affirm the court below in its rejection of the plaintiff's prayer, and reverse its decision granting the prayers of the defendants.

If left to conjecture, we may imagine, that the case was a hard one on Diffenderffer, as it was undoubtedly on Kell, who paid a full price; but it may, also, on the other side, be supposed, that Diffenderffer had actual as well as constructive notice of the deed of 1792, when he accepted that of 1795 , but, that relying upon what may be very reasonably supposed, at that time, to have been the opinion of the profession, as to the true construction of the statute of Elizabeth, he believed it competent to the elder Bankson to give him a good title. But with surmises we have nothing to do. Unless the defendants can establish fraud in fact, the registration of the deed of 1792 , concludes them in this action.

\section{Judgment reversed and procedendo awarded. ${ }^{4}$}

4 The matter of conveyances in fraud of creditors is not considered here. It seems more appropriately considered in the course on Bankiuptcy.

Purchaser for VAlue.-It is well settled that to bling a converance under the protection of the statute of 27 Eliz. c. 4 , it is necessary that it be made upon a valuable consideration. Upton v. Easset, Cro. Eliz. 445 (1596). The assumption of liability on the covenants in a lease makes one a purchaser for value, at least under the saring clause. Price v. Jenkins, 5 Ch. D. 619 (1S7T). But see Lee v. Mathews, 6 I. R. Ir. 530 (1Ss0). Cf. Townsend v. Toker, L. R. 1 Ch. 446 (1S66); Rosher v. Williams, L. R. 20 Eq. 210 (1875). But a consideration which is merely nominal or colorable, such as "5s. and other valuable considerations," is not sufficient. Walker v. Purrows. 1 Atk. $94(1745)$. See, also, shtirmur v. Sedgwick, 24 Ch. 1). 597 (1883). The paynent of $\$ 50$ for conveying an estate worth $\$ 25,000$ does not make one a purchaser for value. Fullenwider v. Roberts, 20 N. C. 420 (1S39). But see Boyer v. Tucker, 70 MIo. 457 (1879).

Marriage is a valuable consideration. Prodgers v. Laughan, 1. Sid. 133 (1663); Sterry r. Arden, 1 Johns. Ch. (N. Y.) 62, 261 (1S14). But only those coming within the marriage consideration are protected. Johnson $\mathrm{v}$. Legard, $6 \mathrm{MI}$. \& S. 60 (1817); Irice $\nabla$. Jenlins, 4 Ch. D. 483 (1S76); Mackie v. Herbertson, 9 App. Cas. 303 (18S4); In re Cameron \& Wells, 37 Ch. D. 32 (1S87); De Mestre v. West, [1S91] A. C. 264 . But see Newstead v. Searles, 1 Atk. 265 (1737); Clarke v. Wright, 6 H. \& ×. 849 (1861); Gale v. Gale, 6 Ch. D. 144 (1S76); Jenkins v. Keymes, 1 Ler. 287 (1668); Clayton v. Wilton, 6 1I. \& S. 67 (1517). It has been held that one taking a conveyance to secure antecedent debts is not a purchaser for value. Manhattan Co. v. Erertson, 6 Paige (N. Y.) 457 (1837). See. also, McKay r. Gilliam, 65 N. C. 130 (1S71). So one who has given a mortgage to secure the purchase price, but has in fact paid nothing, is not protected. Alden $v$. Trubee, 44 Conn. 455 (1577). A converance roidable when entered into for want of consideration may be made valid by matter ex post facto. Prodgers v. Laughan and Sterry r. Arden, supra.

A conveyance to charitable uses has never leen regarded as within the statute. Ramsay v. Gilchrist, [1S92] L. R. A. C. 412. 


\section{SECTION 2.-RECORDING}

\section{IN ENGLĀND}

\section{ST. 7 ANNE, c. 20 (17OS).}

17 hercas by the different and sccret ways of conveying lands, tenemenis, and hereditaments, such as are ill disposed have it in their power to commit frauds, and frequently do so, by means whereof severil persons (who through many years industry in their trades and employments, and by great frugality, have been enabled to purchase lands, or to lend moneys on land security) have been undone in their purchases and mortgages, by prior and secret conveyances, and fraudulent encumbrances, and not only themselves, but their whole families thereby utterly ruined: for remedy whereof, may it please your most excellent Majesty (at the humble request of the justices of the peace, gentlemen, and freeholders of the county of Middlesex) that it may be enacted, and be it enacted by the Queen's most excellent Majesty, by and with the advice and consent of the Lords spiritual and temporal, and Commons in this present Parliament assembled, and by the authority of the same, That a memorial of all deeds and conveyances, which from and after the twenty-ninth day of September, in the year of our Lord one thousand seven hundred and nine, shall be male and executed, and of all wills and devises in writing made or to be made and published, where the devisor or testatrix shall die after the said twenty-ninth day of September, of or concerning, and whereby any honors, manors, lands, tenements, or hereditaments in the said county, may be any way affected in law or equity, may be registered in such manner as is hereinafter directed; and that every such deed or conveyance that shall at any time after the said twenty-ninth day of September, be made and executed, shall be adjudged fraudulent and void against any subsequent purchaser or mortgagee for valuable consideration, unless such memorial thereof be registered as by this Act is directed, before the registering of the memorial of the deed or conveyance under which such subsecuent purchaser or mortgagee shall claim; and that every such devise by will shall be adjudged fraudulent and void against any subseguent purchaser or mortgagee for valuable consideration; unless a memorial of such will be registered at such times and in manner as is hereinafter directed.

XVII. Provided, always, and be it further enacted, That this Act shall not extend to any copyhold estates, or to. any leases at a rack rent, or to any lease not exceeding one and twenty years, where the actual possession and occupation goeth along with the lease, or to any 
of the chambers in Serjeants Inn, the inns of court, or inns of Chancery; anything in this Act contained to the contrary thereof in any wise notwithstanding.

\section{BEDFORD v. BACCIIUS.}

(High Court of Chancery, 1730. 2 Eq. Cas. Ab. 615, pl. 12.)

A. lent money on a mortgage of lands in Middlesex, and the mortgage was duly registered. Afterwards B. lent money on the same security, and his mortgage was registered. Then A. aclvanced a farther sum upon the same lands, without notice of the second mortgage. And it was held by Lord Cilarcelion King that the registry of the second mortgage was not constructive notice to the first mortgagee bcfore his alvancement of the latter sum, for tho' the statute avoids deeds not registered as against purchasers, yet it gives no greater efficacy to deeds that are registered than they had before; and the constant rule of equity is, that if a first mortgagee lends a farther sum of money without notice of a second mortgage, his whole money shall be paid in the first place. ${ }^{\circ}$

\section{MIORECOCK v. DICKINS et al.}

\section{(Jligh Court of Chancery, 1768. 2 Amb. Gis.)}

On 16th June, 1749, Henry Fandal leased a piece of ground, and buildings, at Wapping, for 51 years, to the defendant George Wilson.

On 23d February following, George IVilson assigns the premises to the plaintiff Morecock, for the remainder of the term, to secure the sum of $\ell 800$. and interest.

In 1751, Morecock went abroad, and left the mortgage deed in the hands of Wilson, having first signed a receipt on the back of it, by which it appeared that Morecock had been repaid the principal and interest: and this transaction was stated in the bill to have passed at the request of Wilson, who apprehended he might want money to carry on trade in Morecock's absence; and promised, that if he borrowed money thereon, he would repay it, and restore the mortgage to Norecock, clear of incumbrances.

In 1755, Morecock returned to England, and Wilson delivered back the mortgage to him, without having borrowed any money upon it; where it remained till 1760, when he again trusted Wilson with the mortgage deed and receipt, with a view, as stated in the bill, to enable Wilson to borrow a large sum of money upon security of the premises, out of which Morecock was to be paid.

In 1763, Wilson mortgaged the premises to John Athinson, for $£ 300$.

s So also in Bushell v. Bushell, 1 Sch. \& I.ef. 90 (1S03). 
and being pressed by Athinson for payment of the money, prevailed on Moreccek to sign a writing, by which he agreed to give Athinson priority of his demand.

It did not appear in the cause, whether the original lease was ever out of Wilson's custody; or whether it was delivered to Morecock at the time of the mortgage, and sent back to Wilson, with the mortgage deed: but it appeared to be in IVilson's hands in 1765, for on 24th January, 1765, Wilson surrendered up the lease, and took a new lease for 71 years.

On the 11th February, 1765, Morecock and Wilson settled their acconnts, and there being a balance of $£ 2065$. 5s. due to Morecock, it was agreed, that the new lease should stand as a security for $£ 800$. and interest, at all events: and Wilson gave a bond and judgment for the remainder of the balance, to be paid by instalments; but in case Vilson should neglect to make good any of the payments, it was agreed that IVilson should give Morecock a security for the same upon the premises:

This deed was registered within a few days afterwards.

On 6th April, 1765, Wilson mortgaged the premises to defendant Dickins, for $£ 800$. and interest; and delivered to him the lease itself. Dickins had no notice of plaintiff's security at the time he took the mortgage, but being afterwards informed of it, on 15 th February 1766, gave Morecock a notice in writing, that he would pay him $\$ 1000$. on the 25th of March following, or as soon after as an assignment of Wilson's lease could be prepared, according to the agreement of the 11 th February, 1765; and at the same time informed Norecock of the mortgage assignment to himself of the 6th April, 1765.

Wilson soon after becoming bankrupt, nothing was done in consequence of the notice.

Bill by Norecock, inter alia, to be paid the $£ 800$. agreed to be secured on the premises, at all events, prior to the defendant Dickins' mortgage.

Bill by Dickins, to be paid his mortgage money, or to foreclose.

The question respecting this matter was, Whether Dickins, though he had not actual notice of Morecock's security at the time he took the mortgage, should be affected by a constructive notice, arising from the circumstance of the deed being registered at the time?

It was admitted by the counsel, for Morecock, that Dickins having got the legal interest would be entitled to priority, unless he could be affected by notice. That there was no evidence of actual notice. But it was insisted that the registration was notice of itself. That to give the Register Act its proper and intended effect, the act of registration ought to operate as notice; and it was compared to the case of judgments; that which is first docketed shall have priority.

On the other side, it was argued for defendant Dickins, That the Registry Act was made for one single purpose, to give preference to a purchase deed registered, before a prior deed not registered; but 
the Act gives no greater efficacy to deeds which are registered than they had before, and the case of Bedford v. Bacchus, 2 Eq. Ca. Abr. 615, 26th November, 1730, was cited for that purpose; where a first mortgagee of lands in Middlesex having registered his mortgage, lent a further sum, without actual notice of a second mortgage, which had been registered. Lord King, Chancellor, was of opinion, That he ought not to be affected by such constructive notice, but that the rule of equity took place, and the first mortgagee was entitled to be paid his whole money before the second mortgagee. That in the present case, Dickins having got the legal interest, was entitled to be paid before a prior equitable incumbrancer, unless he was affected by notice. That here was no actual notice, and the registration was not constructive notice according to the above determination.

LORD CAMDEN, Chancellor. Q. Whether registration is presumptive evidence to all mankind?

If this was a new point, it might admit of difficulty; but the determination in Bedford v. Bacchus seems to have settled it, and it would be mischievous to disturb it. The act provides for one single case only, that is, to make unregistered deeds void against registered deeds ; but there is no provision by the Act, in a case where all the deeds are registered. And yet it becomes a serious question. Whether a Court of Equity should not say, that in all cases of registry, which is a public depository for deeds, and to which any person may resort, a subsequent purchaser ought not to search, or be bound by notice of the registry, as he would of a decree in equity, or judgment at law? It is a point in which a great deal of property is concerned, and is a matter of consequence. Much property has been settled, and conveyances have proceeded upon the ground of that determination. In the case of Vandebendy, in the House of Lords, the doctrine about dower prevailed, because it had been practised in a course of conveyance. A thousand neglects to search have been occasioned by that determination, and therefore I cannot take upon me to alter it. If it was a new case, I should have my doubts; but the point is closed by that determination, which has been acquiesced in ever since.

\section{LE NEVE v. LE NEVE.}

\section{(Court of Chancery, 1747. 1 Amb. 436.)}

LORD HARDwickE, Chancellor. ${ }^{8}$ The bill was brought by the plaintiffs, Peter Le Neve and Hugh Pigott, and Elizabeth his wife, late Elizabeth Le Neve, as the only surviving children of the defendant Edward Le Neve, by Henrietta his late wife.

6 Portions of the opinion are omitted. 
The end of the bill in general is, to have the execution of trust of leasehold estates settled upon the late wife of Edward Le Neve, and the issue of that marriage, by articles previous to the marriage, dated 1st July, 1718; and that the conveyances made by the defendant Edward Le Neve, and the defendant Mary his now wife, to trustees, may be set aside. and delivered up, being made after notice of the articles of the 1st of July, 171S, or of the other conveyances made in pursuance thereof; and to have the leasehold exonerated and disincumbered.

The facts are, that in 1718, the defendant. Edward Le Neve, intermarried with his first wife Henrietta Le Neve, who had a considerable fortune; and articles were executed previous to the marriage, dated the 1st July, 1718, whereby the father of Edward, in consideration of Henrietta's fortune, \&c., covenanted with trustces, to convey to them several estates, and some leasehold amongst the rest, near Soho Square in the county of Middlesex; to permit Edward Le Neve, the younger, to receive the rents and profits churing his own iife, and after his death, to pay to Henrietta $\{250$. a year, in case she survived Edward; and after the decease of Edward and Henrietta, then the said estates should remain to their issue in such manner as Edward the younger should, by will or otherwise, appoint; and for want of such issue, to the use of Edward Le Neve the father, and his heirs.

The 16 th June, 1719, a settlement was made in pursuance of the articles.

The marriage took effect; and Edward and Flenrietta had issue, plaintiffs Peter and Elizabeth. Henrietta died July, 1740, leaving no other children.

Twenty-five years after the first marriage, Edward Le Neve entered into a treaty of marriage with the defendant Mary, and by articles dated the 16th of November, 1743, previous to the marriage, Edward, in consideration of such marriage, covenanted with the trustees, the defendants Dandridge and Norton, to convey these very leasehold estates near Soho Square to them, their executors, \&c., within three months after the marriage, in trust to pay to defendant Mary, out of the rents of these messuages, in case she survived him, a clear annuity of $£ 150$. for her life, for her jointure, \&c.

The marriage took effect, and three months after, on the 20th January, 1743 , a settlement was made pursuant to the articles.

The settled estate, being houses in Middlesex, was subject to the Register Act, the 7th Q. Anne, cap. 20.

The second articles and settlement were registered, but not the first.

Edward has mortgaged the houses likewise.

The bill is brought, in order to set the second articles and settlement out of the way, and that they may be postponed to the first articles and settlement; upon this equity, That the defendant Mary Le Neve had notice of them. 
The counsel for the plaintiffs admit, That the registering of the second articles and settlement has, in point of law, affected the leasehold estates, as the 7 th Q. Anne gives the legal estate where the effect of the registering has placed it.

The question is, Whether equity will enable the children of the first marriage to get the better of the defendant's legal right? And this will depend upon the question of notice:

1st, Whether it appears sufficiently, that Joseph Norton was attorney for the defendant Mary in the transaction of her marriage?

2dly, Whether Norton himself had sufficient noice of the first articles and settlement?

$3 \mathrm{dly}$, Whether that will affect Mary as a purchaser, and postpone her articles and settlement, notwithstanding the Register Act? * * * ?

The third and last general question is, Whether the notice to Norton will affect the defendant Mary as a purchaser, and postpone her articles and settlcment, notwithstanding the Register Act?

'Ihis depends on two things:

1st. Whether any notice whatsoever would be sufficient to take from the defendant the benefit of the Register Act?

2d. Whether personal notice to the defendant Mary is requisite to postpone her? or, Whether notice to her agent is sufficient to do it likewise?

As to the 1 st, it is a question of great extent and consequence.

The preamble of the statute of the 7 th $Q$. Anne, ch. 20, is in substance, "Whereas, by the different and secret ways of conveying lands, $\&$ c., such as are ill-disposed have it in their power to commit frauds, and frequently do so, by means whereof several persons have been undone in their purchases and mortgages, by prior and secret conveyances, and fraudulent incumbrances."

Then comes the enacting clause, "That a memorial of all deeds and conveyances which, after the 27th of September, 1709, shall be made and executed, and of all wills and devises in writing, whereby any honours, manors, lands, \&c., in the county of Middlesex, may be any way affected in law or equity, may be registered in such manner as is after directed: and that every such deed or conveyance that shall at any time after, \&c., be made and executed, shall be adjudged fraudulent and void against any subsequent purchaser or mortgagee for valuable consideration, unless such memorial be registered as by this act is directed, before the registering of the memorial of the deed or conveyance under which such subsequent purchaser or mortgagee shall claim, \&c."

What appears by the preamble to be the intention of the act?

Plainly, to secure subsequent purchasers and mortgagees against prior secret conveyances and fraudulent incumbrances.

Where a person had no notice of a prior conveyance, there the reg-

7 The court decided the first two questions in the aflirmative. 
istering his subsequent conveyance shall prevail against the prior; but if he had notice of a prior conveyance, then that was not a secret conveyance by which he could be prejudiced.

The enacting clause says, that every such deed shall be void against any subsequent purchaser or mortgagee, unless the memorial thereof be registered, \&c.; that is, it gives him the legal estate; but it does not say, that such subsequent purchaser is not left open to any equity which a prior purchaser or incumbrancer may have; for he can be in no danger when he knows of another incumbrance, because he might then have stopped his hand from proceeding.

This case has been very properly compared to cases on the 27 th $\mathrm{H}$. 8 , for inrollment of bargains and sales.

That act is formed pretty much in the same manner with this.

The words of the enacting cläuse: "That from, \&c., no manors, lands, tenements, \&c., shall pass, alter, or change, from one to another, whereby any estate of inheritance or freehold shall be made, or take effect in any person or persons, or any use thereof to be made thereof, by reason only of any bargain and sale thereof, except the same bargain, and sale be by writing indented, sealed, and inrolled, in one of the King s Courts of Records at Westminster, or else within the same county, \&c., where the same manors, \&c., so bargained and sold do lie, \&c.; and the same inrollment to be had and made within six months next after the date of the same writings indented, \&c. Nor any use shall pass thereof from one to another."

What is the meaning of this?

Before the making of the act, any paper writing passed the use from the bargainor to the bargainee, whereby great mischief arose; for it entangled the purchasers, and injured the Crown, and was contrary to the rule of law, which required notoriety in purchases by feoffment and livery, \&c.

But what has been the construction of this statute ever since? Why, if a subsequent bargainee has notice of a prior, he is equally affected with that notice as if the prior purchase had been a conveyance by feoffment and livery, \&c.

The operation of both acts of Parliament and construction of them is the same; and it would be a most mischievous thing, if a person taking that advantage of the legal form appointed by an act of Parliament, might under that protect himself against a person who had a prior equity of which he had notice.

The cases put by the Attorney-General are very material:

Suppose (he said) the defendant Mary had by letter of attorney empowcred Norton to transact the affair with her husband, and he by means of this agency comes to the knowledge of the prior articles and settlement, would not this affect the principal? Or suppose a purchaser of lands in a register county orders his attorney to register it, and he neglects to do it, and then buys the estate himself, and registers his own conveyance, shall this be allowed to prevail? 
It certainly shall not; for such a purchaser is out of the consequence which the register act guards against, of imposition from a prior secret conveyance, as he had personal lnnowledge of the first.

There have been three cases on the Register Act:

1. Lord Forbes v. Nelson, 4 Bro. P. C. (Ed. Toml.) 189.

2. Blades v. Blades, 1 Eq. Ca. Abr. 358, pl. 2.

3. Chival v. Nicholls, 10th December, 1725, in the Exchequer, (1 Stra. 564.) * * *

Consider, therefore, what is the ground of all this, and particularly of those cases which went on the foundation of notice to the agent. The ground of it is plainly this, That the taking of a legal estate after notice of a prior right, makes a person malâ fide purchaser, and not, that he is not a purchaser for a valuable consideration in every other respect. This is a species of fraud and dolus malus itself; for he knew the first purchaser had the clear right of the estate, and after knowing that, he takes away the right of another person by getting the legal estate.

And this exactly agrees with the definition of civil law of dolus malus, Dig. libr. 4, tit. 3. Dolum malum Servius ita definit. Machinationem quandam alterius decipiendi causâ, cum aliud simulater, cum aliud agitur. Labeo autem posse et sine simulatione id agi ut circumveniatur. Posse et sine dolo malo aliud agi, aliud simulari, sicuti faciunt, qui jus ejusmodi dissimulationem deserviant et tuentur vel sua vel aliena. Itaque ipse sic definit dolum malum esse omnem callidiatem fallacium machinationem ad circumveniendum, fallendum, decipiendum alterum adhibitum. Labeonis definito vera est.

Now if a person does not stop his hand, but gets the legal estate when he knew the right was in another, machinatur ad circumveniendum. It is a maxim, too, in our law, That fraus et dolus nemini patrocinari debent. Vid. Co. 3 Rep. 78; 7 Rep. 38.

Fraud, or mala fides, therefore, it is the true ground on which the Court is governed in the cases of notice; and it is a consequence of the decision of the former question, that notice to the agent is sufficient; for if the ground is the fraud, or mala fides, of the party, then it is all one, whether by the party himself or his agent; still it is a machinatio ad circumveniendum, and the putting a copy of the first articles and settlement into Norton's hands, to take the opinion of counsel in what manner they could be set aside, is a contrivance to circumvent.

It has been said, If this woman has been imposed on by her husband, she, instead of cheating, has been cheated.

But then who ought to suffer? the person entrusting an agent, or a stranger who did not employ him? He certainly who trusts most ought to suffer most.

Mrs. Hatt, the third mortgagee in the case in 2 Vern. mentioned before, was imposed on; and so was Moore, in the other case reported Aig.Prop. - 53 
there, clearly imposed on; and yet if this was to be any excuse, it would make all the cases of notice very precarious; for it seldom happens but the agent has imposed on his principal; and notwithstanding that, the person trusting ought to suffer for his ill-placed confidence.

Therefore, in both respects, as agent and trustee, notice to Joseph Norton, is notice to defendant Mary likewise. And as to the Registry Act, here is sufficient equity in the plaintiff to postpone the second articles and settlement, notwithstanding those only have been registered. And decreed accordingly. ${ }^{8}$

\section{IN UNITED STATES}

\section{(A) Statutes}

\section{CALIFORNIA CIV. CODE (1908).}

Section 1213. Every conveyance of real property, acknowledged or proved, and certified and recorded, as prescribed by law, from the time it is filed with the recorder for record, is constructive notice of the contents thereof to subsequent purchasers and mortgagees; and a certified copy of any such recorded conveyance may be recorded in any other

8 As to the rule of the princijal case in.an action at law, see Doe d. Robinson r. Allsop, 5 B. \& Ald. 142 (1\$21), Bayley, J., there said: "The wolds of the statute are that such deeds or converances shall be adjudged fraudulent and roid against every subsequent purchaser for raluable consideration. It is to be observed that the words 'bona fide purchaser' are not used. I think, therefore, that we are lound in a conrt of law to give effect to these words. That seens to have been the opinion of the judges in the cases cited, although they thought that a court of equity would, in sone cases, interfere to relieve the party. It is so laid down los Lord Hardricke, in Le Neve $r$. Le Neve and the words of Lord Manstield, in Doe ex dem. Watson 5 . Routledge, Cowp. 712 (177t) are those: 'Equity says, if the party linew of the unregistered deed, his registered deed shall not set it aside, because he has that uotice which the act of Parliament intended he shoul have. IIe therefore puts it as a rase in which efuity wonld interfere; and the circumstances of this case shew the propriety of our adhering to the worls of the act; for I am by no means clear that we should not work great injustice, if we were to decide in favour of ihe defendant."

In Hine $v$. Dodd, 2 Atk. 275 (1741), a bill was filed by a judgment creditor to be let in upon an estate in Middlesex rreferably to the defendant, a mortwacree of the same estate. on the ground that the ciefendant had notice of the judgment hefore the mortgage was executed. The judgment was entered Xlarch 12, 1739, and registered June 12, 17:5. The mortgage was made May $24,17: 5$, and registeled June 2, 17:5. Jord Chancellor Hardwicke said: "This (ase depmuls upon the notice the defendant had of the judgment before his 101019age was registered. The register act, the 7 th of Anne, c. 20. is notice to the labies, and a notice to everybody; and the meaning of this statute was, to furvent parol proofs of notice, or not notice. But notwithstanding there are cases whore this court have broken in upon this, though one incumbrauce was lectisteled before another, but it was in rases of frand. **** There nlag fossilly have been cases upon notice divested of frand, but then the prof must be extremely clear. But though in the present case there a re strong circumstances of notice betore the execution of the mortgage, yet, unon mere suspicion , nly. I will not overturn a positive law." see, howerer, Whitbread r. Bovluois, 1 Y. \& (.. (F.x. R.) $30 \%(150 \%)$. 
county, and when so recorded the record thereof shall have the same force and effect as though it was of the original conveyance.

Section 1214. Every conveyance of real property, other than a lease for a term not exceeding one year, is void as against any subsequent purchaser or mortgagee of the same property, or any part thereof, in good faith and for a valuable consideration, whose conveyance is first duly recorded, and as against any judgment affecting the title, unless such conveyance shall have been duly recorded prior to the record of notice of action.

Kerr's Cyc. Code.

\section{REVISED LAWS OF ILLINOIS (1912).}

Section 28. Deeds, mortgages, powers of attorney, and other instuments relating to or affecting the title to real estate in this state, shall be recorded in the county in which such real estate is situated; but if such county is not organized, then in the county to which such unorganized county is attached for judicial purposes.

Section 30. All deeds, mortgages and other instruments of writing which are authorized to be recorded, shall take effect and be in force from and after the time of filing the same for record, and not before, as to all creditors and subsequent purchasers, without notice; and all such deeds and title papers shall be adjudged void as to all such creditors and subsequent purchasers, without notice, until the same shall be filed for record.

Section 31. Deeds, mortgages and other instruments of writing relating to real estate shall be deemed, from the time of being filed for record, notice to subsequent purchasers and creditors, though not acknowledged or proven according to law; but the same shall not be read as evidence, unless their execution be proved in manner required by the rules of evidence applicable to such writings, so as to supply the defects of such acknowledgment or proof.

Hurd's Rev. St. c. 30.

\section{REVISED LAWS OF MASSACHUSETTS (1902).}

Section 4. A conveyance of an estate in fee simple, fee tail or tur life, or a lease for more than seven years from the making thereof, shall not be valid as against any person, except the grantor or lessor, his heirs and devisees and persons having actual notice of it, unless it, or an office copy as provided in section fifteen of chapter twenty-two, is recorded in the registry of deeds for the county or district in which the land to which it relates is situated.

Chapter 127. 


\section{CONSOLIDATED LAWS OF NEW YORK (1909).}

Section 290. 1. The term "real property," as used in this article, includes lands, tenements and hereditaments and chattels real, except a lease for a term not exceeding three years.

2. The term "purchaser" includes every person to whom any estate or interest in real property is conveyed for a valuable consideration, and every assignee of a mortgage, lease or other conditional estate.

3. The term "conveyance" includes every written instrument, by which any estate or interest in real property is created, transferred, mortgaged or assigned, or by which the title to any real property may be affected, including an instrument in execution of a power, although the power be one of revocation only, and an instrument postponing or subordinating a mortgage lien; except a will, a lease for a term not exceeding three years, an executory contract for the sale or purchase of lands, and an instrument containing a power to convey real property as the agent or attorney for the owner of such property.

Section 291. A conveyance of real property, within the state, on being duly acknowledged by the person executing the same, or proved as required by this chapter, and such acknowledgment or proof duly certified when required by this chapter, may be recorded in the office of the clerk of the county where such real property is situated, and such county clerk shall, upon the request of any party, on tender of the lawful fees therefor, record the same in his said office. Every such conveyance not so recorded is void as against any subsequent purchaser in good faith and for a valuable consideration, from the same vendor, his heirs or devisees, of the same real property or any portion thereof, whose conveyance is first duly recorded.

Chapter 52, art. 9.

\section{GEN. CODE OF OHIO.}

Section 8542. All mortgages, executed agreeably to the provisions of this chapter, shall be recorded in the office of the recorder of the county in which the mortgaged premises are situated, and take effect from the time they are delivered to the recorder of the proper county for record. If two or more mortgages are presented for record on the same day, they shall take effect from the order of presentation for record. The first presented must be the first recorded, and the first recorded shall have preference.

Section 8543. All other deeds and instruments of writing for the conveyance or incumbrance of lands, tenements, or hereditaments, executed agreeably to the provisions of this chapter, shall be recorded in the office of the recorder of the county in which the premises are situated, and until so recorded or filed for record, they shall be deemed 
fraudulent, so far as relates to a subsequent bona fide purchaser having, at the time of purchase, no knowledge of the existence of such former deed or instrument.

Page \& A. Gen. Code.

\section{OREGON LAWS.}

Section 7129. Every conveyance of real property within this state hereafter made, which shall not be recorded as provided in this title within five days thereafter, shall be void against any subsequent purchaser in good faith and for a valuable consideration of the same real property, or any portion thereof, whose conveyance shall be first duly recorded.

Lord's Oregon Laws, 1910.

\section{(B) Scope of Operation and Effect of Statutes}

\section{SIMONSON v. WENZEL.}

(Supreme Court of North Dakota, 1914. 27 N. D. 638, 147 N. W. 504.)

FISk, J. ${ }^{9}$ This is an appeal from a judgment of the district court of McHenry county, decreeing the foreclosure of a real-estate mortgage in plaintiff's favor. The appeal is upon the judgment roll proper, appellants' contention being that the conclusions of the trial court are not warranted by the findings of fact.

Such findings of fact are in substance as follows:

1. That on and prior to March 20,1906, the defendant, Dakota Development Company, was the owner in fee of the real estate in controversy as disclosed by the public records in the office of the register of deeds. On such date this company entered into an executory contract with defendant Carl F. Wenzel, in the usual form, whereby, for a stated consideration of $\$ 100, \$ 35$ of which was paid in cash and the balance to be paid in equal instalments on March 20,1907, and March 30,1908 , with interest, it promised and agreed to sell and convey such premises to the said Wenzel, such contract obligating the purchaser to pay all taxes and assessments levied, assessed, or imposed upon the premises in each year, and also contained a stipulation that "no assignment or transfer of any interest in and to this agreement or the lands described, less than the whole thereof, will be recognized by said vendor under any circumstances or in any event whatever, and no assignment shall be binding upon the vendor unless approved by its president." It also contained a stipulation "that time is to be the very essence of this agreement." Such contract also contained other stipulations relative

- Portions of the opinion are omitted. 
to the vendor's right to declare a forfeiture in case the vendee failed in any respect to comply with his part of the contract, but we deem it unnecessary to set such provisions out in extenso.

2. Defendant Wenzel entered into the possession of the premises, and constructed a dwelling house thereon, which he and his family occupied as their homestead until about January 20, 1908, when he sold and assigned such contract to defendant M. C. Krupp.

3. On April 17, 1907, Wenzel and wife, for a valuable consideration, executed and delivered to plaintiff their promissory note for the sum of $\$ 914.70$, payable on November 1st thereafter, with interest at the rate of $S$ per cent per annum; and to secure the payment thereof they executed and delivered to plaintiff a mortgage on the land in controversy, which was filed in the office of the register of deeds of McHenry county on April 18, 1907, and recorded in Book 31 of Mortgages, at page 516.

4. That such note and mortgage have not been paid, and plaintiff is the present owner and holder thereof.

5. That Carl F. Wenzel paid to the Dakota Development Company the sum of $\$ 35$ at the time of the execution of the contract for deed, but made default in the payment due March 20, 1907, and the same was not paid until after the assignment of such contract to defendant Krupp, as hereinafter set forth. That such contract for deed was at no time recorded or filed for record in the office of the register of deeds of McHenry county, and the record title of the premises at all times up to January 29, 1908, remained in the Dakota Development Company.

6. On or about January 20, 1908, Wenzel, while in possession of said land as his homestead, entered into negotiations with defendant Krupp for the sale to him of the contract for deed aforesaid, and the premises therein described, upon the terms that such contract was to be assigned to Krupp, who was to receive a warranty deed of the premises direct from the Development Company. Wenzel and wife thereupon assigned their interest in such contract to Krupp, and the latter paid to the Development Company the amount then remaining due upon said contract (\$65 and interest), and Krupp also paid to Wenzel the agreed consideration of $\$ 1,000$ less the payment aforesaid to the Development Company, and the Development Company did not, nor did its president or any one of its authorized officials, have any knowledge or actual notice of the execution or delivery of the mortgage to the plaintiff aforesaid.

7. That defendant Krupp purchased Wenzel's interest in such contract in good faith, and without any actual notice or knowledge of the existence of plaintiff's mortgage, and he had no intent to cheat or defraud the plaintiff, but acted in absolute good faith in the making of said purchase, and purchased and paid for the same in utter ignorance of the plaintiff's mortgage, but he knew that Wenzel and family were living on and occupying said premises, but had no notice or 
knowledge of such mortgage other than that imparted by the record thereof.

8. On January 24, 1908, the Development Company duly executed and delivered to Krupp a warranty deed in the usual form, conveying the premises to him, which deed contained the usual covenants, and which was duly filed for record on January 29, 1908.

9. The trial court also found that the defendant Wenzel was on March 3, 1910, adjudged a bankrupt in the Federal court, and on June 22, 1910, that court, in due form, discharged him from all debts and provable claims, the notes held by plaintiff being scheduled in such bankruptcy court.

Upon such findings of fact the district court made conclusions of law favorable to plaintiff, adjudging a foreclosure of his mortgage.

Among other conclusions, the trial court found that at the time of the execution of the mortgage by Wenze he had a mortgagable interest in and to the said premises by virtue of the contract for deed, and that the recording of such mortgage was due and legal notice to all the world of the rights of the plaintiff as mortgagee, and that defendant Krupp therefore had constructive notice of such mortgage at the time he purchased the assignment of the contract for deed to the said premises, and the conveyance of the premises to him by the Development Company was subject to the lien of plaintiff's mortgage.

From the above it is apparent that the crucial question for decision is whether appellant Krupp, who, as the trial court found, in good faith and for value purchased an assignment of the Wenzel contract and a deed of the premises from its codefendant, the Development Company, without any actual knowledge of the plaintiff's mortgage, was nevertheless affected with constructive notice thereof so as to confer upon plaintiff a lien under his mortgage superior and paramount to the rights of such defendant. In answering this question we must bear in mind the fact, as found by the trial court, that the contract for deed executed and delivered by the Development Company to Wenzel was not entitled to record, nor was the same disclosed in any way by the public records, and, as far as such records disclosed, Wenzel had no interest whatever in the property in controversy, but the same stood in the name of and was owned exclusively by the Development Company. It is no doubt true that Wenzel, by such executory contract of purchase which gave him possession, acquired an equitable interest in such property which he might sell or mortgage (Cummings v. Duncan, 22 N. D. 534, 134 N. W. 712, Ann. Cas. 1914B, 976); and it is likewise no doubt true that his possession under the contract operated to convey notice to the world of his equities thereunder. But Wenzel's interest under such contract was cognizable merely in equity, not in law. Miller v. Shelburn, 15 N. D. 182, 107 N. W. 51; Cummings v. Duncan, supra. His possession under such executory contract operated, no doubt, as notice to the world of his equities thereunder. It is, however, quite a different proposition to say that such posses- 
sion constituted notice of the rights of persons claiming to hold as assignees, vendees, or mortgagees of such equitable interest.

Was appellant Krupp, under the facts, charged with constructive notice of plaintiff's mortgage? As stated by appellant's counsel this suggests two main inquiries.

First, was the mortgage a conveyance within the meaning of the recording laws? Second, was it a conveyance in the chain of title?

Plaintiff's right to recover. depends upon an affirmative answer to both of these questions. Counsel for appellant assert, with apparent confidence in the correctness of their position, that both of such questions must receive a negative answer, and they have presented a very able and ingenious argument in support of their contention. They apparently concede that under the general statutory rule in other states, either in express terms or by judicial construction, the record of an instrument conveying or encumbering a mere equitable estate or interest, as well as a legal estate or interest, operates to give constructive notice thereof, but they seek to differentiate our recording act from the statutes of other states, and contend for a construction eliminating from its operation mere equitable interests or liens. As suggested by them, it is undoubtedly true that the doctrine of constructive notice by recording instruments is of purely statutory creation, and that the recording of an instrument not within the statute does not impart constructive notice thereof. This, of course, is elementary. 2 Devlin, Deeds, § 646, and cases cited.

The recording acts of this state are embraced in sections 5038, 5039, and 5042, Rev. Codes 1905.

Section 5038 reads in part as follows: "Every conveyance by deed, mortgage, or otherwise, of real estate within this state, shall be recorded in the office of the register of deeds of the county where such real estate is situated, and every such conveyance not so recorded shall be void as against any subsequent purchaser in good faith, and for a valuable consideration, of the same real estate, or any part or portion thereof, whose conveyance, whether in the form of a warranty deed, or deed of bargain and sale, deed of quitclaim and release, of the form in common use, or otherwise, is first duly recorded."

Section 5039 defines the term "conveyance" as used in the last section as embracing "every instrument in writing by which any estate or interest in real property is created, aliened, mortgaged, or encumbered, or by which the title to any real property may be affected, except wills and powers of attorney."

Section 5042 provides: "An unrecorded instrument is valid as between the parties thereto and those who have notice thereof; but knowledge of the record of an instrument out of the chain of title does not constitute such notice."

The first clause of the section last quoted constituted the entire section as originally enacted, but in 1899 the legislature, by chapter 167 . Taws of 1899. added thereto the latter clause, which, no doubt, as 
counsel state, was for the purpose of changing the rule announced by this court in Doran v. Dazey, 5 N. D. 167, 64 N. W. 1023, 57 Am. St. Rep. 550. In that case it was held that actual knowledge of the record of an instrument out of the chain of title was constructive notice of the original instrument and of the rights of the parties under it, and by such amendment the rule was changed so that now mere knowledge of the record of an instrument out of the chain of title does not constitute notice thereof.

Our first inquiry, therefore, is whether plaintiff's mortgage, which covered Wenzel's equitable interest under his executory contract to purchase the real property in question, is such an instrument as was entitled to be recorded. In other words, was such mortgage a "conveyance" within the meaning of the recording laws aforesaid. ${ }^{10} * * *$

Do our recording laws include such a mortgage? IVe are entirely satisfied that this question must also receive an affirmative answer. The contention of appellant's counse! to the contrary is, we think, based upon an unwarranted and erroneous construction of our statute. We are unable to distinguish our law from the Michigan law and the corresponding statutes in most states. The fact that the Michigan statute in defining the word "conveyance," as used in its recording law, in addition to the language in section 5039 of our Code adcis the words "in law or equity," does not make their statute broader than ours. We think the statute would convey the same meaning without these words, and they were evidently inserted through a superabundance of precaution. Furthermore, the language in the first portion of the section, "the term conveyance * * * shall be construed to cmbrace every instrument * * * by which any estate or interest in real property is created, aliened, mortgaged, or assigned," clearly was intended to cover a mortgage of an equitable title. In support of our views see Clark v. Lyster, 155 Fed. 513, 84 C. C. A. $27 ; 27$ Cyc. 1157 , and cases cited in note 28 on page 1158 ; also 1 Jones, Mortg. $\$ 476$.

Having reached the conclusion that plaintiff's mortgage was entithed to record under our recording acts aforesaid, it only remains for us to determine whether the record thereof imparted constructive notice to defendant Krupp at the time he purchased an assignment of Wenzel's contract and procured the deed from Wenzel's grantor, the Dakota Development Company. In considering this question it is important to bear in mind the fact that Krupp knew that Wenzel was in possession of the premises, asserting equitable ownership under the contract of purchase, and that he expressly recognized IVenzel's contract rights by purchasing from him an assignment thereof.

In the light of these facts, can Krupp successfully urge that IVenzel's mortgage to plaintiff was out of the chain of title, and hence, under section 5042, Rev. Codes, the record of such mortgage did not

10 The court concluded it was. 
constitute notice thereof to him? We think not. The basic fallacy in appellant's argument, as we now view it, consists in the unwarranted assumption that such mortgage, as to him, was out of the chain of title. The reverse is true. He dealt with Wenzel, and therefore was bound in law to know, and in fact did know, that he was the equitable owner of the premises, and that his equitable title came from the Dakota Derelopment Company through such contract. He was also bound in law to know, therefore, that Wenzel had a mortgagable interest in the premises, and that he might have sold, assigned, or mortgaged such interest,. and the conveyance in either form would have been entitled to record. As to Krupp, therefore, the chain of title did not stop with the Development Company, but the last link in such chain was in Wenzel. He was therefore charged with constructive notice of plaintiff's mortgage, and bought subject thereto. It would have been entirely different had he dealt alone with the Development Company in ignorance of Wenzel's rights. In such event section 5042, supra, would have afforded him protection, but under the facts it can have no application.

As said in 1 Jones on Mortgages, $\S 476$ : "The registry of a conveyance of an equitable title is notice to a subsequent purchaser of the same interest or title from the same grantor. *** The record of a mortgage or other conveyance which is entitled to be recorded operates as constructive notice to subsequent purchasers claiming under the same grantor, or through one who is the common source of title"-citing Edwards v. McKernan, 55 Mich. 520, 526, 22 N. W. 20. See also Jones v. Lapham, 15 Kan. 540, wherein Judge Brewer, while on the supreme bench of Kansas, in spealing to the point, said: "As to Maggie Murray, it appears that she had knowledge of the equitable interest, but not of the mortgage. Hull, however, was in possession of the lots, and had made valuable improvements on them. These improvements she bought. Now, section 20 of the conveyance act (Gen. St. § 187) provides that 'every such instrument in writing (and this, by prior description, includes mortgages, and mortgages upon equitable interest) shall, from the time of filing the same with the register of deeds for record, impart notice to all persons of the contents thereof; and all subsequent purchasers and morigagees shall be deemed to purchase with notice.' While this general provision, as respects notice, may be limited, so far as relates to conveyances or mortgages of equitable interests, by the condition of the legal title, and the knowledge which the holders thereof have of the existence of the equity, as indicated in Kirkwood v. Koester, 11 Kan. 471, yet, aside from that limitation, it is of controlling force. Whoever buys a legal estate, having knowledge of an outstanding equitable interest, is chargeable with notice of any record of conveyance or encumbrance thereof. Whoever buys an equitable interest in land is also chargeable with like notice. In fact, knowledge of an equitable interest carries with it notice of the condition of such interest as is apparent from the public 
records." We understand that the rule thus stated by Judge Brewer is generally recognized and well established, and we do not think that such rule is changed in this state by chapter 167, Laws of 1899 , heretofore referred to. ***

The District Court will modify its judgment accordingly, and as thus modified the judgment is affirmed. No costs shall be taxed to either party on the appeal.

\section{LOSEY v. SIMPSON.}

(Court of Chancery of New Jersey, 1856. 11 N. J. Eq. 246.)

The Chancellor. The bill is filed upon a mortgage, given by Ferdinand G. Simpson to Pamela Adams, and by her assigned to the complainants. The controversy is in reference to the priority of this mortgage, and a mortgage given by Calvin $\mathrm{A}$. Kanouse to Noah Estell, now held by the defendant, Mary Estell, as the executrix of the last will of Noah Estell, deceased.

Stephen Adams, being indebted to Noah Estell in the sum of twelve hundred dollars for money lent, had given a mortgage to secure the same on several tracts of land, embracing the land which is covered by the mortgages in dispute. By an arrangement between Adams, Estell and Kanouse, Adams conveyed to Kanouse the portion of the mortgaged premises embraced in the disputed nortgages. The money received by the mortgagee was reduced from $\$ 1600$ to $\$ 1310$; and to secure this latter sum Kanouse executed a mortgage to Estell, embracing the land conveyed in the deed from Adams. Estell then canceled his $\$ 1600$ mortgage, or delivered it up to Adams for that purpose. The deed from Adams to Kanouse was dated the 2d of August, 1847. The mortgage bears the same date. Both were acknowledged on the 12 th of August, 1847. The mortgage was recorded on the 2d day of September of the same year. The deed has never been recorded. It is alleged that it was, some time after its delivery, destroyed by Kanouse. Kanouse entered into the possession of the premises under his deed, and continued in possession until after the execution of the mortgage under which the complainants claim their priority.

The complainants had a claim against Pamela Adams and Calvin A. Kanouse for debt, and were prosecuting it at law. Kanouse offered to compromise this claim. He stated to the complainants, through his attorney, that Pamela Adams owned certain premises, which Stephen Adams held in his name in trust for her, and that the premises were sold to one Ferdinand G. Simpson, who was to give to Pamela Adams a mortgage of sixteen hundred dollars for the purchase money. Kanouse offered this mortgage to the complainants, if they would advance, in cash, the balance of the mortgage money, after deducting their claim of $\$ 797.98$. The proposition was acceded to; and on the 6 th of December, 1849, Stephen Adams, at the procurement of 
Kanouse, executed a deed to Simpson for the same premises which he, Adams, had, as before stated, conveyed to Kanouse, and Kanouse had mortgaged to Estell. Simpson executed a mortgage to Pamela Adams to secure the purchase money of $\$ 1600$, and she assigned the mortgage to the complainants, who, in consideration of the assignment, receipted their claim of $\$ 797.98$, and for the balance gave their promissory notes, at a short date, which were paid at maturity. The deed to Simpson and the mortgage from Simpson to Pamela Adams were duly recorded. The deed from Stephen Adams to Kanouse, through which Mary Estell, who holds the mortgage from Kanouse to Noah Estell, claims title, has never been recorded.

Both parties claim under Stephen Adams. The complainants' mortgage is subsequent, in date and execution, to that of the defendant, Mary Estell; but the complainants claim priority, on the ground that, at the time their mortgage was executed, the deed from Adams to Kanouse was not recorded; and the title on the record being in Stephen Adams, they insist that the recording of the Estell mortgage afforded no notice of its existence.

On behalf of Mary Estell, it is insisted that the mortgage she holds is protected by the very language of the statute; that the statute declares mortgage void and of no effect against a subsequent bona fide purchaser or mortgagee for a valuable consideration, unless such mortgage shall be recorded at or before the time of recording the said mortgage or conveyance to such subsequent purchaser or mortgagee, and that, in point of fact, the Estell mortgage was recorded before the subsequent mortgage held by the complainants. But, by the very language of the statute, the deed from Adams to Kanouse is void and of no effect against the subsequent deed from Adams to Simpson, because it was not recorded at or before the time of recording the subsequent deed to Simpson. The defendant Mary Estell, then, claims under a grantor whose deed is void, and who, at the time of the conveyance, had no title against the grantor under whom the complainants hold. Now it could be of no advantage to Simpson that his recorded deed should be valid against the unregistered deed of Kanouse, if a grantee under the latter could claim a title superior to that of Simpson's or of his grantee.

The whole object of the registry acts is to protect subsequent purchasers and encumbrancers against previous conveyances which are not recorded, and to deprive the holder of the previous unregistered conveyance, \&c., of the right, which his priority in execution would have given him at the common law. But if the construction contended for be adopted, this object is totally defeated; the registry will afford no protection to an innocent purchaser. When one link in the chain of title is wanting, there is no clue to guide the purchaser in his search to the next succeeding link by which the chain is continued. The title upon the record is the purchaser's protection, and when he las traced the title down to an individual, out of whom the record does 
not carry it, the registry acts make that title the purchaser's protection. The registry of a deed is notice only to those who claim through or under the grantor by whom the deed was executed. Raynor v. Wilson, 6 Hill (N. Y.) 473; Stuyvesant v. Hall, 2 Barb. Ch. (N. Y.) 151; Murray v. Ballou, 1 Johns. Ch. (N. Y.) 556; Keller v. Nutz, 5 Serg. \& R. (Pa.) 446; Lightner v. Mooney, 10 Watts (Pa.) 412; Bates v. Norcross, 14 Pick. (Mass.) 224; Tilton v. Hunter, 24 Me. 29; Crockett v. Maguire, 10 Mo. 34; Leiby v. Wolf, 10 Ohio, 83. Nor will a purchaser be bound to take notice of the record of a deed executed by a prior grantee whose own deed has not been recorded. Embury v. Conner, 2 Sandf. 98; Roberts v. Borune, 23 Me. 165, 39 Am. Dec. 614. And where the deed of a vendor is not recorded, the record of a mortgage given by the vendee for the purchase money will not be notice to a subsequent purchaser. Veazie v. Parker, 23 Me. 170; Pierce v. Taylor, 23 Me. 246. For in any such case the purchaser is without a clue to guide him in searching the record. 2 A. L. C. in Eq. 129.

The mortgage to Estell is void against the complainants' mortgage, if Simpson, under whom the complainants hold, was a bona fide purchaser for a valuable consideration without notice of the Estell mortgage.

\section{RANKIN v. MILLER.}

\section{(Supreme Court of Iowa, 1876. 43 Iowa, 11.)}

Action in chancery to establish and quiet in plaintiff the title to the undivided eleven-eighteenths of two hundred and eighty acres of land in Black Hawk county. The relief was granted as to one hundred and sixty acres of the land, and denied as to the remainder. Both parties appeal. The facts of the case are-stated in the opinion.

BECK, J. The admitted or established facts, as we find them in this case, are as follows:

I. Plaintiff's title is based upon the following conveyances and facts:

1. November 24, 1853, Benjamin H. Towner entered, at the United States land office at Dubuque, all the lands in controversy, which are all in section 13 , township 88 , range 13 west, and received a certificate

11 The balance of the opinion is omittel. The court concluded that Simpson was a bona fide purchaser for value.

Tan Diviere v. Mitchell, 45 S. C. 127,22 S. E. 759 (1895), contra.

Eliza K., the owner, convesed to her brother, F. K., who mortgaged the premises to $P$. P. recorded. R., after examining the records and satisfying himself that Eliza had title, took a deed from her. paying value therefor. Because $\mathbf{F}$. K. had been acting as his sister's agent, R. procured a quitclaim deed covering the same premises from him. The day after the delivery of the two deeds to R., the deed from Eliza to $\mathbf{F}$. $K$. was placed on record. In an action by $P$. to foreclose his mortgage, $R$. claimed protection as a bona fide purchaser for value without notice. Was he entitled to such protection?

A. conveys to $\mathrm{B}$., who at once gives back a purchase noney mortgage. The mortgrge is recorded, but the deed from $A$. to $\mathbf{F}$. is not. A. later convess to $\mathbf{X}$., a bona fide purchaser for value with no knowledge of the deed to $B$. Does he have constructive notice? See Veazie r. Parker, 23 Me. 170 (1843); Hart v. Gardner, 81 Miss. 650, 33 South. 442, 497 (1902). 
of entry, issued by the proper officer in the usual form. On the 18th of October, 1858, a patent was issued to him for the lands.

2. August 13,1854, Towner sold and conveyed the lands to Daniel $\mathrm{J}$. and Armstrong Rankin. The deed is lost, but was filed and recorded in Black Hawk county. The name Ambrose appears in the record instead of Armstrong, the christian name of one of the grantees. This is alleged to be a mistake, either in the deed or record thereof, and it is averred that the conveyance was intended to be to Armstrong Rankin, who was intended to be described therein as one of the grantecs.

3. Armstrong Rankin died February 1st, 1855, leaving plaintiff as his only heir. His wirlow, Nancy M., married Cyrus Hays in 1858.

4. Daniel J. Rankin re-conveyed his undivided interest in the lands to Towner, who, in July 28, 1861, sold and conveyed the undivided one-half thereof then held by him to plaintiff's mother, Nancy M. Hays.

5. In 1863 Nancy M. Hays died, leaving children by her second husband, Cyrus Hays, who subsequently married a second wife, Sarah, and died February 5th, 1868, leaving one child, the fruit of the last marriage. Sarah Hays died in 1868. Plaintiff, as heir of his father and mother, claims title to eleven-eighteenths of the land in controversy.

Alleged defects and objections to deeds, under which plaintiff's ancestors acquired title to the lands, will be hereafter stated when they come up for consideration in this opinion.

II. The defendants' title rests upon the following conveyances:

1. October 13, 18.53, Abraham Turner, who is a defendant in this action, entered one hundred and twenty acres of land in section 13, township 88, north range 12 west, at the United States land office at Dubuque, and received the usual certificate of entry, which is number 15,700 .

2. On the 2Sth day of February, 1854, which it will be remarked was subsequent, in point of tine, to the entry of the land under which plaintiff claims, the register of the Dubuque land office, upon application of 'Turner, changed the duplicate certificate of entry, No. 15,700, returned in his office, which had been issued upon Turner's entry of the land in section 13, township $S 8$, north range 12 west, so that it read "north range 13 west," being the same description as that of part of the lands before entered by the grantor of plaintiff's ancestor.

3. A patent was issued to Turner for one hundred and twenty acres of land in range 13, June 15, 1854.

4. In 1868 a patent was issued to Turner for the land in range 12, and he afterwards sold and conveyed it to E. K. Ware and D. J. coleman.

5. 'The defendants claim the land in section 13 , township 88 , north range 13 west, which is covered by Turner's patent, under that instrument and conveyances by Turner and his grantees. 
6. They claim title to the other lands in controversy under a sale and deed by the guardian of plaintiff, made in 1865 .

7. For a part of the same land they also set up a tax title based upon a sale of the land by the county treasurer, for 1862 , for the delinquent taxes of 1860, and a treasurer's deed thereon, dated May 14, 1864. The remainder of these lands are covered by a tax deed recorded in 1865 , which is also set up by defendants.

III. It is necessary to consider separately the conflicting claims and titles set up by the respective parties to the land in controversy. The first point of inquiry involves the validity of the conflicting patents covering a part of the land.

1. The validity of Towner's entry cannot be questioned. At that time the full and perfect title to the land, both legal and equitable, was in the government. There had been no sale or transfer of any interest in it which defeated the right of the government to dispose of it, in the manner all public lands are disposed of as provided by law. If we admit that Turner's first entry of lands was made through mistake and the subsequent alteration of his duplicate certificate was without fraud, Towner's entry is not defeated by these considerations. Turner did not enter the land in range thirteen, and the certificate issued to bim did not cover it. There was, therefore, no sale of that land to him by the government. The land was then sold to Towner and a proper certificate issued to him. Surely, it cannot be claimed that the register of the land office, simply upon the application of Turner, without proof of the mistake which the evidence shows was not made, had authority to change the entry and alter Turner's certificate so as to defeat 'Towner's prior entry. The register was clothed with no authority to change the entry, and in no case can such a thing be done by any officer of the government where the land to be covered by the change has been before sold. U. S. Rev. St. $\$ \S 2369$ (U. S. Comp. St. 1913, § 4777), 2372. The government having sold the land to Towner, no other disposition thereof can be made. Arnold v. Grimes, 2 Iowa, 1; Cavender v. Smith, 3 G. Greene, 349, 56 Am. Dec. 541.

2. "The patent for lands belonging to the United States, when issued to a party vests in him the perfect legal title, which relates back to the date of entry of the land. The entry of the land and the issuing of the certificate of location transferred to him at the time all the property held by the government in the land, and conferred upon him all 'the equity' thereto which is an absolute and unconditional right to the land." WVaters v. Bush, 42 Iowa, 255; Heirs of Klein v. Argenbright, 26 Iowa, 493 ; Cavender v. Heirs of Smith, 5 Iowa, 157.

3. The patent to Turner, having been issued contrary to law, for land which had been before sold by the government, is void, and the patentee acquired no rights under it. Stoddard et al. v. Chambers, 2 How. 284, 11 L. Ed. 269; Cunningham v. Ashley et al., 14 How. 377, 14 L. Ed. 462 ; Wright v. Rutgers, 14 Mo. 585 ;. Boring v. Lemmon, 
5 Har. \& J. (Md.) 223; Perry v. O'Hanlon, 11 Mo. 585, 49 Am. Dec. 100; State v. Delesdinier, 7 Tex. 76; Todd v. Fisher, 26 Tex. 239.

IV. The conclusion is reached that Turner's patent conferred no right whatever in the land which he could convey to another. We do not understand that counsel deny the correctness of this conclusion, but seek to avoid its consequences on the ground that defendants are innocent purchasers without notice of plaintiff's title. This position is based upon the fact that Towner's deed to plaintiff's ancestor, executed in 1854, was acknowledged before a justice of the peace of the state of Illinois and the certificate of acknowledgment, in other respects, does not comply with the requirements of the law, especially in failing to show that the grantor acknowledged the deed to be his voluntary act. At that date, the acknowledgment of deeds for lands in this state could not be made before justices of the peace in other states. The deed was recorded October 1, 1855. Defendants insist that, as this deed was insufficiently acknowledged, though recorded, it does not impart notice to them of plaintiff's title. Code 1873, 1942.

I et us consider for a moment the position of the parties as claimants of the land in dispute. They claim under distinct chains of titles, having, however, a common origin in the government. The government made two grants of the land; on one, plaintiff's title rests, the other is the foundation of defendants' title. The deed from the purchaser to plaintiff's ancestor, under whom plaintiff claims, is defectively acknowledged and it is not, therefore, lawfully recorded. Now, no question of registry, or want of notice, can arise upon the assurances given by the ge vernment for the land. Arnold v. Grimes, 2 Iowa, 1; Heirs of Klein v. Argenbright, 26 Iowa, 493; David v. Rickabaugh, 32 Iowa, 540. Does the law protect defendants because they had no notice by the record of the deed from the grantee of the government to the plaintiff's ancestor?

Code $1873, \S 1941$, the statute requiring the registry of deeds, is in the following language: "No instrument affecting real estate, is of any validity against subserpuent purchasers for a valuable consideration, without notice, unless recorded in the office of the recorder of the county, etc." The statute protects subsequent purchasers and no others. The very language of the statute leads to the conclusion that there are such as claim under the chain of title of which the deeds affected by the provision are a part. It is intended to protect the purchaser whose deed is recorded, against another conveyance that is not recorded, and contemplates the case of conflicting deeds conveying title and having a common source. No protection is intended against an independent title, distinct from that upon which the recorded deed is hased. The conclusion is supported by the consideration that, in such cases, notice in fact by a record thereof could not be given. No point of commencenent for an examination of the records would be suggesterl to the party seeking information therein. The indexes of the record, which under our statute are a part of the record and serve to 
impart notice, would give no aid in such an examination. It is, therefore, our conclusion that the term subsequent purchaser, occurring in the statute, is used to describe purchasers claiming under some common grantor. This position is supported by the following authorities: Long v. Dollarhide, 24 Cal. 218; Roe et al. v. Neal et al., Dud. (Ga.) 168; Fenno v. Sayre, 3 Ala. 458; Whittington v. Wright, 9 Ga. 23; Tilton v. Hunter, 24 Me. 29; Crockett et al. v. Maguire, 10 Mo. 34; Ely v. Wilcox, 20 Wis. 530, 91 Am. Dec. 436; Rodgers v. Burchard et al., 34 Tex. 441, 7 Am. Rep. 283; Losey et al. v. Simpson et al., 11 N. J. Eq. 246; Bates v. Norcross, 14 Pick. (Mass.) 224; Quirk v. Thomas et al., 6 Mich. 76; Murray v. Ballou, 1 Johns. Ch. (N. Y.) 566.

If, then, the record of the deed would not impart notice provided for by law, defendants cannot claim any strength for their title because it was not in fact recorded; they are not prejudiced thereby. It is a case where the principles of registry do not apply. ${ }^{12} * *_{*}^{*}$

\section{YOUNGBLOOD v. VASTINE.}

(Supreme Court of Missouri, 1870. 46 Mo. 289, 2 Am. Rep. 509.)

BuIss, J. Sarah G. Wright, deceased, by herself and her trustee, on the 20th day of July, 1859, executed to E. T. Xaupi, in trust, to secure the payment of a promissory note of same date for $\$ 3700$, givell to Joseph Tuley, then living, a deed of certain real estate, her separate property, situate on the corner of Pine and Eighth streets, in St. Louis, which deed was not put upon record until the 19th of October, 1866. The said Joseph Tuley and Sarah G. Wright died in 1860 and 1861, and on the first of October, 1865, D. Robert Barclay, as trustee for Mrs. Ann A. Macdonald, and with her funds, purchased said property of the heirs of said Sarah G. Wright, and received a warranty deed of the same, which was recorded April 28, 1866. It appears from the evidence that neither Barclay nor Mrs. Macdonald had any knowledge of the trust deed to Xaupi; that the records were examined before the purchase to see if there were any encumbrances upon the property; that a full consideration was paid for it ; that the estate of Mrs. Wright had been settled by the public administrator, and that all debts presented had been paid, but this note was not among them.

12 The remainder of the opinion relating to other matters is omitted.

In an action by the assignee of a mortgage to foreclose same, the mortgagor sounht to set off certain claims held by him against the mortcagee, which claims had been acquired after the assignment of the mortgage to the complainant. The mortgagor had no knowledge of the assignment, but the assignment had been properly recorded prior to the acquisition of the claims. A statute of the state, adopting the prevalent equity rule, provided that, "in the case of an assignment of a thing in action, the action of the assignee shall be without prejudice to any set-off or other defense, existing at the time of or before notice of the assignment." Should the mortgayor be allowed his set-off?

AIG.Prop.-54 
This suit was brought by the administrator of Tuley to foreclose his trust deed, and the contest arises in consequence of the failure on the part of Xaupi, to whom it was made, to place it upon record. Had the second deed been executed by Mrs. Wright while living, there would be no question that it would hold against the unrecorded deed. But in some of the reported cases upon the subject it is held that the same preference can not be given to the second deed if made by the heirs of the first grantor. I confess I am not struck with the forcc of the reasoning upon which the distinction is made, for it is based upon the idea that the second deed is inoperative because nothing descended to the heirs, and hence they had nothing to convey. If that he so, it was because nothing was left in the ancestor that could descend; that his whole estate was divested by the first deed. 'If his whole estate was so divested, how could a second deed, if made by himself, be operative? Yet it is not disputed that such second deed would convey the estate, notwithstanding the first.

Yet the distinction is made by some of our most respectable courts, and it is apparently recognized by this court. In Hill et al. v. Meeker, 24 Conn. 211, the majority of the court held that the unrecorded deed from the ancestor so divested him of his title that his son and heir "took nothing by inheritance that he could convey or mortgage to a bona fide purchaser who had no knowledge of the deeds." The case is a much harder one than the one at bar, and the decision is based upon "a clear distinction between a purchaser from him (the ancestor) and one from his heir, Arza. In relation to a purchase from Arza, the difficulty is that he never had any title."

The same distinction was made in Hancock v. Beverly's Heirs, in 6 B. Mon. (Ky.) 531. The judge delivering the opinion acknowledges the question to be a doubtful and difficult one, and in reasoning upon the subject says: "It has always been held that a deed, though never recorded, is good between the parties, and as to all the world, except creditors and innocent purchasers for value. The grantor in such deed can pass no title to his subsequent donee or devisee, and the law will pass none to his heir, because there was none in him, after his conveyance, to be passed, but in favor of a creditor or bona fide purchaser for value. Does the conveyance of the heir, or donee or devisee, who, as such, never had title, made to a purchaser for value and without notice, operate to divest the title conveyed by the unrecorded deed, and, bringing it in another line of conveyances, vest it in subsequent purchasers?" This question the court, on the authority of Ralls v. Graham, 4 T. B. Mon. (Ky.) 120, answers in the negative.

Our own court, in McCamant v. Patterson, 39 Mo. 110, 111, seems to recognize the same doctrine, though, from the peculiarity of the title to the New Madrid grants, the question in its general application could not have arisen in that case.

Other authorities, however, equally respectable, have held that the heir of the grantor in an unrecorded deed can convey a good title to 
an innocent purchaser for value. The Supreme Court of Pennsylvania, in Howers v. McFerran, 2 Serg. \& R. 44, in giving its opmion, remarks that "the purchaser for a valuable consideration, seeng no deed on record, had a right, under the sanction of the recording act, to take for granted that the whole estate had descended." The sane question was raised in McCulloch v. Eudaly, 3 Yerg. (Tenn.) 3+6, and in sustaining a deed from the heir, the following language is used by the court: "But it is contended that this (the saving to suosequent purchasers) only applies to cases where the purchase should be made trom the same vendor by whom the prior decd was executed. It is true the subsequent purchaser must hold under the same title; but whether he holds under the ancestor or heir, it can make no difference. The estate is thrown upon the heir with all the rights the ancestor enjoyed and subject to all encumbrances he had created on it."

The subject has also been considered in the State of Illinois, in Tennedy v. Northup, 15 Ill. 14S; and after reviewing the authorities, the title from the heir was sustained. "After much reflection," says the judge who delivered the opinion, "I am satisfied that this is the true and proper construction of the statute. It meets the object designed to be accomplished by the law, and is within the reason which gave rise to the enactment. It was the object of the Legislature to make patent the titles to real estate, that purchasers might know what titles they were acquiring. Where a deed is not recorded, the title is apparently still in the grantor, and the law authorizes purchasers who are ignorant of the conveyance to deal with him as the real owner. In case of his death the heir becomes the apparent owner of the legal title, and it is equally important and equally as just that the public may be allowed to deal with him as with the original grantor if living."

There is no substantial difference between the statutes of the different States whose decisions I have quoted and our own. Different language is used, but the same result is aimed at; some expressly declaring unrecorded deeds to be void against subsequent purchasers, while ours negatively does the same thing by saying that no such in- strument shall be valid except between the parties thereto, etc.

The discrepancy in the authorities has doubtless arisen in part from the endeavor to reconcile the statute with the subtleties of the old law of tenures, which treats a title as a substantial entity, and almost applies to it the powers of locomotion. The attempt involves the reasoner in contradictions, for in one breath it is said that the title passes by the deed to the grantee and still so remains with the grantor, that in a contingency it may again pass from him to another grantee, but if the grantor dies it can not descend like all his other titles, but goes back to the original grantee, with whom it has always remained.

It would be more rational to say that the law controls the manner in which rights of property are acquired, and that it will not favor any mode of acquirement that shall encourage fraud. Thus purchasers 
are required to spread upon record the evidence of their ownership; and if others suffer from their neglect, the law will not recognize such ownership. Or, in using the language of the law of tenures, we might perhaps say that in a conveyance the absolute title rests with the grantor and his heirs in abeyance, to vest irrevocably only upon the record of the deed, and that it will vest in the first grantee in condition to receive the grant, who shall so place it upon record.

The Circuit Court held that the defendant's deed from the heirs of Mrs. Wright conveyed the whole estate, whereupon the plaintiff took a nonsuit, and his motion to set the same aside was overruled. In this the cont committed no error, and the other judges concurring, the judgment will be affirmed. ${ }^{18}$

\section{MORSE v. CURTIS.}

(Supreme Judicial Court of Massachusetts, 1855. 140 Mass. 112, 2 N. E. 929, 54 Am. Rep. 456.)

Morton, C. J. This is a writ of entry. Both parties derive their title from one Hall. On August 8, 1872, Hall mortgaged the land to the demandant. On September 7, 1875, Hall mortgaged the land to one Clark, who had notice of the earlier mortgage. The mortgage to Clark was recorded on January 31, 1876. The mortgage to the demandant was recorded on September 8, 1876. On October 4, 1881, Clark assigned his mortgage to the tenant, who had no actual notice of the mortgage to the demandant. The question is which of these titles has priority.

The same question was directly raised and adjudicated in the two cases of Connecticut v. Bradish, 14 Mass. 296, and Trull v. Bigelow, 16 Mass. 406, 8 Am. Dec. 144. These adjudications establish a rule of property which ought not to be unsettled, except for the strongest reasons.

It is true, that, in the later case of Flynt v. Arnold, 2 Metc. 619, Chief Justice Shaw expresses his individual opinion against the soundness of these decisions; but in that case the judgment of the court . was distinctly put upon another ground, and his remarks can only be considered in the light of dicta, and not as overruling the earlier adjudications.

Upon careful consideration, the reasons upon which the earlier cases were decided seem to us the more satisfactory, because they best follow the spirit of our registry laws and the practice of the profession

13. Sye Iron v. Gleason, 40 Minn. 434, 42 N. W. $2 S 6$ (18s9); Whittemore v. I:an, (i N.II. 47 (1832), where it was the derisee of the grantor in the unrecord: erl cherd thit made the later deed to the good faith purchaser.

Sunnus the grantor in the unrecorded deed himself makes a deed to one who talins either as a volunteer or with knowledge of the earlier deed, and that srilltwe in 1 urn conteg's to a good faith purchaser. What would be the position of the srantere in the umrecorded deed? 
suder them. The earliest registry laws provided that no conveyance of land shall be good and effectual in law "against any other person or persons but the grantor or grantors, and their heirs only, unless the deed or deeds thereof be acknowledged and recorded in manner aforesaid." St. 1783 , c. $37, \S 4$.

Under this statute, the court, at an early period, held that the recording was designed to take the place of the notorious act of livery of seisin; and that, though by the first deed the title passed out of the grantor, as against himself, yet he could, if such deed was not recorded, convey a good title to an innocent purchaser who received and recorded his deed. But the court also held that a prior unrecorded deed would be valid against a second purchaser who took his deed with a knowledge of the prior deed, thus engrafting an exception upon the statute. Reading of Judge 'Trowbridge, 3 Mass. 575; Marshall v. Fisk, 6 Mass. 24, 4 Am. Dec. 76.

This exception was adopted on the ground that it was a fraud in the second grantee to take a deed, if he had knowledge of the prior deed. As Chief Justice Shaw forcibly says, in Lawrence v. Stratton, 6 Cush. 163, the rule is "put upon the ground, that a party with such notice could not take a deed without fraud, the objection was not to the nature of the conveyance, but to the honesty of the taker; and, therefore, if the estate had passed through such taker to a bona fide purchaser, without fraud, the conveyance was held valid."

This exception by judicial exposition was afterwards engrafted upon the statutes, and somewhat extended, by the Legislature. Rev. St. c. 59, § 28; Gen. St. c. $89, \S 3$; Pub. St. c. $120, \S 4$. It is to be observed that, in each of these revisions, it is provided that an unrecorded prior deed is not valid against any persons except the grantor, his heirs and devisees; "and persons having actual notice" of it. The reasons why the statute requires actual notice to a second purchaser, in order to defeat his title, is apparent; its purpose is that his title shall not prevail against the prior deed, if he has been guilty of a fraud upon the first grantee; and he could not be guilty of such fraud, unless he had actual notice of the first deed.

Now, in the case before us, it is found as a fact that the tenant had 110 actual knowledge of the prior mortgage to the demandant at the time he took his assignment from Clark; but it is contended that he had constructive notice, because the demandant's mortgage was recorded before such assignment.

It was held in Connecticut v. Bradish, ubi supra, that such record was evidence of actual notice, but was not of itself enough to show actual notice, and to charge the assignee of the second deed with a fraud upon the holder of the first unrecorded deed. This seems to us to accord with the spirit of our registry laws, and with the uniform understanding of and practice under them by the profession.

These laws not only provide that deeds must be recorded, but they also prescribe the method in which the records shall be kept and in- 
dexes prepared for public inspection and examination. Pub. St. c. 24, $\S \S 14-26$. There are indexes of grantors and grantees, so that, in searching a title, the examiner is obliged to run down the list of grantors, or run backward through the list of grantees. If he can start with an owner who is known to have a good title, as, in the case at bar, he could start with Hall, he is obliged to run through the index of grantors until he finds a conveyance by the owner of the land in question. After such conveyance, the former owner becomes a stranger to the title, and the examiner must follow down the name of the new owner to see if he has conveyed the land, and so on. It would be a hardship to require an examiner to follow in the indexes of grantors the names of every person who, at any time, through perhaps a long chain of title, was the owner of the land.

We do not think this is the practical construction which lawyers and conveyancers have given to our registry laws. The inconveniences of such a construction would be much greater than would be the inconvenience of requiring a person, who has neglected to record his prior deed for a time, to record it, and to bring a bill in equity to set aside the subsequent deed, if it was taken in frand of his rights.

The better rule, and the one the least likely to create confusion of titles, seems to us to be, that, if a purchaser, upon examining the registry, find a conveyance from the owner of the land to his grantor, which gives him a perfect record title completed by what the law, at the time it is recorded, regards as equivalent to a livery of seisin, he is entitled to rely upon such record title, and is not obliged to search the records afterwards, in order to see if there has been any prior unrecorded deed of the original owner.

This rule of property, established by the early case of Connecticut v. Bradish, ought not to be departed from, unless ${ }^{\circ}$ conclusive reasons therefor can be shown.

We are therefore of opinion, that, in the case at bar, the tenant has the better title; and, according to the terms of the report, the verdict ordered for the demandant must be set aside, and a

New trial granted.

\section{WOODS v. GARNETT.}

(Sunreme Court of Mississippi, 1894. 72 Miss. 78, 16 South. 390.)

Bill to cancel defendant's claim to certain land and to recover possession. Decree for defendants. Complainant appeals. The opinion sufficiently states the facts.

CoOper, C. J., delivered the opinion of the court.

The parties to this suit all claim title from one Riley, who, in 1891, was the owner of the land in controversy. On the ninth day of November, A. D. 1891, Riley executed a decd of trust, whereby he conveyed the land to one M. H. Trantham, as trustee, to secure the payment of a 
promissory note of that date for $\$ 3,500$, payable to the order of $\mathrm{C}$. $\mathrm{H}$. Pond. This deed contained the usual power of sale if default should be made in the payment of the secured debt at maturity, and also provided that Pond, or the assignee of the note, might at pleasure substitute any other person in lieu of the trustee, Trantham. This deed was acknowledged before Trantham, the trustee, who was a justice of the peace of the county. The certificate stated only that the grantor acknowledged that he had "signed" the deed, omitting the words "and delivered," as required by law. This deed was filed for record in the proper office on the twelfth day of November.

On May 6, 1892, Riley executed a deed of trust to one Oliver, as trustee, to secure the payment of a debt to W. G. Cocke \& Co. of $\$ 397.22$. This deed also contained a power of sale if the debt secured should not be paid at maturity. Before accepting this security, W. D. Lester, a member of the firm of Cocke \& Co., examined the records, and there saw and read the prior deed, but was of opinion that, by reason of the defective acknowledgment, and because it had been taken by the trustee therein, it was not entitled to registration, and, being of that opinion, decided to accept the deed to secure his firm.

Some time prior to October, 1892, Pond assigned the note executed by Riley payable to him to the complainant, Chas. R. Woods. About this time it was discovered that the deed of trust by which this note had been secured had not been so acknowledged as to entitle to registration, and thereupon Woods exhibited his bill in equity to enjoin Riley from disposing of the lands to his injury, and an injunction was allowed.- The attorney of Woods, being of opinion that a re-execution and acknowledgment of the deed by Riley, and another registration thereof, would serve the same purpose as the injunction, sent the clerk of the chancery court to see Riley and get a re-acknowledgment of the deed, which he did on October 7, 1892, when the deed was on that day again filed for record and recorded on the twenty-fourth.

On November 16, 1892, Riley and his wife conveyed the land to the appellee, Mrs. L. A. Garnett. On November 19, 1892, the land was sold under each of the two deeds of trust, the sales being at different places. At the sale under the deed of trust first made, but junior in record (the Pond deed), the appellant became the purchaser. At the sale under the deed junior in date, but the first recorded, the appellee, Mrs. D. L. Garnett, purchased. The appellant exhibited his bill in this cause to cancel the titles of the defendants, Mrs. D. L. Garnett and Mrs. L. A. Garnett, as clouds upon his own, and to recover possession of the land, they having been let into possession by Riley.

Mrs. D. L. Garnett defends the suit upon the ground that she was a bona fide purchaser, without notice of the deed of trust under which complainant claims title. Mrs. L. A. Garnett defends only as to 160 acres of the land, which, she says, was the homestead of Riley at the time he executed the deed of trust to secure the note to Pond, which deed, she contends, was void as to the homestead, because Mrs. Riley 
did not join her husband in the conveyance, as is required by law for the sale or incumbrance of the homestead. In the controversy between the appellant and Mrs. D. L. Garnett, the question involved is one of law, the facts being undisputed. In the controversy with Mrs. L. A. Garnett, the question is purely of fact, the parties not differing as to the law, which is plain, and not susceptible of controversy.

1. Were Cocke \& Co. bona fide incumbrancers of the land, without notice of the Pond mortgage? It has been generally held by the Anierican courts, though with some exceptions, that, notwithstanding the registry acts, one who has notice of such facts in reference to an unrecorded conveyance, as devolves on him, as an honest man, the duty of making further inquiry, is to be held as having such knowledge as such inquiry, honestly made, would have disclosed. In those states in which this rule does not apply, it will be found that the registry acts require actual knowledge of the unrecorded conveyance. One who sees upon the record, and reads an instrument improperly recorded, because not acknowledged or proved as required by law, cannot claim to be a bona fide purchaser of the property therein described. $\mathrm{He}$ knows that what he sees is the copy of an instrument purporting to have been made by the grantor to the grantee. Good faith requires that he shall prosecute further inquiry, and, if he negligently or wilfully neglects so to do, he is to be held to have known all the facts to which that inquiry would have led. The notice to Lester by reading the improperly recorded mortgage, was notice to his firm of the existence of that conveyance, and Cocke \& Co. were not bona fide purchasers of the property. ${ }^{14}$

2. Where a conveyance is made to one who fails to record his deed until after another has received and recorded a conveyance from the same grantor, but with notice of the first deed, what are the rights of the first grantee against a purchaser from the second, where such purchaser, having no actual knowledge of the facts, buys after the record of the prior deed? This question is determinable by a construction of our registry act, for, at the common law, a second purchaser of the fee could take nothing, since, by the first conveyance, the grantor would have divested himself of all his estate, and would have nothing to convey. Basset v. Nosworthy, 2 Ldg. Cas. in Eq. 110, and note; Coke on Littleton, 390d.

By our registry act it is declared that the instruments thereby required to be recorded "shall be void as to all creditors and subsequent purchasers for valuable consideration without notice, unless they shall be acknowledged or proved and lodged with the clerk of the chancery court of the county, to be recorded in the same manner that other conveyances are required by this act to be acknowledged or proved and recorded; but the same, as between the parties and their heirs, and as to all subsequent purchasers with notice, or without valuable considera-

14 But see Nordman v. Rau, infra, p. 909. 
tion, shall, nevertheless, be valid and binding." Code 1S80, $\S 1212$; Code 1892, § 2457. "Every conveyance, covenant, agreement, bond, mortgage, and deed of trust shall take effect, as to all subsequent purchasers for a valuable consideration without notice, and as to all creditors, only from the time when delivered to the clerk to be recorded." Code 1880, $\$ 1213$; Code 1892, $\S 2458$. In Massachusetts and Vermont it is held that a purchaser is not bound to examine the record, after the date of a recorded conveyance, to discover whether the grantor therein has made another conveyance prior in time but junior in record, but may safely purchase from the grantee in the first recorded conveyance, if he, the purchaser, has no actual notice of the prior deed, and no notice of facts which makes it his duty to prosecute inquiry. Connecticut v. Bradish, 14 Mass. 296; Trull v. Bigelow, 16 Mass. 406, 8 Am. Dec. 144; Morse v. Curtis, 140 Mass. 112, 2 N. E. 929, 54 Am. Rep. 456: Day v. Clark, 25 Vt. 397. And this is said to be the more reasonable rule by the annotators of the leading cases in equity (Le Neve v. Le Neve, 2 Ldg. Cas. 180), and by Mr. Jones (1 Jones on Mortg. $\$ 574$.) The decided weight of authority is, however, to the contrary, though Mr. Jones cites none of them as supporting the contrary view, except the New York decisions. Among others, the following cases may be noted: Van Rensselaer v. Clark, 17 Wend. (N. Y.) 25, $31 \mathrm{Am}$. Dec. 280; Westbrook v. Gleason, 79 N. Y. 23; Clark v. Mackin, 30 Hun (N. Y.) 411 ; Mahoney v. Middleton, 41 Cal. 41 ; English v. Waples, 13 Iowa, 57 ; Fallass v. Pierce, 30 Wis. 443 ; Erwin v. Lewis, 32 Wis. 276; Van Aken v. Gleason, 34 Mich. 477 ; Bayles v. Young, 51 Ill. $12 \pi$.

The question has never been decided in this state, though in Harrington v. Allen, 48 Miss. 492, there is a dictum in which Judge Simrall, mistaking the facts of his case, seems to favor the Massachusetts rule. The decisions in Massachusetts and Vermont, while resulting in practically the same end, proceed on irreconcilable and opposite principles. In Massachusetts it is held that the purchaser from the grantee in the leed junior in date, but senior in record, need not examine the records after the date of the registration of the conveyance to his grantor. Morse v. Curtis, 140 Mass. 112, 2 N. E. 929, 54 Am. Rep. 456. In Vermont it is held that he is bound by the constructive notice afforded by the registration of the first deed, that it is notice to him of the fact that a deed prior to that of his grantor had been made; but is not notice that his grantor had notice of the first deed; and so the conveyance to the purchaser from the second grantee is preferred in Vermont, not because the purchaser is himself a purchaser without notice, for the registration of the prior deed is notice of its existence, nor because his grantor was a purchaser without notice, for that may or may not be true, but because the purchaser did not know that his grantor was not a Lona fide purchaser, and thus, under the Vermont decision, one may secure protection as though he were a bona fide purchaser when neither he nor any one under and through whom he derives title was in fact 
such purchaser. This rule has no recognition except in Vermont, so far as we have discovered.

We think the Massachusetts decisions are erroneous, because they hold that one not bound by the registry law is protected by it. But for the registry law, where one has conveyed his legal title, he has nothing left to convey to another, and that other, with or without notice of the prior conveyance, would get nothing, for his grantor had nothing to convey. Now, the statute comes and provides that, though a conveyance of the class named in the statute may be made, it shall as to certain persons, viz., creditors and purchasers without notice, be valid only from a certain time, viz., the tine when it is filed for record. In other words, the operation of the unrecorded conveyance is supended until it shall be recorded, as against creditors and purchasers without notice, and, when recorded, it does not operate by relation as against such persons from the day of its execution, but is effective only from and of the date of its delivery for record. But when filed for record it has full scope and effect against the world. One who buys after that event can find no protection in the statute, for its terms have been complied with by the holder of the adverse title. It is no answer to say that it is inconvenient to the purchaser to examine a long and voluminous record, made after the record of the title of his grantor. To this the sufficient reply is that, but for the registry acts, he would not have even the protection which such records afford, but would deal at his peril with his grantor, and secure only such title as he might assert. If that grantor had good title because a purchaser for value without notice, that is a defense to his vendee; but if such grantor was not such purchaser, then the validity of the title he conveys must depend upon the character of his vendee, and if such vendee is not a bona fide purchaser under the common law or the statute, we cannot perceive from what source a principle can be deduced which will afford him protection. It seems clear to us that one who buys an estate cannot invoke the protection of the registry act as against a deed recorded under such act at the time of his purchase. ${ }^{25}$

\section{TEFFT v. MUNSON.}

(Court of Appeals of New York, 1874. 57 N. Y. 97.)

Appeal from judgment of the General Term of the Supreme Court in the third judicial department, affirming a judgment in favor of defendants entered upon the decision of the court upon trial at Special Term.

This was an action to restrain defendants, loan commissioners for Washington county, from foreclosing a mortgage executed to them by Nartin B. Perkins and wife.

15 The halance of the opinion, which discusses the position and rights of Mrs. 1. A. ciamett, is omitted.

See Fullass y. I'ierce, 20 Wis. 443 (1572), a most interesting case. 
On the 18th day of January, 1848, Gamaliel Perkins purchased of Cortland Howland certain lands in Washington county, which were conveyed to him by warranty deed recorded March 7, 1848, in the clerk's office in said county. Gamaliel Perkins, immediately after his purchase, let his son, Martin B. Perkins, into possession of the premises, who forged a deed of the land from his father to himself and placed it upon record in the clerk's office of said county, May 27, 1850. On the 1st day of October, 1850, Martin B. and his wife executed a mortgage upon said land to the loan commissioners of said county, to secure the sum of $\$ 1,000$ loaned to him. This mortgage contained covenants that Martin B. and his wife were lawfully seized of a good, sure, perfect, absolute and indefeasible estate of inheritance in the premises, and that they were free and clear of and from all former and other gifts, grants, bargains, sales, liens, etc.; and this mortgage was; on the flay of its date, duly recorded in the book kept by the loan commissioners, as required by law. On the $23 \mathrm{~d}$ of January, 1860 , a deed of said lands bearing date April 1, 1853, was recorded in the county clerk's office, which purported to be executed by Martin B. and wife to his father. On the 16th day of December, 1859, Gamaliel Perkins conveyed said land to Martin B., by deed recorded January 14, 1860 . Until this conveyance from his father Martin B. had no title to the land, although he remained in possession of the same from 1848. On the 31st day of January, 1867, Martin B., being still in possession of the lands, conveyed them to the plaintiff, who paid full value for the same without any actual notice of the mortgage to the loan commissioners. The deed to the plaintiff was recorded February 9, 1867.

The court below decided that plaintiff was not entitled to the relief sought and directed a dismissal of the complaint. Judgment was perfected accordingly.

EARL, C. The plaintiff claims that the mortgage to the loan commissioners has no validity as against him, and that his deed has priority over it under the laws in reference to the registry of deeds and mortgages. It is a principle of law, not now open to doubt, that, ordinarily, if one who has no title to lands, nevertheless makes a deed of conveyance, with warranty, and afterward himself purchases and receives the title, the same will vest immediately in his grantee who holds his deed with warranty as against such grantor by estoppel. In such case the estoppel is held to bind the land, and to create an estate and interest in it. The grantor in such case, being at the same time the warrantor of the title which he has assumed the right to convey, will not, in a court of justice, be heard to set up a title in himself against his own prior grant; he will not be heard to say that he had not the title at the date of the conveyance, or that it did not pass to his grantee in virtue of his deed. Wark v. Willard, 13 N. H. 389; Kimball v. Blaisdell, 5 N. H. 533, 22 Am. Dec. 476; Somes v. Skinner, 3 Pick. (Mass.) 52; Bank of Utica v. Mersereau, 3 Barb. Ch. 528, 567, 49 Am. Dec. 189; Jackson v. Bull, 1 Johns. Cas. 81, 90 ; White v. Patten, 24 Pick. (Mass.) 
324; Pike v. Galvin, $29 \mathrm{Me}$. 183. And the doctrine, as will be seen by these authorities, is equally well settled that the estoppel binds not only the parties, but all privies in estate, privics in blood and privies in law; and, in such case, the title is treated as having been previously vested in the grantor, and as having passed immediately upon the execution of his deed, by way of estoppel. In this case, Martin B. Perkins conveyed the lands to the loan commissioners, by mortgage with warranty of title, and thereby became estopped from disputing that, at the date of the mortgage, he had the title and conveyed it; and this estoppel applied equally to the plaintiff to whom he made a subsequent conveyance, by deed, after he obtained the title from his father, and who thus claimed to be his privy in estate. The plaintiff was estopped from denying that his grantor, Martin B. Perkins, had the title to the land at the date of the mortgage, and he must, therefore, for every purpose as against the plaintiff, be treated as having the title to the land at that date.

I, therefore, can see no difficulty in this case, growing out of the law as to the registry of conveyances. Martin B. Perkins, having title, made the mortgage which was duly recorded. He then conveyed to his father and the deed was recorded. His father then conveyed to him and the deed was recorded. He then conveyed to the plaintiff and his deed was recorded. Thus the title and record of the mortgage were prior to the title and record of the deed to plaintiff, and the priority claimed by plaintiff cannot be allowed. Assuming it to be the rule that the record of a conveyance made by one having no title, is, ordinarily, a nullity, and constructive notice to no one; the plaintiff cannot avail himself of this rule, as he is estopped from denying that the mortgagor had the title at the date of the mortgage. The case of White v. Patten, supra, is entirely analogous to this. In that case, the plaintiff derived his title from a mortgage, made to him by one Thayer, containing covenants of seizin, warranty, etc., and recorded February 19, 1834. At the time of the execution of this mortgage the title was not in Thayer, but in one Perry, his father in law. Perry afterward, by deed, recorded August 2, 1834, conveyed the land in fee simple to Thayer, who conveyed the land by mortgage to the defendant, recorded the same day. The counsel for the defendant used the same arguments in a great measure, which have been urged upon our attention by the counsel for the plaintiff in this case, both as to the title and the registry of the mortgages; and, yet the court held in a very able opinion, that the plaintiff had the prior and better title.

I am, therefore, of opinion that the judgment should be affirmed, with costs.

REynol,ds, C. (dissenting.) When Martin B. Perkins gave the mortgage to the loan commissioners he had possession, but no title to the mortgaged property. He had forged a deed of the premises from Gamaliel I'erkins to himself, and caused it to be put on record in the clerk's office of the county of Washington; and by this device, imposed 
upon the loan commissioners. The forged deed, was, of course, a nullity, and could not in the eye of the law, have any effect by way of constructive notice or otherwise. It conveyed nothing, and was not a "conveyance" within the meaning of the recording acts, and did not affect the title to the land "in law or equity." It may be assumed, therefore, that the loan commissioners took the mortgage, knowing that Martin B. Perkins had no title, it being very clear that they acquired no legal rights by being imposed upon, against any one, save Martin E. Perkins. They got no interest in the land, either in law or equity. It is not in principle, unlike the case of a forged negotiable promissory note, where a bona fide holder for value can have no protection. It follows, therefore, that the entry of the mortgage in the books of the loan office at the time it was made, was of no legal consequence whatever, except as against the mortgagor. It was no notice under the recording acts; for it did not in the remotest degree affect the title to the land described in it. The mortgage contained a covenant of title, and it seems to be clear, that a title subsequently acquired by Martin B. Perkins, would, ordinarily, inure by estoppel, or otherwise, to the benefit of the mortgagees if other rights have not intervened. The title to the mortgaged premises was in Gamaliel Perkins, from the 18th of January, 1848, to the 16th of December, 1859, when he conveyed it to Martin B. Perkins. By this conveyance, the mortgage given by Martin B. Perkins to the loan commissioners, in October, 1850, acquired legal vitality by way of estoppel, or in some other form, and if it had then been in any proper form recorded, constructive notice of its existence, as a valid lien upon the property, would have been given to all the world. It is urged, that there was no necessity of making any further record of the mortgage, because the title in the mortgagees comes under the warranty by way of rebutter or estoppel. This will not do. It is sufficient, to say, that by virtue of the transactions under which the defendants look to enforce the lien of the mortgage, the title to the land is affected, and such a paper must be properly put on record to bind subsequent purchasers in good faith.

If this be not so, it is impossible to see how a subsequent bona fide purchaser can have any protection, and when it is said to be impossible to record the estoppel which gave the mortgage vitality; it may be answered; that, until the estoppel became operative, the mortgage was a nullity and the record of it no notice whatever. When, however, Martin B. Perkins obtained the title to the premises, it became by some operation of law valid against him; but it was of no greater force or effect, than if he had on that day given it to the loan commissioners. It then, for the first time, affected the title to the land, and in order to bind subsequent purchasers, in good faith, must be duly recorded, and this was not done in any such way as to operate as constructive notice under the recording acts.

It is not questioned, but that the plaintiff is to be protected as a boni fide purchaser, for value, unless the mortgage given in 1850 , and then 
entered in proper order in the books of the loan office, which, at the time, did not affect the title to the land in any way, was constructive notice of the lien. It is well settled, that a conveyance that is not duly recorded according to law, even when the actual title has passed, is not effectual as constructive notice. Frost v. Beekman, 1 Johns. Ch. 288; Lessee of Heister v. Fortner, 2 Bin. (Pa.) 40, 4 Am. Dec. 417. Much less can it be, that a conveyance which does not affect the title, can give any legal notice whatever. In the very best aspect of the defendant's case, the record of the mortgage was made out of the order required by law, and failed to give notice to anybody dealing with the title to the land. N. Y. Life Ins. Co. v. White, 17 N. Y. 469; Sawyer v. Adams, 8 Vt. 172, $30 \mathrm{Am}$. Dec. 459. In this view, the deed of the plaintiff was first recorded, and he is entitled to protection in his title.

The judgment should be reversed, with costs, the mortgage declared no lien upon the land of the plaintiff, and the loan commissioners perpetually enjoined from attempting to enforce it.

For affirmance, Earl, Gray and Johnson, CC.

For reversal, LotT, Ch. C., and REYNolds, C.

Judgment affirmed. ${ }^{16}$

\section{WHEELER v. YOUNG.}

(Supreme Court of Errors of Connecticut, 1903. 76 Conn. 44, 55 Atl. 670.)

Action to forcclose a mortgage and for other equitable relief, brought to the Superior Court in Fairfield County and tried to the court, George W. Wheeler, J.; facts found and judgment renclered for the defendant Young, upon his cross-complaint, and appeal by. the plaintiff.

HALL, J. The plaintiff asks for a judgment of foreclosure under a mortgage which on the 13th of December, 1900, was assigned to him by Burr \& Knapp, real estate and mortgage brokers of Brilgeport. Burr \& Knapp as mortgagees received the mortgage from Charles B. and Edward H. Marsh, builders in Bridgeport, under the firm name of Marsh Brothers, on the 26th of October, 1900, to secure the payment of a loan of $\$ 3,500$ made by them, on that day, to Narsh Brothers. The mortgage was recorded on said 26th of October at 3:01 P. M. Burr \& Knapp took no other security for said loan. and Marsh Brothers are insolvent. Both Burr \& Knapp and the plaintiff took said mortgage in good faith, for value, in reliance upon the certificate of an attorney that the premises were free and clear of all incumbrance, and that the legal title at the time said mortgage was given was in Marsh Brothers, and without knowledge of any prior conveyance by Marsh Brothers to the grantor of the defendant Young, or of any incumbrance upon said property prior to their mortgage

16 sn. alko. in Jarvis v. Aikens. surra, p. 801 : Rernardy v. Colonial \& U. S. Mortg. Co., 17 S. D. 637, 98 N. W. 166, 106 Am. St. Rep. 791 (1904). 
of October 26th. Marsh Brothers obtained title to the premises described in the mortgage by a quitclaim deed from Orange Merwin of Bridgeport, which was executed on the 1st of May, 1900, but not delivered until the 26th of October, 1900, when it was recorded at 3:05 P. M. On the same day Marsh Brothers paid to Merwin the purchase price for said property.

Apparently there was no evidence presented at the trial, other than the facts herein stated, showing the precise time on the 26th of October when either the deed from Merwin to Marsh Brothers, or the mortgage from Marsh Brothers to Burr \& Knapp, was actually delivered, or showing whether or not they were delivered at the same time and together given to the town clerk to be recorded.

Orange Merwin acquired title from Marsh Brothers by deed executed and recorded September Sth, 1899. The defendant Harry S. Young, who is now in possession of the mortgaged premises, claims under a deed from Alfred Young dated January 2d, 1901. Alfred Young claimed title under a warrantee deed from Marsh Brothers dated April 30 th, 1900, delivered and recorded on the 7 th of July, 1900. Marsh Brothers had, on the 21st of April, 1900, agreed with said Alfred Young to sell him the lot described in the mortgage, and which was then owned by Merwin, and to erect a house thereon for $\$+, 600$, for which Alfred Young was to transfer to Marsh Brothers a cottage valued at $\$ 3,800$, on which there was a mortgage of $\$ 2,800$ and was to give a mortgage back, upon the premises purchased, for the remainder of the $\$ 4,600$. In accordance with such agreement Alfred Young conveyed the cottage, and on April 30th, 1900. gave to Charles B. Marsh a mortgage upon the lot in question for $\$ 3,500$, upon Marsh's promise not to use it until the house was completed, which mortgage Marsh, on the same day, assigned to one Mary E. Beardsley, one of the defendants.

Alfred Young caused no search to be made of the land records to ascertain the true state of the title to said land, before receiving said deed from Marsh Brothers, but relied upon the statement of Charles B. Marsh that they had acquired title to said land. Young was in the employ of Marsh Brothers and did as Charles B. Marsh directed, intending no fraud toward any one.

Marsh Brothers commenced the erection of a house upon said lot in May, 1900, which was apparently completed on the 26th of October, 1900, and Merwin on said day gave his said deed to Marsh Brothers as aforesaid to enable them to carry out their said agreement with Alfred Young, which was known to Merwin, and on his business records Merwin treated the sale as a sale to Young.

The plaintiff has purchased for $\$ 1,750$ the mortgage so assigned by Marsh Brothers to Mary E. Beardsley.

Upon these facts the defendant Young claims title to the premises in question, and by his cross-complaint asks that the mortgage of October 26th, sought to be foreclosed, be declared void. 
No question is made and none can be made, upon the facts beiore $11 \mathrm{~s}$, but that the mortgage deed to Burr \& Knapp, and the Merwin deed to Marsh Brothers, both of which were delivered on the 26th of October as above stated and were received for record by 3:05 P. M. of the same day, were left for record within a reasonable time after they were delivered. The mere fact that the deed of Merwin to Marsh Brothers appears to have been received for record four minutes later than the mortgage of the latter to Burr \& Knapp, would not justify a conclusion, especially under the circumstances of this case, that Marsh Brothers had not received their deed from Merwin at the time of the delivery of the mortgage to Burr \& Knapp, and that for that reason Burr \& Knapp took nothing by their mortgage. Deeds recorded within a reasonable time take effect according to the time they were actually delivered. Hartford Bldg. \& Loan Ass'n v. Goldreyer, 71 Conn. 95, 100, 41 Atl. 659; Goodsell v. Sullivan, 40 Conn. 83, 85; Beers v. Hawley, 2 Conn. 467, 469. The deed and mortgage were delivered on the same day. The mortgage recites the ownership by the mortgagor at the time of its delivery of the same property described in the deed. Looking at the record of the two deeds, the mortgage therefore indicates upon its face that it was delivered after or at the same time with the Merwin deed. The Merwin deed, confessedly, not having been recorded when the mortgage was delivered, Burr \& Knapp would be presumed to have ascertained that it had been delivered before they made the loan of $\$ 3,500$, and the information which they received to that effect does not appear to have been false. As between the parties to this case and in the absence of any evidence to the contrary-unless the slight difference in the time the two deeds were received for record can properly be regarded as conflicting evidence-the Merwin deed must, under the circumstances, be regarded as having been delivered either before, or at the same time with, the mortgage, and especially since no one appears to have been deceived to his injury by the fact that the Merwin deed, which bore an earlier date than the mortgage, appears to have been received for record four minutes later than the mortgage.

But we do not understand that the trial court held that the Merwin deed was in fact delivered after the mortgage, or held that it did not sufficiently appear that the Merwin deed was delivered first, but decided that by the common-law doctrine of estoppel the title acquired by Marsh Brothers from Merwin on the 26th of October inured to the benefit of Alfred Young, the first purchaser from Marsh Brothers, the moment Marsh Brothers acquired their title, even assuming that the decd from Merwin was delivered before the mortgage, and decided that the title having thus vested in Young there remained nothing which Narsh Brothers could convey to Burr \& Knapp by the mortgage, or which Burr \& Knapp could assign to the plaintiff. •

the rule referred to is, that where one without title has conveyed with corenants of warranty, and has afterwards acquired title, he 
is estopped from asserting his want of title at the time of making such first conveyance; and the contention of the defendant is, in effect, that under this rule, upon the facts before us, not only Marsh Brothers, but their mortgagees, Burr \& Knapp, are estopped from denying that Marsh Brothers had title at the time of their conveyance to Young on July 7 th, 1900.

To carry this doctrine to the extent of giving priority to the title of one who from his negligent failure to examine the records has been induced to purchase land of a person having no title, over that of one who without negligence, in good faith and for value, and without knowledge of such prior deed, has purchased, after his grantor has acquired title from one having both the legal and record title, is opposed to the principles of equity and to the spirit of our registry laws. Bingham v. Kirkland, 34 N. J. Eq. 229, 234; Calder v. Chapman, 52 Pa. 359, 91 Am. Dec. 163; Farmers' L. \& T. Co. v. Maltby, \& Paige (N. Y.) 361; Way v. Arnold, 18 Ga. 181; Salisbury Sarings Society v. Cutting, 50 Conn. 113, and reporter's note, page 122 .

The doctrine of estoppel is one which, when properly applied, "concludes the truth in order to prevent fraud and falsehood, and imposes silence on a party only when in conscience and honesty he should not be allowed to speak." Van Rensselaer v. Kearney, 11 How. 297, 326, 13 L. Ed. 703. "As understood and applied in modern times, there is nothing harsh or unjust in the law of estoppels. It cannot be used but to subserve the cause of justice and right." Buckingham v. Han11a, 2 Ohio St. 551, 559. "To allow a title to pass by conveyance, executed and recorded before it is acquired, may, therefore, be a surprise on subsequent purchasers, against which it is not in their power to guard, and is contrary to the equity which is the chief aim of the doctrine of estoppel as molded by the liberality of modern times." 2 Smith's Lead. Cases (7th Amer. Ed.) page 701, s. p. 63+.

It may be said that such estoppel by deed is not an equitable doctrine, but is a rule of the common law based upon the recitals or covenants of the deed. IVe reply, that as a rule of law, it has been so far modified by the registry laws as to be no longer applicable to cases where its enforcement would work such an injustice as to give priority to the title of one who negligently failed to examine the records before purchasing of a grantor having no title, or who purchased at the risk that his grantor might thereafter acquire title, over that of a subsequent purchaser in good faith and in reliance upon the title as it appeared of record. "The whole system of registering deeds of land would become of no value if a purchaser could not rely upon the records as he finds them." Kinney v. Whiton, 44 Conn. 262, 270, 26 Am. Rep. 462 ; Whiting v. Gaylord, 66 Conn. 337, 349, 34 Atl. 85, 50 Am. St. Rep. 87. In the case above cited of Salisbury Savings Society v. Cutting, 50 Conn. 113 , the question of whether a deed with covenants of title, given before the grantor acquired title to the land conveyed, and placed on rec-

AIG.Prop.-55 
ord, would prevail over a deed given after the title was acquired, to a purchaser taking it in good faith and without knowledge of the first deed, was left an open question. The case was decided upon the ground that the second grantee was neither a purchaser for value nor, because of certain facts found, a purchaser without notice of the title of the first grantee. The note to the case by the reporter, the late Mr. Hooker, contains an able discussion of the question left undecided by the court, in which he reaches the conclusion that the deed of the subsequent bona fide purchaser for value and without knowledge of the prior deed, must prevail, under our registry laws, over that of the prior recorded deed of the negligent grantee. We think his reasoning is convincing, and is especially applicable to the facts of the present case.

The plaintiff here asks for the enforcement of the registry laws. He says that from September Sth, 1899, until October 26th, 1900, both the legal and the record title to this property was in Orange Merwin, and that on said 26th of October his, the plaintiff's, assignors, Burr \& Knapp, purchased from those who on the same day acquired title from Merwin. The defendant asks for the enforcement of the law of estoppel, by which he claims that neither Burr \& Knapp, nor the plaintiff, should be permitted to assert that Merwin had title, and that Marsh Brothers had no title from September 8th, 1899, until October 26th, 1900.

In inquiring which of the two grantees, Young or Burr \& Knapp, has acted in good faith and without negligence in purchasing from Marsh Brothers, and which is entitled to priority of title under the registry laws, we must examine their conduct in connection with certain facts, with a knowledge of which they are charged by our registry laws.

The effect given by the law of this State to the proper record of conveyances of land has been very clearly declared in the recent case of Beach v. Osborne, 74 Conn. 405, 412-415, 50 Atl. 1019, 1118. We said in that case, as conclusions from the authorities there cited, "that every person who takes a conveyance of an interest in real estate is conchusively presumed to know those facts which are apparent upon the land records concerning the chain of title of the property described in the conveyance, and $* * *$ that this presumption of knowledge is for all legal purposes the same in effect as actual knowledge;" that "this presumed knowledge is present at every step he takes, at every act he does." and that his good faith and belief must be, "consistent with actual knowledge of the facts affecting his title which are apparent upon the land records;" that "one who fails to examine to see what the records disclose concerning the title to the land he proposes to take, is, in the eye of the law, negligent; and exuity does not as a general rule relieve from the consequences of one's own negligence."

Aptlying these principles to this case, we find that Alfred Young, in the eye of the law knew, when he purchased from Marsh Brothers, 
that they had no title, but that Marsh Brothers on the Sth of September, 1899, had conveyed to Merwin, and that the title was still in Merwin, and that it so appeared upon the public records. In contemplation of law, therefore, he did not act in good faith, but was negligent in making such purchase without having first examined to see what the records disclosed concerning the title to the land he proposed to purchase. When Burr \& Knapp took their mortgage from Marsh Broth.. ers on the 26th of October, they knew that the title to the mortgaged property had been in Micrwin from September Sth, 1899, until October 26th, 1900. Since they had no reason to suppose that one having no title to the property would convey it during that period, they had no occasion to search the records to ascertain whether Marsh Brothers had made any conveyance during that period. They were only reyuired to search against each owner during the time he held the record title. The deed of Marsh Brothers to Young was not in the line of record title, and Burr \& Knapp were not charged with knowledge of its existence. See Bingham v. Kirkland, 34 N. J. Eq. 229, and the other cases cited. It is said, however, that the Merwin deed was not on record when Burr \& Knapp took their mortgage on the 26th of October. But the Merwin deed was not in fact delivered until that day, and Burr \& Knapp had no reason to think that a deed delivered on that day, and before their mortgage was delivered, that is, before 3:01 P. M., ought to be recorded when their mortgage was delivered, nor was there any reason why they should require it to be recorded before accepting the mortgage. The records showed a good title in Merwin up to the time of the delivery of the mortgage deed. Burr \& Knapp had only to satisfy themselves that a deed had been given by Merwin to Marsh Brothers that day, which was the fact, and that no conveyance had been made by Marsh Brothers since they received their deed from Merwin, which was also true. As the deed of Marsh Brothcrs to Young and the mortgage back by Young to Charles B. Marsh were not incumbrances upon the title of record, the information given to Burr \& Knapp by the searcher, that "the premises were free and clear of all incumbrance and the legal title in Marsh Brothers," was entirely consistent with the facts as they appeared by the records concerning the chain of title, and the fact that Marsh Brothers had that day acquired title from Merwin. The facts before us show that Burr \& Knapp acted in good faith, and without negligence, and without knowledge of the Young deed, and that having on the 26th of October taken a mortgage from those, who on that day had received a deed from the legal owners, and the owners of record, their mortgage is valid. As Alfred Young had no title superior to the Burr \& Knapp nortgage when he conveyed to the defendant Young on January 2d, 1901, the defendant Young by his deed of that date took no titlc superior to the mortgage. The plaintiff is entitled to a judgment of foreclosure. 
There is error in the judgment of the trial court and it is reversed, and the case remanded for the entry of a judgment of foreclosure in favor of the plaintiff.

In this opinion the other judges concurred. ${ }^{17}$

\section{HOLDEN v. GARRETT.}

(Supreme Court of Kansas, 1579. 23 Kan. 9S.)

Action brought by Nina Garrett against Uriah Stephens and Martha J. Stephens, his wife, John Dial, John M. Wheeler, IV. H. Ryus, and Howard M. Holden, upon a note, exectuted by the said Uriah Stephens, November 25, 1S69, payable in seven years and nine months after date, with interest at ten per cent. per annum, and to foreclose a mortgage given at the same time to secure the payment of said note, by the said Uriah Stephens and wife, upon certain real estate situated in the county of Pottawatomie. The other defendants were made parties for the purpose of determining any interest they might have in and to said real estate, and the priority of all clains or liens thereon. Service of summons was duly made upon all of the defendants. Uriah Stephens, Martha J. Stephens and IV. H. Ryus filed no answers, but made default in said action. John Dial, John M. Wheeler and Howard .I. Holden, each filed separate answers in the action, setting up his claim or interest in said real estate. Trial at the August Term, 1S78, of the district court, by the court, (a jury being waired,) when the court found for the plaintiff, and against all of the defendants except Dial, whose clain to the land described in his answer therein was conceded by the plaintiff, and judgment was accordingly rendered in favor of the plaintiff, Nina Garrett, for the amount due on said note, and declaring said mortgage to be a prior and first lien upon the lands therein described as against the clain or interest of any and all of the other defendants. Holden brings the case to this court for review.

The facts, as they appear in the plaintiff's petition, the answer of the defendant Holden, and the testimony on their part, are in substance as follows: Prior to the 25th day of November, 1869, the said Nina Garrett was the owner in fee, in her own right, of the real estate described in her said petition, situated in the county of Pottawatomie. On said 25 th day of November, 1869, the plaintiff being a minor, said real estate was sold under the direction of the probate court of Wyandotte county, by virtue of an order of said court, by Eliza J. Stone, the legally-constituted guardian of the plaintiff, and by her conveyed to Triah Stephens. The note and nortgage sued on in said action were given for a portion of the purchase money therefor. This mortgage was not recorded until March 5th, 1S75, at which time it was duly

17 Lithardion v. Atlantic Coast I.umber Corporation, 93 S. C. 254, 75 S. E.

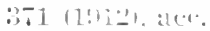


recorded in the office of the register of deeds for the county of Pottawatomie. On the 4th and 12th days of March, 1874, respectively, two certain personal judgments were rendered by the consideration of the district court of Wyandotte county against the said Uriah Stephens, and in favor of Jacob Luke and John Olson and Nels Olson, respectively. Afterward, executions were issued by the clerk of said district court of Wyandotte county on said judgments, directed to the sheriff of the county of Pottawatomie; and on the 20th day of July, $18 \bar{T}$, these executions were, by the sheriff of said county of Pottawatomie, levied upon a portion of the lands described in the mortgage of said plaintiff. No sale was made or attempted under and by virtue of said executions, but the same were returned to the court from which they were issued, and alias and pluries executions issued, which were in turn levied upon said lands until the 25th day of November, 1576, when a sale thereunder was made by the sheriff of the county of Pottawatomie, to one W. H. Ryus. On the 30th of March, 1876, the two above-named judgments were assigned to Holden, and the assignments thereof were duly filed in the office of the clerk of the district court of Wyandotte county. Whatever interest Holden had in said real estate was derived from the said sheriff's sale to W. H. Ryus.

BrEWER, J. 'The contest in this case is between one who claims under the lien of an execution levy, and the holder of a prior but unrecorded mortgage. The judgment was in a county other than that in which the land was situate, and was rendered long after the execution of the mortgage. The levy was made before, but the sale not till after, the record of the mortgage. There was no actual notice of the existence of this mortgage. On the one side it is claimed that by virtue of section 21 , ch. 22,'Gen. St. p. 187, which reads as follows: "No such instrument in writing shall be valid except between the parties thereto, and such as have actual notice thereof, until the same shall be deposited with the register of deeds for record," the mortgage is to be considered as though it had no existence, and the land as free from any incumbrance at the date of the levy, and that the lien then secured by the levy ripened into a title by the sale, and was paramount to the lien created by the subsequent record of the mortgage; and on the other hand it is claimed that the lien of the levy was only upon the actual interest of the judgment debtor in the real estate, and that as such interest was in fact limited by the mortgage, only such limited interest was seized and bound by the levy.

Of course, this is but part and parcel of a still broader question, and that is, does the lien of an execution levy extend to only the actual, or does it also reach the apparent, title of the judgment debtor? Is the inquiry restricted to the face of the record, or may it pass to the actual facts? Authorities are not wanting to support either view, and cogent reasons may be adduced in favor of each. On the one hand it may be said with force that if the mortgage lien is adjudged paramount, then the section quoted is practically nullified, and an in- 
strument which the statute declares invalid is pronounced valid; and on the other, that if the levy is adjudged paramount, then the statute which authorizes a levy upon the lands, tenements and hereditaments of the debtor is extended so as to sustain a levy upon lands which are not in fact wholly lis.

With much hesitation, and after a long and careful examination of the question in its various relations, we have reached the conclusion that the lien of the mortgage must be adjudged prior and paramount. These are the reasons which have controlled us: It gives exact force to the statute declaring to what a judgment lien and an execution levy extend. Judgments "shall be liens on the real estate of the debtor, within the county." Dassler's Comp. Laws 1879, p. 656, § 419. This evidently contemplates actual and not apparent ownership. The judgment is a lien upon that which is his, and not that which simply appears to be his. How often the legal title is placed in one party when the equitable title, the real ownership, is in others. Many reasons induce this-convenience in managing, facility in passing title, number of parties interested, and others needless to mention. And yet the record discloses only the naked legal title. Now if the judgment is a lien upon all that appears, it will cut off all the undisclosed equitable rights and interests. To extend the lien to that which is not, but which appears of record to be the defendant's, is to do violence to the language. "Real estate of the debtor" plainly means that which is in fact of or belonging to the debtor. And he who clains under a judgment lien can take no more than the statlite gives. The question is not what rights some one else may have, but what riglits does he acquire? The answer to this question must first and chiefly be sought in the statute which gives and defines the extent of that lien. The section defining the extent of the execution levy may not be quite so clear in its indications, and yet, taken in connection with that cited concerning the judgment lien, it is perfectly plain. "All real estate, not bound by the lien of the judgment, as well as goods and chattels of the debtor, shall be bound from the time they shall be seized in execution." Dassler's Comp. Laws 1879, p. $660, \S 444$. It might be argued that the words "of the debtor" only qualify the immediately preceding words, "goods and chattels," and not the prior clause, "all real estate," etc.; but, comparing the two sections together, it is plain that no larger or other intcrest is taken by the levy of an execution upon real estate outside the county, than is covered by the lien of the judgment upon real estate within the county. Again, this construction of the extent to which the lien goes was settled early in the history of this court, and has never been departed from. In Swarts v. Stees, 2 Kan. 241, 85 Ann. Dec. 588, Crozier, C. J., spealing for the court, says: "Their lien," (i. e., the lien of judgment creditors,) "is upon the lands and tenements of the debtor, and not upon lands and tenements not in fact belonging to hinn." True, the decision in that case was under a different recording act, and much of the argument in the opinion is entirely inapplica- 
ble to the present question; but still, the extent of a judgment lien is plainly recognized and stated. See also Harrison v. Andrews, 18 Kan. 542. It may also here be rcmarked, that we have had occasion to notice the fact that priority of lien or title, even in the absence of actual notice, does not alivays hinge upon the mere priority of record. Other matters may enter into and affect the question, and equities not shown of record may control. School District v. Taylor, 19 Kan. 287; Tucker v. Vandermark, 21 Kan. 263. Again, it may be laid down as familiar law, that a judgment creditor is not a bona fide purchaser. He parts with nothing to acquire his lien. He is in a very different position from one who has bought and paid, or has loaned on the face of a recorded title. The equities are entirely unlike. One has, and the other has not, parted with value upon the face of the record. If the real prevails over the apparent title, the one is no worse off than before he acquired his lien-has lost nothing; while the other loses the value paid or loaned. Hence equity will help the latter, while it cares nothing about the former. Further, in nearly every state in which an unrecorded mortgage has been postponed to a judgment lien, the statute has expressly declared that such a mortgage shall be void as against creditors; and the courts have laid stress upon this fact in their opinions. Thus, the statute of Illinois, $18+5$, p. $108, \S 23$, provides: "All deeds, mortgages or other instruments of writing which are required to be recorded, shall take effect, and be in force after the time of filing the same for record, and not before, as to all creditors and subsequent purchasers, without notice; and all such deeds and title papers shall be adjudged void as to all such creditors and sulusequent purchasers, without notice, until the same shall be filed for record." It has been decided under this statute that a deed not filed for record is, as to creditors and subsequent purchascrs, wholly without effect. Martin v. Dryden, 1 Gilman (Ill.) 187; Cook v. Hall, 1 Gilman (I11.) 575; Chotean v. Jones, 11 I11. 300, 50 Am. Dec. 460; Kennedy v. Northup, 15 I1l. 148; Curtis v. Root, 28 I1l. 367; Brookfield v. Goodrich, 32 Ill. 363. ${ }^{18}$ See also McNitt v. Turner, 16 Wall. 352. 21 L. Ed. $3+1 .{ }^{19} * * *$

The only other state ${ }^{20}$ in which we have found or been refcred to a statute exactly like ours is Iowa, in which at one time was in force a section like the one first quoted in this opinion. Under that in Brown v. Tuthill, 1 G. Greene (Iowa) 189, it was held that a "lien by attachment will hold against a prior unrecorded deed." The section of the statute was soon after modified, and in a case arising under the

18 Not uncommonly the statutes extend the protection to creditors. By construction, however, the benefit of such statutes gencrally has been limited to lien creditors. See the cases referred to in 24 Am. \& Eng. Encyc. of Law, 126 et sel.

19 A portion of the opinion, in which the court reriers the statutes of a number of states and the decisions thereunder, is omitted.

20 That is, besides Missouri. See Daris r. Owenly. 14 Mo. 170, $55 \mathrm{Am}$. Dee. 105 (1851), quoted from and relied upon in the portion of the opinion omitted. 
new law, (Norton v. Williams, 9 Iowa, 52S), the court says: "We incline to the opinion that, under the statute of 1843, the case of Brown v. Tuthill is against the current of the decisions."

The weight of authority, therefore, upon the exact statute before us, is decidedly with the conclusion we have reached. Without extending this opinon, we close by saying that our conclusion gives full and exact force to the statute which creates and defines a judgment lien; that it is in accord with the prior adjudications of this court; that it sustains and enforces the real equities of all parties; and that it is upheld by the decided weight of authority elsewhere upon the exact question.

The judgment will be affirmed. All the Justices concurring. ${ }^{21}$

\section{STERNBERGER \& WILLARD v. RAGLAND.}

(Supreme Court of Ohio, 1S97. 57 Ohio St. 14S, 4S N. E. S11.)

Error to the Circuit Court of Jackson county.

On the 22d day of January, 1889, the defendant in error, William Ragland, purchased a town lot in Jackson, from the Wood-Coffman Manufacturing Company, then the owner thereof, and obtained a deed for the same in fee simple. He paid a part of the purchase price, at the time of the conveyance to him, and gave a mortgage on the lot to secure the payment of the balance. This mortgage, which contains a recital that it was given to secure the unpaid purchase money, was recorded in April, 1889. The deed was never filed for record. After the conveyance was made and the mortgage recorded, judgments were recovered in the court of common pleas of Jackson county, against Ragland's grantor, which were purchased in good faith by the defendant in error, Morris L. Sternberger, who paid full value therefor; and executions issued thereon were levied on the lot in question, which then appeared of record to belong to the judgment debtor, and it was thereafter sold under the writs to satisfy the judgments. Sternberger became the purchaser at the sale, which was confirmed by the court, and the sheriff in pursuance of the order of the court executed a deed to Sternberger for the lot, in due form of law, which he caused to be placed upon record. The proceeds of the sale, after payment of the costs and taxes, were applied under the order of the court toward the satisfaction of the judgments. Sternberger then sold, and conveyed by quitclaim deed, the undivided one-half of the lot to his co-plaintiff in error, Henry S. Willard, who paid full value therefor, and promptly placed his deed on record.

21 Under the Ohio mortgage registry statute a judgment lien takes precedence over a mortginge exccuted before the lien attaclied, but recorded after. Jackson v. Luce, 14 Ohio, 514 (1S46). But it seems that in Ohio recording of mortgages is really a part of their execution. 
Thereafter, Ragland brought suit to quiet his title to the lot agctinst Sternberger and Villard, who set up their respective claims to its ownership. The case went on appeal to the circuit court where a finding was made of the facts, which, in addition to those already stated, are as follows: "The lot described in the petition was not improved, or fenced, and not occupied except occasionally for the storage of small quantities of lumber by the plaintiff, and some fence posts have remained and still remain on said lot; otherwise, said lot was vacant, and, at the time of the purchase by said Sternberger, at sheriff's sale, the character and nature of the plaintiff's possession was not of such nature as to place said Sternberger upon inquiry or notice, nor was it of such a character as to place said Willard upon incuiry nor notice when he purchased. The Wood-Coffman Manufacturing Company was, upon the deed records of said county, the apparent owner when the sheriff's sale was made. The defendant, Morris L. Sternberger, when he purchased said lot at sheriff's sale, paid value therefor in the purchase of said judgments, and he had no notice, actual or constructive, of plaintiff's claim thereto, unless the mortgage of plaintiff to said company was constructive notice, which we hold not to be constructive notice to him; and the defendant, Willard, when he purchased from said Sternberger, paid value therefor, and he had no notice, actual or constructive, of plaintiff's claim, unless such mortgage was constructive notice, which we hold was not constructive notice to him; and neither of the defendants had notice of plaintiff's deed to said lot or claim thereto."

Upon this state of facts the court held, as its conclusions of law, as appears from the record that: "The IVood-Coffman Manufacturing Company having conveyed said lot by deed to plaintiff, although said plaintiff never had said deed recorded, had no further interest in said lot which conld be sold at judicial sale, although it was the apparent owner of said lot upon the records, and the defendant, Sternberger, though purchasing said lot for value and without notice, could not obtain title thereto by purchasing at said judicial sale."

Thereupon judgment was rendered against Sternberger and Willard, which they seek to have reversed here.

Williams, J. The question in the case is whether Sternberger, under the judicial sale, became a bona fide purchaser within the rule which protects such purchasers against unrecorded conveyances. It must be regarded as established by the facts found in the court below, that there was not such possession of the lot by Ragland as put Sternberger upon inquiry, or charged him with notice of any claim or equity of the former, either, when the judgments were recovered, or the executions levied, or when the sale was made and confirmed, or the deed from the sheriff was received by Sternberger; and also, that Sternberger was without any actual knowledge of Ragland's unrecorded deed, or of any claim by him to any interest in the lot.

The record of the mortgage executed by Ragland for the unpaid pur- 
chase money for the lot, was not constructive notice of his anregistered deed, to a subsequent purchaser from his grantor.

When a prospective purchaser finds a complete record title in the proposed seller, he is not bound to examine for mortgages made to the latter after he becane the owner; such a mortgage is not in the chain of his title, and is not, therefore, constructive notice to a subsequent purchaser, of a prior unrecorded deed made by him to the mortgagor. The circuit court so held. But, notwithstanding its finding that Sternberger was a purchaser at the judicial sale for value and without notice, actual or constructive, of any adverse claim of Ragland to the premises he so bought, the judgment of the court was adverse to him. The judgment appears to rest upon the ground that the deed to Ragland, though unrecorded, divested his grantor of all interest in the lot, and thereafter nothing remained in the judgment debtor, although appearing of record to be the owner of the lot, upon which the judgments became liens, or that could be sold at judicial sale thereunder.

It is undoubtedly the general rule, except in so far as it is modified and controlled by statute, that a judgment creditor obtains a lien only on such interest in lands as his debtor had when the judgment was rendered, and, it is subject to such equities as could then be successfully asserted against the debtor. But our statute (section 4134, Revised Statutes 1890), requires that all deeds and instruments for the conveyance of lands, or interests therein, "shall be recorded in the office of the recorder of the county in which the premises are situated," and provides that, "until so recorded or filed for record, the same shall be deemed fraudulent, so far as relates to a subsequent bona fide purchaser, having, at the time of purchase, no knowledge of the existence of such former deed or instrument." This statute renders any prior unrecorded deed wholly ineffectual to convey the title out of the grantor, as against a subsequent bona fide purchaser from him, and leaves him with as full and ample power to convey a good title to such subsequent purchaser as if the prior conveyance had not been made. And, it is settled by the adjudications of this court, that purchasers at judicial sales, without notice of a prior unrecorded deed from the judgment debtor, are within the protection of the statute equally with purchasers at pritate sale. Scribner's Lessee v. Lockwood, 9 Ohio, 184; Morris v. Daniels, 35 Ohio St. 406.

The title acquired by Sternberger at the judicial sale was, therefore, superior to that of Ragland, unless the former is to be denied the position of a bona fide purchaser because he was the owner of the judgments under which the sale was made.

It is claimed that as he was the owner of the judgments at the time of his purchase, and their satisfaction pro tanto was the only consideration he paid, he does not come within the rule in favor of bona fide purchasers. This position is sought to be sustained by Lewis v. Anderson, 20 Ohio St. 281. But that case simply holds, that: "Where there 
is no consideration for a mortgage of real estate other than a pre-existing debt of the mortgagor, and the mortgagee is not induced thereby to change his condition in any manner, he cannot be regarded as a bona fide purchaser for value."

That decision is placed upon the ground, as stated in the opinion, that, "the rule which favors a bona fide purchaser of land, and that which protects the holder of negotiable paper for value before due from infirmities affecting the instrument before it was transferred, are based substantially on the same equitable grounds, and upon the policy of the law which favors trade and the security of titles, as conducive to the public good." And in that case, Roxborough v. Messick, 6 Ohio St. 448, 67 Am. Dec. 346, is cited, where the rules applicable in determining what considerations are sufficient to protect the holders of commercial paper are fully considered, which, as there laid down, have since been regarded as the settled law on that subject. It is there held, that while a voluntary transfer of a negotiable instrument to secure a pre-existing debt, where the parties are left in respect to such debt in statu quo, there being no new consideration, stipulation for delay, or credit given, or right parted with, is not sufficient to protect the holder against equities existing between the prior parties at the time of the transfer, yet, when the note is transferred in payment of the precedent debt, the consideration is sufficient to entitle the holder to such protection. "The weight of authority," says Swan, J., in that case, "seems to settle the principle, that where a negotiable instrument of a third person is transferred before due, in payment of a pre-existing debt, and is bona fide received by the creditor, without notice, the defenses existing as between the prior parties cannot be set up against such holder." And that learned judge further says, in that case, that there is "no substantial difference between the consideration for the transfer of negotiable paper in payment of a precedent debt, or in payment of goods sold at the time of such transfer." Applying these principles to a purchaser of real property, it was held in Clements v. Doerner, 40 Ohio St. 632, that a purchaser who takes a conveyance of real estate in payment of a pre-existing debt is a bona fide purchaser for value, and entitled to be protected as against a prior defective mortgage made by his grantor. When the conveyance is received in payment of the debt, there is a change in the situation of the parties; the debt is for the time being, at least, discharged; and, though the creditor may be restored, upon failure of his title to the property, to his right to enforce the collection of the debt, so recovery may be had for any other consideration parted with for the property, where the title for any cause fails.

If it be said Sternberger could have the satisfaction of his judgments vacated and new process issued for the collection of the judgments out of any property of the judgment debtor, so, any stranger, who might have become the purchaser at the sale, would be entitled to the same remedy. Revised Statutes 1890, $§ \S 5410,5412$. The necessity 
of resorting to such a remedy is sufficient, of itself, to show that a substantial change occurred in the situation of the parties by the satisfaction of the judgments on the confirmation of the sale; and the neglect of Ragland to have his deed placed on record, does not entitle him to drive the purchaser, in either case, to that remedy. Had Sternberger made his purchase at private sale, instead of at a judicial sale, there could be no doubt, we think, of the superiority of his right to the property over that of Ragland; and his right in that respect is none the less, because the conveyance was made through the instrumentality of the sheriff and the forms of judicial proceedings, instead of immediately from the judgment debtor. The deed of the sheriff conveyed a title as good and complete as the judgment debtor could have conreyed.

In the note to Basset v. Nosworthy, 2 Leading Cases in Equity, 110, 111 , the conclusion reached after a full discussion of the subject, and review of the cases, is that the weight of authority in this country is "in favor of the proposition that a purchaser at a judicial sale, stands on the same footing with a purchaser directly from the debtor; and, that a purchaser at such sale will take the land discharged of any claim or title, whether arising under an unregistered deed, or a mere equity, of which he had no notice at the time of the purchase, and which would be invalid as against an ordinary purchaser ;" and furthermore, that the rule is the same "when the judgment creditor becomes the purchaser, because the money which he pays goes in satisfaction of the debt; and every additional bid is necessarily an advantage to the defendant in the judgment." The following, among others, may be added to the cases there cited in support of the rule as stated: Foorman v. IVallace, 75 Cal. 552, 17 Pac. 680; Evans v. McGlasson, Is Iowa, 150; Butterfield v. WValsh, 21 Iowa, 97, 89 Am. Dec. 557 ; Rorer on Judicial Sales, sec. 866.

Judgment reversed and judgment for the plaintiffs in error. ${ }^{22}$

22 Minshall and Spear, JJ., dissented in part and from the judgment of rerersal.

See Shirk v. Thomas, 121 Ind. 147, 22 N. E. 976, 16 Am. St. Rep. $3 \$ 1$ (1SS3), semble contra.

Compare Cary r. White, 52 N. Y. 198 (1573), where a mortgage given as security for a pre-existing debt, there being no surrender of securities nor extemsion of time by the mortgagee, was held to be inferior to an earlier unrerolded deed of the mortgagor. See, too, Western Grocer Co. v. Alleman, S1 Kan. 543, 106 Pac. 460, 27 L. R. A. (N. S.) 620, 135 Am. St. Rep. 398 (1910).

A., a creditor of $X$., acquires a lien by judmment unon land of $X$. in a state where creditors are within the protection of the recording acts. A. has no notice of an earlier unrecorded deed by $\mathrm{X}$. On sale of the land under A.'s judgment, B., who linors all about the unrecorded deed, purchases same and rereires a deed therefor. What is the situation as between him and the grantee in the unrecorded deed? See Grace v. Wade, 45 Tex. 522 (1876). 


\section{STRONG v. WHYBARK.}

(Supreme Court of Missouri, 1907. 204 Mo. 341, 102 S. W. 968, 12 L. R. A. [N. S.] 210, $120 \mathrm{Am}$. St. Rep. 710 .).

Woodson, $J$. This is a bill in equity, instituted in the circuit court of Butler county, wherein plaintiff seeks to have her title quieted to five hundred and twenty acres of land. John R. Boyden was one of the several defendants named in the bill. He filed an answer claining an interest in and to one hundred and sixty acres of said land, and also denied generally the allegations of the bill. No point is made against the pleadings, and he is the only defendant whose interest is involved in this appeal.

The facts in the case are undisputed and are as follows:

Seth D. Hayden was the common source of title, and on March 6, 1861 , by his warranty deed, for a recited consideration in the deed of six hundred and forty dollars, conveyed said land to William A. Moore, and on August 26, 1863, said Hayden, by his quitclaim deed, for a recited consideration of "natural love and affection and five dollars," conveyed the same land to Josephine Hayden. The deed to Hayden was recorded April 11, 1868, and the one to Moore was recorded December 14, 1874 .

The plaintiff's title is derived through mesne conveyances from Josephine Hayden, while defendant's title is derived through similar conveyances from IVilliam A. Moore. It was admitted that the land -was wild and unoccupied. This was all the evidence in the case.

The court found for defendant and rendered judgment for him. The plaintiff in due time filed his motion for a new trial, which was overruled by the court, and to the action of the court in overruling said motion the plaintiff duly exccpted, and has appealed the cause to this court.

I. The sole question involved in this case is, did the subsequently executed quitclaim deed of Seth D. Hayden to Josephine Hayden, dated August 26, 1863. by virtue of its prior recordation, have the force and effect of conveying to her the title to the land in controversy by force and operation of the registry act, and thereby render invalid and inoperative the prior warranty deed made by him to William A. Moore, dated March 6, 1861, but not filed for record until December 14, 1874?

There is no evidence whatever in this record tending to show that Josephine Hayden had any notice or knowledge of the execution of the prior unrecorded warranty deed from Seth D. Hayden to said Moore, at the time he made the quitclaim deed to her, nor is there any evidence of fraud or collusion between Seth D. Hayden and Josephine Hayden. Both William A. Moore and Josephine Hayden neglected for years to file their deed for record, as provided for by section 923, Revised Statutes 1899, yet the latter filed her deed about six years prior to the time when he filed his. 
The statute provides that "no such instrument in writing shall be valid, except as between the parties thereto, and such as have actual notice thereof, until the same shall be deposited with the recorder for record." Rev. St. 1899 , § 925.

According to the provisions of this section, the deed from Hayden to Moore was invalid and conveyed no title to the land in controversy in so far as Josephine Hayden was concerned, because she had no notice of its execution at the time she filed her deed for record. If the exception mentioned in the section just quoted was the only exception or limitation to that statute, then there would be no question as to the title of Josephine Hayden and those claiming under her, but the courts upon principles of equity and justice have repeatedly held that if the subsequent purchaser either had notice of the prior unrecorded deed, or if he was a purchaser without having paid a good and valuable consideration for the land, then he would take nothing by his purchase and deed. Maupin v. Emmons, 47 Mo. 304; Aubuchon v. Bender, 44 Mo. 560. The question which now presents itself is, was Josephine Hayden a purchaser of the land in question for a good and valuable consideration? The deed recites that the conveyance was made for and in "consideration of natural love and affection and five dollars to him in hand paid by the party of the second part, the receipt of which is hereby acknowledged."

A valuable consideration is defined to be money or something that is worth money. 2 Washburn on Real Prop. (4th Ed.) p. 394; 1 Chitty on Contracts (11th Am. Ed.) 27. It is not necessary that the consideration should be adequate in point of value. Although small or even nominal, in the absence of fraud, it is enough to support a contract entered into upon the faith of it. Forbs v. Railroad, 107 Mo. App. loc. cit. 674, 82 S. IV. 562 ; Marks v. Bank, S Mo. 316; Ridenbaugh v. Young, 145 Mo. loc. cit. 280, 46 S. IV. 959; Blaine v. Knapp \& Co., 140 Mo. loc. cit. 251, 41 S. W. 7S7; Anderson v. Gaines, 156 Mo. 664, 57 S. W. 726; Green v. Higham, 161 Mo. 333, 61 S. W. 798, 6 Am. and Eng. Ency. Law (2d Ed.) p. 694, par. 5. It seems to us that it would be a useless waste of time and energy to cite authorities in support of the proposition that five dollars or any nther stated sum of money in excess of one cent, one dime, or one dollar, which are the technical words used to express nominal considerations, is a valuable consideration within the meaning of the law of conveyancing. ${ }^{23}$

23 In Morris v. Wicks, 81 Kan. 790. 106 Pac. 1048,26 L. R. A. (N. S.) 681, 19 Imn. Cas. 819 (1910), the consideration pair was one dollar. Held not suffiriont to make ont a case of bona ficle purchaser for ralue. But in Ennis v. Tucker, 68 Kan. 55. 96 Pac. 140. 130 Am. St. Rep. 552 (1908), a consideration of \$10, though inadequate, was held suflicjent to make out a case of purchaser for rallue.

In 'Ten Eyck v. Witbeck, 185 N. Y. 40, 31 N. I. 994. 31 Am. St. Rep. S09 (1892), the sulbseruent conveyance was made to a child of the grantor in considera$1 \mathrm{im}$ of $\$ 10$ paid and an agreement by the grantee to pay annually to designated presons the receipts from the property. The property was worth twenty thou- 
It has been suggested that a quitclaim deed is notice of pre-existing eqtities, and that those who claim under Josephine Hayden had notice that her title to this land was questionable, and that neither she nor they could defend upon the ground that they were bona fide purchasers for valuable consideration without notice of the title of the true owner. Stivers v. Horne, 62 Mo. 473; Mann v. Best, 62 Mo. 491 ; Ridgeway v. Holliday, 59 Mo. 444.

But the rule last suggested has no application to a case where the grantee under a subsequent quitclaim deed from the same grantor acquired the title for value and without notice of the former unrecorded deed. Fox v. Hall, 74 Mo. 315, 41 Am. Rep. 316. "A purchaser for value by quitclaim deed is as much within the protection of the registry act as one who becomes a purchaser by a warranty deed." Munson v. Ensor, 94 Mo. loc. cit. 509, 7 S. IV. 110; Campbell v. Gas Co., St Mo. 352; Brown v. Coal Co., 97 Ill. 21t, 37 Am. Rep. 105; Eilliott v. Buffington, 149 Mo. loc. cit. 676,51 S. W. 408; Ebersole v. Rankin, 102 Mo. 48s, 15 S. W. 422.

Where the controversy is between the vendee of a duly recorded deed and the vendee of a prior unrecorded deed from the same vendor, the settled rule of law in this State seems to be that the consideration in the latter must be such as the law denominates a valuable consideration as distinguished from a good consideration. We know of no case which has gone farther and holds that the purchaser under the recorded deed must have paid a full and adequate consideration for the land.

If fraud is made an issue in the case, then the inadequacy of the consideration paid may be taken into consideration with all the other facts and circumstances in the case for the purpose of establishing fraud; but in the absence of fraud, a want of consideration cannot be shown against a recital of consideration for the purpose of defeating the operative words of a deed. Bobb v. Bobb, 89 Mo. 411, 4 S. W. 511; Henderson v. Henderson's Ex'rs, 13 Mo. 151; Hollocher, v. Hollocher, 62 Mo. loc. cit. 273; McConnell v. Brayner, 63 Mo. loc. cit. 463; McCrea v. Purmort, 16 Wend. (N. Y.) 475, 30 Am. Dec. 103; Farrington v. Barr, 36 N. H. 86; Kimball v. WValker, 30 In. 511.

sind dollars. Held that the child was not a purchaser for raluable consideration under the recording statute so as to be preferred over an earlier unrecorded deed of the same grintor. The court said: "We deem it unnecessary to undertake to determine here what degree of adequacy of price is required to uphold a subsequent deed first recorded. Upon this branch of the case we have no occasion to go, farther, than to hold that a small sum, inserted and paid, perhaps because of a popular belief that some slight money consideration is necessary to render the deed valid, will not of itself satisfy the terms of the statute, where it appears upon the face of the conveyance, or by other competent evidence, that it was not the actual consideration."

See, also, Dunn v. Barmum, 51 Fed. 355, 2 C. C. A. 265 (1S92), wliere the consideration for the second conveyance was $\$ 100$, the property then being worth $\$ 30,000$, and at time of the suit $\$ 1,000,000$. 
In the case at bar, however, there was no evidence introduced tending to prove the recited consideration of five dollars was not in fact paid.

Counsel for defendant, in both his oral and written arguments, contends that Josephine Hayden procured her deed from Seth D. Hayden by fraud. It is a sufficient answer to that to say that no such issue is made by the pleadings in the case, nor was there a word of evidence introduced at the trial tending to establish that fact.

If defendant wished to rely upon fraud as a defense, he should have alleged and proved it. The burden of proving such an issue is upon the defendant. Jackson v. Wood, SS Mo. 76; Namman v. Oberle, 90 Mo. 666, 3 S. W. 3S0; Taylor v. Crockett, 123 Mo. 300, 27 S. W. 620.

It follows from what has been said that the judgment of the circuit court must be reversed, and the cause remanded for a new trial. All concur. ${ }^{24}$

\section{THOMAS v. STONE \& GRAHAM. \\ (Court of Chancery of Michigan, 184\%. Walker Ch. 117.)}

This was a bill to foreclose a mortgage.

The complainant, January 31st, 1837 , in consideration of $\$ 900$, conveyed to Stone certain real estate situate in Auburn, Oakland county, and took back a mortgage on the same premises, for $\$ \$ 00$ of the purchase money. On the 24th day of August following, and before the mortgage to Thomas was recorded, Stone conveyed the premises to Graham by warranty decd, which was recorded on the same day. The bill cliarged Graham with notice of the mortgage when he purchased, and that nothing had been paid by him to Stone. Graham, by his answer, denied all notice, and stated that, at the time of the execution of the decd to him, he executed and delivered to Stone his obligation for $\$ 200$, which was umpaid, and also a bond in the penal sum of $\$ \$ 00$, conditioned to reconvey a part of the premises to Stone, on his return from the South, where he expected to be gone five years. The bill was taken as confessed against Stone, who was a non-resident defendant. Several witnesses were examined by complainant; and Graham, by consent of the partics, was examined concerning the consideration that had been paid by him.

Tine Chancellor. ${ }^{25}$ The mortgage to Thomas and the deed to Graham, were given long before the Revised Statutes took effect; and, 1)y the statute in force at the time for the registry of mortgages, it was provided that no mortgage, nor any deed, conveyance, or writing, in the nature of a mortgage, should defeat or prejudice the title or inter-

24 See, further, Brown r. Welch, 1 Ill. 343,68 Am. Dec. 549 (1857).

25 A portion of the opinion is onitted. 
est of any bona fide purchaser of any lands or tenements, unless the same had been duly registered. Laws of Michigan 1833, p. 284, $\S 2$.

A plea of a bona fide purchaser without notice must aver not only a want of notice at the time of the purchase, but also at the time of its completion, and of the payment of the money. The money must have been actually paid before notice. If a part has been paid, and a part remains unpaid, the purchaser will be protected in what he has paid, but not in any subsequent payments made by him. Frost v. Beeknan, 1 Johns. Ch. (N. Y.) 301 ; Jewett v. Palmer, 7 Johns. Ch. (N. Y.) $65,11 \mathrm{Am}$. Dec. 401. This is what is meant by bona fide purchaser in the act referred to. Dickerson v. Tillinghast, 4 Paige (N. Y.) 215, 25 Am. Dec. 52S. There is no difference "between a purchaser in good faith, under the recording act, and a bona fide purchaser within the decision of Courts of Equity in other cases." Grimstone v. Carter, 3 Paige (N. Y.) 421, 24 Am. Dec. 230. The registry laws were designed to protect subsequent purchasers and mortgagees, who had parted with their money, and taken a deed, against prior conveyances by their grantors, of which they had no notice. They were not made for the protection of prior purchasers or mortgagees, who stood in need of nothing of the kind. But equity will not permit a subsequent purchaser to use what the law has placed in his hand as a shield, for a purpose not necessary to his protection, and to the injury of a prior bona fide purchaser. By the English registry laws all prior conveyances are declared fraudulent and void against subsequent purchasers, whose deeds are first recorded. Sug. on Vend. 49S. And, at law, the last conveyance, when first recorded, carries with it the legal title, although the vendee had notice of the prior conveyance; but in equity, where the intention is looked at, rather than the words of the registry act, he is held to be bound by the previous conveyance. Sug. on Vend. 511, Ed. of 1820 .

Graham denies he had any notice of the mortgage when. he purchased; and there is no positive evidence on that point. The transaction, when viewed in all its parts, looks much like a piece of contrivance to defraud Thomas. It is not necessary, however, to go into the testimony; for, admitting Graham had no notice of the mortgage, still he is not a bona fide purchaser. He has paid nothing. It is not enough that the party has secured the purchase money; he must have paid it, or became bound for it in such a way that this Court could not relieve him from the payment of it; as, by a promissory note, which had been negotiated, or the like. The bond for $\$ 200$, if it has been assigned by Stone; (of which there is no evidence,) would, in the hands of the assignee, be subject to all equities existing against it before it was assigned. * * *

Reference to Master to compute amount due, \&c. ${ }^{26}$

2f What would be the situation where notice of the earlier conreyance or claim is received after part, but not all, of the consideration has been paid? Arg.Prop. -56 


\section{MARSHALL v. ROBERTS.}

(Supreme Court of Minnesota, 1822. 1S Mimm. 40 J [Gil. 365], 10 Am. Rep. 201.)

The plaintiff, claiming that the defendant was the owner of certain real estate, and that after having sold and conveyed the same to him, and knowing his deed was unrecorded, he sold and conveyed the same premises to other parties, who were purchasers in good faith, and whose deeds were recorded, brought this action to recover damages therefor. At the trial, after the plaintiff had introduced his evidence and rested, the defendant moved for a dismissal of the action. The court granted the motion and judgment of dismissal was entered. The plaintie appeals to this court. The facts upon which the decision is based, are fully stated in the opinion of the court.

BERRY, J. For the purpose of determining the only question necessary to be considered in this case, we may assume that the following propositions, which plaintiff claims to have proved, or to have offered to prove, are true as matter of fact:

1st. That on the 12th day of May, 1860, Louis Roberts was the owner of lot four, in block four, of the town of St. Paul, according to the recorded plat thereof.

2d. That on said 12th day of May said Roberts, together with his wife, executed and delivered to the plaintiff, Joseph M. Marshall, a quit-claim deed of all their right, title, interest, claim, and demand, in and to said lot, which deed through inadvertence on plaintiff's part has never been recorded.

$3 \mathrm{~d}$. That on the $2 \mathrm{~d}$ day of August, 1865, said Roberts (well knowing his deed to Marshall, and Marshall's inadvertent omission to have the same recorded) for a valuable consideration, executed and delivered (his wife joining) to Uri L. Lamprey a quit-claim deed of all their right, title, interest, claim and demand in and to said lot, which deed was duly recorded August 3d, 1865, the said Lamprey at the time of said conveyance to him, and at the time of paying the consideration therefor, having no notice of the aforesaid conveyance to the plaintiff.

4th. That on the 22d day of May, 1867, said Lamprey and wife, for a valuable consideration, executed and delivered to William J. Cutler a warranty deed of said lot, which was duly recorded on the 29 th day of May, 1867, the said Cutler at the time of such conveyance to him, and at the time of paying the consideration therefor, having no notice of said conveyance to the plaintiff, and having purchased in good faith.

Plaintiff's claim is, that by reason of defendant's deed to Lamprey, and the recording thereof, he (plaintiff) has lost his title to the lot in question, and has therefore suffered damage to the value of said lot, which damage he seeks to recorer of defendant in this action.

Bearing on the general question, see Youst v. Martin, 3 Serg. \& R. (Pa.) 423 (1S17); Wenz r. Pastene, 209 Mass. 359,95 N. E. 793 (1911). 
If the deed from Roberts to plaintiff conveyed nothing to slaintiff, the subsequent deed to Lamprey can have taken nothing away from him, or, in other words, it cannot have danaged the plaintiff.

If on the other hand, as would appear from the facts before assumed, the deed from Roberts to plaintiff conveyed a good, title to the lot in question, or any right, title, interest, claim or demand in or to it, then, neither such good title, nor any such right, title, interest, clain or demand, could be taken away or impaired by the subsequent conveyance to Lamprey. For the deed to Lamprey is a quit-claim deed in common form, the effect of which, under our statute, is to pass such estate as the grantor could lawfully convey by the ordinary deed of bargain and sale. In Martin v. Brown, 4 Minn. 291 (Gil. 201), it is held that the legislature by the words "lawfully convey," intend to limit the estate conveyed by a quit-claim deed; to such as the grantor has a legal right to convey, and that as he may not lawfully convey land which he has already conveyed to another, nothing passes by such deed beyond the grantor's actual interest at the time of the conveyance. And in Hope v. Stone, 10 Minn. 152 (Gil. 114), where there was a conveyance (by warranty deed) of all the right, title, interest, etc., etc., of the grantor in and to certain land, it was held that nothing passed to the grantees by the conveyance which the grantor had previously conveyed to the other parties. See also cases there cited. In Everest v. Ferris, 16 Minn. 26 (Gil. 14), the rule thus laid down in Martin v. Brown, is reiterated; and independently (so far as appears) of any statute, it is held in May v. Le Claire, 11 Wall. 232, 20 L. Ed. 50, that a party who has acquired his title by a quitclaim deed cannot be regarded as a bona fide purchaser without notice, and that such conveyance passes the title as the grantor held it, and the grantee takes only what the grantor could lawfully convey.

The provisions of our statute in regard to the effect of recording and failing to record deeds, are also in entire harmony with the views expressed in the case cited. Section 54, ch. 35, Pub. Stat., which seems to have been in force at the time when Roberts made the deed to Lamprey, enacts that every conveyance by deed, \&c., shall be recorded, \&c., and that every such conveyance not so recorded shall be void, as against any subsequent purchaser in good faith and for a valuable consideration, of the same real estate or any portion thereof, whose conveyance shall be first duly recorded. Substantially the same provisions as those above mentioned, are also found in section 24 , c. 46 , Rev. Stat. and section 21, c. 40, Gen. Stat., so that our statute in this particular seems to have remained unchanged. These provisions, as will appear upon a moment's reflection, so far from militating against the views expressed in the cases cited, come to their aid, since it is only the purchaser of the same real estatc, or any portion thereof, who by his priority of record cuts out the title of a prior purchaser. For when the second purchaser obtains by his quit-claim deed only what his grantor had (his grantor's right, title and interest) at the time 
when such deed was made, he is not a purchaser of the same real estate (or any part thereof) which his grantor had previously conveyed away and therefore no longer has. But besides this, the grantee in a quit-clain deed like that from Roberts to Lamprey, though he may not in fact have known that his grantor had previously conveyed the described premises to another, and though he may not in fact have intended to defraud such prior grantee, is not a purchaser in good faith as against such prior grantee, for nothing is attempted to be transferred to him, except whatever right, title, \&c., the grantor has at the time when the quit-claim deed is executed, so that as in the case of Hope $v$. Stone the very terms of the deed are notice of the existence of the rights which have been conferred upon such prior grantee, or any other person.

These considerations, as it seems to us, dispose of this case and prevent us from reaching the questions mainly discussed by plaintiff's counsel. The judgment entered below dismissing the action is affirmed. ${ }^{27}$

27 American Morts. Co. v. Mutchinson, 19 Or. $33 t, 2 t$ Pac. 515 (1S90), acc. Wickham v. Henthom, 91 Iowa, 242, 59 N. W. $276(1894)$; Reed v. Kunghts, st Me. 1S1, 32 Atl. S70 (1895); Messenger v. Peter, 129 Mich. 93, SS N. W. 209 (1901): Fowler v. Will, 19 S. D. 131, 102 N. W. 598, 117 Am. St. Rep. 9:3s. S Ann. Cas. 1093 (1905); Thorn v. Newsom, 64 Tex. 161, 5:3 An. Rep. 747 (1SS5), accol's in result.

"Under the cloak of quitclaim deeds, schemers and speculators close their exes to honest and reasonable inquiries, and trathc in apparent imperfections in titles. The usual methods of conveying a good title-one in which the grantor has confidence-is by warranty deed. The usual method of conveying a doubtful title is by quitciaim deed. The rule is wise and wholesome which holds tlat those who take by quitclaim deed are not bona fide purchasers, and take only the interest which their mrantors had." Peters v. Cartier, 80 Mich. 124, $129.45 \mathrm{~N} . \mathrm{T} .73,74,20 \mathrm{Am}$. St. Rep. $50,5(1 \leqslant 90)$.

"While nonregistered deeds are declired void by the statute as to subsequent purchasers for value and mithout notice, still the doctrine is well settled that a subsequent purchaser, although for value and withont actual notice, who takes muder strictly a quitclaim leed-that is, one by which the chance of litle, and not the land itself, is conveyed-rill not be accolded the protection of the statute, for the obrious reason that he contracted for the interest only that his venclor then had in the land. If the rendor had previously divested hinself of the title to a portion or all of the land, to the extent of the divestiture there would be no right remaining in the rendor to pass by the quitclaim to the vendee. It is, then, the interest of the vendor for which he contracts, and it is to such interest only that he is entitled under the quitclaim deed." Thorn v. Newsom, supra.

After the decision in Marshall $\nabla$. Roberts, the Minnesota Legislature amended the recording statute so that a rantee in a subsequent quitclaim deed would be on the same footing, as to prior mmecorded deeds, as a grantee in a harwill and sale deed. Strong, L. Lyn, 38 Minn. $315,37 \mathrm{~N}$. W. 448 (1SSS). And in Maine the lule of Reed v. Knights, supra, has been changed by statute. Iier. st. 1903, c. $75, \S 11$. 


\section{SMITH'S HEIRS v. BRANCH BANK AT MOBILE.}

(Supreme Court of Alabama, 1852. 21 Ala. 125.)

Chilton, J. ${ }^{28}$ In order to disembarrass this case from the confusion in which so many mesne conveyances involve it, we may consider Smith, the defendant, as the vendor to Dubose and Kible, and as holding their mortgage to secure the purchase money. We may then, without changing the legal effect of the facts, lay out of view the sale to Meggison by $D$. and K., and the foreclosure of the mortgage taken by them; since the land was purchased by their agent, J. C. Dubose, who was the mere conduit for convenience sake of the interest of Dubose and Kibbe to the Bank.

It is too clear to admit of doubt, that an unrecorded mortgage, as between the parties themselves, is valid and binding. It is also valid as to all subsequent creditors or purchasers with notice of its existence. Smith v. Zurcher, 9 Ala. 208; Myers v. Peek's Adm'r, 2 Ala. 648; Tuttle v. Jackson, 6 Wend. (N. Y.) 226, 21 Am. Dec. 306.

It is equally clear, that if the mortgagor sells the land to an innocent bona fide purchaser, taking a mortgage from him to secure the purchase money, and obtains a decree of sale upon a foreclosure suit, at which, by himself or his agent, he becomes the purchaser, he is not in a condi tion to invoke the protection afforded a bona fide purchaser without notice, so as to defeat the mortgage he has executed to his vendor; for this would be to take advantage of his own wrong. "His conscience," says Judge Story, "is still bound by his meditated fraud, and if the estate revests in him, the original rights attach." 1 Story's Eq. § 410. The case, then, resolves itself into this: Considering Dubose and Kibbe as mortgagors to Smith, whose mortgage was not recorded, and as the vendors to the Bank, through their agent, J. C. Dubose, who swears he was a mere naked trustee, without any interest whatever, does the Bank, under the circumstances, and in view of the character of the deed executed to it, occupy the position of a bona fide purchaser for a valuable consideration without notice, within the meaning of our statutes declaring mortgages of real estate not recorded within sixty days to be void as against such purchasers?

The instrument under which the Bank claims, is a quit claim deed, or, what is more appropriately designated by the common law term, a release. The effective words are, "that the said Dubose doth remise, release and forever quit claim, all his right, title, claim, \&c., unto the said Branch Bank, in the full and actual possession now bcing, and its successors and assigns forever." It is said in the Touchstone (p. 320) that the words most common and appropriate in a release, are, remisi, relaxavi, and quietum clamavi; and that a relcase may enure by way of passing the estate, as where one joint tenant or co-parcener releases

${ }_{28}$ The statement of facts and a portion of the opinion are omitted. The case appears from the opinion. 
his right to the other; or by way of passing the right, as where the disseisce releases to the disscisor; or, it may operate by way of enlarging an estate, where the releasee lias an estate capable of being enlarged, and is in privity with the releasor; or by way of extinguishment. Gilb. on Ten. 55 ; Shep. Touch. 321; Co. Lit. 272; Bouv. Inst. vol. 2, p. 412.

At the common law; it is said, a frechold title could be released in Give ways: 1. To the tenant of the freehold in fact or in law without any privity; 2. To the remainder-man; 3. To the reversioner without privity; 4. To one having a right only by privity; and, 5. To one having a privity only without right. 2 Bouv. Inst. 412; Gilb. Ten. 53 ; Co. Lit. 265. So that, according to the principles of the common law governing releases, the Bank, the releasee in this case, filling none of the above requisites, would not take the title of the releasor. But in this conntry, the technical rules relating to a release are generally held not to apply, and a quit claim deed is considered as passing the title of the releasor, withont any warranty as to outstanding titles or incumbrances, but merely against the grantor himself, and those claiming under him, by descent, or by subscquent conreyances of the same interest previously transferred.

The grantor in this case only purports to release and quit claim the title and interest which he had. The question then arises, what interest did he have? The plain answer is, the mere equity of redemption, nothing more, and this only passed by the quit claim deed. Thus the Bank stands in the place of Dubose and Kibbe, the mortgagors, holding only what they could sell, the equity of redemption.

Were we to hold that M. Dubose intended that his agent, J. C. Dubose, should sell a greater interest than he really had, and by so doing enable the Bank to shelter itself under the plea of being a bona fide 1)urchaser for a valuable consideration, so as to defeat the mortgage which D. and K. had executed to Anderson, we should impute a fraudvilent intent to the parties when the deed which their agent has entered into justifies no such inference.

The unregistered mortgage being valid and effectual as between the mortgagor and mortgagee, the subsequent sale of the entire estate by the mortgagor is a frand upon the rights of the mortgagee; and the reason. I apprchend, upon which the statute proceeds in preferring the subsequent bona fide purchaser to the mortgagee, is, that one of two imnocent persons must suffer by the frand of a third party, and the mortgagee, failing to use the diligence which the statute requires in recording his mortgage, is considered most in default, and is therefore properly adjurlged by the statute to bear the loss.

But we are not allowed by the rules of law, any more than by the principles of common charity, to suppose fraud, when the facts out of which it is supposed to arise may well consist with honesty and pure intention. Steele v. Kinkle \& Lehr, 3 Ala. 352.

We cannot, therefore, in this case presume that the vendor of the Bank attempterl to sell more than he might lawfully sell, which was 
the equity of redemption. This was his title, and this alone enures by the quit claim.

To enlarge the interest by construction, would be to make a different contract from that which the parties have entered into; would be, by judicial interpretation, contrary to the face of the deed and the facts on which it is founded, to pass the entire estate, by investing it with the consequences of a fraudulent sale of the whole, when the grantor had but the equity of redemption; and this, too, for the purpose of defeating the just lien of Smith for the purchase money which is due from Dubose and Kibbe. We feel quite confident no case can be found which carries the doctrine thus far.

The case of Oliver v. Piatt, 3 How. (U. S.) $333-410,11$ L. Ed. 622, which is cited with seeming approval by this court in Walker et al. v. iriller \& Co., 11 Ala. 1067, fully sustains us in the position, that the Bank, holding a mere quit claim deed, cannot be regarded as a bona fide purchaser for a valuable consideration without notice. And we see no reason why such purchaser should be allowed to invoke the aid of the registry statute, to avoid a prior mortgage which has not been recorded, any more than the aid of the Chancery Court for his protection.

We express no opinion as to what we should decide, had the deed to the Bank, even though it contained no warranty, purported to convey the entire title to the premises, instead merely of that which the grantor had. But we desire to limit our opinion to the facts of the case before us, lest parties should be misled as to the extent of it. * * *

After the best consideration we have been able to bestow upon this case, we are satisfied that the court mistook the law in several of the charges given. Its judgment must, therefore, be reversed, and the cause remanded.

\section{BOYNTON v. HAGGART.}

(Circuit Court of Appeals, Fighth Circuit, 1903. 120 Fed. S19, 57 C. C. A. 301.)

Sanborn, Circuit Judge. These appeals present controversies between three sets of claimants to the title to certain timber lands in the state of Arkansas. Lucetta B. Boynton and her associates, the complainants below, are the devisees under the will of C. O. Boynton, deceased, who brought this suit against James Haggart and William McMasters, hereafter called the "defendants," to quiet in himself the title to about 20,000 acres of land which he bought of the Citizens' Bank of Louisiana in the year 1883. L. D. Rozell and his associates, the heirs of A. B. Rozell, deceased, intervened in this suit, and claimed the title to a portion of these lands. There was a hearing and a decree for the defendants, which the complainants and the interveners challenge by separate appeals.

The principal question which the appeal of the complainants presents is whether or not an innocent purchaser under a deed of all the right, 
title, and interest in the lands owned by his grantor in a certain state, without a more definite description, may successfully hold the lands which his grantor appeared by the registry to own when he made this deed as against a claimant under a prior unrecorded conveyance of the same lands by the same grantor. The question arises in this way: From 1873 until October 26, 1S83, the records of the counties in which these lands were situated disclosed a complete chain of title to them from D. C. Cross, the grantee of the state of Arkansas, to the Citizens' Bank of Lonisiana. On May 3, 1880, however, a decree had been rendered in one of the courts of the state of Arliansas in a suit between the executor, the executrix, and the devisees of the will of Jeptha Fowlkes, complainants, and the Citizens' Bank of Louisiana, defendant, to the effect that the heirs of Jeptha Fowlkes were the owners of this land, and that the bank had no title or interest in it. One of the statutes of the state of Arkansas required those in whose favor such a decree was rendered to register it in the recorder's office of the county in which the lands it affected were sitnated within one year after its rendition, and provided that, "if such decree be not recorded within such time, it shall be void as to all subsequent purchasers without notice." Gould's Digest of the Laws of A.rkansas, p. 637, § 35. This. decree was not recorded until November 4, 1884.

Meanwhile, and in the year 1883, W. L. Culbertson, the agent and associate of C. O. Boynton, without any notice of this decree, purchased the lands in controversy in this stit from the Citizens' Bank of Lonisiana, paid that bank $\$ 13,000$ therefor, and took and recorded a quitclaim deed from it to himself of "all and singular its right, title, interest, and claim of whatever nature, legal and equitable in and to all the lands, lots, and parcels of land and any and all interests in the same belonging to and owned by said Citizens' Bank of Louisiana, in the state of Arkansas, at the date of this conveyance (except its lands and interest in Chicot county in said state); the said lands and interests therein conveyed being situated and lying within the counties of Clay, Crittenden, Craighead, Cross, Greene, Mississippi, Poinsett, and Woodruff, in the said state of Arkansas; and this conveyance to operate and lie as absolute, full and complete as if the said lands and interests aforesaid were herein specifically described." Before making this purchase, Culbertson procured a list of these lands, and an abstract of the recorded title to them, from which it appeared that the bank had a perfect record title to them, subject only to a tax title, which Culbertson bought at the same time that he purchased the lands from the bank. He sccured his deed from the bank on September 26, 1883, and recorded it on October 26, 1883. C. O. Boynton, his principal, furnished the money to make this purchase, and on October 23, 1883, Culbertson conveyed the lands in controversy in this suit to Boynton by means of a warranty deed which describes them by government subdivisions, and this deed was recorded on October 29, 1883. Culbertson appears to have heen interested with Boynton in the purchase of the lands, but 
what his interest was does not appear. The title of the complainants rests upon the purchase from the bank and the conveyance to Boynton while he was ignorant of the existence of the decree. The defendants have succeeded to the title of the heirs of Fowlkes under their decree against the bank of May 3,1880, and the question is whether that title or that of the devisees of Boynton should prevail.

Counsel for the defendants argue that the deed from the bank to Culbertson conveyed only the lands which the bank owned at the date of the deed, and that, as the title to the lands here in question had been devested from the bank before the deed to Culbertson was made by the decree of May 3, 1880, and as the bank did not in fact own any right, title, or interest in the lands when it made this deed, the deed conveyed nothing, and the purchasers took nothing thereby. In support of this contention they cite Brown v. Jackson, 3 Wheat. 449, 4 L. Ed. 432. That was the first of a long line of decisions rendered by the Supreme Court in which it held that the grantee in a quitclaim deed could not become a bona fide purchaser under the registry statutes because the prior deed had conveyed all that the grantor had, and the form of the quitclain deed was notice of that fact to its grantee. Oliver v. Piatt, 3 How. 333, 11 L. Ed. 622; Van Rensselaer v. Kearney, 11 How. 297, 13 L. Ed. 703; May v. Le Claire, 11 Wall. 217, 20 L. Ed. 50; Villa v. Rodriguez, 12 Wall. 323, 20 L. Ed. 406; Dickerson v. Colgrove, 100 U. S. 578, 25 L. Ed. 618; Baker v. Humphrey, 101 U. S. 494, 25 L. Ed. 1065 ; Hanrick v. Patrick, 119 U. S. 156, 7 Sup. Ct. 147, 30 L. Ed. 396.

Counsel for the interveners cite the cases of Adams v. Cuddy, 13 Pick. (Mass.) 460, 25 Am. Dec. 330; Jannaica Corporation v. Chandler, 9 Allen (Mass.) 159, 169; Chaffin v. Chaffin, 4 Gray (Mass.) 280 ; Fitzgerald v. Libby, 142 Mass. 235, 7 N. E. 917 ; and Eaton v. Trowbridge, 38 Mich. 454, in support of the position of the defendants. But these decisions fail to give any adequate effect or force to the estoppel of the registry statutes, and are in accord with the early holdings of the Supreme Court regarding the effect of a quitclaim deed. The riper experience and more thoughtful consideration of later years have exploded the fallacy upon which the earlier decisions of the Supreme Court rested, and have led the court to adopt the rule which has now become firmly established both upon reason and authority that the innocent purchaser under a quitclaim deed may acquire the title under the registry statutes as against the holder of a prior unrecorded deed from the same grantor notwithstanding the fact that the latter had no title, and had nothing to convey when he exectted his second deed. Moeile v. Sherwood, 148 U. S. 21, 29, 30, 13 Sup. Ct. 426, 37 L. Ed. 350; United States v. California, etc., Land Co., 148 U. S. 31, 47, 48, 13 Sup. Ct. 458,37 L. Ed. 354; Prentice v. Duluth Forwarding Co., 58 Fed. $437,447,7$ C. C. A. 293,303 ; Memphis Land \& Timber Co. v. Ford, $5 \&$ Fed. 452, 7 C. C. A. 304. 
No reason is perccived why the case at bar should not be governed by this just and salutary rule. Registry statutes are legislative extensions of the doctrine of estoppel. They forbid those who have, and yet withhold from the record, their muniments of title, from asserting the title those muniments disclose against others who have innocently purchased the land from him who appears by the record to be the owner while the holders of the real title silently conceal it. They rest upon and enforce the equitable proposition that he who knowingly conceals his ownership when he ought to disclose it shall not assert it to the detriment of his neighbor who has acted in reliance upon his silence. When Culbertson purchased these lands, the record disclosed a perfect .title to them in the bank. That record was evidence of title both in the courts of the land and in the ordinary commercial transactions of men. Gould's Digest, p. 268, § 26. The agent of the vendor, the bank, furnished to the purchaser a list of these lands, and offered to sell them to him for his principal. Culbertson took the list, procured an abstract of the record title to the lands it described, and bought them in reliance upon the representation which the record and the silence and inaction of the grantors of the defendants exhibited.

The defendants, or those under whom they claim, in violation of the statute, which required them to record the decree of May 3, 1880, which had devested the title of the bank, silently withheld it from the record, and thereby induced, or at least permitted, Culbertson and Boynton to buy from one who had no actual title. May they now be allowed to avail themselves of that decree, to deprive these vendees of the land, and to entail upon them the loss of their purchase money? The question is answered by the salutary statute of Arkansas. It declares that, if such a decree is not recorded within one year after its rendition, "it shall be void as. to all subsequent purchasers without notice." The evidence is satisfactory-nay, it is conclusive-that Cu1lertson and Boynton were subsequent purchasers of these lands without notice of this decree, and they fall far within both the reason and the terms of the statute whose protection they invole.

It is true, as coinsel insist, that, in the absence of the estoppel of the registry statutes, a conveyance of what one owns carries nothing which he does not own, and that under that rule the deed to Culbertson conveyed nothing, because the bank had nothing when it was made. But the question here is not what the bank owned when that deed was made. It is not what the bank could convey. It is what the bank appeared to own by the authorized records of the cosunties in which these lands were situated. The statute and the negligence of the defendants, or of their grantors, estop them from proving, or from successfully claiming, that the title to these lands was other than that which they permitted it to appear to be upon these records when Culbertson and Boynton bought. The contention that the grantor had nothing when this deed was made, and hence that the purchasers acquired nothing by it, proves too much. It applies with equal cogency to the purchaser 
under every deed subsequent to a prior unrecorded conveyance, and its adoption would annul every statute of registration, for it may be said with equal truth of every such subsequent conveyance that the grantor has nothing when he makes it, and therefore the subsequent purchaser can take nothing.

The argument is fallacious, because it utterly ignores the purpose, the policy, and the effect of the statutes of registration. It is the purpose and the legal effect of these statutes to make the title that appears of record-the record title-stiperior in the hands of an innocent purchaser for value to the real title that is withineld from registration. Hence, while one who has parted with his title to land by an unrecorded deed or decree has no title or interest remaining in himself, yet his deed to an innocent purchaser for value, by virtue of the registry statutes, avoids the effect of the prior unrecorded deed or decree, and vests the title to the land in the subsequent purchaser to the same extent as it would have done if the title of record had been the real title. The holders of unrecorded instruments are estopped by the statute and their negligence from denying that the record title is the real title. Memphis Land \& Timber Co. v. Ford, 58 Fed. 452, 455, 456, 7 C. C. A. 304, 307, 308. The defendants cannot be heard to say, as against Culbertson, Boynton, and their successors in interest, that the Citizens' Bank of Louisiana was not the owner of the lands which it appeared by the records of the counties to be the owner of when Culbertson and Boynton made their purchase.

There is another reason why the title of the complainants must prevail. Boynton was not only an innocent purchaser of these lands, but he secured them in October, 1883, by means of a warranty deed from Culbertson, which properly described and conveyed them to him by government subdivisions. If Culbertson could not have claimed the benefit of the estoppel of the registry statute because the deed to him did not specifically describe the lands, Boynton was under no such disability. Even in those courts in which the rule once prevailed that one who takes under a quitclaim deed cannot be a bona fide purchaser, that rule was sometimes limited to the grantee in such a deed. It did not apply to those who succeeded to the title of such a grantee by deeds of bargain and sale or by warranty deeds, and this was a reasonable limitation. Snowden v. Tyler, 21 Neb. 199, 31 N. W. 661; United States v. California, etc., Land Co., 148 U. S. 31, 47, 13 Sup. Ct. 458, 37 L. Ed. 35t. The form of the deed to Culbertson, his grantor, did not charge Boynton with notice of the unrecorded decree against the bank, or of any other defect in its title, even if it could have charged Culbertson. A subsequent purchaser of lands properly described in a warranty deed to himself is not charged with notice of unrecorded conreyances or decrees by the fact that some prior deed in the chain of title is a quitciaim deed, or conveys only the lands which the grantor then owned, or of which some apparent owner died seised; or which some bankrupt owned at the time of his adjudication, but he may safely 
rely upon the presumption that the record title is the real title. Memphis Land \& Timber Co. v. Ford, 58 Fed. 452, 455, 456, 7 C. C. A. 304 , 307, 308; United States v. California, etc., Land Co., 148 U. S. 31, 46, 47, 13 Sup. Ct. 458, 37 L. Ed. 354 ; Kennedy v. Northup, 15 Ill. 148, 157; Bowen v. Prout, 52 I11. 354, 357 ; Youngblood v. Vastine, 46 Mo. 239, 242, 2 Am. Rep. 509; Powers v. McFerran, 2 Serg. \& R. (Pa.) 44, 47 ; Earle v. Fiske, 103 Mass. 491, 494. ${ }^{20}$

\section{MOORE v. BENNETT.}

\section{(Court of Chancers, 167s. 2 Ch. 246.)}

A. malies a conveyance to $\mathrm{B}$. with power of revocation by will, and limits other uses if $\mathrm{A}$. dispose to a purchaser by the will: another ptrichaser subsequent is intended to have notice of the will as well as of the power to revoke, and this is in law a notice; and so it is in all cases where the purchaser cannot make out a title but by a deed, which leads him to another fact, the purchaser shall not be a purchaser without notice of that fact, but shall be presumed cognisant thereof; for it is crassa negligentia, that he sought not after it.

29 The balance of the opinion, relating to other matters, is omitted.

In Fitzgelald r. Libby, 142 Iass. 25, 7 N. E. 917 (1S\$6), there was a mortgage of land described as "the land by me orned" in a certain designated locality, "for" boundaries and deseription reference is made to deeds to me, recorded in said registry." In filct the mortgagor had already conveyed a portion of the lands covered by the above description, but the deed had not been recorded at the time the mortwage was given and recorded, and the nortgagee had no knowledge of such deed. Held, that such previously convered portion did not laiss by the mortgage. under the recording act. But compare Dow v. Whitney, 147 Miss. 1,16 ‥ E. 72 . 2 (1SSS), where the conveyance was of "all my interest" in a slecitically described tract of land, "except such portions thereof as I have heretofore sold." The question was whether such deed placed the grantee therein in pusition to give a clear title as against possible prior unrecorded deeds. 'The court sairl: "A deed of 'all the right, title, and interest,' or of 'all the interest,' of the grantor in a lot of land, convers the same title as a deed of the land. It is the polics of onr laws that a purchaser of land, by examining the registry of deeds, may ascertain the title of his grantor. If there is no recorded deed, he has the right to assume that the record title is the true title. The law has established the rule, for the protection of creditor's and purchasers, that an unrecorded deed, if unknown to them, is as to them a mere nullity. The reasons for the rule apply with equal force in the case of a deed of the mrantor's richt, title, and interest, as in that of a deed of the land. We are of olmion, therefore, that the deed of Stephen Dow conreged to his grantee a title which is good against any prior deed, if unrecorded. To bold otherwise would drefeat the purpose of the registration laws, and create confusion in the titles to land." 


\section{BAKER v. MATHER.}

(Supreme Court of Michigan, 1S72. 25 Mich. 51.)

\section{Appeals in Chancery from Ionia Circuit.}

Esther E. Baker filed her bill against Amos R. Mather, Dennis H. Burns, Horace Roatch, and Henry W. King to foreclose a mortgage made to her by Mather and Burns, dated Jantuary 21, 1864, but which was not recorded until March 3, 1869. Roatch and King were made defendants as subsequent purchasers or incumbrancers. King alone answered, and the bill was taken as confessed by the other defendants. Subsequently Henry W. King filed his bill against Horace Roatch, Caroline E. Roatch, Esther E. Baker, and Dennis H. Burns to foreclose a mortgage made to him by said Roatch and wife, dated February 16, 1869, and recorded March 1, 1869. Baker and Burns were made defendants as subsequent purchasers or incumbrancers. Baker alone answered, and the bill was taken as confessed by the other defendants.

These two mortgages covered the same premises, and the question involved was, which should take precedence. The two cases were heard together, and the same proofs used on the hearing of both. From the proofs it appeared that the Baker mortgage was a purchase-price mortgage, given on the sale of the premises by Esther E. Baker to Burns and Mather; that said Burns and his wife subsequently conveyed their interest in the premises, subject to said mortgage, to said Mather, who afterwards conveyed the same, subject to said mortgage (which was expressly referred to in, and excepted from, the covenant of warranty in the conveyance), to Roatch; and that the latter, with his wife, afterwards executed the King mortgage. On the hearing, King's bill was dismissed as to Esther E. Baker; and decree was entered in the sitit brought by the latter, declaring her mortgage a prior lien on the premises to the King mortgage. King brings both causes to this court by appeal, where the two are heard together.

Per Curiam. The question in these cases is one of priority between two mortgages. The second mortgage was recorded first, and there is no evidence that the mortgagee therein had actual notice of the existence of the prior mortgage when he took his. It appears, however, that the deed, under which the mortgagor held the land, expressly referred to this prior mortgage, and made his title subject to it. The deed was not recorded, but this is an immaterial circumstance. Everybody taking a conveyance of, or a lien upon, land, takes it with constructive notice of whatever appears in the conveyances which constitute his chain of title. Decrees below affirmed. ${ }^{30}$

30 T. sold and conveyed land to D., the deed containing the following: "The party of the first part (the venflor. for and in consideration of the sum of $\$ 700$, to be paid on or before the first lay of July, 1872 , by the party of the second part." D. took possession, and, in 1s $i t$, without having paid 'T. in full, conveyed the premises to II., who subsequently sold to M. H. and M. had no 


\section{PATMAN v. HARLAND.}

Motion.

(Chancery Division, 1SS1. 17 Ch. D. 353.)

By an indenture dated the 25th of October, 1876, the plaintiff conveyed to one Herve two freehold plots of land, being parts of a building cstate at 17 imbledon, subject, nevertheless, to the restrictions and obligations as to building and other matters contained in an indenture of 1nttual corenants, also dated the 25 th of October, 1876 , executed by the plaintiff and Herve, and the purchasers of other building plots, jart of the same estate. One of the covenants contained in the latter leed provided that on the several plots private divelling-houses only should be erected.

By an indenture dated the 1 th th of July, 1S78, Herve conveyed the sanc two plots of land to the defendant Harland, subject to the same restrictions and obligations as to building by reference to the deed of mutual covenants, as were contained in the conveyance to Herve.

The defendant Harland having erected a dwelling-house on the propcrty, by an indenture dated the 29th of March, 1881, demised it to the defendant Lonisa Bennett for the term of seven years, for the ptriposes of an "Art College," and the lease contained a proviso that the defendant Bennett, her executors, administrators, or assigns, should be at liberty to erect in the garden belonging to the premises a studio, with necessary rooms connected therewith, of corrugated iron on a brick fonndation, and a covenant by the lessee not to carry on any trade, business, or employment, on the premises, without the consent in writing of the lessor, but to use the premises as a private dwellingllonse only, with a proviso, however, that the user of the premises for the purpose of a school for instruction in art or otherwise should not be deemed a breach of any covenant in the lease.

Neither the defendant Rennett nor her solicitor was informed or was aware before the execution of the lease, nor till shortly before the issuing of the writ in the action, that there was any restrictive covenant affecting the land, and she had proceeded to erect the studio which was llearly completed.

This was a motion for an injunction to restrain the defendants from crecting, or continuing to erect, or permitting any building or buildings, other than private dwelling-houses, to remain on the land, and in praticular, the huilding then in the course of erection.

Irser., N. R. T must say that on the point of law I have a very clear ofinion, and not the less so hecause there are dicta in the books which at first sight appear to lead to a different conclusion. I say

andald lanowlodge of any claim against tho land by $T$. In an action by $T$. to sulfind fhe land to the payment of the muntid purchase price, H. and M. claim(1) h burolected as purehisurs without notice. Deason v. Taylor, 53 Miss $1917(1,7+i)$. 
at first sight, because, when carefully examined, they do not bear out the argument which has been supposed to be fortified by, them.

The first question I have to consider is the notice which a man who takes a lease has of his lessor's title. It has been settled for more than a century that he has constructive notice of his lessor's title. Lord Eldon treated it as settled law. That means this, that the man who takes a lease is in a similar position as regards constructive notice as a man who buys. There could not be any reason for any distinction between purchasing a fee simple and taking a lease for 10,000 years. If a man who purchases a fee simple is bound to look into the title in a regular way, so is a man who takes a lease for 10,000 years, or 1,000 years, or for 100 years, or any lease at all, bound to make reasonable inquiry into his lessor's title. Well, what is reasonable inquiry? It has been held that he is to require the usual title, whatever the usual title may be.

In this case the lessor's title began in 1878, and if the lessee had only asked to see the conveyance to the lessor, that is without going back 40 years, she would have found that it was subject to this restrictive covenant, because the grantor in $187 \mathrm{~S}$ took care to convey the land, subject to the covenants, though the covenants themselves were in a separate deed.

Now it is not to be supposed that I am going to restrict the doctrine to looking at the actual conveyance-not at all — because that would be to destroy it altogether. If the lessor had a conveyance made to inim the day before that would not do, the lessee must ask for the conveyance to him and a fair and reasonable deduction of title. In this case, as I said before, the actual conveyance refers to this covenant, but if it had not shewn it, I should have come to the same conclusion, as the conveyance of 1876 referred to it, and that must have appeared on any investigation of title.

The result, therefore, is, the lessee had constructive notice. Now it has been argued that if the lessee, having this constructive notice, was told by the lessor that there was no restrictive covenant, that representation would in equity do away with the effect of constructive notice. I entirely dissent from that proposition. Constructive notice of a deed is constructive notice of its contents, subject to what I am going to say presently. If, therefore, you have notice of a deed relating to the title, and forming a part of the chain of title, you have notice of the contents of that deed, and it is no excuse for not asking to look at it to say you were told that the deed contained nothing which it was necessary for you to look at, otherwise in every case you might be satisfied with a statement of the contents of a deed without going to look at it. Of course there may be cases where the deed cannot be got at, or, for some other reason, where, with the exercise of all the prudence in the world, you cannot see it, and then there may be no constructive notice affecting the title, but that is another question. Where you know of a deed it is no answer to be told that it does not 
prejudicially affect the title, as if it does affect the title you are bound by its contents.

There is a class of cases, of which I think Jones v. Smith, 1 Hare, $43,1 \mathrm{Ph} .244$, is the most notorious, where the purchaser was told of a deed which might or might not affect the title, and was told at the same time that it did not affect the title. Supposing your are buying land of a married man, as in Jones v. Smith, 1 Hare, 43, 1 Ph. 244, and you are told at the same time that there is a marriage settlement, but the deed does not affect the land in question, you have no constructive notice of its contents, because although you know there is a settlement you are told it does not affect the land. If every marriage settlement necessarily affected all a man's land then you would have constructive notice, but as a settlement may not relate to his land at all, or only to some other portions of it, the mere fact of your haring heard of a settlement does not give you constructive notice of its contents, if you are told at the same time it does not affect the land. I take it, under the modern practice, you are not bound to inquire, because the abstract furnished you is an abstract of every document affecting the land, and although you have been told that the man made a marriage settlement, you are not entitled to assume that the solicitor suppressed improperly the deed of settlement. I take it, if you asked for it, he might say, "it has nothing to do with you." But that line of cases has no bearing at all on a case where you know the deed does affect the land, and the question as to the extent to which it does affect the land is to be ascertained only by looking at the deed itself. Therefore you have no right to rely on the statement of somebody else that the deed which you can look at does not contain something which it does in fact contain.

I have said so much on this point because there is no doubt an observation which was let fall by Lord Justice Turner in Wilson v. Hart, Law Rep. 1 Ch. 463, and which does to some extent countenance the contrary doctrine; but as regards the case of Carter v. Williams, Law Rep. 9 Eq. 678, before the Vice-Chancellor James, that, as I read it, entirely confirms my view. It is not fair to criticize the words used by the Vice-Chancellor, but when you look at the argument addressed to him you see the objection there was that the covenant was contained in a collateral deed, which was not recited. In Coles v. Sims, 5 D. M. \& G. 1, cited in Carter v. IVilliams, the restrictive covenant was recited in the conveyance. The Vice-Chancellor in Carter v. Williams, Law Rep. 9 Eq. 678, says that the covenant is contained in a separate deed, but what he means is this, that the deed is not noticed either by way of recital or by being referred to in the deed of conveyance, so that a person might get a complete chain of title without any notice of that deed. That is what he means, and that being so, of course if the tenant had asked for his lessor's title, and got it, he would not necessarily have got that information. The solicitor ought no doubt to lave put it in the abstract if he knew of it, but he would not neces- 
sarily know of it. Then the Vice-Chancellor came to the conclusion that there being no evidence of anything to bring home to the tenant actual knowledge or notice of the restrictive covenant he could not hold he had constructive notice of it. Therefore, it appears to me, that case rather follows out the doctrine of Jones v. Smith, 1 Hare, $43,1 \mathrm{Ph} .244$, and by no means affects the other cases cited where the document in question affecting the title is recited or otherwise noticed in the title-deeds. In Carter v. Williams, any one could have accepted the title without being aware of the document containing the covenant.

I am therefore of opinion that the constructive notice which the lessee in this case obtained, would not have been done away with by the most express statement obtained from the lessor that there was no restrictive covenant. I must say that $\mathrm{I}$ am not satisfied in this case that there was any such representation. What appears to have occurred was this, the lessor did not of course shew his title, but he was aware that the lessee intended to use this property in the way she attempts to use it, and there was a proviso which excepted such user from the covenant in the lease, and consequently a person reading that lease would have assumed, and fairly assumed, that she had a right to use it in the way mentioned in the exception from the covenant. In that way there was a representation-an indirect representation-and there were in addition to that some further words in the lease which tended in the same direction. Therefore I think there was sufficient to put the lessee off her guard, if I may say so, if it were not that she had constructive notice, the effect of which no representation could have destroyed.

I wish to notice one other point; it is said that the new law as to the extent of title to be required by purchasers alters the rule. I think it does not: what the Vendor and Purchaser Act does is this, in order that a lessee may obtain his lessor's title, it makes an express stipulation to that effect necessary, whereas formerly the rule was the other way, that without express stipulation the lessee had a right to the title. Formerly, if the lessee had expressly stipulated not to look into his lessor's title, it would not have affected the constructive notice. This is the meaning of the doctrine; you may bargain to shut your eyes, but if you do wilfully shut your eyes, whether as a bargain or not, you must be liable to the consequences of shutting your eyes. If, therefore, the lessee had formerly expressly bargained to take a lease without looking into the lessor's title, the lessee would have been bound by constructive notice, and now if the lessee says nothing it is exactly the same as if formerly he had bargained expressly not to look into the lessor's title. Therefore, as he may refuse to take a lease without looking into the title (in some cases, especially in case of building leases, lessees do look into the title, in other cases they do not), it appears to me that the law is unaltered. AIG.I'ROP. - 57 
and that the doctrine of Tulk v. Moxhay, $2 \mathrm{Ph} .774$, and that line of cases applies.

Then the lessee being bound by the covenant, the only remaining question is, What is the covenant, and has there been a breach of it? The covenant is not well worded, and will not perhaps carry out the full intention of the covenantee, but it is a covenant that they "shall erect private dwelling-houses only" on the piece of land. The lessee is builling something which it would be rather absurd for any one to describe as a private dweiling-house, and I an glad to see that nobody does so describe it; it is described in the affidavit as a corrugated iron building, not in any way connected with the dwelling-house, or so situated at present as possibly to be used for a private dwelling-house. The lessee says it has been built as an addition to the house which is intended to be used as an art studio for ladies. There is no question that it has been erected for that purpose, and not for a private dwelling-house. It has been argued that this building, being within the same curtilage as the house, must be treated as appurtenant to the dwelling-house, and forming part of it, in the same way as a billiard-room or smoking-room might be. But this is a thing of a totally different character. It could not be suggested that having built a private dwelling-house with a garden, if you then built a church or chapel at the other end of the garden, that church or chapel would be treated as a portion of the private dwelling-house, merely because it happened to be within the same curtilage-it would be a separate erection and not a private dwelling-house. It is in my opinion a clear breach of the covenant, and so I shall restrain the further proceeding with its construction, which is all I think it right to order now, though if it is not taken away altogether before the trial of the action I may order it to be taken away then. The lessee has, I think, a right to convert the building if she can into a fair and reasonable adjunct to the private dwelling-house; that is the reason I do not now grant the mandatory injunction asked for. I shall not grant any injunction against the defendant Harland, and his costs and the costs of all other parties will be costs in the action.

\section{GALI_EY v. WARD.}

(Supreme Court of New Hamphire, 18s0. 60 N. 11. 331.)

Bill in equity, to set aside the levy of an execution. Facts found by a referee. May 13, 1871, Jane Smith, wife of Robert Smith, being seized in her own right of a tract of land called the "Little Lot," sold it to the plaintiff for $\$ \$ 00$, and intended and believed that she did then convey it in fee simple to him. But the deed, by mistake of the scrivener, was executed by her husband, in which she merely released dower and homestead. This was not recorded till November 12, 1875. September 18, 1878, Jane and Robert executed and delivered to the 
plaintiff a deed of the lot, for the purpose of ratifying and confirming the latter's title, and of fulfilling all that they supposed they did do by their former deed. The plaintiff entered into possession of the lot upon receiving the first deed, and has remained in the open, visible, exclusive, and notorious possession of it ever since, cultivating the land, cutting the grass, pasturing his cattle therein, cutting off the wood, rebuilding the walls and fences, and tearing down the buildings, iwhich were old and dilapidated, and from the best of the timber erecting a coopers' shop.

The defendant Ward, in 1876, without any consideration, assigned to the defendant Morris a claim against Jane Smith; Morris, in April, 1876 , brought suit on this claim, and obtained an execution, which was levied on the "Little Lot." Before bringing the suit, Morris made inquiries at the registry of deeds to ascertain if Jane Smith had conveyed this lot, and was informed that she had not. The deed of May 13, 1871, was indexed "Smith Robert to Galley William." Before the attachment, Morris had no knowledge or suspicion that Jane had sold the lot, and it did not appear when he first learned of it. Ward and Morris both live in Boston, Mass.

Foster, J. At the time of Morris's attachment and levy, the plaintiff held the equitable title to the "Little lot" by virtue of the agreement made with Jane Smith in 1871, under which he had paid the full consideration for the property, and had entered into its occupation. He was entitled to a decree for a specific performance of this agreement, and to such a conveyance as he received September 18, 1878 . 2 Story, Eq. § 761; Scoby v. Blanchard, 3 N. II. 170, 177; Hadduck v. Wilmarth, 5 N. H. 181, 189, 20 Am. Dec. 570; Chartier v. Marshall, 51 N. H. 400; Newton v. Swazey, 8 N. H. 9; Cutting v. Pike, 21 N. H. 347 ; Kidder v. Barr, 35 N. H. 235, 254; Doe v. Doe, 37 N. H. 268; Ewins v. Gordon, 49 N. H. 444.

It is not claimed that Morris had any actual knowledge of the plaintiff's title. He merely knew as a fact that the legal title appeared by the record to be in Jane Smith. And if the plaintiff's title is to prevail in this suit, it must be on the ground of constructive notice. It is substantially admitted in the brief for Morris, and is undoubtedly the law in this state, that a purchaser of land, knowing that a third person is in the open, visible, and notorious occupation of it, - an occupation inconsistent with the idea that he is a tenant,- - is chargeable with notice of such facts in reference to the latter's title, whether legal or equitable, as he would have learned upon reasonable inquiry. Colby v. Kenniston, 4 N. H. 262; Hadduck v. Wilmarth, 5 N. H. 181, 20 Am. Dec. 570; Warren v. Swett, 31 N. H. 332; Patten v. Moore, 32 N. H. 383; Jones v. Smith, 1 Hare, 43 ; Tardy v. Morgan, 3 McLean, 358, Fed. Cas. No. 13,752; Landes v. Brant, 10 How. 348, 375, 13 L. Ed. 449; Ferrin v. Errol, 59 N. H. 234; Cooper v. Newman, 45 N. H. 339; Nute v. Nute, 41 N. H. 60; Braman v. Wilkinson, 3 Barb. (N. Y.) 151; Bank v. Flagg, 3 Barb. Ch. (N. Y.) 316; Doo- 
little v. Cook, 75 I11. 354; Losey v. Simpson, 11 N. J. Eq. 246; Big. Fr. 288; 1 Story, Eq. § 399, note 4; Hill. Vend. 408; Jones, Mort. 600. And the nature of the plaintiff's possession in this case was sufficient to put a purchaser having knowledge of the facts on inquiry as to the plaintiff's title.

But it is contended that Morris did not know of the plaintiff's possession of the land, and that therefore the doctrine of constructive notice cannot be applied to him. If he had known it, on the authoritics above cited he could have gained no title against the plaintiff by his attachmont and levy. Is his ignorance sufficient excuse? When a grantee records his deed, a subsequent purchaser is chargeable with constructive notice of its contents. It is wholly immaterial whether he has seen the deed, or has any knowledge of its existence. It is, as sometimes expressed, a conclusive presumption of law that he had notice of the grantce's deed. Malone, Real Prop. Trials, 427; Morrison v. Kelly, 22 I11. 610, 74 Am. Dec. 169. On the same ground it is at least a prima facie presumption, that when there is such a possession by a third party as would charge a purchaser who knew of that possession with knowledge of an adverse title, a purchaser ignorant of that possession without excuse would be equally chargeable. And this doctrine, in both cases, rests on the ground of fraud or culpable negligence. As it is a part of a purchaser's duty to examine the record, to inform himself as to the legal title he expects to acquire, a failure to attend to that duty would amount to negligence on his part, and would be a frand on a previous purchaser under a recorded deed, if he could, by proving his ignorance, acquire a title. By the same mode of reasoning, if he is wilfully ignorant of such facts of notorious occupation by a stranger as would put a purchaser cognizant of those facts on his guard against some unrecorded deed or equitable claim, his want of knowledge is due to his own laches and failure to attend to an apparent duty. In Hughes v. U. S., 4 Wall. 232, 18 L. Ed. 303, Field, J., say's that if a purchaser neglects to make inquiry as to the possession, "he is not entitled to ary greater consideration than if he had made it and ascertained the actual facts of the case." See, also, Edwards v. Thompson, 71 N. C. 177 ; McKinzie v. Perrill, 15 Ohio St. 162; Bailey v. Richardson, 9 Hare, 734; Gooding v. Riley, $50 \mathrm{~N}$. H. 400, 403-405; Strong v. Shea, 83 Ill. 575; Hommel v. Devinney, 39 Mich. 522; Patton v. Hollidaysburg, $40 \mathrm{~Pa}$. 206; Perkins v. Swank, 43 Miss. 349. Nor is there any distinction in this respect between a purchaser and a creditor. A creditor is bound by constructive notice of the contents of a recorded deed, as well as a purchaser, and there seems to be no reason why they should not both stand on the same ground with reference to an equitable title in a third party, in a case like the present. Priest v. Rice, 1 Pick. (Mass.) 164, $11 \mathrm{Am}$. Dec. 156; Flynt v. Arnold, 2 Metc. (Mass.) 619; Farnsworth v. Childs, 4 Mass. 637, 3 Am. Dec. 249; Scripture v. Soapstone Co., 50 N. H. 571. 
The defendant Morris had no knowledge that the plaintiff was in possession of the land in question, but, so far as the plaintiff or anybody else was concerned, he was at liberty to examine the apparent condition of the premises. He was not deceived by any misrepresentations or concealments of the plaintiff. He relied on his own judgment, and neglected an apparent duty. Like a purchaser having knowledge of facts sufficient to put him on his guard, he must be helu chargeable with what he would have learned upon reasonable inquiry as to the plaintiff's right of possession. And it appears from the case that he would have learned of the plaintiff's equitable title. His tille therefore cannot prevail in this suit.

It is unnecessary, in the view we have taken of the case, to consider the further question, whether the want of consideration for the assignment of the claim to Morris by Ward would prevent the former from acquiring a title against the plaintiff. Decree according to the prayer of the bill. ${ }^{31}$

31 The orner of lands conresed same to A., B., and C., the deed being duly recorded. A, took possession, and shortly thereafter acnuired deeds from $\mathrm{B}$. and C. conveying their interests to him. These leerls were not recorded. B. and C. later made a deed of their undivided interests in the salue Iremises to D., who prid ralue therefor with no kwowledge of the unrecorded deeds to $\mathrm{A}$. should D, be charced with notice hy reasom of A.'s possussion? See Dutton v. Mcliegnolıs, 31 Minn. 66, $16 \mathrm{~N}$. W. His (1-s:3); Farmers' \& Merchants' Nat. Bank r. Wallace, 45 Ohio, St. 152,12 N. E. $4: 39$ (1857).

Lands were conveyed to A., the deen beins nrolerly recorded. A. later conreyed them to her lusband. and that deed was not rerorderl. Still later, and white A. and husband were livin mon the memises. A. conveyed to B., who paid ralue and had no knowledse of the converance from A. to her hushancl. Shomld IB, he charged nith notice of the husbinll's interest? See Westerfield v. Kinmer, s.2 Ind. $30 J$ (1S82); Atwool v. Bearss, 47 Mich. $72,10 \mathrm{~N}$. W. 112 (1s $s 1)$.

A., a married woman, haring purchased certain lands, had a converance of same male to $\mathrm{B}$. to hold on her behalf. B. later muregd the premises to A., but the deed was never recorded. After the death of $\mathrm{B}$., his heir's executed a deed of these prenises to C., who paid ralue therefor without knowledse of the rights of A. Since the time of the first converance mentioned to P.. A. and her lnsband have resided upon the premises. Should $C$. he charged with

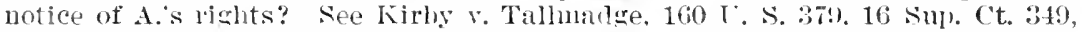

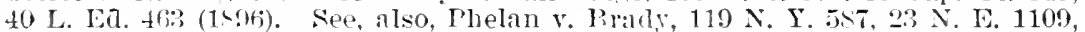
S L. R. A. 211 (1890); Boyer v. Chandler, 160 Ill. 394,43 N. E. $\$ 03,32$ L. R. A. $113(1<96)$.

What would have been the situation if, instead of $\mathrm{A}$. and her hushand being in possession, a lessee of $A$. had been occupying the premises? See Innt $v$. Luch, [1902] 1 Ch. 428; Randall v. Lingwall, 43 Or. 895, 73 Pac. 1 (1903).

As to whether possession by a grantor in a recorded deed is notice of any rights held by him, see Bloomer v. Ifenderson, 8 IIich. 395. $77 \mathrm{Am}$. Dec. 453 (1860); Yan Keuren v. Central R. Co., 3S N. J. I.aw, 165 (1875) ; Randall v. Lingtrall, supra; Groff $v$. State Bank of Minneapolis, 50 Minn. $234,52 \mathrm{~N}$. W. 651, 36 Am. St. Rep. 640 (1S92); Illinois Cent. R. Co. v. McCullough, 59 Ill. 166 (1871). 


\section{WILLIAMSON v. BROWN.}

(Court of Appeals of New York, 1Sj7. 15 న̃. T. 354.)

The defendant, Brown, was the owner of fifty acres of land in Hannibal, Oswego county, which, on the 4th of April, 1851, he sold and conveyed to one Jackson Earl, taking back from Earl a mortgage for $\$ \$ 00$ of the purchase money, but omitting at that time to put his mortgage upon record.

On the 29th of October, 1851, Earl conveyed the land to the plaintiff by deed, which was duly recorded on the same day; and on the 28 th of January, 1852, the mortgage from Earl to the defendant was put upon record. In May following the defendant commenced proceedings for the foreclosure of the mortgage by advertisement. This suit was commenced to restrain the defendant from proceeding with this foreclosure, on the ground that the plaintiff was protected by the recording act against the defendant's prior but unrecorded mortgage.

The cause was tried before a referee, who reported that he found as matter of fact "that the plaintiff did not at the time he purchased the premises have actual notice of the existence of the mortgage mentioned in the pleadings, given by Jackson Earl to the defendant," but also found that he had "sufficient information, or belief of the existence of said mortgage to put him upon inquiry, before he purchased and received his conveyance of the premises in question; and that he pursued such inquiry to the extent of his information and belief, as to the existence of the said mortgage, and did not find that such mortgage existed, or had been given."

Upon these facts the referee held that the plaintiff was chargeable with notice of the mortgage, and dismissed the complaint, and the plaintiff excepted to the decision. Judgment was entered for the defendant upon the referee's report which, upon appeal to the general term of the fifth district, was affirmed.

Selden, J. The referee's report is conclusive as to the facts. It states, in substance, that the plaintiff had sufficient information to put him upon inquiry as to the defendant's mortgage; but that after making all the inquiry, which upon such information it became his duty to make, he failed to discover that any such mortgage existed. This being, as I think, what the referee intended to state, is to be assumed as the true interpretation of his report.

The question in the case, therefore is, as to the nature and effect of that kind of notice so frequently mentioned as notice sufficient to put a party upon inquiry. The counsel for the plaintiff contends that while such a notice may be all that is required in some cases of equitable cognizance, it is not sufficient in cases arising under the registry acts, to charge the party claiming under a recorded title with knowledge of 
a prior unregistered conveyance. He cites several authorities in support of this position.

In the case of Dey v. Dunham, 2 Johns. Ch. 182, Chancellor Kent says, in regard to notice under the registry act: "If notice that is to put a party upon inquiry be sufficient to break in upon the policy and the express provisions of the act then indeed the conclusion would be different; but I do not apprehend that the decisions go that length." Again, in his commentaries, speaking on the same subject, he says: "Implied notice may be equally effectual with direct and positive notice; but then it must not be that notice which is barely sufficient to put a party upon inquiry."

So in Jackson v. Van Valkenburgh, 8 Cow. 260, Woodworth, J., says: "If these rules be applied to the present case, the notice was defective. It may have answered to put a person on inquiry, in a case where that species of notice is sufficient; but we have seen that to supply the place of registry, the law proceeds a step further."

A reference to some of the earlier decisions under the registry acts of England, will tend, I think, to explain these remarks, which were probably suggested by those decisions. One of the earliest, if not the first of the English recording acts was that of 7 Anne, ch. 20. That act differed from our general registry act in one important respect. It did not, in terms require that the party to be protected by the act should be a bona ficle purchaser. Its language was: "And that every such deed or conveyance, that shall at any time after, \&c., be made and executed, shall be adjudged fraudulent and void, against any subsequent purchaser or mortgagee for valuable consideration, unless," \&c.

The English judges found some difficulty at first in allowing any equity, however strong, to control the explicit terms of the statute. It was soon seen, however, that adhering to the strict letter of the act would open the door to the grossest frauds. Courts of equity, therefore, began, but with great caution, to give relief when the fraud was palpable. Hine v. Dodd, 2 Atk. 275, was a case in which the complainant sought relief against a mortgage having a preference under the registry act, on the ground that the mortgagee had notice. Lord Hardwicke dismissed the bill, but admitted that "apparent fraud, or clear and undoubted notice would be a proper ground of relief." Again he said: "There may possibly have been cases of relief upon notice, divested of fraud, but then the proof must be extremely clear."

Jolland v. Stainbridge, 3 Ves. 478, is another case in which relief was denied. The master of the rolls, however, there says: "I must admit now that the registry is not conclusive evidence, but it is equally clear that it must be satisfactorily proved, that the person who registers the subsequent deed must have known exactly the situation of the persons having the prior deed, and knowing that, registered in order to defraud them of that title." 
Chancellor Kent refers to these cases in Dey v. Dunham, supra, and his remarks in that case, as to the effect, under the registry acts, of notice sufficient to put a party upon inquiry, were evidently made under the influence of the language of Lord Hardwicke and the master of the rolls above quoted.

But the English courts have since seen, that if they recognized any equity founded upon notice to the subsequent purchaser of the prior unregistered conveyance, it became necessarily a mere question of good faith on the part of such purchaser. They now apply, therefore, the same rules in regard to notice, to cases arising under the registry acts, as to all other cases.

It will be sufficient to refer to one only among the modern English cases on this subject, viz., Whitbread v. Boulnois, 1 You. \& Coll. Ex. R. 303. The plaintiff was a London brewer, and supplied Jordan, who was a publican, with beer. It was the common practice with brewers in London to lend money to publicans whom they supplied with beer, upon a deposit of their title deeds. Jordan had deposited certain deeds with the plaintiff, pursuant to this custom. He afterwards gave to one Boulnois, a wine merchant a mortgage upon the property covered by the deeds deposited, which was duly recorded. Boulnois had notice of Jordan's debt to the plaintiff, and of the existing custom between brewers and publicans, but he made no inquiry of the brewers. The suit was brought to enforce the equitable mortgage arising from the deposit. Baron Alderson held that the notice to Boulnois was suficient to make it his duty to inquire as to the existence of the deposit; that his not doing so was evidence of bad faith; and the plaintiff's right, under his equitable mortgage, was sustained. No case could show more strongly that notice which puts the party upon inquiry is sufficient even under the registry act.

The cases in our own courts, since Dey v. Dunham and Jackson v. Van Valkenburgh, supra, hold substantially the same doctrine. Tuttle v. Jackson, 6 Wend. 213, 21 Am. Dec. 306; Jackson v. Post, 15 Wend. 588; Grimstone v. Carter, 3 Paige, 421, 24 Am. Dec. 230.

I can see no foundation in reason for a distinction between the evident requisite to establish a want of good faith, in a case arising under the recording act, and in any other case; and the atthorities here referred to are sufficient to show that no such distinction is recognized, at the present day, by the courts. The question, however, remains, whether this species of notice is absolutely conclusive upon the rights of the parties. The plaintiff's counsel contends, that knowledge sufficient to put the purchaser upon inquiry is only presumptive evidence of actual notice, and may be repelled by showing that the party did inquire with reasonable diligence, but failed to ascertain the existence of the unregistered conveyance; while, on the other hand, it is insisted that notice which makes it the duty of the party to inquire, amounts to constructive notice of the prior conveyance, the law presuming that due inquiry will necessarily lead to its discovery. 
The counsel for the defendant cites several authorities in support of his position, and among others the cases of Tuttle v. Jackson and Grimstone v. Carter, supra. In the first of these cases, Walworth, Chancellor, says: "If the subsequent purchaser knows of the unregistered conveyance, at the time of his purchase, he cannot protect himself against that conveyance; and whatever is sufficient to make it his duty to inquire as to the rights of others, is considered legal notice to him of those rights;" and in Grimstone v. Carter, the same judge says: "And if the person claining the prior equity is in the actual possession of the estate, and the purchaser has notice of that fact, it is sufficient to put him on inquiry as to the actual rights of such possessor, and is good constructive notice of those rights."

It must be conceded that the language used by the learned Chancellor in these cases, if strictly accurate, would go to sustain the doctrine contended for by the defendant's counsel. Notice is of two kinds: actual and constructive. Actual notice embraces all degrees and grades of evidence, from the most direct and positive proof to the slightest circumstance from which a jury would be warranted in inferring notice. It is a mere question of fact, and is open to every species of legitimate evidence which may tend to strengthen or impair the conclusion. Constructive notice, on the other hand, is a legal inference from established facts; and like other legal presumptions, does not admit of dispuie. "Constructive notice," says Judge Story, "is in its nature no more than evidence of notice, the presumption of which is so violent that the court will not even allow of its being controverted." Story's Eq. Juris. § 399.

A recorded deed is an instance of constructive notice. It is of no consequence whether the second purchaser has actual notice of the prior deed or not. He is bound to take, and is presumed to have, the requisite notice. So, too, notice to an agent is constructive notice to the principal; and it would not in the least avail the latter to show that the agent had neglected to communicate the fact. In such cases, the law imputes notice to the party whether he has it or not. Legal or implied notice, therefore, is the same as constructive notice, and cannot be controverted by proof.

But it will be found, on looking into the cases, that there is much want of precision in the use of these terms. They have been not infrequently applied to degrees of evidence barely sufficient to warrant a jury in inferring actual notice, and which the slightest opposing proof would repel, instead of being confined to those legal presumptions of notice which no proof can overthrow. The use of these terms by the chancellor, therefore, in 'Tuttle v. Jackson and Grimstone v. Carter, is by no means conclusive.

The phraseology uniformly used, as descriptive of the kind of notice in question, "sufficient to put the party upon inquiry," would seem to imply that if the party is faith ful in making inquiries, but fails to discover the conveyance, he will be protected. The import of the terms is, that it becomes the duty of the party to inquire. If, then, he per- 
forms that duty is he still to be bound, without any actual notice? The presumption of notice which arises from proof of that degree of knowledge which will put a party upon inquiry is, I apprehend, not a presumption of law, but of fact, and may, therefore, be controverted by evidence.

In Whitbread v. Boulnois, supra, Baron Alderson laid down the rule as follows: "When a party having knowledge of such facts as would lead any honest man, using ordinary caution, to make further inquiries, does not make, but on the contrary studiously avoids making, such obvious inquiries, he must be taken to have notice of those facts, which, if he had used such ordinary diligence, he would readily have ascertained." This very plainly implies that proof that the party has used due diligence, but without effect, would repel the presumption. In this case, it is true, the decision was against the party having the notice. But in Jones v. Smith, 1 Hare, 43, we have a case in which a party, who had knowledge sufficient to put him on inquiry, was nevertheless held not bound by the notice.

The defendant had loaned money upon the security of the estate of David Jones, the father of the plaintiff. At the time of the loan he was informed, by David Jones and his wife, that a settlement was made previous to the marriage, but was at the same time assured that it only affected the property of the wife. He insisted upon seeing the settlement, but was told that it was in the hands of a relative, and that it could not be seen without giving offense to an aged aunt of the wife, from whom they had expectations. David Jones, however, after some further conversation, promised that he would try to procure it for exhibition to the defendant. This promise he failed to perform. It turned out that the settlement included the lands upon which the money was loaned. Here was certainly knowledge enough to put the party upon inquiry; for he was apprised of the existence of the very document which was the foundation of the complainant's claim. He did inquire, however, and made every reasonable effort to see the settlement itself, but was baffled by the plausible pretences of David Smith. The vice-chancellor held the notice insufficient. He said: "The affairs of mankind cannot be carried on with ordinary security, if a doctrine like that of constructive notice is to be refined upon until it is extended to cases like the present."

Possession by a third person, under some previous title, has frequently but inaccurately been said to amount to constructive notice to a purchaser, of the nature and extent of such prior right. Such a possession puts the purchaser upon inquiry, and makes it his duty to pursue his inquiries with diligence, but is not absolutely conclusive upon him. In Hanbury v. Litchfield, 2 Myl. \& Keene, 629, when the question arose, the Master of the Rolls said: "It is true that when a tenant is in possession of the prenises, a purchaser has implied notice of the nature of his title; but if, at the time of his purchase, the tenant in possession is not the original lessee, but merely holds under a deriva- 
tive lease, and has no knowledge of the covenants contained in the original lease, it has never been considered that it was want of due diligence in the purchaser, which is to fix him with implied notice, if he does not pursue his inquiries through every derivative lessee until he arrives at the person entitled to the original lease, which can alone convey to him information of the covenants."

This doctrine is confirmed by the language of Judge Story, in Flager v. Mann et al., 2 Sumn. 554, Fed. Cas. No. 4,847. He says: "I admit that the rule in equity seems to be, that where a tenant or other person is in possession of the estate at the time of the purchase, the purchaser is put upon inquiry as to the title; and if he does not inquire, he is bound in the same manner as if he had inquired, and had positive notice of the title of the party in possession."

It is still further confirmed by the case of Rogers v. Jones, $8 \mathrm{~N}$. H. 264. The language of Parker, J., in that case, is very emphatic. $\mathrm{He}$ says: "T'o say that he (the purchaser) was put upon inquiry, and that having made all due investigation, without obtaining any knowledge of title, he was still chargeable with notice of a deed, if one did really exist, would be absurd."

If these authorities are to be relied upon, and I see no reason to doubt their correctness, the true ductrine on this subject is, that where a purchaser has knowledge of any fact, sufficient to put him on inquiry as to the existence of some right or title in conflict with that he is about to purchase, he is presumed either to have made the inquiry, and ascertained the extent of such prior right, or to have been guilty of a degree of negligence equally fatal to his claim, to be considered as a bona fide purchaser. This presumption, however, is a mere inference of fact, and may be repelled by proof that the purchaser failed to discover the prior right, notwithstanding the exercise of proper diligence on his part.

The judgment should be reversed, and there should be a new trial, with costs, to abide the event.

Paige, J. The question to be decided is, whether under the finding of the referee, the plaintiff is to be deemed to have had at the time of his purchase, legal notice of the prior unrecorded mortgage of the defendant. The referee finds that the plaintiff had sufficient information or belief of the existence of such mortgage to put him upon inquiry, but that upon purstiing such inquiry to the extent of such information and belief, he did not find that such mortgage existed or had been given. It seems to me that the two findings are inconsistent with each other. If the plaintiff on pursuing an inquiry to the full extent of his information and belief as to the existence of the defendant's mortgage, was unable to find that it either then existed or had been given, the highest evidence is furnished that the information received or belief entertained by the plaintiff was not sufficient to put him on inquiry as to the existence of such mortgage. The last part of this finding effectually disproves the fact previously found of the suffi- 
ciency of notice to put the plaintiff on inquiry. The two facts are utterly inconsistent with each other, and cannot possibly coexist.

The remarks of Parker, Justice, in Rogers v. Jones, 8 N. H. 264, 269, are directly apposite to the facts found by the referee. Judge Parker says: "To say that he (demandant), was put upon inquiry, and that having made all due investigation without obtaining any knowledge of title, he was still chargeable with notice of a deed, if one did really exist, would be absurd." The sound sense of these observations is clcarly shown by the principle of the rule that information sufficient to put a party upon inquiry is equivalent to evidence of actual notice, or to direct and positive notice. That principle is, that such information will, if followed by an inquiry prosecuted with due diligence, lead to a knowledge of the fact with notice of which the party is sought to be charged. Hence, in all cases where the question of implied notice of a prior unrecorded mortgage or conveyance arises as a question of fact to be determined, the court must decide whether the information possessed by the party would, if it had been followed up by proper examination, have led to a discovery of such mortgage or conveyance. If the determination is that such an examination would have resulted in a discovery of the mortgage or conveyance, the conclusion of law necessarily results that the information possessed by the party amounted to implied notice of such instrument. But if the determination is the converse of the one stated, the information of the party cannot be held to be an implied notice of the deed or mortgage. These propositions will be found to be fully sustained by authority. Kennedy v. Green, 3 Myl. \& Keene, 699; 2 Sugden on Vendors, 552 (Am. Ed. of 1851, marg. page 1052); 4 Kent's Com. 172; Howard Ins. Co. v. Halsey, 4 Sandf. (6 Super. Ct.) 577, 578; same case, 4 Seld. 274,275 ; 1 Story's Eq. Jur. $\S \S 398-400$; J Jackson v. Burgott, 10 Johns. 461, 6 Am. Dec. 349; Dunham v. Dey, 15 Johns. 568, 569, S Am. Dec. 282, in error; Jackson v. Given, S Johns. 137, 5 Am. Dec. 328; Jolland v. Stainbridge, 3 Vcs. 478; Pendleton v. Fay, 2 Paige, 205. Where the information is sufficient to lead a party to a knowledge of a prior unrecorded conveyance, a neglect to make the necessary inquiry to acquire such knowledge, will not excuse him, but he will be chargeable with a knowledge of its existence; the rule being that a party in possession of certain information will be chargeable with a knowledge of all facts which an inquiry, suggested by such information, prosecuted with due diligence, would have disclosed to him. 4 Sandf. (6 Super. Ct.) 578; 3 Myl. \& Keene, 699. In this case the fact being found by the referee, that the plaintiff after pursuing an inquiry to the extent of his information, failed to discover the existence of the defendant's mortgage, it seems to me that neither law nor justice will justify us in holding the plaintiff chargeable with implied notice of stich mortgage. The doctrine of notice and its operation in favor of a prior unrecorded deed or mortgage rests upon a question of fraud, and on the evidence necessary to infer it. 4 Kent's Com. 172. Actual notice affects the 
conscience, and convicts the junior purchaser of a fraudulent intent to defeat the prior conveyance. His knowledge of facts and circumstances at the time of the second purchase sufficient to enable him on due inquiry to discover the existence of the prior conveyance, is evidence from which a fraudulent intent may be inferred. 15 Johns. 569; 2 Johns. Ch. 190; Jackson v. Burgott, 10 Johns. 462, 6 Am. Dec. 349. Now if it is ascertained and found as a fact, that the facts and circumstances within the knowledge of the second purchaser, at the time of his purchase, were insufficient to lead him, on a diligent examination, to a discovery of the prior conveyance, how upon this finding can a fraudulent intent be inferred, and if not, how can he be charged with notice, which implies a fraudulent intent? It is not in the nature of things, that a knowledge of the same facts and circumstances, shall at one and the same time, be held evidence of both innocence and guilt. I think the rule well established that an inference of a fraudulent intent on the part of a junior purchaser or mortgagee, must in the absence of actual notice, be founded on clear and strong circumstances, and that such inference must be necessary and unquestionabie. McMechan v. Griffing, 3 Pick. (Mass.) 149, 154, 155, 15 Am. Dec. 198; Hine v. Dodd, 2 Atk. 275; Jackson v. Given, S Johns. 137, 5 Am. Dec. 328; Norcross v. Widgery, 2 Mass. 509; 2 Johns. Ch. 189; 15 Johns. $569 ; 8$ Cow. 264, 266.

For the above reasons, both the judgment rendered on the report of the referee, and the judgment of the general term affirming the same, should be reversed, and a new trial should be granted.

\section{NORDMAN v. RAU.}

(Supreme Court of Kansas, 1911. S6 Kall. 19, 119 Pac. 551, 3S L. R. A. [N. S.] 100, Ann. Cas. 1913B, 106s.)

Mason, J. Johamne Nordman brought an action to enforce her rights as to a tract of land under a mortgage given by Jacob Rau. S. A. Webb, a defendant, claimed to be the absolute owner of the land as an innocent purchaser without notice of the mortgage. Findings of fact were made to the effect that the mortgage was executed and in fact recorded in the office of the register of deeds of the county where the land was situated, but was never acknowledged; that while matters were in this situation a personal judgment was rendered against Rau, an execution was issued and levied on the land as his property, and it was sold to Webb at a sheriff's sale, which was duly confirmed, and under which a deed was subsequently made to him; that the resident attorney who acted for Webb in bidding in the land at the sheriff's sale, knew of the existence and contents of the record of the unacknowledged mortgage. The trial court gave judgment for the owner of the mortgage, holding it to be valid as to Webb because his agent knew of the actual state of the record. Webb appeals. 
The appellant argues that inasmuch as the attorney who bid in the land for Webb represented him only in that particular transaction and had no other connection with him, the knowledge of the agent was not equivalent to the knowledge of the principal. It fairly appears, however, that the attorney gained his knowledge of the state of the record after having been employed to attend the sale, and before bidding in the property, and that in this aspect of the matter the case falls within the rule that "a principal is * * * affected with knowledge of all material facts of which the agent receives notice or acquires knowledge while acting in the course of his employment." 31 Cyc. 1587. A purchaser at a sheriff's sale is entitled to the protection of the recording act. Lee v. Bermingliam, $30 \mathrm{Kan} .312,1$ Pac. 73; note, 21 L. R. A. 33.

It is therefore necessary to decide whether an unacknowledged mortgage, which has been copied into the record book of the register of deeds, is void against one who buys the property knowing the contents of the record, but is otherwise an innocent purchaser for value. An instrument affecting real estate is entitled to record only when it has been acknowledged or proved as provided by the statute. And where such an instrument is recorded without having been so acknowledged or proved, the record does not impart notice to anyone. Wickersham v. Chicago Zinc Co., 18 Kan. 481, 26 Am. Rep. 784; Wiscomb v. Cubberly, 51 Kan. 580, 589, 33 Pac. 320. The statute relating to the effect of a failure to record instruments affecting real estate reads: "No such instrument in writing shall be valid, except between the parties thereto, and such as have actual notice thereof, until the same shall be deposited with the register of deeds for record." Gen. St. 1S68, c. 22, § 21, Gen. St. 1909, § 1672.

The precise question involved is whether one who has seen and read in the records in the office of the register of deeds what is in fact a copy of an existing unacknowledged instrument is to be regarded as having "actual notice" of the instrument itself, within the meaning of the statute. In Massachusetts and in Indiana "actual notice" is interpreted as equivalent to actual knowledge. Webb, Record of Title, $\S$ 222 , p. 356 , note 3 . But the general rule is that evidence of facts and circumstances sufficient to put upon inquiry amount to actual notice. Webb, Record of Title, $\S 222$, p. 356, note 4. "Actual notice does not mean that which in metaphysical strictness is actual in its nature, because it is seldom that ultimate facts can be communicated in a manner so direct and unequivocal as to exclude doubts as to their existence or authenticity. Actual notice means, among other things, knowledge of facts and circumstances so pertinent in character as to enable reasonably cautious and prudent persons to investigate and ascertain as to the ultimate facts." Pope v. Nichols, 61 Kan. 230, 236, 59 Pac. 257, 259. "Actual notice may be either express or implied; that is, it may consist of knowledge actually brought personally home, or it may consist of knowledge of facts so informing that a 
reasonably cautious person would be led by them to the ultimate fact. * * * Actual notice is implied only when the known facts are sufficiently specific to impose the duty to investigate further, and when such facts furnish a natural clue to the ultimate fact." Faris v. Finnup, S4 Kan. 122, 124, 113 Pac. 407, 40 S.

This court is of the opinion (not shared by the writer) that one who has seen the record of an unacknowledged instrument is not deemed because of that fact to have actual notice of the instrument itself, upon these grounds: To charge him with such notice is to require him to assume, without proof and without competent evidence, that a valid conveyance is in existence corresponding to the unauthorized copy. If he is required to give any attention to the matter at all he may with equal or greater reason suppose the parties to have abandoned whatever intention they may have had to execute such a conveyance, from the fact that they failed to have a certificate of aclinowledgment attached. To charge him with actual notice of the existence of a conveyance because he has seen a copy of it which, without legal authority, has been written in a book of public records, is essentially to give such copy the force of a valid record. To hold that the record of an unacknowledged conveyance, if known to a prospective buyer, amounts to actual notice of the instrument, is to compel him to give it force as evidence which the court itself would refuse it. 'The view is thus elaborated in Kerns v. Swope (Pa. Sup. Ct. 1833) 2 Watts, 75 :

"The registration being without the authority of the law, was the unofficial act of the officer, which could give the copy no greater validity than the original deprived of legal evidence of execution; nor even so much, for an original deed exhibited to a purchaser would affect him though it were unaccompanied with the evidence of its execution. But here the registry was no better than a copy made by a private person in a memorandum book; from which a purchaser would be unable to determine whether there were, in fact, an indorsement on the deed, or whether it had been truly copied-especially when neither the copy, nor an exemplification of it, would be legal evidence of the fact in a court of justice. Unquestionably a purchaser would not be affected by having seen the copy of a conveyance among the papers of another, or an abstract of it in a private book. The whole effect of a registry, whether as evidence of the original or as raising a legal presumption that the copy thus made equivalent to the original had been actually inspected by the party to be affected, is derived from the positive provisions of the law; and when unsustained by these, a registry can have no operation whatever. Stripped of artificial effect, it is but the written declaration of the person who was the officer at the time, that he had seen a paper in the words of the copy which purported to be an original. But to say nothing in this place of the incompetency of such a declaration as evidence of the fact, on what principle would a purchaser be bound to attend to the hearsay information of one who is not qualified to give it?" 2 Watts (Pa.) 78. 
The same view was indicated in Banister v. Fallis, S5 Kan. 320, 116 Pac. 822, where it was said of the record of an unacknowledged instrument: "The instrument itself, if there were one, had no validity except between the parties and those having actual notice, not of what was on record, but of the instrument itself." 85 Kan. 322, 116 Pac. 823.

The judgment is reversed and the cause remanded with directions to render judgment upon the findings quieting the title of Webb.

Mason, J. (dissenting). My own view of the question presented is this: Where a prospective buyer of land sees upon the record what purports to be the copy of an instrument bearing no certificate of acknowledgment (or a defective one, for the rule would necessarily be the same), the inference which he would naturally and almost necessarily draw would be that the record was made at the instance of the grantee, and that the grantee claimed to have an interest in the land under an instrument in the language of the copy. The record would not be competent legal evidence that such an instrument had been executed, but it would suggest that probability so strongly that a prudent person having knowledge of it would be put upon inquiry. It would give him a definite and tangible clue, which, if diligently followed up, would ordinarily bring the truth of the matter to light. In the present case, if an inquiry had been prosecuted with reasonable diligence, the existence of the mortgage would necessarily have been developed.

In Banister v. Fallis; 85 Kan. 320, 116 Pac. 822, the purchaser of land objected to the title because the record contained what purported to be a copy of a contract affecting it. The objection was held untenable because, the contract not having been acknowledged, the record was not evidence of its execution, and no other evidence on the subject was offered; and because the contract could not constitute a cloud in any event, inasmuch as it purported to be made by a stranger to the title. An additional reason was stated in the language quoted in the foregoing opinion: "The instrument itself, if there were one, had no validity except between the parties and those having actual notice, not of what was on record, but of the instrument itself." 85 Kan. 322,116 Pac. 823. I do not regard that decision as a definite determination of the question here involved.

I think the only case involving the exact question and supporting the decision here made is Kerns v. Swope (Pa. Sup. Ct. 1833) 2 Watts, 75 , cited in the opinion. That case is disapproved in the American notes to White \& Tudor's Leading Cases in Equity, vol. 2, p. 152. In 24 A. \& E. Encycl. of L. 142,.143, it is said: "If an instrument be not *** entitled to record because of its defective execution or a failure to comply with some of the prerequisites to recordation, the record thereof will be a mere nullity and will not operate to give constructive notice. * * * But, *** of course, such a record may be instrumental in giving actual notice of the rights claimed un- 
der the instrument where the knowledge of its existence is brought home to the party claiming against such instrument."

Of the four cases cited in support of this text, these three are directly in point: Rooker v. Hoofstetter, 26 Can. Supr. Ct. 41; Woods v. Garnett, 72 Miss. 78, 16 South. 390; and Musgrove v. Bonser, 5 Or. 313, 20 Am. Rep. 737. To these may be added Walter v. Hartwig et al., 106 Ind. 123, 6 N. E. 5, and Hastings v. Cutler, 24 N. H. 481, which are directly in point, and Gilbert and others v: Jess, impleaded, 31 Wis. 110, and Musick v. Barney, 49 Mo. 458, which are substantially so. The New Hampshire case is the leading one on the subject. The grounds of the decision are shown by this extract from the opinion, which is typical of the reasoning in the other cases:

"As the deed in this case was not executed according to the statute, the registration as sucl is inoperative; that is to say, the registration is not constructive notice of the conveyance. But if by means of that registration of the defective deed the defendants had actual notice of the plaintiff's title, they are charged with the notice as in other cases. The defendants, when they found the copy of the plaintiff's deed on record, must have understood that the intended record was to give information that such a deed had been made, and that the plaintiff claimed the land under it. This must be regarded as actual notice, such as every reasonable and honest man would feel bound to act upon." Hastings v. Cutler, 24 N. H. 4\$1, 483.

A writer in the Central Law Journal, in discussing the source fron: which "actual notice" should come, says: "It is not essential in every case that the notice should come from a party in interest, but that it should come from some one who is capable not only of informing the party of the adverse claim, but who can give such definite information as to details as will lead to the acquisition of full knowledge of the facts. If this is a correct deduction, then the copy of a deed, even though it were defectively acknowledged, would amount to actual notice of a higher degree than mere oral information of the existence of such deed, even though the copy was made by a third party, and the oral information came from a prior grantee. Hence the registry of a defectively acknowledged deed would amount to notice of the conveyance, provided it were either admitted or proved, that the subsequent purchaser saw and examined the record where the deed was transcribed." 4 Central Law Jour. p. 293.

The author of Wade on Notice, in an article published in the Amerjcan Law Review in 1885, said: "Registration of a deed, void 'for informalities, as constructive notice, coming to the knowledge of the subsequent purchaser, puts him in the direct line of inquiry, and is actual notice of every fact to which that inquiry would lead." 19 Am. Law Rev. p. 88.

PORTER, J. (dissenting). I concur in the foregoing discent, and believe that the decision, especially when applied to recorded instruments AIG.Prop. -58 
which have defective acknowledgments, may work great injustice to innocent persons, and will produce results which the legislature in adopting the recording act never intended..$^{32}$

\section{(C) Effectiveness of Record}

\section{SIGOURNEY v. LARNED. •}

(Supreme Judicial Court of Massachusetts, 1830. 10 Pick. 72.)

This was a bill in equity to redeem. Isaac Amidon, under whom both parties claimed, made a deed of mortgage to the defendant, dated the 7 th of April, 1827.

It appeared by the deposition of the register of deeds, that on the Sth of April, which was Sunday, Amidon came to his dwelling-house and entered the door while the clock was striking twelve at midnight, and that Amidon handed the deed to the register, who was a justice of the peace, requesting him to take the acknowledgment of the deed and to record it.

The register received the deed, but he did not recollect whether the certificate of the acknowledgment was affixed at that time, or after daylight on the same morning.

The register made a memorandum on the deed, that it was received and recorded on the 9th of April at one minute after twelve $0^{\circ}$ clock a. $m$.

32 As to mhat is sufficient "notice" to affect the subsequent purchaser in Massilchusetts, see l'omroy v. Stevens, 11 Mete. (Mass.) 24t (1S4ti). But cf. George $r$. Kent, 7 Allen (Mass.) 16 (1S63). In Maine, see Spofford v. Weston, 29)

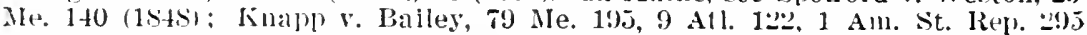
(1SST). In ()hio, nuder the mortgage registry statute, tlie clearest sort of notice does not affect. Mayham v. Coombs, 14 Ohio, 429 (1846). And in North Callina the same is true as to all couveyances. Wood v. Lewey, 15: N. C. 401, (!) S. E. $268(1910)$.

A. takes possession of land belonging to $B$. and holds same adversely for the period of the statute of limitations. B. then sells and comreys the land to $X$., who pals value therefor witlout any linowledge of $\Lambda$.'s rights. What effect, if any, does such sale and conveyance have mpon A.'s rights?

Lis l'ENBENS. - A purchaser of land from a party involved in litigation regarding the title to that land takes subject to the revults of such litigation. "It is scarcely correct to speali of lis pendens as alfecting a purchaser through the doctrine of notice, though undoubted!y the language of the conrts often so describes its operation. It affects him, not beciluse it amounts to notice, but because the law does not allow litigant parties to give to others, fending the litigation, rights to the property in dispnte, so as to prejulice tlue opposite party." Bellany v. Saline, 1 De G. \& J. 566,575 (155T). The principle is as applicable to actions at law as to suits in equity, though the occasions for its operation seldom arise in the case of actions at law.

By statute in many states a notice of the pending litigation must be recorded. Without such recolding pursuant to the statute, a holla tide purchiser for ralue without other notice of the litigation may acquire rights even from a party to the suit, which will prevail over the rights of other farties, though surcessful in the litigation. See, generally, on the subject, 2 I'onleroy, Ly. Juris. $\$(; 32$ et seq. 
The land was subject to two previous mortgages, which were afterwards assigned to the defendant.

The plaintiff derived his title from an attachment made "instantly after twelve o'clock" on the morning of the 9th of April, without notice of the mortgage to the defendant.

The plaintiff tendered the sum due on the two mortgages of which the defendant was the assignee, and the question was, whether the attachment was to be preferred before the third mortgage.

Per Curiam. Whether a delivery of a deed to the register at his dwelling-house is equivalent to a delivery at his office, need not be determined, as the Court are of opinion, that independently of that question, the deed to the defendant was received and recorded under such circumstances as will not allow it to have the preference over the attachment. It was not in a state to be considered as recorded, until after the attachment was made. It should not only be acknowledged, but the certificate of acknowledgment should be completed, before the delivery to the register, in order that such delivery shall constitute a record. The certificate of acknowledgment is to be a part of the record. It is not sufficient that the register is informed of the acknowledgment; the object of recording is to give notice to others. Until this certificate was affixed, the fact that the deed was acknowledged and in the register's hands, could not be notice. By the statute, (St. 1783, c. $37, \S 4$, ) a deed, to have effect against any but the grantor and his heirs, and to entitle it to be recorded, must be acknowledged by such grantor before a justice of the peace. Here Mr. Ward acted in the double capacity of justice of the peace, and register of deeds. He could not consider the deed as in his official custody in the latter capacity, until he had done his office in taking the acknowledgment of the grantor in the former, which must necessarily take some time. The exact time when the certificate was made, does not distinctly appear; but the probability is, that it was not done till the next morning.

But we do not decide the case upon that ground; had the magistrate proceeded instantly to write the certificate of acknowledgment, it must have taken some time, during which the attachment took effect. Where, in a controverted question of property, the parties stand upon equal grounds, in point of equity, the legal title shall prevail; and in such cases slight circumstances are sufficient to determine that priority, upon which the preferable legal title depends. Here we think the attachment was prior in time, and the maxim prior in tempore, potior in jure, must decide in favour of the attaching creditor. Redemption decreed. 


\section{PRINGLE v. DUNN.}

(Supreme Court of Wisconsin, 1575. 37 Wis. 449, 19 Am. Rep. 772.)

Action commenced in Columbia county, August 24, 1863, to foreclose a mortgage alleged to have been executed by the defendants, Andrew Dunn and wife, to the La Crosse \& Milwaukee Railroad Company upon the northeast quarter of the southeast quarter of section six, township twelve north, of range nine east, in Columbia county, to secure one of the bonds of said company for $\$ 5,000$ payable Jan. $1,186+$; said mortgage bearing date April 11, 1S54, and alleged to have been recorded on that day in the office of the register of deeds for Columbia county. The plaintiff claimed to hold the bond and mortgage as a bona fide purchaser for value before due. The assignment to him was not of record. The action was originally brought against the Dumns, the La Crosse \& Milwaukee Railroad Company and Hans Crocker, its receiver. Numerous other defendants were afterwards brought in by amendment, and among them the Mihwaukee $\&$ St. Paul Railway Company, Thomas Maloy, Stanislaus Bartosz, and Felix McLindon. The complaint, as amended, contained as against all the defendants, except the Dunns, the allegation, that they had, or claimed, some interest in, or title to the mortgaged premises which, if any, was subsequent and subject to the mortgage of the plaintiff.

The Milwaukee \& St. Paul Railway answered and, among other things, denied specially that the plaintiff's mortgage was, at or before the time of recording witnessed so as to entitle it to record, and alleged that the record of the same has and shows no subscribing witnesses' names thereon, and that the said company had since in good faith purchased a portion of the premises covered by said mortgage without any actual knowledge of the plaintiff's mortgage. It appeared that the quarter quarter section embraced in the mortgage had subsequently been platted as an addition to the city of Portage, and the various lots thereof conveyed to divers parties, who were made defendants. The mortgagor Dumn died before suit brought.

Venue was changed to Milwaukee county. The testimony as to the witnessing and recording of the plaintiff's mortgage, on which action was brought, was voluminous and conflicting, but substantially as follows; The plaintiff offered in evidence the mortgage which purported to have been signed by Andrew Dunn and Sarah J. Dunn as mortgagors and by H. C. Baker and A. J. McFarlane, as subscribing witnesses, and acknowledged before Harvey C. Baker, as notary public. The defendant offered in evidence a certified copy of the record of said mortgage, certified by the register of deeds of Columbia county, which shows the mortgage the same as the original, except that there are no witnesses' names in the record. The original record was also offered showing the same discrepancy. The deposition of Wm. Owen was read, who testified that he was the register of deeds of Columbia 
county, at the time the mortgage was recorded; that he signed the certificate indorsed thereon; that after the recording he compared the mortgage with the record, assisted by one P. M. Johnson, he holding the mortgage and comparing, while Johnson read the record; that the record was written by Johnson, who was at the time in the employ of the La Crosse \& Milwaukee Company; that the company were desirous of having their farm mortgages speedily recorded, and made an arrangement with the register whereby the copying of the deeds into the records was done by Johnson, and the register thereafter compared with him and certified to the record. The witness was confident he had compared this mortgage by the mark "ex." made at the foot of the page, which was, as he was positive, in his own handwriting; that at the time of the comparing there were no names of subscribing witnesses on the deed; that, as he thought, the fact was mentioned at the time, and that Johnson said he would go and have witnesses' names subscribed to the mortgage. Hugh McFarlane testified that he was father of A. J. McFarlane, whose name was upon the mortgage as witness; that A. J. McFarlane was dead; that he knew his handwriting and was positive the signature upon the mortgage was not his son's handwriting; that the son was 14 or 15 years old at the date of the mortgage. Four other witnesses testified to knowledge of A. J. McFarlane's handwriting, and that they thought the signature upon the mortgage was not his.

The plaintiff, as rebutting evidence, produced P. M. Johnson, who testified that he recorded the mortgage; that he could not recollect whether the witnesses' names were upon the original mortgage at the time of recording; that it was his special business at the time to see that the mortgages were properly executed, and, if they had been wanting, he thought it hardly possible that the fact would have escaped his notice; that the record was made hastily, and the omission of the names in the record was probably an oversight on his part; that this was more likely than that he should have suffered the deed to pass through his hands incompletely executed. The plaintiff also offered in evidence the original general index from the office of the register of deeds of Columbia county and read therefrom the entry of the reception and record of said mortgage in form and manner as prescribed by section 123 , c. 10, R. S. 1849.' The plaintiff also introduced as a witness Harvey C. Baker, who testified that both the grantors in the mortgage signed and acknowledged the same before him as notary and that he subscribed the same as a witness at the time; that A. J. XIcFarlane went with him to the house of Andrew Dunn to obtain the signature and acknowledgment of Mrs. Dunn ; could not positively remember as to McFarlane's signing; but his best recollection was, that he was present and witnessed the signing of the mortgage; did not know young MIcFarlane's handwriting. Witness's recollection in regard to the circumstances was quite indistinct. He was contradicted, as to conversations held with A. B. Alden, who was introduced by 
defendants and testified that Baker had admitted to him that one of the mortgages given by Dunn had been returned to him by Johnson to have witnesses procured. Some evidence was introduced tending to impeach his reputation for truth and veracity. Mrs. Sarah J. Dunn testified that she had no recollection of signing and acknowledging the mortgage, or of Baker and McFarlane coming to the house, as Baker had testified.

Thomas Maloy, one of the defendants, admitted in his deposition that he had heard at the time he purchased his lots, that there was a defective railroad mortgage said to be upon the lots, but which was reputed to be good for nothing; that Mary Maloy, his wife, also owned a lot purchased after the mortgage; that he was present at the purchase and did the business for her; that he had previously heard that there was such defective mortgage. There was no evidence that she had heard of, or had any notice of its existence.

Felix McLindon, one of the defendants, admitted in his deposition that he "knew by report that there was a railroad mortgage on the place at the time he bought two of the lots covered by the mortgage in suit."

Stanislaus Bartosz, a defendant, who owned and lived on several of the lots, testified that he had no actual knowledge of the mortgage; but it appeared in evidence that his grantor, Simon Bartosz, had purchased from $\mathrm{H}$. W. Tenney, one of the parties who had platted the forty acres embraced in the mortgage in suit, and that Tenney's deed to Simon Bartosz contained the clause: "said premises are free and clear from all incumbrances, except a mortgage to the La Crosse Railroad Company, which I am to save said Bartosz harmless from."

The court below found that the mortgage was not subscribed by Baker and McFarlane as witnesses at the time of the execution thereof, and not until after the recording thereof, but was so subscribed afterwards, but was not again recorded; that the plaintiff purchased the bond and mortgage in regular course of business, and was the owner and holder thereof; that none of the defendants had actual notice of the mortgage, and that the record thereof, before the same was witnessed, was not constructive notice of the mortgage; and that the defendants are entitled to judgment that the complaint be dismissed.

To these findings the plaintiff excepted, and appealed from the judgment.

Cole, J. Before approaching the legal questions involved in this case, it is necessary to determine a question of fact. And that is, Does the evidence show that the mortgage sought to be foreclosed was properly attested when first left at the office of the register, so as to entitle it to record? There is considerable testimony in the case which tends strongly to prove that the mortgage had no witnesses when it was recorded. And the court found as a fact that the mortgage was not subscribed by the witnesses, Baker and McFarlane, at the time of its execution and before it was transcribed upon the records and en- 
tered in the general index, but was subscribed by these witnesses after it was recorded, and that it was not again recorcled. This finding affirms one important fact which is much contested by the defendants, which is, the genuineness of the signature of the witness A. J. McFarlane to the instrument. An attempt was made to prove, and it is argued that the evidence shows, that McFarlane never signed the mortgage as a witness, and that his signature thereto is a forgery. On this point we will only make the remark, that we are satisfied from the evidence, and especially by an inspection of the writings themselves, of the authenticity of the signature. Whether the mortgage was subscribed by the witnesses at the time of its execution, and before it was left at the office for registry, is a question of more doubt, upon the evidence. The testimony is quite strong and positive, that the mortgage had no subscribing witnesses when it was recorded. But this tesiimony is contradicted; and, considering the circumstances attending the execution and delivery of the mortgage, we think the probabilities favor the inference that the instrument was witnessed when it was left for record. According to this view, there was a mistake in transcribing the mortgage upon the record, by omitting the names of the witnesses. The weight of the evidence to our minds supports this inference or conclusion. It is to be observed that the mortgage is perfect and fair on its face, showing two witnesses. A strong presumntion fairly arises from the instrument itself, that it was witnessed at the time of its execution. This presumption is not overcome nor repelled by the testimony offered to show that it was not witnessed at that time.

In respect to the degree or quantity of evidence necessary to justify a finding that the subscribing witnesses signed the instrument after it was executed and recorded, the case would seem to come within the rule laid down in Kercheval v. Doty, 31 IVis. 478, where it is said: "The proposition being to set aside or invalidate a written contract by evidence of a far less certain and reliable character than the writing itself, the greatest clearness and certainty of proof should be required. It is like the cases where the object is to correct or reform a deed or other instrument on the ground of mistake, or to set aside or rescind it on the same ground; where the rule is, that the fact must be established by clear and satisfactory evidence." The testimony offered to show that the mortgage was not witnessed when executed, and before it was recorded, falls short of this rule. The fact is not established by clear and conclusive proof that it was not witnessed when executed. It would serve no useful purpose to go into a detailed discussion of the evidence upon this point, and we shall not do so. It -is sufficient to say that, giving to the testimony offered to show that the mortgage was not witnessed before it was received for record, all the weight to which it is entitled, it fails to establish that fact in a clear, satisfactory manner. 
Assuming, then, that the mortgage was witnessed when it was left at the office of the register to be recorded, the further important inquiry arises as to what effect must be given to the record as constructive notice to subsequent bona fide purchasers for value. 'This record was in this state. The entry of the mortgage was made in the general index book, but the full record of the instrument had no stlbscribing witnesses. And therefore the question is, Would such a record operate as constructive notice to subsequent purchasers for value, independent of any actual notice? It is claimed by the counsel for the plaintiff that the record does and should so operate, notwithstanding the mistake in the registration or recording of the instrument in extenso. This presents a question of no little difficulty, which must be solved by the application of general principles of law to the provisions of our statute.

It is a familiar rule, that an instrument must be properly executed and acknowledged so as to entitle it to record, in order to make the registry thereof operate as constructive notice to a subsequent purchaser. Says Mr. Justice Story: "The doctrine as to the registration of deeds being constructive notice to all subsequent purchasers, is not to be understood of all deeds and conveyances which may be de facto registered, but of such only as are authorized and required by law to be registered, and are duly registered in compliance with law. If they are not authorized or required to be registered, or the registry itself is not in compliance with the law, the act of registration is treated as a mere nullity: and then the subsequent purchaser is affected only by such actual notice as would amount to a fraud." 1 Eq. Jur. § 40t. See also Ely v. Wilcox, 20 Wis. 528, 91 Am. Dec. 436; Fallass v. Pierce, 30 Wis. 444 ; Lessee of Heister v. Fortner, 2 Bin. (Pa.) 40, 4 Am. Dec. 417; Shove v. Larsen, 22 Wis. 142, and cases cited on page 146.

Under our statute, anong other requisites, two witnesses are essential to a conveyance, to entitle it to record. The statute requires every register to keep a general index, each page of which shall be divided into eight columns, with heads to the respective columns as prescribed; and the duty is imposed upon the register to make correct entries in said index of every instrument received by him for record, under the respective and appropriate heads, and immediately to enter in the appropriate column, and in the order of time in which it was received, the day and hour of reception; and it is declared that the instrument "shall be considered as recorded at the time so noted." R. S. c. 13 , §§ 142, 143. In Shove v. Larsen, supra, the effect of this index containing correct entries of matters required to be made therein was considered. And it was held that by force of the statute it operated as constructive notice to a subsequent purchaser. In that case the index contained an accurate description of the land mortgaged, but, in transcribing the mortgage at large upon the records, a mistake was made in the description. And it was claimed in behalf of the subsequent purchaser, 
that it was the registration of the instrument at large which alone amounted to constructive notice. But this construction of the statute was not adopted, the court holding that a subsequent purchaser was bound to take notice of the entries in the index, which the law required the register to make. This result seemed to follow necessarily from the language of the statute, which declared that the instrument should be considered as recorded at the time noted. Time might elapse before the instrument was transcribed at large on the record, or it might be lost and not transcribed at all, leaving the index the only record of its contents. And the manifest intention of the statute scemed to be to make the index notice of all proper entries from its date, and also of the instrument itself till it was registered in full. The further consequence would seem necessarily to result from this view of the statute, that the registration of the conveyance in extenso relates back to the registration in the index, and from thence there is constructive notice of the contents of the instrument. The doctrine of Shove v. Larsen was approved in Hay v. Hill, 24 Wis. 235; but the court refused to make the entry in the index in that case operate as constructive notice, because upon its very face it bore conclusive evidence that it was not made at its date. In other words, the rectitude and integrity of the index were successfully impeached by the index itself. See also International Life Ins. Co. v. Scales, 27 Wis. 640.

Where there is nothing upon the face of the index to impeach or throw suspicion upon its accuracy, there it would affect a subsequent purchaser with notice of those facts which the law required to appear therein. Doubtless a still further consequence follows from this construction of the statute, namely, that where by some mistake there is a discrepancy between the proper index entries and the instrument as registered, there each supplies the defects of the other in the constructive notice thereby given. That is, it appears to be the intention of the statute to charge the subsequent purchaser constructively with such knowledge as the proper index entries afford, as well as with notice of those facts derived from the registration itself. He is presumed to have examined the whole record, and is affected with notice of what it contains. But when the instrument, as registered in full, appears defective in some material and essential parts which are not supplied by the index entries, what effect then must be given the record as constructive notice? This is really the difficult question in this case. From the entries in the index it would not appear whether the mortgage was witnessed or not. The presumption from the mere entries themselves would be, that it was witnessed and acknowledged so as to entitle it to record. But when the mortgage as registered in full was examined, it would be found that it had no witnesses and had no business on the records. As the record itself is only constructive notice of its contents, it is difficult to perceive how it can go beyond the facts appearing upon it, and charge a purchaser constructively with knowledge of a fact not in the record. 
One of the counsel for the defendants states the argument on this point as follows: He insists and claims that the entries in the index book, so far as they indicated that the mortgage had been filed for record, indicated also that the mortgage was so executed as to entitle these entries of it to be made; but that when the full record was looked at for all the particulars of the mortgage, and perhaps for the express purpose of verifying the entries in the index, it is found that the apparent assertion by the index entries that the mortgage was properly executed was wholly untrue, and that the mortgage in fact was no incumbrance. The fact, as truly shown to exist by the full record, overcomes and destroys the false assertion as to the fact in the index. And it appearing by the instrument registered that it was not entitled to record, both the registration and index itself cease to affect the purchaser with constructive notice.

It is not readily perceived wherein this argument as to the effect of our various provisions upon the subject of registration is unsound. The question mainly depends upon the construction of our own statutes. So far as we are aware, this is the first time the point has been presented in this court for adjudication. We have derived but little aid from the decisions in other states, for the reason that few of them have similar statutory provisions. We have been referred by the counsel for the plaintiff to two cases in Michigan, Brown v. McCormick. 28 Mich. 215, and Starkweather v. Martin, Id. 472. In Brown v. McCormick the effect of the registry, as notice to subsequent purchasers, was made to turn upon the curative act of 1861, mentioned in the opinion. In Starkweather v. Martin the question was, how far the absence, on the registry of a deed, of any mark or device indicating a seal, or of any statement of the register that the original was sealed, affecterl the validity of the record entry as evidence of title. The record entry of the deed was made more than forty years before the cause was decided, by the proper officer, and in the appropriate place for the registry of deeds, under the law permitting the registry of only sealed instruments; and the instrument was in the form of a warranty deed, purporting to be acknowledged and dated at a time when it was the common and lawful course to seal conveyances, and contrary to official duty to take the acknowledgment unless the conveyance was sealed, and where the conclusion, attestation clause, and certificate of acknowledgment of the instrument all spoke of it as under seal. The court said that these facts and incidents taken together afforded a very strong presumption that the original was sealed.

The doctrine of this case does not seem to have a very strong bearing upon the question under consideration. It may be said that it was contrary to the duty of the register to record the mortgage unless it was properly acknowledged and witnessed, and that a presumption arises that he would not have done so. But in answer to this it may also be said that the law made it the duty of the register to record, or cause to be recorded correctly, all instruments authorized by law to be 
recorded. Section 140 , c. 13 , R. S. 1858 . And the presumption that he performed his duty in recording the mortgage correctly, is as strong as the presumption that he would not have recorded it unless it was entitled to registry.

In Shove v. Larsen, a number of cases are referred to which hold that a mistake in recording a deed, or recording it out of its order, renders the registration ineffectual as notice to subsequent incumbrancers and purchasers. The doctrine of those cases would seem to be applicable to the case before us. The registration and index entries being incomplete, because showing that the mortgage had no subscribing witnesses, constructive notice could not be presumed of such a record. For the principle "that the registry is notice of the tenor and effect of the instrument recorded, only as it appears upon that record," fully applies. Shepherd v. Burkhalter, 13 Ga. 443, 58 Am. Dec. 523. See, in addition to the cases cited in Shove v. Larsen; Brown v. Kirkman, 1 Ohio St. 116; Stevens v. Hampton, 46 Mo. 404; Bishop v. Schneider, 46 Mo. 472, 2 Am. Rep. 533; Terrell v. Andrew County, 44 Mo. 309; Frost v. Beekman, 1 Johns. Ch, (N. Y.) 288.

The question then arises, whether the evidence shows that any of the defendants were affected with actual notice of the mortgage. This question, we think, must be answered in the affirnative, so far as the defendants Thomas Maloy and Stanislaus Bartosz are concerned.

In the deposition taken on his own behalf, but read as a part of the plaintiff's case, Thomas Maloy distinctly admits that he had heard, when he purchased his lots, that there was a defective railroad mortgage upon them, but that he did not look for it, because his abstract did not show it. It is claimed by one of the counsel for the defendants, that this related to the Aiken mortgage, and not to the one upon which this action is brought. It seems to us, however, that this is a totally inadmissible construction of the testimony. He most certainly refers to the mortgage in suit. And what he had heard about there being a defective railroad mortgage upon the property, was sufficient to put him upon inquiry. Parker v. Kane, 4 Wis. 1, 65 Am. Dec. 283. "What is sufficient to put a purchaser upon an inquiry is good notice; that is, where a man has sufficient information to lead him to a fact, he shall be deemed conusant of it." Sugden on Vendors (9th London Ed.) p. 335. "In regard to the inquiry required of a party, it should be such as a prudent and careful man would exercise in his own business of equal importance. Accordingly, where the mortgagee is informed that there are charges affecting the estate, and is cognizant of two only, he cannot claim to be a purchaser without notice of other charges, because he believes that the two, which satisfy the word charges, are all the charges upon it. $\mathrm{He}$ is bound to inquire whether there are any others. The rule with respect to the consequences of a purchaser abstaining from making inquiries does not depend exclusively upon a fraudulent motive; a man may abstain from mere heedlessness, or stupidity, and be none the less responsible for the consequences; but 
if he make reasonable inquiry, and is deterred by a false answer, he is excusable, if it be of a character to delude a prudent man." 1 Story's Eq. Jur. $\S 400$ b; Jackson v. Van Valkenburgh, 8 Cow. (N. Y.) 260. Independently of the record, Maloy had notice of the existence of the mortgage, or had a knowledge of such facts as to call for further inquiry. He cannot, therefore, be protected as an innocent purchaser for value.

The defendant Bartosz must be charged with notice of the mortgage by the recitals in the deed from Tenney and wife to his immediate grantor. He was present when that deed was executed and delivered to his uncle. He testifies that he did not know whether anything was said about the railroad mortgage at that time or not; that he did not understand English very well. The purchase was really made by his uncle for him. And whether he fully understood the conversation at the time about incumbrances, he must be chargeable with notice of what appears in his chain of title. This clause was in the deed to his uncle: "Said premises are free and clear from all incumbrances except a mortgage to the La Crosse Railroad Co., which I an to save said Bartosz harmless from." The general rule upon this subject is, "that where a purchaser cannot make out a title but by a deed which leads him to another fact, he will be presumed to have knowledge of the fact." The following authorities are very clear and decisive upon that point: Fitzhugh v. Barnard, 12 Mich. 105; Case v. Errwin, 18 Mich. 434; Baker v. Mather, 25 Mich. 51; Howard Insurance Co. v. Halsey, 8 N. Y. 271, 59 Am. Dec. 478; Frost v. Beekman, supra, 1 Johns. Ch. (N. Y.) 298; Gilbert v. Peteler, 38 N. Y. 165, 97 Am. Dec. 785; Acer v. Westcott, 46 N. Y. 384, 7 Am. Rep. 355; Coles v. Sims, 5 De Gex, M. \& G. 1. The clause in the deed referred to the mortgage as an existing incumbrance, and he cannot now in good faith claim that it is not a lien upon his property.

The counsel for the plaintiff claims that the defendant McLindon had actual knowledge of the existence of the mortgage. It is true, he testified that when he purchased, he knew by report that there was a railroad mortgage upon the property, but he says that the report stated that the mortgage was void. Were he not protected by another principle, he could not certainly be regarded as a bona fide purchaser. But he purchased from S. S. Johnson, or claims through Johnson, in whom the title stood free from any taint. For the rule is well settled, that a purchaser affected with notice may protect himself by purcliasing of another who is a bona fide purchaser for a valuable consideration. For a similar reason, if a person who has notice sells to another who has no notice and is a bona fide purchaser for a valuable consideration, the latter may protect his tille, although it was affected with the equity arising from notice in the hands of the person from whom he derived it. Mr. Justice Story says this doctrine, in both of its branches, has been settled for nearly a century and a half in England. $1 \mathrm{Eq}$. Jur. § 410. He states an exception to the rule, which was recog- 
nized and enforced in Ely v. Wilcox, 26 Wis. 91, where the estate became revested in the original fraudulent grantee, when the original equity 'was held to reattach to it. 'There is no pretense that McLindon comes within the exception; and as a bona fide purchase of an estate, for a valuable consideration, purges away the equity from the estate in the hands of all persons who derive title under it, he is protected. It is said that it does not appear that Johnson's title was derived from the conmon source. As we understand the bill of exceptions, an abstract was offered in evidence to show title from Dunn, by various intermediate conveyances, to the defendant, which was ruled out on the plaintiff's objection. But perhaps it is a better answer to the objection to say that the plaintiff has made the defendants parties under the general allegation that they claim some interest in or title to the mortgaged premises, which was subject to the mortgage. This allegation implies that this interest was not adverse, but was derived from Dunn, though subsequent in date and inferior in right to the plaintiff's mortgage.

It was further insisted that the evidence showed that the defendant Mary Maloy had actual notice of the mortgage. We do not think this position is sustained by the testimony. It is attempted to charge her with the same actual knowledge her husband had, because he aided her when she made her purchase of Martin Maloy. It does not appear that anything was said at this time about the railroad mortgage, or that she ever had any notice of it. It does not appear, even, that he was acting as her agent in any legal sense; and besides, if he were, his knowledge acquired at another time, when not engaged in her business, ought not to be imputed to her. Notice, to bind the principal, should be brought home to the agent while engaged in the business or negotiation of the principal, and when it would be a breach of trust in the former not to communicate the knowledge to the latter. 1 Story's Eq. Jur. § 408, and cases cited in note $I$. 'The evidence fails to bring her within that rule.

A number of other questions were discussed upon the argument; but we believe these observations dispose of all the more important ones.

The judgment of the circuit court as to the defendants Thomas Maloy and Stanislaus Bartosz must be reversed, and the cause remanded for further proceedings in accordance with this decision.

By THE COURT. It is so ordered. ${ }^{33}$

33 Parret v. Shaubhut, 5 Minn. 329 (Gil. 25S), 80 Am. Dec. 424 (1S61), acc.

The matter of acknowledgment, witnessing, etc., as prerequisites to effectire recording, is dependent entirely unon the statutes of the state where the land is. The student should consuit the statutes. 


\section{FROST v. BEEKMAN.}

(Court of Chancery of New Tork, 1S14. 1 Johns. Ch. 2SS.)

The Chancelitor. ${ }^{3 *} * *$ * Another, and a more interesting question, is, respecting the extent and effect of the registry of the defendant's mortgage, as notice to purchasers. It was a mortgage for $\$ 3,000$, and, by mistake, the registry was only for $\$ 300$. This mistake is the whole cause of the controversy.

The mortgage act of the sess. 24 , ch. 156 , declared, among other things, that the registry of a mortgage should contain, not, indeed, the mortgage at large, but the essential parts of the mortgage, and, among other specified parts, "the mortgage money, and the time or times when payable." To this register all persons whomsoever, at proper seasons, are at liberty to have recourse; and the act declared that mortgages were to have preference, as to each other, according to the times of registry, and that "no mortgage should defeat or prejudice the title of any bona fide purchaser, unless the same should have been duly registered, as aforesaid." This registry is notice of the mortgage to all subsequent purchasers and mortgagees; and so the act was construed, and the law declared, by the court of errors, in the case of Johnson v. Stagg, 2 Johns. 510. 'The English authorities, on this point, do not, therefore, govern the case. The language of those authorities, undoubtedly, is, that the registry is not notice, though that doctrine is much questioned, and the point seems still to be floating and unsettled. Bedford v. Backhouse, 3 Eq. Cas. Abr. 615, pl. 12; Wrightson v. Hudson, Id. 609, pl. 7 ; Morecock v. Dickins, Amb. 678; Latouche v. Dunsany, 1 Schoale \& Lefroy, 157; Sugden (3d Lond. Ed.) 524-7; Com. Dig. tit. 32 , Deed, ch. $21, \S 11$. The only question with us is, when, and to what extent, is the registry notice? Is it notice of a mortgage unduly registered? or is it notice beyond the contents of the registry?

The true construction of the act appears to be that the registry is notice of the contents of it, and no more, and that the purchaser is not to be charged with notice of the contents of the mortgage, any further than they may be contained in the registry. The purchaser is not bound to attend to the correctness of the registry. It is the business of the mortgagee. and if a mistake occurs to his prejudice, the consequences of it lie between him and the clerk, and not between him and the bona fide purchaser. The act, in providing that all persons might have recourse to the registry, intended that as the correct and sufficient source of information; and it would be a doctrine productive of immense mischief to oblige the purchaser to look, at his peril, to the contents of every mortgage, and to be bound by them, when different from the conients, as declared in the registry. The registry might prove only a snare to the purchaser, and no person could be safe in his purchase,

\footnotetext{
34 Onfy that part of the opinion dealing with the matter of registry is printed.
} 
without hunting out and inspecting the original mortgage, a task of great toil and difficulty. I am satisfied that this was not the intention, as it certainly is not the sound policy, of the statute; nor is it repugnant to the doctrine contained in the books, that notice to a purchaser, of the existence of a lease, is notice of its contents. Taylor v. Stibbert, 2 Ves. Jun. 437 ; Hiern v. Mill, 13 Ves. Jun. 118, 120; Hall v. Smith, 14 Ves. Jun. 426. In that case, the party is put upon inquiry, and he must make it, or abide the consequences. The decision, in Jackson v. Neely, 10 Johns. 374, was made upon the same principle; and it was held that the recital in a deed of a letter of attorney, by which it was made, was notice to the purchaser of the existence of such a power. But here the statute did not mean to put the party upon further inquiry. The registry was intended to contain, within itself, all the knowledge of the mortgage requisite for the purchaser's safety.

The question does not necessarily arise, in this case, how far the unauthorized registry of a mortgage, as one made, for instance, without any previous legal proof, or acknowledgment, would charge a purchaser with notice of the mortgage. The better opinion, in the books, seems to be, that it would not be notice, and that equity will not interfere in favour of an incumbrancer, when he has not seen that his mortgage was duly registered. Sugden's Law of Vend. 527; 1 Schoale \& Lefroy, 157; Heister v. Fortner, 2 Bin. (Pa.) 40, 4 Am. Dec. 417. But here every thing was done that could have been previously required of the mortgagee. The mortgage was duly presented for registry, and he was not bound to inspect and correct the record. This was the exclusive business and duty of the clerk, and there is no reason why the registry should not operate as notice, to the amount of the sum mentioned therein; and, indeed, so far the obligation of the registry is admitted by the bill.

I conclude, therefore, that the registry was notice to purchasers, to the amount, and only to the amount, of the sum specified in the registry.

\section{TERRELL v. ANDREV COUNTY.}

(Supreme Court of Missouri, 1S69. 44 Mo. 309.)

IVAGNER, J. The argument in reference to the execution of the power contained in the mortgage, and the frauds between the Terrells in the purchase of the property at the mortgagee's sale, is beside and irrelevant to any issue in the case. If the facts alleged are true, they may have furnished sufficient reason for Holt, the mortgagor, to move to set aside the sale; but in the absence of any complaint on his part, the defendant can not make the objection for him. There is but one question in this case to be determined. It scems that Andrew county loaned to one Holt the sum of four hundred dollars belonging to the common-school fund, for the securing of which he gave personal se- 
curity, and also executed a mortgage on a lot owned by him in the city of Savannah. The county duly deposited the deed for record with the recorder of the county, and that officer, in recording the same, by mistake inserted two hundred dollars in the record instead of four hundred dollars, showing an encumbrance for the former instead of the latter sum. After the mortgage was recorded, Holt applied to one of the plaintiffs for a loan of money, and offered to secure him by mortgage liens on real estate, the lot mortgaged to the county being among the property. On examination, the record showed a mortgage for two hundred dollars; the money was loaned, and a junior mortgage given subject to the prior lien. Subsequently the county ordered the lot sold in default of payment, claiming the full amount of four hundred dollars, together with accrued interest. The plaintiff paid the two hundred dollars, with interest thereon, and proceeded to enjoin the collection of the remainder.

The Court of Common Pleas in Buchanan county, to which the cause was removed by change of venue, rendered judgment of perpetual injunction, and this judgment was reversed in the District Court.

The only question, therefore, is whether, under the law, the record imparted notice for any greater amount than two hundred dollars. It is not pretended that, at the time Terrell loaned the money and took his mortgage, he had any other notice of the county's claim than that disclosed by the record.

It is contended here on behalf of the county that, according to our statute, when a person files with the recorder an instrument, it imparts notice of its real contents to all subsequent purchasers, regardless of any mistake that the recorder may conmit in placing it on record; that the statute provides that every instrument in writing, certified and recorded in the manner prescribed, shall, from the time of filing the same with the recorder for record, impart notice to all persons of the contents thereof; and all subsequent purchasers and mortgagees shall be deemed, in law and equity, to purchase with notice. R. S. 1855, p. 364, § 41.

According to the literal interpretation of the section, no notice is imparted till the instrument is actualiy placed on record, and then it relates back to the time of filing. It was, no doubt, the intention of the Legislature to give a person filing an instrument or conveyance all the benefit of his diligence; and when he deposits the same with the recorder, and has it placed on file, he has done all that he can do, and has complied with the requirement of the law. From that time it will give full notice to all subsequent purchasers and encumbrancers.

A person, in the examination of titles, first searches the records; and if he finds nothing there, he looks to see if any instruments are filed and not recorded. If nothing is found, and he has no actual notice, so far as he is concerned the land is unencumbered. If he finds a conveyance, he goes no further; he never institutes an inquiry to find whether the deed is correctly recorded or the contents literally transcribed. Indeed, to attempt to prosecute such a search would be idle 
and nugatory. Grantees do not usually leave their deeds lying in the recorder's office for the inspection of the public. After they are recorded, they take them out and keep them in their posscssion. In a large majority of cascs it would not only entail expense and trouble, but it would be useless, to attempt to get access to the original papers.

Hard and uncertain would be the fate of subsequent purchasers if they could not rely upon the records, but must be under the necessity, before they act, of tracing up the original deed to see that it is correctly recorded. The statute says that when the deed is certified and recorded it shall impart notice of the contents from the time of filing. Certainly; but this is to be understood in the sense that the deed is rightly recorded, and the contents correctly spread upon the record. It never was intended to impose upon the purchaser the burden of entering into a long and laborious search to find out whether the recorder had faithfully performed his duty. The obligation of giving the notice rests on the party holding the title. If he fails in his duty, he must suffer the consequences. If his duty is but imperfectly perfor:med, he can not claim all the advantages and lay the fault at the door of an innocent purchaser.

But it is said the recorder is required to give bond for the faithful performance of all the duties enjoined on him by law, and that this is for the benefit of the subsequent purchaser who is injured by his dereliction, and that he must pursue his remedy against the recorder. This bond is for the benefit of any and every person who may suffer injury by reason of the recorder's neglect to faithfully discharge the duties of his office. It was not Terrell, in this case, who was injured; it was Andrew county. The county deposited the deeds with the recorder, and paid him for recording it. Through his negligence and inattention he did his work inaccurately, so that it imparted notice for only half the consideration, and the county suffered loss and injury in consequence thereof. The privity springs and exists between the county and the recorder, and the county is the proper party to proceed against him to recover the loss.

The judgment of the District Court must be reversed. The other judges concur.

\section{MANGOLD v. BARLOW.}

(Supreme Court of Mississippi, 1884. 61 Miss. 593, 48 Am. Rep. 84.)

Ballou and wife executed a deed of trust to Faler \& Co. on 19th of February, 1877, on the land in controversy, and on that day it was lodged with the clerk of the chancery court for record. It was recorded but the clerk misdescribed the land, giving a different quarter section from that described in the deed. Three years afterward the same grantors executed a deed of trust on the same land to $H$. H. Barlow, 
appellee, which was duly recorded on the day of its execution, 27th lanuary, 1830. There was no actual notice of the first deed or anything to put the last grantee on inquiry. In a contest between the prior and subsequent grantees the court below rendered judgment for the iatter, and from this judgment an appeal is taken.

Canpiell, C. J. The question is, who shall suffer loss from an error of the clerk in recording a deed duly acknowledged and lodged with him for record? Does the grantee acquit himself fully of all duty when he delivers the deed to the proper officer for record, or is it his duty to see that the instrument is properly recorded? And if a mistake is made in recording by which a subsequent grantee is misled and injured, whose claim shall prevail, that of the first grantee, who relied on the officer to do his duty, or of the second grantee, who, in the faith that the record is true, acts upon it? Shall the deed prevail or the record of it? There is great contrariety of opinion on this subject in other States. The courts of New York, Ohio, Vermont, Michigan, Iowa, Wisconsin, Minnesota, Georgia, Tennessee, Missouri, and California hold that subsequent purchasers are bound only by what the record shows, while those of Alabama, Illinois, Pennsylvania. Connecticut, Rhode Island, Virginia, and Texas hold that a grantee who lodges the deed for record has done all that is required of him, and that the deed must prevail although a mistake is made in recording it; that from the time of its delivery to the proper officer for record it is considered as recorded, and for any error in recording by which a subse"iuent purchaser is misled and injured, he must look to the clerk for redress and cannot throw the loss on the first grantee, who did all he was required to do and should not suffer from the negligence of the clerk. The decided weight of authority seems to be in favor of the view that the record may be relied on by a subsequent purchaser, and that he camnot be affected by a deed not truly recorded. Frost v. Beekman, 1 Johns. Ch. (N. Y.) 28s; Beekman v. Frost, 18 Johns. (N. Y.) 544. 9 Am. Dec. 245; Barnard v. Campau, 29 Mich. 162; Sawyer v. Adans, 8 Vt. 172, 30 Am. Dec. 459; Sanger v. Craigue, 10 Vt. 555 ; Terrell v. Andrew Connty, 44 Mo. 309; Lally v. Holland, 1 Swan (Temn.) 395: Baldwin v. Marshall, 2 Imimph. (Tenn.) 116; Chamberlain v. Bell, 7 Cal. 292, 68 Am. Dec. 260; Shepherd v. Burkhalter, 13 Ga. 443, 58 Am. Dec. 523; Miller v. Bradford, 12 Iowa, 14; Brydon v. Campbell, 40 Md. 331; Pringle v. Dunn, 37 Wis. 449, 19 Am. Rep. 772. For the other view, are Franklin v. Cannon, 1 Root (Conn.) 500; I udd v. Wondruff, 2 Root (Conn.) 298; MicGregor v. Hall, 3 Stew. \& P. (Ala.) 397 ; Mims v. Mims, 35 Ala. 23 ; Nichols v. Reynolds, 1 R. I. 30, 36 Am. Dec. 238; Merrick v. Wallace, 19 Ill. 486; Throckmorton v. Price, 28 Tex. 605, 91 Am. Dec. 33t; Glading v. Frick, 88 Pa. 460; Clader v. Thomas, $\$ 9$ Pa. 343; Beverley v. Ellis, 1 Rand. (Va.) 102.

After the most careful consideration we range ourselves with the minority, and hold that a grantee fully acquits himself of all duty imposed by law when he lodges the instrument with the proper officer 
for record, and from that time it is notice to subsequent purchasers and creditors of what it contains, and not of what the recording officers may make it to show on the record. The clerk is not the agent of the grantee and he is not responsible for his blunders. He has as much right to rely on the fidelity of the officer as has a subsequent purchaser. While his deed is in the clerk's office it shows its contents, and when it is withdrawn from the office it has annexed a certificate by the officer that it has been duly recorded. Either this may be relied on, or the grantee must compare the deed with the record to see if it is truly transcribed. This would be an unreasonable requirement. The first grantee having done all that he is required to do to give notice of the instrument may safely repose on the presumption that the recording officer has done his duty, and if subsequent purchasers or creditors suffer injury from official negligence or misconduct, they must seek redress from the party at fault, and cannot visit the loss on him who has done no wrong. In announcing this view we follow the language of our statute and the rule most consonant with justice and sound policy. The statutes declare that certain instruments shall be "void as to all creditors and subsequent purchasers for valuable consideration, without notice, unless they shall be acknowledged or proved and lodged with the clerk of the chancery court of the proper county to be recorded." The grantee is not required to record the instrument or to see that the officer does his duty. All that is imposed on the grantee is that the instrument shall be acknowledged or proved and lodged with the clerk of the chancery court of the proper county. There his duty ends. That done, his deed is not to be void as to subsequent purchasers or creditors. That is a performance of the condition without which it would be void, and the condition having been performed the instrument is discharged of all conditions and is thenceforth valid as to all. The State has established depositories for instruments to be recorded and has prescribed the duties of recording officers. 'This is for the benefit and protection of subsequent purchasers from a grantor and his creditors. A grantee must have his deed put in condition for being rccorded and must lodge it at the proper place for record. That is all that is required of him. He is not a guarantor of compliance by the recording officer with the law as to recording. It is not for his benefit that the recording is to be done, but for others. The State has undertaken to have the recording done, and if one suffers from the negligence of the officer he must seek redress from the officer.

The judgment of the circuit court is reversed and the cause remanded for a new trial. 


\section{PROUTY v. MARSHALL.}

(Supreme Court of Pennsylvania, 1909. 225 Pa. 570, 74 Atl. 550, 25 L. R. A. [N. S.] 1211.)

POTTER, J. The precise question here presented for determination is whether, when a mortgage is defectively recorded, and wrongly indcxed, by inserting a wrong initial, in entering the name of the mortgagor, the correct name being entirely omitted from the record, a purchaser of the mortgaged premises, without actual notice, is chargeable with notice of such mortgage, and as terre-tenant of the premises, subject to its enforcement against him.

It appears from the record, that on January 20, 1900, L. J. Marshall executed and delivered to Agnes Prouty a purchase money mortgage, sccured upon premises in Dubois borough, Clearfield county. On Februtary 6,1900 , the mortgage was delivered for record by the mortgagee to the recorder of deeds for Clearfield county, and the fee for recording paid to him. The recorder subsequently returned the mortgage to the mortgagce, with his certificate indorsed upon it, certifying that it had been recorded.

The recorder, however, had not recorded the mortgage as executed by L. J. Marshall, and had not indexed it under the name of L. J. Marshall. But upon the record the name of the mortgagor, wherever it appeared, was written "S. J. Marshall," and the only name entered on the inderes was that of "S. J. Marshall."

On August 25, 1903, A. A. La Rue purchased the mortgaged premises and the same were conveyed to him by Marshall. La Rue had no actual notice of the mortgage to Prouty. On July 10, 1906, a scire facias was issued on the mortgage against M.Iarshall as mortgagor and La Rue as terre-tenant, to recover a balance claimed to be due the mortgagee. La Rue, the terre-tenant, defended upon the ground that neither the mortgage books nor the mortgage indexes in the recorder's office showed any mortgage executed by L. J. Marshall or contained any record of the mortgage sued on.

Upon the trial in the court of common pleas, the trial judge directed a verdict for the plaintiff, reserving a point requesting binding instructions for the defendants. The court subsequently overruled a motion for judgment on the reserved point non obstante veredicto, and entered julgment on the verdict. The terre-tenant appealed to the Superior Conrt, which affirmed the judgment of the court below. The present apneal is by the terre-tenant from the decree of the Superior Court, which is assigned for error. ${ }^{35}$

In examination of the cases cited in the opinion of the Superior Court, shows that none of them presented facts similar to those in the case at bar, and in none of them was the exact question here presented, 
considered. Thus in Speer v. Evans, $47 \mathrm{~Pa}$. 141, the case turied upon the question of actual notice, and it was held that actual notice is equivalent to the constructive notice given by the mortgage index. In Brooke's Appeal, $6+\mathrm{Pa} .12 \%$, the point decided was, that, under the Act of May 28, 1775 [1715], 1 Smith's Laws, p. 94, a mortgage has priority of lien from the moment when it is left with the recorder for record, not from the time when it is actually recorded. In Schell $v$. Stein, $76 \mathrm{~Pa}$. 398, $18 \mathrm{Am}$. Rep. 416, the instrument was properly recorded, but not indexed, in a general index. It was held that as the law then stood, the recorder of deeds was not required by the Act of March 29, 1827 (P. L. 154), to keep a general index of all the deed and mortgage books in his office, but only to keep an index for each book. The law in this respect has been changed by the Act of March 18, 1875 (P. L. 32), and general indexes are now required to be kept, and failure to index renders the record defective. The case of IVood's and Brown's Appeal, 82 Pa. 116, also arose beiore the passage of the act of 1875, and it held, that the entry of the mortgage in the proper book gave it a lien, which failure to index would not disturb. The case of Glading v. Frick, SS Pa. 460, also arose before the act of 1875. It was there decided that, "I!"here certain instruments of writing are not required by law to be recorded in a particular book, they may be recorded in any book kept by the recorder; and a builling contract is valid although recorded in a deed book." In Nyoming $\mathrm{Na}$ tional Bank's Appeal, 11 Wkly. Notes Cas. 567, the syllabus rearls: "There a mortgage is left for record and actually recorded, its lien will not be postponed to a subsequent judgment, by reason of the fact that the recorder has failed to enter the same on the book of entries, or upon the index." But this court was careful to point out (page 568; that, "The mortgage in question was left at the recorder's office in 1873, prior to the passage of the act of March 18,1875 , so that it is not necessary to inquire whether the failure to index deprived the mortgagee of his security." Clader v. Thomas, $89 \mathrm{~Pa} .343$, and Paige v. Wheeler, $92 \mathrm{~Pa}$. 282, enunciate no new principle, and both cases arose prior to the act of 1875. Stockwell v. McHenry, 107 Pa. 237, 52 Am. Rep. 475, does not bear directly upon the question raised by the present appeal. As pointed out by thẹ Superior Court, the case related to an instrument recorded in 1865, and therefore the indexing act of 1875 did not apply. It was expressly held (107 Pa. 244, $52 \mathrm{Am}$. Rep. 475 ) that the act of 1875 was not retroactive. In the case of Farabee v. McKerrihan, 172 Pa. 234, 33 Atl. 583, 51 Am. St. Rep. 734, the mortgage was actually recorded and indexed, but in the deed book and deed index, and not in the mortgage book and mortgage index. It was held that as recording in the deed book, and indexing in the deed index placed the incumbrance in the line of title of the mortgagor. where it could be discovered with the same ease and certainty as if it had been placed in the mortgage book index, by anyone examining the title, it was sufficient notice to preserve the lien. 
The great object to be attained, by recording and indexing an instrument affecting the title to real estate, is to give notice of the incumbrance. This principle seems to have been overlooked in the present case, for in reaching a conclusion, both the Superior Court and the trial court apparently gave little heed to the fact that the prime purpose of the law, in providing for the recording of deeds and mortgages, is to give notice to intending purchasers, or to others who may be interested, that the conveyance or incumbrance stands in the line of title to the property which it describes. The object of the recording acts is to give notice to the world of that which is spread upon the record. Therefore, the record is constructive notice to all persons, without resard to the fact of actual notice. Under our system, the record is open to everyone who desires to ascertain the condition of the title to any piece of real estate, in so far as its ownership is concerned, or as to incumbrances thereon, and everyone is bound to take notice of what the record shows, and searchers may rely upon the record as it stands. If this were not so, no one would be safe in purchasing real estate, or in loaning upon the strength of it, as security.

In the present case, the mortgage sued upon was never correctly recorded. The mortgage on record purports to have been executed by S. J. Marshall, and the name of L. J. Marshall does not appear upon it. The record of a mortgage given by S. J. Marshall is not notice to anyone seeking for incumbrances against L. J. Marshall. The same error was made in indexing the instrument. It was indexed as S. J. Marshall, and no mortgage given by L. J. Marshall appears upon the index. As the statute requires the recorder to keep mortgage indexes, and section 3 of the Act of March 18, 1875 (P. L. 32), expressly provides that the entry of mortgages in said index, shall be notice to all persons of the recording of the same, the appellant here was entitled to rely upon what appeared on the index, and that showed no mortgage given by L. J. Marshall.

Considerable stress was laid upon the fact that the recorder had certified that the mortgage was recorded; but that can make no difference whatever as to notice to the purchaser, which is the only question that concerns him. He never saw the certificate of the recorder; that was given to the mortgagee, and was for her benefit. If the recorder was negligent in his duty, and gave her a false certificate, she has doubtless her right of action for danages against him. But the error made by the recorder does not alter the fact that no notice of the mortgage, either actual or constructive, was given to the purchaser. He therefore took the land free of any such incumbrance, and it cannot be enforced against him. The motion for judgment in favor of defendant, non obstante veredicto, should have been sustained.

It should be remembered that in this case the nortgage was neither recorded properly nor indexed properly; both recording and indexing were alike defective, and each of the defects was fatal to the clain of the mortgagee. 
The failure to index properly is made so by the Act of March 18, 1875 (P. L. 32), which after requiring in the first section, the recorder to prepare and keep two general indexes, the one direct, and the other ad sectum, of all nortgages recorded in his office, goes on to provide:

"Sec. 2. As soon as said indexes are prepared, it shall be the duty of the recorder to index in its appropriate place and manner every deed and mortgage thereafter recorded in his office, at the time the same is recorded, and in case he neglect to do so, he and his sureties shall be liable in damages to any person aggrieved by such neglect." In Pyles v. Brown, 189 Pa. 164, 168, 42 Atl. 11, 12, 69 Am. St. Rep. 794, our Brother Fell said that this act "was probably passed to remedy the defects in the recording acts pointed out by Chief Justice Agnew in the opinion in Schell v. Stein, 76 Pa. 398 [18 Am. Rep. 416], decided in 1874." There it was said (76 Pa. 400, 18 Am. Rep. 416): "The question presented by the record in this case is, whether a deed regularly anowiedsed or proved, and recorded in the proper book, and indexed in the separate index appropriated to the book, but not in the general index of all the deed books, is not defectively recorded. If it be, the conceded principle is, that a deed defectively registered is a nullity as to subsequent purchasers or mortgagees. There is no law which requires the recorder to keep a general index to all the deed or mortgage books in his office. That it is a great convenience, and in the populous counties of the state has become a necessity, is evident, but it is the province of the legislature, and not of this court, to make this convenience or the necessity the subject of law."

The needed legislation thus pointed out, requiring the keeping of general indexes, was provided by the act of 1875 , and thereafter under the reasoning of Justice Agnew, supra, the failure to index in the geieral index became such a defect in the recording, as to make it a nullity to subsequent purchasers or mortgagees. ${ }^{36}$

In 1 Jones on Mortgages (6th Ed. 1904) § 515, it is said: "If the record of a deed be defective for any cause, it is constructive notice of only what the record contains, in case the record is not an accurate transcript of the instrument. This is the view sustained by the greater number of decisions and by the greater weight of reason, as distinguished from the view that the filing of the deed operates as a record of it, and that it is constructive notice from such time of the actual contents of the deed," citing Heister v. Fortmer, 2 Bin. 40, 4 Am. Rep. 417; Schell v. Stein, 76 Pa. 398, 18 Am. Rep. 416, and cases in Cali-. fornia, Indiana, Maine, Maryland, Michigan, Minnesota, Missouri, New Jersey, New York, Virginia and Wisconsin.

So also in 2 Pomeroy's Equity Juris. (3d Ed., 1905) $\S 654$, there is a clear statement of what we think is a sound principle. It is there said: "A record is a constructive notice only when and so far as it is a true copy, substantially even if not absolutely correct, of the instru-

38 So, also, in Iowa the failure to index is fatal. Barney v. McCarty, 15 Iowa, 510, $83 \mathrm{Am}$. Dec. $4: 7$ (1564). 
ment which purports to be registcred, and of all its provisions. Any material omission or alteration will certainly prevent the record from being a constructive notice of the original instrument, although it may appear on the registry books to be an instrument, perfect, and operative in all its parts. The test is a plain and simple one. It is whether the record, if examined and read by the party dealing with the premises, would be an actua! notice to him of the original instrument and of all its parts and provisions. By the policy of the recording acts, such a party is called upon to search the records, and he has a right to rely upon what he finds there entered as a true and complete transcript of any and every instrument affecting the title to the lands with respect to which he is dealing. A record can only be a constructive notice, at most, of whatever is contained within itself. $* * *$ The same rule - applies to the record of mortgages and all other incumbrances which can be recorded. The language, both of the original and of the record, must be such that if a subserpuent purchaser or inctumbrancer should examine the instrument itself, he would obtain thereby an actual notice of all the rights which were intended to be created or conferred by it."

In the case at bar, the duty was upon the mortgagee to give notice that L. J. Marshall had exectuted to her a mortgare upon the premises in question. If from any cause she fell short of giving legal notice, the consequence must fall upon her. She cannot hide behind the mistake of the recorder. It is an easy matter for a mortgagee, or a grantee in each particular instance, either in person, or by a representative, to look at the record, and see that the instrument has been properly entered. The instrument itself is at hand. The names of the parties are known, and comparisons are easily made. How would it be possible for a subsequent purchaser to know anything about the facts? The duty thus imposed upon the mortgagee in this respect, involves no more, and no less, than is required of a mortgagee, for his own protection, when before the money is paid out upon the loan, an inspection of the judgment indexes is necessary to see whether or not a judgment has been entered against the mortgagor upon the same day on which the mortgage is recorded. Some care must be exercised in every such transaction. There is every reason why it should be made the duty of the mortgagee to sce that his instrument is properly recorded. This will not in any way interfere with the principle that when the instrument is certified as recorded, it shall import notice of the contents from the time of filing. But that must be understood as in connection with an instrument properly recorded. As said above, the record is notice of just what it contains, no more and no less. The obligation of seeing that the record of an instrmment is correct, must properly rest upon its holder. If he fails to protect himself, the consequence cannot justly be shifted upon an innocent purchaser.

The judgment of the Superior Court is reversed, as is also that of the court of common pleas, and it is ordered that judgment in favor of the terre-tenant be entered, non obstante veredicto. 
MUTUAL L. INS. CO. v. DAKE.

(Court of Appeals of New York, 1S\$1. 87 N. Y. 257.)

EARL, J. This action is brought to foreclose a mortgage which was executed by the defendant Teeple and his wife, to the plaintiff on the 4 th day of June, 1870, upon lands in Livingston county, to secure payment of the sum of $\$ 2,000$ with interest.

On the 7 th day of December, 1870, the plaintiff left the mortgage at the office of the clerk of Livingston county, for record, and paid the fee for recording it. On the same day the clerk duly transcribed the mortgage in full, in the proper record book in his office, and indorsed on it his certificate in due form, and returned the mortgage, so indorsed, to the plaintiff. The clerk omitted, however, by mistake, to index the mortgage, and the plaintiff was ignorant of the omission until September, 1875, when the omission having been discovered. the morlgage was indexed by the clerk. The defendant, Jabez IV. Dake, is the assignee of two mortgages exectited by Teeple, on the same premises, one prior to the plaintiff's mortgage, dated April 6, 1868, for $\$ 600$ and interest, given to one Nichols; the othei, executed to one Balty, on the 14th of March, 1874, duly recorded and indexed on that day, and assigned by Balty to Dake, on the 10th of March, 1875. The mortgage to Balty was given to secure the payment of the sum of $\$ 1$,400 loaned by Balty to Teeple at the time of the execution of the mortgage. Before making the loan, and in view of it, Balty procured from the clerk a certificate of search, as to the title to the premises, and incumbrances thereon. The certificate did not show the existence of the plaintiff's mortgage, and Balty had no actual notice or knowledge of it until after he assigned his mortgage to Dake. The assignment to Dake was for a valuable consideration, and was duly recorded on the 16th of March, 1875. Before taking it, Dake saw the certificate of search which Balty had, and also procured for himself a certificate of search from the clerk, which, as well as the one in Balty's hands, did not show the existence of the plaintiff's mortgage, and Dake had no actual notice or knowledge of such mortgage till the 6th if December, 1875. The question now to be determined is, whether the plaintiff's mortgage or the Balty mortgage shall have priority, Dake claiming that although the plaintiff's mortgage was prior in time, it lost its priority because it was not indexed.

We have carefully examined the able and exhaustive briefs submitted to us, and are satisfied that no error was committed in the court below by its holding that plaintiff's mortgage had the priority. The carefully prepared and able opinion of Smith, I., at the Special Term, leaves but little now to be said; but as the question is claimed to be a new one in this State, we will briefly state the reasons for our affirmance of the judgment appeal in from. 
The plaintiff's mortgage, being prior in time, is entitled to priority over the Balty mortgage, unless it has lost such priority by force of the Recording Act, and a reference to it is therefore needful. It is found in chap. 3, part 2, of the Revised Statutes, which chapter is entitled, "of the proof and recording of conveyances of real estate, and the canceling of mortgages." Section 1 provides, that "Every conveyance of real estate within this State, hereafter made, shall be recorded in the office of the clerk of the county where such real estate shall be situated; and every such conveyance not so recorded, shall be roid as against any subsequent purchaser, in good faith and for a valuable consideration, of the same real estate, or any portion thereof, whose conveyance shall be first duly recorded." The record here intended was plainly a copy of the conveyance, transcribed into the proper book of records. Section 2 provides, that "Different sets of books shall be provided, by the clerlis of the several counties, for the recording of deeds and mortgages." Section 24 provides, that "Every conveyance entitled by law to be recorded, shall be recorded in the order, and as of the time, when the same shall be delivered to the clerk for that purpose, and shall be considered as recorded, from the time of such delivery." Section 25 provides, that "The recording officer shall make an entry in the record, immediately after the copy of every conveyance recorded, specifying the time of the day, month and year when the said conveyance was recorded, and shall endorse upon every conveyance recorded by him, a certificate, stating the time as aforesaid, when, and the book and page where, the same was recorded;" and a later section (3S) provides that the term "Conveyance" shall embrace a mortgage.

Here there is a complete system for the registry of deeds and mortgages prescribing the place and mode of registry, and not one word is said of any index to be made. It will be observed that the clerk is not required to certify, upon the conveyance recorded, that he has indexed the same, and yet if the index was an essential part of the record, it cannot be supposed that a matter so important would have been omitted from the certificate required.

By chapter 313 of the Laws of 1826 , county clerks were required to make separate indices in separate books of all deeds and mortgages recorded or resistered in their respective offices, whenever directed by the Court of Common Pleas, and it was provided that they should be paid for making such indices by the board of supervisors, and that was the first act in this State, in reference to indexing deeds and mortgages. It did not provide for indexing conveyances thereafter to be recorded.

The only provision in the Revised Statutes on the subject of indexing conveyances is found in part 3 , chapter 3 , article 2 , which article is entitled "Of the powers and duties of certain judicial officers." Section 61 of the article provides, that "It shall be the duty of the clerk 
of each county in the State, and of the register of the city and county of New York, to attach to every book kept in his office, in which deeds or mortgages shall be recorded, or collectors' bonds entered, an index to the matters contained in such books, arranged in alphabetical order, under the names of the several parties to such matters, with references to the pages where the same may be found, which, together with such books, shall at all proper times be open for the inspection of any person paying therefor the fees allowed by law." That section is still in force; it does not make the index a part of the record; it recognizes the record as complete without the index, and simply provides for an index to the records.

The first law requiring county clerks to make and keep books of general indices is found in chapter 199 of the Laws of 1843, section 1 of which provides, that "The clerks of the several counties in this State, and the register of the city and county of New York, in those counties in which general indices of deeds and mortgages have not been made and preserved, according to the act passed April 18th, 1826, shall provide proper books for making such general indices, and shall form indices therein in such manner as to afford correct and easy reference to the several books of record in their offices respectively. There shall be one book for deeds and another for mortgages. In each book there shall be made double entries, or two lists of names, in alphabetical order. In one shall be set the names of the grantors or mortgagors, followed by the names of their grantees or mortgagees; and in the other, the names of the grantees or mortgagees, followed by the names of the grantors, or mortgagors, leaving proper blanks between cach class of names for subsequent entries; and in those counties in which indices were made under the said act of April 18, 1826, and have been preserved, the several clerks shall complete the same by bringing them down to the present time, and in either case, the said clerks shall keep the said indices complete by adding to the lists, as deeds and mortgages shall be sent in to be recorded." "And section 2 provides, that "Each county clerk is hereby authorized to charge in his account against his county, all necessary expenses which he may incur in the purchase of books for such indices, and at and after the rate of fifty cents for every hundred names, which he may enter in such book." .The indices here provided for clearly form no part of the record, but are intended, in the language used in section 1, "to afford correct and easy reference" to the books of record; and the record is thus recognized as existing independently of the indices. It must be noticed further, that while a person who procures a conveyance to be recorded must pay the clerk his fee for recording, it is provided in section 2 that the expense of indexing is a public cliarge.

I have thus quoted at length the main provisions of the Recording Act, and of the acts in reference to indices, that the full force of the language used in them may be fully and easily comprehended; and 
thus it is plainly seen that there is nothing in them which makes the index a part of the record. It is clear that the only purpose which was intended to be served by the indices is as a guide to the records for the convenience of searchers.

That our conclusion is the correct one is made still more manifest by section 26 of the Recording Act, which provides that the transcript of any record of a deed or mortgage, recorded as provided in the act, may be read in evidence, when certified by the clerk to be a true copy of such record. The record intended in that section is unquestionably the record made by a transcript of a conveyance in the proper book, as provided in the act, and the index is no part of such record which is required to be certified. It was never heard that a certified copy of the record of a deed or mortgage was objected to, or excluded as evidence, because a copy of the index was not included as a portion of the record; and yet if it formed an essential portion of the record, it would always have to be certified as part thereof.

There is nothing in the history of the legislation on the subject of the registration of deeds and mortgages, from the earliest time in England and in this State, which tends, in the least degree, to show that it has ever been supposed that indexing was any essential or necessary part of registration. Such legislation is ably reviewed in the opinion of Smith, J., at Special Term, and needs no further notice here.

Whatever forms part of a perfect record, as prescribed in the act, is essential; that is, the conveyance must be recorded in the proper book, in the proper order, and with substantial accuracy. If the record be defective in any thing essential, it will not serve the purpose of giving constructive notice to subsequent bona fide grantees or incumbrancers.

It is claimed, on the part of the appellant, that if the index is no part of the record, it is useless, and even worse than useless, as it might operate to ensnare and mislead persons relying upon it. It is true that an index may, by mistake, be omitted; but such mistakes must rarely occur, and the legislature undoubtedly deemed it sufficient to make it part of the duty of county clerks to make the indices. It is an adequate guaranty that the indices will be sufficiently correct and reliable that county clerks are liable to be indicted if they willfully or fraudulently omit to make them correctly, and are at the same time liable in a civil action to the party injured by their omission or neglect. The duty to make the indices is a public duty, for which the clerks are paid by the public, and for the violation of such a duty, it cannot be doubted that any one of the public specially injured has his action.

When a conveyance is delivered to the clerk the statute provides, that it shall be "considered as recorded from the time of such delivery." After such delivery nothing more need be done to keep the record periect, except at the proper time to record it in its proper order, in the proper book; and yet if the conveyance, in the meantime, before 
the record the reof, should be mislaid in the clerk's office, or lost or purloined, the record would still remain complete. In such case there could be no index of such conveyance, because, until the time for recording it had arrived, it could not be known in what book, or in what place in any book, it would be recorded.

That the index is no part of the record, and may be omitted by the clerk without impairing the record, is the view sanctioned by the current of decisions, in the other States, and by elementary writers. In 4 Kent's Com. 174, note, it is said: "An index or alphabet of a mortgage is no part of a mortgage, and a mortgage is duly registered if no index of it is made." In 1 Washburn on Real Property, 578, the rule is laid down as follows: "The proposition is a general one, that an irregular registration of a deed is no notice to others of the existence of such deed; but an omission of the register to note the time of receiving the deed for record, or to enter it in the index or alphabet, will not invalidate the effect of the registration;" and in 1 Hilliard on Mortgages, 721 (4th Ed.), as follows: "The record of a mortgage is sufficient, though not mentioned in the alphabet, or index;" and also in 1 Jones on Mortgages as follows: "The index is no part of the record, and a mistake in it does not invalidate the notice afforded by a record otherwise properly made; although the mortgage be omitted from the index it is just as much an incumbrance upon the land, and notice of it from the time it was left for record, or transcribed, aifects all subsequent purchasers."

It may be that the index, both for conrenience and safety, shoulc be made a part of the record; but until it is so made by the legislature, we can but pronounce the law as it is.

The judgment should be affirmed, with costs. All concur Judgment affirmed. ${ }^{37}$

37 TuE TorRens Srstem.-The present system of reording. nnder which, as is evident trom the cases ahove, only instruments of title are recorded or filed. has many shortcomines. Even after the most careful examination of the records, showing, perhays, a perfect record title in a certain person, no oue can be wholly safe in relyins thereon. There are many matters, any ong of which would be amply suflicient to npset completely such apparently perfect title, tiat do not show upon the records, and that camot he discloserl hy an examinition thereof. In fict many of such matters are almest inuossible of disclosure by an ordinarily careful additional examination ontside the records. Among the many matters which may thus affect an apparently perfect title are nondelivery, forgery, incapacity, etc. See 12 Mich. I. Rev. 3↔9 et seq.

Aside from the foregoing, the recording system orlinarily involves at each sale or incumbrance an expert examination of the entire record, which means expense, often large expense.

Because of these deficiencies of the prevalent sistem there has been a steadily growing demand for something better. By many it is clained that the so-called Torrens system of Land Title Registration will obriate many, if not all, our present ills. Cnder that system title itsolf is registered, and therein lies the fundamental difference between it and our present system of recording title instruments. The srstem takes its mame from sir Robert R. Torrens, a native of Ireland, who emisrated to Anstralia in 1840, later becoming the first Premier of South Australia. It is said that it was in 1850 , when he was 
rollector of customs at Adelaide, that he first thought of applying to land the methol of registering and transferring ownership in shins. In 1858 . the first "Tor"sus Title Act" went into effect in South Australia, hargely through the efforts of Sir Rohert R. Torrens. Although the system in Eurland and her dependencies and in the United States is known by lus name, he was by no means its imrentor, so to sleak, for similar systems had been in operation in parts of Enrope tor many years. Sheldon, Iand Registration, c. 7 .

In the lnited states the first difliculty is to draw a statute that will with. stand constitutional objections. The first Anerican statute introlucing the Torlens system was enacted in Illinois in 1895; the second, in Ohio in 1896. Colifolnia. Iassachusetts, Oregon, Minnesota, Colorado, Washington, and New Fork tollowed. The first Torrens Aet in Illinois was held unconstitutional. People v. Chase. 165 Ill. 527, 46 N. I. 454, 36 L. R. A. 105 (1597). Following that decision, the Illinois Legislature enacted a new statute, which has so far withstoor constitutional attacks. The Ohio statute of 1596 also was held inFalic. State :. Fuilbert, 56 Ohio St. 575,47 N. E. 551, 35 L. R. A. 519.60 Am. st. Rep. 7.fi (1S97). In 1912, the Ohio Legislature, pursuant to provisions of an ampoiment to the Constitution adopted in 1912, enacted a new statute for recristration of land titles.

The statutes are too lengthy to give even in summary. The procedure in bringing land moler the system and the manner of dealing therewith afterwards are wall stated in the following language used by the supreme Court of Mimnsota in State r. Westfall, 85 Minn. 437, 89 N. IV. 175, 57 I. R. A. 297, 89 Am. St. Rel) 571 (1902), in which the court declared the Minnesota Torrens Act constitutional:

"The act provicles, among other things, that the owner of any estate or interest in land may have the title thereto registered by maling an application in writing, staliner certain facts, to the district court of the county wherein the land is situated. Therempon the comrt has power to inquire into the state of the title, and make all decrees necessary to determine it arainst all persons, known or unknown. The application must be filed and dockoted in the oflice of the alerk of the comrt, and a duplicate thereof filed with the register of deeds, who is ex officio registrar of titles. The application is then referred by the court to an examiner of titles. who investigates the titles, and inquires as to the truth of the allegations of the application, particularly whether the land is occupich or not, and makes and files a report of his examination with the clerk. Linom the tiling of the report the clerk issnes a summons by orcler of the cont, wherein the aplicant is numed as llaintifi, and the land described, and all other polsons known to have any interest in or chim to the land and 'all other persons or partios mknown' claiming any interest in the real estate described in the application are named as defendants. The smmmons must be directed to such defendants, and require them to appear and answer within twenty days. It must be served in the mamer now urovided for the service of smmons in civil actions, with this excention: That the summons shall be served on nomresiclent defendants and upon all unknown persons by publishing it in a newspaper printed and pubished in the county where the application is hiled once a week for thee consecutive weeks. In addition to such publication the clerk shall, within twenty days after the first publication, mail a copy of the summons to all nomlesident defendants whose place or address is known, and the cont may orler such additional wotice of the application as it may cirect. Any intelested lalty ma appear and answer. If no appearance is made, the cont may cnter the defanlt, but must talie proof of the applicant's right to a decree, and is not bound by the report of the examiner, but may reguire further lroof. If appearance is made, the case shall be set for trial, and heard as other civil actions. If the court finds that the applicant has title proper for registration, a decree confrming the title and ordering resistration shall be entered. Every such decree shall bind the lands and quiet title there' to, except as otherwise provided in the act, and shall be forever binding and conclusive upon all persons, whether mentioned by name or included in the exjression 'all other persons or parties unkmown, and such decree shall not open by the reason of absence, infancy, or other disalility $* * *$ except as provided in the act. **** Every person receiving a certificate of title and every subsequent purchaser in good faitl takes the same free from all il!cumbrances, except such as are noted thereon. Cipon entering the decree of 
resistration, a certified copy thereof must be filed by the clerk in the office of the registrar of titles, who proceeds to register the title pursuant to the decree. This he does by entering an original certificate in the registry of titles, and delivering a duplicate thereof to the owner, who may thereafter convey his title by the execution of deeds and the surrender of his certificate to the registrar for cancellation, who issues a new certiticate to the purchaser."

And such is the only method by which the land, after registration, nay be. convered; the old duplicate certificate must be delivered up and eanceled; and it new rertiticate issued to the new owner. Most of the statutes, as in Minnew sota, still preserre the use of the deed, which, however, does not act in itsci; as a coureyance, even after complete execution. 


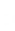

,

$$
\text { • }
$$




\section{INDEX}

[THE FIGURES REFER TO PAGES]

\section{ACCEPTANCE,}

Of conveyance, necessity, 375 Thompson, 383 note, 384 Welch.

Of dedication, necessity to bind landowner, 182 Cassidy. To bind public corporation, 183 Downing.

\section{ACCRETION,}

Apportionment of, 155 note.

Artificially induced, 146 note.

Effect upon defined boundaries, 147 Volcanic Oil \& Gas Co.

To banks or shores, ownership, 140 Gifford.

What is, 140 Gifford, 145 Halsey.

ACKNOWLEDGMENT,

Reyuired for what, 279, 914 Sigourney.

ADVERSE POSSESSION,

Disabilities, 91 Doe.

Minerals, so note.

Tacking, 2.1-13.

What constitutes, 49-80.

Claim of title, 43 Rirard, 51 French, 56 Preble, 61 Bond.

Devisee for life under invalid will, 68 Hanson.

Donee under parol gift, 63 note.

Mistaken belief of limited right, 61 Bond.

Mistaken belief of ownership, 51 French, 56 Preble.

Possessor supposing title in one not really the owner. 72 Dean, 78 note, 79 Mitchell.

Squatter, 51 note.

Tenant after disclaimer, 65 Fortier.

Tenant for life after death of cestui que vie, 66 Parker.

See Constructive Adrerse Possession; Lapse of Time; Prescription.

AFTER-ACQUIRED TITLE,

Transfer by estoppel, 793-809.

ASSIGNMENT,

Defined, 231.

ATTESTATION,

Required for what, 279.

ATTORNMENT,

Abolished, 162 note.

BARGAIN AND SALE,

Consileration for, 248 Jackson, 254 note.

Nature of, 236.

Operation of Statute of Uses upon, 248 Lutwich.

Words sufficient for, 248 Grey.

BOUNDARIES,

Conflict between course and distance, 411 Hall. 416 Temple.

Between conrse and monument, 402 Hoban, 405 Whitehead, 407 Lernor. 405 Burkholder.

AIg.Prop. - 60 
BOUNDARIES-Continued,

Mistake in location, adverse possession, 51 French, 56 Preble.

Necessity for, 391 Harris, 395 Lego, 401 Morehead.

On private way, 429 Saccone.

Streets and streams. 421 Sizer, 426 note, 436 C. \& E. I. R. Co., 438 Iow, 440 Jonas. 443 note, 444 Trowbridge, 447 Dodd.

Unopened street, 426 Bangor House Prop.

Ways on margin of land, 429 Saccone, 434 Geddes Coarse Salt Co. Reversal of calls, 402 Hoban, 404 note.

Lndetermined part of larger tract, 401 Norehead.

CANCELLATION,

Of lease as surrender, 190 Lord Ward.

COLOH OF TITLE,

Ileaning of, 81 Jackson, 82 note.

COMMON RECOTERY,

Defined, 160.

CONCLRRENT OWNERSHIP,

Accounting by cotenant, $711 \mathrm{Pico}, 715$ note.

Conreyance of part by metes and bounds, 723 Griswold, 725 Cressy, 72s Lessee of White.

Improrements by cotenant, 722 Kelsey.

Outstanding title acquired by cotenant, 700 Van Horne, 702 note, $703 \mathrm{El}$. ston, 706 Hurley, and note, 709 Jackson.

Repairs by cotenant, 716 Calvert, 719 note, 720 Piclering.

CONFIRMATION,

Defined, 188.

Distinguished from quitelaim, 188 note.

CONSTILCTIVE ADVERSE POSSESSION,

Color of title, requirement of, 81 Jaclison, 82 note.

Conflicting or overlapping, $\$ 9$ Ralph, 91 note.

Necessity for actual adverse possession, 84 Bailey, 81 Jackson.

CONVEYANCES,

See Mode of Conveyance.

COPARCENARY,

Nature of, $6 \mathrm{ss}$.

Partition, 689.

COVENANTS FOR TITLE,

Action for breach, effect of transfer of after-acquired title by estoppel upon, S04 Resser.

Release of covenantor, itS note.

Run with the land, $73 \pm$ Noke.

Broken covenants, 754 Lewes, 755 Kingdon, 757 Kingdon, 759 Mitchell, 767 Schotield.

Claim on covenants available to successors to covenantee's estate, 746 Andrew, 74 S Williams, 749 Beardsley, 753 St. Clair.

Privity of estate between covenanting parties required, 734 Noke, 736 Beddoe, 740 Solberg.

successive corenants, 776 Wilson.

When assignor may sue on covenant broken after assignment, 770 Markland.

COVENANT TO STAND SEISED,

Freehold in futuro by, 255 Roe.

Nature of, 236 .

Relationship, 255 Roe, 258 Murray.

CREATION OF EASEIIENTS BY IMPLICATION,

see Implication.

CROPPING CONTRACTS,

see Years, Estates for. 
CURTESY,

Defined, 5 so.

Extent of interest. 582 Mattock, 583 note, 584 Foster.

Nature of husband's title, 595 Watson.

Interest remaining in wife, 584 Foster.

Seisin of wife, 5SS Borland's Lessee.

\section{DEDICATION,}

Acceptance to bind landowner, 1S2 Cassidy.

Municipality, 183 Downing.

Proof of, 184 Ogle.

By equitable owner, 165 Cincinnati.

Character of user required, 164 Rex, 174 Waters, 177 note.

Effect of, 1 (f) Lade. 165 Cincinnati.

For cemetery, 177 Wormley.

Grantee unnecessary, 165 Cincinnati.

Length of time required, $163 \mathrm{Rex}$, and note.

Limited, 164 note.

Proof of, 164 Rex, 174 waters.

DEFEASANCE,

Defined, 231.

DELIVERY,

Acceptance, 375 Thompson, 383 note, 384 Welch.

In escrow to grantee, 324 Whyddon, 3.35 Hawksland, 386 Williams, 336 London F. \& L. Prop. Co., 342 Wipfler, 344 Lee.

To agent of grantor and grantee, 336 London F. \& L. Prop. Co.

Effect of improper delivery by custodian, 347 Everts, 351 note, 352 Schurtz.

Necessity for valid contract, 357 Campbell, 360 note.

When title passes, 361 Hull, 362 Farley, 362 Hall, $365 \mathrm{May}, 368$ Scoti, 370 Baker.

Manual not required, 288 Doe, 295 Fryer, 297 Mitchell, 303 Matson, 305 Burnet.

Recording as presumptive, 297 Mitchell, 300 note.

Requisites of in general, 297 Stanton, 281 Curry, 282 note, 283 Tisher, 286

Parrott.

To third party, 288 Doe.

To be delivered on grantor's death, 308 Wheelwright, 312 Ruggles, 314 Johnston, 316 Moore, 316 note, 320 Owings.

When title passes, 322 Stone, 325 Stonehill, 329 Smiley, 331 Rathmell.

DERIVATIYE TITLES, 156-913.

DESCENT CAST,

Abolished, 11 note.

Right of entry lost by, 5, 159.

When arises, 9.

DESCRIP'TION,

See Boundaries; Exceptions and Reserrations.

DEVISE,

Defined, 232.

DISABILITIES,

See Adverse Possession.

DISSEISIN,

By election, 9.

Defined, 3, 4, and note.

Distinguished from dispossession, 7 Smith.

Effect of, 4.

Remedies upon, 4-7, 159.

DOWER,

Barred how, 619 Ingram, 620 Grady, 622 Catlin, 624 Robinson.

Defined, 597. 
DOWER-Continued,

Fraudulent conveyance, effect upon, 624 Robinson.

In estates held for husband in trust, 600 shoemaker.

In remainder, 600 Shoemaker, 602 Bates.

Limitation over on death of husband, 603 Edwards.

Iomentarily held, 595 Holbrook.

Cpon condition subsequent, 608 Fllis.

Nature of interest while inchoate, 612 Flynn, 616 note. After death of husband, 610 Wallis.

Protection of against waste, 616 note.

Signing deed as bar of, 622 Catlin.

Statutory modifications, 627 note.

Taxation of under inheritance tax, 616 Crenshaw.

Talue determined as of when, 624 note.

Where husband had executed escrow deed, 365 note. Deed to be delirered on death, 329 smiley.

Widow of surriving joint tenant, 597 Broughton.

\section{EASEMENTS,}

See Implication.

EMINENT DOMAIN,

Extent of interest acquired, 154 note.

Nature of title by, 154 note.

When title passes, 154 note.

ENTIRETIES, ESTATE BY.

Created how, 686, 692 'Thornburg, 698 Pegg.

Defined, 689.

ENTRY,

Restoration of seisin by, 4.

ESTATES CREATED, 547-733.

ESTOPPEL BY DEED,

Br representation, 783 Hannon, 789 note.

- Efiect of warranty, 779,780 Jackson, 790 Aser.

In quitclaim deed, 781 Bayles.

Transfer of after-acquired title by, 793 Doe, 796 note, 790 Perkins, 797 Jordan, S01 Jarvis, S04 Resser.

As affecting actions upon covellants for title, s04 Resser.

Effect of recording statutes upon, 858 Tefft, $\$ 62$ Wheeler.

EXCEPTIONS AND RESERVATIONS,

Coal reserved, 449 Whitaker.

Easement "reserved," 455 Dee, 461 Smith's Ex'r.

Exception of part of water privilege, 450 note.

Must not be repugnant, 449 Dor'rell.

Pleading, 452 note.

Road "reserred," 452 Kister.

To stranger, 463 Haverhill Sav. Bank.

See Implication.

EXCHANGE.

Detined. 161.

EAECUTION OF DEEDS, 275-393.

FEE SIMPLE,

Defined, 547.

How created, 547 and note.

Conflicting clauses. Jis McCullock, 549 note, 550 Carl Lee.

Upon limitation, 552 First Universalist Soc.

FEE TAIL,

After possibility of issue extinct, 579 .

Defined, $55 \bar{\tau}, 5 \%$ s.

How converted into fee simple, 560 Ewing. 
FEE TAIL-Continued,

How created, 558, 559.

Recognized in modern cases, 560 Ewing.

statute De Donis, 556.

Under statutory modifications, 566 Dungan, 569 note.

FEOFEMENT,

Defined, 156.

Necessity for, 156.

Tortious, 4, 158.

FINE,

Defined, 160.

FORCIBLE ENTRY,

Rights of tenant upon, 636 Turner, 638 Hilary, 639 Pollen, 645 Reader, 652 Low, 657 note.

FRAUDUIANT CONVEYANCES,

Voluntary comveyances where subsequent conveyances for value, 512 Doe, \$20 Cooke.

Purchaser for value, 825 note.

GD. $\mathrm{NTT}$,

Defined, 162.

HUSBAND'S INTEREST IN WIFE'S REALTY,

After birth of issue, see Curtesy.

Before birth of issue, 580 Montgomery.

IMPIICATION,

General, 466 Coppy, 467 Robins, 469 Palmer.

Implied grant.

Construction, 538 Weeks, 541 City of Battle Creek.

Necessity, 469 Pinnington, 494 Brigham.

Quasi easements that are apparent, 535 Butterworth.

Continuous, 474 Polden, 526 Tooth, 527 Liquid Carbonic Co., 5:9 Adams.

Necessary, 518 Buss, 526 Tooth.

Implied reservation where necessity, 469 Pinnington, 49- Brigluam, 491 Ray, 497 note, 509 Mancuso, 511 Brown.

Reciprocal easements, 486.

Simultaneous conveyances, 4 S7 Phillips.

JOINT TENANCY,

Created how, 686, 690 Mustain, 692 Thornburg.

Defined, 685, 686.

Partition, 687.

LAPSE OF TIME,

Disabilities, 91 Doe.

Effect of when coupled with possession, 19-43.

Tacking possessions in defense, 24 Goody, 31 Shannon, 32 Harlan, 31 Sherin, 36 McNeely.

In attack, 26 Carter.

Prescription, 139 note.

Privity, 36 MaNeely, 39 Ruch.

LEASE,

Uefined, 161.

See Surrender.

LIFE ESTATES,

Created, 572 .

Defined, 570.

For indefinite time, 575 Thompson.

Life of lessee and others, 573 Rosse.

Life of lessee and heir, 573 Amos.

See Curtesy; Dower; Tee Tail. 
I.IGHTS,

Easement of by implication, 469 Palmer, 491 Ray.

LIS PENDENS,

Doctrine of, 914 note.

Record of, 914 note.

MODE OF CONTEYANCE,

Common liw, 156-232.

Iodern statutes. 268-275.

Statute of L'ses, 232-268.

MONLIENTS.

See Boundaries.

NOTICE.

See Record.

PARTITION,

Defined, 162.

POSSESSION.

Basis for ejectment, 11 Asher, 26 Carter.

Compeusation in eminent domain, 13 Perry.

Taxation, 16 note.

Effect of wrongful possession upon owner, 17 Sohler.

For period of statute of linitations, 21 Hughes, 72 Dean. See Adverse Possession.

PRESCRIPTION,

Adverse user, 121 Pavey, 125 Rarber. 128 Lechman.

Character of rights subject to acquisition by, 112 Webb, 121 note.

Continuity of user, 132 Lehigh V. R. Co.

Interrening disabilities, 94 Wallace, 104 Lamb.

Iight and air, 111, 112, 117 Hubbard.

Tacking, 139 note.

Theory and development, 94 Wallace.

Time period commences, $11 t$ Sturges.

Serrient estate held by tenant, 109 Baxter.

PRIORITIES,

See Fraudulent Convesances; Record.

PRIVITY

See Lapse of Time.

I'ROPERTY CONVEYED,

See Boundaries; Exceptions and Reservations.

PURCHASER FOR VALUE,

See Fraudulent Conveyances; Record.

QUARANTINE,

Widow's right of, 610 Wallis.

RECORD,

As notice in England, 827 Bedford, 827 Morecock.

In Cnited States, S37 Simonson.

Necessity of as against purchaser from heir, 849 Youngblood.

Creditors, 868 Holden.

Grantee in quitclaim, 882 Marshall, 834 note, 885 Smith's Helrs, 887 Boynton, 892 note.

Grantee of purchaser with notice, 852 Morse, 854 Woods.

Purchasers for value, 877 Strong, $\$ 78$ note, 880 Thomas.

Purchasers on execution, 872 Sternberger.

Notice instead of, 829 La Neve, 834 note.

Knowledge of deed on record improperly, 909 Nordman. 
[The figures refer to pages]

RECORD-Continued,

Possession, 898 Galley, 901 note, 902 Williamson.

Recitals, 892 Moore, 893 Baker, \$94 Patman.

Of equitable title, 837 Simonson.

Lis peudens, 914 note.

Unacknowledged deed, 914 Sigourney.

Out of chain of title, S43 Losey, 845 Rankin, 854 Woods.

Sufficiency of, 916-943.

Incorrect amount stated, 926 Frost, 927 Terrell, 929 Mangold.

Index, 932 Prouty, 937 Mutual L. Ins. Co.

Names of witnesses omitted, 916 Pringle.

RELEASE,

Defined, 187.

REMAINDERS, 731-733.

RESERVATION,

See Exceptions and Reservations; Implication.

REVERSIONS, 731-733.

SEAIING,

Abolished, 278

Required, 275 Jackson.

Sufficiency of, 278.

SEISIN,

Defined, 2.

Importance of, 2,7 note.

Mystery of, 1.

SIGNING OF DEEDS, 275.

STATUTES,

Enrolments, 247.

Frauds, 157.

Fraudulent conveyances, 810-812

Limitation, $19-21$.

Recording, 826, 834-837.

Uses, 236.

STREAMS,

See Boundaries.

STREETS,

See Boundaries.

SUFFERANCE,

Teuancy at, 636.

SURRENDER,

Defined, 188, 189.

In fact by cancellation, 190 Lord Ward.

Conditional, 191 Allen.

In law,

Acceptance of third party as tenant, 207 Thomas.

Incorporeal property, 221 Lyon.

New lease not creating interest intended, 195 Davison, $197 \mathrm{Zick}$, and note, 200 Schieffelin.

New lease to commence in futuro, 195 Ive.

Reletting after abandonment, 209 Walls, 211 Gray, 217 Oldewurtel, 220 note.

Yielding possession to landlord, 206 Whitehead.

TACKING,

See Lapse of Time.

TAX TITLES, 155 note. 
TENANCY PY ENTIRETIES,

Created how, 689, 692 'Thornburg, 698 Pegg.

Jefined, 6\$.

See Conicurrent Ownership.

TENANTS IN COMAION,

Created how, 687, 688, 698 Pegg.

Defined, essi.

See Concurrent Ownership.

TORRENS SYSTEM, 941 note.

TRLST,

I'st upon a use upheld as, 262 note.

USES,

Actlve, 26f Ure, 268 note.

After Statute of Lses, 239-268.

Bargain and sale, 2:36.

Before Statute of Ises, 232-236.

Covenant to stand seised, 236.

Created how, 235, 236.

Enforcement of, 233.

Enroluents, statute of, 247.

Estates in, 2:34.

Operation of Statute of Lses, 239 Green; 248 Lutwlch.

I'ersonal property, 266 i're.

Raised in connection with common law conveyance, 2:?-246.

Raised independently of common law conveyance, 247-261.

Re'asons for introduction of, $2: ; 2$.

Resulting, 235, 240 Shortridge, 241 Armstrong, 241 Van der Volgen.

Shifting, 234.

Springing, 2:34.

Statute of, 236.

Ise upon a use, 261 Tyrrel, 262 Doe.

WATERS,

See Boundaries; Accretion.

WAYS OF NECESSITY,

liy inplication, 469 I'innincton, 494 Prigham, 495 Dabney.

WIFE'S INTEREST IN HLSLAND'S REALTY, See Dower.

WIIL,

Sice Devise.

WIJJ, WSTATE AT,

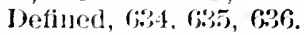

betermined by conveyance, 641 Cnrtis.

When, (:3); Ieighton.

Where rent payable periodically, Giz Say.

see Forcible Entry.

YEAR TO YEAR, ESTATES FROM,

Assignalle, (j:5 linithwaite.

Lintry under agreement for lease and payment of periodlc rent, 657 Praytbwaite.

Voin parol agreement for lease providing for periodic reut, 665 Griswoll.

Toiri furol lease, fifi4 Clayton, 665 note.

IInlan' over, 670 Iiisht, 672 Jjerter, 675 roldshorough, 677 King.

Notice to guit, fojo Arlienz.

Paymmit based on foots purehased, as periodic rent, 609 hyons. 
[The figures refer to pages]

YEAR TO YEAR, ESTATES FROM-Continued,

Terms of, as contained in agreement for lease unexecuted, 660 Doe, 602 Coudert.

When terminable, 657 Layton, 062 Coudert.

XLARS, ESTATES FOR,

Created how, 628, 629.

Cromping agreements as, 629 Hare, 630 Caswell, 631 Steel.

Defined, 628. 
. 


.




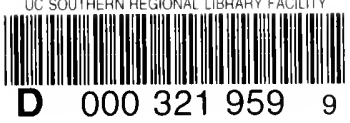


